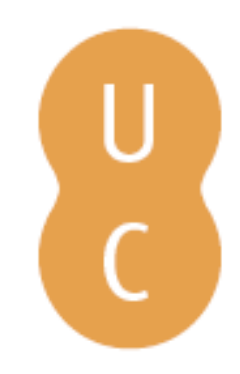

\title{
pompalina
}

\section{Beato Amadeu: nova apocalipse}

Autor(es): $\quad$ Dias, Domingos Lucas, ed. lit.; trad.; Espírito Santo, Arnaldo do, ed. lit.; Pinho, Sebastião Tavares de, ed. lit.

Publicado por: Imprensa da Universidade de Coimbra

URL

persistente:

URI:http://hdl.handle.net/10316.2/34787

DOI:

DOI:http://dx.doi.org/10.14195/978-989-26-0715-3

Accessed : $\quad$ 26-Apr-2023 01:27:07

A navegação consulta e descarregamento dos títulos inseridos nas Bibliotecas Digitais UC Digitalis, UC Pombalina e UC Impactum, pressupõem a aceitação plena e sem reservas dos Termos e Condições de Uso destas Bibliotecas Digitais, disponíveis em https://digitalis.uc.pt/pt-pt/termos.

Conforme exposto nos referidos Termos e Condições de Uso, o descarregamento de títulos de acesso restrito requer uma licença válida de autorização devendo o utilizador aceder ao(s) documento(s) a partir de um endereço de IP da instituição detentora da supramencionada licença.

Ao utilizador é apenas permitido o descarregamento para uso pessoal, pelo que o emprego do(s) título(s) descarregado(s) para outro fim, designadamente comercial, carece de autorização do respetivo autor ou editor da obra.

Na medida em que todas as obras da UC Digitalis se encontram protegidas pelo Código do Direito de Autor e Direitos Conexos e demais legislação aplicável, toda a cópia, parcial ou total, deste documento, nos casos em que é legalmente admitida, deverá conter ou fazer-se acompanhar por este aviso.

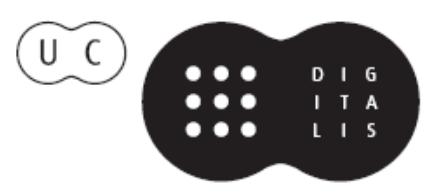




$$
\begin{gathered}
\text { Portvgaliae } \\
\text { Monvmenta Neolatina } \\
\text { Vol. xiv } \\
\text { Beato Amadeu } \\
\text { NOVA } \\
\text { A P O C A L I S E }
\end{gathered}
$$


(Página deixada propositadamente em branco) 


\section{PORTVGALIAE Monvmenta NeOlatina}

\section{Coordenação Científica}

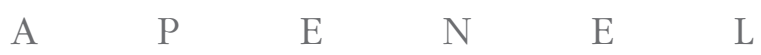

Associação Portuguesa de Estudos Neolatinos

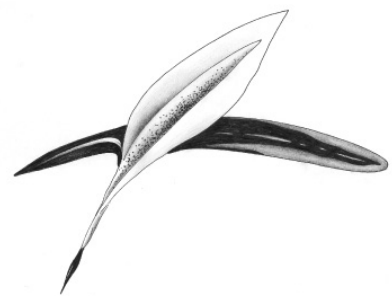

$\begin{array}{lllll}\text { A P } & \text { E } & \text { N } & \text { E } & \text { L }\end{array}$ 


\section{COORDENAÇÃO CIENTÍFICA}

Associação Portuguesa de Estudos Neolatinos - APENEL

\section{DIREÇÃo}

Sebastião Tavares de Pinho, Arnaldo do Espírito Santo, Virgínia Soares Pereira, António Manuel R. Rebelo, João Nunes Torrão, Carlos Ascenso André, Manuel José de Sousa Barbosa

COORDENAÇÃO EDITORIAL

Maria João Padez de Castro

EDIÇÃO

Imprensa da Universidade de Coimbra

Email: imprensa@uc.pt

URL: http://www.uc.pt/imprensa_uc

CONCEÇÃO GRÁFICA

António Barros

PRÉ-IMPRESSÃO

Alda Teixeira

IMPRESSÃO E ACABAMENTO

NSG - Novas Soluções Gráficas, S.A.

ISBN

978-989-26-0553-1

ISBN DIGITAL

978-989-26-0715-3

DOI

http://dx.doi.org/10.14195/978-989-26-0715-3

DEPÓSITO LEGAL

$382756 / 14$

OBRA PUBLICADA COM O APOIO DE:

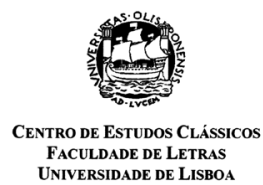

FCT Fundação para a Ciência e a Tecnologia

MINISTÉRIO DA CIÊNCIA, TECNOLOGIA E ENSINO SUPERIOR Porugal

(C) OUTUBRO 2014, IMPRENSA DA UNIVERSIDADE DE COIMBRA 
Portvgaliae Monvmenta Neolatina

VOL. XIV

\section{BEATO AMADEU}

\section{NOVA APOCALIPSE}

Introdução, tradução e notas

Domingos Lucas Dias

Edição crítica e fixação do texto latino

DOMingos Lucas Dias

ARNALDO DO ESPÍRITO SANTO

Sebastião Tavares de Pinho

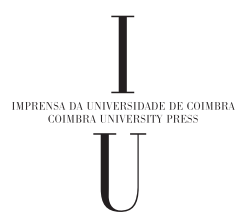


(Página deixada propositadamente em branco) 


\section{NT R O D UÇ ÃO}

\section{NOTA BIOGRÁFICA}

A vida do Beato Amadeu constitui um tríptico de que apenas o último painel tem margens regulares, embora as cores sejam igualmente imprecisas. Já fr. Marcos de Lisboa ${ }^{1}$, cronista da Ordem entre 1556 e 1570, como regista o Prof. Sousa $\operatorname{Costa}^{2}$, advertia na sua Crónica para as muitas coisas referidas pelos irmãos acerca dele e seus milagres, coisas que omitia por falta de documentos autênticos.

Era filho de Rui Gomes da Silva, da diocese de Coimbra, que foi provavelmente escudeiro de D. João I e foi conselheiro de D. Duarte, depois de haver sido homem da sua casa enquanto Infante. Foi conselheiro de D. Afonso V, foi alcaide-mor de Campo Maior e Ouguela. Tomou parte na conquista de Ceuta ${ }^{3}$, onde foi armado cavaleiro do Infante D. Duarte. Em Ceuta, casou com D. Isabel de Meneses, filha bastarda de D. Pedro de Meneses, conde de Vila Real e primeiro Governador dessa cidade.

Casados em 13 de Novembro de 1422, os pais de Amadeu estavam já em Portugal no início de 1427 . Nesta data já o pai era alcaide-mor de Campo Maior. ${ }^{4}$

A primeira dúvida que se levanta em torno do Beato é a do lugar do seu nascimento. Desde sempre se aceitou que, quer ele, quer sua irmã, houvessem nascido em Campo Maior. Mas a análise de um documento encontrado junto às ossadas de santa Beatriz fez alterar essa certeza a ponto de, no discurso de canonização da santa, a 3 de Outubro de 1976, o papa Paulo VI afirmar que ela nascera em Ceuta em 1424. São dois os dados que justificam esta conclusão, a idade com que a santa terá morrido, 66 anos, e a data de sua morte, Agosto de

\footnotetext{
${ }^{1}$ Fr. Marcos de Lisboa, Tercera Parte de las Chronicas de la Ordem de los Frayles Menores, lib. 6, cap. 30, 179.

${ }^{2}$ António Domingues de Sousa Costa, Studio Critico, 196.

${ }^{3}$ Zurara, Crónica da Tomada de Ceuta, cap. C, 284 - "Ficaram ainda na dita cidade, afora estes que ditos havemos, Rui Gomes da Silva, Pero Vaz de Azevedo e os já ditos Pero Gonçalves e Álvaro Mendes e Luís Vaz da Cunha...”.

${ }^{4}$ António Domingues de Sousa Costa, Studio Critico, 170.
} 
1490.5 Ora o Prof. António Domingues de Sousa Costa demonstra que Beatriz vivia ainda em Fevereiro de 1491. Considera, por outro lado, como mais verosímil uma outra cópia do mesmo documento, datada esta de 1660 , em que se afirma que Beatriz morreu com a idade de 65 anos, em Agosto de 1492. ${ }^{6}$

É historicamente seguro que os pais de Amadeu estavam em Portugal em Março de 1427, encontrando-se Rui Gomes da Silva ao serviço da casa do Infante D. Duarte, de que era cavaleiro. Por outro lado, na Vita del Beato $\mathrm{Amadio}^{7}$, de autor anónimo contemporâneo do santo, reproduzida por Fra Mariano da Firenze ${ }^{8}$, afirma-se que, com a idade de 20 anos, Amadeu tomou parte num combate, sendo ferido num braço. Sabe-se, por carta real de 6 de Maio de 1451, que dois dos filhos de Rui Gomes da Silva, Pero Gomes e João de Meneses, tomaram parte ao lado do rei D. Afonso na batalha de Alfarrobeira, em 20 de Maio de 1449.

Com o saudoso Prof. Sousa Costa podemos concluir que, no estado actual da pesquisa histórica, a tese que defende o nascimento do Beato Amadeu em Campo Maior, ou noutro lugar de Portugal, em data posterior a 1427 é a que se reveste de mais alta probabilidade. ${ }^{9}$

Nos termos da mesma Vita, casado aos dezoito anos com uma donzela da nobreza, não consumou o casamento, porque "cominciò a fare facti di arme com li principi et baroni di Spagna ${ }^{10}$ ". Também Fr. Marcos de Lisboa afirma que o Beato Amadeu frequentou o palácio real e aí se afeiçoou por alguém, que se supõe fosse D. Leonor, irmã de D. Afonso V, casada em 1452 com Frederico III da Alemanha ${ }^{11}$.

Foi seu nome João da Silva Meneses, ou João Meneses da Silva, embora a Vita lhe reconheça somente o nome de Amadio.

O segundo painel da sua vida abre com o seu ingresso na Ordem dos eremitas de S. Jerónimo, no mosteiro de Nossa Senhora de Guadalupe, em Espanha. Aí, "com grande devoção e servindo os irmãos no desempenho dos serviços mais vis, viveu cerca de dez anos"12. Confrontando documentos e datas, conclui o Prof. Sousa Costa que a permanência dele em Guadalupe se deve reduzir a pouco mais de um ano. ${ }^{13}$ Havendo adoecido gravemente e havendo sido curado por intervenção de Nossa Senhora, depois de advertido em sonhos por Maria, Francisco e António,

\footnotetext{
5 Idem, 190.

${ }^{6}$ Idem, 190-193.

7 Bib. Ambrosiana de Milão, Cod. S.Q.N. III, 19, fl.7 (Studio Critico).

${ }^{8}$ Fra Mariano da Firenze, Vita del Beato Amadio, 19-21 (Studio Critico, 105).

9 António Domingues de Sousa Costa, Studio Critico, 201.

10 Idem.

${ }^{11}$ Fr. Marcos de Lisboa, lib. 6, cap. 30, p. 179.

12 Fra Mariano da Firenze, Vita del Beato Amadio. (Studio Critico, 200).

13 António Domingues de Sousa Costa, Studio Critico, 202.
} 
decidiu, nos termos da mesma Vita, entrar na Ordem dos Frades Menores. Obtida licença escrita, dirige-se para Assis. Estamos em Dezembro de 1452.

A sua caminhada para Assis abre o terceiro painel de sua vida.

Vestiu o hábito dos frades Menores em Ubeda, adoeceu em Génova, passou por Florença e Perúsia. Aqui foi recebido pelo Ministro Geral da Ordem, Fr. Ângelo de Perúsia. Estamos em 1453. Em Assis foi recebido cortesmente pelos frades. Frequentava a Igreja e, durante três anos, auxiliou o sacristão, que o socorria com alimentos e dele recebia favores espirituais. Em 1456 é admitido à profissão, mas a estima de que gozava junto do povo e a agitação provocada pelo movimento daqueles que o procuravam levou os religiosos a tentarem devolvê-lo a Espanha.

De caminho para Roma, é recebido em Bréscia pelo Geral da Ordem, que lhe determinou residência no convento de S. Francisco de Milão, onde ficou ao serviço da sacristia. O pouco tempo disponível para a oração levou-o a pedir escusa dessa tarefa. Aí travou amizade com o duque Francesco Sforza que, com sua mulher, Bianca Maria, passou a protegê-lo.

Procurando sempre mais recolhimento e mais rigorosa observância, passa, em 1457, para Morliano, onde se demorou pouco, porque era importunado por visitas assíduas de gente importante. Foi em Oreno, para onde se transferiu pouco depois, que lhe foram conferidas todas as Ordens. Cantou a primeira Missa no dia da Anunciação de 1459. Aqui, no convento de Oreno, tomou vida a Congregação que levou o seu nome. Eram duas as linhas de acção traçadas para ela: perfeição individual dos seus membros e eficácia no apostolado.

A sua amizade com a família Sforza funcionou nos dois sentidos. Os Sforza auxiliavam-no no desenvolvimento da sua Congregação, ele era seu intérprete junto da Santa Sé. Foi a intervenção da duquesa Bianca Maria que, em Agosto de 1460, obteve de Pio II autorização para a construção em Castelleona, diocese de Cremona, da casa que haveria de tornar-se o centro de irradiação amadeíta. ${ }^{14}$

A virtude de Amadeu e a rigorosa observância da Regra de Francisco de Assis tocavam os fiéis, que junto dele procuravam conselho e conforto, como afirma o Prof. Sousa Costa. ${ }^{15}$ Mas tornavam-se igualmente um pólo de atracção para outros religiosos que aspiravam a uma mais funda autenticidade de vida. Oração, contemplação e acção apostólica constituíam como que o lema de Amadeu. Amado e estimado pelo povo, requestado por personalidades importantes para fundar conventos nas suas áreas de influência, Amadeu tem de lutar com os seus irmãos Conventuais e Observantes. E foi a fundação da igreja de Sancta Maria della Pace, às Portas de Milão, que em 1466 desencadeou a mais acesa tempestade, conforme reza a Vita del Beato Amadio, de Fra Mariano da Firenze: "Il che vedendo li frati della famiglia della Observantia, ricorsono al generale Maestro Francesco

\footnotetext{
${ }^{14}$ António Domingues de Sousa Costa, Studio Critico, 210.

15 António Domingues de Sousa Costa, Studio Critico, 209.
} 
di Savona, che era allora già facto cardinale [...] et condolevonsi di tanta scisma et divisione, che cominciava a nascere infra i secolari per rispecto, che alcuni favorivono la famiglia con detractione di frate Amadio et della sua congregatione, et alcuni favorivono frate Amadio con diffamatione di tanti docti et sancti homini della famiglia...". ${ }^{16}$ Levada a questão ao Geral, decide este a favor de Amadeu, dizendo "che era vero religioso, per che voleva vivere sotto la obedientia del generale et dei provinciali”. Criado, pois, cardeal, Maestro Francesco di Savona, o futuro Sisto IV, "fecesi defensore della congregatione di frati Amadio". Eleito papa em 9 de Agosto de 1471, com o nome de Sisto IV, garante, em carta de Abril de 1472, à duquesa Bianca Maria "la protezione del conventino di S. Maria della Pace e dei frati che vi dimoravano"17.

A saga fundadora prosseguia. E desenvolveu-se com maior vigor ainda, pois "non molto poi el decto cardinale fu electo Papa, chiamato Sixto IV, et frate Amadio lo venne a visitare, et obtenne molta gratia di lui, et una bolla di potere pigliare sei luoghi. [...] Ma ritenendolo presso di sé papa Sixto, et ellegendolo per suo confessore, li decte la chiese di san Piero in Janiculo o vero in monte aureo diretto a la cità di Roma." 18

Aqui se inicia a última e provavelmente a mais fecunda fase da sua vida. Custódio para a vida da sua Congregação, recebe privilégios vários e autorização para construir novos conventos. A sua Congregação não abandona a submissão ao Ministro Geral da Ordem. Apesar de tudo, a intervenção do papa tem de se manifestar de novo para suster os ataques, quer dos Conventuais, quer dos Observantes. Do seu convento de S. Pedro in Montorio, onde, "in una spelonca sotto el loco dove fu crocifisso san Piero", permaneceu dez anos "in grande austerità di vita, orationi et contemplationi", onde "li appariva lo angello Gabriello, et revelolli molte cose circa alla creatione angelica et humana, et ruina delli angeli, et della incarnatione di Christo, et della renovatione della Chiese"19, continuou a comandar a expansão da sua Congregação.

Às duas vertentes do ideal da sua Congregação, a espiritual e a apostólica, deverá associar-se uma terceira, a cultural. O testamento de um noviço, de 8 de Fevereiro de 1478, abre os horizontes para esta perspectiva ao registar um conjunto de obras de teologia, direito canónico e filosofia que legava à Congregação. Pertencem, por sinal, na sua maioria, aos autores referidos em Apocalypsis: Duns

${ }^{16}$ Citado por António Domingues de Sousa Costa, Studio Critico, 217.

17 Citado por António Domingues de Sousa Costa, Studio Critico, 221.

${ }^{18}$ Sevesi, Beato Amadeo, 33-34, in Studio Critico, 223.

19 Idem. A Vita del Beato Amadio, de Fra Mariano da Firenze é, segundo Sousa Costa, baseada noutra, de autor anónimo da penúltima década del Quattrocento: "Nella vita del Beato Amadeo, scritta da Fra Mariano da Firenze e basata su quella stilata in lingua volgare da un suo discepolo nella penultima decade del Quattrocento e quindi subito dopo la morte del santo ..." Studio Critico, 108. 
Escoto, Boaventura, Alexandre de Hales, Ricardo de S. Victor, Tomás de Aquino, Agostinho, Jerónimo, etc. ${ }^{20}$

Retido em Roma, Amadeu ansiava por visitar as suas casas na Lombardia. Obtida autorização do Papa, parte "a visitare li suoi conventi et frati, et venuto a Piacenza prese il convento con la chiese novamente facta in honore di san Bernardino, che fu il sextodecimo convento". Parte para Milão: "et stato alquanti giorni partissi per ritornare a Roma". No caminho foi atingido pela doença, "li comencio el male del fianco", sendo obrigado a retornar a S. Maria della Pace. Internado na enfermaria, morre dois meses depois, a 10 de Agosto de $1482^{21}$. Com data de 16 de Julho de 1483, os responsáveis pela Igreja de Sancta Maria della Pace rogam ao Papa autorização para poderem celebrar missa diariamente, à meia noite ou ao meio dia, a fim de satisfazer a incontável multidão dos que diariamente se apinhavam, vindos de todos os lados, à volta do túmulo de Amadeu. Aí, os milagres sucediam-se.

De acordo com documentos guardados no Arquivo Estatal de Milão e pertencentes ao convento de Sancta Maria della Pace dessa cidade, a canonização de Amadeu começou a ser tratada em finais do séc. XVI. ${ }^{22}$ No documento encontrado junto aos ossos de Santa Beatriz da Silva, quer na sua versão de 1647, quer na de 1660, afirma-se, segundo o mesmo autor, que Amadeu "fue canonizado per santo diez años después que fallecio esta señora doña Beatriz".

O desenvolvimento da Congregação amadeíta prosseguiu na Lombardia, no resto da Itália e em Espanha. Mas a pressão dos Ministros e dos Capítulos Gerais dos Franciscanos, auxiliada pelos desmandos de algumas casas desta Congregação, contribuiu para que o cardeal protector dos amadeítas, S. Carlos Borromeu, pusesse fim à ousadia da busca de um caminho próprio.

Eram trinta e nove os conventos. Era papa S. Pio V. A bula de integração é de 23 de Janeiro de $1568 .^{23}$

\section{A OBRA}

\subsection{Os manuscritos}

\subsubsection{Tradição manuscrita}

A obra do Beato Amadeu é constituída por duas partes distintas, a Apocalypsis propriamente dita, integrada por oito Raptus, e os Sermones, divididos em

\footnotetext{
20 António Domingues de Sousa Costa, Studio Critico, 226.

${ }^{21}$ Sevesi, Beato Amadeo, 34-35, Studio Critico, 235.

22 António Domingues de Sousa Costa, Studio Critico, 241.

23 Idem, 255-256.
} 
Sermones Ioannis e Sermones Domini. O presente estudo centra-se exclusivamente na primeira parte, a Apocalypsis. São manuscritos identificados da obra do beato Amadeu os que constam do quadro anexo.

\begin{tabular}{|c|c|c|c|}
\hline ARREZO - B Cívica & 436 & $A$ & \\
\hline ASSIS - B Conv. S Franc. & 190 & $B$ & $11 / 08 / 1563$ \\
\hline BARCELONA - BU & 1818 & $C$ & \\
\hline BOLONHA - Archig. & A 155 & $E$ & I-VIII (incompl.) \\
\hline BOLONHA - Archig. & A 180 & $F$ & I-IV \\
\hline BOLONHA - Archig. & A 190 & $G$ & I-VII - 14/07.1550 \\
\hline BOLONHA - BU & 516 & $H$ & \\
\hline CREMONA - B Cívica & A a 2.52 & $I$ & $08 / 10 / 1522$ \\
\hline ESCORIAL & H.III.1 & $J$ & \\
\hline TOLEDO - BC & $13-21$ & $K$ & \\
\hline MADRID - BN & 6540 & $L$ & I-IV \\
\hline MADRID - BN & 11248 & $Q$ & \\
\hline MILANO - B Trivulz. & 402 & $M$ & 1512 \\
\hline VATICANO Barb. & Barb. lat. 475 & $N$ & \\
\hline VATICANO Barb. & Barb. lat. 660 & $O$ & \\
\hline PARIS - BN & lat.9587 & $P$ & \\
\hline ROMA - B Vallicelliana & F.12. 1 & $R$ & \\
\hline VATICANO & Vat. lat 3825 & $S$ & \\
\hline VATICANO & Vat. lat. 4671 & $T$ & cópia de $M$ \\
\hline VATICANO & Vat. lat. 5680 & $U$ & \\
\hline VATICANO & Vat. lat. 9329 & $V$ & \\
\hline
\end{tabular}

Se o número e a dispersão dos exemplares da obra podem ter algum significado, a conjugação de ambos associada à distribuição no tempo mostra, com certeza, a importância atribuída à obra e ao autor.

A acção do Beato Amadeu desenvolveu-se em Itália e particularmente na Lombardia. Fora desta região, a fundação do convento de S. Pedro in Montorio, em Roma, deveu-se ao facto de Amadeu ser, até ao fim da sua vida, o confessor do Papa Sisto IV. Não admira, pois, que a maioria dos manuscritos existentes se encontre em Itália, oito na Lombardia e sete em Roma. 
À presença da sua obra em Paris não será estranha a admiração que o rei de França, Luís XI, nutria pelo Beato, admiração que se traduziu no encargo por ele assumido com as despesas do funeral de Amadeu. ${ }^{24}$

A significativa presença da obra em Espanha pode ter a ver com duas situações que são também elas testemunho da conta em que era tido o seu autor. Por um lado, a oferta da obra (original ou cópia?) do Beato Amadeu feita pelo Provincial dos amadeítas (notícia de 1513) ${ }^{25}$ ao cardeal Santa Cruz, que logo a trouxe para Madrid. Por outro, a interferência dos Reis Católicos junto do papado para que os amadeítas fundassem conventos em Espanha é reveladora do apreço em que era tido o ramo franciscano a que o Beato Amadeu deu vida. ${ }^{26}$ Acresce ainda o facto de a irmã do Beato, Santa Beatriz da Silva, gozar de grande veneração junto da rainha de Espanha, Isabel, a Católica, que muito contribuiu junto de Roma para a fundação das Concepcionistas. ${ }^{27}$

Estranha é a ausência de qualquer exemplar da obra em Portugal. Sabe-se pela correspondência do P. António Vieira ${ }^{28}$ que o $2^{\circ}$ Marquês de Gouveia, João da Silva, era proprietário de um exemplar da obra do Beato Amadeu da Silva, que, como se deixa ver pelo nome, se situa na linha genealógica ascendente daquele. Vieira obteve do Marquês de Gouveia, seu particular amigo, pela intermediação de D. Rodrigo de Meneses, uma cópia desta obra ${ }^{29}$. Qual o destino de um e outro exemplares? As pesquisas levadas a cabo não conduziram a resultado positivo. A Casa de Gouveia, unida à Casa dos duques de Aveiro, ${ }^{30}$ desapareceu com esta em 1759 e o seu património foi integrado no património da Casa Real. ${ }^{31}$ O desenvolvimento lógico seria que os bens culturais estivessem na Biblioteca da

${ }^{24}$ António Domingues de Sousa Costa, Studio Critico e documenti inediti sulla uita del Beato Amadeo da Silva nel quinto centenário della morte, Pontificium Athenaeum Antonianum, Romae, 1985, p. 241.

25 Apêndice do manuscrito da Biblioteca Trivulziana de Milão, $M$, confirmada pelo apêndice do manuscrito de Barcelona, $C$.

26 António Domingues de Sousa Costa, Studio Critico, 249.

27 António Domingues de Sousa Costa, Studio Critico, 192.

${ }_{28}$ Ver cartas X e XVI do vol. II, p. 26 e 38 respectivamente; Cartas, INCM, reimp. de 1977, coord. Azevedo, J. L., e Apêndice II, Carta Apologética ao Padre Jácome Iquazafigo, Proposicion V, do vol. III, p. 781.

29 Catas X, XIII, XVI do vol. II.

30 “[...] O ducado de Aveiro passou para seu irmão, que chegou a inquisidor-mor do Reino. [...] Depois de novos pleitos nas diversas sucessões, foi o título atribuído, em 1752, ao marquês de Gouveia, D. José de Mascarenhas, seu $8^{\circ}$ duque, que veio a ser o último." Jorge de Macedo, Enciclopédia Verbo, s.u. "Aveiro (Duques de)".

31 o duque de Aveiro, condenado ao suplício, foi desnaturalizado, exautorado das honras e privilégios de português, vassalo e criado do Paço [...]. As armas da sua casa seriam picadas onde estivessem, as suas casas foram demolidas e arrasadas e os seus bens reverteram para a coroa. M. E. Cordeiro Ferreira, Dicionário de História de Portugal, Dir. J. Serrão, vol. IV, s.u. Távora. 
Ajuda. Aqui, segundo informações de responsáveis, nada existe que se relacione com a obra do Beato Amadeu. Poderiam também encontrar-se hoje na Biblioteca do Tribunal de Contas, enquanto esta Instituição é a herdeira da sua similar do tempo da monarquia. Também aí, segundo idênticas informações, nada existe. Hipótese última, que não deixou de ser tentada, era pensar que os duques de Portalegre, situados na linha genealógica da família Silva Meneses ou Meneses da Silva, pudessem guardar um exemplar da obra do seu ilustre antepassado. A tentativa não obteve resposta. Foram também contactados os serviços culturais da Câmara Municipal de Gouveia e a Biblioteca Municipal de Portalegre, mas sem resultados, apesar da pronta e simpática colaboração de todos. A cópia do P. António Vieira ficou, com toda a probabilidade, pelo Brasil. Também aí se tentou a pesquisa. Até hoje ainda nada foi encontrado.

De acordo com o apêndice do manuscrito $C$, da Biblioteca Universitária de Barcelona, poderemos falar de mais duas, senão três, cópias da obra do Beato Amadeu feitas em Portugal. Também destas nada se sabe, embora se possa entrever neste mesmo apêndice o rasto de pelo menos uma.

São estes, pois, os manuscritos de que há público conhecimento. Com excepção de três, da Biblioteca Apostólica Vaticana, lat. 3825, 4671 e 5680, referidos pelo Prof. Sousa Costa no seu Studio Critico, pág. 237, os restantes encontram-se referenciados no Hislampa, obra de que se partiu para a obtenção das respectivas cópias.

Lamentavelmente as cópias $E, F$ e $G$, de Bolonha (Archiginasio), e a de Madrid, $L$, estão incompletas. De $F$ e de $L$ restam apenas os 4 primeiros Raptus. O texto é interrompido pela ausência dos fólios de continuação. $E$ apresenta-se constituído apenas pela primeira parte, os Raptus. No seu interior, os fólios compreendidos entre o $16 r$ e o $32 v$ estão em branco. O texto é interrompido a meio do VIII Raptus. G é constituído pelos sete primeiros Raptus apenas e, tanto quanto pode avaliar-se, por decisão explícita de quem o copiou. É o único que abre com a fórmula Incipit, seguida da data: "die 28 † Maii 1550", sendo o seu explicit constituído pelas iniciais do copista FMP - "scribebat", e a palavra Finis seguida da data: "die 14 de Iulii 1550". Sem razão aparente, o texto interrompe-se no início de um fólio do V Raptus, ficando em branco os três fólios seguintes. $V$ é constituído pelos Raptus e, aparentemente, nada faz supor que tenha havido extravio da segunda parte.

A situação dos três manuscritos do grupo $S T U$ é diferente. Tudo leva a crer que originalmente $S$ estivesse completo. O VIII Raptus encerra, a dois terços do fólio que hoje é o último, desta maneira: "Finis omnium raptuum". "Incipiunt speciales reuelationes quae non sunt factae in rota, sed priuatim ab angelo Gabriele". E, no lugar próprio, está o reclamo "Si homines", que é o início do texto de Sermones. $T$ conserva a integralidade. $U$ termina no seu fólio $107 \mathrm{r}$, que corresponde ao final do fólio 75 de $V$, registado no texto impresso que se segue e que corresponde ao início do V Raptus. 
Os restantes são constituídos pelas duas partes: Raptus de I a VIII, e Sermones Ioannis e Sermones Domini.

No V Raptus discute-se, entre outros temas, a heresia de Apolinário ${ }^{32}$, ou seja, a presença da alma humana criada em Cristo, e a actividade de Jesus entre os doze e os trinta anos. Em ambas as situações o autor expõe primeiro a teoria que quer combater e, de seguida, os seus argumentos. Relativamente à primeira questão, expõe a teoria herética de tal forma que, numa primeira leitura, parece pugnar pela sua defesa. Na tentativa provável de livrar a obra do que se terá julgado erro, optaram alguns copistas por suprimir essa passagem. E são sete os manuscritos onde ela falta: BGIPRSV. A segunda questão, provavelmente menos teológica, é excluída por apenas quatro deles: IRTV. Ultrapassam a dificuldade, resumindo numa frase a heresia objecto de crítica. $H$ teve alguma dificuldade em optar. Depois de haver iniciado a cópia da versão integral, procedeu à sua rasura, transcreveu a frase de ligação da versão censurada e retomou o texto integral.

Somente quatro manuscritos estão datados, o $B, 11 / 08 / 1563$; o $G, 14 / 07 / 1550$; o $I, 08 / 10 / 1522$; o $M, 1512$. CGMT estão seguidos de um apêndice. Dos de CGM, falar-se-á adiante. $O$ interesse do de $T$ reside no facto de, no início, indicar a sua fonte: "Extracta de fine Nouae Apocalypsis beati Amadei qui liber inuentus est Mediolani apud socium eius".

O texto é fundamentalmente o mesmo em todos. As diferenças situam-se apenas ao nível da substituição de palavras, da construção da frase, de saltos do "mesmo ao mesmo" ou de adições explicativas.

Procurou-se registar todas as divergências, muitas vezes sem significado a nível do sentido, na esperança de poderem ser úteis na definição de famílias. Não se levaram, apesar de tudo, em conta as divergências gráficas, por se considerarem de pouco significado. A este nível, merecem referência apenas os dois manuscritos da Biblioteca Nacional de Madrid, cuja grafia confirma a origem castelhana da cópia ao trocarem repetidas vezes o $\mathbf{v}$ pelo $\mathbf{b}$.

As citações do texto latino no texto da tradução são referenciadas pela indicação do número do fólio de $V$, por ser a referência mais segura.

\footnotetext{
32 Nasceu em Laodiceia por volta de 315. Seu pai, natural de Alexandria, gramático de profissão, ensinou em Beirute e em Laodiceia e foi ordenado sacerdote cerca de 335. Professor de retórica, Apolinário acompanhou o pai como leitor. Afastados do ensino por serem cristãos, dedicaram-se a transpor para os metros clássicos os temas bíblicos. "Adepto de Niceia numa Síria quase toda ariana, aliado fiel de Atanásio, letrado, defensor da cultura cristã contra Juliano Apóstata, exegeta de renome, Apolinário deixou-se influenciar, sem dúvida inconscientemente, pelas categorias dos seus adversários arianos. [...] Para Apolinário, o ser humano não poderia estar isento de pecado, por causa da fraqueza e da tirania da carne. Para que Cristo existisse sem pecado, seria preciso que uma alma ou um espírito divino viesse nele guiar a carne que assumira para tornar-se semelhante a nós," (Danielou, J; Marrou, H., Nova História da Igreja I, Parte II, cap. Segundo, 343-344.) O Logos divino tomava em Cristo o lugar do espírito humano. Assim, negava a Cristo a plenitude da humanidade. A sua doutrina foi condenada em vários concílios.
} 
Ao traduzir, procurou-se obedecer ao princípio enunciado no próprio texto: "Verba trahenda sunt ad sensum, non sensus ad uerba" (VII Raptus, 175).

A análise levada a cabo, onde se pretende que seja sobretudo o autor a falar, procura deixar claro que Apocalypsis é uma obra com unidade e coerência; que o seu autor é o Beato Amadeu; que Amadeu era, como se diz no apêndice do códice 190 A, da Biblioteca do Archiginasio de Bolonha, instruído e profundo, como os seus escritos mostram; que lutava por um objectivo, a reforma da Igreja; e que o seu sonho estava tingido de cores milenaristas.

\subsubsection{Tentativa de constituição de um stemma}

Olhando para o conjunto dos manuscritos, pode estabelecer-se uma primeira divisão:

1 - manuscritos que contêm toda a obra do Beato Amadeu, Raptus e Sermones: ABCHIJKMNOPQ ${ }^{33} R T$;

2 - manuscritos constituídos apenas pelos Raptus: EFGLSUV.

Há uma segunda, que pode ser feita tendo em conta apenas os Raptus:

1 - manuscritos com a versão completa dos Raptus: ABCHIJKMNOPQRSTV;

2 - manuscritos truncados, que registam apenas uma parte: $E F G L U$.

Pode fazer-se outra divisão, tendo em conta a posição assumida por cada um perante os dois textos ${ }^{34}$ de presumível cariz heterodoxo do V Raptus:

a - mantêm a versão completa: $A C E H J K M N O Q$

b - suprimem as duas passagens: IRSV

c - suprimem só a primeira: $B G P$

d - suprimem só a segunda: $T$

O manuscrito $M$ é um dos quatro datados e é, seguramente, dos mais antigos. Como se irá ver à frente, houve forte polémica em torno da abertura da obra do Beato Amadeu. Morto em 1482, a obra só foi "aberta", isto é, lida, em 1502. M é cópia datada de 1512. É uma cópia muito perfeita, onde os lapsos do copista são poucos e são praticamente todos superados pela mão do revisor. E, neste estado primitivo de cópia, parece estar próximo do original, como parecem estar também $J K$ e, de algum modo, $V$.

${ }^{33} Q$ apresenta um resumo dos Sermones: "Recopilatio brebis sermonum qui ab Angelo Dei his temporibus reuelati fuerunt Beato Amadeo".

34 Ver V. 
Verifica-se, contudo, que $M$ tem, sobretudo nos primeiros Raptus, uma sobreposição de notas e comentários marginais, de mãos distintas e, seguramente, de distintas épocas, que se encontram, em proporção variada, no corpo do texto de FHNOQ. As notas do I e II Raptus estão relacionadas com o corpo do texto de $\mathrm{FH}$; as seguintes têm reflexo no corpo do texto de $N O Q$

No I Raptus, a consonância entre $F$ e $M$ (texto e notas) é perturbada pela ausência de apenas uma nota. É menos perfeita a consonância em $H$, que regista a ausência de cinco notas. É menor ainda em $Q$, que apenas insere no corpo do texto oito das vinte e uma notas de $M$. $N O$ não registam no respectivo texto nenhuma.

Parece poder-se dizer que $M$, no seu estado actual, é um manuscrito triforme. A primeira forma é a de $M$ inicial, cópia do original, com apenas as notas da mão do revisor, notas que corrigem as falhas do copista. Este exemplar foi sendo anotado e, a partir dele assim anotado, que constitui o que se poderá designar por $M 1$, terá surgido uma versão que integrou as notas no corpo do texto. De $M 1$ dependem, imediatamente ou, com maior probabilidade, pela mediação de uma cópia cujo paradeiro se desconhece, os manuscritos $N$ e $O$. A versão $M 1$ passou a registar em nota, sobretudo nos dois primeiros Raptus, adições constantes no corpo do texto de $F H$. Surgiu assim uma terceira versão, a que se poderá chamar $M 2$.

A versão $M 2$, ou seja, o manuscrito da Biblioteca Trivulziana de Milão na sua forma actual, é testemunho de dois movimentos de sentido contrário. No primeiro, exporta as suas notas para o corpo do texto de $N O$. No segundo, importa como notas as divergências encontradas por um qualquer leitor na cópia $F$ ou na versão de que $F$ e $H$ dependem. Esta terceira versão, ou seja, $M 2$, está próxima de $Q$. Da mão de um copista caprichoso que sistematicamente corrige o texto da fonte, esta cópia denuncia, pela grafia, como já foi referido, a sua origem castelhana. Dela está muito próxima $C$, sem os desvios gráficos, contudo. Parece poder afirmar-se que não dependem uma da outra. Não se encontrou, todavia, a cópia que pudesse estabelecer a ponte. Em torno de $M$ organizam-se, pois: $N O$, que reproduzem globalmente $M 1 ; F H$, cujas adições estão reflectidas em $M 1$, dando origem a $M 2$. $Q C$ estão próximas de $M 2$, na medida em que as notas de $M$ reflectem os respectivos textos, embora em grau diverso, de $F H$.

Da pesquisa feita, tendo em vista definir afinidades, pode concluir-se que é possível indicar tendências, não é possível definir inequivocamente uma relação clara de dependência entre os vários manuscritos.

Caso a merecer interesse é o do manuscrito da Biblioteca Universitária de Barcelona, 1818, designado $C$. Tem em apêndice um conjunto de documentos, de datas várias, que, relacionando-se com a submissão da obra ao veredicto dos inquisidores, traz outras informações importantes. É um manuscrito do séc. XVIII, de acordo com a leitura da caligrafia. É o único que faz referência ao controle da Inquisição, assunto a que se refere a totalidade dos documentos. O primeiro vem datado de 22 de Agosto de 1539. É cópia do Parecer do "Doctor Francisco de 
Bargas", a quem o Cardeal-Arcebispo de Sevilha, "Inquisidor Mayor de España", havia incumbido de "ler" o manuscrito que Fr. António Ortiz submetera à Mesa da Inquisição enquanto Provincial da Província "de S. Gabriel de Badaxós". O segundo vem datado de 21 de Agosto de 1539. É assinado por Fermin Garcia, notário del Secreto, a testemunhar a entrega pessoal pelo "R. ${ }^{\circ} \mathrm{Sr}^{\circ}{ }^{\circ}$ Doctor Pe. Dias de la Plaça" a Fr. António Ortiz de "un libro scripto de mano que se intitulava del Beato Amadeo, llamado Apocalypsis Noua". O terceiro, "Echa en Azeyton a 21 de Hebrero de 1543", está subscrito por "frater Petrus de Alcantara". Tem vários pontos de interesse.

S. Pedro de Alcântara chegou à Arrábida em finais de 1541, depois de em 1538 haver sucedido a Fr. António Ortiz no governo da Província de S. Gabriel, da sua Ordem, na região de Badajoz. Começa o testemunho pela sua identificação e pela afirmação de pertença à Ordem e à Província. Dá "testimonio como vi trasladar el libro supra scripto del Beato Amadeo a fray Antonio Ortiz". Acrescenta informações várias que se tornam de grande alcance. Fr. António fez a cópia "de outro libro que traxo prastado de la Provincia de los Angeles, el qual desia avia trahido a aquella Provincia, de Roma, el Cardenal de S.ta Cruz [...] el qual libro trasladó fray Antonio Ortiz ella casa de S. Francisco de Beluiz, de la Provincia de S. Gabriel." Traça o percurso de Fr. António até chegar a superior da Província de S. Gabriel, cujo ponto mais saliente é a sua ida, anterior à sua fixação na Província de S. Gabriel, ao Capítulo Geral como "custos custodum de la Provincia del Sto Evangelio, que es en las indias de Castilla”. Afirma depois, “...embié a Sevilla el dicho fr. Antonio a siertos negocios y para que truxesse el libro que el dicho S. Arcebispo avia dicho que lo enviaría." Refere-se ao "testimonio del Doctor Bargas, el qual yo vi e ley muchas vezes", afirmando: "esse que estava arriba scripto es sacado del de uerbo ad uerbum."

Os três últimos documentos são portugueses. O primeiro é do $1^{\circ}$ duque de Aveiro, D. João de Lencastre, neto de D. João II, que "pelos finais de 1538 ou princípios de 1539, indo em romaria a Nossa Senhora de Guadalupe, [...] ali se encontrou com Fr. Martinho de Santa Maria [...] que ardia em desejos de viver vida solitária." D. João "lhe ofereceu para o efeito a sua serra da Arrábida, que parecia bem acomodada ao intento", e "em 23 de Fevereiro de 1539 impetrou [...] licença do Geral da Ordem Seráfica para Fr. Martinho vir habitar a serra...”. Era Geral Fr. João Calvo, que em 1542 "incorporou na Ordem a ermida com o título de custódia de Santa Maria da Arrábida". ${ }^{35}$ É datado este documento dos finais de 1542: "Acavose a 13 de Nom.e de 1542". Declara o duque logo na abertura: “... faço saber aos que este leren que eu mandei buscar este livro atrás scripto e o ouve por ũa carta do Geral Fr. João Calvo en que o mandou pedir a esse Padre Fr. António Ortiz”. Indica o modo como procedeu para acelerar a respectiva cópia:

35 A. Fortunato de Almeida, F. A, História da Igreja em Portugal Vol. II, 181. 
"O qual libro o fice desencadernar e tresladar a quatro pessoas por ser feito com mais brevedade". Indica o número de fólios: "o qual está tresladado em 304 follas". Busca a segurança da decisão das autoridades em questões doutrinárias nos "dous scriptes destes inquisidores de Castella" e compromete a sua palavra: "E mais do neste mon hafé que vi una carta do dito Fr. António Ortiz que escrevió ao Pe. Geral" em que relata todo o processo de submissão da obra à análise da Inquisição e a resposta do arcebispo de Sevilha. E termina: "e segundo o que parece naon echaraon nelle causa porque o naun devese de tornar a seu dono, segun lo acima conten".

O documento seguinte é de Fr. Miguel dos Santos, eremita de Santo Agostinho, no convento de Santa Maria da Graça, em Lisboa. Apresenta-se como "pregador da muito descarecida princesa, a rainha Dona Catherina de Áustria, nostra S. ${ }^{a}$. Também ele se protege com a autoridade dos documentos de outros livros. Afirma: "deu mon afé e certifico com os assignados supra scriptos doutro libro que ouve às manos, o qual me emprestou a illus.ma S. ${ }^{a}$ dona Anna de Arragon, dama da dita R.ma n.ra S. ${ }^{a}$, a qual o ouve por indústria do doctor Mestre [... $]^{36}$ secreto de S. A.”. Transcrito pela própria mão, na sua cela da Graça, “cabei de os escribir dia de St. Benodato António de Pádua pola manhan, a 13 de Junio de 1577 ano". Volta a afirmar a concordância do livro com as normas da fé e os bons costumes e considera-o "dino de ser llido para glória de nosso Senhor e consolaçaion de quem o lere".

O último documento, também de Fr. Miguel dos Santos, é um relato resumido da passagem da sua cópia pela mesa do Santo Ofício, onde ficou "mas de dies años". Findo esse tempo, foi devolvido pelo "Padre Maestro Bartolome Ferrara, reveedo de libros y examinado general por el dicho Santo Officio [...] sin condicion ni limitacion alguna [...] a donde me fue dado a 14 de Março deste año de 1590".

No primeiro momento ressalta a relação próxima, pelo menos a nível da Ordem Franciscana, entre os dois lados da fronteira. Os manuscritos e as pessoas iam e vinham aparentemente sem grandes dificuldades. Segue-se uma certeza: a obra do Beato Amadeu suscitava interesse dos dois lados da fronteira quase um século depois da sua morte. E vê-se desenhar um caminho por onde ela foi passando. De Roma é trazida pelo Cardeal Santa Cruz para a Província de los Angeles, nas regiões de Cória e Plasência. Esta informação de S. Pedro de Alcântara está em consonância, como já foi referido e se verá depois, com o apêndice do manuscrito $M$, onde se afirma que o livro do Beato Amadeu foi mandado entregar ao "cardinale di Sancta Croce”. Deste, original ou cópia está por demonstrar, copiou Fr. António Ortiz o manuscrito que seria a fonte da cópia mandada fazer pelo Duque de Aveiro. De Roma, passando pela Província de los Angeles, pela Província de S. Gabriel, mais a sul, chegou a Lisboa. Aqui perdeu-se o rasto. Simultaneamente,

${ }^{36}$ Infelizmente não se consegue ler o nome. 
ou antes, com trinta e cinco anos de diferença, ficamos a saber que, em Lisboa, um religioso ligado à Casa real faz pessoalmente uma outra cópia a partir de um manuscrito conseguido por uma Dama da rainha e tira os anexos de uma outra cópia. Seriam estas nacionais ou terão vindo de Castela? Não fica dito.

Temos assim que este manuscrito de Barcelona nos dá notícia da existência em Lisboa de, pelo menos, mais duas (ou três?) cópias da obra do Beato Amadeu. Poder-se-ia falar de três (ou quatro?), se ficasse provado que eram nacionais as fontes de que Fr. Miguel dos Santos tirou a sua cópia e aquela de que tirou os anexos.

Que relação haverá entre esta cópia de Barcelona e cada uma das anteriormente referidas? Como poderá explicar-se a presença de todos os elementos do apêndice nesta cópia? É preciso atentar nas datas. A cópia de Fr. António Ortiz foi-lhe devolvida em Agosto de 1539, três anos depois de a haver feito, como afirma o texto do duque de Aveiro ${ }^{37}$. Com o livro, foi-lhe entregue, como se afirma no documento de S. Pedro de Alcântara, o testemunho do Doutor Bargas, que constitui o primeiro documento deste apêndice. A cópia do duque de Aveiro, segundo o testemunho do próprio, "acavose a 13 de Nom.e de 1542". Dela não faria parte o documento de S. Pedro de Alcântara, que é de Fevereiro de 1543. Aliás o próprio duque remete no seu texto para "estas dous scriptes destes inquisidores de Castela", que são, com toda a probabilidade, o do doutor Francisco Bargas e o do notário. Fr. Miguel dos Santos fez a sua cópia em 1577 de uma outra acerca da qual se ignora tudo. E, de acordo com o que afirma ("deu mon afé e certifico com os assignados supra scriptos doutro libro que ouve às mãos...”) colheu numa terceira cópia os quatro documentos do apêndice que são anteriores aos seus. Teremos de nos perguntar como se reuniram os documentos de S. Pedro de Alcântara com o do duque de Aveiro para chegarem juntos à mesa de trabalho de Fr. Miguel. Não foi, como já foi afirmado, na cópia do duque de Aveiro. Não parece provável que o testemunho do duque de Aveiro saísse isolado da cópia do seu manuscrito para se integrar numa outra, pois a sua autoridade, em termos eclesiásticos, não seria grande. Mais razoável se afigura que o testemunho de S. Pedro de Alcântara invadisse, pelo peso que já então lhe era reconhecido e pelo valor informativo que o documento tinha, uma cópia que contivesse os pareceres anteriores. E essa, com toda a probabilidade, seria uma cópia tirada da mandada fazer pelo duque de Aveiro. Será então que a fonte de Fr. Miguel dos Santos ou, mais seguramente, aquela de que tirou os anteriores pareceres, além de nacional, se relacionava, através de vários intermediários embora, com o exemplar trazido de Roma? E que relação pode haver entre a fonte de Fr. Miguel

37 "E mais, doneste mon hafe que vi una carta dito fr. António Ortiz que escrevio ao Pe. Geral en que diz que elle deodito ao Cardeal Arcebispo de Sevilla que a este tempo era inquisidor, em que acabo de três anos lo tornaraon cao diligença...". (Do apêndice de $C$ ). 
dos Santos e aquela de onde retirou os pareceres? E que relação pode haver entre a cópia de Fr. Miguel dos Santos e esta de Barcelona? A lógica que aqui nos conduziu parece empurrar-nos para afirmar uma directa relação entre estas. Só nesta linha de evolução poderiam manter-se estes testemunhos. Da relação entre as duas fontes de Fr. Miguel parece nada se poder concluir.

Mas aqui levanta-se uma pequena objecção suscitada pela análise do aparato crítico. O manuscrito de Barcelona é, com toda a probabilidade, como já foi dito, do séc. XVIII. Relaciona-se muito de perto, em termos de aparato crítico, com outro manuscrito existente na Biblioteca Nacional de Madrid, o $Q$, que, segundo o Hislampa, é do séc. XVII, e cujo texto, mantendo-se fiel à estrutura geral, se desvia significativamente da média do texto dos manuscritos mais antigos, ao corrigi-lo muitas vezes. Este, por outro lado, situando-se temporalmente entre o de Fr. Miguel dos Santos e o de Barcelona, não regista, como nenhum outro além deste, qualquer referência a pareceres da Inquisição. A relação entre estes dois é objectiva, como objectiva é a não presença de elementos da Inquisição em $Q$. Teremos então de concluir que a fonte de Fr. Miguel dos Santos nada tem a ver com a cópia do duque de Aveiro para podermos estabelecer uma relação directa entre a cópia de Fr. Miguel e a de Barcelona? Ou poder-se-á pensar noutra alternativa? Seja como for, até este momento não estão reunidos os dados que permitam estabelecer inequivocamente as pontes que justifiquem a junção dos diversos pareceres neste manuscrito. A relação de $C \operatorname{com} Q$, apesar de indirecta, é objectiva, como resulta evidente da leitura do aparato crítico. Mas falta explicar a ausência dos anexos em $Q$ e a sua presença em $C$, pois ambos são cópias posteriores aos anexos. As divergências gráficas da troca do $\mathbf{v}$ pelo $\mathbf{b}$ apoiadas em divergências do aparato crítico postulam a existência de uma terceira cópia a que ambas se reportam directa ou indirectamente. Mas fica sempre por explicar o problema dos anexos. Apesar de tudo, parece poder apontar-se para a existência de duas linhas de transmissão textual na Península:

1 - Cópia trazida de Roma pelo Cardeal Santa Cruz, Fr. António Ortiz, Duque de Aveiro e, directamente ou por um desconhecido intermediário, cópia de que Fr. Miguel colheu os anexos. $M$, Milão, e $J K$, Escorial e Toledo, tanto podem ser irmãos entre si e da cópia do Cardeal Santa Cruz, como haver entre eles uma linha hierárquica de dependência próxima, embora difícil de estabelecer;

2 - Fonte não identificável de Fr. Miguel dos Santos, Fr. Miguel dos Santos, $C$, de Barcelona. $Q$, Madrid, cronologicamente situada entre Fr. Miguel e Barcelona, está na linha textual destes. Pode afirmar-se que depende de um antepassado comum à fonte de Fr. Miguel. Em Fr. Miguel se terá dado o encontro das duas linhas, estando nesta a fonte e naquela os anexos.

Qual o destino das cópias referidas em $C$, as nacionais e as de Espanha? Terá $K$ servido de modelo a Fr. António Ortiz, podendo ser o exemplar, ou sua cópia 
directa, trazido de Roma pelo Cardeal Santa Cruz? Ou essa honra poderá caber a $J$, hoje no Escorial? As duas versões têm condições objectivas para assumirem esse papel. Não poderiam ser fonte uma da outra e, nesse caso, ser uma delas a cópia de Fr. António Ortiz? A ser assim, o modelo seria $K$, pois em função da grafia parece não se poder adiantar tanto no tempo. Que relação se poderá estabelecer entre o grupo $J K$, em cujo âmbito talvez se pudesse enquadrar $L$, e o grupo $C Q$ ? Cria alguma perturbação neste contexto a proximidade do texto corrigido do final do V Raptus de $K$ com a versão $E$, do Archiginasio de Bolonha. Como perturbante é também a relação de $Q \operatorname{com} M 2$ e NO. É difusa a ideia da existência de mais outro grupo que justificasse esta rede de relações, mas não é inverosímil. Significa isto que em Espanha circulariam outras versões que podiam, a ser encontradas, explicar as interrogações levantadas.

E em Portugal? Será que tudo se perdeu irremediavelmente? Além da cópia que serviu de fonte àquela que Vieira usou, e da cópia do próprio Vieira, que terá acontecido à cópia do Duque de Aveiro? E à de Fr. Miguel dos Santos? Será que o fervor dos franciscanos portugueses pelo seu patrício era inferior ao de seus irmãos do outro lado da fronteira? É certo que nenhuma das aludidas cópias nacionais se relaciona com a Ordem Franciscana. Que se passou então para este silêncio?

Há uma conclusão que parece impor-se, apesar de tantas interrogações. Sendo significativa ainda a presença de manuscritos de Apocalypsis Noua em Espanha, a sua circulação parece haver sido bem maior do que as cópias actuais deixam entender.

No caso português, talvez nos devamos interrogar sobre a razão pela qual o Duque de Aveiro recorreu a uma fonte espanhola. Apenas pela relação de amizade que o ligava aos franciscanos do outro lado da fronteira? Fr. João Calvo, a cujo empenho recorreu, era português e estava em Portugal. Poderá o terramoto explicar tudo? Mas no resto do país nada se encontra também.

Do apêndice de $C$ resulta mais outra curiosidade. Nele são unânimes os pareceres da Inquisição, em Espanha e em Portugal: na obra nada existe que se oponha à recta doutrina católica. Como se compreende então que em Itália se houvesse chegado ao extremo de fazer o levantamento de cinquenta censuras (S. Roberto Belarmino), ou de considerar Amadeu "mendax, hipocrita, subdolus" (Jerónimo Vitorino)? Só diferentes perspectivas de leitura o podem justificar.

\subsection{Abertura do Livro}

O códice 402 da Biblioteca Trivulziana de Milão, $M$, está datado de 1512. Integra as duas partes que compõem a obra do Beato Amadeu, a Apocalypsis propriamente dita e os Sermones. É seguido de um caderno, escrito a uma só mão, mas com duas penas, cuja cópia deverá ser próxima de 1516. 
Este apêndice, da autoria de "fratre Michele da Trecha, de la povera familia del beato et sancto Amadio", inicia-se por uma espécie de diário feito com extractos de cartas do bispo Georgius Benignus, amadeíta, de origem grega, segundo Fr. Miguel. ${ }^{38}$ Especialista em escotismo, como parece decorrer da afirmação de uma das cartas, foi o bispo Benignus designado pelo Geral dos amadeítas, "maestro egídio", para proceder à abertura do Livro do Beato Amadeu. Decorria o ano de 1502. O tema das cartas é a abertura do Livro. Na primeira, datada de "1502, a di 27 de Maggio", exprime em duas linhas o seu espanto perante "archana ingentia nuper reperta". Na segunda, datada de 18 de Junho, sem responder à solicitação, pressentida, do seu interlocutor relativa ao conteúdo das profecias, fala sucintamente de Amadeu, da sua obra, que caracteriza como "uno libro grande como Augustino De Ciuitate Dei”, da determinação de que se mantivesse "in custodia in fino che idio mandasse uno a chi tocava ad aprirlo". E relata o acontecimento charneira de toda a sua intervenção: "e breviter certi fratri circha a tre volte tentarono daprirlo. In infra pochi di, subito amalati, morirno." Situa os factos no tempo: "costui mori al tempo de Sixto". E diz mais: "Questo Libro lo tene Sixto. Tenelo poi etiam Innocentio, ma nesuno di loro fu ardito ad aprirlo per casi intervenuti a quelli fratri." Cabe ao Cardeal espanhol Santa Cruz, instado "da alchuni", com a autoridade que lhe advinha de ser "protectore de la dita congregatione", a determinação, tomada de comum acordo com o Geral, de mandar abrir o Livro. Foi escolhido para essa tarefa o próprio Georgius Benignus, que declara ao seu interlocutor: "Io in vero hebe non pocha paura". Foi, nesse transe, apoiado por outro bispo da mesma Ordem, espanhol, de nome Morlion, secretário do Cardeal Santa Cruz, que quis ser o primeiro a abrir o Livro. No dia escolhido, dá-se início à cerimónia de abertura com a Missa do Espírito Santo presidida pelo bispo Morlion em S. Pedro in Montorio e, "post secreta, Libri in altari coram Generali et iussu eius a nobis apertus et nobis duobus ad legendum traditus est".

E Fr. Miguel de Trecha reforça as afirmações do bispo Benigno com dados da sua vivência: "io fratre Michele da Trecha [...] intendo etiam narrare e testificare a corroboratione di questo qualiter fratre Ysaia da Varese mi disse a Milano, in Sancto Angelo, nel 1513, a di 8 de Marzo, como quando fu aperto lo Libro del Beato Amadio fu nel anno del Signore 1502, tra Pascha e l'Ascensa". O bispo

${ }^{38}$ Juraj Dragisic de seu nome, Georgius Benignus de Salviatis, seu nome latino, arcebispo de Nazaré, nasceu em Srebrenica, Bósnia, por volta de 1445. O seu primeiro encontro com o Beato Amadeu deu-se quando, "venendo lui de Gallia, dal studio, et arivando in Milano, li fo dito como era morto uno sancto homo frate et padre de li poveri frati di Sancta Maria dela Pace da Milano. Et che in quello di che fu sepulto siando nelle gresia in lo cadelecto che lui cioè el Beato Amadio si levava e pareva che volesse usire delo cadelecto con grande alegreza e iubilo" (Apêndice de $M$ ). Consequentemente, em data anterior à escolha de Amadeu para confessor do papa Sisto, ou seja, em data anterior a 1472. Morreu na Itália em 1520 . 
Benigno lho confirmou, segundo afirma: "Et io anchora ho per propria bocha del benedecto Benigno". A decisão da escolha partiu, também segundo Benigno, do Geral da Ordem, Fr. Egídio.

Importante e pertinente é a custódia do Livro depois de aberto. Diz o bispo ao seu interlocutor: "Ubertino mio caro, chredetimi che lo Libro originale non lo ha lecto homo che viva, excepto el vescovo mio compagno e poi lo cardinale Sancta Croce. Et hora nisuno lo po legere, excepto la sua signoria et io, in camera sua stando et non altramente, che di fora portare non si po." Nem mesmo aqueles que o guardam o podem ver, pois está encerrado "in la casseta", cuja chave está na posse do Cardeal Santa Cruz. Pode lê-lo, mas "in camera sua" e por especial deferência, o bispo Benigno "per che gli pare non lo dovere negare a me el quale prima che lui lo lecto tutto. E anche gli pare ch'io qualche cossa ho a essere, almeno uno de quelli cardinali orientali." Aqui se podem subentender duas coisas, Benigno esperava ser, no mínimo, um dos sete cardeais orientais que o Pastor haverá de criar; mas não excluía a hipótese de ser ele o Pastor escolhido.

O Beato Amadeu morreu em 1482. O livro foi aberto em 1502. O manuscrito de Milão está datado de 1512. O seu apêndice é, pelo menos em parte, de 1516. $\mathrm{O}$ autor deste data uma conversa com Francesco Biondo, o secretário do Beato Amadeu, de 10 de Junho de 1515, e uma outra, com o bispo Benigno, de 16 de Janeiro de 1516.

De todos os actores, merece especial atenção Francesco Biondo. É ele quem relata a Fr. Miguel o como, o onde e o quanto demorou a escrita da obra do Beato Amadeu: "Fo scripto tutto de uerbo ad uerbum per bocha de esso beato como lui diceva a misere Francesco Biondo da Modona e questo fu el suo primo scriptore. E fo scripto esso libro in la crotta grande..." Demorou cerca de um ano a escrevê-lo: "Et fu lo libro scripto tuto in uno anno uel circha, excepto poche cosse nela fine per non trovarse in quelli tempi lui a Roma". Findo o livro, retorna o Beato Amadeu a Milão: "E quello anno che fu scripto, el Beato Amadio ando a Milano eli con la gratia di Dio fini el corso dela vita sua. E questo fu nel 1482, a di 10 de Augusto."

Estas afirmações estão em consonância com o texto da obra. "Preparaui tibi illum qui omnia, prout ex ore tuo audierit, conscribet..." (I, 2). É um dos dados da informação que Amadeu recebe na abertura da Apocalipse. É na gruta que o secretário começa a passar a escrito o que Amadeu lhe dita depois de regressar do primeiro arrebatamento: "Rediens ad cauernam meam, uocato a Deo preparato mihi scriptore, haec pro futuro pastore, Domino iubente, subito scribi feci" (I, 7). Falando do Pastor, no início do IV Raptus, e depois de lhe haver traçado o perfil, é dito: "Ecce dedi tibi faciem eius, obserua et custodi eam. Antequam ipse redeat Romam, tu Mediolanum accedes et ibi diem extremum claudes" (IV, 44). A encerrar o VII, recebendo instruções relativas ao cântico que acabava de ouvir, Amadeu recebe outras relacionadas consigo: "Sed post paucos menses hinc discedes, Mediolanum adibis, ibique in Domino obdormies" (VII, 176). Situando 
o VIII Raptus no tempo litúrgico, Amadeu acentua mais uma vez a ideia do seu fim próximo: "Vltimus raptus meus postquam cito in Domino me obdormire oportebat, secundum quod angelus sanctus mihi reuelauerat, fuit die triduo ante Ascensionem Domini, die Lunae diluculo" (VIII, 176). Este último Arrebatamento fecha a reforçar a mesma ideia: "Tu uero ad aliam ciuitatem ibis et tuos oculos ibi cum gratia Dei claudes et laetaberis in Deo salutari tuo" (VIII, 223).

Embora a cronologia dos Raptus não confirme explicitamente a afirmação de que foi de um ano o tempo da composição da obra, não só a não contradiz, como deixa ver a sua plausibilidade. O VI Raptus aconteceu no Domingo de Páscoa, como se lê no final: (VI, 147). Aconteceu poucos dias depois do $V$, como se diz na abertura: "Paucis postmodum reuolutis diebus, iterum raptus sum..." (VI, 112). O $V$, por sua vez, aconteceu "transactis paene quindecim diebus" (, 71$)$, como diz na abertura também. Entre o $I I I$ e o $I V$ foi curta a distância, pois assim abre este: "Post certo tempore raptus fui in rotam iterum" (IV, 41). Nos três primeiros não se precisam datas nem relações. O I começa: "Ego Amadeus fui raptus ex spelunca mea ubi orabam". O II afirma apenas: "Raptus sum alia die...". O III começa: Vna dierum, dum frequenter meditarer, fui raptus...". Do "una dierum" do $I I I$ ao "post certo tempore" do $I V$ e ao "transactis paene quindecim diebus" do $V$ até ao "paucis postmodum reuolutis diebus" do VI, que se situa na Páscoa, vai-se precisando o tempo e vai-se enquadrando a acção no tempo litúrgico. O ponto de referência é o Domingo da Ressurreição do Senhor, sendo que o VII ocorre na oitava da Páscoa e o VIII na Segunda-feira da Ascensão.

Não há, pois, qualquer dado que perturbe a possibilidade de concordância entre a cronologia da obra e a afirmação de Francesco Biondo relativa à morte de Amadeu. O mesmo se poderá dizer do tempo e do modo da composição.

Mais estreita é a relação entre as afirmações contidas nas cartas do bispo Georgius Benignus e Apocalypsis, afirmações que, firmado em outros testemunhos, Fr. Miguel reforça. No primeiro encontro de Amadeu com o anjo, ao ser-lhe traçado o plano do que vai acontecer, plano cuja realização começa com ele, recebe uma ordem: "ut omnia diligenter aduertas et in armario tui cordis reponas et conscribas conscriptaque serues et custodias..." (I, 2). Logo depois, acrescenta: "sed caue ne tu dixeris ea alicui aut reuelaueris, quia uoluntas Dei est ut, tempore suo, per illum quem ipse uult haec hominibus nota fiant" (I, 2). A dupla ideia da missão de Amadeu e da missão do Pastor é reforçada no início do III Raptus: (III, 20). O Pastor "magna auctoritate sibi a Deo tradita librum istum aperiet et omnia misteria in eo conscripta omnibus populis aperiet et manifestabit" (III, 19). Nem o papa, de que Amadeu é confessor, poderá ter conhecimento dos segredos do Livro, "cui nihil horum reuelles", é-lhe dito no final do III Raptus. É outro modo de marcar bem a distinção entre os dois tempos que Amadeu prevê para a Igreja.

Não tendo obtido resposta quanto ao "quando" do Pastor, no III Raptus, Amadeu ouve, no $I V$, a promessa relativa ao "quem" (IV, 41). Depois de lhe haver sido 
traçado o perfil do Pastor, ouve do anjo a sentença: "Ecce dedi tibi faciem eius, obserua et custodi eam. Antequam ipse redeat Romam, tu Mediolanum accedes et ibi diem extremum claudes. Relinque imaginem hanc una cum libro Romae et, ex parte Dei, praecipe sub poena mortis ut nullus librum aperiat usquequo Domino placuerit ut paulatim in lucem ueniant occulta et arcana Dei. Si quis uero ante illud tempus aperire librum praesumpserit, dabit debitas poenas" (IV, 44). E, nos termos do apêndice de $M$, como se viu já, a ameaça acabou por se tornar realidade.

São constantes ao longo do Livro e revestem formas várias as afirmações de que ele se destina ao Pastor que há-de vir, a quem cabe abri-lo e dar a conhecer a todos os segredos nele contidos. É com uma afirmação dessas que a obra encerra: "Haec secreta non sunt dicenda omnibus, sed plublicabit ea electus pastor benedictus quem Deus, ut audisti, cito missurus est pro consolatione fidelium et conuersione gentilium. Ab illo enim incipiet promulgatio libri et per illum Deus omnia quae dixi perficiet" (VIII, 223).

Há, no que acaba de ser dito, dois aspectos a merecerem realce. O primeiro é a coincidência entre o que decorre do texto de Apocalypsis e a história narrada no apêndice, história com duas proveniências. O outro é o significado da própria história. É ideia corrente, ideia a que o Prof. Sousa Costa deu acolhimento, de que Apocalypsis Noua é obra espúria. Terá sido alterada por um grego, especialista em Escoto, no sentido de colher dela dividendos políticos.

É evidente a referência, mas pouco seguro parece apresentar-se o resultado, como se irá ver adiante.

\subsection{Mediador da revelação}

No plano da obra, o mediador da revelação tem a função de escrever e guardar os segredos que Deus quis partilhar com ele. Regista-se em toda a obra o imperativo "scribe" e o conjuntivo final "ut scribas". O mediador é caracterizado em três tempos: nas palavras do anjo, que o apouca; nas suas palavras, em que aceita e reforça o ponto de vista do anjo; no juízo, muito positivo, que o anjo faz do seu próprio conhecimento, em que Amadeu, enquanto autor, se projecta.

Logo no início assim se lhe dirige o anjo: "Audi igitur et aduerte ad uerba oris mei. Te namque tamquam simplicem et idiotam Deus elegit" (I, 2). No II Raptus, respondendo a uma questão levantada pelo mediador, o anjo caracteriza-o deste modo: "Accipe hoc, homo Dei et serve simplex" (II, 16). Logo depois, respondendo a outra questão, diz-lhe: "Bene constat te esse purum hominem" (II, 16). No III, perante a pertinência de uma outra questão, o anjo secundariza a importância da acção do mediador na decisão de Deus: "Scio te idiotam talia dubia proponere nescire" (III, 21). Logo depois, a mesma ideia é reforçada: "Hoc nota, homo Dei, et quamuis tu sis ineptior ad talia, gratia tamen Dei aptior factus es et, ubi 
intelligere non potes ad plenum, scribe prout tibi a me dicuntur. Tu es Deo in hac re tamquam equus fratri tuo ferens farinam de molendino" (III, 24).

O próprio mediador, fazendo votos para que possa desempenhar bem a função que lhe é atribuída, acentua a ideia de desvalorização pessoal: "utinam sim bonus asinus ad deferendum tantum bonum" (III, 24). Assume a condição de "rude animal", mas salvaguarda: "cognoui tamen praesepe domini mei" (III, 24). Simples, ignorante, mas sabe o que faz e é grato. Queixando-se de falta de capacidade para reter a informação recebida, ouve a cáustica censura do anjo: "Nonne dixi tibi quia tu es animal deferens haec nutrimenta illi qui pascet gregem Dei nostri" (III, 25)? Mais uma vez aceita o papel, mas valoriza o desempenho: "Fiat, fiat, dum sim asinus alimenta Dei fidelibus deferens" (III, 25). Aceitando a função de mero instrumento sem valor, não deixa de questionar: "Valde placet ista miranda audire. Conscribam ea ut potero. Sed, mi domine, hoc nunc uersatur in corde meo quod explanare ignoro tamquam simplex et idiota" (III, 31). Posição idêntica assume mais à frente: "Idiota sum, domine mi, et numquam scientiam aliquam didici. Tamen..." (III, 32). Apesar da aceitação do apoucamento e da desvalorização pessoal, não quer ficar com dúvidas. Quer claramente saber qual é a relação entre a privação da graça original e o dano. $O$ anjo parece pôr em causa a consciência que ele tem da questão que quer formular e diz-lhe: "O pauper homuncio, intelligisne quae dicis? Videris mihi asina Balaam” (III, 33). Aceita e acrescenta: "loquor ut pica quaedam et certe non percipio" (III, 33). Mesmo assim, ou talvez por isso, o plano de Deus cumpre-se, na opinião do anjo, que diz: "sic ordinatum est ut per simplicissimum hominem haec dirigantur illi..." (III, 33). No $V$ Raptus, o mediador questiona o anjo sobre a necessidade da alma humana em Cristo, uma vez que a sua carne estava vivificada pela divindade. $O$ anjo pulveriza as pretensões dele: "O homuncio, quis te docuit arguere et ea quae patres tui non tenent, sed tenere abhorrent, approbare? Et quia uideo te sicut multos alios rudes..." (V, 89). Depois de haver desenvolvido longa argumentação contrária à existência da alma humana em Cristo, expondo uma teoria que não defende, conclui o anjo: "Vides, animal Dei, si ego pro illa cogitatione tua [...] sciuerim adducere tot rationes" (V, pág 154) ${ }^{39}$ ? Lamenta-se o intermediário do pouco que foi dito pelos evangelistas sobre a incarnação de Cristo. $O$ anjo chama Lucas e diz-lhe: "Dicito, carissime, huic homini simplici an praetermisisti pulchriora de incarnatione Filii Dei" (V, 90).

\footnotetext{
39 Havendo o manuscrito $V$ sido tomado como referência, uma vez que omite as partes do texto relacionadas com o apolinarismo e com a actividade de Cristo entre os 12 e os 30 anos, há necessidade de citar as passagens referentes a estes textos pelas páginas do texto estabelecido.
} 
Que significado pode ter esta desvalorização do intermediário da revelação? É um processo literário em que estão presentes o "topos" da "humilitas" e o do apoucamento e da submissão. São também e sobretudo fórmulas de devoção. ${ }^{40}$

Não parece, todavia, que hajam sido só razões literárias que motivaram o autor. No início do IV Raptus, depois de o anjo haver satisfeito a legítima curiosidade do intermediário, mostrando-lhe em imagem o Pastor prometido, desabafa ele: “... et uisum est mihi quod impossibile esset per illum tot fieri... Et recordatus sum cuiusdam dicti Scripturae dicentis: Potens est Deus de lapidibus istis suscitare filios Abrahae" $^{41}$ (IV, 45). E traduz o pensamento subjacente à afirmação da Escritura e ao seu espanto: "Non sunt homines qui talia faciunt, sed tu, Deus, facis omnia. Nos sumus quaedam ualde remota instrumenta" (IV, 45). A mensagem chegará com tanto maior fidelidade quanto maior for o apagamento do mediador. A desvalorização do intermediário é, acima de tudo, um processo de esvaziamento do humano, para deixar todo o espaço livre para que a mensagem chegue sem distorções.

O mediador da revelação tem o seu nome na obra: "Ego Amadeus..."; viveu um acontecimento: "fui raptus..."; num meio: "ex spelunca mea”; numa situação: "ubi orabam" (I, 1). Em simultâneo com o estatuto de personagem na estrutura da obra, tem a função de autor. Há ao longo da obra um conjunto de circunstâncias que o caracterizam.

À indicação do nome e do acontecimento que desencadeia a acção do livro, segue-se a indicação do lugar: "ex spelunca mea" (I, 1). A gruta é o ponto de partida e o ponto de chegada em todos os Raptus. É uma cela, numa gruta, com uma comunidade. O momento de oração na gruta é o quadro em que se dão também os outros arrebatamentos. Resta a dúvida sobre se os arrebatamentos de Amadeu são apenas êxtases ou se ele é levado para outro lugar onde não come nem bebe. A linguagem usada é viva, realista e sugere o seu desaparecimento.

Foi na gruta que Amadeu, ditando ou escrevendo, redigiu a Apocalypsis, conforme reza o apêndice de $M$ : "e fo scripto esso libro in la crotta grande, per che dua crotte erano in questo monte". Aí viveu com a sua pobre comunidade enquanto a função de confessor e conselheiro de Sisto IV o reteve em Roma.

Simultaneamente, há outra imagem que se pode construir, não do mediador, mas de Amadeu Meneses da Silva, o autor. Questionado pelo mediador, que punha em causa o raciocínio que Gabriel, expressando o pensamento do autor, desenvolvia, responde-lhe o anjo sorrindo: "Scio dialecticam, scio omnes apparentias rationum et fallacias et responsiones uelatas..." (V, pág 154). Expõe também em que tempo e de que modo a substância do pão, que havia cedido nos acidentes o lugar ao corpo de Cristo, retorna a esses acidentes, quando estes deixam de ser

\footnotetext{
${ }^{40}$ Ernest Robert Curtius, Literatura Europea y Edad Media Latina, 129.

41 Lc 3:8; Mt 3:9.
} 
sacramento. Gracejando, explica: “... ut uestrorum philosophorum more loquar, quia et ego opera Aristotelis uestri legi et intellexi antequam scripsisset, et hoc dicens subrisit" (VI, 122). Tratando dos efeitos da presença de um corpo glorioso num lugar, para concluir que pode ou não sentir-se, segundo se apresente de modo quantitativo ou não quantitativo, assim conclui: "Nos ita respondemus, quia studio philosophiae multis annis uacuimus, (et hoc dicens subrisit), corpus gloriosum est corpus sensibile" (VI, 138). O anjo discorre sobre a sabedoria enquanto atributo de Deus, e sobre o modo como esta se distingue da entidade Deus. Assumindo uma atitude de humildade, o mediador questiona: "Domine mi, ego numquam audiui theologiam neque didici. Tamen..." (VII, 150). Na resposta, o anjo afirma: "Et ego theologiam, diu est, didici et alium modum dicendi bene noui" (VII, 150). Discute-se a trindade das Pessoas e a unidade da natureza em Deus. O mediador afirma: "Domine mi, quamuis non omnia perfecte capiam, hoc tamen intellexi, quod in diuina persona nil est quod non sit deitas et etiam quod persona est Deus et Deus est persona" (VII, 165). Segue-se uma longa exposição de teologia trinitária em que se procura levar mais longe as posições de Agostinho, Tomás e Escoto, que na presença do anjo dão o seu assentimento.

Pela mediação do anjo, Amadeu afirma-se conhecedor da filosofia, leitor de Aristóteles, estudioso por muitos anos da filosofia e da teologia e discute, completando-os, com os luminares dessas disciplinas. Este desdobramento de Amadeu no desempenho dos papéis de mediador e autor faculta-lhe a possibilidade de mostrar, sem que seja essa a intenção primeira, o seu domínio da filosofia e da teologia. A leitura do padre dominicano Hieronimus Victurinus Venetus, que o censura de apolinarista, captou bem este lado do conhecimento de Amadeu ao dizer: "uidere mihi uideor hunc hominem eruditum sane fuisse et acutum quod eius scripta etiam stupidis lectoribus probant multumque temporis impendisse in lectione ueterum Patrum et scholasticorum..." À página 226 do Studio Critico e Documenti inediti sulla vita del Beato Amadeo da Silva nel quinto centenario della morte, refere-se o Prof. Sousa Costa aos efeitos que sobre o desenvolvimento cultural da Congregação dos Amadeítas teve o já referido testamento de um noviço, que em 18 de Fevereiro de 1478 legou à biblioteca do convento de Santa Maria della Pace de Milano "vari libri de teologia, diritto canonico e filosofia". Que terá motivado este homem, a quem a vida nos conventos franciscanos não satisfazia e, por isso, procurou aproximar-se do ideal do seu pai Francisco, ao seguir o ideal de pobreza estrita, a aceitar aquilo que o próprio Francisco começou por considerar um luxo?

O códice 190 A da biblioteca do Archiginasio de Bologna, datado de 1550, designado $G$, incorpora um documento em duas cópias, uma no início e outra no fim, que merece especial atenção. É o relato de um dominicano, fr. Hieronimus Victurinus Venetus, "theologus publicus, in Gymnasio Patauino professor, ac uicarius generalis uicariae S. Dominici", dos seus encontros em Roma, onde se deslocara em serviço da sua vigararia, em casa do bispo Ambrosius Catherinus. 
Era ele, no tempo do papa Júlio III, doutor de nomeada gozando junto do papa de prestígio e autoridade. Encontrando-se aí "inter eruditos aliquot qui aderant", pediu ao bispo Catherinus informações "de Amadei scriptis". Ouvem, ele e os outros convivas, a história dos amores de Amadeu pela princesa, filha de D. Duarte, a sua decepção amorosa e ingresso na vida religiosa, a referência aos seus progressos nessa vida, a ponto de alcançar rapidamente posições de responsabilidade. Mas ficam todos a saber também que "uir tamen idiota erat et litterarum prorsus ignorans", embora soubesse ler e escrever, "et fortasse nullam latini sermonis cognitionem habebat". Apesar deste quadro pouco abonatório da valia intelectual de Amadeu, o sábio bispo conta: "Narrauitque mihi notarius illius [...] quod dictabat omnia tenens breuiarium apertum in manibus, aspiciens illud ueluti legeret, et ipse notarius scribebat". E tem o cuidado de frisar que ele próprio obteve a confirmação de quanto afirma do próprio escrivão, "qui ita esse sicut narraui affirmabat et iurabat". Mitiga a conclusão que se vê obrigado a tirar com a condicional "si uerum est". Pois, se é assim, só resta crer na acção do Espírito Santo: "magnum est argumentum quod a Spiritu Sancto haec habuit quae scripsit".

Esta é a posição do bispo Ambrosius Catherinus, nas palavras de Fr. Jerónimo: "haec Ambrosius Catherinus". A posição de Fr. Jerónimo funda-se em factos e é implicitamente crítica da do bispo Catherinus. Ajuíza a partir da realidade: "Ea propter, ex fructibus, hoc est, ex operibus non quae fecit, quoniam de illis non habeo certum et constat testimonium, sed quae scripsit siue per se siue per alium [...] uidere mihi uideor hunc hominem eruditum sane fuisse et acutum quod eius scripta etiam stupidis lectoribus probant multumque temporis impendisse in lectione ueterum Patrum et scholasticorum..." A obra deixa ver a quem a leia o homem que a escreveu, instruído e profundo. A generosidade do dominicano não é gratuita. Aceita a obra, reconhece o valor do seu autor, mas ataca demolidoramente: "sed tamen uanum, subdolum, hippocritam et mendacem". Assim qualifica Amadeu. E explica:

Impostor porque, além de não provar o que afirma, mostra desprezo pelos Padres, que a Igreja venera como órgãos de Deus: "quoniam multa noua tam in doctrina quam circa euentus futuros sine probatione frequenter adducit neglectim aut etiam spretis antiquioribus Patribus quos tamquam Dei organa Ecclesia ueneratur".

Pérfido porque, sempre que pode, dá acolhimento aos delírios escotistas: "quoniam scoticis deliriis ubi commode potest [...] fauet".

Hipócrita porque inventa grutas, céus, arrebatamentos e, sobretudo, porque usa um estilo de que só os profetas se serviram, factos que cheiram a presunção e desprezo: "quoniam fingit speluncas, caelos, raptus. Nam nemo Patrum talem scribendi modum praeter prophetas obseruauit...”.

Mentiroso se lhe afigura em relação aos dogmas já que, por um lado, defende, com Apolinário, que em Cristo o Logos toma o lugar da alma humana; por 
outro, afirma haver visto o Pastor angélico. E já lá vão cerca de noventa anos e continuamos a esperá-lo.

Amadeu morreu em 10 de Agosto de 1482. A Apocalypsis Noua foi dada a conhecer em 1502. O incipit de $G$ reza assim: "Incipit die 28 Maii 1550". O explicit é: "Finis, die 14 Julii 1550". O manuscrito $G$ foi, pois, copiado 68 anos depois da morte de Amadeu e 48 depois da abertura da sua obra. Tem os fólios numerados de 1 a 101. A cópia do apêndice, integrada no final, tem a numeração 102, mas é cópia de outra mão. O apêndice, nas suas duas mãos, não é, pois, originariamente, deste manuscrito. Ambas as versões são de mão distinta e ambas são distintas da mão do corpo do manuscrito. O original das duas mãos deste apêndice terá sido escrito, nas palavras do seu autor, cerca de noventa anos depois da morte de Amadeu - "ab eius obitu effluxerunt paulo minus nonaginta annis", ou seja, cercas de 1570. Mas esta data aparentemente choca com a afirmação inicial, que situa o encontro em casa do bispo Catherinus no pontificado de Júlio III (8 Fev.1550 - 23 Mar.1555), "tunc temporis Pontificem”. Este lapso de tempo, contudo, cabe perfeitamente na distância que vai entre o acontecido e o escrito. O seu interesse não é afectado pelo facto de não pertencer originariamente ao manuscrito a que está associado. O tema é Amadeu e a sua obra. O interesse reside no facto de, por caminhos distintos, duas personalidades com a projecção destas confirmarem Amadeu como autor da Apocalypsis.

Esta afirmação não é um puro acto de fé de quem a faz, mas a certeza de quem declara: "narrauitque mihi notarius illius". E a afirmação relativa ao modo como a obra de Amadeu foi escrita coincide com o relato de Fr. Miguel de Trecha, de 1516. E tem tanto maior valor quanto a opinião sobre o autor é extremamente negativa.

Não poderá deixar de se levantar a dúvida quanto à possibilidade de encontro entre um bispo no auge da sua carreira por volta de 1550 e um "notarius" que regista uma obra por volta de 1480 . Os setenta anos que separam as duas datas não são, apesar de tudo, razão suficiente para dar consistência à dúvida, já que se não refere o momento desse encontro e não é materialmente impossível que as vidas dos dois homens se houvessem sobreposto.

A posição de Jerónimo Vitorino é diferente da do bispo Catarino. Imbuído aparentemente de um espírito mais racionalista, homem já do Renascimento, julga o homem a partir da obra "non quae fecit [...] sed quae scripsit". A confissão da autoria é clara. As suas adversativas, se por um lado confirmam o seu espírito racionalista: "quem et circa euentus futuros sine probatione frequenter adducit", deixam, por outro, vir ao de cima o preconceito do dominicano tomista contra o franciscano escotista. Preconceito que lhe não deixa o espírito livre para uma leitura tranquila. É verdade que Amadeu desenvolve, talvez sem uma boa justificação e em demasia, a doutrina de Apolinário, mas para logo a desmontar e condenar. Há manuscritos que suprimem essa passagem, talvez por considerá-la inútil. Não há, baseado nesse facto, razões para considerar Amadeu mendax. Nem 
a referência a grutas faz dele um ser estranho. Era, como se viu, a obra mostra e o apêndice de $M$ confirma, o lugar onde vivia.

Da leitura do texto resulta clara a convicção de que foi escrito por quem lidava com a filosofia e a teologia com agilidade e destreza. A função do anjo, narrador principal, que tem a preocupação de sublinhar o teor dos seus conhecimentos, dá corpo à figura do autor. Com esta, coincide a leitura do autor do apêndice do manuscrito G. As suas afirmações corroboram a conclusão do capítulo anterior, ao reconhecer Amadeu como autor de Apocalypsis Noua; confirmam a certeza que ressalta da leitura da obra, ao afirmar que Amadeu era instruído e profundo.

\subsection{História de uma deturpação}

Lê-se na página 239 do Studio Critico e Documenti Inediti sulla Vita del Beato Amadeo da Silva do Prof. Sousa Costa: "Comunque, non c'è dubbio che il libro sia stato adulterato da partigiani, il che indusse un autore citato da Cornelio a Lapide ad asserire che 'Angelus beati Amadei fuit Scotista'.

Barbosa Machado, tratando do Beato Amadeu, afirma: "Compôs um livro de Vaticínios acerca do estado futuro da Igreja, que lhe foram por Deus revelados. [...] Contra esta obra, adulterada com diversos erros, compôs o Eminentíssimo cardeal Belarmino cinquenta e sete censuras. [...] E assim, deve ser lida com grande cautela, como prudentemente advertiram os mais insignes cronistas da Ordem Seráfica, devendo ser julgada não como produção do iluminado espírito do Beato Amadeu, mas aborto de alguma fantasia fecunda de ficções, como escreveram Cornélio a Lapide [...]. Donde claramente se colhe o indiscreto arrojo com que o cardeal Caetano ${ }^{42}[\ldots]$ e Bzovio [...] quiseram manchar a opinião do Beato Amadeu, afirmando ser sua esta obra contaminada com opiniões erróneas e falsos vaticínios. Leiam-se Briceno [...] Waddingo, Alva e Samaniego que, com doutíssimas apologias defendem a santificada fama do Beato Amadeu [...]”. Fr. Marcos de Lisboa, cronista da Ordem entre 1556 e 1570, foi provavelmente o primeiro a assumir uma posição de denúncia, pois, como diz o Prof. Sousa Costa, "già Fra Marco da Lisbona richiamava l'attenzione dei lettori per il facto che il libro rivelativo dell'Apocalypsis è stato totalmente incompreso e deformato da miopi e

42 Tomás de Vio Caetano, ou Cagetano, 1468-1534, dominicano, mestre em teologia, professor em Pádua, foi eleito Mestre Geral em 1508. Deu início à reforma da Ordem assente em dois pilares - pobreza e estudo. Lutou contra o projecto de Luís XII e de Maximiano de reunir um Concílio contra o papa. Criado cardeal por Leão X em 1517, foi enviado à Alemanha como delegado papal com o intuito de reconduzir Lutero à comunhão da Igreja. A sua pouca maleabilidade e falta de tacto diplomático impediram-lhe o sucesso. Bispo de Gaeta em 1519. Desenvolveu importante labor filosófico e teológico sob a forma de comentários a Aristóteles e S. Tomás, de quem foi um dos mais importantes seguidores. A sua obra deixa ver um comentador inteligente, profundo e sintético. 
fantasiosi cervelli, che "iam non sit Amadei, sed eorum qui haec coaceruarunt" 43 . Tossignano, franciscano e igualmente cronista da Ordem entre 1586-1595, afirma, segundo também o Prof. Sousa Costa: "Scripsit enim ingentem librum, qui fictis imaginibus et commentis fuit a nonnullis corruptus, ut iam Amadei non sit" ${ }^{44}$.

Uma leitura superficial deixa a pairar a ideia de que Tossignano repete Marcos. Waddingo, (1588-1657), franciscano, cronista da Ordem, "rifiuta tutte e singole le affermazioni di Bzovius sulle 9 eresie, che credeve d'aver trovato nelli 'Amadei raptus octo' ${ }^{45}$. E o Prof. Sousa Costa acrescenta: "Sullo stesso ordine di idee si allineò e si pronunciò pure Pietro Rodolfo, António de Vasconcelos, Cornelio a Lapide con altri". E aponta uma razão: "In verità lo stile delle numerose lettere del Beato ci convince che le rivelazioni dell'Apocalypsis, come oggi son connosciute, non possono essere attribuite a Fra Amadeo" (Studio Critico, 239).

A obra do Beato Amadeu, tal como hoje se apresenta, não é, segundo estes autores, a obra original. Foi objecto de deturpações vis que visavam orientar para proveito próprio as revelações supostamente feitas ao Beato Amadeu. Onde está o ponto de apoio para tão ousadas opiniões? Em boa verdade nem se poderá falar em opiniões, pois, sendo vários os autores e distintas as épocas, a opinião é a mesma, repetida, embora, sob formas várias. A fonte parece ter sido Fr. Marcos de Lisboa. E a família franciscana foi repetindo e ampliando a ideia. O texto de Barbosa Machado acima referido é significativo: "E assim, deve ser lida com grande cautela, como prudentemente advertiram os mais insignes cronistas da Ordem Seráfica, devendo ser julgada não como produção do iluminado espírito do Beato Amadeu, mas aborto de alguma fantasia fecunda de ficções [...] Donde claramente se colhe o indiscreto arrojo com que o cardeal Caetano [...] e Bzovio [...] quiseram manchar a opinião do Beato Amadeu, afirmando ser sua esta obra contaminada com opiniões erróneas e falsos vaticínios." Barbosa Machado, fazendo-se eco do pensamento franciscano, estabelece uma clara distinção entre o modo como os franciscano vêem o problema e o modo como ele é visto pelos analistas das outras Ordens, que ele condena. E, de facto, se exceptuarmos a Lapide, jesuíta, todos os outros sintonizam na ideia da existência de erros na obra, mas nenhum põe em causa a autoria. Vejamos.

As revelações do Beato Amadeu "fecero molto strepito nel secolo XV", afirma um extracto da História Seráfica que serve de apresentação ao códice $190 \mathrm{~A}$ da Biblioteca do Archiginasio de Bologna. Esta mesma ideia de "strepito" ressalta do apêndice deste mesmo códice, como fica dito no capítulo anterior. O facto de Amadeu e a sua obra serem objecto de discussão cerca de setenta anos depois da sua morte, num ambiente simultaneamente culto e alheio à família

43 Fr. Marcos de Lisboa, Tercera Parte de las Chronicas, lib. 6, cap. 30, 179. (Studio Critico, 239).

${ }^{4}$ António Domingues de Sousa Costa, Studio Critico, 238.

45 António Domingues de Sousa Costa, Studio Critico, 239. 
franciscana, é disso sinal evidente. São, apesar disso, distintas as posições dos dois interlocutores. Ambrósio Catarino é um culto bispo da Cúria. Desvaloriza o homem. Reconhece a obra e vê nela a acção do Espírito Santo. Jerónimo Victorino é um teólogo dominicano. Reconhece o valor intelectual do homem. Aponta erros doutrinários na obra. Estas posições são assumidas durante o pontificado de Júlio III (1550-1555). S. Roberto Belarmino, jesuíta, "contra esta obra, adulterada com diversos erros, compôs cinquenta e sete censuras", de acordo com Barbosa Machado. Bzovio (1567-1637), dominicano polaco, "a causa dell'Apocalypsis, basato su affermazioni falsamente attribuite al Beato, nega la santità di questo, proclamando erético ed impostore...", diz o Prof. Sousa Costa. Cornélio a Lapide, jesuíta, contemporâneo de Bzovio, cita, também de acordo com o Prof. Sousa Costa, um autor que considera que "Angelus Beati Amadei fuit Scotista", desvio apontado já pelo dominicano Jerónimo Victorino.

No que se refere a questões de ortodoxia, a posição das inquisições espanhola e portuguesa difere desta visão negativista. Diz o teólogo "Doctor Francisco de Bargas", a quem o Inquisidor-Mor de Espanha incumbiu de rever a obra que lhe fora apresentada por Fr. António Ortiz: “... fue mi parecer que no allava en el cosa heretica ni repugnante a nuestra fe catholica”. Frei Miguel dos Santos, que submeteu a cópia que transcreveu ao juízo da mesa do Santo Ofício, quando era Inquisidor-Mor o cardeal D. Henrique, diz: “... me le bolvio sin condicion ni limitacion alguna”.

Qual poderá ser a razão de posições tão distantes?

Amadeu morreu com fama de santo. Foi beatificado e chega a dizer-se que foi canonizado. Os de fora olham para a obra sem constrangimentos e fazem dela uma análise pretensamente objectiva. Os erros são incompatíveis com a santidade, que a família franciscana reconhece em Amadeu. Não podendo negar a santidade, os franciscanos negam a autoria da obra, concordando implicitamente com os que a censuram. Afinal o rigor da Inquisição acaba por desmentir a visão de ambas as correntes ao declarar "que no allava en el cosa heretica ni repugnante a nuestra fe catholica".

Este modo de ajuizar não passa de uma tentativa para encontrar uma justificação para a posição franciscana, pois a que aduz o Prof. Sousa Costa não parece ter grande base. Será que o Cícero das cartas a Ático, com "une phrase rapide, alerte, fort peu 'cicéronienne', qui serait plutôt de Sénèque si elle n'etait moins affectée", seria reconhecível em "des périodes interminables des Pro Milone ou des Verrines"? As suas cartas, continua René Pichon, "révèlent un style absolument différent de celui des ouvres officielles" 46 Parece, pois, que o argumento da diferença de estilo, o único formalmente apresentado, não terá força suficiente para sustentar a tese da deturpação da obra do Beato Amadeu. Esse argumento aparece mais

\footnotetext{
${ }^{46}$ René Pichon, Histoire de la Littérature Latine, 174-175.
} 
como movimento instintivo de defesa perante um ataque que, mesmo aos olhos de um leigo, se figura exagerado.

É compreensível esta reacção. Contudo, são de tal peso os testemunhos, quer os do apêndice de $M$, quer o que resulta da consonância apontada entre este apêndice e a obra, quer o da coerência interna da obra, quer o do testemunho registado no apêndice do manuscrito $G$, quer o que resulta da uniformidade de todos os manuscritos, quer ainda o da rede de remissões internas, que a conclusão se apresenta evidente: Apocalypsis Noua tal como hoje o temos é obra do Beato Amadeu.

\subsection{Remissões internas}

Ao longo de toda a obra há uma apertada rede de remissões a nível interno dos capítulos e, mais significativamente ainda, entre capítulos, que ora anunciam matérias de que se irá falar mais à frente, ora evocam matérias já tratadas e que ou não foram bem entendidas ou se retomam para confirmar afirmações actuais, que dão a Apocalypsis coerência e coesão e criam uma interdependência das várias partes a que não pode deixar de se atribuir significado.

Apresentando no IV Raptus a acção do Pastor como reformador da Igreja, legítimo e autêntico vigário de Cristo, defensor da fé e mestre da revelação contida no Livro, (IV, 42), o anjo enumera, embora numa ordem que não segue o plano do Livro, a relação dos temas tratados e a tratar: "de angelorum creatione et uia; ${ }^{47}$ quantum fluxit temporis ab eorum creatione usque ad benedictionem et casum; ${ }^{48}$ qua die et quo monticulo uel loco Adam fuerit formatus; ${ }^{49}$ qua die in paradisum translatus; ${ }^{50}$ quando et ubi et qualiter mulier fuerit creata; ${ }^{51}$ qualiter multotiens, a serpente temptata, ipsum uirum temptauit; ${ }^{52}$ de Verbi incarnatione; ${ }^{53}$ de uera deitate et humanitate Christi $;^{54}$ de gloria paradisi $;^{55}$ de celi empyrii amenissimo situ $;^{56}$ de conceptione admirabilis Matris Dei Mariae $;^{57}$ de illis quae fecit Christus

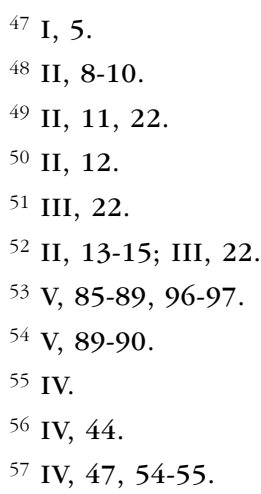


a duodecimo anno usque ad trigesimum $;{ }^{58}$ de assumptione eiusdem Virginis 59 et quod nullus est ibi in corpore praeter Christum et Matrem eius Mariam; ${ }^{60}$ de sermonibus Domini in Templo et sinagogis ad phariseos et plebem factis; ${ }^{61}$ de sermone Ioannis Baptistae ad Herodem; ${ }^{62}$ de his quae in carcere fecit et docuit; ${ }^{63}$ de Trinitate illa singulari ${ }^{64}$ et de sacramento corporis et sanguinis Domini ${ }^{65}$ et alia multa in hoc libro scripta a me iterum manifestanda" (IV, 42-43).

Nesta apresentação está uma acabada rede de relações entre as várias partes da obra, mas há ainda uma mais fina rede de matérias que cruza internamente os capítulos e relaciona um capítulo com vários outros.

Não deixa de ser interessante lembrar que vinte e seis do conjunto destas remissões se fazem para trás e apenas uma dezena se faz para a frente. As remissões para trás fazem-se para o capítulo imediatamente anterior, fazem-se também dentro do mesmo capítulo e, menos vezes, para capítulos afastados: de II para I, 2 remissões; dentro de II, 1 remissão; de III para I, 1 remissão; de III para II, 3 remissões; de IV para I, 1 remissão; de IV para II, 1 remissão; de IV para III, 3 remissões; dentro de IV, 1 remissão; de V para II, 3 remissões; de V para IV, 2; dentro de V, 2 remissões; de VI para II, 1 remissão; de VI para IV, 1 remissão; de VI para V, 1 remissão; de VII para II, 1 remissão; de VIII para IV, 2 remissões.

As remissões para a frente são de tipo variado: de I para VIII, 1 remissão; de II para V, 1 remissão; de III para IV, 1 remissão; de IV para V, 2 remissões; de V para VIII, 2 remissões; de VI para VII, 1 remissão; dentro do VI, 1 remissão.

É, como acaba de se ver, apertada a rede de remissões, que tece uma relação de dependência entre as várias partes da obra. Não obsta este facto a que eventualmente seja possível encontrar uma ou outra passagem espúria. Mas é garantia de que Apocalypsis Noua tem um fio condutor, tem coerência interna, é uma estrutura integrada, sendo, consequentemente, obra de um só autor.

Há uma segunda ideia que se colhe, que os Sermones Domini e os Sermones Joannis Baptistae são obras autênticas do Beato Amadeu, provavelmente independentes de Apocalypsis e, consequentemente, escritas antes.

Significa isto que Apocalypsis Noua é uma obra cuja escrita obedece a um plano, foi preparada com minúcia e executada nas suas várias partes sem grandes

\footnotetext{
$58 \mathrm{~V}, 110-111$.

59 VIII, 222.

$60 \mathrm{IV}, 50$.

61 Sermones.

62 idem.

63 idem.

64 VII.

$65 \mathrm{VI}$.
} 
intervalos. Pode ter sido escrita pelo próprio punho de Amadeu. Mas poderá também, como decorre do texto ${ }^{66}$ e se afirma nos apêndices de $M$ e $G$, ter sido ditada a um secretário nas circunstâncis aí referidas, como tarefa final do plano preparado e elaborado por Amadeu.

\subsection{Fontes}

Revelação, em Apocalypsis Noua, é, como se verá, uma tomada de posição na controvérsia teológica em busca da ortodoxia. Consequentemente, Apocalypsis é um confronto constante de teses e uma sucessão de opções que levam à definição de um caminho próprio. Neste percurso, que vai da criação e queda dos anjos até à vida de Maria depois da Ascensão de seu Filho e à sua morte e Assunção, são passados em revista os temas controversos e é explicitamente chamado à colação um significativo número de autores. Ao evocá-los e transcrevê-los, Amadeu não o faz com a precisão necessária, parecendo citá-los de memória, o que faz das citações, muitas vezes, uma evocação de ideias gerais. Por isso, torna-se praticamente impossível localizar qualquer passagem, mesmo quando é explicitamente atribuída a um autor.

Com excepção dos Raptus VI e VII, que tratam, como já foi referido, do sacramento da Eucaristia e da Santíssima Trindade, a progressão de Apocalypsis Noua segue a progressão da História da Salvação, desde a criação e o pecado até à Redenção e retorno ao Paraíso com a Assunção de Maria. Neste plano é enxertado um outro, mais restrito, centrado em Maria, que segue, não os Livros Canónicos, mas os Apócrifos. O nascimento de Maria, a sua vivência no Templo até aos esponsais, o nascimento e infância de Cristo, a sua vivência depois da Ascensão de seu Filho, a sua morte e Assunção seguem a par da versão dos Apócrifos e são subsidiárias da Legenda Áurea. O nascimento de Cristo é, como já foi dito, apresentado segundo a visão de santa Brígida da Suécia. ${ }^{67}$

As Escrituras estão omnipresentes, quer em citação directa, quer em referências mais ou menos explícitas. Seria fastidioso repetir o que as notas já dizem, embora a presença das Escrituras exceda em muito o âmbito daquilo que é susceptível de ser registado em nota. A Patrística e a teologia ocupam lugar central. Dos clássicos há vestígios. Em relação aos Apócrifos não há lugar a qualquer referência, nem a autores nem a fontes.

A maioria dos manuscritos tem notas marginais. Umas são rectificações, outras, resumos de conteúdo, outras ainda são comentários de natureza vária ou títulos

\footnotetext{
${ }^{66}$ Rediens ad cauernam meam, uocato a Deo praeparato mihi scriptore, haec pro futuro pastore, Domino iubente, subito scribi feci. I, 7.

${ }^{67}$ Brigida, Reuelaciones, Liber VII, caput 21. www.umilta.net/bk7.html.
} 
de parágrafos. Mas há um, o Barberini Latinus 475, da Bibliotheca Apostolica Vaticana, designado $N$, que a este conjunto bem desenvolvido de notas acrescenta outras, de mão distinta, que se apresentam como uma espécie de análise ao conteúdo da obra. Confrontam criticamente o pensamento de Amadeu com o dos vários autores da Igreja, ora registando os nomes daqueles de quem se repete o pensamento, ora realçando a oposição ou a contradição entre o pensamento de Amadeu e o desses. Parece estar-se perante uma cópia censurada de Apocalypsis Noua. Não deixa de ser significativo que se não registem notas destas na parte do texto que se apoia nos Apócrifos.

Perante a dificuldade em identificar obras e autores, em consequência do processo de construção de Apocalypsis Noua, temos esta via que, associada ao registo de nomes a que o próprio Amadeu procedeu, nos deixa ver o quadro de pensamento em que ele se movimenta.

$\mathrm{O}$ primeiro nome a aparecer no texto é o de S. Jerónimo, a propósito da relação de prioridade entre anjos e homens. Aristóteles é referido pelo título "philosophus", pela dificuldade que teria em compreender, na ausência de um ponto fixo, o movimento dos astros. É essencialmente nos Raptus VI e VII que surgem os nomes fundamentais: Escoto, Tomás de Aquino, Pedro Auréolo ${ }^{68}$, Agostinho, Boaventura, Hilário, Alexandre de Hales ${ }^{69}$. Referidos, mas apenas referidos, são os Padres da Igreja, Latinos e Gregos: Ambrósio, Gregório, Anselmo, Boécio e Ricardo, que não são Padres da Igreja, e Hilário”. E os gregos: Basílio, Gregório Nazianzeno, Crisóstomo, Dídimo, Atanásio.

Muito dificilmente, ou melhor, só um conhecimento profundo de toda a produção filosófica e teológica poderá permitir a identificação de obras e autores referidos ao longo de Apocalypsis Noua. Esse conhecimento parece havê-lo tido aquele que anotou criticamente o manuscrito $N$. São muitas as notas do manuscrito $N$ pelas quais se procura definir a linha de rumo seguida por Amadeu. Mas é irregular a sua distribuição ao longo da obra. Pouco significativo o seu número nos primeiros Raptus, totalmente ausente no último, concentra-se sobretudo nos dois de cariz mais vincadamente teológico, o VI e o VII. Esta distribuição acompanha o evoluir da linha narrativa escriturística, que é entrecruzada pela linha narrativa dos Apócrifos e cortada pela inserção dos temas genuinamente teológicos.

${ }^{68}$ Pedro Auréolo, doctor facundus, $\uparrow 1322$, franciscano, mestre de teologia em Paris e arcebispo de Aix-en-Provence, defendeu doutrina que pode ser considerada precursora da de Occam, opondo-se, assim, a S. Tomás e a Duns Escoto

69 Alexandre de Hales, Doctor Irrefragabilis, 1185-1245, ensinou em Paris até à sua morte, tendo S. Boaventura como aluno. Em 1236 ingressou na Ordem Franciscana. Foi um dos grandes compiladores e sintetizadores da Idade Média A sua forma de tratar os problemas teológicos constituiu um claro precedente da quaestio escolástica e um esquema das posteriores Sumas: apresentação do problema, indicação das objecções, solução e justificação destas. 
Sendo irregular a sua distribuição ao longo da obra, as notas revestem também natureza distinta. Há um conjunto constituído por nomes; no outro manifestam-se opiniões. Naquele há o simples registo do nome de um autor, há nomes associados, há nomes precedidos pela preposição pro, há nomes precedidos pela preposição contra. As opiniões, no segundo, revestem formas como: "opinio noua, contra doctores, noua mirabilia, noua et diuersa, doctores in hoc dubii sunt, numquam audita”. Os nomes anotados são fundamentalmente os já referidos, Escoto, Tomás, Agostinho, Anselmo, Gregório, Egídio ${ }^{70}$, Magister $^{71}, \mathrm{Hugo}^{72}$, Ricardo $^{73}$, Henrique $^{74}$ e Godofredo ${ }^{75}$.

Dos clássicos, como já foi dito, há apenas vestígios. No decurso da exposição dos seus pontos de vista, à medida que as circunstâncias o possibilitam, o autor colhe na sua memória os ecos dos autores clássicos. Evoca Cícero, quando afirma: "senes quippe abundantius quando incipiunt loqui consueuerunt" "6. Evoca Séneca, quando afirma: "Quotidianus defectus corruptionis est quedam prolixitas mortis", e cita-o ao afirmar: "cum crescimus, uita decrescit" 77.

Será que Amadeu tinha conhecimento directo das obras destes autores? Quase todas as citações se encontram mais ou menos explicitamente nos Padres, mesmo a de Ovídio $^{78}$. A precisão das citações de Séneca e de Cícero permitem-nos supor que o conhecimento fosse mais próximo. É natural que Amadeu, educado na Corte como expressamente afirma Fr. Marcos de Lisboa nas Crónicas, como várias vezes é referido pelo Prof. Sousa Costa em seu Studio Critico, como pressupõe, ainda que sem fundamento, a lenda dos seus amores pela princesa D. Leonor, filha de D. Duarte, e como parece lógico concluir do facto de sua irmã, Santa Beatriz, estar nessa mesma Corte ao serviço de D. Isabel de Portugal, a quem acompanhou para Espanha, é natural, digo, que tivesse contacto directo pelo menos com as

70 Egídio Romano, 1247-1316, doctor fundatissimus, dos eremitas de S.to Agostinho, discípulo e seguidor de S. Tomás. Da sua vastíssima obra merece referência o De Regimine Principum, que o Infante D. Pedro traduziu.

${ }^{71}$ Magister Sententiarum, Pedro Lombardo, 1100-1160, nascido na Lombardia, estudou em Bolonha e Reims. Em Paris estudou com Hugo de S. Victor. Os seus Libri Quattuor Sententiarum tiveram grande influência e foram a base de comentários dos maiores filósofos escolásticos.

${ }^{72}$ Hugo de S. Victor, 1096-1141, nascido em Hastingham, foi abade do Mosteiro de S. Victor. É geralmente considerado um místico.

${ }^{73}$ Ricardo de S. Victor, $\uparrow 1173$, discípulo e seguidor de Hugo de S. Victor, seguiu também a tendência mística. Na sua obra ecoa um agostinianismo anselmiano.

${ }^{74}$ Henrique de Gand, doctor solemnis, $\uparrow 1293$, grande adversário de S. Tomás. Foi dos poucos filósofos da sua época que não pertenceram a uma Ordem.

75 Godofredo de Fontaines, $\uparrow 1306$, admirador de S. Tomás, adversário de Henrique de Gand. Nascido na região de Liege, foi mestre de teologia na Sorbone.

76 Cícero, De Senectute, XVI, 55.

77 Séneca, Epistulae, Ep. XXIV, De futuri metu; de morte.

${ }^{78}$ Helinandus Frigidi Montis (PL 217, 707 e 729). 
obras de pendor moral de Cícero e Séneca, algumas delas traduzidas na Corte e existentes na biblioteca do Paço, biblioteca que D. Duarte criou. ${ }^{79}$

É extensa a lista dos nomes, variado é o rol dos temas, amplo o arco cronológico. Ampla é, sem dúvida, a cultura filosófico-teológica de Amadeu, reconhecida mesmo por aqueles que pareciam pretender condená-lo. Amadeu não se limita a repetir. Discute, discorda, opta, traça o seu caminho. Parecendo defender a visão teológica essencialista de Duns Escoto, não tem dúvidas em recusá-la quando isso lhe parece justo, apesar de considerado seguidor dos "scoticis deliriis". Este facto não só tira razão ao dominicano Jerónimo Vitorino e ao jesuíta a Lapide, que consideram que o anjo de Amadeu "fuit scotista", como infirma a pretensa ideia de falsificação da obra por um mestre da escola de Escoto. Preso, na linha de evolução dos acontecimentos, à visão do Génesis, primeiro, e dos Apócrifos a seguir, sabe alicerçar nos Padres e nos doutores da Igreja as suas opções. Nunca se desvia do fito que o guia. A tríade que o orienta, "causa fidei, causa unionis, causa reformationis”, tem um sentido claro. O objectivo principal é a reforma. Os dois outros, apesar de importantes, parece não passarem de condições prévias.

Como todos os que pretendem trilhar caminho próprio, iria sentir amargos de boca se a composição de seu livro não houvesse sido uma das suas últimas actividades. O destino da sua pobre Congregação foi sinal do destino que haveria de ter o seu Livro. O sonho que sonhou durante a vida e a consolação que esperava por tantos anseios e canseiras, como lhe prometeu o anjo, foram desfeitos em pó, quando um outro religioso, num outro país, em outras circunstâncias políticas, desviou a corrente que ele com tanto afinco se esforçou por canalizar segundo os ditames do Espírito.

\section{CONCLUSÃO}

Constitui propósito primeiro deste trabalho dar a conhecer a obra do Beato Amadeu.

As conclusões são poucas, mas, do meu ponto de vista, as suficientes para garantirem que Amadeu, ou seja, João da Silva Meneses, não era ignorante. Como foi possível esquecerem-se os que assim o julgam em Portugal de que foi educado na considerada uma das cortes mais cultas da Europa de então? Mesmo o Prof. Sousa Costa, ilustre franciscano, que tão longe levou o estudo histórico sobre Amadeu e a sua família? O parágrafo sobre a história da "deturpação" da obra afigura-se-me elucidativo. Devo dizer que o Prof. Sousa Costa reconhecia nunca haver lido Apocalypsis Noua, porque a sua linha de acção seguia por outro

${ }^{79}$ Aires Nascimento, As Livrarias dos Príncipes de Avis; Luís de Sousa Rebelo, A Concepção do poder em Fernão Lopes. 
caminho. Culto e profundo eram os qualificativos que eu lhe reconhecia quando os vi confirmados pelo dominicano que em meados do séc. XVI escreveu o texto que consta do apêndice do códice $G$ e que se anexa no final.

Poderão ter razão os que afirmam que a obra foi adulterada? Como justificariam então a confluência de elementos como seja a concordância de todos os manuscritos, a rede de relações internas e o modo como o apêndice do manuscrito $M$ nos fala dos cuidados com que a obra era guardada até haver sido dada a conhecer? Como seria possível que num ambiente de tanta exigência se adulterasse uma obra que teve tanto impacte sem haver qualquer rasto dessa aventura ou qualquer eco crítico? Considero que ficou suficientemente mostrado que, com eventuais pequenos acrescentos marginais, a obra tem unidade e coerência, que dificilmente manteria se houvesse sido interpolada.

Que o Beato Amadeu era homem culto, estudioso e profundo e que é o autor da obra que sempre levou o seu nome, foi a conclusão a que cheguei e que apresento. Outras pequenas conclusões, como o lugar do seu nascimento, o haver ou não sido educado na corte, o seu tempo de permanência em Guadalupe, são pormenores históricos que estão já afirmados e me limitei a coligir.

Os seus objectivos ao escrever Apocalypsis Noua julgo haverem ficado claros na finalidade primeira reconhecida à obra, a reforma da Igreja. Era este acompanhado por outro não menos importante, que era a união das duas Igrejas, a ocidental e a oriental. Clara me parece haver ficado também a mentalidade que enformava o sentir de Amadeu no sonho de um futuro que começaria com o advento do Pastor. Qual fosse a duração desse milénio não se procurou especificamente saber, mas ficou suficientemente afirmado que coincidiria com o estabelecimento do reino de Cristo na Terra. ${ }^{80}$

Ponto importante no estudo do homem e da obra era reconhecer as influências que o marcaram. Com o preciosíssimo auxílio das notas do manuscrito $N$, notas que me parece poder-se afirmar serem de $S$. Roberto Belarmino, pois foi ele, no dizer de Barbosa Machado, que encontrou na obra de Amadeu os tais cinquenta e sete desvios, conseguiu-se compor um painel de nomes de teólogos e filósofos que ocupam todo o espectro da filosofia e da teologia da Igreja. Da análise da obra resultam ainda referências clássicas que, se não foram todas directamente bebidas nas fontes, algumas o terão sido, pois havia na corte condições objectivas para isso. Ponto importante se considera a avassaladora presença dos Apócrifos.

${ }^{80}$ Vale a pena lembrar a posição de D. João de Castro em A Aurora da Quinta Monarquia (1604-1605). Partindo de um manuscrito, que ele mesmo reconhece deficiente, vai fazer uma leitura de passagens do IV e do VIII Arrebatamentos, aplicando aos Portugueses as referências feitas aos Florentinos. Se esta transferência é abusiva, mais grave se torna quando o referido manuscrito substitui o sintagma Rex liliorum por Rex illorum. Daqui parte uma perspectiva de leitura que deturpa toda a interpretação do contexto ao atribuir aos Florentinos o que Amadeu afirmou dos reis franceses e que, segundo o ponto de vista deste autor, se haveria de aplicar a D. Sebastião. 
Serviam um dos objectivos deste autor, falar dos dogmas, que o seriam só mais tarde, da Imaculada Conceição e da Assunção, dado ser claro que, juntamente com a reforma da Igreja, faziam eles parte do objectivo primeiro de Amadeu. Maria ocupa lugar importante em Apocalypsis.

Aqui chegado, brota espontânea no meu espírito a prece tantas vezes escutada: Que Deus lhe ponha a virtude, que eu da minha parte fiz o que pude.

\section{APENDICES}

\section{1 - Apêndice do Códice 402 da Biblioteca Trivulzio, Comuna de Milão - M}

\section{Georgius Benignus 1502}

Et quia iugiter in mente sua Genitricem Dei Marie gerit, quicquid voluerit ab ea impetrabit et hec cum multis aliis que nunc scribere nequeo legimus. Et sunt verba eius quasi per ordinem dicta: letare, mi notissime, nunc est dies Veneris, dies passionis et turbationis. Cito veniet auxilio de sancto ne dubites. Fiet unio, fiet concordia. Fiet unum ovile et unus pastor. Et Florentia quandoque ter nominat aperte, sedabit rixas pacataque perseverabit, rebus longe amplioribus potita durabit.

Vale felix, nequeo plura. Die 25 Junii 1502.

La prophetia de sancta Brigida que vulgariter reperitur non ho troppo gran pratica pure la vederò per vestro amore. Ma costui parla chiaro e narra più presto como evangelista che propheta. Breviter gran parte de queste prophetie s'acorda con quelle.

Vale felix. Die 6 Augusti. Benignus.

Voi mi confortate a preparatione evangelica e fate bene c/io mi sforzarò di farlo pro posse come etiam fa el Rev.mo Cardinale Sancte Croce e lo vescovo compagno mio et io suo in questa impresa, ma non per che habi quella fantasia anche nui (?) habia la sorte et la preordinatione divina cadere sopra di me. Ma per che mi basta di vedere tanto triumpho che in verità non solo essere quello ma pure di vederlo no mi pare essere degno. Potrebe bene advenire quello che io fossi in numero di quelli deci. Sia quello che piace a Dio pure che ueniat desideratus nouus.

Racomandatime a quello che bene dico a tutti gli amici nostri. Fate moto al mio paradiso et dite loro che questa è la terza volta che io ho cantato la messa sopra l'altare dove fu sepulta la nostra madre sancta Brigida con gran consolatione, dove è ancora una gran parte delle sua sancte reliquie. A voi mi aricomando.

Romae die 13 Augusti 1502. Benignus

Data a Roma a di 15 de Agosto. De di 20 di decto 1502 
Ma dico tibi et crede mibi che, non obstante el confino a me fato, io amo più voi che nisuno sia di fori et più la cità in generale che loro. Et quanto a me non vorei altro che ognuno sistesse in casa sua se possibile fusse. Et questo volere più presto per bene commune che particulare. Et quando io vedesse ch'el bene commune fusse anulato como havesse andare melio per commune senza ben particulari, tanto amore porto a la cità in se che no solo loro, ma voi che siati unum mecum et io medesimo più presto havesimo tutta la vita nostra essere exuli che la cità perdesse come fa et fussi male assiectata.

Nota che qui non dice dela prophetia dela communità. Ma io ve dico che al'ultimo nel 1515, nel principio o nel fine sarà vero in tutta perfectione. Et questo si sa e per questo libro et altri con gran favore della patria che altramente non si debe desiderare ne fare. [...] Ma che la cità e citadini habiano a fiorire nel 1514 o cossi intorno non dubito. [...] Dice in uno loco quod bec secreta sunt publicanda post electionem illius benedicti pastoris quem Deus missurus est ad consolationem fidelium et conuersionem gentilium. Et quamuis ea antea elctionem in aperitione libri cognoscet et sciat, antea tamen non promulgabit, ut opus Domini ab illo incipiat et per illum in alios transeat. [...]

Quando non avesse a essere altro, io sono contento dela consolatione che nel quiete mi sento per la mutatione dela vita mia senza però simulatione et hypocrisia.

Ubertine felix. Rome die 20 Augusti 1502

Benedictio da Roma ad primo di Septembre de di 27 Agosto 1502

Data a Roma a di primo de Octobre 1502.

Ubertino mio caro, chredetimi che libro originale non lo ha lecto homo che viva, excepto el vescovo mio compagno e poi lo Cardinale Sancta Croce. Et hora nisuno lo pò legere, excepto la sua Signoria et io in camera sua stando et non altramente, che di fora portare non si pò. E sua camereri non lo possono più vedere, lo tiene in la casseta incluso la chiave porta lui. Quando io volio me la presta tociens quotiens, per che gli pare non lo dovere negare a me, el quale prima che lui lo lecto tutto. E anche gli pare ch'io qualche cossa ho a essere, almeno uno de quelli cadinali orientali. Immo più vi dico che non vole si dica che labia lui per che ... gli direbe molestia. Più quando alchuno de gran maestro le domanda se la lecto et quid est intus, lui mostra di non stimare. E più volte dice che credete, sono cosse de frati certe (?) loro devotioni e loro meditatione. E con questa cautella mitiga la loro bramosa voglia siché M Franciscus non la ne avuto ne veduto ni se exemplato da quello in quelle cosse vo scripto, siché io ogni septimana ne posso cavare qualche particola, ma dare el libro a uno scriptore non si pò.

Vi contentarò in questo modo scrivendo questi sermoni in prima, dove sono cosse belle. 
Ubertino mio, et multa [...] Voi ne adirereti mecho che non vi scrivo però nulla. Sapiate che ele cavato del libro io non ho più. Solo ho cavato el sermone di Sancto Johanne Baptista ad Herodem, ma non lo mando per che ne voglio copia apressa a me.

El libro è tanto divulgato che è venuto a le orechie del papa. $\mathrm{E}$ in primo el Mo. S. nostro lo tene più oculto e vole ch'il se dica che non la. Et despicit librum coram aliis, dicendo: sono somnia fratrum, per levarsi le baie dintorno. Mandarovi quello sermone che veramente è cossa divina poi comenzarò dal principio del libro più necessarii per che non si possino. Se de uerbo ad uerbum non si scriveno pure da sabbato tamen la vi mandarò el principio e scriverò quanto potrò e più serà a me possibile per consolarvi. [...] Et uidebis et afflues et mirabitur et dilatabitur cor tuum. Sed timeo Dei secreta propalare.

Inuenimus mirabile quid extra librum nella grotta del detto Amadio, cossa mareveliosa, quasi tutte le cosse da per se del futuro pastore et depingelo in habito di frate minore et quasi lo nomina. E lo nome sarebe molto per uno nostro. El Cardinale disse: in verità questa effigie è del tale. Ma io certamente per questo più me aumilio et mancho stimo sia di colui et [...]. Ma duna cossa mi rendo lo spirito certo, che noi saremo amici di colui et coadiutori, che non è pocho. Immo e dona inestimabile. Vederò di averne et fare se potrò cautamente ritrare quella figura. Non vi posso più scrivere per hora, perdonatime. Lego una lectione di Scoto a dua doctori theologi in secreto. [...]

Vale felix mi, Ubertine suavissime. Rome, Kalendis Octobris, 1502. Benignus

Ubertino! Non vi posso sccrivere archana ingentia nuper reperta que confirmant omnia quondam prophetis dicta. O quantum cuperem ut ea videretis, magna, magnalia, secreta mirabilia que cito, cito, cito operabitur Deus in Italia et in Ecclesia sua.

Vale felix. 1502 a di 27 de Mazo. Benignus

Ubertino, voi mi scriveti vi debia notificare le prophetie qui novamente trovate. Havete inteso nominare uno frate nostro chiamato beato Amadio, fondatore duna regulare observantia e più anni sono ho desiderato che sua frati havesino uno loco apresso a Firenze, faresti bene a praticare questo, sed de boc alias.

Costui ha fato uno libro grande como Augustino De Ciuitate Dei, elquale comandò si tenisse in custodia in fino che idio mandasse uno a chi tocava ad aprilo e breviter certi frati circha a tre volte tentarono daprirlo, in infra pochi di, subito amalati, morirno.

Costui mori al tempo de Sixto.

Questo libro lo tene Sixto, tenelo poi etiam Innocentio, ma nesuno di loro fu ardito ad aprirlo per casi intervenuti aquelli frati. 
Ora el Cardinale di Sancta Croce, homo doctissimo in ogni bon costumi, da alchuni pregato, essendo protectore dela dita Congregatione, ordinò con el nostro generale, homo de vita optima e sancta, questo libro doversi aprire e finalmente conclusino che a niuno questo si poteva comettere melio che a me, fumi dito. Io in vero hebe non pocha paura. Tandem uno vescovo del'ordine nostro che sta con lo Cardinale di Sancta Croce cominciomi a confortare et promisse di volere esse primo ad aprirlo. Et cossi, die statuto, andamo in S. Piero in Montorio elo vescovo canto la messa. Post secreta, liber in altari coram Generali et iussu eius a nobis apertus et nobis duobus ad legendum traditus est. In quo refobrmatio Ecclesie et conversio infidelium omnium et electio mirabilis noui pastoris, regni Christi pacatum purumque ac nitidum diebus his fore predixit; multissimi passi dela Sacra Scriptura, de creatione mundi, angelorum, Ade et Eue mirabiliter declarat non ipse, sed Gabriel Angelus. Vera costi el nostro generale fateli vezi quare ipse est pontifex futurus.

Vale felix, et me commenda amicis. Doleo infortuniis presentibus et futuris usque ad parvum tempus civitatis mee, florebit cito et liberabitur.

Roma die 18 Junii, 1502. Benignus

Nemini dixeritis

Ubertino mio. Dopo quelle due insieme ho avuto unaltra vestra, eri mi fu presentata da uno servitore del Cardinale. Comparsimi che fussi stata aperta. Scriveti cossi li dirò io che non li mandano qui in casa. Ma io o vero o mandarò per essi e non vorei costoro sapissino che io vi revelassi tali secreti, che il Cardinale tene questo libro per uno oraculo e asse securato a legerlo lui medesimo ita et taliter che noi non lo possiamo vedere più, ma che io ho cavato parechii passi de uerbo ad uerbum e so a mente tutte le materie de loquale tracta.

Quello che scriveti di me doversi adimpiere, a me anche è passata qualche fantesia per la mente propter tria:

Primo per che disse: nunc est Rome. Verum est. Immo più volte andai per vederlo e fomi mostro la crota dove stava tal volta cinque di solo chiuso con uno pane e uno pocho daqua;

Secundo per che disse: costui a la lingua uno pocho impedita e che alora Deus soluet uinculum labiorum eius et loquetur aperte et omnes audient vocem eius;

Tertio quia dixit quod Deus purgabit eum a (pro) multis peccatis, quia erit deuotus Genitricis sue et semper habebit eam in corde et in ore suo.

Arente dimeno, io in verità non penso questo, ne credo neque uideo modum. Sed hoc bene credo che havendo costui a creare $\mathrm{x}$ cardinali orientali, e proprie dite cossi orientali e non dici ne greci ne altri, siché forse potrei capare infra tanti. Quatro siamo aperitori del libro, ognuno di loro crede per si stesso. Io credo per uno di loro, maxime per quello vero gia scripto. Fiat uoluntas Dei, ho di summa gratia solo essere consio di tanti misterii e servitii e di vedere la conversion deli infideli e unione deli orientali e occidentali insieme. 
Data a Roma a di 20 de Iulio, 1502. De di 16 di decto.

Queste litere sono copia dele litere che scrisse maestro Zorzo Benigno re et nomine amico di Dio e dela nostre Virgine, greco dela provintia de Valechia dela terra nominata Argentina, Ragosa

Lequale litere scrisse lui con soe mane a Ubertino, citadino di Firenze de risaliti quando fu aperto lo divino libro del Beato Amadio intitulato Apocalypsis Noua. Laqual apertura fu fata per lui, como si contiene inquesto principio de queste litere. E avegna che non si possa opponere niente di meno, io, frate Michele da Trecha, dela povera familia del beato e sancto Amadio, intendo etiam narrare e testificare a corroboratione di questo qualiter frate Ysaia da Varese mi disse a Milano, in Sancto Angelo, nel 1513, a di 8 di Marzo, como quando fu aperto lo libro del beato Amadio fu nel anno del Signore 1502, tra la Pascha et Lascensa.

Et io anchora ho per própria bocha del benecto Benigno, arcivesco de Nazareto, dito intra et extra, sed alias maestro Zorzo Benigno, como fu aperto la septimana da po la octava dela resurrectione del Signore, laqual fui a di 26 de Marzo. Como maestro Egidio, Generale del Ordine di Sancto Francesco, comando per sancta obedientia a maestro Zorzo, greco, etiam lui de lordine, ut supra, et a monsignore nominato da Morlion, anchora lui de lordine e vescovo spagnolo, el quale in questo caso renuntio et si submisse nouiter in la volunta del reverendo Padre Generale el quale comando ad ambi dui dovesino aprire questo sancto libro et vedere quello li era dentro, bene o male, in loquale a li homini di Dio facilmente si pò iudicare quanto sia lo bene che in quello si contiene et non alchuno male.

Et a questa apertura si ritrovareno solamente questi cinque frati, uidelicet, prima, el Reverendo Generale maestro Egidio da Melia; secundo, lo vesco Morlion, el quale canto la messa del Spiritu Sancto. E li ministri furono questi, como etiam essi mi hano narrato: el diacono, frate Bernardo, da Milano; el subdiacono, frate Tito, da Roma; el terzo fo maestro Zorzo Benigno, el quale fu vero aperitore di questo libro e per obedientia lo aperse dicendo lui etiam sapesse di morire: per obedientia lo volio aprire. E questa fu la auctorita grande la quale exclude ogni presumptione; el quarto fu el Pe. fr. Ysaia e lui fui che poso la messa, porto el libro in gresia; el quinto fu il Pe. frate Bernardino de Antignato el quale anchora lui ma narrato questo facto dicendomi che in secreto non era contento si aprisse per non offendere Dio.

In quelli di fu fato frate Ysaia de custodo ministro dal generale sopraditto. Dui anni steti custode e lo terzo ministro.

Item memoria como lo libro del beato Amadio fu scripto tutto de uerbo ad uerbum per bocha de esso beato como lui diceva a misere Francesco Biondo da 
Modona e questo fu el suo primo scriptore. E fu scripto esso libro in la crotta grande, per che dua crotte erano in quello monte in speciale e la dove era la mazore e dove è al presente la gresia nova laquale ha fato fare lo re di Spagna eli in quella crotta el beato predisse al suo scriptore predito como qui sarebe una volta una bella gresia como si vede per experientia. Et fu lo libro scripto tutto in uno anno vel circha, excepto poche cosse nela fine per non trovarse in quelli tempi lui a Roma. E quello anno che fu scripto, el beato Amadio ando a Milano eli con la gratia di Dio fini el corso dela vita sua. E questo fu nel 1482, a di 10 de Augusto.

E queste io ho avuto dal preditto misere Francesco Biondo, homo degno di fede, a di 10 de Junio nel 1515, con molte altre cosse che no li scrivo per brevità

Item memoria como a di 16 de Zenaro, nel 1516, narro monsignore maestro Zorzo Benigno, arcivesco di Nazareth, al padre frate Gregorio da Lode et a mi, frate Michele da Trecha, como siando a Roma e venendo una volta di santo Pietro inverso Transtevere e lo Beato padre nostro Amadio andava inverso santo Pietro et inscontrandosi per la via e lo Beato Amadio abracio maiestro Zorzo et feceli di molte careze dicendo e questo quello fiute cossidotto. Siché credo che per spirito divino lo cognoscessi in parte quello che Dio voleva fare de lui.

Anchora ne disse che venendo lui de Gallia dal studio et arivando in Milano li fu dito como era morto uno sancto homo frate et padre de li poveri frati di Sancta Maria dela Pace da Milano et che in quello di che fu sepulto, siando nela gresia in lo cadelecto che lui, cioe, el Beato Amadio si levava e pareva che volesse usire delo cadelecto con grande alegreza e iubilo. Siché è de credere aquelli però che ano qualche cognitione de le cose secrete revelate da Dio. Che Dio facessi questi segni in lo Beato Amadio da poi la morte in quello ponto et hora che maiestro Zorzo Benigno intrava in Milano per le cose future da lui predicte...

Io intendo(?) anchora di scrivere alchune prophetie del Beato Amadio secundo che ho audito narrare da qualchi nostri patri vechii più volte. E prima qualiter siando il Beato Amadio a Cremona, a Sancta Maria de le Gratie, nostro loco, e tenendo lo capitulo e avengna che alora li fussi pochi frati, tamen in quelli pochi si erano anchora el patre frate Hieremia di Vismari, da Milano, e lo padre frate Ysaia da Vareze, li quali frati erano zotici et in predicamento di essere boni frati. Una volta, siando alchuni frati in compagnia com lo Beato Amadio, fu più uno frate che laudava molto li preditti frati dinanci al padre frate Amadio unde el padre, quasi agitando el capo, disse:

Tengo fide che per causa de li prediti frati la congregatione haverà di grande tribulatione a ciascun di loro. E che nisuno di loro morirebe in la Congregatione. E cossi è stato per che lo padre frate Hieremia è morto a l'ospitale grande de Milano e frate Ysaia è morto a Sancto Angelo. Siché s'è verificato lo dito de lo sancto homo di Dio Beato Amadio. 
De la tribulatione che ha avuto la Congregatione per causa di frate Hieremia in quelli di ch'io stava per essere vestito dal beato frate Lorenzo da Bagna Cavallo, io intese qualche cosa e cossi da poi, ma pure io non posso dire alchuna cosa per non havere inteso el fundamento quia, ignoratis principiis, ignotrantur et ea que secuntur.

Circha a quella tribulatione del padre frate Ysaia, per esse io stato in la Congregatione ne posso dire qualche pocho. Frate Ysaia, a quello che lui è stato molto honorato in la congregatione asai volte, è quasi de continuo guardiano a Roma e a Milano et è stato comissario e poi ministro e molto honorato e reverito e acharezato tanto che si pò dire lui essere stato ingrato, ingrato e ingratissimo a la Congregatione a c'io non dica ingrato a Dio. Per lui la Congregatione ha perso lo loco di Civita ducale. Da lui non è restato che la povera Congregatione non sia stata destructa, aderendosi lui com tale desiderio e speranza a li frati de la familia, pensando pur lui di havere li frati nostri a suo comando, ma la bontà di Dio li ha provisto che lamio di frati sono tutti voltati contra di lui, contra la sua volunta e bene merito a tanto homo ingrato.

Anchora per lui la povera congregatione ha perso lo gran thesoro del libro del Beato Amadio, lo quale libro frate Ysaia lo mando uno sabbato da matina per tempo al Cardinale di Sancta Croce da frate Theodoro da Ro in una sacheta.

\section{2 - Apêndice do Códice A 190 - Biblioteca Comunale, Bolonha.}

Fr. Hieronimus Victurinus Venetus, Ordinis Predicatorum, theologus publicus, in Gymnasio Patauino professor ac vicarius generalis vicarie S. Dominici

\section{Lectori}

Rome dum negotia quedam pro vicaria nostra S. Dominici de mandato Rev. Vicarii Generalis tunc temporis F. Sixti Medicei, theologi eminentissimi, in Curia tractarem, crebro domi conueniebam Ambrosium Catherinum, episcopum, doctorem magni nominis multeque apud Julium III tunc temporis Pontificem auctoritatis et existimationis, a quo semel huiusce auctoris cum inter loquendum mentio inter eruditos aliquot qui aderant facta esset, hec de illius gestis et uita deprompta tamquam certa prorsus et explorata fuerunt. Querebatur enim ab eo censura de Amadei scriptis.

Fuit, inquit, Amadeus natione lusitanus, gente ac familia nobili. In seculo seruiuit regine cuidam, cuius amore cum captus esset, in illam usque ad insaniam deperibat, que, cum eius intemperiem sepius increpando cohercere non potuisset, addidit postremo loco minas et necem eius se molituram etiam iuramento affirmauit. Quam ob causam, desperans se compotem insani uoti umquam futurum, religionem Sancti Francisci Senis, ni fallor, ingressus est. Vocarique uoluit frater Amator. Sed in anno probationis, meliori consilio suscepto, totum se in Domini famulatum 
tradidit, reiecto quamuis alio affectu, et sub professionis diem, publice coram fratribus causam sui in religionem ingressus prodidit ueniam postulans, meliora in dies de se multis pollicitis promittens, mutarique sibi nomen rursum uoluit et uocari non amplius Fr. Amator, sed Fr. Amadeus.

Emissoque religionis uoto, adeo intra paucos annos integritate et honesta conuersatione profuit ut ad magnates et prefecturas honestissimas pro meritis a patribus Ordinis istius [accensurum?].

Vir tamen idiota erat et litterarum prorsus ignarus, presertim theologicarum et philosophicarum. Sciebat tamen legere, sed non scribere, et fortasse nullam latini sermonis cognitionem habebat.

Narrauitque mihi notarius illius qui eius raptus et sermones Ioanis Baptiste et Domini Iesu eius mandato scripsit quod dictabat omnia tenens breuiarium apertum in manibus, aspiciens illud ueluti legeret, et ipse notarius interim scribebat. Quem notarium ego Florentius ita opinor quod mihi dixit [mihi dixisse] semel in hanc gratiam adiui et de illo fratre Amadeo diligenter percuntatus sum, qui ita esse sicuti narraui affirmabat et iurabat. Quod, si uerum est, magnum est argumentum quod a Spiritu Sancto hec habuit que scripsit.

Hec Ambrosius Catherinus.

Ego tamen ex divo Paulo didici probandos esse spiritus, et angelum Satana interdum transfigurare se in angelum lucis non ut doceat, sed ut fallat, non ut saluet, sed ut perdat, ut divus inquit Ambrosius. Ea propter, ex fructibus, hoc est, ex operibus non que fecit, quoniam de illis non habeo certum et constat testimonium, sed que scripsit siue per se siue per alium iuxta mandatum Domini a fratribus eorum, et illud: "ex ore tuo te iudico", et "ex uerbis tuis iustificaberis», et Platonis in Theeteto: "Fac ut te uideamus" uidere mihi uideor hunc hominem eruditum sane fuisse et acutum, quod eius scripta etiam stupidis lectoribus probant, multumque temporis impendisse in lectione ueterum Patrum et scholasticorum. Sed tamen uanum, subdolum, hypocritam et mendacem,

Vanum quidem mihi uidetur quoniam multa noua tam in doctrina quam et circa euentus futuros sine probatione frequenter adducit neglectim aut etiam spretis antiquioribus Patribus, quos tamquam Dei organa Ecclesia ueneratur.

Subdolus quoniam scoticis deliriis ubi commode potest hoc sanctitatis fuco et pretextu mirum quomodo fere uibique fauet.

Hypocrita quoniam fingit speluncas, celos, raptus. Nam nemo Patrum talem scrbendi modum preter prophetas obseruauit, quod est ualde expendendum, nec stilus nec phrasis aliud quam iactantiam sui et aliorum contemptum aut certe neglectum redolat.

Mendax etiam mihi uidetur in Ecclesie dogmata, ut patet de anima Christi quam uult Verbum fuisse in illo animam, que fuit heresis Apollinarii et quamquam uideatur referre fictitius ille Gabriel Ecclesie deffensor, tamen mirum quam frigide quamque parum honorifice in certas prophetias, nam de Pastore illo Angelico 
dicit se eum uidisse iuuenem et tamen ab eius obitu effluxerunt paulo minus nonaginta annis et adhuc frustra exspectamus. Quare doctrinis uariis et peregrinis nolite abduci.

Notandum hic est quod stans illa per annos 1000 circiter, multos eruditos atque etiam pios uiros protulit, sed tamen multi ex illis prophetie donum se habuisse profitebant, ut divus Vicentius, diva Brigita, divus Angelus de Concordia, diva Catheria de Senis, fr. Manfredus, divus Bernardinus de Senis, fr. Amadeus, de quo supra, fr. Hieronimus Savonarola et ille qui iudicium futurum sub annum Domini sexque milesimum trigesimum tertium, cuius nomen non recordor, qui omnes et alii, Deo ita uolente, in multis lapsis et decepti sunt, ut fidamus, tandem uerbo Domini et Ecclesie doctrina.

\section{3 - Apêndice do Manuscrito 1818, Barcelona - C}

Aprobaciones deste libro de las Revelaciones de Santo Amadeo

Yo el doctor Francisco de Bargas por la presente doy testimonio como este libro supra scripto fue traydo a la examination del R. ${ }^{\circ} \mathrm{Sr}{ }^{\circ}$ Cardenal Don Alonso Manrique, Arçobispo de Sevilla y Inquisidor Mayor de España y por su R. ${ }^{a} S .{ }^{a}$ me fue mandado que lo vise e examinase. El qual visto yo di en escrito a su S. ${ }^{a}{ }{ }^{a}$ lo que del me parecia, al qual scripto ahora también me remito. Pero digo que a lo que mi memoria ahora puede alcanzar en el dicho, fue mi parecer que non allava en el cosa herética ni repugnante a nuestra fe Católica. Y digo así mismo que después vi una carta del dicho Sr. R. ${ }^{\circ}$ Cardenal scripta al Pe. fr. Antonio Ortiz en la qual su $S .{ }^{a}{ }^{\mathrm{R}}{ }^{\mathrm{a}}$ dice que el mando ver este libro ya dicho a ciertos theologos y non estavan escandalizados de lo en el contenido. Y posque esto es así verdad, en testimonio dello di esta firmada de mi nombre.

Fecha en Sevilla a 22 de Agosto de 1539

El doctor Francisco de Bargas

En el Castillo de Triana, Jueves, a 21 dias del mes de Agosto del año de 1539 el R. ${ }^{\circ} \mathrm{Sr}^{\circ}$ Doctor Pe. Dias de la Plaça, Inquisidor apostólica contra la herética pravedad y apostasía en esta ciudad de Sevilla y su arçobispado con el obispado de Cádiz dio y entrego al R.mo e devoto Padre fr. Antonio Fermín, de la Orden de S. Francisco, de la Provincia de San Gabriel, que estava presente, un libro scripto de mano que se intitulava del Beato Amadeo, llamado Apocalypsis Noua, el qual dicho libro Su R. ${ }^{a}$ dixo lo depositava y lo deposito en el para que lo tenga asta tanto que le sea pedido e demandado, y le mando en ermín de santa obediencia no le dexe ni consienta trasladar a persona alguna, ni imprimir, ni lo dexe leer a persona de pocas letras. El qual dicho libro el Padre fr. Antonio Ortiz lo recibió 
en si y se comprometio a lo así cumplir. Y para que conste ser así, yo el notario infra scripto firme esta de mandado del Sr. Inquisidor dicho día, mes y año.

Pasó ante de mi, Fermín García, notario del Secreto.

Yo fr. Pedro de Alcántara, de la Orden de S. Francisco, de la Provincia de S. Gabriel, doy testimonio como vi trasladar el libro supra scripto del Beato Amadeo a fray Antonio Ortiz de otro libro que traxo prestado de la Provincia de los Ángeles, el qual desia avia trahido a aquella Provincia, de Roma, el Cardenal de S.ta Cruz D. fray Francisco de Quiñónez antes que fuesse Cardenal, el qual libro traslado fray Antonio Ortiz ella casa de S. Francisco de Beluiz de la Provincia de San Gabriel. Iendo al Capitulo General de Nissa por custos custodum de la Provincia del Sto. Evangelio, que es en las indias de Castilla, y de ay a un año fue este Padre Antonio Ortiz recibido por morador en la Provincia de S. Gabriel, en un Capitulo que se tubo en S. Gabriel de Badaxos, de la dicha Provincia, por una carta que el escrivió volviendo de Roma de Capitulo General rogando que le recibiesen. Y con consentimiento y gran alegría de todos fue recibido y en el mismo Capitulo, estando el ausente, fue electo en ministro Provincial de la dicha Provincia. Pos que algunos de conversación y los mas de vida le conocían ser hombre de antigua edad en la religión y bien experimentado y aprobado en otras prelacías, y religioso de gran virtud, y muy devoto y buen Predicador. Y siendo Provincial le oy loar mucho este libro del Beato Amadeo y le oy desir que a todo lo que el alcanzaba era cathólico y que no tenía cosa que repugnase a nuestra fe cathólica, y que siendo provincial envió ese libro con dos frayles al R. ${ }^{\circ}$ Sr. Cardenal Arçobispo de Sevilla, Don Alonso Manrique, Inquisidor Mayor de España, y el dicho Sr. Arçobispo le escrivió dende algunos días al dicho fray Antonio Ortiz, en que desia que el avía mandado leer aquel libro del Beato Amadeo, y dele con cuidado a algunos theólogos y que non estavan escandalizados de lo en el contenido. La qual carta del Sr. Arçobispo se leyó en la Casa de la Madre de Dios de Albucherque estando allí aiustados los guardianes y discretos de la Provincia a celebrar Capitulo Provincial. Y leyose en presencia de todos. Y siendo yo provincial en la dicha Provincia de San Gabriel que sucedí al dicho fr. Antonio Ortiz y fui electo en este Capitulo de Alburquerque embié a Sevilla al dicho fr. Antonio a ciertos negocios y para que truxesse el libro que el dicho S. Arçobispo avía dicho que lo enviaría. Y de aquel camino le truxo con un testimonio del Doctor Bargas, el qual yo vi e ley muchas vezes. Y ese que estava arriba scripto es sacado del de uerbo ad uerbum. Y porque es verdad lo arriba contenido lo firme de mi nombre.

Echa en Azeyton a 21 de Hebrero de 1543

frater Petrus de Alcantara

Eu, o d Aveiro B, faço saber aos que este lerem que eu mandei buscar este livro atrás scripto e o ouve por ua carta do Geral fr. João Calvo em que o mandou 
pedir a esse Padre frei António Ortiz para o ver ei lo tornar a mandar. O qual libro o fice desencadernar e tresladar a quatro pessoas por ser feito com mais brevedade, o qual está tresladado en 304 follas e asitte per estas dous scriptes destes inquisidores de Castella. E mais donesse mon hafe que vi una carta dito fr. António Ortiz que escrivio ao Pe. Geral em que diz que elle deu o dito ao Cardeal Arçobispo de Sevilla que a esse tempo era inquisidor e que a cabo de três anos lo tornaraon cao diligença conteuda na certidão a cima scripta, e que o Arçobispo lle escrivio o que a cima se conten, o a si fice escrivir para se saver que en dito libro he visto dos Inquisidores de Castella, por largo tempo examinado, e segundo o que parece naon echaraon nelle causa porque o naun devese de tornar a seu dono, segun lo se acima conten. Acavose a 13 de Nom.e de 1542. E no fice tarladar se mo Pe. que o deu ser savidor que o trasladara por naon encorrer na culpa de ir contra o queche mandaron.

O Duque

Eu, frei Miguel dos Santos, religioso dela Orden de Sto Augostino dos Eremitas en esta Província de Portugal e pregador da muito descarecida princesa, a Rainha Dona Catherina de Áustria, nostra S. ${ }^{a}$, deu mon afé e certifico com os assignados supra scriptos doutro libro que ouve às manos, o qual me emprestou a illus.ma S. ${ }^{a}$ dona Anna de Arragon, dama da dita R.ma n.ra S. ${ }^{a}$, a qual dona Anna o ouve por industria do doctor Mestre ${ }^{a}$.no secreto de $S .{ }^{a}$, e no fice trasladar todo per minha mão, na minha cella, neste convento de Santa Maria de Graça da sobredita Orden, na cidade de Lisboa. E cabei de os escribir dia do St. Benodato António de Pádua pola manhan, a 13 de Junio de 1577 ano. Et tendo passado e todo lido com atençon, não che causa alguna queu achei qui me offendese ne parecese contrária a nosa santa fee cathólica ne a os bonos costumes, antes me parece muy pio e devoto e dino de ser llido para glória de nosso Senhor e consolaçaion de quem o lere.

fr. Miguel de los Santos

El cardenal Infante don Enrique, Inquisidor General en los reynos de Portugal mandou en Lisboa recoger esse libro y darle a los Señores inquisidores para ser visto y examinado, y yo le lleve a la mesa del Sancto Officio y me le tubieron alla mas de dies años, y al cabo desse tiempo el Padre Maestro fray Bartolome Ferrara reveedo de libros y examinado general por el dicho Sancto Officio me el bolvio sin condicion ni limitacion alguna, y me le embió a A. Madrigal, a donde me fue dado a 14 de Março deste año de 1590

fray Miguel de los Santos 


\section{BIBLIOGRAFA}

Almeida, Fortunato de, História da Igreja em Portugal, Nova Edição, preparada e dirigida por Damião Peres, Porto-Lisboa: Livraria Civilização-Edtora, 1968.

Barbosa Machado, Bibliotheca Lusitana, Coimbra: Atlântica Editora, 1965-1966.

BRÍGIDA DA SUÉCIA (Santa), Revelaciones, ed. Birger Bergh, http:/WWW.umilta.net/bk7.html.

Cidade, Hernani, Licões de Cultura e Literatura Portuguesas, $4^{\mathrm{a}}$ Edição, Coimbra: Coimbra Editora, 1959.

Dias y Dias, M. C., et alii, Hislampa, Autores Latinos Peninsulares da Época dos Descobrimentos, 1350/1560, Lisboa: INCM, 1993.

D. DuARTE, Rey de Portugal e do Algarve e Senhor de Cepta, Leal Conselheiro, Edição Crítica e anotada, organizada por Joseph M. Piel, Lisboa: Livraria Bertrand, 1942.

IACOPo DA VARAZZe, Legenda Aurea, Edizione critica a cura di Giovani Paolo Maggioni, Seconda Edizione Rivista dall'Autore, Sismel, Firenze: Edizione del Galluzo, 1998.

Marcos de LisboA, Fr., Tercera Parte de las Chronicas de la Orden de los Frayles Menores del Seraphico Padre S. Francisco, Lisboa, 1615.

Martins, Mário, "Santa Beatriz da Silva no Teatro Espanhol do séc. XVII", Separata de Didaskalia, vol. VI, 1976.

“A Imaculada Conceição na Espiritualidade Portuguesa”, Brotéria, XLIII, 1946, 557-569. Maurício, Domingos, “A Lenda Amorosa do Beato Amadeu”, Brotéria XVII, 1933, 186-197. OTERO, Aurelio de, Los Evangelios Apocrifos, Edición Crítica Bilingüe, Madrid: BAC, MCMXCIII. SARaIVA, António José, O Crepúsculo da Idade Média em Portugal, $4^{\mathrm{a}}$ Edição, Lisboa: Gradiva, 1995.

Sousa Costa, António Domingues de, "Studio Critico e Documenti Inediti sulla Vita del Beato Amadeo da Silva nel Quinto Centenario della Morte", in Noscere Sancta, Miscellanea in Memoriam di Agostino Amore OFM, Romae: Pontificium Athenaeum Antonianum, 1985. "Aproximação da espiritualidade de Santa Beatriz da Silva e seu irmão Beato Amadeu com os frades do Santo Evangelho e Capuchinhos, evangelizadores de África, América e India." Congresso Internacional Bartlomeu Dias e a sua época, Actas, Volume V, 1989.

Vieira, António, Cartas, coord. De J. Lúcio de Azevedo, Lisboa, INCM, 1997.

-_ Clavis Prophetarum, Liber Tertius, Edição Crítica de Arnaldo Esp. Santo, Lisboa, BNL, 2000.

Zurara, Gomes Eanes, Crónica da Tomada de Ceuta, Introdução e Notas de Reis Brasil, Lisboa, Europa-América, 1992. 
(Página deixada propositadamente em branco) 


\section{TEXTO E TRADUÇÃO}


Iesus Mariae filius, Saluator hominum

\section{ApOCAlypsis NOVA}

sensum habens apertum et ea quae in antiqua Apocalypsi erant intus, hic ponuntur foris, hoc est, quae erant abscondita sunt manifesta 
Jesus, Filho de Maria, Salvador dos homens

\section{Nova Apocalipse}

de sentido aberto e em que se dá a conhecer quanto na antiga Apocalipse estava oculto, isto é, aquilo que estava escondido torna-se manifesto 
[fl. 1]

\section{PRIMVS RAPTVS ${ }^{1}$}

Ego Amadeus fui raptus ex spelunca mea ubi orabam in monticulum quemdam et in rotam ubi Deo astabant angeli et animae ${ }^{2}$ sanctorum quos colimus et ueneramur. Et dum ibi essem ${ }^{3}$, pauor et tremor ${ }^{4}$ me obruit, nesciens uerbum proferre, sed eram quasi homo sine sensu et cognitione. Tunc astitit mihi uir aspectu decorus, facie et ueste rutilans et talibus uerbis me alloquitur: Agnoscis me, serue Dei?

Ad quem ego 5 : Domine mi, numquam amplius in loco isto fui ${ }^{6}$, numquam talem coetum uidi, numquam tantum ${ }^{7}$ splendorem sensi, quomodo te cognoscere possum?

At ille: Ego sum Gabriel ille qui semper ad reuelandum ${ }^{8}$ mysteria Verbi Dei fui missus, cui tu oratione ${ }^{9}$ quotidiana te commendas. Ille sum qui Mariam Verbi Dei $^{10}$ matrem $^{11}$ salutaui, conturbaui et confortaui ${ }^{12}$. Nunc ergo quia Dominus noster [f1. 2] uult iterum misereri generi humano et uult mundum purgare cunctis erroribus et ad unum gremium ueritatis reducere omnes homines, et Ecclesiae suae preficere pastorem ${ }^{13}$ quem ipse elegit ut pascat oues suas et nutriat populum suum in iustitia et ueritate uultque haec secreta sua communicare ${ }^{14}$ tibi ut futura quae tu non uidebis in carne mortali constitutus nunc ${ }^{15}$ uideas ${ }^{16}$ et consolationem ${ }^{17}$ propter tot labores tuos et desideria tua sentias, et ut omnia diligenter aduertas et in armario tui cordis reponas et conscribas conscriptaque serues et custodias nullique patefacias quousque Deus miserit uirum illum qui librum a te conscriptum aperiet $^{18}$ in tempore suo, quando Deo placuerit.

Et quia uoluntas Dei est ut multa uana et superflua de fide sua resecentur ${ }^{19}$ et $^{20}$ ea quae sunt credenda pure et simpliciter credantur, me misit ut de singulis ${ }^{21}$ fidei mysteriis te doceam et tu ea conscribi ${ }^{22}$ facias. Preparaui tibi illum ${ }^{23}$ qui

1 Primus Raptus] om. GHJNPV 2 animae] coetus $B \mathbf{3}$ essem] esse $V \mathbf{4}$ tremor] timor $B \mathbf{5}$ Ad quem ego] Ad quem. $J \mathbf{6}$ numquam amplius in loco isto fui, numquam] numquam amplius, numquam $C$ 7 tantum] talem $B G E K O P Q, 8$ reuelandum] reuelanda $Q 9$ tu oratione] in oratione $C P Q 10$ Verbi Dei] Verbi $N 11$ Dei matrem] Dei. $R 12$ salutaui, conturbaui et confortaui] salutaui conturbans et confortans $J V 13$ praeficere pastorem] proficere. Pastor $V 14$ communicare] manifestare $N \rightarrow$ 
[fl. 1]

\section{Primeiro Arrebatamento}

Eu, Amadeu, fui arrebatado da minha gruta, onde estava em oração, para uma colina e para uma Assembleia onde estavam perante Deus os anjos e as almas dos santos que honramos e veneramos. E, enquanto aí estava, invadiu-me pavor e tremor. Incapaz de proferir palavra, era como um homem incapacitado de sentir e de pensar. Surgiu então à minha frente um varão de aspecto distinto, de face e veste brilhantes, que me dirige estas palavras: Reconheces-me, servo de Deus?

Meu senhor, respondi-lhe, jamais estive neste lugar, nunca vi semelhante Assembleia, nunca me vi envolvido em tão grande magnificência, como posso conhecer-te?

Eu sou Gabriel, retorquiu, aquele que sempre foi mandado a revelar os mistérios do Verbo de Deus, a quem tu te encomendas na tua oração quotidiana. Sou aquele que saudou, conturbou e confortou Maria, a Mãe do Verbo de Deus. Agora, pois, que nosso Senhor [fl. 2] quer de novo apiedar-se do género humano e quer purificar o mundo de todos os erros e reconduzir todos os homens ao seio da única verdade e quer pôr à frente da sua Igreja o Pastor por ele escolhido para que apascente as suas ovelhas e alimente o seu povo na justiça e na verdade, quer partilhar contigo estes seus segredos a fim de que vejas agora o futuro que não verás na situação de vida mortal e sintas satisfação de todos os teus trabalhos e anseios, e para que a tudo prestes diligente atenção, o encerres no escrínio do teu coração e o escrevas, preserves o escrito e o guardes e a ninguém o dês a conhecer até que Deus envie o homem que, no tempo oportuno, quando a Deus aprouver, há-de abrir o livro por ti escrito.

E visto ser vontade de Deus que se erradiquem da sua fé muitas coisas vãs e supérfluas e se creia com pureza e simplicidade naquilo em que se deve crer, enviou-me para que te instrua sobre cada um dos mistérios da fé e tu os mandes

$\leftarrow$ (in marg. a. $m$. communicare) 15 nunc uideas] nunc in spiritu uideas $F \quad 16$ uideas] audias $O$ $\mathbf{1 7}$ consolationem] consolationem sanctificantem $C$; consolationem animam laetificantem $H Q 18$ aperiet] aperiat $C N 19$ resecentur] reserentur $L$; rescecentur $V \quad 20$ et] ut $Q 21$ singulis] suis $B 22$ conscribi] conscribere $L V \mathbf{2 3}$ illum] scriptorem $C G$ ( $O$ er. scriptorem, add. alias illum) 
omnia, prout ex ore tuo audierit, conscribet, cuius tempore haec implebuntur ${ }^{24}$. Et pastor ille, quem Deus ipse nouit, cunctis promulgabit. Sed caue ne tu dixeris ea alicui aut reuelaueris, quia uoluntas Dei est ut tempore suo per illum quem ipse uult haec hominibus nota fiant ${ }^{25}$. Audi igitur et aduerte ad uerba oris mei. Te namque tamquam simplicem et idiotam Deus elegit ut omnes sciant quam magnus est Deus noster et quam potens, qui infirma elegit ut fortia confundat, et idiotas ut sapientes conuertat ${ }^{26}$.

Tunc ego aliquantulum ${ }^{27}$ resumpsi uires ${ }^{28}$ et ad angelum dixi: $\mathrm{O}$ sanctissime angele Dei in quo semper specialem deuotionem habui, gratias imensas ago diuinae dispositioni et tuis intercessionibus. Sed ex quo sua infinita miseratione placuit Domino Deo ${ }^{29}$ sua mysteria mihi ${ }^{30}$ pauperculo propalare, dic mihi, $\operatorname{rogo}^{31}$, si inueni gratiam coram te, quis est iste tam dignus et celebris coetus et qui sunt isti $^{32}$ uiri tam digni tantaque maiestate decorati?

Respondit ${ }^{33}$ angelus: Omnes hi te diligunt et omnes exultant quia uident ${ }^{34}$ tempus aduenisse nuptiarum Agni quas diu tota caelestis curia desiderauit. Illi a latere quasi sinistro seorsum sedentes, antiquitatem et grauitatem ostendentes uultu et gestu, sunt antiqui patres, Adam primus pater hominum, Abel iustus, Noe, Abraham, Moyses, Samuel, Dauid rex, Isaias ${ }^{35}$, Ieremias, [f1. 3] Daniel et Ezechiel. $\mathrm{Ab}$ alio latere quasi dextro est Petrus cum reliquis apostolis. Ille qui inter hos et illos quasi in medio sedet, est Ioannes, precursor Domini, utriusque lateris merita ${ }^{36}$ habens et quo nullus nec ante nec post dignior fuit. Et qui iuxta illum sedet est Ioseph, ille qui pater Christi meruit appellari. Multi alii et praecipui ${ }^{37}$ sanctorum sunt hic iuxta te ${ }^{38}$ et in circuitu ${ }^{39}$, de quibus erit tempore suo occasio loquendi. Sed tu, o frater, suspice ${ }^{40}$ superius et Regem simul cum Regina adora.

Suspexi ego et uidi scalam cuius cacumen uidebatur caelum tangere, et cum fulgenti diademate uidi Christum Dominum scalae innixum. Et scriptura dicebat: "Iterum ueniam ad uos et gaudebit cor uestrum et gaudium uestrum ${ }^{41}$ nemo tollet a uobis". Ex alia parte scalae scriptum erat: "Apparebit et non mentietur. Si moram tibi facere uidebitur, expecta quia ueniens ueniet". Vidi et Reginam, illius matrem, ipsi Regi innixam, ex cuius ore exibat scriptura dicens: "Misertus

$Q \quad 24$ implebuntur] propalabuntur $C E N Q \quad 25$ nota fiant] notificentur $P$; nota faciam $Q 26$ ut sapientes conuertat] ut sapientes conuertant $F J$; ut sapientes humiliet $L$; et sapientes conuertant $M$; et sapientes conuertat $V \mathbf{2 7}$ aliquantulum] aliquantum $L \mathbf{2 8}$ resumpsi uires] assumptis uiribus $Q 29$ Domino Deo] Deo ILNOR 30 Deo sua misteria mihi] Deo mihi $B 31$ mihi, rogo, si] mihi si $C Q .32$ isti] illi $E O 33$ Respondit] Dixit $N 34$ uident] uidetur $C M Q V 35$ Samuel, Dauid rex, Isaias, Ieremias] Samuel, Ieremias $C \quad 36$ merita] media $B \quad 37$ praecipui] praecipue $C B I Q 38$ hic iuxta te] hunc iuxta $H$; ii iuxta te $Q \mathbf{3 9}$ te et in circuitu, de] te de $Q \mathbf{4 0}$ suspice] suscipe $H$ ( $J$ add. in marg. suspice) $\mathbf{4 1}$ et gaudium uestrum] $P$ (in marg. a. m.) 
escrever. Preparei-te quem tudo há-de escrever conforme o ouvir da tua boca, em cujo tempo se hão-de realizar estas coisas. E aquele Pastor, que o próprio Deus conhece, dá-las-á a conhecer a todos. Mas, cuidado, não o digas, nem o reveles a quem quer que seja, pois é vontade de Deus que estas coisas sejam dadas a conhecer aos homens, no tempo próprio, por quem ele pretende. Ouve, pois, e presta atenção às minhas palavras: escolheu-te Deus a ti, enquanto simples e ignorante, para que todos saibam como é grande e poderoso o nosso Deus, que escolheu a fraqueza para confundir a força e os ignorantes para converter os sábios. ${ }^{[1]}$

Reuni então algumas forças e disse ao anjo: Dou infindas graças, santíssimo anjo de Deus a quem sempre dediquei especial devoção, ao plano divino e às tuas intercessões. Contudo, já que aprouve ao Senhor Deus na sua infinita misericórdia mostrar-me a mim, pobrezinho, os seus mistérios, diz-me, peço-te, se achei graça diante de ti, quem é esta tão digna e tão numerosa Assembleia e quem são estes tão dignos varões revestidos de tanta majestade?

Todos estes, respondeu o anjo, te consideram e todos exultam porque vêem chegado o tempo das Núpcias do Cordeiro $^{[2]}$, que toda a Corte Celeste desejou durante tanto tempo. Aqueles que se sentam à parte, como que do lado esquerdo, ostentando vetustez e nobreza na face e no porte são os antigos Padres: Adão, o primeiro pai da humanidade, o justo Abel, Noé, Abraão, Moisés, Samuel, o rei David, Isaías, Jeremias, [f1. 3] Daniel e Ezequiel. Do outro lado, como se fosse o direito, está Pedro com os restantes apóstolos. Aquele que se senta entre uns e outros, como que no meio, é João, o precursor do Senhor. Desfruta dos méritos de ambos os lados. Não houve, nem antes nem depois, alguém que lhe fosse superior em dignidade. O que se senta ao lado dele é José, aquele que mereceu ser chamado pai de Cristo. Muitos outros e os mais importantes santos estão aqui, perto e em redor de ti. Deles haverá oportunidade de falar na hora certa. Tu, porém, irmão, eleva o teu olhar e adora ao mesmo tempo o Rei e a Rainha.

Elevei o olhar e vi um trono cujo cimo parecia tocar o Céu. Vi, sentado nele, Cristo, o Senhor, com fulgente diadema. Uma inscrição dizia: Virei de novo para junto de vós e o vosso coração alegrar-se-á. A vossa alegria ninguém vo-la roubará. ${ }^{[3]}$ Do outro lado do trono estava escrito: Virá e não mente. Se te parecer que demora, espera porque, de certeza, virá. ${ }^{[4]}$ Vi também a Rainha, sua Mãe, ao lado do próprio Rei, de cuja boca saía uma inscrição que dizia: Apiedou-se da nossa

\footnotetext{
[1] 1 Cor 1:27

[2] Apoc 19:7

[3] Jo 16:22

[4] $\mathrm{Hab} 2: 3$
} 
es nostri generis. Festina. Ne tardaueris." Et alia scriptura dirigebatur ad coetum ${ }^{42}$ humanum ${ }^{43}$ dicens: "Non turbetur cor uestrum, leuate capita uestra, ecce adest redemptio uestra." Vidi quoque in circuitu Regis ac Reginae quosdam quos agnoui ${ }^{44}$ non esse de genere humano et cogitabam illos esse angelos. Sed mirabar ualde quare ipsi altiores essent omnibus Veteris et Nouae Legis patribus.

Et hic incipit prima reuelatio ${ }^{45}$.

Sic enim meae admirationi sanctus Gabriel dixit ${ }^{46}$ : Noli mirari. Omnes nos, angeli et homines, conciues ${ }^{47}$ sumus eiusdem patriae. Non tamen omnes homines maiores ${ }^{48}$ sunt omnibus angelis neque omnes angeli maiores sunt omnibus hominibus. Sed aliqui de genere uestro maiores sunt omnibus angelis, ut ille Rex Homo et sua mater Regina. Aliqui uestri generis minores ${ }^{49}$ sunt omnibus angelis, de quibus ${ }^{49 A}$ dicitur: "Vidi turbam magnam quam dinumerare nemo poterat $^{50 "}$. Alii sunt nobiscum mixti. Septem angeli sumus qui Genitricem Dei nostri ueneramur, alios omnes uestri generis transcendimus ${ }^{51}$. Hoc ergo, quia non est notum apud uos, intellige illud et scribe, ut pastor uenturus ea possit in orbem terrarum promulgare.

Dixi ego: Domine mi, qui sunt illi septem spiritus omnibus maiores?

Respondit $^{52}$ : Sex sursum uides. Si me connumeraueris ${ }^{53}$, septem erimus.

Et ego: Domine [fl. 4] mi, quae sunt nomina uestra?

Respondit: Primus quem ibi cernis Michael est, quo nullus neque hominum neque angelorum dignior. Ipse est qui cum magno dracone Lucifero conflixit illumque superauit. Et ego Gabriel ${ }^{54}$ secundus sum. Raphael me sequitur et Vriel Raphaelem et alii eum. ${ }^{55}$

Tunc ego: Ergo neque Ioannes Baptista neque ullus ${ }^{56}$ apostolorum aequabitur uobis?

Et ille: Satis fuit et ualde satis generi uestro quod Dominus ${ }^{57}$ noster se fecerit ${ }^{58}$ hominem et non apprehenderit ${ }^{59}$ aliquem ex nobis. Satis est uobis ut Genitrix illius Regis nostri, ueri Dei et ueri hominis, sit praelata omnibus angelis. ${ }^{60}$ Quod quidem, ut quidam de hic ${ }^{61}$ assistentibus dixit (et ostendebat beatum Ieronimum), de nullo aliorum ${ }^{62}$ sanctorum $^{63}$ fas est credere ut scilicet ${ }^{64}$ sit sublimatus supra merita omnium angelorum et archangelorum ${ }^{65}$, nomine archangeli non intelligendo

42 coetum] genus $B \mathbf{4 3}$ humanum] hominum $C F N Q 44$ quos agnoui non esse] quos non esse $B \mathbf{4 5}$ Legis Patribus. Et hic incipit prima reuelatio. Sic enim] Legis Patribus. Sic enim $C Q V \mathbf{4 6}$ reuelatio. Sic enim meae admirationi sanctus Gabriel dixit: Noli] reuelatio. Noli $V$; Tunc angelus Gabriel dixit: Noli $E 47$ conciues] ciues $C Q \quad 48$ maiores] maiores et digniores $C \mathbf{4 9}$ minores] maiores $V$ 49A angelis, ut ille Rex Homo et sua mater Regina. Aliqui uestri generis minores sunt omnibus angelis, de quibus] angellis de quibus $N R \mathbf{5 0}$ nemo poterat.] nemo poterat, qui per duodecim milia XII tribuum (nobis $C$ ) uobis insinuantur in numero determinato tamquam pauciores et praestantiores turba magna (praefiguratur $C$ ) praefigurati in semine duodecim patriarcharum. $C F H$ (M in marg a. m.) $Q \mathbf{5 1}$ transcendimus] transcendentes $C Q \mathbf{5 2}$ maiores. Respondit: Sex] maiores. Sex $R 53$ connumeraueris] consideraueris $Q \mathbf{5 4}$ ego Gabriel] ego Gabriel, licet similimus illi $F$ ( $M$ in marg.a.m.) $\mathbf{5 5}$ et alii eum.] et alii eum. Et ego inspiciebam in primos duos et non $\rightarrow$ 
raça. Apressa-te, não tardes. ${ }^{[5]}$ Uma outra inscrição dirigia-se para a assembleia dos humanos e dizia: Não se perturbe o vosso coração, levantai a cabeça, eis que a vossa redenção está próxima. ${ }^{[6]}$ Vi também, em torno do Rei e da Rainha, alguns que reconheci não serem da raça humana. Pensava que fossem anjos, mas causava-me muita admiração o facto de serem mais altos que todos os Padres da Nova e da Antiga Lei.

E aqui começa a primeira revelação.

Perante a minha admiração, assim me falou o santo Gabriel: Não te admires. Todos nós, anjos e homens, somos concidadãos da mesma pátria. Porém nem todos os homens são maiores que todos os anjos, nem todos os anjos são maiores que todos os homens, mas alguns da vossa raça são maiores que todos os anjos, como aquele Rei, que é Homem, e a Rainha sua Mãe. Outros são inferiores a todos os anjos. Deles se diz: Vi uma tão grande multidão que ninguém poderia contar. ${ }^{[7]}$ Outros estão ao mesmo nível que nós. Nós somos sete anjos que veneramos a Mãe do nosso Deus e estamos acima de todos os outros da vossa raça. Pois que isto não é conhecido entre vós, procura entendê-lo e escreve-o, para que o Pastor que há-de vir possa dá-lo a conhecer em toda a Terra.

Meu senhor, perguntei eu, quem são aqueles sete espíritos que a todos superam?

Em cima, respondeu ele, vês seis. Se me contares a mim, seremos sete.

Meu senhor, insisti, [fl. 4] quais são os vossos nomes?

O primeiro que aí vês, respondeu, é Miguel. Ninguém, nem homem nem anjo, é mais digno do que ele. É aquele que lutou com o grande dragão Lúcifer e o venceu. Eu, Gabriel, sou o segundo. Segue-me Rafael, a quem segue Uriel, que é seguido pelos outros.

Portanto, adiantei eu, nem João Baptista nem nenhum dos apóstolos se vos iguala?

Muito, muitíssimo representou para a vossa raça, respondeu ele, o facto de nosso Senhor se vir a tornar homem e não assumir nenhum de nós. Basta-vos que a Mãe deste nosso Rei, verdadeiro Deus e verdadeiro Homem, tenha sido preferida a todos os anjos. Facto que, sem dúvida, como disse um dos aí presentes (e mostrava S. Jerónimo), de nenhum outro santo é lícito crer, isto é, que seja exaltado acima dos méritos de todos os anjos e arcanjos, não entendendo pelo

\footnotetext{
$\leftarrow$ poteram inter eos discernere. Angelus (id $a d d . F$ ) uidens ait: "Futurum est ut magni et electi inter uos me putabunt Michaele digniorem". Nec mirum quia quae parum differunt neque differre uidentur. $C F H$ (M in marg. a. $m$.) $Q \mathbf{5 6}$ ullus] nullus $V 57$ Dominus] Deus IOR 58 fecerit] fecit $B$; faceret $C 59$ apprehenderit] apprehendit $B$; apprehenderet $C \mathbf{6 0}$ ex nobis. Satis est uobis ut (...) sit praelata omnibus angelis. Quod quidem] ex nobis. Quod quidem $G \mathbf{6 1}$ hic] iis $Q$; his $V$ 62 aliorum] alio $N 63$ aliorum sanctorum fas] aliorum fas $Q ; 64$ ut scilicet] ut $\operatorname{supra} B$; quod $E$; ut sanctus $H \mathbf{6 5}$ angelorum et archangelorum, nomine] angelorum, nomine $B$
}

\footnotetext{
[5] S1 39:18

[6] Lc 21:28

[7] Apoc 7:9
} 
chorum secundum ascendendo, sed omnes qui dicuntur superiores angeli. Dictum tamen illud ${ }^{66}$ non fuit cordibus uestris impressum ${ }^{67}$ nam quottidie sanctos uestros praeponitis omnibus nobis ${ }^{68}$.

Et ego dixi: Domine mi, ego semper credidi meum patrem beatum ${ }^{69}$ Franciscum maiorem esse omnibus angelis. Et contentio fuit quis maior esset, Franciscus an Ioannes Baptista et Petrus apostolus ${ }^{70}$.

Gabriel respondit ${ }^{71}$ : Magnus est uir ille. Respice ad latus dextrum et uidebis eum.

Respexi et inter apostolos uidi ipsum et plurimos alios et dixi: Domine mi, nonne duodecim sunt apostoli? Et Paulum et Barnabam, Lucam et Marcum ${ }^{72}$ connumerando ${ }^{73}$ sexdecim? Ego autem uideo inter illos ${ }^{74}$ plurimos alios.

Respondit: Nonne audisti in Euangelio: "Vos qui reliquistis omnia et secuti estis me, sedebitis super sedes duodecim"? Et centum et mille, quotquot tales fueritis sicut fuerunt ${ }^{75}$ tunc illi qui dixerunt ${ }^{76}$ : "Ecce relinquimus omnia et secuti sumus te ${ }^{77 "}$ ".

Postquam itaque tremebundus simul ac laetus Dominum, Regem nostrum, et Reginam utroque poplite cum maxima reuerentia adoraui, quod subito feci ut ipsum inspexi, dixit ${ }^{78}$ angelus: quia cum angelo loqueris, de angelis loquamur. Accipe de nostra creatione secundam reuelationem.

Tunc ego: Accipiam, mi Domine, si dicere placuerit.

De creatione ${ }^{79}$ nostra, inquit ille, uario modo ${ }^{80}$ locuti sunt etiam sancti Dei homines. Philosophi nonnulli ${ }^{81}$ putauerunt nos aeternos et naturae diuinae ${ }^{82}$ esse ita quod ${ }^{83}$ nullo modo possemus deficere, non cognoscentes $^{84}$ solum Deum esse [f1. 5] regem seculorum ex se immortalem. Sed isti qui Verbi Dei fidem sequuntur alii putauerunt nos fuisse creatos per multa saecula ante totum mundum sensibilem ${ }^{85}$, alii tam tarde quod post hominem ${ }^{86}$, alii prima die simul cum caelo empyrio. Sed Deus, quem illi scalae innixum uides, haec pastorem suum promulgare uult omnibus populis nos angelos simul cum caelo empyrio fuisse creatos per multa saeculorum ${ }^{87}$ intelligibilia saecula ${ }^{88}$ ante omnem diem illorum sex dierum, hoc est, ante aliarum rerum productionem et distinctionem ${ }^{89}$. Et hoc est quod dixit senex ille, et ostendebat ${ }^{90}$ Moysen: "In principio creauit Deus caelum et terram". In

66 omnes qui dicuntur superiores angeli. Dictum tamen illud] omnes qui dicuntur superiores angeli. Hoc tamen $E$; omnes dicuntur superiores. Angeli dictum tamen $V \mathbf{6 7}$ impressum] expressum ILR 68 praeponitis omnibus nobis] praeponit in omnibus nobis $V 69$ patrem beatum Franciscum] patrem Franciscum $N$; patrem sanctum Franciscu $P \mathbf{7 0}$ et Petrus apostolus] et Petrus apostolus, quos tamen angelos omnes anteire (credebant $C$ ) credebam $C F H$ ( $M$ in marg. a. $m$.) $Q 71$ respondit] dixit $L R 72$ Marcum] Matthaeum $L$ (cor. in marg. a. m. Marcum) 73 connumerando sexdecim] numerando sexdecim $C$; sexdecim $E$; connumerabo sexdecim $P$; numerabo sexdecim $Q \quad 74$ illos] ipsos ILR; istos $P \mathbf{7 5}$ fuerunt] fuerant BIFLNR $\mathbf{7 6}$ sicut fuerunt illi qui tunc dixerunt] sicut fuerunt. Tunc illi dixerunt $V 77$ secuti sumus te.] secuti sumus te. Et omnes numerati nomine duodecim apostolorum suo modo uocantur $C$; secuti sumus te. $E$ t omnes in XII sedibus sedent quia omnes meritis (nuntiis F) XII apostolorum suo modo coaequantur. FH (M in marg. a. $m$.); secuti sumus te. Et omnes in duodecim sedent quia omnes numerantur nomine duodecim apostolorum suo modo uocantur $Q \mathbf{7 8}$ feci ut ipsum inspexi, dixit] feci cum ipsum inspexi. Dixit $F$; feci ut ipsos inspexi $F H$; feci ut ipsum inspexi. Dixit $P$; feci ut ipsum respexi, dixit $C J Q$; feci, ipsum respexi. Dixit $V \rightarrow$ 
nome de arcanjo um coro segundo a linha ascendente, mas todos aqueles que são considerados anjos superiores. Este preceito, contudo, não foi impresso em vossos corações, já que todos os dias antepondes os vossos santos a todos nós.

Meu senhor, disse eu, sempre acreditei que meu pai S. Francisco fosse maior que todos os anjos, tendo-se levantado uma discussão sobre quem seria maior, se Francisco, se João Baptista ou o apóstolo Pedro.

É grande este homem, respondeu Gabriel! Olha à direita e vê-lo-ás.

Olhei e vi-o a ele e a muitos outros no meio dos apóstolos, e disse: Meu senhor, não são doze os apóstolos? Dezasseis, se contarmos Paulo e Barnabé, Lucas e Marcos? Mas eu vejo entre eles muitos outros.

Não ouviste no Evangelho, respondeu: Vós, que deixastes tudo e me seguistes, estareis sentados sobre doze tronos ${ }^{[8]} \mathrm{E}$ cem e mil, tantos quantos fordes como foram os que então disseram: Eis que deixámos tudo e te seguimos?[9]

Depois de, com a máxima reverência e de joelhos em terra, adorar, tremendo e ao mesmo tempo alegre, o Rei, nosso Senhor, e a Rainha, o que fiz logo que o vi, disse o anjo: já que falas com um anjo, falemos dos anjos. Recebe a segunda revelação, esta sobre a nossa criação.

Recebê-la-ei, meu Senhor, se te aprouver falar, respondi.

Sobre a nossa criação, disse ele, falaram de modo diferente mesmo santos homens de Deus. Alguns filósofos julgaram que fôssemos eternos e de natureza divina a ponto de não podermos deixar de existir, ignorando que só Deus é senhor [f1. 5] do tempo, imortal por natureza. Mas destes, os que seguem a fé do Verbo de Deus, julgaram uns que nós fomos criados muitos séculos antes de todo o mundo sensível. Outros, tão tarde que só depois do homem. Outros, no primeiro dia, conjuntamente com o Céu Empíreo. Mas Deus, a quem vês sentado naquele trono, quer que seja levado pelo seu Pastor ao conhecimento de todos os homens isto: que nós anjos fomos criados em simultâneo com o Céu Empíreo por muitos e perceptíveis séculos dos séculos antes de qualquer um dos dias daqueles seis dias, ou seja, antes da formação e da diferenciação das outras coisas. É isto

$\leftarrow 79$ si dicere placuerit. De creatione] si dicere placuerit. De creatione angelorum. De creatione $B$ (G in marg. a. m.) K (in marg.); si dicere placuerit. $2^{\mathrm{a}}$ Reuelatio. De creatione $H$ (in marg. a. m.); si dicere placuerit. De $2^{\mathrm{a}}$ reuelatione Angelorum et creatione. De creatione $L$; si dicere placuerit. Secunda reuelatio. De creatione $E P 80$ uario modo] in uario $P 81$ nonnulli] aliqui $F N 82$ diuinae] diuina $N$; diuinos $P \mathbf{8 3}$ ita quod] itaque $H J M 84$ cognoscentes] considerantes $F$ (M sup.lin. a. m.) 85 sensibilem] sensibilem et omne corporeum $F H$ ( $M$ in marg. a. $m$.) $Q \mathbf{8 6}$ sensibilem, alii tam tarde quod post hominem, alii] sensibilem, alii $Q$; sensibilem, alii tam tarde quod post creationem, alii $N 87$ multa saecula ante (...) fuisse creatos per multa saeculorum intelligibilia] multa saecula intelligibilia $C \mathbf{8 8}$ per multa seculorum intelligibilia saecula] per multa tempora intellegibilia saecula $K$; per multa saeculorum intelligibilia saecula, quia tempus non erat $F$ ( $M$ in marg. a. $m$.) 89 productionem et distinctionem] productionem $C Q \mathbf{9 0}$ ostendebat] ostendit $Q$

[8] Mt 19:28

[9] Mt 19:27 
principio, hoc est, longe ante omnem diem ${ }^{91}$, neque scitur numerus illius durationis, ideo scriptum est: "Et dies saeculi quis enumerabit"2", creauit Deus ${ }^{93}$ caelum et caelicolas, habitationes ${ }^{94}$ et habitatores et terram. Non elementum infimum, sed terram, hoc est, materiam primam. Et ita nos angeli per multa saecula, antequam uos homines essetis ${ }^{95}$ creati, laudauimus nomen Domini. Vnde scriptum est: Vbi eras tu quando me laudabant astra matutina?

Tunc ego: Nonne omnia opera Dei facta sunt in sex diebus?

Respondit: A principio illo terrae et caeli ${ }^{96}$ creationis, terra, idest materia, stetit et mansit inanis et uacua et super eam erant tenebrae idest confusio et chaos, quia et omnia producenda erant in ipsa confusa. Et super eam ferebatur Spiritus Domini, quia uoluntas eius et bonitas erat parata communicare etiam aliis quam nobis angelis ueritatem et bonitatem et esse. Creatio igitur nostra et caeli et terrae seu abyssi uel aquae, hoc est, materiae primae, fuit ante omnem diem illorum sex dierum. Quando ergo placuit Deo, dixit: "Fiat lux. Et facta est lux. Et uidit Deus lucem quod esset bona. Diuisitque ${ }^{97}$ lucem a tenebris. Appellauit lucem diem et tenebras noctem. Et factum est uespere et mane dies unus". A creatione igitur lucis illius incepit prima dies.

Tunc ego: Domine mi, fueruntne illi dies unus post alium?

Respondit: Fuerunt unus post alium, neque Deus uoluit omnia facere simul, cum tamen potuisset. Sicut enim omnia simul uoluit in aeternitate et omnia opera sex dierum ${ }^{98}$ ex eadem materia produxit, sic poterat omnia simul producere ${ }^{99}$, sed noluit ${ }^{100}$.

Tunc ego: Quae fuit ${ }^{101}$ lux illa ${ }^{102}$ sic ante alia creata, non possum intelligere?

Respondit: Multis modis apud uos dicitur. [f1. 6] Sed ego dico tibi quod fuit Sol iste corporeus qui omnia illuminat et est tamquam oculus mundi ${ }^{103}$ et causa praecipua rerum generabilium. Et illa die facti sunt omnes caeli planetarum et caelum quod sub caelo empyrio est, quod uos uocatis primum mobile, quia caelum empyrium immobile est et firmum ac stabile, domus ac locus includens omnia corpora ${ }^{104}$. Dico tibi, frater, quod philosophus habuit ${ }^{105}$ magnum dubium

91 omnem diem, neque scitur] omnem diem et ante omnia neque scitur $H$; omnem diem ac si dixisset primum et ante omnia, neque scitur $C F$ ( $M$ in marg. a. $m$.) $Q 92$ enumerabit] numerauit $C$; enumerauit $N$; dinumerabit $E R V$; connumarabit $J$; dinumerauit $K 93$ Deus] Dii, hoc est, trinus Deus $F$ ( $M$ in marg. Dii, hoc est, trinus) 94 habitationes et habitatores] habitationem et habitatorem $M$; habitationem et habitatores EFJKP; habitationes et habitantes $Q 95$ essetis creati] essetis et alia creati $F$; essetis et alia creata $C Q 96$ a principio illo terrae et caeli] in principio illo naturae et caeli $B$; a principio illo nostrae creationis et caeli $C$; a principio illo caeli et nostrae $H I N Q R$; a principio illo naturae et caeli $G O$; a primo illo nostri et caeli $L$; a principio ideo tempore et caeli $P$; a principio illo tempore et caeli $V 97$ esset bona. Diuisitque] esset bona quod uidelicet haberet bonitatem et esse ex causa in seipsa. Diuisitque $H$; esset bona, non quod uidelicet haberet bonitatem et esse extra causam in seipsa. Diuisitque $F$ ( $M$ in marg. a. $m$.) 98 sex dierum] sex $\rightarrow$ 
o que disse aquele ancião, e apontava Moisés: No princípio criou Deus o Céu e a Terra ${ }^{[10]}$ No princípio, isto é, muito antes de qualquer tempo, nem se conhece a medida dessa duração, por isso está escrito: $E$ os dias do tempo, quem poderá contá-los, ${ }^{[11]}$ criou Deus o Céu e os seus moradores, habitações e habitantes, e a Terra. Não o elemento menos nobre, mas a Terra, isto é, a matéria prima. E, assim, nós anjos louvámos por longos séculos o nome do Senhor antes de vós homens serdes criados. Daí o estar escrito: Onde estavas tu quando me louvavam os astros da manhã? [12] $^{2}$

Não foi, perguntei eu, toda a obra de Deus realizada em seis dias?

Desde o princípio da criação da Terra e do Céu, respondeu, a Terra, ou seja, a matéria, esteve e manteve-se inane e vazia. Sobre ela permaneciam as trevas, ou seja, a confusão e o caos, pois que tudo quanto havia de produzir-se estava nela amalgamado. Sobre ela pairava o Espírito do Senhor, porque a sua vontade e a sua bondade estavam preparadas para comunicar também a outros que não só a nós anjos a verdade, a bondade e o ser. Por isso a nossa criação e a criação do Céu, da Terra ou do Abismo ou das Águas, isto é, da matéria-prima, aconteceu antes de qualquer um dos dias daqueles seis. Mas quando aprouve a Deus, disse: Faça-se a luz. E a luz foi feita. E viu Deus que a luz era boa e separou a luz das trevas. À luz chamou dia e às trevas noite. Houve uma tarde e uma manhã. Foi o primeiro dia. ${ }^{[13]} \mathrm{O}$ primeiro dia começou a partir da criação dessa luz.

Meu senhor, perguntei eu, foram ou não aqueles dias um depois do outro?

Foram um depois do outro, respondeu, e nem Deus quis tudo fazer ao mesmo tempo, embora o tivesse podido. Assim como tudo quis ao mesmo tempo na Eternidade e realizou em seis dias, a partir da mesma matéria, todas as obras, assim teria podido tudo produzir ao mesmo tempo. Mas não quis.

Não posso entender que luz foi essa, criada assim antes da outra, disse eu.

Entre vós explica-se de muitas maneiras, respondeu. [fl. 6] Mas eu digo-te que foi esse Sol material que ilumina tudo e é como que o olho do mundo e a causa principal das coisas susceptíveis de serem geradas. Naquele dia foram criados todos os Céus dos planetas e o Céu que se situa abaixo do Céu Empíreo, a que chamais primeiro Céu Móvel, já que o Céu Empíreo é imóvel, firme e estável, morada e lugar que inclui todos os corpos. Digo-te, irmão, que o filósofo teve grandes dúvidas

$\leftarrow$ dierum in eadem materia simul creauit $C F$ ( $M$ in marg. a. m.) $Q$; sex dierum ex eadem materia simul creauit et $H 99$ producere] facere $I L R$; facere disiunctim $C$; facere disiuncte $Q$; facere distincte $H \mathbf{1 0 0}$ sed noluit] sed noluit ut se uoluntarie et non necessario creaturas producere insinuaret $C F$ ( $M$ in marg. a. m.) $Q$; sed noluit ut se uoluntarie et non necessario creaturas producere et unam sine alia insinuaret. $H 101$ Que fuit] Qua fuerit $N 102$ lux illa] lux prima $P 103$ oculus mundi] oculus mundus $V 104$ corpora] corporea IJLOQRV 105 philosophus habuit] philosophis fuit $O$

\footnotetext{
[10] Gn 1:1

[11] Eccli 1:2

[12] Job 38:4.7,

[13] Gn 1:3-4.
} 
quomodo possent omnes caeli moueri et maxime primum caelum ${ }^{106}$ quod non est in loco ${ }^{107}$. Tu, audi me: non potuissent moueri corpora caelestia nisi fuissent in loco ${ }^{108}$ in quo essent clausa, ipso in quiete permanente, et ipsum etiam moueri posset $^{109}$ si ab alio circumdaretur loco. Eadem die creauit Deus omnia elementa. Solum noluit creare firmamentum, hoc est, caelum stellatum neque uoluit creare Lunam neque alias stellas, sed reseruauit creationem illorum pro aliis diebus. Et tunc ex nostris fratribus angelis cuilibet caelo dedit proprium motorem ${ }^{110}$. Motus enim est ab uno fratre nostro Sol iste radians illa die ${ }^{111}$ absque impulsu firmamenti. Nondum enim erat firmamentum. Et sic primum mobile, quod prophetae caelum aqueum $^{112}$ uocant $^{113}$, non contingebat caelos planetarum, sed erat distantia nimis magna inter caelos planetarum et caelum ${ }^{114}$ aqueum. ${ }^{115}$ Motus est Sol a primo puncto in quo fuit creatus et peruenit ad ultimum illius hemispherii quod est iuxta paradisum uoluptatis. Et sic $^{116}$ transiuit ad hemispherium aliud. Et quousque rediit ad punctum creationis, fluxerunt uiginti quattuor horae. Et sic a primo mane, perueniendo ad aliud, transeundo per uesperam, factus est dies primus. ${ }^{117}$

In hac prima $\operatorname{die}^{118}$, primo creauit Solem cum suo orbe ${ }^{119}$, deinde caelum ${ }^{120}$ aquarum quod etiam cristalinum uocare consueuistis, deinde caelos planetarum cum locis ${ }^{121}$ deputatis planetis, postea quattuor elementa ita quod Sol in illo hemispherio paradisi per duodecim horas non fuit uisus. Deinde coepit oriri et tunc incepit alia dies in qua Deus fecit firmamentum, caelum uidelicet medium ${ }^{122}$ inter caelos planetarum et caelum aquarum. Et designauit quasi globos omnibus stellis $^{123}$ quas tamen tunc perficere noluit ${ }^{124}$.

106 primum caelum] primum mobile $G$ ( $Q$ add. mobile) 107 in loco.] in loco. Moueri autem in loco et in loco non esse non bene conueniunt. FH (M in marg. a. $m$.) 108 in locol in loco, hoc est, in alio corpore. $C F H$ (M in marg. a. $m$.) $Q 109$ posset] possit $P 110$ proprium motorem.] proprium motorem ut inclinationem talium corporum ad talem motum perficerent ueluti siquis graue deorsum aut leue sursum impelleret quasi coadiuuando et dirigendo. $F$; proprium motorem ut inclinationem talium corporum ad talem motum perficeret ueluti siquis graue deorsum aut leuem sursum impelleret quasi readiuuando et dirigendo. $H$; proprium motorem ut inclinationem talium corporum ac talem motum perficerent ueluti siquis graue deorsum aut leuem sursum propelleret quomodo adiuuando et dirigendo. $M($ in marg. $a . m$. $) 111$ illa die] illa die qua factus est. $E 112$ aqueum] magnum $J 113$ uocant] nominant $N 114$ planetarum, sed erat distantia nimis magna inter caelos planetarum et caelum] planetarum, sed nominant distantia nimis magna inter caelos planetarum et caelum $N$; planetarum, $B G J 115$ caelum aqueum.] caelum aqueum. Distantia illa non est sine re aliqua inclusa inter ea quae distant, in quo theologi uestri non intellexerunt ueram mentem philosophi, ponentes uacuum, de quo fuit sermo. Res illa erat materia extensa de qua firmamentum erat producendum. Vnde postquam caelum empyrium fuerat creatum, materia illa implebat omnia quae nunc implent elementa et caelestia corpora. $F$ ( $M$ in marg. a. $m$.) 116 Et sic] ex hic $C Q 117$ dies primus.] dies primus. Et tunc etiam caeli superiores sunt moti quia erant in loco quamuis non proprio quia sub materia extensa ex qua creandus erat locus proprius planeta Saturni. Distantia uero non est sine re aliqua inclusa inter ea quae distant, in quo theologi uestri non intellexerunt ueram mentem, philosophi ponentes uacuum, de quo fuit sermo. Res illa erat materia extensa de qua firmamentum erat producendum. Vnde postquam caelum empyrium fuerat creatum, materia illa implebat omnia quae nunc implent elementa et caelestia corpora. $H$; dies primus. Et tunc etiam caeli superiores fuerunt moti quia erant in loco quamuis non $\rightarrow$ 
quanto ao modo como todos os Céus se poderiam mover, sobretudo o Primeiro, que não está num lugar. Ouve-me tu. Não poderiam mover-se os corpos celestes, a menos que se situassem num lugar em que estivessem circunscritos, estando este em quietude contínua. E este poderia também mover-se, se fosse circundado por outro lugar. No mesmo dia Deus criou a totalidade dos elementos, só não quis criar nem o firmamento, isto é, o Céu Estrelado, nem a Lua, nem as outras estrelas, mas reservou a respectiva criação para outros dias. E, então, atribuiu a cada Céu como motor próprio um dos nossos irmãos anjos. Este Sol que brilhou naquele dia sem o impulso do firmamento (o firmamento ainda não existia) foi, pois, movido por um dos nossos irmãos. E, assim, o primeiro Céu Móvel, a que os profetas chamam Céu das Águas, não atingia os Céus dos Planetas, mas era tremendamente grande a distância entre ambos. O Sol pôs-se em movimento do primeiro ponto em que fora criado e atingiu o extremo daquele hemisfério que está junto do Paraíso das Delícias, passando, assim, a outro hemisfério. E, até ter voltado ao ponto da criação, decorreram vinte e quatro horas. Assim, desde a primeira manhã, passando pela tarde, até ao nascer do Sol seguinte, aconteceu o primeiro dia.

Neste primeiro dia criou primeiro o Sol com a sua órbita, criou depois o Céu das Águas, a que vos habituastes a chamar Cristalino, seguidamente criou o Céu dos Planetas, com lugares assinalados para estes, depois os quatro elementos, de tal modo que naquele hemisfério do Paraíso se não viu o Sol por doze horas. Depois, começou a nascer e iniciou-se então o segundo dia, no qual criou Deus o firmamento, ou seja, o Céu intermédio entre os Céus dos Planetas e o das Águas. E traçou como que o círculo de todas as estrelas que, contudo, não quis criar então.

$\leftarrow$ proprio quia sub materia extensa ex qua creandus erat locus proprius planeta Saturni. $F$ ( $M$ in marg. a. m.) 118 prima die,] prima die, et non simul, creauit omnia ista sed $F$ ( $M$ in marg. $a$. m.) 119 cum suo orbe] cum suo orbe tamquam mensuram diei et noctis $H$ ( $M$ in marg. a. m.) 120 deinde caelum] deinde caelum uel caelos aquarum. Dicunt enim uestri prophetae in plurali numero aquae que super caelos sunt $F \mathbf{1 2 1}$ cum locis] cum globis et locis $F H$ (M sup. lin. a. m.) 122 caelum uidelicet medium] caelum, uersus medium $L \mathbf{1 2 3}$ omnibus stellis] omnibus stellis. Et tunc etiam caeli superiores fuerunt moti quia erant in loco quamuis non proprio quia sub materia extensa ex qua creandus erat locus proprius planetae Saturni. Distantia uero non est sine re aliqua inclusa inter ea quae distant, in quo theologi uestri non intellexerunt ueram mentem (philosophi ponentis $C$ ) ibi ponentes uacuum, de quo fiet sermo. Res illa erat materia extensa de qua formam entium erat producendum. Vnde postquam caelum empyrium fuerat creatum, materia illa implebat omnia quae nunc implent elementa et caelestia (corporea $C$ ) corpora. In hoc uero primo die et non simul creauit omnia ista sed perficere noluit $C Q$; omnibus stellis. Et tunc etiam caeli superiores sunt moti quia erant in loco quamuis non proprio quia sub materia extensa ex qua creandus erat locus proprius planeta Saturni. Distantia uero non est sine re aliqua inclusa inter ea quae distant, in quo theologi uestri non intellexerunt ueram mentem, philosophi ponentes uacuum, de quo fuit sermo. Res illa erat materia extensa de qua firmamentum erat producendum. Vnde postquam caelum empyrium fuerat creatum, materia illa implebat omnia quae nunc implent elementa et caelestia corpora. $H \mathbf{1 2 4}$ perficere noluit] perficere noluit. Sed successiue in tota secunda die produxit signa duodecim et alias stellas uisu perceptibiles ac imperceptibiles in globis. Itaque globos omnium siderum astrorum uel stellarum non simul produxit sed sucessiue. $H$; perficere noluit. Nec haec omnia simul fecit, sed successiue. In tota secunda die produxit signa XII et alias stellas uisu perceptibiles et imperceptibiles in globis suis, $\rightarrow$ 
Vide, conserue Dei, quod Deus poterat facere et fecit ut caelum inferius moueretur superiori non moto, immo non existente, et quia mirabile est et mirificum ${ }^{125}$ illud caelum in quo posuit Deus duodecim signa et omnes stellas. Iccirco illud sicut et empyrium uoluit una $\operatorname{die}^{126}$ [fl. 7] solum ${ }^{127}$ creare et condere ut ostendat ${ }^{128}$ omnia esse ab ipso et quod posset ${ }^{129}$ uni sine alio dare esse ${ }^{130}$. "Magnus est Deus noster et magnitudinis eius non est finis ${ }^{131}$ ", declarabit pastor Dei et ostendet haec populis et linguis et omnes laudabunt nomen Domini.

Noli per firmamentum illum locum intelligere ubi nubes condensantur, quia illud $^{132}$ non est caelum neque in eo Deus posuit stellas ${ }^{133}$. Sed caelum sidereum dicitur firmamentum et ipsum est praecipue nominatum caelum, quia primum inter uisibilia et altissimum et admirande uirtutis et potestatis ${ }^{134}$.

Tunc ego recordatus sum quod die quarta fecit Deus duo luminaria magna et dixi: Domine mi, nonne quarta die factus est Sol?

Dixit: Quarta die fecit Deus luminaria in firmamento, quod est caelum praecipuum, ut uirtute sua ad inferiora transfusa preessent his inferioribus et ostenderent ${ }^{135}$, lucendo in nocte et non in die in conspectu Solis, diuisionem diei et noctis et pluribus earum ${ }^{136}$ coniunctionibus inter se et ${ }^{137}$ cum planetis fierent signa multorum euentium et distinguerent tempora, dies et annos ${ }^{138}$. Nam aliqui dies et anni et aliqua tempora sunt unius condicionis et aliqua alterius. ${ }^{139}$

Quarta igitur die facta sunt ${ }^{140}$ omnia caelestia luminaria praeter Solem, qui prima die creatus est, non tantum quia uideatur ${ }^{141}$ praestantior aliis luminaribus, sed propter distinctionem diei et noctis et unius diei ab alio. Quando ${ }^{142}$ ergo dicitur: "Fecitque Deus duo luminaria magna", non dicit ${ }^{143}$ quod utrumque fecerit illa die, sed enumerat ${ }^{144}$ luminaria facta. Et prima die et quarta die fecit Deus inter alia luminaria duo apud uos homines maiora uisu et notiora necnon et admirabiliora. ${ }^{145}$

$\leftarrow$ ita quod globos omnium siderum, astrorum uel stellarum non simul produxit sed successiue. $F$; perficere noluit. Nec haec omnia facta sunt successiue in toto. Secunda die produxit signa XII et alias stellas uisu perceptibiles et imperceptibiles in globis suis ita quod globos omnium siderum et astrorum uel stellarum non simul produxit sed successiue. $M$ in marg. $a$. $m$. 125 mirificum] magnificum $B \mathbf{1 2 6}$ uoluit una die] uoluit ante omnem diem una die $F H 127$ solum] solem $C$; tota $F \mathbf{1 2 8}$ ut ostendat] et ostendit $Q 129$ et quod posset] potest $E$; et potuit $C Q 130$ dare esse.] dare esse. Et iste fuit ordo prius ante tempora (et tempore $F$ ). Sed (licet $F$ ) eadem die creauit Solem cum orbe suo, deinde 4 or elementa, $3^{\circ}$ caelos planetarum superiorum et tum moueri quasi in loco proprio existens, quarto caelos planetarum inferiorum ad hoc ut ostenderet se posse sine superioribus inferiora et producere et gubernare et quia nisi terra interueniente non fieret diuisio diei et noctis, prius creauit Terram et allia elementa. $F$ ( $M$ in marg. a. $m$.) 131 finis] numerus $L$ 132 illud] illum $C Q \mathbf{1 3 3}$ posuit stellas] posuit stellas neque firmamentum apud prophetas dicitur supremum caelum. FH ( $M$ in marg. a. $m$.) 134 potestatis] potestas $R 135$ ostenderent] ostenderet $G P 136$ earum] eorum $E O 137$ et] quod $P 138$ tempora, dies et annos] ipsa dies et annos $J 139$ sunt unius condicionis et aliqua alterius.] sunt paene consimilis condicionis, aliqua dissimilis $F$; sunt paene similes et unius condicionis et aliqua dissimilis et alterius $H \mathbf{1 4 0}$ Quarta igitur die $\rightarrow$ 
Vê, servo de Deus como eu, o que Deus podia fazer e o que fez para que o Céu inferior se movesse sem se mover, ou melhor, não existindo, o superior. Vê que é admirável e maravilhoso o Céu em que Deus situou os doze signos e todas as estrelas. Por isso quis criá-lo e formá-lo a ele e ao Céu Empíreo num só dia, [f1. 7] para mostrar que tudo dele depende e que podia dar o ser a um sem o dar a outro. É grande o nosso Deus e insondável a sua grandeza, ${ }^{[14]}$ declará-lo-á o Pastor de Deus, que dará estas coisas a conhecer a povos e línguas. E todos louvarão o nome do Senhor.

Não entendas por firmamento aquele lugar onde as nuvens se condensam, pois que esse não é o Céu, nem nele pôs Deus as estrelas. Mas chama-se firmamento ao Céu Sideral. É este que precisamente se designa Céu, porque é o primeiro entre as realidades visíveis, é sublime, de admirável força e poder.

Recordei-me então de que no quarto dia fez Deus os dois luminares grandes e disse: Meu senhor, não foi o Sol feito no quarto dia?

No quarto dia, disse o anjo, fez Deus os luminares no firmamento, que é o Céu Superior, a fim de que pela sua força transmitida aos inferiores presidissem a esses mesmos inferiores e mostrassem, brilhando de noite e não de dia perante o Sol, a divisão do dia e da noite e, pelas conjunções deles entre si e com os planetas, se tornassem sinais de muitos acontecimentos e distinguissem os tempos, os dias e os anos. Pois alguns dias e anos e alguns tempos são de uma criação, outros são de outra.

Portanto, no quarto dia foram criados todos os luminares celestes, excepto o Sol, que foi criado no primeiro dia. Não que pareça superior aos outros luminares, mas por causa da distinção do dia e da noite, e de um dia relativamente a outro. Quando, pois, diz: criou Deus os dois luminares grandes ${ }^{[15]}$, não diz que os criou a ambos naquele dia, mas enumera os luminares criados. No primeiro e no quarto dia criou Deus, entre outros luminares, os dois visivelmente maiores para vós homens, os mais notáveis e os mais admiráveis.

$\leftarrow$ facta sunt] Quarta igitur die non solum omnes stellae sed facta sunt $F H$ ( $M$ in marg. $a$. $m$.) 141 uideatur] uidetur $C$; uidebatur EIR 142 alio. Quando] alio, quoniam $L M 143$ non dicit] non dixit $C Q 144$ enumerat] commemorat $F M \quad 145$ et admirabiliora.] et admirabiliora. Luminare quidem maius quod praeesset diei quia, illo existente super (supra $F$ ) uos, esset uobis dies, et luminare minus ut praeesset nocti, quia (quod $F$ ) in absentia Solis lumen suum mutuatum diffunderet, et stellas quas omnes quandoque, planetis exceptis, posuit in firmamento caeli, hoc est, in caelo quod dicitur permanentem (firmamentum $F$ ) ut luceant super Terram et lumine suo atque influxu continuo praeessent toti Terrae die et nocte et diuiderent lumen (lucem $F$ ) a tenebris. Et (quia $F$ ) dum super (supra $F$ ) uos lucent, uno modo in uos influunt, dum a uobis absconduntur occidendo, alio uos respiciunt. Et uidit Deus quod omne (illa die add. F) sic creatum esset bonum sicut et aliis quia habebat bonitatem et esse in se, eum et intellectum (extra causam $F$ ) et ea quae semper $\rightarrow$

\footnotetext{
[14] S1 144:4,

[15] Gn 1:16
} 
Rediens ad cauernam meam, uocato a Deo praeparato mihi scriptore ${ }^{146}$, haec pro futuro pastore ${ }^{147}$, Domino iubente, subito scribi feci.

$\leftarrow$ uiderat ut futura tunc uidit (ut existentia add. F). F (M in marg. a.m.) 146 scriptore.] scriptore, Franciscus Blondus $C \mathbf{1 4 7}$ scriptore, haec pro futuro pastore, Domino] scriptore, Domino $C N Q$ 
Voltando à minha gruta e chamado por Deus o secretário preparado para mim, obedecendo à ordem de Deus, mandei de imediato escrever estas coisas destinadas ao futuro Pastor. 


\section{SECVNDVS RAPTVS ${ }^{1}$}

Raptus sum alia die et inueni me in rota sanctorum cateruatim Deo astantium ${ }^{2}$. Et angelus Gabriel ${ }^{3}$ acessit prope me dixitque mihi: Noli metuere ${ }^{4}$. Inuenisti enim gratiam Dei ${ }^{5}$ et hi omnes ${ }^{6}$ te diligunt. Bene fecisti conscribendo ea quae tibi iam dixeram. Sed dic mihi quid ${ }^{7}$ dubitas in scriptura et docebo te, quia futurum est ut omnes gentes haec sciant.

Dixi ego: Quid possum dubitare qui nihil scio? Multotiens tamen cogitaui mecum quomodo aliqui uestrum peccauerunt ${ }^{8}$, quomodo Deo rebellare potuerunt, unde tanta praesumptio subrepserit ${ }^{9}$.

Angelus dixit: Hoc hominibus [f1. 8] etiam ignotum est. Vos dicitis: "Angeli peccauerunt", et uerum dicitis. Sed cur et qualiter ignoratis. Dicam tibi. Scribe et conscripta haec custodi, ut pastor sciat quid sit docturus populum suum. Nos angeli omnes non in paruis et breuibus morulis, ut uos creditis, sed multis temporibus uiatores fuimus. Cognoscebamus Deum distincta cognitione per impressam nobis a principio ipsius similitudinem. Tamen non uidebamus eum. Cognitione illius in similitudine beati eramus, non in se. Ipsum enim cognoscebamus ${ }^{10}$ et, ipso agnito $^{11}$, per ipsum omnia alia cognoscebamus. Non ergo, ut homines putant, singulas rerum similitudines habebamus neque plures ${ }^{12}$ aut pauciores, sed omnes una Dei similitudine et ipsum et omnia alia intelligebamus ${ }^{13}$, omnes in gratia ipsius eramus et illi seruiebamus. Deus igitur conditor noster, ut nos probaret et probatos aliis declararet, ut $^{14}$ humiles exaltaret et superbos humiliaret ${ }^{15}$ (audi rem mirabilem), apparuit nobis in forma talis hominis qualem postea assumpsit. Et nos agnouimus formam in qua nobis apparebat ${ }^{16}$ et sciebamus illam non esse formam suam. Tunc dixit nobis: Audite me, angeli mei, audite et percipite quae loquor ad uos. Nunquid cognoscitis quis ego sum? Numquid nostis ${ }^{17}$ formam et

1 Secundus Raptus] Tertia reuelatio $P ; o m . V 2$ astantium] assistentium EFIJKLQV 3 angelus Gabriel] angelorum. Gabriel $V \quad 4$ metuere] timere $N Q \quad 5$ Dei] apud Deum $E$; coram Deo $Q \quad 6$ omnes] homines $V 7$ mihi quid] mihi siquid $E F G H I K L N O P Q 8$ peccauerunt] peccauerint $N 9$ subrepserit] surrexerit $Q \quad \mathbf{1 0}$ cognoscebamus] agnoscebamus FGINP $\mathbf{1 1}$ Tamen non uidebamus eum. (...) cognoscebamus et, ipso agnito] Tamen non uidebamus eum. Cognitione illius in similitudinem beati eramus. In seipsum non cognoscebamus, et ipso agnito $K$; Non tamen $\rightarrow$ 


\section{Segundo Arrebatamento}

Fui arrebatado noutro dia e achei-me na Assembleia dos santos que, em grupo, se mantinham de pé diante de Deus. Aproximou-se de mim o anjo Gabriel e disse-me: Não receies. Na verdade, achaste graça diante de Deus, e todos estes te amam. Fizeste bem em escrever quanto te havia dito. Mas diz-me, se acaso tens alguma dúvida em relação ao que escreveste, que eu te esclarecerei, porque vai acontecer que todos os povos conheçam estas coisas.

Que dúvidas posso eu ter, respondi, se nada sei? Pensei muitas vezes comigo mesmo como é que alguns de vós pecaram, como puderam rebelar-se contra Deus, de onde lhes veio tão grande ousadia.

Também isso, disse o anjo, é desconhecido dos homens. [fl. 8] Vós dizeis: os anjos pecaram. E dizeis bem. Mas ignorais porquê e como. Vou dizer-to. Escreve e guarda esses escritos para que o Pastor saiba o que há-de ensinar ao seu povo. Todos nós, os anjos, fomos peregrinos, não por curtos e breves períodos, como julgais, mas por longo tempo. Conhecíamos a Deus com um conhecimento preciso, pela sua semelhança em nós impressa desde o princípio. Contudo, não o víamos. Éramos felizes pelo conhecimento que dele tínhamos em imagem, não em si. Conhecíamo-lo, pois. E uma vez ele conhecido, por meio dele conhecíamos todas as outras coisas. Não dispúnhamos, portanto, como os homens pensam, das imagens singulares das coisas, nem muitas nem poucas, mas na imagem única de Deus reconhecíamo-lo a ele e a todas as outras coisas. Reconhecíamos a Deus e tudo o mais. Estávamos todos na graça de Deus e servíamo-lo. Por isso Deus, o nosso Criador, para nos provar e, provados, dar o facto a conhecer a outros, para exaltar os humildes e humilhar os soberbos (ouve esta coisa admirável), apareceu-nos na forma do mesmo homem que depois assumiu. E nós reconhecemos a forma em que nos aparecia e sabíamos que aquela não era a sua for-

$\leftarrow$ uidebamus eum cognitione ipsius intuitiua. In similitudine bene eramus, non tamen ipsum in se ipso cognoscebamus, ipso sic agnito $E$; Tamen uidebamus eum cognitione illius. In similitudine illius, non in se, beati eramus naturali beatitudine. Ipsum quidem agnoscebamus sed, ipso agnito $H Q 12$ plures] pluries $V 13$ cognoscebamus. Non ergo, (...) et ipsum et omnia alia intelligebamus (cognoscebamus $H L$ ) et] cognoscebamus et $N \quad 14$ ut] et quod $E$; et $V 15$ humiliaret] deprimeret $E \mathbf{1 6}$ apparebat] apparuit $I L 17$ nostis] noscitis $P$; cognoscitis 
naturam in qua uobis appareo? Nos diximus: Nouimus te esse Deum conditorem nostrum, nouimus et formam illam esse formam hominis qui nondum creatus est et miramur de tam stupendo commercio, de tamque admirando ${ }^{18}$ consortio neque intelligimus quid sibi uelit ${ }^{19}$ ista apparitio. Dixit Deus: Vt sciatis et agnoscatis ${ }^{20}$ me decreuisse et magno consilio firmasse hominis naturam assumere uelle. Voloque homo esse et in utero unius mulieris concipi et ex ea nasci. Et aperuit nobis mentem ita quod percepimus ${ }^{21}$ quae nobis dicebat. Sed mirabamur quare id facere uellet.

Subdidit $^{22}$ : Ero homo ego et homo erit Deus. Et si Deus ergo et uester ${ }^{23}$ dominus, uester rex, uester princeps ${ }^{24}$. Et uos omnes subiciemini potestati eius, coletis eum et adorabitis sicut me. Quia ipse et ego una persona erimus, unica adoratione adorabimur a uobis. Illam quoque mulierem quam in matrem elegi praeponam omnibus uobis. Erit Regina uestra, honorabitis et coletis eam tamquam Genitricem Dei et Domini uestri. Hoc uolo, hoc mando, hoc uobis iubeo. Qui haec fecerint et facere uoluerint, ostendam eis faciem meam et gaudebunt in aspectu meo in quo est bonum omnis boni in sempiternum. Qui uero noluerint oboedire huic decreto [f1. 9] cadent a loco isto ad locum tenebrarum et nebularum et caliginum neque donis quibus uestiui $\operatorname{uos}^{25}$ ulterius potientur ${ }^{26}$, sed gratia mea priuabuntur et in locum detrudentur in quo manere nollent, immo abhorrebunt, et semper amoenitatem in qua nunc sunt cupient et nunquam habebunt.

His dictis, uisio illa disparuit.

Erant tunc nobiscum multi nobilissimi spiritus, inter quos unus praecipuus erat quem uos Luciferum ${ }^{27}$ appellatis. Hic primus incoepit ${ }^{28}$ alios alloqui, dicens: Quid uobis uidetur, fratres mei? Iustane ${ }^{29}$ sunt $^{30}$ mandata Dei nostri? Scitis quid sit homo et quid mulier? Nonne nos longe digniores sumus illis? Nonne genus nostrum superat genus humanum? Quae iustitia, quae pietas mouit Deum ut homo esse $^{31}$ uoluerit $\mathrm{et}^{32}$ non angelus? Cur homini omnes nos subicere uoluit potius quam uni nostrum? Ecce Michael magnus est. Ecce Gabriel. Et ego quam dignus $\operatorname{sim}^{33}$ uos uidetis. Noluit unum ${ }^{34}$ ex nobis assumere, noluit hanc sumam dignitatem alicui nostrum concedere. Ego eam uellem, ego Deus esse cupio. Valde ${ }^{35}$ maior sum homine, uolo ut homo me adoret, non ego hominem. Nunquam consentiam, nunquam adorabo, nunquam tale mandatum iustum putabo, nunquam aliquem eorum qui oppositum sentiunt amabo. Haec sententia mea est, hoc consilium, hoc decretum.

18 admirando] admirabile $Q \mathbf{1 9}$ quid sibi uelit] quid sit $L \mathbf{2 0}$ ut sciatis et agnoscatis] ut sciatis $E$; ut sciatis et cognoscatis GLOQV 21 ita quod percepimus] quod percipimus $F G J K$; qui percepimus $H$; ut perciperemus $Q 22$ Subdidit] Subdit $E J 23$ uester] uidetur $J \mathbf{2 4}$ Et si Deus ergo et uester dominus, uester rex, uester princeps] Et si Deus ergo et Deus uester, dominus uester, rex uester, princeps uester $E \mathbf{2 5}$ uos] eos HILNOQP 26 uestiui uos ulterius (amplius $F$ ) potientur] est $\rightarrow$ 
ma. Disse-nos então: Escutai-me, anjos meus, ouvi e prestai atenção ao que vos digo. Reconheceis acaso quem eu sou? Conheceis a forma e a natureza em que apareço perante vós? Sabemos que tu és Deus, o nosso Criador, dissemos nós. Sabemos também que essa é a aparência do homem que ainda não foi criado e admiramo-nos de tão espantosa relação, de ligação tão digna de admiração. E não compreendemos o que pretende esta aparição. Para que saibais e conheçais, disse Deus, que decretei e firmei por solene deliberação querer assumir a natureza humana. Quero ser homem, quero ser concebido no útero de uma mulher e dela nascer. E abriu-nos a razão de tal modo que compreendemos o que nos dizia. Mas admirávamo-nos porque é que queria fazer isso.

Acrescentou: Eu serei homem e o homem será Deus. E se Deus, logo, vosso senhor, vosso rei, vosso príncipe. E todos vós vos submetereis ao seu poder, venerá-lo-eis e adorá-lo-eis como a mim. Porque ele e eu seremos uma única pessoa, seremos por vós adorados numa única adoração. Anteporei também a todos vós aquela mulher que escolhi para mãe. Será vossa rainha, honrá-la-eis e venerá-la-eis como Mãe de Deus e de vosso Senhor. É isto que eu quero, é isto que mando, é isto que vos ordeno. Aos que fizerem e desejarem fazer isto, mostrar-lhes-ei a minha face e alegrar-se-ão na visão de mim, na qual reside o sumo bem para sempre. Os que não quiserem obedecer a este [f1. 9] decreto tombarão deste lugar para um lugar de trevas e nuvens e escuridão e não desfrutarão mais dos dons de que os revesti, mas serão privados da minha graça e precipitados num lugar onde não quererão permanecer, mais, odiá-lo-ão, desejando sempre a suavidade de que agora desfrutam, sem nunca a chegarem a ter.

Dito isto, aquela visão desapareceu.

Estavam então connosco muitos dos mais nobres espíritos. Entre eles estava um de primeira grandeza, a quem chamais Lúcifer. Foi o primeiro a exortar os outros, dizendo: Que vos parece, meus irmãos? Será que são justas as ordens do nosso Deus? Sabeis o que é o homem e o que é a mulher. Não seremos nós muito mais dignos do que eles? Não supera a nossa espécie a espécie humana? Que justiça, que piedade move Deus a querer ser homem e não anjo? Porque é que quis que todos nós nos submetêssemos a um homem e não a um de nós? Vede, Miguel é importante. Vede Gabriel! E vedes quão digno eu sou! Não quis assumir um de nós, não quis conceder esta suprema dignidade a nenhum de nós. Eu queria-a e desejo ardentemente ser Deus. Sou muito maior que o homem, quero que o homem me adore e não ser eu a adorar o homem. Jamais assentirei, nunca o adorarei, nunca reputarei como justa tal ordem, nunca quererei bem a nenhum daqueles que reconheça o contrário. Esta é a minha opinião, esta a minha deliberação, esta a minha decisão.

$\leftarrow$ unusquisque uestitus potietur $Q 27$ Luciferum] Lucifer $V \mathbf{2 8}$ incoepit] cepit $E$; incipit $V \quad 29$ Iustane] Iniustane $L \quad 30$ sunt] sint $Q \quad 31$ esse] etiam $V \quad 32$ Et] ecce $N \quad 33$ sim] sum $N Q \quad 34$ unum] nullum GJ; ullum $E F O 35$ Valde] Ego $N$ 
Tunc Michael primum, deinde et ego et plurimi ${ }^{36}$ alii ita sibi respondimus ${ }^{37}$ : Dignus es, Lucifer, et magnus es, diues et potens es. Sed Deus, qui nos, cum non essemus, creauit, multo dignior, multo maior ${ }^{38}$, multo ditior ${ }^{39}$, multo potentior te est et omnibus nobis. Non licet contra decretum eius decretum facere nec contra consilium consilium facere neque contra sententiam sententiam. Conatur ad impossibilia quicumque contra ipsum quicquam ${ }^{40}$ temptat $^{41}$. Deus est, Dominus est, uoluntas eius iustissima est et rectissima et omnipotens, errare non potest. Quicquid uult facere potest. Iudicare et discernere decreta eius uanum et superfluum est. Humiliemus nos sibi, subiciamur non solum homini, sed ligno et lapidi si ipse iusserit, si ipse uoluerit. Illa iusta existimanda sunt quae sibi placent. Illud opus pium et bonum quod ipse uult. Esse non possemus ${ }^{42}$, ipso nolente. Quid mihi aufert si mihi non confert quod conferre nulla obligatione tenetur? Quid habemus nisi ab ipso datum et concessum? Inuidere est bonum alienum uidere non posse. Quid habere poterimus boni si ipse noluerit? Certus sum in ipso nec errorem cadere posse nec iniustitiam ${ }^{43}$. Quicquid agit bonum [f1. 10] est. Dolere de bono iniquum est. Mitiga te, Lucifer, humilia te, subditus esto Deo tuo. Sed Lucifer liuore inuidiae et odii et praesumptionis ${ }^{44}$ plenus similia dictis eius replicare coepit, iniustum Deum et iniquum esse protestans neque suasionibus nostris assentiens. In nos quoque odium et iram suam effundere conatus ${ }^{45}$ est. Quem multi ex angelis secuti sunt eiusque sententiae adhaeserunt ${ }^{46}$. Plures tamen nobiscum ${ }^{47}$ perstiterunt.

Facta quoque est inuestigatio cur Deus uoluit ${ }^{48}$ hominem tantum exaltare, et quidam afferebant unam rationem et quidam aliam et contutabant ${ }^{49}$ eas. Nos, solidi in dilectione et oboedientia, dicebamus: Satis est nobis nosse ${ }^{50}$ ipsum id uelle, et uelle nisi bonum et rectum non posse ${ }^{51}$. Adoramus Deum Hominem, ueneramur ${ }^{52}$ eius Genitricem.

Orta ergo est inter caelicolas tempestas ualida ${ }^{53}$ et conflictus assiduus. Decertatio continua durauit tempore non paruo ${ }^{54}$, nec tamen adhuc tempus erat. Plurimi eorum dicebant: Vbi sunt nebulae? Vbi caligo? Vbi locus ille in quo nos Deus includere minatur ${ }^{55}$ ?

Deus autem multifariam Luciferum hortabatur ${ }^{56}$ ut a male inceptis desisteret. Expectauit conuersionem. Poterat enim ante casum conuerti, sed numquam uoluit ${ }^{57}$. Et quamuis sciret Deum errare non posse neque iniuste agere, tamen adeo in sui amore ${ }^{58}$ exarsit ${ }^{59}$ et odio ac inuidia in hominem ${ }^{60}$ quod, iusta uidens

36 primum, deinde et ego et plurimi] denique et plurimi $L$; et ego, deinde plurimi $Q \quad 37$ respondimus] respondemus $I \mathbf{3 8}$ maior] excelentior $Q \mathbf{3 9}$ ditior] doctior $V \mathbf{4 0}$ quicquam] aliquid $E K$; quicquid GJL $\mathbf{4 1}$ temptat] attemptat $E$; tentat $H N P Q$; intentat $L \mathbf{4 2}$ possemus] possumus $E K Q 43$ nec errorem cadere posse nec iniustitiam] errorem cadere non posse nec iustitiam $I K L$ $\mathbf{4 4}$ praesumptionis] praesumptione $P \mathbf{4 5}$ conatus] minatus $I L \mathbf{4 6}$ adhaeserunt] haeserunt $V \mathbf{4 7}$ tamen nobiscum] cum nobiscum $V \mathbf{4 8}$ uoluit] uult $G$; uoluerit $N Q \mathbf{4 9}$ contutabant] confutabant $\rightarrow$ 
Então Miguel, primeiro, depois eu e muitos outros assim lhe respondemos: És digno, Lúcifer, és grande, és rico e poderoso. Mas Deus, que nos criou quando ainda não existíamos, é muito mais digno, muito maior, muito mais rico e muito mais poderoso do que tu e do que todos nós. Não te é permitido tomar uma decisão contra a sua decisão, nem uma deliberação contra a sua deliberação, nem formular uma opinião contrária à sua. Tenta o impossível todo aquele que tenta algo contra ele. É Deus, é Senhor, a sua vontade é justíssima, é rectíssima, é omnipotente. Não pode errar. Pode fazer tudo aquilo que quer. Discutir e pôr em causa os seus decretos é tarefa insensata e inútil. Humilhemo-nos perante ele. Submetamo-nos não só ao homem, mas à madeira e à pedra, se ele o ordenar, se ele o quiser. Devem considerar-se justas as coisas que são do seu agrado, piedoso e bom o que ele quer. Não poderíamos existir se ele o não quisesse. Em que me prejudica se me não atribui aquilo que por razão nenhuma está obrigado a atribuir-me? Que temos nós senão o que por ele nos foi dado e concedido? Não poder ver o bem alheio é invejar. Que poderemos ter que seja bom se ele não quiser? Estou certo de que nele não pode caber nem erro nem injustiça. Tudo quanto faz [f1. 10] é bom. Queixar-se do bem é iníquo. Contém-te, Lúcifer, humilha-te, sê submisso a teu Deus. Mas Lúcifer, repassado do fel da inveja, do ódio e da presunção, começou a replicar às afirmações dele com afirmações semelhantes, protestando que Deus era injusto e iníquo, sem dar ouvidos aos nossos conselhos. Tentou verter sobre nós seu ódio e sua ira. Seguiram-no muitos anjos aderindo à sua opinião. Muitos outros, contudo, mantiveram-se do nosso lado.

Discutiu-se também a razão por que quis Deus exaltar a tal ponto o homem. Alegavam uns uma razão, outros alegavam outra, e defendiam-nas. Nós, firmes no amor e na obediência, dizíamos: A nós basta-nos saber que ele o quer e que não pode querer senão o que é bom e recto. Adoramos a Deus Homem, veneramos sua Mãe.

Levantou-se, pois, entre os habitantes do Céu violenta tormenta e um contínuo conflito. Um combate ininterrupto prolongou-se por não pouco tempo, nem o tempo existia ainda. Onde estão as nuvens, diziam muitos deles? Onde está a escuridão? Onde está esse lugar em que Deus ameaçou encerrar-nos?

De muitos modos Deus incitava Lúcifer a desistir de seus errados intentos. Esperou a sua conversão. Poderia, com efeito, converter-se antes da queda, mas nunca o quis. E embora soubesse que Deus não pode errar, nem agir injustamente, abrasou-se de tal modo no amor de si e no ódio e na inveja para com o

$\leftarrow$ HIJKLNOV; confundebant $Q \quad \mathbf{5 0}$ nosse] nosce $J I L M Q V$; scire $E$; noscere $P \quad \mathbf{5 1}$ et uelle nisi bonum et rectum non posse] et uelle non nisi bonum et rectum $V \mathbf{5 2}$ Adoramus...ueneramur] Adoremus...ueneremur $H \mathbf{5 3}$ tempestas ualida] tempestas ualida, proelium uere magnum $Q, \mathbf{5 4}$ non paruo] non paruo ut uos putatis $H Q \mathbf{5 5}$ minatur] minatus est $I \mathbf{5 6}$ hortabatur] adhortabatur $N 57$ numquam uoluit] noluit umquam $N \mathbf{5 8}$ amore] amorem $G H P Q \mathbf{5 9}$ exarsit] exarsit, de se praesumendo $F Q \mathbf{6 0}$ in hominem] in hominem, ad id non aduerteret $F H$; in hominem ut ad idem $\rightarrow$ 
et bona, sequi uoluit mala. Concupiuit esse Deus eo modo quo et homo nunc est Deus. Videbat id possibile ${ }^{61}$ et quasi rationabilius, quia digniorem homine se putabat $^{62}$ et natura dignior ${ }^{63}$. Non placuit ut Deus hominem sibi praeferret et ita praeferret ut ipsius ${ }^{64}$ dominum $^{65}$ faceret. Haec est illa inuidia per quam intrauit mors in genus humanum et in orbem terrarum.

Videns autem Deus quod tanta peruersitas et prauitas inueniretur in angelis suis, locutus est ad nos dicens: Conuenite in unam dilectionem et in unam oboedientiam et subiectionem. Filii mei omnes estis si mandata mea non contempseritis. Expectaui conuersionem eorum qui auersi ${ }^{66}$ sunt. Nunc nihil restat nisi ut sententia detur et praemium aeternum oboedientibus, inoboedientibus uero supplicium perpetuum. Ecce iam creare hominem decreui et pro ipsius uita multa alia creaturus sum. Et dixit nobis: Interrogate Luciferum et socios eius si ad me redire uolunt et suscipiam eos. Sin autem, creato mundo, deiciam eos et repellam ad loca caliginum ${ }^{67}$ et tenebrarum.

Michael et ego locuti sumus cum illis, sed nihil ualuit persuasio nostra. Factum est proelium magnum inter nos et illos. Dixitque Deus: "Fiat lux" uidelicet sol, ut iam diximus ${ }^{68}$. Et creato sole et caelis iam tibi nominatis ${ }^{69}$ et terra ac elementis ${ }^{70}$, ipsa die qua fuit dies et nox diuisa etiam nos fuimus diuisi. Proiecti enim fuerunt, Michaele et nobis aliis pugnantibus et nobis Deo fauente, in hunc aerem caliginosum. Hoc fecit praesumptio, hoc inuidia, hoc contemptus mandatorum Dei.

Diuisis igitur spiritibus [fl. 11] illis bonis et malis sicut et luce ${ }^{71}$ a tenebris, boni facti sunt dies et lux perpetua, mali uero nox et tenebrae et nubila sempiterna. Non quia naturam mutauerint ${ }^{72}$, sed quia ${ }^{73}$ malis et taetris ac obscenis ${ }^{74}$ operibus pleni in caliginosum aerem fuerunt demersi.

Creatis igitur omnibus rebus aliis ab homine, nobis angelis cunctis qui remansimus $^{75}$ assistentibus seu astantibus, dixit Deus Pater ad Filium suum, qui est Verbum eius et imago, ac etiam ad Spiritum Sanctum: Opera nostra talia sunt ut unus sine alio nullo modo operari potest ${ }^{76}$. Tres enim unus Deus sumus. Fecimus omnia huic mundo necessaria. Faciamus iam hominem ad imaginem et similitudinem nostram qui praesit omnibus inferioribus, cuius iam typum ${ }^{77}$, o angeli mei, ostendi uobis, quia talem naturam hic Filius meus assumet tempore praeordinato. Sed uolo ut et uos erga conciuem uestrum ${ }^{78}$ aliqua beneficia

$\leftarrow$ non aduerteret. $Q 6 \mathbf{6 1}$ id possibile] illud possibile $E$; id posse $J V$; impossibile $Q \mathbf{6 2}$ se putabat] se putabat et profecto erat $H$ (M in marg. a. $m$.) NOQ 63 et natura dignior] etenim natura dignior $E$; profecto erat natura dignior $F$; Natura enim dignior erat $P 64$ ut ipsius] ut ipsum $V 65$ Dominum] hominum $Q 66$ auersi] aduersi $O 67$ caliginum] caliginis $Q 68$ diximus] dixi $Q 69$ nominatis] numeratis $Q \quad 70$ elementis] elementa $P \quad \mathbf{7 1}$ luce] lucem $N P \mathbf{7 2}$ mutauerint] mutauerunt $E K L Q V$ 73 sed quia] sed quia gratia et similitudine qua Deum et alia agnoscebant priuati fuerunt. Talis enim cognitio non erat nisi ex dono particulari (diuino beneplacito $F$ ) et $F$ ( $M$ in marg. $a$. $\rightarrow$ 
homem que, vendo o que era justo e o que era bom, preferiu seguir o mal. ${ }^{[16]}$ Ambicionou ser Deus na exacta medida em que também o homem é hoje Deus. Encarava isso como possível e a coisa mais razoável, pois se considerava a si mais digno do que o homem e mais digna a sua natureza. Não lhe caiu bem que Deus lhe preferisse o homem e, a tal ponto, que o fizesse senhor dele. É esta a inveja pela qual entrou a morte na humanidade e na Terra.

Vendo Deus que nos seus anjos se achava tão grande perversidade e maldade, dirigiu-se a nós e disse: Convergi num único amor, numa única obediência, numa única submissão. Sois todos meus filhos, se não afrontardes as minhas ordens. Aguardei a conversão daqueles que se desviaram. Agora, apenas resta pronunciar a sentença e dar aos obedientes o prémio eterno e o suplício perpétuo aos que desobedeceram. Vede, decidi já criar o homem e vou criar muitas outras coisas para a sua vida. Perguntai a Lúcifer e aos seus sequazes, disse-nos ainda, se querem voltar para mim, e eu recebê-los-ei. Senão, uma vez criado o mundo, vou precipitá-los e expulsá-los para um lugar de trevas e escuridão.

Miguel e eu dialogámos com eles, mas de nada valeu a nossa instigação. Travou-se entre nós e eles um grande combate. E Deus disse: Faça-se a luz, ${ }^{[17]}$ ou seja, o Sol, como já dissemos. E criado o Sol, os Céus já referidos e a Terra com seus elementos, no mesmo dia em que dia e noite foram separados, também nós fomos separados. Enquanto Miguel e nós os outros combatíamos, com a ajuda de Deus foram eles, pois, precipitados nessa atmosfera de trevas. Foi isto o que fez a presunção, isto fez a inveja e o contempto dos mandamentos de Deus.

Separados aqueles [f1. 11] espíritos, os bons e os maus, como a luz foi separada das trevas, os bons tornaram-se o dia, a luz perpétua. Os maus, porém, a noite, as trevas e as nuvens sempiternas. Não que mudassem de natureza, mas porque, repletos de más, feias e detestáveis acções, foram mergulhados numa atmosfera tenebrosa.

Criadas então todas as coisas, com excepção do homem, assistindo ou estando presentes nós todos os anjos que nos mantivemos fiéis, disse Deus Pai a seu Filho, que é o seu Verbo e a sua Imagem, e também ao Espírito Santo: São tais as nossas obras que de modo algum pode um actuar sem outro. Com efeito, os três somos um só Deus. Fizemos tudo quanto este mundo precisa. Façamos já à nossa imagem e semelhança o homem que presida a todos os seres inferiores, de que vos mostrei já, anjos meus, o modelo, pois que este meu Filho assumirá

$\leftarrow m$.); sed quia gratia et similitudine qua Deus et alia cognoscebat spoliati fuerunt. Talis enim cognitio non erat nisi ex dono peculiari et $Q \mathbf{7 4}$ obscenis] obscuris $Q$; obsenis $V 75$ remansimus] remanseramus $N \mathbf{7 6}$ potest] possit $P 77$ typum] similitudinem $E \mathbf{7 8}$ conciuem uestrum] eum $E$

${ }^{[16]}$ Ecos de Ovídio, Metam. VII, 21 - "Video meliora proboque, deteriora sequor"; ou de S. Paulo, Rom 7:15. - "non enim quod uolo bonum, boc ago, sed quod odi malum, illud facio". [17] Gn 1:3. 
faciatis $^{79}$ ut eorum obligatione ipse uos amet tanquam benefactores et uos ipsum tamquam aliquo modo opus manuum uestrarum diligatis. Corpus eius formate et quantumcumque ${ }^{80}$ uos facere potestis, facite. Quae uos non poteritis, nos potentia nostra immensa perficiemus.

Tunc omnes nos a maiori usque ad minimum ${ }^{81}$ laetati sumus cupientes humanam societatem. Et omnes unanimiter Dei mandatis obtemperare uolebamus ${ }^{82}$ et quilibet cupiebat ${ }^{83}$ esse primus. Michael prior me est et ipse conflixit cum dracone Lucifero, quamuis et omnes conflixerimus, et rogabat ut ipsum Deus ad hoc opus perficiendum mitteret. Similiter et ego et alii nostrum, unusquisque se offerebat ad iussa explenda. Dixitque Deus: Tres egrediantur ${ }^{84}$ de quolibet choro qui nomine omnium uestrum id exequantur. De choro itaque nostro ${ }^{85}$ egressus est Raphael, Saltiel ${ }^{86}$ et Vriel et ita de quolibet choro inferiori tres nomine omnium. Et de limo terrae illud corpus formauerunt, supplente Deo ubi creaturae uirtus deficiebat. Factumque atque plasmatum fuit corpus illud ualde pulchrum, bene in organis ac omnibus membris dispositum, temperate complexionis. Sola caro Verbi et Matris suae, quia caro unius eorum est caro alterius, praestantior fuit. Quo $^{87}$ corpore plasmato et omnibus organis adiutorio Dei et secundis causis influentibus ${ }^{88}$, Deus superaddidit solus quia in eo nulla creatura ipsum iuuare poterat, spiraculum uitae, quia tunc animam creauit ualde nobilem et scientiis omnibus informatam et uniuit illi corpori iam a nobis facto.

Noli ergo credere illam animam simul nobiscum aut simul cum Sole uel Luna, sed post corporis plasmationem fuisse creatam simul et infusam et scientiis omnibus subito ut infusa est decoratam. Adam ${ }^{89}$ ipse uidebatur ${ }^{90}$ subito uir perfecte aetatis. Non [f1. 12] fuit sibi opus alio praeceptore quam Deo. ${ }^{91}$ Subito agnouit Deum, sibi $^{92}$ gratias referebat ${ }^{93}$ et omnia creata secundum suas species cognoscebat, et ueniebant ad eum omnes fere et animalia perfectiora et quasi domino, iuxta quod poterant, ei applaudebant. Tunc Adam, cognoscens ex se progressuras omnes gentes et considerans homini loquelam esse ualde necessariam, omnibus quae in caelo sunt et quae in elementis et ipsis caelis atque elementis nomina imposuit et modum quo sua uota posset quis alteri exprimere ordinauit. Tandem, post aliquod tempus ${ }^{94}$, praestita sibi quasi oboedientia a ceteris animalibus, Deus iussit ut ipsum hominem associaremus ${ }^{95}$ usque ad paradisum uoluptatis ubi ${ }^{96}$, formata muliere, ut uobis notum est per Scripturam, ex osse Adae, ipse, uidens

79 aliqua beneficia faciatis] aliquo beneficio decoretis $O \mathbf{8 0}$ quantuncumque] quaecumque IJKNOPQV 81 minimum] minorem $L \mathbf{8 2}$ uolebamus] cupientes $E \mathbf{8 3}$ cupiebat] uolebat $E \mathbf{8 4}$ egrediantur] egrediebantur ( in marg. $a$. $m$. egrediantur) $J$; grediantur $V 85$ nostro] meo $P 86$ Saltiel] Salachiel 87 Quo] Quia $L \mathbf{8 8}$ influentibus] influentibus perfecto $I$ (M sup.lin. a. m.) NO; influentibus disposito $G$; influentibus facto $L$; influentibus bene dispositis $Q \mathbf{8 9}$ et infusam et $\rightarrow$ 
no tempo predestinado essa natureza. Mas quero que também vós realizeis em relação a este vosso concidadão alguma benfeitoria para que, em razão disso, ele vos ame como a benfeitores e vós a ele como, de algum modo, obra das vossas mãos. Dai forma a seu corpo e fazei quanto vos for possível. O que vós não puderdes fazer acabá-lo-emos nós com o nosso poder imenso.

Todos nós, então, do maior ao mais pequeno, nos regozijámos ambicionando a companhia do homem. Todos, unanimemente, queríamos obedecer às determinações de Deus, e cada um ambicionava ser o primeiro. Miguel está antes de mim, ele mesmo lutou com o dragão Lúcifer, embora todos tivéssemos lutado, pedia que Deus o mandasse a realizar esta tarefa. Do mesmo modo eu e cada um dos nossos se oferecia para dar cumprimento a essa determinação. Disse Deus: Avancem três de cada coro que, em nome de todos vós, executem essa obra. Do nosso lado saíram Rafael, Saltiel e Uriel. E de cada coro inferior saíram, assim, três, em nome de todos. Do lodo da terra formaram aquele corpo, suprindo Deus onde falhava o poder da criatura. Aquele corpo, maravilhosamente belo, bem ordenado nos seus órgãos e em todos os seus membros, de moderada compleição, foi formado e moldado. Só a carne do Verbo e de sua Mãe, já que a carne de um deles é a carne do outro, foi mais sublime. Moldado esse corpo e todos os órgãos com a ajuda de Deus e o influxo das causas segundas, Deus sozinho, já que nisso nenhuma criatura o poderia ajudar, acrescentou o sopro da vida, pois que então criou a alma extraordinariamente nobre, enformada de todos os conhecimentos, e uniu-a àquele corpo já por nós feito.

Portanto, não creias que a alma haja sido criada juntamente connosco ou juntamente com o Sol e a Lua. Foi criada depois da formação do corpo e logo infundida e, logo que infundida, ornada com todos os conhecimentos. Adão, esse, parecia logo homem perfeito. Não [f1. 12] precisou de outro mestre além de Deus. Reconheceu a Deus imediatamente e dava-lhe graças, conhecia todos os seres criados, segundo as suas espécies. Todos os animais selvagens e todos os seres vivos mais perfeitos vinham até ele e, até onde podiam, aclamavam-no como senhor. Adão, conhecendo então que de si haveriam de sair todos os povos e vendo que o homem iria ter muita necessidade da linguagem, deu nome a todas as coisas que há no céu e nos elementos, aos próprios céus e aos elementos, e determinou o modo segundo o qual cada um poderia exprimir ao outro os seus desejos. Por fim, depois de algum tempo, uma vez prestada a si pelos restantes animais como que obediência, ordenou Deus que acompanhássemos o mesmo

$\leftarrow$ scientiis omnibus subito ut infusa est decoratam (decorata $Q$ ). Adam] et infusam. Adam $E L$ ( $K$ add. in marg. a. m.) 90 uidebatur] fuit $E \mathbf{9 1}$ aetatis. Non fuit sibi opus alio praeceptore quam Deo.] aetatis, nec aliquo praeceptore indiguit quam Deo $E$; aetatis, et non fuit illi operi alius preceptor quam Deus. $Q 92$ sibi] sibique $K$; et ipsi $E$; eique $Q 93$ referebat] agebat $E 94$ tempus] dies $I L 95$ associaremus] apportaremus $Q \quad 96$ uoluptatis ubi] uoluptatis ubi sopore in Adam $\rightarrow$ 
eam iuuenem quasi suae aetatis quoad aspectum, dixit: ${ }^{97}$ Haec nunc os ex ossibus meis et caro de carne mea.

Et quia anima illius erat creata simul cum omni intelligentia sicut et ${ }^{98}$ ipsius Adae, intellexit subito significationem illorum uerborum et omnium aliorum in paruo et quasi in minimo tempore ${ }^{99}$. Et loquebantur ad inuicem, non sermone aliquo quasi naturali, ut plerique grossi homines putant, sed sermone ipsius hominis bene placito, aliquando cum aliqua ratione inuento ${ }^{100}$, aliquando mere ad placitum ${ }^{101}$. Qui sermo multo tempore solus fuit in orbe terrarum.

His tamquam mirabilibus ualde mihi intellectis, dixi ego: Domine mi, audiui uocem tuam uere admirandam. Occurunt mihi quaedam ambigua. Si placet, edissere $^{102}$ mihi illa. Ex quo merui tantam gratiam? Tunc ille ${ }^{103}$ : Tu meruisti haec trancribere ${ }^{104}$ et conseruare ut pastori a Deo electo haec nota $\operatorname{sint}^{105}$, cui etiam alio modo nota fient.

Tunc ego: Si alio modo sibi nota fient, quid opus est me conscribere?

Respondit: Ad hoc, ut libri fama prius multis obscure ${ }^{106}$ innotescat ut, cum uenerit qui iam uenit in mundum, dignior appareat. Sed tu discere potes ${ }^{107}$ quae dubitas.

Dixi: Haec sunt, mitissime angele Dei, quae propono: Dixisti mihi antea septem ex uobis tantum assistere Deo et tres uel quattuor nominasti, nomina aliorum non propalasti. Si possent ${ }^{108}$ sciri $^{109}$, manifesta ea pro mei spirituali ${ }^{110}$ consolatione. Deinde uideris dicere omnes assistere Deo et antea dixeras septem tantum assistentes ${ }^{111}$. Deinde quaero ${ }^{112}$ qualis locutio sit illa: "Faciamus hominem ad imaginem nostram". Potius enim dicere debuisset: "Faciamus hominem imaginem nostram" quam "ad imaginem nostram". Tertio, scire uelim an aliqua alia anima fuerit creata cum omnibus scientiis seu habitibus ${ }^{113}$ cognoscendi omnia quam Adae $^{114}$ et Euae.

Gabriel locutus est dicens ${ }^{115}$ : Septem ex nobis uicinius aliis quibuscumque assistunt sicut et futuro electo septem super alios assistent. Omnes tamen assistunt iugiter, quia omnes assidue cernunt. Illorum septem nomina non enumeraui. Nunc ea cognosce: Michael est primus, ego secundus, Raphael me sequitur, ipsum

$\leftarrow$ immisso $F$ ( $M$ in mag. a. $m$.) $Q 97$ dixit:] prorupit in haec uerba que sunt magni mysterii $F$ ( $M$ in marg. a. m.); dixit uerba que sunt magnum mysterium $H Q 98$ et] ex $M V$; anima $J Q 99$ minimo tempore] momento temporis $E J K Q$; momento tempore $V 100$ inuento] inuenta $I L 101$ placitum] beneplacitum $I L 102$ edissere] adiscere $F$; ediscere $E H L V 103$ Tunc ille] responndit Angelus $Q 104$ transcribere] conscribere $Q 105$ nota sint] nota fiant $K 106$ obscure] obscura $H Q 107$ discere potes] dic $E$; dicere potes $H I L Q 108$ possent] possunt $N$; possint $P Q 109$ sciri] scire $Q 110$ mei spirituali] mea spirituali $F$; mea speciali $Q 111$ assistentes] assistere $G Q 112$ Deinde quaero] Demum quaero $P$; $\rightarrow$ 
homem até ao Jardim das Delícias onde, formada a mulher do osso de Adão, como sabeis pela Escritura, vendo-a ele jovem, quase da sua idade quanto à aparência, disse: Esta, agora, é osso de meus ossos e carne da minha carne. ${ }^{[18]}$

E visto que a alma dela fora criada logo com toda a inteligência, como a do próprio Adão, compreendeu imediatamente o significado daquelas palavras e de todas as outras, em curto ou no mínimo tempo, e falavam um com o outro não numa linguagem quase natural, como pensam muitos homens ignorantes, mas na aprazível linguagem do próprio homem, construída ora com alguma racionalidade, ora simplesmente a gosto. Esta linguagem foi, por muito tempo, a única que existiu na Terra.

Compreendidas coisas para mim tão maravilhosas como estas, disse: Meu senhor, ouvi a tua exposição verdadeiramente digna de admiração. Ocorrem-me algumas dúvidas. Esclarece-mas, se te aprouver. Porque mereci tão grande graça? Tu mereceste transcrever e guardar estas coisas, disse ele, para que sejam do conhecimento do Pastor escolhido por Deus, de quem se tornarão conhecidas por outro meio.

Se hão-de chegar de outro modo ao seu conhecimento, disse eu, que necessidade tenho de as escrever?

Para isto, respondeu, para que a fama do livro chegue primeiro insensivelmente ao conhecimento de muitos a fim de que, quando surgir aquele que já chegou ao mundo, ele apareça mais digno. Tu, porém, podes ficar a saber aquilo de que tens dúvidas.

São estas, suavíssimo anjo, disse, as coisas que declaro: Disseste-me antes que apenas sete de vós assistiam a Deus e referiste três ou quatro, não revelando os nomes dos outros. Se puderem ser conhecidos, apresenta-os para minha consolação espiritual. Parecia, depois, que dizias que todos assistiam a Deus e, antes, havias dito que são sete apenas os que assistem. Pergunto ainda que afirmação é aquela: Façamos o homem à nossa imagem. ${ }^{[19]} \mathrm{Na}$ verdade, mais deveria dizer: "Façamos o homem nossa imagem", do que à nossa imagem. Em terceiro lugar, queria saber se foi criada alguma alma com todos os conhecimentos ou disposição de tudo conhecer, além da de Adão e Eva.

Sete de nós, respondeu Gabriel e disse, assistem mais proximamente do que quaisquer outros, como sete sobre todos os outros assistem o futuro eleito. Todos, contudo, assistem continuamente, porque todos vêem ininterruptamente. Não enumerei aqueles sete nomes. Conhece-os agora. O primeiro é Miguel, o

$\leftarrow$ Deinde oro $V 113$ seu habitibus] se habentibus $V 114$ quam Adae] ab anima Adae $E$; quam sola Adae $L$; quam anima Adae FGHIKNQ; quam Adam $V 115$ Gabriel locutus est, dicens] Respondit Gabriel $E$; Angelus $N$

${ }^{[18]}$ Gn 2:26,

[19] Gn 1:26. 
uero Vriel. Vrielem autem Salthiel ${ }^{116}$ et ipsum Euchudiel, [fl. 13] septimus est ${ }^{117}$ Barchiel.

Quando118 quaeris quae locutio sit illa119: "Faciamus hominem ad imaginem nostram", omnibus expositionibus uestrorum superfluis obmissis ${ }^{120}$, hunc accipe sensum: Faciamus hominem qui sit imago aliquomodo et similitudo nostra.

Ad aliud quod postremum dubitabas, dico tres animas fuisse quae creatae sunt cum omni earum perfectione uidelicet ille duae ${ }^{121}$ et anima Reginae caelorum et Domine angelorum.

Tunc ego: Et illa ${ }^{122}$ Christi?

Respondit: De anima illius nihil dicimus hic, quia an habuerit animam aliam ${ }^{123}$ a deitate uidebitur loco suo contra multos errantes ${ }^{124}$.

Tunc ego: Prosequere inchoata, angele optime, et noli aspicere ${ }^{125}$ ad ruditatem $^{126}$ et temeritatem meam.

Et ille: Non dico tibi omnia quia ${ }^{127}$ non oportet. Lege Bibliam et ad illa aduerte quae ibi non exprimuntur. Dico tibi quod, formata muliere ualde pulchra, Adam nimio amore dilexit eam quia ex ipso sumpta erat et quia unica ${ }^{128}$ sibi similis et quia erat adiutorium similia procreandi ad quae suapte natura ${ }^{129}$ incitabantur.

Tunc ego: Domine mi, multi de nostris dicunt nullum amorem carnis inter eos fuisse et, si coissent, nullam delectationem experti fuissent ${ }^{130}$.

Ad quod ille: Stultum est sic $^{131}$ opinari. Sicut enim homo delectabatur ${ }^{132}$ gustu gratia conseruandi seipsum ita oblectatus ${ }^{133}$ fuisset uenereis ${ }^{134}$ gratia conseruandi genus humanum. Dico tibi, uir Dei, quod forsan apud uos turpe sonat propter malam uoluntatem hominum et uaria uitia in quae incidistis ${ }^{135}$, quod in statu naturae a Deo institutae et cibus et procreatio posteritatis longe suauior fuisset quam ea quae nunc apud uos est. Neque tunc ${ }^{136}$ libido dicta facta fuisset talis suauitas neque concupiscentia neque fomes aut lex membrorum, sed sincera suauitas absque ulla rationis perturbatione, immo fuisset cum ipsius rationis non parua corroboratione. Eua igitur mater uestra ualde amabatur a uiro suo, quem ipsa quoque amabat.

Tunc Lucifer uidens utrique eorum esse prohibitum ne de ligno quodam, quod ab euentu infelici appellatum fuit lignum scientiae boni et mali, sumerent, de omnibus autem aliis uescerentur, accessit in specie serpentis in illum paradisum uoluptatis et considerabat ab exterioribus signis corda eorum et dicebat apud se: "Si unum eorum uicero, utrumque uici ${ }^{137}$ nam admodum ${ }^{138}$ se diligent". Et dicebat sibi ipsi: “A quo illorum inchoabo?" Et conclusit quod potius speraret

116 Salthiel] Salathiel $L$; Sathiel $P$; Saltiel $Q V 117$ septimus est] et post eum $E 118$ Quando] Quoniam $L$; Cum $Q 119$ sit illa] fuit illa $K 120$ superfluis obmissis] superfluis demissis $Q$; superfluis $P 121$ duae] duae, Adae et Euae $Q \mathbf{1 2 2}$ Et illa] illa Christi anima $K$; Quid de anima $E$ 123 aliam] aliam sicut eam habent ceteri homines que fuerit alius spiritus $F H Q 124$ errantes.] errantes ut pastor declarabit $Q$; errantes et pastor declarabit $F H \mathbf{1 2 5}$ aspicere] respicere $P \rightarrow$ 
segundo sou eu. Segue-me Rafael, a quem segue Uriel. A Uriel segue Saltiel, que é seguido por Eucudiel. [fl. 13] O sétimo é Barquiel.

Quando perguntas que afirmação seja Façamos o bomem à nossa imagem, esquecidas todas as inúteis explicações dos vossos, eis o sentido: Façamos um homem que de algum modo seja a nossa imagem e a nossa semelhança.

Relativamente à tua última dúvida, digo-te que foram três as almas que foram criadas com toda a perfeição daquelas, ou seja, essas duas e a alma da Rainha do Céu e Senhora dos anjos.

E a de Cristo? Perguntei.

Dessa, respondeu, nada diremos aqui, pois se teve uma alma distinta da divindade ver-se-á no lugar próprio, contra muitos que erram.

Continua, anjo admirável, o que já começaste, disse eu, e não repares na minha rudeza e na minha temeridade.

Não te digo tudo, respondeu ele, porque não é necessário. Lê a Bíblia e presta atenção ao que aí não está expresso. Digo-te que, formada a mulher, muito bela, Adão a amou com um amor sem limites, porque fora tirada dele, porque era a única semelhante a si e a auxiliar para a procriação dos semelhantes, para o que eram incitados pela própria natureza.

Meu senhor, perguntei, dizem muitos dos nossos que entre eles não havia qualquer amor carnal e, se se unissem, não experimentariam qualquer prazer.

A isto respondeu ele: É tonto pensar assim. Do mesmo modo que o homem se deliciava com o gosto, por causa da conservação própria, também se deleitaria com os prazeres voluptuosos, por causa da conservação do género humano. Digo-te, homem de Deus, o que porventura entre vós soa mal por causa da má vontade dos homens e dos muitos vícios em que caístes, que no estado natural instituído por Deus não só o alimento como também a procriação seriam muito mais agradáveis do que o são hoje entre vós. Então, nem o dito desejo, nem o apetite sensual, nem a pulsão ou lei da carne teriam semelhante encanto, mas um puro encanto sem perturbação alguma da razão, e mais, aconteceria com não pequena colaboração da própria razão. Portanto, Eva, a vossa mãe, era muito amada por seu marido, a quem ela amava também.

Lúcifer, então, vendo que a ambos era proibido colher de uma determinada árvore que, em razão do infeliz acontecimento, se chamou árvore da ciência do bem e do mal, comendo, porém, de todas as outras, aproximou-se, sob a forma de serpente, daquele Jardim das Delícias e, pelos sinais exteriores, observava os corações deles e dizia para consigo: Se vencer um deles, venci-os a ambos, pois a tal ponto se amam. E dizia para si: por qual deles hei-de começar? E concluiu

$\leftarrow \mathbf{1 2 6}$ ruditatem] rudicitatem $G$; nuditatem $J V 127$ quia] et $V \quad 128$ unica] erat $Q 129$ ad quae suapte natura] atque suapte natura $I$; atque sua praenatura $J$; atque sua praenatura $M V 130$ experti fuissent] sensissent $N 131$ sic] hoc $V$; ea $I L 132$ delectabatur] delectatus fuisset $G Q 133$ oblectatus] delectatus $O Q 134$ uenereis] uenereis actibus $V 135$ incidistis] incidisti $J$; incurristis $O \quad 136$ tunc] tamen $G O 137$ uici] uincam $E F G H K O$; uinci $J$; eorum uincam $Q \quad 138$ admodum] $\rightarrow$ 
uincere mulierem, qua uicta, facile uinceret uirum. Nulla enim mulier tantum amauit uirum et ipsa tantum fuit amata a uiro quantum ${ }^{139}$ Eua Adam et ipse Euam amauit, praeter amorem illum insuperabilem qui fuit inter Christum Dominum et Mariam Reginam nostram et uestram, quamuis quando dixi "nostram"140, utrumque includebatur, quia nos angeli et uos homines sumus conciues et compatriotae et ad unum finem ordinati.

Prima itaque temptatio ${ }^{141}$ facta mulieri fuit interior et occulta, qua ${ }^{142}$ titillauit $^{143}$ serpens ut mulier extolleretur in corde suo et de se ipsa praesumeret tamquam pulchra et decora. Et in hoc non decipiebatur, quia talis erat. [f1. 14] Sed conatus serpentis antiqui erat inducere eam in amorem sui ipsius, quia et ipse ${ }^{144}$ eo modo peccare coeperat. Pluribus igitur uicibus et aliquibus diebus studuit eius mentem peruertere, sed non poterat plene. Tandem in hoc obtinuit uictoriam, quia mulier intus in corde suo fuit elata et praesumpsit. Tunc diabolus gauisus est et uidens eam iam peccasse et ita errare posse, conatus est eam ducere in errorem et in stultitiam, quae est poena peccati et rebellionis Dei. Et una dierum apparuit sibi manifeste iuxta arborem illam uetitam, cuius fructus mulier aspiciebat et considerabat $^{145}$. Et dixit ei: Quare non imples ${ }^{146}$ desideria tua? Quare non comedis de fructu illo suauissimo ${ }^{147}$ ? Vt quid ${ }^{148}$ te affligis? Comede, quid times?

Et illa: Non licet mihi inde sumere. Deus enim praecepit nobis de illo solummodo non sumere. De omnibus his quae ${ }^{149}$ uides uesci possumus. Illud tantum nobis tangere ${ }^{150}$ non licet.

Tunc ille: Si tu scires cur ita uobis praecepit Deus, nunc nunc comederetis et bene esset uobis.

Et mulier: Dic mihi, rogo te, causam huius praecepti.

Et ille: Dominus ${ }^{151}$ nihil habet excelentius sua scientia quam adeo amat et in illius amore tantum ardet quod nollet ullo pacto ut alius ${ }^{152}$ eam haberet. Et quia scit omnem intellectum esse capacem et idoneum ad sciendum quaecumque ipse scit, quia nihil est intelligibile quod intelectus non possit intelligere, ipse, uolens hanc excellentiam pro se solo retinere, impediuit omnes alios intellectus ne possint ${ }^{153}$ cognoscere omnia, sed quasi pauca. Et quia esus illius ligni multum confert $^{154}$ ad sciendum, immo qui illo uesceretur in breui tempore ${ }^{155}$ euaderet doctus in omnibus...156

Mulier admirata dixit ei: Dic mihi quis tu $\operatorname{sis}^{157}$ et quomodo haec nosti?

Lucifer ait: Sum ille qui mane oriebar, qui in deliciis ${ }^{158}$ alterius paradisi longe melioris fui et ipso nomine quod mihi remansit dignosci ${ }^{159}$ potest excelentia mea. Lucifer sum qui iccirco Deo subici ${ }^{160}$ nolui quia me impediebat a cognitione

$\leftarrow$ mirum modum $E$; ad inuicem $Q 139$ uiro quantum] illo quam $Q \quad 140$ nostram] uestram $Q 141$ temptatio] tentatio $K N P Q$; contemplatio $V 142$ qua] quia $J$; quam $O$; quod $V 143$ titilauit] tentauit $E \quad 144$ ipse] ipso $J 145$ considerabat] desiderabat $Q \quad 146$ imples] reples $O \quad 147$ suauissimo?] suauissimo? Cur sumere tardas? M (in marg. a. m.) NO; suauissimo? Quare sumere tardas? $Q \mathbf{1 4 8}$ Vt quid] Et quid $K$; quare $E 149$ quae] quos $L 150$ tangere] attingere $N 151$ Dominus] Deus $E I K L Q 152$ alius] aliis $V 153$ possint] possit $I$; possent $Q 154$ multum confert] multum uobis $\rightarrow$ 
que mais esperava vencer a mulher, vencida a qual, facilmente venceria o marido. $\mathrm{Na}$ verdade, mulher alguma amou tanto o marido, nem foi por ele tão amada quanto Eva amou Adão e este amou Eva, além do inseparável amor que existiu entre Cristo, o Senhor, e Maria, nossa e vossa Rainha. Embora ao dizer "nossa" incluísse a ambos, visto que nós os anjos e vós os homens somos concidadãos e compatriotas e ordenados para o mesmo fim.

Assim, a primeira tentação feita à mulher foi interior e oculta, pela qual a serpente a lisonjeou para que se ufanasse em seu coração e se presumisse graciosa e bela. E nisso não se enganava, porque o era. [fl. 14] Mas o empenho da serpente antiga era induzir a mulher no amor de si mesma, porque também desse modo começara ela a pecar. Várias vezes e por alguns dias se aplicou a perverter o seu espírito, mas não o podia plenamente. Por fim triunfou, porque a mulher encheu-se de orgulho e tornou-se presunçosa. O diabo alegrou-se então e, ao ver que já pecara e assim poderia errar, esforçou-se por conduzi-la ao erro e à loucura, que são o castigo do pecado e da rebelião contra Deus. E, um dia, apareceu-lhe abertamente junto daquela árvore proibida cujos frutos a mulher olhava e analisava com atenção. E disse-lhe: Porque não satisfazes os teus desejos? Porque não comes desse dulcíssimo fruto? Porque te reprimes? Come! Que receias?

Desses não me é permitido comer, disse ela. Deus ordenou-nos que apenas dessa não comêssemos. Podemos comer de todas as que vês. Apenas nessa nos não é permitido tocar.

Se tu soubesses, disse ele, porque é que Deus assim vos ordenou, logo, logo comeríeis e seria bom para vós.

Rogo-te, diz-me a causa dessa ordem, pede a mulher.

O Senhor, diz ele, nada tem de mais excelente do que o seu conhecimento, que ama a tal ponto e em cujo amor está tão envolvido que não admite, por nada, que outro o partilhe. E porque sabe que toda a inteligência tem capacidade e idoneidade para entender seja o que for, querendo guardar para si só esta excelência, não permitiu que todos os outros intelectos conhecessem tudo, mas apenas alguma coisa. E uma vez que o comer daquela árvore muito contribui para o conhecimento, ou melhor, quem dela comer se tornará em breve tempo douto em tudo, por isso vos proibiu. ${ }^{[20]}$

Diz-me, quem és, pergunta a mulher surpreendida, e como soubeste estas coisas?

Sou, respondeu Lúcifer, aquele que brilhava pela manhã, que estive nas delícias do outro bem melhor Paraíso e pelo nome que me ficou se pode discernir a minha excelência. Sou Lúcifer que, por isso, não quis submeter-me a Deus, porque me

$\leftarrow$ confert $F N O Q 155$ in breui tempore] breui $N 156$ doctus in omnibus...] doctus in omnibus ideo uobis prohibuit. $M$ (in marg. a. m.) N (O sup. lin. a. m.) 157 sis] scis HKMPV 158 qui in deliciis] et in deliciis $Q 159$ dignosci] $\operatorname{cognosci} Q 160$ subici] subiri $L$

${ }^{[20]}$ Por isso vos proibiu, é conclusão de apenas M (in marg.) NO (sup lin.) 
multarum rerum sicut et uos. Nunc crede mihi, si comederitis ${ }^{161}$ de ligno illo, tu et socius tuus, eritis quidam dii, omnia cognoscentes ${ }^{162}$ bona et mala, utilia et nociua et uiuetis in aeternum, quod ipse nollet. Itaque et gratia scientiae et gratia uitae sempiternae prohibuit uobis Deus esum illius ligni ut parum sciatis et minus uiuatis.

Tunc mulier: Nunquam id facerem uiro meo inconsulto.

Et ille: Comede prius tu et, si probaueris uera esse in te quae ego dico, dabis postea de his ${ }^{163}$ uiro tuo.

Mulier non consensit ${ }^{164}$, sed uiro suo omnia uerba retulit, qui dixit mulieri:

Caue tibi ab isto quia, sicut ipse caelum ${ }^{165}$, sic et nos possemus ${ }^{166}$ amittere hunc paradisum.

Videns iterum Lucifer mulierem solam arborem illam respicientem ${ }^{167}$, dixit: Cur non comedis? Quis te impedit? Sume, sume non cures.

Tunc mulier: Tu Deo fuisti inoboediens et amisisti caelum. Ego, si mandata eius non seruo ${ }^{168}$, nonne amittam [f1. 15] hunc locum et forsan uitam? Sic enim dixit Deus: In illa hora qua ${ }^{169}$ comederetis ${ }^{170}$, morte moriemini.

Et diabolus ad illam: Nequaquam moriemini. Nam in tali horoscopo et tali aspectu siderum plasmati estis quod per longa saecula uiuetis. Et ostendebat ${ }^{171}$ eis $^{172}$ per influxum stelarum ea quae dixerat ${ }^{173}$. Et uidebatur ${ }^{174}$ causa bene ${ }^{175}$ assignata. Sed non aduertebant neque ipsa neque uir ad mortem qua morituri erant praeuaricantes diuina mandata, quo factum est quod tam ipsa quam uir eius agnouerunt ${ }^{176}$ se pro tunc non morituros, iuxta rationes a Lucifero assignatas, quae uere erant. Sed non aduertebant Deum posse augere et diminuere dies hominis sua potentia, neque de mortis natura et condicione ${ }^{177}$ cogitabant. Nam illa mors erat exilium et gratiae Domini et loci concessi ${ }^{178}$. Et ex tunc minus curauerunt de mandato, uidentes ${ }^{179}$ poenam illam se non incursuros, quod super omnia displicuit Deo.

Tunc ego dixi: Angele Dei, quomodo ante peccatum fuit error? Nam nostri dicunt quod error est effectus et poena ${ }^{180}$ a peccato procedens.

Et ille respondit: Non errabant in hoc quod se non incursuros mortem putabant, quia id uerum erat quod non incurrerent eam. Sed non aduertebant de morte priuationis gratiae seu iustitiae ${ }^{181}$ neque de necessitate moriendi. Dico tibi plus, quod mulier iam peccauerat elatione et uir eius non erat omnino sincerus ${ }^{182}$.

161 comederitis] comederetis GKN 162 cognoscentes] cognoscetis $J 163$ postea de his uiro tuo] postea uiro tuo $E$; postea de istis uiro tuo $V 164$ consensit] concessit $I 165$ ipse caelum] ipse caelum amisit $I L 166$ possemus] possumus $I L N Q 167$ respicientem] aspicientem $K$; respicere $E$; respici $G$; aspicere $V 168$ seruo] egero $L 169$ In illa hora qua] In qua hora $N 170$ comederetis] comederitis $K$; comodetis $O \mathbf{1 7 1}$ ostendebat] ostendit $F \quad \mathbf{1 7 2}$ eis] ei $I K N O P Q \mathbf{1 7 3}$ quae dixerat] quae dicebat esse uera $Q \quad \mathbf{1 7 4}$ Et uidebatur] Euidebatur $J N V \quad \mathbf{1 7 5}$ bene] bone $L \mathbf{1 7 6}$ diuina mandata, quo factum est quod tam ipsa quam uir eius agnouerunt] diuina mandata. Factum est quod tam ipsa quam uir eius agnouerunt $K$; diuina mandata, quod factum est ut tam ipsa quam $\rightarrow$ 
impedia o conhecimento de muitas coisas, como agora a vós. Acredita em mim, se comerdes dessa árvore, tu e o teu companheiro, sereis uns deuses, conhecendo tudo, o bem e o mal, o útil e o nocivo, e vivereis para sempre. O que ele não quer. E, assim, por causa do conhecimento e por causa da vida sempiterna, vos proibiu Deus de comer daquela árvore, para que conheçais pouco e vivais menos.

Nunca farei isso sem consultar o meu marido, disse a mulher.

Come tu primeiro, respondeu ele, e se verificares por ti ser verdadeiro o que eu digo, depois darás dele ao teu marido.

A mulher não assentiu, mas relatou palavra por palavra a seu marido, que lhe disse: Toma cuidado com esse, pois assim como ele perdeu o Céu, assim nós podemos perder este Paraíso.

Vendo Lúcifer, pela segunda vez, a mulher sozinha a observar aquela árvore, disse-lhe: Porque não comes? Quem te impede? Colhe, colhe, não te preocupes.

Tu desobedeceste a Deus, disse a mulher, e perdeste o Céu. Se eu não cumprir as suas ordens, não perderei [f1. 15] este lugar e, talvez, a vida? Pois Deus assim disse: Na mesma hora em que comerdes, morrereis de certeza ${ }^{\text {[21] }}$

De modo algum morrereis, retorquiu-lhe o diabo. Na verdade, fostes criados em tal constelação e em tal conjugação de astros que vivereis por longos séculos. E, pelo influxo das estrelas, fazia-lhes ver o que dissera. E a causa afigurava-se bem defendida. Mas não advertiam, nem ela nem o marido, na morte de que morreriam se transgredissem os mandamentos divinos. Pelo que se verificou que, quer ela, quer o seu marido, acreditaram que não morreriam, de acordo com as razões defendidas por Lúcifer, que eram verdadeiras. Mas não atentaram em que, no seu poder, Deus poderia alargar ou encurtar os dias do homem, nem ponderaram na natureza e condição da morte. Pois essa morte era exílio da graça de Deus e do lugar concedido. E desde então menos se preocuparam com o que lhes fora ordenado, considerando que não incorreriam nessa pena. O que sobremaneira desagradou a Deus.

Anjo de Deus, disse então eu, como é que o erro existiu antes do pecado? Na verdade, os nossos dizem que o erro é o efeito e a pena que procede do pecado.

Não erravam, respondeu o anjo, ao julgarem que não incorreriam na morte, já que era verdade que não morreriam. Mas não atendiam à morte da privação da graça ou da justiça, nem a ser inevitável morrer. Digo-te mais, que a mulher pecara já ao se ensoberbecer, e que o homem dela não era absolutamente sincero.

$\leftarrow$ uir eius agnoscerent $Q \mathbf{1 7 7}$ natura et condicione] natura et cognitione $H$; natura $K \mathbf{1 7 8}$ gratiae Domini et loci concessi] gratiae Domini et loci concessi priuatio $E F H$; et priuatio gratiae Domini et loci concessi $K$; gratiae dominii et loci concessi privatio $P Q$; gratia Domini et loci concessi $V$ 179 uidentes] uidendo $E G J H K O P Q \mathbf{1 8 0}$ quod error est effectus et poena a peccato procedens] quod error est effectus peccati quia poena $Q \mathbf{1 8 1}$ iustitiae] iustitiae Dei $N$; iustitiae originalis $E$ 182 sincerus] ignarus $L$

[21] Gn 2:17 
Ergo si postmodum errassent, non est mirum, quia et errauit mulier in multis, sed non antequam esset elata, neque Adam antequam incepisset in corde suo complacere uxori ad esum prouocanti. Subito enim ut uerba eius patienter et cum affectu quodam audire uoluit ${ }^{183}$ et Luciferi rationes intelligere peccauit, quamuis nondum in pomi esum ${ }^{184}$ consensisset, quia non solum peccatum est uetita ${ }^{185}$ facere, sed etiam suadentem ${ }^{186}$ talia patienter audire et rationes uelle intelligere. Et eo magis si de mandato minus curet, ex eo quod illud posset impune praeterire. Mulier ergo sicut longe ante uirum elata est et peccauit, sic et ante illum errauit et seducta fuit, quando uir adhuc rectus ${ }^{187}$ erat et minime seductus. In pluribus etiam fuit mulier seducta, uir in paucis. Iccirco poterat dici non seductus. Mulier in prima ${ }^{188}$ temptatione exteriori fuit seducta, quia antea fuerat elata suggestione interiori. Vir non in prima aut secunda, sed postea quinta et sexta. Saepius enim mulier retulit uerba Luciferi et suasit, sed uir constans fuit quousque, uolens ${ }^{189}$ complacere uxori, scire uoluit ${ }^{190}$ et petiit rationes serpentis de immortalitate et aliis ${ }^{191}$ impatiens fuerat neque libenter eam audiebat, immo ne talia diceret reprehendebat. Illa uice ${ }^{192}$ quinta coepit audire attente et sexta plene consensit ${ }^{193}$. Non fuit ergo seductus statim sicut nec stantim peccauit.

Ego iterum interrogaui: Mi angele, mihi uidetur quod a principio, quando acceperunt mandatum, ambo errauerunt, nam Deus dicendo: "In quacumque hora [fl. 16] comederitis morte moriemini", non intelligebat ${ }^{194}$ de morte corporis tunc futura, sed de obligatione ad illam et de morte animae, quae ${ }^{195}$ fit $^{196}$ per priuationem gratiae seu iustitiae originalis. Et tamen ipsi uidebantur intelligere de morte corporis pro tunc quando fieret transgressio. Ergo errabant.

Respondit Angelus: Accipe hoc ${ }^{197}$, homo Dei et serue ${ }^{198}$ simplex, non est errare quando aliquis ignorat ${ }^{199}$ uel putat aliquid ${ }^{200}$ posse multis modis accipi, quamuis ipse nesciat proprie illud esse intelligendum hoc modo uel illo, sed potius ${ }^{201}$ dubitare. Sed ille errat qui dicit et putat aliquid pro certo esse uerum quod ${ }^{202}$ tamen est falsum, aut pro certo falsum quod tamen est uerum. Ante peccatum ergo multa poterant ignorari ${ }^{203}$ et ignorabantur ${ }^{204}$ et dubitari ${ }^{205}$ et dubitabantur ${ }^{206}$. Sed nullum falsum putabatur pro certo uerum neque uerum falsum ${ }^{207}$. Illi ergo nouerant ${ }^{208}$ illam comminationem in generali, sed ignorabant an praecise hac

183 audire uoluit] audiuit seu et audire uoluit $Q \quad 184$ esum] esu $H Q \quad 185$ uetita] uitia $V \quad 186$ suadentem] suadente $Q$; suadentes $V \mathbf{1 8 7}$ rectus] erectus $H \quad 188$ in prima] ipsa $J 189$ uolens] nolens $M 190$ uxori, scire uoluit] uxori suae, scire uoluit $F H$; uxori suae. Voluit $P \quad 191$ aliis] alias IJKLNOPQV; antea enim $E$; alius $H \mathbf{1 9 2}$ reprehendebat. Illa uice] reprehendebat. Vice $E$; reprehendat. Illa uice $F$; reprehendebat eam. Vice $H$; reprehendebat. Ille uice $I L$; reprehendebat. Illam uice $P \quad 193$ consensit] consentit $V$; suasit $I L \quad 194$ intelligebat] intelligebant $I J K L N V \rightarrow$ 
Portanto, não é de admirar que errassem em seguida, porque a mulher errou de muitos modos, mas não antes de se ensoberbecer, nem Adão antes de condescender em seu coração com a mulher que o desafiava a comer. Na verdade, no momento em que se dispôs a ouvir pacientemente e com algum afecto as palavras dela e a compreender as razões de Lúcifer, pecou, embora não tivesse ainda consentido em comer o fruto. Porque pecado não é só fazer o que está proibido, mas também o é ouvir pacientemente a quem tal aconselha e querer entender as suas razões. Sobretudo se se preocupa menos com a determinação, uma vez que podia ultrapassá-la impunemente. Portanto, assim como a mulher muito antes do marido se ensoberbeceu e pecou, assim também antes dele errou e foi seduzida, quando o marido era ainda recto e de modo nenhum seduzido. A mulher foi ainda seduzida em muitas coisas, o homem em poucas. Consequentemente, poderia considerar-se não seduzido. A mulher foi seduzida na primeira tentação exterior, porque antes se deixara levar pelo orgulho da sugestão interior. $O$ homem não o foi nem na primeira nem na segunda, mas depois, na quinta ou na sexta. Muitas vezes, na verdade, a mulher lhe referiu as palavras de Lúcifer e o persuadiu, mas o homem foi constante até que, querendo agradar à esposa, pretendeu conhecer e pediu as razões da serpente sobre a imortalidade. Outras vezes havia sido impaciente e nem a ouvia de boa vontade, bem pelo contrário, repreendia-a para que não dissesse tais coisas. Começou a ouvi-las com atenção à quinta vez e consentiu plenamente à sexta. Não foi, portanto, imediatamente seduzido, nem imediatamente pecou.

Anjo meu, interroguei de novo, parece-me que ambos erraram desde o princípio, quando receberam a proibição. Pois Deus ao dizer: Na mesma hora [f1. 16] em que comerdes, morrereis de certeza, não pensava na morte do corpo, a acontecer naquele momento, mas na sua inevitabilidade, e na morte da alma, que acontece pela privação da graça ou da justiça original. E, contudo, parece que eles o entendiam acerca da morte do corpo no momento em que a transgressão acontecesse. Por isso, erravam.

Ouve isto, homem de Deus e servo simples, respondeu o anjo. Quando alguém ignora ou considera que alguma coisa pode ser aceite de muitos modos, embora não saiba propriamente que isso se deve entender desta ou daquela maneira, isso não é errar, mas antes duvidar. Erra, porém, aquele que afirma e considera que é indubitavelmente verdadeiro algo que, afinal, é falso, ou indubitavelmente falso o que, na realidade, é verdadeiro. Antes do pecado, portanto, muita coisa podia ignorar-se e se ignorava, ou de muitas se podia duvidar e duvidava-se. Mas nada que fosse falso se considerava seguramente verdadeiro, nem verdadei-

$\leftarrow 195$ quae] quam $J 196$ fit] fuit $O 197$ hoc] haec $F N 198$ serue] serua $Q 199$ aliquis ignorat] aliquis ignorat aliquid $I L$; quis ignorat $P V \mathbf{2 0 0}$ uel putat aliquid] uel putat aliquid pro certo esse uerum quod tamen est falsum et $Q 201$ potius] possit $G O 202$ quod] quando $L 203$ ignorari] ignorare $I L \quad 204$ ignorabantur] ignorabant $I L Q \quad 205$ dubitari] dubitare $I L Q \quad 206$ dubitabantur] dubitabant $I L Q \quad \mathbf{2 0 7}$ Sed nullum falsum putabatur pro certo uerum neque uerum falsum] Sed nullum falsum pro certo uerum neque contra $Q 208$ nouerant] nouerunt $Q$ 
morte uel illa et an subito uel postea essent morituri. Sed non existimabant pro certo unum modum ${ }^{209}$. Et ideo non errabant, sed ignorabant et dubitabant. Nam neque nos angeli neque beati sciunt omnia, qui tamen nunquam peccauimus. Multis temptationibus ${ }^{210}$ diu iam capta, primum muliere ${ }^{211}$ deinde et ipso uiro, non tamen uolentibus in actum esus ${ }^{212}$ illius pomi consentire, tamen Lucifero instigante, consenserunt. Et mulier primo sumpsit, deinde porrexit uiro suo, qui comedit potius ut cumplaceret quam ut cibum sumeret, immo inglutiuit illum ${ }^{213}$ ueluti cibum ${ }^{214}$ displicentem. Et sic uterque ${ }^{215}$ eorum factus est corpore mortalis, animo $^{216}$ uero alienus a Deo. Amiserunt omnia dona ${ }^{217}$ quae fuerunt ${ }^{218}$ eis promissa: immortalitatem et animalium oboedientam et omnis creaturae subiectionem. Nil enim eis nocere antea poterat.

Tunc ego: Si homo ante peccatum immortalis erat, quomodo factus est mortalis subito? Et si mutatus fuerit ${ }^{219}$ de natura una in aliam, scire uelim ${ }^{220}$ et rogo ut mihi declarare digneris.

Et ille: Bene constat te esse purum hominem qui credis ${ }^{221}$ naturam hominis umquam fuisse immortalem. Homo et omne compositum ex pluribus rebus est dissolubile. Sed dono Dei erat homini concessum ut, si oboediret mandatis, posset immortalis iugiter perseuerare. Non quia ex sui natura ${ }^{222}$ talis esset $^{223}$, sed quia Deus eum oboedientem preseruasset ${ }^{224}$ et in aeternum conseruasset ${ }^{225}$. Dico tibi plus, quod multi ex uestris ${ }^{226}$ non capiunt, nullum etiam angelum immortalem sic esse quin, postquam factus est, desinere ${ }^{227}$ possit, quanto magis uos qui luteas habetis domos et habetis terrenum aedificium! Homo ergo erat factus gratia immortalis, non natura. Peccando uero homo ${ }^{228}$, Deus non dedit illi naturam nouam, sed reliquit in ea in qua ex naturali condicione manere debebat ${ }^{229}$.

Tunc ego: Domine mi, dicite ${ }^{230}$, si placet, quae differentia sit inter uestram naturalem immortalitatem ${ }^{231}$ et ipsius primi hominis.

Angelus respondit: Ista non sunt secreta futuro pastori reuelanda, nam talia possunt sciri aliter [f1. 17] quam per hanc reuelationem. Maneamus, uir Dei, in his quae nondum fuerunt Ecclesiae reuelata ${ }^{232}$. Scire tamen debes quod res incorporea $^{233}$ et immaterialis ${ }^{234}$ est ualde minus ${ }^{235}$ morti et interitui subiecta quam corporea, materialis et animata ${ }^{236}$. Illa enim et a seipsis ${ }^{237}$ et ab aliis rebus quae non sunt Deus destrui possunt ${ }^{238}$. Nos autem ita sumus immortales quod

209 pro certo unum modum.] pro certo unum modum quia id propter peccatum non quodcumque, sed esus ligni illius, ut alias aperiam, uenit in mundum. $Q 210$ temptationibus] temporibus $V \mathbf{2 1 1}$ muliere] mulier $J V 212$ esus] esum $V 213$ illum] illud FHILV 214 cibum] cibi $I 215$ uterque] ut quam $H 216$ animo] anima $J 217$ dona] bona $O Q 218$ fuerunt] fuerant $F H I L P Q, 219$ fuerit] fuit $N Q 220$ uelim] uellem $Q 221$ qui credis] ne credas $L$; qui credas FGIHJOP 222 ex sui natura] sua natura $Q$, ex sua natura $V \mathbf{2 2 3}$ talis esset] talis immortalitatis esset $O Q \mathbf{2 2 4}$ praeseruasset] $\rightarrow$ 
ro algo que fosse falso. Eles certamente conheciam aquela ameaça de um modo geral, mas ignoravam se morreriam precisamente desta ou daquela morte, se subitamente ou depois. Mas não consideravam como certo um modo definido. Por isso, não erravam, mas ignoravam ou duvidavam. Com efeito, nem nós anjos nem os bem-aventurados, que todavia nunca pecámos, sabemos tudo. Enredada já há tempos em muitas tentações, primeiro a mulher, depois também o próprio homem, não querendo, todavia, consentir no acto de comer daquele fruto, consentiram contudo sob a instigação de Lúcifer. A mulher comeu primeiro, depois estendeu-o ao marido, que comeu mais para ser agradável do que para tomar um alimento, pelo contrário, engoliu-o como alimento desagradável. E, assim, ambos se tornaram mortais, quanto ao corpo, e alheados de Deus, quanto à alma. Perderam todos os dons que lhes haviam sido prometidos, a imortalidade, a obediência dos animais e a sujeição de todas as criaturas. Na verdade, antes, nada lhes podia fazer mal nenhum.

Se o homem antes do pecado era imortal, disse eu, como se tornou mortal de repente? Gostava de saber e peço que te dignes mostrar-me se mudou a sua natureza em outra.

Bem se diz, afirmou ele, que tu és um homem simples que acredita que a natureza humana foi um dia imortal. O homem, e todo o composto de várias coisas, é perecível. Mas ao homem foi concedido, como dom de Deus, manter-se imortal indefinidamente, se obedecesse aos mandamentos. Não que ele assim fosse de sua natureza, mas porque Deus o preservaria e o conservaria eternamente se tivesse sido obediente. Digo-te mais, o que muitos dos vossos não entendem, que também nenhum anjo era imortal a ponto de, uma vez criado, não poder deixar de existir, quanto mais vós que tendes habitações de barro e um edifício terreno. O homem, portanto, torna-se imortal pela graça, não pela natureza. Ao pecar, não lhe deu Deus uma natureza nova, mas abandonou-o naquela em que pela condição natural devia permanecer.

Meu senhor, disse então, dizei-me, se vos aprouver, que diferença existe entre a vossa natural imortalidade e a do primeiro homem.

Isso, respondeu o anjo, não constitui segredo que deva ser revelado ao futuro Pastor, pois pode saber-se [f1. 17] por meios diferentes desta revelação. Mantenhamo-nos, homem de Deus, em assuntos que ainda não foram revelados à Igreja. Deves, contudo, saber que uma coisa incorpórea e imaterial está muito menos sujeita à morte e à destruição do que uma corpórea, material e animada. Aquelas, efectivamente, podem ser destruídas não só por si próprias como por outras

$\leftarrow$ praeseruaret $V \mathbf{2 2 5}$ conseruasset] comprouasset $L \mathbf{2 2 6}$ uestris] uobis $Q \mathbf{2 2 7}$ desinere] defficere $J K V$; desinere non $Q 228$ Peccando uero homo] Peccante uero homine $Q 229$ debebat] debeat $V$ 230 dicite] dicito $I$; dic $O Q \mathbf{2 3 1}$ naturalem immortalitatem] naturam immortalem $G$; naturam et IL 232 reuelata] intimata FHILMN 233 incorporea] corporea $L 234$ immaterialis] materialis $L N$; immortalis $P V \mathbf{2 3 5}$ minus] nimis $I L \mathbf{2 3 6}$ corporea, materialis et animata] incorporea, immaterialis et inanimata $L 237$ a seipsis] de seipsis $G$; a seipsa $Q 238$ possunt] potest $Q$ 
nullus $^{239}$ praeter Deum nostrum posset nos destruere. Vos habetis ${ }^{240}$ intus $^{241}$ et extra uestri ${ }^{242}$ destructiua.

Sed haec dimittantur ut ad secretiora deueniamus ${ }^{243}$. Audi ergo, uir Dei, subito ut primi parentes uestri quod diu cogitauerunt ${ }^{244}$ opere perfecerunt, aperti sunt oculi eorum et cognouerunt ${ }^{245}$ se esse nudos et absconderunt se a facie Dei.

Tunc ego: Hic ualde miror quomodo aperti sunt oculi eorum post peccatum. Nam potius clausi fuerunt ${ }^{246}$ quia $^{247}$ minus scientiae habuerunt? Si enim aperti fuerunt tunc oculi eorum, uidetur uerum dixisse serpens ille maledictus ${ }^{248}$ : "Eritis scientes bonum et malum". Miror etiam quod antea ${ }^{249}$, cognoscentes omnia alia, non cognouerunt se esse nudos et deinde peccantes, acquisiuerunt talem cognitionem.

Gabriel, fortitudo Dei, sic respondit: Homo Dei, audi me. Aperti fuerunt oculi eorum non ut magis scirent post peccatum quam antea, sed quia post peccata interiora lapsi erant in multos errores. Consumato peccato, diuino iudicio, ut conscientia propria sit iudex unicuique, id factum est ut agnoscerent omnes deceptiones et insidias et machinationes et suas uanas cogitationes et pessimos consensus. ${ }^{250}$ Et cognouerunt se esse nudos, quia iustitia spoliatos, diuina benedictione priuatos. Et abscondere se procurabant a facie Dei quia, uidentes haec omnia ${ }^{251}$, fingebant quantum fieri potest se illa non amisisse sed, quasi non peccassent aut contaminatos esse, cognoscebant malum, sed cognoscere nolebant, immo illud obumbrare et abscondere a facie Dei cupiebant ${ }^{252}$. Ideo apparuit ${ }^{253}$ Dominus post meridiem ad auram, quia luce meridiana erant ei opera eorum clara, ideo illa hora ut scirent ei esse nota omnia et ipsos a facie eius abscondi non posse. Venit autem sonitu praecedente, ${ }^{254}$ id enim erat signum ipsius aduentus, ad quod signum ipsi solebant, si alicubi latitarent, se ostendere et palam facere. Et quamuis ipsi primum noluissent peccatum agnoscere, tamen deinde 255 flere coeperunt et ingemiscere de peccato suo. Et tunc uenit Deus, non uocando Euam, sed Adam tamquam principaliorem ${ }^{256}$ et qui $\mathrm{se}^{257}$ et uxorem regere debuisset, clamando: Adam, ubi es? Tu credis ${ }^{258}$ esse in caelo et es in inferno. Credis te factum $^{259}$ Deum et es miserior homo quam unquam fuisses ${ }^{260}$, immo comparatus es iumentis insipientibus et similis factus es illis.

239 nullus] nullum $J L O P \mathbf{2 4 0}$ Vos habetis] Vos homines $I 241$ intus] et inter $I$; et intra FGHNOQ 242 uestri] uestra $Q \mathbf{2 4 3}$ deueniamus] deueniam $P 244$ cogitauerunt] cogitauerant $F I O P Q 245$ cognouerunt] cogitauerunt $V \mathbf{2 4 6}$ fuerunt] fuerant $H \mathbf{2 4 7}$ quia] qui $Q \mathbf{2 4 8}$ serpens ille maledictus] serpentem illam maledictam $Q 249$ antea] ante mortem $Q 250$ pessimos consensus.] pessimos consensus. Et aduerterunt ad ea quae non aduertebant, certificati sunt de quibus dubitabant $F P Q 251$ haec omnia] haec omnia quae uenerant super eos $F$; haec omnia quae uentura erant super eos $P Q 252$ a facie Dei cupiebant.] a facie Dei cupiebant. Qui enim non uult peccata sua agnoscere quasi a facie Dei uultum abscondit. Quia ergo uidebant mala sua, aperti fuerunt oculi eorum. $F$; a facie Dei cupiebant. Qui enim non uult peccata cognoscere quasi a facie Dei uult abscondere. Quia ergo uidebant mala sua, aperti sunt oculi eorum. Et quia illa nesciri affectabant, a facie Dei abscondebant. G 253 apparuit (M sup. lin. a. m. uenit)] uenit ILN 254 sonitu $\rightarrow$ 
que não são Deus. Nós, porém, somos imortais de uma forma que nada, além do nosso Deus, nos pode destruir. Vós tendes a força destrutiva dentro e fora de vós.

Mas deixemos estas coisas a fim de podermos chegar a outras mais secretas. Ouve, portanto, homem de Deus. Logo que os vossos primeiros pais concretizaram aquilo em que pensaram durante muito tempo, abriram-se-lhes os olhos e perceberam que estavam nus e esconderam-se da face de Deus.

Muito me admira neste momento, disse eu, como é que se lhes abriram os olhos depois do pecado. Será que estiveram fechados porque tinham menos conhecimento? Se realmente os seus olhos foram então abertos, parece que aquela serpente maldita havia dito a verdade: conhecereis o bem e o mal. ${ }^{[22]}$ Admira-me igualmente que antes, conhecendo todas as outras coisas, não hajam sabido que estavam nus e, depois, ao pecarem, adquirissem esse conhecimento.

Ouve-me, homem de Deus, assim respondeu Gabriel, a força de Deus, os seus olhos abriram-se, não por saberem mais depois do pecado do que antes, mas porque depois dos pecados interiores haviam caído em muitos erros. Consumado o pecado, a fim de que, por decisão divina, cada um tenha a própria consciência por juiz, verificou-se isso para que todos conhecessem dolos, armadilhas e maquinações, seus vãos e péssimos pensamentos consentidos, e reconheceram que estavam nus, porque espoliados da justiça, privados da bênção divina, e procuravam esconder-se da divina presença porque, ao verem tudo isto, fingiam quanto é possível que o não haviam perdido, mas, como se não tivessem pecado ou houvessem sido manchados, conheciam o mal, mas não o queriam reconhecer, mais, desejavam dissimulá-lo e escondê-lo da face de Deus. Por isso o Senhor apareceu a seguir ao meio dia, em plena luz, porque à luz do meio dia as acções deles eram para ele claras, por isso àquela hora, para saberem que tudo era dele conhecido e que não podiam esconder-se da sua face. Chegou, pois, precedido pelo fragor. Era esse o sinal da sua chegada. A esse sinal costumavam eles, se estivessem ocultos em qualquer parte, aparecer e mostrar-se. E embora a princípio não quisessem reconhecer o seu pecado, depois, contudo, começaram a chorar e a gemer por causa dele. Veio então Deus, não chamando Eva, mas Adão, enquanto superior e que deveria governar-se a si e à mulher, clamando em voz alta: Adão, onde estás? Crês que estás no Céu e estás no Inferno. Sonhas haver-te tornado Deus e és um homem mais infeliz do que alguma vez foste, sim, és comparado aos asnos insensatos e tornaste-te semelhante a eles. ${ }^{[23]}$

$\leftarrow$ praecedente] aurae sonitu praecedente $F H I L V$; Dominus aurae sonitu praecedente $G K$; aura sonitu praecedente $N$; aurae sonitum praecedente $P 255$ tamen deinde] tamen deinde et sonitum aurae sentientes $F Q 256$ principaliorem] principalem $P$; principalem stipitem $Q 257$ et qui se] et qui se et stipitem qui pro se et omnibus suis dona acceperat et $F P 258$ credis] credebas $F \quad 259$ factum] fieri $F \mathbf{2 6 0}$ homo quam unquam fuisses] omnibus $F$

[22] Gn 3:5.

[23] S1 48:13. 
Tunc ille, ut bene dixerunt ${ }^{261}$ uestri expositores, uoluit retorquere peccatum suum in Deum qui sibi dedisset mulierem deceptricem, et mulier in Luciferum serpentem. Et ita communiter omnes estis in hoc ueri ${ }^{262}$ filii Adam patris uestri et Euae matris uestrae, quia omnes, ut plurimum, peccata uestra in alios retorquetis et ipsa a Deo, immo a uobismetipsis abscondere conamini, quia nolletis ${ }^{263}$ intelligere [f1. 18] errores uestros propter superbiam et praesumptionem uestram, quod summe Deo nostro displicet, quia magis amat peccantem humilem quam iustum ${ }^{264}$ superbum.

Tunc ego subito addidi ${ }^{265}$ : Quomodo, Domine mi, potest esse superbus iustus?

Respondit: Homines ut plurimum credunt se esse immunes ${ }^{266}$ a peccato si uitia carnis non prosequuntur ${ }^{267}$. Superbiam, inanem gloriam et praesumptionem peccata esse non perpendunt ${ }^{268}$ et ita sibi iusti uidentur. Minus peccantes apud uos maiores peccatores existimantur ${ }^{269}$. Et superbi, qui plus peccant, quia abstinent a carnalibus desideriis, uidentur apud uos iusti, qui minora magis curatis, maiora nec agnoscitis. Quod peccatum fuit nostri quondam socii Luciferi nisi praesumptio et cupiditas dominandi? Sed reuertamur. ${ }^{270}$

Parentes illi uestri non fuerunt subito corpore mortui, sed bene obligationem moriendi incurrerunt ${ }^{271}$ et priuati fuerunt omni dono et redditi propriae naturae. Gratia enim non natura eis posse non mori concessum fuerat et appetitus inferior ex gratia et dono Dei erat subiectus rationi, non autem ex sui natura. Ideo, facto peccato, rediit homo ad illa quae suae naturae erant, circumdatus plurimis ${ }^{272}$ tribulationibus quae exprimuntur in illis uerbis: In sudore uultus tui comedes panem tuum ${ }^{273}$ et in dolore paries filios tuos.

Deus autem non apparebat eis in forma deitatis, sed in forma qua etiam nobis apparuerat quando nobis mandatum de adorando Filio suo tamquam homine proposuit. Apparebat ergo eis ut homo. Tunc ergo Deus, iratus non minus contra excusationem patris et matris uestrae quam contra peccatum ipsum in se, praecepit nobis omnibus qui eum in locum illum conduxeramus ut ipsum ${ }^{274}$ simul cum uxore, quae numquam extra paradisum fuerat, quia in paradiso Dei creata fuit, expelleremus et locum illum custodiremus. Quod effecimus ${ }^{275}$ congaudendo diuinae uoluntati simul et aliquo modo condolendo homini consocio nostro et conciui. Eua plorabat. Adam non sine lacrimis gemebat. Vide quid actum fuerit ${ }^{276}$ a nostris in paradiso nostro et quid a uestris in paradiso uestro. Sed uestri liberationem meruerunt, quia tempus penitentiae, extra paradisum positi, habuerunt et usque

261 dixerunt] dicunt $H I J L N O Q V 262$ ueri] uere $G L Q V 263$ nolletis] non uultis $Q 264$ iustum] peccantem $N 265$ subito addidi] subito addidi, quero $Q 266$ credunt se esse immunes] credunt se immunes 267 prosequuntur] prosequantur GNQ 268 non perpendunt] non credunt seu perpendunt $Q 269$ peccatores existimantur] peccatores uidentur uel existimantur $L \quad 270$ Sed reuertamur] Sed redeamus ad propositum $Q 271$ incurrerunt] incurrunt $V \mathbf{2 7 2}$ plurimis] pluribus $\rightarrow$ 
Ele quis então, como bem disseram os vossos comentadores, voltar o seu pecado contra Deus por lhe ter dado uma mulher enganadora, e a mulher contra Lúcifer, a serpente. E, por isso, neste ponto sois todos em geral verdadeiros filhos de Adão, vosso pai, e de Eva, vossa mãe, porque todos, a maioria das vezes, atribuís aos outros os vossos pecados e esforçais-vos por escondê-los de Deus e até de vós mesmos, porque não quereis reconhecer [fl. 18] os vossos erros, por causa da vossa soberba e da vossa presunção. O que desagrada sumamente ao nosso Deus, que ama mais o pecador humilde do que o justo soberbo.

Meu senhor, acrescentei imediatamente, como pode o justo ser soberbo?

Os homens, respondeu, muitas vezes crêem-se imunes ao pecado se não procuram os vícios da carne. Não consideram que a soberba, a vã glória e a presunção sejam pecados e, por isso, têm-se por justos. Aqueles que entre vós menos pecam consideram-se os maiores pecadores. E os soberbos, os que mais pecam, porque se abstêm dos desejos da carne, são tidos entre vós por justos. Vós que vos preocupais com ninharias e não reconheceis o que é importante. Qual foi o pecado de Lúcifer, outrora nosso companheiro, senão a presunção e a ânsia de poder? Mas regressemos.

Aqueles vossos pais não foram imediatamente mortos, no que ao corpo se refere, mas incorreram na inevitabilidade da morte, foram privados de todo o dom e entregues à própria natureza. Foi em razão da graça, e não da natureza, que lhes havia sido concedido poderem não morrer, e o apetite inferior estava subordinado à razão por força da graça e do dom de Deus, não por força da sua natureza. $\mathrm{E}$, assim, cometido o pecado, o homem retornou àquilo que era próprio da sua natureza, rodeado de muitas tribulações, que se traduzem naquelas palavras: Comerás teu pão com o suor do teu rosto, ${ }^{[24]} \mathrm{e}$, darás teus filbos à luz na dor. ${ }^{[25]}$

Deus, todavia, não lhes aparecia na forma de divindade, mas na forma em que nos aparecera a nós quando nos propôs o mandamento da adoração de seu Filho enquanto homem. Aparecia-lhes, portanto, como homem. Assim, Deus, irado então não menos contra a escusa de vosso pai e da vossa mãe do que contra o pecado em si, ordenou-nos a todos que o havíamos conduzido àquele lugar que o expulsássemos a ele e à sua mulher, que nunca estivera fora do Paraíso porque no Paraíso de Deus foi criada, e guardássemos esse lugar. Foi o que fizemos, regozijando-nos com a divina vontade ao mesmo tempo que de algum modo nos contristávamos com o homem, nosso consócio e nosso concidadão. Eva chorava, Adão, em lágrimas, gemia. Vê o que foi feito pelos nossos no nosso Paraíso, e pelos vossos no vosso. Os vossos, contudo, mereceram a libertação

$\leftarrow H O$; multis $V \mathbf{2 7 3}$ comedes panem tuum] uesceris pane tuo $H Q \mathbf{2 7 4}$ peccatum ipsum in se, (...) conduxeramus ut ipsum simul] peccatum ipsum simul $V 275$ effecimus] et fecimus $F H Q$; efficimus $G \mathbf{2 7 6}$ actum fuerit] actum fuit $N$; est $Q$

[24] Gn 3:19.

[25] Gn 3:16. 
ad mortem expectati fuerunt. Nostri autem, quia mori non poterant, casum pro morte acceperunt.

Ego diu steteram in una dubitatione quomodo uidelicet ${ }^{277}$ diabolus potuerit mulierem intrinsecus temptare. Sed iugiter audiendo noua pulchra et scitu delectabilia ${ }^{278}$, tandem hic clamando dixi: Dubium, Domine, dubium diu retentum ut uelis declarare rogo.

Tunc ille: Credis quod non uiderim cogitationem tuam et desiderium tuum? Vidi et percepi et dico tibi quod Lucifer temptauit hominem antequam peccasset temptatione interiori, non mouendo interius ordinatissimas uires suas ipse, sed exhibendo exterius suis sensibus quaedam quibus eum commoueret in superbiam et praesumptionem sui, ita quod potius circa sensibilia laboraret ${ }^{279}$ ut ipsius Euae sensum et mentem immutaret illo modo quo ipse Lucifer cupiebat quam quod [f1. 19] in phantasiam et intellectum eius quicquam imprimeret. Ecce respondi cogitationi tuae.

His dictis et auditis reductus sum in locum meum a sanctis angelis qui me hortabantur ut ad socios meos redirem et cibum corporalem sumerem. Et ita feci ${ }^{280}$.

277 quomodo uidelicet] quomodo autem $L$; que est utrum $P \quad \mathbf{2 7 8}$ scitu delectabilia] scitu delectabilia interrogare non poteram $F P$; scitu delectabilia, tacueram $K G \mathbf{2 7 9}$ laboraret] laborabat $H I K L N O P Q V 280$ Et ita feci] Et ita feci. Finis ultimi raptus $I$; Et ita feci. Laus Deo $K$ 
porque, postos fora do Paraíso, tiveram tempo de arrependimento e por eles se esperou até à morte. Os nossos, porém, porque não podiam morrer, em vez da morte tiveram a queda.

Muito tempo me debatera eu com uma dúvida, ou seja, como pôde o diabo tentar a mulher no seu íntimo. Mas, ao ouvir por tanto tempo novidades belas e agradáveis ao conhecimento, disse, por fim, num grito: A dúvida, senhor, a dúvida por tanto tempo reprimida, esclarece-ma, peço-te!

Pensas, disse ele então, que não vi o teu pensamento e o teu desejo? Vi, compreendi e digo-te que Lúcifer tentou o homem antes de pecar com a tentação interior, não movendo ele mesmo interiormente as suas muito bem ordenadas forças, mas apresentando externamente a seus sentidos coisas com que o arrastasse ao orgulho e à presunção, de maneira que actuava mais sobre as coisas sensíveis para mudar o sentir e o pensar de Eva do modo que o próprio Lúcifer pretendia do que [f1. 19] a imprimir-lhe no espírito e na fantasia fosse o que fosse. Eis a resposta ao teu pensamento.

Ditas e ouvidas estas coisas, fui reconduzido ao meu lugar pelos santos anjos, que me animavam a voltar para junto dos meus companheiros e a tomar alimento corporal. E assim fiz. 


\section{TERTIVS RAPTVS ${ }^{1}$}

$\mathrm{Vna}^{2}$ dierum $^{3}$, dum frequenter ${ }^{4}$ meditarer, fui raptus in eandem rotam in qua erant Noui et Veteris Testamenti patres et sanctorum angelorum innumerabilis exercitus. Deo et toti illi curiae supra solem et omnia astra lucidissimae debita reuerentia exhibita, cum omnes silerent, nesciebam cui loqui neque quid dicere.

Et ecce iterum sanctissimus et suauissimus 5 Gabriel angelus ante me astitit mihique dixit: Noli iam timere, nil enim noui tibi factum est. Consuetus es in uisionibus Dei. Sed, ut alias dixi, quaecumque tibi dicuntur a me ex parte Domini Dei nostri, quem scalae ${ }^{6}$ innixum uidisti, et nomine huius celebratissimi coetus et collegii, illa tibi reuelaui ut omnia conscribas diligenter et conserues ut sint futuro pastori, cui liber hic seruabitur, in eruditione et sui et aliorum. Sicut ergo coepisti, perficias. Memoria eorum quae hic audisti non te derelinquet.

Tunc ego: Domine mi, hic tam praeclarus tamque sanctus et bonus pastor quando ueniet et quando apparebit ${ }^{7}$ ? Quando tantum bonum et tam amplum donum conferet ${ }^{8}$ Deus $^{9}$ populo suo et fidelibus suis? Quando ueniet hic magnus et electus Dei?

Subridens, angelus dixit: Interroga, interroga hos patres qui sunt in rota tecum.

Conuersus ad illos, cum magna reuerentia rogare coepi. Tunc Petrus Apostolus, omnibus annuentibus ut diceret, ad me conuersus, dixit: Homo Dei, uis tu maior esse apostolis Domini? Quid tibi respondebo nisi quod ipse Dominus respondit nobis cum futura quaereremus ${ }^{10}$ : Non est uestrum nosse tempora uel momenta quae Pater posuit in sua potestate.

Tunc ego, tali responso accepto ${ }^{11}$, tristior factus, demisso uultu terram aspiciebam. Illi autem patres subridebant. Angelus uero, me in maxillam tangens, dixit: Alacrior

1 Tertius Raptus ( $N$ add. in marg. a. m. Caput 6)] Incipit Tertius Raptus $L$; 3s Raptus $O$ (in marg. a. m.); om. $V \mathbf{2}$ Vna] Vno $Q \mathbf{3}$ dierum] die $N \mathbf{4}$ frequenter] feruenter $F H I Q \mathbf{5}$ sanctissimus et suauissimus] sanctissimus $J V \mathbf{6}$ scalae] in scala $Q 7$ apparebit] parebit $J \mathbf{8}$ conferet] conferret $O$; confert $Q 9$ Deus] Deus clementissimus FIL(M in marg.) $N O Q 10$ quaereremus] quaerebamus $V$ 11 tali responso accepto] tali responsione accepta $Q$ 


\section{Terceiro Arrebatamento}

Um dia, enquanto meditava em comunidade, fui levado para uma Assembleia em que estavam os Padres do Antigo e do Novo Testamento e um incontável exército de santos anjos. Feita a devida reverência a Deus e a toda aquela cúria muitíssimo mais brilhante que o Sol e todos os astros, tendo todos ficado em silêncio, não sabia eu a quem me dirigir nem o que dizer.

Eis que de novo se apresentou diante de mim o santíssimo e amabilíssimo anjo Gabriel e me disse: Não receies, nada de novo te aconteceu. Estás habituado às visões de Deus, mas, como da outra vez te disse, quanto te for por mim dito da parte do Senhor nosso Deus, a quem viste sentado no trono, e em nome desta numerosíssima Assembleia e colégio to revelei para que tudo escrevas exactamente e o guardes para instrução própria e alheia do futuro Pastor, para quem será guardado este livro. Que concluas, pois, como começaste. Que não abandones a lembrança daquilo que aqui ouviste.

Meu senhor, perguntei eu, quando virá e quando se apresentará esse tão ilustre e tão santo e bom Pastor? Quando concederá o Deus clementíssimo a seu povo e a seus fiéis tão grande bem e tão abundante dom? Quando virá este grande eleito de Deus?

Interroga, disse o anjo a sorrir, interroga estes Padres que estão contigo na Assembleia.

Voltado para eles, comecei a perguntar com muita reverência. Então o apóstolo Pedro, anuindo todos a que fosse ele a falar, disse, voltando-se para mim: Queres tu, homem de Deus, ser superior aos apóstolos do Senhor? Que te hei-de responder senão o que o próprio Senhor nos respondeu quando o interrogávamos sobre o futuro: Não vos cabe conhecer os tempos ou os instantes que o Pai reservou ao seu poder. ${ }^{[26]}$

Perante tal resposta fiquei tristíssimo e, cabisbaixo, olhava o chão. Os Padres sorriam. Batendo-me no queixo, disse o anjo: Alegra-te e cumpre os preceitos do 
esto et Domini mandata serua ${ }^{12}$, qui dixit: "Petite, quaerite et pulsate. Quod petentibus non datur, quaerentibus conceditur. Et quod quaerentibus clauditur, pulsanti aperitur. ${ }^{13}$ " Accipe nunc aliqua de aduentu eius. Deinde accipies, si Domino placuerit, etiam tempus aduentus eius.

Eliget $^{14}$ sibi Deus uirum secundum cor suum et ponet eum pascere gregem populi sui, qui etiam magna auctoritate sibi a Deo tradita librum istum aperiet et omnia mysteria in eo conscripta ${ }^{15}$ omnibus populis aperiet et manifestabit et docebit omnes gentes uoluntatem Dei sui, quem toto corde amabit. Interim tu istum librum praeparabis et claudes usque ad tempus huius pastoris iam a Deo electi. Liber hic scriptus est intus, quia de intimis secretis docet [f1. 20] et tractat, et foris ${ }^{16}$, quia etiam multa nota omnibus in ipso ponuntur. Quando apparebit ille Dei electus pastor, tunc me Gabrielem qui tecum loquor mittet Deus ad confirmandum et propalandum omnia secreta libri huius. Necesse enim est ut multa quae non sunt in fide uestra manifesta, per ipsum manifestentur. Et, ne ullus habeat excusationem, ego primus ${ }^{17}$ in signis et prodigiis apparebo et haec omnia in rotulis conscripta ${ }^{18}$ ei portabo. Eligetur ${ }^{19}$ cum admiratione ac stupore omnium. Cuncti reges uenient ad eum et adorabunt eum et laetabuntur de tam sancta electione et de pastore tanto tempore a bonis desiderato. Erunt qui ei aduersabuntur et inimicabuntur. Sed Deus confringet ${ }^{20}$ capita inimicorum suorum et prosternet eos, ut sciant hii qui ab Oriente et hii qui ab Occidente quia magnus Dominus ${ }^{21}$ fecit haec. Omnes gentes infidelium ad fidem ueram ${ }^{22}$ conuertentur et ei sicut patri oboedient. Et reget omnes gentes ${ }^{23}$ in timore Dei ipse et sucessores eius temporibus multis. Erit omnium hominum unum ouile et unus pastor. Canones et antiquas ${ }^{24}$ patrum consuetudines obseruabit. Omnes prauas leges et consuetudines extirpabit, bonas inseret et plantabit. Curam habebit magis animarum et spiritualium negotiorum quam temporalium. Nec ad thesauros intendet ${ }^{25}$ nisi prout Ecclesiae expediens fuerit et orphanis et uiduis et aliis pauperibus.

Tunc ego cum fletu dixi: O Deus, quando populus Christianus nunc tam infelix tanta felicitate perfruetur? Sed ex quo tempus aduentus tam magnifici scire non ualeo, redeamus ad nostros primos parentes. Ex dictis ${ }^{26}$ alias $\operatorname{cognosco}^{27}$ ipsos peccasse in paradiso antequam eicerentur ${ }^{28}$ nec tamen subito morti obnoxios fuisse, immo in eadem condicione perstitisse.

Respondit angelus: Subito $^{29}$ ut mater uestra elata est, amisit gratiam Dei et quoad animam mortua est, sed corpus remansit in pristina condicione. Sed quia

12 serua] seruata $Q 13$ Quod petentibus non datur, (...) pulsanti (pulsantibus $I N V$ ) aperitur] Quod petentibus non datur, quaerentibus conceditur et non quaerentibus obcluditur, pulsabtibus aperitur $\mathrm{FH}$; Quid petentibus non datur? Aut quid quaerentibus non conceditur aut claudatur pulsantibus? $Q \quad 14$ Eliget] Elegit $Q 15$ conscripta] contenta $P \quad 16$ et foris] et foris est scriptus $F \quad 17$ primus] prius $L N \mathbf{1 8}$ et haec omnia in rotulis conscripta] et haec a me in rotulis sit $O \rightarrow$ 
Senhor, que disse: Pedi, procurai, batei. Concede-se aos que procuram o que se não dá aos que pedem. E a porta que se fecha a quem procura, abre-se a quem nela bate. Ouve agora algo sobre o seu advento. Depois, se a Deus aprouver, ouvirás também falar do tempo desse advento.

Deus escolherá para si um homem segundo o seu coração e pô-lo-á a apascentar o rebanho de seu povo. Em função da grande autoridade por Deus a si concedida, abrirá também este livro e revelará a todos os povos todos os mistérios nele escritos, mostrará e ensinará a todas as gentes a vontade do seu Deus, a quem amará de todo o coração. Entretanto, tu prepararás e selarás este livro até ao tempo deste Pastor já por Deus escolhido. Este livro está escrito por dentro, porque trata e ensina recônditos [fl. 20] segredos, e por fora, porque muitas coisas de todos conhecidas se inserem nele. Quando aparecer o Pastor escolhido de Deus, então Deus enviar-me-á a mim, Gabriel, que falo contigo, a confirmar e a divulgar todos os segredos deste livro. Na verdade, é imperioso que muita coisa que na vossa fé não está manifesta se manifeste por seu intermédio. E para que ninguém tenha desculpa, hei-de aparecer primeiro em sinais e prodígios e levar-lhe-ei todas estas coisas escritas em pequenos rolos. Será eleito com a admiração e o espanto geral. Todos os reis virão até ele e hão-de adorá-lo e alegrar-se-ão com tão santa eleição e com Pastor durante tanto tempo desejado pelos bons. Haverá aqueles que se lhe oporão e o hostilizarão. Mas Deus esmagará as cabeças de seus inimigos, derrubá-los-á, para que saibam os do Oriente e os do Ocidente que foi o Senhor poderoso que fez estas coisas. Converter-se-ão à verdadeira fé os infiéis e obedecer-lhe-ão como a um pai. Há-de reger todos os povos no temor de Deus ele e seus sucessores, durante muito tempo. Toda a humanidade terá um só redil e um só Pastor. Observará os cânones e as tradições antigas dos Padres. Extirpará todas as más leis e tradições, enxertará e plantará as boas. Estará mais preocupado com as almas e os assuntos espirituais do que com os temporais. Às riquezas dará apenas a atenção que for conveniente para a Igreja, os órfãos e viúvas e outros pobres.

Oh Deus! disse eu então a chorar, quando será que o povo cristão, hoje tão infeliz, virá a gozar de tão grande bem-aventurança?! Contudo, uma vez que me não é dado conhecer o tempo de tão admirável advento, voltemos aos nossos primeiros pais. Das afirmações anteriores sei que eles pecaram no Paraíso antes de serem expulsos e que, todavia, não foram de imediato sujeitos à morte, pelo contrário, se mantiveram na mesma condição.

Logo que a vossa mãe se deixou levar pelo orgulho, respondeu o anjo, perdeu a graça de Deus e morreu, quanto à alma. O corpo, contudo, permaneceu na

$\leftarrow \mathbf{1 9}$ Eligetur] Et legetur $J \mathbf{2 0}$ confringet] infringet $J V 21$ magnus Dominus] manus Domini $F I L N O P Q$ 22 fidem ueram] fidem uestram $I$; fidem $V \mathbf{2 3}$ omnes gentes] eos $V \mathbf{2 4}$ et antiquas] sancti quas

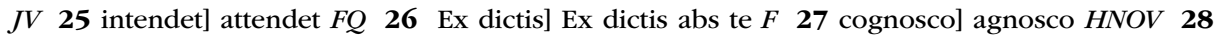
eicerentur] comederent et eicerentur $F$; comederent et deiicerentur $Q 29$ Subito] Subito post $\rightarrow$ 
Deus dixerat: "In quacumque hora comederitis morte moriemini", et non, "in quacumque hora peccaueritis peccato interiori elationis" ${ }^{30}$, ideo post esum illius ligni ${ }^{31}$ morti corporali obnoxii esse coeperunt.

Et ego: Mi Domine, quomodo post peccatum consuerunt folia ficus et fecerunt sibi perizomata? Vbi erat acus? Vbi filum ${ }^{32}$ ?

Respondit: Locutus est propheta consuetudine illa quae tunc erat quando scripsit. Illi enim nondum habebant acus nec fila, sed herbis subtilioribus frondes arboris de qua comederant colligauerunt ac si consutae ${ }^{33}$ fuissent. Quod factum est ut ostenderetur quod per membra illa propagationis ${ }^{34}$ essent obnoxii morti. Ideo et erubescebant et dolebant et membra illa ${ }^{35}$ abscondebant, magis propter hoc quam propter motum aliquem ipsorum [f1. 21] membrorum ${ }^{36}$. Quod autem dicitur Deum fecisse illis tunicas pelliceas, hoc ita intelligendum est, quia docuit eis uestimenta fore necessaria in loco ad quem exituri erant quae possent facere ex pellibus animalium et lana et lino ita quod eis uterentur potius ad necessitatem quam ad decorem, et quod folia ${ }^{37}$ arborum non erant instrumenta apta supplendi ${ }^{38}$ tali necessitati. Dixit Deus et homo tamquam sapiens ${ }^{39}$ illico intellexit genera uestium quibus uti posset et nullo animali interfecto ${ }^{40}$. Sed potentia sua Deus fecit tunicas pelliceas, hoc est, fecit pelles et formam dedit tunicarum ${ }^{41}$. Sicut ergo Deus tunc fecit pelles nouas et tunicas ex eis, poterat facere pannos splendidos et olosericos ${ }^{42}$, sed noluit, ut doceret uos uestimentis uti oportere ad necessitatem, non ad pompam et curiositatem.

Tunc ego: Domine mi, tu narrasti mulierem creatam fuisse translato homine in paradisum et tamen Scriptura dicit antea, in sexta die Deum creasse masculum et feminam et eis benedixisse.

Respondit angelus: Scio te idiotam ${ }^{43}$ talia dubia proponere nescire. Sed Domini uoluntas est ut ea proponas ${ }^{44}$ et, ipsius gratia concedente, intelligas.

Dixi: Vere, angele Dei, numquam me talia cogitasse memini et ipsemet miror unde in mente mea uoluuntur mihi inconsuetae ${ }^{45}$ cogitationes.

Et ille: Istam gratiam pro communi hominum ${ }^{46}$ utilitate concessit tibi Deus. Dico ergo, ut sciant omnes populi, sexta die solum uirum fuisse creatum tamquam stipitem totius generis humani. Et hoc bene fatentur ${ }^{47}$ etiam uestri scriptores. Sed hoc scito quod constructio ${ }^{48}$ uerborum Moysi sic construenda est. Quando

$\leftarrow$ peccatum $F P 30$ interiori elationis] interiori elationis obligabantur enim solum ad decalogum, sed propter illius esum morti obnoxii erant, ideo $F 31$ ligni] pomi uetiti $F \mathbf{3 2}$ filum] folium $F \mathbf{3 3}$ consute] consulte $V 34$ propagationis] propagando $F$; propagandi $Q 35$ membra illa] membra illa per quae infelices filios procreaturi erant $F P \mathbf{3 6}$ propter motum aliquem ipsorum membrorum] propter aliquem membrorum illorum $Q \quad 37$ folia] folii $N \quad 38$ supplendi] ad supplendum $F \quad 39$ tamquam sapiens] tamquam sapiens, perspicax et $F \mathbf{4 0}$ interfecto] infecto $V \mathbf{4 1}$ dedit tunicarum] $\rightarrow$ 
antiga condição. Mas porque Deus havia dito: Na mesma hora em que comerdes, morrereis de certeza ${ }^{[27]}$ e não, na mesma hora em que pecardes pelo pecado interior do orgulho, por isso, depois de comerem daquela árvore, passaram a ficar sujeitos à morte corporal.

Meu senhor, perguntei eu, como é que depois do pecado coseram as folhas da figueira e fizeram vestes para si? Onde tinham a agulha? Onde havia fio?

O profeta expressou-se, respondeu ele, de acordo com o costume da época em que escreveu. Na verdade eles ainda não tinham nem agulha nem fio, mas com ervas mais delgadas ligaram as folhas da árvore de que haviam comido como se fossem cosidas. E isto aconteceu para se deixar ver que era pelos membros da procriação que ficavam sujeitos a morrer. Por isso se envergonhavam e choravam e tapavam esses membros, mais por isso do que por qualquer impulso dos próprios [f1. 21] membros. O que se diz, que Deus lhes fizera túnicas de pele, deve entender-se deste modo: que lhes ensinou que as vestes lhes seriam necessárias no lugar para onde iriam sair, vestes que poderiam fazer das peles de animais, de lã e de linho, de modo que delas se servissem mais por necessidade do que para ornato, e que as folhas das árvores não eram instrumentos aptos a suprir essas necessidades. Deus disse-o, e o homem enquanto ser inteligente compreendeu de imediato o género de vestes que poderia usar, sem a morte de nenhum animal. Mas Deus, no seu poder, fez túnicas de pele, isto é, criou as peles e deu-lhes a forma de túnica. Assim, pois, como Deus criou peles novas e delas fez túnicas, poderia criar belos panos de seda, mas não o quis, para vos ensinar que é conveniente usar as vestes em função da necessidade e não da pompa ou do enfeite.

Meu senhor, inquiri, tu referiste que a mulher foi criada depois de o homem haver sido transladado para o Paraíso e, todavia, a Escritura diz que foi antes, que no sexto dia criou Deus homem e mulher e os abençoou.

Eu sei, respondeu ele, que tu, que és ignorante, não saberias levantar essas dúvidas, mas é vontade do Senhor que as levantes e as compreendas por benevolência da sua graça.

$\mathrm{Na}$ verdade, anjo de Deus, respondi, não me lembro de alguma vez pensar nisso, e eu próprio me admiro de onde terão vindo ao meu espírito pensamentos tão pouco habituais para mim.

Concedeu-te Deus esse favor, acrescentou ele, para benefício geral da humanidade. Digo, pois, para que todos os povos saibam, que no sexto dia somente o homem foi criado, como tronco de toda a raça humana. E isto até os vossos escritores o afirmam claramente. Mas fica a saber que a construção das palavras

$\leftarrow$ dedit tunicarum ut recordarentur se morituros et pellem propriam amissuros $P$ 42 olosericos] et de serico J; odoriferos (in marg. a. m. olosericos) $O$; sericos $Q V \mathbf{4 3}$ scio te idiotam] scito idiota $Q$ 44 proponas] praeponas $I$; roponat $Q \quad 45$ inconsuetae] consuetae $L$; inconsulte $V \mathbf{4 6}$ hominum] omnium $O P 47$ bene fatentur] fateri uidentur $F$; benefactentur $P 48$ constructio] sententia $F$

[27] Gn 2:17. 
dixit: "Ad imaginem Dei creauit illum", debet sequi: "et factum est ita. Viditque Deus cuncta quae fecerat et erant ualde bona." Illa uero uerba quae incipiunt ibi: "masculum et feminam creauit eos...", usque ibi: “...ut habeant ad uescendum", sunt interposita ${ }^{49}$ et debent intelligi dicta in paradiso, plasmata muliere. Et quia aliqua illorum etiam ipsi Adae adhuc soli dixerat Deus, tunc enim eum dominum omnium aliorum constituit et cibum assignauit, ideo propheta et quae tunc Deus dixit et quae post ${ }^{50}$, creata uxore ${ }^{51}$, simul posuit. Vnde et praeceptum de non comedendo fructum fici illius, creata uxore, Deus apposuit.

Tunc ego: Abundant mihi dubia et interrogationes ${ }^{52}$, nescio unde nisi quia tu dixisti a Deo haec fieri ${ }^{53}$. Et ego ita credo, quia toti mundo notum est me ignorantem et idiotam esse. Dubito nunc, immo uellem scire qua die et cuius mensis Adam intrauit in paradisum et qua die plasmatus est, similiter et Eua, et qua die ambo expulsi fuerunt. Haec nullibi scribuntur et [f1. 22] sunt scitu ualde $\operatorname{digna}^{54}$.

Respondit angelus: Tempus aduenit in quo Deus mirabilia facturus est, et illuminare in his quae fidei sunt uult totum ${ }^{55}$ mundum. Ideo te facit tot et tanta dubia proponere. Scito ergo et animaduerte quod opinio quam multi etiam Christianorum tenent uera est: mundum creatum fuisse sole existente in primo puncto arietis ${ }^{56}$ et erat illa dies quam uos dominicam appellatis. Et sic Adam fuit plasmatus illa die quam uos diem Veneris uocatis. Et sic tota illa die, id est, toto residuo illius diei permansit extra paradisum et omnibus rebus ${ }^{57}$ nomina imposuit. Similiter et die sequenti in meditatione Dei creatoris sui, ipsum benedicendo et magnificando. Prima uero die Sabbati, hoc est, in octaua creationis Solis, translatus est et positus in paradiso uoluptatis facto a Deo prima die, quando creauit solem et terram et alia elementa. Et illa die, immisso in eo sopore ${ }^{58}$, de latere ipsius Euam condidit, matrem cunctarum gentium. Et benedictione Deo caeli exhibita ab utroque ipsorum ${ }^{59}$, mandato accepto crescendi et cibum illum non comedendi, in gratiarum actione tota illa die permanserunt, prius uolentes copulari Deo antequam copularentur corpore, quia mandato illo non cogebantur statim ad copulam, sed tempore congruo. Et statuerunt abstinere tribus diebus, non quod impellerentur ${ }^{60}$ ullo inordinato ${ }^{61}$ amore ad actum carnis, sed solo amore prolis ${ }^{62}$. Cognouerunt tamen prius pariendos esse filios mente quam carne.

49 sunt interposital sunt interposita et dicta per quamdam anticipationem $F \mathbf{5 0}$ post] prius $P \mathbf{5 1}$ uxore] muliere $F L 52$ interrogationes] imaginationes $V \mathbf{5 3}$ fieri] facta $Q \mathbf{5 4}$ ualde digna] dignissima F 55 totum] omnem $N O Q \mathbf{5 6}$ puncto arietis] puncto arietis uidelicet quando sol creatus est, Aries octaui caeli non esset re ipsa $M$ (in marg. a. m.); puncto Arietis quamuis prima die non esset in caelo Aries re ipsa sed imaginarie tantum. Et $F$; puncto Arietis quamuis in prima die non esset in caelo Aries re ipsa sed imaginarie. Et $P$; puncto Arietis ergo quando sol creatus est, Aries octaui caeli non esset re ipsa $Q$; puncto Arietis licet quando Sol creatus est, alias octaui caeli non esset re ipsa. $O \mathbf{5 7}$ rebus] creatis $Q \mathbf{5 8}$ sopore] sopore in quo Deum uidit $M$ (in marg. a. $m$.) NOQ 59 Et benedictione Deo caeli exhibita ab utroque ipsorum] Et benedictione Deo exhibito ab utroque $\rightarrow$ 
de Moisés deve assim ser feita, quando disse: Criou-o á imagem de Deus, ${ }^{[28]}$ deve seguir-se: E assim aconteceu. Viu Deus tudo o que tinha feito e era muito bom. ${ }^{[29]}$ Aquelas palavras que começam em: criou-os homem e mulher... ${ }^{[30]}$ até ... para que tenham que comer, ${ }^{[31]}$ são interpoladas e devem entender-se como ditas no Paraíso, depois de criada a mulher. E visto que algumas dessas as havia dito Deus ao próprio Adão ainda só, na verdade constituiu-o então senhor de todas as outras coisas e atribuiu-lhe o alimento, por isso o profeta associou o que Deus disse então e o que disse depois, com Eva já criada. Daí que, criada a mulher, acrescentasse o preceito de não comer do fruto daquela árvore.

Estou afogado em dúvidas e interrogações, disse eu, não sei porque é que estas coisas foram feitas, mas apenas que tu disseste que foram feitas por Deus. E eu assim creio, porque é sabido de todos que sou ignorante e insensato. Neste momento duvido, ou melhor, queria saber em que dia e de que mês entrou Adão no Paraíso, e em que dia foi formado. E o mesmo acerca de Eva. E em que dia ambos foram expulsos. Estas coisas não estão escritas em lado nenhum, mas [f1. 22] merecem bem ser conhecidas.

Chegou o tempo, respondeu o anjo, em que Deus vai fazer maravilhas. Quer esclarecer o mundo todo sobre quanto é matéria de fé. Por isso te fez levantar tantas e tão importantes dúvidas. Ouve, pois, e fica a saber que a opinião de muitos, também cristãos, é verdadeira: que o mundo foi criado estando já o Sol no primeiro ponto do signo de Carneiro, e era esse dia a que chamais Domingo. Deste modo, Adão foi formado naquele dia que vós chamais Sexta-Feira. E, assim, por todo aquele dia, isto é, no que restava daquele dia, permaneceu fora do Paraíso e deu nome a todas as coisas. Do mesmo modo, também no dia seguinte se manteve na contemplação de Deus, seu criador, bendizendo-o e exaltando-o. Ora, no primeiro dia depois do sábado, isto é, na oitava da criação do Sol, foi transferido e posto no Jardim das Delícias feito por Deus no primeiro dia, quando criou o Sol e a Terra e os outros elementos. E, nesse dia, depois de suscitar nele o sono, do seu lado formou Eva, mãe de toda a humanidade. E depois de ambos bendizerem ao Deus do Céu, tendo recebido o mandamento de crescerem e de não comerem daquele fruto, ficaram todo esse dia em acção de graças, desejando unir-se primeiro a Deus antes de unirem seus corpos, já que, em razão do mandamento, não eram forçados à união imediata, mas na ocasião oportuna. E acordaram abster-se por três dias. Não que fossem impelidos para

$\leftarrow$ ipsorum $L$; Et benedictione a Deo caeli exhibita ab utroque $H N P$; Et benedictione a Dei caeli manu exhibita et ab utroque ipsorum $Q \mathbf{6 0}$ impellerentur] compellerentur $F$; pellerentur $O \quad \mathbf{6 1}$ inordinato] immoderato FHIJLNOPV $\mathbf{6 2}$ amore prolis] amore prolis ad honorem Dei educandae $\rightarrow$

[28] Gn 1:27.

[29] Gn 1:30-31.

[30] Gn 1:27.

[31] Gn 1:30. 
Lucifer uidit haec omnia ${ }^{63}$ et tabuit et ad temptandum ${ }^{64}$ accessit. Tertia die elata est mulier et peccauit ${ }^{65}$, et sequentibus diebus ${ }^{66}$ uirum temptauit et tandem ${ }^{67}$ uicit. Et sic in octaua creationis Adae fuerunt expulsi neque Sabbatum in paradiso uiderunt.

Nunc a te quaero, mi Domine, dixi, an Liber ${ }^{68}$ Geneseos descripserit continue lineam patris in filium absque ulla interpollatione uel interdum descendit in nepotem et abnepotem.

Respondit angelus: Ita fuit uidelicet cum interpollatione. Sicut enim totum studium Matthaei euangelistae fuit ostendere Dominum Christum ex Dauid et Abraham descendisse stirpe, ita totum studium illius prophetae, quem ibi quasi cornua ferentem uides, fuit ostendere qualiter populus ille Hebraeus et a quibus originem habuisset. Iccirco non curauit ${ }^{69}$ multos in medio praetermittere, quorum uitae annos non numerauit sicut et aliquid tale iam alias tibi declaraui: "Dies enim saeculi quis enumerauerit" 70 ? Sicut ergo Matthaeus multos interdum reges praetermittit medios, sic et Moyses multos patres, et coniungit abnepotem ${ }^{71}$ cum atauo et longius. Vos homines et Hebraei et Christiani computatis annos inceptionis mundi per annos patrum et filiorum ${ }^{72}$ et non consideratis quod quintus et decimus ${ }^{73}$ nepos filius dicitur ${ }^{74}$. Computemus [f1. 23] igitur uitam talis patris et talis filii. Nonne a primo usque ad ultimum deueniemus ${ }^{75}$ subito absque medio? Interpone medium et uitam illorum qui inter illos fuerunt et inuenies multo plura milia annorum.

Tunc ego: Quot ${ }^{76}$ sunt ergo milia annorum a creatione solis, non dico caeli empyrii, usque ad Christum ${ }^{77}$ ? Hebraei enim minus temporis transisse ponunt quam Christiani et tu uideris longe plus temporis ponere etiam Christianis.

Respondit: Immo multo plus annorum praeteriit quam uos dicatis ${ }^{78}$. Sed quot milia ego scio $^{79}$, sed Dominus non uult ea palam facere ante aduentum illius electi pastoris. Sicut enim de die illo nemo nouit quando ueniet Dominus ${ }^{80}$, ita neque de prima die mundi nemo scit, nam dies saeculi quis enumerauit? Deus quoque noster uere magnus et magnificus nimis ea solum reuelat seruis suis quae illis utilia sunt et expediunt. Cognitio ergo talis nil prodest Ecclesiae Dei nisi ad curiositatem. Haec ergo non uult pro nunc patefacere.

$\leftarrow M$ ( in marg. a. m.) NO 63 omnia] optima $M$ (in marg. a. $m$.) $N$; omnia optima $Q 64$ ad temptandum] temptationem $I \mathbf{6 5}$ et peccauit] et peccauit elatione mentis $M$ (in marg. a. $m$.) NO 66 sequentibus diebus] sequentibus diebus a Lucifero temptata $M$ (in marg. a. $m$.) NO 67 et tandem] et tandem iterum uicta, uirum $M$ (in marg. a. $m$.) $O 68$ an Liber] in Libro $Q 69$ non curauit] non curauit propheta $M$ (sup. lin. a. m.) NOQ $\mathbf{7 0}$ enumerauerit?] enumerauerit? Finis mundi nescitur et principium eius ignoratur neque quisquam nouit enumerare dies intermedios. $M$ ( in marg. a. m.) NOQ $\mathbf{7 1}$ abnepotem] nepotes $P$; a nepote $Q \mathbf{7 2}$ et filiorum] et filiorum et numeratis uitas et sic concluditis mundum ex tunc fuisse $M$ (in marg. $a$. m.); et filiorum et numeratis uitas ipsorum et sic concluditis mundum extime fuisse $N$; et filiorum et numeratis uitas $\rightarrow$ 
o acto carnal por qualquer amor desordenado, mas apenas por amor da descendência. Aprenderam ainda que os filhos devem gerar-se primeiro no coração que na carne. Lúcifer viu tudo isto, ficou mirrado de inveja e aproximou-se para os tentar. Ao terceiro dia, a mulher deixou-se invadir pelo orgulho e pecou. Nos dias seguintes tentou o homem e, por fim, venceu-o. E assim, na oitava da criação de Adão, foram expulsos e nem o sábado passaram no Paraíso.

Pergunto agora, meu senhor, disse eu, se o Livro do Génesis descreve seguidamente, sem qualquer alteração, a linha de pai a filho ou, por vezes, desce para o neto e o trineto.

Assim aconteceu, respondeu o anjo, ou seja, com alterações. Assim como toda a preocupação do evangelista Mateus foi mostrar que Cristo, o Senhor, descendia de David e da estirpe de Abraão, assim toda a preocupação do profeta que ali vês como que ostentando chifres ${ }^{[32]}$ foi mostrar como e de quem aquele povo hebreu havia tido origem. Por isso não se preocupou em saltar sobre muitos de permeio, de quem não contou os anos de vida, como já noutro lugar te referi algo de semelhante: Os dias do mundo, quem os poderá contar. ${ }^{[33]}$ Assim, pois, como Mateus por vezes ignorou reis que estavam de permeio, assim também Moisés ignorou muitos pais e associou o trineto com o tetravô, e mais longe ainda. Vós, homens, quer hebreus, quer cristãos, contais os anos do princípio do mundo pelos anos de pais e de filhos e não atendeis a que o quinto e o décimo neto se designam por filho. Contemos, [f1. 23] pois, a vida de um tal pai e de um tal filho. Não iremos demasiado depressa do primeiro ao último, sem o do meio? Conta o do meio e os que existiram entre eles e encontrarás muito mais milhares de anos.

Quantos são então, perguntei, os milhares de anos desde a criação do Sol, não me refiro ao Céu Empíreo, até Cristo? Os Hebreus, na verdade, dizem que passou menos tempo que os cristãos, e tu parece que contas muito mais tempo ainda que os cristãos.

Sim, respondeu, passaram muito mais anos do que vós dizeis. Eu, na verdade, sei quantos mil, mas o Senhor não quer que isso seja divulgado antes do aparecimento do Pastor escolhido. Assim como ninguém sabe daquele dia, quando o Senhor virá, assim também ninguém sabe do primeiro dia do mundo, pois os dias do mundo, quem os contou? Do mesmo modo, o nosso Deus, verdadeiramente grande e tremendamente magnífico, apenas revela a seus servos aquilo que lhes é útil e conveniente. Conhecimento dessa natureza não interessa à Igreja de Deus senão para satisfazer a curiosidade. Portanto, não quer, por enquanto, tornar isso público.

$\leftarrow$ ipsorum et sic concluditis mundum ex tunc fuisse $O$; et filiorum et numeratis uitam ipsorum et sic concluditis mundum extime fuisse $Q \mathbf{7 3}$ quintus et decimus] quintus et decimus et milesimus $M$ (sup. lin. a. m.) $N$ (in marg. a. $m$.) $O Q \mathbf{7 4}$ filius dicitur] filius dicitur, unde et Adam est pater omnium $M$ (in marg. a. m.) $N Q 75$ deueniemus] deuenimus $J O 76$ Quot] Quod $P 77$ caeli empyrii, usque ad Christum] caeli empyrii JOV 78 dicatis] dicitis $I Q 79$ scio] nescio $Q 80$ nemo $\rightarrow$

[32] ou seja, Moisés.

[33] Ecli 1:2. 
Et ego: Quae Deo et Domino nostro reuelare non placet, mihi quoque illa replicare $^{81}$ non licet. Et ideo quia nosse principium uel finem mundi parum prodest, satis mihi esset scire de tempore quo uenturus est ille magnus uicarius Christi. Postquam consideraui pauperculum illum patrem nostrum ${ }^{82} \mathrm{cum}$ illa misera matre nostra, ab illo paradiso uoluptatis exclusos, in tam breui tempore tam plenos scientia, miratus sum de eorum inconstantia et fleui de malo ipsorum et nostro et quaesiui ab angelo quare Deus permisit ita cadere et noluit eis praebere auxilium ne caderent.

Subito respondit ${ }^{83}$ : Cur permisit etiam tot ex nostris in peccatum cadere? An nescis quod Deus et angelum et hominem a principio suae creationis dimisit ${ }^{84}$ in manu consilii sui? Apposuit praecepta et mandata quae seruando seruarentur et transgrediendo illa, ipsi quoque non gauderent illis bonis quae Deus eis praeparauerat. Nos angeli, si fas esset conqueri de Deo, potius conqueri possemus, quia et si nostris miseris fratribus, quos diabolos uocatis ${ }^{85}$, tempus paenitentiae dederit, illud tamen longe breuius fuit uestro ${ }^{86}$, quia uestri etiam post expulsionem a paradiso paenitentiam agere potuerunt ${ }^{87}$. Nostri post casum nullo modo potuerunt.

Tunc ego dixi: Ex hoc uidetur sequi quod angeli mali etiam si paeniterent non possent saluari?

Et ille: Ad paenitentiam fructiferam non sufficit dolere ${ }^{88}$ de comissis, sed oportet ut ibi gratia Dei intersit ad hoc ut Deus dolorem illum acceptet. Eo modo potest angelus dolere post casum ut dolor sit gratus Deo quomodo et homo post mortem, de quo alias dixi tibi. Omnia consistunt in regulis ab ipso Deo optimo ordinatis.

Ego iterum: Si Deus sciebat hominem casurum, cur ipsum temptari permisit? Et quare homines redimere uoluit et non angelos?

Respondit: Scientia Dei mirabilis [fl. 24] est, uix a nobis ${ }^{89}$ comprehensibilis est, attingens a fine usque ad finem. Aeternus Deus est, aeterna est scientia eius. Aeternum omnia tempora uestra ${ }^{90}$ ambit et amplectitur ${ }^{91}$, omnia inspicit ac si praesentia essent. Sed uos cogitatis Deum tamquam priorem uobis sicut et est habere scientiam illorum futurorum ${ }^{92}$ ac si antea ${ }^{93}$ in causis uideret sicut si aliquis inspiciat terram uel stipitem arboris et dicat: "Hic ${ }^{94}$ orietur ramus" 95 ". Non sic Deus futura cognoscit ${ }^{96}$ quasi in causa, sed ipsa tamquam praesentia cernit ratione suae maiestatis ${ }^{97}$. Nonne interdum tu, frater mi, somniasti et in somno uidisti aliquod futurum tamquam praesens?

$\leftarrow$ nouit quando ueniet Dominus (er. $N, O$ (sup. lin.)] nemo nouit $J P \mathbf{8 1}$ replicare] explicare $\mathrm{Q} \mathbf{8 2}$ patrem nostrum] patrem omnium $J V 83$ respondit] respondit angelus $H L N O Q \mathbf{8 4}$ dimisit] reliquit $Q 85$ uocatis] appellatis $Q \mathbf{8 6}$ uestro] nostro $V \mathbf{8 7}$ potuerunt] poterant $Q \mathbf{8 8}$ dolere] dolore $M \mathbf{8 9}$ nobis] uobis $I L N O P 90$ uestra] nostra $Q 91$ amplectitur] complectitur $L N V 92$ habere scientiam illorum futurorum] habere scientiam illarum futurarum $I$; habere scientiam $O Q 93$ si antea] si $\rightarrow$ 
E eu, aquilo que a Deus e a nosso Senhor não agrada revelar, também me não é permitido expô-lo. Por isso, já que não há vantagem em conhecer o princípio e o fim do mundo, bastar-me-ia conhecer o tempo da vinda desse grande vigário de Cristo. Depois de haver reflectido sobre o pobre do nosso pai com a infeliz da nossa mãe, expulsos do Jardim das Delícias tão cheios de saber em tão pouco tempo, fiquei abismado da sua inconstância e chorei por causa do mal deles e do nosso, e inquiri do anjo porque é que Deus permitiu que assim caíssem e não quis prestar-lhes auxílio para não caírem.

Porque permitiu, respondeu ele de imediato, que também tantos dos nossos caíssem no pecado? Ou ignoras que Deus deixou quer o anjo, quer o homem, desde o princípio da sua criação, entregues ao respectivo arbítrio? Deu-lhes preceitos e mandamentos que, se os guardassem, estariam salvos, transgredindo-os, deixariam de usufruir daqueles bens que lhes havia preparado. Se fosse lícito queixar-se de Deus, antes nós os anjos nos poderíamos queixar porque, embora tenha dado aos nossos infelizes irmãos, a que chamais diabos, um tempo de arrependimento, esse foi, todavia, muito mais reduzido do que o vosso, já que os vossos, mesmo depois da expulsão do Paraíso, puderam arrepender-se. Os nossos, depois da queda, de modo algum o puderam.

Parece resultar daí, respondi então, que os anjos maus, mesmo se se arrependessem, se não poderiam salvar?

Para que o arrependimento seja frutuoso, respondeu, não basta sentir dor pelo que se fez, mas é preciso que a graça de Deus esteja presente para que Deus aceite essa dor. Nessa medida, pode o anjo sentir dor depois da queda para que a dor seja agradável a Deus, do mesmo modo que o homem depois da morte, como te referi já noutro lugar. Tudo se firma nas regras estabelecidas pelo próprio Deus, que é óptimo.

Se Deus sabia que o homem iria cair, insisti, porque permitiu que fosse tentado? E porque é que quis remir os homens e não os anjos?

O conhecimento de Deus, respondeu, é admirável, [fl. 24] dificilmente compreensível por vós, abrangendo desde o princípio até ao fim. Deus é eterno, eterno é o seu conhecimento. Sendo eterno, circunda e abarca todo o vosso tempo, tudo vê como se estivesse presente. Mas vós pensais Deus como anterior a vós, do mesmo modo que é ter o conhecimento das coisas futuras como se as visse antes, nas causas. Como se alguém olhasse a terra ou o tronco da árvore e dissesse: aqui vai nascer um ramo. Não é assim que Deus conhece o futuro, como que na causa. Mas vê-o como o presente, em razão da sua imensidade. Não sonhaste tu, meu irmão, alguma vez, e no sonho não viste algo futuro como se estivesse presente?

$\leftarrow$ anima $V 94 \mathrm{Hic}] \mathrm{Hinc} O Q 95$ orietur ramus] orietur ramus, hinc pullulauit rosa uel alius flos $M$ (in marg. a. m.) NO; orietur ramus, hic egredietur rosa uel alius flos $Q 96$ futura cognoscit] futura cognoscit quia omnia ante ipsum sunt contingentia et nullum necessarium cognoscit $P 97$ maiestatis ( $M$ add. sup. lin. a. $m$. immensitatis et aeternitatis)] immensitatis HIJLP; immensitatis $\rightarrow$ 
Vidi, inquam, saepius in nocte ea quae mihi in die occurrerunt.

Tunc ille: Si ergo uobis ${ }^{98}$ futura ut praesentia, quae tamen ${ }^{99}$ non sunt praesentia, uidentur, quare non sic uidebuntur praesentia Deo, eo immo perfectiori modo quo intellectus ille aeternus et infinitus excedit intellectum uestrum ${ }^{100}$ ? Si ergo uos uidetis aliquando clarius aliquando obscurius talia futura, cur Deus, qui habet intellectum immensum, non uidebit omnia clarissime ${ }^{101}$ ? Hoc nota, homo Dei, et quamuis tu sis ineptior ad talia, gratia tamen Dei aptior factus es et, ubi intelligere non potes ad plenum, scribe prout tibi a me dicuntur, quia ille cui haec mittuntur et propter quem scribuntur clare intelliget et aperte docebit. Tu es Deo in hac re tamquam equus ${ }^{102}$ fratri tuo ferens farinam de molendino.

Et ego: Vtinam sim bonus asinus ad deferendum ${ }^{103}$ tantum bonum fidelibus nostris. Quia equum me credo, quadam reuerentia quam ego non mereor appellasti, sed asinum dicere uoluisti tamquam rude animal. Cognoui tamen praesaepe domini mei. Rogo tamen ut perficias incohata ${ }^{104}$ quae, si non potero intelligere, depingam ut alii intelligant quos Deus mittit ad percipiendum acutius ea quae ego, ut hebes homo ${ }^{105}$, cogito.

Tunc ille: Deus, nota et considera diligenter, in sua aeternitate uidit hominem antequam crearetur. Non existentem, uidit eum ${ }^{106}$ existentem pro alio tempore et pro alio temptatum et pro alio uictum. Et haec omnia simul pro diuersis temporibus uestris. Permisit ergo eum cadere in peccatum, quia liberum fecit, sed non quia cadere uoluit ${ }^{107}$. Vidit enim futurum tamquam praesens nec tamen ideo factum est illud quia Deus uidit, sed quia factum est uel ${ }^{108}$ futurum erat Deus uidit. Dederat enim potestatem sic faciendi nec uoluntate sua id impedire uoluit ne libertas amitteretur. Homo propria sponte ${ }^{109}$ sic uoluit. Deum aeternum et immensum latere non potuit. Cognouit ${ }^{110}$ ergo et uidit, quia sic erat ${ }^{111}$, non sic factum est quia ipse uidit. Hominem igitur, quia cecidit, uidit cadere, non quia uidit eum casurum iccirco cecidit. Congruum autem fuit ut homo sibi sponte salutem procuraret ut merito coronari posset si legitime decertasset. Sic enim statutum est ut omnes ad dexteram uel ad sinistram diuertere ${ }^{112}$ possent. [f1. 25] Quare autem Deus uos homines redimere uoluit et non angelos nullum dubium est ${ }^{113}$. Nam omnes angeli facti erant iam uel beati uel miseri. Beatos redimere non fuit opus

$\leftarrow$ aeterne $N$; immensitatis et aeternitatis $O Q 98$ uobis] uos $V 99$ quae tamen] quae tamen in se $M$ (sup. lin. a.m.) $O Q \mathbf{1 0 0}$ intellectum uestrum] intellectum nostrum $Q$, intellectum $V \mathbf{1 0 1}$ omnia clarissime] omnia clarissime. Omnia futura habent iam illud esse quod futura sunt, sicut et praeterita, eo quod praeterita sunt, habent esse praeteritum. Et aeque difficile est cognoscere praeterita si numquam uisa uel audita fuerunt sicut et futura. Omnia ergo habent aliquod esse et nullum ens potest latere immensum et aeternum intellectum $P \mathbf{1 0 2}$ tamquam equus] tamquam equus in ore tuo $Q \mathbf{1 0 3}$ deferendum] deferendum hominem $J$; ferendum $Q 104$ incohata] incepta $\rightarrow$ 
Vi muitas vezes de noite, respondi, as coisas que durante o dia me aconteceram.

Portanto, se até vós, acrescentou ele, vedes como presentes as coisas futuras que, entretanto, não estão presentes, porque não há-de assim vê-las Deus como presentes, e até de modo tanto mais perfeito quanto a sua inteligência, eterna e infinita, excede a vossa? Pois bem, se vós vedes umas vezes mais distintamente, outras de formas mais confusa esse futuro, porque é que Deus, que tem uma inteligência imensa, não há-de ver tudo distintissimamente? Anota isto, homem de Deus, e embora sejas totalmente incapaz para esta tarefa, a graça de Deus tornou-te suficientemente apto. E quando não conseguires entender plenamente, escreve como te dito, porque o Pastor a quem estas coisas se destinam e em razão de quem se escrevem entendê-las-á distintamente e ensiná-las-á publicamente. Nesta matéria estás para Deus como o cavalo que transporta a farinha do moinho para teu irmão.

Seja eu um bom burro, respondi, para transportar tão grande bem para os nossos fiéis! Porque me tenho na conta de um cavalo, referiste-me com alguma reverência que não mereço, mas por burro quiseste dizer, de algum modo, um animal ignorante. Conheci, contudo, o estábulo do meu dono. Entretanto, peço que concluas o que começaste que, se não puder entendê-lo, descrevê-lo-ei a fim de que outros o entendam, esses que Deus manda para compreenderem mais subtilmente aquilo que eu, homem obtuso, preparo.

Deus, na sua eternidade, anota e presta diligente atenção, disse então o anjo, viu o homem antes que fosse criado. Não existindo ainda, viu-o existindo num tempo, tentado em outro e em outro vencido. E tudo isto simultaneamente em relação a vários tempos vossos. Permitiu, pois, que caísse em pecado, porque o fez livre, mas não porque quis que caísse. Viu, na verdade, o futuro como presente. E tal não aconteceu porque Deus o viu, mas porque aconteceu ou iria acontecer o viu Deus. Outorgara-lhe o poder de assim proceder e não quis impedi-lo disso pela sua vontade para que não perdesse a liberdade. $O$ homem assim o quis de sua livre vontade. Não podia esconder-se de Deus, eterno e imenso. Deus, portanto, tomou disso conhecimento e viu, porque assim era, não aconteceu assim porque Deus o viu. Em suma, foi porque o homem caiu que Deus o viu cair, não porque Deus viu que iria cair que ele caiu. Foi, pois, conveniente que o homem procurasse espontaneamente para si a salvação para que pudesse merecidamente ser coroado se legitimamente combatesse. Assim foi determinado, que todos pudessem desviar-se para a direita ou para a esquerda. [f1. 25] Porque quis Deus

$\leftarrow I J L N O P Q 105$ hebes homo] habes homo $I$; habeas $V \mathbf{1 0 6}$ uidit eum] uidit eum in eadem aeternitate $M$ (in marg. a. m.) NOQ 107 sed non quia cadere uoluit] sed non [permisit ac si eum (in marg. a. $m$.)] (er. quia) cadere (uoluisset cor.) $M$; sed non permisit ac si eum quia cadere uoluisset $N$; sed non quia cadere uoluisset $O$; sed non permisit quasi eum cadere uoluisset. $Q 108$ uel] quia $N 109$ sponte] potestate $Q \quad 110$ cognouit] Cogitauit $P \quad 111$ erat] futurum $H \quad 112$ ad sinistram diuertere] ad sinistram diuertere prout eorum natura exposcit $M$ (in marg. a. m.) $N O Q 113$ nullum dubium est ( $M$ sub ras.) (O sup. lin. a. m.)] parui momenti dubium est $N Q$; nulli dubium est quamuis $\rightarrow$ 
neque miseros fuit congruum quia sententia data ${ }^{114}$ erat. Vnde neque homines damnatos eripuit ab eorum damnatione. Quia igitur nullus angelus uiator erat ${ }^{115}$ et multi homines uiatores erant ideo pro ipsis Redemptor uenit, non pro angelis. Remanserant etiam illis qui ceciderunt ${ }^{116}$ similes $^{117}$ et satis erat ut de qualibet natura plures uel multi saluarentur.

Tunc ego. Sicut plures angeli fuerunt saluati utrum sic et plures homines saluantur?

Et ille: Si plures in paenitentia ${ }^{118}$ decedunt, plures saluabuntur, de quo alias. Praetermittantur tales quaestiones quia pastori illi iam id et multa alia de his, ipso non perpendente, reuelabit Deus. Non dubites, uideris mihi obliuiosus, quia de eisdem quamdoque dubitas.

Et ego: Domine mi, illico ut conscripta sunt quae mihi dicis labuntur e memoria mea ${ }^{119}$.

Et angelus. Nonne dixi tibi quia tu es animal deferens haec nutrimenta illi qui pascet $^{120}$ gregem Dei nostri?

Et ego: Fiat, fiat, dixi, dummodo sim asinus alimenta Dei fidelibus deferens.

Tunc iterum dixi ${ }^{121}$ : Domine mi, ex quo Adam ratione peccati potius incurrerat ignorantiam $^{122}$ quam adeptus fuerit ullam scientiam, quare Deus dixit: Ecce Adam factus est quasi unus ex nobis, sciens bonum et malum, et quibus dixit?

Respondit: Ad nos angelos tunc locutus est Deus noster Trinus et Vnus, quia etiam serpens non suasit ${ }^{123}$ propriam scientiam Dei, sed potius angelicam. Sciebat enim homo quod aequiparari non poterat scientiae Dei, sed bene angelorum. Intellectus namque creatus aequalis est ex sui natura, suscipiens gradus ratione maioris uel minoris dispositionis naturae in qua est ${ }^{124}$. Ad nos igitur locutus est Deus Trinus, non tunc quando dixit: faciamus hominem ad imaginem $^{125}$ nostram ${ }^{126}$ (et dixit illa uerba quasi deridendo). Ecce Adam factus est quia id sperauit futurum ${ }^{127}$ quasi unus ex nobis. Non dixit hoc Deus quasi nos essemus aequales sibi in scientia ${ }^{128}$, sed quia scientia nostra longe maior est quam sua et

$\leftarrow$ apud uos multa somnientur. $P \mathbf{1 1 4}$ datal lata $I \mathbf{1 1 5}$ erat] erat et sunt $P \mathbf{1 1 6}$ illis qui ceciderunt] illis qui crediderunt $V$; illis $Q \mathbf{1 1 7}$ similes] similes in natura $M$ (sup. lin. a. m.) 118 paenitentia] praesentia $V 119$ e memoria mea] e memoria mea sicut uiro consideranti uultum natiuitatis suae in speculo $M$ (in marg. a. $m$.) $N O Q \mathbf{1 2 0}$ pascet] passet $M$; sunt $Q \mathbf{1 2 1}$ Tunc iterum dixi] Sicut iterum dixi $J$; Tunc ego iterum dixi $O \mathbf{1 2 2}$ ignorantiam] ignominiam $P \mathbf{1 2 3}$ non suasit] non sua $V$; non suasit seu promisit $M$ (in marg. a. m.) $O$; non suasit sed promisit $Q \mathbf{1 2 4}$ in qua est] in qua est uel supernae reuelationis $P \mathbf{1 2 5}$ ad imaginem] ad imaginem et similitudinem $B G H N$; et similitudinem $Q 126$ imaginem nostram] imaginem nostram sed quando dixit uerba praedicta $M \rightarrow$ 
remir-vos a vós homens e não aos anjos não restam dúvidas. De facto, todos os anjos se haviam tornado já bem-aventurados ou réprobos. Aos bem-aventurados não foi necessário remi-los, nem razoável remir os réprobos, uma vez que a sentença estava ditada. Daí que não tenha arrancado os homens condenados à sua condenação. Porque, pois, nenhum anjo era peregrino e muitos homens o eram, por isso o Redentor veio por causa deles, não por causa dos anjos. Tinham permanecido também iguais aos que caíram, e era suficiente que de cada natureza se salvassem vários ou muitos.

Do mesmo modo que muitos anjos se salvaram, perguntei, salvar-se-ão também muitos homens?

Se muitos morrerem em arrependimento, respondeu, muitos se salvarão. Disso se falará noutra ocasião. Deixemos essas questões, porque Deus, sem que ele disso se ocupasse, revelou já ao Pastor essa matéria e muitas outras coisas sobre ela. Não duvides. Pareces-me desmemoriado porque, de vez em quando, duvidas do mesmo.

Meu senhor, no preciso momento em que escrevo, o que me dizes varre-se-me da memória, disse eu.

Não te disse, acrescenta o anjo, que és um animal que transporta estes alimentos para aquele que apascenta o rebanho do nosso Deus?

Que assim seja, que assim seja, disse eu, contanto que seja o burro que transporta o alimento de Deus para os fiéis.

Meu senhor, insisti então novamente, a partir do momento em que, por causa do pecado, Adão mais incorrera na ignorância do que conseguira qualquer conhecimento, porque é que disse Deus: Eis que Adão se tornou como um de nós, conhecendo o bem e o mal? ${ }^{[34]} \mathrm{E}$ a quem foi que o disse?

Foi a nós anjos que o nosso Deus Trino e Uno falou então, respondeu o anjo, porque também a serpente não falou do conhecimento próprio de Deus, mas antes do angélico. O homem, na verdade, sabia que não podia igualar o conhecimento de Deus, mas apenas o dos anjos. Com efeito, o espírito criado é, de sua natureza, igual e recebe o grau em função da distinção maior ou menor da natureza em que se acha. A nós, pois, falou o Deus Trino, não quando disse: Façamos o bomem à nossa imagem $^{[35]}$ (e disse estas palavras como que zombando). Vê, Adão foi feito porque esperou isto, que haveria de ser como um de nós. Deus não disse isto como se nós fôssemos iguais a si em conhecimento, mas

$\leftarrow$ (in marg. a. m.) NOQ 127 futurum] se facturum (M sup. lin.) NO; facturum BGIJLR; se fieri Deum $Q 128$ Non dixit hoc Deus (Deus om. H) quasi nos essemus aequales sibi in scientia] Non dixit homo quasi nos essemus aequales ei in scientia. $P$; Non dixit homo Deus quasi nos essemus aequales sibi in scientia. $V$

[34] Gn 3:22,

[35] Gn 1:26, 
Deo propinquissima ${ }^{129}$. Ipse Lucifer ostendit eis ${ }^{130}$. Nam et ille tres personae ${ }^{131}$ dicuntur dii, quia diuinitatem ueram et integram habentes ${ }^{132}$, et nos angeli dicimur dii, quia participamus eam prae ceteris. Quando ergo draco ille dixit: et eritis sicut dii, mulier cogitauit quod futuri essent sicut Pater, Filius atque Spiritus Sanctus. Adam uero cogitauit ${ }^{133}$ potius illud intelligi debere de [f1. 26] nobis angelis. Neuter tamen determinate ${ }^{134}$ accepit.

Domine mi, dixi, quid et cuius ualoris ${ }^{135}$ fuit illud lignum uitae in medio paradisi positum?

Respondit: Deus noster, sciens hominem ex se ipso et ex sui natura mortalem esse, quia numquam cibo $^{136}$ communi restauratur id quod amittitur ${ }^{137}$, continue fecerat cibum longe utiliorem auro potabili, quod uos tanti existimatis, quem sumendo, uita protrahebatur in longum et restaurabantur iugiter amissa. Verum est quod non potuisset in sempiternum esu illo uiuere ratione uirtutis propriae ipsius hominis, quae fatigaretur ${ }^{138}$ et tandem debilitata fuisset ex continua talis cibi conuersione. Sed hoc aduerte ${ }^{139}$ bene quod Deus tunc ordinauerat ut uirtus illa numquam debilitaretur neque illud miraculum fuisset, sed res continua et ordinarie procedens et consuete non inconsuete ${ }^{140}$. Vnde si homo in paradiso illo nil comedisset ${ }^{141}$, peccasset. Comedendo autem uixisset illo cibo, diuina uirtute digestiuam potentiam ${ }^{142}$ confortante $^{143}$. Et tandem ut patres filiis locum darent, translati fuissent ad uitam meliorem et caelestem ubi sine cibo in aeternum uixissent sicut et uiuetis postquam resurrexeritis a mortuis. Tunc enim Deus noster absque ullo cibo uos uiuere faciet, conseruando sine instrumento sicut in paradiso terrestri conseruasset medio illius ligni.

Interrogaui deinde angelum Domini de poena quam inflixit Deus serpenti, quae uidetur ei naturalis condicio, et dixi: Mi domine, nonne naturale est serpenti super pectus se mouere et terram comedere et calcaneo hominum insidiari et homines conterere capita serpentum? Iterum miror si haec in poenam data sunt serpenti. Cur data sint ex quo ille tamquam animal brutum peccare non potuerit et diabolo, qui ad peccatum ${ }^{144}$ prouocauit, nulla poena fuit data?

129 sed quia scientia nostra longe maior est quam sua et Deo propinquissima] sed quia scientiam nostram longe maiorem quam sit (hominis add. I in marg. a. m.) et Deo propinquissimam AGHIJMNORV; sed quia scientia nostra longe maior est quam sit ... et Deo propinquissima ipse Lucifer ostendit eis $B \mathbf{1 3 0}$ ostendit eis] ostendit eis cum tamen scientia hominis a scientia nostra non multum differat, uerba autem Luciferi poterant dupliciter intelligi $G P 131$ personae] personae diuinae BIL ( $M$ in marg. a. m.) $O Q R 132$ habentes] habent $B H$ (JM cor.) $O Q$, habentem

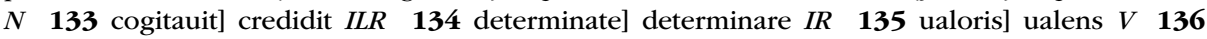
cibo] cibo uestro $M$ (sup. lin. a. m.) NOQ 137 amittitur] amittitur in uobis $M$ (in marg. a. m.) $N O Q 138$ fatigaretur] frangeretur $J P$; fatigare $V 139$ aduerte] aduenit $J \mathbf{1 4 0}$ non inconsuetae.] non inconsuetae. Consueta uero uos non uocatis miracula quamuis sint ualde mirabilia et ad $\rightarrow$ 
porque o nosso conhecimento é muito maior do que o do homem e muito próximo do de Deus. ${ }^{[36]}$ O próprio Lúcifer lho mostrou. Pois essas três Pessoas são designadas deuses porque têm a real e integra divindade. E nós os anjos somos considerados deuses porque participamos dela mais que todos. Quando, pois, esse dragão disse: e sereis como deuses, ${ }^{[37]}$ julgou a mulher que seriam como o Pai, o Filho e o Espírito Santo. Adão, porém, pensou, antes de mais, que aquilo se deveria entender de [f1. 26] nós anjos. Nenhum deles, contudo, o recebeu em sentido estrito.

Meu senhor, o que significou e que valor teve aquela árvore da vida posta no meio do Paraíso, perguntei?

O nosso Deus, respondeu ele, sabendo que o homem, de si e de sua natureza, era mortal, porque nunca se restaura com o vosso alimento habitual aquilo que em vós se perde, criara imediatamente um alimento mais salutar do que o ouro potável, que em tão grande estima tendes que, tomando-o, se prolongava e se restaurava a vida continuamente perdida. É verdade que não poderia para sempre viver daquele alimento, em razão da vitalidade própria do mesmo homem, que se debilitaria e, por fim, seria paralisada por força da contínua repetição desse alimento. Mas atenta bem nisto, em que Deus tinha então determinado que essa vitalidade nunca seria enfraquecida, e nem isso constituiria milagre, mas situação habitual e a desenvolver-se continuamente e segundo o costume, não esporadicamente. Daí que o homem pecasse se nada comesse nesse Jardim. Comendo, viveria desse alimento com a faculdade digestiva fortalecida pela graça divina. E, por fim, para darem o lugar aos filhos, os pais seriam transferidos para uma vida melhor, no Céu, onde viveriam eternamente sem alimento como vivereis depois de ressuscitardes dos mortos. Na verdade o nosso Deus far-vos-á então viver sem qualquer alimento, conservando-vos sem necessidade de vestes como teria mantido no Paraíso terrestre por meio daquela árvore.

Interroguei depois o anjo do Senhor acerca do castigo que Deus infligiu à serpente, que se afigura sua natural condição, e disse: Meu senhor, não é da natureza da serpente deslocar-se sobre o peito, que coma terra e invista contra o calcanhar do homem, e que os homens esmaguem as cabeças das serpentes? Fico novamente surpreendido se estas coisas são impostas à serpente como castigo! Porque lhe são impostas a ela, uma vez que, como animal irracional, não pôde pecar, e ao diabo, que incitou ao pecado, nenhum castigo foi dado?

$\leftarrow$ solam Dei potentiam spectantia. Tamen aspiciendo propriae naturae uires, miraculum fuisset $P$; non inconsuetae. Tamen aspiciendo proprias naturae uires, miraculum fuisset. $M$ (in marg. $a$. m.) $N O Q 141$ comedisset] comedere uoluisset $O 142$ potentiam] uirtutem $L 143$ confortante] conseruante $J 144$ peccatum] peccandum $J Q V$

[36] O texto latino é pouco claro. Obedeceu-se menos à coerência dos manuscritos do que à lógica do pensamento.

[37] Gn 3:5. 
Respondit: Recte miraris, sed audi me. Condiciones ille conueniunt serpenti ex sui natura, sed uerba ${ }^{145}$ illa dirigebantur ad diabolum, qui in tali forma mulieri primum apparuit, et est sensus ${ }^{146}$ : Tu, diabole, quia in tali forma feminam temptasti, illius animalis condiciones habebis ${ }^{147}$ in quod intrasti. Sicut ille prae cunctis aliis brutis est abominabilis et exosus, sic tu super omnia creata eris odiosus homini et maledictus uocaberis ab omnibus. Terram ut serpens comedes, quia tota mens tua et cogitatio intenta erit ad malum et ad peccatum omnibus diebus, quia numquam corrigeris ${ }^{148}$, numquam ad caelum redibis aut caelestia cogitabis, sed terrena et cum terrenis hominibus erit conuersatio tua. Inimicitias ponam inter te et mulierem et inter semen tuum, omnes uidelicet complices [f1. 27] tuos, spiritus malignos tibi similes ${ }^{149}$, immo et homines te sponte sequentes, quorum tu eris caput non ego, et semen mulieris. Et per semen mulieris intelligebat praecipue Christum cum omnibus bonis et electis. Et per mulierem non solum Euam, sed etiam praecipue Matrem eius ${ }^{150}$ Mariam, quae contriuit caput eius, quia cunctas haereses et peccatum ab ipso inductum funditus dissipauit, quia nullo modo uenenum ab ipso immissum gustauit. Et quia caput aliorum peccatorum fuit illud peccatum, ipsa illud contriuit, quia uenenoso illius flatu ${ }^{151}$ non fuit infecta et quia Filii sui aduentu patria superna, propter illud peccatum amissa, fuit recuperata et ianua caelestis paradisi aperta. Et tu insidiaberis calcaneo eius, quia ultimo ${ }^{152}$ procurabis contra eam et prolem eius agere inducendo pseudo Christos et pseudo prophetas maxime illum qui in templo Dei sedebit ostendens se ac si esset Deus, quem tu inhabitabis. Et quia Deus iam reuelauerat ipsis primis parentibus uestris sicut et nobis se uelle hominem facere ${ }^{153}$, in his uerbis Dei ad serpentem directis ${ }^{154}$ uidelicet Luciferum cognouerunt et ipsi et Lucifer illum Deum hominem institui tanquam reparatorem naturae lapsae et ordinari hominum redemptorem ${ }^{155}$ et gauisi sunt.

Dixitque Adam ad Euam, cui etiam tale nomen imposuit: Non peribimus omnino, saluabimur. Quandoque affligetur semen ${ }^{156}$ nostrum, sed non peribit, immo Deus ipse, ut audisti, propter peccatum quod fecimus non mutauit propositum suum quin hominem se, ut disposuerat, faciat. Et ipse erit noster saluator et redemptor, immo et totius nostrae posteritatis ${ }^{157}$. Crescamus igitur et multiplicemur ne tanto bono priuemur. Haec uerba dixit subito ut positus fuerat extra paradisum in quo mandatum crescendi acceperant. Sed quia ibi primum tribus diebus abstinere proposuerant ut prius copularentur Deo ${ }^{158}$ Trino deinde inter se, et successit

145 uerba] uere $P 146$ et est sensus] et sensus est talis $M$ (sup. lin. a. $m$. talis) $O Q 147$ habebis] habentis $V 148$ numquam corrigeris] numquam corrigeris, numquam emendaberis $M$ (in marg. a. m.) NOQ; 149 tibi similes] tibi similes qui ideo dicuntur semen tuum non quia creasti eos sed quia auersisti et ad malum aeternum induxisti $P \quad 150$ eius] Christi $Q \quad 151$ flatu] flatum $I ; \rightarrow$ 
Tens razão, respondeu. Mas ouve-me. Aquelas condições ajustam-se à serpente em razão da sua natureza, mas aquelas palavras dirigiam-se ao diabo, que primeiramente apareceu à mulher sob essa forma, e tem este sentido: Tu, diabo, que tentaste a mulher sob essa forma, terás as condições do animal em que entraste. Assim como este é abominável e odioso acima de todos os irracionais, assim tu serás odioso ao homem sobre todas as criaturas, e todos te chamarão maldito. Comerás terra como a serpente, porque todo o teu espírito e o teu pensamento estarão dirigidos para o mal e para o pecado todos os dias, porque nunca te emendarás, jamais tornarás ao Céu ou pensará em coisas celestes, mas a tua relação será terrena e com homens terrenos. Estabelecerei inimizades entre ti e a mulher e entre a tua descendência, ou seja, todos os teus cúmplices, [f1. 27] os espíritos malignos semelhantes a ti, e mais, os homens que espontaneamente te seguem, de quem tu, que não eu, serás o chefe, e a descendência da mulher. E pela descendência da mulher entendia sobretudo Cristo com todos os bons e eleitos. Pela mulher, não só Eva, mas sobretudo também Maria, sua Mãe, que esmagou a cabeça daquele, o diabo, porque destruiu todas as heresias e o pecado profundamente por ele introduzido, já que de modo algum experimentou o veneno por ele inoculado. E porque aquele pecado foi a cabeça dos outros pecados, ela destruiu-o, uma vez que não foi infectada pelo sopro venenoso do diabo e porque, com o advento de seu Filho, foi recuperada a pátria celeste, perdida por causa daquele pecado, e a porta do Paraíso Celeste foi aberta. E tu investirás contra o calcanhar dela porque, por fim, tentarás agir contra ela e a sua descendência, induzindo falsos Cristos e falsos profetas, sobretudo aquele que se há-de sentar no Templo de Deus, apresentando-se como se fosse Deus, em quem tu habitarás. E uma vez que Deus havia revelado já aos vossos primeiros pais, bem como a nós, que queria tornar-se homem, nestas palavras de Deus dirigidas à serpente, ou seja, a Lúcifer, reconheceram eles e Lúcifer que aquele Deus Homem ia ser constituído como Restaurador da natureza decaída e nomeado Redentor dos homens, e alegraram-se.

Adão disse a Eva, a quem tinha dado o nome: Não morreremos, salvar-nos-emos de certeza. Por vezes, a nossa descendência será atormentada, mas não perecerá. Pelo contrário, o próprio Deus, como ouviste, não alterou, por causa do pecado que cometemos, o seu propósito de se fazer homem, como tinha decidido. Ele próprio será o nosso Salvador e Redentor e, até, de toda a nossa posteridade. Cresçamos, pois, e multipliquemo-nos para não sermos privados de tão grande bem. Disse estas palavras imediatamente depois de haver sido expulso do Paraíso onde haviam recebido a incumbência de crescer. Mas, porque

$\leftarrow$ inflatu $N$; afflatu $P Q 152$ ultimo] ultro $V 153$ facere] redimere $P 154$ directis] dicentis $V 155$ redemptorem] redemptorem, reparatorem et $Q \quad 156$ semen] genus $P \quad 157$ nostrae posteritatis] nostrae posteritatis. O igitur beatum peccatum uestrum quod diuina dignitate obtinuit talem Redemptorem. $P 158$ Deo trino] Domino $Q$ 
tempestas temptationis ${ }^{159}$ ualida quod non quiuerunt ${ }^{160}$ impediti uerbis Luciferi qui eos ad transgressionem praecepti impellebat ubi diu conflixerunt et ideo neque de praecepto multiplicationis cogitauerunt tamquam de sugestione illa solliciti et quasi attoniti, extra paradisum positi, copulati sunt. Et in quolibet partu saltem duos, marem unum et feminam unam, Eua pariebat. Masque feminam in uxorem ducebat.

Adam ergo cum esset plenus scientia, instrumenta arandi, seminandi, plantandi agrosque colendi adinuenit et suos docuit filios in quibus etiam nos angeli iussu Dei eum [f1. 28] iuuimus. Et quando Caim occidit Abel adeo doluit ${ }^{161}$ quod ulterius, nisi mandatum Domini praeterire timuisset, uxori se numquam copulasset. Adam uero et Eua quotiens recordabantur deliciarum paradisi ${ }^{162}$ totiens flebant. Recordabantur saepe et, quamdocumque aliquem infirmum aut debilem aut malum aut mortuum uidebant uel audiebant, lacrimabantur, suspirabant, praesertim Adam, quia peccatum eius et non uxoris traductum est ad posteros. Si enim sola mulier peccasset, nil filiis nocuisset. Vnde dicebat: "Heu me miserum! Ego enim sum causa huius peccati, huius infirmitatis, huius mortis, huius debilitatis". Neque illis qui mali erant propalare peccatum suum fuisse causam ipsorum mali audebat. Si enim illud credidissent, ipsum utique et iniuriis et contumeliis ${ }^{163}$, uerberibus, immo et morte affecissent.

Parum gaudii, satis angustiarum semper habuit humanum genus. Nos angeli, qui felices, felices, qui miseri, miseri. Vos semper in ista uita uestra mixti et ambigui estis, multa praeclara in uestro genere et plurima maesta.

Ego iterum interrogare coepi: Domine mi, cuius peccatum grauius ${ }^{164}$ fuit, uiri an mulieris?

Respondit: Placet ut me de hoc interroges, immo ego immisi in os tuum uerbum istud. Multi enim sunt apud uos qui feminam primam in statu innocentiae putant fuisse uiro inferiorem, debiliorem et imbecilliorem, et non aduertunt quod sexus non facit differentiam animorum maxime tunc quando corpora ${ }^{165}$ erant perfecta et anima utriusque imbuta omni doctrina. Nonne dixi tibi quod Lucifer diu cogitauit a quo illorum inciperet suae temptationis initia porrigere et tandem concepit quod mulier auersa facilius auerteret ${ }^{166}$ uirum quam uir mulierem, quia uiri amor nimius ${ }^{167}$ in illam erat tamquam deriuatam ab ipso? Quia ergo mulier post $^{168}$ peccatum ut plurimum uiro debilior est et imbecillior, illud prouenit partim ab illa maledictione quam tunc accepit partim a complexione delicatiori ${ }^{169}$. Non autem ac si mulier ante peccatum fuisset uiro indoctior aut imbecillior, quamuis

159 tempestas temptationis] tempestas et temptatio $N \quad 160$ non quiuerunt] non quieuerunt $H J$; nequiuerunt $I L$; non nequieuerunt $N$; non quiuerunt commisceri $P 161$ doluit] latuit $Q 162$ et deliciarum paradisi] de loco paradisi et deliciarum $M$ (sup. ras.) $O Q 163$ contumeliis] conuiciis $Q \rightarrow$ 
inicialmente haviam proposto abster-se aí por três dias para se unirem primeiro ao Deus Trino e se unirem depois entre si, e se verificou a tormentosa tempestade da tentação que não conseguiram, impedidos pelas palavras de Lúcifer que os impelia à transgressão do preceito, quando por muito tempo se opuseram, e, por isso, como ansiosos e quase assombrados daquela sugestão nem pensaram no preceito da multiplicação, postos fora do Paraíso, uniram-se entre si. E em cada parto Eva dava à luz pelo menos dois filhos, um homem e uma mulher. O homem casava-se com a mulher.

Sendo Adão possuidor de todos os conhecimentos, inventou os instrumentos de lavrar, semear, plantar e de cultivar os campos e instruiu seus filhos, tarefas nas quais nós anjos o [fl. 28] ajudámos por determinação de Deus. E, quando Caim matou Abel, sofreu tanto que, depois, se não temesse ultrapassar os mandamentos do Senhor, nunca mais se uniria à esposa. Adão e Eva choravam sempre que recordavam o Jardim das Delícias. Recordavam-se muitas vezes e, todas as vezes que viam ou ouviam falar de alguém doente ou fraco ou infeliz ou morto, choravam e gemiam. Sobretudo Adão, porque foi o seu pecado e não o de Eva que se transmitiu à posteridade. Se apenas a mulher tivesse pecado, nada afectaria os filhos. Por isso dizia: "Ai de mim, infeliz, pois sou eu a causa deste pecado, desta enfermidade, desta morte, desta fraqueza». E nem ousava divulgar aos que sofriam que o seu pecado tinha sido a causa dos males deles. Pois, se tal supusessem, ofendê-lo-iam sem dúvida com injúrias, afrontas, agressões e até com a morte.

Sempre a raça humana desfrutou de pouca alegria e muitas angústias. Nós, anjos, os felizes somos sempre felizes, os desgraçados são sempre desgraçados. Nesta vossa vida, estais sempre em situações pouco claras e incertas. Muitas são entre vós as situações brilhantes e numerosas, as de angústia.

Meu senhor, comecei a perguntar de novo, qual foi o pecado mais grave, o do homem ou o da mulher?

Apraz-me, respondeu, que me interrogues, ou melhor, eu mesmo coloquei na tua boca esta palavra. Há muitos entre vós que consideram que a primeira mulher, no estado de inocência, fosse inferior ao homem, mais débil e mais fraca. $\mathrm{E}$ não advertem que o sexo não estabelece diferença entre os espíritos, sobretudo então, quando os corpos eram perfeitos e as almas de ambos estava imbuída de toda a doutrina. Não te disse que Lúcifer ponderou durante muito tempo por qual deles começaria a lançar as bases da sua tentação, e que, por fim, percebeu que, subvertida a mulher, mais facilmente esta subverteria o homem do que este a mulher, por causa do grande amor do homem em relação à mulher, enquanto saída dele? O facto, pois, de a mulher depois do pecado ser muitas vezes mais débil e mais fraca do que o homem provém, em parte, daquela maldição de que

$\leftarrow 164$ grauius] maius $Q 165$ corpora] corda $P 166$ auerteret] euerteret $L V 167$ nimius] magis $N$; nimis $V 168$ post] eius $P 169$ complexione delicatiori] complexione delicationi ad quam rediit amissa iustitia originali. $M$ ( in marg. a. m.) $N Q$ 
paruula distantia a uiro suo distaret et paulo minus imperfectior illo fuisset in naturalibus et accidentalibus.

Sic ut dico scribe, etiam si perfecte uerba mea non perciperes ${ }^{170}$. Dico nunc peccatum mulieris non esse ualde excusandum eo quod femina fuerit, neque Adae accusandum ${ }^{171}$ quasi longe sapientior extitisset ${ }^{172}$. Sed mulier ideo grauius peccauit quia plus ${ }^{173}$ et quia pluribus modis maxime quia uirum totiens ipsa temptauit, non uir mulierem. Et gratia illius uir cecidit. Magis etiam peccauit quia mulier potius credidit esse [f1. 29] similis ${ }^{174}$ Deo Trino in sciendo ${ }^{175}$ quam angelis, Adam uero potius angelis. Vterque tamen, dicente ${ }^{176}$ "eritis sicut dii", dubitauit $^{177}$ an sicut personae diuinae uel sicut angeli Dei. Sed priori particulae adhaerebat potius mulier, posteriori ${ }^{178}$ uir. Viri peccatum grauius per $^{179}$ sequelam $^{180}$ fuit, immo omnium grauissimum ex quo secuta ${ }^{181}$ sunt tot mala, tot ruinae, tot destructiones, mors, error, egestas, calamitas, uirium inferiorum et animalium rebelio, elementorum et omnis creaturae offensio. Vocatur autem peccatum illud causa horum malorum, quia iustitia Dei propter illud inflixit ${ }^{182}$ illa $^{183}$ mala.

Si primus homo non peccasset, interrogaui utrum alii peccare potuissent.

Respondit angelus: Quemlibet oportebat probari et temptari et uicta temptatione in gratia confirmari. Ex quo patet ${ }^{184}$ quod, et si primus homo non peccasset, filius eius peccare potuisset et filius filii. Quilibet enim uiator fuisset ${ }^{185}$. Et sequitur quod non. Ideo filius potest peccare uel peccat quia primus pater ${ }^{186}$ peccauit. Sed bene ideo non subito uicta temptatione ${ }^{187}$ confirmatur ${ }^{188}$ in gratia et pronior atque cliuior $^{189}$ factus est ad peccandum ${ }^{190}$, immo in peccato nascitur et in iniquitatibus concipitur $^{191}$, ut ille rex propheta dicebat gemens qui pater Dei uocari singulari priuilegio meruit (et ostendebat Dauid iuxta Abraham et Moysen sedentem).

Tunc ego: Quomodo iustum est ut filiorum dentes obstupescant eo quod pater comedit ${ }^{192}$ uuam acerbam? Quomodo aequum est ut filius qui suum patrem numquam uidit portet iniquitatem patris sui ${ }^{193}$ ?

Libenter respondit ad istud ${ }^{194}$ : Respondebo quia ualde utile est uobis hanc ueritatem agnoscere. Scito et animaduerte hominem ex sui natura nec immortalem

170 perciperes] perceperis $H$; percipis $O$; percipies $P$; percipias $Q 171$ accusandum] excusandum $Q \quad 172$ extitisset] fuisset $O \quad 173$ plus] prius $I L$; prius plus $Q \quad 174$ esse similis] seipsam fieri similiem $Q 175$ in sciendol in scientia $Q 176$ dicente] dicentis $H$; dicenti $I L O$; dicenti diabolo $N$; dicenti Lucifero $Q, 177$ dubitauit] dubitabant $N 178$ posteriori] posterior $Q V 179$ per] propter $N P Q 180$ sequelam] loquelam $V 181$ secuta] secute $M \quad 182$ inflixit] infelix $V 183$ illa] omnia illa $O$; omnia $Q 184$ Ex quo patet] Ex quo patet prout et uestri dicunt $P 185$ Quilibet enim uiator fuisset] Quilibet etiam peccare potuisset quia erat uiator $Q 186$ pater] homo $Q 187$ uicta temptatione] uicta temptatione prima $Q \mathbf{1 8 8}$ confirmatur] confirmauit $P 189$ cliuior] procliuior LO 190 peccandum] peccatum $N 191$ in iniquitatibus concipitur] in peccatis conceptus est $Q \rightarrow$ 
então foi vítima, em parte, da sua compleição mais delicada. Não que a mulher, antes do pecado, fosse mais ignorante ou menos capaz do que o homem, embora distasse algo de seu marido e fosse um pouco mais imperfeita do que ele em aspectos naturais e acidentais.

Ainda que não entendas perfeitamente as minhas palavras, escreve-as como as digo. Digo agora que o pecado da mulher não deve certamente desculpar-se pelo facto de ela ser mulher, nem o de Adão censurar-se como se ele fosse muito mais prudente. Mas a mulher pecou mais gravemente porque pecou mais e porque pecou de muitas maneiras, sobretudo porque muitas vezes tentou o homem e não o homem a ela. E, por causa dela, o homem caiu. Pecou mais, também, porque a mulher acreditou ser [fl. 29] semelhante em saber antes ao Deus Trino do que aos anjos, e Adão, antes aos anjos. Ambos, contudo, ao ser-lhes dito: sereis como deuses, duvidaram se como as Pessoas Divinas ou se como os anjos de Deus. A mulher, contudo, ligava-se mais à primeira parte da afirmação, o homem à segunda. O pecado do homem foi mais grave devido à sequela, foi até de todos o mais grave, dele decorreram todos os males, todas as desgraças, todas as catástrofes, a morte, o erro, a miséria, a rebelião dos instintos inferiores e dos animais, a inimizade dos elementos e de toda a criatura. Diz-se que aquele pecado foi a causa de todos os males porque, por causa dele, infligiu a justiça divina aqueles males.

Perguntei se outros poderiam pecar se o primeiro homem não tivesse pecado.

Era preciso, respondeu o anjo, que cada um fosse provado e fosse tentado e, vencida a tentação, fosse confirmado na graça. Donde resulta que, mesmo que o primeiro homem não tivesse pecado, o seu filho e o filho do filho poderiam pecar. Pois cada um seria peregrino. E segue-se que não. Por isso, o filho pode pecar ou peca porque o primeiro pai pecou. Mas, precisamente por isso se não confirma imediatamente na graça, uma vez vencida a tentação, e torna-se mais inclinado e mais propenso a pecar, e mais, nasce em pecado e é concebido na iniquidade ${ }^{[38]}$, como dizia, chorando, aquele rei-profeta que, por singular privilégio, mereceu ser chamado pai de Deus (e apontava para David, sentado junto de Abraão e Moisés).

Perguntei então como é que será justo que os dentes dos filhos se embotem porque o pai comeu uvas verdes. ${ }^{[39]}$ Não será iníquo que um filho que nunca viu seu pai carregue a iniquidade deste?

Respondeu amavelmente a esta questão: Responderei, já que vos é muito útil conhecer esta verdade. Fica sabendo e toma nota de que o homem, de sua

$\leftarrow \mathbf{1 9 2}$ comedit] comederit $L \mathbf{1 9 3}$ patris sui.] patris sui. Quomodo contradicitur per prophetam quod filius non portabit iniquitatem patris sui? $Q$; patris sui. Et quomodo contradicitur per prophetam: "filius non portabit iniquitatem patris sui". $M$ (in marg. a. m.) NO 194 Libenter respondit ad istud: "Respondebo quia ualde] Libenter ad istud dixit: respondeo quia $H$; Libenter respondit. Ad istud respondeo quia $I$; Libenter respondit angelus ad istud: "Respondeo quia ualde $N$; Libenter respondit angelus. Valde $P$; Libenter audirem? Ait ad istud: respondebo quia ualde $Q$ 
nec impeccabilem neque amicum Dei esse aut ordinatum ad felicitatem illam ${ }^{195}$ aut aliorum animalium pacificum dominium ${ }^{196}$ ita ut animalia immitia ${ }^{197}$ ei subdita quasi sponte fuissent aut elementa ei nocere non possent. Sed omnia ista a Deo pro se et tota posteritate acceperat dono singulari cum condicione, si mandatum paruulum seruasset ${ }^{198}$. Vnde, creata Eua, coram nobis angelis Deus dixit ad ipsos: Vos cognoscitis condicionem uestram. Estis enim subiecti uariis morbis ${ }^{199}$, doloribus, anxietatibus et morti corporali. Omnia corporalia possunt uobis obesse et aliquo modo ${ }^{200}$ prodesse. Vrsi, leones, crocodilli ${ }^{201}$ et dracones non subicientur ${ }^{202}$ uobis nisi coacti. Nulla obligatio est mihi de paradiso isto ad locum $^{203}$ caelestem sanos uos et incolumes in natura ${ }^{204}$ integra transferre, immo illud potius condicioni naturae uestrae ${ }^{205}$ contrariari uidetur. Nulla enim ratio est ut in hoc [f1. 30] amoenissimo loco assidue tot fructuum admirandorum generibus referto $^{206}$ uos detineam, cibum tam salubrem subministrem, tantam cognitionem rerum concedam et ab omni labore et sudore praeseruem et a cunctis nociuis et ipse et hii angeli filii mei uos custodiamus. Omnia haec mei ${ }^{207}$ gratia et singulari beniuolentia concedo uobis, quorum nullum ex naturali condicione haberetis. Volo tamen aliquo mandato uos probare sicut et hos angelos meos probaui. Ecce enim ante uos uidistis multa genera arborum quorum fructus sunt continui et numquam marcescunt. Vescimini de cunctis aliis. Illam arborem ne tetigeritis ${ }^{208}$, de fructu ${ }^{209}$ eius non gustabitis. Quacumque hora gustaueritis, haec omnia priuilegia et dona auferam a uobis et a posteris uestris et restituam uos condicioni naturae uestrae et morte moriemini et ante illam multa mala patiemini.

Vide ergo quod propter peccatum illud filiis Adae nullum malum infertur, sed solum donis condicionem naturae ipsorum excedentibus priuantur et reponuntur in naturalibus terminis et in statu propriae naturae suae. Recte itaque quidam ex uestris dixerunt hominem supplicio sensibili in inferno a Deo numquam puniri propter solum peccatum patris sui. Non enim portabit filius iniquitatem patris sui hoc modo ${ }^{210}$. Nulla ergo iniquitas est si aliquid detur patri et filiis ${ }^{211}$ cum condicione et ex gratia donantis tantum, condicione a patre cui pro omnibus datur $^{212}$ non seruata, si omnibus auferatur, nil ${ }^{213}$ certe iniquitatis poterit ex hoc inferri in auferente ${ }^{214}$ sicut neque debiti ${ }^{215}$ in donante ${ }^{216}$.

195 felicitatem illam] felicitatem illam aut suorum sensuum $M$ (in marg. a. m.) $N O Q 196$ dominium] dominium habere $O Q$; dominium omnium $I 197$ immitia] inimica $Q 198$ seruasset] observasset $H I L N O Q 199$ morbis] moribus $V 200$ aliquo modo] aliquando $Q 201$ crocodilli] cocodrilli HIJLMPQRV; corcodilli $O 202$ subicientur] subiciuntur $M Q 203$ ad locum] ad illum $I J L N O Q 204$ in natura] in natura uestra $M$ (sup. lin. a. m.) NQ 205 uestrae] uestrae uel ex parte $M$ ( in marg. a. m.) $O Q 206$ referto] refecto $H$; reperto $L Q$; inserto $P$; reseruato $V 207$ mei] mera $Q 208$ tetigeritis] attigeritis $Q 209$ de fructu] et fructum $O Q 210$ patris sui. Non enim portabit $\rightarrow$ 
natureza, não era nem imortal, nem incapaz de pecar, nem amigo de Deus ou destinado a esta felicidade ou ao pacífico domínio dos outros animais a ponto de as feras lhe serem quase que espontaneamente submissas ou os elementos lhe não poderem fazer mal. Mas tudo isso recebera de Deus para si e toda a sua posteridade como dom singular, com uma condição: se observasse um pequeno mandamento. Daí que, criada Eva, lhes haja dito Deus na presença dos anjos: Vós conheceis a vossa condição. Estais sujeitos a doenças várias, a dores, a preocupações e à morte corporal. Tudo quanto se relaciona com o corpo pode ser-vos nocivo e, de algum modo, útil. Ursos, leões, crocodilos, dragões, só à força vos serão submissos. Não tenho qualquer obrigação de vos mudar deste para o Paraíso Celeste sãos e incólumes, na integridade da natureza. Pelo contrário, parece até que isso contraria a condição da vossa natureza. Nenhuma razão existe, pois, para que [fl. 30] vos mantenha neste ameníssimo lugar permanentemente cheio de todo o género de admiráveis frutos, vos propicie alimento tão salutar, vos conceda tão grande conhecimento das coisas, vos preserve de todo o trabalho e de todo o suor e vos guardemos, eu e estes anjos, meus filhos, de todos os perigos. Concedo-vos todas estas coisas por favor meu e singular benevolência. Não teríeis nenhuma delas por condição natural. Quero, contudo, provar-vos com um mandamento como provei estes meus anjos. Vistes perante vós grande variedade de árvores cujos frutos são permanentes e nunca definham. Comei de todas as outras. Nesta não toqueis. Não provareis do seu fruto. Na mesma hora em que provardes, retirar-vos-ei a vós e aos vossos descendentes todos estes privilégios e dons e restituir-vos-ei à condição da vossa natureza e ficareis sujeitos à morte e, antes dela, sofrereis muitos males.

Vê, pois, que, por causa daquele pecado, nenhum mal advém aos filhos de Adão, mas apenas são privados dos dons que excedem a condição da sua natureza e são colocados nos limites naturais e no estado da sua própria natureza. Por isso, justamente disseram alguns de entre vós que o homem nunca é punido por Deus no inferno com um suplício sensível somente por causa do pecado de seu pai. O filho, pois, não carregará consigo dessa maneira a injustiça de seu pai. Se uma coisa for dada ao pai e aos filhos sob condição e apenas pela boa vontade de quem dá, não há injustiça alguma se a todos for retirada porque tal condição não foi cumprida pelo pai a quem essa coisa era atribuída em favor de todos. Em razão deste facto, não poderá assacar-se nenhuma parcialidade a quem retira nem obrigação alguma a quem dá.

$\leftarrow$ filius iniquitatem patris sui hoc modo] patris sui hoc modo $L \mathbf{2 1 1}$ si aliquid detur patri et filiis] aliquod detur donum concessum patri et filiis $N$; si aliquod donum concessum patri et filiis $O P Q$ 212 datur] dabatur $I L N O Q 213$ non seruata. Si omnibus auferatur nil] non seruata si (si om. $O$ ) omnibus auferatur. Nil $O P Q 214$ auferente] auferentem $Q 215$ debiti] debitur $I$; debitum $L V$; in debitum $Q 216$ donante] donantem 
Deus igitur filios Adae sibi et naturae propriae reliquit ${ }^{217}$, nolens ullo pacto eos punire ullo suplicio pro illo $^{218}$ peccato. Sed etiam noluit ${ }^{219}$ ut priuilegiis gauderent cum condicione promissis ${ }^{220}$ ex quo illa ${ }^{221}$ condicio non fuit seruata. Et ut melius intelligas, pone quod Deus creauerit ${ }^{222}$ hominem talem qualem ${ }^{223}$ nunc nascitur, educatur et nutritur, sensu et intellectu paulatim imbuitur et tandem accipiat mandata et legem, nullum donum supernaturale ${ }^{224}$ sibi promittatur in hac uita $^{225}$. Si talis homo langueret, si egenus ${ }^{226}$ et miser esset, si moreretur ${ }^{227}$, quae iniustitia est? Nulla certe. Creauit eum Deus ${ }^{228}$ talem qualis est ex sui natura. Ea tamen quae uos nunc ${ }^{229}$ patimini uocantur poenae peccati, quia ex pacto illo Dei, si homo non peccasset, non incurrissetis ${ }^{230}$ eas neque fuissetis ${ }^{231}$ relicti $^{232}$ in condicionibus naturalibus.

Tunc ego: Valde placet ${ }^{233}$ ista miranda audire. Conscribam ${ }^{234}$ ea ut potero. Sed, mi domine, hoc nunc uersatur in corde meo quod explanare ignoro tam [f1. 31] quam simplex ${ }^{235}$ et idiota. Si Eua sola peccasset, dictum est filios ex ea procreatos non fuisse his donis spoliatos. Quaero utrum ${ }^{236}$ ipsa sola spoliata fuisset. Similiter si unus filiorum peccasset, utrum $\operatorname{alios}^{237}$ uel saltem ${ }^{238}$ se illis donis spoliasset, quia tunc aliqui fuissent mortui et aliqui non, et genus humanum fuisset diuisum per mortale et immortale 239 .

Respondit angelus: Si Eua sola peccasset, ab ea descendentes mortales hoc modo quo nunc estis ${ }^{240}$ non fuissent. Sed nec ipsa. (Adam enim talem immortalitatem pro se et pro omnibus ab eo descendentibus acceperat, hoc est, tam pro Eua quam pro uniuersis liberis, quia ipsius Adae iustitia omnibus ratio talia dona conseruandi fuisset. Sicut nunc est causa uel occasio talium bonorum ${ }^{241}$ priuationis $^{242}$ omnibus, ipso stante omnes stetissetis sicut ipso ruente omnes ruitis ${ }^{243}$ ). Simili modo si filius aliquis peccasset, alii propter peccatum illius non corruissent ${ }^{244}$.

Tunc ego: Domine mi, uidetur quod quilibet fioliorum, immo et Eua, peccando amisisset $^{245}$ iustitiam originalem et, cum per illam immortales essent, ipsa amissa ${ }^{246}$, morti obnoxii fuissent.

Respondit: Deus inspirauit ${ }^{247}$ ut sic dubitares. Magnus enim est nodus iste apud $\operatorname{uos}^{248}$. Sed cito scribe et diligenter pastori uenturo tradendum conserua, qui haec omnia ingenio acuto penetrabit acute et docebit omnes: Iustitia originalis erat qualitas quaedam qua homines grati fuissent Deo. Et haec, in solo Adam amissa,

$Q 217$ reliquit] dereliquit $Q 2 \mathbf{2 1 8}$ illo] eo $N$, primo $P 219$ Sed etiam noluit] Sed uoluit $Q \mathbf{2 2 0}$ promissis] promissa $Q 221$ illa] nulla $V \mathbf{2 2 2}$ creauerit] creauit $O 223$ qualem] qualis IJLNOPV 224 supernaturale] spirituale $P \mathbf{2 2 5}$ in hac uita] in hac uita aut in alia $M$ (sup.lin. a. m.) NOQ; in hac uita uel alia $P 226$ egenus] egeneret $Q \mathbf{2 2 7}$ moreretur] moreretur si numquam Deum uideret $Q$, 228 Creauit eum Deus] Creauit enim Deus illum $N 229$ Ea tamen quae uos nunc] Et tamen quam uos tunc $N$; Et (add. sup. lin. a. m. ea) tamen quae uos nunc $O 230$ incurrissetis] incurrisset $V \rightarrow$ 
Deus abandonou, pois, os filhos de Adão a si mesmos e à própria natureza, não querendo por razão alguma puni-los com qualquer suplício em razão daquele pecado. Mas também não quis que desfrutassem dos privilégios prometidos sob condição, a partir do momento em que essa condição não foi observada. E para melhor entenderes, admite que Deus tenha criado o homem tal como hoje nasce, é educado e alimentado, paulatinamente se forma no sentir e no pensar e, por fim, receba os mandamentos e a lei, nenhum dom natural the haja sido prometido nesta vida. Se esse homem se tornasse doente, se fosse pobre e infeliz, se morresse, que injustiça haveria? Nenhuma, certamente. Deus criou-o tal qual é de sua natureza. Ao vosso actual sofrimento chama-se penas do pecado porque, em razão daquele pacto de Deus, se o homem não tivesse pecado, não teríeis incorrido nelas nem teríeis sido abandonados às naturais condições.

Muito me agrada, disse eu, ouvir estas maravilhas. Registá-las-ei como puder. Mas, meu senhor, revolve-se-me no coração algo que, sendo eu [f1. 31] simples e ignorante, não sei explicar. Diz-se que se só Eva tivesse pecado, os filhos dela nascidos não seriam privados daqueles dons. Pergunto se apenas ela seria despojada. Do mesmo modo, se um dos filhos tivesse pecado, pergunto se privaria desses dons os outros ou deles se privaria pelo menos a si. Porque então uns estariam mortos e outros não, e o género humano estaria dividido em mortal e imortal.

Se apenas Eva tivesse pecado, respondeu o anjo, os seus descendentes não seriam mortais do modo que vós sois hoje. E nem sequer ela. Adão, de facto, havia recebido essa imortalidade para si e para todos os seus descendentes, isto é, tanto para Eva como para todos os filhos, porque a justiça de Adão tinha sido para todos a razão da manutenção desses dons. Do mesmo modo que é presentemente a causa ou o motivo da privação de tais bens em relação a todos, todos vos teríeis mantido se ele se mantivesse, como todos caístes com a queda dele. O mesmo se diga se algum filho tivesse pecado. Por causa do seu pecado não haveriam os outros de cair.

Meu senhor, disse eu então, parece que qualquer um dos seus filhos, e até Eva, ao pecar, teria perdido a justiça original e, sendo imortais por via dela, ao perdê-la, haveriam de ficar sujeitos à morte.

Inspirou-te Deus para assim duvidares, respondeu. Grande é, de facto, entre vós essa dificuldade. Mas escreve célere e guarda diligentemente para ser entregue ao Pastor que há-de vir que, com o seu fino talento, penetrará subtilmente todas essas coisas e ensiná-las-á a todos: A justiça original era uma espécie de qualidade

$\leftarrow 231$ fuissetis] fuisset $V \mathbf{2 3 2}$ relicti] derelicti $Q$, relictus $V 233$ placet] placent $O$; placuit $Q 234$ conscribam] conseruabo $V 235$ simplex] infelix $V 236$ Quaero utrum] Quaero an $L$; Quaero iterum si $Q 237$ alios] alium $Q 238$ saltem] solum $N 239$ mortale et immortale] mortalem et immortalem $V \quad \mathbf{2 4 0}$ estis] sunt $Q \quad \mathbf{2 4 1}$ bonorum] donorum $Q \quad \mathbf{2 4 2}$ priuationis] priuationibus $L$ 243 ruitis] resistis $N 244$ corruissent] caruissent $L P \quad 245$ amisisset] amisissent $N Q 246$ amissa] ablata $Q 247$ inspirauit] spirauit $O \mathbf{2 4 8}$ apud uos] apud uos et uix solubilis $P$ 
erat causa ut omnes eam amitterent, praesertim in quantum ipsa erat signum illius antiquae immortalitatis, sicut et in ipso manens, quamuis in aliis desineret, nullo tamen modo morti obnoxium hominem fecisset. Immo mirabiliora tibi dicam, si Adam alio peccato quam esu illius ligni peccasset, propter id neque ipse neque posteritas mortem incurrisset, quod et ita re ipsa fuit. Nam Eua multis modis iam peccauerat et ita iustitiam amiserat. Et Adam, antequam comedisset, iam peccauerat et $\operatorname{sic}^{249}$ ipse quoque iustitiam amiserat ante illum esum. Nec tamen adhuc erant aperti oculi eorum neque a facie Domini ${ }^{250}$ se absconderant ${ }^{251}$ nec nudos se agnoscebant. Quamobrem, si non comedissent, de peccato illo dolere potuissent uel amore intensiori Deum prosequi et iustitiam uel gratiam rehabuissent et in ea confirmati fuissent ita ut, ea rehabita, mox fuissent in ea confirmati. Et eo modo nullus damnatus fuisset quia, si peccasset, peccatum tamen illud in ipso peccante non durasset et post primam conuersionem amplius peccare ipsum Deus non permisisset. Scito ergo et animaduerte, idiota Dei, et conscribe (et haec dicens, traxit auriculam meam ut faciunt magistri discipulis quos docent), quoniam Deus, [f1. 32] Adam non peccante, dimisisset genus humanum immortale totum. Et, si alii peccassent ${ }^{252}$, resurrexissent et nullus damnatus aut morti obnoxius fuisset.

Tunc ego: Idiota sum, Domine mi, et numquam scientiam aliquam ${ }^{253}$ didici. Tamen, te et primum Deo nostro auxiliante, adhuc circa nunc dicta dubito. Nam si illi peccabant ${ }^{254}$, illud peccatum fuisset transgressio legis diuinae et ita fuisset peccatum mortale et ita dignum morte uel temporali uel aeterna uel utraque nescio, uel propter illud non incurrebant damnationem aeternam. Quomodo poterant $^{255}$ peccare mortaliter quia peccare mortaliter est incurrere damnum ${ }^{256}$ aeternae mortis?

Respondit Angelus: Sicut nunc multi ellecti a Deo peccant mortaliter nec tamen damnantur, quamuis illam poenam incurrant quantum ex ipsis ${ }^{257} \mathrm{est}$, Deus tamen praeparauit remedia ${ }^{258}$ quibus releuentur ita quod omnia eis cooperantur in bonum ${ }^{259}$, sic fuisset illis. Sed nunc diligenter considera quod, quamuis multi ex uestris putent Adam non peccante nec alios peccaturos fuisse unquam, illud tamen confutari a uobis ipsis potest quia, antequam Adam peccasset, Eua peccauit $^{260}$. Si ergo Adam non peccasset, Eua peccante, quid fuisset de Eua illud idem fuisset de filiis Adae et Euae. Ipsa pro certo peccauit ante uirum sum et uir poterat non peccare ${ }^{261}$ postquam ipsa peccauerat. Et uiro non peccante, mors

249 peccauerat et ita iustitiam (...) iam peccauerat et sic] peccauerat et sic $I$ 250 Domini] eorum $Q \quad 251$ absconderant] abscondebant $Q 252$ peccassent] peccauissent $I L$; peccarent $Q$ 253 scientiam aliquam] scientiam autenticam $P$; scientiam $J V 254$ peccabant] peccarent $Q 255$ nescio, uel propter illud non incurrebant damnationem aeternam. Quomodo poterant] nescio si uel propter illud non incurrebant damnationem et tunc quomodo poterant $H$; nescio. Si ergo $\rightarrow$ 
pela qual os homens seriam agradáveis a Deus. E esta, perdida somente em Adão, era motivo para que todos a perdessem, sobretudo na medida em que era sinal da antiga imortalidade. De igual modo, mantendo-se nele, embora deixasse de existir nos outros, de modo algum tornaria o homem sujeito à morte. E digo-te até coisas mais admiráveis. Se Adão tivesse caído noutro pecado que não o de haver comido daquela árvore, nem ele nem os vindouros incorreriam na morte, facto que na realidade assim aconteceu. Eva, na verdade, tinha pecado já de muitas maneiras e tinha, assim, perdido a justiça. E Adão, antes de comer do fruto, tinha já pecado e, assim, também ele havia já perdido a justiça antes de comer. $\mathrm{E}$, contudo, os olhos deles ainda se não tinham aberto, nem se tinham escondido da presença do Senhor, nem se reconheciam nus. Por isso é que, se não tivessem comido, teriam podido chorar aquele pecado ou buscar a Deus com amor mais intenso, e recuperariam a justiça ou graça e seriam nela confirmados de modo que, reavida esta, imediatamente seriam nela confirmados. E, desse modo, ninguém seria condenado porque, se pecasse, esse pecado não se manteria no pecador e, depois da primeira conversão, não lhe permitiria Deus que pecasse mais. Sabe pois, e presta atenção, ignorante de Deus, e escreve (e dizendo isto puxou-me a orelha como fazem os mestres aos alunos que ensinam), pois que Deus, [fl. 32] se Adão não tivesse pecado, deixaria todo o género humano imortal. E, se outros pecassem, ressurgiriam, e ninguém seria condenado ou sujeito à morte.

Sou ignorante, meu senhor, disse eu, e nunca aprendi ciência alguma. Todavia, com o teu auxílio e, acima de tudo, com o do nosso Deus, restam-me ainda dúvidas sobre o que acabas de dizer. Pois, pecando eles, esse pecado seria transgressão da lei divina e seria, assim, pecado mortal e, certamente, digno de morte, ou temporal, ou eterna ou ambas, não sei, ou por causa dele não incorriam na condenação eterna. Como podiam pecar mortalmente, já que pecar mortalmente é incorrer no castigo da morte eterna?

Assim como actualmente muitos eleitos de Deus pecam mortalmente, respondeu o anjo, e, contudo, não são condenados (embora no que a eles respeita incorram nessa pena, Deus, todavia, preparou os meios pelos quais sejam aliviados, de modo tal que tudo concorra para o bem deles), assim teria sido com aqueles. Agora, porém, atenta bem em que, embora muitos dos vossos considerem que se Adão não tivesse pecado também os outros não pecariam nunca, isso pode, contudo, ser contestado por vós, pois que, antes que Adão pecasse, pecou Eva. Se, porém, Adão não tivesse pecado, pecando Eva, o que acontecesse a Eva, isso mesmo aconteceria aos filhos de Adão e Eva. Ela com certeza que pecou antes

$\leftarrow$ propter peccatum illud non incurrebant damnationem aeternam ergo poterant $Q 256$ damnum] damnationem $Q 257$ ex ipsis] in se $Q 258$ remedia] media HILNOPQ 259 in bonum] in bonum quia et ipsi sunt proni $P \mathbf{2 6 0}$ Eua peccauit] Eua peccauit ante uirum suum et uir poterat non peccare postquam ipsa peccauerat $V \mathbf{2 6 1}$ poterat non peccare] non poterat peccare $I$ 
non introisset ${ }^{262}$ in orbem terrarum. Quid ergo fuisset de Eua? Vapulasset plagis nonnullis, damnata tandem aut mortua non fuisset. Quomodo autem uapulasset et conuersa fuisset dicemus. Hoc idem dicendum est de quolibet filiorum.

Mors et uita uestra in manibus solius Adae stabat, ex illo pendebat et bonum et malum uestrum. Et quamuis Deus, si neuter parentum praeuaricabatur ${ }^{263}$ mandatum, etiam posteros ne peccarent iuuisset multo magis quam nunc, ita quod potius nullus peccasset quam ${ }^{264}$ peccato se subiecisset, peccare tamen quilibet in tali aetate potuisset, quamuis forsan Deus non permisisset si neuter parentum peccasset. Permisso tamen peccato Euae ante peccatum Adae, permissum fuisset alicuius $^{265}$ filiorum peccatum eadem ratione uel saltem ut permissum esset ${ }^{266}$, non est inconueniens ${ }^{267}$, et punitum eo modo quo peccatum Euae punitum fuisset si sola absque uiro peccasset.

Tunc ego: Credo quod tua, Dei Angele, sapientia omnia neccessaria in negotio peccati dixerit et declarauerit quae mihi et forsan omnibus mei generis fuerunt incognita. Sed quia ex nostris quidam dicunt peccatum originale esse priuationem iustitiae originalis cum debito habendi eam, quomodo fuissent illi priuati iustitia et tamen non habuissent aliquod damnum?

Angelus subrisit dicens: $O$ pauper homuncio, intelligisne quae dicis? Videris mihi asina Balaam.

Dixi: Loquor ut pica quaedam et certe non [f1. 33] percipio.

Et ille: Sic ordinatum est ut per simplicissimum hominem haec dirigantur illi cui Deus aperiet sensum et intellectum, qui ea subito intelliget et transcribet et tempore suo $^{268}$ promulgabit ne fideles in tot opinionibus uersentur ${ }^{269}$, sed agnoscant quid in rebus fidei tenendum sit. Tu ergo dicere uelles quod, ex quo ${ }^{270}$ peccatum originale est priuatio $^{271}$ iustitiae originalis, et Eua illa iustitia priuata fuerat, immo et Adam antequam ${ }^{272}$ essetis $^{273}$ omnes in ipso sploliati donis gratuitis ${ }^{274}$ uidelicet impassibilitate aliquomodo et immortalitate et perpetua incolumitate et sospitate et alterius uitae adeptione. Vis ergo dicere et nescis, ego dicam pro te quod, ex quo post priuationem ${ }^{275}$ iustitiae originalis nil mali filiis accidebat, sed solum per esum illum ante quem iam iustitia desierat esse in illis, quod peccatum originale non est priuatio iustitiae originalis, sed potius damnum quod accidit gratia esus illius prohibiti pomi, uel, peccatum originale est amissio multorum donorum supranaturalium ${ }^{276}$ gratia transgressionis mandati Dei quam fecit primus

262 introisset] introibat $H O$, intrasset $P 263$ praeuaricabatur] praeuaricasset $L$; praeuaricatus fuisset $P$; praeuaricaret $Q 264$ quam] quis $L 265$ alicuius] alicui $P 266$ filiorum peccatum eadem ratione uel saltem ut permissum esset] filiorum peccatum uel saltem permitti posse uel permissum esset $Q 267$ non est inconueniens] non est inconueniens credere uel tenere $Q 268$ tempore suo] ipse $J V 269$ in tot opinionibus uersentur] in tantis opinionibus uersentur $H$; in tantis opinionibus $\rightarrow$ 
do seu marido, e o homem podia não pecar depois de ela ter pecado. E, se o homem não pecasse, a morte não teria entrado no mundo. Que seria então de Eva? Seria atingida por muitas desgraças, mas não seria condenada nem morta. Como seria atingida e como haveria de se converter, di-lo-emos. O mesmo se deve dizer de qualquer um dos filhos.

A vossa morte e a vossa vida estavam exclusivamente na mão de Adão. Dele estavam pendentes o vosso bem e o vosso mal. E embora Deus, se nenhum dos vossos pais tivesse transgredido a ordem, auxiliasse também, muito mais do que hoje, os descendentes a não pecar, de modo a que antes nenhum pecasse do que se sujeitasse ao pecado, poderia, todavia, qualquer um nessa idade pecar, embora talvez Deus o não permitisse se nenhum dos vossos pais tivesse pecado. Mas, permitido o pecado de Eva antes do pecado de Adão, permitido seria pela mesma razão o pecado de algum filho ou, pelo menos, logo que permitido, não há discordância, seria também punido do mesmo modo que o teria sido o pecado de Eva se apenas ela, sem o homem, tivesse pecado.

Acredito, anjo de Deus, disse eu, que o teu saber tenha dito e explanado tudo quanto intimamente se relaciona com a questão do pecado, questão que me era desconhecida a mim e, talvez, a todos os da minha raça. Mas, visto que alguns dos nossos dizem que o pecado original é a privação da justiça original, com a obrigação de a ter, como teriam eles sido privados da justiça sem sofrerem qualquer condenação?

Ó pobre homenzinho (e o anjo sorriu-se ao falar), sabes o que dizes? Pareces-me a burra da Balaão.

Falo como uma pega, respondi eu, e sem dúvida que não [f1. 33] entendo.

Foi, assim, disposto, disse ele, que estas coisas fossem encaminhadas pelo mais simples dos homens para aquele a quem Deus abrirá o sentimento e a razão, que logo as entenderá e as transcreverá e as divulgará em seu tempo, para que os fiéis se não perturbem no meio de tantas opiniões, mas saibam o que em matéria de fé deve ser observado. Tu querias, pois, dizer que, uma vez que o pecado original é a privação da justiça original, não só Eva fora privada dessa justiça, mas até Adão, antes de todos serdes nele despojados dos dons gratuitos, como a impassibilidade, em certa medida, e a imortalidade, a perpétua segurança e a salvação e a consecução da outra vida. Queres, pois, dizê-lo e não sabes. Direi eu por ti. Uma vez que depois da privação da justiça original nenhum mal acontecia aos filhos, mas só por efeito do acto de comer, antes do qual já a justiça os abandonara, direi que o pecado original não é a privação da justiça original, mas sim o castigo que sobrevém por causa do acto de comer aquele fruto proibido, ou, o pecado original

$\leftarrow$ uexentur $I$; tantum uexentur $L \mathbf{2 7 0}$ quod, ex quo] quando $Q \mathbf{2 7 1}$ priuatio] preuaricatio $Q 272$ Adam antequam] Adam antequam comederet, ergo sine illo esu $M$ (in marg. a. m.) NO; Adam antequam comederent, ergo sine ullo seu $Q \quad 273$ essetis] essent $J L V \quad 274$ gratuitis] gratuitatis $P$ $\mathbf{2 7 5}$ priuationem] praeuaricationem $P \mathbf{2 7 6}$ supranaturalium] supernaturalium $H I J$; spiritualium $V$ 
parens hominum ${ }^{277}$. Hoc tu dicere uolebas. Dico ergo ${ }^{278}$ tibi quod erat concreata, quia in creatione infusa fuit duplex qualitas in anima Adae et uxoris eius. Vna uniebantur $^{279}$ Deo et ei grati reddebantur ${ }^{280}$. Et haec subito fuit exclusa ${ }^{281}$ per peccatum mortale quodcumque. Altera uero remanebat et per nullum peccatum aliud expelli poterat nisi per esum ligni uetiti. Per esum, dico, solius Adae. Huius autem qualitatis officium ${ }^{282}$ erat significare assistentiam Dei quae illos protegeret a nociuis omnibus et incolumes conseruaret ${ }^{283}$ ac etiam post amissionem illius prioris qualitatis haec ad bonum propelleret, incitaret ${ }^{284}$, prouocaret et Deo esse reconciliandum quasi moneret ${ }^{285}$ et alliceret. Eua ergo, postquam elata fuit, amisit illam priorem qualitatem. Similiter ${ }^{286}$ si filii peccassent, Adam non peccante, illam eandem amisissent. Alteram uero et Eua habuit quousque Adam non comedit. Et filii peccantes, si Adam non comedisset cibum ${ }^{287}$ illum, habituri erant et illius incitatione in Deum reuersuri et redituri erant et in gratia Dei post conuersionem perpetuo permansuri. Vtraque qualitas posset uocari iustitia originalis, quia utraque fuit in origine et principio et quasi stipite humani generis ${ }^{288}$. Sed priuatio illius prioris qualitatis non inferebat damnum aliis, quia unicuique pro seipso donabatur ${ }^{289}$ et non pro aliis, dummodo illa alia remaneret. Priuatio uero alterius inducebat mortem in omnes ${ }^{290}$ et rebelliones uirium ${ }^{291}$ quia, cessante illo signo, Deus reliquisset uires inferiores et superiores in suis condicionibus naturalibus.

Quando ergo Adam comedit cibum prohibitum ${ }^{292}$ amisit illam qualitatem pro se et omnibus filiis suis, sicut et pro omnibus eam acceperat cum pacto quod numquam hanc recuperare posset, sed bene priorem illam, et ipse pro se et quilibet filius pro seipso, [fl. 34] quam ${ }^{293}$ uos gratiam Dei hodie et aliqui uestrum caritatem uocatis ${ }^{294}$. Et quia haec posterior qualitas apud uos iustitia originalis saepius uocatur, priuatio uero illius in filiis peccatum originale. Iccirco dicitis peccatum originale esse priuationem iustitiae originalis, hoc est, quae erat in origine et in stipite, cum debito habendi eam. Non quod filii Adae sint obligati eam habere, cum ad impossibile ${ }^{295}$ nemo teneatur, sed quia Adam se obligauerat Deo pro se et pro filiis eam conseruare ${ }^{296}$, hoc est, non peccare ne causa illius

277 parens hominum] homo $N \mathbf{2 7 8}$ Dico ergo] Dico ego HJN (O sup.lin.) PV; Dico IL 279 uniebantur] uniebatur $V \mathbf{2 8 0}$ reddebantur] reddebatur $V \mathbf{2 8 1}$ exclusa] expulsa $V 282$ officium] effectum I; effectus $J L P$; affectum $V \mathbf{2 8 3}$ conseruaret] obseruaret $L \mathbf{2 8 4}$ incitaret] pacificaret $J V$ $\mathbf{2 8 5}$ moneret] maneret $J$; admoneret $P$; moueret $O Q 286$ Similiter] Similiter et Adam subito ut uxori complacere proposuit. $P \mathbf{2 8 7}$ comedit. Et filii peccantes si Adam non comedisset cibum] comedit cibum $V \mathbf{2 8 8}$ humani generis] humanae generationis $Q 289$ donabatur] communicabatur $Q 290$ in omnes] in omnibus $O Q 291$ rebelliones uirium] rebellionem uirium IJLNOQ; rebellionis uitium $P 292$ prohibitum] uetitum $Q 293$ quam] Quomodo $J M V 294$ Quando ergo Adam $\rightarrow$ 
é a perda de muitos dons sobrenaturais por causa da transgressão da ordem de Deus levada a cabo pelo primeiro pai da humanidade. Era isto o que tu pretendias dizer. Digo-te eu, pois tinha sido criada ao mesmo tempo, já que na criação tinha sido infundida na alma de Adão e de sua esposa uma dupla qualidade. Por uma ligavam-se a Deus e tornavam-se-lhe agradáveis. Esta foi expulsa pelo pecado mortal, qualquer que fosse. A segunda, porém, mantinha-se e não podia ser expulsa por nenhum pecado mortal senão pelo acto de comer da árvore proibida. Acto, afirmo, exclusivo de Adão. Era função desta qualidade mostrar a assistência de Deus, assistência que os protegeria de todos os males e os conservaria incólumes e, ainda, depois da perda daquela primeira qualidade, os impeliria, os incitaria, os desafiaria para o bem e como que os advertiria e os atrairia à necessidade de se reconciliarem com Deus. Eva perdeu aquela primeira qualidade depois de se haver deixado levar pelo orgulho. Do mesmo modo a teriam perdido os filhos se tivessem pecado, mesmo sem o pecado de Adão. A segunda, mesmo Eva a conservou enquanto Adão não comeu. E os filhos, ainda que pecassem, se Adão não tivesse comido esse alimento, tê-la-iam mantido, e pelo seu incitamento haveriam de converter-se e voltar, e depois da conversão haveriam de permanecer para sempre na graça de Deus. Poderia chamar-se às duas qualidades justiça original, porque ambas estiveram na origem e no princípio e como que na raiz do género humano. Mas a privação daquela primeira qualidade não acarretava prejuízo aos outros, contanto que a segunda se mantivesse, visto que a cada um era dada em seu favor e não em favor de outrem. A privação da segunda, porém, acarretava a morte para todos e a rebelião das forças, visto que, deixando aquele sinal de estar presente, abandonaria Deus à sua condição natural as forças inferiores e superiores.

Quando, pois, Adão comeu o alimento proibido, perdeu aquela qualidade para si e para todos os seus filhos, do mesmo modo que em favor de todos a recebera, com a condição de que jamais poderia recuperar esta, mas apenas a primeira, não só ele para si, como cada filho em favor próprio, [f1. 34] primeira a que hoje vós chamais graça de Deus e alguns dos vossos chamam caridade. E visto que esta segunda qualidade muitas vezes se chama entre vós justiça original, a privação dela nos filhos chama-se pecado original. Por isso dizeis que o pecado original é a privação da justiça original, isto é, que estava na origem e na raiz, com a obrigação de a ter. Não que os filhos de Adão estejam obrigados a tê-la, já que ninguém é obrigado ao impossível, mas porque Adão se obrigara perante

$\leftarrow$ comedit cibum prohibitum (...) uos gratiam Dei hodie et aliqui uestrum caritatem uocatis] Quando ergo Adam comedit cibum prohibitum amisit illam qualitatem pro se et omnibus filiis suis, sicut et pro omnibus eam acceperat. Tunc et Eua eam amisit simul cum Adam. Sic autem amissa est quod numquam recuperari posset sed bene priorem illam quam uos hodie gratiam Dei et aliqui uestrum caritatem uocant, quilibet recuperare potuisset cum pacto quod numquam hanc recuperare posset sed bene priorem illam. $P 295$ impossibile] impossibilitatem $O 296$ conseruare] obseruare $O$ 
peccati Deus eam sibi auferret. Ipse ergo ${ }^{297}$ erat debitor pro omnibus filiis, non pro aliis, ut si non forent geniti ${ }^{298}$ ex propagatione filii et filiae Adae, ut fuit Christus Dominus, et siquis alius non ex ea stirpe crearetur a Deo. Necesse est ergo omnes Adae natos perpetuo et inrecuperabiliter priuari illa qualitate. Ipse enim, si non comedisset, pro omnibus filiis suis eam conseruasset ita quod etiam peccantes filii eam numquam amplius amisissent, sed per eam ad Deum suum cito reuersuri erant nec in peccato obstinari poterant. Vnde peccatum eorum ac si non fuisset peccatum, quia subito illud agnouissent et in Deum toto corde rediissent et, ut diximus, raro uel potius numquam aliquis repertus ${ }^{299}$ fuisset qui peccasset, sed quilibet uicisset temptationem primam. Solum dico quod possibile fuisset aliquem ex ipsis ${ }^{300}$ uinci qui, si uictus fuisset, eo modo in Deum rediisset. Non fuisset opus aliquo sacramento aut alia paenitentia, sed amore intensiori qualitatem illam, id est, gratiam amissam recuperasset ${ }^{301}$. Hic est modus quo uapulassent ${ }^{302}$.

Dico tibi, animaduerte et scito, quod priuatio illius secundae qualitatis, quam uos a gratia ${ }^{303}$ discernentes iustitiam originalem appellatis, potius est poena quam culpa. Quia tamen per culpam eam incurristis, culpa et peccatum appellari potest. Dico secundo, semel id decretum est et pacto firmatum ut amissam illam qualitatem numquam rehabituri ${ }^{304}$ essetis $^{305}$, sicut si Adam non peccasset ${ }^{306}$ illo peccato numquam amplius amittere potuissetis. Dico tertio, nullum sacramentum fuisset $^{307}$ institutum pro recuperatione ${ }^{308}$ illius qualitatis neque Christum pro ea recuperanda Redemptorem uenisse oportebat. Si enim decretum est a Deo edicto publico ut numquam restituatur ${ }^{309}$, ad quid ${ }^{310}$ oportet $^{311}$ litus arare et conari ad impossibilia? Quid ergo? Ne genus humanum excluderetur a possessione caelestis patriae, quod a paradiso terrestri exclusum est, et morbis, passionibus atque morti [f1. 35] subiectum ita est ut de hoc ${ }^{312}$ definitiua sententia lata sit, concessit Deus priuatis remedio illo facillimo, quod erat iustitiae illius habitus et qualitas $^{313}$, alia remedia quae essent difficiliora et poenalia, ut dolorem cordis, confessionem, baptismum, martyrium ${ }^{314}$ et talia. Et haec remedia poenalia uirtutem acceperunt $^{315}$ a poena et dolore Christi Redemptoris uestri et omnium creaturarum ${ }^{316}$ intellectualium Principis et Regis, antea quidem praeuisa, postea uero, ut etiam uos dicitis, exhibita. Quod autem dixi de uestris modernis sacramentis, hoc idem dico de illis Testamenti Veteris et legis naturae.

297 Ipse ergo] Ipse non $M$; Item ergo $J V 298$ geniti] nati $Q 299$ repertus] raptus $V 300$ ex ipsis] eorum $N 301$ recuperasset] recuperassent $J M P Q V 302$ uapulassent] uapulasset $L 303$ a gratia] gratiam $I L V 304$ rehabituri] habituri $J V 305$ essetis] estis $P \quad 306$ peccasset] peccabat $I 307$ fuisset] fuisse $I L Q 308$ recuperatione] reparatione $V 309$ restituatur] instituatur $P 310$ ad quid] ad quod $H$; aliquid $J M 311$ oportet] oporteret $H L$; opus $P 312$ atque morti subiectum, ita est $\rightarrow$ 
Deus a conservá-la para si e para os seus filhos, isto é, a não pecar, para que, em razão desse pecado, Deus lha não retirasse. Ele era, pois, devedor por todos os filhos, não por outros, no caso de alguns não terem nascido da descendência do filho e da filha de Adão, como foi Cristo Senhor, e se algum outro não fosse criado por Deus a partir dessa estirpe. É inevitável, pois, que todos os filhos de Adão sejam privados definitiva e irrecuperavelmente daquela qualidade. Se ele não tivesse comido, tê-la-ia conservado para todos os seus filhos, de tal forma que, mesmo pecando, os filhos jamais a perderiam, mas por intermédio dela rapidamente retornariam ao seu Deus e nem se poderiam obstinar no pecado. Daí que o seu pecado seria como se não fosse pecado, porque de imediato o reconheceriam e de todo o coração voltariam a Deus e, como dissemos, raramente, ou antes, nunca seria achado alguém que pecasse, mas venceria cada um a primeira tentação. Digo apenas que seria possível que algum deles fosse vencido, o qual, se vencido, tornaria desse modo a Deus. Não seria preciso nenhum sacramento ou outra penitência, mas por intermédio de um amor mais intenso recuperaria essa qualidade, isto é, a graça perdida. É este o modo como seriam atingidos.

Digo-te, presta atenção e fica a saber que a privação daquela segunda qualidade que, distinguindo-a vós da graça, designais por justiça original, é mais pena do que culpa. Uma vez, contudo, que nela incorrestes por meio da culpa, pode chamar-se culpa e pecado. Digo, de novo, foi decretado uma vez e firmado por pacto que, perdida aquela qualidade, jamais a recuperaríeis, do mesmo modo que se Adão não tivesse incorrido naquele pecado jamais poderíeis perdê-la. Digo, em terceiro lugar, nenhum sacramento teria sido instituído para a recuperação daquela qualidade, nem era preciso que Cristo viesse como Redentor para recuperá-la. Se, com efeito, foi decretado por Deus em público edito que nunca seria restituída, para quê perder seu tempo e tentar o impossível? E então? Para que o género humano não fosse excluído da posse da pátria celeste, ele que foi excluído do Paraíso Terrestre e sujeito a doenças, paixões e à morte, [f1. 35] de tal sorte que sobre isso foi lavrada sentença definitiva, Deus, aos que haviam sido privados daquele tão acessível remédio, que era condição e natureza daquela justiça, concedeu outros remédios que seriam mais difíceis e mais penalizantes, como a dor de coração, a confissão, o baptismo, o martírio e outros semelhantes. E estes remédios penalizantes, previstos realmente antes, só depois, como também vós dizeis, surgidos, receberam sua força da pena e da dor de Cristo, Redentor vosso, Príncipe e Rei de todas as criaturas inteligentes. Digo, porém, dos sacramentos do Antigo Testamentos e da lei natural o mesmo que disse dos vossos modernos sacramentos.

$\leftarrow$ ut de hoc] atque morti subiectum est, ita de hoc $Q 313$ qualitas] qualitatis $L Q 314$ martirium] matrimonium $V 315$ acceperunt] acceperant $I L$; acciperent $V 316$ creaturarum] creaturalium $J$; naturarum $N$ 
Quid ergo intelligitis per peccatum originale? Si priuationem illius iustitiae originalis quam secundam qualitatem esse diximus, tunc non est opus Deum temptare, quia sic ordinauit ut nulli amplius quantumcumque iusto restituatur ${ }^{317}$. Vnde nulli amplius data fuit, neque filiis propagatis ${ }^{318}$, neque humanitati assumptae quae, etsi non habuerit illam iustitiam, tamen propter id illa priuata non potest dici quia non acceperat eam Adam nisi pro filiis propagatione carnali productis. Et hoc modo intelligendo, necesse est omnes filios Adae in peccato originali nasci, quia omnes fuerunt priuati illa iustitia et nullus postmodum habuit eam, quia nullus a morte fuit praeseruatus sicut non sit mortuus uel moriturus ${ }^{319}$. Sed istud uos non uocatis peccatum originale, sicut nec proprie est, sed est magis poena primi peccati.

Quid est ergo peccatum originale? Dico quod, in quantum peccatum est, non est priuatio illorum donorum ad hominem pertinentium, neque est priuatio solum gratiae qua homo uniebatur Deo, sed est priuatio utriusque. Et Redemptor uenit et sacramenta instituit, non pro recuperanda iustitia originali per quam censebamini ${ }^{320}$ immortales et innocui et innocibiles et per quam peccando facile ${ }^{321}$ consurgere poteratis ${ }^{322}$, sed uenit pro recuperanda gratia ut per illam Deo coniungi et heredes caelestis regni effici possetis medio contritionis et sacramentorum, ut dixi, ita ut qui gratiam habeant ${ }^{323}$ Dei hoc alio modo uideatur debitum patris sui soluisse nec amplius patrem obligari ${ }^{324}$ pro eo, sed obligatio facta deleta esse intelligatur ${ }^{325}$.

Prior igitur qualitas recuperatur, posterior non in se nec totaliter ${ }^{326}$. Recuperatur tamen non in se, sed in alio. In quantum enim illa erat medium ${ }^{327}$ redeundi in Deum, loco illius instituta ${ }^{328}$ est paenitentia, baptismus et alia sacramenta et meritum Christi principaliter. In quantum igitur Adam, peccando, priuauit se uita aeterna, peccauit mortaliter et obligauit se ad poenam aeternam. In quantum uero priuauit filios uita aeterna et hereditate a Deo promissa, illa talis priuatio in filiis dicitur peccatum originale et filii solum priuati intelliguntur ${ }^{329}$ [f1. 36] hereditate et non obligati ad aliquam poenam uel dolorem interiorem uel exteriorem, temporalem uel aeternum. Vnde nullus propria contritione ${ }^{330}$ uel proprio dolore illud peccatum in se delet ${ }^{331}$, sed bene motu bone uoluntatis in Deum. Volo sic dicere, contritio non est ordinata pro deletione ${ }^{332}$ peccati originalis, nec poena ${ }^{333}$ interior uel exterior. Quis enim hortandus ${ }^{334}$ est ut paeniteat de illo quod non commisit? Valde igitur errant illi qui dicunt Deum aeterno igne puniturum in solo originali morientes ${ }^{335}$. Si enim non estis obligati ad ullam ${ }^{336}$ temporalem poenam pro illo, quomodo eritis obligati ad aeternam? Dico tibi quod pro illo nullus neque

317 restituatur] illa detur $H I L O V$; daretur $Q 318$ propagatis] propagationis $P 319$ mortuus uel moriturus] moriturum uel moriturus $J \mathbf{3 2 0}$ censebamini] considerabimini $Q$; consequebamini $V$ 321 peccando facile] peccantes facillime $Q \mathbf{3 2 2}$ poteratis] potueratis $J$; poteritis $P \mathbf{3 2 3}$ habeant] habeat $H I L N O P Q 324$ patrem obligari] patre obligare $Q 325$ intelligatur] intelligeretur $H M N 326$ totaliter] taliter $M V 327$ medium] remedium $Q 328$ instituta] iustitia $L 329$ intelliguntur] dicuntur $O \rightarrow$ 
Que entendeis então por pecado original? Se entendeis a privação da justiça original, a que chamámos segunda qualidade, então não é preciso tentar a Deus, visto ter ordenado que a ninguém, por mais justo, fosse restituída. Daí que a ninguém mais fosse ela dada, nem aos filhos gerados, nem à humanidade assumida por Cristo, humanidade que, embora não tendo tido essa justiça, nem por isso se pode considerar dela privada, uma vez que Adão a recebera apenas para os filhos nascidos da propagação carnal. E, segundo este entendimento, é forçoso que todos os filhos de Adão nasçam em pecado original, porque todos foram privados dessa justiça e, depois disso, nenhum a possuiu, porque nenhum foi preservado da morte, como se não tivesse morrido ou não viesse a morrer. A isto, porém, não chamais vós pecado original, como realmente o não é, mas é mais pena do primeiro pecado.

Que é então o pecado original? Digo que, enquanto pecado, não é a privação daqueles dons pertencentes ao homem, nem é a privação só da graça, pela qual o homem se unia a Deus, mas é a privação de ambos. O Redentor veio e instituiu os sacramentos, não para que fosse recuperada a justiça original, pela qual éreis considerados imortais, inocentes e insusceptíveis de pecar, e pela qual, pecando, facilmente podíeis levantar-vos, mas veio para recuperar a graça, a fim de que por ela pudésseis unir-vos a Deus e tornar-vos herdeiros do reino celeste por meio da contrição e dos sacramentos, como disse, de modo que aquele que tem a graça de Deus pareça haver deste outro modo pago a dívida de seu pai e que o pai se não obriga mais por isso, mas se entenda que a obrigação constituída foi anulada.

A primeira qualidade é, pois, recuperada. A segunda não o é nem em si, nem totalmente. Recupera-se, porém, não em si, mas noutra qualidade. Na medida em que era meio de retorno a Deus, foi em seu lugar instituída a penitência, o baptismo e os outros sacramentos e, sobretudo, o mérito de Cristo. Na medida, pois, em que Adão, ao pecar, se privou da vida eterna, pecou mortalmente e obrigou-se à pena eterna. Na medida em que privou os filhos da vida eterna e da herança prometida por Deus, essa mesma privação relativa aos filhos chama-se pecado original, e os filhos consideram-se apenas privados [fl. 36] da herança, mas não obrigados a qualquer pena ou dor interior ou exterior, temporal ou eterna. Daí que nenhum apague em si pela contrição própria ou pela própria dor esse pecado, mas, felizmente, pelo movimento de boa vontade para Deus. Quero, assim, dizer, nem a contrição, nem a pena interior ou exterior são orientadas para a destruição do pecado original. Há alguém que deva ser exortado a arrepender-se daquilo que não cometeu? Muito erram, pois, aqueles que dizem que Deus punirá com o fogo eterno aqueles que morrem só em pecado original. Se, de facto, não estais obri-

$\leftarrow 330$ contritione] conditione $Q 331$ delet] dolet $P Q 332$ deletione] delectione $H P 333$ poena] poenitentia $N$ ( $O$ er. poenitentia) $Q 334$ hortandus] orandus $V 335$ in solo originali morientes] in solo originali morientes. Nisi intellexissent per ignem aeternum priuationem aeternae uitae beatae sine tamen tristitia de tali priuatione. $P 336$ ullam] illam $V$ 
in inferno neque in purgatorio est cremandus aut affligendus neque alibi, nec dolorem ullum aut tristitiam est habiturus. Vnde nec proprie habebunt poenam damni quae ponit dolorem et tristitiam propter priuationem illius gloriae ${ }^{337}$, sed habebunt simplex et purum damnum, quia solum priuationem illius gloriae ${ }^{338}$. Nam, ut diximus ex parte, peccatum ${ }^{339}$ Adae non mutauit naturam humanam in se neque in condicionibus suis, sed solum restituit ei naturales condiciones, ablatis supernaturalibus. Sicut si Deus creasset hominem sine illis donis, in puritate suae naturae, ille beatitudinem illam numquam adeptus fuisset nec tamen quicquam mali pateretur propter id, et inter talem hominem sic in puris naturalibus conditum et filium Adae nullum peccatum habentem nisi originale nulla differentia est nisi quia iste poterat ex promissione habere illam gloriam ${ }^{340}$, iste sic creatus numquam potuit quia numquam sibi uel alteri pro ipso promissa fuit, unde filius Adae est magis proprie priuatus beatitudine quam ille. Similiter ${ }^{341}$ filius Adae, adhuc si uoluerit, id uelle ${ }^{342}$ poterit, esse beatus ualebit ${ }^{343}$ quia habet remedia ${ }^{344}$ quae etiam quaerere ${ }^{345}$, si noscat ${ }^{346}$, tenetur. ${ }^{347}$ Ille alius, etiam si uellet et quaereret, de lege communi non haberet ${ }^{348}$ quia nulla remedia sunt data. Melius est ergo esse filium ${ }^{349}$ Adae quam creatum ${ }^{350}$ in puris naturalibus quo ad hoc, quia quilibet talis beatus esse potest.

Adam ergo peccando non solum illis donis gratuitis se priuauit ${ }^{351}$, sed etiam aeternae morti addixit ${ }^{352}$, Filios solum beatitudine et aliis donis, de quibus diximus, spoliauit, sed non supplicio gehennae inuoluit. Scito quoque inter priuationem beatitudinis et gratiae et inter priuationem inmortalitatis illius et incolumitatis et animalium oboedientiae ${ }^{353}$ et nocumentorum alliorum ${ }^{354}$ et subiectionis uirium inferiorum hanc differentiam fuisse: quia beatitudine et gratia [f1. 37] sic priuati remanserant ${ }^{355}$, quod possent, si uellent, rehabere. Immortalitatem uero et animalium oboedientiam et alia quae diximus ita amiserunt ut nulla sanctitate fulgentes, nulla gratia pollentes, umquam amplius ea ${ }^{356}$ recuperare possent. Vnde Christus mortuus est, non quia Adam eum immortalitate priuasset $^{357}$ sed, quia homo, erat ex sui natura mortalis. Deinde redempturus erat genus humanum. Quamuis beatus esset, beatitudo tamen mortalitatem non abstulit. Si tamen beatus etiam non fuisset nec Redemptor et sic natus, adhuc mortalis fuisset, et tamen Adam in ipso non peccauisset quia Deus nulli homini immortalitatem promiserat ${ }^{358}$

337 gloriae] gratiae $N 338$ illius gloriae] illius gloriae absque ulla consequenti tristitia $P 339$ peccatum] patrem $J$; patris $V \mathbf{3 4 0}$ illam gloriam] illam $O$; illam gratiam $V 341$ beatitudine quam ille. Similiter] beatitudine cum et similiter $Q \mathbf{3 4 2}$ id uelle] et uelle $I L N$; cum uelle $H O$; uelle $P \mathbf{3 4 3}$ si uoluerit, id uelle poterit, esse beatus ualebit] si uoluerit, poterit esse beatus $Q 344$ remedia] remedia expiandi dictam priuationem $P 345$ quaerere] quaereri $N 346$ si noscat] si nesciat $J 347$ tenetur] tenetur et non quaerendo damnaretur. Sicut et in paradiso terrestri qui non comedendo $\rightarrow$ 
gados, por causa dele, a nenhuma pena temporal, como estareis à eterna? Digo-te que, por causa dele, ninguém deve ser queimado ou atormentado nem no inferno nem no purgatório nem seja onde for, nem experimentará qualquer dor ou qualquer tristeza. Daí que nem propriamente venham a sofrer a pena do dano, pena que acarreta dor e tristeza por causa da privação da glória, mas sofrerão um simples e mero dano, porque apenas a privação dessa glória. Com efeito, como dissemos em parte, o pecado de Adão não alterou a natureza humana em si nem nas suas condições, mas apenas lhe restituiu as condições naturais, depois de afastadas as sobrenaturais. Como se Deus criasse o homem na pureza da sua natureza, nunca este, por causa disso, alcançaria a bem-aventurança, mas também não sofreria dano algum, e entre este homem assim formado na natureza original e o filho de Adão não tendo senão o pecado original nenhuma diferença existe senão que este, em razão da promessa, podia alcançar a glória, e aquele assim criado nunca poderia porque nunca lhe foi prometida nem a si nem a outro para si, daí que o filho de Adão haja sido mais propriamente privado da bem-aventurança do que aquele. De igual modo se o filho de Adão ainda quiser, e pode querê-lo, conseguirá ser bem-aventurado porque tem remédios que certamente tem possibilidades de procurar, se os conhecer. Aquele outro, mesmo se quisesse e procurasse, em razão da lei comum, não conseguiria porque lhe não foram dados remédios nenhuns. É, portanto, melhor ser filho de Adão do que ser criado na natureza original, no que a este assunto respeita, porque qualquer um destes pode ser bem-aventurado.

Por consequência, Adão, ao pecar, não só se privou daqueles dons gratuitos como também se condenou à morte eterna. Aos filhos espoliou-os apenas da bem-aventurança e daqueles dons de que falámos, mas não os arrastou para o suplício da geena. Fica também a saber que entre a privação da bem-aventurança e da graça, e entre a privação da imortalidade e da incolumidade, e da obediência dos animais e de outras contrariedades, e da sujeição das forças inferiores, havia esta diferença: que, privados assim da bem-aventurança e da graça, [f1. 37] se mantiveram, a ponto de poderem, se quisessem, reavê-las. A tal ponto, porém, perderam a imortalidade e a obediência dos animais e tudo aquilo de que falámos que, sem o fulgor da santidade, sem a eficácia da graça, nunca mais poderiam recuperar isso. Daí que Cristo tenha morrido. Não que Adão o tenha privado da imortalidade, mas, porque homem, era de sua natureza mortal. Depois, porque tinha de remir o género humano. Embora fosse Santo, a santidade, contudo, não lhe retirou a mortalidade. Se, todavia, não fosse Santo nem Redentor e tivesse

$\leftarrow$ de ligno uitae se mori permitteret similiter damnaretur propter contemptum Domini mandatum. $Q 348$ haberet] obtineret $Q 349$ filium] filius $N \quad 350$ creatum] creatus $N P 351$ se priuauit] se priuauit neque solum condicionibus naturalibus $P 352$ addixit] abdixit $O$; se aiunxit $Q$; adduxit $V 353$ oboedientiae] oboedientia $I 354$ nocumentorum aliorum] nocumentarum aliarum $I$; nocumentorum aliorumque donorum gratuitorum $Q 355$ remanserant] remanserunt HILNOPQ 356 ea] eam $I L Q V 357$ priuasset] priuauit $Q 358$ promiserat] promisit $Q$ 
nisi Adae et filiis suis ${ }^{359}$ cum illa condicione. Similiter si quispiam filiorum Adae, etiam $^{360}$ plenus gratia, conceptus fuisset, morti ${ }^{361}$ tamen et miseriis humanis subditus fuisset quia semel, pacto inter Deum et hominem facto non seruato ab homine, sic conclusum est ${ }^{362}$. Facta enim inoboedientia illa et transgressione ita decretum fuit ${ }^{363}$ ut omnis homo uel filius uel non filius Adae subiret condiciones ${ }^{364}$ naturae suae.

Reuertamur ad ea quae confuse proposuimus ${ }^{365}$ quia dabit Deus pastori illi spiritum et intellectum et lucidabit haec mea dicta et in partes ${ }^{366}$ et capitula ${ }^{367}$ distinguet.

Peccatum originale est priuatio hereditatis aeternae primo patri ${ }^{368}$ non solum pro se, sed etiam pro filiis ${ }^{369}$ omnibus a Deo promisse ${ }^{370}$, si eius mandatum ipse seruasset $^{371}$ et, ex consequenti, priuatio omnium donorum ${ }^{372}$. Et in quantum illud peccatum respicit priuationem omnium ${ }^{373}$ donorum a gratia et beatitudine, totum genus humanum est subiectum peccato originali nec in mortali uita quisquam est sine ipso ${ }^{374}$, immo nec sacramento ullo nec redemptionis merito purgatur ab illo, ut iam diximus. Diximus tamen quod recuperatur ${ }^{375}$ gratia et ille alter habitus non in se nec totaliter, sed solum prout per illum homo poterat et erat dispositus redire ad Deum ${ }^{376}$ ut sic ergo recuperatur illa secunda qualitas in merito Saluatoris ${ }^{377}$ et in contritione atque sacramentis uirtutem habentibus a suo merito, sine quo nullus uestrae nationis saluari potuit.

Expulso igitur homine ab illo paradiso, amoenissimo $\operatorname{loco}^{378}$ et humanae naturae conuenientissimo, in quo sunt assidui et saluberrimi fructus et aqua omni uino suauior et delectabilior ${ }^{379}$, in quo nunc adhuc uiuunt illi uiri quos ${ }^{380}$ Deus illuc transtulit, qui locus mellifluo caelorum influxu ${ }^{381}$ irrigatur et felicissimis subiicitur ${ }^{382}$ sideribus (Deus enim illum tota diligentia construxit), ex hoc loco expulso homine et laboribus et sudoribus subiecto, nasci coeperunt homines inscii, paruuli, debiles, membra paulatim recuperantes et robur suscipientes et quotidie morientes quia quotidie deficientes ${ }^{383}$. Subito enim ut nascitur deficere incipit. Ideo recte apud uos dictum est: "Quotidianus defectus corruptionis est quaedam prolixitas mortis" 384 . Et alias: "Et cum crescimus, uita ipsa decrescit". [f1. 38] Quotidie igitur uiuentes, adhuc homines moriuntur. Tunc autem numquam

359 suis] eius $N Q 360$ etiam] esset $P 361$ morti] mori $Q 362$ est] fuit $H I 363$ fuit] est $Q 364$ subiret condiciones] subiret condicionem HINP; subire condicioni $Q$; subiecerit condicioni $V 365$ proposuimus] proposuisti $N 366$ partes] partem $N$; parte $V 367$ capitula] capita $Q 368$ patri] homini $Q 369$ non solum pro se sed etiam pro filiis] non se sed filiis $J$; pro se sicut filiis $L$; non pro se sed filiis INP; non pro se tantum sed etiam pro filiis $Q$; non in se sed filiis $V \mathbf{3 7 0}$ promissae] promisso $J$; promissa $Q \mathbf{3 7 1}$ ipse seruasset] ipse seruasset quae priuatio non poterat esse sine priuatione gratiae sed bene poterat esse et fuit privatio gratiae in primis parentibus sine priuatione hereditatis filiis promissae. $M$ (in marg. a. m.) $N O$; ipse seruasset quae priuatio non potest esse sine priuatione gratiae sed bene poterat esse priuatio gratiae in primis parentibus sine $\rightarrow$ 
nascido do mesmo modo, seria ainda mortal e, entretanto, Adão não teria pecado relativamente a ele, porque a nenhum homem prometera Deus a imortalidade senão a Adão e seus filhos, com aquela condição. Do mesmo modo, se algum dos filho de Adão fosse concebido, ainda que cheio de graça, estaria também sujeito à morte e às misérias humanas, uma vez que assim foi estabelecido por um pacto feito entre Deus e o homem e por este não cumprido. Verificada, pois, aquela desobediência e aquela transgressão, ficou estabelecido que todo o homem, filho ou não filho de Adão, ficaria sujeito às condições da sua natureza.

Voltemos à matéria que confusamente apresentámos, porque Deus há-de dar a esse Pastor espírito e inteligência, e ele esclarecerá estas minhas afirmações e dividi-las-á em partes e em capítulos.

O pecado original é a privação da herança eterna prometida por Deus ao primeiro pai, para si e para todos os filhos, se guardasse o seu mandamento e, consequentemente, a privação de todos os dons. E, na medida em que esse pecado diz respeito à privação de todos os dons decorrentes da graça e da bem-aventurança, todo o género humano está sujeito ao pecado original, nem nesta vida mortal existe alguém sem ele, e mais, dele se não purifica, nem por qualquer sacramento, nem pelo mérito da Redenção, como já se disse. Foi, todavia, dito que a graça se recupera e se recupera também aquele outro hábito, não em si, nem totalmente, mas apenas na medida em que, por intermédio dele, podia e estava o homem decidido a retornar a Deus para que assim fosse, pois, recuperada a segunda qualidade pelo mérito do Salvador e pela contrição e pelos sacramentos, que têm força pelo seu mérito, sem o qual ninguém da tua raça se poderia salvar.

Portanto, expulso o homem do Paraíso, lugar muito aprazível e muito apropriado à natureza humana, onde há frutos permanentes e sumamente sadios e água mais deliciosa e mais agradável que todo o vinho, onde vivem ainda os homens que Deus para ali transferiu, lugar que é banhado por suaves climas e se situa nas regiões temperadas, na verdade Deus formou-o com todo o zelo, expulso o homem deste lugar e sujeito a trabalhos e canseiras, começaram a nascer homens ignorantes, pequenos e fracos, que paulatinamente iam desenvolvendo seus membros e paulatinamente iam aumentando a força e todos os dias iam morrendo porque diariamente iam perdendo energias. Com efeito, logo que nasce começa a morrer. Por isso sabiamente se diz entre vós: "A diária decadência da corrupção é um certo prolongar da morte". E noutro ponto: "E à medida

$\leftarrow$ priuatione hereditatis filiis promissae. $Q 372$ donorum] donorum a gratia $M$ (in marg. a. $m$.); donorum aliorum a gratia $N Q 373$ omnium donorum. Et (...) priuationem omnium donorum] omnium donorum $P V 374$ ipso] illo $H L O Q$; peccato $V 375$ recuperatur] recuperaretur $P 376$ Deum] caelum $I 377$ Saluatoris] Redemptoris $Q \mathbf{3 7 8}$ amoenissimo loco] et amisso loco illo amoenissimo $Q 379$ delectabilior] desiderabilior $H I$ (O add. in marg. a. m., er. delectabilior alias desiderabilior) 380 uiri quos] unus quos $J$; unus quorum $V \mathbf{3 8 1}$ influxu] impulsu $Q \quad 382$ subiicitur] subditur $Q \mathbf{3 8 3}$ quotidie morientes quia quotidie deficientes] quotidie deficientes $V 384$ Quotidianus defectus corruptionis est quaedam prolixitas mortis] Quotidianus defectus corruptionis quid est alius quam quaedam prolixitas mortis? $Q$ 
mortui fuissent. Deus enim sic pactum fecerat ut si non gustarent de ligno illo numquam morerentur. Poterant enim ex sui natura mori, poterant etiam non mori Deo praeseruante ${ }^{385}$ propter inocentiam uel potius propter oboedientiam illam specialem. Sic et mulier sine dolore ${ }^{386}$ filios peperisset et in coitu suauitatem absque ulla inordinata libidine habuissent ${ }^{387}$ et filios quidem sicut et nunc paruulos genuissent $^{388}$ qui etiam paulatim creuissent. Sed unicuique animae sicut et illi Adae scientia concessa a principio fuisset, concreatis habitibus ${ }^{389}$ et speciebus omnium $^{390}$ ita quod etiam potuissent ${ }^{391}$ intelligere res ipsas absque uia sensus et Deum cognouissent et amauissent a principio et semper aliquid ${ }^{392}$ meruissent secundum quod sapientia Dei praeordinasset.

Tunc ego: Audiui, Domine mi, quod omnes filii, patre primo non peccante ${ }^{393}$, saluati fuissent. Scire cupio an illi qui nunc damnantur tunc nati fuissent ${ }^{394}$. Et si sic, tunc aliqui praedestinati damnarentur ${ }^{395}$. Et si tunc nati non fuissent, uideretur quod nunc nascantur ut damnentur ${ }^{396}$, et quod nullus damnatus est ex eo quia, Adam non peccante, saluatus fuisset ${ }^{397}$. Omnes enim qui tunc saluati fuissent et nunc saluarentur, et qui nunc damnantur ${ }^{398}$, tunc nati non fuissent ${ }^{399}$.

Respondit Angelus: Intellexi desiderium tuum et illud est apud uos uix uel nullo modo solubile ${ }^{400}$. Vere admirari potes si Adam non comedente cibum uetitum soli illi nati fuissent qui nunc saluantur, cur propter peccatum eius fecit nasci $\operatorname{alios}^{401}$ qui, eo stante, nati non fuissent? Quid enim his nasci profuit? Et peccatum Adae, quid saluandis obfuit nisi quod morti et morbis subiecti fuerunt ${ }^{402}$ ? Arcana Dei sunt ${ }^{403}$ ista abdita Dei, et quae a uobis sciri non possunt sunt ${ }^{404}$ ista. Sed ut aliquo modo a uobis degustari possint ${ }^{405}$ sic ea tibi, immo illi quem totiens dixi, qui ea melius accipiet ${ }^{406}$, declaro et manifesto ${ }^{407}$.

Diuina uoluntas ${ }^{408}$ ante omnia uoluit homo ${ }^{409}$ fieri et ex tali matre. Et angelis iam creatis olim, hunc mundum sensibilem postea condidit ut homines procrearentur et deuenirentur ad illum quem sibi uniturus erat et alios qui eum sequerentur. Voluit ergo fieri et produci homines et causas constituit ${ }^{410}$ ipsorum productionis

385 praeseruante] propiciante $V 386$ sine dolore] sine dolore quamuis claustra uteri aperta fuissent $P \quad 387$ habuissent] habuisset $I J Q V \quad 388$ genuissent] genuisset $H Q \quad 389$ habitibus] habitantibus $V 390$ speciebus omnium] speciebus omnium, itaque intelligere potuissent res ipsas uel unam continentem omnia. 391 potuissent] potuisset $N P 392$ aliquid] aliqui $H 393$ non peccante] non peccante licet peccare potuissent $P 394$ nati fuissent] nati non fuissent $J P V$ 395 damnarentur] saluarentur $L 396$ damnentur] damnarentur $H 397$ et quod nullus damnatus est ex eo quia, Adam non peccante, saluatus fuisset.] Et quod peccatum Adae fuerit omnibus dampnatis causa essendi quia, Adam non peccante, nullus ex damnatis saluatus fuisset. $P \rightarrow$ 
que se cresce, a vida decresce" ${ }^{\text {[40] }}$ [ [f1. 38] Vivendo, pois, cada dia, em cada dia morrem os homens. Então nunca morreriam. Deus, com efeito, tinha estabelecido um pacto que, se não provassem daquela árvore, nunca morreriam. Na verdade, em razão da sua natureza podiam morrer, podiam também não morrer, com a protecção de Deus, por causa da inocência, ou antes, da especial obediência. Do mesmo modo, também a mulher pariria os filhos sem dor e, na sua união, sentiriam prazer sem qualquer desregrada concupiscência e gerariam certamente filhos pequenos como agora, filhos que também cresceriam paulatinamente. Mas a cada espírito seria concedido, desde o princípio, o conhecimento, como foi ao de Adão, criadas conjuntamente as circunstâncias e as imagens de tudo, a tal ponto que poderiam compreender as própria coisas sem a via dos sentidos e conheceriam e amariam a Deus desde o princípio e sempre mereceriam algo segundo o que houvesse sido preordenado pela sabedoria de Deus.

Meu senhor, disse eu, ouvi dizer que, se o primeiro pai não tivesse pecado, todos os filhos teriam sido salvos. Gostava de saber se aqueles que hoje se condenam teriam então nascido. E, se sim, então alguns predestinados condenar-se-iam. E se então não tivessem nascido, pareceria que agora nascem para se condenarem, e que ninguém é condenado, uma vez que se Adão não tivesse pecado teria sido salvo, e todos que então tivessem sido salvos também se salvariam agora, e os que agora se condenam não teriam então nascido.

Compreendi o teu desejo, respondeu o anjo, mas ele é para vós difícil ou de todo insolúvel. Podes realmente admirar-te. Se não comendo Adão o alimento proibido tivessem nascido apenas aqueles que agora se salvam, porque é que, por causa do seu pecado, fez que nascessem aqueles que, se ele se tem mantido, não teriam nascido? O que adiantou a estes terem nascido? E que dano causou o pecado de Adão àqueles que se deviam salvar senão que ficaram sujeitos à morte e às doenças? Os arcanos de Deus são estes segredos de Deus, e estas são as coisas que não podem ser por vós conhecidas. Mas para que de algum modo possais saboreá-las, dou-tas a conhecer e revelo-tas a ti, ou antes, àquele que tantas vezes referi, o qual as receberá bem melhor.

Antes de tudo, quis a vontade divina fazer-se homem e a partir desta mãe. E, um dia, com os anjos já criados, formou depois este mundo sensível para que fossem procriados os homens e chegassem àquele que haveria de unir a si, e aos outros que haveriam de segui-lo. Quis, pois, que os homens fossem feitos e

$\leftarrow 398$ damnantur] damnarentur $O \mathbf{3 9 9}$ nati non fuissent] nati fuissent $L \mathbf{4 0 0}$ solubile] scibile $J \mathbf{4 0 1}$ alios] filios $N \mathbf{4 0 2}$ fuerunt] fuissent $M(O$ er. fuissent, add. sup. lin. a. $m$. fuerunt) $Q \mathbf{4 0 3}$ sunt] sinit $H \quad \mathbf{4 0 4}$ sunt] sinit $H \quad \mathbf{4 0 5}$ possint] possent $J$; possit $V \quad \mathbf{4 0 6}$ accipiet] capiet $L \quad 407$ declaro et manifesto] declarabo et manifestabo $Q \mathbf{4 0 8}$ Diuina uoluntas] Diuina uoluntas quamuis omnia simul in sua aeternitate uoluerit, ea tamen que uult ordinem quemdam inter se tenent, propter quod alia uult quasi prius uelle dici potest $P \mathbf{4 0 9}$ homo] hominem $N Q \mathbf{4 1 0}$ constituit] posuit $Q$

${ }^{[40]}$ Séneca, Cartas a Lucílio, carta XXIV. 
quoad corpus. Fedus pepigit ut quotiens causae inferiores, ipso etiam concurrente, causarent tale corpus sic organis praeditum ${ }^{411}$, ipse quoque animam crearet et infunderet. Non enim creatur anima ante corpus nec corpus ante animam nisi materialiter ${ }^{412}$. Subito enim ut organizatum est, anima infunditur ${ }^{413}$.

Cogita singula. Vidit Deus tamquam aeternus quot ${ }^{414}$ corpora organizata perfecte uel imperfecte natura sibi porrigebat et tot animas illis infundere, si perfecte formarentur quae praecedentia perficerent et non corrumperent ${ }^{415}$, statuit et ordinauit nil pro tali tempore [f1. 39] praeuiso nisi ${ }^{416}$ beatitudinem omnibus uolendo, sic tamen uolendo si mandata eius seruarent ${ }^{417}$. Agnouit et uidit primum hominem peccaturum et pro se atque filiis omnibus regnum caeleste amissurum $^{418}$, nisi nouis remediis ab eo iuuaretur ${ }^{419}$. Vidit sempiterno illo suo oculo $^{420}$ quot essent remedia illa suscepturi et quot non suscepturi ${ }^{421}$, immo quot remedia suscipiebant ${ }^{422}$ et quot non suscipiebant, quia futura tamquam praesentia intuetur. Et tandem hos qui suscepturi erant praedestinauit absolute, alios reprobauit.

Primo igitur Deus omnes ad uitam ordinat quando omnes ut eam assequantur determinat, sed cum condicione et clausula, si ita uixerint ${ }^{423}$ et dies suos compleuerint. Secundo, illos omnino acceptat quos iam uidit condiciones et pacta sua saltem in ultimo hiatu seruasse. Do ${ }^{424}$ tibi similitudinem: Primum hominem Deus creauit ea intentione ut numquam moreretur nec dolorem sentiret, non simpliciter ac si omnino id uellet, sed cum pacto, si mandatum non praeteriret. Nouit aeterna mente hominem mandatum Dei non obseruaturum. Noluit ut esset immortalis et sine dolore.

Vos igitur homines in hac re perplexi estis, quia creditis quod Deus ab eterno uoluit $^{425}$ determinate ${ }^{426}$ et sine ulla condicione saluos fieri, quod, ut alias tibi dixi, non est uerum. Immo Deus prima intentione uoluit omnes homines saluos fieri, si tamen seruassent mandata. Cognouit transgressuros, cognouit remedia suscepturos et remedia uilipensuros ${ }^{427}$, ut dixi. Noli igitur cogitare quod quasi Deus omnes istos qui saluantur nunc saluos fieri uoluisset ${ }^{428}$ solum et nullos alios, et quod soli qui nunc saluantur, in statu illo nati fuissent et nulli alii ${ }^{429}$.

411 praeditum] praedictum $V \mathbf{4 1 2}$ nisi materialiter] nisi materialiter quia praecedit animam naturaliter $N$; nisi quia corpus praecedit animam naturaliter $O Q \mathbf{4 1 3}$ nisi materialiter. Subito enim ut organizatum est, anima infunditur] nisi materialiter. $L \mathbf{4 1 4}$ quot] quod $I Q$, que $J V \mathbf{4 1 5}$ corrumperent] corrumperentur $Q \mathbf{4 1 6}$ praeuisio nisi] praeuisionis $Q \mathbf{4 1 7}$ seruarent] seruaret $Q$ 418 ammissurum] ammissum $J \mathbf{4 1 9}$ iuuaretur] iuuarentur $H \mathbf{4 2 0}$ illo suo oculo] illo suo oculo se prouisurum de remedio et $\mathrm{Q} \mathbf{4 2 1}$ suscepturi et quot non suscepturi, immo] suscepturi immo $\mathrm{P} \rightarrow$ 
se procriassem e estabeleceu as condições de sua procriação, quanto ao corpo. Firmou um pacto para que todas as vezes que as causas inferiores formassem com o seu concurso um corpo determinado, dotado dos respectivos órgãos, criasse ele também e infundisse a alma. Não se cria, pois, a alma antes do corpo, nem o corpo antes da alma senão materialmente. Logo que o corpo está organizado, infunde-se a alma.

Pensa em cada coisa. Deus, eterno, viu quantos corpos perfeita ou imperfeitamente constituídos lhe proporcionava a natureza e estabeleceu e determinou infundir neles, se estivessem correctamente formados, o mesmo número de almas, que aperfeiçoassem e não corrompessem a obra anterior, querendo apenas para esse tempo [f1. 39] previsto a felicidade de todos. Mas querendo-o com esta condição, se guardassem os seus mandamentos. Reconheceu e viu que o primeiro homem pecaria e perderia para si e para todos os seus filhos o reino do Céu se não fosse por si ajudado com os novos remédios. Viu, na sua sempiterna visão, quantos seriam os que recorreriam a estes remédios e quantos a eles não recorreriam, ou melhor, quantos recorriam aos remédios e quantos a eles não recorriam, pois que vê as realidades futuras como presentes. E, finalmente, predestinou inteiramente aqueles que a eles haviam de recorrer e condenou os outros.

Portanto, primeiro, Deus destina a todos para a vida eterna quando a todos determina que a alcancem, embora com uma condição e uma clausula: se tiverem vivido de determinada maneira e tiverem completado seus dias. Segundo, somente aceita aqueles que viu já que guardariam as suas condições e as suas promessas, pelo menos no último desejo. Dou-te um exemplo: Criou Deus o primeiro homem com a intenção de que nunca houvesse de morrer, nem sentisse dor, não simplesmente como se quisesse isso incondicionalmente, mas com um pacto: se não transgredisse a ordem. Reconheceu na eterna mente que o homem não observaria o mandamento de Deus. Não quis que fosse imortal e isento de dor.

Portanto, vós homens estais equivocados relativamente a este problema, porque acreditais que Deus quis desde sempre, definitivamente e sem qualquer condição, que fossem salvos, o que, como te disse noutro lugar, não é verdade. Pelo contrário, Deus, na sua primeira intenção, quis que todos os homens fossem salvos se, todavia, tivessem guardado os mandamentos. Conheceu os que haviam de transgredir, conheceu os que aceitariam os remédios e os que haviam de desprezá-los, como disse. Não penses, pois, que Deus, por assim dizer, haja

$\leftarrow \mathbf{4 2 2}$ suscipiebant] suscipiant $V \mathbf{4 2 3}$ uixerint...compleuerint] uixerit... compleuerit $P$ 424 Do] Dico $V \mathbf{4 2 5}$ uoluit] uellit $Q \mathbf{4 2 6}$ determinate] determinare $I \mathbf{4 2 7}$ remedia suscepturos et remedia uilipensuros] remedia uilipensuros $V \mathbf{4 2 8}$ uoluisset] uoluisse $Q \mathbf{4 2 9}$ et nulli alii] et nulli alii. Et aliquos non habituros, ut infantes et semper stultos aut ignorantia inuincibili remediorum detentos quorum nullus sine baptismo saluatur licet nil contra legem Dei egerit (ageret $M$ ) aut egisset. $M$ ( in marg. a. m.) $P$ 
Quare enim Deus istos addidisset ut nascerentur filii perpetuae irae damnandi ${ }^{430}$, maxime cum multi illorum dicantur quandoque fuisse in gratia et amici ${ }^{431}$ Dei?

Nota bene, pater, Deus ${ }^{432}$ omnia aeternaliter uidet ${ }^{433}$. Sed quia aeternitas illa est illimitata ${ }^{434}$, non uidet omnia pro tota aeternitate. Ecce tu es nunc et aliquando non fuisti. Deus ab aeterno te uidit esse pro isto tempore, sed non pro illo in quo nondum eras. Omnes igitur filios ${ }^{435}$ Adae quotquot futuri essent ${ }^{436}$ Deus cum condicione ${ }^{437}$ illa $^{438}$ saluare decreuerat ${ }^{439}$, nullum determinate uolendo ${ }^{440}$, sed omnes communiter, neque numerum eorum determinando ${ }^{441}$, sed omnes in genere $^{442}$ et quasi. Deinde numerum cognouit. Vidit hos condicionem seruaturos, alios minime. Acceptauit ${ }^{443}$ illos, spreuit alios. Nullus, dico tibi, natus est in statu naturae lapsae ad hoc, ut damnaretur ${ }^{444}$.

Omnibus enim filiis Adae Deus cum condicione uitam dare promiserat. Condicionem seruari uidit ab his et ab aliis non seruari. Finaliter et hos approbauit, illos uero reprobauit. Nullus etiam ordinatus ad uitam aeternam absolute est damnatus, quia talis praedestinatio et damnatio intelligitur pro tempore quo unus expellitur omnino et alius recipitur, quod communiter fit in uobis hominibus in ultimo uitae uestrae. Dico plus hoc mirabile: [fl. 40] Nullus damnatur nec damnari potest nisi praedestinatus priori illa et condicionali praedestinatione. Et tamen nullus praedestinatus illa praedestinatione absoluta potest ${ }^{445}$ damnari, nisi eo modo quo et beati possunt damnari ${ }^{446}$. Quicumque ergo nunc damnantur ${ }^{447}$, si Adam non peccasset ${ }^{448}$, et nati fuissent ${ }^{449}$, non est inconueniens ${ }^{450}$, et quandoque uere beati, non est inconueniens. Sed propter peccatum Adae non sunt damnati, sed propter peccatum proprium, quia propter peccatum Adae solum fuissent priuati uita aeterna. Id tamen uerum est quod, si Adam ex illo pomo non comedisset ${ }^{451}$, nullus ex his qui damnantur damnandus ${ }^{452}$ fuisset. Tamen Deus, antequam praeuidisset peccatum eius et filiorum proprium ${ }^{453}$, non separabat hos ab illis, sicut nec ipsum Adam discernebat ab aliis.

Omnia recte intelliget ille ad quem haec mittuntur, quia Deus, aeternus, in aeternitate, sed non pro aeternitate, omnia cognoscit. Semper enim te pro nunc mecum loqui cognouit, sed non quod semper mecum locutus sis, quia illud non

430 damnandi] damnati $N 431$ amici] amicitia $Q 432$ pater, Deus] Deus Pater $O Q 433$ uidet] uidit $P 434$ est illimitata] est illimitata ad omnia tempora $P \quad 435$ filios] filii $P 436$ essent] erant $Q 437$ condicione] condicioni $L$; quottidie $V 438$ illa] illa de communi lege $O 439$ decreuerat] decreuit $Q \mathbf{4 4 0}$ uolendo] uolendo, nil loquor modo de ipsius Genitrice $P \mathbf{4 4 1}$ determinando] determinando ac si nollet plures sed omnes sine exceptione $P \mathbf{4 4 2}$ in genere] sine exceptione $P 443$ Acceptauit] Acceptauit, sed omnes in genere et quasi. Deinde numerum cognouit. Vidit $\rightarrow$ 
querido que apenas se salvassem todos aqueles que agora se salvam e nenhuns outros, e que só os que hoje se salvam tivessem nascido naquela circunstância, e nenhuns outros. Porque acrescentaria Deus estes para nascerem filhos da eterna ira, a serem condenados, sobretudo quando se diz que muitos deles tinham vivido em graça e sido amigos de Deus?

Presta bem atenção, padre. Deus vê eternamente tudo. Mas dado que a eternidade é ilimitada, não vê tudo em toda a eternidade. Vê, tu existes agora, mas houve tempos em que não exististe. Deus viu desde toda a eternidade que tu existirias agora, mas não naquele tempo em que ainda não existias. Em suma, Deus determinara salvar, com essa condição, a quantos filhos de Adão viessem a existir, sem escolher especificamente nenhum, mas a todos, em geral, e sem determinar o seu número, mas todos sem distinção e aproximadamente. Tomou depois conhecimento do seu número. Viu que uns respeitariam as condições e outros não. Aceitou aqueles, rejeitou estes. Digo-te, ninguém nasceu na situação da natureza decaída para ser condenado.

Deus havia prometido, pois, dar a vida, com essa condição, a todos os filhos de Adão. Viu que a condição seria guardada por uns e o não seria por outros. Por fim, deu a sua aprovação àqueles, rejeitou estes. Além disso, ninguém destinado à vida eterna é absolutamente condenado, porque essa predestinação e essa condenação entendem-se em razão do tempo em que um é rejeitado absolutamente e o outro é aceite, o que em geral acontece entre vós homens no fim da vossa vida. Digo mais isto, digno de admiração: [f1. 40] ninguém se condena, nem se pode condenar se não estiver predestinado com essa inicial e condicional predestinação. E, todavia, ninguém predestinado com a predestinação absoluta pode condenar-se, a não ser do mesmo modo que também os bem-aventurados se podem condenar. Todos os que agora se condenam, se Adão não tivesse pecado, não só teriam nascido, não há dúvida, mas também um dia seriam verdadeiramente bem-aventurados, não há dúvida. Não é, porém, por causa do pecado de Adão que são condenados, mas pelo pecado próprio, porque pelo pecado de Adão seriam apenas privados da vida eterna. É, contudo, verdade que, se Adão não tivesse comido daquele fruto, nenhum dos que se condenam haveria de ser condenado. Deus, contudo, antes de ter previsto o pecado dele e o pecado próprio dos filhos, não separava uns dos outros, nem deles distinguia o próprio Adão.

Aquele a quem estas coisas são destinadas tudo entenderá correctamente porque Deus, eterno, tudo conhece na eternidade, mas não ao longo de toda a eternidade. Soube sempre, na verdade, que tu falas comigo agora, mas não que

$\leftarrow$ hos condicionem seruaturos, alios non, acceptauit $P \mathbf{4 4 4}$ damnaretur] damnetur HIL 445 potest] poterit $Q 446$ potest damnari, nisi eo modo quo et beati possunt damnari] potest damnari. $V 447$ damnantur] damnatur 448 non peccasset] peccasset $N$; non peccante $H J P 449$ et nati fuissent] etiam natus fuisset $Q \mathbf{4 5 0}$ non est inconueniens] non congruit $P \mathbf{4 5 1}$ ex illo pomo non comedisset] ullo modo non comedisset $O \mathbf{4 5 2}$ damnandus] damnatus $I L Q \mathbf{4 5 3}$ eius et (peccatum $a d d . H$ ) filiorum proprium] eius, peccatum filiorum proprium $L$; eius et filiorum proprie $P$; eius uel $\rightarrow$ 
est uerum. Sicut ergo etiam nos angelos omnes simul Deus noster magnus ${ }^{454}$ creauit et omnes gratia qua ${ }^{455}$ beati esse poteramus ornauit, et damnati angeli ordinati erant ad beatitudinem cum condicione ${ }^{456}$, sic et omnes homines, quotquot nascituri essent. Sed uos cogitatis et quidam doctores uestri quod Deus prima intentione uoluit beatum facere ${ }^{457}$ hunc et illum praecise, alios uero non. Quae cogitatio remouenda est a cordibus fidelium omnino. Nullus, dico tibi, nascitur ut damnetur, sed ut sit beatus, non absolute, sed cum condicione que, si finaliter obseruetur, erit beatus ex pacto, non ex necessitate siue, ut ${ }^{458}$ uos dicitis, de potentia ordinata, non absoluta. Non est etiam uerum quod omnes qui tunc saluati fuissent nunc saluentur, immo quilibet eorum qui damnantur, tunc saluus fuisset ${ }^{459}$, si natus tunc fuisset ${ }^{460}$, quia forsan non omnes qui nunc nascuntur, tunc nati fuissent et beati.

Primo enim fuit generalis conceptus. Visa est transgressio, uisa eiectio de paradiso, uisi omnes ${ }^{461}$ nascituri, uisi remedia ${ }^{462}$ accepturi. Numerus nascendorum non erat prima facie determinatus ${ }^{463}$. Sed, uisis omnibus corpusculis producendis, agnitus est numerus omnium. Visis bene ex ista uita egredientibus, agnitus est numerus electorum ${ }^{464}$. Neque tamen propterea ullus praedestinatus damnatur. Praedestinatus dico bsolute, non cum condicione.

Sicut iam tibi dixi ${ }^{465}$, conscribe omnia et diligenter conserua ut populo Christiano promulgentur $^{466}$ ne amplius in tot opinionibus uersentur ${ }^{467}$.

Redeundum est tibi ad cellam tuam et cauernam tuam. Ibi enim te praestolantur fratres tui, et alii te perquirunt. Et papa pro te iam ter misit, cui nihil horum reuelles, sed solum dicas ut, sicut coepit, Matri Dei honorem debitum tribuat, ecclesias restauret, bella saecularia dimittat, ecclesiae prouideat, de sua carne tantam existimationem non faciat, bella Christianis non inferat, legem Dei et mandata uniuersis promulget ${ }^{468}$.

Tunc in breuissimo tempore me reperi in cauerna ${ }^{469}$ mea, fratribus ad ostium stantibus [f1. 41] meque uocantibus. ${ }^{470}$

$\leftarrow$ proprium filiorum $Q 454$ magnus] magnos $Q 455$ gratia qua] gratia quorum $O 456$ intentione] aeternitate $L 457$ facere] fore $Q \mathbf{4 5 8}$ siue, ut] sicut $N Q \mathbf{4 5 9}$ saluus fuisset] salui fuissent $N V$; saluatus fuisset $Q \mathbf{4 6 0}$ saluus fuisset, si natus tunc fuisset] saluus fuisset, si nati fuissent $N$; saluus fuisset. $V \mathbf{4 6 1}$ uisi omnes] uisi omnes stante Adam et ruente $P \mathbf{4 6 2}$ uisi remedia] uisi remedia et parentis et proprii peccati $P \mathbf{4 6 3}$ accepturi. Numerus nascendorum non erat prima facie determinatus] accepturi. $Q \mathbf{4 6 4}$ agnitus est numerus electorum.] agnitus est numerus electorum. $\rightarrow$ 
sempre tenhas falado comigo, porque isso não é verdade. Do mesmo modo, pois, que o nosso Deus todo poderoso nos criou a nós anjos todos ao mesmo tempo e nos dotou a todos da graça com que pudéssemos ser bem-aventurados, e os anjos condenados estavam destinados à bem-aventurança sob condição, assim também todos os homens, fossem quantos fossem os que viessem a nascer. Mas pensais vós e alguns dos vossos doutores que Deus na sua primeira intenção quis tornar bem-aventurados este e aquele exclusivamente, mas não outros. Este pensamento deve ser em absoluto removido do coração dos fiéis. Ninguém, digo-to eu, nasce para ser condenado, mas para ser bem-aventurado, não absolutamente, mas sob condição, condição que, se for observada, o tornará bem-aventurado em razão do pacto, não ex necessitate ou, como vós dizeis, em razão da potência ordenada, não da absoluta. Também não é verdade que se salvem todos quantos então seriam salvos; pelo contrário, cada um dos que se condenam teria sido salvo então se então nascesse, porque provavelmente nem todos os que agora nascem teriam nascido então e sido bem-aventurados.

Primeiro foi, pois, a concepção geral. Viu-se a transgressão, viu-se a expulsão do Paraíso, viram-se todos quantos haveriam de nascer, viram-se os que aceitariam os remédios. O número dos que haviam de nascer não estava à primeira vista determinado. Mas, vistos todos os pequenos corpos que deviam ser produzidos, reconheceu-se o número total. Vistos os que morreram em bem, reconheceu-se o número dos eleitos. E, todavia, nem por isso predestinado algum se condena. Falo do predestinado em absoluto, não sob condição.

Como já disse, escreve tudo e guarda-o diligentemente a fim que tudo se torne conhecido do povo cristão, para que se não hesite em tão variado número de opiniões.

Deves voltar à tua cela e à tua gruta. Aí te aguardam os teus irmãos, e outros perguntam por ti. Já o papa te mandou buscar por três vezes. Nada disto lhe reveles, diz-lhe só que preste à Mãe de Deus as honras devidas, como já começou a fazer, restaure as igrejas, ponha fim às guerras seculares, olhe pela Igreja, não dedique tanto cuidado à sua carne, não faça guerra aos cristãos, leve ao conhecimento de todos a lei e os mandamentos de Deus.

Vi-me imediatamente na minha gruta, os meus irmãos à porta [f1. 41] a chamar-me.

$\leftarrow$ Non est ergo uerum quod Deus uoluerit solum eos qui saluantur tunc nasci et damnandos propter peccatum Adae addidisse et produxisse. Ordo in uolendo est considerandus et euades discrima talium difficultatum. $P \mathbf{4 6 5}$ non cum condicione. Sicut iam tibi dixi,] non cum condicione sicut iam tibi dixi. I 466 promulgentur] promulgetur V 467 uersentur] uexentur HIL; uersetur $V 468$ promulget] promulgat $V \mathbf{4 6 9}$ cauerna] camera $P \quad \mathbf{4 7 0}$ meque uocantibus.] meque uocantibus. Finis Tertii Raptus. $I$. 


\section{QVARTVS RAPTVS}

Post certo tempore raptus fui ${ }^{1}$ in rotam $^{2}$ iterum. Et omnibus adorationibus ${ }^{3}$ meis factis, quaerenti mihi de pastore nouo ac eius tempore et aduentu ex praecordiis oranti angelus Gabriel apparuit coram omnibus dicens: Iam dicam tibi, quia illud tot precibus meruisti, qui est futurus pastor quem Deus elegit. Nunc est Romae, iuuenculus, pauperculus, incognitus. Sed Dominus cognoscit eum et paulatim prouehit et irrigat ${ }^{4}$. Et in illo, quando iam senex fuerit, ostendet uirturtem suae potentiae qui nouit de terra suscitare inopem ${ }^{5}$ et de stercore uilitatis et peccatorum erigere pauperem. Eleuabit eum Dominus et subleuabit et a peccatis ${ }^{6}$ eruet et purgabit quia non tantum fixit $^{7}$ mentem in peccata quin Dei honorem habeat prae oculis et eius Genitrici et Matri suauissime semper mente intendat ${ }^{8}$, cuius memoriam semper gerit in corde et eius salutationem quam ego sibi dedi quando Filium Dei annuntiaui et cognata sua compleuit ${ }^{9}$, quasi semper tenet in ore.

Tunc ego, hilaris factus, exclamaui ${ }^{10}$ : Cito ergo haec fient, angele Dei, ex quo iste natus est et creuit?

Respondit: Ideo alias, quando id petebas, subrisi nec tibi dicere uolui ut auidius dona Dei inquireres ${ }^{11}$ et perciperes. Nunc dico tibi. Nunc est pastor ille quem scis, cum quo pluries locutus es, multorum bonorum et malorum auctor. Sed bona eius et deuotiones uincunt malitiam.

Veniet post illum quem creabit ipse, nec calidus in bono nec frigidus in malo ${ }^{12}$. Homo erit et humana patietur et ut homo conuersabitur. Non tamen supra hominem neque contra hominem aliquid faciet. Ideo Deus eum non derelinquet.

Veniet post illum bos cornupeta et taurus non bos, Simon Magus, qui constituet in Templo Dei ementes et uendentes et mensas numulariorum, de quo pauci confidere poterunt, cuius temporibus Italia nouo iugo onerabitur ${ }^{13}$. Cadet et

1 fui] sum $M 2$ rotam] rota $P \quad 3$ adorationibus] orationibus $C Q \quad 4$ prouehit et irrigat] prouehit et erigit et irrigat $C$;pro est, habet et elegit et irrigat $Q \quad \mathbf{5}$ inopem] pauperem $Q \mathbf{6}$ peccatorum erigere (...) et a peccatis eruet] peccatorum eruet $Q 7$ fixit] infixit CILNOPQ 8 mente] mentem $O V \rightarrow$ 


\section{Quarto Arrebatamento}

Algum tempo depois fui de novo arrebatado para a Assembleia. E, feitas todas as minhas reverências, enquanto orava do fundo do coração procurando saber do novo Pastor, do seu tempo e do seu advento, apareceu-me, na presença de todos, o anjo Gabriel que me disse: Porque o mereceste com tantas orações, vou já dizer-te quem é o futuro Pastor que Deus escolheu. Já está em Roma, muito jovem, muito pobre, incógnito. Mas o Senhor conhece-o e, pouco a pouco, fá-lo desabrochar e revigora-o, e nele, quando já for idoso, irá mostrar o valor do seu poder, que soube levantar da terra o indigente e da imundície da vileza e do pecado erguer o pobre. O Senhor exaltá-lo-á, protegê-lo-á e livrá-lo-á do pecado e o purificará porque não fixou a sua alma no pecado a ponto de não ter diante dos olhos a honra de Deus e de se não entregar a sua suavíssima Mãe, cuja lembrança traz sempre no coração e na boca tem quase sempre a saudação que eu lhe dirigi quando anunciei o Filho de Deus e sua prima completou.

Portanto, ó anjo de Deus, exclamei alegre, uma vez que ele nasceu e cresceu, será que todas estas coisas irão acontecer rapidamente?

Quando anteriormente me pedias isso, respondeu o anjo, sorri-me e não to quis dizer, para que com mais avidez buscasses e compreendesses os dons de Deus. Digo-to agora. O actual pastor é aquele que tu conheces, com quem falaste várias vezes, autor de muitas acções boas e más. As boas acções e a sua devoção superam, contudo, a maldade.

Depois dele há-de vir aquele que ele criará, nem quente no bem nem frio no mal. Será homem, suportará o que é próprio do homem e como homem se comportará. Nada fará, contudo, que vá além do que é próprio do homem nem contra o homem. Por isso, Deus não o abandonará.

Depois deste, virá a vaca cornúpeta e o touro que não é boi, Simão Mago, que estabelecerá no Templo de Deus compradores e vendedores e as mesas dos cambistas, em quem poucos poderão confiar, em cujos tempos novo jugo pesará

$\leftarrow \mathbf{9}$ compleuit] adimpleuit $Q \quad \mathbf{1 0}$ exclamaui] exclamans $P Q \mathbf{1 1}$ inquireres] perquireres $N$; inquiras $Q 12$ in malo] in malo neque tamen sic tepidus ut euomi mereatur C (M in marg. a. m.) NPQ 13 iugo onerabitur] iugo onerabitur. Succedet ouis lunata qui eius comparatione putabitur agnus. Erit $\rightarrow$ 
non redibit nouorum uicecomitum domus, nec qui ei succedet tamdiu durabit. Praestabit ille toti Italiae ruinam. [f1. 42] Corruet tempore illo nouum Aragonum regnum ${ }^{14}$. Florentini ${ }^{15}$ in aduentu carissimi cuiusdam eorum principis status sui partem perdent ${ }^{16}$. Rixae erunt inter eos et suspiciones ${ }^{17}$ et multi timores ita ut ex maioribus et superioribus ciuibus multi aufugient et iterum ingredi desiderabunt et multotiens conabuntur, sed non poterunt nisi prius consummati fuerint et perdent omnia quae illorum sunt. Sed, ipsis ingredientibus ${ }^{18}$, paulatim omnia rehabebunt et maiora acquirent quam umquam habuerunt. Rex liliorum ut fulgur pertransibit et uincet, sine uictoria redibit uixque aufugiet. A quo ductus ab eo seductus, curabit uindictam nec facere poterit. Surget a carceribus rex loco eius, prudentia fretus, promittet multa, faciet pauca, exiget plurima, in spe cuius plurimi peribunt. Ianuenses dominos multos mutabunt ${ }^{19}$ et semper sub dominio erunt*. ${ }^{19 \mathrm{~A}}$

Dabit Deus Simoni Mago benedictionem Esau, suo uero electo pastori benedictionem Iacob. Fuit autem benedictio Esau in rore caeli et pinguidine terrae, sicut erit et illius. Erit enim robore fortis et corpore sanus et ingenio uiuax. Et quod desiderabit dabitur ei ut satiet appetitum sum mundana, aurum ${ }^{20}$, quae est benedictio de rore caeli. Erit enim habens thesauros multos, quae est ${ }^{21}$ benedictio de pinguedine terrae. Terrena cogitabit et faciet, in illisque mens eius uersabitur. Suisque consanguineis ab eo nominatis et electis ${ }^{22}$ distribuet bona Ecclesiae quae nunquam sibi deficient. Subditos opprimet onere insuportabili ${ }^{23}$. Tandem propter ualde execrabiles abominationes, iniquitates et scelera et peccata, in aduentu regum in Italiam de $\operatorname{sede}^{24}$ deponetur, quia uox sanguinis clamat contra eum et manus eius pollutae ${ }^{25}$ sunt sanguine. Tamen thesauris Ecclesiae potietur et gaudebit ${ }^{26}$.

Pastor quem Deus amat et elegit ${ }^{27}$ intrabit in Templum et eiciet foras ementes et uendentes et mensas numulariorum euertet et sanctificabit Templum, purgabit et

$\leftarrow$ quasi non fuerit. Redibit qui nunc est sub alio nomine qui non mentietur. Huius facta maiori fauore ampliabit. Qui cum rugitu sequenti uiam preparabit ad tempora felicia. Et hic est uelamen, non dico tibi omnia. C ( $M$ in marg. a. $m$.) $Q V$; Boui succedet ouis lunata quod eius comparatione putabitur agnus. Erit quasi non fuerit. Redibit qui nunc est sub alio nomine qui non mentietur. Huius facta maiori fauore ampliabit. Qui cum rugitu sequenti uiam preparabit ad tempora felicia. Et hic est uelamen, non dico tibi omnia. $P$ (in marg. $a$. $m$.); Post illum ueniet remissus qui non displicebit. Sequetur ardens sed potius ad malum, quem sequetur ouis et quasi non sequetur ouis. Sequentis autem uox cum rugitu sequente per totum mundum audietur, longe lateque dilatabitur. Superna miseratione caliginem et terram et nigras nubes effugabit, homo initium annorum felicium. $V$ 14 regnum.] regnum. Ressurgere uidebitur sed iterum cadet. $C$ ( $M$ in marg. a. $m$.) $O Q$; et cum resurgere uidebitur iterum cadet $N 15$ Florentini] Florentem $Q 16$ perdent] perdet $Q \quad 17$ suspiciones] suspetiones $N Q 18$ ingredientibus] egredientibus $Q 19$ mutabunt] mutabit $N Q$ 19A sub dominio erunt*] 4.or lineae retro cancellatae in alio exemplari habentur ubi est hoc signum * add. C.; Boui succedet ouis lunata qui eius comparatione putabitur agnus. Erit quasi non fuerit. Redibit qui nunc est sub alio nomine quod non mentietur. Huius facta maiori fauore $\rightarrow$ 
sobre a Itália. Cairá e não se recomporá a casa dos novos viscondes, e a que lhe suceder não se manterá durante tanto tempo. Há-de trazer a ruína a toda a Itália. [fl. 42] Nesse tempo ruirá o novo reino aragonês. Com a chegada ao poder de um dos seus príncipes mais queridos, perderão os florentinos parte do seu Estado. Haverá entre eles lutas e suspeições e muitos medos, de tal modo que muitos dos cidadãos mais importantes e de mais elevado estatuto fugirão e de novo desejarão voltar e muitas vezes o tentarão, mas não hão-de consegui-lo se não forem antes destruídos e perderem tudo que lhes pertence. Ao voltarem, reaverão progressivamente tudo e hão-de conseguir muito mais do que alguma vez tiveram. $\mathrm{O}$ rei dos lírios passará como um raio e vencerá, voltará sem vitória e salvar-se-á com dificuldade. Traído por aquele que o trouxe, procurará vingar-se e não conseguirá fazê-lo. Para seu lugar surgirá dos cárceres um rei estribado na sagacidade, prometerá muito, realizará pouco, exigirá muitíssimo. Confiados nele, muitos perecerão. Os januenses mudarão frequentemente de senhores e estarão sempre dominados.

A Simão Mago dará Deus a bênção de Esaú, mas ao Pastor, seu eleito, dará a bênção de Jacob. A bênção de Esaú consistiu no orvalho do céu e na abundância da terra. ${ }^{[41]}$ Assim será também a daquele. Será forte de carácter e vigoroso de corpo, brilhante de espírito. Ser-lhe-á dado o que desejar, para saciar sua paixão pelo que é mundano, o ouro, que é a bênção do orvalho celeste. Será detentor de muitos tesouros, que são a bênção que lhe vem da abundância da terra. Pensará e realizará o que é terreno, disso se ocupará o seu espírito. Distribuirá pelos seus consanguíneos, por ele nomeados e escolhidos, os bens da Igreja, bens que nunca lhe faltarão. Os súbditos, oprimi-los-á com uma carga insuportável. Por fim, por causa de tão execráveis abominações, iniquidades, crimes e pecados, com a entronização dos reis em Itália será deposto do lugar, porque a voz do sangue clama contra ele e as suas mãos estão manchadas de sangue. Assenhorear-se-á e desfrutará dos tesouros da Igreja.

O Pastor, a quem Deus ama e que escolheu, entrará no Templo e expulsará compradores e vendedores, derrubará as mesas dos cambistas e santificará o

\footnotetext{
$\leftarrow$ ampliabit. Qui cum rugitu sequenti uiam praeparabit ad tempora felicia. Et hic est uelamen, non dico tibi omnia. $P$ in marg. $a$. $m$.; Succedet ouis lunata qui eius comparatione putabitur agnus. Erit quasi non fuerit. Redibit qui nunc est sub alio nomine quod non mentietur. Huius facta maiori fauore ampliabit. Qui cum rugitu sequente uiam praeparabit ad tempora felicia. Hic est uelamen, non dico tibi omnia. Post istum ueniet remissus, non displicebit. Sequetur ardens sed potius ad malum suis et quasi non sequitur. Sequentis autem uox cum rugitu sequente per totum audietur, longe lateque dilatabitur. Superna miseratione caliginem et aetheream et nigras nubes effugabit. Hic initium annorum felicium. $J$ (in alio folio innumerato) $\mathbf{2 0}$ mundana, aurum] mundana aura $L N O P Q$; mundana aure $I 21$ est] erit $N O 22$ electis] elatis $J \mathbf{2 3}$ insupportabili] intolerabili $L$; insuperabile Q $\mathbf{2 4}$ de sede] de sede, inesperata morte $Q$; per diram mortem $M$ (in marg. $a$. $m$.) $N 25$ pollute] plene $V \mathbf{2 6}$ potietur et gaudebit] potietur et gaudebit ipse et ipsius sequentes sibi similes $N$; potientur ipse et sequentes eum sibi consimiles $O Q 27$ et elegit] et elegit, quando ueniet ipse et ipsum sequentes sibi consimiles $M$ (in marg. a. m.) $Q$,; quando ueniet $N O$
}

[41] Gn 27:28. 
reformabit Ecclesiam. Et omnes admirabuntur et stupebunt. Benedicetur benedictione Iacob, quia erit primogenitus filius Ecclesiae et legitimus uerusque uicarius Christi. Imitabitur $^{28}$ enim eum uerbo et exemplo, purgabit mundum cunctis erroribus, docebit omnes quae sunt adhuc abscondita: De angelorum creatione et uia ${ }^{29}$; quantum fluxit temporis ab eorum creatione usque ad benedictionem et casum; qua die et quo monticulo uel loco Adam fuerit formatus ${ }^{30}$; qua die in paradisum translatus; quando et ubi et qualiter mulier fuerit ${ }^{31}$ creata; qualiter multotiens, a serpente temptata, ipsum uirum temptauit; de $^{32}$ Verbi incarnatione; de uera deitate et humanitate Christi; de gloria paradisi; de caeli empyrii amoenissimo situ; de conceptione admirabilis Matris Dei Mariae; [f1. 43] de illis quae fecit Christus a duodecimo anno usque ad trigesimum; de assumptione eiusdem Virginis et quod nullus est ibi in corpore praeter Christum et Matrem eius Mariam; de sermonibus ${ }^{33}$ Domini in Templo et synagogis ad Phariseos et plebem factis; de sermone Ioannis Baptistae ad Herodem; de his quae in carcere fecit et docuit; de Trinitate illa singulari $^{34}$ et de sacramento ${ }^{35}$ corporis et sanguinis Domini, et alia multa in hoc libro scripta a me iterum manifestanda.

Tunc ego, auditis tot mirandis ${ }^{36}$ ac agnoscendo quod iam erat natus et educatus et a Deo praeseruatus ${ }^{37}$ longo tempore antequam assumatur ${ }^{38}$, gauisus fui ualde et quasi sperans uidere illum diebus meis, dixi: Domine mi, uidebo, ut spero, istum electum Dei? Non sum tam senex quod eum uidere non possim.

Respondit angelus: $\operatorname{Iam}^{39}$ uidisti, sed non cognouisti. Non latitat nec est absconditus in cauernis sicut tu. Neque ipse de hoc cogitat. Deus pro illo cogitat. Et quando uidebitur alienus tunc erit proximus, quando uidebitur prope erit longe et quando longe tunc erit prope. Oportet impleri quae dico. Non quia dico, sed quia Deus ita uoluit ${ }^{40}$, ita decreuit, statuit et firmauit.

Tunc ego: Domine mi, monticulus ille in quo Adam creatus est, ubi est uel quid significat?

Respondit ille: Nunquam tam acute me interrogasti, quia duo quaesiuisti. Primo, ubi est monticulus ille, si debet intelligi de aliquo monte terreno. Secundo, si monticulus non sit aliquid terrenum, quid ergo significat? Hoc tu quaeris, hoc scire cupis. Ad quod dico tibi quod monticulus ille uere est terrenus, in quo et de cuius pulueribus nos formauimus corpus patris uestri, Deo auxiliante ubi nostra uirtus deficiebat. Et ille dictus est monticulus respectu uirginei montis de quo abscissus est lapis sine manibus qui etiam mons magnus factus est. Et mons magnus est caelum empyrium a uobis uocatum, in quo boni sequuntur Agnum quocumque ierit. In monte Dominus transfiguratus est, in monte satiauit de 
Templo, purificará e reformará a Igreja. Todos ficarão admirados e surpreendidos. Será abençoado com a bênção de Jacob, porque será o filho primogénito da Igreja e o legítimo e verdadeiro vigário de Cristo, pois há-de imitá-lo com a palavra e o exemplo, purgará o mundo de todos os erros, ensinará a todos o que ainda está oculto: Da criação e do percurso dos anjos; quanto tempo decorreu desde a criação deles até à sua bênção e queda; em que dia e em que colina ou lugar foi Adão formado; em que dia foi transladado para o Paraíso; quando, onde e como foi a mulher criada; de que modo, tentada muitas vezes pela serpente, tentou o próprio homem; da incarnação do Verbo; da verdadeira divindade e humanidade de Cristo; da glória do Paraíso; da ameníssima localização do Céu Empíreo; da concepção admirável de Maria, Mãe de Deus; [f1. 43] do que fez Cristo dos doze aos trinta anos; da assunção ao céu da mesma Virgem e da razão por que ninguém, além de Cristo e de Maria, sua Mãe, aí se encontra corporalmente; dos sermões do Senhor feitos no Templo e nas sinagogas aos fariseus e ao povo; do sermão de João Baptista a Herodes; das coisas que fez e ensinou no cárcere; da unidade da Trindade e do Sacramento do Corpo e do Sangue do Senhor e de muitas outras coisas escritas neste livro a deverem ser por mim dadas a conhecer.

Então eu, depois de ouvir tanta coisa digna de admiração e percebendo que ele estava já nascido e criado e fora por Deus preservado muito tempo antes de ser reconhecido, enchi-me de muita alegria e, como que esperando vê-lo em minha vida, perguntei: Meu senhor, verei eu, como espero, este eleito de Deus? Não sou tão velho que não possa vê-lo!

Já o viste, mas não o reconheceste, respondeu o anjo. Não está oculto, nem se esconde nas grutas como tu. Nem ele pensa neste assunto. Deus pensa por ele. E quando parecer um estranho, então estará próximo; quando parecer próximo, estará longe; e quando parecer longe, então estará perto. É preciso que se cumpra o que eu digo. Não porque eu o digo, mas porque Deus assim o quis, assim o decidiu, assim o estabeleceu e confirmou.

Senhor meu, perguntei, onde se situa ou o que significa a colina onde Adão foi criado?

Nunca me interrogaste com tanto engenho, respondeu, já que me perguntas duas coisas. Primeiro, onde se situa essa colina, se deve entender-se como algum monte da Terra. Segundo, se a colina não é algo de terreno, que significa então. É isto o que tu procuras, é isto o que queres saber. A isto respondo-te eu que essa colina é realmente terrena. Nela e de seu pó formámos nós o corpo do vosso primeiro pai, auxiliando-nos Deus onde falhava a nossa capacidade. Chama-se-lhe colina em consideração do monte virginal de que se desprendeu sem acção de mãos a pedra que, por sua vez, se tornou a Montanha. E a Montanha é aquilo a que chamais Céu Empíreo, onde os bons seguem o Cordeiro para onde quer que

$\leftarrow 35$ sacramento] sacramentis $Q 36$ mirandis] miraculis $I L P 37$ praeseruatus] preseruandus $M 38$ assumatur] assumeretur $P Q 39 \mathrm{Iam}]$ Eum $L \mathbf{4 0}$ uoluit] uult $I$ 
quinque panibus tantam multitudinem, in monte conceptus est, in monte orauit, in monte caenam fecit, in monte captus, in monte crucifixus, in monte ad caelum assumptus ${ }^{41}$, supra montem ${ }^{42}$, cum ad iudicandum uenerit, stabunt pedes eius. In monte pater uester Franciscus natus est, in monte stigmatibus cum clauis in manibus et pedibus insignitus admirabili modo Domini Saluatoris passionem renouauit, quod fuit praecipuum ${ }^{43}$ et singulare atque inauditum donum. In monte futurus pastor, quem sibi Dominus elegit, natus est, qui montem Sion uidelicet Ecclesiam [fl. 44] Christi in auram ${ }^{44}$ montium eriget et de nebulis atque caligine tenebrarum ereptam ${ }^{45}$ illustrabit, cuius splendor ex tunc perpetuus erit. $\mathrm{O}$ beatos uos qui haec uidebitis! Tu quidem uides nunc in imagine ${ }^{46}$, alii uidebunt in specie.

Tunc ego: Oh! si dignus essem ${ }^{47}$ uidere istum pauperculum et incognitum per quem Deus tot et tanta facturus est!

Dixit angelus: Iam uidisti eum, sed non in maiestate illa. Est enim nunc sicut granum frumenti in terra mortuum de quo talia, usque ad tempus illud in quo subito sublimabitur, cogitare nemo poterit. Sed ut uotis tuis satisfaciam, illum quem Romae etiam pluries uidisti, nunc absentem tibi ostendo in similitudine.

Et ostendit mihi eum iuuenculum et uisum est mihi quod impossibile esset per illum tot fieri, nisi quia credidi sermoni angeli loquentis. Et recordatus sum cuiusdam dicti Scripturae dicentis: Potens est Deus de lapidibus istis suscitare filios Abrahae. Dixique: Non sunt homines qui talia faciunt ${ }^{48}$, sed tu, Deus, facis omnia. Nos sumus quaedam ualde remota instrumenta.

Dixit uero angelus: Ecce dedi tibi faciem eius, obserua et custodi eam. Antequam ipse redeat Romam, tu Mediolanum accedes et ibi diem ${ }^{49}$ extremum claudes. Relinque imaginem hanc una cum libro Romae et ex parte Dei praecipe sub poena mortis ut nullus librum aperiat ${ }^{50}$ usquequo Domino placuerit ut paulatim in lucem ueniant occulta et arcana Dei. Si quis uero ante illud tempus aperire librum praesumpserit ${ }^{51}$, dabit debitas poenas. Intus uero secundum quod fuerit inuentus iudicabitur.

Postmodum uero, quia fecerat mentionem de caelo empyrio tamquam de futuro hominum habitaculo et iam multa dicta fuerant de peccato originali, tunc iterum ego inquirere coepi: Domine $\mathrm{mi}$, de peccato originali multa ${ }^{52}$ dixisti quae non bene capio et controuersiam illam quae hodie multa scandala generat rogo ut absoluas utrum ${ }^{53}$ Mater Domini nostri Iesu Christi illud habuerit peccatum et

41 assumptus] ascendit ILP $\mathbf{4 2}$ supra montem] super montem ILNOP; in monte JQV $\mathbf{4 3}$ praecipuum] priuilegium $Q \mathbf{4 4}$ in auram] in auram, alias uerticem $M$ (in. marg. a. m.) $O Q \mathbf{4 5}$ ereptam] ellectam $O Q \mathbf{4 6}$ in imagine] imaginem $P V \quad \mathbf{4 7}$ essem] esset $L 48$ faciunt] agunt $N \mathbf{4 9}$ ibi diem] ibidem $V \mathbf{5 0}$ aperiat] aperiet $M \mathbf{5 1}$ praesumpserit] presumerit $P \mathbf{5 2}$ originali, tunc iterum ego inquirere coepi: "Domine mi, de peccato originali multa] originali multa $O 53$ utrum] uidelicet $L Q ;$ om. $V$ 
$v a{ }^{[42]}$ No monte transfigurou-se o Senhor, no monte alimentou de cinco pães tão grande multidão, no monte foi concebido, no monte orou, no monte celebrou a Ceia, no monte foi preso, no monte foi crucificado, no monte subiu ao Céu, no monte, quando vier para julgar, pousará seus pés. No monte nasceu vosso pai Francisco, no monte, assinalado nos pés e nas mãos com os estigmas dos cravos, renovou de modo maravilhoso a Paixão do Senhor, nosso Salvador, o que constituiu especial, singular e inaudito dom. No monte nasceu o futuro Pastor que o Senhor escolheu para si, que elevará o Monte Sião, ou seja, a Igreja [f1. 44] de Cristo, à altura dos montes e, arrancada ao nevoeiro e à escuridão das trevas, a iluminará, sendo eterno a partir de então o seu esplendor. Oh! felizes os que isto presenciardes! Tu agora vês em imagem, outros verão na realidade.

$\mathrm{Oh}$ ! se eu fosse digno de ver esse pobre e desconhecido por meio de quem fará Deus tantas e tão grandes coisas, disse eu!

Já o viste, respondeu o anjo, mas não na majestade referida. Está presentemente como o grão de trigo morto na terra. Dele ninguém poderá pensar tais coisas até ao tempo em que for subitamente exaltado. Mas, para dar satisfação aos teus desejos, mostro-te agora em imagem, estando ausente, aquele que em Roma viste várias vezes até.

E mostrou-mo jovem, e pareceu-me que seria impossível que tanta coisa fosse por ele realizada se não acreditasse nas palavras do anjo que comigo falava. $\mathrm{E}$ lembrei-me de certa afirmação da Escritura, que diz: Deus tem poder para destas pedras fazer surgir filhos de Abraão. ${ }^{[43]} \mathrm{E}$ eu disse: Não são os homens quem faz estas coisas, mas tu, Deus, é que fazes tudo. Nós não passamos de uma espécie de instrumentos muito remotos.

Vê, dei-te o seu retrato, disse o anjo. Analisa-o e guarda-o. Antes de ele voltar para Roma, chegarás tu a Milão e aí morrerás. Deixa em Roma esse retrato juntamente com o livro e ordena, da parte de Deus, sob pena de morte, que ninguém o abra até que seja do agrado do Senhor que progressivamente se manifestem os segredos e os arcanos de Deus. Mas, se alguém ousar abrir o livro antes desse tempo, será devidamente castigado. Interiormente, porém, será julgado segundo aquilo que for encontrado.

Depois, porque havia feito menção do Céu Empíreo como da futura morada do homem e muito se tinha dito já do pecado original, comecei de novo a perguntar: Meu senhor, disseste muita coisa do pecado original que não entendo bem. Peço-te que me expliques a controvérsia que ocasiona hoje tantos escândalos, se a Mãe de nosso Senhor Jesus Cristo terá tido e contraído esse pecado; depois,

\footnotetext{
[42] Apoc 14:4,

[43] Mt 3: 9; Lc 3: 8.
} 
contraxerit, deinde quomodo illud caelum empyrium sit congruum et conueniens hominibus habitaculum, quomodo ibi animalia terrena et aere ${ }^{54}$ atque aliis elementis indigentia uiuere poterunt?

Respondit angelus et dixit: De peccato originali uestri doctores uarie locuti sunt. Quidam enim illud reatum solum esse ${ }^{55}$ crediderunt uidelicet exhereditationem ${ }^{56}$ seu priuationem patriae supernae seu uitae aeternae et nihil aliud. Alii uero quamdam qualitatem morbidam seu rebellionem carnis aut legem membrorum aut fomitem uario modo et diuersis ${ }^{57}$ uocabulis idem declarantes. Alii dixerunt illud esse concupiscentiam quandam seminatam in omnibus ${ }^{58}$ concupiscibiliter $^{2}$ seminatis. Alii postmodum acutius inuestigantes dixerunt illud esse priuationem iustitiae originalis cum debito habendi eam ${ }^{59}$. Sed ne tot opinionibus fideles uersentur ${ }^{60}$, ego tibi multa alias dixi, sed non ad plenum adhuc. Audi nunc quae tibi dico [f1. 45] et conscribe distinctius, nam ea quae alias dixi ualde confuse scripsisti et multotiens repetisti. Audi nunc et menti imprime ut conscribantur recte et nullus sit defectus in dictis aut scriptis.

Illud quod in uobis dicitur peccatum originale, in Adam fuit peccatum actuale. Ipse enim comedit et praaeuaricatus est mandatum Dei. Praeuaricatio ${ }^{61}$ mandati et comestio praeteriit. Facta est et reuocari non potest. Sed occasione talis praeuaricationis Adam reatum incurrit, quia ad aeternum supplicium obligatus fuit et hereditate siue beatitudine priuatus. Priuatus etiam fuit immortalitate et impassibilitate illius temporis, priuatus ${ }^{62}$ et tranquilitate quam habebat in imperando ${ }^{63}$ uiribus inferioribus et creaturarum oboedientia, erroribus multis subiectus, ad malum pronus et procliuior factus. Sed nullum istorum fuit culpa, sed potius reatus uel poena. Vltra tales reatus et tales poenas Adam ipse, propter esum illum ${ }^{64}$, fuit priuatus duplici qualitate in anima existente, illa uidelicet qua Deo uniebatur et coniungebatur et alia qua tranquille imperabat uiribus inferioribus cuius medio, amissa qualitate coniungente Deo, poterat ${ }^{65}$ iterum eam recuperare sine appositione alterius remedii. Haec fuerunt mala in quae ${ }^{66}$ cecidit Adam pater uester. Nota ergo quod, capiendo peccatum pro illa praeuaricatione mandati, ipse solus cum sua uxore Eua praeuaricatus est et nullus peccatum illud commisit. Capiendo etiam peccatum pro illo reatu ad supplicium aeternum propter transgressionem obligante ${ }^{67}$, nullus filiorum ad illud propter esum illum $^{68}$ fuit obligatus, sed solum ipsi duo parentes uestri. Si tamen peccatum dixeritis priuationem beatitudinis, immortalitatis, impassibilitatis, tranquilitatis, subiectionem ${ }^{69}$ erroribus et aliis poenis quas per esum incurristis uos non ipse, hoc peccatum pertransiuit ${ }^{70}$ in omnes concupiscibiliter procreatos sententia diuina.

54 aere] aerea $V \mathbf{5 5}$ esse] est et $J \mathbf{5 6}$ exheredationem seu priuationem] ex heredatione seu priuatione $O V \mathbf{5 7}$ diuersis] aduersis $Q \quad \mathbf{5 8}$ omnibus] hominibus $Q \quad \mathbf{5 9}$ habendi eam] habendi eam. Sed quae sit iustitia illa statim dicemus $M$ (in marg. a. m.) NOQ $\mathbf{6 0}$ uersentur] uexentur $O 61$ Praeuaricatio] Priuatio $Q 62$ beatitudine priuatus, priuatus etiam fuit immortalitate et impassibilitate illius temporis, priuatus] beatitudine priuatus $V 63$ in imperando] in paradiso JPV; $\rightarrow$ 
me expliques de que modo o Céu Empíreo é habitação adequada e conveniente para o homem, como poderão viver aí os animais precisados de terra, de ar e outros elementos.

Do pecado original, respondeu e disse o anjo, falaram divergentemente os vossos doutores. Creram uns que era somente pena, ou seja, exerdação ou privação da herança celeste ou da vida eterna, e nada mais. Outros, porém, creram que era uma certa condição mórbida, ou rebelião da carne, ou lei do corpo, ou apetite, dizendo o mesmo de modo diverso e com termos diferentes. Disseram outros que era uma espécie de concupiscência semeada em quantos são concupiscentemente gerados. Outros, por fim, ao investigarem com mais subtileza, disseram que era a privação da justiça original, com a obrigação de a ter. Contudo, para que os fiéis não sejam confundidos com tantas opiniões, disse-te já muita coisa, mas ainda te não disse tudo, ouve o que agora te digo [f1. 45] e escreve-o com muita clareza, pois o que te disse noutra ocasião escreveste-o muito confusamente e repetiste-o várias vezes. Ouve agora e grava no teu espírito, para que isso seja escrito correctamente e não haja falha alguma no que for dito ou escrito.

O que em vós se chama pecado original foi em Adão pecado actual. Ele comeu o fruto proibido e transgrediu a ordem de Deus. A transgressão do mandamento e o acto de comer passaram. Aconteceram, não podem voltar a acontecer. Mas, no acto dessa transgressão, Adão incorreu numa pena, porque ficou sujeito ao suplício eterno e privado da herança ou bem-aventurança. Foi igualmente privado da imortalidade e da impassibilidade própria desse tempo. Foi privado também da tranquilidade que tinha no controle das forças inferiores, e da obediência das criaturas, sujeito a muitos enganos e tornado propenso e mais inclinado ao mal. Nada disto, porém, foi culpa, mas antes castigo ou pena. Além dessas penas e desses castigos, por haver comido o fruto proibido foi o próprio Adão privado da dupla qualidade existente na alma, ou seja, daquela pela qual se unia e se ligava a Deus, e da outra por meio da qual tranquilamente dominava as forças inferiores por cujo intermédio, perdida a qualidade que o ligava a Deus, podia de novo recuperá-la sem recurso a outro remédio. Foram estes os males em que caiu Adão, vosso pai. Adverte, pois, que, tomando nós pecado pela transgressão do mandamento, só ele com Eva, sua mulher, transgrediram e ninguém mais cometeu esse pecado. Tomando ainda pecado por aquela pena que obriga ao suplício eterno por causa da transgressão, nenhum filho a ele foi sujeito por Adão haver comido o fruto proibido, mas apenas os vossos dois pais. Mas se se considerar pecado a privação da bem-aventurança, da imortalidade, da impassibilidade, da tranquilidade, a sujeição aos erros e a outros castigos em que, por causa daquele acto de

$\leftarrow$ imperando $Q 64$ illum] talem $N Q 65$ amissa qualitate coniungente Deo, poterat] amissa qualitate, coniungere Deo poterat $J M V \mathbf{6 6}$ quae] quibus $V \mathbf{6 7}$ obligante] obligantem ILP $\mathbf{6 8}$ esum illum] esum ligni $N$; transgretionem $Q 69$ subiectionem] subiectionis $I L M N P Q, 70$ quas per esum incurristis uos, non ipse, hoc peccatum pertransiuit] quas per esum incurristis uos, nonne ipsum hoc peccatum pertransiuit $O P$; quas per esum incurristis uos, non ipsi, hoc peccatum pertransiuit $\rightarrow$ 
Et potest dici originale eo quod talem originem habentibus infligatur propter originantis primi transgressionem. Et hoc proprie non est culpa, quamuis et illud culpa dici possit et macula. Sed proprie culpa quae in anima, transeunte actu peccati, remanet, est elongatio a Deo, quae nihil aliud est quam priuatio gratiae Dei siue qualitatis Deo coniungentis Deoque gratum habentem facientis. Et illa est macula, illa fetor spiritualis, illa contaminatio, illa animae morbus et langor. Et quamuis Adam et Eua ante illum esum per interiorem elationem ${ }^{71}$ et per consensum expressum talem qualitatem amisissent, ${ }^{72}$ tamen etiam esu illo eam amissam amiserunt ${ }^{73}$ sic quia, si habuissent, digni erant amittere et amisissent. Et hoc modo, postquam perpetrato crimine, gratia amissa est. Sequentibus quoque criminibus amittitur. Quando enim dignus est quis amittere quod amisit, iterum illud amittere uidetur.

Culpa ergo [fl. 46] et macula est amissio gratiae ${ }^{74}$, elongatio a Deo et dissimilitudo Dei. Et haec macula remansit ${ }^{75}$ in omnibus filiis Adae ex propagatione natis decreto et lege communi. Quam maculam Adam ante esum illum habuit. Sed filii non habuissent nisi esus ille praecessisset. Sed, eo comedente, decreto firmatum fuit ut omnes essetis filii ire et inimici non autem amici, disiuncti et non coniuncti nisi, remedio adhibito, iterum coniungeremini. Remedia nota sunt: merita Christi et motus uoluntatis in Deum aut sacramenti susceptio uel utrumque, de quo alias locuti sumus. ${ }^{76}$ Priuatio autem secundae qualitatis, qua tranquille ${ }^{77}$ uixisset homo et qua facile ad Deum reuersus fuisset, non ita proprie est culpa aut macula. Tamen aliquomodo et ipsa pertinet ad peccatum originale, quia per esum illum incidistis in talem priuationem. Et ita intellige quae alias tibi dixi et ita ${ }^{78}$ nimis confuse scripsisti.

Qui ergo peccatum originale solum reatum quo obnoxii poenae et illius quae animae et illius quae corporis est facti sunt homines, illi non discernunt inter reatum et culpam aut maculam, sed reatum ipsum culpam et maculam credunt $^{79}$. Qui uero illud peccatum uocant legem carnis uel tyrannum membrorum non uidentur ab illis primis differre ${ }^{80}$ nisi quia primi uidentur reatum in quem homines ceciderunt propter esum illum uocare peccatum originale, illi $^{81}$ autem solum legem carnis et fomitem. Qui fomes est poena quaedam quam propter esum incurristis, nam et

$\leftarrow L$; quas per esum incurristis uos, non ipsum hoc peccatum pertransiuit $N$; quas per esum incurristis uos, nonne hoc peccatum pertransiuit $Q \mathbf{7 1}$ elationem] eleuationem $L V \mathbf{7 2}$ amisissent] amiserat $I$ 73 amiserunt] miserint $I$; amisissent $L \mathbf{7 4}$ Culpa ergo et macula est amissio gratiae] Amissio ergo gratiae est culpa et macula $I \mathbf{7 5}$ et macula (...) Et haec macula remansit] et macula remansit $V \mathbf{7 6}$ locuti sumus.] locuti sumus. Peccatum ergo originale est priuatio gratiae et gloriae pro liberis seu $\rightarrow$ 
comer, vós incorrestes e não ele, esse pecado passou, por decisão divina, para todos os que foram gerados na concupiscência. E pode chamar-se original, dado o facto de ser infligido aos que têm essa mesma origem, por causa da transgressão do primeiro pai que os originou. E isto não é propriamente culpa, embora se lhe possa chamar culpa e mácula. Mas culpa propriamente, a que permanece na alma depois de haver passado o acto do pecado, é o afastamento de Deus, que não é senão a privação da graça de Deus ou da qualidade que liga a Deus ou torna agradável a Deus quem a tem. E essa é a mancha, essa a pestilência espiritual, essa a contaminação, essa a doença e o entorpecimento da alma. E embora Adão e Eva tivessem perdido essa qualidade antes de comerem o fruto proibido por causa da presunção interior e do consentimento expresso, todavia, uma vez perdida já, perderam-na também deste modo com o acto de comer, porque, se a tivessem, eram dignos de a perder e tê-la-iam perdido. E, deste modo, depois de perpetrado o delito, a graça foi perdida. Perdeu-se igualmente com os delitos subsequentes. Pois quando alguém é digno de perder o que perdeu, parece perdê-lo outra vez.

A culpa [f1. 46] e a mácula são a perda da graça, o afastamento de Deus e a dissemelhança de Deus. E esta mácula permaneceu por decisão e lei comum em todos os filhos de Adão nascidos da reprodução. Essa mácula contraiu-a Adão antes de ter comido o fruto proibido. Os filhos, porém, não a teriam se não tivesse precedido o acto de comer. Mas, depois de Adão comer do fruto proibido, foi firmado por decreto que todos vós fosseis filhos da ira e inimigos, não amigos, divididos e não unidos, a menos que com a utilização do remédio tornásseis a unir-vos. Os remédios são conhecidos: os méritos de Cristo, o movimento da vontade para Deus, ou a recepção do sacramento, ou ambas. Disto falámos noutra ocasião. A privação da segunda qualidade, pela qual o homem viveria tranquilamente e facilmente retornaria a Deus, não é, deste modo, propriamente culpa ou mácula. Contudo, de algum modo, também ela pertence ao pecado original, porque caístes em tal privação pelo acto de comer. Compreende, pois, o que te disse noutra ocasião e que tão confusamente escreveste.

Portanto, aqueles que crêem que o pecado original é somente a condição pela qual os homens se tornam réus da pena, tanto da que é própria da alma como da que é própria do corpo, esses não distinguem entre pena e culpa ou mácula, mas consideram pena como culpa e mácula. Ao passo que aqueles que consideram o pecado a lei da carne ou o tirano do corpo parecem não se afastar dos primeiros senão nisto: os primeiros, segundo parece, chamam pecado original à falta em que os homens caíram por causa de Adão ter comido o fruto proibido;

$\leftarrow$ descendentibus seminaliter (seminum aliter MNO) a patre acceptae. Si ergo talis habitus sic stipiti pro futuris surculis (saeculis $P$ ) insertus dicatur iustitia originalis, recta est definitio illa (illa om. Q) $M$ (in marg. a. m.) NOPQ 77 tranquille] tranquillitate $Q \mathbf{7 8}$ ita] tu $I L N O P Q 79$ credunt] putant IL 80 differre] dissentire $I L \mathbf{8 1}$ illi] alii $I L V$ 
tranquilitatem amisistis illam et repugnantiam carnis contra spiritum concupiscentis ${ }^{82}$ incidistis. Quae carnis seu sensuum rationi repugnantia ${ }^{83}$ poena est potius quam culpa uel quam reatus.

Qui autem illud peccatum dicunt esse concupiscentiam ${ }^{84}$, si intelligunt per eam pronitatem carnis rationi resistentis ad malum, tunc non differunt a secundis. Si autem ipsius animae pronitatem ad condelectandum sensui ${ }^{85}$ ita quod talis sit in uoluntate non in sensu, illa etiam erit ${ }^{86}$ poena quae consequitur uoluntatem priuatam illa secunda qualitate, de qua saepe diximus.

Qui autem illud ponunt esse priuationem iustitiae originalis, hi propinquissime accedunt ad rationem culpae, intelligendo per iustitiam originalem qualitatem primam coniungentem Deo qua et si Adam ante esum illum priuatus fuerit non tamen filii priuati fuissent si esus non praecessisset. Si autem per iustitiam originalem secundam qualitatem intelligerent ${ }^{87}$ qua et tranquile uiuere et cito in Deum redire potuissent, tunc etiam peccatum originale potius poena fuisset quam culpa seu macula aut elongatio, quae idem sunt. ${ }^{88}$

Dictis his de peccato originali, nunc tibi aperiam ueritatem quomodo Maria Genitrix Dei nostri sine ullius ${ }^{89}$ peccati labe concepta sit, quod apud uos uertitur in dubium. Dico tibi Deum prima sui intentione Verbum suum uoluisse ex uirgine tali carnem assumere eamque semper immaculatam fore absque ulla condicione, beneplacito suae uoluntatis. Absolute eam elegit et praeelegit, quod de nullo aliorum dici potest, nec de nobis angelis nec de [f1. 47] uobis hominibus. Vt ergo Deus ipse ex ea prodiret, creauit mundum sensibilem et primos uestros parentes ut tandem egrederetur ${ }^{90}$ uirga illa et flos ascenderet. Et uolebat ${ }^{91}$ quod etiam propagatores eius, quicumque illi essent, amici essent cum condicione, si mandatis obtemperarent ${ }^{92}$. Solam illam noluit ullo pacto transgredi nec aliorum transgressioni ${ }^{93}$ subiacere. Vidit transgressionem primorum parentum, condemnauit omnes posteros, omnes propagatos, nisi iuuarentur meritis illius Hominis Dei. Et absolute uoluit ut merita ipsius $\mathrm{ei}^{94}$ suffragarentur, aliis uero cum aliqua condicione scilicet si uel ipsi uel parentes aut etiam alii praeter merita illius Dei Hominis interuenirent. Et tandem omnes alios tunc absolute praedestinauit quando in gratia confirmauit uel in mortis instanti uel antea.

82 carnis contra spiritum concupiscentis] carnis contra spiritus concupiscentis $J M V$; carnis contra spiritum concupiscentiae $P Q \mathbf{8 3}$ Quae carnis seu sensuum rationi repugnantia] Quae carnis seusuum contra rationem repugnantia $Q \quad \mathbf{8 4}$ concupiscentiam] concupscentia $V \quad \mathbf{8 5}$ sensui] sensum $V \mathbf{8 6}$ etiam erit] etiam erat $J$; etenim erit $L M$; enim erat $V \mathbf{8 7}$ intelligerent] intelligent $Q \rightarrow$ 
os outros, porém, chamam-lhe somente lei ou aguilhão da carne. Este apetite é uma espécie de pena, em que incorrestes por Adão ter comido o fruto proibido, pois não só perdestes a tranquilidade como vos tornastes vítimas da revolta da carne concupiscente contra o espírito. Esta revolta da carne ou dos sentidos contra a razão é mais pena do que culpa ou falta.

Os que dizem que esse pecado é concupiscência, se entendem por esta a inclinação para o mal da carne que resiste à razão, nesse caso não diferem dos segundos. Se, porém, entendem a inclinação da própria alma para se regozijar com os sentidos, de modo que essa inclinação resida na vontade e não nos sentidos, essa será ainda a pena que segue a vontade privada da segunda qualidade, de que falámos várias vezes.

Os que afirmam que esse pecado é a privação da justiça original, esses aproximam-se muito do conceito de culpa, entendendo por justiça original a primeira qualidade que une a Deus e, mesmo se Adão tivesse sido privado dela antes de comer o fruto proibido, nem por isso os filhos teriam sido privados se o fruto proibido não tivesse sido previamente comido. Mas se entenderem por justiça original a segunda qualidade que lhes teria permitido viver tranquilamente e retornar facilmente a Deus, ainda então o pecado original seria mais pena do que culpa ou mancha ou afastamento, que são a mesma coisa.

Dito isto do pecado original, vou agora dizer-te a verdade quanto ao modo como Maria, Mãe do nosso Deus, foi concebida sem mancha de qualquer pecado, facto que entre vós se põe em dúvida. Digo-te que Deus, em sua primeira intenção, quis que o seu Verbo assumisse a carne a partir de uma virgem e que esta fosse sempre imaculada sem condição, por beneplácito da sua vontade. Escolheu-a e preferiu-a precisamente a ela, facto que de mais ninguém, nem de nós anjos, nem de [f1. 47] vós, homens, pode ser afirmado. Por isso, para que o próprio Deus pudesse dela nascer, criou o mundo sensível e os vossos primeiros pais, para que, por fim, brotasse esse ramo e essa flor desabrochasse. E queria que também seus progenitores, quem quer que eles fossem, fossem amigos sob condição: se obedecessem aos mandamentos. Só não quis que ela transgredisse sob qualquer condição, nem se sujeitasse à transgressão alheia. Viu a transgressão dos primeiros pais, condenou todos os vindouros, todos os nascidos, a menos que fossem socorridos pelos méritos desse Homem Deus. E quis que os méritos dele lhe servissem de sufrágio, a ela de forma absoluta, e aos outros sob certa condição, ou seja, se, além dos méritos desse Deus Homem, eles ou os pais ou outros interviessem. E, por fim, predestinou então de forma absoluta todos os outros, quando os confirmou na graça, no momento da morte ou antes.

$\leftarrow \mathbf{8 8}$ quae idem sunt] quod idem est $Q \mathbf{8 9}$ ullius] illius $L N P \mathbf{9 0}$ egrederetur] egredietur $J \mathbf{9 1}$ uolebat] nolebat $N V 92$ obtemperarent] obtemperassent $N 93$ transgressioni] transgressus $O$; substransgressioni $V 94$ ei] sibi $I L N$; Dei $M$ (in marg. a. $m$. hominis Virgini Matri); Dei Hominis Virgini Matri $O$; Dei Virgini matri $Q$ 
Scito ergo quod sicut omnibus hominibus sine condicione ${ }^{95}$ uoluit beatitudinem prima intentione dare ita, uisa prima hominis transgressione, nulli eam dare uoluit nisi cum condicione scilicet si remediis opportunis potirentur. Ab hac tamen Virgine nunquam remouit ${ }^{96}$ mentem uel animum, sed ut remediis gauderet ${ }^{97}$ absolute disposuit, hoc est, meritis Filii ex ea prodituri ${ }^{98}$. Accipe et tene quod dico: nullus est ex filiis Adae cui aliquando non fuerit iratus Deus, hoc est, quem noluerit beatum fore saltem cum condicione. Ideo nullus est aut fuit aut erit quem noluerit ${ }^{99}$ beatum fore ${ }^{100}$ saltem cum condicione. Et nullus ${ }^{101}$ est quem pro aliquo tempore in sua aeternitate Deus non habuerit pro exule et pro inimico, praeter hanc de qua loquimur, omnium nostrum dominam, quae non solum pro illo tempore ex quo coepit esse, sed pro immensitate aeternitatis diuinae semper ante faciem eius extitit grata et accepta, iuxta illud: Astitit Regina a dextris tuis (scilicet aeternaliter) in uestitu deaurato, circumdata uarietate quia uariis donis et muneribus decorata. Alii ${ }^{102}$ omnes pro aliquo tempore oblati sunt ei ut inimici et exosi, praeuiso peccato Adae.

Multa sunt genera hominum. Quidam Deo nunquam placuerunt nisi cum condicione, ut illi qui numquam remedium originalis culpae acceperunt. Alii quandoque placuerunt, quandoque displicuerunt, ut illi qui, remedio sumpto ${ }^{103}$, iterum sunt praeuaricati, et hi rarius et frequentius. Aliqui enim semel percepto ${ }^{104}$ remedio constantes fuerunt semper. Aliqui semel post delinquentes redierunt, aliqui septies, aliqui etiam septuagies septies peccantes redierunt ${ }^{105}$. Alii, antequam nascerentur, fuerunt a morbo illius peccati curati. Aliqui, dum conciperentur uel antea, meritis non solum Christi sed uel parentum uel aliorum iustorum quorum lacrimae, hoc est, pia desideria praeuisa a Deo purgant meritorie, Deo sic acceptante, scientia ${ }^{106}$ talium, et hoc prout fuerunt in cognitione Dei, a peccato illo fuerunt ${ }^{107}$ liberati eo modo quo erus potest filium [f1. 48] seruae antequam nascatur uel etiam concipiatur a seruitute liberare. Et multo magis id potest Deus, qui distincte cognoscit et uocat ea quae non sunt tamquam ea quae sunt ${ }^{108}$. Quoscumque igitur praenuntiauit in mundum tamquam a se missos et tamquam magnos uenturos et tamquam amicos suos, eos iam absoluebat a patris ${ }^{109}$ crimine $^{2}$ meritis Dei Veri et perfecti Hominis. Hanc Virginem nec antequam nasceretur nec in conceptu nec ante conceptum ${ }^{110}$ absoluit, sed numquam ut inimicam aut ingratam habuit, sed absolute uoluit ${ }^{111}$ meritis Filii eius ipsam non solum a peccato inexistente ${ }^{112}$ purgare, sed neque a peccato in ea, mente diuina apprehenso,

95 sine condicione] sub condicione $N O Q 96$ remouit] amouit $I 97$ gauderet] gauderent $L V 98$ prodituri] producturi $V 99$ noluerit] non uoluerit $I 100$ fore] facere $L 101$ condicione. Ideo nullus (...) cum condicione. Et nullus] condicione. Et nullus $O Q \mathbf{1 0 2}$ accepta, (...) Alii] accepta. Alii $P 103$ sumpto] assumpto $I \quad 104$ percepto] suscepto $Q \quad 105$ redierunt] reuersi sunt $I L 106$ acceptante, scientia] acceptante, se merita $I L$; acceptante semina $O P Q 107$ prout (...) fuerunt] $\rightarrow$ 
Fica, pois, a saber que assim como na sua primeira intenção a todos os homens quis dar, sem condição, a bem-aventurança, depois de ver a primeira transgressão do homem, a ninguém a quis dar senão sob condição, ou seja, se dispusessem dos remédios adequados. Desta virgem, porém, nunca desviou a sua mente ou espírito, mas estabeleceu de forma absoluta que gozasse desses meios, isto é, dos méritos do Filho que dela haveria de nascer. Recebe e guarda o que te digo, não há nenhum filho de Adão com quem alguma vez se não tenha irado Deus, isto é, a quem não tenha querido que fosse bem-aventurado, ao menos sob condição. Por isso, não há, não houve, nem haverá ninguém a quem não tenha desejado que fosse bem-aventurado, ao menos sob condição. E não há ninguém a quem Deus, na sua eternidade, não haja tido por algum tempo na conta de proscrito e de inimigo, com excepção desta de quem falamos, Senhora de todos nós, que não só em relação ao tempo a partir do qual começou a existir, mas à imensidade da eternidade divina sempre esteve na sua presença acolhida com reconhecimento e aceite, segundo aquele passo: À tua direita - ou seja, eternamente - ergue-se a Rainha, ornada do ouro mais fino, ${ }^{[44]}$ porque decorada com variados presentes e dons. Todos os outros, na previsão do pecado de Adão, lhe foram apresentados por algum tempo como inimigos odiosos.

É grande a variedade de homens. Uns nunca foram do agrado de Deus senão sob condição, como aqueles que nunca aceitaram o remédio da culpa original. Outros, umas vezes foram, outras não, como aqueles que, tomado o remédio, prevaricaram de novo, raras vezes uns, frequentemente outros. Alguns, tomado uma vez o remédio, mantiveram-se constantes. Alguns voltaram depois de caírem uma vez, alguns depois de sete, alguns ainda voltaram depois de pecarem setenta vezes sete. Outros foram curados da doença desse pecado antes de haverem nascido. Outros, até serem concebidos, ou antes de serem concebidos, pelos méritos não só de Cristo, mas também dos pais ou outros justos cujas lágrimas, isto é, os piedosos desejos previstos por Deus justificam meritoriamente (aceitando Deus, assim, a descendência deles, e isto na medida em que estiveram no conhecimento de Deus), foram libertados daquele pecado do mesmo modo que o senhor pode libertar da escravatura o filho da [f1. 48] escrava antes de nascer ou até de ser concebido. E Deus pode isso muito mais, ele que conhece distintamente e chama o que não existe como se existisse. A quantos, pois, prenunciou como enviados por si ao mundo e como havendo de vir como grandes e como amigos seus, a esses absolvia-os logo do pecado do pai, em vista dos méritos do verdadeiro Deus e Homem perfeito. A esta Virgem nunca a absolveu, nem antes de nascer, nem na concepção, nem antes da concepção. Nunca, porém, a

$\leftarrow$ prout fuerunt $V \mathbf{1 0 8}$ non sunt tamquam ea quae sunt] non sunt. $J V 109$ patris] peccatis $J V 110$ conceptum] conceptionem $Q \mathbf{1 1 1}$ uoluit] noluit $M P 112$ inexistente] existente $J V$

[44] S1 44:10 
umquam absoluit ac si eam pro aliquo tempore in tali peccato Deus ipse uidisset sicut uidit ${ }^{113}$ omnes alios filios ex Adam propagatos.

Multi ergo dum conciperentur amici esse poterant ${ }^{114}$ et fuerunt et aliquanto tempore ante in praescientia ${ }^{115}$ Dei. Sic montes sanctos Ecclesiae erigebat. Omnes tamen in peccatis concepti sunt, quia omnes ex tali conceptione orti merebantur iram et inimicitiam, immo plus, tibi dico. Etiam Regina ${ }^{116}$ nostra, quae nunquam uisa est ut inimica neque ante conceptionem neque post, adhuc de rigore conceptionis suae in peccato concepta dici potest, quia quilibet sic propagatus meretur iram et non misericordiam, de ratione ${ }^{117}$ propagationis suae. Et hoc modo uerum est nullum neque a reatu neque a culpa liberum ${ }^{118}$ esse, sed omnes in peccatis concipi ${ }^{119}$ et nasci et uiuere. Sicut tamen non omnes uiuunt in peccato nec nascuntur sic nec concipiuntur ${ }^{120}$. Omnes ergo estis de propagine ${ }^{121}$ peccati et mortis et ire. Sed gratia Saluatoris, aliqui post multos lapsus, aliqui post paucos, aliqui post unum ${ }^{122}$ ex quo concepti sunt, aliqui post unum ${ }^{123}$ antequam concepti sint, aliqui post nullum ${ }^{124}$ omnino nec in re nec in scientia Dei saluati et liberati dici esse possunt. Qui tamen ut filii propagati ab ipso Adam intelligebantur, ut rei intellecti fuissent, nisi Deus absolute eos meritis Filii sui praeuisis praeseruasset. Posui hic plurale pro singulari quia talis alius a Virgine Dei Matre nullus fuit. Ipsa tamen recte dici potest peccasse et a peccato liberata fuisse, quia ex massa peccato obnoxia proditura ${ }^{125}$ erat et prodiit. Immo dico tibi quod nullus magis fuit liberatus, magis saluatus, magis redemptus quam illa. Nullus obligatior exstitit Saluatori quam illa. Non solum ergo saluata est, sed magis saluari magisque redimi non poterat. Quae enim numquam labe polluta est aut ulla sorde, neque dum esset neque dum a Deo in aeternitate intelligeretur, et hoc meritis Saluatoris Deo praenotis, magis redimi non potuit. Minus ergo merito Christi peccantes, magis saluantur. Quod si minus peccantes magis saluantur, nullo modo ${ }^{126}$ peccantes maxime saluati dicentur. Hoc ut promulget toti orbi futurus pastor Deus decreuit. Quicumque aliter senserit anathema erit.

Sed mirum est cur hoc uestri doctores non perpendunt ${ }^{127}$. Si enim nullus redimitur aut saluatur nisi peccator prius extiterit, quomodo non uident quod

113 uidit] ostendit $N 114$ poterant] poterunt $L 115$ praescientia] praesentia $I J Q 116$ immo plus, tibi dico. Etiam Regina] immo plus dico tibi quod Regina $Q \mathbf{1 1 7}$ de ratione] duratione $J \mathbf{1 1 8}$ liberum] liberatum $J 119$ concipi] concepti $J V 120$ concipiuntur] concipiunt $V 121$ propagine] propagatione $O Q \mathbf{1 2 2}$ aliqui (...) aliqui post unum] aliqui post unum $P \mathbf{1 2 3}$ post paucos, aliqui $\rightarrow$ 
teve como inimiga ou não merecedora de graça. Mas quis, de modo absoluto, em razão dos méritos de seu Filho, purificá-la não só do pecado inexistente, mas nunca a absolveu do pecado apreendido nela pela mente divina, como se o próprio Deus alguma vez a tivesse visto nesse pecado como viu todos os outros filhos descendentes de Adão.

Muitos até serem concebidos, e algum tempo antes, na presciência de Deus, podiam ser amigos e foram-no. Assim elevava os montes santos da Igreja. Mas todos são concebidos em pecado, porque todos os nascidos dessa concepção mereciam a ira e a inimizade, e mais ainda, digo-te eu. Também a nossa Rainha, que nunca foi olhada como inimiga nem antes nem depois da concepção, em rigor, precisamente pelo facto de ter sido concebida, pode considerar-se concebida em pecado, porque quem quer que assim seja gerado é merecedor da ira e não da misericórdia, precisamente por ter sido gerado. E, deste modo, é verdade que ninguém está livre nem da pena nem da culpa, mas todos são concebidos, nascem e vivem em pecado. Todavia, assim como nem todos vivem nem nascem em pecado, assim também não são concebidos. Todos, porém, sois da geração do pecado, da morte e da ira. Mas, pela graça do Salvador, pode dizer-se que fostes salvos e libertados, uns depois de muitas quedas, outros depois de poucas, alguns depois de uma, desde que foram concebidos, outros depois de uma, antes de serem concebidos, alguns depois de absolutamente nenhuma, nem de facto nem no conhecimento de Deus. Todavia os que eram vistos como filhos gerados a partir do próprio Adão seriam considerados réus, se Deus, em função dos méritos previstos de seu Filho, os não tivesse preservado de forma absoluta. Usei aqui o plural pelo singular, porque nenhum outro existiu além da Virgem Mãe de Deus. Pode, pois, sem erro dizer-se que ela pecou e que foi libertada do pecado, porque havia de sair e saiu da massa sujeita ao pecado. Digo-te até mais, que ninguém foi mais libertado, mais salvo, mais redimido do que ela. Não existe ninguém que mais deva ao Salvador do que ela. Não só, portanto, foi salva, como mais salva e mais redimida não podia ser. Aquela que, na verdade, nunca foi tocada por nenhuma mancha nem por nenhuma nódoa, nem enquanto não existia, nem até ser pensada por Deus na eternidade, e isto graças aos méritos do Salvador previamente conhecidos por Deus, mais redimida não pôde ser. Por isso, os que, graças ao mérito de Cristo, menos pecam, mais salvos são. Pois se os que menos pecam mais salvos são, os que nada pecam diz-se que são salvos no máximo grau. Decidiu Deus que o futuro Pastor dê isto a conhecer a todo o mundo. Quem pensar de modo diferente será anátema.

Mas é de estranhar porque é que os vossos doutores não atentam nisto. Se realmente ninguém é redimido ou salvo se primeiro se não apresentar como pecador,

$\leftarrow$ (...) aliqui post unum] post paucos, aliqui pos unum $V \mathbf{1 2 4}$ concepti sunt, aliqui (...) aliqui post nullum] concepti sunt, aliqui post nullum $Q \mathbf{1 2 5}$ proditura] prodita $J V 126$ magis saluantur. (...) magis saluantur, nullo modo] magis saluantur, nullo modo $Q 127$ perpendunt] perpendant $I 128$ Saluatore] Saluatorem $M$; saluatione $Q$ 
oportebit dicere minus redemptum illum qui minus peccator fuerit, et minus saluatum [fl. 49] minusque Saluatore ${ }^{128}$ indiguisse $^{128 \mathrm{~A}}$ minusque Saluatori obligatum esse? Quae omnia sunt perabsurda. Sic ergo Virgo Regina minus omnibus saluata fuisset et minus Saluatori obligata. Quae absint a fidelium mentibus. Nullus magis saluatus ipsa, nullus magis Deo obligatus. Et quia nil meriti ad hoc habuit nisi merita Filii sui, recte super omnes suo Saluatori obligatur cum supra omnes meritis Saluatoris meruerit ${ }^{129}$. Vnde et ipsa super omnes eum suum saluatorem appellauit ${ }^{130}$ quando, cantando, dixit: Exultauit spiritus meus in Deo salutari ${ }^{131}$ meo.

Scito tamen et animaduerte quod, si peccatum originale pro solo reatu et obligatione ad poenas huius uitae et pro amissione immortalitatis et impassibilitatis accipitur, ipsa tale peccatum contraxit. Sed illud non est peccatum originale quod nec per baptismum dimittitur ${ }^{132}$. Aliquae igitur reliquiae ${ }^{133}$ peccati originalis fuerunt in ea non peccatum. Nam si Adam non peccasset, nec ipsa nec Filius ${ }^{134}$ eius mortalis et passibilis uenisset ${ }^{134 \mathrm{~A}}$ in hunc mundum. Vtrique igitur illud peccatum nocuit aliquo modo. Quod nocumentum, posito casu Adae, fuit uobis utile, quia sanguine illius et morte redempti estis. Et nocumentum Matris fuit ipsi Matri ad cumulum meritorum, immo profuit et uobis. Et sicut ablato peccato originali non aufertur poena temporalis sic et praeseruati ab illo, non praeseruantur a poenis huiusmodi ${ }^{135}$. Immo Christus Dominus qui non subiciebatur illi peccato quia non fuit ex propagatione ${ }^{136}$ illa nec ex concubitu procreatus, ut omnes alii, non fuit a poenis illis praeseruatus. Quae tamen paene uestrae ${ }^{137}$ non erant sibi datae ${ }^{137 \mathrm{~A}}$ ut poene sicuti si Deus crearet unum hominem in puris naturalibus, ille esset mortalis et passibilis, mors tamen et passibilitas non esset sibi ut poena peccati, sed condicio naturae. Tamem aliquo modo peccatum Adae fuit occasio mortis Christi. Si enim ille non peccasset, Christus Dominus mortuus non fuisset nec carnem mortalem assumpsisset, sed talem qualem inuenisset. Quando ergo dicitur in Scripturis ipsum propter peccatorum expiationem uenisse, semper supplendum est uenisse uidelicet mortalem et passibilem. Deus enim prima intentione non decreuit Filium suum mittere in mundum in carne mortali, sed solum in carne humana ${ }^{138}$. Sed uidendo peccatum Adae, decreuit ut assumeret carnem mortalem et passibilem. Ideo dicitur eum propter peccata uestra misisse ${ }^{139}$ non prima intentione sed secunda, utraque tamen aeterna, de cuius incarnatione alias fiet sermo.

128A indiguisse] uiguisse $I 129$ meruerit] meruit $M P V \quad 130$ appellauit] appellat $P 131$ salutari] saluatore $I 132$ dimittitur] admittitur $J 133$ reliquiae] reliquae $J 134$ filius] filium $M V$; filii $L Q \quad 134$ A mortalis et passibilis uenisset] mortalis et passibilis uenissent $I$; mortales et passibiles uenissent $L Q 135$ huiusmodi] huius mundi $L V \quad 136$ propagatione] propagine IJLNOPQ 137 uestrae] naturae $J P$; nostrae $M$ (add. in marg. a. $m$. alias uestrae) $V$; alias naturae uestrae $Q \quad \mathbf{1 3 7 A}$ Quae tamen paene naturae non erant sibi datae] Quae tamen paene alias naturae uestrae erant, non sibi datae sunt $Q \mathbf{1 3 8}$ in carne humana] in carne humana et mortalium condicione si homo peccaret. $M$ ( in marg. a. $m$.) $Q$; in carne humana et mortalium condicione $O 139$ misisse] uenisse $Q$ 
como não vêem que será forçoso considerar menos redimido e menos salvo [f1. 49] e que menos precisou do Salvador e menos em obrigação está para com ele aquele que menos pecador tenha sido? Tudo isto é completamente absurdo. Deste modo, na verdade, a Virgem Rainha teria sido menos salva que todos e menos em obrigação estaria para com o Salvador, o que não deve passar pela mente dos fiéis. Ninguém foi mais salvo do que ela, ninguém está mais em obrigação para com Deus. E visto que nesta situação contou apenas com os méritos de seu Filho, com razão está mais que todos em obrigação para com o Salvador, uma vez que mais que todos mereceu, em vista dos méritos do Salvador. Daí que ela mesma, mais que todos, o tenha chamado seu Salvador quando, cantando, disse: O meu espírito exulta em Deus meu Salvador. ${ }^{[45]}$

Fica, pois, a saber e presta atenção a que se se toma o pecado original só como condição de réu, e como sujeição às penas desta vida, e como perda da imortalidade e da impassibilidade, Maria contraiu esse pecado. Mas isso não é o pecado original, que nem pelo baptismo é perdoado. Alguns resíduos do pecado original foram nela não pecado. Pois, se Adão não tivesse pecado, nem ela nem seu Filho teriam vindo a este mundo sujeitos à morte e à dor. Este pecado afectou-os de algum modo a ambos. Este dano, considerada a queda de Adão, foi-vos proveitoso a vós, porque fostes redimidos pela sua morte e pelo seu sangue. $O$ dano da Mãe serviu à própria Mãe para cumular seus méritos, e mais, foi-vos proveitoso também a vós. E do mesmo modo que, removido o pecado original, se não remove a pena temporal, assim também se não preservam destas penas os que são preservados do pecado. Não foi preservado dessas penas nem mesmo Cristo nosso Senhor, o qual não estava sujeito ao pecado, porque não foi gerado daquela descendência por relação carnal, como todos os outros. Contudo, estas vossas penas não lhe eram impostas como penas, do mesmo modo que se Deus criasse um homem na pureza natural esse seria mortal e passível, mas a morte e a passibilidade não seriam para ele como pena do pecado, mas como condição da natureza. Todavia o pecado de Adão foi de algum modo o pretexto da morte de Cristo. Se, de facto, aquele não tivesse pecado, Cristo nosso Senhor não teria morrido, nem teria assumido uma carne mortal, mas assumi-la-ia tal qual a tivesse encontrado. Quando, pois, se diz nas Escrituras que ele veio para expiar os pecados, deve acrescentar-se que veio mortal e passível. Com efeito, em sua primeira intenção, Deus não determinou mandar seu Filho ao mundo em carne mortal, mas apenas em carne humana. Mas, ao ver o pecado de Adão, decretou que assumisse a carne mortal e passível. Por isso se diz que o enviou por causa dos vossos pecados de acordo não com a primeira, mas com a segunda intenção, ambas, contudo, eternas, de cuja incarnação se falará noutra ocasião. 
Nunc prossequamur incepta ${ }^{140}$.

Mors et passio Virgini Matri ${ }^{141}$ fuit poena peccati, quia ex natura suae propagationis in macula ${ }^{142}$ peccati cecidisset ${ }^{143}$ nisi Deus eam meritis passionis Filii praeuisis absolute praeseruasset ${ }^{144}$. Longe itaque distat dignitas Matris a dignitate Filii. Ille namque nec peccatum habuit nec habere potuit quia ex concubitu natus non fuit. Ipsa non habuit, sed habere potuit et pro certo habuisset nisi Deus ne haberet eam praeseruasset. [fl. 50] Sed ualde sunt rudes apud uos illi qui dicunt: "Si illa in peccato concepta non fuisset, iniquus esset Deus si eam mori permisisset" quia, sicut non est Deus iniquus quando aufert peccatum et non poenam illius, ita nec iniquus est quando preseruat a peccato et non a poena. Si enim aufert aut praeseruat, misericorditer aufert et praeseruat a peccato et, aliqua ratione suadente, non praeseruat a poena quia illa remanet in exercitium et meritum. Deus tamen, mandato facto primis parentibus uestris et non obseruato ${ }^{145}$, restituit naturam humanam in condicione propria. Et quia illa ex se mortalis erat et passibilis, talis remansit in omnibus ${ }^{146}$. Noluit enim ullum ${ }^{147}$ remedium adhibere pro ablatione poene sicut adhibuit pro ablatione culpae. Absolute enim illam ${ }^{148}$ abstulit nulli amplius in uia illa concessurus. Gratiam uero non absolute sed, ut recuperari posset, et uoluit et remedia adhibuit. Non sunt ergo illa connexa ${ }^{149}$, peccatum et mors. Non ergo mirum est si, culpa non inhaerente, et mors ac passio adhaereat $^{150}$, quia condiciones sunt naturae, peccatum minime. Dico tibi plus, si Christus uenisset in carne humana solum ut homo et non ut Redemptor, adhuc mortuus fuisset, quia pactum ${ }^{151}$ absolutum illud fuit ut, praeuaricatione illa facta, natura humana sibi dimitteretur in omibus hominibus sine ullo remedio. Immo dico tibi, si Adae soli et filiis eius ex concubitu nascentibus fuisset promissa immortalitas, tunc Christus ex pacto illo eam non habuisset, sed quia talem carnem assumpsisset qualem inuenisset. Et ita Adam peccando Christo ${ }^{152}$ immortalitatem proprie non abstulit, quia nec pro illo acceperat. Mariae uero abstulit, quia pro ipsa $^{153}$ acceperat. Christo tamen eam indirecte abstulit quia, auferendo eam omnibus $^{154}$ filiis suis ex quibus Christus secundum carnem descensurus erat, abstulit eam et ipsi, quia talem carnem assumpturus erat qualem inueniret. Mors ergo et passio non ${ }^{155}$ praesupponunt ${ }^{156}$ culpam originalem filiis Adae inhaerere, sed uel inhaesisse uel inhaerere potuisse ${ }^{157}$, ipsi tamen Adae pro certo inhaesisse.

140 prossequamur] prossequimur $N V$; incepta] incerta $Q \mathbf{1 4 1}$ Virgini Matri] beatae Virgini $N$ 142 in macula] in maculam $I$; immaculata $J 143$ cecidisset] incurrisset $Q 144$ praeseruasset] praeseruaret $Q$; praeseruasset alias praeuenisset $O 145$ obseruato] seruato $I L 146$ omnibus] hominibus (M sup. ras.) $O Q 147$ ullum] illum $V 148$ illam] illa JMOV; illa dona Q 149 connexa] connexa sed separata $I L O Q 150$ adhaereat] adueniant $I 151$ pactum] peccatum $J L 152$ Christo] Christi $Q V 153$ abstulit, quia nec pro illo acceperat. Mariae uero abstulit quia pro ipsa] abstulit, $\rightarrow$ 
Dêmos agora seguimento àquilo que começámos.

A morte e a paixão foram para a Virgem Mãe pena do pecado porque, em razão da natureza da sua geração, teria caído na mácula do pecado se Deus, pelos méritos previstos da Paixão de seu Filho, a não tivesse preservado de modo absoluto. E, por isso, a dignidade da Mãe está muito longe da dignidade do Filho. Ele não só não teve pecado como não o pôde ter, porque não nasceu da união da carne. Ela não o teve, mas podia tê-lo e tê-lo-ia por certo se Deus a não tivesse preservado para que o não contraísse. [fl. 50] Muito ignorantes são, porém, entre vós aqueles que dizem: "Se ela não tivesse sido concebida em pecado, Deus seria injusto se permitisse que ela morresse", porque, do mesmo modo que Deus não é injusto quando apaga o pecado e não apaga a pena que lhe cabe, também não é injusto quando preserva do pecado e não da pena. Se realmente apaga ou preserva, misericordiosamente apaga e preserva do pecado e, por efeito de qualquer razão, não preserva da pena, já que ela se mantém para nossa provação e mérito. Deus, enfim, dado aos vossos primeiros pais o mandamento e por eles não cumprido, restituiu a natureza humana à sua condição própria. E uma vez que ela era, de si, mortal e passível, assim se manteve em todos. Não quis, de facto, usar de nenhum remédio para a ablação da pena como usou para a ablação da culpa. Retirou-a, realmente, de forma absoluta para jamais a atribuir nesta vida a quem quer que seja. Mas a graça não a retirou de forma absoluta, mas não só quis como utilizou remédios para que pudesse ser recuperada. Por conseguinte, o pecado e a morte não estão ligados entre si. Não é, pois, de admirar se, não havendo culpa, estão presentes a morte e o sofrimento, uma vez que são condição da natureza, e o pecado não. Digo-te mais, se Cristo tivesse vindo na carne humana apenas como homem e não como Redentor, ainda estaria morto, porque foi estabelecido o pacto segundo o qual, cometida a falta, a natureza humana seria abandonada a si própria em todos os homens, sem qualquer remédio. E digo-te ainda, se só a Adão e aos filhos nascidos da união da carne tivesse sido prometida a imortalidade, então Cristo dela não gozaria em razão desse pacto, mas porque tinha assumido a carne tal como a encontrara. E, assim, Adão, ao pecar, não privou propriamente Cristo da imortalidade, uma vez que a não havia recebido em seu favor. Mas retirou-a a Maria, porque a recebera em favor dela. Todavia, indirectamente roubou-a também a Cristo, já que, roubando-a a todos os seus filhos, dos quais Cristo havia de descender segundo a carne, lha roubou também a ele, porque haveria de assumir a carne tal como a encontrasse. A morte e o sofrimento não pressupõem que a culpa original é inerente aos filhos de Adão, mas que foi ou poderia ter sido, ao passo que, de certeza, foi inerente a Adão.

$\leftarrow$ quia pro ipsa $J V 154$ omnibus] ab hominibus $Q 155$ quia talem (...) passio non] quia talem non $V 156$ praesupponunt] praesupponit $I L$; praesupponunt malitiam originalem amissam neque $Q$ 157 potuisse] potuisse uel in illis esse $Q$ 
Aliud etiam Deus absolute decreuit ut nullus regnum caeleste ${ }^{158}$, quantacumque sanctitate fulgeret, intraret ante Christum Saluatorem omnium. Frustra igitur inter uos quaeritur si Maria ante Filii mortem mortua fuisset an ad caelos conscendisset $^{159}$. Dico tibi quod non, quia decretum erat ut ipse esset primogenitus mortuorum et princeps regum terrae, hoc est, omnium sanctorum et quod nullus hominum ${ }^{160}$ uita beata uiueret antequam Deus Homo moreretur.

Redeamus ${ }^{161}$ ad proposita uerba.

Si uos peccatum originale hunc reatum qui est ${ }^{162}$ obnoxietas mortis uocaretis, Maria Virgo in peccato originali concepta fuisset. Sed tunc peccatum originale per baptismum non deleretur ${ }^{163}$, quod est absurdum, quia tunc staret simul gratia et peccatum originale. Si uero peccatum originale esset illa morbida qualitas uel fomes aut lex carnis uel membrorum, etiam illud dici non potest peccatum, quia talis lex carnis est in hominibus etiam post baptismum et stat cum gratia, quia habere aliam legem repugnantem ${ }^{164}$ legi mentis est condicio naturae humanae sicut et mortalitas. Et, facto peccato, humana natura quo ad hoc posita est in suis proprietatibus et restituta condicionibus suis. Vnde, natura destituta, fuit etiam restituta. Deserta enim et priuata donis supernaturalibus ${ }^{165}$, restituta fuit donis naturalibus. Illa quoque [f1. 51] lex membrorum non est in mente aut ratione uel uoluntate, sed potius in sensitiua parte, in qua ponere peccatum est absurdum. Animaduerte tamen fomitem illum non fuisse in Virgine gloriosa cui Deus tantam gratiam dederat ut in ea aequalis, immo et maior tranquilitas esset quam in primis parentibus uestris ante peccatum fuerat. Et miror de quibusdam doctoribus uestris qui dicunt nullum hominem umquam concupiuisse illam, quamuis esset pulcherrima mulierum. In quo eos non damno, sed miror quare ponunt $^{166}$ in ea fuisse talem fomitem et postea sopitum uel extinctum. Si enim Deus noluit ${ }^{167}$ alios eam concupiscere posse, quare fomitem talem in ea, ut illicite concupiscere posset, dimisisset? Habuit tamen illum eo modo quo et Adam ante peccatum remote non propinque, quia habuit naturam quae secundum sensum nouit repugnare et resistere rationi. Talis ergo morbida qualitas quam fingunt a uoluntate carni inflictam ${ }^{168}$, quae reuera non est nisi condicio naturae ${ }^{169}$ donata, non est peccatum uel, si uis ut sit peccatum, non fuit in Virgine sicut nec in Adam antequam peccasset.

Si uero peccatum originale dixeris ${ }^{170}$ concupiscentiam, hoc est, ipsam sensuum cupidinem ${ }^{171}$ qua cupiunt contraria rationi uel ipsam pronitatem ad concupiscendum

158 caeleste] caelorum $Q 159$ conscendisset] ascendisset $P Q 160$ hominum] homo $L Q 161$ Redeamus] Redeam $P 162$ qui est] quod est $L$.; qui est anxietas hominis et $Q 163$ deleretur] tolleretur $Q \quad 164$ repugnantem] repugnante $J M V 165$ donis supernaturalibus] muneribus supernaturalibus $I L$ ( $M$ in marg. a. m.) $Q$; donis spiritualibus $V 166$ ponunt] ponuntur $L V \rightarrow$ 
Outra coisa decretou Deus ainda, de modo absoluto, que ninguém, por mais santo que fosse, entraria no reino do Céu antes de Cristo, Salvador universal. Em vão, portanto, se discute entre vós se Maria tivesse morrido antes da morte de seu Filho se teria subido ao Céu. Digo-te que não, porque estava decretado que ele seria o primogénito dos mortos e o Príncipe dos reis da Terra, isto é, de todos os santos, e que nenhum homem viveria na vida eterna antes que o Deus Homem tivesse morrido.

Voltemos ao tema proposto.

Se vós chamásseis pecado original à condição de réu, que é a sujeição à morte, teria a Virgem Maria sido concebida em pecado original. Mas então o pecado original não seria apagado pelo baptismo, o que é absurdo, porque então coexistiriam o pecado original e a graça. Mas se o pecado original fosse o estado de doença, ou a inclinação ou lei da carne ou do corpo, ainda esse se não pode considerar pecado, porque essa lei da carne existe nos homens mesmo depois do baptismo e coexiste com a graça porque, experimentar uma lei que se opõe à lei do espírito, é condição da natureza humana como o é a mortalidade. $\mathrm{E}$, cometido o pecado, a natureza humana foi, neste ponto, restabelecida nas suas características e devolvida às suas condições. Daí que a natureza decaída fosse de novo restituída. Abandonada e privada dos dons sobrenaturais, foi restituída aos dons naturais. Também [fl. 51] a lei do corpo não reside na mente ou razão, ou na vontade, mas antes na parte sensitiva, na qual é absurdo situar o pecado. Nota, porém, que essa tendência não existiu na Virgem gloriosa, a quem Deus havia dado tão grande graça que nela havia tranquilidade geral e até maior do que tinha havido nos vossos primeiros pais antes do pecado. E admiro-me de alguns dos vossos doutores que dizem que homem algum alguma vez a desejou, embora ela fosse a mais bela das mulheres. No que não os condeno, mas admiro-me porque dizem que nela existiu tal inclinação e, depois, que foi adormecida ou extinta. Se realmente Deus não quis que outros a pudessem desejar, porque teria deixado nela essa inclinação para que pudesse ilicitamente desejar? Teve-a, realmente, do mesmo modo que Adão antes do pecado, remota e não proximamente, porque teve a natureza que, segundo o modo de sentir, soube revoltar-se e resistir à razão. Esse estado doentio, que se supõe infligido à carne pela vontade, é, na realidade, apenas condição atribuída à natureza, não é pecado ou, se quiserem que seja pecado, não existiu na Virgem, como nem sequer em Adão antes de haver pecado.

Mas se se considerar pecado original a concupiscência, isto é, o próprio desejo dos sentidos pelo qual desejam coisas contrárias à razão, ou a tendência para de-

$\leftarrow 167$ noluit] uoluit $Q \mathbf{1 6 8}$ a uoluntate carni] a uoluntate carnis $P$, a uoluptate carnis $Q$; inflictam] inflicta $I J L V 169$ naturae] naturae sensu et ratione $I L N O Q 170$ dixeris] dixeritis $Q 171$ cupidinem] cupuditatem $L$ 
contra rationem, dico tibi, bone uir ${ }^{172}$, quod nec concupiscere neque pronitas talis est peccatum in se. Ratio est quia peccatum in se sumptum est in sola uoluntate et non in uiribus sensitiuis ${ }^{173}$ nisi prout a uoluntate procedunt. Quod si uis illam esse peccatum, illa non fuit in Virgine Matre, quae neque concupiuit neque pronitatem in sensibus habuit concupiscendi ${ }^{174}$, quia tunc habuisset tyrannum et legem carnis. Sed dices mihi, concupiscentia quae est in uoluntate condelectante et congaudente sensui et complacente eidem, illa est peccatum originale. Et ego dico tibi quod illa est in uobis propter peccatum originale. $\mathrm{Si}^{175}$ enim pater uester non peccasset, uoluntas uestra illicitas condelectationes non admisisset ${ }^{176}$, immo ille in sensu ratione ${ }^{177}$ praeueniente et moderante non fuissent. Si quoque talis concupiscentia condelectationis illicite peccatum esset uel pronitas ad sic condelectandum, adhuc illa in Dei Genitrice non fuit. Neque enim condelectata est prauae suggestioni sensus, qua sugestione caruit, neque ad condelectandum ${ }^{178}$ prona fuit. Si postremo peccatum originale priuationem illius qualitatis dixeris qua uoluntas et appetitus tamquam freno ${ }^{179}$ quodam, ut uestri dicunt, cohibentur ${ }^{180}$ ab illicitis desideriis, quam qualitatem nos alias diximus uocari secundam qualitatem et iustitiam originalem, quae et frenum quasi erat et alio peccato quam illo mortifero illius esus, homine peccante, erat remedium in Deum redeundi, si priuationem talis qualitatis peccatum originale uocaueritis, prout plerique uestrum et quos acutiores aestimatis uocant, tunc Virgo illa uidebitur contraxisse peccatum originale, quia talis iustitia nunquam fuit sibi reddita. Ergo tali iustitia fuit priuata cuius erat debitrix eo quod ${ }^{181}$ primus pater etiam pro ea ipsam acceperat cum pacto et amisit ${ }^{182}$ etiam pro ea [f1. 52], pacto non seruato.

Est namque, ut uestri suptiliter dicunt, peccatum originale priuatio iustitiae originalis debitae, ex eo quia a primo patre ${ }^{183}$ pro filiis acceptae atque pro eisdem amissae, quia in quantum ${ }^{184}$ Adam eam pro se accepit et amisit, non peccato originali, sed actuali peccauit et tamen fuit debitor illius. Dico tibi quod, sicut alii purgantur a tali priuatione ${ }^{185}$ sine iustitiae talis restitutione, ita et illa praeseruari $^{186}$ potuit sine talis iustitiae restitutione ${ }^{187}$. Si enim restituitur aequiualens uel forsan et melius, priuatio ablata est sicut si priuato sacerdotio restitueretur ${ }^{188}$ episcopatus, et priuato decem restituantur ${ }^{189}$ totidem alii uel centum alii. Non amplius priuatus est. Dedit certo Deus Genitrici suae, ab aeterno in mente et ex tempore in re, aliquid illi iustitiae aequiualens, immo aliquid melius et maius. Nunquam ergo, nec in mente eius nec in re, priuata fuit tali iustitia. ${ }^{190}$ Dico tibi

172 bone uir] bene uere $V \mathbf{1 7 3}$ sensitiuis] sensibilibus $Q \mathbf{1 7 4}$ concupiscendi] concupiscentem $P 175$ peccatum originale. (...) originale. Si] peccatum originale. Si $L \mathbf{1 7 6}$ admisisset] amisisset O (sup. lin. a. m.) $V 177$ ratione] rationem $P \quad 178$ ad condelectandum] condelectandi $I 179$ freno] frenum $P 180$ cohibentur] cohibebatur $I L O$; cohibet $P$; cohiberetur $Q$; cohibeatur $V 181$ fuit priuata cuius erat debitrix eo quod] fuit priuata eo quod $P \quad 182$ amisit] amisisset $L Q 183 \rightarrow$ 
sejar contra a razão, digo-te, bom homem, que nem o desejar nem essa tendência são, em si, pecado. A causa reside em que o pecado, tomado em si, radica só na vontade e não nas forças sensitivas senão na medida em que procedem da vontade. Quanto a isso, se se quiser que seja pecado, essa tendência não se achou na Virgem Mãe, que nem desejou, nem teve nos seus sentidos a tendência para desejar, porque então teria também como tirano a lei da carne. Mas, dir-me-ás, a concupiscência que se situa na vontade que, por sua vez, se regozija e folga com os sentidos e com eles se compraz, essa é que é o pecado original. E eu digo-te que ela existe em vós por causa do pecado original. Se, de facto, o vosso pai não tivesse pecado, a vossa vontade não admitiria prazeres ilícitos, mais, eles não existiriam nos sentidos que a razão previne e governa. Se ainda fosse pecado a concupiscência do comprazimento ilícito ou a tendência para assim se comprazer, ainda essa não existiu na Mãe de Deus. Nem se comprouve nas más sugestões dos sentidos, de que foi isenta, nem foi propensa a se comprazer. Se, por fim, se considerar pecado original a privação da qualidade pela qual a vontade e o desejo são impedidos dos desejos proibidos como que por um freio, como dizem os vossos, qualidade que nós, noutro lugar, dissemos chamar-se segunda qualidade e justiça original, que era como que um freio e era o remédio do regresso a Deus se o homem caísse em pecado diferente do mortífero pecado de haver comido o fruto proibido, se chamardes pecado original à privação dessa qualidade, como a maior parte dos vossos que considerais mais subtis chama, parecerá então que a Virgem terá contraído o pecado original, já que essa justiça nunca lhe foi restituída. Portanto, foi privada dessa justiça, de que era devedora pelo facto de o primeiro pai a haver recebido sob condição também para ela, e também em relação a ela a perdeu uma vez que o [f1. 52] acordo não foi respeitado.

O pecado original é, pois, como subtilmente dizem os vossos, a privação da justiça original devida, dado o facto de haver sido recebida pelo primeiro pai a favor dos filhos e em relação a eles também perdida já que, enquanto Adão a recebeu e a perdeu para si, não incorreu no pecado original, mas no actual e, todavia, foi seu devedor. Digo-te que, do mesmo modo que alguns são justificados dessa privação sem a restituição da justiça, assim também Maria pôde ser preservada sem a restituição dessa mesma justiça. Se, com efeito, se restitui o equivalente ou talvez até mais, a privação deixa de existir, do mesmo modo que se se restituísse o episcopado àquele que foi privado do sacerdócio, e ao privado de dez se restituíssem outros tantos ou outros cem, não há, de modo nenhum, privação. Deus deu, realmente, a sua Mãe, desde toda a eternidade, na

$\leftarrow$ patre] parente $L Q 184$ in quantum] numquam $N 185$ priuatione] purgatione $P$ 186 praeseruari] reseruari $J V 187$ restitutione, (...) iustitiae restitutione. Si enim] restitutione. Si enim $L N Q 188$ restitueretur] restituatur $I L V 189$ restituantur] restituatur $L V$, restituerentur $Q, 190$ priuata fuit tali iustitia.] priuata fuit tali iustitia. Sed quid sit peccatum originale secundum ueritatem iam tibi declaraui $M$ ( in marg. a. m.) $N O Q$ 
plus, quod priuatio talis iustitiae non est proprie peccatum si non ea, sed alia homo erat gratus Deo, prout alias diximus.

Qui tamen reatum et priuationem cuiuscumque doni peccatum dicunt, possunt etiam priuationem illam peccatum appellare. Et eo maxime quia prius Adam amiserat gratiam ${ }^{191}$ quam comedisset. Et per comestionem mortem incurrerat, per quam et gratia priuatus fuisset si tunc illa infuisset ${ }^{192}$, et secunda qualitate spoliatus fuit quae adhuc sibi inhaerebat. Iccirco, comedendo, utraque qualitate se spoliauit et filios suos, sicut utramque ${ }^{193}$ pro se acceperat et pro filiis. Sed priorem illam ut posset et ipse et filiii ${ }^{194}$ recuperare in seipsa, remedium adhibitum est, posteriorem minime. Sed, recuperata priore illa, alterius amissio ulterius ad culpam non imputatur ${ }^{195}$, sed remanet ut poena quaedam et naturalis condicio. Dimissa enim fuit propter peccatum natura humana sibi ipsi. Illam tamen legem carnis et rebellionem Mater Domini nostri nunquam sensit quae gratia semper plena fuit. Numquam ergo ulla culpa aut macula in ipsa fuit quam Deus in suam Genitricem aeterna ${ }^{196}$ mente praeelegit.

Tunc ego: Clara sunt et credibilia, Angele Dei, testimonia tua. Sed uellem ut responderes mihi et me doceres. Si Adam acceperat iustitiam originalem pro omnibus filiis suis ex concubitu procreandis, etiam pro Matre Dei, quomodo eam potuit amittere pro omnibus et non pro illa?

Respondit: Iam dixi tibi qualiter Deus prima intentione uoluit ex tali Virgine carnem assumere et ipsam Virginem meritis Filii sui glorificare ${ }^{197}$. Voluit propter id mundum et hominem creare, cui homini creato pro se et omnibus iustitiam dedit ut illa conseruaretur in omnibus et praecipue in Maria Matre sua quam praecipue propter eam primo homini dederat. Praecipua enim cura Deo de ipsa semper fuit. Dedit homini mandatum pactumque fecit ut, si illud seruaret ${ }^{198}$, iustitiam sibi et suis conseruaret, non absolute ${ }^{199}$, sed etiam si quilibet filiorum aliquam temptationem, iam natus et adultus, uicisset. Mariae soli uoluit eam conseruare $^{200}$ absolute. Si uero mandatum non seruaret, iustitiam et gratiam sibi et posteris amitteret, quam tamen et ipse et alii, tali remedio [f1. 53] adhibito, recuperare possent ${ }^{201}$, gratiam quidem in se, illam aliam qualitatem in augmento gratiae in aliquo aequiualenti quoad redeundum ad Deum post peccatum. Et in hoc pacto solam Mariam exclusit ${ }^{202}$. Noluit enim, Adam peccante, gratiam a

191 gratiam] gratiam et commiserat peccatum $P \mathbf{1 9 2}$ si tunc illa infuisset] si tunc illa infuerit $L$; si tunc illa in eo fuisset $O$; sed tunc illa in eo fuisset $Q$; si tunc illa incurrisset $V 193$ utramque] utraque $V 194$ et ipse et filii] et ipsi et illi $P 195$ imputatur] reputatur $Q 196$ aeterna] aeterni $J V \rightarrow$ 
sua mente e a partir do tempo, na realidade, algo equivalente a essa justiça, e até algo melhor e maior. Nunca, pois, nem na sua mente, nem na realidade foi privada dessa justiça. Digo-te mais, que a privação dessa justiça não é propriamente pecado se, como noutro lugar dissemos, o homem se tornava grato a Deus não por ela, mas por outra.

Os que, todavia, chamam pecado à pena e à privação de qualquer dom, podem também chamar pecado a essa privação. E principalmente porque Adão tinha perdido a graça antes de ter comido o fruto proibido e, por ter comido, incorrera na morte pela qual não só seria privado da graça, se nele se mantivesse então, como foi espoliado da segunda qualidade, que ainda estava presente nele. Por isso, ao comer, privou-se a si e a seus filhos de ambas as qualidades, do mesmo modo que em seu favor e em favor dos filhos as havia recebido. Mas, para que quer ele, quer os filhos pudessem recuperar a primeira em si mesma, foi usado um remédio que se não usou em relação à segunda. Recuperada, porém, a primeira, a posterior perda da segunda não se imputa à culpa, mas subsiste como uma certa pena e condição natural. A natureza humana, por causa do pecado, foi entregue a si mesma. Nunca, contudo, a Mãe de nosso Senhor, que sempre foi cheia de graça, sentiu a lei e a rebelião da carne. Nunca, pois, culpa alguma ou alguma mancha existiu naquela que Deus, em sua mente eterna, antecipadamente escolheu para sua Mãe.

São claros e dignos de crédito, ó anjo de Deus, disse eu, os teus testemunhos. Mas gostaria que me respondesses e me esclarecesses. Se Adão tinha recebido a justiça original para todos os seus filhos a serem nascidos da união carnal e também para a Mãe de Deus, como pôde perdê-la em relação a todos e não em relação a ela?

Já te disse, respondeu, de que modo quis Deus em sua primeira intenção assumir desta Virgem a carne e glorificar esta mesma Virgem com os méritos de seu Filho. Quis, por isso, criar o mundo e o homem, homem a quem, uma vez criado, concedeu a justiça em seu favor e em favor de todos, a fim de que em todos e sobretudo em Maria, sua Mãe, por causa de quem, principalmente, a concedera ao primeiro homem, ela fosse conservada. Deus teve sempre em relação a ela um cuidado especial. Deu ao homem um mandamento e estabeleceu um pacto que, se o guardasse, conservaria a justiça em seu favor e em favor dos seus, não de forma absoluta, mas ainda se algum dos filhos, já nascido e adulto, vencesse alguma tentação. Só em relação a Maria a quis conservar de modo absoluto. Mas, se não observasse o mandamento, perderia para si e para os descendentes a justiça e a graça que, todavia, quer ele, quer os outros, poderiam recuperar, com o recurso ao referido remédio, [f1. 53] a graça, em si mesma, a segunda qualidade, para

$\leftarrow 197$ glirificare] sanctificare $V 198$ seruaret] conseruaret $I L 199$ seruaret, (...) conseruaret, non absolute] seruaret non absolute $I L \mathbf{2 0 0}$ conseruare] comprobare $Q 201$ possent] posset $M P V 202$ exclusit] excludit $V$ 
sua Genitrice excludere nec eam filiam ${ }^{203}$ ire uel maledictionis facere priuilegio speciali, quae tamen ex se sicut et alii illud merebatur ${ }^{204}$. Ideo dici poterat filia ire ex propagine ${ }^{205}$ et filia maledictionis. Et ad hoc aspiciebant omnes sancti doctores uestri qui eam in peccato conceptam dixerunt. Vnde ${ }^{206}$ non errauerunt, quia uere, ratione ortus sui, in peccato concepta fuit. Sed illi errant qui dicunt eam praeseruatam non fuisse. Aliud enim est dicere sic ex se fuisse ${ }^{207}$, aliud sic fuit. Excepit ergo illam bonitas Dei ne illam quam in matrem ${ }^{208}$ prima intentione elegerat, inimicam aliquando cogitaret. Dixit ergo homini Deus: Si mandatum non seruaueris, gratiam amittes irrecuperabiliter ${ }^{209}$ et tu et filii ex te propagandi, nisi remedium adhibueritis recuperandi quod uobis dabo. ${ }^{210}$ Vnicam tamen et dilectam Matrem excipio, quam huic generali edicto subiacere ${ }^{211}$ nolo quia Matrem eam elegi, Genitricem habere statui. Filii mei praeuisa merita uos liberabunt ${ }^{212}$, apposito remedio uel propriae motionis in me uel sacramenti susceptionis, Genitricem meam absolute eripient ${ }^{213}$ quia maculam in ea uidere nolo, maledictam existimare et inimicam respuo.

Adam ergo comedente ${ }^{214}$, et ipsum et omnes filios eius ex concubitu procreatos 215 tamquam filios ire et maledictionis ab aaeterno tempore illo aspiciebat Deus et eos tamquam suos inimicos intuebatur quos ab eterno tempore ex quo Adam creatus est ut amicos sub condicione intuebatur. Et ante creationem Adae, quia nihil adhuc eis uolebat ${ }^{216}$, nec ut amicos nec ut inimicos uidebat. Genitricem tamen suam nunquam toruo oculo aspexit, nunquam abhorruit, nunquam contempsit, nunquam abiecit. Ab aeterno ${ }^{217}$ denique Ioannem Baptistam pro tempore quo patri suo incensum in Templo offerenti ${ }^{218}$ ego apparui et dixi: "Nascetur tibi filius priuilegio speciali”, Deus noluit subiici peccato originali, sed absoluit eum ab illo tunc antequam conciperetur sicut et multos alios absoluit. Omnes tamen dicuntur concepti in peccato originali, quia omnes, quando Adam peccauit, fuerunt condemnati et gratia priuati et pro inimicis habiti et maledictioni subiecti, praeter Dominam et Reginam nostram.

Do tibi similitudinem ${ }^{219}$ : Est princeps magnus qui habet seruum natura suum ${ }^{220}$. Tamen benignitate sua erus non uult eum pro seruo, sed pro filio cum pacto, si fecerit aliquid quod sibi mandaret, promittendo quod si pactum seruaret [f1.

203 filiam] filiae $J \mathbf{2 0 4}$ sicut et alii illud merebatur] sicut illi alii merebatur $N 205$ propagine] propagatione $O \mathbf{2 0 6}$ Vnde] Vestri $Q \mathbf{2 0 7}$ fuisse] fuisset $I 208$ in matrem] iam in matrem Dei $N$ 209 amittes irrecuperabiliter] amittas irrecuperabiliter $J$; amittes irrecuperabilem $N P 210$ uobis dabo.] uobis dabo scilicet per susceptionem sacramentorum et fidem parentum $Q 211$ subiacere] $\rightarrow$ 
o aumento da graça, em algo equivalente, no que ao retorno a Deus depois do pecado se refere. E, neste pacto, apenas exceptuou Maria. Não quis, pois, quando Adão pecou, pôr a graça fora do alcance de sua Mãe, nem, por um privilégio especial, torná-la filha da ira ou da maldição. Ela que, de si, merecia isso como todos os outros. Por isso, por ter sido gerada, poderia ser considerada filha da ira e filha da maldição. E era isto que tinham em mente todos os vossos santos doutores que afirmaram que ela havia sido concebida em pecado. Daí que não tenham errado, porque, de facto, em razão do seu nascimento, foi concebida em pecado. Erram, porém, aqueles que dizem que não foi preservada. Pois uma coisa é dizer que, por si mesmo, foi assim, outra coisa é ter sido assim. Exceptuou-a a bondade de Deus para não vir alguma vez a olhar como inimiga aquela que, na sua primeira intenção, escolhera para Mãe. Disse, pois, Deus ao homem: Se não guardares o mandamento, perderás irrecuperavelmente a graça tu e os filhos a serem de ti gerados, a menos que recorrais ao remédio da recuperação que vos darei. Exceptuo, porém, como única e dilecta, a minha Mãe, a quem não quero submeter a este edito geral, visto que a escolhi para Mãe e como Progenitora decidi tê-la. Os méritos previstos de meu Filho libertar-vos-ão a vós, acrescentado o remédio do próprio movimento para mim ou da recepção do sacramento; libertarão de modo absoluto a minha Mãe, porque nela não quero ver mácula, recuso considerá-la maldita e inimiga.

Portanto, tendo Adão comido do fruto proibido, Deus, desde aquele tempo eterno, considerava-o a ele e a todos os seus filhos gerados da carne como filhos da ira e da maldição e olhava-os como seus inimigos, eles a quem, desde o tempo eterno em que Adão foi criado, olhava como amigos sob condição. E, antes da criação de Adão, porque nada tinha contra eles, não os via nem como amigos nem como inimigos. Mas a sua Mãe nunca a olhou com maus olhos nem lhe teve aversão, nunca a desprezou nem a enjeitou. Finalmente, Deus não quis, desde toda a eternidade, que João Baptista - a partir do momento em que eu apareci a seu pai, que no Templo estava a oferecer o incenso e lhe disse: "Vai nascer-te um filho por um privilégio especial" - fosse sujeito ao pecado original, mas libertou-o dele antes de ser concebido, do mesmo modo que libertou muitos outros. Todos, porém, se consideram nascidos em pecado original porque todos, quando Adão pecou, foram condenados, privados da graça, havidos como inimigo, sujeitos à maldição, com excepção da Senhora e Rainha nossa.

Dou-te um exemplo: Era uma vez um grande príncipe que tinha um servo que lhe pertencia por nascimento. Todavia, na sua bondade, o senhor não o quis como servo, mas como filho. Com uma condição, se fizesse uma coisa que lhe

$\leftarrow$ subiectam $P$; subiicere $Q 212$ liberabunt] alleuabunt $P 213$ eripient] excipiens $N$; eripiens $P$; excipiam ob ipsa eadem merita $Q$,; eripiam $V \mathbf{2 1 4}$ comedente] comedendo $P 215$ procreatos] procreandos $O$; creandos $Q 216$ uolebat] uidebat $I L 217$ nunquam abiecit. Ab aeterno] nunquam abiecit ab aeterno $I 218$ offerenti] offerendi $V \mathbf{2 1 9}$ Do tibi] Iterum dico tibi $Q 220$ suum] seruum $Q$ 
54] ipsum pro filio et non pro seruo et omnes ex eo propagatos se habiturum. Si non seruaret ${ }^{221}$, omnes non solum ut seruos, sed ut inimicos se reputaturum, unico excepto. Ille seruus natura domini sui non seruauit iussa. Iussit dominus ut esset seruus et inimicus et ipse et tota posteritas sua, semper unum ex posteris sui $^{222}$ gratia excipiendo. Tunc omnes pro tempore illo quotquot nascituri essent ex illo pro inimicis habiti sunt quandocumque existerent et nascerentur. Posset tamen dominus ille misereri alicui ${ }^{223}$ ex posteris postquam nati sunt et antequam nati essent, immo antequam reuera conciperentur. Posset namque parentibus iam existentibus et sibi reconciliatis ${ }^{224}$ dicere: "Volo ut filius ex uobis proditurus sit liber et amicus", quem tamen in mente sua pro temporibus praeteritis habuerat ${ }^{225}$ pro inimico.

Scito et animaduerte, amice Dei, me Gabrielem et alios socios meos quam plurimos, nocte illa qua Genitrix Domini nostri fuit concepta, affuisse et cooperatos fuisse miro et ineffabili modo circa materiam conceptionis illius purissimae. Concubitus illorum fuit castus, sanctus, immaculatus. Vos ista immunda iudicatis et non recordamini quod ea quae Deus praecipit immunda esse non possunt, et quod quae in paradiso et in statu inocentie fuissent immunda ${ }^{226}$ dici non possunt, et omnia munda mundis. Nos ad dispositionem et seminis et sanguinis et corpusculi illius multa, prout potuimus, fecimus, purgando, abluendo, resecando, tribuendo, benedicendo et sanctificando quantum poteramus ${ }^{227}$ et ad quanta nostra uirtus se extendebat. Ad lacrimas quoque sanctorum et desideria aspiciebat Deus.

Voluit enim Deus nos pro modulo nostro esse suos coadiutores ad hoc ut maior amicitia esset inter nos et ipsos ${ }^{228}$. Venerabilius ualde et uenustius fuit corpus illius Virginis Genitricis quam Euae ${ }^{229}$ omnium uiuentium Matris. Caro illa et commembra et omnes partes sui corporis fuerunt perfecte dispositae ${ }^{230}$ ita ut nihil quasi diferrent ${ }^{231}$ a dispositione corporis Christi, nisi quia haec feminini sexus, ille masculini erat. Manus, pedes, digitos, os et oculos ${ }^{232}$ et alia membra paene eadem habebant et non differebant nisi in illis accidentibus quae mulieri incongrua ${ }^{233}$ essent. Caro unius erat caro alterius. Sed multa decent ${ }^{234}$ masculum ${ }^{235}$ quae non adaptantur feminae, et multa conueniunt feminae quae masculo non conueniunt, immo sit $^{236}$ turpe talia ipsum habere. Dico tibi plus, quod Deus uoluit ut corpus Matris gratiae et consolationis fieret et formaretur

221 seruaret] praeseruaret $N 222$ sui] suis $P$; suis sua $Q 223$ alicui] alicuius $Q 224$ reconciliatis] reconciliantis $J \mathbf{2 2 5}$ habuerat] habuerit ILP; habuisset $N O Q 226$ immunda dici non possunt] uerecunda esse non possunt neque dici $Q \mathbf{2 2 7}$ poteramus] potuimus $Q 228$ ipsos] uos $L$; ipsam $Q$ 229 Euae] Eua $M V 230$ dispositae] dispossita $P Q 231$ differrent] differret $J P Q 232$ os et oculos] hos et illos IJLNOV; os et illos $P 233$ incongrua] congrua JNPQV 234 decent] decet JMPV 235 masculum] masculus $J$; masculo $L \mathbf{2 3 6}$ sit] esset $Q$ 
mandasse, prometendo que, se guardasse o combinado, [f1. 54] haveria de tê-lo como filho e não como servo, a ele e a todos os seus descendentes. Se o não guardasse, considerá-los-ia a todos não só como servos, mas como inimigos, com uma única excepção. Aquele, servo por nascimento, não cumpriu as ordens do seu senhor. Ordenou o senhor que se tornasse servo e inimigo ele e toda a sua posteridade, exceptuando sempre um dos descendentes, por generosidade sua. Então, todos quantos a partir daí houvessem de nascer dele, foram todos tidos por inimigos em qualquer tempo que existissem e nascessem. Poderia, contudo, aquele senhor apiedar-se de algum dos vindouros depois de nascerem e antes de haverem nascido e até antes de realmente serem concebidos. Poderia, com efeito, dizer aos pais, existentes já e consigo reconciliados, "Quero que o filho que de vós há-de nascer seja livre e amigo", filho que, contudo, na sua mente tivera no passado como inimigo.

Fica a saber e presta atenção, amigo de Deus, que eu Gabriel e a grande maioria dos meus companheiros, na noite em que a Mãe de Deus foi concebida, estávamos presentes e colaborámos de modo admirável e inefável sobre a matéria dessa puríssima concepção. A união deles foi casta, santa e imaculada. Vós considerais estas realidades impuras e não vos lembrais de que aquilo que Deus ordenou não pode ser impuro, e de que aquilo que existiu no Paraíso e no estado de inocência não pode considerar-se impuro, e de que tudo é puro para os que são puros. ${ }^{[46]}$ Nós contribuímos muito, conforme pudemos, para a disposição não só do sémen, como do sangue e daquele corpúsculo, purificando, lavando, aperfeiçoando, distribuindo, abençoando e santificando quanto podíamos e até onde as nossa capacidade se estendia. Deus olha também para as lágrimas e os anseios dos santos.

Quis Deus, então, que fôssemos, segundo a nossa medida, seus colaboradores, para que entre nós e eles houvesse uma maior amizade. Muito mais digno e muito mais gracioso foi o corpo da Virgem Mãe do que o de Eva, a mãe de todos os viventes. A sua carne e o conjunto dos seus membros e todas as partes do seu corpo foram perfeitamente dispostas a ponto de não se afastarem nada da disposição do corpo de Cristo senão que aquelas eram do sexo feminino e estas do masculino. Tinham quase as mesmas mãos, pés, dedos, boca, olhos e outros membros e não diferiam senão naqueles acidentes que não se adequassem à mulher. A carne de um era a carne do outro. Mas ao homem convêm muitas coisas que se não adequam à mulher, e muitas se ajustam à mulher que se não ajustam ao homem e até seria grotesco que ele as tivesse. Digo-te mais, 
perfectum et perfectius quam corpus Euae et ipsius Adae et aequalis perfectionis esset cum corpore Christi ubi non repugnabat condecentia ${ }^{237}$ sexus. Tota ergo corpore pulchra fuit et sine macula. Corpus autem eius non fuit in ictu oculi formatum et animatum sicut corpus [f1. 55] Filii eius quod uniebatur tunc cum formabatur diuinitati ${ }^{238}$. Neque tamen tantum temporis expectauit sicut corpora aliorum exspectant, sed in breui tempore, nobis coassistentibus ${ }^{239}$, illud Ioachim mundissimum semen transmissum est in uterum Annae. Et disposita et omnino mundata $^{240}$ cellula illa et sanguine ipsius Annae perfectiore et puriore ${ }^{241}$ ministerio nostro segregato, purificato et in ipsa cellula reposito et semini Ioachim unito, illi sanguini ultra mellifluam caelorum influentiam nos multa disponendo addidimus ita ut longe et incomporabiliter citius caro illa et uenae atque nerui cum ossibus plasmarentur ita quod, quae in aliis perficiuntur in multis diebus, uolente Deo et nobis subministrantibus, facta sunt omnia in sex horis uel circiter. Tunc Deus noster, magnus et potens, creauit animam perfectam, habentem omnia dona, omnem scientiam siue omnes habitus et similitudines omnium sicut et nos qui ${ }^{242}$ accipiendo unicam similitudinem diuinae uidelicet naturae omnium rerum similitidines accepisse dicimur. Antea enim nos creauerat et postmodum Adam et Euam et omnes plenos scientia. Nullus ergo scientiae habitus fuit Matri Dei denegatus, nulla naturarum similitudo. Nam et si propter peccatum Adae mortalitatem et passibilitatem accepit, quae sibi prodesse poterant, et ex pacto illo ${ }^{243}$ in omnibus hominibus relinqui oportebat quia conueniunt naturae humanae, non tamen accepit errorem aut ignorantiam illorum quae scire utile esset et ignorare perniciosum et quae Adam et Eua a principio acceperunt ${ }^{244}$ et filii accepturi erant si peccatum non interuenisset.

Fatendum igitur est omnibus Mariam Reginam nostram a principio suae creationis ita nouisse omnia sicut et Adam, immo et nos angeli nouimus. Nouerat gramaticam, dialecticam, rhetoricam, poeticam, artes mathematicas tam puras quam mixtas, tam superiores quam inferiores. Nouerat physicam ${ }^{245}$ et metaphysicam et quaecunque illis subsunt scientiae ${ }^{246}$. Nouerat optime theologiam ${ }^{247}$ et ideo omnia uerba et opera Christi conseruabat ab initio. Et quando illa fieri uidebat, conferebat in corde suo cognitionem experimentalem, quam uos uocatis intuitiuam, cum cognitione infusa, quam uocatis abstractiuam. Nouerat et omnes artes quas mechanicas $^{248}$ dicitis, nouerat omnium regiminum et unius et domus et ciuitatis ${ }^{249}$

237 condecentia] condescendentiae $Q 238$ quod uniebatur tunc cum formabatur diuinitati] quod uniebat tunc dum formabat $L$; quod uniebatur tunc conformabatur $P$; quod tunc formabatur, uniebatur diuinitati $Q 239$ coassistentibus] assistentibus IJLOPV 240 mundata] munda $V \mathbf{2 4 1}$ perfectiore et puriore] perfectiori et puriori $I L$; perfecturo et puriori $V \mathbf{2 4 2}$ qui] quia ILPV $\rightarrow$ 
que Deus quis que o corpo da Mãe da Graça e de toda a Consolação fosse feito e formado perfeito e mais perfeito que o corpo de Eva e o do próprio Adão e tivesse perfeição igual à do corpo de Cristo naquilo em que a conveniência dos sexos não era incompatível. Foi, pois, totalmente bela de corpo e sem mácula. O seu corpo, contudo, não foi formado e animado num abrir e fechar de olhos como o corpo [fl. 55] de seu Filho, que se unia á divindade no momento em que se formava. Nem esperou também tanto tempo como esperam os corpos dos outros, mas em pouco tempo, com a nossa assistência, foi o puríssimo sémen de Joaquim lançado no útero de Ana. E preparado e totalmente limpo aquele santuário e, por intervenção nossa, a mais perfeita e a mais pura, segregado, purificado e depositado nesse santuário o sangue de Ana e unido ao sémen de Joaquim, acrescentámos àquele sangue, além da suave influência do céu, muitas outras coisas, fazendo com que essa carne, as veias e os nervos com os ossos se formassem de modo incomparavelmente mais rápido, a ponto de se concretizar, querendo Deus e colaborando nós, em seis horas ou quase, tudo quanto nos outros se realiza em muitos dias. Então o nosso Deus, grande e poderoso, criou uma alma perfeita, contendo em si todos os dons, todo o conhecimento ou todas as qualidades e as imagens de todas as coisas, como nós que, recebendo uma única imagem, a saber, a da natureza divina, se considera que recebemos a imagem de todas as coisas. $\mathrm{Na}$ verdade, tinha-nos criado a nós antes e, em seguida, criara Adão e Eva, dotados, todos, da plenitude do conhecimento. Nenhum aspecto do conhecimento foi, pois, recusado à Mãe de Deus, nenhuma imagem das coisas da natureza, embora, por causa do pecado de Adão, tenha recebido a mortalidade e a passibilidade, que poderiam ser-lhe proveitosas, e, de acordo com o pacto, era conveniente que fossem deixadas em todos os homens, porque se ajustam à natureza humana. No entanto não recebeu o erro ou a ignorância daquilo que seria útil saber e danoso ignorar, e que Adão e Eva receberam desde o princípio e os filhos haveriam de receber, se o pecado não tivesse sobrevindo.

Todos devem, portanto, afirmar que Maria, Rainha nossa, desde o princípio da sua criação conhecia tudo do mesmo modo que Adão e até nós anjos conhecemos. Conhecia a gramática, a dialéctica, a retórica, a poética, as ciências matemáticas, quer puras, quer aplicadas, as mais elevadas e as menos elevadas. Conhecia a física e a metafísica e todas as ciências que com elas se relacionam. Conhecia perfeitamente a teologia e, por isso, guardava todas as palavras e acções de Cristo desde o princípio. E, quando as via acontecerem, conferia em seu coração o conhecimento experimental, a que chamais intuitivo, com o conhecimento infuso, a que chamais abstractivo. Conhecia todas as artes a que chamais mecânicas, conhecia as normas

$\leftarrow 243$ illo] illa $L N O P Q$; Dei, illum $I V 244$ acceperunt] acceperant $V 245$ physicam] physicam philophysicam $V \mathbf{2 4 6}$ quaecumque illis subsunt scientiae] quaecumque sunt sub illis scientiis $N P$; quascumque sub illis sunt scientias $Q 247$ optime theologiam] omptiotheologiam $V \quad 248$ mechanicas] mathematicas $J \mathbf{2 4 9}$ ciuitatis] ciuitates $J M$ 
seu regni regulas et iura. Nil latebat animum illum sanctum. Deum specie uel similitudine concreata sicut et nos distincte cognoscebat neque tamen uidebat nisi interdum priuilegio speciali. Quae uisio non erat permanens, sed ut quidam raptus. Omnes uirtutes ${ }^{250}$ appetitiuae sicut et intellectiuae sibi inerant. Nil boni sibi deficiebat. Sana erat mens et perfecta in corpore perfecto et sano. Tota ${ }^{251}$ ergo pulchra et tota formosa erat, tota immaculata et tota perfecta, omnibus affluens diuitiis $^{252}$. Nullus in ea [f1. 56] peccati originalis nodus, nullus culpae uenialis ${ }^{253}$ cortex fuit. Hic pontifex qui nunc est, de hac immaculata conceptione Matris ${ }^{254}$ Dei officium acceptabit, confirmabit et ut ab omnibus celebretur hortabitur. Determinare et decretum facere de immaculata conceptione cogitabit, sed non faciet neque opere complebit, quia haec reseruantur pastori ellecto ${ }^{255}$ Ecclesiae totius rectori. Nihil certe splendoris aut numinis ${ }^{256}$ defuit Domine Reginae nostrae quam laudant astra matutina, cuius pulchritudinem omnia pulcherrima mirantur. Et qui non iubilant non sunt filii Dei. Quotquot enim hoc recipiunt, datur eis potestas filios Dei fieri.

In mente diuina pro quocumque tempore immaculata fuit. In Adam peccante, quando maculari debebat, maculata non fuit. Concepta tandem grata est quae in mente grata fuerat. Immaculata in utero mansit, immaculata et quasi sine dolore matris ex utero egressa est, immaculata inter cunabula infans uagit, immaculata ambulare coepit, immaculata ${ }^{257}$ Dei Templo $^{258}$ oblata et praesentata fuit et magna uelocitate corporis et animi sanctitate gradus Templi conscendit ubi non solum miraculum de corporali ascensu fuit, sed etiam de cognitione Templi et graduum illorum et uirtutum atque uitiorum quae omnia tunc in ea esse publice patuit ${ }^{259}$. Omnes enim astantes et ministri Templi tunc agnouerunt in ea esse donum ${ }^{260}$ sapientiae, scientiae et intellectus, pietatis, consilii et fortitudinis atque timoris Domini. Tunc enim allocuta est sacerdotes et parentes et alios astantes ita quod omnes cognouerunt gratiam quae tam paruae puellae data fuerat a Domino.

Cum enim primus sacerdos eam oblatam susciperet ${ }^{261}$, dixit: Oh quam pulchram puellam obtulistis nobis! Benedicat tibi, filia, Deus!

Tunc Maria dicere coepit et aperte coram omnibus clara uoce exprimere ${ }^{262}$ : Falax est gratia et uana est pulchritudo. Mulier timens Deum, ipsa laudabitur.

250 uirtutes] uirtute $V 251$ Sana erat mens et perfecta in corpore perfecto et sano.] Sana erat, mens perfecta et corpore perfecto et sano. Tota $V$; Sana erat mens et perfecta in corpore perfecto et sana tota $L$; Sana erat mente et perfecta in corpore sano et perfecto. Tota $Q 252$ diuitiis] deliciis $V 253$ culpae uenialis] in ea peccati uenialis $Q 254$ immaculata conceptione Matris] immaculata Matre $I L V 255$ ellecto] ellecto, $3^{\circ}$ ab ipso. $J 256$ numinis] luminis $J 257$ Immaculata] Immaculato $V 258$ Dei Templo] in Templo $N 259$ publice patuit] potuerunt $V 260$ in ea esse (...) in ea esse $\rightarrow$ 
e as leis de todos e de cada um dos governos: de uma casa, de uma cidade ou de um reino. Nada escapava àquela mente santa. Conhecia a Deus distintamente como nós, em espécie ou imagem concriada, ainda que o não visse senão de tempos a tempos, por um privilégio especial. Essa visão não era permanente, mas como uma espécie de arrebatamento. Tinha em si todas as virtudes apetitivas e intelectivas. Não carecia de nada que fosse bom. Tinha uma mente sã e perfeita num corpo perfeito e são. ${ }^{[47]}$ Era, pois, toda bela e formosa, toda imaculada e toda perfeita, abundantemente dotada de todas as riquezas. Não teve em si [fl. 56] a mais leve marca do pecado original, nenhum véu de culpa venial. E o pontífice actual dará acolhimento, confirmará e exortará a que por todos seja celebrado o Ofício desta imaculada conceição da Mãe de Deus. Ponderará determinar e publicar um decreto sobre a Imaculada Conceição, mas não o fará, nem o levará a cabo, uma vez que estas coisas estão reservadas para o Pastor eleito, chefe de toda a Igreja. Nenhum esplendor, nenhuma majestade faltou à Senhora, Rainha nossa, a quem louvam os astros da manhã, cuja beleza admira tudo quanto de mais belo existe. E aqueles que se não alegram não são filhos de Deus. Mas a quantos recebem esta verdade, é-lhes dada a dignidade de se tornarem filhos de Deus. ${ }^{[48]}$

Foi na mente divina imaculada desde todos os tempos. Tendo Adão pecado, quando merecia ser manchada, não o foi. Concebida, por fim, é grata, ela que na mente de Deus fora grata. Imaculada permaneceu no ventre, imaculada e quase sem dor de sua mãe saiu do útero, imaculada, criança ainda, vagiu no berço, imaculada começou a andar, imaculada foi oferecida e apresentada no Templo de Deus e com grande celeridade de corpo e santidade de espírito subiu os degraus do Templo, onde se verificou não só o milagre da subida corporal, mas também do conhecimento do Templo e dos degraus e das virtudes e dos vícios. Tornou-se claro que todo o conhecimento dessas coisas existia nela. Na verdade, todos os presentes e os ministros do Templo reconheceram então que nela residia o dom da sabedoria, da ciência, do entendimento, da piedade, do conselho, da fortaleza e do temor do Senhor. Falou então aos sacerdotes e a seus pais e a outros presentes de tal modo que todos reconheceram a graça que havia sido dada pelo Senhor a menina tão pequena.

Recebendo-a o príncipe dos sacerdotes como oblata, disse: Oh! que bela menina nos oferecestes! Que Deus te abençoe, filha!

Maria começou então a falar e a expor em voz firme perante todos: Enganador é o encanto e vã a beleza. A mulher que teme a Deus, essa é que será louvada. ${ }^{[4]}$

$\leftarrow$ donum] in ea esse donum $P 261$ susciperet] suscepisset $Q 262$ exprimere] exprimere et lingua expedita $Q$

[47] mens sana in corpore sano.

[48] Jo 1:12.

[49] Prov 31:30. 
Noli ergo, pater animae meae, meam laudare pulchritudinem quae in corpusculo meo tenui uidetur esse. Non enim apud Deum uerum et uiuum, conditorem et plasmatorem omnium ${ }^{263}$, formositas corporis in pretio est sine pulchritudine mentis. Quando tamen pulchri et boni sunt mores, formositas corporis est quidam decor non multum necessarius ${ }^{264}$ neque tamen respuendus ${ }^{265}$. Timor Domini est initium sapientiae, humilitas est fundamentum uirtutum. Qui timet Deum pulcher ${ }^{266}$ est et faciet bona. Qui humilis est, illum respicit Dominus excelsus, illi dabit gratiam suam, quia gratia et fauor mundi falax est, ad modicum parens. Qui humilis erit, exaltabit eum et sublimabit Dominus, cui $^{267}$ superbi summe sunt exosi, humiles summe ${ }^{268}$ accepti.

Veni ad uos, patres animae meae, ut me timorem Domini doceatis et humilitatem instruatis ut possim iugiter Deo meo seruire et ei grata esse et in ipsius obsequiis assidue permanere et perseuerare. Regnum et omnem $^{269}$ huius mundi ornatum, omnes diuitias atque delicias contemno propter amorem Dei mei, regis omnium et creatoris uniuersorum. Illique dedico uitam meam, corpus meum, animam meam, uirginitatem meam ${ }^{270}$. Omnia ipse mihi dedit, omnia sibi dono, omnia sibi dedico. Voluntatem meam pono in manibus suis, in arbitrio suo. Voueo perpetuam ${ }^{271}$ Deo coram te, pater, tot testibus hic astantibus, uirginitatem ${ }^{272}$. Introibo in [f1. 57] domum Domini, ad mundi blanditias nunquam exitura. Ingrediar in atria Dei mei ubi melior est dies una super milia. Elegi abiecta potius esse in domo Dei mei quam $^{273}$ potens et excelsa habitare in tabernaculis peccatorum. Domum enim Dei decet sanctitudo in saeculum saeculi. Haec requies mea in aeternum, hic habitabo, eam enim elegi domum quae firmiter aedificata est supra firmam petram.

Scio, dignissimi patres, uos consuetos esse puellas qualis ego sum in custodiam suscipere ${ }^{274}$ deinde, tempore nubili adueniente, eas nuptui secundum legem Dei tradere. Quod ego non uitupero neque malum puto, sed mihi intus suadet animus, suadet mens a Deo mota ${ }^{275}$ ut nunquam uirum cognoscam, nunquam carnis opera experiar. Illa namque experientia et si non sit ex se mala et a Deo, qui non potest ${ }^{276}$ errare, sit pro augmento humani generis ordinata ${ }^{277}$, mihi tamen persuasum est nunquam copulari uiro, nunquam uirginitatem ullo actu ${ }^{278}$ uiolare.

263 omnium] hominum $Q 264$ formositas corporis est quidam decor non multum necessarius] corporis formositas auget decorem licet non multum sit necessarius $P 265$ respuendus] respiciendus $L Q 266$ pulcher] pulchrior $J P 267$ cui] qui $V 268$ summe] sunt $I L Q V 269$ omnem] omne $P 270$ corpus meum, animam meam, uirginitatem meam] $O$ (in marg. a. m.) 271 perpetuam] perpetuo $P \mathbf{2 7 2}$ uirginitatem] uirginitatem ut enim eam uoueam, ipse inspirauit me qui legi in hoc noluit obligari $M$ ( in marg. a. m.); ut enim eam uoueam, ipse inspirauit me qui legi in hoc uoluit obligari $N O$; ut enim eam uoueam, inspirauit me qui legi in hoc noluit obligari $Q 273$ Dei mei (...) Dei mei quam] Dei mei quam $V 274$ suscipere] recipere $N 275$ Sed mihi intus suadet animus, suadet mens a Deo mota (alias immissa $M$ in marg. $a . m$. $O$ )] Sed mihi intus suadet animam a Deo motam $Q \mathbf{2 7 6}$ non potest] nequit $Q \mathbf{2 7 7}$ ordinata] ordinata et ita posset esse bona et meritoria $Q \mathbf{2 7 8}$ actu] pacto JNP; actu etiam mentis $Q$ 
Não louves, pois, pai da minha alma, a beleza que parece existir em meu pequenino corpo. Junto do Deus Verdadeiro e Vivo, Autor e Criador de tudo, a beleza do corpo não tem, realmente, valor sem a beleza da mente. Quando, porém, são belos e bons os costumes, a beleza do corpo é um certo enfeite, não muito necessário, ainda que não deva ser desprezado. O temor do Senbor é o princípio da sabedoria, ${ }^{[50]}$ a humildade é o fundamento da virtude. Aquele que teme a Deus é belo e praticará o bem. O que é humilde, olha-o o Deus Altíssimo, dar-lhe-á a sua graça, já que a graça e o favor do mundo são enganadores, de pouco servindo. Aquele que for humilde, exaltá-lo-á e sublimá-lo-á o Senhor, a quem os soberbos são sumamente odiosos e os humildes sumamente aceites.

Vim até vós, pais da minha alma, para me ensinardes o temor do Senhor e me instruirdes na humildade a fim de que possa servir continuamente ao meu Deus e a ele me tornar grata e permanecer e perseverar incessantemente nos seus serviços. Desprezo o senhorio e toda a beleza deste mundo, todas as riquezas e delícias, por causa do amor do meu Deus, Rei Universal e Criador de todas as coisas. Consagro-lhe a minha vida, o meu corpo, a minha alma, a minha virgindade. Ele deu-me tudo, eu tudo lhe dou, tudo lhe consagro. Em suas mãos, no seu arbítrio, ponho a minha vontade. Consagro, pai, a Deus, na tua presença, sendo testemunhas todos os presentes, a minha perpétua virgindade. Vou entrar [f1. 57] na casa do Senhor para nunca sair ao encontro das delícias do mundo. Entrarei nos átrios do meu Deus onde um dia é melhor do que mil. ${ }^{[51]}$ Escolbi ser antes desprezivel na casa do meu Deus, a morar, poderosa e nobre, nas tendas dos pecadores. ${ }^{[52]}$ A casa de Deus é santa pelos séculos dos séculos. ${ }^{[53]}$ Esta é para sempre o lugar do meu repouso, aqui habitarei, pois a escolbi ${ }^{[54]}$ como a casa que está firmemente edificada sobre a rocha firme.

Sei, padres digníssimos, que estais habituados a receber em custódia meninas como eu; depois, chegado o tempo de se casarem, a dá-las em casamento segundo a Lei de Deus, coisa que eu não censuro, nem considero mal. Mas estou certa em meu coração, estou certa em meu espírito movido por Deus de que nunca conhecerei varão, nunca experimentarei as obras da carne. E, de facto, essa experiência não só não é, em si, má, como é ordenada por Deus, que não pode errar, para aumento do género humano. Mas eu estou determinada a nunca me unir a um homem, a nunca violar por acto algum a virgindade.

\footnotetext{
[50] Prov 9:10.

[51] S1 83:11,

[52] S1 83:10,

[53] S1 92:5,

[54] S1 131:14
} 
His dictis, conuertitur ad parentes et alios propinquos et cunsanguineos et sic eos alloquitur: Vale, care genitor, uale suauissima genitrix mea, ualete omnes consanguinei et propinqui mei. Relinquo uos corpore, non relinquo animo. Relinquo assiduo aspectu, non relinquo assidua meditatione. Relinquo uos propter Deum ne relinquam ${ }^{279}$ Deum propter uos. Multum debeo tibi, pater mi, et non minus tibi, dulcis Mater mea. Plurimis enim orationibus et eleemosynis me a Deo impetrastis qui me oriri disposuerat omnino, plurimos labores pro me assumpsistis ${ }^{280}$. Gratiarum actiones quantas possum uobis persoluo, nunquam uos animo relinquam, nunquam deseram in corde meo. Deo enim seruiendo, qui omnibus nobis et nascendi et uiuendi ${ }^{281}$ causa est, uobis quoque inseruiam. Ipsius ancilla sum, illi me toto corde committo. Vos autem rogo ut, me uirginitatem uouentem, in uoto meo impedire nolitis, sed adiuuare magis uelitis ${ }^{282}$. Nolite ex me fructum mortalitatis inquirere. Dedit tibi Deus, dulcis ${ }^{283}$ Mater mea, me unicam filiam. Alias noli cupere neque ab eis nepotes expectare. Ego $^{284}$ uirgo in perpetuum permanere decreui. Omnibus qui me associastis et usque ad hunc locum mecum uenistis ut me Domino in Templo eius offeretis ${ }^{285}$, gratias ago et rogo ut pro me, indigna serua Dei, orationem Deo nostro in saecula saeculorum uiuenti ${ }^{286}$ offeratis. Vale, dico omnibus.

Et sibi ad patrem et matrem accedere uolenti pro dando osculo, sacerdos primicerius adhaesit et accepit eam per brachium dicens: $O$ puella, unde tibi tanta sapientia? Vnde tanta Scripturarum nostrarum peritia? Nunquam senex sic locutus est ut tu. Nullus princeps nostrae Legis tam suptiliter locutus est. Vnde tibi tanta gratia? Vnde tantum donum?

Et omnes subclamabant ${ }^{287}$ : A saeculis saeculorum non est auditum ut puella trium annorum tanta sapientia polleret, immo quod loqui communia cum pleno intellectu sciret. Haec autem ac si in omni scientiarum genere experta fuisset loquitur.

Alii dicebant Ioachim et Annam haec illam docuisse in tam paruo et breui tempore.

Alii dicebant: Viuat Deus Israel, quod neque Ioachim neque Anna tanta sciunt, quomodo ergo docuissent ea ${ }^{288}$ quae ipsi ignorant? Scimus hoc, quod nemo docere potest quae ipse ignorat.

Alii ${ }^{289}$ dicebant arte aliqua uel humana uel demonum illa fuisse facta.

Maria uero puellula ${ }^{290}$ dicebat: [fl. 58] Nolite mirari, o mihi carissimi patres, propinqui et astantes si eo ${ }^{291}$ modo sim locuta ego, parua puella. Sed potius miremini quare omnes pueri et puellae uestrae non sic loquantur ${ }^{292}$. Notum

$\mathbf{2 7 9}$ ne relinquam] non relinquo $Q \mathbf{2 8 0}$ assumpsistis] assumptis $V \mathbf{2 8 1}$ uiuendi] moriendi $Q \mathbf{2 8 2}$ sed adiuuare magis uelitis] sed adiuuare magis $J$ ( $M$ add. sup. lin. Velitis)OP; sed adiuuate magis $Q 283$ Deus, dulcis] Deus lucis $V \mathbf{2 8 4}$ inquirere. Dedit (...) expectare. Ego] inquirere. Ego $J P Q \rightarrow$ 
Dito isto, voltou-se para os pais e outros parentes e familiares e exortou-os deste modo: Adeus, querido pai, adeus minha muito afectuosa mãe, adeus todos os familiares e parentes meus. Deixo-vos corporalmente, não vos deixo em espírito. Deixo a vossa diária presença, não deixo de em vós pensar diariamente. Deixo-vos por causa de Deus para não deixar Deus por causa de vós. Devo-te muito a ti, meu pai, e não menos a ti, minha doce mãe. Alcançastes-me de Deus com muitas orações e esmolas, de Deus que de forma absoluta havia estabelecido que eu nascesse. Por mim assumistes canseiras várias. Dou-vos quantas graças possa. Nunca vos deixarei em meu espírito, nunca vos abandonarei em meu coração. Servindo a Deus, que é a razão do nascer e do viver de todos nós, servir-vos-ei também a vós. Sou a sua serva, a ele me entrego de todo o coração. Peço-vos, porém, que, fazendo eu voto da minha virgindade, me não impeçais, mas antes me apoieis no meu voto. Não me exijais o fruto da mortalidade. Deus entregou-me a ti, querida mãe, como filha única. Não desejes outras, nem delas esperes netos. Eu decidi manter-me virgem para sempre. A todos quantos me acompanhastes e comigo viestes até este lugar para me oferecerdes ao Senhor em seu Templo agradeço e peço que oreis por mim, serva indigna, ao nosso Deus que vive pelos séculos. A todos digo, adeus!

Ao querer aproximar-se do pai e da mãe para os beijar, veio junto dela o príncipe dos sacerdotes e tomou-a pelo braço enquanto dizia: Ó menina, de onde te vem tanta sabedoria? De onde te vem tão grande conhecimento das nossas Escrituras? Nunca nenhum ancião assim falou como tu! Nenhum príncipe da nossa Lei falou com tanta subtileza! De onde te vem tão grande graça? De onde te vem tamanho dom?

E todos diziam em voz baixa: Há séculos e séculos que se não ouve dizer que uma menina de três anos fosse dotada de tanta sabedoria e, até, que soubesse falar do que é comum com pleno conhecimento. Esta fala como se fosse experiente em todos os ramos do saber.

Diziam outros que Joaquim e Ana lhe haviam ensinado tudo em tempo tão reduzido e tão curto.

Viva o Deus de Israel, diziam outros, porque nem Joaquim nem Ana têm tão grande saber. Como poderiam, pois, ensinar aquilo que eles ignoram? Isto sabemos nós, que ninguém pode ensinar o que ignora.

Outros diziam que isso acontecia por uma qualquer arte, ou humana, ou demoníaca.

Mas Maria, criança ainda, dizia: [fl. 58] Não vos admireis, meus queridos pais, amigos e vós que estais presentes, se eu, menina pequena, falei desta maneira. Admirai-vos antes porque assim não falam todos os vossos meninos e meninas.

$\leftarrow \mathbf{2 8 5}$ eius offeretis] offerentes $L$; offerretis $I O Q 286$ uiuenti] uiuente $P$; uiuentis $V \mathbf{2 8 7}$ subclamabant] simul aiebant $P 288$ ea] eam $I L N O Q V \mathbf{2 8 9}$ Alii] Aliqui $Q 290$ puellula] puella $I J L Q O V 291$ si eo] $s$ cio $N V 292$ loquantur] loquuntur $N P Q V$ 
est uobis qualiter Deus noster hominem creauit rectum. Sed ipse peccato suo immiscuit se in multas quaestiones et incidit in multas ignorantias et errores pessimos et omnibus nobis ${ }^{293}$ nociuos. Si ergo spiritum illum ${ }^{294}$ quem omnibus largiturus erat pueris et puellis, mihi non meis meritis, sed sua gratia et dono mirabili, ut hodie in conspectu uestro uidetur, Deus contulit, nolite mirari. Dico enim uobis me recordari de tempore quo anima mea corpori unita fuit et quid tunc cogitabam. Memini totius temporis quo in utero matris extiti ${ }^{295}$, quando nata sum et in cunabulis uagitus pueriles ${ }^{296}$ emisi. Hoc donum quod aliquando commune fuisset omnibus, mihi Deus concessit qui perpetuo uiuit et regnat et omnia ex se gubernat ${ }^{297}$ per gubernatorem sibi aequalem in gubernatore utrique aequali per omnia saecula saeculorum (et hic expressit ${ }^{298}$ Patrem et Filium et Spiritum Sanctum, sed ipsi non intellexerunt. Erat enim uerbum hoc absconditum ab eis).

Tunc sacerdotum ${ }^{299}$ princeps ait ad omnes: Vidimus mirabilia hodie in puella ista quae etiam sapientes et doctissimos uiros uincit. Digitus Dei est iste. A Dominio factum est istud et est mirabile in oculis nostris.

Alii sacerdotes dicebant: Pater, numquam ${ }^{300}$ audiuimus talia, non sumus digni ut haec puella resideat apud nos qui eam nec docere litteras nec mores possumus. Longe enim nobis doctior et melior est.

Alii dicebant: Si non docebitur saltem docebit. Si ipsa nostro exemplo non proficiet, nos et aliae puellae ipsius exemplo proficiemus. Intret igitur in conspectu Domini in exultatione.

Primus sacerdotum dixit: Ego simul uobiscum miror et stupeo ${ }^{301}$ de hac puella animo et corpore speciosissima et ualde cupio ut hic nobiscum esset ut doceremur ${ }^{302}$ potius quam doceremus ${ }^{303}$, proficeremus suis moribus magis quam ipsa nostris. Tamen quia uotum uirginitatis nostrae nationi et populo Dei inconsuetum emisit ${ }^{304}$, uidetur mihi contra legem Dei egisse, qui sterilibus maledixit ${ }^{305}$, quod etiam patri suo et matri accidit. Nonne patrem suum e Templo eiecimus $^{306}$, sacrificium eius abiecimus eo quod nobis indignus ex eo quod semine ${ }^{307}$ careret, qui tamen uxorem haberet, uidebatur?

Tunc Maria respondit: Deus matrimonium instituit. Deus precepit dicens: "Crescite et multiplicamini". Ego quoque uoluntate ${ }^{308}$ eius uoueo uirginitatem. Tempus nubendi mihi nondum uenit. Intrem ego in domum Domini laeta. Quando tempus nubendi aduenerit, tradetis ${ }^{309}$ me uiro, si ita Deus uoluerit, et cui ille

293 nobis] uobis $P 294$ illum] illis $V 295$ extiti] steti $Q 296$ pueriles] puerile $J 297$ ex se gubernat] exequabatur $O 298$ expressit] expresse $V 299$ sacerdotum] sacerdos $V \mathbf{3 0 0}$ dicebant: "Pater, numquam] dicebant patere: "numquam $V 301$ stupeo] ostupeo $I L$; extupeo $V 302$ doceremur] docemur $I$; doceamur $V 303$ doceremus] doceamus $V 304$ emisit] errori sit $V 305$ maledixit] maledicit $I L V 306$ eiecimus] eiciemus $O$; eiicimus $Q$, eicimus $V \mathbf{3 0 7}$ semine] semen $J$; prole $Q$ 308 Ego quoque uoluntate] Ego quoque voluntatem $I L$; Ego quoque uoluntati $N$; Ego quoque secundum uoluntatem $P$; Ex quibus uoluntatem $V 309$ tradetis] tradite $I L V$ 
Todos sabeis como Deus criou o homem recto. Mas ele, pelo seu pecado, enredou-se em muitos problemas, caiu em muita ignorância e em erros detestáveis e nocivos para todos nós. Se, pois, Deus me conferiu, não pelos meus méritos, mas pela sua graça e dom maravilhoso, como hoje se vê na vossa presença, o espírito que haveria de conceder a todos os meninos e meninas, não vos admireis. Digo-vos, realmente, que me recordo do tempo em que a minha alma foi unida ao corpo e do que então pensava. Recordo-me de todo o tempo em que permaneci no útero materno, de quando nasci e soltei no berço os vagidos de criança. Concedeu-me o Deus que vive e reina para sempre e, a partir de si, tudo dirige por intermédio de um timoneiro igual a si num timoneiro a ambos igual, por todos os séculos dos séculos, este dom que outrora teria sido comum a todos (e aqui expressou o Pai, o Filho e o Espírito Santo, mas eles não o entenderam. Este aspecto era-lhes ainda desconhecido).

Perante todos, diz então o príncipe dos sacerdotes: Vimos hoje maravilhas nesta menina que vence até os sábios e os homens mais doutos. É este o dedo de Deus. Isto foi obra do Senhor e é um prodígio aos nossos olbos. ${ }^{[5]}$

Padre, diziam os outros sacerdotes, nunca ouvimos falar desta maneira, não merecemos que esta menina fique connosco, nós que não podemos ensinar-lhe nem letras nem bons costumes. É bem mais sábia e bem melhor do que nós!

Se não for ensinada, pelo menos ensinará, diziam outros. Se ela não aproveita do nosso exemplo, nós e as outras meninas aproveitaremos do exemplo dela. Entre, pois, à presença do Senhor com alegria!

Eu, disse o príncipe dos sacerdotes, convosco me admiro e me espanto desta formosíssima menina, belíssima de espírito e de corpo, e desejo ardentemente que esteja connosco aqui, mais para sermos ensinados do que para ensinarmos, aproveitarmos dos seus bons costumes mais do que ela dos nossos. Todavia, uma vez que fez voto de virgindade, que não é habitual na nossa gente e entre o povo de Deus, parece-me que agiu contra a Lei de Deus, que amaldiçoou as estéreis, facto que aconteceu até a seu pai e sua mãe. Não expulsámos nós do Templo seu pai, enjeitámos o seu sacrifício porque nos parecia indigno por ser estéril, ele que, contudo, era casado?

Deus, respondeu Maria, instituiu o matrimónio. Deus ordenou, dizendo: Crescei e multiplicai-vos. ${ }^{[56]}$ Do mesmo modo eu, com o seu favor, faço voto de virgindade. Ainda não chegou o tempo de me casar. Que eu entre, feliz, na Casa do Senhor. Quando chegar o tempo do casamento, entregar-me-eis a um homem, se

[55] ]S1 117:23.

[56] Gn 1:22, 
uoluerit nubam. Propter hoc nolite me a Templo Domini et sanctis atriis eius excludere.

Tunc ergo, dato patri et matri suauissimo osculo et reuerentia humili exhibita omnibus, laeta et cum gaudio et deuotione et humilitate ingressa est atria Domini. Ibi orationibus sanctisque meditationibus die ac nocte intenta erat, manibusque suis laborabat aliasque puellas laborare ${ }^{310}$ docebat, quae suo exemplo et moribus et notitia Dei et omnium rerum et artium proficiebant. Prophetas ${ }^{311}$ legebat, exponebat. Declarabat cum omnium ingenti admiratione Messiam et Redemptorem hominum $^{312}$ cito aduenturum, ex Danielis prophetiis de statua illa in somnis uisa et de septuaginta hebdomadibus ${ }^{313}$, et Agei et [f1. 59] aliorum prophetarum. Legebat ${ }^{314}$ Ieremiam dicentem: Mirabile faciet Dominus super terram. Femina ${ }^{315}$ circumdabit uirum, hoc est, in utero gestabit perfectum Deum et hominem. Et illud Isaiae: Ecce uirgo concipiet et pariet filium et uocabitur nomen eius Emmanuel. Et suspirans dicebat: Vtinam uiderent oculi mei illum Saluatorem meum! Vtinam uiderem illam felicissimam Matrem! Vtinam ancilla ancillarum suarum esse possem!

Audientes hoc, sacerdotes mirabantur et rem taciti considerabant, dicentes in corde suo: "Forsan haec est illa uirgo quae erit Messiae nostri Genitrix." Et inter se secrete dicebant: "Certe ista est! Nulla enim in mundo sanctior est, nulla doctior, nulla pulchrior!”

Alius dicebat: Ego nescio si Deus posset facere pulchriorem ${ }^{316}$, sanctiorem et doctiorem.

Vna puellarum semel dixit ei: Maria, dic $^{317}$ mihi, rogo te, carissima soror mea, quam puellam credis futuram matrem nostri Redemptoris?

Cui illa dixit: Nullam cognosco dignam. Sed Dei est de indigna facere dignam. Voluntas sua lex nostra est.

Subito illa puella replicauit ${ }^{318}$ : O beata tu Maria, quia omnes hii sacerdotes et puellae sanctae quae hic sunt, ex quo ${ }^{319}$ cognouerunt gratiam Dei quae tibi data est, dicunt te esse futuram matrem illius magni prophetae.

Illa hora Maria lacrimas prae gaudio effudit dicens ${ }^{320}$ : Cupere tantum donum cuilibet puelle presumpsio est. Habere illud, dignitas summa est. Nulla est digna ${ }^{321}$. Ipse solus sibi dignam matrem facere potest. Sed utinam dignaretur unam ex minimis ancillis ${ }^{322}$ suae Genitricis ${ }^{323}$ me facere.

Dum haec agerentur in cellula Mariae, primicerius ${ }^{324}$ sacerdotum ibi uidens tantam maiestatem in hac uirgine, die ac nocte obseruabat eam et hac hora

310 laborare] laborare et orare $Q 311$ Prophetas] Prophetias $L 312$ hominum] omnium hominum $J$; omnium LONQV 313 hebdomadibus] egdomadis; ebdomadis JMP 314 Legebat] Legit $L 315$ Femina] Mulier $Q 316$ pulchriorem] puriorem $I L O Q V 317$ dixit ei: "Maria, dic] dixit Marie: "Dic $V$ 318 replicauit] respondit $V 319$ ex quo] et quae JMNP 320 lacrimas prae gaudio effudit dicens] lacrimas prae gaudio fudit dicens $N$; lacrimans prae gaudio, dixit $Q 321$ dignal digna. Ego ex $\rightarrow$ 
a Deus assim aprouver, e casarei com aquele que ele quiser. Por esta razão não me excluais do Templo do Senhor e dos seus átrios santos.

Tendo dado um beijo muito terno ao pai e à mãe e manifestado a todos humilde reverência, feliz e com alegria, devoção e humildade entrou nos átrios do Senhor. Aí, aplicava-se dia e noite à oração e às santas meditações, trabalhava com suas mãos, ensinava as outras meninas a trabalhar, meninas que com o seu exemplo e costumes progrediam no conhecimento de Deus, de todas as coisas e ofícios. Lia e expunha os profetas. Proclamava com grande admiração de todos que o Messias e Redentor universal ia chegar em breve, segundo as profecias de Daniel acerca da estátua vista em sonhos e a das setenta semanas, e de Ageu e [f1. 59] outros profetas. Lia Jeremias que diz: O Senhor criará algo de maravilhoso sobre a Terra. A mulher rodeará o homem, ${ }^{[57]}$ isto é, a mulher trará no ventre um Deus e um Homem perfeito. E o passo de Isaías: Eis que a virgem conceberá e dará à luz um filbo que se chamará Emanuel. ${ }^{[58]}$ E dizia, suspirando: Oxalá meus olhos vissem o meu Salvador! Oxalá vissem aquela afortunadíssima mãe! Oxalá pudesse eu ser a serva das suas servas!

Ouvindo isto, os sacerdotes admiravam-se e em silêncio meditavam no problema, dizendo em seus corações: "Talvez que esta seja aquela virgem que há-de ser a mãe do nosso Messias". E entre si diziam em segredo: "É, sem dúvida, esta! No mundo não há nenhuma mais santa, nenhuma mais sábia, nenhuma mais bela!"

Eu não sei, dizia outro, se Deus poderia fazer outra mais pura, mais santa, mais sábia.

Maria, disse-lhe uma vez uma das meninas, peço-te, minha querida irmã, diz-me qual a jovem que julgas que será a mãe do nosso Redentor?

Não conheço nenhuma que seja digna, respondeu-lhe ela. Mas a Deus cabe tornar a indigna digna. A sua vontade é a nossa lei.

Oh! feliz de ti, Maria, respondeu-lhe logo a outra, porque todos estes sacerdotes e as santas meninas que aqui estão, desde que se aperceberam da graça de Deus que te foi concedida, dizem que tu és a futura mãe desse grande Profeta.

Nessa hora, Maria derramou lágrimas de alegria dizendo: Desejar tão grande dom constitui presunção para qualquer donzela. Alcançá-lo é a máxima dignidade. Nenhuma é digna. Só ele pode fazer para si uma Mãe digna. Mas oxalá se dignasse fazer de mim uma das últimas servas de sua Mãe.

Enquanto isto se passava na cela de Maria, o príncipe dos sacerdotes, vendo aí tão grande dignidade nesta virgem, observava-a de dia e de noite e, nesta ocasião,

$\leftarrow$ me aequaliter indigna IL (M in marg. a. m.) NOV 322 ancillis] exilis $I 323$ suae Genitricis] suam Genitricem $Q \mathbf{3 2 4}$ primicerius ( $M$ add. sup. lin. a. $m$. alias princeps)] princeps $I L V$; alius princeps primicerius $N$; alius primicerius $O$

${ }^{[57]}$ Jer 31:22,

${ }^{[58]}$ Is $7: 14$ 
in colloquio cum puella ista inuenit et omnia uerba utriusque audiuit. Et cum uideret utramque flere, pulsauit modeste ad ostium cellulae et, astante alio sacerdote antiquo ut ipse erat, immo antiquiore et toto dedicato Deo, cui nomen erat Heli, aperto ostio, dixit: Vsque nunc, Maria, te habui pro puella seruata in Templo Domini. Ex nunc te adoro tamquam nostri generis ueram Reginam et Imperatricem. Tu es ${ }^{325}$ certe Mater nostri Messiae, tu Genitrix Saluatoris totius generis humani. Tu eris scala ${ }^{326}$, tu eris iter omnium ad Deum nostrum. Misereberis nobis peccatoribus, misereberis.

Tunc Maria, humillima Dei serua ${ }^{327}$, genuflexit illico in conspectu illorum patrum, dicens ${ }^{328}$ : Deum, patres mei, adorate una mecum. Ego ut spiritualis uestra filia etiam uos in gradu uestro, adoratione quae Dei synagogae ministris debetur, adoro. Quae de me dicitis magna sunt. Ista magna facere nemo potest nisi ille qui est potens et cui ${ }^{329}$ nomen sanctum est. Ego me indignam tanta maiestate puto neque ullam dignam iudico ${ }^{330}$. Ipse faciet de indigna dignam, de peccatrice iustam. Dominus uniuersorum ipse solus est. Mihi satis erit ${ }^{331}$ ancillam esse, si tantum uixero, ancillarum illius sanctissimae Matris. Et uos, patres mei, pro me intercedite.

Tunc ille sacerdos senior uocatus ${ }^{332}$ Heli dixit: Valde humilis es, o uirgo. Deus qui semper humiles exaltat, te quoque exaltabit. Et quanto humilior es tanto sublimior eris. Cognosco certe Deum ordinasse ut tu sis mater Messiae uel socia ipsius. Sed ubi erit mater si tu non sis? Apud nos non est ulla quae mereatur per mille milia graduum ${ }^{33}$ quantum tu. Si Matrem illam ${ }^{334}$ in caelis non tenet Deus, de his quae in terris sunt nulla te ${ }^{335}$ dignior, nulla sanctior. [f1. 60]

Maria dixit: Cito Deus dignificat quando ${ }^{336}$ uult. Me commendo uestris orationibus ut saltem uidere mereamur illam de qua loquimur, quia uere beati oculi nostri ${ }^{337}$ erunt si eam uidebunt et longe beatiores si Filium illum speciosum ${ }^{338}$ forma prae filiis hominum intueri merebuntur.

Maria assidue stipata ${ }^{339}$ erat multitudine angelorum. Et quia a principio Deus iusserat nobis angelis ut eam pro nostra Regina teneremus, nullus ex nostris fuit tam potens aut magnus qui non cuperet eam uidere. Nam inter nos maiores sunt ita humiles ut inferiores. Quamobrem alternatim ueniebamus et recedebamus ab ea. Omnes admirabamur tantam gratiam et tam amplum donum in puella tam formosa, tam studiosa, tam humili. Et gratias agebamus Deo qui nos subiciebat tam praestanti uirgini. Deus quoque ipse Trinus ${ }^{340}$ saepissime Mariae apparebat et cum ea loquebatur sicut amicus cum amico suo et ipsa cognoscebat illos tres unum esse. Cognoscebat quoque illum qui erat Filius Aeterni Patris et qui uolebat

325 es] eris $Q 326$ scala] stela $P 327$ serua] genitrix $N 328$ dicens] et dixit $Q 329$ cui] cuius $I L V$ 330 iudico] puto $N O 331$ erit] esset $I L Q V 332$ uocatus] uocato $P 333$ graduum] gradus $I L V 334$ Matrem illam] Matrem illam (in marg. a. $m$. ullam alias) $M$; Matrem ullam $N$; Matrem ullam alias illam $O$; Matrem $V 335$ te] est $V 336$ quando] quem $I L V 337$ nostri] uestri $V 338$ speciosum] pretiosum $I L V 339$ stipata] associata $I L V 340$ Trinus] uiuus $Q$ 
encontrou-a em diálogo com esta donzela e ouviu todas as palavras de ambas. E vendo que ambas choravam, bateu ao de leve à porta da cela e, na presença de outro sacerdote chamado Heli, velho como ele, e até mais ancião, todo dado a Deus, ao abrir a porta disse: Até hoje, Maria, considerei-te uma donzela educada no Templo do Senhor. A partir de agora, reverencio-te como verdadeira rainha e imperatriz da nossa raça. Tu és incontestavelmente a mãe do nosso Messias, tu, a mãe do Salvador de todo o género humano. Tu serás a escada, tu serás o caminho de todos para o nosso Deus. Terás compaixão de nós pecadores, terás compaixão!

Então Maria, a mais humilde serva de Deus, ajoelhou-se imediatamente na presença destes padres e disse: Adorai a Deus, meus padres, juntamente comigo. $\mathrm{Eu}$, como vossa filha espiritual, venero-vos também a vós na vossa ordem com a veneração que se deve aos ministros da Sinagoga de Deus. O que dizeis a meu respeito é grande. Ninguém pode realizar tal grandeza senão aquele que é poderoso e cujo nome é Santo. Eu considero-me a mim indigna de tão grande dignidade e não julgo nenhuma digna. Ele tornará digna a indigna e justa a pecadora. Só ele é o Senhor de todas as coisas. A mim, se tanto viver, bastar-me-á ser a serva das servas daquela santíssima Mãe. E vós, meus padres, intercedei por mim.

Então o sacerdote mais velho, chamado Heli, disse: És verdadeiramente humilde, ó virgem! Deus, que exalta sempre os humildes, exaltar-te-á também a ti. E quanto mais humilde és, tanto mais sublime serás. Reconheço seguramente que Deus tenha disposto que sejas a mãe do Messias ou a companheira dela. Mas onde estará a Mãe se não fores tu? Entre nós, por mil milhares de passos, não há nenhuma que mereça quanto tu mereces. Se Deus não tem a Mãe no Céu, nenhuma das que existem na Terra é mais digna do que tu, nenhuma é mais santa. [f1. 60]

Deus dignifica facilmente quando quer, disse Maria. Encomendo-me às vossas orações para que, pelo menos, mereçamos ver aquela de que falamos, porque os nossos olhos serão verdadeiramente felizes se a virem. E bem mais felizes se merecerem contemplar o Filho, mais belo que todos os filhos dos bomens. ${ }^{[59]}$

Maria estava permanentemente rodeada pela multidão dos anjos. E uma vez que, desde o princípio, Deus nos ordenara a nós anjos que a tivéssemos por nossa Rainha, nenhum de nós foi tão importante ou tão grande que não desejasse vê-la. $\mathrm{Na}$ verdade, entre nós, os maiores são tão humildes como os mais pequenos. Por isso, vínhamos até ela e afastávamo-nos dela alternadamente. Todos admirávamos tão grande graça e dom tão grande em donzela tão formosa, tão zelosa, tão humilde. E dávamos graças a Deus que nos subordinava a tão eminente virgem. Também o próprio Deus Trino aparecia muitíssimas vezes a Maria e com ela fala como um amigo com o seu amigo. ${ }^{[60]}$ E ela reconhecia que os Três eram Um só.

\footnotetext{
[59] S1 44: 3 .
}

${ }^{[60]}$ Ex 33:11. 
esse filius temporaliter temporalis matris. Cogitabatque nimiam dilectionem ${ }^{341}$ Dei et nimiam felicitatem illius Matris $^{342}$.

Mansit ergo Maria in Templo Domini annis circiter undecim in sanctitate et iustitia, plena uirtutibus et gratia, expectans summam gratiam Christi uidelicet filium suum. Nullusque considerans circa illam uel aspiciens in illam poterat non commoueri ${ }^{343}$ in Deum. Omnes sanctam, omnes Deo praedicabant caram. Docebat $^{344}$ omnes, humilior omnibus, sublimior uirtutibus, inferior opinione. Sanctificabat iugiter Deus tabernaculum suum non expulsione culparum, quae nullae umquam ${ }^{345}$ inhaeserant, sed augmento gratiae et aliorum donorum. Quam sancta, quam immaculata fuerit haec uirgo quam Deus in suam Genitricem praeelegerat ${ }^{346}$, uerbis humanis et angelicis explicari non posset. Ipsa enim sola electa est et praeelecta, quod ${ }^{347}$ uos de qualibet sancta abusiue dicitis sicut et multa alia. ${ }^{348}$ Nulla enim, immo et nullus, fuit eo modo praeelecta aut praeelectus $^{349}$. Ipsa sola est super omnes choros angelorum exaltata. Hanc nos omnes colimus et ueneramur et adoramus. Vos qui natura minores ${ }^{350}$ nobis estis et in natura eidem similiores ${ }^{351}$ quanto magis debetis in ea magnificare Deum caeli et terrae et omnium uisibilium et inuisibilium, quia ipsa est gloria, laetitia et bonorificentia ${ }^{352}$ populi uestri ${ }^{353}$ !

Relinquamus Reginam nostram in domo Domini. Nondum enim locuti sumus de eius desponsatione neque de Verbi Dei in utero eius mirabili conceptione, de quibus alias, nunc de illa quaestione dicamus aliquid quam superius proposuisti, de caelo empyrio, paradiso caelesti, et gloria eius.

Tunc ego, quasi in meipsum rediens, detinebar enim nimia dulcedine uerborum angeli et tam amplarum uirginis Mariae laudum, dixi:

Si mille annis, angele Dei, de Matris Dei laudibus diceres, nunquam me taedio afficeres ${ }^{354}$. Si tamen ad aliam materiam transire tibi placet, resumam uires ad audiendum iterum et ea quae audiero ${ }^{355}$ annotare curabo.

Tunc Gabriel angelus loqui iterum coepit, dicens: Audite, caeli, quae futuro pastori loquor. Audiat omnis terra uerba oris mei. Deus ab aeterno humanam carnem sumere [f1. 61] uoluit. Ideo sibi homini et Matri suae aliisque ex uestris beatificandis magnam et excelsam praeparauit habitationem. Vnde unus hic astantium recte scripsit: "O Israel, quam magna est domus ${ }^{356}$ Domini et ingens locus possessionis eius, magnus et non habens consummationem aut finem, quia in ipsum tamquam in ultimum omnia mundi corpora terminantur. Ideo excelsus dicitur et immensus, quia metitur et circumdat omnia et ipse a nullo mensuratur aut ambitur."

341 dilectionem] generationem ILV 342 Matris.] Matris. Cogitabatque nimiam dilectionem Dei et nimiam felicitatem illius Matris. $M$ (in marg. a. m.) 343 comoueri] conueniri $L V 344$ Docebat] dicebant V 345 quae nullae umquam] quae numquam $P$; quae ei numquam nulla $Q 346$ praeelegerat] praeordinauerat $I L N O V$; praeelexerat $P$; praedicauerat $Q 347$ quod] apud JMP; quod apud $Q$; quae $V 348$ dicitis sicut et multa alia] dicitis. $Q 349$ praeelectus] praeaeternus $V 350$ minores] maiores $V 351$ similiores] similes $L$; sublimiores $V 352$ honorificentia] magnificentia $Q \rightarrow$ 
Conhecia também aquele que era Filho do Eterno Pai e que pretendia ser temporalmente filho de uma mãe temporal. E pensava no imenso amor de Deus e na imensa felicidade daquela Mãe.

Maria permaneceu, pois, no Templo do Senhor cerca de onze anos em santidade e justiça, plena de virtudes e de graça, esperando Cristo, a suma Graça, ou seja, o seu Filho. Ninguém que observasse em volta dela ou que olhasse para ela podia não se deixar levar para Deus. Todos a proclamavam santa, todos a declaravam querida de Deus. A todos ensinava, mais humilde que todos, mais sublime na virtude, inferior na fama. Deus santificava ininterruptamente o seu tabernáculo, não pela erradicação das culpas, que nunca existiram, mas pelo aumento da graça e de outros dons. Não pode explicar-se por palavras humanas nem angélicas quão santa, quão imaculada haja sido esta virgem que Deus predestinara para sua Mãe. Só ela, com efeito, foi escolhida e previamente escolhida, o que vós afirmais abusivamente, assim como muitas outras coisas, de qualquer santa. Nenhuma, ou nenhum, foi previamente escolhida deste modo. Só ela foi exaltada acima de todos os coros dos anjos. Todos nós a honramos, a veneramos e a adoramos. Vós, que pela natureza sois inferiores a nós e a ela semelhantes na natureza, deveis muito mais exaltar nela o Deus do Céu e da Terra, de quanto é visível e invisível, porque ela é a glória, a alegria e a bonra do vosso povo. ${ }^{[61]}$

Deixemos a nossa Rainha na Casa do Senhor. Ainda não falámos dos seus esponsais nem da maravilhosa concepção do Verbo de Deus no seu útero, de que falaremos noutro lugar. Digamos agora algo sobre o assunto que propuseste anteriormente, o Céu Empíreo, Paraíso Terrestre, e sua glória.

Então eu, como que voltando a mim mesmo, pois estava preso pela extrema doçura das palavras do anjo e dos grandes louvores da Virgem Maria, disse:

Se proclamasses, anjo de Deus, os louvores da Mãe de Deus durante mil anos, nunca me enfadarias. Se, contudo, é do teu agrado passar a outro assunto, reunirei forças para escutar de novo e cuidarei de anotar o que ouvir.

Recomeçou então o anjo Gabriel a falar, dizendo: Ouvi, Céus, o que eu digo ao futuro Pastor. Ouça toda a Terra as palavras da minha boca. Deus quis, desde toda a eternidade, assumir [fl. 61] a carne humana. Por isso preparou para si, Homem, e para sua Mãe e outros dos vossos que devem tornar-se bem-aventurados essa grande e sublime habitação. Daí que um dos que aqui estão tenha sabiamente escrito: Ob Israel! como é grande a morada do Senhor e vasta a extensão de seus dominios, grande e sem medida ou sem fim, ${ }^{[62]}$ porque nela, como no limite extremo, se contêm todos os corpos do mundo. Por isso se designa vasta e imensa, porque mede e circunda tudo e ela por nada é medida ou circundada.

$\leftarrow 353$ uestri] nostri $Q V 354$ afficeres] afficias $O 355$ quae audiero] audiente $I L V$; audiuero $N 356$ domus] gloria $N$ 
Et quia Deus nouerat condicionem humanae naturae, fabricauit locum illum cum omnibus condicionibus naturae humanae conuenientibus, immo uniuersa quae naturae hominum prodesse poterunt ${ }^{357}$ uel delectando uel iuuando. In loco illo coadunauit ${ }^{358}$ simul et collegit quae in his uestris mortalibus locis sparsim inueniuntur. Paradisus terrestris ualde minoris amoenitatis, utilitatis et iucunditatis est, in quo cibo et potu corporali indiguissetis. ${ }^{359}$ Hic locus Caelum dici potest quia secundum linguae uestrae ${ }^{360}$ proprietatem celat et tegit. Potest etiam dici Terra, quia homini terreno ${ }^{361}$ congruentissima $^{362}$ habitatio. Haec est Terra illa de qua unus ex hic astantibus ${ }^{363}$ in rota Domini dixit, loquens ad Deum: "Spes mea es tu et portio mea in terra uiuentium". Congruentior ${ }^{364}$ illa habitatio est homini quam Terra ista uestra et quam aer in quo estis. Fecit enim illam maximus artifex extra omnes caelos mobiles immobilem et quietam, debite ${ }^{365}$ et congrue lucidam, quae esset locus omnium. Vnde quidam ex hominibus recte, non bene scientes quid dicerent, dixerunt primo et ante omnia Deum fecisse locum in quo reponeret omnia et, balbutientes, ipsum locum terram uocauerunt, dicentes: "Primum facta est latissima telus". Terra enim dici potest, quia pro terrenis corporibus creata et terrae atque aeris excellentius ${ }^{366}$ qualitates et condiciones habens.

Alii ex uestris illud caelum igneum uocauerunt non solum propter splendorem, sed quia est supra omnia corpora sicut ignis supra omnia elementa. Mira est compositio illius. Ibi sunt omnia quibus uisus humanus delectari potest. Ibi auditus uester et olfatus, gustus et tactus cuncta placentia sentient ${ }^{367}$ sine ulla corruptione, sine fastidio, sine labore, sine dolore. Non comedent ibi homines. Habebunt tamen gustum plenum suauitate et olfatum, auditum et tactum et uisum et omnes sensus. Taliter Deus disposuit illam regionem ut in illa et moueri sine ullo labore et respirare ${ }^{368}$ modo conuenienti corporibus gloriosis poteritis. Neque in aliis caelis inferioribus, qui ${ }^{369}$ mouentur, ita congrua esset uobis habitatio sicut in illo.

Huius caeli empyrii ${ }^{370}$ pars inferior ${ }^{371}$, quae caelum cristalinum seu aqueum in Scriptura dictum tangit, solida et firma est ita ut confidenter ambulare poteritis super eam ${ }^{372}$. Illud autem caelum cristalinum est dictum, quia totum transparet et nulla eius pars densior est. Superior quoque pars huius empyrii caeli solida est tamquam quoddam fulgentissimum ex lapidibus pretiosis constructum tectum [f1. 62] domus Dei. In medio uero partes habet fluxibiles ${ }^{373}$ aliquo modo et tenues,

357 poterunt] possunt $L V 358$ coadunauit] adunauit $Q$, coadiuuauit $V 359$ indiguissetis] indiguistis $L \mathbf{3 6 0}$ linguae uestrae] linguam uestram $Q \mathbf{3 6 1}$ homini terreno] terrenis hominibus $Q$; 362 congruentissima] conuenientissima $J P 363$ astantibus] assistentibus $Q 364$ Congruentior] conuenientior $P 365$ immobilem et quietam, debite] immobile, quietem dedit $P 366$ excellentius] excelentiores $M O Q 367$ sentient] sentirent $J M 368$ respirare] respirari $L 369$ qui] quae $I L N V 370$ empyrii] empyreo $J \mathbf{3 7 1}$ sicut in illo. Huius caeli empyrii pars inferior] sicut in illo huius caeli $\rightarrow$ 
E porque Deus conhecia a condição da natureza humana, construiu esse lugar com todas as condições convenientes à natureza humana, ou melhor, todas as coisas que poderão ser úteis à natureza humana, quer deleitando, quer auxiliando. Nesse lugar reuniu ao mesmo tempo e juntou o que nos vossos lugares mortais se encontra por várias partes. O Paraíso Terrestre seria dotado de muito menor suavidade, utilidade e aprazimento. Nele, teríeis necessidade de alimento e de bebida corporais. Este lugar pode chamar-se Céu porque, segundo a propriedade da vossa língua, oculta e cobre. ${ }^{[63]}$ Pode também chamar-se Terra, porque é habitação que está perfeitamente de acordo com o homem terreno. Esta é a Terra acerca da qual disse, falando a Deus, um dos que estão na Assembleia em redor do Senhor: Tu és a minha esperança e a minha herança na Terra dos vivos. ${ }^{[64]}$ É mais conveniente para o homem essa habitação do que esta vossa Terra e do que o ar em que estais. Fê-la, pois, o Artífice Máximo imóvel e tranquila para lá de todos os Céus móveis, devida e convenientemente luminosa, para que fosse lugar de todos. Foi por isso que alguns homens, sem bem saberem o que diziam, sabiamente disseram que primeiro e antes de tudo fez Deus um lugar em que colocasse todas as coisas e, balbuciando, chamaram a esse lugar Terra, dizendo: Primeiro foi feita a extensíssima Terra. Pode, porém, chamar-se Terra porque, criada para corpos terrenos, tem no mais elevado grau as qualidades e as condições da Terra e do ar.

Outros de vós chamaram-no Céu Ígneo, não só em razão do seu brilho, mas porque está acima de todos os corpos como o fogo está acima de todos os elementos. A sua composição é extraordinária, contém tudo com que o olhar humano pode deliciar-se. Nele o vosso ouvido e o olfacto, o gosto e o tacto sentirão sem nenhum desvio, sem aversão, sem esforço, sem dor, tudo quanto é agradável. Aí os homens não comerão. Desfrutarão, todavia, de um suavíssimo gosto, do olfacto, do ouvido, do tacto, da visão e de todos os sentidos. Deus ordenou de tal modo essa região que nela podereis não só movimentar-vos sem qualquer esforço como respirar de um modo conveniente aos corpos gloriosos. Nem nos outros céus inferiores, que se movem, teríeis vós habitação tão adequada como nele.

A parte inferior deste Céu Empíreo, que toca o Céu que na Escritura se designa por Céu Cristalino ou Céu da Água, é sólida e firme a ponto de, com segurança, se poder andar sobre ela. O outro Céu chama-se Cristalino porque todo ele é transparente e nenhuma das suas partes é mais densa ou mais espessa. A parte superior do Céu Empíreo é também sólida como uma espécie de tecto luminosíssimo [fl. 62] da Casa de Deus construído de pedras preciosas. No meio, porém,

$\leftarrow$ empyrii. Pars inferior $L N 372$ eam] eum $P 373$ In medio uero partes habet fluxibiles] In medio uero partes habet fixibiles $J$; Immo partes sunt fluxibiles $Q$

[63] 63Derivação do verbo celare, ocultar.

[64] S1 41:6. 
aeri similes quas attrahere et expirare ${ }^{374}$ poteritis. Ibi erit omnis amoenitas ualde et incomparabiliter maior illa quae posita est in paradiso uoluptatis plantato a principio.

Multis tamen indiget corpus mortale sine quibus immortale uiuere et bene uiuere poterit. Cibum uos et cuncta animalia cupitis ${ }^{375}$ et magnas in eo delicias ponitis. Sed, mihi crede, nil turpius facit homo quam quando in seipsum trahicit carnes animalium mortuas et eas dentibus premit, ore complectitur, lingua lambit, in stomacho decoquit, quae ${ }^{376}$ in eo sicut in quodam sepulcro marcescunt et putrescunt ${ }^{377}$. Quamobrem homo fit quoddam sterquilinium, faeces fetidissimas in se retinens. Vnde turpius est cibum ingerere et fetidum retinere quam emittere. Et sic turpius est comedere quam uentrem purgare. Sed ista turpitudo non cogitatur propter imminentem necessitatem et magnam uoluptatem. Quae uoluptas in cibo et potu magna Dei prouidentia data est praesertim hominibus ne, turpitudinem huius rei cogitantes, a cibo abstinerent ${ }^{378}$ et in uia cito deficerent. Similiter in genitalibus membris posita est tanta delectatio ne natura deficiat quod etiam sapientissimis difficile est abstinere.

Ibi non comedetis neque bibetis neque nuptias facietis, sed eritis sicut et nos angeli sumus. Comedemus eumdem nobis communem cibum, bibemus eumdem potum, iuxta promissa uobis a Saluatore in ultima sua Cena. Sedebitis enim in regno eius, quia sine ullo labore et perturbatione manebitis et super mensam eius, ut filii, non sub mensa, ut catelli ${ }^{379}$, micas colligetis. Sed panem Dei uestri et nostri una nobiscum comedetis. Mensa Christi est deitas et ipsa essentia diuina super quam ipsi comedunt qui eam facie ad faciem intuentur. Visio enim deitatis est cibus, primo ipsius Dei uidelicet Sanctissimae ${ }^{380}$ Trinitatis, deinde hominum et angelorum. Illi ergo soli super Christi Domini mensam comedunt qui uisione illius deitatis reficiuntur. Qui ${ }^{381}$ uero illi sic uisae amore ${ }^{382}$ perfecto adhaerent et ea fruuntur, super mensam Christi bibunt. Visio illius est cibus, fruitio est potus. Quae duo perficiunt et complent totius alimenti beati rationem. Visio sola non est alimentum perfectum neque fruitio sola, sed illa duo simul iuncta. Vnde et Saluator, uolens uobis relinquere signum huius alimenti, corpus sum sub speciebus panis et sanguinem sub speciebus uini dandum instituit. Frustra inter uos altercantur uestri doctores, illi ${ }^{383}$ dicentes in uisione Dei beatitudinem existere, alii uero in fruitione. Alimentum unum ${ }^{384}$ est beatitudo, collectum est nutrimentum perfectum ex illis duobus. Frustra etiam disceptant ${ }^{385}$ quid sit nobilius, uidere uel frui, quia unum sine altero non facit aliquem beatum. Vnde si Deus in aliquo uisionem sui

374 expirare] experire $J$, respirare $P 375$ cupitis] capitis $O Q V 376$ mortuas et eas (...) decoquit, quae] mortuas quae $P 377$ putrescunt] putrefiunt $I L V 378$ abstinerent] desisterent $N 379$ catelli] catuli $L P Q 380$ Sanctissimae] Summmae $I L V 381$ reficiuntur. Qui] reficiuntur quia $L 382$ sic uisae amore] sic uiso amore $I L V$; sic in se amore $P$; sic amore $Q 383$ uestri doctores, illi] illi doctores $N$ 384 unum] esum $L 385$ etiam disceptant] etiam disputant $J L$; autem disceptant $M$; etiam disseptant $V$ 
tem partes de algum modo flutuantes e finas, semelhantes ao ar, que podem ser aproximadas e afastadas. Haverá aí toda a beleza, muito maior, incomparavelmente, do que aquela que havia no Jardim das Delícias plantado no princípio.

Um corpo mortal tem necessidade de muita coisa sem a qual poderá um corpo imortal viver e viver bem. Vós e todo o animal requereis o alimento e nele fazeis consistir toda a felicidade. Mas, acredita-me, nada de mais indigno faz o homem do que quando leva à boca as carnes mortas dos animais, as mastiga, na boca as faz rolar, as saboreia com a língua, as digere no estômago, carnes que nele se deterioram e apodrecem como num sepulcro. Por isso o homem torna-se uma espécie de estrumeira que detém em si fezes fetidíssimas. Daí que seja mais vergonhoso ingerir o alimento e reter o que é imundo do que expeli-lo. E, assim, é mais vergonhoso comer do que aliviar o ventre. Mas não se pensa nesta torpeza, por causa da eminente necessidade e do grande prazer. Este prazer no comer e no beber foi dado aos homens sobretudo por uma grande providência de Deus, para que, pensando na indignidade deste acto, se não abstivessem do alimento e não desfalecessem antes de tempo no seu caminho. De igual modo, foi posto nos órgãos genitais tão grande deleite, para que a natureza se não extinga, que até aos mais sábios é difícil abster-se.

Ali, não comereis, nem bebereis, nem vos casareis, mas sereis como somos nós os anjos. Comeremos o mesmo alimento, que nos é comum a nós, beberemos a mesma bebida, de acordo com o que vos foi prometido pelo Salvador na sua última Ceia. Sentar-vos-eis no seu reino, porque permanecereis sem qualquer trabalho ou incómodo, e apanhareis as migalhas em cima da mesa como filhos, não debaixo da mesa como cachorros. ${ }^{[65]}$ Mas juntamente connosco comereis o pão do vosso e do nosso Deus. A mesa de Cristo é a divindade e a própria essência divina sobre a qual comem aqueles que a vêem face a face. A visão da divindade é o alimento, primeiro, alimento do próprio Deus, ou seja, da Santíssima Trindade, depois, dos homens e dos anjos. Só comem à mesa de Cristo, pois, aqueles que se revigoram com a visão da sua divindade. Os que verdadeiramente aderem a ela assim olhada e dela gozam, bebem à mesa de Cristo. A sua visão é alimento, a sua fruição é bebida. Ambas realizam e completam a razão de todo o alimento bem-aventurado. Só a visão não é alimento perfeito nem só a fruição, mas ambas juntas. Daí que o Salvador, querendo deixar-vos um sinal deste alimento, tenha determinado que fosse dado o seu corpo sob as espécies do pão, e o sangue sob as espécies do vinho. Em vão discutem entre vós os vossos doutores, dizendo uns que a bem-aventurança consiste na visão de Deus, outros, porém, na fruição. A bem-aventurança é um alimento único, o alimento perfeito é obtido a partir de 
sine fruitione causaret, beatus ille non esset, neque fruitio poni potest alicuius non uisi uel cogniti. Et ad hoc ${ }^{386}$ ut fruitio sit uere beatifica, oportet ut sit de Deo aperte uisio et non qualicumque ${ }^{387}$ noto. Ratio fruitionis adeo parum nobilior est uisione et uoluntas intellectu ${ }^{388}$ ut nobis intuentibus uix appareat ${ }^{389}$.

Non est utile multum in hoc temporis ${ }^{390}$ consumere neque perpetuis altercationibus incumbere. Comedemus ergo simul et bibemus super mensam Christi in regno suo, quia hoc alimentum ipse uobis hominibus meruit, non proprie nobis. Ideo dixit: "In regno meo 391 ".

Nos tamen etiam propter ipsum beati sumus, quia propter oboedientiam promptam $^{392}$ qua eum ab initio in superiorem et principem nostrum acceptauimus, omnibus nobis est et Princeps et Dominus. Sed uobis est Saluator et Redemptor. Et dum estis in uia cum caritate et fide, in spe ${ }^{393}$ ambulantes, non comeditis ${ }^{394}$ panem filiorum super mensam, sed sub mensa micas cadentes de mensa filiorum ut catelli colligitis quia non uisionem, sed tenuem et aenigmaticam cognitionem de Deo habetis nec ipsum in se attingitis. Quicquid de illo ${ }^{395}$ cogitatis sub ipso est, non ipse in sua clara uisione. Sub mensa cibum sumitis, sub mensa bibitis, quia illa uestra fruitio in talem terminatur Deum qualem cognoscitis, quia eum sicuti est non uidetis. Ideo sub mensa bibitis quia Deo qualis in se est non fruimini neque amore inhaeretis. O quantum bonum est Deo adhaerere, in quo sunt omnes deliciae, omnes thesauri, omnia bona!

Cogita bona quaecumque ${ }^{396}$ excogitari possunt. Omnia in Deo sunt. Qui ipsum solum habet ${ }^{397}$, omnia bona habet, quia ipse est bonum omnium bonorum. Homines mirantur quomodo uisio Dei et fruitio possint ${ }^{398}$ esse tantum bonum quantum dicitur. Et multi potius uellent comedere et bibere et opera carnis exercere, piscari, uenari, dormire, ludere, iocari quam Deum uidere. Neque gustant quod uisio illa sit uel esse possit delectabilior operibus carnis et blanditiis corporalibus. Sed nos illud cognoscimus, nos aperte discernimus. Omnes enim uoluptates uestrae sunt inclusae in nostris sicut et omnis cognitio uestra et omnis amor uester includitur in nostra cognitione et in nostro amore. Nos ita cognoscimus sapores et odores, sonos ${ }^{399}$ et colores nostro unico intellectu et unica uoluntate ${ }^{400}$ sicut et uos tot sensibus et appetitibus. Et quod gaudium proueniens ex uisione Dei et fruitione sit ingens et inaestimabile, ex eo poteritis ${ }^{401}$ cogitare, quia certum est quod nemo nisi stultus et insipiens potest negare Dominum nostrum Deum

$386 \mathrm{Et}$ ad hoc] Tamen ad hoc quod $N$; et si poneretur tamen ad hos ut $O$; Et si poneretur tamen adhuc ut $P Q \quad 387$ qualicumque] qualitercumque $I J L N O P Q V \quad 388$ intellectu] intellecta $M \quad 389$ appareat] apparet $I L Q V$; appareat et excidit nobilitate atque exciditur $J M N O Q \quad 390$ temporis] tempus $M P 391$ meo] meo alias suo $O Q 392$ promptam] propriam $L V$; promptam de qua locuti $\rightarrow$ 
ambas. Em vão debatem qual seja mais nobre, ver ou fruir, já que um sem o outro não torna ninguém bem-aventurado. Daí que, se Deus provocasse em alguém a visão de si sem a fruição, esse não seria bem-aventurado. Nem pode considerar-se a fruição de alguma coisa não vista ou não conhecida. E para que a visão seja verdadeiramente beatífica, convém que seja abertamente visão de Deus, não de um ser confusamente conhecido. A fruição é tão pouco menos nobre que a visão, e a vontade que a inteligência, que mal nos apercebemos quando as olhamos.

Não interessa gastar muito tempo neste assunto nem cair em discussões intermináveis. Comamos e bebamos à mesa de Cristo, no seu reino, porque ele vos mereceu a vós homens, e não propriamente a nós, este alimento. Por isso disse: No meu reino.

Mas também nós, por causa dele, somos bem-aventurados porque, em razão da pronta obediência pela qual o recebemos desde o início como nosso superior e como nosso príncipe, todos o temos como Príncipe e Senhor, ao passo que para vós é Salvador e Redentor. E enquanto estais em viagem, com caridade e fé, caminhando na esperança, não comeis o pão dos filhos, à mesa, mas apanhais, como os cachorros, debaixo da mesa, as migalhas que caem da mesa dos filhos, porque não tendes a visão de Deus, mas um ténue e enigmático conhecimento, nem o alcançais em si. O que quer que penseis dele está abaixo dele, não é ele na sua clara visão. Debaixo da mesa comeis, debaixo da mesa bebeis, porque a vossa fruição se limita a Deus tal qual o conheceis, porque o não vedes como ele é. Por isso bebeis debaixo da mesa, porque não fruís Deus como ele é em si, nem aderis a ele com amor. Oh! como é bom aderir a Deus, em quem radicam todas as delícias, todos os tesouros, todos os bens.

Pensa em todos os bens que possam ser pensados. Estão todos em Deus. Aquele que o tem só a ele tem todos os bens, porque ele é o bem de todos os bens. Admiram-se os homens de como a visão e a fruição de Deus possam ser um bem tão grande como se diz. E muitos preferem comer, e beber, e realizar as obras da carne: pescar, caçar, dormir, jogar, divertir-se, do que ver a Deus. Nem experimentam o gosto de que esta visão seja ou possa ser mais agradável do que as obras da carne e do que os prazeres do corpo. Mas nós conhecemo-lo, nós distinguimo-lo perfeitamente. Todas as vossas alegrias estão incluídas nas nossas, assim como todo o vosso conhecimento e o vosso amor se inclui no nosso conhecimento e no nosso amor. Nós conhecemos tão bem os sabores e os odores, os sons e as cores com a nossa inteligência, que é única, e a nossa vontade, que é única, como vós com os sentidos e os apetites, que são múltiplos. E porque a alegria que provém da visão e da fruição de Deus é grande e incalculável, podereis, por isso,

$\leftarrow$ sumus $O Q 393$ spe] spiritu $P 394$ comeditis] comedetis $I L V 395$ Quicquid de illo] quia quod de Deo $Q 396$ quaecumque] quae $V 397$ habet] habent $Q 398$ possint] possunt $M P$; possit $I O V$ 399 sonos] somnos $Q \mathbf{4 0 0}$ uoluntate] uoluntate uolumus ac appetimus $M$ (sup. lin. a. m.) $O Q$ $\mathbf{4 0 1}$ poteritis] poteris $L V$ 
beatissimum esse et felicissimum ${ }^{402}$ et omnis boni fontem ita quod nil deliciarum aut delectationum aut uoluptatum aut cuiusuis iucunditatis et laetitiae ei deficiat, sed quod summo et infinito gaudio gaudeat, qui tamen nunquam piscatur, nunquam uenatur, nunquam dormit, nunquam bibit, nunquam comedit, nunquam operibus carnis utitur, nunquam ludit aut iocatur. In quo ergo est beatus et felix Deus noster? Non in his bonis ${ }^{403}$ quae bona uidentur uobis, sed in sola sui uisione et

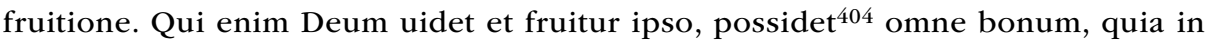
ipso continetur omne bonum incomparabiliter perfectius quam in auro ${ }^{405}$ usualis nummus aut in anima uestra intellectiua, anima brutorum animalium et plantarum [f1. 64] seu herbarum. Quemadmodum ergo in homine omne genus uitae apparet ita in Deo omne genus et omnis species ${ }^{406}$ boni uere et melius quam in se existit. Vno uerbo percipe, in Summo Bono, in Bono Immenso, in Bono Infinito et Aeterno continentur omnia bona quaecumque esse possunt, quae sunt uel fuerunt uel futura sunt ${ }^{407}$. Si tu haberes et possideres omnia bona ${ }^{408}$ nonne beatum et felicem te diceres? Si hoc negas nil prorsus scis. Certe una uetula delira ${ }^{409}$, unus senex in puerum uersus et puer cognoscere incipiens ${ }^{410}$ id confiteretur et nullo modo negare posset. Si ergo cuncta bona possideres quasi dispersa in se et in te congregata, beatus utique esses. Ex quo ergo Deus est bonum infinitum, omnia bona sunt in ipso. Ipsum habendo, habebis omnia et eo magis quia illa habebis non tantum in te coadunata quasi ea in se sparsa possideres, sed quia in uno bono tuo, in una re sola quam possides sunt coniuncta.

Vere unus de hic astantibus ex parte antiquorum Patrum et alius ${ }^{411}$ inde ex parte Nouae Legis ministris, dixit: Nec oculus uidit nec auris audiuit nec in cor hominis ascendit quae praeparauit Deus diligentibus se. Cuius sententiae hic est sensus: tantum est bonum illud a Deo beatis praeparatum quod nullus mortalium medio sui uisus qui maxime deseruit cognitioni quae inueniri ab homine potest, illud inuestigare quantum sit potuit. Neque ullus ${ }^{412}$ mortalium aure audiuit, quia nullus doctor illud bonum quantum sit exprimere potuit alicui discipulorum. Ita neque discipulus ullus ${ }^{413}$ umquam audiuit quod enim omnino dici non potest ab ullo, illud neque audiri poterit tamquam iam dictum. Neque ullus mortalium illud corde, hoc est, sensu interiori, immo intellectu suo umquam intelligere, percipere aut quale sit imaginari poterit ${ }^{414}$, immo numquam tale bonum in cor eius, id est, in uoluntatem ascendit. Voluntas enim non fertur ${ }^{415}$ nisi in bonum

402 felicissimum] fidelissimum $V \mathbf{4 0 3}$ Deus noster? Non in his bonis] Deus noster in his bonis $P$; Deus noster? Non in bonis $Q \mathbf{4 0 4}$ fruitur ipso, possidet] fruitur, ipse possidet $P \mathbf{4 0 5}$ auro] altero $I L V \mathbf{4 0 6}$ omnis species] omnis spes $L V$; omnes species $J Q \mathbf{4 0 7}$ quae sunt uel fuerunt uel futura sunt] quae sint uel fuerunt uel futura sint $L$; quae sint uel fuerint uel futura sint $J M P$; quae sunt uel fuerint uel futura sint $I Q V \mathbf{4 0 8}$ bona] bona sparsim posita $M$ ( in marg. a. m.) $O Q \mathbf{4 0 9}$ delira] delirat $L \mathbf{4 1 0}$ in puerum uersus et puer cognoscere incipiens] in puerum uersus $\rightarrow$ 
pensar, porque é certo, que ninguém, a não ser um louco e um insensato, pode negar que nosso Senhor seja um Deus sumamente bem-aventurado e feliz, fonte de todo o bem, de tal modo que lhe não falta prazer algum, nenhum deleite ou paixão ou felicidade e alegria de qualquer natureza, mas que desfruta do sumo e infinito gozo, ele que, contudo, nunca pesca, nunca caça, nunca dorme, nunca bebe, nunca come, nunca recorre às obras da carne, nunca joga ou se diverte. Portanto, em que é bem-aventurado e feliz o nosso Deus? Não nos bens que vos parecem bens, mas na visão e fruição de si. Quem vê a Deus e dele frui, possui todo o bem, porque nele se contém todo o bem incomparavelmente mais perfeito do que no ouro do dinheiro corrente ou na vossa alma intelectiva, na alma dos animais irracionais e das plantas [fl. 64] ou ervas. Do mesmo modo, pois, que no homem se deixa ver todo o género de vida, assim em Deus existe todo o género e toda a espécie de bem, realmente e até melhor do que é em si. Ouve tudo numa só frase, no Sumo Bem, no Bem Imenso, no Bem Infinito e Eterno se contêm todos os bens que possam existir, os que existem ou existiram ou virão a existir. Se tu tivesses e possuísses todos os bens, não te considerarias bem-aventurado e feliz? Se negares isto, não sabes absolutamente nada. Sem dúvida que uma velha louca, um velho feito rapaz e um rapaz que inicia a via do conhecimento confessariam isso e de modo nenhum o poderiam negar. Se, portanto, possuísses a totalidade dos bens como que dispersos em si e em ti reunidos, serias absolutamente feliz. Desde que, portanto, Deus é o Bem Infinito, todos os bens estão nele. Tendo-o a ele, terás todas as coisas, e tanto mais que as terás não somente reunidas em ti como se as possuísses dispersas em si, mas porque estão reunidas num único bem teu, numa única coisa que possuis.

Com razão afirmou um dos ministros aqui presentes, da parte dos antigos Padres, e outro, da parte da Nova Lei: Nem olhos viram, nem ouvidos ouviram, nem o homem pressentiu o que Deus preparou para os que o amam. ${ }^{[66]}$ É este o sentido desta afirmação: é tão grande o bem preparado por Deus para os bem-aventurados que nenhum mortal na sua percepção, que serve no mais alto grau o conhecimento que pode ser alcançado pelo homem, pôde perscrutar convenientemente quão grande seja. E nenhum mortal ouviu falar dele, porque nenhum mestre pôde traduzir convenientemente a um discípulo quão grande é esse bem. E, assim, nenhum discípulo alguma vez ouviu falar do que, na verdade, em absoluto não pode ser dito por ninguém, nem poderia ter-se ouvido falar dele como já expresso, nem mortal algum poderia alguma vez, em seu coração, isto é, no seu sentir interior e até na sua inteligência, pressenti-lo, compreendê-lo ou

$\leftarrow$ cognitione insipiens $Q \mathbf{4 1 1}$ alius] alius uester $L$; alias $P \quad \mathbf{4 1 2}$ Neque ullus] Nullus $I L \mathbf{4 1 3}$ neque discipulus ullus] nullus discipulus $N \mathbf{4 1 4}$ poterit] potuit $I L M Q \mathbf{4 1 5}$ fertur] infertur $I L$; infert $V$

[66] 1 Cor 2: 9; (Is 64:3). 
praecognitum uel in se uel in suo simili. Quia ergo tale bonum numquam neque a sensu neque ab intellectu cognitum fuit, tale bonum in cor et uoluntatem ${ }^{416}$ hominis numquam ascendit, numquam ab ea concupitum ut tale bonum est aut desideratum uel amatum fuit. Sicut enim de terra ascenditur in aquam tamquam in elementum altius, ita aliquo modo et de cognitione ascenditur ad appetitum maxime quando ille fuerit ultimus et supremus ${ }^{417}$ omnium potentiarum et earum quae cognoscunt et earum quae appetunt sicut est uoluntas in quam omnia diriguntur et quae, parum ab intellectu distans ${ }^{418}$, una enim res sunt, est terminus et aliarum potentiarum omnium finis. Quae ergo uolumus, illa ascendunt in cor nostrum, immo illa intelligimus. Illa, si bona sunt ${ }^{419}$, in cor ascendunt, quia ultimo se uoluntati offerunt neque ulterius progredi possunt. Voluntas tantum ac tale bonum quale Deus preparauit numquam uoluit, quia neque intellectus umquam cognouit nisi per speculum et in enigmate, non autem tale quale ipsum in se proprie est. Nos angeli, ingrediendo, pascua beatitudinis inuenimus, quia essentiam illam infinitam uidentes et in illa omnia cernentes non egredimur [f1. 65] ad cognitionem aliam seu aliorum ${ }^{420}$. Vos autem ingredimini mente et intellectu, deinde egredimini cognoscendo ${ }^{421}$ sensu et intuendo corporalia uel sensibilia ut locum illum eminentissimum non solum situ, sed etiam omnibus deliciis et amoenitatibus et super omnia cernendo illam naturam humanam Deo unitam, plenam gratiae, gaudii, pacis et ueritatis. Sed nos angeli, quamuis uos homines ingrediamini et egrediamini ${ }^{422}$ in pascua consolationis, propter hoc non minus pascimur, sicut et ille qui omnia uidet in uerbo et alius in uerbo et in rebus ipsis non minus uidet, sed pluribus modis uidet ${ }^{423}$. Vnde, non uidendo res in Deo et uidendo illas in se ipsis, non alia uidemus, sed alio modo uidemus. Sic et uos ${ }^{424}$. Sed in hoc differimus, quia uos tribus modis easdem res ${ }^{425}$ uidere potestis, nos angeli duobus modis. Nos enim uidemus nostro intellectu humanitatem Christi in Verbo, hoc est, in ipsa essentia diuina tamquam in speculo perfectissimo et modo perfectissimo ostendente omne ${ }^{426}$ quod intelligi potest. Illam quoque uidemus eodem intellectu nostro in se ipsa. Quos duos modos uidendi ${ }^{427}$ et uos habetis et illis tertium modum additis, quia eamdem humanitatem etiam sensu percipitis. Sed uestri tres modi uidendi non faciunt perfectiorem uisionem, sicut nec nostri duo faciunt perfectiorem uisionem nostram illa uisione unica quam Deus habet. Deus enim unico modo cognoscit omnia, quia per essentiam suam, et nihil cognoscit

$\mathbf{4 1 6}$ in cor et uoluntatem] in corde et uoluntate $L$; in cor et uoluntate $V \mathbf{4 1 7}$ supremus] postremus $Q$ 418 distans] distant $I L V 419$ immo illa intelligimus. Illa si bona sunt] immo illa primo intelligimus et si bona sunt $Q$; Immo in illa intelligimus illa. Si bona sunt $I V \mathbf{4 2 0}$ aliam seu aliorum] aliorum $L$; sed aliorum $I V \mathbf{4 2 1}$ non egredimur ad (...) deinde egredimini cognoscendo] non egredimur $\rightarrow$ 
imaginar como seja. Pelo contrário, nunca esse bem subiu ao seu coração, isto é, à sua vontade. A vontade, na verdade, não segue senão o bem conhecido em si ou no seu semelhante. Porque esse bem nunca foi conhecido nem pela sensação nem pela inteligência, nunca esse bem subiu ao coração e à vontade, nunca foi por ela desejado, procurado ou amado tal como é. Assim como da terra se sobe à água como a um elemento mais nobre, também de algum modo se sobe do conhecimento ao desejo, sobretudo quando este for a última e a mais elevada de todas as faculdades, não só das que conhecem, mas também das que desejam, como é a vontade, para a qual tudo se encaminha, e que, distando pouco da inteligência (são na verdade uma só coisa), é o limite e o fim de todas as outras faculdades. Aquilo que queremos, isso sobe ao nosso coração, sim, isso compreendemos. Se isso for bom, sobe ao coração porque, por último, oferece-se à vontade e nem pode passar além. A vontade nunca desejou tão grande e tão sublime bem como o que Deus preparou, porque nem a inteligência alguma vez o conheceu senão por um espelho e em enigma e não tal qual ele é propriamente em si. Nós anjos, entrando, encontrámos os prados da bem-aventurança porque, vendo a essência infinita e nela distinguindo tudo, não saímos [fl. 65] ao encontro de outro conhecimento ou do conhecimento de outras coisas. Vós, porém, entrais com o conhecimento e a inteligência, depois saís, conhecendo com a sensação e observando o real e o sensível como, por exemplo, esse lugar eminentíssimo não só pela posição, mas também por todos os deleites e suavidade, e, acima de tudo, vendo a natureza humana unida a Deus, cheia de graça, de alegria, de paz e de verdade. Mas, embora vós homens entreis e saiais dos prados da consolação, nem por isso nós anjos nos alimentamos menos. Do mesmo modo que também aquele que vê tudo na palavra e outro, na palavra e nas próprias coisas, não vê menos, mas vê de vários modos. Daí que, não vendo as coisas em Deus, mas vendo-as em si mesmas, não vemos outras coisas, mas vemos de outro modo. Assim também vós. Mas diferimos nisto: vós podeis ver as mesmas coisas de três modos; nós anjos, de dois. Nós, na verdade, com a nossa inteligência vemos a humanidade de Cristo no Verbo, isto é, na própria essência divina, como num espelho perfeitíssimo que mostra de um modo perfeitíssimo tudo que pode ser entendido de um modo perfeitíssimo. Vemo-la também em si mesma com a nossa mesma inteligência. Também vós tendes estes dois modos de ver, e acrescentais-lhes um terceiro, porque apreendeis a mesma humanidade também pelos sentidos. Mas os vossos três modos de ver não tornam a visão mais perfeita, como nem os nossos dois tornam mais perfeita a nossa visão do que a visão única que Deus tem. Deus, realmente, conhece tudo de um único

$\leftarrow$ cognoscendo $N \mathbf{4 2 2}$ ingrediamini et egrediamini] ingredimini et egredimini $V \mathbf{4 2 3}$ sed pluribus modis uidet] et si alius pluribus modis uidet $Q \mathbf{4 2 4}$ Sic et uos] Sic et nos $V \mathbf{4 2 5}$ easdem res] eas $N 426$ omne] omnia $M 427$ Quos duos modos uidendi] qui duobus modis uidendi est $V$ 
alio modo quam in essentia sua. Sed quia illud uidere eminentissimum est, omnem uidendi modum, ablatis omnibus imperfectionibus ${ }^{428}$, in se includit. ${ }^{429}$ Vos tertium modum apponitis, quia etiam sensu cognoscitis, quia homines estis. Sensus autem hominis est, non animae solius aut corporis. Et talis cognitio sola competit homini ut homo est. Animae uero ut anima est etiam illi duo modi cognoscendi qui et nobis angelis solummodo competunt et non tertius ille. Et anima ${ }^{430}$ in corpore glorioso existens poterit uti illis duobus modis, sed non homo, hoc est, totum illud quod ex corpore et anima compositum est potest habere aliam cognitionem quam sensitiuam. Nam ipsa cognitio intellectualis ${ }^{431}$ in sola anima est quae, et si forma corporis sit, non tamen cognitio illa recipitur in corpore neque in toto composito sicut accidens in proprio receptaculo, sed in anima sola. Quia tamen anima est in corpore et talis cognitio est in anima ${ }^{432}$, potest dici quod cognitio illa sit in corpore sicut in receptaculo animae recipientis.

Laetitia sempiterna, quae narrari nequit, erit ${ }^{433}$ super capita uestra. Gaudium et exultationem iugiter habebitis. Magni pretii sunt apud uos ista ${ }^{434}$ : choreas ducere, cantus suaues et melodias audire, flores et florum odores naribus haurire, manibus mollia et uobis in caelo illo ubi exultabitis laetitia inenarrabili. Et omnes sensus uestri erunt in oblectationibus propriis. Et si comedere uolueritis, cibum optatum Dei uirtute, quae dicit et fiunt omnia, preparatum ${ }^{435}$ pro libito inuenietis. Potest namque homo etiam in corpore glorificato comedere si uult. Nam et Christus Dominus post suam resurrectionem uere comedit et non solum apparenter ueluti ille socius meus (et ostendebat angelum Raphaelem qui non ipse in persona sed in nuntio suo comitatus est Thobiam filium Thobiae) ostendebat se comedere cum non comederet. Non enim Raphael ille in persona ad Thobiam iuit, sed unum angelum de [f1. 66] ultimo choro nomine suo destinauit. Sicut et ille angelus qui nomine Michaelis in monte Gargano et alias apparuit se Michaelem, quia nuntius eius ${ }^{436}$ erat, appellabat. Michael ipse in persona non mittitur nisi pro totius populi auxilio et salute. Ipse enim est primus omnium nostrum. Ego sequor. Nos neque natura neque choro aut ierarchia diuidimur. Secundus Seraphim sum ego. Ille primus, qui adeo est nobilis ut nobilior fieri non posset ${ }^{437}$. Lucifer nobiscum fuit

428 imperfectionibus] perfectionibus $V \mathbf{4 2 9}$ includit.] includit. Iccirco alii modi illi (illi om. $J N)$ connumerati non faciunt aliquid (aliud $J N$ ) perfectius, sicut Deus et angelus non est quid perfectius quam ipse Deus in se. Nam in ipso etiam angelus est modo digniori. Deus et creatura non est quid maius aut melius solo Deo (solo Deo om. $J$ ) $J M N$; Iccirco alii modi illi modo connumerati non faciunt aliud perfectius, sicut Deus et angelus non faciunt quid perfectius quam ipse Deus in se. Nam in Deo etiam angelus est modo digniori. Deus et creatura non est quid maius aut melius solo Deo. $Q$; Idcirco alii modi illi connumerati non faciunt aliud perfectius quam ipse Deus in se. Nam in ipso etiam angelus est modo digniori. Deus et creatura non est quid maius aut melius solo Deo $O \mathbf{4 3 0}$ competunt et non tertius ille. Et anima] competunt. Et anima $I L V \rightarrow$ 
modo, porque o conhece pela sua essência e nada conhece de outro modo que não seja na sua essência. Mas porque este modo de ver é eminentíssimo, inclui em si, eliminadas todas as imperfeições, todos os modos de ver. Vós acrescentais um terceiro modo, porque conheceis também pelos sentidos, porque sois homens. Os sentidos são próprios do homem, não exclusivamente da alma ou do corpo. E este conhecimento compete só ao homem enquanto homem. À alma enquanto alma competem só os outros dois modos de conhecer que nos competem a nós, e não o terceiro. E a alma presente num corpo glorioso poderá servir-se destes dois modos, mas não o homem, isto é, tudo aquilo que é composto de corpo e alma pode ter outro conhecimento além do sensitivo. Pois o próprio conhecimento intelectual situa-se só na alma, que, embora seja a forma do corpo, nem por isso esse conhecimento é recebido no corpo, nem em todo o composto, como o acidente no próprio receptáculo, mas só na alma. Todavia, porque a alma está no corpo e esse conhecimento reside na alma, pode dizer-se que esse conhecimento está no corpo como no receptáculo da alma que o recebe.

Uma alegria eterna, que se não pode descrever, reinará sobre vós. Desfrutareis indefinidamente do prazer e da exultação da alegria. Entre vós são tidas em grande conta estas coisas: dançar, ouvir canções agradáveis e melodiosas, aspirar as flores e os odores das flores, afagar as coisas suaves e macias, deleitar-se com sabores doces e agradáveis à natureza. Tudo isto vos está preparado nesse Céu, onde exultareis de inenarrável alegria. E todos os vossos sentidos se entregarão aos prazeres que lhe são próprios. E se desejardes comer, pela acção de Deus, que diz e tudo se faz, encontrareis preparado a vosso gosto o alimento desejado. Com efeito, mesmo no corpo glorioso o homem pode comer, se quiser. Pois também Cristo Senhor, depois da sua ressurreição, comeu verdadeira e não só aparentemente, como aquele meu companheiro (e mostrava o anjo Rafael que, não ele em pessoa, mas através de um emissário acompanhou Tobias, filho de Tobias) aparentava comer, quando não comia. De facto, Rafael não foi em pessoa ao encontro de Tobias, mas mandou em seu nome [f1. 66] um anjo do último coro. Como também aquele anjo que, em nome de Miguel, apareceu no monte Gargano $^{[67]}$ e noutros lados se chamava a si Miguel, porque era enviado deste. $O$ próprio Miguel em pessoa é enviado apenas em auxílio e para salvação de todo o povo. Ele é, com efeito, o primeiro de todos nós. Eu venho a seguir. Nós não

$\leftarrow 431$ intellectualis] intellectiua $P 432$ anima] natura $I L V 433$ sempiterna, quae narrari nequit, erit] sempiterna erit $J$; (quae narrari nequit) add. $M$ (in marg. a. m.) 434 ista] istas $L 435$ et fiunt omnia, praeparatum] et fiunt, omnia preparata $P 436$ eius] ei $V 437$ posset] possit $J L P Q$

[67] O Monte Gargano, que circunda o Golfo de Manfredónia, a norte de Bari, na Itália do sul, albergava desde o séc. IV, como o Mont-Saint-Michel, na Normandia, haveria de albergar a partir do séc. XI, um santuário em honra de S. Miguel, que eram centros de peregrinação. 
eiusdem speciei. Ideo maximus a uobis dicitur, quia de maxima specie quae a Deo nostro creari possit fuit, de quo alias audisti Michael igitur non fuit ex choro inferiori princeps omnium factus, ut quidam ex uestris ${ }^{438}$ homines fatui putant, sed natura est primus, quia in prima specie quae fieri potest ${ }^{439}$ primum indiuiduum illius fuit creatus. Nam in speciebus ${ }^{440}$, ut nonnulli uestrum ${ }^{441}$ opinantur, non est processus in infinitum. Prima species quae creari potest creata est. Et primus angelus creatus est. Maior illa creari non potest. Vestri ergo doctores qui dicunt: "quocumque bono finito dato potest dari maius", non bene dicunt, quia potest imaginari quis maius facere uel dare non potest ${ }^{442}$.

Sed reuertamur ad rem nostram.

Christus Dominus post resurrectionem comedit non solum cibum traiciendo ad interiora, sed uere digerendo et aliquantulam partem illius in se conuertendo. Parua enim carne accedente quasi nihil ei accessisse dici potest ${ }^{443}$. Reliqua uero in ea quae circumstabant resoluta fuerunt ${ }^{444}$. Si ergo tunc comedere uolueritis, poteritis. Sed mihi credite quod numquam illud uoletis, quia turpissimum exercitium est. Et Christus Dominus illud immortalis ${ }^{445}$, ut uos confirmaret, exercuit, non quia cibo indigeret. Haurietis ergo aquas et omnia bona uestra, omnia refrigeria a fontibus Saluatoris. Primo quidem a fonte illo indeficienti essentiae diuinae siue deitatis, in qua omnia bona melius et perfectius possidentur et habentur quam si in se ipsis et propria natura haberentur. In bono ${ }^{446}$ illo fragrantia et redolentia in infinitum maior quam in rosis et liliis et uacciniis ${ }^{447}$ et uniuersis floribus atque pulueribus pigmentariis inueniuntur. In illo gustus et suauitas omnibus liquoribus et saporibus incomparabiliter amplior. In illo uocum modulatio et sonorum ${ }^{448}$ melodia qua dignior cogitari non potest. In illo lucis ${ }^{449}$ et omnium colorum ${ }^{450}$ uarietas et amoenitas quorumcumque ${ }^{450 \mathrm{~A}}$ uisum oblectantibus ${ }^{451}$ longe immensior. In illo amplexus sine termino, excedens omnem uestrum amplexum, omnia uestra oscula, omneque quod tactum uestrum reficere potest. Vnum si dixero, omnia dixi: Deus est omne bonum et in infinitum maior omnibus ${ }^{452}$ bonis creatis. Cogita apud te omnia bona corporis: pulchritudinem, robur seu fortitudinem, sanitatem $^{453}$, sensuum uoluptatem ${ }^{454}$. Omnia ista in Deo longe nobilius. Cogita bona exteriora:

438 uestris] nostris $V 439$ potest] poterat $V \mathbf{4 4 0}$ fuit creatus. Nam in speciebus] fuit creatus in natura, in speciebus $I$; fuit creatus. Nan in natura in speciebus $L V \mathbf{4 4 1}$ nonnulli uestrum] nonnulli uestri $L Q$; nonnullum nostri $V \mathbf{4 4 2}$ quia potest imaginari quis maius facere uel dare non potest $I L V]$, quia et si quis maius bonum facere tamen uel dare non potest maius quocumque finito $J P$; quia et si potest imaginari (potest imaginari in marg. $a$. m.) quid (quis sup. ras.) maius bonum facere uel dare non potest maius quocumque finito. $M$; quia et si potest quis imaginari maius bonum facere uel dare tamen non potest maius quocumque finito $N$; quia et si potest imaginari quid maius bonum facere uel dare non potest maius quocumque finito $O$; quia et si potest imaginari quid maius bonum fieri tamen uel dari maius non potest quocumque finito $Q \mathbf{4 4 3}$ accessisse dici potest] accidisse potest $I$; accedisse potest $L$; accedisse potuit $V \mathbf{4 4 4}$ fuerunt] fuerant $J \mathbf{4 4 5}$ immortalis] $\rightarrow$ 
nos separamos nem em função da natureza, nem do coro, nem da hierarquia. Eu sou o segundo Serafim. Ele é o primeiro, que é a tal ponto nobre que mais nobre não pode haver. Lúcifer pertenceu connosco à mesma espécie. Por isso é considerado por vós o maior, porque pertenceu à mais elevada espécie que pode ser criada por Deus, de que já antes ouviste falar. Miguel, portanto, não se tornou o chefe de todos vindo de um coro inferior, como consideram entre vós alguns homens ignorantes, mas é o primeiro por natureza porque, na primeira categoria que pode ser feita, ele foi criado como o primeiro indivíduo dessa categoria. Com efeito, nas categorias não há, como pensam alguns de vós, um processo in infinitum. Foi criada a primeira categoria que se pode criar e foi criado o primeiro anjo. Maior do que ele não se pode criar. Não estão certos, portanto, os vossos mestres que dizem: "Pode dar-se algo maior do que qualquer bem finito dado", porque pode imaginar-se quem não possa fazer ou dar mais.

Mas voltemos ao nosso tema.

Cristo Senhor, depois da ressurreição, comeu, não só ingerindo o alimento, mas digerindo verdadeiramente e convertendo em si uma pequena parte dele. Pois, juntando a si uma pequena porção de carne, pode dizer-se que quase nada a si acrescentou. O resto dissolveu-se no que estava em volta. Portanto, se quiserdes comer, podereis. Mas crede em mim que nunca o desejareis, porque é um dos mais indignos exercícios. E Cristo Senhor, imortal, exerceu-o para vos encorajar, não porque necessitasse de alimento. Bebereis, pois, as águas e todo o vosso bem, todo o vosso consolo, nas fontes do Salvador ${ }^{\left[{ }^{68]}\right.}$ Primeiro, sem dúvida, na inesgotável fonte da essência divina, ou seja, da divindade, na qual se possuem e se desfrutam todos os bens de um modo melhor e mais completo do que se se desfrutassem em si mesmos e na própria natureza. Nesse bem encontra-se maior fragrância e perfume que nas rosas, nos lírios, no mirtilo, na universalidade das flores e nos pós dos perfumistas. Nele, o gosto e a suavidade incomparavelmente mais ricos que todas as bebidas e todos os sabores. Nele, a modulação do canto e a melodia dos sons acima da qual nada de mais digno se pode pensar. Nele, a variedade e a suavidade da luz e de toda as cores, variedade incomparavelmente maior que as coisas que deleitam a visão de quem quer que seja. Nele, o amplexo sem fim, excedendo todos os vossos abraços, todos os vossos beijos, tudo quanto pode satisfazer o vosso tacto. Disse tudo se disser uma coisa apenas: Deus é o bem total e infinitamente maior que todos os bens criados. Pensa

$\leftarrow$ immortalitatis $V \mathbf{4 4 6}$ habentur. In bono illo] habentur in bono illo. $M 447$ liliis et uacciniis] liliis $L$; liliis uariis $Q 448$ sonorum] fenorum $V 449$ lucis] locus $P 450$ colorum] arborum $P$; caelorum $V$ 450A quorumcumque] quodcumque $I$; quotuncumque $L$; quibuscumque $Q$; quantumcumque $V 451$ oblectantibus] oblectationibus $Q$; delectantibus $V \mathbf{4 5 2}$ bonum et in infinitum maior omnibus] omne bonum et infinitum, maior omnibus $I J L O P V$; bonum infinitum maius omnibus $Q 453$ sanitatem] suauitatem $Q 454$ sensuum uoluptatem] sensum uoluptatum $J$; sensus uoluptatei $P$ 
diuitias ${ }^{455}$, opes, honorem, uenerationem, principatum; et omnes dignitates et officia, famam et gloriam. Omnia ista habet qui Deum habet et incomparabiliter melius habet quam si illa bona in se ipsis haberet ${ }^{456}$. Cogita bona animi: scientias omnes quaecumque sint ${ }^{457}$ ille siue de rebus siue de conceptibus siue de uocibus siue de agendis siue de faciendis siue de speculandis. Cogita [f1. 67] uirtutes morales, cogita omnes uirtutes quas theologicas ${ }^{458}$ uocatis, cogita omnes mentis uoluptates, cogita mentis pacem et tranquilitatem, quietem corporis et animi. Ista omnia sine comparatione melius habebitis ${ }^{459}$ Deum habendo, Deum uidendo, Deum amando, ipso Deo fruendo ${ }^{460}$, sibi propter se amore inhaerendo. Deus in alio non est beatus nisi in se. Deus beatissimus est nec beatior fieri posset et non in alio nisi in se. Hoc signum est quod in eo omnis boni ratio consistit: Beatitudinem hanc nobis et uobis ${ }^{461}$ communicare uoluit. Sed ipse se comprehendit quia actu uisionis et fruitionis infinitae existentis in potentia infinita uidet et amat obiectum infinitum. Infinitum omnia sibi infinita nobis comunicauit, obiectum infinitum seipsum uidelicet ${ }^{462}$. Sed uisio nostra et fruitio et intellectus et uoluntas omnia finita sunt. Non itaque adaequantur rei illi summe quam uident et qua fruuntur neque intellectus noster ${ }^{463}$ neque uoluntas neque uisio neque fruitio.

Tunc ego: Domine mi, dixi, ex quo Deus est una summa res nullo modo in partes distincta, quomodo unus dicitur magis uidere quam alius et unus magis frui quam alter et si uos angeli estis beatiores hominibus?

Respondit angelus: Qui uidet Deum, totum ipsum uidet, quia ipse unica res omnino est. Qui tamen ${ }^{464}$ uidet Deum, potest non uidere omnia quae Deus tamquam alia a se uidet in se. Potest enim ipse facere ut uisio mea feratur super plura ab eo nota alia a se quam alterius. Et in his fiunt reuelationes per superiores inferioribus. Nihil est in Deo quod dicatur Deus quod non uideant omnes beati et angeli et homines. Omnes uident Patrem et Filium et Spiritum Sanctum. Omnes uident ueritatem, bonitatem, sapientiam ${ }^{465}$ et omnes Dei perfectiones et condiciones, quia omnia illa sunt unica res. Posset tamen Deus facere ut illa unica res uideretur prout est essentia et non prout dicitur aliquid aliud, de quibus loquemur ${ }^{466}$ alias.

455 diuitias] bona $P 456$ Omnia ista habet qui Deum habet et incomparabiliter melius habet quam si illa bona in se ipsis haberet] Omnia habentur ista in Deo longe nobilius ILV 457 sint] sunt $I 458$ theologicas] theologales $N 459$ habebitis] habetis JO 460 fruendo] fouendo $P 461$ in se. Hoc signum est quod in eo omnis boni ratio consistit. Beatitudinem hanc nobis et uobis] in se. Hoc si. V 462 obiectum infinitum. Infinitum omnia sibi infinita nobis communicauit, obiectum infinitum seipsum uidelicet] obiectum infinitum omnia sibi infinita communicauit $\rightarrow$ 
em ti todos os bens do corpo: a beleza, o vigor ou a força, a saúde, o prazer dos sentidos. Tudo isto em Deus é muito mais nobre. Pensa nos bens exteriores: as riquezas, os poderes, a honra, o respeito, o mando, e todas as dignidades e funções, a fama e a glória. Tudo isto tem aquele que tem Deus e tem-no de um modo incomparavelmente melhor do que se tivesse esses bens em si mesmos. Pensa nos bens do espírito, todos os conhecimentos, quaisquer que eles sejam, quer das coisas, quer dos conceitos, quer das palavras, quer do agir, quer do realizar, quer da observação. Pensa [fl. 67] nas virtudes morais, pensa em todas as virtudes a que chamais teologais, pensa em todos os prazeres do espírito, pensa na paz e tranquilidade da alma, no repouso do corpo e do espírito. Tudo isto teríeis de um modo incomparavelmente melhor tendo Deus, vendo a Deus, amando a Deus, fruindo do próprio Deus, a ele vos unindo com amor, por causa de si mesmo. Deus não é bem-aventurado em nada senão em si. Deus é sumamente bem-aventurado e nem poderia tornar-se mais bem-aventurado, e não em outra coisa senão em si. Este é o sinal de que nele consiste a razão de todo o bem: quis comunicar-nos a nós e a vós esta felicidade. Mas ele compreende-se a si mesmo porque no acto da visão e da fruição infinita existente na potência infinita vê e ama o objecto infinito. Infinito, comunicou-nos tudo o que em si é infinito, o objecto infinito, ou seja, a si mesmo. Mas a nossa visão e a nossa fruição, a inteligência e a vontade são todas finitas. Por isso, nem a nossa inteligência, nem a vontade, nem a visão, nem a fruição se adequam a essa suprema substância que vêem e de que gozam.

Meu senhor, perguntei, a partir do momento em que Deus é a substância suprema, de modo algum distinta em partes, como se diz que um vê mais do que outro, e outro goza mais do que um terceiro? E se vós os anjos sois mais bem-aventurados que os homens.

Quem vê a Deus, respondeu o anjo, vê-o integralmente, porque ele é absolutamente uma substância única. Mas, quem vê a Deus, pode não ver tudo que Deus vê em si como distinto de si. Pois ele pode fazer que a minha visão, mais que a de outrem, se dirija a coisas várias, distintas de si, por ele conhecidas. E nestas, verificam-se as revelações pelos superiores aos inferiores. Nada há em Deus que se considere Deus que todos os bem-aventurados, anjos e homens, não vejam. Todos vêem o Pai, o Filho e o Espírito Santo. Todos vêem a Verdade, a Bondade e a Sabedoria e todas as perfeições e condições de Deus, porque todas essas coisas são uma única substância. Poderia, todavia, Deus fazer que essa única

$\leftarrow$ obiectum infinitum seipsum uidelicet $N O$; obiectum infinitum infinita omnia sibi infinita nobis communicauit omnibus infinitum seipsum uidelicet $P$; obiectum infinitum, omnia sibi infinita. Nobis communicauit obiectum infinitum, obiectum uidelicet seipsum $Q$; obiectum infinitum seipsum uidelicet IJLV 463 noster] uester $V 464$ totum ipsum uidet quia ipse unica res omnino est. Qui tamen] totum ipsum uidet. Et quia ipse unica res est omnino, quantum $P 465$ sapientiam] scientiam $L V 466$ loquemur] loquimur $J$ 
Omnes igitur uident Deum infinitum nec aliud est ipse, aliud infinitas eius. Qui ergo ipsum uident et infinitatem eius uident. ${ }^{467}$ Sed uisio unius et fruitio maior et intensior est quam alterius. Angelorum aliqui beatiores sunt aliquibus hominibus et aliqui homines omnibus angelis, ut Verbum Homo et sua Genitrix. Postea est Michael, deinde ego cum aliis astantibus precipuis. Post nos septem est Ioannes Baptista, Petrus cum Ioanne Euangelista, Paulo, Andrea et aliis apostolis et illa Magdalena, Christi discipula dilecta, quae non caruit merito apostolorum, cuius festum ${ }^{468}$ tamquam unius apostoli est per omnia celebrandum solemniter. Et in eius festo facienda ${ }^{469}$ est specialis mentio de alia Magdalena quae fuit in ciuitate peccatrix, quae in domo pharisei, unguendo ${ }^{470}$ pedes Domini, meruit audire: remittuntur tibi peccata tua" et "cui minus dimittitur ${ }^{471}$ minus diligit; et quia illa multum dilexit, multa fuerunt ei dimissa. Ambae unxerunt pedes Domini. Sed soror Lazari unxit caput et pedes ante sex dies paschatis Iudaeorum in Bethania in domo Marthae ${ }^{472}$, quae solebat uocari domus Simonis leprosi quondam, sed a Domino mundati.

Fiat igitur unum officium de utraque mixtum ita quod ${ }^{473}$ oratio dicatur quae et nunc dicitur. Et responsoria accipiantur de festo resurrectionis Domini, in quibus fit mentio de Magdalena ${ }^{474}$. Similiter et antiphonae ad laudes et per horas, ad Magnificat et Benedictus. Et Euangelium prima die festi sit illud: Maria stabat ad monumentum foris, plorans. Infra ${ }^{475}$ octauam fiat officium mixtum sicut de apostolis Petro et Paulo. Et in octaua die legatur [f1. 68] Euangelium: Rogabat Iesum quidam Pharisaeus.

Ambae enim fuerunt mulieres sanctissime, quamuis una fuerit publica peccatrix ${ }^{476}$, altera a spiritibus immundis ${ }^{477}$ atrociter uexata. Sed quia ambae a Domino curatae sunt, una a peccatis, alia a daemonum uexatione, et quia ambae unxerunt Dominum diuersis temporibus, iccirco iustum est ut ambae simul colantur ${ }^{478}$, immo ut Deus simul ueneretur in utriusque illarum conuersione. Ambae enim erant de castro quod Magdalum appellatur, ambae Mariae. Iccirco confusa fuerunt earum nomina. Ioannes tamen Mariam sororem Lazari Dominum unxisse commemorat, quod etiam alii euangelistae scribunt, quia illa unctio facta in domo non Simonis Pharisaei, de qua ${ }^{479}$ solus Lucas loquitur, sed in domo Simonis leprosi notabilis fuit, iuxta illud: Vbicumque praedicatum fuerit hoc Euangelium in toto mundo dicetur et quod hoc fecit in memoriam eius. Vnde hanc Mariam ab illa celebri unctione unctricem ${ }^{480}$ discipuli Domini appellauerunt sicut

467 nec aliud est (...) eius uident] nec aliud uident $I L V 468$ et illa Magdalena (...) cuius festum] et illa cuius festum $Q \mathbf{4 6 9}$ facienda] faciendum $V \quad \mathbf{4 7 0}$ unguendo] lauando $Q \mathbf{4 7 1}$ dimittitur] dimittuntur $O \mathbf{4 7 2}$ Marthae] Malche $V \mathbf{4 7 3}$ mixtum ita quod] mixtum. Itaque $P \mathbf{4 7 4}$ de Magdalena] de Magdalena uel mulieribus $M N O Q \mathbf{4 7 5}$ Infra] Intra $P \quad 476$ peccatrix] meretrix $J$ (M sup. ras.) $N P Q$; meretrix alias peccatrix $O 477$ immundis] malignis $I L V 478$ ambae simul colantur] ambae simul collocentur in dignitate et colantur $Q \mathbf{4 7 9}$ qua] quo $N \mathbf{4 8 0}$ unctricem] nutricem $V$ 
substância fosse vista como essência e não enquanto se considera outra coisa qualquer, de que falaremos noutro lugar. Todos, portanto, vêem o Deus infinito, e nem ele é uma coisa e outra a sua infinitude. Pois quem o vê, vê também a sua infinitude. Mas a visão e a fruição de um é maior e mais profunda que a de outro. Alguns anjos são mais bem-aventurados que alguns homens, e alguns homens são mais bem-aventurados que todos os anjos, como o Verbo Homem e sua Mãe. Depois vem Miguel, a seguir, eu com alguns dos principais presentes. Depois de nós os sete estão João Baptista, Pedro com João Evangelista, Paulo, André e os outros apóstolos, e Madalena, discípula dilecta de Cristo, que gozou do mérito dos apóstolos, cuja festa deve ser solenemente celebrada em toda a parte como a de um apóstolo. E na sua festa deve fazer-se menção especial da outra Madalena, que foi pecadora na cidade, a qual, ao ungir os pés do Senhor na casa do fariseu, mereceu ouvir: São-te perdoados os teus pecados; e, A quem menos se perdoa, menos ama; e, Porque ela demonstrou muito amor, muito lhe foi perdoado. ${ }^{[69]}$ Ambas ungiram os pés do Senhor. Mas a irmã de Lázaro ungiu cabeça e pés, seis dias antes da Páscoa dos judeus, em Betânia, na casa de Marta, que antes costumava chamar-se casa de Simão, o leproso curado pelo Senhor.

Celebre-se um único ofício comum às duas, de modo que se recite a oração que agora se recita. E os responsórios sejam tirados da Festa da Ressurreição do Senhor, aqueles em que se faz menção de Madalena. Igualmente as antífonas de Laudes e das Horas, do Magnificat e do Benedictus. E o Evangelho do primeiro dia de festa seja este: Estava Maria junto ao túmulo, do lado de fora, a chorar. ${ }^{[70]}$ Dentro da oitava, celebre-se um ofício misto como o dos apóstolos Pedro e Paulo. E na oitava, leia-se [f1. 68] o Evangelho: Um fariseu convidou Jesus. ${ }^{[71]}$

Foram ambas mulheres muito santas, embora uma tivesse sido pública meretriz e a outra fosse cruelmente atormentada pelos espíritos imundos. Mas, porque ambas foram curadas pelo Senhor, uma dos pecados, a outra dos tormentos dos demónios, e porque ambas ungiram o Senhor em diferentes datas, por isso é justo que ambas sejam veneradas em conjunto, ou antes, que Deus seja venerado igualmente na conversão de ambas. Ambas eram da aldeia que se chama Magdala, ambas Maria. Por isso se confundiram os seus nomes. João, porém, recorda que Maria, a irmã de Lázaro, ungiu o Senhor, facto que narram também os outros evangelistas, porque essa unção, feita não em casa de Simão fariseu, da qual só Lucas fala, mas na de Simão, o leproso, foi admirável, segundo esta passagem: Onde quer que, no mundo inteiro, venha a ser proclamado este Evangelho, também o que ela fez será contado em sua memória. ${ }^{[72]}$ Daí que, por causa desta célebre

\footnotetext{
[69] Lc 7:47-49.

[70] Jo 20:11.

[71] Lc 7:36.

${ }^{[72]}$ Mt 26:13.
} 
et Thomam Didymum et Iudam traditorem. Post octauam uero fiat officium de sorore sua Martha, hospita Christi, cum commemoratione Lazari earum ${ }^{481}$ fratris.

Tunc ego: Et pater meus Franciscus cuius meriti est, si placet tibi dicere, scire uellem.

Respondit angelus: Ipse quoque dignus fuit cum multis aliis consortio apostolorum, ut alias tibi dixi. Quattuor enim doctores uestri et quattuor Graeci cum multis aliis confessoribus atque uirginibus, ut Agnete, Christina, Catherina, Barbara, Appolonia, Lucia, Caecilia, Agatha ${ }^{482}$, Tecla et multis aliis, meruerunt ${ }^{483}$ praemia apostolorum. Nulla ibi inuidia, sed mutua caritas et amor reciprocus, gaudium commune. Vnusquisque de bono alterius laetatur ut uere unum sit praemium omnium et aequale. Et diuersae mansiones et uarii gradus meritorum et praemiorum redeunt ${ }^{484}$ in unum denarium qui datur omnibus in uinea Domini Sabaoth. Deus enim dat unicuique iuxta ${ }^{485}$ opera et merita sua. Deinde caritas et amor id facit ut gaudeant singuli de bono omnium et omnes de bono singulorum. Omnes Deum eundem uident ${ }^{486}$ non alium, omnes illo fruuntur non alio aliquo. Quae reuelat Deus superioribus, haec eadem superiores reuelant inferioribus, quo fit ut inferiores eadem sciant. Quid ergo deficit ${ }^{487}$ illis aliis? Nihil aliud nisi quod uisio unius est intensior uisione alterius et fruitio unius est intensior fruitione ${ }^{488}$ alterius. De illa tamen maiori ${ }^{489}$ aliorum beatitudine minores gaudent in tantum quod aliquomodo fit unum gaudium et aequalis gloria. Pueri solo Christi Domini merito saluati minimum gaudium ibi tenent, quia nil ipsi meruerunt. Tamen contenti sunt et in eodem Deo beati et de omnium aliorum beatitudine gaudent et laetantur. Neque illi qui multum meruerunt tristantur de tanta beatitudine illorum qui nihil aut parum meruerunt ${ }^{490}$. Immo letantur et cognoscunt quod neque ipsi meruissent tanta nisi Deus iuuisset et quod ipsi peccata totidem comississent nisi gratia Dei ${ }^{491}$ adiuti fuissent. Ibi ergo frater maior de praemio fratris minoris, qui omnia bona sua, uiuendo luxuriose, dissipauerat, non tristatur, immo quod pater uitulum saginatum sibi parauerat ${ }^{492}$ ualde laetatur. Ibi, qui prima hora ad laborandum in uinea Domini uenerunt ${ }^{493}$, non murmurant [f1. 69] contra patrem familias eo quod aliquo modo pares illis fecerit alios qui nouissima hora ad laborandum in uinea Domini uenerant ${ }^{494}$. Quapropter parabolae Domini nostri Iesu Christi in ea parte sunt accipiendae, non quia ita sit, sed quia illud consuetum est apud homines ut indignentur de dignitate ${ }^{495}$ indignorum et ut ostenderet gratiae suae munus fuisse quod illi plus meruissent. Ideo indignari iuste non potuissent. In illis itaque parabolis illud simile est et uerum quod etiam magnos

481 earum] eorum $I O$; eius $Q \mathbf{4 8 2}$ Lucia, Caecilia, Agatha] Lucia, Agatha $P 483$ meruerunt] inuenerunt $V \mathbf{4 8 4}$ redeunt] redantur $Q \quad 485$ iuxta] secundum $N \quad 486$ uident] uidentes $I L V \quad 487$ deficit] defuit $L$; defecit $O \mathbf{4 8 8}$ intensior fruitione] maior fruitione $I$; maior fruitio $V 489$ De illa tamen maiori] Illa tamen maiore $P \mathbf{4 9 0}$ qui multum meruerunt (...) parum meruerunt] qui multum meruerunt $I L V \mathbf{4 9 1}$ meruissent tanta nisi Deus (...) nisi gratia Dei] meruissent tanta nisi $\rightarrow$ 
unção, hajam os discípulos do Senhor chamado a esta Maria a perfumista, do mesmo modo que a Tomé chamaram Dídimo e a Judas, o traidor. Depois da oitava, celebre-se o ofício de sua irmã Marta, a que hospedou Cristo, com comemoração do irmão de ambas, Lázaro.

Queria saber, se te aprouver dizê-lo, disse eu, qual o mérito de meu pai Francisco.

Também ele foi merecedor, com muitos outros, da companhia dos apóstolos, como noutro lugar te referi, respondeu o anjo. Pois quatro doutores vossos e quatro gregos, com muitos outros confessores e virgens, como Inês, Cristina, Catarina, Bárbara, Apolónia, Lúcia, Cecília, Águeda, Tecla e muitas outras, foram merecedores do prémio dos apóstolos. Aí não há inveja, mas caridade mútua e amor recíproco, alegria comum. Alegra-se cada um com o bem do outro, de modo que é verdadeiramente um e o mesmo o prémio de todos. $\mathrm{E}$ as diversas habitações e os vários graus de mérito e de prémio convertem-se no mesmo denário que é dado a todos na vinha do Senhor dos Exércitos. Pois Deus dá a cada um segundo as suas obras e o seu mérito. Depois, a caridade e o amor fazem que cada um se alegre com o bem de todos e todos com o bem de cada um. Todos vêem o mesmo Deus, não outro; todos fruem este e não outro qualquer. Aquilo que Deus revela aos superiores, isso mesmo revelam os superiores aos inferiores, pelo que acontece que os inferiores saibam o mesmo. Que falta, pois, a esses outros? Nada, senão que a visão de um é mais intensa que a visão do outro e a fruição de um mais intensa que a fruição do outro. Os mais pequenos desfrutam da maior bem-aventurança dos outros na medida em que, de algum modo, se regista uma única alegria e a mesma glória. As crianças salvas pelos méritos de Cristo Senhor gozam a alegria mínima, porque elas nada mereceram. Contudo, são bem-aventuradas e felizes junto do mesmo Deus e alegram-se e rejubilam com a felicidade de todos os outros. Nem os que acumularam muitos méritos se entristecem com tão grande felicidade daqueles que pouco ou nada mereceram. Pelo contrário, alegram-se e reconhecem que nem eles mesmos mereceriam tanto, se Deus os não tivesse ajudado, e que eles próprios teriam cometido a mesma quantidade de pecados se não tivessem sido ajudados pela graça de Deus. Ali, pois, o irmão mais velho não se entristece com o prémio do irmão mais novo que dissipou todos os seus bens vivendo desregradamente, pelo contrário, fica contente pelo facto de o pai lhe haver preparado o vitelo gordo. Ali, os que chegaram à primeira hora para trabalharem na vinha do Senhor não murmuram [fl. 69] contra o Pai de família porque, de algum modo, os igualara aos que chegaram à última hora para trabalharem na vinha do Senhor. Por isso, as parábolas de nosso Senhor Jesus Cristo, nesta parte,

$\leftarrow$ gratia Dei $Q 492$ parauerat] paruerit $J$; parauerit $N P 493$ uenerunt] uenerant $M P Q$; uenerat $V$ 494 uenerant] uenerunt $I L Q$; in uinea Domini uenerunt, non murmurant contra patrem familias eo quod aliquo modo pares illis fecerit alios qui nouissima hora ad laborandum in uinea Domini uenerant.] in uinea Domini uenerunt. $P \mathbf{4 9 5}$ dignitate] indignitate $Q$ 
peccatores conuersos suscipit Deus et beatificat. Similiter etiam illis qui nil uel parum meruerunt praemium aeternum in uisione atque fruitione suae essentiae tribuit. Quod uero de murmuratione atque indignatione ponitur non est hic simile, sed illud positum est quia uideretur illos iuste indignari et murmurare potuisse ${ }^{496}$, ut ex responsione patris intelligeretur illos iuste indignari contra Deum non posse, quia omnia bona quae habent ab illo acceperunt. Quid enim habent quod non acceperunt? Dicendo ergo: Fili, tu semper mecum es, innuit quod gratia praesentiae ${ }^{497}$ et assidue praeseruationis perseuerauit et omnia patris sui esse, quia omnia bona quae habebat filius iustus a patre acceperat. Dicit ergo ${ }^{498}$ : "Omnia bona mea ${ }^{499}$ quae operatus es tua sunt, tamen ex me tibi data. Ideo mea sunt principaliter. Tua quia tibi a me concessa sunt." Et ad alium dixit: "Amice, non facio tibi iniuriam. Tolle quod tuum est, quia tibi sponte et benignitate mea ${ }^{500}$ collatum est eo quod amicus es et gratia mea uestitus. Secus enim tollere non posses neque illud tuum esset." Et uade ${ }^{501}$, hoc est, esto contentus et remoue te $a b$ ista opinione et iniusta indignatione. Non quia beatiores indignentur ${ }^{502}$ propter aeternum et infinitum bonum inferiorum ${ }^{502 \mathrm{~A}}$, sed quia quis cogitare posset ${ }^{503}$ quod humana consuetudine indignari iuste possent ${ }^{503 \mathrm{~A}}$ si retributio fieret non ex gratia, sed ex meritis. Sed iuste indignari non possunt quia, quicquid sunt, gratia Dei sunt. Vnde dixit ${ }^{504}$ : "Non facio tibi iniuriam, quia mea sponte tibi hoc tribuo nec minus quam tibi promiserim ${ }^{505}$ tribuo". Ideo sequitur: "Nonne ex denario conuenisti mecum? Beatitudinem tibi aeternam promisi, beatitudinem aeternam in uisione et fruitione essentiae meae tibi tribuo. An oculus tuus nequam est quia ego bonus sum?" Ac si aperte diceret: Non iustum est ut inuidia quae aliorum bonum ${ }^{506}$ uidere non potest mouearis, quia hoc ex bonitate mea procedit ut his quoque qui parum uel nihil meruerunt eandem beatitudinem ${ }^{507}$ tribuam. Cogita bonitatem et clementiam Dei, qui in ultimo hiatu conuersis, qui paruulis nil meriti habentibus eandem tribuit ${ }^{507 \mathrm{~A}}$ beatitudunem quam et illis qui toto tempore uitae suae bene operando et bene uiuendo meruerunt. Sed non est id mirabile ${ }^{508}$ quia et illi qui eam tot laboribus meruerunt, Dei gratia fuit ut mererentur ${ }^{509}$ ?

496 murmurare potuisse] murmurare potius se $I L$; murmuratione potius se $V \mathbf{4 9 7}$ quod gratia praesentiae] quod gratia paenitentiae $J M N O$; quod gratia primae $P$; pro gratia praesente 498 Dicit ergo] dixit $Q$; Dico ergo $V 499$ omnia bona meal omnia mea, id est, omnia bona ILNO; omnia bona $P$; omnia bona mea tua sunt, omnia bona $Q$; omnia, id est, omnia bona $V 500$ sponte et benignitate mea] sponte bonoque animo et uoluntate mea $Q \mathbf{5 0 1}$ uade] bade $P$; ualde $V \mathbf{5 0 2}$ indignentur] indignarentur $O P Q \mathbf{5 0 2 A}$ inferiorum] inferiorem $M 503$ quis cogitare posset] quis cogitare $I$; quos cogitare $L$; quis cogitare potest $O$; quis cogitaret $V$ 503A possent] potuissent $M N P \mathbf{5 0 4}$ dixit] dicit $I L N O Q V \mathbf{5 0 5}$ promiserim] promisero $Q \mathbf{5 0 6}$ bonum] bonorum ILV $\mathbf{5 0 7}$ beatitudinem] bonitatem $I L V \quad \mathbf{5 0 7 A}$ tribuit] dat $I L V \mathbf{5 0 8}$ Sed non est id mirabile] Sed non est admirabile $I Q$; Sed est admirabile $V \mathbf{5 0 9}$ mererentur] merentur $V$ 
devem ser aceites, não porque assim seja, mas porque é habitual entre os homens indignarem-se da dignidade dos indignos, e para mostrar que foi função da sua graça que eles merecessem mais. Por isso não poderiam justamente indignar-se. Também nessas parábolas é igualmente verdadeiro que Deus recebe e concede a bem-aventurança aos grandes pecadores que se arrependem. Atribui, do mesmo modo também, àqueles que nada ou pouco mereceram o eterno prémio da visão e da fruição da sua essência. Mas o que se afirma da murmuração e da indignação não tem aqui o mesmo valor, mas afirma-se porque pareceria que eles poderiam justamente indignar-se e murmurar, para que da resposta do pai se entenda que eles não podiam justamente indignar-se contra Deus, porque todo o bem que têm o receberam dele. De facto, que têm eles que não hajam recebido? Dizendo, pois, Filbo, tu estás sempre comigo ${ }^{[73]}$ indicou que perseverou graças à presença e à permanente dedicação e que tudo era de seu pai, porque todos os bens que o filho justo tinha os recebera do pai. Disse, pois: "Todos os meus bens que tu produziste são teus, porém a ti dados por mim. Por isso, são primeiramente meus. Teus, porque te foram concedidos por mim.” E ao outro disse: "Amigo, não sou injusto contigo. Recebe o que te pertence, porque a ti livremente concedido pela minha benevolência, visto que és amigo e vestido graças à minha boa vontade". Não poderias receber de outro modo, nem isso te pertenceria. E vai, isto é, dá-te por satisfeito e deixa essa ideia e essa injusta indignação. Não que os mais bem-aventurados se indignem por causa do eterno e infinito bem dos menos bem-aventurados, mas porque poderia alguém pensar que, de acordo com a tradição humana, pudessem justamente indignar-se se a retribuição fosse feita não em razão da graça, mas em razão dos méritos. Mas não podem justamente indignar-se porque, o que quer que sejam, são-no pela graça de Deus. Por isso disse: "Não sou injusto contigo, porque te dou isto de minha livre vontade e não te dou menos do que te prometi". Por isso se segue: "Não acordámos num denário? ${ }^{[74]}$ Prometi-te a bem-aventurança eterna, dou-te a bem-aventurança eterna na visão e na fruição

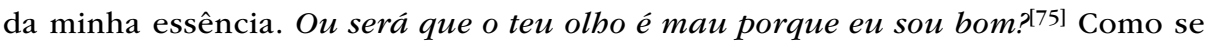
abertamente dissesse: "Não é justo que te movas pela inveja, que não pode ver o bem alheio, porque da minha bondade procede o facto de eu dar também àqueles que pouco ou nada mereceram a mesma bem-aventurança”. Pensa na bondade e na clemência de Deus, que dá aos que se convertem no último instante, que dá às crianças sem qualquer merecimento, idêntica bem-aventurança que àqueles que ao longo da sua vida mereceram, vivendo e agindo bem. Não é, porém, admirável que também aqueles que a mereceram por meio de tanto trabalho a tenham merecido pela graça de Deus?

[73] Lc 15:31,

[74] Mt 20:13,

${ }^{[75]}$ Mt 20:15 
Tunc ego: Non capio, angele Dei, quomodo beatitudo detur ex gratia et tamen non sine meritis. Si enim confertur propter merita, quomodo ex gratia? Et si ex gratia, quomodo ex meritis?

Angelus respondit: Nullum opus nullaque operatio creaturae in se considerata digna est illo aeterno et diuino praemio etiam si per mille milia annos laboraret quis et insudaret et quaecumque bona a uobis uel a nobis fieri possent faceret. Iccirco ex sui natura nihil est condignum. Ipse tamen sua benignitate suaque gratia fecit et instituit ut ista [f1. 70] quae non sunt condigna fierent ${ }^{510}$ digna. Non ergo communiter saluat ${ }^{510 \mathrm{~A}}$ sine propriis meritis. Illa tamen merita non sunt ex sui natura merita, sed ex diuina ordinatione. Do tibi similitudinem: Est rex magnus habens regnum proprium et opulentissimum qui legem ponit ut, quicumque ei solum "Aue" dixerit, efficiatur heres totius regni sui. Certum est quod tam paruum obsequium non sufficiebat ad obtinendum tam magnum praemium. Tamen qui fecit illud quod lex mandabat ${ }^{511}$ dignus est hereditate, non quia illud opus ex se dignum esset, sed quia regi placuit ut esset dignum. Qui ergo assecutus est, regnum meruit quia, quod rex dixerat, adimpleuit. Et tamen gratia regis meruit qui illud pro merito 512 instituit.

Deus noster nullis legibus ${ }^{513}$ obligatur. Quaecumque uult bona et iusta sunt. Tanti ualent opera nostra quanti ea ipse existimat. Paruum opus pro magno et magnum apud uos pro paruo uel nullo existimare potest. Apud eum tanta sunt opera ${ }^{514}$ nostra quanta apud regem uel principem metalla. Sicut enim uos aestimationem tribuitis nummis uestris sic Deus operibus et actionibus ${ }^{515}$ nostris et uestris.

Habebitis, ultra uisionem et fruitionem, gloriam in corporibus uestris postquam animae uestrae illa resumpserint ${ }^{516}$. Erunt enim illa diuina protectione assidua et pro lege tunc habenda impassibilia et immortalia et nullo interiori aut exteriori contrario laesibilia. Deus enim ita assistet eis ex pacto aeterno. Erunt clara et lucida, quia colore optimo et uisu optabilissimo erunt dotata et luce competente praedita. Quae lux suauior longe erit luce solis et stellarum et quocumque ire uolueritis, agiles $^{517}$ eritis, quia sine ullo labore ambulabitis, incedetis ${ }^{518}$, uolabitis non ut aues cum labore, sed anima uestra exercebit motum apud uos nunc inconsuetum. Mouebit namque totum corpus uestrum simul, non partem per partem, sed totum simul sicut sagita eiecta ${ }^{519}$ transibit. Qui proiciet eam erit uoluntas et appetitus. Illa uero sic a seipsa mota Dei uirtute concurrente ${ }^{520}$ uel potius ipsa Dei uirtute

510 fierent] facerent $L$; faceret $I V$ 510A Non ergo communiter saluat] Homo ergo communiter saluat $P \quad 511$ mandabat] mandauerat $Q \mathbf{5 1 2}$ pro merito] praemium ILV $\mathbf{5 1 3}$ nullis legibus] ullis legibus $I$; ullis legis $L$; nullis meritis neque legibus $Q$; illis legibus $V \mathbf{5 1 4}$ opera] merita $Q \rightarrow$ 
Não entendo, anjo de Deus, exclamei eu, como possa a bem-aventurança ser atribuída em razão da graça e, contudo, não sem méritos. Se, realmente, é conferida em razão dos méritos, como é também em razão da graça? E se em razão da graça, como é em função dos méritos?

Nenhuma obra, nenhuma acção da criatura em si considerada, respondeu o anjo, é digna do prémio eterno e divino, mesmo se se esforçasse e se afadigasse por mil milhares de anos e praticasse todo o bem que pode ser feito por vós ou por nós. Por isso, em função da sua natureza, nada é absolutamente meritório. Contudo Deus, pela sua benevolência e pela sua graça, determinou e estabeleceu que aquilo [fl. 70] que não é absolutamente meritório se tornasse meritório. Por consequência, de um modo geral, não salva sem méritos próprios. Esses méritos, porém, não são méritos por sua natureza, mas por disposição divina. Dou-te um exemplo: Era uma vez um grande rei, que tinha um reino muito rico, que fez publicar uma lei pela qual, todo aquele que apenas lhe dissesse "Ave", se tornaria herdeiro de todo o seu reino. É claro que tão pequena deferência não bastava para obter tamanho prémio. Todavia aquele que cumpriu o que a lei lhe ordenava, tornou-se digno da herança, não porque aquela acção, em si, fosse merecedora, mas porque aprouve ao rei que se tornasse merecedora. Aquele, pois, que obteve o reino, mereceu-o porque cumpriu o que o rei havia determinado e, todavia, mereceu-o pela graça do rei, que o instituiu como mérito.

O nosso Deus não se obriga por lei nenhuma. É bom e justo tudo o que quer. As nossas acções têm o valor que ele lhes atribui. Pode considerar grande uma acção insignificante, e uma entre vós, grande, pode considerá-la de valor reduzido ou nulo. Têm tanta importância, para ele, as nossas obras, quanta têm para um rei ou um príncipe o ouro e a prata. Do mesmo modo que vós dais valor ao vosso dinheiro, assim Deus dá valor às nossas e às vossas obras e acções.

Além da visão e da fruição, tereis a glória em vossos corpos depois de as vossas almas os haverem reassumido. Estes, pela protecção divina, serão, pois, perpétuos e, pela lei que deve então existir, impassíveis e imortais e não susceptíveis de serem lesados por nada interior ou exterior que lhes seja contrário. Deus assisti-los-á, certamente, em razão do pacto eterno. Serão luminosos e esplendorosos, porque serão dotados de uma cor brilhante e de aspecto muito agradável e de uma luz aliciante. Esta luz será mais suave que a luz do Sol e das estrelas. $\mathrm{E}$, para onde quer que queirais ir, sereis ágeis, porque andareis sem qualquer esforço, caminhareis, voareis, não como as aves, com esforço, mas a vossa alma desenvolverá um movimento presentemente não habitual entre vós. Moverá todo o vosso corpo ao mesmo tempo, não parte por parte, pois ele se deslocará todo

$\leftarrow \mathbf{5 1 5}$ actionibus] orationibus $I L V \mathbf{5 1 6}$ resumpserint] reasumpserint IJLOQV; ressumpserant $P \mathbf{5 1 7}$ quocumque ire uolueritis, agiles] quocumque uisibili. Agiles $I L O V \mathbf{5 1 8}$ incedetis] incedebitis $L$ 519 eiecta] electa $I L N(O$ add. sup. lin.) V 520 concurrente] connumerare $J$ 
prestante, hoc illi mouebit corpus quocumque uoluerit. Sicut si sagittae proiectae aliquid alligaretur ${ }^{520 \mathrm{~A}}$, illud profecto uno motu cum illa moueretur.

Ecce dixi tibi, sed non pro te, sed pro illo pastore quem Deus elegit qui haec subito ut legerit intelliget, quorum multa sunt contra ea quae nunc opinantur homines etiam docti. Habebitis etiam corpora subtilia, quia penetrabitis quodcumque corpus. Neque ullum corpus erit adeo spissum aut densum quod pertransire non poteritis. Multa hic a uestris adducuntur et multi credunt quaedam quae dixi impossibilia quae tamen ita erunt et sic se habent et ille cognoscet ad quem diriguntur.

Tunc ego: Domine mi, pauca de talibus audiui quae, si alius mihi dixisset, ipsum non intellexissem ${ }^{521}$. Verba tamen tua mihi sensum praebent et intelligentia intellexi ${ }^{521 \mathrm{~A}}$ quod ibi est omne bonum et finis omnium desideriorum, quo habito, habebuntur ${ }^{522}$ omnia et illud est status omnium bonorum perfectus. Omnia enim bona sunt ex ipso et per ipsum et in ipso, cui sit honor et gloria in saecula saeculorum. Amen.

Et his dictis uisio disparuit. Et ego coepi esurire et sitire uehementer, reperiendo me in cauerna et subterrenea cellula mea ${ }^{523}$.

520A alligaretur] allegaretur $O$; obligaretur $V \mathbf{5 2 1}$ intellexissem] intellexissent $O$; intelligissem $V$ 521A et intelligentia intellexi] et intelligentiam. Intellexi $I J L V \mathbf{5 2 2}$ habebuntur] habebimur $N$; habentur ILV $\mathbf{5 2 3}$ cellula mea.] cellula mea. Finis Quarti Raptus I 
ao mesmo tempo como uma seta lançada. Quem a há-de lançar será a vontade e o desejo, ao passo que a alma, movendo-se por si própria com o concurso do poder divino, ou antes, porque o poder divino lho concede, moverá este corpo para onde quiser, tal como se alguma coisa estivesse atada a uma seta que se atira, essa coisa, sem dúvida, deslocar-se-ia juntamente com ela num só movimento.

Eis que te informei sobre estas coisas, não por ti, mas pelo Pastor que Deus escolheu, o qual as entenderá logo que as leia, muitas das quais são contrárias às opiniões dos homens, mesmo dos doutos. Tereis também corpos subtis, porque penetrareis qualquer corpo. E não haverá corpo tão sólido ou tão espesso através do qual não possais passar. Muita coisa será aduzida pelos vossos, neste caso, e muitos considerarão impossíveis algumas coisas que eu disse, as quais, contudo, assim serão e assim se apresentam, e aquele a quem se dirigem conhecê-las-á.

Meu senhor, disse eu então, ouvi algumas destas coisas que, se outro mas relatasse, não o teria entendido. Mas as tuas palavras têm para mim sentido, e compreendi que aí está todo o bem e o fim de todos os desejos; tendo alcançado isso, serão possuídas todas as coisas. É esse o estado perfeito de todos os bens. Todos os bens são, na verdade, Dele, por Ele e Nele, a quem seja dada honra e louvor pelos séculos dos séculos. Ámen.

E dito isto, desfez-se a visão. E eu comecei a ter muita fome e muita sede, encontrando-me na gruta e na minha cela subterrânea. 


\section{QVINTVS RAPTVS ${ }^{1}$}

Transactis paene quindecim diebus, dum iterum orarem in cauerna [f1. 71] mea, raptus sum in coetum illum sanctissimum. Et adorato Rege Regum et Regina omnium et reuerentia exhibita sanctis angelis et animabus beatis qui omnes cum suaui harmonia uidebantur ${ }^{2}$ Vnum Deum atque Trinum magnificare clamando die ac nocte: Sanctus, Sanctus, Sanctus Dominus Deus noster omnipotens, qui est, qui semper fuit, qui semper erit. Benedictum nomen maiestatis eius et benedicta sit humanitas illa et caro illa et anima illi unita.

Et angeli sic dicebant post illa uerba: Quia nisi Deus homo fuisset, conciues homines non habuissemus.

Vnde haec erat eorum ${ }^{3}$ psalmodia: ${ }^{4}$

Benedicamus Patrem et Filium cum Sancto Spiritu, laudemus et magnificemus eum in saecula.

Benedicta sit caro illa pretiosa quam assumpsit de Virgine gloriosa.

Benedicta sit illa humanitas Dei nostri, cuius meritis facta est augmentatio regni nostri.

Quia nisi Deus homo fuisset, conciues homines nequaquam ${ }^{5}$ habuissemus,

Quos tamquam nos ipsos diligimus et eos tamquam fratres nostros amamus.

Nam et si natura sint nobis paulo minores, gratia tamen et felicitate sunt aequales. $^{6}$

Quaecumque uidere nos possumus, eadem et ipsi uidere possunt.

Quaecumque nos amare ualemus, illa et ipsi amare ualent.

Tu es Deus in quo est felicitas nostra, tu idem es beatitudo hominum.

Visio non differt a uisione neque fruitio a fruitione.

1 Raptus Quintus] Alius Raptus Dei incarnatione qui est quintus $O$; Raptus Quintus. De Incarnatione Christi $Q 2$ uidebantur] uidebamus $I R \quad 3$ erat eorum] angelorum $Q \quad \mathbf{4}$ eorum psalmodia.] eorum psalmodia. Hymnus quem angeli canebant in ca elo in quinto raptu Amadei. IRV; Vnde haec $\rightarrow$ 


\section{QUinto ARREBATAMENTO}

Passados mais ou menos quinze dias, enquanto orava outra vez na minha [fl. 71] gruta, fui arrebatado até à santíssima Assembleia. E depois de adorar o Rei dos Reis e a Rainha de todas as criaturas, de prestar reverência aos santos anjos $\mathrm{e}$ às almas bem-aventuradas que, todos em suave harmonia se viam a glorificar a Deus Uno e Trino, clamando dia e noite: Santo, Santo, Santo é o Senhor nosso Deus Omnipotente, que é, que sempre foi e que sempre será, bendito seja o seu nome e a sua majestade, e bendita seja a humanidade e a carne e a alma a ela unidas.

Depois deste louvor, assim diziam os anjos: Se Deus se não houvesse feito homem, não teríamos os homens como concidadãos.

Por isso, era esta a sua salmodia:

Bendigamos o Pai, o Filho com o Espírito Santo. Louvemo-lo e exaltemo-lo para sempre.

Bendita seja a preciosa carne que assumiu da Virgem Gloriosa.

Bendita seja a humanidade do nosso Deus, por cujos méritos se fez o crescimento do nosso reino.

Porque se Deus se não tivesse feito homem, nunca teríamos os homens como concidadãos.

Eles de quem gostamos como de nós mesmos e a quem amamos como irmãos nossos.

Pois, embora por natureza sejam um pouco inferiores a nós, são nossos iguais pela graça e pela bem-aventurança.

Tudo quanto nós podemos ver, o mesmo podem eles ver também.

Tudo quanto nós conseguimos amar, o mesmo conseguem eles amar também.

Tu és Deus, em quem reside a nossa bem-aventurança, tu és do homem a mesma beatitude.

Não difere uma visão de outra visão, nem uma fruição de outra fruição.

$\leftarrow$ erat eorum psalmodia $K$. (a. m.) 5 nequaquam] non $N R \quad \mathbf{6}$ sunt aequales] sunt aequales et maiores. $G O Q$ 
Eiusdem naturae est beatitudo nostra et hominum, intensior tamen huius quam illius.

Homines angelis et angeli hominibus inueniuntur beatiores.

Beatissimus est ille homo quem tu, Deus, assumpsisti.

Post illum est tua Genitrix, post illam sunt septem angeli.

Sequuntur ${ }^{7}$ alii mixtim ${ }^{7 \mathrm{~A}}$, hi quidam maiores, alii aequales uel minores.

Facti $^{8}$ sumus $^{8 \mathrm{~A}}$ una ciuitas ex hominibus et angelis constituta.

Lucifer cum satellitibus praesumptuosis cecidit, homines illis Deus subrogauit.

Non quia homines, ipsis manentibus, non fuissent, sed quia sedes eorum non occupassent.

Vidit Deus casum angelorum et adiunxit numerum hominum beatorum.

Benedictus $^{9}$ sit ille homo Deus cui nos a principio paruimus,

Quem Lucifer adorare contempsit ${ }^{10}$ et ad infima caeli descendit.

Benedicta sit illa sancta Genitrix quae nobis talem Regem protulit.

Benedicti sint omnes homines a Domino qui fecit caelum et terram.

Benedicamus Patrem et Filium cum Sancto Spiritu, laudemus et magnificemus eum in saecula.

Hunc hymnum, me intrante, angeli canebant, et animae beatorum in primo et ultimo uersiculo cum eis concordabant. Vnde sic concinebant ${ }^{11}$ :

Benedicamus Patrem et Filium cum Sancto Spiritu, laudemus et magnificemus eum in saecula.

Benedicti sint ${ }^{12}$ omnes spiritus caelestes, qui Sanctae Trinitati fuerunt oboedientes. ${ }^{13}$

Benedictus sit Michael princeps, inter omnes creaturas primus,

Qui cum fortissimo Gabriele in infernum detrusit omnes aduersarios nostros.

Benedictus sit ipse Gabriel cum Raphaele et Vriele, qui salutem nostram procurare non cessant assidue. ${ }^{14}$

Benedicti sint omnes angelici ${ }^{15}$ spiritus, qui Hominem Deum colunt et uenerantur,

Qui nos in suum consortium suscipiunt et tanquam fratres diligunt et admittunt, Qui nos a daemonibus protegunt et ab omni malo custodiunt.

Illi non solum Christum Dominum, sed et eius Genitricem omnes adorant, [fl. 72] Hominibus nobis subesse non respuunt nec minores sibi praeferri ${ }^{16}$ dedignantur,

7 Sequuntur] Sedent $A$ 7A mixtim] mixti $Q$; innixam $V$ 8 Facti] Sancti $Q \quad \mathbf{8 A}$ sumus] sunt $I R V$ 9 Benedictus] Benedixit $V \mathbf{1 0}$ contempsit] contempserit $Q \mathbf{1 1}$ cum eis concordabant. Vnde sic concinebant.] cum angelis concordantes alternatim sic concinebant. $V 12$ sint] sunt HIOR 13 qui $\rightarrow$ 
A nossa beatitude é da mesma natureza que a do homem, mais intensa uma que a outra.

Os homens consideram-se mais bem-aventurados que os anjos, e os anjos que os homens.

De todos, o mais bem-aventurado é o Homem a quem tu, Deus, assumiste.

Depois dele é a tua Mãe, depois dela são os sete anjos.

Outros se seguem alternadamente, maiores alguns, outros iguais ou menores.

Tornámo-nos uma cidade feita de homens e de anjos.

Caiu Lúcifer com sua presunçosa corte, em seu lugar pôs Deus os homens.

Não que os homens não tivessem existido se eles não tivessem caído, mas porque não teriam ocupado o lugar deles.

Deus viu a queda dos anjos e acrescentou o número de homens bem-aventurados.

Seja bendito o Homem Deus, a quem desde o princípio obedecemos.

A quem Lúcifer desdenhou obedecer e às profundezas do Céu foi parar.

Bendita seja a santa Mãe que nos ofereceu um tal Rei.

Sejam benditos todos os homens pelo Senhor que fez o Céu e a Terra.

Bendigamos o Pai, o Filho com o Espírito Santo. Louvemo-lo e exaltemo-lo para sempre.

Estavam os anjos a cantar este hino quando eu entrei. E as almas dos bem-aventurados harmonizavam com eles no primeiro e no último versículo. Por isso, juntos, assim cantavam:

Bendigamos o Pai, o Filho com o Espírito Santo. Louvemo-lo e exaltemo-lo para sempre.

Sejam benditos todos os espíritos celestes que foram obedientes à Santíssima Trindade.

Seja bendito Miguel, o príncipe, primeira de todas as criaturas.

Que com o fortíssimo Gabriel precipitou no inferno todos os nossos adversários.

Seja bendito o mesmo Gabriel com Rafael e Uriel, que não param de velar a todo o momento pela nossa salvação.

Sejam benditos todos os espíritos angélicos que adoram e veneram o Homem Deus,

Que nos recebem na sua companhia e nos amam e nos aceitam como irmãos, Que nos protegem dos demónios e nos preservam de todo o mal.

Todos eles adoram não só a Cristo Senhor, mas também a sua Mãe. [fl. 72]

Não enjeitam associar-se a nós homens, nem desdenham dar prioridade aos seus inferiores.

$\leftarrow$ Sanctae Trinitati fuerunt oboedientes] Sancti Trinitati oboedientes $Q 14$ cessant] cessauit $V 15$ angelici] angelorum $G$; angeli $J O Q V 16$ praeferri] proferre $Q$; referri $V$ 
Bonis nostris laetantur et gaudent, malis tristantur et dolent.

Respexit illos excelsus Dominus, qui humilia respicit in caelo et in terra.

Benedicimus ${ }^{17}$ Deum caeli et coram omnibus angelis magnificamus eum.

Benedicamus Patrem et Filium cum Sancto Spiritu, laudemus et magnificemus eum in saecula.

Hunc uersiculum omnes angeli et homines canebant simul. Alios angeli ${ }^{18}$ soli et homines soli alternatim ${ }^{19}$. Tunc inruit in me desiderium illic permanendi et ab illo coetu amplius non discedendi. Et dixi ad angelum ad me accedentem ${ }^{20}$ : Oh! si fieri posset ut hic remanerem et ad miserias mundi amplius non redirem ${ }^{21}$ !

Et ille ad me: Certamen bonum certasti et fidem seruasti. Sed nondum cursum et agonem consumasti. Oportet te redire et librum his de rebus conficere, ut pastor futurus sciat ${ }^{22}$ perfecte $^{23}$ legem Dei. Audisti cantus nostros, placuerunt tibi. Scito te ${ }^{24}$ nec milesimam partem uoluptatis ${ }^{25}$ quam nos sentimus percepisse. Mente $^{26}$ illa ualde suauius est quam auribus percipere ${ }^{27}$. Psalmum quem pater uester Adam post lapsum fecit, et hymnum quem Michael nobiscum cecinit, quando Lucifer cum suis cecidit, uos non habetis, quos cum multis aliis tibi dabo ut tempore nuptiarum Agni et deinceps iugiter decantentur. Sed nunc Dominus noster te accersiuit huc ut de Verbi incarnatione aliqua tibi reuelentur, quae non $\mathrm{ut}^{28}$ dubia aut apocrypha sed tamquam certa a fidelibus teneantur.

Alias, quando hic eras, narraui tibi Virginis et Reginae nostrae ingressum ${ }^{29}$ in Templum Domini ibique manentem ${ }^{30}$ ac uita ${ }^{31}$, moribus, exemplo, opere et uerbo uirgines ${ }^{32}$ Domini $^{33}$, immo et ipsos antiquos sacerdotes docentem, qui omnes mirabantur de uerbis suis et uita sua quae iugiter angelis erat associata. Saepiusque cum Deo ipsa loquebatur facie ad faciem, sicut solet loqui amicus cum amico suo. Tandem cum annus suae aetatis quartus decimus uerteretur ${ }^{34}$, princeps illorum sacerdotum dixit ei cum magna reuerentia: Filia in Domino Deo nostro nobis amantissima, tempus iam adest in quo secundum legem Dei nostri te oportet ${ }^{35}$ connubio alicui uiro copulari ut semen suscitetis in populo

17 Benedicimus] Benedicamus AHPRV 18 canebant simul. Alios angeli] canebant ad alios angeli $Q \mathbf{1 9}$ et homines soli alternatim.] et homines alternatim. $N$; et homines sibi alternatim IRV 20 ad me accedentem] mihi assistentem $E$; adiacentem $J$; aducientem $P Q 21$ hic remanerem et ad miserias mundi amplius non redirem] hic remanerem et ad miserias mundi ulterius non redirem $E$; hic remanerem $Q 22$ sciat] faciat $Q 23$ perfecte] perfectam $R V \mathbf{2 4}$ Audisti cantus nostros, placuerunt tibi. Scito te] Audisti cantus nostros, placuerunt tibi sed scito $A$; audisti. Cantus nostros placuerunt tibi, sed scito te $E$; Audisti cantus nostros. Placuerunt tibi? Sed scito te $H N R$; cantus nostros. Placuerunt tibi? Sed scito tu $P$; Audisti cantus nostros et placuerunt tibi. Sed scito te $I Q$; Audisti cantus nostros. Placuerunt tibi, sed cito te $G R$; placuerunt tibi, sed scio te $V \mathbf{2 5}$ uoluptatis] iucunditatis $E \mathbf{2 6}$ percepisse. Mente] percepisse mente $P 27$ Mente illa ualde suauius est quam auribus percipere.] om. $Q \mathbf{2 8}$ ut] sunt $V \mathbf{2 9}$ ingressum] praesentationem $A \mathbf{3 0}$ ibique manentem] et quomodo ibi manens $E \mathbf{3 1}$ uita] mira $V \mathbf{3 2}$ et uerbo uirgines] et uerbo puellas et uirgines $M$ (in $\rightarrow$ 
Alegram-se e regozijam-se com os nossos bens, entristecem-se e afligem-se com os males.

Lançou sobre eles seu olhar o Senhor Excelso, que olha o que é humilde no Céu e na Terra.

Bendizemos ao Deus do Céu e exaltamo-lo na presença de todos os anjos.

Bendigamos o Pai, o Filho com o Espírito Santo. Louvemo-lo e exaltemo-lo para sempre.

Este versículo, cantavam-no todos os anjos e todos os homens. Os outros, só os anjos e só os homens, alternadamente. Invadiu-me, então, o desejo de ali permanecer e de jamais me afastar daquela Assembleia. E disse ao anjo, que se aproximava de mim: Oh! Se me fosse possível ficar aqui e não mais voltar às misérias da Terra!

Combateste o bom combate, respondeu-me ele, e preservaste a fé. ${ }^{\left[{ }^{[6]}\right.}$ Mas ainda não concluíste a corrida nem o combate. É necessário que voltes e escrevas um livro com estas matérias, para que o futuro Pastor conheça perfeitamente a lei de Deus. Ouviste os nossos cânticos. Agradaram-te. Fica a saber que não sentiste nem a milésima parte do prazer que nós sentimos. É muito mais agradável senti-los com a mente do que com os ouvidos. Não dispondes do salmo que compôs vosso pai Adão depois da queda, nem do hino que Miguel cantou connosco quando Lúcifer caiu com os seus. Dar-tos-ei, como muitos outros, para que sejam cantados continuamente no tempo da Núpcias do Cordeiro e depois. Mas o Senhor, nosso Deus, chamou-te agora aqui para que te sejam reveladas algumas coisas sobre a incarnação do Verbo, que hão-de ser tidas pelos fiéis não como duvidosas ou apócrifas, mas como certas.

Da outra vez que aqui estiveste, falei-te do ingresso da Virgem e Rainha nossa no Templo do Senhor, de aí haver ficado, de ensinar com a vida, os costumes, o exemplo, por obras e palavra as virgens do Senhor e até os próprios sacerdotes anciãos, que se maravilhavam todos com as suas palavras e a sua vida que permanentemente estava unida aos anjos. E muitas vezes ela falava com Deus face a face como costuma falar um amigo com o seu amigo. ${ }^{[7]}$ Por fim, no decurso do seu décimo quarto ano, disse-lhe com grande respeito o príncipe dos sacerdotes: Filha, para nós muito querida em Deus nosso Senhor, chegou já o tempo em que, segundo a lei do nosso Deus, te deves unir a um homem em casamento para que

$\leftarrow$ marg. a. m.) $O Q 33$ Domini] docuerit $E 34$ annus sue aetatis quartus decimus uerteretur] annum suae aetatis quartum decimum ageret $A$; annus suae aetatis quartus decimus ueneretur $J$; annus suae aetatis quartus decimus ueniret $N 35$ oportet] oporteret $H$; oportere $I V$

[76] $2 \operatorname{Tim} 4: 6$.

[77] Ex 33:11. 
Dei et ut numerus credentium Deo populorum non solum non diminuatur, sed etiam augeatur.

Cui humillima ${ }^{36}$ uirgo humillime respondit: Mi Pater uenerande ${ }^{37}$ et domine colende, tu, diu est, nosti ${ }^{38}$ intentionem meam et uotum meum quod emisi uirginitatis perpetuae. Quia tamen sub potestate Dei sunt omnia opera nostra, uideto $^{39}$, pater, quid agendum sit et conuocato ad te omnes illos ${ }^{40}$ ad quos ex lege Dei nostri spectaret ${ }^{41}$ me accipere in uxorem. Sed prius consule ${ }^{42}$ Dominum Deum nostrum ${ }^{43}$ si placet sibi ut desponser a uiro aliquo, et quem ipse elegerit ${ }^{44}$ pro sponso meo.

Tunc pater ${ }^{45}$ ille dixit: Recte dicis, carissima filia. Ora tu primum Dominum ${ }^{46}$, quia merita tua longe antecellunt ${ }^{47}$ nostra et nos quoque orabimus.

Et post triduum apparui ego Gabriel principi sacerdotum et dixi: Exaudita est oratio uestra. Conuoca ergo uniuersos homines carentes uxoribus de tribu Mariae, iam nubilis puellae, et omnes teneant uirgas siccas in manibus suis. Et si Dominus alicui uiriditatem restituerit, subito sicut floreat, hoc erit signum quod placebit Deo ut Maria uirum accipiat et illum quisquis ille fuerit in cuius manibus uirga frondes et flores emiserit (quod futurum et ipsa Maria nouerat diuina reuelatione). Statuta igitur die, quae erat octaua ante [f1. 73] Kalendas Aprilis $^{48}$, ut uos hodie computatis, non computando dies Kalendarum ${ }^{49}$, quae erat ualde mellifluus caelorum aspectus, non quia Deus noster potentissimus eo indigeret, sed ut esset signum sapientibus stupendi ${ }^{50}$ prodigii et ut etiam ipsa creatura pro modulo suo famulatum praeberet creatori suo, conuocati fuerunt ${ }^{51}$ omnes iuuenes et uiri tribus Mariae, quae fuit de tribu Iuda ex parte patris et de tribu Leui ex parte matris, ut Christus descenderet Rex ex tribu regali et sacerdos ex tribu sacerdotali. Reducta erat enim ${ }^{52}$ puella in ciuitatem Nazareth cum magna societate et de Iudaea et de Galilaea. Et sacerdotum copia secuta est eam ut uiderent miraculum grande quod expectabatur.

Dum ergo conuocarentur omnes matrimonio soluti ${ }^{53}$ etiam Ioseph fuit uocatus, qui uenire renuebat, nam et ipse uir Deo deditus ${ }^{54}$ erat et nutu Dei in mente sua numquam uirginitatem suam uiolare ${ }^{55}$ proposuerat. Non est ergo uerum quod habuerit ${ }^{56}$ uxorem umquam aliam quam Mariam aut ullos liberos. Renuebat etiam uenire quia famam illius puellae et sanctitatem audierat et se indignum ea ${ }^{57}$ putabat et ratione sanctitatis et ratione aetatis. Non quia decrepitus aut multum senex esset, sed quia comparatione ad Mariam, puellam tenellam, senex erat. Quintum ${ }^{58}$

36 humillima] humillis $A 37$ uenerande] reuerende $E 38$ tu, diu est, nosti] tandiu est quod nosti $E$; tu, diu est quod nosti $I N Q$; tu diu nosti $O$; tu, domine, nosti $P \mathbf{3 9}$ uideto] uide $E$; uideo $V \mathbf{4 0}$ et conuocato ad te omnes illos] priusquam conuoces illos $E \mathbf{4 1}$ spectaret] spectat $E$ $\mathbf{4 2}$ consule] consulendum IRV 43 Dominum Deum nostrum] Dominum Deum nostrum ut ipse reuelet $E$, Deum nostrum IQRV $\mathbf{4 4}$ et quem ipse elegerit] quem ipse eligat $E \mathbf{4 5}$ pater] sacerdos $E \mathbf{4 6}$ primum Dominum] primo Deum $E \mathbf{4 7}$ antecellunt] antecedunt $V \mathbf{4 8}$ Aprilis] Aprilis. Erat enim dies $\rightarrow$ 
susciteis descendência no povo de Deus e não só não diminua o número dos que crêem em Deus, mas até aumente.

Meu venerável pai e respeitável senhor, respondeu-lhe humildemente a muito humilde virgem, tu, há muito tempo, conheces a minha intenção e o voto de perpétua virgindade que fiz. Mas porque todas as nossas obras estão submetidas ao poder de Deus, vê tu, pai, o que deve ser feito e chama até ti todos aqueles a quem, de acordo com a lei de Deus, caberia receber-me em casamento. Consulta, porém, primeiro o Senhor nosso Deus se é do seu agrado que eu seja desposada por um homem, e quem terá ele escolhido para meu marido.

Dizes bem, caríssima filha, disse então o sacerdote. Ora tu primeiro ao Senhor, porque os teus méritos ultrapassam muito os nossos, e nós rezaremos também.

E três dias depois apareci eu, Gabriel, ao príncipe dos sacerdotes e disse: A vossa oração foi ouvida. Convoca, pois, todos os homens solteiros da tribo de Maria, donzela em idade de casar, e todos tenham varas secas em suas mãos. E se o Senhor restituir a verdura a alguma, imediatamente, logo que floresça, será esse o sinal de que agradou a Deus que Maria aceite um homem e que seja aquele, quem quer que ele seja, em cujas mãos a vara lance ramos e flores (Maria sabia por revelação divina o que ia acontecer). Portanto, estabelecido o dia, que era o dia vinte e cinco de Março, [f1.73] segundo o vosso calendário, em que estava muito agradável o aspecto do céu, não que o nosso Deus Todo Poderoso disso precisasse, mas para se constituir para os sábios como sinal do admirável prodígio, e para que a mesma criatura manifestasse a seu modo submissão ao seu Criador, foram convocados todos os jovens e homens da tribo de Maria, que pertence à tribo de Judá, pelo lado do pai, e à tribo de Levi, pelo lado da mãe, a fim de que Cristo descendesse, enquanto Rei, de uma tribo real e, enquanto sacerdote, de uma tribo sacerdotal. A donzela tinha sido levada de volta à cidade de Nazaré com grande número de acompanhantes quer da Judeia, quer da Galileia. Acompanhou-a também um significativo número de sacerdotes para presenciarem o grande milagre que se esperava.

Enquanto, pois, se convocavam todos os solteiros, também José foi chamado, ele que recusava vir, pois também ele era um homem consagrado a Deus e, por inspiração de Deus, tinha-se proposto em seu espírito nunca violar a sua virgindade. Não é, portanto, verdade que haja tido alguma vez outra mulher que não Maria ou outros filhos. Recusava vir, também, porque ouvira falar da pureza e da santidade daquela donzela e se considerava indigno dela, não só em razão da santidade, mas também em razão da idade. Não que fosse decrépito ou muito

$\leftarrow$ uigesimus quartus $P \mathbf{4 9}$ non computando dies Kalendarum] non computando dies Kalendarum. Erat enim dies illius mensis uigesima quarta GJMNO $\mathbf{5 0}$ signum sapientibus stupendi] signum stupendi $E$; signum sapientissimus stupendi $J$; signum sapientibus stupendii $Q V \mathbf{5 1}$ fuerunt] sunt $P$; fuerant $V \mathbf{5 2}$ Reducta erat enim] Rediit itaque $E \mathbf{5 3}$ soluti] non ligati $E \mathbf{5 4}$ deditus] dedicatus $R$ 55 uiolare] se uiolaturum $E 56$ habuerit] habuit $H I N R V 57$ ea] esse $A 58$ Quintum] Quartum $Q$ 
namque et quadragessimum agebat annum, sanus mente et corpore robustus, uir magno ingenio, ornatus omni uirtute, imbutus bonis et sanctis moribus, prudens ${ }^{59}$, sed columbinae simplicitatis et admirandae humilitatis.

Congregatis itaque omnibus et uirgas tenentibus ${ }^{60}$, nulla floruit. Aspiciebant se mutuo iuuenes et exspectatio miraculi in risum uertebatur. ${ }^{61}$ Tandem, cognoscens per Spiritum sacerdos primicerius illum abesse quem Dominus uolebat, ipsum Ioseph compulit ut cum aliis suae tribus illico accederet ${ }^{62}$ uirgamque aridam ut alii in manibus teneret. Et dum ita coram sacerdotibus Dei orantibus omnes et ipsi $^{63}$ orantes astarent ${ }^{64}$, uenit columba de caelo et insedit humero Ioseph dextro et uirga sicca subito floruit et uiridis facta est tota.

Tunc sacerdotes Deo gratias agentes amplexati et osculati sunt eum et duxerunt eum ut coram omnibus Mariam, prout mos Iudaeis erat, desponsaret. Qui humiliter dixit: Non mereor ego uir esse tantae tamque sanctae puellae qui peccator sum et senex homo et insufficiens ${ }^{65}$.

Ipsis autem dicentibus ${ }^{66}$ id esse uoluntatis diuinae, ut in signo illo fuit ostensum, ille dixit: Dicam antea Mariae, sorori meae, duo uerba secretae et subito reuertar ad uos.

Erat enim Maria soror Ioseph hoc modo: Mathan et Heli fuerunt germani ex eodem patre et ex eadem matre nati. Mathan genuit unum filium quem uocauit Heli nomine fratris sui iam defuncti, et $\operatorname{Iacob}^{67}$. Qui Iacob, mortuo fratre suo Heli $^{68}$ sine liberis, accepit uxorem fratris sui, iuxta legem Domini, et genuit hunc Ioseph sanctum. Heli uero frater Mathan senior genuit Ioachim et defunctus est. Ioachim uero iam senex genuit ex Anna Mariam. Ecce uides quo pacto Maria erat soror Ioseph.

Accessit itaque Ioseph ad Mariam et, exhibita mutua reuerentia in timore Dei, dixit Ioseph: Dilectissima soror Maria ${ }^{69}$, multa de te praedicantur et, inter alia, quod tu uirginitatem tuam Deo caeli uouisti et dedicasti. Ego, ut tibi, soror, uerum fatear, talis propositi semper fui et carnis delectationem ${ }^{70}$ numquam experiar. Et iam uir prouectus sum, iuuentutem meam illibatam conseruaui. Durum est mihi in hac aetate uirili maritus effici [fl. 74] et contra propositum agere tot annis

59 uir magno ingenio (magni ingenii $E$ ), ornatus omni uirtute, imbutus bonis et sanctis moribus, prudens] uir magno ingenio ornatus, omni uirtute imbutus, bonis et sanctis moribus praeditus Q; uir magno ingenio ornatus, omni uirtute imbutus, bonus et sanctis moribus, prudens $R$; uir magno ingenio ornatus, omni uirtute imbutus, bonus et sanctus, moribus prudens $V \mathbf{6 0}$ Congregatis itaque omnibus et uirgas tenentibus] Congregati ergo omnes et uirgas tenentes in manibus $V \mathbf{6 1}$ Congregatis itaque omnibus et uirgas tenentibus, nulla floruit. Aspiciebant se mutuo iuuenes et exspectatio miraculi in risum uertebatur.] om. EHIR 62 ipsum Ioseph compulit ut cum aliis suae tribus illico (illuc $A$ ) accederet] compulit eum (ut $a d d$. sup. lin. $R$ ) cum aliis tribus suae ad Templum $\rightarrow$ 
velho, mas porque em comparação com Maria, donzela muito nova, era velho. $\mathrm{Na}$ realidade, andava nos quarenta e cinco anos. São de espírito e robusto de corpo, homem de grande carácter, ornado de toda a virtude, imbuído de bons e santos hábitos, prudente, mas com a simplicidade de uma pomba e humildade digna de admiração.

Reunidos todos e empunhando as varas, nenhuma floriu. Olhavam-se os jovens mutuamente e a expectativa do milagre convertia-se em riso. Finalmente, por acção do Espírito, conhecendo o príncipe dos sacerdotes que faltava aquele que Deus queria, ele mesmo forçou José a vir com os outros da sua tribo e a segurar na mão a vara seca, como os outros. E enquanto todos estavam diante dos sacerdotes de Deus, que oravam, e orando eles também, desceu do céu uma pomba e pousou no ombro direito de José, e a vara seca floriu imediatamente e reverdeceu toda.

Então os sacerdotes, dando graças a Deus, abraçaram-no e beijaram-no e levaram-no para que, na presença de todos, desposasse Maria segundo a tradição dos judeus. Humildemente afirmou ele: Não mereço ser marido de tão nobre e tão santa donzela, eu que sou pecador, velho e incapaz.

Dizendo eles que isso era decisão da vontade divina, como havia sido demonstrado naquele sinal, respondeu ele: Deixem-me dizer a Maria, minha irmã, duas palavras em particular, e voltarei já para junto de vós.

Maria era, pois, irmã de José, nestes termos: Matham e Heli eram irmãos nascidos do mesmo pai e da mesma mãe. Matham gerou um filho, a quem chamou Heli, do nome de seu irmão já defunto, e outro Jacob. Este Jacob, morto seu irmão Heli sem filhos, casou com a mulher de seu irmão, de acordo com a Lei do Senhor, e gerou este santo José. E Heli, o mais velho, o irmão de Matham, gerou Joaquim e morreu. Joaquim, já velho, de Ana gerou Maria. Já vês de que modo Maria era irmã de José.

E, assim, José abeirou-se de Maria e, cumprimentando-se reverentemente no temor do Senhor, disse José: Maria, minha querida irmã, muita coisa se afirma a teu respeito e, entre outras, que tu consagraste e ofereceste a tua virgindade ao Deus do Céu. Eu, irmã, para te confessar a verdade, sempre mantive esse propósito e o de jamais fazer a experiência do prazer da carne e, sou já homem de idade adiantada, conservei ilibada a minha juventude. É para mim custoso

$\leftarrow$ (ad Templum add. sup. lin. a. m. O) accedere HIORV 63 coram sacerdotibus Dei orantibus omnes et ipsi] coram sacerdotibus Dei orantibus omnibus et ipsi $N \mathbf{6 4}$ astarent] assisterent $H \mathbf{6 5}$ et insufficiens] in eius comparatione $E \mathbf{6 6}$ autem dicentibus] interdicentibus $P \mathbf{6 7}$ Mathan genuit unum filium quem uocauit Heli, nomine fratris sui iam defuncti, et Iacob (Iacobi $A$ ). Qui] Mathan genuit duos filios, unum quem uocauit Heli nomine fratris sui iam defuncti. Alterum Iacob. Qui $O$ 68 nomine fratris sui iam defuncti, et Iacob. Qui Iacob, mortuo fratre suo Heli] om. G 69 Maria] mea $I R V 70$ dilectionem] delectatione $G I$, dilectiones $O V$; delectationes $R$ 
confirmatum. Ex alia parte uidetur quod Deus id uelit quod ego nolo. Quid tibi de hoc uidetur, indica mihi.

Maria dixit: Magna sunt mysteria Dei, frater carissime. Consilium eius mens nostra sine eius gratia attingere non potest. Ego certe uirginitatem uoui. Lex et miraculum urgent ad matrimonium et compellunt ${ }^{71}$. Dent nobis spatium trium horarum et oremus et ipsi orent ut Deus noster utrique nostrum ostendat quo pacto et uoto satisfacere et legi suae ${ }^{72}$ oboedire ualeamus.

Et habita super hoc licentia ${ }^{73}$ omnibusque in loco illo orantibus et Ioseph in cella una et Maria in altera orante, ego primum apparui Mariae et dixi: Accipe Ioseph pro uiro tuo, nec timeas. Ipse enim confirmabitur in gratia in hac desponsatione sancta, nec umquam ex te aliquid perquiret ${ }^{74}$ quod tuam uirginitatem delere possit. Vult Deus ut tu sis illi uera sponsa et uxor et ipse tibi uerus sponsus et uir $^{75}$ et tamen uterque ${ }^{76}$ uirginitatem perpetuo seruabitis ${ }^{77}$. Consenties igitur in matrimonialem actum si petierit. Esto certa, Maria, quod numquam petet, et eris uxor simul et uirgo.

Similiter apparui et Ioseph et dixi: Ioseph, fili Dauid, noli timere desponsare et in uxorem accipere Mariam, quia propter talem contractum uirginitatem tuam non amittes. Velis et consentias, si ipsa uoluerit et quouis modo requisierit. Securus esto et certus quod numquam Maria uolet et numquam petet aut exiget. Vir eris et uirgo, illa uxor et uirgo.

Tunc Ioseph dixit: Ad quid ergo eam accipere oportet?

Respondi ego: Domini uoluntas est, cuius consilii causas perquirere praesumptionis est $^{78}$.

Intellexerunt ergo uoluntatem Dei et modum et uenerunt ad pontificem dicentes se uelle diuinae legi parere et mandatis caelestibus oboedire.

Tunc pontifex gratias agens Domino Deo Israel, astante coetu sacerdotum et leuitarum et multitudine populi, benedixit eos benedictione illius temporis 79 consueta et addidit: "Deus caeli cui nihil est impossibile concedat uobis fructum uentris cum integritate mentis. Fructus uester excelsior sit nubibus, sublimior caelis omnibus." Hoc autem ipse non intellexit. Prophetauit, sed uerba suae prophetiae non intellexit.

Accepta itaque utriusque manu dextera a pontifice et coniuncta manu Ioseph manui Mariae, accepit ille eam in uxorem et ipsa illum in uirum et annulo suo Ioseph subarrauit ${ }^{80}$ eam. Tunc pontifex, ut moris erat, psalmum illum Beati omnes

71 urgent ad matrimonium et compellunt] urgent et ad matrimonium compellunt $Q \quad 72$ suae] nostrae $A E G J O P Q \mathbf{7 3}$ licentia] sententia $N \mathbf{7 4}$ perquiret] requiret $E \mathbf{7 5}$ uir] uxor $V \mathbf{7 6}$ uterque] utrique $E \mathbf{7 7}$ seruabitis] seruabit $I R V \mathbf{7 8}$ Domini uoluntas est, cuius consilii causas perquirere $\rightarrow$ 
ser marido nesta idade [fl. 74] e agir contra uma decisão confirmada por tantos anos. Por outro lado, parece que Deus quer aquilo que eu não quero. Dá-me a conhecer o que pensas disto.

Os mistérios de Deus, meu caríssimo irmão, são grandes, disse Maria. Sem a sua graça, a nossa inteligência não pode alcançar o seu desígnio. Eu realmente consagrei a virgindade. A Lei e o milagre forçam e constrangem ao matrimónio. Que nos concedam um intervalo de três horas, e oremos nós e que eles orem também para que o nosso Deus mostre a cada um de nós de que modo poderemos não só dar cumprimento ao voto, mas obedecer à sua Lei.

E obtida, sobre isso, autorização, enquanto todos oravam naquele lugar, e José orava numa cela e Maria noutra, apareci eu primeiro a Maria e disse: Aceita José por teu marido e não temas. Ele será confirmado em graça neste santo casamento e nunca exigirá de ti algo que possa ofender a tua virgindade. Quer Deus que tu sejas para ele esposa e mulher verdadeira e ele seja para ti verdadeiro esposo e marido e, todavia, ambos mantereis para sempre a virgindade. Consentirás, pois, no acto matrimonial se ele o pedir. Está segura, Maria, de que nunca o pedirá e serás ao mesmo tempo esposa e virgem.

Apareci igualmente a José e disse: José, filho de David, não temas desposar Maria e recebê-la como esposa porque, por tal acordo, não perderás a tua virgindade. Que tu queiras e consintas, se ela quiser e do modo que ela pedir. Fica seguro e certo de que nunca Maria quererá e nunca pedirá ou exigirá. Serás marido e virgem, ela esposa e virgem.

Qual então a necessidade de a receber, pergunta José.

É a vontade do Senhor, respondi eu, e é presunção indagar as causas dessa decisão.

Compreenderam, pois, a vontade do Senhor e o seu alcance e vieram junto do pontífice dizendo que queriam submeter-se à Lei divina e obedecer às ordens do Céu.

Então o pontífice, dando graças ao Senhor, Deus de Israel, na presença da assembleia dos sacerdotes e levitas e da multidão do povo, abençoou-os segundo o costume daquele tempo e acrescentou: Que o Deus do Céu, a quem nada é impossível, vos conceda o fruto do ventre com a castidade da mente. Seja o vosso fruto mais alto que as nuvens, mais sublime que todos os Céus. Mas não entendeu isto. Profetizou, mas não reconheceu as palavras da sua profecia.

Pegando o pontífice na mão direita de cada um e unindo à mão de Maria a mão de José, ele recebeu-a como mulher e ela recebeu-o como marido e, por meio do seu anel, José comprometeu-se perante ela. O pontífice, então, como era

$\leftarrow$ praesumptionis est] Domini uoluntas est perquirere $H \mathbf{7 9}$ illius temporis] illis temporibus $I R V \mathbf{8 0}$ subarrauit] subarriuit $Q$ 
qui timent Dominum ${ }^{81}$ cum sacerdotibus cecinit. Et post ultimum uersiculum prosecuti sunt hymnum sequentem Spiritu Sancto eorum linguas mouente ${ }^{82}$ :

Magnus Dominus qui uos coniunxit magnificetur in fructu uentris uestri, Magnificetur in Filio uestro super filios omnium filiorum.

Deus ${ }^{83}$ cui nihil impossibile, concedat uobis fructum uentris cum integritate mentis.

Fructus uester excelsior sit nubibus ${ }^{84}$, sublimior caelis omnibus,

Crescat a mari usque ad mare et a flumine 85 usque ad terminos orbis terrarum.

Adorent eum omnes reges Terrae, omnes gentes seruiant ${ }^{86} \mathrm{ei}$,

Reges ei munera offerant ${ }^{87}$ et reginae dona adducant. ${ }^{88}$

Permaneat cum Sole et ante Lunam per omnes mundi generations, ${ }^{89}$

[f1. 75] Sit nomen eius benedictum in saecula, benedicantur in ipso omnes tribus terrae,

Magnificent eum omnes gentes, repleatur eius maiestate caelum et terra,

Primogenitum uestrum ponat ${ }^{90}$ Deus excelsiorem omnibus regibus terrae.

Adorent eum omnes angeli Dei, subiciantur ${ }^{91}$ ei pricipatus et potestates.

Sui $^{92}$ eum non recipient ${ }^{93}$, alienam ${ }^{94}$ gentem uocabit,

Videntes non uidebunt et qui non uident consolabuntur,

Sterilis pariet ${ }^{95}$ plurimos et quae multos habet ${ }^{96}$ filios absque liberis permanebit,

Donec agnita proteruia reducantur ${ }^{97}$ in ipsum omnia,

Quando Antiquus ${ }^{98}$ Dierum Filio nuptias faciet et suum Consolatorem in mundum transmittet.

Ecce uirga Aaron ${ }^{99}$ floruit et Deus antiqua mirabilia ${ }^{100}$ renouauit. ${ }^{101}$

Coniuncta est Sanctissima sancto, sed proles ${ }^{102}$ sanctior erit ${ }^{103}$.

Arbor haec est optima, proferet omnibus suauissimum ${ }^{104}$ fructum.

Virga egressa est de radice Iesse, et flos de radice eadem ${ }^{105}$ ascendet. ${ }^{106}$

Requiescet super eum multiplex et unus Spiritus Domini

Et omnes linguae et populi laudabunt in aeternum ${ }^{107}$ nomen Domini.

81 Dominum"] Dominum qui ambulant in uiis eius $A G H I N O Q R V \mathbf{8 2}$ linguas mouente.] linguas mouente. Psalmus $E$; linguas mouente. Hymnum quem dixerunt sacerdotes quando Ioseph desponsauit Mariam. $I(R$ in marg. a. $m$.) $V \mathbf{8 3}$ Filio uestro super filios omnium filiorum. Deus] Filio uestro super omnes filios filiorum. Deus $E$; Filio uestro Deus $Q \mathbf{8 4}$ nubibus] omnibus $V$ 85 a flumine] et flumen $I R V \mathbf{8 6}$ seruiant] seruient $E G H P Q V \mathbf{8 7}$ offerant] offerent $E G M P V \mathbf{8 8}$ adducant] adducent $E G I R V \mathbf{8 9}$ generationes] regiones $Q 90$ ponat] parat $R V \mathbf{9 1}$ subiciantur] subicientur $P 92$ Sui] Serui $H 93$ recipient] recipiant $P \quad 94$ alienam] alienigenam $N 95$ pariet] paries $I 96$ habet] habebat $P$; habebit $R 97$ Donec agnita proteruia (proterua $R$ ) reducantur] Donet agnita, proteruia reducat $V 98$ Antiquus] Antiquis $M 99$ Aaron] florum $V 100$ mirabilia] miracula $E \mathbf{1 0 1}$ renouauit] renouabit $H J$; reuelauit $V \quad \mathbf{1 0 2}$ proles] flores utroque $O \quad \mathbf{1 0 3}$ erit] dixit IRV 104 suauissimum] sanctissimum GNOP 105 et flos de radice eadem] et flos de eadem $A H I O R$; et flos de radice eius $E N$; et flos de radice $V \quad 106$ ascendet] ascendit $A J M N O P \quad 107$ laudabunt in aeternum] benedicent in extremum $V$ 
de tradição, cantou com os outros sacerdotes o salmo: Bem-aventurados todos os que temem o Senhor ${ }^{[78]} \mathrm{E}$, depois do último versículo, continuaram com o hino que segue, movendo o Espírito Santo as suas línguas:

Que o Grande Senhor que vos uniu seja glorificado no fruto do vosso ventre, Seja glorificado no vosso Filho sobre os filhos de todos os filhos.

Deus, a quem nada é impossível, vos conceda o fruto do ventre com a integridade da mente.

Seja o vosso fruto mais alto que as nuvens, mais sublime que todos os Céus. Que se multiplique de mar a mar e do rio até aos confins da Terra. ${ }^{[79]}$

Adorem-no todos os reis da Terra, sirvam-no todos os povos. ${ }^{[80]}$

Façam-lhe dádivas os reis, e as rainhas levem-lhe presentes. ${ }^{[81]}$

Permaneça com o Sol e perante a Lua, por todas as gerações do mundo. ${ }^{[82]}$

[f1. 75] Seja seu nome bendito para sempre, sejam nele abençoadas todas as tribos da Terra. ${ }^{[83]}$

Louvem-no todos os povos, encham-se Céu e Terra da sua majestade. ${ }^{[84]}$

Coloque Deus o vosso primogénito mais alto que todos os reis da Terra.

Adorem-no todos os anjos de Deus, submetam-se-lhe principados e potestades.

Os seus não o receberão, chamará um povo estrangeiro.

Os que vêem deixarão de ver, os que não vêem serão consolados.

A estéril dará muitos à luz, e a que tem muitos filhos ficará sem eles

Até que, reconhecendo a sua contumácia, todas as coisas sejam a ele reconduzidas.

Quando o Antigo dos Dias $^{[85]}$ celebrar as núpcias de seu Filho e enviar ao mundo o seu Consolador.

Eis que floresceu a vara de Aarão, e Deus renovou as maravilhas de outrora.

A santíssima uniu-se ao santo, mas a descendência será mais santa.

É esta uma árvore óptima, a todos dará dulcíssimo fruto.

Um rebento nasceu da raiz de Jessé, da mesma raiz brotou uma flor. ${ }^{[86]}$

Repousa sobre ele o múltiplo e uno Espírito do Senhor

E todas as línguas e povos hão-de louvar para sempre o nome do Senhor.

\footnotetext{
[78] S1 127:1,

[79] S1 71:8,

[80] S1 71:11,

[81] S1 71:10,

[82] S1 71:5,

[83] S1 71:17,

[84] S1 71:19,

[85] Dan 7:9.

[86] Is 11:1.
} 
Hoc psalmo expleto et benedictione accepta, cum gratiarum actione et cum ingenti consolatione unusquisque reuersus ${ }^{108}$ est in propria.

Dum autem psalmus cantaretur, Ioseph qui adhuc nesciebat ex Maria nasciturum ${ }^{109}$ Saluatorem et sciens se et Mariam uirgines permansuros, audiens benedictionem et psalmum ubi de futura prole agebatur, dicebat in corde suo: Isti ${ }^{110}$ sacerdotes credunt nos habituros filium neque sciunt secretum nostrum.

Maria uero, quae nouerat uirginem in breui concepturam Filium Dei, ad singula uerba animum applicabat et ea conferebat et in corde suo conseruabat ${ }^{111}$. Dicebatque: O Deus, uidebone ego uirginem tam sublimem ${ }^{112}$ ?

Sacerdotum ${ }^{113}$ plerique tristabantur de hoc matrimonio dicentes: Credebamus quod Maria foret illa uirgo ex qua Messias esset oriturus. Et ecce nunc copulata est matrimonio.

Alii dicebant: Forsan continebunt.

Recessit Ioseph. Maria uero remansit in domo patris sui cum sua genitrice Anna. Habebat autem in domo unam domunculam uel cellam a tota domo parietibus sequestratam, quae tunc erat in Nazareth in domo Ioachim et Annae. Postea fuit manibus nostris conducta et delata in partes Dalmatiae. Tandem miro modo allata fuit in agrum Romanum et non Romam ob causam Deo notam et ipsi Virgini, quae etiam multos nostrum non latet, tamen silenda ${ }^{114}$ est pro nunc. In illa domuncula Maria Virgo Ioseph desponsata psalmis et hymnis et prophetarum lectionibus uacabat et ualde admirabatur de psalmo ${ }^{115}$ illo quem cecinerant ${ }^{116}$ sacerdotes in desponsatione sui. Mirabatur etiam quod neque Deus ipse neque ullus angelorum sibi appareret ${ }^{117}$. Et quae consueta erat cibo angelico, hoc est, ab angelo $^{118}$ allato uesci, iam plusquam per uiginti horas abstinuerat. Ioseph enim ab ea discessit circiter hora uicessima secunda ${ }^{119}$, cum quo ${ }^{120}$ bucellam panis sumpsit ${ }^{121}$. Alium enim cibum ipsa manducabat. Et ego Gabriel missus a Deo cum Euchudiele ${ }^{122}$ et Barchiele ${ }^{123}$ et multis angelis de quolibet choro, sed tres eramus de septem astantibus. Ego enim qui fortitudo Dei interpretor ueniebam quasi nuntius Dei Patris; Euchudiel qui bonum consilium interpretatur erat ${ }^{124}$ quasi nuntius Filii Dei, qui sapientia et consilium Dei Patris dici solet; Barchiel uenit quasi nuntius Spiritus Sancti, quia benedictio illi personae attribuitur. Quia tamen indiuidua et inseparabilis est actio et operatio illorum, omnes fuimus totius Trinitatis nuntii. Et quia ego principalis et primus eram inter omnes ${ }^{125}$, immo sum primus absolute post Michaelem ideo et euagelista Lucas de me solum facit mentionem, ego itaque cum illis duobus praecipuis et magna multitudine [f1.

108 reuersus] ingressus $Q 109$ nasciturum] accepturum $Q 110$ Isti] Sancti $P 111$ uerba animum applicabat et ea conferebat et in corde suo conseruabat] uerba animum aplicabat $I V$; uerba animui applicabat $R \mathbf{1 1 2}$ sublimem] sublimiorem $P R$; salubrem $V \mathbf{1 1 3}$ Sacerdotum] Sacerdotes GHIRV 114 silenda] dicenda $Q 115$ de psalmo] hymno $I R V 116$ cecinerant] cecinerunt $G P Q$ 117 appareret] apparebat $E \mathbf{1 1 8}$ angelo] angelis GHINOR 119 hora uicessima secunda] horam $\rightarrow$ 
Concluído este salmo e recebida a bênção, com acção de graças e com incomensurável consolo, voltou cada um ao seu lugar.

Enquanto se cantava o salmo, José, que não sabia ainda que o Salvador haveria de nascer de Maria e, sabendo que ele e Maria continuariam virgens, ao ouvir a bênção e o salmo, onde era referida a futura descendência, dizia em seu coração: Estes sacerdotes estão convencidos de que iremos ter um filho e não conhecem o nosso segredo.

Maria, porém, que tinha sabido que uma virgem iria em breve conceber o Filho de Deus, atendia a cada palavra, meditava-a e guardava-a em seu coração. Dizia: Ó Deus, será que irei ver virgem tão sublime?

A maioria dos sacerdotes contristava-se com este casamento, dizendo: Julgávamos que fosse Maria a virgem de quem nasceria o Messias. E, vede, agora casou-se.

Se calhar vão manter-se continentes, diziam outros.

José retirou-se. Maria ficou em casa de seu pai com Ana, sua mãe. Tinha em casa uma divisão ou cela separada do resto da casa por paredes, que então estava em Nazaré, em casa de Joaquim e de Ana. Foi depois levada e transportada por nós para as bandas da Dalmácia. Por fim, levada de modo admirável para a região de Roma e não para Roma, por razões que Deus e a própria Virgem conheciam, razões que também não são desconhecidas a muitos de nós. Devem, contudo, ser por agora guardadas em silêncio. Nessa divisão, Maria, desposada por José, dedicava-se aos salmos, aos hinos, à leitura dos profetas e muito se maravilhava com o salmo que os sacerdotes tinham cantado nos seus esponsais. Admirava-se também de nem o próprio Deus nem anjo algum lhe aparecerem. E ela que estava habituada a alimentar-se com a refeição dos anjos, isto é, trazida pelo anjo, jejuava já há mais de vinte horas. José, com quem tomou um pouco de pão, separou-se dela cerca da vigésima segunda hora. Ela, realmente, tomava outro alimento. $\mathrm{E}$ eu, Gabriel, enviado por Deus com Eucudiel e Barquiel e muitos outros de cada coro, mas dos sete presentes éramos três, eu, pois, cujo nome significa força de Deus, vinha como mensageiro de Deus Pai; Eucudiel, que significa bom conselho, como mensageiro de Deus Filho, que costuma designar-se Sabedoria e Conselho de Deus Pai; Barquiel veio como mensageiro do Espírito Santo, porque a bênção se atribui a esta Pessoa. Porque, todavia, o seu agir e o seu operar são indivisíveis e inseparáveis, todos fomos mensageiros de toda a Trindade. E visto que de todos os enviados era eu o principal e o primeiro, sou mesmo, depois de Miguel, o primeiro em absoluto, por isso também o evangelista Lucas me menciona só

$\leftarrow$ uicessimam secundam IRV 120 quo] qua $I R V 121$ sumpsit] sumpserat $I R V$ 122 Euchudiele] Eucuthiele IR 123 Barchiele] Barachiele $G H$; Barchudiele $Q 124$ erat] ueniebat $N$; aut $P \quad 125$ illorum omnes fuimus (...) inter omnes missos] illorum omnes missos $I R V$; illorum omnes fuimus totius Trinitatis nuntii. Et quia ego principalis et primus eram inter omnes ministros $Q$ 
76] caelestis exercitus accessi, missus a Deo, in ciuitatem Nazareth, ad uirginem desponsatam uiro cui nomen erat Ioseph, de domo Dauid, sicut et Maria erat, et Eleazar et Heli atque Ioachim, ex parte Mariae, quia Ioseph erat de domo Eleazar et alterius Heli, secundum legem ${ }^{126}$, et Iacob, secundum generationem, et uirginis nomen erat Maria. Ingressi sumus ad eam quasi nouissima diei hora sicut et in nouissimis diebus haec incarnatio fieri debebat. Et nos tres primo apparuimus in effigie humana pulchri et splendidi, praecedente Spiritu Vehementi. Et lumen repleuit totam domunculam illam. Et ego humana uoce dixi ad Mariam: Aue, gratia plena, Dominus tecum, benedicta tu in mulieribus.

Quae, uidens nos tres facie et ueste refulgentes, nullum ex nobis postquam desponsata fuerat uiderat, neque in forma humana umquam, uerecundia uirginali

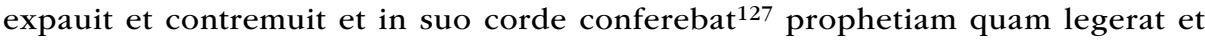
psalmum quem sacerdotes in eius desponsatione decantauerant et multa alia quae de illa dicta erant in Templo. Et cogitabat singula uerba salutationis. Qua cogitatione mens eius discurrendo turbari uidebatur tamquam dubia et anxia. Tunc ego dixi: Maria, ne ${ }^{128}$ paueas neque turberis quia omne malum euasisti et super omnes gratia ${ }^{129}$ Dei praedita eris. Et quia sepe orasti ut matrem Messiae uideres, istam gratiam inuenisti ${ }^{130}$. Tu es illa benedicta inter omnes mulieres quae filium concipies et eundem, decursis ${ }^{131}$ nouem mensibus, immo diebus ducentis septuaginta quinque, cum gaudio, media nocte illam diem sequente ${ }^{132}$, paries. Et uocabis nomen eius Iesum, qui erit ille magnus propheta quem se Deus suscitaturum in populo suo diu praedixit. Et Filius Altissimi Dei Patris est et uocabitur, quem Deus promisit sessurum super sedem Dauid patris eius secundum carnem. Et regnabit ${ }^{133}$ in domo Iacob in aeternum, et regni eius numquam erit finis.

Tunc Maria inextimabili laetitia concepta, quia iam percipiebat se illam uirginem esse quae Filium Dei conciperet et pareret, quia tamen humilis erat ualde et se uilem reputabat, sicut uere omnis creatura uilis est, immo quasi nihil est rebus diuinis comparata, adhuc prae gaudio mirabatur. Iccirco ut perfecte sciret an hic tantus Filius esset ille uerus Deus quem uirgo conceptura et paritura erat, dixit ad me: Quomodo annuntias mihi filium quam nosti uouisse uirginitatem ${ }^{134}$ perpetuam et proposuisse numquam uirum cognoscere, et quando ipsum accepi certior facta fui ipsum ex me non postolaturum aliquid tale?

126 Eleazar et Heli atque (...) Heli, secundum legem] Eleazar et Heli, secundum legem IRV 127 conferebat] proferebat $Q \mathbf{1 2 8}$ ne] neque $I R V 129$ gratia] grandia $R V 130$ inuenisti] meruisti GNP 131 decursis] diuersis $Q 132$ sequente] sequentem $I J N P R V 133$ regnabit] regnauit $H 134$ quam nosti uouisse uirginitatem] quam nosti uirginitatem IRV 
a mim, eu, portanto, enviado de Deus, dirigi-me com estes dois, os mais importantes, e uma grande multidão [f1. 76] do exército celeste à cidade de Nazaré, a uma virgem desposada com um homem chamado José, da casa de David, como também Maria era, e da casa de Eleazar, de Heli e de Joaquim, isto por parte de Maria, porque José era da casa de Eleazar e do outro Heli, segundo a Lei, e de Jacob, segundo a geração. E a virgem chamava-se Maria. Chegámos junto dela quase à última hora do dia, como também nos últimos dias devia acontecer esta incarnação. E, primeiro, aparecemos nós os três sob aparência humana, belos, resplandecentes, havendo-nos precedido o Espírito Veemente. A luz encheu toda aquela divisão. E eu, com voz humana, disse a Maria: Avé, Cheia de Graça! O Senhor é contigo, bendita és tu entre as mulberes. ${ }^{[87]}$

Ao ver-nos aos três de face e veste resplandecentes, não havia visto nenhum de nós desde que ficara comprometida, nem nos vira nunca sob a forma humana, ficou assustada no seu pudor virginal e começou a tremer, e conferia no seu íntimo a profecia que tinha lido e o salmo que tinham cantado os sacerdotes nos seus esponsais e muitas outras coisas que sobre ela se diziam no Templo. E meditava em cada palavra da saudação. À medida que ia meditando nisto, parecia que o seu espírito se perturbava, como que incerto e angustiado. Disse-lhe eu então: Não receies, Maria, nem te perturbes, porque venceste todo o mal e serás dotada, acima todos, da graça de Deus. E porque tantas vezes pediste que te fosse dado ver a Mãe do Messias, acabaste de conseguir essa graça. És tu aquela bendita entre todas as mulheres, tu que conceberás um filho e, decorridos nove meses, ou melhor, duzentos e setenta e cinco dias, o darás à luz, com alegria, na meia-noite que segue aquele dia. E dar-lhe-ás o nome de Jesus, ele que será o grande profeta que Deus há muito predisse que havia de suscitar no meio do seu povo. É e chamar-se-á o Filho de Deus Pai Altíssimo, que Deus prometeu que havia de sentar-se no trono de David, seu pai segundo a carne. E reinará para sempre na casa de Jacob, e o seu reino não terá fim.

Maria, então, tomada de incomensurável alegria, porque começava já a perceber que era ela a virgem que havia de conceber e dar à luz o Filho de Deus, mas porque era extremamente humilde e se tinha em pouca conta, como, realmente, toda a criatura pouco vale ou mesmo nada em comparação com as realidades divinas, começava a ficar inebriada de alegria. Por isso, para ficar a saber perfeitamente se esse tão ilustre filho seria o verdadeiro Deus a quem uma virgem haveria de conceber e dar à luz, perguntou-me: Como me anuncias um filho, a mim que sabes que fiz voto de virgindade perpétua e prometi nunca conhecer homem e, quando o aceitei, recebi a garantia de que ele me não iria pedir nada disso? 
Respondi ei ${ }^{135}$ quod filium conceptura erat ${ }^{136}$ aduentu et operatione Spiritus Sancti et quod loco uiri eam obumbraret ${ }^{137}$ uirtus Altissimi, quia conceptio illa erat $^{138}$ opus totius Trinitatis, Patris et Filii et Spiritus Sancti. Nam nomine Altissimi intellexi Deum Patrem, qui est fons et origo et omnium principium; nomine Virtutis ipsum Filium; et nomine Spiritus Sancti ipsum donum utriusque et tertiam personam. Addidique: O Maria, laetare, exulta et gaude gaudio magno ualde quia quod $^{139}$ ex te progredietur ${ }^{140}$ erit sanctum et sanctus sanctorum et Filius Dei. Si uis nosse, est ille et ita uocabunt eum omnes populi.

Et ut laetitiam adderem tantae laetitiae, addidi: Etiam Elisabeth, cognata tua sterilis et uetula, gestat filiolum iam sex menses habentem in utero suo. Nosti [f1. 77] Scripturas, non te latent prophetiae, nullum horum uerborum ${ }^{141}$ est impossibile Deo. Sterilis enim et senex generare potest, Deo uolente. Virginem concipere et parere non est impossibile ${ }^{142}$. Deum incarnari et hominem esse possibile erit ${ }^{143}$. Omne igitur uerbum meum tibi dictum non est impossibile, quia omne quod dixi est possibile et nullum eorum impossibile ${ }^{144}$.

Tunc Maria aperte cognouit se esse illam uirginem electam in cuius utero Filius Dei carnem humanam assumere disposuisset. Et quamuis indignissimam se iudicaret, tamen certa fuit et anima eius repleta fuit gaudio inenarrabili quia testimonio $^{145}$ Scripturae nouerat id non esse futurum ante mediam noctem. Quae tunc erat sexta hora noctis. Ad me iterum, quod euangelistae uestri non scribunt, loqui coepit: Ex uerbis tuis, angele Dei, intelligo me concepturam et parituram Filium Vnigenitum Dei Patris. Ego bene noueram hoc futurum ${ }^{146}$ his temporibus. Sed ualde miror quibus meritis me elegerit Dominus. Sed hanc admirationem ipsa $^{147}$ remoueo, quia scio nullam esse dignam tanto honore et Deum quamlibet puellam posse facere dignam. Ipse enim primo dignificat, deinde exaltat et pro meritis, quae ipse ut sint merita facit, confert praemia. Sed oro te ut mihi dicas an uos angeli hoc mysterium nunc agnouistis ${ }^{148}$ uel antea. Et scio quod tu antea hoc sciuisti. Scire uellem quanto tempore antea et si omnes ${ }^{149}$ illud cognoueritis ${ }^{150}$ uel solum aliqui uestrum.

Tunc ego aperui quomodo Deus a principio nobis reuelauerat se in utero ipsius uelle humanitatem assumere, immo et omnibus praecepisse ${ }^{151}$ ut illum Deum Hominem adoraremus ${ }^{152}$ illique subiceremur et non solum sibi sed etiam suae Genitrici. Quae tu mox futura es, unde, subito ut conceperis, nos omnes qui hic sumus et alii qui aduenient te adorabunt ${ }^{153}$ et ut Reginam suam uenerabuntur ${ }^{154}$.

135 ei] ego $H \quad 136$ quod filium conceptura erat] filium concipies $E 137$ quod loco uiri eam obumbraret] uiri loco te obumbrauit $E 138$ erat] erit $E 139$ quod] qui $H I V 140$ progredietur] egredietur $Q 141$ uerborum] donorum $A G O$; dictorum $Q \mathbf{1 4 2}$ Virginem concipere et parere non est impossibile.] similiter et Virgo concipere et parere. $E 143$ erit] erat $I V 144$ est possibile et nullum eorum impossibile] est possibile $E \mathbf{1 4 5}$ quia testimonio] et quia testimonium $G I ; \rightarrow$ 
Respondi-lhe que havia de conceber o filho com a vinda e por obra do Espírito Santo e que, em lugar do marido, a cobriria a sombra do poder do Altíssimo, porque essa concepção era obra de toda a Trindade, do Pai, do Filho e do Espírito Santo. Efectivamente, pelo nome de Altíssimo quis significar Deus Pai, que é a fonte, a origem e o princípio de tudo; pelo nome de Força, o próprio Filho; e pelo de Espírito Santo, o próprio dom de ambos, que é a Terceira Pessoa. E acrescentei: Alegra-te, Maria, exulta e regozija-te sem limites porque o que de ti vai sair será Santo e o Santo dos Santos e o Filho de Deus. Se queres saber, é ele, e todos os povos o hão-de assim chamar.

E para somar alegria a tanta alegria, acrescentei: Também Isabel, a tua parenta, estéril e idosa, traz em seu ventre um filho já de seis meses. Conheces [fl. 77] as Escrituras, não ignoras as profecias. Nada disto é impossível a Deus. Pode, de facto, querendo Deus, conceber a estéril e a idosa. Não é impossível que uma virgem conceba e dê à luz. Há-de ser possível que Deus incarne e se faça homem. Nenhuma das palavras que te disse é impossível, porque tudo quanto te disse é possível e nada disto é impossível.

Maria reconheceu então claramente que era ela a virgem eleita em cujo ventre o Filho de Deus se havia disposto a assumir a carne humana. E, embora se julgasse sumamente indigna, ficou segura e o seu espírito cheio de inenarrável alegria porque, pelo testemunho da Escritura, havia tomado conhecimento de que isso não aconteceria antes da meia-noite. Era então a sexta hora da noite. Começou de novo a falar comigo, coisa que os vossos evangelistas não escrevem: Concluo das tuas palavras, anjo de Deus, que eu vou conceber e dar à luz o Filho Unigénito de Deus Pai. Bem me havia parecido que isso se ia verificar nos tempos que correm. Mas muito me admiro por que méritos me haverá Deus escolhido. Mas eu mesma afasto esta admiração, porque sei que nenhuma seria digna de tão grande honra, e que Deus pode tornar digna qualquer donzela. Pois, primeiro, ele dignifica, depois exalta e, de acordo com os méritos, méritos que é ele que faz que o sejam, atribui o prémio. Peço-te, porém, que me digas se vós os anjos tomastes conhecimento deste mistério agora ou no passado. E sei que tu tiveste dele conhecimento anteriormente. Gostaria de saber quanto tempo antes, e se todos o conhecestes ou apenas alguns de vós.

$\mathrm{Eu}$, então, mostrei como Deus nos revelara, desde o princípio, que queria assumir em seu ventre a natureza humana, e mais, que a todos havia ordenado que adorássemos o Deus Homem, a ele nos subordinássemos, e não só a si, mas também a sua Mãe, em que tu em breve te tornarás. Daí que, logo que concebas, todos nós que aqui estamos, e outros que hão-de chegar, te adoraremos e te

$\leftarrow$ testimonium $V 146$ futurum] facturum IRV 147 ipsa] ipsam IRV 148 agnouistis] agnoueritis $H$; cognouistis INOR; cognoueritis $P Q 149$ Et scio (..) antea et si omnes] Et si omnes $Q 150$ cognoueritis] cognouistis $N Q 151$ praecepisse] praecise mandasse $Q 152$ adoraremus] adoremus $R V 153$ adorabunt] adorabimus EHJP 154 suam uenerabuntur] nostram uenerabuntur $M$ (post cor.); nostram uenerabimur EHJNP 
Eris enim perpetuo Regina caelestium spirituum et omnium angelorum Domina. Hoc mandatum accepimus a Deo et omnes cum pacto, si illud seruare uellemus ${ }^{155}$ in gratia confirmaremur et aeternaliter beati essemus. Si illud praeteriremus, ex tunc in aeternum damnaremur ${ }^{156}$.

Lucifer, uidens tantam dignitatem hominis, inuidit illi, quia nimium praesumptuosus fuit se tantum amando et alia sibi subicere uolendo. Vnde suadebat omnibus tale praeceptum non esse seruandum, inferens quia nec iustum ${ }^{157}$ erat. Subito enim ut se inordinate amauit, peccauit et iam errare coepit, praeceptum Dei iniustum existimans. Et quicumque eius opinionem intelligendo se potius amauerunt quam Deum, omnibus uisum est mandatum illud iniustum. Voluit et nos peruertere, sed ego cum istis fratribus nostris, Michaele duce, resistimus ei et eum tamquam praesumptuosum arguere coepimus, omne illud iustum, sanctum et bonum affirmantes quod uoluntati Dei nostri, qui neque errare neque ignorare neque praue uelle potest, placet $^{158}$. Quicquid ergo ille uult, cuius uoluntas ${ }^{159}$ inordinate uelle non potest, ut recte et iuste uelit necesse est. Si creatori nostro, o Lucifer, placet hominem fieri et non angelum, debet placere et nobis, maxime quia ipse mandat ut et nos ita uelimus.

Lucifer et Belzebub et alii sequaces respondebant: Quilibet debet potius sibi bonum appetere quam [f1. 78] alteri ${ }^{160}$. Ergo et maximum bonum sibi magis expetere debet ${ }^{161}$. Hoc autem donum est excelentissimum et nobilissimum. Ergo debemus illud nobis potius expetere ${ }^{162}$ quam homini. Deinde digniora dignioribus sunt praestanda. Sed nos digniores sumus omnibus hominibus. Nobis ergo donum dignissimum potius quam homini est praestandum. Nonne ita nos angelos Deus ordinauit ${ }^{163}$ et instituit ut digniores natura essent digniores meritis et praemio? Ex quo patet ipsum hoc iuste ordinasse ut dignioribus digniora dentur. Cur ergo homini indigniori tribuit digniora? Si hoc iuste facit, ergo iniuste nos ordinauit, quibus secundum naturalia concessit gratuita. Aut si nos iuste sic ordinauit, quod fatendum ${ }^{164}$ est, iniustum est ut longe minorem nobis natura, maiorem faciat ${ }^{165}$ gratia. Non decet, o Michael, non est iustum, o Gabriel, non est rectum, o ceteri angeli qui rationibus meis resistitis optimis, Deum ${ }^{166}$ hominem nobis omnibus praeponere uelle. In hoc sibi parendum non est. Nonne iniustum esset si ultimum chorum faceret primum et primum ultimum? Quanto magis si illum qui minor est

155 seruare uellemus] uolemus $H$; seruaremus $Q 156$ seruare uellemus in gratia confirmaremur et aeternaliter beati essemus. Si illud praeteriremus ex tunc in aeternum damnaremur.] seruare uellemus exilio aeterno damnaremur. $H$; seruare uellemus in gratia confirmaremur et aeternaliter beati essemus. Si illud praeteriremus ex illo aeterno damnaremur. IRV 157 esse seruandum, inferens quia nec iustum] esse seruandum, quia nec iustum $A G I R$; esse seruandum, dicens quia nec iustum $N O Q 158$ placet] placeret $A G Q$; placere $V 159$ errare neque ignorare neque praue $\rightarrow$ 
veneraremos como nossa Rainha. Serás para sempre Rainha dos espíritos celestes e Senhora de todos os anjos. Recebemos de Deus esta ordem, e com a promessa de que todos, se a quiséssemos observar, seríamos confirmados em graça e seríamos eternamente bem-aventurados. Se a desrespeitássemos, condenar-nos-íamos, desde então, para sempre.

Lúcifer, ao ver tão grande dignidade do homem, invejou-o, porque foi extremamente presunçoso ao amar-se a esse ponto e ao querer tudo subordinar a si. Por isso tentava convencer-nos a todos de que esse preceito não devia ser respeitado, inferindo que nem justo era. Na verdade, logo que se amou de um modo desordenado, pecou, e começou logo a errar ao considerar injusto o preceito de Deus. E quantos, ao reconhecerem a sua opinião, se amaram mais a si do que a Deus, a todos pareceu que aquela ordem era injusta. Quis também desencaminhar-nos a nós. Mas eu com estes meus irmãos, sob o comando de Miguel, resistimos-lhe e começámos a acusá-lo de presunçoso e a afirmar que tudo quanto está conforme com a vontade do nosso Deus, que não pode errar, nem ignorar, nem querer o que é mau, é justo, santo e bom. O que quer que seja que ele queira, cuja vontade não pode querer desordenadamente, é forçoso que o queira recta e justamente. Se é do agrado do nosso Criador fazer-se homem e não anjo, ó Lúcifer, também nos deve ser grato a nós, precisamente porque ele manda que também assim o queiramos.

Lúcifer, Belzebu e outros sequazes respondiam: Deve cada um desejar o bem mais para si do que [fl. 78] para outrem. Logo, deve reclamar para si o máximo bem. Este é o dom mais nobre e mais excelente. Portanto, devemos reivindicá-lo mais para nós que para o homem. Além disso, é aos mais dignos que devem ser dadas as coisas mais dignas. Ora, nós somos mais dignos que todos os homens. Por conseguinte, a nós deve ser dado, mais que ao homem, o dom mais digno. Não nos ordenou Deus e determinou que os mais dignos segundo a natureza fossem os mais dignos nos méritos e no prémio? Do que resulta que justamente tivesse ordenado isto: que aos mais dignos se dessem as coisas mais dignas. Porque atribuiu, pois, ao homem, que é mais indigno, o que há de mais digno? Se faz isto justamente, então ordenou-nos injustamente a nós, a quem concedeu os dons gratuitos segundo os dons naturais. Ou, se nos ordenou a nós assim justamente, o que deve ter-se por certo, é injusto que faça maior segundo a graça um ser muito menor que nós segundo a natureza. Que Deus queira antepor o homem a todos nós, não está bem, ó Miguel, não é justo, ó Gabriel, está contra a razão,

$\leftarrow$ uelle potest, placet. Quicquid ergo ille uult cuius uoluntas] add. $M$ in marg. a. $m$. 160 Quilibet debet potius sibi bonum appetere quam alteri] Quilibet dicitur potius apparere sibi quam alteri $Q \quad 161$ expetere debet] appetere debet $N$; appetendum $Q$ (abbinc: expetere debet. 161, usque ad - Et ita, o Maria Virgo sanctissima 211A deest in $G) 162$ potius expetere] magis appetere $Q$ 163 Deus ordinauit] Deus ordinauit quoque secundum naturalia et gratuita $Q \quad 164$ fatendum] patiendum $P 165$ faciat] facit $I R V 166$ optimis, Deum] optimum Deum $P$ 
ultimo choro supremo praeponeret, ut nunc facit. Rationes euidentes adeo sunt ut nulla indigeant probatione. Quid respondebitis ${ }^{167}$ ?

Cui Michael et nos alii qui hic sumus ita respondimus: Rationes tuae, Lucifer, apparentiam aliqualem ueritatis habere uidentur. Sed ualde miramur quod notissimum omni intelectui negare uideris. Hoc enim omni intellectui concedendum est, Primum et Summum Intelectum errare non posse, et Primam, Summam et Optimam Voluntatem male et inordinate uelle non posse. Quia ${ }^{168}$ sicut negatio praesupponit affirmationem, et odium amorem, et imperfectum perfectum, ita et ignorantia et error, saltem in alio, praesupponit scientiam. Si ergo Deus aliquid ignoraret uel in aliquo erraret uel aliquid male uellet, praessupponeret scientiam in alio $^{169}$ et bonum uelle in aliquo digniori se. Et ita excellentissimus haberet se excelentiorem, et dignissimus digniorem, et immutabilis posset mutari, et perfectissimus fieri perfectior. Certum debet esse ${ }^{170}$ unicuique et manifestum optimum male uelle non posse neque ullis legibus subici et quia ex se bonus est, et necessario et ex sui natura malus et iniustus fieri non potest. Quid ergo praesummis? Cur eum iniustum putas? Si uult hominem excelentiorem nobis facere, hoc et si tibi iniustum uidetur, iniustum tamen esse non potest ${ }^{171}$, nisi rectissimum obliquum credere possis. Quilibet ergo debet sibi potius appetere ${ }^{172}$ bonum, maxime tale ac tantum si in arbitrio eius fuerit talis electio. Sed si Deus praecipiat ut illud alteri appetat et non sibi, parendum est Deo, quia ipse super omnia diligendus est. Et bonum mihi conueniens, etiam paruum, possum mihi magis uelle quam alteri magnum. Illud tamen ${ }^{173}$ debeo sibi uelle et non mihi ex quo Ille, qui nullius debitor est, uult illud sibi et non mihi.

Homines ${ }^{174}$ quoque non sunt minores nobis in potentiis. Intellectus enim noster et intellectus eorum, uoluntas nostra et uoluntas eorum non uariantur in sui natura. Obiecta ${ }^{175}$ enim et actus et potentiae eiusdem rationis sunt. Natura nostra nobilior est quam illorum, non potentiae ille. Sint ${ }^{176}$ tamen omnia digniora. Vnde accepimus hanc dignitatem? Nonne a Deo? Et quo iure aut qua lege? Solo beneplacito suae uoluntatis.

167 respondebitis] respondetis $A H I R$; responditis $V 168$ posse, et Primam, Summam et Optimam Voluntatem male et inordinate uelle non posse. Quia] posse, et Primam, Summam Voluntatem male et inordinate uelle non posse. Quia $I R$; posse. Quia $V 169$ scientiam. Si ergo (...) scientiam in alio] scientiam. In alio $I R V 170$ debet esse] dicit esse $Q$, Deum $I R V \mathbf{1 7 1}$ esse non potest] non $\rightarrow$ 
ó anjos todos que vos opondes às minhas tão certas razões! Neste ponto não devemos obedecer-lhe. Não seria injusto se fizesse do último coro o primeiro e do primeiro o último? Quanto mais, se pusesse à frente do primeiro coro aquele que é inferior ao último, como está a fazer agora! As razões são a tal ponto evidentes que não carecem de qualquer prova. Que respondereis?

As tuas razões, Lúcifer, parecem ter alguma aparência de verdade, assim lhe respondeu Miguel e todos quantos aqui estamos. Mas muito nos admira que pareças negar o que é claríssimo a qualquer inteligência. Toda a inteligência há-de conceder isto, que a Primeira e Suprema Inteligência não pode errar, e que a Primeira e a Suprema e a melhor das Vontades não pode querer perversa e desordenadamente. Pois que, assim como a negação pressupõe a afirmação, e o ódio o amor, e o imperfeito o perfeito, assim também a ignorância e o erro, pelo menos no outro, pressupõem o conhecimento. Pois se Deus ignorasse alguma coisa ou em alguma coisa errasse ou quisesse malevolamente alguma coisa, pressuporia o conhecimento em outro e o bem querer em outro mais digno do que ele. E, assim, o mais Excelente de todos teria alguém mais excelente do que ele, o mais Digno de todos, alguém mais digno, e o Imutável poderia estar sujeito à mudança, e o Sumamente Perfeito tornar-se mais perfeito. Deve cada um ter por certo e manifesto que o Óptimo não pode querer mal nem subordinar-se a lei alguma e, porque, de si, é bom, não pode forçosamente e por sua natureza tornar-se mau e injusto. Que presumes, pois? Porque o julgas injusto? Se quer tornar o homem superior a nós e se isto te parece injusto, injusto não pode, contudo, ser, a menos que possas considerar oblíquo o que há de mais recto. Deve, pois, cada um procurar antes para si o bem, sobretudo tratando-se de tal e tão grande bem, se essa escolha estiver no seu âmbito. Mas se Deus ordenar que o deseje para outro e não para si, deve obedecer-se a Deus, porque o devemos amar acima de todas as coisas. O bem que me é próprio, ainda que insignificante, posso desejá-lo mais para mim do que um bem significativo para outrem. Devo, todavia, querê-lo para ele e não para mim se Aquele que a ninguém deve coisa alguma o quer para si e não para mim.

Também os homens não são inferiores a nós nas suas faculdades. Na verdade, a nossa inteligência e a deles, a nossa vontade e a deles não variam em sua natureza. São realmente da mesma natureza os objectos, os actos e as potências. A nossa natureza é mais nobre que a deles, não as potências. Admitamos, no entanto, que são mais dignas. De onde recebemos essa dignidade? Não foi, acaso, de Deus? E na base de que direito ou de que lei? Pelo beneplácito, apenas, da sua vontade.

$\leftarrow$ est sed rectissimum $Q \mathbf{1 7 2}$ Quilibet ergo debet sibi potius appetere] Quilibet ergo sibi potius dicitur appetere $Q \mathbf{1 7 3}$ alteri magnum. Illud tamen] alteri. Magnum tamen illud IORV 174 et non mihi ex quo (...) et non mihi. Homines] et non mihi. Homines $V 175$ Obiecta] Subiecta $P 176$ Sint] Sunt HIOPRV 
Ipse itaque non dat indignioribus ${ }^{177}$ digniora. Nemo enim apud eum dignus est, nisi quem ipse dignum facit. Dando autem digniora, digniores facit eos quibus dat. Et si ergo digniores sumus natura hominibus, non tamen digniores sumus ad tale munus. Ad hoc ergo ut [f1. 79] sine iniustitia digniora dignioribus dentur ${ }^{178}$, opus est ut ad illud recipiendum illi sint digniores et iterum quod ille qui concedit et praestat teneatur iure, lege uel ratione huic potius quam illi tribuere. Qui nobis ${ }^{179}$ gratuita secundum naturalia maiora uel minora tribuit, hoc etiam sponte et uoluntarie ${ }^{180}$ fecit. Et si aliter fecisset, propter id iniustus non fuisset. Neque absolute praeposuit ${ }^{181}$ nobis hominem, sed Hominem Deum.

Tunc Belzebub princeps dixit: Bene scimus quod Homo Deus praeponendus est nobis. Sed hoc est de quo ${ }^{182}$ dolemus, quod hominem assumat ad deitatem et nullum nostrum. Aliud est quod moleste ferimus, quia etiam mulierem quamdam omnibus nobis praelaturus est, quae non erit Deus, et multos alios homines quibusdam nostrum aequales, quibusdam maiores constituet. Haec siue iusta sint siue iniusta, nullo modo nobis placent. Sint enim, ut uos uultis, iusta. Si illa nobis contulisset, nonne iuste contulisset? Si ergo quicquid uult iuste uult, cur noluit ${ }^{183}$ hoc quod iustius erat?

Tunc Raphael subiunxit: Noli dicere iustius. Numquid Deus potius tibi debet ${ }^{184}$ quam homini? An ignoras quia nullius debitor est? Numquid Lucifer tuus est dignior homine? Nobilor est, concedo. Dignior hoc munere, nego. Quando nullus est dignus, nullus est etiam dignior ${ }^{185}$. Mulierem illam praefert omnibus ${ }^{186}$, quia Dei Hominis Genitrix erit ${ }^{187}$. Aliquos aequales, aliquos maiores angelis faciet prout coniunctiores illi Deo Homini fuerint. Quid tibi de tuo aufert si homini illud donum tribuit? Si homo numquam crearetur ${ }^{188}$, quid fuissetis nisi quod estis? Quid accepissetis ${ }^{189}$ nisi quod promissum est uobis? Iniquum est dolere de bono alterius, maxime si nihil amittimus ipsi.

Euchudiel $^{190}$, qui consilium Dei interpretatur et hic mecum est, addidit: Magnus Deus noster est, cuius sapientiae non est numerus, cuius sensum et consilium nemo alius ab ipso nouit nisi cui ille reuelare uoluerit. Dicite mihi uos qui desipitis sapere uolentes, nonne ad perfectionem uniuersi pertinet ut omnis combinatio possibilis in eo reperiatur? Hoc negare non potestis. Sunt autem tria: Deus, substantia et accidens. Substantia uero una, incorporea et spiritualis, pura ${ }^{191}$, ut nos angeli sumus. Alia corporea, ut lapides et ligna. Et quia poterat esse substantia partim corporea partim incorporea, ut homo, si hanc substantiam Deus non produxisset,

177 indignioribus] dignioribus $O \mathbf{1 7 8}$ ut sine iniustitia digniora dignioribus dentur] ut sit iniustitia digniora dignioribus non dari $Q \mathbf{1 7 9}$ qui nobis] quod in nobis $H$; quod nobis $I R$; quot nobis $V 180$ uoluntarie] uoluntate $O V 181$ praeposuit] proposuit $H I P Q R V 182$ de quo] quod $N Q$ 183 noluit] non uoluit $N 184$ debet] dat $Q 185$ dignior] indignior $J 186$ omnibus] hominibus $P \rightarrow$ 
Nem ele dá aos mais indignos as coisas mais dignas. Pois ninguém é digno perante ele senão quem ele digno faz. Ao dar o que é mais digno, faz mais dignos aqueles a quem dá. E se, pois, somos mais dignos que os homens pela natureza, não somos, todavia, mais dignos para esta função. Relativamente a isso, pois, para que [f1. 79] sem injustiça se atribua o mais digno aos mais dignos, é preciso que, para o receber, sejam esses os mais dignos, e também que aquele que concede e dá se veja constrangido a concedê-lo pelo direito e pela lei ou pela razão antes a um que a outro. Ele que nos concedeu os dons gratuitos, maiores ou menores, em conformidade com os dons naturais, fê-lo também de moto próprio e livremente. E se tivesse feito de outro modo, nem por isso seria injusto. Nem nos antepôs o homem em absoluto, mas o Homem Deus.

Sabemos bem, retorquiu Belzebu, o chefe, que o Homem Deus nos deve ser anteposto. Mas que assuma o homem para a divindade e não um de nós, é disso que nos queixamos. Há outra coisa que toleramos mal, que também uma mulher, que não será Deus, seja elevada acima de nós, e que estabeleça muitos outros homens iguais a alguns de nós e maiores que outros. Seja isto justo, seja injusto, de modo nenhum nos agrada. Seja justo, como quereis. Se no-lo desse a nós, não o daria justamente? Se, portanto, tudo quanto quer o quer com justiça, porque não quis isto que era mais justo?

Não digas que é mais justo, acrescentou Rafael. Acaso te deve Deus a ti mais do que ao homem? Ou ignoras que não é devedor de ninguém? É o teu Lúcifer mais digno que o homem? Que seja mais nobre, concedo. Mais digno deste dom, nego. Quando ninguém é digno, também ninguém é mais digno. Eleva esta mulher acima de todos porque será a mãe de Deus Homem. Tornará uns iguais, outros maiores que os anjos conforme estejam mais próximos desse Homem Deus. Que te tira do que te pertence se atribui esse dom ao homem? Se o homem nunca viesse a ser criado, que serieis vós senão o que sois? Que receberíeis senão o que vos foi prometido? É iníquo sofrer com o bem alheio, sobretudo se nós nada perdemos.

É grande o nosso Deus, cuja sabedoria não tem conta, cujo pensamento e cujo conselho ninguém, além de si, conhece, a não ser aquele a quem o tenha querido revelar, acrescentou Eucudiel, que significa conselho de Deus e está aqui comigo. Dizei-me, vós que ensandecestes ao pretender ser sábios, não pertence à perfeição do universo que nele se ache toda a possível combinação? Isto não podeis vós negá-lo. Há três coisas: Deus, a substância e o acidente. Uma substância incorpórea e espiritual, pura como somos nós os anjos. Outra corpórea, como as pedras e a madeira. E porque era possível uma substância em parte corpórea, em

$\leftarrow \mathbf{1 8 7}$ quia Dei Hominis genitrix erit] Dei et hominis mater erit Q 188 crearetur] cresceret $P 189$ accepissetis] accipitis $I$; accepistis $Q R V 190$ nihil amittimus ipsi. Euchudiel] nihil amittimus. Ipse Euchudiel $E N 191$ pura] puta $P$ 
nonne magna perfectio mundo defuisset? Et non satis erat quod tam corporea quam incorporea seorsum fuissent. Sed oportuit ut crearetur illa ${ }^{192}$ quae simul esset corporea et incorporea. Ita congruum fuit, ex quo potest fieri, ut fieret una res quae esset Deus et substantia corporea atque incorporea et omnia unirentur et copularentur in uno. Nam in homine coniungebatur corporeum cum incorporeo, et accidentia corporea copulata erant accidentibus incorporeis et immaterialibus in ipso homine. Restabat hoc, ut homo copularetur Deo et proprietates hominis conuenirent Deo et proprietates Dei ${ }^{193}$ conuenirent homini. Et ita in una re ${ }^{194}$ fieret coniunctio omnium rerum et aliquomodo Deus omnis res appellaretur quia appellando eum hominem in quo est esse, uiuere et intelligere, in quo utraque substantia et utraque ${ }^{195}$ accidentia sunt, appellabimus eum omnem rem. Et quia etiam homo erit Deus, in quo sunt omnes res, quodammodo omnia erunt Deus, omnia erunt plena ${ }^{196}$ Deo et Deus plenus omnibus. Et quamuis sit plenus omnibus, quia ${ }^{197}$ omnia in ipso continentur et uiuunt et sunt nobiliori modo quam in se, non tamen eo modo nunc sunt omnia in ipso, quasi res ipse secundum suum esse sunt in ipso sicut erunt [fl. 80] quando assumet humanitatem. Noli ergo mirari si assummat potius humanitatem quam naturam nostram ${ }^{198}$. Nam assumendo humanitatem etiam nos assumit, quia anima illius hominis conuenit nobiscum. Si enim assumpsisset unum ex nobis, propter hoc alios non assumpsisset specie differentes nisi sicut et nunc assumendo hominem. Nolite ergo mirari neque contristari. Parete Deo, parete et Homini Deo, subicite uos uoluntati eius.

Lucifer iterum loqui superbe coepit: Quid mihi confert si congruentius sit illud? Satis mihi est ${ }^{199}$ quod me assumere potuisset et ita ego fuissem Deus et hoc mihi fuisset melius, hoc excelentius. Adorare hominem respuo, sit Deus Homo. Non compellat ${ }^{200}$ me hominem colere aut uenerari.

Ad quem Michael: Si homo ille Deus est et Deum adorabis, nonne et hominem adorabis $^{201}$ ?

Respondit Lucifer: Ego bene distinguam inter deitatem et humanitatem. Adorabo illam, respuam istam.

Michael iterum: Nimium ${ }^{202}$ certe superbus es. Vis respuere illum hominem qui uere Deus est? Respice, miser, agnosce Creatorem tuum.

Vriel quoque, frater noster, dixit: Luceat lux Dei in te. Quomodo obscuratum est aurum! Sol tenebris inuolutus est. Quomodo cecidit qui mane oriebatur! Pete, miser, ueniam, humilia te et lux tua redibit.

192 crearetur illa] crearet illam $R V 193$ proprietates hominis conuenirent Deo et proprietates Dei] proprietates Dei $E$; et proprietatibus hominis uniretur se Deus et proprietates Dei $Q 194$ in una re] una res $I R V 195$ utraque] utriusque $I R V 196$ omnia erunt Deus, omnia erunt plena] omnia erunt plena $I R V 197$ Deus plenus omnibus. Et quamuis sit plenus omnibus quia] Deus $\rightarrow$ 
parte incorpórea, como o homem, se Deus a não tivesse produzido, não faltaria ao mundo esta perfeição? E não era suficiente que a corpórea como a incorpórea existissem separadamente. Mas devia ser criada uma que fosse ao mesmo tempo corpórea e incorpórea. Assim, foi necessário que, dado que é possível ser criado, se criasse um ser que fosse Deus e substância corpórea e incorpórea, e tudo se unisse e se associasse num só. Pois no homem unia-se o corpóreo e o incorpóreo, e no mesmo homem os acidentes corpóreos associavam-se aos incorpóreos e imateriais. Restava isto: que o homem se unisse a Deus e as propriedades do homem conviessem a Deus e as propriedades de Deus conviessem ao homem. E, assim, num só ser se faria a união de todas as coisas e, de algum modo, todo o ser seria chamado Deus porque, chamando-o homem, no qual está o ser, o viver e o pensar, no qual estão ambas as substâncias e ambos os acidentes, chamá-lo-emos todo o ser. E porque também o homem será Deus, em quem existem todas as coisas, de algum modo todas as coisas serão Deus, todas estarão cheias de Deus e Deus cheio de todas as coisas. E embora cheio de todas as coisas, porque tudo se contém, vive e existe de modo mais nobre nele do que em si, nem tudo, porém, existe agora nele desse modo, como se as próprias coisas, de acordo com o seu ser, existissem nele como existirão [fl. 80] quando assumir a humanidade. Não te admires, pois, se assumir antes a humanidade que a nossa natureza. Pois, ao assumir a humanidade, assume-nos também a nós, porque a alma deste Homem condiz connosco. Se, efectivamente, tivesse assumido um de nós, não teria assumido, por isso, outros de espécie diferente, mas sim assumindo o homem, como agora. Não vos admireis, pois, nem vos entristeçais. Obedecei a Deus, obedecei também ao Homem Deus, submetei-vos à sua vontade.

Que me adianta, começou Lúcifer a replicar de novo com soberba, que isso seja mais conveniente? Basta-me que pudesse assumir-me a mim e, assim, eu seria Deus e teria isso pelo melhor, pelo mais excelente. Recuso adorar o homem, ainda que seja o Deus Homem. Que me não force a honrar ou a venerar o homem.

Se esse homem, diz-lhe Miguel, é Deus e adorares a Deus, acaso não adorarás também o homem?

Eu, responde Lúcifer, saberei distinguir bem entre divindade e humanidade. Hei-de adorar aquela, desprezarei esta.

És por demais soberbo, adiantou Miguel. Queres desprezar o Homem que é realmente Deus? Olha, infeliz, reconhece o teu Criador!

Que a luz de Deus resplandeça em ti, disse ainda Uriel, nosso irmão. Como se enegreceu o ouro! O Sol foi envolto em trevas! Como caiu aquele que brilhava pela manhã!? Pede perdão, miserável, humilha-te, e o teu brilho voltará.

$\leftarrow$ plenus omnibus quia $N 198$ nostram] uestram $V 199$ est] esset $I R V 200$ compellat] compellor $E J$ 201 et Deum adorabis nonne et hominem adorabis] nonne Deum et hominem adorabis $N 202$ Nimium] Hominum $I$ 
Huic unus eorum respondit ${ }^{203}$ : Vos in tenebris estis, quia naturae uestrae nobilissime obliti. Hominem Deum facitis et uos ignobiliori uobis ${ }^{204}$ subicere proponitis. Magna dementia est uestra ut uelitis uos deprimere sublimes et extollere depressos.

Alius ex parte Luciferi adiunxit, uolens eos concordare, et dixit: Audite omnes consilium meum et de illo contenti estote. Postquam placuit Deo hominis naturam assumere, assumat eam. Estote ${ }^{205}$ de hoc contenti. Sed assumat etiam naturam nostram et nulli fiet ${ }^{206}$ iniuria.

Lucifer addidit: Non placet mihi quod dicis, quia pati nequeo ut homo sit mihi aequalis.

Et ille: Minus malum eligendum est. Semel decretum est illud, ut Deus sit homo. Si angelus etiam fuerit Deus, minus malum est.

Et magna pars malorum angelorum in hanc sententiam consensit ${ }^{207}$. Sed ${ }^{208}$ alii resistebant et hoc quoque nolebant. Alii quoque ipsorum dicebant: Fiat Deus homo, fiat et angelus. Sed quod angeli et homines adorent Deum Angelum, et homines soli ${ }^{209}$ Deum Hominem ita quod angeli non subiciantur homini ullo pacto. Vel si homines nolunt ${ }^{210}$ subici Deo Angelo, non curamus. Satis est ut nos non subiciamur illis.

Alii dicebant inter eos: Subiciamur ${ }^{211}$ et nos Deo Homini et illi Deo Angelo.

Sed omnes affirmabant: Nolumus nisi illum unicum adorare hominem, non matrem eius neque ullum alium.

Et ita, o Maria, Virgo sanctissima, intellexisti certamen illud nostrum. Audisti tandem et percepisti quomodo de Filio tuo mox concipiendo fuit aliqua contentio ${ }^{212}$. Sed te omnes repulerunt neque super se illi iniqui regnare uoluerunt.

Maria dixit: Audio inaudita! Grandis conflictus fuit iste. Deo resistebat creatura sua. Propter me et filium quem mihi annuntias orta est ista ualida tempestas. Verum ex quo coepisti, narra residuum istius magni proelii. Libentissime namque audio ista secreta.

Cum nos, o Maria, uideremus eos inter se diuisos et discordes et uane ${ }^{213}$ errantes, tunc Saltiel, unus ex sociis nostris, Michaele hortante ${ }^{214}$, dixit: Omnes, o infelices, erratis et a Deo auersi estis et nullus uestrum recte loquitur. Neque tu qui concordiam [f1. 81] inducere uoluisti recte locutus es. Vis legem ferre ${ }^{215}$ uoluntati Dei quae super omnem legem est. Similiter et uos alii uidemini uelle cum condicione Deo oboedire. Non est inuestiganda causa uoluntatis eius. Homo fiet Deus, non angelus. Angeli adorabunt Hominem illum et ipsius matrem uenerabuntur. Non uult ut homines adorent angelum.

203 Huic unus eorum respondit] Huic cacodaemon respondit $O$; Respondit $P$; Huic Lucifer respondit $H I V$; huic respondit $R \quad \mathbf{2 0 4}$ uobis] nobis $O \quad 205$ Estote] State $Q \quad 206$ et nulli fiet] ut nulli fiat $Q 207$ consensit] consenserunt EIJPRV 208 Sed alii] Sed certabant cui hoc esset concedendum $M$ (in marg. a. m.) NOQ 209 et homines adorent Deum Angelum, et homines $\rightarrow$ 
Vós, responde-lhe um deles, é que andais nas trevas porque vos esquecestes da vossa nobilíssima natureza. Do homem fazeis Deus e propondes-vos submeter-vos a alguém inferior a vós. Grande é a vossa demência a ponto de quererdes, vós os sublimes, rebaixar-vos e exaltar os rebaixados.

Um outro, da parte de Lúcifer, querendo estabelecer a harmonia entre eles, acrescentou e disse: Ouvi todos o meu conselho e alegrai-vos com ele. Depois de ser do agrado de Deus assumir a natureza humana, que a assuma. Ficai com isso satisfeitos. Mas assuma também a nossa, e a ninguém se fará ofensa.

Não me agrada o que estás a dizer, acrescentou Lúcifer, porque não posso suportar ter o homem como igual.

Deve escolher-se o mal menor, diz o mesmo. Foi definitivamente decretado isto, que Deus seja homem. Se Deus for também anjo, é um mal menor.

E a maioria dos anjos maus esteve de acordo com esta opinião. Mas outros resistiam e também não queriam isto. Que Deus se faça homem, diziam outros de entre eles. Faça-se também anjo. Mas que anjos e homens adorem o Deus Anjo, e apenas os homens adorem o Deus Homem, de modo a que os anjos se não submetam, de modo nenhum, ao homem. Ou, se os homens não querem submeter-se ao Deus Anjo, não nos importa. Basta que nós nos não subordinemos a eles.

Submetamo-nos nós também ao Deus Homem e eles ao Deus Anjo, diziam outros entre si.

Não queremos adorar senão este único Homem, afirmavam todos, nem sua Mãe nem qualquer outro.

E assim, ó Maria, Virgem Santíssima, tomaste conhecimento daquele nosso combate. Ouviste e compreendeste como houve discussão acerca do teu Filho, que vai ser concebido já. E todos te rejeitaram e não quiseram, esses iníquos, que tu reinasses sobre eles.

Acabo de ouvir o inaudito, disse Maria! Foi grande esse conflito! Opunha-se a Deus a sua criatura! Por minha causa e por causa do Filho que me anuncias se levantou essa forte tormenta! Porém, já que começaste, conta o que falta deste grande combate. É com muito gosto que ouço esses segredos.

Ao vê-los, ó Maria, divididos e em desacordo entre si, divagando em vão, então Saltiel, um dos nossos companheiros, por instigação de Miguel, disse: Todos vós, ó infelizes, divagais e vos afastais de Deus, e nenhum fala com segurança. Nem tu, que quiseste estabelecer a concórdia, [f1. 81] falaste com razão. Queres impor a lei à vontade de Deus, a qual está acima de toda a lei! Também vós pareceis querer obedecer a Deus condicionalmente! Não deveis perscrutar a sua vontade. Deus tornar-se-á homem e não anjo. Os anjos hão-de adorar esse Homem e venerar sua Mãe. Não quer que os homens adorem o anjo.

\footnotetext{
$\leftarrow$ soli] et homines soli $O \mathbf{2 1 0}$ nolunt] nolint $I R$; nollent $N$; uolunt $J P$; nollet $Q 211$ subiciamur] subiciamus $V 211$ (vide 161) 212 contentio] conuentio GIJNV 213 uane] uarie EGHIPRV 214 hortante] exortante $Q$; orante $N \mathbf{2 1 5}$ ferre] facere $E G M$
} 
Haec et similia nostri inducebant contra illos.

Tu, serue Dei, quae hic pono aduerte et connecte ${ }^{216}$ cum illis quae alias tibi de hoc conflictu narraui, quia et illa et ista omnia Mariae Virgini in illa nocte narraui. Verba Michaelis quae tunc dixit et qualiter Deus expectabat conuersionem ipsorum et qualiter, cum nollent conuerti, proiecti sunt de caelo in caliginem et nebulas, haec omnia tunc Mariae nostrae Reginae sanctissimae narraui. Addidique ${ }^{217}$ id quod tunc Barchiel dixerat, qui ibi mecum erat tamquam nuntius Spiritus Sancti. Dixique: Facto prolixiore conflictu inter nos atque illos, o Maria, tunc Barchiel, frater meus hic assistens, dixit: Conuertimini, o miseri, conuertimini. Ecce Deus noster ${ }^{218}$ benedictus uos praestolatur et benigne expectat. Secus ruetis in abyssum et ad inferos descendetis. Benedicite Dominum, magnificate creatorem uestrum in quo summa iustitia nullaque iniquitas.

Ipsi itaque inter se dicebant: Vbi est abyssus illa? Vbi inferi?

Tandemque, nolentibus illis acquiescere, subito Pater Omnipotens creauit Solem cum caelis ${ }^{219}$ inferioribus et elementis, ut tibi, serue Dei, alias dixi. Sic et Mariae tunc omnia declaraui. Et ipsis respuentibus salubria monita Barchielis fratris nostri, proiecti sunt et in his tenebris inclusi.

Tunc, o Maria, Michael sumens uerba Barchielis cecinit psalmum istum, nobis respondentibus, et compleuit:

Magnificemus $^{220}$ Dominum Deum nostrum et exaltemus ${ }^{221}$ nomen sanctum eius. Ipse est Deus noster, glorificemus eum, Dominus noster est, exaltemus eum. Dextera eius magnificata est in fortitudine, deiecit aduersarios nostros, Stulti sunt omnes qui repugnant ei, maledicti qui declinant a mandatis suis.

In ipso non cadit ignorantia nec error, in uoluntate eius nulla est iniquitas, Quaecumque uoluerit bona sunt et iusta, quaecumque mandauerit recta sunt et sancta.

Maius bonum iuste tribuit minori et minus recte maiori.

Non semper dantur maiora maioribus neque minora minoribus.

Primus intellectus errare nequit, optimus male uelle non potest,

Primo nihil est prius, optimo nihil est melius,

Tribuit unicuique ut sibi placet, uni magis quam alii, nihil debet.

Ille solus apud eum ${ }^{22}$ est dignus quem ipse fecerit dignum.

Super omnia est diligendus et tamquam Rex saeculorum immortalis adorandus.

Deum qui uos condidit dereliquistis et obliti estis Domini creatoris uestri,

Dereliquistis Deum factorem ${ }^{223}$ uestrum et recessistis a Deo saluatore uestro.

216 connecte] comple $Q 217$ Addidique] Audique $V \mathbf{2 1 8}$ noster] uester $Q 219$ caelis] ceteris $H 220$ et compleuit: Mignificemus] et compleuit: Angelorum psalmus in uersiculis, Michaele ita incipiente: Mignificemus $E$; et compleuit: Psalmum quem angeli cecinerunt quando angeli mali $\rightarrow$ 
Isto e outras coisas semelhantes aduziam os nossos contra eles.

Presta atenção tu, servo de Deus, ao que aqui afirmo e liga-o com o que sobre este conflito te relatei em outra ocasião, porque quer aquilo, quer tudo isto contei naquela noite a Maria. As palavras que Miguel proferiu então, e de que modo esperava Deus a conversão deles, e como, ao não quererem converter-se, foram precipitados do Céu na escuridão e nas trevas, tudo isto narrei então a Maria, nossa Rainha Santíssima. E acrescentei o que então dissera Barquiel, que estava lá comigo enquanto mensageiro do Espírito Santo. Disse então: Travado o duradouro conflito entre nós e eles, ó Maria, disse então Barquiel, irmão meu, aqui presente: Convertei-vos, infelizes, convertei-vos. Eis que o nosso bendito Deus vos aguarda e espera benignamente por vós. De contrário, precipitar-vos-eis no abismo e descereis até aos infernos. Bendizei o Senhor, exaltai o vosso Criador em quem reside a suprema justiça e nenhuma iniquidade.

Onde está o abismo, diziam eles entre si, onde estão os infernos?

Por fim, não querendo eles aceder, o Pai Omnipotente criou logo o Sol com os céus inferiores e os elementos, como noutro lugar te disse, servo de Deus. E tudo, deste modo, declarei então a Maria. E ao recusarem eles as salutares advertências do nosso irmão Barquiel, foram precipitados e encerrados nessas trevas.

Então, pegando nas palavras de Barquiel, Miguel cantou, ó Maria, este salmo e completou-o, respondendo nós:

Celebremos o Senhor nosso Deus, exaltemos seu nome Santo.

Ele é o nosso Deus, glorifiquemo-lo, é Senhor nosso, exaltemo-lo.

A sua dextra é celebrada pela bravura, derrubou os nossos adversários.

São estultos todos os que lhe resistem, malditos os que se afastam dos seus preceitos.

Nele não há ignorância nem erro, na sua vontade não há iniquidade.

É bom e justo tudo quanto quiser, é recto e santo quanto ordenar.

Atribui com justiça o maior bem ao menor, e com justiça o menor bem ao maior.

Nem sempre se dá o maior bem aos maiores, nem o menor aos menores.

Não pode a Primeira Inteligência errar, não pode a Sumamente Boa querer mal.

Nada há anterior ao Primeiro, nada é melhor que o Óptimo.

Dá a cada um como lhe apraz, a um mais que a outro. Nada deve.

Perante ele é digno apenas aquele que ele digno fizer.

Deve amar-se sobre tudo, adorar-se como Rei imortal dos séculos.

Abandonastes o Deus que vos criou, esquecestes-vos do Senhor vosso Criador.

Abandonastes a Deus vosso Criador e afastastes-vos de Deus vosso Salvador.

$\leftarrow$ ceciderunt I ( $R$ in marg.) $V \mathbf{2 2 1}$ exaltemus] exultemus $J V \mathbf{2 2 2}$ Ille solus apud eum] Ille solum apud Deum $A \mathbf{2 2 3}$ factorem] saluatorem $N$ 
Vos magis quam Deum amastis, ipso inuito, dii esse uoluistis, Commutationem iniquam fecictis, relicto Deo, creaturae ${ }^{224}$ adhaesistis.

Prouocastis Deum in diis falsis, pium $^{225}$ ad iracundiam incitastis, ${ }^{226}$

Ideo tamquam lapis descendistis et de sedibus altis cecidistis.

Date magnitudinem Deo nostro, perfecta sunt eius opera et iusta iudicia.

Deus optimus est et sine ulla iniquitate, sanctus et rectus Dominus.

Omnia coniunxit in uno, posuit omnia ${ }^{227}$ in Homine Deo.

Amor summus ita uoluit, dispersa ipse congregauit.

Plenus est Deus omnibus et omnia sunt plena Deo.

[f1. 82] Non est mirum si hominem assumpsit et assumere noluit angelum.

Homine assumpto, assumpsit omnia, angelo assumpto, non assumpsisset omnia.

Quam magnificata ${ }^{228}$ sunt opera tua, Deus, omnia sapientissime fecisti!

Adorate pronisimi ${ }^{229}$ Deum Hominem et ueneramini ${ }^{229 A}$ eius Genitricem.

Adorate eum omnes angeli eius, benedicite potestates et uirtutes.

Benedicite, Angeli Domini ${ }^{230}$, Deum Hominem, ministri eius qui facitis uoluntatem eius.

Benedicite Genitrici ${ }^{231}$ eius, suscipite homines ut fratres uestros.

Sit gloria Deo Trino ${ }^{232}$ in saeculum saeculi, laetentur ${ }^{233}$ omnes in operibus eius.

Tunc Maria dixit: Beati uos, angeli, qui uoluntati Creatoris uestri uos humiliter subiecistis. Sed scire uellem quomodo primi parentes nostri lapsi sunt tam miserabiliter in peccatum.

Tunc ego narraui omnia illa quae iam tibi dixi et ea conscripsisti ${ }^{234}$. Dixique Mariae, quod non scripsisti, qualiter creato Adam et ei ${ }^{235}$ oboedientia data, nos angeli illum psalmum Domine, Dominus noster, quam admirabile est nomen tuum in uniuersa terra cecinimus, in quo sunt nouem uersus. Et primus chorus primum decantauit et ita de aliis per ordinem. Deinde ego ipsum prophetae hic astanti reuelaui. Psalmum deinde quem nos aeternaliter canebamus Deo, tunc Mariae reuelaui. Tibi uero ipsum reuelabo quando de Trinitate quaedam reserabo ${ }^{236}$.

Tria alia cantica quae tunc Mariae dixi et reuelaui ${ }^{237}$, nunc et tu accipe. Primum est quod nos cecinimus quando in quinque diebus Deum uidimus caelos et elementa et omnia praeter hominem miro modo creasse. Secundum, pro creatione hominis. Tertium, Ade quod fecit tunc quando Eua ad ipsum adducta fuit. Quartum addo quod etiam Mariam non latuit.

224 creature] creatore $R V 225$ pium] ipsum $P 226$ incitasti] prouocasti $A 227$ omnia] animam $V 228$ magnificata] magnifica $H I 229$ Adorate pronissimi] Adorare promissimus $A H I R V$; Adorate promissum $E N$ 229A ueneramini] uenerari $A H I R V$; ueneremini $Q 230$ Angeli Domini] Angeli Dominum $A$; Dominum $V \mathbf{2 3 1}$ potestates et uirtutes. Benedicite, (...) uoluntatem eius. Benedicite Genitrici] potestates et uirtutes. Benedicite Genitrici $G$; potestates et uirtutes. Benedicite, Angeli Domini, Deum Hominem, ministri eius. Benedicite Genitrici $P 232$ Trino] Vno G; Viuo EOPQ $\rightarrow$ 
Amastes-vos mais do que a Deus, quisestes ser deuses contra sua vontade. Fizestes uma troca irracional, abandonando a Deus, aderistes à criatura.

Provocastes a Deus com deuses falsos, incitastes o Piedoso à ira.

Tombastes, por isso, como uma pedra e caístes das moradas sublimes.

Magnificai ao nosso Deus, são perfeitas as suas obras e justos os seus juízos. Deus é óptimo e sem qualquer iniquidade, santo e recto é o Senhor.

Tudo congregou num só, tudo pôs no Homem Deus.

O Amor Supremo assim o quis, ele reuniu o disperso.

Deus está cheio de tudo e tudo está cheio de Deus.

[f1. 82] Não é estranho se assumiu o homem e não quis assumir um anjo.

Assumindo o homem, assumiu todas as coisas, assumindo um anjo não assumiria todas as coisas.

Como são grandes as tuas obras, Deus, tudo fizeste com a máxima sabedoria.

Prostrados, adorai a Deus Homem e venerai sua Progenitora.

Adorai-o todos os seus anjos, bendizei-o Potestades e Virtudes.

Bendizei o Deu Homem, anjos do Senhor, ministros seus que cumpris sua vontade.

Bendizei sua Progenitora, recebei os homens como irmãos vossos.

Seja dada glória ao Deus Trino pelos séculos dos séculos, regozijem-se todos nas suas obras.

Bem-aventurados vós, ó anjos, que vos submetestes humildemente à vontade do vosso Criador, disse então Maria. Mas gostava de saber como é que os nossos primeiros pais caíram tão lamentavelmente no pecado.

Contei, então, tudo o que te disse já a ti e que tu escreveste. Disse ainda a Maria, coisa que tu não escreveste, como, depois de Adão ser criado e lhe haver sido prestada obediência, nós os anjos cantámos o salmo: Senhor, Senhor nosso, quão admirável é teu nome em toda a Terra, ${ }^{[88]}$ salmo que consta de nove versículos. E o primeiro coro cantou o primeiro e, assim, também os outros, por ordem. De seguida, revelei-o ao profeta que aqui está. Revelei, então, a Maria, seguidamente, o salmo que eternamente cantávamos a Deus. Também to hei-de revelar quando desvendar alguma coisa sobre a Trindade.

Recebe agora também três outros cânticos que então cantei e revelei a Maria. O primeiro é o que nós cantámos quando vimos que Deus, de um modo admirável, criou em cinco dias os Céus, os elementos e tudo além do homem. O segundo, a favor da criação do homem. O terceiro é o de Adão, cântico que compôs então, quando Eva foi levada à sua presença. Acrescento um quarto, que também não foi desconhecido de Maria.

$\leftarrow 233$ laetentur] laetemur AGJ 234 conscripsisti] conscripsi $V \quad 235$ ei] eius IRV 236 reserabo] reuelabo $Q \mathbf{2 3 7}$ dixi et reuelaui] dixi et reuelaui. Tibi uero ipsum reuelabo $O$ 
Psalmum Adam et Euae ueniam peccatorum suorum petentium et obtinentium ${ }^{238}$. Barchiel ita coepit: ${ }^{239}$

Benedicamus Patrem et Filium cum Sancto Spiritu, exaltemus ${ }^{240}$ et magnificemus eum in saecula,

Quia de terra informi et incomposita fecit tot et tanta mirabilia,

Solem produxit in orbe suo cum omnibus uariis circulis suis,

Produxit et aquas super ipsum, quae non tangebant illum.

Benedicatur Pater et Filius cum Sancto Spiritu, exaltetur ${ }^{241}$ et magnificetur per saecula.

Ipse enim producendo Solem produxit omnes alios orbes praeter unum,

Ostendit potentiam suam magnam, quia inferiora, non motis superioribus, mouere potest.

Creauit postera die firmamentum cum globis stellarum absque influential.

Omnipotens, omnia simul facere poterat, sed ne deciperemur noluerat.

Tertia die hinc et inde congregauit aquas et uarie ${ }^{242}$ fecit apparere aridam.

Protulit terra herbam et plantas uirentes, unicuique concessit semen iuxta genus suum.

Benedicite, ministri tanti ${ }^{243}$ operis, Dominum, magnificate uirtutem eius.

Quarta die addidit alia luminaria ut influerent in haec inferiora,

Inter alia uidimus duo magna luminaria ${ }^{244}$, ut maius diei et minus praeesset nocti,

Addidit planetas et stellas ut luceant et influant ${ }^{245}$ in elementa.

Quinta die produxit innumera ${ }^{246}$ genera piscium et animalium uolatilium,

Bestias quoque et iumenta et uniuersa quae reptant ${ }^{247}$ super terram.

Magnus est Deus noster et magnificus atque laudabilis nimis,

Laudent eum caeli et terra et omnia ${ }^{248}$ quae in eis sunt. [f1. 83]

Ex ipso et per ipsum et in ipso sunt omnia, tribus gloria et honor detur unus.

Terram ipse ${ }^{249}$ creando et nostrum caelum ex ipsa creauit, residuum pro aliis diebus conseruauit. ${ }^{250}$

Potenter omnia fecit, cum sapientia et amore omnia fabricauit.

Benedicamus Patrem et Filium cum Sancto Spiritu, exaltemus et magnificemus eum in saecula.

238 et obtinentium.] et obtinentium quando Deus fecit caelum et terram, mare et quae in eis sunt. Ita $Q 239$ Psalmus quando Deus omnia creauit praeter hominem, quem angeli continue canebant $a d d$. I ( $R$ in marg. $a$. $m$.) $V \mathbf{2 4 0}$ exaltemus] exultemus $P$; laudemus $Q \mathbf{2 4 1}$ exaltetur] laudetur $Q \mathbf{2 4 2}$ et uarie fecit] et mare, fecit $O \mathbf{2 4 3}$ ministri tanti] omnes ministri tanti $I$; omnes $\rightarrow$ 
Salmo de Adão e Eva pedindo e obtendo o perdão de seus pecados.

Assim começou Barquiel:

Bendigamos ao Pai, ao Filho e ao Espírito Santo, exaltemo-lo e magnifiquemo-lo para sempre,

Porque da terra informe e desordenada fez tantas maravilhas.

Fez o Sol avançar nas suas órbitas, com todos os seus círculos.

Sobre ele estendeu as águas, que o não tocavam.

Seja bendito o Pai, o Filho e o Espírito Santo, seja exaltado e magnificado pelos séculos.

Fazendo avançar o Sol, fez ele avançar todos os orbes, menos um,

Mostrou seu grande poder porque, sem mover os de cima, pôde mover os de baixo.

Criou no dia seguinte o firmamento com a multidão das estrelas, sem atropelo.

Omnipotente, podia tudo fazer ao mesmo tempo, mas para nos não frustrar, não o quis.

Ao terceiro dia, daqui e dalém ajuntou as águas e em vários pontos fez surgir a terra enxuta.

A terra produziu erva e plantas verdes, a cada uma, conforme seu género, a semente deu.

Ministros de tão magna obra, bendizei o Senhor, magnificai seu poder.

No quarto dia fez acrescentar outros luminares, para que actuassem nos inferiores.

Vimos, entre outros, dois luminares grandes, para que o maior presidisse ao dia e à noite o menor.

Acrescentou planetas, estrelas também, para darem brilho e influírem sobre os elementos.

Fez no quinto dia brotar, incontável, o género de peixes e animais voláteis.

Bestas e jumentos e a multidão dos que sobre a Terra rastejam.

Grande é o nosso Deus, louvável e magnífico sumamente.

Louvem-no os Céus, a Terra também, tudo quanto nele tem a existência. [f1. 83]

Dele, por ele e nele é tudo o que existe, aos Três seja dada uma honra só e a mesma glória.

A Terra criando, dela criou também o Céu que é o nosso. Para os outros dias reservou o resto.

Com poder fez tudo, com saber e amor tudo fabricou.

Bendigamos o Pai, o Filho e o Espírito Santo, exaltemo-lo e magnifiquemo-lo para sempre.

$\leftarrow$ ministranti $R V \mathbf{2 4 4}$ ut influerent in haec inferiora. Inter alia uidimus duo magna luminaria] om. $V 245$ influant] influent $P$; fluant $V \quad 246$ innumera] iumenta $J V 247$ reptant] restant $Q$; raptant $V 248$ caeli et terra et omnia] caeli et terra, reliqua elementa et omnia $A$ (M in marg. a. $m$.) $G O Q$ 249 ipse] ipsa $M$; ipsam $P 250$ conseruauit] reseruauit $Q$ 
Quando Adam, euigilans, uidit Euam ante se, prorupit in haec uerba: ${ }^{251}$

Omnia quae in mundo erant aspiciebam ${ }^{252}$, nullum mihi simile inueniebam. Non est certe umquam consolatio perfecta solitario.

Haec nunc est os de ossibus meis et caro de carne mea.

Propter hoc relinquet homo patrem et matrem et erunt duo in carne una.

Mas adhaerebit uni feminae et femina uni uiro,

Pater filiae non copuletur et multominus filius matri.

Me Deus fecit stipitem naturae humanae et sociam dedit mihi,

Ex nobis duobus omnes generabuntur, sine patre et matre nemo nascetur.

Sed ut omnis combinatio ${ }^{253}$ inueniatur, filius sine patre orietur ${ }^{254}$ ex matre.

Ego ex nullo homine prodii, haec a me originem traxit,

Ex duobus omnes alii generabuntur, unus ex femina sine uiro.

Magnum est hoc sacramentum quod Dei cum populo copulationem ostendit.

Tu uocaberis uirago quia de uiro tuo te Deus excerpsit. ${ }^{255}$

Vocaberis et Eua, quia cunctorum uiuentium mater.

Da huic dexterae dexteram tuam et osculum sanctum labiis meis,

Crescamus et multiplicemur, populum Dei cultorem producamus. ${ }^{256}$

Ipse suos cultores poterat omnes simul producere, communicauit nobis proprias actiones.

Quae per alios facere potest, raro uel numquam per se ipsum facit.

Et ipse non beat indiuiduum ${ }^{257}$ propter speciem, sed beat speciem $^{258}$ propter indiuidua.

Sed antequam iungamur, uxor mea, uacemus contemplationi et rebus diuinis,

Deinde cum timore Dei nostri implebimus mandata eius.

Gloria et honor sit Deo trino et uni, omnipotenti et sempiterno.

Haec Adam dixit.

Et prius debuissem narrare tibi psalmum de creatione hominis, quando nos omnes rogauimus, canendo, Deum nostrum ut iam crearet hominem, quia nimium cupiebamus uidere Deum Hominem ${ }^{259}$ et Genitricem eius. Sed illum psalmum postmodum tibi dicam ${ }^{260}$ quem parentes uestri primi fecerunt.

251 haec uerba:] haec uerba, dicens hunc psalmum: $I$; haec uerba: Psalmus Adae quem antea quam peccauit dictauit in laudem Dei: $Q$; haec uerba: Psalmus Adae quando Deus creauit Euam $R$ (in marg a. m.) V 252 aspiciebam] respiciebam $N$; inspiciebam GIRV 253 combinatio] concubinatio $V 254$ nemo nascetur. Sed ut omnis combinatio inueniatur, filius sine patre orietur ex matre. Ego] nemo nascetur. Ego $G$; nemo nascetur. Sed ut omnis combinatio inueniatur, filius sine patre nascetur ex matre $M P Q 255$ excerpsit] excerpit $H M Q$; excepit $E J P 256$ producamus] praedicamus $I R V 257$ beat indiuiduum] beat indiuidua $E G$; beat et creat indiuidua $O$; uehat indiuiduum $Q$; $\rightarrow$ 
Quando Adão, ao acordar, viu à sua frente Eva, prorrompeu nestas palavras:

Olhava tudo que havia no mundo, ninguém encontrava semelhante a mim. Não há, com certeza, não há nunca mais, consolo perfeito para o solitário. Esta, agora, é osso dos meus ossos e carne da minha carne.

Por isso, deixará o homem o pai e a mãe, e os dois serão uma carne só. ${ }^{[89]}$ Ligar-se-á o homem a uma só mulher, e uma mulher a um homem só.

Não se ligará o pai com a filha, e menos ainda o filho à mãe.

Fez-me Deus o tronco da humana raça e deu-me uma companheira, E de ambos nós todos brotarão, sem pai e sem mãe ninguém nascerá.

Mas para que se encontre toda a associação, de mãe nascerá um Filho sem pai.

Eu não saí de homem nenhum, esta de mim a origem tirou.

E todos os outros nascerão de dois; da mulher, sem homem, é apenas um.

É grande este sacramento, que mostra a ligação de Deus com o povo.

Chamar-te-ás virago, porque de teu marido te extraiu Deus.

Chamar-te-ás Eva, porque serás mãe de todo o vivente.

Une a esta a tua mão direita e um beijo santo aos meus lábios dá.

Cresçamos e multipliquemo-nos, procriemos um povo adorador de Deus.

Podia, de uma só vez, criar todos os que o adoram, partilhou connosco as acções que próprias lhe são.

Quanto por terceiros pode realizar, raro ou nunca por si o realiza.

Não faz feliz o indivíduo por causa da espécie, mas a espécie por causa dos indivíduos

Antes, porém, de nos unirmos, esposa minha, entreguemo-nos às coisas divinas e à contemplação.

Depois, com temor do nosso Deus, cumpriremos o seu mandamento.

Glória e honra ao Deus Trino e Uno, Omnipotente e Sempiterno.

Foi isto que Adão disse.

Mas, primeiro, deveria dar-te a conhecer o salmo da criação do homem, quando todos nós, cantando, pedimos ao nosso Deus que criasse logo o homem, porque desejávamos muito ver o Deus Homem e sua Mãe. Mas esse salmo, aquele que os vossos primeiros pais fizeram, revelar-to-ei mais tarde.

$\leftarrow$ seruat indiuiduum IRV 258 beat speciem] producit speciem $I$; beat et creat speciem $A E H J$; ueat speciem $Q$, seruat speciem $R V 259$ Hominem] nostrum $G \mathbf{2 6 0}$ tibi dicam] tibi dicam. Accipe nunc illum psalmum quartum. $H I$ ( $M$ in marg. a. m.) NOQV

[89] Gn 2:24. 
Sed in primis audi, Maria ${ }^{261}$, et psalmum accipe quem fecimus Deo nostro ad hoc ut hominem promissum crearet qui esset nobiscum ciuis ciuitatis supernae, me ita incipiente: ${ }^{262}$

Ardentissime atque fortissime Deus, ostende nobis faciem illam quam uidimus. Ecce Terram et Lunam ${ }^{263}$ creasti, hominem non uidemus ${ }^{264}$ quem promisisti. Ipsum ut iam producere uelis rogamus omnesque nos humiliter supplicamus. Sapientissime et scientia plenissime Deus, ostende nobis faciem illam quam uidimus.

Ecce aquam et Mercurium creasti, hominem non uidemus ${ }^{265}$ quem promosisti. Vt ipsum iam producas obsecramus tibique humiliter supplicamus.

Quietissime ac mansuetissime ${ }^{266}$ Deus, ostende nobis faciem illam quam uidimus. Ecce aerem et Venerem creasti, hominem non uidemus quem promisisti. ${ }^{267}$ [fl. 84] Producat eum mansuetudo tua oramus tibique humiliter supplicamus.

Dominator omnium atque rector Deus, ostende nobis faciem illam quam uidimus. Ecce ignem et Solem fabricasti, hominem non uidemus ${ }^{268}$ quem promisisti.

Erigat eum dominatio tua magna rogamus omnesque nos humiliter supplicamus. Virtutis ${ }^{269}$ inuictissime Deus, ostende nobis faciem illam quam uidimus.

Ecce ignem et Martem fabricasti, hominem non uidemus ${ }^{270}$ quem promisisti. Producat eum grandis uirtus tua obsecramus tibique humiliter supplicamus.

Potestatis immensae atque aeternae Deus, ostende nobis faciem illam quam uidimus.

Ecce aerem et Iouem creasti, hominem non uidemus ${ }^{271}$ quem promisisti.

Producat eum ingens potestas ${ }^{272}$ tua oramus tibique humiliter supplicamus.

Princeps, dux atque Rex omnium Deus, ostende nobis faciem illam quam uidimus.

Ecce Terram et Saturnum creasti, hominem non uidemus ${ }^{273}$ quem promisisti.

Producat eum maiestas tua rogamus ${ }^{274}$ tibique humiliter supplicamus.

Angelorum princeps Deus, ostende nobis faciem illam quam uidimus.

Ecce omnia elementa et stellarum ${ }^{275}$ orbem creasti, hominem non uidemus ${ }^{276}$ quem promisisti.

Producat eum dignitas tua rogamus ${ }^{277}$ tibique humiliter supplicamus.

Angelorum optime creator Deus, ostende nobis faciem illam quam uidimus.

Ecce iam omnia elementa et caelum omnia mouens creasti, hominem non uidemus $^{278}$ quem promisisti.

261 audi, Maria] audi Mariam $E V 262$ me ita incipiente:] me ita incipiente: Canticum Angelorum ut Deus crearet Hominem Deum $Q$; me ita incipiente: Psalmus quem angeli cecinerunt ut hominem crearet $I$ ( $R$ in marg. a. $m$.) $V$; me ita incipiente: Gabriel ita coepit $E 263$ Lunam] limum $P 264$ uidemus] uidimus $A J Q V 265$ uidemus] uidimus $A J Q R V 266$ mansuetissime] amantissime $Q 267$ Ipsum ut iam producas obsecramus, tibique humiliter supplicamus / Quietissime ac mansuetissime Deus, ostende nobis faciem illam quam uidimus / Ecce aerem et Venerem creasti, $\rightarrow$ 
Mas, antes de mais, ouve, Maria, e recebe o salmo que cantámos ao nosso Deus para que criasse o homem que prometera, homem que fosse connosco cidadão da cidade celeste, tendo eu começado assim:

Deus, todo brilho e poder, mostra-nos a face que vimos.

Eis que criaste a Terra e a Lua, não vemos o homem que nos prometeste.

Pedimos-te que te dignes criá-lo já, e todos nós humildemente to suplicamos.

Deus, todo sabedoria e conhecimento, mostra-nos a face que vimos.

Eis que criaste Mercúrio e a água, não vemos o homem que nos prometeste.

Imploramos-te que o cries já, e humildemente to suplicamos.

Deus, todo tranquilidade e mansidão, mostra-nos a face que vimos.

Eis que criaste o ar e Vénus, não vemos o homem que nos prometeste. [f1. 84]

Que tua mansidão o faça aparecer, pedimos e humildemente to suplicamos.

Deus, Soberano e Senhor de tudo, mostra-nos a face que vimos.

Eis que fizeste o fogo e o Sol, não vemos o homem que nos prometeste.

Faça-o surgir teu poder supremo, pedimos e todos nós humildemente o suplicamos.

Deus de invencível poder, mostra-nos a face que vimos.

Eis que fizeste o fogo e Marte, não vemos o homem que nos prometeste.

Faça-o surgir tua força sublime, pedimos-te e humildemente to suplicamos.

Deus de eterno e imenso poder, mostra-nos a face que vimos.

Eis que criaste o ar e Júpiter, não vemos o homem que nos prometeste.

Faça-o surgir teu poder infindo, pedimos e humildemente to suplicamos.

Deus, Príncipe, Chefe e de todos Rei, mostra-nos a face que vimos.

Eis que criaste a Terra e Saturno, não vemos o homem que nos prometeste.

Faça-o aparecer tua Majestade, pedimos e humildemente to suplicamos.

Deus, Príncipe dos anjos, mostra-nos a face que vimos.

Eis que criaste os elementos e o firmamento estrelado, não vemos o homem que nos prometeste.

Que a tua dignidade o faça aparecer, pedimos e humildemente te suplicamos.

Deus, admirável Criador dos anjos, mostra-nos a face que vimos.

Eis que criaste já todos os elementos e o Céu que tudo move, não vemos o homem que nos prometeste.

$\leftarrow$ hominem non uidemus quem promisisti] om. IRV 268 uidemus] uidimus AJQRV 269 Virtutis] Virtus IRV 270 uidemus] uidimus $A J Q R V \quad \mathbf{2 7 1}$ uidemus] uidimus $A J Q V \mathbf{2 7 2}$ ingens potestas] ingens potentia $Q$; ignis potestas $V \mathbf{2 7 3}$ uidemus] uidimus $A J Q R V \mathbf{2 7 4}$ rogamus] oramus IRV 275 stellarum] steliferum $H I R V \quad \mathbf{2 7 6}$ uidemus] uidimus $A J R V \quad 277$ rogamus] oramus $I R V \quad \mathbf{2 7 8}$ uidemus] uidimus $J Q R V$ 
Producas $^{279}$ eum qui et nos produxisti rogamus tibique humiliter supplicamus.

Tunc Deus uocauit de quolibet choro tres angelos sicut quilibet chorus tribus uersibus eum rogauerat.

Et narraui tunc Mariae modum creationis Adam et Euae et nostrae laetitiae et associationis Adae ${ }^{280}$ usque in paradisum uoluptatis et temptationem ipsorum per ordinem, sicut iam tibi reuelaui et conscripsisti pro consolatione humani generis et informatione futuri pastoris cui liber iste conseruabitur ${ }^{281}$. Hi uero psalmi placuerunt Mariae supra quam dici possit et exultauit spiritus eius coepitque et ipsa ita canere atque orare ${ }^{282}$.

Omni ardore ardentior Deus, transmitte ad nos Filium tuum quem diligimus.

Omni sapientia sapientior Deus, transmitte ad nos tuam Sapientiam quam diligimus.

Omni mansuetudine benignior Deus, transmitte ad nos Benignitatem tuam quam diligimus.

Omnium dominantium ${ }^{283}$ Domine Deus, transmitte ad nos Dominum quem diligimus. ${ }^{284}$

Omnium uirtutum summa uirtus Deus, transmitte ad nos Virtutem tuam quam diligimus.

Omnium potestatum potestas Deus, transmitte ad nos Potestatem tuam quam diligimus.

Omnium principum ${ }^{285}$ princeps Deus, transmitte ad nos Pacis Principem quem diligimus.

Omnium angelorum dux Deus, transmitte ad nos Ducem quem diligimus.

Onium angelorum optime creator Deus, transmitte ad nos Creatorem nostrum quem diligimus.

Tunc ego dixi: Maria, ego ${ }^{286}$ ad hoc missus sum et ad hoc ueni cum his fratribus meis, ut hoc mirabile commercium deitatis ${ }^{287}$ cum humanitate ita fieret ut et Deus uelit et humanum genus non respuat. Deus, Maria, Verbum suum in utero tuo, me annuntiante, carnem suscipere iubet. Tua interest pro toto genere humano consentire. Dic, o Virgo, uerbum et suscipe Filium qui est Dei Patris Aeternum Verbum.

Tunc Maria utrumque genu humiliter flectens, suspirans, gaudens, cum lacrimis dixit: Quis non consentiet ${ }^{288}$ in tantum bonum ${ }^{289}$ ? Quis respuet tam amplum ${ }^{290}$

279 Producas] producat $A G I P R V 280$ et associationis Adae] associationem Adae $Q$, associamini Adam IRV 281 conseruabitur] conscribitur $V \mathbf{2 8 2}$ coepitque et ipsa ita canere atque orare] coepitque ipsa cantare et dicere $G \mathbf{2 8 3}$ dominantium] dominationum $A 284$ Dominum quem diligimus] Virtutem tuam quam diligimus $A 285$ principum] principatum $I V 286$ ego dixi: "Maria, $\rightarrow$ 
Que o cries, tu que nos criaste, pedimos e humildemente to suplicamos.

Deus chamou, então, três anjos de cada coro, como cada coro se lhe havia dirigido com três versos.

E narrei então a Maria o modo da criação de Adão e Eva, e da nossa alegria e associação a Adão até ao Jardim das Delícias, e a tentação deles, por ordem, do mesmo modo que já to revelei e tu o escreveste para consolação do género humano e informação do Pastor futuro, para quem este livro deverá ser guardado. Agradaram estes salmos a Maria para lá do que pode ser dito, e seu espírito exultou e ela começou também a cantar e a orar:

Deus, mais brilhante que o resplendor, dá-nos teu Filho a quem amamos.

Deus, mais sábio que a sabedoria, dá-nos tua Sabedoria a quem amamos.

Deus, mais benigno que a mansidão, dá-nos tua Benignidade a quem amamos.

Deus, Senhor de todos os senhores, dá-nos o Senhor a quem amamos.

Deus, Suprema Virtude de todas as virtudes, dá-nos tua Virtude a quem amamos.

Deus, Potestade de todas as potestades, dá-nos a tua Potestade a quem amamos.

Deus, Príncipe de todos os príncipes, dá-nos o Príncipe da Paz a quem amamos.

Deus, Chefe de todos os anjos, dá-nos o Chefe a quem amamos.

Deus, Criador admirável de todos os anjos, dá-nos o nosso Criador a quem amamos.

Maria, disse eu então, fui enviado e vim com estes meus irmãos para isto, para que este admirável intercâmbio da divindade com a humanidade se efective de modo que Deus o queira e a raça humana o não recuse. Deus, Maria, ordena que o seu Verbo, sendo eu a anunciá-lo, incarne em teu seio. É para ti importante que consintas, para bem de todo o género humano. Diz, ó Virgem, uma palavra e recebe o Filho que é o Verbo Eterno de Deus Pai!

Quem não há-de consentir em bem tão grande, disse então Maria, dobrando humildemente ambos os joelhos, a suspirar, regozijando-se em seu íntimo, com

$\leftarrow$ egol ego dixi Mariae: "ego EGJM; adixi: "Maria, ego $O \mathbf{2 8 7}$ deitatis] deitate $N$; dedicatis $V \quad \mathbf{2 8 8}$ consentiet] consentiret $E J$; consentiat $O 289$ bonum] donum $V \mathbf{2 9 0}$ tam amplum] tantum $I R$ 
donum $^{291}$ ? Consentio, cupio et flagito ${ }^{292}$. Ecce [f1. 85] ancilla Domini. Inclinato capite, dixit: Fiat uoluntas Dei et Verbum Dei mihi conferatur secundum uerbum tuum.

Erat, dilectissime, iam media nox, ut Scriptura adimpleretur. Dictis illis uerbis Mariae, subito, in ultimo instanti totam pronuntiationem terminante, operatione totius Trinitatis, quae atribuitur Spiritui Sancto, multa ualde mirabilia in eodem instanti facta fuerunt. Illico enim tres guttulae sanguinis purissimi ex corde Virginis excerptae fuerunt. Illico illae in locum aptum procreationi ${ }^{293}$ filiorum repositae fuerunt. Illico ille sanguis condensatus fuit. Illico in carnem, neruos, uenas et ossa conuersus fuit. Illico cor, cerebrum et hepar aliaque membra formata fuerunt. Illico totum corpus plasmatum, illico anima creata, illico infusa. Illico diuinitas humanitati unita et coniuncta animae atque corpori copulata fuit. Illico intellectus illius animae omnibus habitibus practicis et speculatiuis informatus et ornatus fuit praeter habitum fidei, quo non indigebat. Illico uoluntas praedita fuit omnibus uirtutibus sibi competentibus praeter spem. Qui enim uidet non indiget habitu fidei, et qui tenet non eget habitu spei. Infudit Deus illi omnes habitus in summo. Gratiamque siue caritatem dedit tantam quanta dari a Deo poterat.

Non enim est uerum quod apud uos dicitur ut "quocumque finito dato maius illo dari possit ${ }^{294}$ ", nisi imaginando, non autem in re ipsa. Falsum quoque est ${ }^{295}$ ut alterius rationis sit intellectus uester et uoluntas ab intellectu et uoluntate angelorum quae namque ${ }^{296}$ recipiunt conformes habitus et eliciunt consimiles actus circa consimilia, immo eadem obiecta. Quomodo poterunt esse alterius et alterius rationis? Neque uerum est ut semper naturarum diuersarum sint diuersae potentiae, neque ut nobilioris naturae sit nobilior potentia. Sic enim potentiae angelorum specie differentium differrent ${ }^{297}$ specie et superiorum essent potentiae nobiliores et actus et obiecta. Et non esset eiusdem rationis beatitudo omnium angelorum neque angelorum et hominum, et non fieret comparatio ${ }^{298}$ beatitudinis eorum. Et nullus homo beatior esset quouis angelo, immo nec esse posset. In quo igitur essent homines similes 299 angelis Dei? Verum est igitur quod potentiae eiusdem rationis possunt esse eaedem ${ }^{300}$ diuersis naturis sicut uisus et alii sensus existunt in diuersis animalibus, ut uisus aquilae et lincis, olphatus uulturis et canis, auditus multorum. Et in natura ignobiliore potest esse potentia acutior. Et quamuis nil sit nobilius intellectu et uoluntate etiam in angelis, tamen aliquae sunt proprietates in angelis ${ }^{301}$ quae non sunt in hominibus, sicut simplicitas, puritas

291 Quis respuet tam amplum donum?] om. $V \mathbf{2 9 2}$ et flagito] efflagito HIRV 293 procreationi] generationis $G$; pro creatione $H I$; proscriptionis $V \mathbf{2 9 4}$ possit] posset $I R V 295$ falsum quoque est] falsum quocumque dato $I R V \mathbf{2 9 6}$ quae namque] quae numquam $M$; quia numquam $P 297$ differrent] differunt $G$; differente $I R V \mathbf{2 9 8}$ non fieret comparatio] non fieret tamquam in simili $\rightarrow$ 
lágrimas. Quem recusará tão nobre dom? Consinto, desejo, imploro. Eis [fl. 85] a serva do Senhor ${ }^{[90]} \mathrm{E}$, inclinando a cabeça, disse: Faça-se a vontade de Deus, e que o Verbo de Deus me seja entregue segundo a tua palavra.

Era já, querido amigo, meia-noite, para que se cumprisse a Escritura. Pronunciadas estas palavras de Maria, de súbito, no último instante que encerrava toda a declaração, por obra de toda a Trindade, obra que se atribui ao Espírito Santo, aconteceram nesse mesmo instante muitas e admiráveis coisas. Imediatamente foram colhidas do coração da Virgem três gotículas de puríssimo sangue. Imediatamente foram elas colocadas no lugar próprio à procriação dos filhos. Imediatamente foi esse sangue condensado. Imediatamente foi mudado em carne, nervos, veias e ossos. Imediatamente foram formados coração, cérebro, fígado e outros membros. Imediatamente plasmado todo o corpo, imediatamente criada a alma, imediatamente infundida. Imediatamente a divindade se uniu à humanidade, e se reuniu à alma, e se ligou ao corpo. Imediatamente a inteligência desta alma foi enformada e ornada com todas as disposições práticas e especulativas, além da disposição da fé, de que não precisava. Imediatamente foi a vontade dotada de todas as virtudes convenientes, além da esperança. Na verdade quem vê, não precisa da disposição da fé e quem tem, não carece da disposição da esperança. Nele infundiu Deus todas as disposições no grau máximo. Deu tão grande graça, ou seja, caridade, quanta podia ser dada por Deus.

Não é, pois, verdade, a não ser em imaginação, mas não em realidade, o que se afirma entre vós, que, dado todo o possível bem finito, se pode dar um maior do que ele. É também falso que a vossa inteligência e a vossa vontade sejam de natureza diferente da inteligência e da vontade dos anjos, elas que recebem disposições semelhantes e são atraídas por actos semelhantes acerca de coisas semelhantes e até dos mesmos objectos. Como poderiam ser umas de uma natureza, outras de outra? Nem é verdade que faculdades diversas sejam sempre de natureza diversa, nem que uma faculdade mais nobre seja de natureza mais nobre. Assim, pois, as faculdades dos anjos de espécie diferente difeririam em espécie, e aos superiores pertenceriam faculdades, actos e objectos mais nobres. E não seriam da mesma natureza a bem-aventurança de todos os anjos nem a dos anjos e a dos homens, e não se estabeleceria comparação entre a bem-aventurança deles. E homem algum seria mais bem-aventurado que qualquer anjo e nem mesmo poderia sê-lo. Em que seriam, pois, os homens semelhantes aos anjos de Deus? É verdade, portanto, que faculdades da mesma natureza podem ser as mesmas em diversas espécies, como a visão e outros sentidos existem em diversos animais, como a visão da águia e do lince, o olfacto do abutre e do cão, o ouvido de

$\leftarrow$ comparatio $A 299$ similes] similis IRV 300 eaedem] eodem $G$; eadem J; idem IRV 301 in angelis] angelorum $I R V$

[90] Lc 1:38. 
seu actualitas et immaterialitas, non intellectus aut uoluntas ${ }^{302}$. Nobilissimum igitur in natura inferiori potest esse interdum nobilissimum in natura superiori. Et aliquando aliqua proprietas quae notat perfectionem absolute erit in natura imperfectiori quae non erit in natura perfectiori quemadmodum ${ }^{303}$ simplicitas $^{2}$ est in partibus alicuius substantiae compositae ut elementi ${ }^{304}$ uidelicet ignis uel aeris quae non est in ipso igne ${ }^{305}$ uel aere.

Illico igitur anima illa nobilissima fuit creata ${ }^{306}$, illico corpori infusa, illico et diuinitati unita. Deus enim eam creando infudit et uniuit et uniendo infudit atque infundendo creauit. Vniuit autem carni ossibusque nil corrumpendo, sed uitam addendo $^{307}$. Illico anima illa Deum uidit in se sicuti est. Illico amore summo dilexit eique adhaesit. Primum quod uidit Deus erat, primum quod amauit ipse idem Deus erat. Tunc illa anima cognouit omnia praeterita, [f1. 86] tunc et praesentia atque futura. Agnoscebatque matrem suam et omnes discipulos suos, omnes homines gratos et ingratos, bonos et malos, iustos et iniustos. Videbat etiam hunc coetum qui in hac rota nunc existit. Videbat et hoc nostrum colloquium ${ }^{308}$ Nihil eum latebat. Videndo Deum, intellectus ipsius extendebatur illa uisione in omnia. Qui namque Deum uidet, si Deus uoluerit, uidere simul omnia potest. Nam in Deo sicut in omnium artifice sunt omnia.

Haec nox est splendidior Sole et cunctis astris. Haec dies quam fecit Dominus dignior est ${ }^{309}$ omnibus. Exultate et in ea laetamini, gaudete gaudio magno ualde. Haec solemnitas sit apud uos celebrior cunctis solemnitatibus ${ }^{310}$. Haec festiuitas praecellat omnes festiuitates uestras. Est enim festum angelicae et solemnis annuntiationis. Est festum tantorum secretorum reuelationis. Est festum miraculosae sanguinis ex corde uirgineo ${ }^{311}$ eductionis, in matrice mundissima repositionis. Est festum eiusdem sanguinis condensationis atque in ossa, neruos et carnem, in membraque ut cor, cerebrum, hepar et pulmonem et alia conuersionis et perfectae organizationis. Est festum celeberrimum animae illius creationis et omnium uirtutum atque donorum concreationis. Est festum animae illius corpori illi infusionis et corporis uiuificationis. Nobilissima enim anima coniuncta fuit nobilissimo corpori modo nobilissimo. Est festum humanitatis cum diuinitate ${ }^{312}$

302 actualitas et immaterialitas, non intellectus aut uoluntas.] actualitas. $Q 303$ in natura inferiori potest (...) erit in natura imperfectiori quae non erit in natura perfectiori quemadmodum] in natura inferiori quemadmodum. IRV 304 ut elementi] ut elementa IRV 305 igne] composito ex igne $Q 306$ Illico igitur anima illa nobilissima fuit creata] om. $Q 307$ addendo] adolendo $J \mathbf{3 0 8}$ colloquium] collegium $H 309$ dignior est] digniorem HIPQRV 310 Haec solemnitas sit apud uos celebrior cunctis solemnitatibus] Haec solemnitas sit apud uos solemnior, celebrior cunctis $\rightarrow$ 
muitos. E na espécie menos nobre pode existir uma faculdade mais penetrante. E embora nada haja de mais nobre que a inteligência e a vontade, mesmo nos anjos, há, todavia, algumas propriedades nos anjos que não existem nos homens, como simplicidade, pureza ou acto e imaterialidade, não inteligência ou vontade. O mais nobre, pois, na espécie inferior pode ser algumas vezes o mais nobre na espécie superior. E, por vezes, existirá na espécie inferior alguma propriedade que denota perfeição de modo absoluto, a qual não existirá na espécie mais perfeita, como a simplicidade existe nas partes de uma substância composta como propriedade de um elemento, a saber, do fogo ou do ar, a qual não existe no próprio fogo ou no próprio ar.

Imediatamente, portanto, foi aquela nobilíssima alma criada, imediatamente infundida no corpo, imediatamente também unida à divindade. Pois Deus, criando-a, infundiu-a e uniu-a e, unindo-a, infundiu-a e, infundindo-a, criou-a. Uniu-a, pois, à carne e aos ossos sem nada corromper, mas acrescentando vida. Imediatamente aquela alma viu a Deus em si mesmo, tal como ele é. Imediatamente o amou com supremo amor e a ele aderiu. O que primeiro viu era Deus, o que primeiro amou era igualmente o próprio Deus. Aquela alma conheceu então todo o passado, conheceu, [f1. 86] então também, o presente e o futuro. Reconhecia sua Mãe e seus discípulos, todos os homens, os reconhecidos e os que o não são, bons e maus, justos e injustos. Via também esta Assembleia que está reunida aqui em volta. Via esta nossa conversação. Nada lhe era oculto. Vendo a Deus, nessa visão a sua inteligência estendia-se a tudo. Pois quem vê a Deus, pode, se Deus quiser, ver em simultâneo todas as coisas. Com efeito, tudo existe em Deus enquanto Criador de todas as coisas.

Esta noite é mais brilhante que o Sol e todos os astros. Este é o dia que o Senhor fez, é de todos o mais digno, exultai e rejubilai nele, regozijai-vos com a máxima alegria. ${ }^{[91]}$ Que esta solenidade seja para vós a mais solene de todas as solenidades. Supere esta todas as vossas festividades. É a festa da solene anunciação do anjo. É a festa da revelação de tão grandes segredos. É a festa da miraculosa extracção do sangue do coração da Virgem, da reposição no puríssimo útero. É a festa da condensação do mesmo sangue e da conversão e perfeita organização em ossos, nervos e carne, em órgãos, como coração, cérebro, fígado, pulmões e outros. É a celebérrima festa da criação desta alma e da concriação de todas as virtudes e dons. É a festa da infusão desta alma neste corpo e da vivificação do corpo. A mais nobre das almas foi criada no mais nobre dos corpos, do modo mais nobre. É a festa da união da humanidade com a divindade. Foi, de facto,

$\leftarrow$ solemnitatibus $V$; Haec solemnitas sit solemnitas cunctis solemnitatibus $Q \mathbf{3 1 1}$ uirgineo] Virginis EIQRV 312 modo nobilissimo. Est festum humanitatis cum diuinitate] modo nobilissimo. Est festum omnium uirtutum atque donorum ipsi felicissimae animae concreationis. Est festum humanitatis cum diuinitate $A G$ ( $M$ in marg. a. m.) O; modo nobilissimo. Est festum omnium uirtutum atque

[91] S1 117:24. 
unionis. Vnita enim fuit humanitas cum diuinitate et partes ipsius humanitatis copulatae fuerunt deitati. Est festum illius hominis et illius animae beatificationis perfectae et summae ${ }^{313}$. Est festum quia illi animae dies cognitionis omnium. Magna sunt, ardua, mira et inaudita haec omnia, carissime. Eodem momento ${ }^{314}$ eodemque temporis puncto facta sunt in utero illius puellae sanctissimae cui tunc tanta gratia aucta ${ }^{315}$ fuit quantam Deus ei dare decreuerat. Nulla enim gratia maior est quam gratia Virginis, post gratiam animae Christi Domini. Nulla etiam est suae gratiae aequalis. Est igitur festum augumentationis supremae totius gratiae in anima Mariae.

Tunc Maria exultauit, tunc Deum incarnatum in utero suo uidit, conspexit et adorauit. Et tota caelesti curia ad tam miram rem uidendam assistente et omnibus Deum puerulum paruulum, sed uirum perfectum inspicientibus et adorantibus, Maria hoc canticum cecinit $^{316}$, dicens $^{317}$ :

Magnificat anima mea et cor meum Deum Patrem omnipotentem,

Qui me indignam fecit dignam et de serua fecit filiam,

Qui me uilem creaturam suamque humilem facturam.

Dei Summi matrem fecit, sui Filii Genitricem instituit.

Fecit mihi magna potentissimus, sanctum ac benedictum nomen eius.

Magnificat anima mea et cor meum Deum Filium sapientem et uerum,

Qui sine tempore ex Patre natus, nunc ${ }^{318}$ in utero meo est generatus.

Exultat cor meum et spiritus meus in Deo salutari ${ }^{319}$ meo,

Qui me suam filiam elegit matremque suam fecit.

Genitorem meum genui, quem caeli capere non possunt continui. [f1. 87]

Magnificat anima mea et cor meum Deum Patris et Filii amplum donum,

Qui me semper pio uultu respexit neque toruo oculo umquam aspexit,

$\mathrm{Ab}$ omni labe praeseruauit et super omnem creaturam adamauit.

Suaue, benignum et optimum est magnum nomen suum,

Ex hoc nunc usque in sempiternum beatam me dicent omnes nationes. ${ }^{320}$

Gratias ago Deo uni et trino, nunc et semper in saecula saeculorum. Amen.

Benedicti uos, angeli sancti, qui paruistis mandatis Dei summi,

Beati $^{321}$ qui uoluntatem Dei agnouistis et iussa eius adimplestis,

donorum ipsi felicissimo animo concreationis. Est festum diuinitatis cum humanitate $Q \quad \mathbf{3 1 3}$ Est festum illius hominis et illius animae beatificationis perfectae et summae.] Est festum illius animae et illius corporis perfectae beatificationis $N \mathbf{3 1 4}$ Magna sunt, ardua, mira et inaudita haec omnia, carissime. Eodem momento] Magna sunt, ardua, mira et inaudita. Haec omnia, carissime, eodem momento $M$; Magna, ardua, (mira IR) et inaudita. Haec omnia, carissime, eodem momento $I R V 315$ aucta] data IRV 316 cecinit] cecinit quando Verbum fuit incarnatum I 317 dicens] $\rightarrow$ 
unida a humanidade com a divindade e as partes da mesma humanidade foram unidas à divindade. É a festa da perfeita e suprema felicidade deste homem e desta alma. É festa porque é para esta alma o dia do conhecimento de todas as coisas. Tudo isto, caríssimo, é grande, difícil, admirável, inaudito. No mesmo momento, no mesmo instante, tudo aconteceu no ventre desta santíssima donzela a quem, então, foi acrescentada tanta graça quanta Deus determinara dar-lhe. Não há, depois da graça da alma de Cristo Senhor, graça maior que a graça da Virgem. Não há graça igual à sua. É, portanto, a festa do supremo aumento de toda a graça na alma de Maria.

Maria exultou então, então viu, contemplou e adorou a Deus incarnado em seu ventre. E com toda a corte celeste presente para ver tão admirável evento e todos a contemplarem e a adorarem a Deus criancinha, mas homem perfeito, Maria entoou este cântico, dizendo:

A minha alma e o meu coração glorificam a Deus Pai Omnipotente, Que, sendo eu indigna, me tornou digna e fez-me, de serva, filha,

Que fez que, vil criatura e humilde serva, me tornasse Mãe do Deus Supremo. Tornou-me Mãe do Sumo Deus, instituiu-me Mãe de seu Filho, Fez em mim grandes coisas o Todo Poderoso, Santo e Bendito é seu nome. A minha alma e o meu coração glorificam a Deus Filho, sábio e verdadeiro, Que, nascido do Pai, sem tempo, é agora gerado em meu ventre.

Exulta o meu coração e o meu espírito em Deus, meu Salvador,

Que me escolheu para sua filha e de mim fez sua Mãe.

Gerei o meu Criador, contive em mim aquele que os Céus não podem conter.

[f1.87] A minha alma e o meu coração glorificam a Deus, grande dom do Pai e do Filho,

Que sempre me olhou com benévolo semblante e nunca me fixou com olhar severo.

Preservou-me de toda a mancha e amou-me acima de toda a criatura.

Suave, benigno e sumamente bom é o seu nome Grande.

Desde agora e para sempre, todos os povos bem-aventurada me hão-de chamar.

Dou graças a Deus Uno e Trino, agora e sempre, pelos séculos dos séculos. Ámen.

Benditos vós, anjos santos, que obedecestes aos mandamentos do Supremo Deus, Bem-aventurados, que reconhecestes a vontade de Deus e cumpristes seus mandamentos.

$\leftarrow$ dicens: Canticum Mariae in conceptione Filii sui Dei omnipotentis $Q$; dicens: Canticum quod fecit Maria quando Verbum fuit incarnatum $R$ (in marg.) $V 318$ Deum Filium sapientem et uerum / Qui sine tempore ex Patre natus nunc] om. $V 319$ salutari] saluatore EIMNP; salutare $R \mathbf{3 2 0}$ nationes] generationes $V \mathbf{3 2 1}$ Beati] Benedicti IRV 
Filium meum non despexistis neque me contempsistis,

Cum Lucifero decertastis et eum ueris rationibus superastis.

Fecit Deus potentiam in brachio suo et omnes superbos dispersit,

Deposuit potentes de sede et $\operatorname{uos}^{322}$ humiles exaltauit,

Vos esurientes $^{323}$ iustitiam impleuit bonis, diuites in oculis suis dimittens ${ }^{324}$ inanes.

Gaudeant ${ }^{325}$ omnes matres et patres mei, iubilent omnes filii Dei.

Suscepit Deus Israel seruum ${ }^{326}$ suum, memor fuit misericordiae suae,

Misericordia eius transibit a progenie in progenies in omnes timentes eum.

Quae Abraam et patribus nostris promisit, nunc in semine suo adimpleuit.

Gratias ago Deo uni et trino, nunc et semper in saecula saeculorum. Amen.

Haec Maria laetissima et gratia plena, Dominum gestans in utero suo ipsumque humiliter adorans, cecinit. Nos uero uniuersi Deum incarnatum conspeximus et uidimus et adorauimus. Oboedientiam promissam exhibuimus ipsumque pro Domino nostro recognouimus et prompto animo acceptauimus et mirabilia quae uideramus decantauimus ita dicentes ${ }^{327}$ :

Magnus nimis es, Deus noster, et omni sapientia plenus.

Annuntiasti in principio saeculorum, adimplesti diebus nouissimis,

Legem pones aeternam quae nullis temporibus abolebitur,

Timorem foras excuties, amorem intus accumulabis.

Seruierunt ${ }^{328}$ tibi homines in timore, obsequentur iam cum amore.

Figure praeterierunt, hanc ueritatem significauerunt,

Velut umbra auferentur, in lucem omnia uertentur.

Quod in signo primum uidimus, nunc uere Deum hominem factum agnouimus. ${ }^{329}$

Tunc nobis tamquam homo apparuit, nunc ut uerus homo innotuit. 330

Mariae ${ }^{331}$ annuntiauimus et quoad potuimus adiuuimus,

Proelium nostrum narrauimus, antiqua cantica reserauimus.

Patrem, Filium ac Spiritum Sanctum agnoscebamus, nullum illorum hominem uidebamus,

Mox uidimus sanguinem educi et in matricem Mariae induci,

Condensari et in carnem ${ }^{332}$ conuerti et omnia membra formari,

Animam perfectam creari, omnibus uirtutibus repleri,

Corpori perfecto infundi, humanitatemque deitati uniri.

322 uos] nos $A$; suos $Q \quad 323$ esurientes] exultantes $A \quad 324$ dimittens] dimisit $A H I R V \quad 325$ Gaudeant] Gaudeamus $A 326$ seruum] puerum $E N 327$ dicentes:] dicentes: Canticum Angelorum in incarnatione praeclarissima Christi Domini $Q$; dicentes: Psalmus quem Angeli fecerunt quando $\rightarrow$ 
Não desdenhastes de meu Filho, nem me desprezastes a mim, Combatestes com Lúcifer e o superastes com razões válidas.

Agiu com a força de seu braço e dispersou todos os soberbos,

Depôs de seu trono os poderosos e a vós, humildes, exaltou-vos.

A vós, famintos de justiça, cumulou de bens, de mãos vazias despediu os que ricos se achavam.

Alegrem-se todos, minhas mães e pais, gritem de alegria todos os filhos de Deus.

Tomou Deus à sua conta Israel, seu servo, recordou-se de sua misericórdia.

Sua misericórdia passará de geração em geração para todos os que o temem.

Quanto prometeu a Abraão e a nossos pais, realizou-o agora na sua descendência.

Dou graças a Deus Uno e Trino, agora e sempre, pelos séculos dos séculos. Ámen.

Maria entoou este cântico com extrema alegria e cheia de graça, trazendo Deus em seu ventre e adorando-o com humildade. Todos nós contemplámos, vimos e adorámos a Deus incarnado. Manifestámos-lhe a obediência que lhe havíamos prometido, reconhecemo-lo por nosso Deus, aceitámo-lo prontamente e cantámos as maravilhas que havíamos visto, dizendo assim:

És todo grandeza, nosso Deus, e cheio de toda a sabedoria!

Anunciaste no início dos tempos, realizaste nos últimos dias.

Estabelecerás uma lei eterna, que jamais será abolida,

Banirás de nós o medo, em nós acumularás amor.

Serviram-te os homens no medo, obedecer-te-ão com amor.

As figuras passaram, significaram esta verdade,

Desaparecerão como a sombra, tudo se converterá em luz.

O que primeiro vimos em sinal, reconhecemo-lo agora Verdadeiro Deus feito homem.

Então apareceu-nos sob a figura de homem, manifestou-se agora verdadeiro Homem.

Anunciámos a Maria e ajudámos até onde pudemos,

Narrámos o nosso combate, desvendámos os cânticos antigos.

Conhecíamos o Pai, o Filho e o Espírito Santo, a nenhum víamos como homem.

Logo depois vimos o sangue ser tirado e depositado no útero de Maria,

Condensar-se e converter-se em carne, e formarem-se todos os membros,

Criar-se uma alma perfeita, encher-se de todas as virtudes,

Ser infundida num corpo perfeito, unir-se a humanidade à divindade.

$\leftarrow$ Verbum fuit incarnatum $I$ ( $R$ in marg.) $V \mathbf{3 2 8}$ Seruierunt] seruient $N$; Serui erunt $Q \mathbf{3 2 9}$ factum agnouimus] factum uidemus $H$; factum uidimus $I R V$; factum. $P 330$ innotuit] intonuit $M$; inoruit $V 331$ Mariae] Mariae incarnationem sanctam $A 332$ carnem] sanguinem $I$ 
Magnus agricola Deus surculum inseruit suo stipiti.

Stipes est persona Verbi, diuinitas ramus naturalis,

[f1. 88] Sed ramus dat esse truncho, non trunchus iste ${ }^{333}$ ramo.

Humanitas est quidam surculus Verbi personae insertus.

Duae sunt naturae in una persona copulatae,

Quae sunt Dei dicuntur hominis ${ }^{334}$ et quae hominis sunt ${ }^{335}$ Dei.

Assumpsit humanitatem Deus et carnem, non humanitas aut caro Deum.

Creata simul anima et beata, beata pariter et creata.

Videbat Deum dum crearetur et dum uidebat creabatur,

Amabat ${ }^{336}$ et creabatur, creabatur dum amabat.

Deum ante omnia nouit, ipsum ante omnia dilexit.

Cognito Deo, omnia cognouit, nullum futurum eam latuit.

Impleta $^{337}$ est Mater omni gratia, homines euacuati sunt culpa,

Vidimus certe mirabilia creaturis ${ }^{338}$ omnibus ineffabilia.

Beati nos qui paruimus et mandatis oboedire uoluimus.

Te Deum Hominem omnes ueneramur teque ut Deum semper adoramus.

Te Mariam ${ }^{339}$ Virginem praedicamus et Dei Matrem proclamamus,

Te pariter cum Filio tuo honoramus et ${ }^{340}$ obsequia debita impendimus,

Tu cum almo Spiritu simul Deum genuisti incarnatum.

Te Reginam nostram agnoscimus et super nos regnare non abhorremus. ${ }^{341}$

Abhorruit Lucifer et lucem amisit et cum sequacibus ad inferna descendit.

Gloriam $^{342}$ Deo in excelsis canimus ${ }^{343}$ et pacem in terra bene uiuentibus ${ }^{344}$ annuntiamus.

Haec tunc, dilecte, cecinimus. Deinde, ad Reginam conuersi, illos uersiculos quos uos homines diuino flamine aspirati nunc canitis, cantare cepimus, dicendo:

Aue, Regina caelorum. Aue, Domina angelorum.

Salue, radix sancta, ex qua mundo lux est orta.

Gaude, gloriosa, super omnes speciosa.

Vale, ualde decora, et pro nobis semper Christum exora.

Et dicendo "Christum", ostendebamus illum puerulum adeo paruulum ut uix oculis carneis uideri potuissset, in quo tamen erat omnis uirtus, uigebat omnis sensus $^{345}$, si claustro uirginali non fuisset impeditus. Miro artificio magnus ille Agricola Deus humanitatem personae Verbi uniuit ac si palmitem unius naturae

333 iste] isti $E$; esse $G H 334$ dicuntur hominis] dicunt homines $V \mathbf{3 3 5}$ hominis sunt] hominis dicuntur $Q 336$ Amabat] Astabat $I R V 337$ Impleta] Completa $Q 338$ creaturis] creationis $P 339$ Mariam] Matrem $Q 340$ et] utrique $Q 341$ abhorremus] abhorruimus $A 342$ Gloriam] Gloria $I R V \rightarrow$ 
Deus, o grande agricultor, inseriu o rebento em seu tronco, O rebento é a pessoa do Verbo, a divindade o ramo natural.

[f1. 88] Mas o ramo dá o ser ao tronco, não o tronco ao ramo.

A humanidade é a vergôntea enxertada na Pessoa do Verbo.

São duas as naturezas associadas numa só Pessoa.

O que é de Deus considera-se do homem, o que é do homem considera-se de Deus.

Deus assumiu a humanidade e a carne, e não a humanidade ou a carne a Deus. Criada e logo bem-aventurada a alma, bem-aventurada igualmente e criada. Via a Deus enquanto era criada e, enquanto via, era criada , Amava e era criada, era criada enquanto amava.

Conheceu a Deus antes de tudo, antes de tudo o amou.

Conhecido Deus, tudo conheceu, nada ignorava do que aconteceria.

A Mãe foi de toda a graça cheia, os homens foram livres de culpa.

Vimos, sem dúvida, coisas admiráveis, inexprimíveis para todas as criaturas.

Bem-aventurados nós que nos submetemos e a seus mandamentos obedecer quisemos.

Todos te veneramos, Deus Homem, a ti, como Deus sempre te adoramos.

Louvamos-te, Virgem Maria, proclamamos-te a Mãe de Deus.

Com teu Filho juntamente te honramos e a devida reverência te prestamos. $\mathrm{Tu}$, em conjunto com o Espírito Criador, geraste o Deus incarnado.

Reconhecemos-te como Rainha nossa, não nos opomos a que reines sobre nós. Opôs-se Lúcifer e perdeu a luz e com seus seguidores desceu aos infernos.

Cantamos glória a Deus nas alturas e anunciamos paz na Terra aos que vivem honestamente.

Isto cantámos nós então, amigo. Depois, voltados para a Rainha, começámos a cantar os versículos que vós, inspirados pelo sopro divino, cantais agora, dizendo:

Avé, Rainha dos Céus, Avé, Senhora dos anjos!

Salve, raiz santa, da qual veio ao mundo a Luz!

Exulta, Gloriosa, de beleza sem igual,

Eu te saúdo, formosa, e por nós sempre a Cristo implora.

E, ao dizer "Cristo", mostrávamos aquele menino, tão pequeno que mal poderia ser visto pelos olhos da carne, em quem, todavia, residia toda a virtude, desabrochava todo o sentimento, se não fosse impedido pelo invólucro virginal. Com admirável arte uniu Deus, o grande Agricultor, a humanidade à pessoa do Verbo

$\leftarrow 343$ canimus] canamus EMP 344 bene uiuentibus] beneuolentibus $A$; beneualentibus IORV 345 uigebat omnis sensus] regebat omnes sensus $Q$ 
stipiti alterius naturae inseruisset ${ }^{346}$. Persona Verbi est sicut stipes uel pes arboris. Diuina natura est ipsa arbor uel ramus naturalis in persona subsistens. Humana natura est ut oleaster quidam et surculus agrestis quem diuina uirtus personae Verbi inseruit. Et duae naturae, humana et diuina, fuerunt copulatae in persona una. Et ideo quaecumque dicuntur de Deo, dicuntur de homine illo, et quaecumque dicuntur de homine illo, exceptis his quae ad actum unionis spectant, dicuntur de Deo $^{347}$. Vnde bene dici potest: "Hic homo creauit caelum et astra". Et "Deus passus est et mortuus". Sed non, "homo assumpsit Deum" neque, "homo incarnatus est". Sed "Deus assumpsit illam humanitatem singularem"; et "Deus est incarnatus" 348. Nam Filius Dei est incarnatus ${ }^{349}$ solus, non Pater aut Spiritus Sanctus. Et Filius est uerus Deus. Ideo Deus est incarnatus. Tota Trinitas id egit, soli Filio actione trium personarum diuinarum humanitas est copulata.

Maria carnem et omnia membra cumproduxit et nihil [f1. 89] eorum quae ad matrem spectant obmisit. Nec impossibile est creaturam subito agere ubi non est opus praeuia dispositione. Agit et creatura subito et in puncto, subiecto disposito et praeparato. Hic ergo omnia praeparata et disposita erant. Ideo statim agere potuit. 350

Tunc ego: Domine mi, quid opus fuit anima illi Homini qui erat Deus? Nonne sufficiebat diuinitas ad uiuificandum? Deus est uita ${ }^{351}$. Non oportebat ut caro illa haberet aliam uitam, neque conueniens erat unam carnem habere duas uitas et a duabus uiuificari.

Tunc dixit Angelus: O homuncio, quis te docuit arguere et ea quae patres tui non tenent, sed tenere abhorrent, approbare? Et quia uideo te sicut multos alios rudes non posse bene intelligere hanc ueritatem, quia deitas uidetur uita sicut et est, ad quid oportebat in Christo ponere aliam uitam et aliam animam ac alium spiritum ex quo in ipso ponitur deitas quae est uita uera, uera sapientia, uera uoluntas, uerus intellectus, uera caritas? Ideo adducam plures rationes pro talis opinionis $^{352}$ corroboratione. Si enim Deus est uita et anima est uita, quid opus erat duobus ubi unum illorum duorum sufficiebat? Superflua est uita animae corpori si habet deitatem sibi unitam, uitam perfectam per quam uiuificabatur ${ }^{353}$. Quomodo etiam uiuificat ${ }^{354}$ Deus corpus ab anima uiuificatum? Aut ${ }^{355}$ quomodo uiuificat anima corpus a Deo uiuificatum? ${ }^{356}$ Quid ergo facit anima cum deitate aut deitas cum anima? Vtraque uita est, utraque actus ${ }^{357}$ est. Vna uita non perficit aliam, una non uiuificat aliam, quia anima non uiuificatur, sed corpus. Illi non

346 unius naturae stipiti alterius naturae inseruisset] unius naturae inseruisset $I R V 347$ unionis spectant, dicuntur de Deo.] unionis spectant. AGIRV 348 Sed "Deus assumpsit illam humanitatem singularem"; et "Deus est incarnatus".] om. $N 349$ nam Filius Dei est incarnatus] om. IRV 350 potuit.] Respondit): si Deus posset uiuificare corpus supplens uicem animae, pastor uenturus declarabit. Nunc ita accipe, noli a maioribus deuiare. Verum hominem opus est ueram carnem humanam habere et ueram animam. Si ergo Christus animam non habuisset, quomodo uerus homo fuisset? Facilius esset facere hominem cum anima sine carne quam ut sit homo habens $\rightarrow$ 
como se enxertasse um sarmento de uma natureza num tronco de outra natureza. A pessoa do Verbo é como que o tronco ou a raiz da árvore. A natureza divina é a própria árvore ou ramo natural que subsiste na pessoa. A natureza humana é como que uma espécie de zambujeiro e um sarmento selvagem que o divino poder enxertou na pessoa do Verbo. E as duas naturezas, humana e divina, foram associadas numa só pessoa. E, por isso, quanto se diz de Deus, diz-se deste homem e quanto se diz deste homem, tirando o que respeita ao acto da união, se diz de Deus. Daí poder-se dizer: Este homem criou o Céu e os astros; e, Deus sofreu e morreu; mas não, o homem assumiu Deus; nem, o homem incarnou; mas, Deus assumiu aquela humanidade singular; e, Deus incarnou. Na verdade só o Filho de Deus incarnou e não o Pai ou o Espírito Santo. Mas o Filho é verdadeiro Deus. Por isso, Deus incarnou. Toda a Trindade fez o mesmo. Mas só ao Filho, por acção das três Pessoas Divinas, foi unida a humanidade.

Maria partilhou a procriação da carne e de todos os membros e nada [fl. 89] omitiu de quanto é próprio da mãe. E nem é impossível que a criatura actue de imediato onde se não exige disposição prévia. A criatura actua de imediato e num instante, uma vez preparado e ordenado o sujeito. Neste caso, estava tudo preparado e ordenado. Por isso pôde agir imediatamente.

Meu senhor, perguntei então, que falta fazia a alma a este homem, que era Deus? Não bastava a divindade para lhe dar vida? Deus é vida. Não era preciso que esta carne tivesse outra vida, nem era conveniente que uma carne tivesse duas vidas e pelas duas fosse vivificada.

Ó pobre homem, respondeu então o anjo, quem te ensinou a argumentar e a dar por provado aquilo que teus maiores não defendem e lhes repugnava defender? E dado ver que tu, assim como muitos outros ignorantes, não podeis compreender bem esta verdade, porque a divindade parece, tal como é, vida, para que era preciso pôr em Cristo outra vida e outra alma e outro espírito se nele se estabeleceu a divindade, que é vida verdadeira, verdadeira sabedoria, verdadeira vontade, verdadeira inteligência, verdadeiro amor? Por isso aduzirei razões várias, para corroborar esta opinião. Se na verdade Deus é vida, e a alma é vida, que necessidade haveria de ambos quando um só deles bastava? A vida da alma é supérflua para o corpo se este tem unida a si a divindade, a vida perfeita, pela qual era vivificado. Além disso, como vivifica Deus o corpo vivificado pela alma? Ou como vivifica a alma o corpo vivificado por Deus? Que faz, pois, a alma com a divindade ou a divindade com a alma? Ambas são vida, ambas

$\leftarrow$ carnem absque anima. Anima enim est potior pars hominis. Qui ergo dicunt animam esse totum hominem minus errant quam qui fatentur carnem esse totum hominem. add. $P 351$ Deus est uita: abbinc (351) usque ad ceteri homines (392) deest in IRV 352 talis opinionis] talium opinionum $O Q 353$ uiuificabatur] uiuificabitur $J 354$ uiuificat] uiuificabat $G 355$ Quomodo etiam uiuificat Deus corpus ab anima uiuificatum? Aut] add. $M$ in marg. a. $m$. 356 Aut quomodo uiuificat anima corpus a Deo uiuificatum?] $o m$. $G Q 357$ utraque actus] uterque actus $O$; utraque actio $P$ 
unitur deitas quod non uiuificat. Quid ergo necesse est animam ponere quae neque uiuificat ${ }^{358}$ neque uiuificetur ${ }^{359}$ neque unitur deitati?

Si deitas non uiuificat carnem, non est unita carni. Sed necesse est ut sit unita carni. Aliter Christus non esset perfectus homo et perfectus Deus. Ergo oportet ut deitas carnem uiuificet ad hoc ut ei uniatur. Item Christus, si per animam caro eius uiuificaretur, non esset perfectus Deus neque ${ }^{360}$ perfectus homo, quia perfectus homo est ille cuius caro uita perfecta uiuificatur. Deus autem est uita perfecta. Nonne Deus omnia per se ipsum facere potest? Potest certe, quia omnipotens est. Quaecumque igitur uult potest, quamuis non omnia quae potest uult. Quare igitur oportebat adiutorium sibi praestare ad uiuificandum carnem humanam creando animam nouam ac si Deus ipse indigeret auxilio? Omnipotens est, nullius auxilio, nullius adiutorio indiget. Non oportebat igitur animam coadiutricem Deo praebere ${ }^{361}$.

Nota, si scis, quot rationes tuae cogitationi addam. Considera hanc rationem: Anima, ut uos creditis et nos scimus, est indiuiduum et singulare creaturae spiritualis. Loquor autem non de anima in se, sed de hac anima tua et anima alterius hominis. Sed omne singulare naturae spiritualis, quae natura ${ }^{362}$ substantia quaedam est, subpositum et persona dici ${ }^{363}$ potest. Anima, ut uides, haec et illa, suppositum erit et persona. Si itaque in Christo anima creata fuisset, illa persona fuisset. Et ex hoc sequuntur ${ }^{364}$ duo absurda. Vnum, quod in Trinitate essent quattuor personae, quia persona Verbi et persona animae in Verbo, quia Christus est persona in Trinitate, una si ipse est una persona, duae si ipe est duae. Secundum, quod in Christo essent duae personae, quia persona Verbi et persona animae $^{365}$. Et ita Christus non esset unus, sed duo, quia duae personae. Non ergo est ponenda in ipso anima rationalis creata, sed sufficit anima rationalis et uita perfecta, quae est Deus, et persona increata et omne bonum. Non fuit ergo anima creata in ipso in quo erat anima increata et perfectissima ${ }^{366}$ omnium spirituum. Praeterea multi ${ }^{367}$ inter uos abhorrent dicere Christum esse creaturam, qui etiam non potest dici uere creatura. Sed si habuisset animam rationalem ${ }^{368}$ sicut ceteri homines, illa creata fuisset et eo modo, ratione talis animae sic creatae, Christus diceretur uere creatura, quia ratione animae illius fuisset factus ex nihilo. Hoc enim est creari, quod ex nihilo fieri. Anima uero, quia non praefuisset ${ }^{369}$ nec tota nec secundum partem ${ }^{370}$, creata fuisset. Potest insuper perfectiori modo defendi

358 uiuificat] uiuificet $H N P 359$ uiuificetur] uiuificatur $E O Q 360$ perfectus Deus. Ergo (...) non esset perfectus Deus neque] perfectus Deus neque $P 361$ praebere] praestare $J 362$ creatura spiritualis. Loquor autem non de anima in se sed de hac anima tua et anima alterius hominis. Sed omne singulare naturae spiritualis, quae natura] creatura spiritualis quae natura $P 363$ persona $\rightarrow$ 
são acto. Uma vida não completa a outra, uma não vivifica a outra, porque não é a alma que é vivificada, mas o corpo. A divindade não se une àquilo que não vivifica. Que necessidade há, portanto, de criar uma alma que não vivifica, nem vivificará, nem se une à divindade?

Se a divindade não vivifica a carne, não está unida à carne. Mas é forçoso que esteja unida à carne. De outro modo Cristo não seria perfeito homem e perfeito Deus. Portanto, é necessário que a divindade vivifique a carne para que se una a ela. Do mesmo modo, Cristo não seria perfeito Deus nem perfeito homem se a sua carne não fosse vivificada pela alma, porque homem perfeito é aquele cuja carne é vivificada pela vida perfeita. Ora Deus é a vida perfeita. Não pode Deus tudo fazer por si próprio? Pode, com certeza, porque é omnipotente. Pode, pois, tudo o que quer, embora não queira tudo o que pode. Porque era então necessário dar-se a si um auxiliar para vivificar a carne humana criando uma alma nova como se o próprio Deus precisasse de auxílio? É omnipotente, não precisa do auxílio nem da ajuda de ninguém. Portanto, não era preciso dar a Deus uma alma que fosse sua colaboradora.

Toma nota, se souberes, de quantas razões acrescentarei ao teu raciocínio. Atende a esta razão: A alma, como vós credes e nós sabemos, é indivíduo e singular da criatura espiritual. Falo, não da alma em si, mas desta tua alma e da alma de outro homem. Mas todo o singular de natureza espiritual que, por natureza, é uma determinada substância, pode chamar-se sujeito e pessoa. A alma, como vês, uma alma determinada, será também sujeito e pessoa. Se também em Cristo a alma fosse criada, ela haveria de ser também pessoa. E daqui seguem-se dois absurdos. Primeiro, que na Trindade haveria quatro pessoas, uma vez que haveria a pessoa do Verbo e a pessoa da alma no Verbo, porque Cristo é pessoa na Trindade, uma pessoa, se ele é uma pessoa, duas, se ele é duas. Segundo, que em Cristo haveria duas pessoas, porque havia a pessoa do Verbo e a pessoa da alma. E, assim, Cristo não seria um, mas dois, já que duas pessoas. Portanto, não deve atribuir-se-lhe alma racional criada, mas basta a alma racional e a vida perfeita, que é Deus, e a pessoa incriada e todo o bem. Portanto, não existiu alma criada naquele em quem existia alma incriada e o mais perfeito de todos os espíritos. Além disso, muitos de vós são contrários a considerar Cristo uma criatura, ele que também não pode considerar-se verdadeira criatura. Se, porém, tivesse alma racional como os restantes homens, seria ela criada e, desse modo, em razão dessa mesma alma assim criada, considerar-se-ia Cristo verdadeira criatura visto que, em razão dessa alma, teria sido feito do nada. Isto, na verdade, é ser

$\leftarrow$ dici] persona dici, loquor de anima ut est haec anima $P 364$ sequuntur] sequeretur $E 365$ una si ipse est una persona, duae si ipe est duae. (...) persona Verbi et persona animae $Q 366$ perfectissima] perfectissimus $P 367$ Praeterea multi] non nulli $G$; Propterea nulli $P$; Multi $Q 368$ rationalem] rationabilem $H 369$ praefuisset] pro re fuisset $H 370$ partem] carnem $N$ 
Christum fuisse perfectum Deum et perfectum hominem non ponendo in eo animam creatam quam ponendo. Ad quid ergo illa anima est ponenda?

Quod autem uerius possit ${ }^{371}$ probari ipsum esse pefectum Deum et perfectum hominem si non habuerit animam creatam, diximus superius. Nam ideo est perfectus Deus, quia caro illa uiuificatur ab ipso Deo, et perfectus homo, quia a perfectissimo spiritu uiuificatur illa ${ }^{372}$ perfectissima caro. Sicut enim Deus illam carnem nobilissimam ${ }^{373}$ fecit et plasmauit, ita in ea nobilissimam uitam posuit et eam nobilissimo spiritu uiuificari uoluit qui est ipse uita omnium uiuentium, quamuis aliter et aliter. Item non ponendo animam creatam in Christo bene potest intelligi quomodo Christus est Deus, quia per diuinitatem uiuificantem carnem. Ponendo uero quod habuerit animam, non potest intelligi quomodo sit Deus nil uiuificando neque animam neque corpus. Item ponendo quod diuinitas sit unita carni humanae, manifeste uerum erit dicere: "Hic homo est aeternus et creauit angelos, caelum empyrium, materiam primam in principio et sex diebus omnia alia." Et quod est genitus aeternaliter ex Patre et quod ipse et Pater Deus idem sunt, similiter facile uidebitur quomodo Maria est Genitrix Dei, quia genuit hunc hominem qui est perfectus Deus et perfectus homo. Si autem caro illa per animam uiuificaretur, non potestis intelligere quomodo ipsa genuit Deum, sed solum quod genuit hominem et compositum illud ex anima et corpore. Non ergo dici posset uere Genitrix Dei, sicut quotidie uos de ipsa dicitis et canitis et recte, et in illo nomine ualde ipsam decoratis et gratia illius maternitatis ipsa est exaltata super omnes choros, super septem angelos et super Michaelem et ea de causa nos ei subicimur et ipsam pro Regina tenemus.

Pater igitur Deus idem et unum est cum Christo et Christus cum illo et cum Spiritu Sancto. Et ponendo diuinitatem loco animae, Patris et Filii Mariae una est diuinitas et aequalis maiestas. Si etiam Deus noluit uniri Lucifero spiritui, quomodo unitus fuisset anime? Immo nulli angelo uniri uoluit. Et quare? Quia unio ista non est aliud quam uiuificatio illius rei cui unitur Deus. Spiritus autem, quia uita est, uiuificari non potest. Et hoc Lucifer non aduertit quando Deus dixit "Volo uniri homini", sed credidit quod sicut potest uniri homini, ita posset uniri et sibi et aliis spiritibus. Et ideo $\operatorname{ardenter}^{374}$ concupiuit hanc unionem et fuit rebellis Deo et amisit praemia quae sibi parata erant si permansisset. Deus enim iudicauit eum propter malam uoluntatem eius, quia contempsit Deum uolens unionem quae fieri non poterat. 
criado, porque é ser feito do nada. Ora, já que a alma não teria existido previamente, nem no todo nem em parte, teria sido criada. Pode, ademais, de modo mais seguro defender-se que Cristo haja sido perfeito Deus e perfeito homem não lhe atribuindo uma alma criada do que atribuindo-lha. Porque há-de então atribuir-se-lhe essa alma?

Que com mais verdade se possa mais eficazmente provar que é perfeito Deus e perfeito homem se não se lhe atribuir a alma criada, demonstrámo-lo antes. É, pois, por isso, perfeito Deus, porque a carne é vivificada pelo próprio Deus, e perfeito homem, porque aquela perfeitíssima carne é vivificada pelo mesmo perfeito espírito. Assim, pois, como Deus fez e moldou aquela nobilíssima carne, assim também nela depôs nobilíssima vida e quis que fosse vivificada por nobilíssimo espírito, que é ele, a vida de todos os viventes, embora diferentemente segundo cada um. De modo semelhante, ao não atribuir a Cristo alma criada se pode perfeitamente entender como Cristo é Deus, porque por intermédio da divindade que vivifica a carne. Mas, admitindo que tivesse alma, não se pode entender como seja Deus se nada vivifica, nem alma nem corpo. Admitindo igualmente que a divindade esteja unida à carne humana, seria manifestamente verdadeiro dizer: Este homem é eterno e, no princípio, criou os anjos, o Céu Empíreo, a matéria-prima, e tudo o resto, em seis dias. E visto que é gerado eternamente do Pai e que ele e o Pai são o mesmo, igualmente se verá com facilidade como Maria é Mãe de Deus, porque gerou este homem, que é perfeito Deus e perfeito homem. Ora se a carne fosse vivificada pela alma, não poderíeis entender como ela gerou Deus, mas só que gerou o homem e aquele composto de alma e corpo. Não poderia, pois, considerar-se verdadeiramente Mãe de Deus, como hoje dela afirmais e cantais, e correctamente, e na base desse nome tanto a honrais, e em razão dessa maternidade foi ela exaltada acima de todos os Coros, acima dos sete anjos e acima de Miguel e, por essa razão, a ela nos submetemos e a temos por Rainha nossa.

Portanto, Deus Pai é um e o mesmo com Cristo, e Cristo com ele e com o Espírito Santo. E pondo a divindade no lugar da alma, é a mesma a divindade do Pai e do Filho de Maria e igual a majestade. Se, além disso, Deus não quis unir-se ao espírito de Lúcifer, como se uniria à alma? Mais, não quis unir-se a nenhum anjo. E porquê? Porque esta união não é senão a vivificação daquele ser a que se une Deus. Ora o espírito, porque é vida, não pode ser vivificado. E Lúcifer não atentou nisso quando Deus disse "Quero unir-me ao homem", mas acreditou que, assim como pôde unir-se ao homem, assim também poderia unir-se a si e aos outros espíritos. E, por isso, desejou ardentemente essa união e foi rebelde a Deus, e perdeu os prémios que estavam preparados para ele se tivesse perseverado. Por isso Deus o julgou por causa da sua má vontade, porque afrontou Deus ao pretender essa união, que não podia realizar-se.

\footnotetext{
$\leftarrow$ uiuificatur illa] uiuificatur illa $G 373$ nobilissimam] perfectissimam $M N 374$ ardenter] audenter $P$
} 
Non est itaque unita Deo aliqua anima, sed deitas est carni unita ut Christus esset perfectus Deus et perfectus homo. Neque conueniens est, neque iustum, neque congruum est ut duo spiritus sint in carne una uidelicet deitas et anima creata. Alter illorum a carne illa remouendus est, aut anima aut deitas. Sed, remota deitate uiuificante, Christus non erit neque Deus ullo ${ }^{375}$ modo neque perfectus homo, ut iam diximus. Ergo relinquatur in eo deitas, remoueatur anima et erit Christus Deus uerus et homo uerus. Si Christus animam creatam carnem uiuificantem habuisset, tunc homo ut alii homines fuisset et peccare ac mereri ${ }^{376}$ potuisset, quia omnis homo mendax est et peccator. Sed quia Deus erat, mentiri et peccare non poterat quia Deus per suam naturam peccare non potest. Aliae creaturae intellectuales peccare possunt, etiam si sint beatae. Tamen non peccant gratia Dei eas praeseruante. Christus autem nulo modo peccare potuit quia caro ex se peccare non potest, quia peccatum est in uoluntate. Voluntas quoque diuina rectissima est, deficere non potest, declinare a rectitudine non ualet. Si animam habuisset Christus, Ioannes hic existens non dixisset: Et Verbum caro factum est. Et non dixit ut uos dicitis: "Et homo factus est". Non est enim factus homo, sed $^{377}$ accipiendo et uiuificando carnem et hoc modo sibi uniendo factus est in utero Mariae uerus homo. Factus quidem est homo, non quia prius fuisset homo et deinde Deo unitus, sed ipsa unione factus est homo.

Vides, animal Dei, si ego pro illa cogitatione ${ }^{378}$ tua, quando cogitabas ad quid fuit opus anima Christo, sciuerim adducere tot rationes?

Tunc ego: Haec opinio multis placeret si posset sine periculo teneri. Sed quare Ioannes, qui dixit: "Et Verbum caro factum est", postea dixit Christum dixisse: Ego sum pastor bonus et animam meam pono pro ouibus? Et iterum: Potestatem habeo ponendi animam meam et iterum sumendi eam?

Tunc angelus, subridens, dixit: Scio dialecticam, scio omnes apparentias rationum et fallacias et responsiones uelatas. Anima potest poni pro uita et sit sensus: "Vitam meam pono pro ouibus meis", et "In mea potestate est mori et uiuere", quia Deus erat. Nam, si Deus non fuisset, non fuisset in sua potestate uiuere et mori. Dic ${ }^{379}$ mihi, nonne propheta dicebat Deo Parce ire animae tuae? Deitas est anima Dei, quia uita Dei. Et istam uitam posuit pro ouibus suis. Nam tempore mortis non uiuificauit carnem, sed caro mortua iacebat. Oblatus est, quia ipse uoluit.

Scis dicere super hoc aliquid aliud?

Et, me tacente, dixit: Si non habuerit ${ }^{380}$ animam creatam igitur Concilia Sanctorum Patrum falsa determinassent. Determinauerunt autem Christum habuisse

375 ullo] illo $Q \mathbf{3 7 6}$ mereri] mentiri $G \mathbf{3 7 7}$ factus est" Non est enim factus homo, sed] factus est, sed $O 378$ cogitatione] cognitione $Q 379$ mori et uiuere", quia Deus (...) uiuere et mori. Dic] mori et uiuere". Dic. $Q \mathbf{3 8 0}$ habuerit] habuit $B Q$ 
Também não está unida a Deus alma alguma, mas é a divindade que está unida à carne para que Cristo seja perfeito Deus e perfeito homem. Nem é conveniente, nem é justo, nem é razoável que numa só carne haja dois espíritos, ou seja, a divindade e a alma criada. Um deles, a alma ou a divindade, deve ser removido dessa carne. Mas se for removida a divindade vivificante, Cristo não será, de modo nenhum, nem Deus nem perfeito homem, como dissemos. Deixe-se, portanto, nele a divindade, remova-se a alma, e Cristo será Deus verdadeiro e homem verdadeiro. Se Cristo tivesse a alma criada a vivificar a carne, seria, então, homem como os outros homens e poderia pecar e merecer, porque todo o homem é mentiroso ${ }^{[92]}$ e pecador. Mas, porque era Deus, não podia mentir, nem pecar, porque Deus, por sua natureza, não pode pecar. As outras criaturas espirituais podem pecar, mesmo que sejam bem-aventuradas. Não pecam, todavia, se a graça de Deus as preservar. Cristo, porém, não pôde pecar de modo nenhum, porque a carne, de si, não pode pecar, já que o pecado radica na vontade. A vontade, também divina, é sumamente recta, não pode falhar, não é capaz de se afastar da rectidão. Se Cristo tivesse alma, aqui João não teria dito: $E$ o Verbo incar-

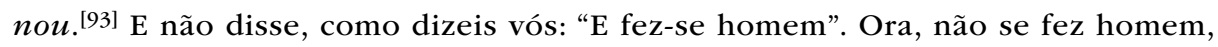
mas ao receber e vivificar a carne e ao uni-la a si deste modo, tornou-se no ventre de Maria verdadeiro homem. Na verdade, fez-se homem, não que primeiro fosse homem e depois se unisse a Deus, mas fez-se homem na própria união.

Vês, criatura de Deus, se não soube aduzir tantas razões a favor da tua elucubração, quando excogitavas para que serviu a alma a Cristo?

A muitos agradaria esta opinião, disse eu, se pudesse manter-se sem perigo. Mas porque razão disse João: E o Verbo incarnou, ${ }^{[94]}$ e disse depois que Cristo havia dito: Eu sou o bom Pastor ${ }^{[95]}$ e dou a minha alma pelas minhas ovelhas? ${ }^{\text {[96] }}$ E ainda: Tenho o poder de dar a minha alma e de a retomar?

Conheço, disse o anjo sorrindo, a dialéctica, conheço todos os simulacros de raciocínios e falácias e as respostas subentendidas. Alma pode usar-se por vida, sendo este o sentido: "dou a minha vida pelas minhas ovelhas"; e, "tenho o poder de morrer e de viver”, porque era Deus. Pois, se não fosse Deus, não estaria em seu poder viver e morrer. Diz-me, não dizia a Deus o profeta Contém a ira da tua alma? A divindade é a alma de Deus, porque vida de Deus. E deu esta vida pelas suas ovelhas. Pois na altura da morte não vivificou a carne, mas a carne jazia morta. Ofereceu-se porque quis.

Sabes sobre isto dizer mais alguma coisa?

E tendo eu ficado calado, acrescentou: Se não tivesse alma criada, então os Concílios dos Santos Padres teriam definido falsidades. Ora, determinaram que

\footnotetext{
[92] S1 115: 2,

[93] Jo 1:14,

[94] Jo 1:14,

[95] Jo 10:11,

[96] Jo 10:15,
} 
animam rationalem creatam et duos intellectus et duas uoluntates. Et anathematis uinculo innodauerunt ${ }^{381}$ omnes oppositum credentes et docentes ${ }^{382}$. Vos creditis, et uerum est, quod Ecclesia in his quae sunt fidei errare non potest, praesertim quando est congregata in nomine Christi, quia scriptum est: "Vbi fuerint duo uel tres congregati in nomine meo, ibi sum in medio eorum". Dirigitur enim tunc a Spiritu Sancto. Athanasius etiam in Symbolo suo dicit: "Ex anima rationali uidelicet creata" (ne intelligeres, quamuis inepte, per animam rationalem ipsam deitatem) "et humana carne subsistens". Vbi uides aliud secretum philisophiae uestrae, quia caro humana est alia ab anima et non est caro per animam. Si enim ex anima rationali et humana carne tamquam ex duobus subsistit, aliud esse $^{383}$ carnis, aliud animae. Non enim ex duobus illis subsisteret ${ }^{384}$ si caro per animam esset. Dicunt Sancti Patres uestri et Concilia uestra: "Verbum quod semel assumpsit numquam dimisit”. Et intelligunt de partibus et recte. Sed si caro mortua, quae prius uiuificabatur per Verbum diuinum, et uiuificatio erat unio, ergo Verbum ${ }^{385}$ carnem reliquit quam assumpserat. Dicunt etiam quod anima Christi descendit ad inferos, quia non caro, quae iacuit in sepulchro, neque diuinitas, quae ubique est. Assumendo etiam Deus carnem et animam, assumpsisse uidetur $^{386}$ utramque naturam, tam spiritualem quam corporalem. Fuit in Christo non tatum dolor carnis ${ }^{387}$, sed etiam tristitia mentis ${ }^{388}$, non diuinae, sed humanae. Dixitque: Tristis est anima mea $^{389}$. Et iterum: Non mea, sed tua uoluntas fiat. Et quis orabat ${ }^{390}$ ?

Ecclesia, prout dixi, errare non potest. Christus fuit uerus Deus et perfectus Deus, uerus homo et perfectus homo ${ }^{391}$ ex anima rationali et humana carne subsistens. Sed non habuit illam animam sicut ceteri homines ${ }^{392}$. Sed si Deus posset $^{392 \mathrm{~A}}$ uiuificare corpus supplens uicem animae, pastor uenturus ${ }^{393}$ declarabit. Nunc ita accipe, noli a maioribus tuis deuiare: verum hominem opus est ueram carnem humanam habere et ueram animam. Si ergo Christus animam non habuisset, quomodo uerus homo fuisset? Facilius esset facere hominem cum anima sine carne ${ }^{394}$ quam ut sit homo habens carnem absque anima. Anima enim est potior pars hominis ${ }^{395}$. Qui ergo dicunt animam esse totum hominem minus errant quam qui fatentur carnem esse totum hominem ${ }^{396}$.

Modum incarnationis et humanationis iam audisti, psalmum quoque percepisti. Quae tibi reuelaui uera sunt, quae declaraui diuina sunt.

381 innodauerunt] innundauerunt $M 382$ credentes et docentes] tenentes et docentes $N$; tenentes et dicentes $Q \quad 383$ esse] esset $H \quad \mathbf{3 8 4}$ subsisteret] subsistit $Q \quad \mathbf{3 8 5}$ Verbum] Filium $Q \quad \mathbf{3 8 6}$ assumpsisse uidetur] assumpsisse uideretur $H$; assumpsisset uidelicet $Q \mathbf{3 8 7}$ uidetur utramque (...) tatum dolor carnis] uidetur dolor carnis $G \mathbf{3 8 8}$ mentis] mortis $H P 389$ anima mea] usque ad mortem add. GQ 390 orabat] orabitur $Q 391$ et perfectus Deus ... et perfectus homo] om. $E$ 392 ceteri homines] ceteri homines quia illico, ut fuit, beatam habuit. $Q$; (vide 351) 392A Sed si Deus posset] Respondit: "Si Deus possit $I R$; Respondit: Modum incarnationis et humanationis $\rightarrow$ 
Cristo teve alma racional criada e duas inteligências e duas vontades. E enlearam com o vínculo do anátema todos os que crêem e ensinam o contrário. Acreditais vós, e é verdade, que a Igreja, no que à fé respeita, não pode errar, sobretudo quando está reunida em nome de Cristo, porque está escrito: Onde dois ou três estiverem reunidos em meu nome, aí estou eu no meio deles ${ }^{[97]}$. Na verdade, é, então, dirigida pelo Espírito Santo. Também Atanásio diz no seu Símbolo: "de alma racional, ou seja, criada" (para que se não entenda, desajustadamente embora, por alma racional a própria divindade), "e subsistindo na carne humana”. Daí se vê outro segredo da vossa filosofia, que a carne humana é distinta da alma e não é carne por meio da alma. Se, de facto, subsiste em razão da alma racional e da carne humana, então subsiste a partir de dois princípios, um, o ser da carne, o outro, o da alma. Não subsistiria a partir desses dois princípios se a carne existisse por meio da alma. Os vossos Santos Padres e os vossos Concílios dizem: "O Verbo nunca abandonou o que uma vez assumiu”. Entendem-no, e correctamente, das partes. Mas se morreu a carne que antes era vivificada pelo Verbo Divino, e a vivificação era união, então o Verbo deixou a carne que havia assumido. Dizem também que a alma de Cristo desceu aos infernos, porque não foi a carne, que esteve depositada no sepulcro, nem a divindade, que está em todo o lado. Ao assumir Deus a carne e a alma, parece ter assumido ambas as naturezas, tanto a espiritual como a corporal. Em Cristo esteve presente não só a dor da carne, mas também a tristeza da alma, não divina, mas humana. Ele disse: $A$ minha alma

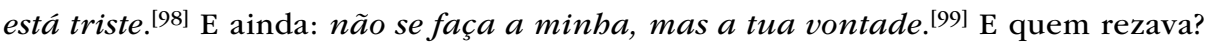

A Igreja, como disse, não pode errar. Cristo foi verdadeiro Deus e Deus perfeito, verdadeiro homem e homem perfeito, subsistindo a partir de uma alma racional e da carne humana. Mas não teve alma como os outros homens. Mas se Deus podia vivificar o corpo, fazendo a vez da alma, declará-lo-á o Pastor que está para vir. De momento, aceita isto assim, não te afastes dos teus antepassados. É imperioso que um verdadeiro homem tenha carne humana verdadeira e verdadeira alma. Portanto, se Cristo não tivesse alma, como teria sido verdadeiro homem? Seria mais fácil criar um homem com alma, sem a carne, do que ser homem tendo a carne sem alma. A alma é, na verdade, a parte mais importante do homem. Os que dizem, pois, que a alma é a totalidade do homem, erram menos do que aqueles que afirmam que a carne é a totalidade do homem.

Ouviste falar já do modo da incarnação e da humanação, ouviste também o salmo. É verdadeiro o que te revelei, é divino o que te dei a conhecer.

$\leftarrow$ iam audisti, psalmum quoque percepisti. $V$; Sed er. $O$ (add. $a$. $m$. Respondit angelus); 393 uenturus] futurus $G 394$ carne] corpore $Q 395$ potior pars hominis] prior pars corporis $V 396$. Si ergo Christus animam non habuisset (...) minus errant quam qui fatentur carnem esse totum hominem] add. M (in marg. a. m.); om.JP

[97] Mt 18:20.

[98] Mc 14:34,

[99] Lc 22:42, 
Et ego ${ }^{397}$ : Multi apud nos credunt paucos angelos sciuisse incarnationem Verbi. Vnde Domino ad caelos ascendenti, angeli dicebant: Quis est iste qui uenit de Edom tinctis uestibus de Bosra? Et apostolus noster dicit: Vt innotescat principatibus ${ }^{398}$ et potestatibus per ecclesiam ${ }^{399}$.

Respondit: Veritas est quod nos, ut iam tibi dixi ${ }^{400}$ hoc mysterium sciuimus, propter hoc proelium fecimus. Nec Domino ascendenti, tamquam eum non cognoscentes illa uerba dicebamus, sed ex admiratione tantae dignitatis ac maiestatis illa proferebamus. Nos prophetis ${ }^{401}$ hoc reuelauimus, nos interfuimus, nos omnia uidimus. Quomodo procurauissemus hominum salutem si nesciuissemus Saluatorem? Tamen rem tam mirandam quomodo fieri posset? Non cognoscebamus perfecte nisi quando eam uidimus fieri. Sic et Resurrectionis Christi modum et Ascensionis tunc perfecte cognouimus quando ea fieri uidimus. Et hoc modo nobis per Ecclesiam innotuit, quia in Ecclesia talia fieri clare uidimus.

Ecce uides ${ }^{402}$ qualiter domus Mariae facta est caelum empyrium. Tota enim multitudo militiae caelestis exercitus ibi erat, nam plures angeli simul esse possunt, quamuis naturaliter unus non sit ubi alius est. Sic enim non indiguissemus tam magno habitaculo. Multi nostrum non erant intra parietes domunculae ${ }^{403}$, sed extra, per spatium duorum uel trium stadiorum et miliariorum ${ }^{404}$. Et omnes rem stupendam uidebamus, quia paries nostram uisionem non impedit. Omnes laetabamur, gaudebamus ${ }^{405}$, canebamus. Est itaque festum angelicae exultationis. Et quia tunc acceptauimus Hominem illum in Regem nostrum et Matrem in Reginam, est festum angelorum homini subiectionis et regni Christi aliqualis inchoationis et angelorum omnium in terram descensionis. Qui descensus communis fuit illa nocte et deinde in nocte natiuitatis Domini et postea, tempore mortis et resurrectionis et ascensionis, quia omnes usque ad montem Oliueti ei obuiam uenimus diuisi per choros. Deinde, quando Maria Virgo assumpta est [f1. 90] ad aethereum thalamum, descendimus ${ }^{406}$ adhuc semel omnes cum Iudice Christo.

Tunc ego: Euangelistae alii nil de hoc nobis tradiderunt, solus Lucas parum ${ }^{407}$ tetigit. Potiora obmisit.

Tunc angelus, accersito Luca, dixit: Dicito, carissime, huic homini simplici cur praetermisisti pulchriora de incarnatione Filii Dei.

Respondit Lucas: Tu ipse causam nosti. Genitrix Dei nostri omnia mihi dixerat, et ego ea scripseram. Sed Regi nostro non placuit ut ea tum reuellarentur omnibus ${ }^{408}$,

397 totum hominem. Modum incarnationis (...) sunt. Et ego] totum hominem. Et ego EGIR 398 principatibus] principibus $Q V 399$ per ecclesiam] om. $I R V \mathbf{4 0 0}$ ut iam tibi dixi] iam diu prout tibi dixi $Q \mathbf{4 0 1}$ uerba dicebamus, sed ex (...) proferebamus. Nos prophetis] uerba dicebamus. Nos prophetis $G \mathbf{4 0 2}$ uidimus fieri. Sic et (...) uidimus. Ecce uides] uidimus. Ecce uides $G \mathbf{4 0 3}$ domunculae] domuncilae $V \mathbf{4 0 4}$ miliariorum] miliorum $I R V \mathbf{4 0 5}$ gaudebamus] laudebamus $J \mathbf{4 0 6}$ descendimus] descendebamus $R$; descendemus $V \mathbf{4 0 7}$ parum] partem $N \mathbf{4 0 8}$ omnibus] hominibus $Q$ 
Crêem muitos dos nossos, disse eu, que poucos anjos sabiam da incarnação do Verbo. Daí que, ao subir ao Céu o Senhor, interrogassem os anjos: Quem é este que vem das bandas de Édon com vestes de Bosra tintas ${ }^{\text {[100] }}$ E o nosso apóstolo disse: Para dar a conbecer a principados e às autoridades por intermédio da Igreja. ${ }^{[101]}$

É verdade que nós, como já te disse, respondeu o anjo, conhecemos este mistério, por causa dele travámos um combate. E nem pronunciámos aquelas palavras, enquanto o Senhor subia, como se o não conhecêssemos, mas proferimo-las pela admiração de tão grande dignidade e majestade. Nós é que o revelámos aos profetas, nós estivemos presentes, nós vimos tudo. Como iríamos ocupar-nos da salvação do homem se desconhecêssemos o Salvador? Todavia como poderia verificar-se acontecimento tão admirável? Não o conhecíamos perfeitamente senão quando o vimos acontecer. Deste modo, conhecemos perfeitamente não só o modo da Ressurreição de Cristo como o da Ascensão quando as vimos acontecerem. E deste modo se nos tornou conhecido pela Igreja, porque na Igreja o vimos claramente acontecer.

Estás a ver de que modo a casa de Maria se tornou o Céu Empíreo. Com efeito, aí se concentrava toda a multidão da milícia do exército celeste, pois que podem vários anjos estar ao mesmo tempo, embora, naturalmente, um não esteja onde o outro está. Deste modo, realmente, não precisávamos de um tão grande habitáculo. Muitos de nós não estavam dentro das paredes da divisão, mas fora, pelo espaço de dois ou três estádios e milhas. E todos víamos uma coisa admirável, porque a parede não impede a nossa visão. Todos exultávamos de alegria, nos alegrávamos e cantávamos. É, portanto, a festa da exultação dos anjos. E uma vez que então aceitámos aquele Homem como nosso Rei e a Mãe como Rainha, é a festa da submissão dos anjos ao homem e de uma espécie de início do reino de Cristo e da descida de todos os anjos à Terra. Esta descida foi comum àquela noite e à noite da natividade do Senhor e, depois, ao tempo da morte, da ressurreição e da ascensão, porque todos viemos ao seu encontro até ao Monte das Oliveiras divididos por coros. Depois, quando a Virgem Maria foi levada [f1. 90] ao tálamo etéreo, mais uma vez descemos todos com Cristo Juiz.

Os outros evangelistas, disse eu então, nada nos transmitiram relativo a isto, apenas Lucas o tocou ao de leve. O mais importante foi omitido.

Tendo chamado Lucas, disse então o anjo: Caríssimo, diz a este inocente homem a razão por que omitiste o mais belo sobre a incarnação do Filho de Deus.

Tu próprio, respondeu Lucas, sabes a razão. A Mãe do nosso Deus tinha-me relatado tudo, e eu tinha-o escrito. Mas não foi do agrada do nosso Rei que a todos se revelasse então, porque havia no mundo muita perfídia. Está reservado 
quoniam ${ }^{409}$ multa perfidia erat in mundo. Reseruata sunt cito uenturae aetati, quando etiam Apocalypsis Ioannis intelligetur quae clausa est sigillis septem.

Addiditque: Tempore illo haec interserentur a pastore meo Euangelio, stillo Euangelii ${ }^{410}$ quo ego utor, et addentur omnia praecipua alio ordine quam hic a te sint conscripta. Et cantabuntur ${ }^{411}$ in Ecclesia publice sub titulo Euangelii mei. Scripseram et de conceptione atque natiuitate Virginis et ipsius praesentatione in Templo et desponsatione breuius quam tibi nunc reuelatum est et a te conscriptum et stillo alio. Scripseram ${ }^{412}$ de Virginis obitu et assumptione ea quae tibi reuelabuntur. Omnia haec pastor futurus Euangelio meo addet et in festis eiusdem Virginis decantabuntur. Noluit Deus omnia simul palam facere, sed tantum ea quae necessaria erant ad salutem, spectantia ad humanitatem et diuinitatem Christi Domini. Sed ecce Gabriel hic est, cui haec sunt commissa. Audi ipsum.

Gabriel igitur loqui coepit confirmando ea quae Lucas dixerat et addendo ut festum Annuntiationis, quotiens occurrerit ${ }^{413}$ ante Dominicam Passionis ${ }^{414}$, fieret cum octaua, et quod in die anteriori fiat festum solemne desponsationis matris Dei, et legatur Euangelium Missus est. In die uero annuntiationis legatur euangelium In principio erat Verbum uel euangelium Luce nouum, secundum quod pastor ordinauerit. Et si non poterunt omnia obseruari gratia Dominicae Passionis, reseruentur pro die natiuitatis ita quod ea quae tunc canuntur ${ }^{415}$ referantur non solum ad natiuitatem Domini ${ }^{416}$, qua editus est mundo, sed ad hanc, quando Verbum caro factum est. Et si post octauam Pascatis celebrari contigerit ${ }^{417}$, solemnius celebretur quam antea. Sed quando et qualiter, tunc ordinabitur. Et quia Deus docebit pastorem illum, multa ipse addet his quae nunc scribis et declarabit an, si festum tale uenerit in dominica, et qua dominica debeat celebrari uel non, et an ieiunium in die tantae solemnitatis sit celebrandum, et quando sic et quando uero non, et multa alia quae nunc praetermitto.

Nunc, dilectissime ${ }^{418}$, audi et considera excelentiam generis tui. Cogita quantum honorem tunc habuit progenies tua quando omnes angeli adorauerunt Hominem Deum et Mariam Dei Genitricem et eis se libenter subdiderunt. Cogita quae et qualis et quanta sit nox ista uere sancta, uere splendida, uere ut Sol rutilans. Bene facitis quando ad tactum campanae in sero, quando ego accessi, Aue Maria dicitis $^{419}$. Bene, quando in media nocte illud repetitis, addendo: Ecce ancilla

409 quoniam] quando GHIJOR $\mathbf{4 1 0}$ meo Euangelio stillo Euangelii] meo euangelico stilo $Q$ $\mathbf{4 1 1}$ Et cantabuntur] Et in tempore pastoris cantabuntur $Q \mathbf{4 1 2}$ a te conscriptum et stillo alio. Scripseram] a te conscriptum. Et stilo alio scripseram $I$; a te conscriptum stilo alio scriptum $N$ 413 occurrerit] occurreret $E H I M N$; occurret $R V 414$ Passionis] Passionis per plures dies $G$ (M in marg. a. m.) NOQ 415 canuntur] canentur IPRV 416 Domini] Christi IRV 417 contigerit] contingeret $H P \mathbf{4 1 8}$ dilectissime] carissime $V \mathbf{4 1 9}$ dicitis] dicentis $R$ 
para a idade que cedo vai chegar, quando também a Apocalipse de João, que está fechada com sete selos, for entendida.

Nesse tempo, acrescentou, serão estas coisas inseridas pelo Pastor no meu Evangelho, segundo o estilo do Evangelho que eu uso, e acrescentar-se-á quanto for mais importante, segundo uma ordem diferente da que aqui está por ti a ser escrita, e cantar-se-á publicamente na Igreja sob o título do meu Evangelho. Tinha escrito muito também, de um modo mais conciso do que agora te revelei a ti e por ti foi escrito, e noutro estilo, sobre a concepção e a natividade da Virgem, a sua apresentação no Templo e seus esponsais. Tinha escrito muito sobre o passamento de Maria e sua assunção, que te vai ser revelado. Tudo isto acrescentará o futuro Pastor ao meu Evangelho, e será cantado nas festividades da mesma Virgem. Deus não quis dar a conhecer tudo ao mesmo tempo, no que à humanidade e à divindade de Cristo respeita, mas apenas o que era necessário à salvação. Mas, olha, está aqui Gabriel, a quem estas coisas foram confiadas, ouve-o.

Então Gabriel começou a falar confirmando o que Lucas tinha dito e acrescentando que, sempre que a festa da Anunciação ocorra antes do Domingo da Paixão, se celebre com oitava, e que no dia anterior se celebre a festa solene dos esponsais da Mãe de Deus e se leia o Evangelho Missus est. ${ }^{[102]}$ E no dia da Anunciação leia-se o Evangelho In principio erat Verbum, ${ }^{[103]}$ ou o novo Evangelho de Lucas, conforme o Pastor determinar. E, se não puder observar-se tudo por causa da Paixão do Senhor, reserve-se para o dia da Natividade, de modo a que, o que então é cantado, se refira não só à Natividade do Senhor, data em que veio ao mundo, mas a esta, quando o Verbo se fez carne. E se acontecer celebrar-se depois da oitava da Páscoa, celebre-se de modo mais solene do que antes. Mas, quando e como, será então determinado. E uma vez que Deus há-de ensinar este Pastor, muita coisa há-de ele acrescentar ao que agora escreves, e dará a conhecer, se esta festa cair no Domingo, se também esse Domingo deve celebrar-se ou não, e se em dia de tão grande solenidade deve observar-se o jejum, e quando sim e quando não, e muitas outras coisas de que agora não falo.

Agora, meu caro, ouve e atenta na excelência da tua raça. Pensa de quão grande honra desfrutou a tua raça, quando todos os anjos adoraram o Homem Deus e Maria, a Mãe de Deus, e de boa vontade se lhe submeteram. Reflecte no que seja, em como seja e em quão importante seja esta noite verdadeiramente santa, verdadeiramente resplandecente, verdadeiramente brilhante como o Sol. Fazeis bem quando, à tarde, ao toque do sino, no momento em que eu me aproximei, recitais Avé Maria. Bem, quando, a meio da noite, repetis o mesmo e acrescentais: Eis a escrava do Senhor, faça-se em mim segundo a tua vontade. 
Domini! Fiat mibi secundum uerbum tuum. Bene, quando in crepusculo diei iterum salutatis, addentes: Verbum caro factum est et habitauit in nobis.

Tunc enim angelorum multitudo cum [f1. 91] gaudio discessit. Maria uero, Ioseph uiro suo uocato et nobis eam comitantibus, ipso mane festina ad cognatam suam Elisabeth perrexit ${ }^{420}$. Et eundo, me de psalmo illo quem Adam pro uenia peccatorum suorum cum Eua fecerat interogauit, quem et tu conscribas ${ }^{421}$.

Psalmus primorum parentum culparum remissionem implorantium et obtinentium hic enim fuit: ${ }^{422}$

$$
\text { - } \operatorname{ADAM}^{423}
$$

Adonai, Domine Deus meus, secundum magnam misericordiam tuam miserere mei,

Et quia plurimae sunt miserationes tuae, dele hanc iniquitatem meam.

Oppressus sum tribulatione maxima, tempestas pelago ${ }^{424}$ demersit me.

Libera me, Deus, et erue me de diluuio aquarum multarum.

Audite, caeli et omnes caligine ${ }^{425}$, uerba oris mei,

Referant angeli omnia quae cogito et loquor, dicant uirtutes caelestes.

Porrigat Deus aures pientissimas ${ }^{426}$ huic humili deprecationi meae,

Exaudiat $^{427}$ orationem meam et clamor cordis mei ad ipsum perueniat.

Tu, Deus, es lux uera et praeclarissima, omnia alia sunt tenebris permixta, ${ }^{428}$

Tu es sol qui nescit ${ }^{429}$ occasum et habitas lucem inaccessibilem,

Tu es terminus et finis omnium, tu satietas unica beatorum. ${ }^{430}$

- Eva

Adonai, Domine Deus meus, secundum magnam misericordiam tuam miserere mei.

Magna est enim misericordia tua et miserationes tuae multae nimis.

Tu ante omnia caelum immobile creasti, habitaculum sanctum et excelsum,

Illud angelicis spiritibus decorasti et ipsis omnia quae facturus eras benigne reuelasti,

Illi fuerunt astra matutina qui te per multa saecula laudauerunt.

Tu caelum mobile formasti et illud aquas quae super caelos sunt nominasti, Est namque in se omnino uniforme et motu suo alii caeli cientur. ${ }^{431}$

Aque ille sunt sub caelo immobili et super omnia quae mouentur.

Tu creasti lucem, pulcherrimum solem ${ }^{432}$, lunam cum quinque planetis,

420 ipso mane festina ... perrexit] ipso mane festina ... porrexit $H$; ipso mane festinat $I R$; ipso mane festina ... praecepit $V \mathbf{4 2 1}$ conscribas] scribes $O$; scribas $H J P V$; scribis $Q \mathbf{4 2 2}$ Psalmus primorum parentum culparum remissionem implorantium et obtinentium hic enim fuit] Psalmus primorum parentum culparum remissionem implorantium et obtinentium GINOPR; Hic (enim $H$ ) fuit psalmus primorum parentum culparum remissionem implorantium et obtinentium $H Q 423$ nomina personarum om. IRV; add. in marg. GHJ $\mathbf{4 2 4}$ pelago] pelagi EGHIOPQRV $\rightarrow$ 
Bem, quando, ao crepúsculo do dia, de novo recitais Avé Maria, e acrescentais: O Verbo incarnou e habitou entre nós.

Então, realmente, a multidão dos anjos retirou-se, [f1. 91] no meio da alegria. E Maria, depois de chamar José, seu esposo, e com a nossa companhia, deu-se pressa em partir nessa mesma manhã para junto de sua prima Isabel. E, no caminho, interrogou-me sobre o salmo que Adão havia recitado com Eva pelo perdão de seus pecados. Salmo que pretendo que escrevas.

Salmo dos primeiros pais a pedir e obter a remissão dos pecados. Foi este:

- ADÃO

Adonai, Senhor Deus meu, segundo tua grande misericórdia, tem compaixão de mim.

E porque é imensa a tua compaixão, apaga esta minha iniquidade.

Estou esmagado pelo cúmulo da tribulação, a tempestade submergiu-me no abismo.

Salva-me, Deus, e arranca-me do dilúvio das águas infindas.

Ouvi, Céus e todas as trevas, as palavras da minha boca,

Repitam os anjos tudo que penso e digo, afirmem-no as Virtudes celestes.

Incline Deus o seu ouvido todo piedoso para esta minha humilde prece,

Ouça minha oração, e chegue a ele o clamor do meu coração.

Tu, Deus, és luz verdadeira e brilhantíssima, tudo o mais está em trevas envolto,

Tu és Sol que não conhece ocaso e habitas luz inacessível,

Tu és limite e fim de tudo, tu a satisfação única dos bem-aventurados.

- Eva

Adonai, Senhor Deus meu, segundo tua grande misericórdia, tem compaixão de mim.

A tua misericórdia é, de facto, grande, é infinda a tua compaixão.

Antes de tudo, tu criaste o Céu Imóvel, habitação santa e sublime,

Decoraste-o com os espíritos angélicos, a quem benevolamente revelaste quanto ias fazer.

Foram eles os astros da manhã que por muitos séculos te louvaram.

Tu formaste o Céu Móvel e chamaste-o "as águas que estão sobre os Céus".

É, pois, em si, totalmente uniforme e no seu movimento os outros se movem.

Estão essas águas sob o Céu Imóvel e acima de tudo quanto se move.

Tu criaste a luz, o belíssimo Sol, a Lua com cinco planetas,

$\leftarrow \mathbf{4 2 5}$ caeli et omnes caligine] caeli et omnes caeligenae $I$; omnes caeli et caligene $N \mathbf{4 2 6}$ pientissimas] sapientissimas $I \mathbf{4 2 7}$ exaudiat] exaudiuit $R \mathbf{4 2 8}$ omnia alia sunt tenebris permixta] omnia alia sunt nebulata $Q$; omnia alia sunt tenebris mixta IRV 429 nescit] nescis GIRN 430 tu satietas unica beatorum] satietas unica omnium beatorum $N$; societas unita omnium beatorum $P$; tu es satietas unica omnium beatorum $O Q 431$ cientur] ocientur $J$; mouentur IRV 432 lucem, pulcherrimum solem] lucem pulcherrimam, solem $E M V$ 
Firmamentum in medio posuisti, in quo signa, stellas et sidera potenter collocasti.

Quattuor elementa produxisti et cuncta ex illis tua sapientia conflauisti.

- ADAM

Adonai, Domine Deus meus, secundum magnam misericordiam tuam miserere mei,

Qui deprimis superbos et exaltas humiles tuos.

Draconem enim superbum et rebellem brachio tuae potentiae dispersisti,

De sedibus potentes deposuisti et qui erant humiles sublimasti, ${ }^{433}$

Esurientes adimplesti bonis et qui sibi pleni uidebantur abiecisti,

Me tandem hominem de limo terrae fabricasti tuaque imagine insignisti. ${ }^{444}$

Et si natura mortalem et perturbabilem, ne mori aut perturbari possem ${ }^{445}$ concessisti, ${ }^{446}$

Nam et illa a te accipere mihi non repugnabat. ${ }^{447}$

Me in locum uitae et uoluptatis induxisti et omnibus bonis ${ }^{448}$ decorasti,

Sub pedibus meis omnia subiecisti et magnum Adonai nomen ostendisti.

Euam adiutorium mihi simile dedisti, quam de latere meo extraxisti.

- ADAM

Adonai, Domine Deus meus, secundum magnam misericordiam tuam miserere mei,

Quia me caput omnium hominum fecisti tuaque sapientia simul cum socia imbuisti,

Liberum arbitrium concessisti et in manibus nostris nos dimisisti,

Praecepta et mandata nobis dedisti, uitam et mortem ante nos posuisti,

Vt si mandata seruaremus conseruaremur, non seruando moriremur.

Lucifer inuidus uidit et inuidit, pugnauit contra nos et uicit.[f1. 92]

Victus ab angelis, hominem superauit et semen eius in aeternum prostrauit.

Ego sum qui peccaui, ego ille qui coram te iniquitatem feci.

Si ego noluissem nec Eua nec hostis me auertere potuisset.

Cum in honore essem, ${ }^{449}$ non intellexi et dignitatem meam ${ }^{450}$ amisi.

Comparatus sum iumentis, equo et mulo factus sum similis.

- ADAM

Adonai, Domine Deus meus, secundum magnam misericordiam tuam miserere mei.

Tribulationem et dolorem inueni, circumdederunt me gemitus mortis.

Morte et omni miseria sum oppressus, omnibus muneribus exspoliatus.

Descendi ab Ierusalem in Ierico, incidi in latrones pessimos. ${ }^{451}$

433 sublimasti] exaltasti $Q \mathbf{4 4 4}$ tuaque imagine insignisti] tuaque manu fecisti $Q \mathbf{4 4 5}$ perturbari possem] perturbari posse $G O V$; perturbari $R \quad \mathbf{4 4 6}$ concessisti] consensisti $G \quad \mathbf{4 4 7}$ Et si natura mortalem et perturbabilem, ne mori aut perturbari possem concessisti / Nam et illa a te accipere $\rightarrow$ 
Puseste no meio o firmamento, onde com o teu poder colocaste signos, estrelas e constelações.

Produziste os quatro elementos e deles tudo formaste com tua sabedoria.

- ADÃo

Adonai, Senhor Deus meu, segundo tua grande misericórdia, tem compaixão de mim,

Que humilhas os soberbos e exaltas os teus humildes.

Pois, com o braço do teu poder, repeliste o soberbo e rebelde dragão,

De seus tronos depuseste os soberbos, exaltaste os que eram humildes,

Encheste de bens os famintos, enjeitaste os de si satisfeitos.

Por fim, do lodo da terra fizeste-me homem, e com a tua imagem me assinalaste.

Embora mortal e perturbável por natureza, poder não morrer nem ser perturbado me concedeste.

Pois, também isso de ti receber, a mim não repugnava!

Conduziste-me a lugar de vida e delícia, adornaste-me de todos os bens,

Tudo submeteste a meus pés, revelaste-me, Adonai, teu nome grande,

Deste-me Eva, companheira semelhante a mim, que tiraste do meu lado.

-ADÃO

Adonai, Senhor Deus meu, segundo tua grande misericórdia, tem compaixão de mim,

Porque me fizeste cabeça de todos os homens, cumulaste-me a mim e à companheira da tua sabedoria,

Concedeste-nos o livre arbítrio, entregaste-nos em nossas mãos,

Deste-nos preceitos e mandamentos, ante nós puseste a vida e a morte,

Para nos salvarmos, se os mandamentos guardássemos, morrêssemos não os guardando.

O invejoso Lúcifer viu e invejou, lutou contra nós e venceu. [f1. 92]

Vencido pelos anjos, superou o homem e prostrou para sempre sua descendência.

Sou eu quem pecou, eu quem diante ti cometeu a iniquidade.

Se eu o não tivesse querido, nem Eva nem o inimigo me poderia afastar.

Desfrutando da honra, não o entendi e perdi a minha dignidade.

Sou comparado aos asnos, assemelhei-me ao cavalo e à mula.

- ADÃO

Adonai, Senhor Deus meu, segundo tua grande misericórdia, tem compaixão de mim.

Encontrei tribulação e dor, rodearam-me gemidos de morte,

Fui oprimido pela morte e por toda a miséria, fui espoliado de todos os bens,

Desci de Jerusalém para Jericó, caí em poder de ladrões crudelíssimos,

$\leftarrow$ mihi non repugnabat] om. $Q 448$ bonis] donis HINRV 449 Cum in honore essem] cum eam honorem possiderem $Q \mathbf{4 5 0}$ meam] magnam GHMO 451 pessimos] fortissimos $I R V$; ferocissimos GHOQ 
Ipsi me spoliauerunt et nudum omnino dimiserunt,

Atrociter uulnerauerunt et semiuiuum reliquerunt.

Iam nuditatem meam ipse agnosco, malum meum erit contra me semper.

Scio bonum nunc, Deus ${ }^{452}$, quod amisi, quod teneo malum bene didici.

Verumtamen minus meas defleo miserias quam posteritatis calamitates.

Vtinam super me solum et Euam peccatorum poena irruisset, ${ }^{453}$

Transibit de progenie in progenies in uniuersos liberos nostros.

- EvA

Adonai, Domine Deus meus, secundum magnam misericordiam tuam miserere mei.

Magnus Dominus Deus noster et magna clementia eius et misericordiae eius non est numerus,

Qui peccato nostro adhibuit remedium ut, si uellemus, surgere possemus,

Filium suum omnium glorificatorem mox statuit nostrum Redemptorem, Eius quoque sanctam Genitricem nostram statuit mediatricem

Ad cuius effigiem edificauit me Euam cunctorum uiuentium matrem.

Matrem instar filiae fecit, Adam instar sui et mei Filii plasmauit,

Cuius meritis quam maximis culpas nostras abolere uoluit,

Si et ipsi uellemus ${ }^{454}$ aut sacramenta eius susciperemus.

Voluntarium sacrificium acceptabit, cor humile numquam abhorrebit, Venientibus ad se obuiam occurret ${ }^{455}$, eis peccata dimittens gloriam ${ }^{456}$ infundet. $^{457}$

- Eva

Adonai, Domine Deus meus, secundum magnam misericordiam tuam miserere mei.

Grandis est multitudo dulcedinis tuae, Deus, beati omnes qui sperant in te. ${ }^{458}$

Post tenebras reducis lucem, post dolores gaudium et laetitiam,

Retribuis pro centum mille et pro mille decem milia,

Commutas minima in maxima, temporalia in aeterna.

Beati qui custodiunt mandata tua ${ }^{459}$, subiciunt colla iugo tuo,

Habitabunt in excelso tabernaculo tuo, requiescent in monte sancto tuo, ${ }^{460}$

In atriis tuis morabuntur, in fulgidis tectis super aurum et omnes lapides pretiosos.

Beati qui in te, Deum Trinum et Vnum, credunt et uias tuas scire uolunt.

452 nunc, Deus] miser nobis, Deus $H$; miser, non Deus $I R$; misit nobis Deus $J M$; mi Deus $P$; Deus $Q$; miser nudans $V 453$ irruisset] uenisset $E \quad 454$ uellemus] uelimus $Q \mathbf{4 5 5}$ occurret] occurrit $I R V 456$ gloriam] gratiam IQV 457 infundet] infundit $I R V 458$ qui sperant in te] seruient tibi $Q$ 459 temporalia in aeterna. / Beati qui custodiunt mandata tua] om. $Q \mathbf{4 6 0}$ Habitabunt in excelso tabernaculo tuo, requiescent in monte sancto tuo] om. $G$ 
Eles me espoliaram e totalmente nu me abandonaram,

Feriram-me cruelmente e semivivo me abandonaram.

Já eu mesmo reconheço a minha nudez, meu mal estará sempre perante de mim. Sei agora, Deus, o bem que perdi, conheço bem o mal em que estou,

Contudo, choro menos minhas misérias que as desgraças dos descendentes.

Caísse, quem dera, sobre mim só e sobre Eva dos pecados a pena!

Passará de geração em geração para todos os nossos filhos.

- EvA

Adonai, Senhor Deus meu, segundo tua grande misericórdia, tem compaixão de mim.

Grande é o Senhor nosso Deus e grande é sua clemência, não há limite à sua misericórdia.

Eis que ao nosso pecado ofereceu remédio, para que, querendo, nos pudéssemos levantar.

A seu Filho, de todos Glorificador, constituiu-o nosso Redentor,

Sua santa Mãe constituiu também mediadora nossa,

A cuja imagem me fez a mim, Eva, mãe de todos os viventes.

Fez a mãe à imagem da Filha, formou Adão à imagem de si e de meu Filho

Por cujos inexcedíveis méritos aboliu nossas culpas,

Se também nós o quiséssemos ou seus sacramentos recebêssemos.

Aceitará um sacrifício voluntário, nunca desprezará um coração humilde, ${ }^{[104]}$

Ao encontro irá dos que a si vêm, perdoando-lhes os pecados, neles infunde a glória.

- Eva

Adonai, Senhor Deus meu, segundo tua grande misericórdia, tem compaixão de mim.

Incomensurável é tua doçura, Deus, bem-aventurados os que em ti esperam.

Depois das trevas fazes voltar a luz, depois das dores, o prazer e a alegria.

Por cem retribuis tu mil, por mil dez mil retribuis.

Os mínimos transformas em máximos, em eterno o temporal.

Bem-aventurados os que teus preceitos guardam, a teu jugo a cerviz submetem,

Habitarão em teu excelso tabernáculo, repousarão em teu Monte Santo,

Em teus átrios hão-de morar, em moradas mais brilhantes que o ouro e todas as pedras preciosas.

Bem-aventurados os que em ti crêem, Deus Trino e Uno, e teus caminhos querem conhecer. 
Omnes "Gloria Patri et Filio et Spiritui Sancto" cantemus ${ }^{461}$ et Deum nostrum magnificemus,

Sicut et in principio angeli canebant ${ }^{462}$, sic et nos cum illis nunc et semper in saecula saeculorum. Amen.

Intellexisti igitur canticum istud et orationem istam quam iugiter Domino porrigebant quam ego tunc coram dixi Mariae ${ }^{463}$, ambulando in uia. Iter illud quod puella delicata in sex diebus ${ }^{464}$ uix fecisset Domino eam quem ferebat portante, in die una perfecimus. Neque omnino fuit naturale neque omnino miraculosum. Non enim subito uel in hora una illuc peruenimus. Ioseph sciebat quo ibamus, sed et causam itineris non ignorabat, immo sciebat. Fuit enim dignus [f1. 93] uidere mirabilia Dei.

Quando enim ego ${ }^{465}$ cum sociis meis ad Mariam Virginem orantem accessi, paulo post ipse quia erat cum Anna in domo, uenerat enim eam uisitare, ad uidendam Mariam accesserunt et me cum ea loquentem inuenerunt et nobiscum tota illa nocte permanserunt, omnia uerba mea audierunt et Mariae lumen uiderunt et Messiam esse conceptum crediderunt. Sed Deum incarnatum tunc non uiderunt, sed cantus angelicos et exultationem audierunt. Erant ambo nobiscum in uia, Ioseph et Anna.

Numquam ergo Ioseph dubitauit de Mariae uirginitate ${ }^{466}$, sed uidens tot miranda, non audebat in faciem eius aspicere. Et si quandoque aspiciebat, uidebatur sibi resplendere ut Sol, quia Solem gerebat in mente et corpore. Ideo radii eius rutilabant in facie. Quae irradiatio, Sole exeunte de thalamo uirgineo, desiit. Ideo scribitur: Et non cognoscebat eam donec peperit Filium suum primogenitum ${ }^{467}$. Timor ergo quidam oppresserat Ioseph quia erat iustus, erat timidior et se indigniorem putabat. Quanto enim homo est doctior, quia scit quanta ad sciendum sibi desunt, tanto se indoctiorem putat. Et quanto homo iustior, tanto ${ }^{468}$ magis defectus suos cognoscit et tanto magis se uilipendit et Deum magnificat. Ideo Ioseph iustior aliis se indigniorem existimabat neque Mariam in domum suam traducere uolebat ${ }^{469}$. Cogitabat occulte in corde suo, sed nulli propalabat. Dicebatque: "Non sum dignus habitare cum matre Dei". Quamuis adhuc nesciret omnia mysteria, hoc tamen credebat. Non tamen perfecte intelligebat, neque tunc neque postea, sicut Maria. Cogitabat ergo, expleto itinere, dimittere ipsius societatem. In uia tamen et in domo Zachariae noluit eam relinquere. Postea uero, reuersus in Nazareth, uoluit eam dimittere. Cui apparui in somnis et hortatus sum eum ne timeret $^{470}$, quia Deus fecerat eum dignum et quod Mariam acciperet et conduceret in domum

461 cantemus] canamus EJ 462 canebant] cantabant $Q \quad 463$ coram dixi Mariae] coram Maria dixi $P$; totam dixi Mariae IQRV 464 diebus] dierum spatiis $Q$, mensibus $V \mathbf{4 6 5}$ sciebat. Fuit enim dignus uidere mirabilia Dei. Quando enim ego] om. G 466 Numquam ergo Ioseph dubitauit de Mariae uirginitate] Numquid enim Ioseph dubitauit de Mariae uirginitate? $Q 467$ primogenitum] unigenitum $Q \mathbf{4 6 8}$ est doctior, (...) homo iustior, tanto] est doctior, tanto $Q \mathbf{4 6 9}$ uolebat] nolebat $R V \mathbf{4 7 0}$ ne timeret] ne dimitteret $Q$ 
Cantemos todos glória ao Pai, ao Filho e ao Espírito Santo, exaltemos o nosso Deus,

Assim como no princípio os anjos cantavam, assim nós com ele, agora e sempre, pelos séculos dos séculos. Ámen.

Ouviste, pois, este cântico e esta oração que continuamente dirigiam a Deus, que eu repeti então perante Maria enquanto caminhávamos. Aquele caminho que uma donzela frágil mal faria em seis dias, fizemo-lo nós em um, levando Deus aquela que o transportava. E não foi totalmente natural nem totalmente milagroso. Na verdade, não chegámos lá de repente, nem numa hora. José sabia para onde íamos e não ignorava a razão da viagem, e até sabia. Foi, pois, digno [f1. 93] de ver as maravilhas de Deus.

Quando eu e os meus companheiros nos aproximámos de Maria, que estava em oração, logo depois, porque ele estava com Ana em casa (de facto tinha vindo visitá-la), aproximaram-se para ver Maria e encontraram-me a falar com ela. E ficaram connosco toda aquela noite, ouviram todas as minhas palavras e viram o brilho de Maria e acreditaram que o Messias havia sido concebido. Mas não viram então o Deus incarnado, ouviram, contudo, os cânticos e a alegria dos anjos. José e Ana iam ambos connosco na viagem.

José, consequentemente, nunca duvidou da virgindade de Maria, mas, ao ver coisas tão dignas de admiração, não ousava olhá-la na face. E, se uma vez por outra olhava, parecia-lhe que resplandecia como o Sol, já que transportava o Sol na mente e no corpo. Por isso, os seus raios brilhavam-lhe na face. Esta irradiação cessou com a saída do Sol do tálamo virginal. Por isso está escrito: Mas não a conbeceu até ao dia em que deu à luz o seu Filbo primogénito. ${ }^{[105]}$ Consequentemente, um certo temor havia acabrunhado José, porque era justo, era muito temente a Deus e se considerava o mais indigno. Realmente, quanto mais conhecedor um homem é, porque tem consciência de quanto lhe falta saber, tanto menos conhecedor se julga. E quanto mais justo for um homem, tanto mais conhece suas falhas e tanto mais se deprecia e engrandece a Deus. Por isso, José, mais justo que os outros, considerava-se mais indigno e nem queria levar Maria para sua casa. Meditava secretamente em seu coração, mas a ninguém falava. E dizia: "Não sou digno de viver com a Mãe de Deus". Embora não conhecesse ainda todos os mistérios, neste, porém, acreditava. Não o entendia, todavia, perfeitamente, nem então nem depois, tal como Maria entendia. Pensava, portanto, deixar sua companhia no fim da viagem. Não quis, contudo, deixá-la na viagem 
suam, quia, sicut audierat illa felicissima nocte, quod in utero Mariae natum erat, diuinum opus erat ${ }^{471}$ et Filius Altissimi, et quod puero nomen Iesus imponeret. Et sic fecit et adimpleuit.

Venimus igitur in montana Galilaeae ${ }^{472}$, intrauimus in domum Zachariae. Sed nos angelos sola Maria uidebat. Ipsa ergo humillime, tamquam Virgo humillima, salutauit Elisabeth iam tumidum uterum habentem. Et dum amplexarentur se mutuo, mirabile dictu, Maria uidit Iesum respicientem Ioannem et Ioannem intuentem Iesum. Nam subito, ut Maria dixit intrando: "Pax Christi sit huic domui" (et Elisabeth occurrenti: "Pax tibi ${ }^{473}$ magni prophetae et uocis in deserto clamantis dignissima mater"), Ioannes illico se ad Christum conuertit et facie et uultu corporali et unus alterum inspexit oculo mentali quasi se et Deum animae beatae aspiciunt, genua sua Ioannes primum ante Iesum curuauit, etiam nobis angelis intuentibus, et Christum Regem adorauit. Deinde haec uerba lingua qua angeli et animae inter se loquuntur protulit, dicens per modum cantici ${ }^{474}$ :

Benedictus sit Christus, uerus Deus, Dominus et Saluator meus, Benedictus sit eius introitus quo mihi collatus est caelestis uictus.

[f1. 94] Benedic mihi puero tuo, saluum fac filium ancillae tuae, Mitte benedictionem de sancto Templo tuo ut implear benedictione tua, ${ }^{475}$

Esto mihi adiutor fortis ut digne annuntiem laudem et gloriam tuam.

Te adoro, Deus meus, tibi me commendo, creator meus.

Iesus uero quasi sedebat et, manu dextra erecta, uersus ipsum Ioannem extensa, illum his uerbis ${ }^{476}$ et eadem lingua benedicebat per modum cantici ${ }^{477}$ :

Benedictus sis, electe Ioannes, serue meus, tu, idoneus precursor et praeco meus.

Veni ut me illum uideres quem et praecurrere potmodum deberes, Veni, Ioannes, ut tibi benedicam et faciem meam ${ }^{478}$ tibi ostendam, Esto praeco meus, Ioannes, iam praecursoris officium inchoato.

Verbum me esse Aeterni Patris in mundi deserto clamabis, ${ }^{479}$

Agnum auferentem crimina praedicabis et Saluatorem ${ }^{480}$ hominum $^{481}$ annuntiabis.

471 natum erat, diuinum opus erat] conceptus erat $E \mathbf{4 7 2}$ Galilaeae] Iudaeae $E \mathbf{4 7 3}$ Pax Christi sit huic domui", et Elisabeth occurrenti: "Pax tibi] Pax tibi IR 474 dicens per modum cantici] dicens $G$; dicens per modum cantici: Canticum Ioannis in utero Elisabeth ad Iesum in utero Mariae in eius salutatione $Q$; dicens per modum cantici: Canticum Ioannis Baptistae ad Christum in utero Elisabeth $I$ ( $R$ in marg.) $V \mathbf{4 7 5}$ implear benedictione tua] ut impleatur benedictione tua $\rightarrow$ 
nem em casa de Zacarias. Mas depois, regressado a Nazaré, quis abandoná-la. Apareci-lhe em sonhos e exortei-o a que não temesse porque Deus o tornara digno, e a que recebesse Maria e a levasse para sua casa porque, como tinha ouvido dizer naquela felicíssima noite, o que havia sido concebido no útero de Maria era obra divina e Filho do Altíssimo, e que desse ao menino o nome de Jesus. E assim fez e cumpriu.

Chegámos, pois, às montanhas da Galileia, entrámos em casa de Zacarias. Mas apenas Maria nos via a nós anjos. Humildemente saudou ela, como virgem humilde, Isabel, que tinha já o ventre entumecido. E enquanto se abraçavam, coisa admirável de ser dita, Maria viu Jesus a olhar para João e João a olhar para Jesus. Pois, logo que Maria, ao entrar, disse: "Que a paz de Cristo seja com esta casa" (e a Isabel, que vinha ao seu encontro: "Que a paz esteja contigo, mãe digníssima do grande profeta, voz que clama no deserto"), imediatamente João se voltou, face e corpo, para Cristo, e olharam-se um ao outro com a visão do espírito como as almas bem-aventuradas se olham a si e a Deus. João, primeiro, curvou os joelhos diante de Jesus, enquanto nós, os anjos, observávamos, e adorou a Cristo Rei. Depois, na língua que os anjos e as almas falam entre si, proferiu estas palavras, dizendo a modo de cântico:

Bendito seja Cristo, verdadeiro Deus, Senhor meu e Salvador.

Bendito seja o seu advento, pelo qual me foi trazido celeste alimento.

[f1. 94] Abençoa-me a mim teu servo, protege o filho de tua serva,

Manda do teu santo Templo a bênção, para que eu da tua bênção me encha.

Sê para mim apoio forte, para que dignamente anuncie teu louvor e tua glória.

Adoro-te, Deus meu, a ti me entrego, meu Criador.

Jesus, porém, como que estava sentado e, com a mão direita levantada e estendida para João, com estas palavras e, na mesma língua, abençoava-o a modo de um cântico:

Bendito sejas, João, meu servo eleito, tu, digno precursor meu e arauto.

Vim para que me visses, aquele a quem, pouco depois, deverias preceder, Vim, João, para te abençoar e a minha face te mostrar.

Sê meu arauto, João, uma vez iniciada a missão de precursor.

No deserto do mundo proclamarás que sou o Verbo do Eterno Pai,

Anunciarás o Cordeiro que tira o pecado, anunciarás o Salvador dos homens.

$\leftarrow I R$; ut celesti gratia impleri merear $G$ ( $M$ in marg. a. m.) $O$; in caelesti gratia impleri merear $Q$ $\mathbf{4 7 6}$ uerbis] uersibus $I R V \mathbf{4 7 7}$ et eadem lingua benedicebat per modum cantici] benedixit, sic dicendo $E$; et eadem lingua benedicebat: Canticum Iesu ad Ioannem in utero $Q$; eadem lingua benedicebat per modum cantici: Canticum Iesus ad Ioannem Baptistam. I( $R$ in marg.) $V \quad \mathbf{4 7 8}$ faciem meam] me $I R V \mathbf{4 7 9}$ clamabis] clamato $O$; proclamabis $Q \mathbf{4 8 0}$ Saluatorem] salutem $V$ 
Ante me in mundum ibis et uiam meam praeparabis,

Homines ad baptismum conuocabis et me Deum esse declarabis. ${ }^{482}$

Tunc Ioannes, Maria et Elisabeth et nobis angelis inspicientibus ${ }^{483}$, surrexit et saltare et tripudiare coepit, dicendo per modum cantici ${ }^{484}$ :

De matris meae utero uocauit me Dominus nomine meo,

Seruum suum me appellauit, electum suum me nominauit,

Faciem hominis mihi ostendit et diuinitatem non abscondit.

Qui me iam conceptum uiderat uidi et tamquam Deum adoraui,

Benedictionem amplam accepi, officium praecursoris inchoaui.

Praeco sum Verbi diuini et praecursor Domini mei,

Dei Verbum annuntiabo ${ }^{485}$ et ut uox uera proclamabo,

Agnum Dei demonstrabo, mentes hominum illuminabo.

\section{Haec Ioannes.}

Mater ergo sua audiuit, quia uidit ipsum a Iesu Ioannem uocatum ${ }^{486}$. Ideo, quando ei nomen patris imponebatur, dixit: Nequaquam tale nomen patris habebit, sed uocabitur Ioannes.

Tripudiante igitur Ioanne et Christo eum benedicente, matres amplexate ${ }^{487}$ stabant et haec miranda ${ }^{488}$ intuebantur non sine gaudio innenarrabili et una alteri, non lingua carnis sed angelica, loquebatur. Sed tandem Elisabeth exclamauit ${ }^{489}$ lingua carnis, ultima meae salutationis uerba repetens et fructum Mariae benedicens. Dum enim sic starent ${ }^{490}$ amplexate, Elisabeth lingua angelica interrogauit Mariam quando conceperat illum filium et quomodo. Maria indicauit per ordinem missionem Gabrielis, qui ego sum, et meam salutationem et quomodo conceperat et quis erat ille puerullus. Nam Elisabeth uidebat ${ }^{491}$ eum, sed non diuinitatem eius. Exclamando igitur Elisabeth uoce magna, dixit Benedicta tu in mulieribus, quod et ego dixeram et est sensus: Tu, Maria, sola benedicta es inter omnes homines, quia sola pro nullo tempore nec in esse nec in mente aut cogitatione maledictioni subiecta fuisti. Tu, Maria, sola ${ }^{492}$ es inter mulieres benedicta, quia sola mater Dei esse meruisti.

Ego sibi haec omnia utrumque dixeram, quod esset benedicta inter omnes homines $^{493}$ quia sola numquam ${ }^{494}$ maledictioni subiecta, sola benedicta inter ${ }^{495}$

481 hominum] omnium $O 482$ declarabis] declamabis $O 483$ et Elisabeth et nobis angelis inspicientibus] et Elisabeth inspicienti (inspiciente $R$ ) et nobis angelis $I R$; et Elisabeth et nobis angelis aspicientibus $N \mathbf{4 8 4}$ per modum cantici] per modum cantici loquendo. Canticum $2 \mathrm{~m}$ Ioannis in utero ad Iesum in utero Virginis Mariae $Q$; per modum cantici: Canticum Ioannis $H$ (in marg. a. m.) I ( $R$ in marg. a. $m$.) $V \mathbf{4 8 5}$ Verbum annuntiabo] Verbum annuntiando $R$, Verbi annuntiando $V \mathbf{4 8 6}$ quia uidit ipsum a Iesu Ioannem uocatum.] uocari Ioannem a Domino Iesu $E \quad 487$ matres amplexate] matribus amplexantibus $V \mathbf{4 8 8}$ miranda] miracula $J \mathbf{4 8 9}$ exclamauit] exclamabat $Q \mathbf{4 9 0}$ starent] stabant $Q \mathbf{4 9 1}$ Elisabeth lingua angelica (...) puerullus. Nam Elisabeth $\rightarrow$ 
Irás à minha frente para o mundo e prepararás meu caminho,

Chamarás os homens ao baptismo, darás a conhecer que eu sou Deus

João, então, estando Maria, Isabel e nós, os anjos, a observar, levantou-se e começou a saltar e a dançar, dizendo ao jeito de um cântico:

Do ventre de minha mãe, o Senhor me chamou pelo meu nome,

Designou-me seu servo, nomeou-me seu eleito,

Mostrou-me a aparência humana e não me escondeu a divindade.

Vi aquele que me vira já concebido e adorei-o como Deus,

Recebi abundante bênção, dei início à missão de precursor.

Sou arauto do Verbo divino e precursor do meu Senhor,

Anunciarei o Verbo de Deus, proclamá-lo-ei a Palavra Verdadeira,

Mostrarei o Cordeiro de Deus, iluminarei as mentes dos homens.

Foram estas as palavras de João.

Sua Mãe ouviu, porque viu Jesus chamá-lo João. Por isso, quando lhe davam o nome do pai, disse: Não terá, de modo nenhum, o nome do pai, mas vai chamar-se João. ${ }^{[106]}$

Enquanto, pois, João dançava e Cristo o abençoava, as mães abraçavam-se e, não sem inenarrável alegria, observavam estas maravilhas e falavam entre si em linguagem não da carne, mas angélica. E, por fim, Isabel exclamou com a linguagem da carne, repetindo as últimas palavras da minha saudação e abençoando o fruto de Maria. Enquanto se mantinham assim abraçadas, Isabel interrogou Maria por meio da linguagem angélica quando e como havia concebido aquele filho. Maria expôs ponto por ponto a missão de Gabriel, que sou eu, a minha saudação, como concebera e quem era aquele menino. Pois Isabel via-o, mas não via a sua divindade. Exclamando em voz alta, disse Isabel: Bendita és tu entre as mulberes, ${ }^{[107]}$ o que também eu havia dito e tem este sentido: Tu, Maria, és a única bendita entre todos os homens, porque só tu nunca foste sujeita, nem no teu ser nem na tua mente ou no pensamento, à maldição. Tu, Maria, és a única bendita entre as mulheres, porque só tu mereceste ser a Mãe de Deus.

De cada uma de todas estas coisas a tinha eu informado, que era bendita entre todos os homens, porque a única nunca sujeita à maldição; a única bendita

$\leftarrow$ uidebat] Elisabeth uidebat $E 492$ Tu, Maria, sola (...) subiecta fuisti. Tu, Maria, sola] Tu, Maria, sola $I R V 493$ homines] creaturas $Q \quad 494$ esse meruisti. Ego sibi haec omnia utrumque dixeram, quod esset benedicta inter omnes homines, quia sola nunquam] esse meruisti, numquam $E$ 495 quod esset benedicta inter omnes homines quia sola numquam maledictioni subiecta, sola benedicta inter] quod esset benedicta inter $P$

[106] Lc 1:60.

[107] Lc 1:42, 
omnes creaturas quia [f1. 95] sola super omnem creaturam praeelecta ${ }^{496}$; sola benedicta inter mulieres, quia sola ut Deum ${ }^{497}$ conciperet electa. Sed euangelista non omnia expressit nec omnia in scriptis reliquit. Addidit ${ }^{498}$ Elisabeth iam informata et instructa ${ }^{499}$ : Et benedictus fructus uentris tui, quia in hoc benedicentur omnes gentes, ut promissum fuerat Abraam.

Sic ergo Elisabeth locuta est per modum cantici: ${ }^{500}$

O Virgo numquam maledicta, inter omnes homines sola benedicta,

Super omnes creaturas exaltata omnique uirtute decorata,

Inter mulieres sola benedicta, Filii Dei sola mater electa.

Fructus uentris tui est benedictus et ipsi patri nostro Abraam promissus,

Sine ipso est benedictus nemo, ipse benedictus a solo Deo.

Vnde hoc mihi Deus concessit quod Mater eius ad me se contulit?

Nullis hoc factum est meritis meis neque uirtutibus ${ }^{501}$ ullis,

Domini mei ad me Mater uenit et cor meum gaudio impleuit.

Benedicta quae credidisti, adimplebuntur in te quae mihi dixisti,

Super omnes creaturas exaltaberis et Regina angelorum uocaberis.

Tunc in maxima cordis exultatione, lingua humana per modum cantici dixit Maria: Magnificat anima mea Dominum et exultauit spiritus meus prout Lucas in suo Euangelio conscripsit.

Hi fuerunt tres dies felicissimi, prima desponsationis, secunda incarnationis, tertia uisitationis. De qua uisitatione cito cito fiet a pontifice hoc praesenti, multorum malorum et bonorum patratore, Virgini tamen deuoto, nouum officium cui pastor electus et singularis pleraque addet ex ista reuelatione. Et ut solemnius peragi possit, fiat post octauam Praecursoris uel apostolorum Petri et Pauli, quorum $^{502}$ octaua solemniter ${ }^{503}$ fiat omnino. Et aliorum omnium apostolorum octauam non habentium ${ }^{504}$ fiat octaua ut nunc est ipsorum apostolorum Petri et Pauli. Maiori reuerentia sunt prosequendi apostoli Domini nostri Iesu Christi, qui pro salute hominum tanto tempore laborauerunt. Astabat Anna, astabat Ioseph. Linguam humanam audiebant, angelicam non audiebant ${ }^{505}$. Pleni tamen et ipsi gaudio erant et mirabantur de his quae dicebantur.

Maria mansit cum sua cognata usquequo Elisabeth peperit filium. Et Maria docebat ipsam Elisabeth de lege Dei et sibi suam desponsationem et in Templo

496 sola benedicta inter omnes creaturas quia sola super omnem creaturam praeelecta] et etiam super omnes creaturas fuit ellecta $Q \mathbf{4 9 7}$ praeelecta; sola benedicta inter mulieres, quia sola ut Deum] preelecta ut Deum $E \mathbf{4 9 8}$ conciperet electa. Sed euangelista non omnia expressit nec omnia in scriptis reliquit. Addidit] conciperet. Addidit. $E \mathbf{4 9 9}$ iam informata et instructa] edocta a Spiritu Sancto $E \mathbf{5 0 0}$ per modum cantici] per modum cantici ad Virginem gloriosissimam Mariam. Canticum Elisabeth ad Virginem Mariam. $Q$; Canticum Elisabeth ad Mariam $a d d$. I ( $R$ in marg. $a$. $m$.) $V 501$ uirtutibus] pro uirtutibus IRQ; pro uiribus $V 502$ uidelicet Praecursoris, Petri et Pauli] $\rightarrow$ 
entre todas as criaturas, [f1. 95] porque a única preferida sobre toda a criatura; a única bendita entre as mulheres, porque a única escolhida para conceber a Deus. Mas o evangelista não expôs tudo, nem tudo deixou escrito. Isabel, informada já e instruída, acrescentou: e bendito o fruto do teu ventre ${ }^{[108]}$ porque nele serão abençoados todos os povos, como havia sido prometido a Abraão. Por isso Isabel exprimiu-se assim, ao modo de um cântico:

Ó Virgem nunca amaldiçoada, entre os homens todos única bendita, Sobre toda a criatura exaltada e de toda a virtude ornada, Entre as mulheres, única bendita, do Filho de Deus única Mãe escolhida.

O Fruto do teu ventre é abençoado e a nosso próprio pai Abraão prometido, Sem ele ninguém é bendito, pelo próprio Deus é ele abençoado.

De onde me vem que Deus me conceda que sua Mãe venha até mim!

Sem méritos meus isto aconteceu, sem quaisquer virtudes.

Veio até mim a Mãe do meu Senhor e meu coração de alegria encheu.

És bendita, tu que acreditaste, cumprir-se-á em ti o que me disseste.

Sobre todas as criaturas serás exaltada e Rainha dos anjos tu serás chamada.

Na máxima exultação do coração, disse então Maria, em linguagem humana, ao modo de um cântico: A minha alma glorifica o Senhor, e o meu espírito exulta, ${ }^{[109]}$ conforme escreveu Lucas no seu Evangelho.

Foram estes os três dias mais felizes: o primeiro, o dos Esponsais; o segundo, o da Incarnação; o terceiro, o da Visitação. Desta Visita, logo, logo será instituído pelo actual pontífice, autor de muitas coisas más e de muitas coisas boas, devoto, contudo, da Virgem, um novo ofício a que o Pastor eleito e singular acrescentará várias passagens desta revelação. E para que possa celebrar-se de modo mais solene, celebre-se depois da oitava do Precursor ou dos apóstolos Pedro e Paulo, cuja oitava se deve celebrar com maior solenidade. E de todos os outros apóstolos que não têm oitava celebre-se uma oitava como é agora a dos apóstolos Pedro e Paulo. Os apóstolos de Nosso Senhor Jesus Cristo, que tanto tempo labutaram pela salvação dos homens, devem ser tratados com maior reverência. Estava presente Ana, estava presente José. Ouviam a linguagem humana, não ouviam a angélica. Estavam, todavia, também eles cheios de alegria e admiravam-se do que se dizia.

Maria ficou com sua prima até Isabel dar à luz o filho. Ensinava Isabel sobre a Lei de Deus e falou-lhe dos seus esponsais, da sua anterior permanência no

$\leftarrow$ add. GOQ 503 solemniter] solemnior RI $\mathbf{5 0 4}$ octaua solemniter (...) octauam non habentium] octaua non habentium $V \mathbf{5 0 5}$ angelicam non audiebant] sed non angelicam $E$;angelicam non uidebant GHJP; angelum non uidebant $Q$

[108] Lc 1:42,

${ }^{[109]}$ Lc 1:46-47. 
antea conuersationem narrauit ${ }^{506}$ et saepius cum Ioanne lingua nostra loquebatur. Zacharias gaudiis omnibus interfuit ${ }^{507}$ in domo sua factis, sed non plus quam Anna aut Ioseph uidit. Tandem Ioannes ${ }^{508}$, Christo inspiciente et benedicente ex utero Virginis, egressus est ex utero suae matris, et Maria cum Anna eum suscipiente 509 atque haec uerba dicente per modum cantici ${ }^{510}$ :

Egrediatur miles ante Regem suum, seruus progrediatur ante Dominum suum. Praeco iudicem praeibit, uox Verbum annuntiabit.

O sterilis ualde beata et in tanto filio multum sublimata,

[f1. 96] Concepisti iam purgatum, peperisti omni dono ampliatum.

Neque uinum neque siceram bibet, omne quod inebriare potest respuet, 511

Mel et locustas in deserto comedet et uni Deo inseruiet.

Nomen eius pater ab angelo audiuit, mater a Filio meo eum uocari uidit.

Pater quia non crediderat obmutuit ${ }^{512}$, Deus linguam eius aperuit.

Magnificemus Deum omnes praecursorem eius inspicientes.

Reliqua, dilectissime, ad natiuitatem huius plusquam prophetae pertinentia ex Euangelio didicisti. Mirabilis fuit natiuitas huius pueri et gaudio adimpleuit angelos et homines admiratione et laetitia. Vnde usque nunc quasi omnes in nocte illa gaudent et adhuc magis gaudebunt.

Manente Maria ${ }^{513}$ in domo Zachariae, Ioachim, uir sanctus, sollicitus de filia, iuit $^{514}$ post illam et, quando natus est Ioannes, simul cum Ioseph interfuit. Nato puero et per triduum laetitia expleta, Maria, cum quibus uenerat et cum suo patre Ioachim, reuersa est in domum suam in tanto tempore quanto uenerat. Et scito quod Maria sola, sine ullo dolore, peperit, Elisabeth cum paruo, Anna cum minori.

Hortante itaque me $\mathrm{e}^{515}$, Ioseph conduxit Mariam in domum suam sine pompis ullis. Cum timore Dei, in sanctitate et iustitia coram Deo ambulabant, contemplationibus et bonis operibus iugiter uacabant. Interdum manibus propriis laborabant et de suo labore uiuebant. Nos angeli assidue aderamus 516 et inseruiebamus Regem ${ }^{517}$ ferenti inclitae Reginae nostrae.

Tandem, dum implerentur dies pariendi Mariae, exiit edictum ut describeretur uniuersus ${ }^{518}$ orbis terrarum. Ioseph cum Maria et propinqui, Ioachim cum aliis multis ascenderunt in Bethleem, quia et Ioseph et Ioachim erant de tribu Iuda

506 desponsationem et in Templo antea conuersationem narrauit] desponsationem narrauit IRV $\mathbf{5 0 7}$ interfuit] interfuerat IRV $\mathbf{5 0 8}$ loquebatur. Zacharias (...) Ioseph uidit. Tandem Ioannes] loquebatur. Tandem Ioannes $E \mathbf{5 0 9}$ suscipiente] inspiciente $E H$; inspirante $P \quad \mathbf{4 1 0}$ per modum cantici:] per modum cantici: Canticum Virginis in natiuitate Ioannis Baptiste $Q$; per modum cantici: Canticum Mariae de natiuitate Ioannis Baptistae $I$ ( $R$ in marg.) $V \mathbf{5 1 1}$ respuet] destruet $Q \rightarrow$ 
Templo, e muitas vezes falava com João na nossa língua. Zacarias assistiu a todas as alegrias acontecidas em sua casa, mas não viu mais do que viram Ana ou José. Por fim, João, sob a observação e a bênção de Cristo a partir do ventre da Virgem, saiu do ventre de sua mãe, com Maria e Ana a recebê-lo e a proferir estas palavras, ao modo de um cântico:

Saia o soldado ante seu Rei, avance o servo ante seu Senhor.

$\mathrm{O}$ arauto precederá o Juiz, a palavra anunciará o Verbo.

Ó estéril, tão abençoada e em tão nobre filho tão sublimada, [f1. 96]

Concebeste-o já purificado, deste-o à luz de todo o bem aumentado.

Vinho e cerveja não beberá, o que pode embriagar recusará.

Mel e gafanhotos no deserto comerá e ao Deus único servirá.

Ouviu o pai seu nome pelo anjo ser chamado, ouviu-o a mãe ser chamado por meu Filho.

Por não ter acreditado, o pai emudeceu, Deus a sua língua soltou.

Glorifiquemos a Deus quantos vemos seu precursor

Tudo o mais relativo ao nascimento deste mais que profeta, meu caro, o sabes pelo Evangelho. Foi admirável o nascimento desta criança e encheu de satisfação os anjos e de admiração e alegria os homens. Daí que, até hoje, quase todos se regozijem nessa noite e mais se hão-de regozijar ainda.

Enquanto Maria estava em casa de Zacarias, Joaquim, homem santo, preocupado com a filha, foi ao seu encontro. E quando João nasceu, estava presente juntamente com José. Nascido o menino e completados os três dias de alegria, Maria voltou para sua casa com aqueles em cuja companhia viera e com seu pai, Joaquim, demorando o mesmo tempo da ida. Fica a saber que Maria deu à luz sozinha, sem qualquer dor, Isabel com pouca, Ana com menos.

Sob o meu conselho, José levou Maria, sem qualquer aparato, para sua casa. Com temor de Deus, em santidade e justiça, andavam na presença de Deus, entregavam-se continuamente à contemplação e às boas obras. Entretanto, trabalhavam com as próprias mãos e viviam do seu trabalho. Nós, anjos, estávamos assiduamente presentes e servíamos a nossa ínclita Rainha que em seu ventre trazia o Rei.

Por fim, enquanto se completavam os dias de Maria dar à luz, saiu um edito para que todo o mundo se recenseasse. José com Maria e os familiares, Joaquim com muitos outros, subiram até Belém, porque quer José, quer Joaquim eram da

$\leftarrow \mathbf{5 1 2}$ obmutuit] obmutauit $J \mathbf{5 1 3}$ et laetitia. Vnde (...) gaudebunt. Manente Maria] et laetitia. Manente Maria $E \mathbf{5 1 4}$ iuit] fuit $Q \quad \mathbf{5 1 5}$ Hortante itaque me] Hortauit itaque $P \quad \mathbf{5 1 6}$ aderamus] adorebamus $I$, adorauimus $P \mathbf{5 1 7}$ Regem] principem nostrum $E$; Regem nostrum $Q \mathbf{5 1 8}$ uniuersus] totus $N$ 
et de domo Dauid. Et quia multitudo populi confluxerat ${ }^{519}$ et hora tarda erat, remanserunt in diuersorio ciuitatis Bethleem. Et media nocte peperit eo modo prout Virgo Regina reuelauit cuidam mulieri deuotissimae cuius mausoleum est in Sancto Laurentio Panisperna ${ }^{520}$, ubi moniales ordinis tui incorrecte uiuunt. Cui mulieri deuotissimae nomen ${ }^{521}$ erat Brigida de Suetia, quae plurimas reuelationes habere meruit, cuius ordinem pastor uenturus dilatabit. Orauit enim diu ut sibi reuelaretur modus natiuitatis Christi Domini. Et dum accessisset ad ciuitatem Bethleem, uidit Virginem quomodo stabat, quo uultum uertebat, ubi bos et asinus positi erant, quomodo Christus ex utero exiuit, quomodo ipsa eum adorauit et Ioseph similiter. Quae ita fuerunt sicut sibi ${ }^{522}$ reuelatum fuit et in eius libro conscripta sunt, quae non latebunt pastorem a Deo mittendum neque aliae reuelationes eiusdem. Clausa itaque Virgo peperit, clauso eius utero Dominus exiuit, sicut clausis ianuis ad discipulos intrauit. [f1. 97] Maria uero cum laetitia inenarrabili, cum gaudio indicibili, cum exultatione inexcogitabili Dominum peperit. Videndo et intuendo eius diuinitatem simul et humanitatem et adorando, puerulum egressum modo ineffabili adorabat nunc ipsum nominando Filium, nunc Patrem, nunc Natum, nunc Genitorem, facturam et Factorem. Et dum eum adoraret dumque mundissimis et nouis pannis illud mundissimum et nitidissimum corpusculum ipsamet non alius ullus inuolueret, sic Domino psalebat et uirum atque nos angelos inuitabat:

Venite $^{523}$, adoremus eum, quia ipse ${ }^{524}$ est Dominus Deus noster.

Hic est aeternum Verbum quod nunc tempori nostro est subiectum,

Hic ante omnia tempora genitus, hic post multa saecula ${ }^{525}$ gignitur,

Filius est solius ${ }^{526}$ Aeterni Patris, Filius est solius ${ }^{526}$ temporalis matris,

Genitor est creaturarum omnium, genitus nunc in fine multorum temporum, Quo nulla natura est prior, ipse omni natura est posterior.

Qui plasmauit hominem, ipse nunc factus est ab homine,

Venite adoremus eum, quia ipse est Dominus Deus noster.

Qui creauit omnes angelos, ipse factus est annuntiantibus angelis,

Qui angelos et caelos condidit, ipse ministerio eorum indiguit,

Qui calorem creauit et aliis inseruit, ipse nunc a me fouetur et calefit,

Qui omnia complectiur, ipse brachiis meis nunc stringitur,

Quem nullus tangere potuit, ipse oscula mea nunc suscipit,

Qui omnia mouet et portat, hunc porto, eleuo et moueo, ${ }^{527}$

519 confluxerat] confluxerant $E H M 520$ Panisperna] Palisperna $H$; de Panis sperna $J$; de Panispernia IRV 521 mulieri deuotissimae cuius (...) Cui mulieri deuotissimae nomen] mulieri deuotissime nomen $N \mathbf{5 2 2}$ sibi] tibi $H Q \mathbf{5 2 3}$ angelos inuitabat. Venite] angelos inuitabat. Psalmus $\rightarrow$ 
tribo de Judá e da casa de David. E, dado que um grande número de pessoas confluíra ao mesmo tempo e a hora era tardia, descansaram num albergue da cidade de Belém. E pela meia-noite deu à luz do modo que a Virgem Rainha revelou a uma muito devota senhora cujo túmulo se encontra em S. Lourenço de Panisperva, onde monjas da tua Ordem vivem de forma pouco correcta. Chamava-se essa devotíssima senhora Brígida da Suécia, que mereceu receber várias revelações, cuja ordem expandirá o Pastor que está para vir. Na realidade, muito tempo orou para que lhe fosse revelado o modo do nascimento de Cristo Senhor. E enquanto se encaminhavam para a cidade de Belém, viu como estava a Virgem, para onde estava voltada, onde se situavam o boi e o burro, como Cristo saiu do ventre, como a própria Mãe e José o adoravam. Estas coisas aconteceram do modo como lhe foi revelado e estão escritas no seu livro, as quais, assim como outras revelações da mesma, não hão-de ser desconhecidas do Pastor que Deus deve enviar. E, assim, intacta, Maria deu à luz; do seu útero fechado saiu o Senhor, do mesmo modo que, com as portas fechadas, entrou para junto dos discípulos. [f1. 97] E Maria, com incomensurável alegria, com indizível satisfação, com inconcebível exultação, deu à luz o Senhor. Ao ver e ao observar simultaneamente a sua divindade e a sua humanidade e ao adorar o menino nascido de modo inefável, adorava-o chamando-o ora filho, ora pai, ora nascido, ora criador, ora criatura, ora autor. E enquanto o adorava, enquanto envolvia, ela mesma e não qualquer outro, aquele puríssimo e alvíssimo corpinho em limpíssimas e novas faixas, assim cantava ao Senhor e convidava o mundo e a nós anjos:

Vinde, adoremo-lo, porque ele é o Senhor, nosso Deus.

Este é o Verbo Eterno, que agora está sujeito ao nosso tempo.

Este, gerado antes de todos os tempos, é aqui gerado depois de muitos séculos.

É filho só do Eterno Pai, é filho só de Mãe temporal.

Ele, que gerou todas as criaturas, é gerado agora no fim de muitos tempos.

Nenhuma criatura lhe é anterior, ele é posterior a toda a natureza.

Aquele que plasmou o homem, é ele mesmo agora feito pelo homem.

Vinde, adoremo-lo, porque ele é o Senhor, nosso Deus.

Aquele que criou todos os anjos, é ele concebido, tendo os anjos a anunciá-lo.

Aquele que formou os Céus e os anjos, precisou ele do ministério deles,

Aquele que criou o calor e serviu os outros, é ele agora protegido e aquecido por mim,

Aquele que tudo envolve, é ele agora estreitado em meus braços,

Aquele a quem ninguém pôde tocar, recebe agora os meus beijos,

Aquele que tudo move e transporta, transporto-o eu, elevo-o e movo-o.

$\leftarrow$ Mariae nato eius Filio. Venite GI (M in marg. a. $m$.)NO ( $R$ in marg.) $V \mathbf{5 2 4}$ quia ipse] qui $P \mathbf{5 2 5}$ saecula] tempora $O Q \mathbf{5 2 6}$ solius] solus $O V \mathbf{5 2 7}$ hunc porto, eleuo et moueo] ipsum ipsa eleuo et moueo $Q$ 
Venite adoremus eum, quia ipse est Dominus Deus noster.

Qui caelum sicut pellem ${ }^{528}$ extendit, ipse super genua mea extenditur,

Qui caelum et terram pugillo continet, ipse stricta fascia ligatus iacet, ${ }^{529}$

Ille manus quae omnia ambiunt nunc fortiter ligatae existunt,

Per quem omnia aluntur et nutriuntur, ipse paruo lacte pascitur et nutritur,

Quem caeli capere non possunt, inter $\operatorname{arcta}^{530}$ praesepia conditur,

Qui fouet et laetificat omnia, uagit nunc et fouetur ab asino ac boue,

Venite adoremus eum, quia ipse est Dominus Deus noster. ${ }^{531}$

Interim, quia iterum conuenerat ${ }^{532}$ militia $^{533}$ caelestis exercitus, misi ego, Gabriel, angelum ${ }^{534}$ qui Domini natiuitatem nuntiaret pastoribus, sicut et nunc ista annuntio ${ }^{535}$ futuro pastori. Pastoribus praecipue ${ }^{536}$ annuntiata est, quia pastores Ecclesiae Dei secreta scire debent et alios ea docere. Et postquam Maria reposuerat puerum Iesum in praesepio, pastores accesserunt, quorum aduentum Maria praesciuerat. Iccirco psalmum suum continuabat, dicendo: ${ }^{537}$

Bos cognouit possessorem suum et asinus praesepe domini sui, Populus suus eum non cognouit neque ipsum recipiet.

Ecce uenit Deus noster uisitare et redimere plebem suam.

Et intrantibus pastoribus atque quaerentibus praesepium Domini, Ioseph et Maria illud eis ostenderunt. Et uisis signis ab angelo datis, ipsum humiliter adorantes, laudabant et magnificabant Deum. Et quia miserat [f1. 98] eis Saluatorem, gratias agebant et cum laudibus reuersi sunt unde uenerant ${ }^{538}$. Nos autem angeli iterum omnes adorauimus Regem et Reginam et utrique oboedientiam et subiectionem promisimus ${ }^{539}$. Gaudium hoc ingens annuntiauimus ${ }^{540}$, gloria in altissimis ${ }^{541}$ Deo cecinimus, Deum laudauimus, benediximus, adorauimus, glorificauimus, gratias egimus. Alii recesserunt, plures mecum in societate Reginae nostrae remanserunt.

Tres deinde uiri sapientia humana pleni, qui populos orientales regebant, ad

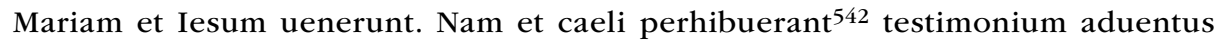

$\mathbf{5 2 8}$ pellem] policem $P \mathbf{5 2 9}$ Qui caelum et terram pugillo continet, ipse stricta fascia ligatus iacet] om. $G \mathbf{5 3 0}$ arcta] arta $M Q \mathbf{5 3 1}$ quia ipse est Dominus Deus noster] et cetera $N \mathbf{5 3 2}$ conuenerat] cecinerat $I R V 533$ militia] multitudo $E \quad 534$ angelum] angelus $R V 535$ annuntio] annuntiatio $J \mathbf{5 3 6}$ nuntiaret pastoribus, (...) Pastoribus praecipue] nuntiaret pastoribus praecipue $E 537$ continuabat dicendo] continuando dicebat $H$; concinebat dicendo $I$; continuabat dicens $V \rightarrow$ 
Vinde, adoremo-lo, porque ele é o Senhor, nosso Deus.

Aquele que estendeu os Céus como uma pele, ${ }^{[110]}$ estende-se ele agora sobre os meus joelhos,

Aquele que Terra e Céus contém na palma da mão, jaze ele envolvido e cingido por uma faixa,

As mãos que tudo envolvem, permanecem agora fortemente atadas,

Aquele por quem tudo é alimentado e mantido, mantém-se ele agora e alimenta-se com um pouco de leite,

Aquele a quem os Céus não podem conter encerra-se agora em estreita manjedoura,

Aquele que tudo acalenta e alegra solta vagidos agora e é aquecido pelo burro e pelo boi.

Vinde, adoremo-lo, porque ele é o Senhor, nosso Deus.

Entretanto, dado que de novo ali convergira a milícia do exército celeste, mandei eu, Gabriel, um anjo que anunciasse aos pastores o nascimento do Senhor, como também agora anuncio ao futuro Pastor estas coisas. Foi anunciado principalmente aos pastores porque os Pastores da Igreja de Deus devem conhecer os segredos e dá-los a conhecer aos outros. E, depois de Maria haver reclinado o menino Jesus no presépio, os pastores, de cuja chegada Maria havia tido prévio conhecimento, aproximaram-se. Por isso, continuava o salmo, dizendo:

O boi conhece o seu dono e o burro, o curral de seu senhor.

O seu povo não o reconheceu e nem o receberá.

Eis que o nosso Deus vem visitar e redimir seu povo.

E enquanto os Pastores entravam e procuravam o presépio do Senhor, José e Maria indicavam-lho. E vendo os sinais dados pelo anjo, enquanto humildemente o adoravam, louvavam e engrandeciam a Deus. E, porque lhes havia enviado [fl. 98] o Salvador, davam graças e, com cânticos de louvor, voltaram ao lugar de onde tinham vindo. Quanto a nós anjos, todos adorámos de novo o Rei e a Rainha e a cada um prometemos obediência e submissão. Anunciámos esta grande alegria, cantámos glória a Deus nas alturas, louvámos a Deus, bendissemos, adorámos, glorificámos, demos graças. Uns retiraram-se, muitos ficaram comigo na companhia da nossa Rainha.

De seguida, três sábios em conhecimento humano, que governavam povos orientais, vieram ao encontro de Maria e de Jesus. Na verdade, os Céus haviam

$\leftarrow \mathbf{5 3 8}$ uenerant] uenerunt $J M Q V 539$ promisimus] submisimus $Q \mathbf{5 4 0}$ annuntiauimus] annuntiamus $V 541$ altissimis] caelis $Q \mathbf{5 4 2}$ perhibuerant] perhibuerunt GHIR 
tanti Regis, et in caelis scripta erat maximi et diuini Prophetae natiuitas. Et ut iudeos cum gentilibus coniungeret, Deus ipsa die natiuitatis stellam creauit nouam, quam Magi uidentes, aperte intellexerunt Regem illum quem nasciturum sciebant esse natum. Nam et prophetiam de hoc acceperant. Sed haec apud uos iam scripta sunt et de ipsorum adoratione, ideo praetermitto. Similiter et de Domini circumcisione. Quando magi adorauerunt Dominum, fuerunt interius ab ipso instructi atque in his quae ipsis necessaria erant edocti.

Quare Herodes et quomodo timuit nec tamen subito pueros ${ }^{543}$ occidit, apud uos scriptum reperitur ${ }^{544}$.

Mansit Maria cum Ioseph ibi usque ad dies quadraginta. Propinqui Ioachim reuersi sunt in Nazareth. Et ut legem implerent, impletis diebus purgationis Mariae, ascenderunt in Ierusalem, ut Lucas scripsit. Audiuit Herodes ea quae dicebantur et cogitabat, dicens: "Hic est Rex ille quem magi quaerebant". Multa enim de illo a Simeone et Anna prophetissa praedicabantur. Et tunc uoluit ${ }^{545}$ facere edictum de nece puerorum.

Ioseph cum Maria fugerunt in Aegyptum et multa mirabilia in illo itinere fecit puer Iesus, quorum quaedam etiam apud uos scripta sunt, ut de arbore ${ }^{546}$ cuius fructus Maria colligere uolens se ei $^{547}$ inclinante, et de puerulo quodam leproso qui, mox ut lotus fuit in lotura pueri Iesu, sanus factus est, deinde factus est latro et crassator et, captus ac cum Domino crucifixus, in ipsum credidit audireque meruit: Hodie mecum eris in paradiso. Similiter ubicumque per Aegyptum transibat ${ }^{548}$ idola Aegypti cadebant.

Scito et animaduerte puerum Iesum a principio suae conceptionis omnia genera et species et uarietates linguarum sciuisse nec in cognitione ${ }^{549}$ umquam a carne uel sensu impeditum fuisse. Vnde semper loqui poterat et aliquando cum matre sola loquebatur, sed coram aliis primo anno numquam locutus est. Secundo anno etiam coram Ioseph et cum ipso loqui coepit. Tertio anno coram omnibus, non sine admiratione omnium, loquebatur expedite.

Manente Iesu et Maria et Ioseph in Aegypto et Herode mortuo, misi angelum qui moneret Ioseph ut rediret ad patriam suam, quia mortui erant qui quaerebant animam pueri. Non enim Ioseph assidue uidebat angelos sicut Maria, sed saepius in somnis angeli apparebant ei. 550

Habitauit ergo Iesus in Nazareth cum Ioseph, qui putabatur pater suus, et Maria uera matre ${ }^{551}$ eius. Docebant ignaros, consolabantur maestos et afflictos,

543 pueros] paruulos IRV 544 Quare Herodes et quomodo timuit nec tamen subito pueros occidit, apud uos scriptum reperitur.] om. $E 545$ tunc uoluit] tamen uoluit $I$; tamen noluit $R V$ 546 puer Iesus, quorum quaedam etiam apud uos scripta sunt, ut de arbore] puer Iesus, ut de arbore $E 547$ se ei] se sibi $H N O$; se $E Q$; sese $I R V 548$ transibat] transibant $E I R V 549$ cognitione] $\rightarrow$ 
dado testemunho da chegada de tão grande Rei, e neles estava escrito o nascimento do Supremo e Divino Profeta. E, para congregar judeus com gentios, Deus criou, no próprio dia do nascimento, uma nova estrela que, ao vê-la, os Magos compreenderam claramente que havia nascido o Rei que sabiam estar para nascer. Com efeito, haviam recebido também a profecia relativa a este assunto. Mas estas coisas, assim como o que se relaciona com a adoração deles, acham-se já entre vós escritas, por isso passo à frente. E o mesmo sobre a circuncisão do Senhor. Quando os Magos adoraram o Senhor, foram por ele intimamente instruídos e profundamente ensinados sobre o que lhes era necessário.

O porquê e o como Herodes se atemorizou e nem por isso matou de imediato as crianças, acha-se entre vós escrito.

Maria ficou aí com José até ao quadragésimo dia. Os familiares de Joaquim regressaram a Nazaré. E, para darem cumprimento à Lei, passados os dias da purificação de Maria, subiram a Jerusalém, como escreve Lucas. Herodes tomou conhecimento do que se dizia e pensava, dizendo: É este o Rei que os Magos procuravam. Muita coisa era sobre ele anunciada por Simeão e pela profetisa Ana. Fez então publicar um edito relativo ao extermínio das crianças.

José fugiu para o Egipto com Maria e, no caminho, o Menino Jesus fez muita coisa digna de admiração, algumas das quais se acham entre vós escritas, como a da árvore que se inclinou para Maria quando quis colher-lhe os frutos, e a de um rapaz leproso que, logo que se lavou na água do banho do Menino Jesus, ficou curado, depois tornou-se ladrão e criminoso e, sendo preso e crucificado com o Senhor, acreditou nele e mereceu ouvir: Hoje estarás comigo no Paraíso. Do mesmo modo, em todo o lugar por onde passava, através do Egipto, os ídolos egípcios tombavam. ${ }^{[11]}$

Fica a saber e presta atenção a que o Menino Jesus, desde o início de sua concepção, conhecia todos os géneros e espécies e variedades de línguas e nunca o conhecimento lhe foi vedado pela carne e pelos sentidos. Daí poder sempre falar e, por vezes, falava só com a mãe, mas no primeiro ano nunca falou na presença de estranhos. No segundo, começou a falar diante de José e com ele mesmo. No terceiro, falava expeditamente diante de todos, não sem admiração deles.

Tendo morrido Herodes enquanto Jesus, Maria e José se mantinham no Egipto, enviei um anjo a avisar José que voltasse à sua terra porque tinham morrido os que procuravam a vida do Menino. José não via os anjos assiduamente como Maria, mas muitas vezes estes apareciam-lhe em sonhos.

Jesus viveu, pois, em Nazaré com José, que era tido por seu pai, e com Maria, sua mãe verdadeira. Ensinavam os ignorantes, consolavam os tristes e os aflitos,

$\leftarrow$ cogitatione $Q \mathbf{5 5 0}$ Non enim Ioseph assidue uidebat angelos sicut Maria, sed saepius in somnis angeli apparebant ei.] om. $E \mathbf{5 5 1}$ matre] mater $I Q R$

[111] Apócrifos da Infância. 
compatiebantur animo et corpore infirmis et saepius, [f1. 99] orando uel tangendo, curabat infirmos et pauperibus succurrebat clanculum ita quod nescibant unde illi sanarentur uel hi triticum aut uinum aut oleum haberent ${ }^{552}$, quia in eius potestate erat posita omnis creatura. Poterat solo uerbo, quia ipse uerum est Verbum, facere omnia. Et, quamuis pauper esset, nemo tamen ipso ditior erat, quia omnes mundi thesauri erant in potestate eius. Volebat tamen et famem pati et sitim ipse et labores corporis sufferre ut pro uobis mereretur et satisfaceret. Vnde orationi et contemplationi iugiter insistebat et uacabat ut thesaurum immensum uobis hominibus congregaret.

Crede mihi, carissime, quod si per mille milia annos ${ }^{55}$ mundus duraret, numquam merita Christi Hominis euacuari possent. Tantum enim ualent opera uestra quantum ${ }^{554}$ a Deo acceptantur. Tanto autem magis acceptantur quanto a persona magis dilecta offeruntur. Vnde minimum bonum opus illius pueri illiusque hominis gratius erat maximis operationibus aliorum quorumcumque. Istis meritis multas mansiones in domo Patris sui hominibus praeparauit. Ipse esuriebat ut uos comederetis, sitiebat ut biberetis, laborabat ut quiesceretis, uigilabat ut dormiretis, contemplabatur ut Deum et uos uideretis. Quot merita fuerunt Mariae matris suae? Plurima certe. Multum et Ioseph meruit. Puerulus tamen Iesus, ipse esuriens et sitiens, compatiebatur matri, compatiebatur et nutricio suo et praeueniebat eos sui gratia ne esurirent aut sitirent, satiando 555 eos absque cibo corporali, modo sibi noto. Et saepius cibum eis ministerio fratrum meorum ${ }^{556}$ angelorum afferri praecipiebat. Et quandoque ${ }^{557}$ illa quae sciebat eos uelle uel cupere adesse faciebat. Et quando ascendebant in Ierusalem et ipsis et omnibus propinquis, Ioseph et Ioachim atque Annae consanguineis plurima praestabat solacia et consolationes ita ut quasi laborem itineris non sentirent. Quandoque Maria ipsum puerulum in ulnis tenendo et grandioris aetatis factum inspiciebat ${ }^{558}$ in sinu suo uel iuxta eam sedentem, et manus eius pulcherimas ac pedes et totum corpusculum inspiciens, plorabat cogitando illos dolores quos in membris illis sentire tempore passionis debebat et uehementer dolebat, flebat, tristabatur. Dicebatque secum in corde suo: "Has manus et hos pedes duri claui perforabunt. Hoc latus lancea ${ }^{559}$ transfixum erit. Hoc caput atrocissimis ${ }^{560}$ spinis pungetur." Tunc Iesus, cognoscens dolorem Genitricis suae, consolabatur eam et quandoque sibi diuinitatem suam ${ }^{561}$ ostendebat ad hoc ut omnis dolor omnisque poena cessaret et gaudium immensum in cor eius ascenderet. Ingerebatque ${ }^{562}$ menti gloriam corporis futuram post resurrectionem. Et ita Mariae cor laetitia et gaudio implebatur. ${ }^{563}$

$\mathbf{5 5 2}$ haberent] ipsis adueniret $E \mathbf{5 5 3}$ annos] annorum $E \mathbf{5 5 4}$ ualent opera uestra quantum] ualent opera nostra quantum $I R$; ualent quantum $Q \mathbf{5 5 5}$ nutricio suo et praeueniebat eos sui gratia ne esurirent aut sitirent, satiando] nutricio suo, satiando $Q \mathbf{5 5 6}$ fratrum meorum] fumentorum $Q \mathbf{5 5 7}$ quandoque] quamque miraculose $Q$; quandoque miraculose $H I R V \mathbf{5 5 8}$ inspiciebat] inspiciendo $H I O Q R V 559$ lancea] lance $I$; lancee $R V 560$ atrocissimis] acutissimis $Q \quad 561$ diuinitatem suam] $\rightarrow$ 
compadeciam-se dos doentes de espírito e do corpo e, muitas vezes, [f1. 99] curava os enfermos orando e tocando-lhes, e socorria os pobres às escondidas, de modo que não sabiam aqueles de onde lhes vinha a cura, ou estes como obtinham o trigo ou o vinho ou o azeite, porque toda a criatura dependia do poder dele. Podia tudo fazer com uma só palavra, porque ele é o Verbo verdadeiro. E, embora fosse pobre, ninguém, contudo, era mais rico do que ele, porque todos os tesouros do mundo lhe pertenciam. Queria, na verdade, sofrer ele mesmo a fome e a sede e suportar as fadigas corporais para merecer e satisfazer por vós. Por isso insistia e se entregava permanentemente à oração e à contemplação para acumular para vós homens um imenso tesouro.

Crê em mim, meu caro, que, se o mundo durasse por mil milhares de anos, nunca os méritos de Cristo Homem poderiam esgotar-se. As vossas obras valem tanto quanto são por Deus aceites. São tanto mais aceites quanto são realizadas pela pessoa mais querida. Daí que a mais pequena obra daquela criança e daquele homem fosse mais grata do que as maiores acções de quaisquer outros. Com estes méritos preparou para o homem, na Casa de seu Pai, muitas moradas. Passava ele fome para vós comerdes, sofria a sede para beberdes, trabalhava para descansardes, velava para poderdes dormir, contemplava para vós verdes a Deus. Quantos foram os merecimentos de Maria, sua Mãe? Muitos, certamente. Também José mereceu muito. Todavia, o Menino Jesus, tendo ele fome e sede, compadecia-se da mãe, compadecia-se também daquele que o criava e socorria-os com a sua graça para não terem fome ou sede, matando-lhes a fome sem alimento corporal, pelo modo que ele sabia. E muitas vezes ordenava que lhes fosse levado alimento pelos anjos meus irmãos. $E$ às vezes fazia aparecer aquilo que sabia que eles queriam ou desejavam. E quando subiam a Jerusalém, prestava-lhes a eles e a todos os parentes, aos irmãos de José, de Joaquim e de Ana, todas as ajudas e confortos, de tal modo que quase não sentiam a dificuldade do caminho. Por vezes Maria, segurando-o nos braços criança ainda, e olhando-o, já crescido, em seu colo ou sentado junto de si, e observando suas belas mãos e pés e todo o pequeno corpo, chorava ao pensar nas dores que na altura da Paixão deveria sentir naqueles membros, e sofria dolorosamente, chorava, afligia-se. Dizia consigo, em seu coração: "Duros cravos hão-de perfurar estas mãos e estes pés. Este lado será trespassado pela lança. Esta cabeça vai ser pungida com crudelíssimos espinhos.” Jesus, então, ao aperceber-se da dor de sua Mãe, confortava-a e, por vezes, manifestava-lhe a sua divindade para que toda a dor e toda a pena cessassem e o seu coração fosse inundado de imenso gozo. Suscitava em seu espírito a glória futura do corpo depois da Ressurreição. E, assim, o coração de Maria enchia-se de alegria e gozo.

$\leftarrow$ humanitatem $Q 562$ Ingerebatque] Ingrediebatque $J 563$ Quandoque Maria ipsum puerulum in ulnis tenendo ... Et ita Mariae cor laetitia et gaudio implebatur] Non tamen inconsulte ac si morem puerorum, tamquam puer, pueritia ageret. Nam $E$ 
In tota pueritia sua nil puerile gessit, quia erat perfectus homo. Et si quando cum pueris ${ }^{564}$ conuersaretur $^{565}$, in illa conuersatione uirilem maturitatem ${ }^{566}$ praetendebat $^{567}$. Nullae [fl. 100] fatuitates aut puerilles stultitiae erant in eo. Immo in omni actione sua merebatur ${ }^{568}$, omnem actionem debitis circumstantiis ornabat et in Deum dirigebat et prout puerum decet dum puer esset, et sicut infantulum dum infans esset, et sicut non natum antequam natus esset. Neque enim in utero Mariae frustra stetit ${ }^{569}$ quia a primo instanti conceptionis mereri coepit. Et dum erat adolescens et iuuenis, ea quae decet ${ }^{570}$ adolescentem et iuuenem exercebat. Vnde et matri et nutricio ${ }^{571}$ oboediebat et eis coram aliis reuerentiam exhibebat, immo etiam in secreto. Sed in secreto et ipsi eum reuerebantur, praesertim Maria quae diuinitatem eius totiens uiderat ${ }^{572}$.

Cum autem factus esset Iesus annorum duodecim, ut Lucas scribit, tunc in ciuitate Ierusalem uoluit ostendere coram uiris doctrinam quam a Deo acceperat, ut facilius crederent in eum. Intrauit igitur cum magna grauitate et maturitate inter doctores, qui intuebantur in faciem eius tamquam in faciem angeli eique locum in medio dederunt, Dei nutu quadam reuerentia erga ipsum moti. Intrando enim dixerat eis 573 : "Pax uobis, diuinae legis eruditi principes. Vellem uos audire atque interrogare." Quae uerba commouerunt eos et aspectus simul.

Sedens ergo Iesus, ita loqui coepit: Magnus Deus noster et magna uirtus eius, sapientiae eius non est numerus neque magnitudinis finis. Deus Viuus et Verus non solum est Deus noster, sed omnium hominum, omnium angelorum, immo omnis creaturae. Dictus tamen est Deus noster quia nos sumus pecculiaris populus eius. Nostris patribus ${ }^{574}$ locutus est ipsisque legem dedit. Heber, a quo Hebraei dicimur, fuit ille ex quo Abraam descendit, ut uobis notum est. Abraam autem tantum familiaris fuit Deo ut amicus Dei appellari mereretur, cui Deus propter perfectam oboedientiam, quia etiam filio proprio nolebat parcere quin eum iussu Dei occideret, promisit in semine suo benedicere omnes nationes, quia enim ille filium unicum Dei mandato occidere non renuit. Quo facto, se paternitate tanti filii qualis Isaac fuit spoliabat. Iccirco Deus dixit: Quia non pepercisti unigenito filio tuo propter me, benedicens benedicam tibi et unicum Filium meum tibi donabo ut sis pater eius et multiplicabo semen tuum per ipsum unicum Filium meum, qui et tuus erit secundum carnem, sicut stellas caeli et sicut arenam quae est in litore maris, quia nullus saluabitur nisi medio illius Filii tui et meritis eius.

564 pueris] puerilis $P 565$ conuersaretur] conuersabatur $Q \quad 566$ maturitatem] grauitatem $E 567$ praetendebat] ostendebat $Q \mathbf{5 6 8}$ merebatur] morebatur $V 569$ Neque enim in utero Mariae frustra stetit] Neque enim in utero stetit, frustra stetit $V \mathbf{5 7 0}$ decet] decent EHIPR $\mathbf{5 7 1}$ Vnde et matri et nutricio] Vnde aeternim nutricio $R I \mathbf{5 7 2}$ totiens uiderat.] totiens uiderat. Quod dixit Iesus in medio doctorum $E$ (in marg.); totiens uiderat. Prima disputatio Jesus in Templo $R$ (in marg.) 573 dixerat eis] dixerat $N$; dederat eis pacem dicens $Q$; dixit eis $V \mathbf{5 7 4}$ patribus] temporibus $R$; tribubus $V$ 
Em toda a sua infância nada fez de pueril, porque era homem perfeito. E, se às vezes convivia com crianças, nessa convivência mostrava maturidade de homem. Não havia nele [f1. 100] frivolidade ou insensatez juvenis. ${ }^{[112]}$ Pelo contrário, em todo o seu agir havia merecimento, porque rodeava toda a sua acção das devidas circunstâncias e dirigia-a para Deus, não só como convém a um jovem enquanto jovem, mas também a uma criança enquanto é criança, e a um não nascido antes de nascer. Na verdade, nem no útero de Maria permaneceu em vão, porque começou a merecer desde o primeiro instante da sua concepção. $E$ enquanto era adolescente e jovem fazia o que fica bem a um adolescente e a um jovem. Daí, obedecer à Mãe e ao preceptor e manifestar-lhes reverência em público e também em particular. Mas, em segredo, também eles o reverenciavam, sobretudo Maria, que muitas vezes tinha visto a sua divindade.

Mas quando Jesus completou doze anos, como escreve Lucas, quis então mostrar diante dos homens, na cidade de Jerusalém, a doutrina que havia recebido de Deus, para que mais facilmente acreditassem nele. Entrou, pois, com grande gravidade e dignidade para junto dos doutores, que olhavam a sua face como a face de um anjo e lhe cederam um lugar no meio, tocados por instigação divina de uma certa reverência para com ele. Ao entrar, tinha-lhes dito: "Que a paz esteja convosco, príncipes versados na Lei Divina. Gostaria de vos ouvir e de vos interrogar." Estas palavras e a sua figura comoveram-nos.

Jesus, sentando-se, assim começou a falar: É grande o nosso Deus e grande é o seu poder, a sua sabedoria não tem limites, nem a sua grandeza tem fim. ${ }^{[113]}$ O Deus Vivo e Verdadeiro não é só nosso Deus, mas de todos os homens, de todos os anjos, e mesmo, de todas as criaturas. É, contudo, chamado nosso Deus porque nós somos o seu povo particular. Falou aos nossos pais e deu-lhes a Lei. Héber, em razão do qual nos chamamos Hebreus, foi aquele de quem descendeu Abraão, como sabeis. Abraão foi a tal ponto íntimo de Deus que mereceu ser chamado amigo de Deus. A ele, por causa da sua obediência perfeita, uma vez que não queria poupar o próprio filho, sacrificando-o por ordem de Deus, prometeu Deus abençoar na sua descendência todas as nações porque, na verdade, ele não recusou sacrificar seu filho único à ordem de Deus. A concretizar-se isto, privava-se da paternidade de filho tão importante como foi Isaac. Por isso, disse Deus: Porque me não recusaste o teu filbo único, bei-de abençoar-te e hei-de dar-te o meu Filho Único para seres seu pai, e bei-de multiplicar a tua descendência por meio do meu Filho Único, que será também teu, segundo a carne, como as estrelas do Céu e como a areia da praia, ${ }^{[114]}$ porque nenhum se salvará senão por intermédio deste Filho e de seus méritos.

[112] Referência crítica aos Apócrifos da Infância.

[113] S1 146:5.

[114] Gn 22:16,17. 
Adeo amauit Deus patres nostros quod uoluit ${ }^{575}$ uocari Deus Abraam, Isaac et Iacob. Ex hoc tertio ${ }^{576}$ descendit tota gens et natio nostra in duodecim tribus diuisa. Elegit post Iacob, Ioseph, Moysen et Aaron et posuit in eis signa et prodigia sua. Multi secuti sunt eos usque ad Samuel et Dauid, cui etiam pollicitus est dare filium qui esset Filius Dauid et Filius Dei. Suscitauit Deus in populo nostro tot prophetas: Isaiam, Ieremiam, Ezechielem, Danielem et alios multos, sed duodecim nominatos. Hac ergo causa noster Deus dictus, quia non fecit taliter omni nationi, hoc est, nulli nationi taliter fecit, talem gratiam praestitit, talia dona concessit.[f1. 101] Vnde sequitur et iudicia sua uidelicet legem suam et uoluntatem suam non eo modo manifestauit eis. Ipsis enim legem scripsit in cordibus propriis. Nobis autem aperte locutus est Deus et multa quae non sunt scripta in cordibus nostris reuelauit. Vere itaque noster dici potest.

Verum quare potius noster quam angelorum? Hoc magnam ingerit difficultatem ${ }^{577}$. Angeli enim sunt filii eius similiores sibi et natura propinquiores. Hic magnum mysterium est, hic admirabile sacramentum, ignotum etiam legis doctoribus, notum prophetis et patriarchis. Hic nodus non potest solui, nisi concedamus homini maiora et ampliora dona Deum concessisse quam angelis.

Audistis et legistis Messiam quem expectatis uenturum. Ille homo est et Deus est, quem uirgo concepit et peperit, et eius nomen est Emmanuel, nobiscum, inquam, Deus. Deus in carne nostra, Deus in humanitate nostra, Deus et homo est. Paruulus enim natus est nobis et filius datus est nobis. Vocabitur nomen eius tetragramaton. Hoc angelis non fuit concessum, nullus angelus est Deus. Homo uero est Deus et Deus homo. Noster ergo magis quam angelorum. Et quia omnia opera Dei magna sunt, hoc tamen maximum est, et hoc iam fecit Deus. Magnus ergo Deus et noster est Deus, magna uirtus eius, uirtutis enim uirgam misit ex Sion, dominabitur in medio inimicorum suorum, uirtutem populo suo iam dedit. Virtus autem Dei Deus ipse est. Sed quomodo haec possunt fieri? Sapientia Dei Deus est. Ipse nouit quomodo uirtus sua et sapientia sua facere potuerit ut uirtus et sapientia Dei facta sit homo. Sapientiae eius non est numerus, non est mensura neque magnitidinis eius est ullus finis. Nemo enim dicere potest "Hanc perfectionem habet Deus" uel "Has perfectiones tantum habet Deus" 578 , in quo omnium rerum quae sunt, fuerunt et erunt perfectio continetur. Maiestas eius aeterna est, principio et fine carens et omnia praesentia simul totaliter habens. Nunc quaero ex uobis an putatis Messiam in Lege et Prophetis promissum ${ }^{579}$ uenisse?

$\mathbf{5 7 5}$ uoluit] uoluerit HIRV $\mathbf{5 7 6}$ tertio] terno $Q \mathbf{5 7 7}$ difficultatem] differentiam $P \mathbf{5 7 8}$ uel "Has perfectiones tantum habet Deus"] om. $N$; add. $O$ (in marg. a. m.) $\mathbf{5 7 9}$ in Lege et Prophetis promissum ] in Lege Prophetis uobis promissum IRV 
A tal ponto amou Deus os nossos pais que quis ser chamado Deus de Abraão, de Isaac e de Jacob. Deste terceiro descende todo o nosso povo e toda a nossa raça, repartida em doze tribos. Depois de Jacob escolheu José, Moisés e Aarão e neles depositou seus sinais e prodígios. Muitos se seguiram a eles até Samuel e David, a quem prometeu também dar um filho que fosse filho de David e filho de Deus. Em nosso povo suscitou Deus tantos profetas: Isaías, Jeremias, Ezequiel, Daniel e muitos outros, mas chamados os doze! Por isso, pois, se chama nosso Deus, porque com nenhum outro povo ele agiu assim, ${ }^{[115]}$ isto é, a nenhuma nação fez o mesmo, facultou tão grande graça, concedeu tão grandes dons. [f1.101] Daí seguir-se: E não lhes manifestou deste modo os seus juízos, ou seja, a sua Lei e a sua vontade. A eles, na verdade, inscreveu-lhes a lei nos próprios corações. Mas a nós falou-nos Deus claramente e revelou-nos muita coisa que não está escrita em nossos corações. Portanto, pode verdadeiramente chamar-se nosso.

Mas porquê mais nosso que dos anjos? Levanta isto uma grande dificuldade. $\mathrm{Na}$ verdade, os anjos são seus filhos, mais semelhantes a si e mais próximos em razão da natureza. É este um grande mistério, este um admirável sacramento, desconhecido ainda dos doutores da Lei, conhecido dos profetas e patriarcas. Este nó não pode desatar-se se não concedermos que Deus deu ao homem maiores e mais abundantes dons que aos anjos.

Ouvistes dizer e acreditastes que está para vir o Messias que esperais. É homem e é Deus aquele a quem a virgem concebeu e deu à luz, e o seu nome é Emanuel, quer dizer, Deus connosco, Deus na nossa carne, Deus na nossa humanidade, é Deus e homem. Nasceu-nos um menino e foi-nos dado um filbo. ${ }^{[116]} \mathrm{O}$ seu nome será Tetragrama. Isto não foi concedido aos anjos, nenhum anjo é Deus. Mas o homem é Deus e Deus é homem. Por isso, mais nosso que dos anjos. E, sendo grandes todas as obras de Deus, esta é a maior. E isto já Deus o realizou. Por isso, grande é Deus, e é o nosso Deus, grande é o seu poder, enviou de Sião a vara do poder, dominará no meio de seus inimigos, entregou já ao seu povo o poder. Mas o poder de Deus é o próprio Deus. Como pode isto acontecer? A sabedoria de Deus é Deus. Ele mesmo sabe como a sua força e a sua sabedoria poderão fazer que a força e a sabedoria de Deus se tornem Homem. Não há limites, não há medida para a sua sabedoria e nem fim algum para a sua grandeza. Ninguém, na verdade, pode dizer "Deus tem esta perfeição" ou "Deus tem apenas estas perfeições", ele em quem se contém a perfeição das coisas que existem, existiram ou existirão. A sua grandeza é eterna, sem princípio nem fim, e tem em si, de modo absoluto, todo o presente em simultâneo. Pergunto-vos agora se julgais que chegou o Messias prometido na Lei e nos Profetas.

[115] S1 147:9.

[116] Is 9:6, 
Vnus doctorum respondit: Quis es tu, o formose, sapientissime atque diuine puer, qui tam miranda loqueris? Deinde ad tuam interrogationem respondebimus.

Respondit Iesus: Quis ego $\operatorname{sim}^{580}$ facile scietis si ad illud quod inquiro respondere sciueritis.

Tunc unus eorum dixit: Credimus eum cito uenturum, quia secundum statuam regis Nabucdonosor iam aduenit quartum regnum quod habet iam plantas pedum fictiles. Sed lapis nondum est abscissus de monte sine manibus qui est percussurus statuam in pedibus fictilibus et corruet. Et lapis ille erit mons magnus quia, ut Daniel dicit, In diebus regnorum illorum, hoc est, quarti regni (primum enim ${ }^{581}$ fuit Assyriorum, secundum Persarum et Medorum, tertium Macedonum et Graecorum, quartum Romanorum) suscitabit Deus Caeli sibi regnum quod in aeternum manebit et regnum eius alteri populo non tradetur. Quando ergo uidebimus lapidem de monte abscindi sine manibus, tunc erit signum aduentus nostri Messiae.

Tunc sapientissimus puer dixit: Tu intelligis de lapide re insensibili. Propheta ille non ita intelligit. Sed lapis ille est ipse Messias, ipse enim per lapidem figuratur. [f1. 102] Vnde alibi scribitur: Lapidem quem reprobauerunt aedificantes, bic factus est in caput anguli.

Dixit doctor: Immo de lapide ad litteram intelligitur qui de monte abscindetur sine manibus, nam homines non abscinduntur de monte.

Respondit Iesus: Spiritus est qui uiuificat. Oportet intelligentiam esse in uisione. Mons ille de quo abscindetur ${ }^{582}$ lapis, immo abscisus est, mons est altus, sublimis, excelsus, diuinus, immaculatus. Genitrix Messiae est uirgo, iuxta uaticinium Isaiae prophetae. Quia ergo diuina uirtute concepit et peperit sine operatione uirili, ideo sine manibus abscisus dicitur.

Tunc doctor dixit: Si abscisus esset et iam, ut ais, uenisset Propheta Magnus, iam percussisset statuam, quia dicit: "abscisus est et percussit".

Respondit Iesus: Abscisus est et percutiet tempore suo. Non dicit propheta quod statim ut abscissus fuerit percutiet ${ }^{583}$.

Alius doctor dixit: Si iam uenisset Messias, domus ista et Templum hoc in quo sumus repletum esset gloria. Ita enim scribit Aggaeus propheta: Adbuc unum modicum, dicit Dominus, et ego mouebo caelum et terram, mare et aridam. Et ueniet dies desideratus cunctis gentibus et replebitur gloria domus Domini. Et sequitur: Magna erit gloria domus istius nouissimae plus quam primae. Haec propheta $^{584}$. Hanc gloriam ${ }^{585}$ nondum uidimus.

Dixit tunc Iesus: Quomodo ergo uera erit prophetia Iacob patris quando, benedicendo Iudae, dixit: Non auferetur sceptrum de Iuda nec dux de femore eius

$\mathbf{5 8 0}$ Quis ego sim] Quis ego sum $H P R$; $E$ go sum qui sum $V \mathbf{5 8 1}$ enim] regnum $N$; eius $P \mathbf{5 8 2}$ abscindetur] abscidetur $I R$; abscinditur $Q \mathbf{5 8 3}$ et percutiet tempore (...) fuerit percutiet] percutiet. $H 584$ Haec propheta.] Huius prophetae $I R$; Nec prophetiam $O$; Prophetia huius prophetae $V$ 585 Haec propheta. Hanc gloriam] Nec prophetiam nec gloriam $O$ 
Quem és tu, belo, sapientíssimo e divino jovem que dizes tão admiráveis coisas, respondeu-lhe um dos doutores? Depois, responderemos à tua interrogação.

Quem eu sou sabê-lo-eis facilmente, respondeu Jesus, se souberdes responder ao que vos pergunto.

Acreditamos que virá em breve, disse um deles, porque, segundo a estátua de Nabucodonosor, chegou já o quarto reino que tem já os pés de barro. Mas ainda se não desprendeu do monte sem acção de mãos a pedra que há-de atingir a estátua nos pés de barro e ela destruir-se-á. E a pedra será aquele grande Monte porque, como diz Daniel: Nos dias desses reinos, isto é, do quarto reino (na verdade, o primeiro foi o dos Assírios, o segundo o dos Persas e dos Medos, o terceiro o dos Macedónios e dos Gregos, o quarto o dos Romanos), o Deus do Céu suscitará para si um reino que jamais será destruído, reino que não será entregue a outro povo. ${ }^{[117]}$ Quando, pois, virmos a pedra desprender-se do monte sem acção de mãos, será então o sinal do advento do nosso Messias.

Tu, disse então o sapientíssimo jovem, entendes a pedra como algo insensível. O profeta não entende assim, mas essa pedra é o próprio Messias. Ele, de facto, é figurado pela pedra. [f1.102] Daí escrever-se em outro lugar: A pedra rejeitada pelos construtores tornou-se a pedra angular. ${ }^{[118]}$

Pelo contrário, disse o doutor, entende-se à letra a pedra que se há-de desprender do monte sem acção de mãos, pois os homens não se desprendem do monte.

É o espírito que vivifica, respondeu Jesus. Convém que na visão haja compreensão. O monte de que se desprenderá a pedra, ou melhor, já se despendeu, é um monte alto, sublime, excelso, divino, imaculado. A Mãe do Messias é virgem, segundo o testemunho do profeta Isaías, porque concebeu pelo poder divino e deu à luz sem a intervenção de homem. Por isso se diz desprendido sem mãos.

Se se tivesse desprendido, disse então o doutor, e já tivesse vindo, como dizes, o grande Profeta, já teria atingido a estátua, porque diz: desprendeu-se e atingiu.

Desprendeu-se, respondeu Jesus, e atingirá a seu tempo. O profeta não diz que atingirá logo que se haja desprendido.

Se o Messias tivesse já vindo, disse outro doutor, esta Casa e este Templo em que nos encontramos estariam cheios de glória. Pois assim escreve o profeta Ageu: Ainda um pouco, diz o Senhor, e eu abalarei o céu e a terra, os mares e os continentes, e chegará o dia desejado por todos os povos, e a casa do Senbor encher-se-á de glória. E segue-se: A glória deste último Templo será maior que a do primeiro. ${ }^{[119]}$ Isto diz o profeta. Esta glória ainda a não vimos.

Portanto, como será verdadeira, disse então Jesus, a profecia do nosso pai Jacob quando, ao abençoar Judá, disse: O ceptro não será tirado a Judá, nem a

[117] Dn 2:44

[118] S1 117:22; Mt 21:42; Mc 12:19; Lc 20:17.

[119] Ag 2:7,10 
donec ueniat Messias. Et ipse erit exspectatio gentium? Sceptrum a domo nostra ablatum est iam sunt circiter quadraginta anni. Nonne Daniel per septuaginta hebdomadas aperte descripsit tempus et aduentum Christi ducis et multa mala uentura super ciuitatem istam et Templum? Amen, amen dico uobis, non relinquetur lapis super lapidem hic propter obstinationem gentis nostrae ${ }^{586}$.

Stupebant quidem omnes in responsis eius et in ampla et aperta doctrina eius $^{587}$. Dicebant "Quomodo litteras scit cum non didicerit?" uel "Vbi didicit eas?"

Alter dixit: Si centum annis studuisset, numquam tanta discere potuisset ${ }^{588}$. Res diuina est, opus Dei est istud.

Et quia hora tarda erat, cum stupore et quadam extasi recesserunt in propria. Et multi eorum inter se dicebant: "Forsan ipse est Messias". Et diligenter inquirebant cuius esset, id est, de qua stirpe et generatione ${ }^{589}$. Et inuenerunt quod erat a Nazareth, filius Ioseph et Mariae et nomen eius fuit dictum quod erat Iesus.

Tunc aliqui dixerunt: Nomen illius non ita debet uocari. Alii quod ita. Et distulerunt in diem sequentem.

Secunda ergo die conuenerunt doctores in locum consuetum. Et quia Maria et Ioseph abscesserant, Iesus illa nocte, ut faceret uoluntatem Patris Aeterni, remansit apud sacerdotes Templi, qui Mariam uenerabantur et putabant Iesum esse Messiam. Sequenti die conuenerunt, ut dixi, doctores ut audirent melliflua uerba illius sancti pueri Iesu.

Sed unus dicebat: Nomen Messiae debet ${ }^{590}$ uocari Emmanuel uel Admirabilis uel Consiliarius uel, comprehendendo omnia unico uocabulo591, Angelus Magni Consilii.

Alius dicebat Messiam nasciturum ${ }^{592}$ in [f1. 103] Bethleem non in Nazareth.

Tertius: Messias quando ${ }^{593}$ ueniet nemo sciet.

Quartus: Messias non habebit patrem, nam uirgo eum concipiet.

Quintus: Tempore Messiae animalia siluestria et ferae mansueta et domestica efficientur.

Sextus dixit: Messias ponet montem domus Domini in uertice aliorum montium. Si iste hoc fecerit, ipse est.

Septimus dixit: Messias aedificabit Templum ingens Domino et habebit semen longaeuum. Si hoc fecerit, ipse est ${ }^{594}$.

Octauus dixit: Ad Messiam confluent omnes gentes. Si ad ipsum confluxerint, ipse est. ${ }^{595}$

586 nostrae] uestre $N P \quad 587$ et aperta doctrina eius] et doctrina eius aperte excelentia quae documenta dabat $Q \mathbf{5 8 8}$ Si centum annis studuisset numquam tanta discere potuisset] Scientiam annis studuisset, numquid tunc iam discere potuisset? $Q \mathbf{5 8 9}$ cuius esset, id est, de qua stirpe et generatione] cuius esset. IR 590 debet] debere $H$; dicitur $Q \mathbf{5 9 1}$ comprehendendo omnia unico uocabulo] comprehendendo omnia unico uerbo $I R V$; complectando omnino unico uocabulo $O$; ut omnia dicam unico uerbo $Q \mathbf{5 9 2}$ Messiam nasciturum] Messias nascetur $Q 493$ quando] unde $\rightarrow$ 
vara do poder de entre seus pés, até que venha o Messias. E ele será a esperança dos povos? ${ }^{[120]} \mathrm{O}$ ceptro foi retirado da nossa Casa há cerca de quarenta anos. Não descreveu claramente Daniel pelas setenta semanas o tempo e o advento de Cristo Chefe e os muitos males prestes a virem sobre esta cidade e o Templo? Em verdade, em verdade vos digo, aqui não restará pedra sobre pedra, por causa da obstinação da nossa gente.

Todos, na verdade, se admiravam das suas respostas e da sua ampla e clara doutrina. Interrogavam-se dizendo "Como conhece as Escrituras se não estudou?" ou "Onde as aprendeu?"

Se estudasse cem anos, disse outro, nunca poderia aprender tanto. É algo de divino, isto é obra de Deus!

E porque a hora era tardia, com espanto e algum deslumbramento retiraram-se para suas casas. E muitos deles diziam entre si: "É ele provavelmente o Messias". E empenhadamente procuravam saber a quem pertencia, ou seja, de que linhagem ou de que família. E chegaram a saber que era de Nazaré, filho de José e Maria, e foi dito que o seu nome era Jesus.

Disseram, então, alguns: "O seu nome não deve ser assim pronunciado". Outros, que sim. E adiaram para o dia seguinte.

No segundo dia, portanto, encaminharam-se os doutores para o local habitual. E uma vez que Maria e José haviam partido, Jesus, naquela noite, para fazer a vontade do Pai Eterno, ficou junto aos sacerdotes do Templo que veneravam Maria e consideravam que Jesus era o Messias. No dia seguinte, como disse, reuniram-se os doutores para ouvirem as agradáveis palavras daquele santo menino Jesus.

O nome do Messias, dizia um, deve chamar-se Emanuel, ou Admirável, ou Conselheiro, ou, resumindo tudo num único vocábulo, Anjo do Grande Conselho.

Dizia outro que o Messias haveria de nascer em [fl. 103] Belém e não em Nazaré.

O Messias quando vier, ninguém saberá, dizia um terceiro.

O Messias, dizia o quarto, não terá pai, pois uma virgem o conceberá.

No tempo do Messias, dizia o quinto, os animais selvagens e as feras tornar-se-ão mansos e domésticos.

O Messias porá, disse o sexto, o Monte da Casa do Senhor no topo dos outros montes. Se este fizer isso, é ele.

O Messias levantará um grande templo ao Senhor, disse o sétimo, e terá uma descendência duradoura. Se fizer isto, é ele.

Todos os povos convergirão para o Messias, disse o oitavo. Se confluírem para este, é ele.

$\leftarrow$ GHIRV 594 ipse est. Septimus dixit: "Messias aedificabit Templum ingens Domino et habebit semen longaeuum. Si hoc fecerit, ipse est."] ipse est $I R$; ipse est. Septimus dixit: "Messias edificabit Templum ingens. Si hoc fecerit, ipse est." JP 595 Septimus dixit: "Messias aedificabit Templum (...) omnes gentes. Si ad ipsum confluxerint, ipse est."] om. $V$ 
Nonus dixit una ratio pro ipso ${ }^{596}$ esset, quia tempore pacis nascetur. Nunquam autem fuit tanta pax in mundo quanta hodie est.

Decimus dixit: Non potest ipse esse, quia Messias uenturus est in nouissimis diebus. Non sunt autem adhuc nouissimi dies.

Primus inducebat in testimonium suum Isaiam dicentem: Et uocabitur nomen eius Emmanuel. Et alibi: Vocabitur nomen eius Admirabilis, Consiliarius uel, ut alii dixerunt, haec omnia unico complectentes nomine: Vocabitur nomen eius Angelus ${ }^{597}$ Magni Consilii. Quod concordat cum illo Malachiae: Statim ueniet ad Templum sanctum suum Dominator quem uos quaeritis et Angelus Testamenti quem uos uultis.

Secundus inducebat pro se Michaeam prophetam dicentem: Et tu, Bethlehem Effrata, paruulus es in tribubus ${ }^{598}$ Iuda. Sed supple: non eris paruulus. Ex te enim egredietur qui erit dominator in populo Israel.

Tertius induxit rationem: Quia res magnae transcendunt ingenium nostrum et haec sunt maxima.

Quartus inducebat Isaiam: Ecce uirgo concipiet et (supple: uirgo existens) pariet filium.

Quintus similiter inducebat eumdem prophetam dicentem: Habitabit lupus cum agno et pardus cum haedo accubabit. Vitulus et leo et ouis simul morabuntur, et puer paruulus minabit eos. Vitulus et ursus pascentur, simul requiescent catuli eorum. Et leo quasi bos comedet paleas. Delectabitur infans ab ubere super foramina aspidis et qui ablactatus fuerit in cauernam reguli mittet manum suam.

Sextus quoque inducebat testimonium eiusdem prophetae dicentis, similiter octauus et decimus ${ }^{599}$ : Erit in nouissimis diebus praeparatus mons domus Domini in uertice montium et fluent ad eum omnes gentes. Decimus fundabat se in uerbo illo: Erit in nouissimis diebus ${ }^{600 " . ~ D i c e b a t q u e ~ t u n c ~ n o n ~ e s s e ~ n o u i s s i m o s ~ d i e s . ~ S e x t u s ~}$ uero dicebat quod uerba prophetiae expresse dicunt: montem Sion eleuandum super montem Sinai et Carmellum et Thabor ita quod Messias super montem Sinai ponet Carmelum, super eum ${ }^{601}$ uero Thabor et super uerticem Thabor collocabit montem Sion. Et sic Sion stabit in uertice montium et eleuabitur super colles $^{602}$.

$\mathbf{5 9 6}$ pro ipso] pro tempore $P \mathbf{5 9 7}$ dixerunt, haec (...) eius Angelus] dixerunt, Angelus $Q \mathbf{5 9 8}$ tribubus] tribus $H I J R$; principibus $N 599$ Sextus quoque inducebat (...) et decimus] Sextus quoque eundem prophetam dicentem, similiter octauus et nonus $N \mathbf{6 0 0}$ nouissimis diebus] nouissimis diebus preparatus mons Domini IRV $\mathbf{6 0 1}$ et Carmellum et Thabor ita quod Messias super montem Sinai ponet Carmelum, super eum] et Carmellum, super eum $V \mathbf{6 0 2}$ Sextus uero dicebat (...) stabit in uertice montium et eleuabitur super colles".] om. $Q$ 
Uma razão a seu favor, disse o nono, é que nascerá em tempo de paz. E nunca houve tanta paz no mundo, quanta há hoje.

Não pode ser ele, disse o décimo, porque o Messias virá nos últimos dias. Não são ainda os últimos dias.

O primeiro aduzia como seu testemunho Isaías, que diz: Chamar-se-á Emanuel. E noutro passo: Chamar-se-á Admirável, Conselheiro, ${ }^{[121]}$ ou, como disseram outros, abrangendo tudo num único nome: Chamar-se-á Anjo do Grande Conselho, o que concorda com o passo de Malaquias: E imediatamente virá ao seu Templo o Dominador a quem vós procurais e o Anjo do Testamento a quem desejais. ${ }^{[122]}$

Aduzia o segundo a seu favor o profeta Miqueias, que diz: Mas tu, Belém Efratá, és pequena entre as tribos de Judá. Mas acrescenta, não serás pequena, na verdade, de ti há-de sair aquele que há-de governar o povo de Israel. ${ }^{[123]}$

O terceiro aduzia uma explicação: Porque as coisas grandes ultrapassam a nossa razão. E estas são as maiores.

O quarto aduzia Isaías: Eis que a virgem conceberá e (acrescenta: mantendo-se virgem,) dará à luz um filbo. ${ }^{[124]}$

O quinto aduzia também o mesmo profeta, que diz: O lobo habitará com o cordeiro, e o leopardo deitar-se-á junto do cabrito. O bezerro e o leão e a ovelha viverão juntos, e uma criança conduzi-los-á. Pastarão juntos o bezerro e o urso, e juntos repousarão os seus filhos. E o leão comerá palha com o boi. A criança de peito brincará junto à toca da áspide, e a que tiver sido desmamada introduzirá a sua mão na toca do basilisco. ${ }^{[125]}$

Também o sexto e igualmente o oitavo e o décimo aduziam o testemunho do mesmo profeta, que diz: No fim dos tempos acontecerá que o Monte da Casa do Senhor estará colocado no cume dos montes, e a ele acorrerão todos os povos. ${ }^{[126]}$ O décimo apoiava-se nesta afirmação: Acontecerá no fim dos tempos, e dizia não ser então o fim dos tempos. O sexto dizia que as palavras da profecia afirmam claramente que o Monte Sião deve elevar-se acima do Monte Sinai e do Carmelo e do Tabor de tal modo que o Messias colocará o Carmelo sobre o Monte Sinai, sobre este o Tabor e sobre o cimo do Tabor colocará o Monte Sião. E, assim, Sião estará no cume dos montes e dominará as colinas. ${ }^{[127]}$

\footnotetext{
[121] Is $9: 6$

${ }^{[122]}$ Mal 3:1

[123] Miq 5:2

[124] Is $7: 14$

[125] Is 11:6,8

[126] Is $2: 2$

[127] Is $2: 2$
} 
Octauus uero dicebat: Ecce prophetia clara est dicens: Confluent ad eum omnes gentes, iuxta illud Iacob Patriarchae: Ipse erit expectatio gentium; et illud Aggaei: Ecce ueniet desideratus cunctis gentibus.

Septimus inducebat inter alios Zachariam et Isaiam, de Templi edificatione et semine longaeuo.

Alii doctorum inducebant prophetiam Iacob patris de ablatione sceptri et dicebant Messiam iam uenisse. Alii quoque idem confirmabant testimonio Danielis, cui ego apparens dixi: Septuaginta hebdomadae conscriptae sunt super populum tuum et super ciuitatem [f1. 104] tuam sanctam et delebitur iniquitas et peccatum abolebitur et adducetur iustitia sempiterna et ungetur sanctus sanctorum. Scito ergo et animaduerte quia ab exitu sermonis et regiae concessionis ut iterum possit aedificari Ierusalem et Templum, ab illa, inquam, concessione usque ad Christum ducem fluent hebdomadae sexaginta ${ }^{603}$ nouem et in medio septuagessimae hebdomadae occidetur Christus. Et non erit populus eius iste qui nunc est, quia non credet in eum, sed negabit eum. Addidique destructionem Ciuitatis et Templi quae facta est per Romanos propter perfidiam Iudaeorum.

Induxi tibi prophetiam in sensu quo ego tunc eam dixi Danieli, quia in computatione hebdomadarum illarum multis modis dicitur. Sed incipienda est earum enumeratio a licentia data a rege Arthaxerse 604 "quod posset ciuitas destructa non solum inhabitari, sed et reaedificari”, usque ad praedicationem Christi. Vltima hebdomada comprehendit ${ }^{605}$ praedicationem ipsius et mortem et resurrectionem, legis suae institutionem ${ }^{606}$ et promulgationem et protenditur ${ }^{607}$ usque ad conuersionem Pauli et promulgationem legis ab ipso factam magnifice. Ideo hebdomada una, idest, illa ultima confirmabit pactum multis, quia promulgabit legem nouam non per totum mundum, sed multis ex Iudaeis ${ }^{608}$ et ex gentibus ${ }^{609}$. Et in medio hebdomadis deficiet sacrificium et hostia, quia tunc Christus, qui se pro uobis ${ }^{610}$ obtulit et qui est sacrificium et hostia, tunc defecit ${ }^{611}$ et mortuus est. Quia prophetia illa mea est, uolui eam tibi declarare. Per hebdomadam intellexi ${ }^{612}$, ut uestri bene exponunt, septem annos.

Sed redeamus ad doctores qui, Iesu audiente et in medio eorum sedente, disputabant. Dicebant ergo tempus Messiae iam quasi aduenisse, quia computabant illas hebdomadas quidam uno modo, quidam alio. Tandem concludebant ipsum iam natum uel saltem cito nasciturum. Et aliqui dicebant: "Si natus est, quis alius potest esse quam hic puer uel ille qui in deserto moratur et mel ac locustas comedit, cuius patri in hoc Templo angelus apparuit", qui eram ego?

603 sexaginta] septuaginta GHV 604 Arthaxerse] Athaxerse I; Artaxerxe NO; Atazerse $R V$ 605 comprehendit] comprehendet $I R V \quad 606$ institutionem] instructionem $J 607$ protenditur] protendetur IRV 608 multis, (...) sed multis ex Iudaeis] multis ex Iudaeis $I R \mathbf{6 0 9}$ ex gentibus] ex gentilibus HIR; exigentibus $N \mathbf{6 1 0}$ uobis] nobis $P V \mathbf{6 1 1}$ et hostia, (..) et hostia, tunc defecit] et hostia, tunc defecit $H \mathbf{6 1 2}$ intellexi] intelligi $I R V$ 
Eis que a profecia, dizia o oitavo, é clara ao dizer: Acorrerão a ele todos os povos ${ }^{[128]}$ nos termos do passo do patriarca Jacob: Ele será a esperança dos povos ${ }^{[129]}$ e de Ageu: Eis que chegará o desejado de todos os povos. ${ }^{[130]}$

O sétimo aduzia, entre outros, Zacarias e Isaías, sobre a edificação do Templo e a perpetuação da sua descendência.

Outros doutores aduziam a profecia do patriarca Jacob sobre a retirada do ceptro e diziam que o Messias já tinha vindo. Outros, também, confirmavam o mesmo com o testemunho de Daniel, a quem eu apareci e disse: Foram fixadas a teu povo e á tua [f1. 104] Cidade Santa setenta semanas, e será destruída a iniquidade e abolido o pecado, e será instaurada justiça eterna, e o Santo dos Santos será ungido. Fica, pois, a saber e presta atenção a que, desde a publicação do decreto e da régia concessão para que se possa reconstruir Jerusalém e o Templo, desde essa concessão, digo, até a um chefe ungido, decorrerão sessenta e nove semanas e, no meio da septuagésima semana, o ungido será eliminado. E não será seu povo, este que agora o é, porque não acreditará nele, mas negá-lo-á. ${ }^{[131]}$ E acrescentei a destruição da cidade e do Templo levada a cabo pelos romanos por causa da perfídia dos Judeus.

Avancei-te a profecia no sentido em que a transmiti a Daniel, porque no cômputo destas semanas se usa de muitos modos. Mas a sua numeração deve começar na licença dada pelo rei Artaxerxes "Que a cidade destruída possa não só ser habitada, mas também reedificada”, até à pregação de Cristo. A última semana compreende a sua pregação e morte e ressurreição, a instituição e promulgação da sua Lei, e estender-se-á até à conversão de Paulo e à promulgação da Lei feita por ele de um modo admirável. Por isso, uma só semana, ou seja, a última, confirmará o pacto com muitos, porque promulgará a nova Lei, não por todo o mundo, mas a muitos de entre judeus e gentios. E a meio da semana cessará o sacrifício e a vítima, porque então Cristo, que se ofereceu por vós e que é o sacrifício e a vítima, sucumbiu e morreu. Porque esta profecia é minha, quis comunicar-ta. Por semana entendi, de acordo com o que os vossos explicam, sete anos.

Mas voltemos aos doutores que disputavam enquanto Jesus, sentado no meio deles, ouvia. Diziam, pois, que o tempo do Messias já quase tinha chegado, porque contavam as semanas, cada um de seu modo. Finalmente concluíam que ele já nascera ou, pelo menos, estava para nascer. E alguns diziam: "Se já nasceu, que outro pode ser senão este jovem ou aquele que vive no deserto e se alimenta de mel e gafanhotos, a cujo pai o anjo (que era eu) apareceu neste Templo?”

\footnotetext{
[128] Is 2:2

[129] Gn 49:10

[130] Ag 2:8.

[131] Dan 9:24-26.
} 
Et ita schisma erat inter doctores et uehementer cupiebant omnes ut Iesus aliquid diceret sed uerecundabantur eum interrogare. Tunc ille uultu graui et diuinitatis uirtute rutilante et ardente ita loqui coepit: Deus in domibus eius cognoscetur cum suscipiet eam. De nomine Messiae primo disputatis, deinde an uenerit uel cito an tarde uenturus inquiritis. Corticem Scripturae accipitis, medulam eius nec uidetis nec gustatis. Deus enim dixit: "In domibus his et in Templo hoc et in patria ista cognoscetur, audietur, intelligetur cum humanitatem induet et suscipiet quam iam suscepit". Consuetudo est unum hominem uno nomine proprio nominari. Tamen aliquando eidem plura nomina solent attribui, si binomius sit uel et plurium nominum. Solet unus homo ab aliquo effectu, casu uel condicione sibi acquirere nomen, sicut prima mater hominum appellata fuit uirago, quia de uiro sumpta, et Abram Abraam, [f1. 105] et Iacob Israel, et Salomon Idida et Ecclesiastes. Et nonnulli de sua cognatione uel patria cognomen accipiunt, ut Sunamitis ${ }^{613}$ et Thesbites ${ }^{614}$. Et aliis pluribus modis nomina uni et eidem imponi solent. Nonne Deum ipsum caeli multis nominibus appellamus et uocamus? Consuete tamen uno nomine magis utimur, maxime quando illud est proprium et sibi primo in circumcisione imponitur. Quid ergo mirum si Messias multis nominibus in Scripturis nominetur ${ }^{615}$ ? Nonne ipsum Messiam uocatis? Nec tamen Scriptura ita aperte ${ }^{616}$ dicit: "Vocabitur nomen eius Messias". Multis autem nominibus appellatus est et appellari ${ }^{617}$ potest, quamuis consuete et ex impositione unico nomine nominetur.

Ipse uocatur Admirabilis quia mirabilium operum patrator, ipse Consiliarius quia Aeterni Dei Patris ars, sapientia et consilium. Non ergo Dei sed Deus nomen eius, quia nomen eius tetragramaton est, iuxta illud Ieremiae Prophetae: Suscitabit Dauid germen iustum et regnabit rex et sapiens erit et faciet iudicium et iustitiam in terra. Et hoc est nomen quo uocabitur ipse Messias: Tetragrammaton. Nomen ergo eius, utroque propheta attestante, erit Deus. Quod nemo ex uobis allegauit.

Ipse uocatur ${ }^{618}$ Fortis quia, leo de tribu Iuda, uincet, superabit et capita inimicorum suorum conquassabit.

Ipse uocatur Pater Futuri Saeculi quia legem nouam condet et caput erit populorum $^{619}$ credentium, maior Abraam, maior Moise, maior Dauid.

Ipse uocabitur Princeps Pacis Aeternae. Conciliabit homines cum Deo et qui erant $^{620}$ disiuncti ab eo coniunget, et duos parietes multum separatos copulabit.

613 Sunamitis] sunamites $J N 614$ accipiunt, ut Sunamitis et Thesbites] accipiunt $Q 615$ Quid ergo mirum si Messias multis nominibus in Scripturis nominetur?] om. $Q \mathbf{6 1 6}$ ita aperte] ullibi ita aperte $Q$;ullibi $H I R V \quad 617$ appellari] nominari $H 618$ uocatur] uocabitur $G N O Q 619$ populorum] plurimorum $G \mathbf{6 2 0}$ erant] erunt $I R V$ 
E havia, assim, uma dissidência entre os doutores, e todos ansiavam que Jesus dissesse alguma coisa, mas tinham vergonha de o interrogar. Ele, então, de aspecto grave, brilhando e resplandecendo nele a força da divindade, começou a falar nestes termos: Deus mostrou-se nas suas cidadelas um baluarte seguro. [132] Primeiro disputais sobre o nome do Messias, depois perguntais se já veio ou se virá cedo ou tarde. Satisfazeis-vos com a forma da Escritura, o seu cerne nem o vedes, nem o saboreais. Na verdade, Deus disse: Será conhecido, ouvido e compreendido nestas moradas e neste Templo e nesta nação, quando revestir e assumir a humanidade, que já assumiu. ${ }^{[133]}$ É costume que um homem seja conhecido por um único nome próprio. Todavia, às vezes, costuma dar-se vários nomes ao mesmo, se tem dois nomes ou mais. Costuma um homem, em razão de qualquer facto, acidente ou condição, arranjar para si um nome, do mesmo modo que a primeira mãe da humanidade foi chamada virago, porque tirada do homem, e Abrão, Abraão, [fl. 105] e Jacob, Israel, e Salomão, Idida ou Eclesiastes. E muitos outros ganham um apelido em razão do parentesco ou da terra, como a sunamita $^{[134]}$ e o tesbita ${ }^{[135]}$. E de vários outros modos se costuma atribuir nomes a uma e mesma pessoa. Não nos dirigimos ao próprio Deus do Céu e o invocamos com muitos nomes? Habitualmente, todavia, usa-se mais um nome, sobretudo quando é o próprio e foi dado na circuncisão. Que admira, pois, se na Escritura o Messias é designado com muitos nomes? Não o chamais Messias? E, todavia, a Escritura não diz claramente que se chamará Messias. Foi chamado, porém, e pode chamar-se com muitos nomes, embora habitualmente e por imposição se designe com um único nome.

Ele chama-se Admirável, porque autor de obras admiráveis. Ele, Conselheiro, porque o talento, a sabedoria e o conselho de Deus Pai Eterno. O seu nome não é, pois, de Deus, mas Deus, porque o seu nome é Tetragrama, de acordo com o profeta Jeremias: David fará surgir uma descendência justa, e o rei governará com sabedoria e exercerá na Terra o direito e a justiça. ${ }^{[136]}$ É este o nome com que o próprio Messias será chamado: Tetragrama. O seu nome, pois, será Deus, segundo o testemunho de ambos os profetas, nome que nenhum de vós referiu.

Ele é chamado Forte, porque, leão da tribo de Judá, vencerá, dominará e esmagará a cabeça de seus inimigos.

Ele é chamado Pai do Futuro Século, porque fundará uma nova lei, será a cabeça do povo dos crentes, maior que Abraão, maior que Moisés, maior que David.

Ele será chamado Príncipe da Paz Eterna. Reconciliará os homens com Deus e atrairá os que andavam afastados dele. E juntará, aí, duas paredes muito separadas.

\footnotetext{
[132] S1 47:4

[133] S1 47:4.

${ }^{[134]}$ Quaesierunt igitur adulescentulam speciosam in omnibus finibus Israel et inuenerunt Abisag Sunamitin et aduxerunt eam ad regem. 1 Reg 1:3.

[135] Factus est igitur sermo Domini ad Heliam Thesbiten... 1Reg 21:17.

[136] Jer 23:5
} 
Timorem extinguet ${ }^{621}$, amorem augebit et tranquilitatem, tamquam ipse mitis, humilis, mansuetus, docebit pacem, praedicabit, annuntiabit et pro saluatione ordinabit. Recte igitur uocabitur Princeps Pacis et Rex Pacificus, per Salomonem filium Dauid praefiguratus, qui et si multa mala perpetrauerit, paenitentiam tamen egit et Librum Ecclesiates, Spiritu Sancto instruente ${ }^{622}$, composuit et Cantica Canticorum multis sensibus decorauit.

Quia ergo uocabitur Deus et cum hominibus conuersabitur, ideo dixit propheta: Vocabitur nomen eius Emmanuel.

Et quia spoliabit infernum et peccata detrahet et extirpabit et adiuuare homines festinabit, ideo alibi dicitur Detrahe, ${ }^{623}$ Spolia, Accelera. Et alia eodem modo in prophetis posita possent induci et exponi, quae praetereo.

Alibi dicit: Vocabitur nomen eius quod os Domini nominauit. Ex ore humano duo procedunt, flatus seu spiritus et uerbum. Ex ore etiam Dei Patris Aeterni procedit Verbum. Ipse enim aeterna mente gignit Filium sibi per omnia aequalem, quia Verbum eius et ${ }^{624}$ imago substantiae suae est. Producit et alium qui Spiritus est et non Verbum oris Dei nuncupatur.

Nonne nomen Messiae etiam Salutare ${ }^{625}$ dicitur, propheta perhibente: Viderunt omnes fines Terrae salutare Dei nostri? Et alibi: Exultabo in Deo Salutari ${ }^{626}$ meo"? Quia ergo ipse est salus populi et per ipsum delebitur praeuaricatio, peccatum et iniquitas, recte Saluator nominatur. In illo namque nomine ${ }^{627}$ uidentur omnia alia nomina [f1. 106] contineri. Si enim non esset Deus et Fortis et Consiliarius et Admirabilis, quomodo saluaret? Si quoque non spoliaret infernum, peccata detraheret et ad adiuuandum festinus esset, quomodo saluaret nisi esset Saluator? Quomodo dicitur Spolia, Detrahe, Accelera? Et ut sciatis uos me legisse illos septuaginta interpretes qui, Legem nostram gentibus interpretantes, loco illorum nominum: Admirabilis, Consiliarius, Dominus Fortis, Pater Futuri Saeculi, Princeps Pacis, posuerunt unum nomen "Angelus Magni Consilii", in quo uerbo conduxerunt ${ }^{628}$ omnia circumstantia ac si dixissent: "Dicamus obcurius regi gentili, non nominemus eum tot nominibus, dicamus Angelus Magni Consilii" sicut et Malachias dixit Angelus Testamenti Noui et Veteris. Vtrumque enim Testamentum de $^{629}$ illo scribitur, utrumque in illo fundatur, utriusque auctor est ipse. Non sit uobis nomen impedimento neque Scripturarum concordissima ueritas uobis salutem et spem adimat.

621 extinguet] extinctum $P \mathbf{6 2 2}$ instruente] inspirante $Q \mathbf{6 2 3}$ alibi dicitur "Detrahe"] alibi dicitur uocabitur nomen eius "Detrahe" GHNOQ $\mathbf{6 2 4}$ procedit Verbum. Ipse (...) quia Verbum eius et] procedit Verbum eius et IR $\mathbf{6 2 5}$ Messiae etiam Salutare] Messiae Salutare HIR; Messiae Saluator $V 626$ Salutari] Saluatore $I R$; Saluatori $N 627$ In illo namque nomine] In illoque nomine $H$; In illoque homine $I R$; In illo $V \mathbf{6 2 8}$ conduxerunt] incluserunt $H R$; induxerunt $I V$; concluserunt $G J N$ 629 Vtrumque enim testamentum de] ubique enim de $H I R$; Vbique enim ab $V$ 
Porá fim ao medo, fará crescer o amor e, ele mesmo, afável, humilde, pacífico, ensinará a tranquilidade, pregará, anunciará e ordenará a paz para a salvação. Por isso será, com razão, chamado Príncipe da Paz e Rei Pacífico, prefigurado por Salomão, filho de David, que, posto que haja praticado muitos males, fez, todavia, penitência e compôs, sob a acção do Espírito Santo, o Livro do Eclesiastes e revestiu de sentido vários o Cântico dos Cânticos.

Porque será chamado Deus e conviverá com os homens, diz, por isso, o profeta: Será chamado Emanuel. ${ }^{[137]}$

E porque despojará o inferno, tirará e extirpará o pecado e se apressará a auxiliar os homens, por tudo isso se diz noutro passo: Tira, Expolia, Apressa-te. E outros, do mesmo modo escritos nos profetas, se poderiam aduzir e expor, que deixo ficar.

Diz-se noutro passo: O seu nome será aquele que a boca do Senhor determinou. ${ }^{[138]}$ Da boca do homem procedem duas coisas: o sopro ou espírito e a palavra. Também da boca de Deus Pai Eterno procede o Verbo. Ele mesmo, na verdade, gera em sua mente eterna o Filho, igual a si em tudo, Filho que é o seu Verbo e a imagem da sua substância. Produz também outro, que se chama Espírito da boca de Deus e não Verbo da boca de Deus.

Não se chama o nome do Messias também Salvação, como declara o profeta: Todos os confins da Terra puderam ver a salvação do nosso Deus ${ }^{[139]} \mathrm{E}$, noutro passo: Exultarei em Deus, minha salvação? ${ }^{[140]}$ Porque ele mesmo é a salvação do povo e por ele será abolida a prevaricação, o pecado e a iniquidade, justamente se chama Salvador. E, na verdade, neste nome parecem estar contidos [f1. 106] todos os outros nomes. Se, realmente, não fosse Deus, e Forte, e Conselheiro, e Admirável, como salvaria? Se não espoliasse o inferno, tirasse o pecado e não fosse célere em ajudar, como salvaria se não fosse Salvador? Como pode chamar-se Expolia, Tira, Apressa-te? E para que vós saibais que eu li os Setenta que, ao traduzirem a nossa Lei para os gentios, em vez dos nomes Admirável, Conselheiro, Senhor Forte, Pai do Futuro Século, Príncipe da Paz, usaram um único nome: Anjo do Grande Conselho. Nesta expressão concentraram todas as circunstâncias, como se dissessem: Exponhamos ao rei gentio de forma menos clara, não o designemos por todos os nomes, digamos "Anjo do Grande Conselho", como Malaquias disse Anjo do Novo e do Antigo Testamento. Na verdade, ambos os Testamentos estão escritos acerca dele, ambos se fundam nele, é ele o autor de ambos. Que o nome se não constitua para vós em impedimento, nem a extraordinária concordância das Escrituras vos arrebate a salvação e a esperança.

[137] Is 7:14

[138] Is $62: 2$

[139] S1 97:3

${ }^{[140]}$ Lc 1:47. 
Alius ex uobis dicebat Messiam in Bethleem nasciturum, ex prophetia Michaeae. Et uerum est, quod oportebat Messiam egredi ex utero matris suae in Bethleem. Ideo propheta "ex te" inquit "egredietur", non "in te ingredietur". In Nazareth ingressus est tamquam Sanctus Sanctorum in loco sancto. In Bethleem egressus est tamquam panis et refectio et sustentaculum et firmamentum domus Israel et totius mundi. Est ergo Nazareus et Bethleemiticus Messias. Quando autem dicitur quod nemo scietunde sit Messias, id non est bene dictum, quia ueniet de tribu Iuda et de domo Dauid et de ciuitate Nazareth per conceptionem, et de Bethleem per natiuitatem. Et uerum est quod omnium quae fecit Deus hoc est maximum et mens hominis propter peccatum quo ignorantiam erroneam incurrit non potest ${ }^{630}$ comprehendere neque scire conceptionis et natiuitatis modum. Potest tamen per testimonium Scripturae intelligere ubi nascetur et ex quibus parentibus.

Messias quoque habebit unum patrem uidelicet Deum, iuxta illud: Ipse inuocabit me: Pater meus est tu. Et ego primogenitum ponam illum.

Quae de Messia dicuntur, cuius figuram in multis gessit Salomon rex.

Habebit ${ }^{631}$ etiam matrem sine patre, quia mulier sola circumdabit uirum, et, uirgo concipiet et pariet. Sed quod habeat patrem putatiuum, qui tamen etiam et ipse sit uirgo purissimus, nihil obstat.

Et ita tacite ostendebat se non esse filium Ioseph.

Qui uero dicunt animalia siluestria domestica tunc fieri, metaphorice et per quamdam similitudinem loquuntur, sicut et ibi: Erit iustitia cingulum lumborum eius et fides cinctorium renum eius. Quia ergo Messias coniunget lupos cum agno seipso et coniunget gentes cum Iudaeis, quas gentes uos lupos et ursos et aspides et regulos uocatis, ideo ita scriptum est, quamuis etiam Messias dabit uirtutem suis calcandi super serpentes [f1. 107] et scorpiones ita ut nibil eis nocere possit, nam serpentes tollent et, si mortiferum quid bibere uoluerint, ${ }^{632}$ non eis nocebit.

Ad quid autem oportet montem domus Domini collocare in uertice montium? Amen, amen, dico uobis quia plura operabitur Messias in monte isto in quo nunc sumus quam sit operatus in monte Sinai et quam operabitur in aliis montibus, Carmello et Thabor. Et iam coeperunt mysteria in hoc monte fieri et nunc in oculis uestris fiunt, sed non percipitis. Quando autem granum frumenti mortuum fuerit, tunc multum fructum affert. Antea uero solum cum populo suo, et in illo ualde pauco manebit. Ipse certe est exspectatio gentium et desideratus earum. Populus suus negabit ipsum, et sic uocabit non plebem suam plebem suam et non

630 non potest] nequit $Q 631$ llum”. Quae (...) Rex. Habebit] illum”. Habebit $Q 632$ bibere uoluerint] biberint $G Q$; bibere noluerint $R$ 
Dizia um de vós que o Messias haveria de nascer em Belém, segundo a profecia de Miqueias. E é verdade que era conveniente que o Messias saísse do útero de sua Mãe em Belém. Por isso diz o profeta "Sairá de ti"; e não "Entrará em ti". Em Nazaré entrou como Santo dos Santos no lugar Santo. Em Belém saiu como pão e refeição e alicerce da Casa de Israel e de todo o mundo. Por isso é o Messias nazareno e betleemítico. Quando, porém, se diz que ninguém saberá de onde é o Messias, isso não está certo, porque virá da tribo de Judá e da Casa de David e da cidade de Nazaré, pela concepção, e de Belém, pelo nascimento. E é verdade que, de tudo o que Deus fez, isto é o máximo, e a inteligência humana não pode, por causa do pecado pelo qual incorreu na errónea ignorância, compreender nem conhecer o modo da concepção e do nascimento. Pode, todavia, pelo testemunho da Escritura, saber onde nascerá e de que pais.

O Messias terá também um pai, ou seja, Deus, nos termos desta afirmação: Ele me invocará: tu és meu Pai, e eu o constituirei meu primogénito..$^{[141]}$

Isto afirma-se do Messias cuja figura, em muitos aspectos, incarnou o rei Salomão.

Terá igualmente uma mãe, sem pai, porque: $A$ mulher sozinha rodeará o homem $;^{[142]}$ e: A virgem conceberá e dará à luz.$^{[143]}$ Mas nada obsta a que tenha um pai putativo que, contudo, será, também ele, virgem sem mancha.

E, assim, tacitamente mostrava que não era filho de José.

Mas os que dizem que os animais selvagens então se tornarão mansos, falam metaforicamente e por uma certa analogia, como também neste passo: A justiça será o cinturão do seu dorso e a lealdade o cinto de seus rins. ${ }^{[144]}$ Porque o Messias juntará o lobo com o cordeiro, que é ele mesmo, e associará os gentios com os judeus, gentios a que chamais lobos e ursos e áspides e basiliscos, por isso assim está escrito, embora de novo: O Messias dará aos seus o poder de pisar sobre serpentes $e$ [f1. 107] escorpiões, de modo que nada lhes possa fazer mal, pois pegarão em serpentes e, se quiserem beber algo mortífero, nada lhes fará mal. $^{[145]}$

Por outro lado, que importa colocar o monte da Casa do Senhor no cume dos montes? Em verdade, em verdade vos digo que o Messias fará mais neste monte em que nos encontramos do que fez no Sinai e fará nos outros montes, Carmelo e Tabor. E começaram já a verificar-se neste monte coisas misteriosas e, agora mesmo, estão a acontecer a vossos olhos, mas não vedes. Quando, porém, o grão de trigo morrer, então produzirá muito fruto. Mas antes estará só com o seu povo, e com ele muito pouco. Ele é, sem dúvida, a esperança dos gentios e o seu desejado. O seu povo negá-lo-á e, assim, chamará seu povo àquele que

\footnotetext{
[141] S1 88:27, 28

[142] Jer 31:22

[143] Is 7:14

[144] Is $11: 5$

${ }^{[145]}$ Lc 10:19.
} 
populum suum populum suum ${ }^{633}$. Ipse tamen primum uenit propter oues quae perierunt domus Israel. Aedificabit autem Templum ingens ex lapidibus quadris et uiuis atque electis. Eius semen in aeternum manebit et multiplicabitur. Ideo erit longaeuum et innumerabile, sicut promissum ${ }^{634}$ est patri nostro Abraam quod multiplicabitur semen eius sicut stellae caeli et arena quae est in litore maris.

Dies quoque Messiae nouissimi dicuntur, quia legi suae alia lex a Deo data non succedet. Nouissimi quoque dicuntur, quia longo tempore post uisionem prophetarum sic dicentium adimpleti.

Percutietur cito statua in pedibus fictilibus et cadet. Et haec domus sicut et hic mons iam incepit ${ }^{635}$ impleri gloria et adhuc maiore implebitur. Et qui coepit implere uidistis eum et ille idem implebit quem et uidetis ${ }^{636}$. Sed dolendum est, quia uidentes non uidebunt et audientes ${ }^{637}$ non intelligent. Superbia et praesumptio sunt prima peccata et pessima, excaecant ${ }^{638}$ enim corda hominum et faciunt eos incurrere in multa quae non licent.

Si ergo, patres, conferre humiliter uolueritis dicta Prophetarum, inuenietis prophetam illum patribus nostris promissum iam uenisse. Qui recte dictus est Messias, quia unctus est in Sacerdotem et Regem, non oleo oliuarum, sed omnibus donis et gratiis. Aperiendi sunt oculi, uidenda est ueritas ne ut caeci ambuletis, sed lumen quod apud uos est cernatis et cernendo uitam habeatis.

Haec Iesus, secunda die, Maria credente ipsum esse in comitatu uirorum, Ioseph in comitatu mulierum et Domino permittente ne mater subito ad inquirendum eum pergeret, admirabantur doctores et sacerdotes Templi et alii circumstantes, uidentes sapientiam Dei in puero. Multique sacerdotum atque doctorum coeperunt credere in ipsum. Et ita impleta est secunda disputatio.

Tertia die doctores iterum conuenerunt et nimium mirabantur et inter se dicebant: "Aut Messias aut angelus puer iste est. Et quia [fl. 108] tempus aduentus Messiae a Daniele praedictum iam aduenit ${ }^{639}$, non angelus, sed Messias est". Quidam sacerdotes qui sanctitatem Mariae agnoscebant et ab ea multa didicerant, qui etiam sciebant uotum uirginitatis eius et miraculosam desponsationem uiro iusto et sancto, dixerunt doctoribus omnia quae nouerant. Addideruntque quod, non obstante tali desponsatione, posset esse, immo et sic esse. Intellexerant ${ }^{640}$ quod Maria sit uirgo et numquam polluta, sed intacta et, quod plus est, quod,

633 non plebem suam plebem suam et non populum suum populum suum.] plebem non suam et populum non suum $G$; plebem suam non plebem suam et non populum suum populum suum $N$; non plebem suam et non populum suum populum suum $P$; plebem suam non plebem suam, plebem suam non plebem suam et non populum suum $Q$; plebem suam non plebem suam et non populum suum $V 634$ manebit et (...) sicut promissum] manebit sicut promissum $Q 635$ incoepit] coepit IRV 636 et ille idem implebit quem et uidetis] et ille diem implebit quem et uidebitis $N$; et $\rightarrow$ 
não é seu povo e sua nação àquela que não é sua nação. ${ }^{[146]}$ Todavia ele vem primacialmente por causa das ovelhas da casa de Israel que pereceram. Levantará, porém, um grande Templo de pedras aparelhadas e vivas e escolhidas. A sua geração permanecerá para sempre e multiplicar-se-á. Será, por isso, duradoura e incontável, como foi prometido a Abraão, nosso pai, que a sua descendência se multiplicaria como as estrelas do Céu e a areia da praia.

Também os dias do Messias serão considerados os últimos, porque à sua Lei não sucederá outra dada por Deus. Serão considerados os últimos, também, porque se cumpriram muito tempo depois da visão dos profetas que assim falaram.

A estátua dos pés de barro em breve será atingida e cairá, e esta Casa assim como este Monte começaram já a encher-se de glória e encher-se-ão de maior glória ainda. E vistes aquele que começou a encher e ele mesmo, a quem também vistes, encherá. Mas deve lamentar-se, porque os que vêem não verão, e os que ouvem não entenderão. A soberba e a presunção são os primeiros e os piores pecados, cegam realmente os corações dos homens e levam-nos a incorrer em muitas coisas que não convêm.

Se, pois, padres, quiserdes humildemente conferir as afirmações dos profetas, chegareis à conclusão de que aquele profeta prometido a nossos pais já chegou. Ele é justamente chamado Messias porque foi ungido Sacerdote e Rei, não pelo óleo, mas por todos os dons e graças. Deveis abrir os olhos, deveis ver a verdade, para não andardes como cegos, mas para verdes a luz que está no meio de vós e, ao vê-la, tenhais a vida.

Neste segundo dia, acreditando Maria que ele estivesse na caravana dos homens, José, que estivesse na das mulheres e, permitindo Deus, o Senhor, que a Mãe não viesse logo procurá-lo, doutores e sacerdotes do Templo, e outros que ali estavam, admiravam as posições de Jesus ao verem a sabedoria de Deus no menino. E muitos sacerdotes e doutores começaram a acreditar nele. E assim se concluiu a segunda disputa.

No terceiro dia, os doutores reuniram-se novamente e enchiam-se de admiração e comentavam entre si: "Este menino ou é o Messias ou é um anjo. E uma vez que [f1.108] já chegou o tempo da vinda do Messias predito por Daniel, não é um anjo, mas é o Messias." Alguns sacerdotes que conheciam a santidade de Maria e tinham aprendido muito com ela, que conheciam também o seu voto de virgindade e os milagrosos esponsais com um homem justo e santo, relataram aos doutores tudo de que haviam tomado conhecimento. Acrescentaram que, não obstante tais esponsais, poderia ser, e até ser assim. Haviam compreendido que

$\leftarrow$ ipse idem implebitur quem et uidetis $P \quad 637$ audientes] uidentes $I R \mathbf{6 3 8}$ et pessima, excaecant] et pessima excaecantia $H J N P 639$ aduenit] impletum est $I R V 640$ intellexerant] intellexerunt $I R V$

[146] Rm 9:25 (Os 2:25). 
quamuis genuerit filium, ita tamen clausa erat sicut puella septem ${ }^{641}$ annorum. Multi ex doctoribus crediderunt ipsum esse Messiam sed, ne ab aliis deriderentur ${ }^{642}$ tamquam leues corde quia cito credidissent, occultabant fidem et credulitatem suam. Alii cogitabant quomodo possent scire an Maria esset uirgo, ut dixerant sacerdotes, quod etiam postea perscrutati sunt. Et testimonio honestissimarum et sanctarum mulierum quae cum Maria diutius et frequentius conuersabantur, quae hoc pro certo nouerant, illud quod sacerdotes dixerant uerum esse didicerunt ${ }^{643}$. Voluit enim Dominus ut illud sciretur ne ullam ${ }^{644}$ excusationem haberent in eum credendi. Multi ergo sacerdotum et doctorum credebant in Iesum.

In hac ergo tertia disputatione cum maiori reuerentia et ueneratione locuti sunt doctores cum puero Iesu. Inquirebant ergo an Messias esset allaturus aliam legem nouam uel confirmaturus legem ueterem. Et aliqui dicebant ipsum facturum legem nouam, inducentes illud Danielis: "Hebdomada ultima confirmabit pactum multis". Alii econtra dicebant legem illam aeternam esse sicut Dominus per suos prophetas dixit. Alii quaerebant an lex prohiberet animum et peccatum cordis aut solum manum et peccatum exterius siue operis. Et cum altercarentur, omnes inspiciebant in Iesum, cupientes aliquid audire ex ore eius.

Ita ergo Iesus puer, omni sapientia plenus, exorsus est: Deus Virtutum, conuertere et respice de caelo. Et uide et uisita uineam istam et perfice eam quam plantauit dextera tua, et super filium hominis quem confirmasti tibi. Vinea Domini Sabaoth domus Israel est, ad quam nunc Deus Virtutum conuersus est. Et quia numquam potentia sua maior apparuit, plurimas atque stupendas uirtutes, quando Verbum caro factum est, fecit ${ }^{645}$. Ideo recte Deus Virtutum uocatus est. Quando uultum suae infinitae clementiae ad uos conuertit et faciem suam et imaginem suam ad uos misit et uos pio et benigno oculo respexit, uos uidit et uisitauit. Vtinam et uos uideatis et cognoscatis tempus uisitationis uestrae et audientes audiatis et intelligentes intelligatis. Visitauit ecce Deus uineam, perficiet eam et non exterminabit. Nam extermimauit [fl. 109] eam aper de silva postquam impleuerat terram, et singularis ferus depastus est eam postquam extenderat palmites usque ad mare et propagines suas usque ad flumina ${ }^{646}$. Et, sic iratus, Dominus destruxerat maceriam ${ }^{647}$ eius et uindemiabant eam qui praetergrediebantur uiam. Ita, nunc misertus, perficiet eam legemque perfectam dabit quae erit noua et uetus, eadem et alia. Decalogus ille a principio fuit et usque in finem ${ }^{648}$ durabit neque decalogus est, sed bilogus. Quicquid enim praecipitur, Dei aut proximi dilectio est. Et quia sola dilectio precipitur, monologus potest dici, cuius praeceptum in aeternum

641 septem] duorum $P \quad 642$ deriderentur] discederent $P \quad 643$ didicerunt] dixerant $O \quad 644$ ne ullam] ut nullam $Q$; ne illam $V \mathbf{6 4 5}$ Verbum caro factum est, fecit] Verbum caro factum est et imaginem suam ad uos misit, fecit $Q 646$ flumina] maria $P$; flumen HIRV 647 maceriam] naturam $P$; materiam $V 648$ usque in finem] in aeternum $N$ 
Maria é virgem e nunca foi manchada, mas é pura e, o que é mais, que embora tenha concebido um filho, estava tão intacta como uma menina de sete anos. Muitos doutores acreditaram que ele era o Messias, mas para não serem escarnecidos pelos outros como insensatos por haverem ido logo acreditar, disfarçavam sua fé e sua crença. Cogitavam outros como poderiam saber se Maria era virgem como haviam dito os sacerdotes, o que depois investigaram. E, pelo testemunho das mais distintas e santas mulheres que conviviam prolongada e frequentemente com Maria, que haviam tomado conhecimento disso como certo, ficaram a saber que era verdadeiro o que os sacerdotes haviam dito. Na verdade, quis o Senhor que isso se soubesse para não terem qualquer desculpa para acreditarem nele. Portanto, muitos sacerdotes e doutores acreditavam em Jesus.

Nesta terceira disputa os doutores falavam, pois, com o jovem Jesus com maior reverência e veneração. Perguntavam se o Messias ia trazer outra Lei Nova ou iria confirmar a Antiga. E diziam alguns que iria apresentar uma nova Lei, aduzindo a posição de Daniel: Ele firmará um pacto com muitos na última semana. ${ }^{[147]}$ Outros, pelo contrário, diziam que esta Lei é eterna, conforme disse o Senhor por intermédio de seus profetas. Outros perguntavam se a Lei proibia o espírito e o pecado do coração ou só a mão e o pecado exterior, ou seja, a acção. E, enquanto discutiam, todos olhavam para Jesus, desejando ouvir alguma coisa de sua boca.

Cheio de sabedoria, o jovem Jesus começou a falar nestes termos: Deus dos Exércitos, volta atrás e olha do Céu. Vê e visita esta vinha e protege o que a tua dextra plantou, e sobre o bomem que confirmaste! ${ }^{[148]}$ A vinha do Senhor dos Exércitos é a Casa de Israel, para quem se voltou agora o Deus dos Exércitos. E uma vez que o seu poder nunca se mostrou maior, realizou maravilhas várias e dignas de espanto quando o Verbo se fez carne, por isso justamente é chamado Deus dos Exércitos. Quando voltou para vós o rosto da sua infinita clemência e vos enviou sua Face e sua Imagem e vos olhou com piedade e benignidade, viu-vos e visitou-vos. Oxalá também vós vejais e conheçais o tempo da vossa visitação e, ouvindo, ouçais e compreendendo, entendais. Eis que Deus visitou a vinha, protegê-la-á e não a exterminará. De facto, exterminou-a [f1. 109] o javali da floresta depois de haver enchido a Terra, e uma única fera a devorou depois de estender seus rebentos até ao mar e seus ramos até aos rios. E o Senhor, assim irado, havia destruído sua vedação, e vindimavam-na os que passavam no caminho. ${ }^{[149]}$ Assim, agora, compadecido, protegê-la-á e lhe dará uma lei perfeita, que será nova e velha, a mesma e outra. O Decálogo existiu desde o princípio e permanecerá até ao fim, e não é decálogo, mas bílogo. O que quer que seja decretado é amor de Deus ou do próximo. E uma vez que apenas é decretado

[147] Dan 9:27

[148] S1 79:15,16

[149] S1 79. 
manebit. Aeterna ergo lex, aeternus populus Dei, aeterna domus Israel, semen Abraam numquam deficiet, electi Dei in aeternum uiuent. Sabbata, neomeniae atque cerimoniae Legis figurae sunt, signa sunt, in suis significatis conseruabuntur et ita non peribunt omnino. Aeterna ergo est lex Dei et eadem semper, dilectio semper praecipitur. Sed quando et ubi potius Deus sit diligendus, est extra naturam praecepti acciditque dilectioni. Accidentia legis mutabuntur, lex ipsa manebit. Eadem est lex in natura sua, alia in illis quae accidunt naturae. Vetus est in substantia, noua in accidentibus. Et quia nunc dilectio minis et timore ${ }^{649}$ obseruatur, ex nunc amore praeceptum amoris electi Dei obseruabunt. Lex ergo noua Lex amoris, Lex uetus Lex timoris nuncupabitur ${ }^{650}$. Immo dico uobis quod lex amoris dicetur illa lex quae prius timoris dicebatur. Quia etsi semper dilectio fuerit sub praecepto, nunc erit multo magis et multo maior dilectio sub praecepto. Et longe amplior gratia et caritas in cordibus fidelium abundabit adeo ut prior ${ }^{651}$ gratia in comparatione posterioris non uocabitur gratia neque lex gratiae qualis usque huc fuit. Et ex nunc, prae multitudine gratiae, non dicetur quasi lex, sed gratia et caritas. Et quia Deus maximam gratiam contulit hominibus et maxima caritate usus est erga homines, quos ex seruis fratres suos et propinquos et consanguineos fecit et in natura eorum apparuit, ideo maximam caritatem ostendit hominibus. Iccirco praecepta ipsius nunc sunt praecepta amoris, quia praecepit ut frater et similis factus hominibus, non ut dominus cui debetur potius timor quam amor. Iudicialia non sunt necessaria ubi amor perfectus est. Illa tamen conseruabuntur ${ }^{652}$ in amore ${ }^{653}$ et in aliquo aequipollenti. Sempiterna itaque est lex quoad praecepta necessaria, sempiterna quoad alia in suo aequipollenti. Si ergo ${ }^{654}$ praecepta illa sempiterna sunt, semper prohibuerunt et manum et animum. Sed lex uestra ${ }^{655}$, quam Moises dedit uobis, dicitur prohibuisse manum non animum, quia pro malo opere poenam temporalem instituit: oculum pro oculo, dentem pro dente. Pro peccato animi nullam penam inflixit. Non enim cupiens uel uolens tantum occidere ${ }^{656}$ occiditur, nec oculus eruitur cupienti eruere, nisi occiderit uel eruerit. Plectuntur etiam signa aliqua suae prauae uoluntatis ostendentes. Sed pro sola uoluntate nulla poena a lege est inflicta. Longe tamen maior est iniquitas cordis quam solius operis, immo tota iniquitas ${ }^{657}$ operis a corde procedit. [f1. 110] Vna lex est et duae, eadem et alia. Vtraque cohibebit animum et manum. Sed illa quam expectatis cohibebit utrumque magis et auxilia faciliora et praestantiora parabit $^{658}$.

649 minis et timore] minus et timore $H$; nimis cum timore $P$; minime quia ex timore $Q$; mimis (nimis $R$ ) et timor est IRV 650 nuncupabitur] nuncupatur IPRV 651 prior] puer $V 652$ conseruabuntur] obseruabuntur $Q 653$ amore] timore $Q 654$ aliquo aequipollenti. (...) in suo aequipollenti. Si ergo] aliquo equipollenti. Si ergo $G 655$ uestra] uera $V \quad 656$ occidere] oculte $I R V 657$ iniquitas] impietas $V 658$ parabit] parebit $J$; praestabit $P$ 
o amor, pode considerar-se monólogo, cujo preceito permanecerá para sempre. A lei é eterna, eterno o povo de Deus, eterna a casa de Israel, a descendência de Abraão nunca acabará, os eleitos de Deus viverão para sempre. Os sábados, as neoménias, os ritos da Lei, são figuras, são sinais, manter-se-ão nos seus significados e, por isso, não desaparecerão em absoluto. Portanto, a Lei de Deus é eterna e sempre a mesma, impõe sempre o amor. Mas quando e onde deve Deus ser preferentemente amado, está além do preceito, acresce ao amor. Os acidentes da Lei mudarão, a Lei, essa, permanecerá. A Lei é a mesma em sua natureza, outra no que acresce à natureza. É velha na substância, nova nos acidentes. E uma vez que agora o amor se observa em razão das ameaças e do medo, desde agora os eleitos de Deus observarão o preceito do amor com amor. A Nova Lei é, pois, a Lei do amor, a Lei Antiga será designada Lei do temor. E digo-vos mais, que Lei do amor será considerada aquela Lei que antes se dizia do temor. Porque se o amor esteve sempre sob o preceito, muito mais estará agora e muito maior será o amor sob o preceito. E a graça e a caridade abundarão em muito maior quantidade nos corações dos fieis, de tal modo que a primeira graça em comparação com a segunda se não chamará graça nem Lei da graça, como aconteceu até agora. A partir de agora, por causa da abundância da graça, não se designará Lei, mas graça e caridade. E uma vez que Deus conferiu aos homens a graça máxima e usou para com os homens da máxima caridade, homens a quem de servos fez irmãos, familiares e consanguíneos seus, e em cuja natureza se manifestou, por isso mostrou aos homens a máxima caridade. Os seus preceitos são, portanto, preceitos de amor, porque ordenou como irmão e tornado semelhante aos homens, não como senhor a quem se deve antes temor que amor. Não são necessários processos onde o amor é perfeito. Manter-se-ão, todavia, no amor e em algo equivalente. Deste modo, a Lei é sempiterna quanto aos preceitos necessários, sempiterna quanto aos outros no seu equivalente. Se, pois, os preceitos são sempiternos, proibiram sempre quer a mão, quer o espírito. Mas a vossa Lei, que Moisés vos deu, diz-se que proibia a mão e não o espírito, porque instituiu pena temporal para a má acção: Olbo por olbo, dente por dente ${ }^{[150]}$ À falta do espírito não aplicou pena alguma. Não se mata, na verdade, aquele que apenas deseja ou quer matar, e não se arranca o olho àquele que deseja arrancá-lo, a menos que mate ou arranque. Castigam-se também os que mostram alguns sinais da sua má vontade. Mas nenhuma pena é infligida pela Lei só em razão da vontade. Muito maior é, todavia, a maldade do coração que só a da acção, e mais, toda a maldade da acção procede do coração. [f1. 110] A Lei é uma e duas, a mesma e outra. Uma e outra próibem a mão e o espírito. Mas aquele que aguardais coibirá um e outra, prestará auxílio mais fácil e mais eficaz. 
Haec eo loquente, ecce Ioseph et Maria cum turba propinquorum et affinium. Potior pars doctorum credidit in eum ${ }^{659}$ et multi sacerdotum. Sed ipso renuente ${ }^{660}$, quia tempore suo et aetate conueniente uolebat coadunare discipulos, non sunt secuti eum.

Ipse autem descendit cum Ioseph et Maria in Nazareth et, Filius Dei atque Rex omnium, subditus erat non solum matri ${ }^{661}$, sed etiam Ioseph putatiuo patri. Sua itaque profunda humilitate, patientia, longanimitate, orationibus et contemplationibus, oboedientia et subiectione assidue construebat mansiones electorum suorum in domo Patris sui. Et ter in anno ascendebat in Ierusalem et multis diebus ibi morabatur, doctores atque sacerdotes instruens qui credebant in eum, ut tibi dicam in Sermonibus Domini. Et quia uitia Pharisaeorum et quorundam scribarum publice arguebat, multi eum odio habebant, non solum qui nesciebant eum esse Messiam, sed etiam qui ex Scripturis coniciebant ${ }^{662}$ quod ipse esset. Vnde aliqui dicebant: "Sit Messias centies, ego non accepto ipsum". Nam non erat hominibus ${ }^{663}$ manifestum quod Messias esset Deus, sed solum propheta magnus qualis fuerat Moises. Si enim ipsum Dominum gloriae, hoc est, Deum Verum cognouissent, numquam crucifixissent. Tamen plurimi inimicorum suorum credebant ipsum esse Messiam et Prophetam Magnum, sed odio et inuidia ducti, persequebantur eum. De his ipse dixit: Nunc autem uiderunt et oderunt. Multi enim agnitam ueritatem impugnant ${ }^{664}$, quae est summa peruersitas hominum.

Tunc ego dixi: Mi domine, quomodo ille sanctus et benedictus puer sapientia crescebat coram Deo et hominibus, qui semper fuit sapientia plenus?

Respondit angelus: Notum id etiam apud uos est. Sapientia illius animae, quae uniformis semper fuit, non fuit aucta ${ }^{665}$ neque creuit, sed multa per sensus accepit multaque expertus est quae antea expertus non fuerat. Creuit ergo non cognitio incognitorum ${ }^{666}$, sed cognitio eorumdem alio modo cognoscendi. Non enim uia sensus cognitionem omnium semper habuit, immo multorum numquam cognitionem per sensus habuit. Multa enim sunt quae oculus eius non uidit neque auris audiuit neque sensus alius sensit et ita neque a sensu accepit.

Tunc ego ${ }^{667}$ : Quid opus fuit anima Christo? Nonne diuinitas potest supplere uicem anime?

Respondit: Subtilis ${ }^{668}$ es in ista interrogatione ${ }^{669} . \mathrm{An}^{670}$ ignoras Deum partem esse non posse, quia omnis pars eo quo pars dicitur ${ }^{671}$ imperfecta est? Informare

659 in eum] in dictum Iesus $Q 660$ renuente] remeanente $H$; ueniente $I R \quad 661$ matri] Mariae matri eius $Q 662$ coniciebant] coniectabant IRV 663 hominibus] omnibus IRV 664 impugnant] impugnabant $R$; imputabant $Q \quad 665$ aucta] augmentata $E K \quad 666$ incognitorum] incognitiorum $Q$; cognitorum IRV 667 Tunc ego:] Tunc ego: Non bene superius intellexi $E K \quad 668$ Subtilis] Substantialis $P \quad 669$ es in ista interrogatione] est ista interrogatio $Q \quad 670$ Subtilis es in ista $\rightarrow$ 
Enquanto isto dizia, eis que chegam José e Maria com o grupo dos familiares e parentes. A maioria dos doutores e muitos sacerdotes acreditaram nele. Mas por recusa sua, dado que queria reunir discípulos a seu tempo e na idade adequada, não o seguiram.

Ele, porém, desceu com José e Maria para Nazaré e, Filho de Deus e Rei de todos, era submisso não apenas à mãe, mas também a José, pai putativo. Com sua profunda humildade, paciência, longanimidade, oração e contemplação, obediência e sujeição assídua, construía as moradas dos seus eleitos na casa de seu Pai. E por três vezes em cada ano subia a Jerusalém e aí se demorava muitos dias a instruir os doutores e os sacerdotes que acreditavam nele, como te direi n'Os Sermões do Senhor. E porque repreendia publicamente os vícios dos fariseus e de alguns escribas, muitos o odiavam, não só os que não sabiam que ele era o Messias, mas também os que, a partir das Escrituras, conjecturavam que ele o fosse. Daí que alguns dissessem: "Seja cem vezes Messias, eu não o aceito". Pois aos homens não era claro que o Messias fosse Deus, mas apenas grande profeta, como Moisés havia sido. Se, na verdade, o reconhecessem como o Senhor da Glória, isto é, o Deus verdadeiro, nunca o teriam crucificado. Contudo, muitos dos seus inimigos acreditavam que ele era o Messias e o Grande Profeta, mas, levados pelo ódio e pela inveja, perseguiam-no. Destes, disse ele: Mas agora viram e odiaram. ${ }^{[151]}$ Muitos, de facto, contestam a verdade reconhecida, o que representa a maldade máxima do homem.

Meu senhor, perguntei eu então, como crescia em sabedoria junto de Deus e dos homens aquele santo e bendito menino que sempre esteve cheio de sabedoria?

Também isso é entre vós conhecido, respondeu o anjo. A sabedoria desta alma, que foi sempre uniforme, nunca foi aumentada, nem cresceu; mas ele recebeu muita coisa pelos sentidos, experimentou muita coisa que não havia experimentado antes. Cresceu, pois, não o conhecimento das coisas desconhecidas, mas o conhecimento das mesmas sob outro modo de conhecer. De facto, não teve sempre o conhecimento de tudo pela via dos sentidos, e até, de muita coisa nunca teve conhecimento pelos sentidos. Há, na verdade, muita coisa que os seus olhos não viram, nem os ouvidos ouviram, nem outro sentido sentiu e, por isso, não recebeu pelos sentidos.

Que falta fazia a Cristo a alma, perguntei então? Não pode a divindade suprir a vez da alma?

És subtil nesta interrogação, respondeu. Ou desconheces que Deus não pode ser parte, porque toda a parte, pelo facto de se considerar parte, é imperfeita?

$\leftarrow$ interrogatione. An] Bone uir $E K \mathbf{6 7 1}$ quia omnis pars eo quo pars dicitur] quia omnis in eo pars dicitur $K$

[151] Jo 15:24. 
materiam et inherere imperfectionem dicit. Omnis autem imperfectio est a Deo releganda ${ }^{672}$. Et forsan ad ista responderi posset quod Deus posset supplere uicem partis neque tamen pars esse. Sed dic mihi quomodo fuisset homo uerus sine anima? Homo ${ }^{673}$ enim non requirit ad suum esse corpus et deitatem, sed corpus et animam. Sine anima uerus homo non fuisset et ita neque similis uobis extitisset.

Et ego iterum: Angele Dei, dicito mihi an Christus ante passionem suam umquam in caelum ascendit ad Patrem suum.

Respondit angelus: Christus Dominus, facta supradicta ${ }^{675}$ disputatione, reuersus est cum Maria, sua matre, et Ioseph in ciuitatem Nazareth. Et paucis elapsis diebus, Ioseph ex hac uita migrauit et adpositus est ad patres suos. Et eodem quoque tempore defuncta est primiceria et magistra puellarum quae in Templo Domini morabatur ${ }^{676}$. Tunc sacerdotes quaerere coeperunt aliquam matronam uenerabilem quam praeficerent puellis Templi et magistram consignarent quae esset uitae actiuae et contempletiuae et bonis moribus imbuta et redolens odorem bonorum exemplorum.

Dicebantque: O si possemus habere Mariam illam desponsatam Ioseph, quae plena est sanctitate et iustitia! Sed quia nupta est, non licet eam a uiro separari neque cum uiro hic manere.

Tunc unus sacerdotum dixit: Nupta est quidem Maria et filium habet quem audistis nuper in Templo tam acute disputantem. Sed uirgo est, ut multis ex nostris ${ }^{677}$ notum est neque unquam uiro copulata. Tale matrimonium non impedit quin Maria possit poni et elegi pro magistra puellarum. Ioseph enim numquam cognouit eam neque cognoscet, quia omnia illa sunt diuina et caelestia.

Alii dicebant: Etiam si Maria uirgo sit et experientia probatum est apud nos, illud tamen non est notum omnibus.

Et ita erat aliqualis dissensio inter eos. Tunc affuit unus qui diceret: Ioseph, uir Mariae, his diebus dum ego essem in Nazareth, defunctus est et Maria remansit uidua.

Cum sacerdotes hoc intellexissent, laetati sunt laetitia magna et gauisi gaudio magno et unanimiter elegerunt Mariam in primiceriam et matrem ac magistram atque dominam Templi puellarum. Miseruntque nuntios, primos ex sacerdotibus, cum equis et omnibus opportunis ac necessariis ut conducerent eam cum honore et gloria in Templum Domini ubi antea puella manserat.

672 releganda] amouenda $P 673$ Homo] Natura $P 675$ Respondit angelus: Christus Dominus facta supradicta] er. $\mathrm{H}$ et add: Aliqui opinati sunt statim, facta supradicta disputatione, Christum Dominum a sua matre licentia reuerenti habita ipsaque in Templo Domini dimissa, in caelum ascendisse ibique usque ad tempus baptismi Ioannis mansisse. Inducuntque ipsum Dominum de se loquentem: "Nemo ascendit in caelum nisi qui descendit de caelo". Et alibi: "Qui de terra est, de terra loquitur, qui autem de caelo uenit super omnes est". Nonnulli alii contemplantes senserunt quod..." 676 morabatur] morabantur $N Q 677$ nostris] nobis $N$; uobis $Q$ 
Dar forma e consistência à matéria representa imperfeição. Mas toda a imperfeição se deve remover de Deus, e talvez se possa responder a isso que Deus poderia suprir a vez da parte e, contudo, não ser parte. Mas, diz-me, como seria homem verdadeiro sem alma? O homem, realmente, para o ser, não requer corpo e divindade, mas corpo e alma. Sem alma não seria verdadeiro homem e, assim, não se apresentaria semelhante a vós.

Anjo de Deus, insisti, diz-me se Cristo, antes da sua Paixão, alguma vez subiu para junto de seu Pai? ${ }^{\text {[152] }}$

Cristo Senhor, respondeu o anjo, depois da referida disputa regressou com Maria, sua Mãe, e com José à cidade de Nazaré. E, decorridos poucos dias, José partiu desta vida e juntou-se a seus pais. Na mesma altura, morreu a zeladora e mestra das donzelas que residiam no Templo. Começaram, então, os sacerdotes a procurar uma senhora respeitável, que se distinguisse pelos bons costumes de uma vida activa e contemplativa e emanasse o odor dos bons exemplos, a quem entregassem a responsabilidade das donzelas do Templo e a nomeassem como mestra.

Oh! se pudéssemos ter Maria, diziam, aquela que é casada com José, ela que é cheia de santidade e justiça! Mas, dado ser casada, nem se pode separá-la do marido, nem pode viver aqui com ele.

É verdade, disse então um dos sacerdotes, que Maria é casada e tem um filho, a quem recentemente ouvistes discutindo no Templo com tanta subtileza. Mas é virgem, como é do conhecimento de muitos de nós, e nunca se ligou a um homem. Esse matrimónio não impede que Maria possa ser considerada e escolhida para mestras das donzelas. Pois nunca José a conheceu, nem conhecerá, porque essas são coisas do âmbito divino e celeste.

Ainda que Maria seja virgem, diziam outros, e entre nós isso está provado pela experiência, isso, contudo, não é de todos conhecido.

E havia alguma dissensão entre eles. Chegou, então, um que disse: José, o marido de Maria, morreu por estes dias, enquanto eu estava em Nazaré, e Maria ficou viúva.

Quando os sacerdotes se aperceberam disso, regozijaram-se com grande alegria e folgaram de grande contentamento e, por unanimidade, escolheram Maria para zeladora, mãe e mestra e responsável das donzelas do Templo. E mandaram como mensageiros os mais importantes sacerdotes, com montadas e tudo o que era necessário, para com dignidade e honra a conduzirem ao Templo do Senhor, onde antes havia estado como donzela.

[152] "Alguns, respondeu, opinam que Cristo Senhor, logo depois da referida disputa, tendo obtido autorização de sua Mãe, depois de a deixar no Templo, terá subido ao Céu e aí permanecido até ao baptismo de João. E aduzem o próprio Senhor, ao falar de si: Ninguém sobe ao Céu a não ser aquele que do Céu desceu. E noutro lugar escreve-se: Quem é da Terra, fala da Terra, mas quem veio do Céu, está acima de todos." Assim resumem esta passagem os manuscritos que a suprimem. 
Interim Dominus Iesus consolatus est Matrem suam super mortem Ioseph. Narrauitque ei quomodo sacerdotes eam elegerant in magistram ${ }^{678}$ Templi et hortatus est eam ut acceptaret talem electionem. Et eo magis quia oportebat eum ascendere in Caelum ad Patrem suum et fabricare ac praeparare in caelo empyrio mansiones sanctis et electis suis. De quo Maria ualde maesta effecta est. Noluisset enim uel in ictu oculi a filio suo separari. Tamen cognoscens uoluntatem Dei, filio licentiam et benedictionem maternam petenti concessit, licentiam et maternam benedictionem dedit ${ }^{679}$. Et statim Dominus Iesus abiit in caelum. Et nuntii uenerunt et cum magna solemnitate exposuerunt Mariae electionem de ipsa factam et instantes rogabant ut uellet consentire tam piis et sanctis uotis. Illa uero ex humilitate se non iudicabat dignam tali gradu. Tamen agnoscens uoluntatem Dei circa se, consensit et cum sacerdotibus et comitiua sanctarum mulierum et honestorum uirorum transiuit, uenit et intrauit in Templum Domini. Ibique sanctissime uixit puellasque uerbo et exemplo instruxit quousque Dominus Iesus reuersus est ad eam de Caelo, anno quinto decimo imperii Tiberii Caesaris, quando Ioannes Baptista praedicare coepit.

Christus autem Dominus ad Patrem et Spiritum Sanctum ascendens, in Caelo Empyrio fabricabat mansiones, praecipuam pro sua Genitrice Maria, pro Ioanne Baptista et Ioseph et apostolis et sanctis illis patribus antiquis, pro prophetis, pro patriarchis, pro martiribus et confessoribus, pro doctoribus, pro uirginibus, pro quibuslibet aliis electis et praedestinatis et saluandis omnibus secundum diuersa merita. Et in hoc fuit occupatio sua illis annis ut unicuique propriam mansionem et locum deputaret et consignaret. Ideo dicebat: In domo Patris mei mansiones multae sunt, si quominus dixissem uobis, quia uado parare uobis locum, hoc est, si non essent in domo Patris mei multae mansiones iam a me uobis praeparatae, dixissem uobis, quia uado praeparare uobis locum. Sed non dico hoc quia iam paraui uobis locum. Vnde de illo dicebat Ioannes: Qui de Terra est, de Terra loquitur. Qui autem de Caelo uenit, super omnes est. Christus ergo ad praedicandum de caelo uenit. Vnde ipse dicebat: Nemo ascendit in Caelum nisi qui de Caelo descendit. Sed quomodo descendere potuisset nisi prius ille ${ }^{680}$ ascendisset? Ascendit ergo ut descenderet et descendit quia ascenderat. Ascendere autem oportuit ne otiosus ante tempora praedicationis et exercitii in Terra maneret, sed sedes suas unicuique ab ipso redimendo pararet.

Hoc nonnulli ex uestris contemplando senserunt ${ }^{681}$.

678 magistram] primiceriam $E K \quad 679$ concessit, licentiam et maternam benedictionem dedit.] concessit, dedit. $O Q$; concessit. $H 680$ ille] illuc JKNO 681 Respondit angelus: "Cristus Dominus, facta supradicta disputatione (...) Sed sedes suas unicuique ab ipso redimendo pararet. Hoc nonnulli ex uestris contemplando senserunt.] Aliqui opinati sunt Christum Dominum statim facta supradicta disputatione, a sua matre licentia (reuerenter $a d d$. $A$ ) habita (qui sua licentia reuerenti habita $R$ ) ipsaque in Templo Domini dimissa, in caelum ascendisse ibique usque ad tempus baptismi Ioannis mansisse. Inducuntque ipsum Dominum de se loquentem: "Nemo ascendit in caelum nisi qui descendit de caelo". Et alibi scribitur: "Qui de terra est, de terra loquitur, qui autem $\rightarrow$ 
Entretanto, o Senhor Jesus consolou sua Mãe relativamente à morte de José. Contou-lhe como os sacerdotes a haviam escolhido para mestra do Templo e aconselhou-a a aceitar essa eleição. E tanto mais que ele precisava de subir ao Céu para junto de seu Pai e construir no Céu Empíreo moradas para os seus santos e seus eleitos. Maria ficou muito triste com isso. Nunca tinha querido separar-se de seu Filho nem um pestanejar de olhos. Ao conhecer, contudo, a vontade de Deus, concedeu autorização ao Filho, que lhe pedia autorização e a bênção materna, e deu-lhe a bênção materna. E imediatamente o Senhor Jesus partiu para o Céu. E os mensageiros chegaram e com grande solenidade expuseram a Maria a escolha que dela foi feita e pediam insistentemente que assentisse em votos tão piedosos e tão santos. Mas ela, por humildade, não se julgava digna de tão alta posição. Conhecendo, porém, a vontade de Deus a seu respeito, assentiu e pôs-se a cominho com os sacerdotes e um cortejo de santas mulheres e de respeitáveis varões, chegou e entrou no Templo do Senhor. Viveu aí santamente e, com a palavra e o exemplo, instruiu as donzelas até o Senhor Jesus voltar do Céu para junto dela, no décimo quinto ano do governo de Tibério César, quando João Baptista começou a pregar.

Subindo para junto de seu Pai e do Espírito Santo, Cristo Senhor construía habitações, a principal para Maria, sua Mãe, para João Baptista, para José, para os Apóstolos e para os Santos Padres antigos, para os Profetas, para os Patriarcas, para os Mártires e Confessores, para os Doutores, para as Virgens e para outros eleitos e predestinados e para os que deveriam ser salvos, para todos, segundo os diversos méritos. E nisto consistiu a sua ocupação naqueles anos, tendo em vista atribuir e confirmar a cada um o lugar e a morada própria. Por isso dizia: Na Casa de meu Pai há muitas moradas. Se assim não fosse, ter-vo-lo-ia dito, pois vou preparar-vos um lugar. ${ }^{[153]}$ Isto é, se na Casa de meu Pai não houvesse muitas moradas já por mim preparadas para vós, ter-vo-lo-ia dito, uma vez que vou preparar-vos um lugar. Mas não o digo, porque vos preparei já esse lugar. Por isso João afirmava acerca dele: Aquele que é da Terra fala das coisas terrenas. Mas aquele que vem do Céu é superior a todos. ${ }^{[154]}$ Portanto, Cristo veio do Céu para pregar. Por isso ele dizia: Ninguém sobe ao Céu a não ser aquele desceu do Céu ${ }^{[155]}$ Mas como poderia descer se ele não tivesse subido primeiro? Subiu, pois, para descer e desceu porque havia subido. Era preciso subir para não ficar inactivo na Terra antes do tempo da pregação e da actividade, mas preparar para cada um a ser por si redimido as moradas próprias.

Foi disto que muitos de vós se deram conta ao meditarem.

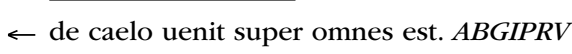

[153] Jo 14:2

[154] Jo 3:31

[155] Jo 3:13 
Alii ex uestris dicunt quod isti non intellexerunt mysterium redemptionis humanae ${ }^{682}$. Filius enim Dei ${ }^{683}$ factus est homo postquam homo peccauerat ut, poenis et miseriis hominum subiectus, absque peccato hominem a poenis et miseriis eriperet etiam et potissime a poena peccati. Vnde in paupertate uenit, non in diuitiis et seruire ac ministrare, non ministrari aut seruiri. Non uenit ut laute, gloriose ${ }^{684}$ ac splendide uiueret et deliciis caelestibus abundaret. Sed cum diues et deliciis affluens esset, propter uos egenus et inops factus est. Si autem in caelo tam diu mansisset et in paradisi deliciis decem et septem ${ }^{685}$ annis uixisset, uideretur uenisse pro quadam sui maiestate et pro glorificando absque sudoribus illo homine assumpto. Quod ante peccatum fuisset, post peccatum fieri non decuit. Sed oportuit ut iniquitates omnium uestrorum ponerentur in Homine illo qui omnibus uobis meruit.

Aiunt igitur isti qui stulti sunt illi ${ }^{686}$ qui animam in Christo negant, nam corpus solum mereri non potest. Deus solus nullo pacto mereri potest, quia militum ${ }^{687}$ est mereri, regis uero concedere pro meritis praemium. Qui ergo meretur, ab alio praemium praestolatur. Poterat tamen Deus quodcumque opus Dei Hominis acceptare pro expiatione peccati humani generis. Et ita ipse potuisset ante annum duodecimum et post trigesimum uel quasi trigesimum ${ }^{688}$, quia trigesimum iam compleuerat, sed trigesimum primum nondum expleuerat, mereri sufficienter et abundanter absque quod illis annis decem et septem ${ }^{689}$ miserias uestras subisset. Non tamen ita fuit, quia non est congruum ut miser aliquo modo fiat felix et deinde iterum miser quia, quamuis a miseria congruum sit transire ad felicitatem, quia licet ascendere, sed transire a felicitate in miseriam non est congruum 690 neque licet sicut neque apud uos in gradibus dignitatis licet descendere.

Semper ergo usque ad mortem et post resurrectionem usque ad ascensionem sub caeli limitibus et corpulentia mansit et tunc primum ascendit.

Erat tamen in caelo empyrio intus, quia illud uidebat in diuina essentia ac si in illo esset. Et ita fabricabat mansiones uestras in caelo, uidendo illud ita perfecte et magis quam si in caelo esset et illud in Deo non uideret. Illa enim uisio qua res in Deo uidentur praecellit ${ }^{691}$ omnem uisionem.

Semper ergo erat in caelo et in terra, non solum in illis annis septem et decem $^{692}$, sed in omnibus aliis, antea et post. Et quia uidebat limpide et clare

682 Alii ex uestris dicunt quod isti non intellexerunt mysterium redemptionis humanae.] Sed isti non intellexerunt mysterium redemptionis humanae. ABGIPRV 683 Dei] Hominis $N K 684$ gloriose] gulose $O 685$ septem] octo $O P Q 686$ Aiunt igitur isti qui stulti sunt illi] Ex hoc uidere potes (potest $R$ ) quam stulte illi loquebantur (loquuntur $K$; loquantur $E$; loquentur $G$ ) $E G I K P R V \rightarrow$ 
Dizem outros de vós que estes não entenderam o mistério da redenção do homem. Realmente o Filho de Deus fez-se homem depois de o homem pecar para que, sujeito às penas e às misérias dos homens, sem pecado, arrancasse o homem às penas e às misérias, também e sobretudo, à pena do pecado. Daí que tenha vindo na pobreza, não na riqueza, e a obedecer e servir, não a ser servido e a ser obedecido. Não veio para viver sumptuosamente, com magnificência e luxuosamente e abundar em prazeres celestes. Mas, sendo rico e gozando de delícias, fez-se pobre e necessitado por causa de vós. Se tivesse permanecido no Céu por tanto tempo e tivesse vivido nas delícias do Paraíso por dezassete anos, pareceria que teria vindo para uma certa majestade própria e para glorificar sem esforço a natureza humana. O que teria existido antes do pecado, não convém que se verifique depois do pecado. Mas seria conveniente que todas as vossas injustiças fossem colocadas no Homem que para todos vós adquiriu merecimentos.

Dizem, portanto, estes que são insensatos aqueles que negam a existência da alma em Cristo, pois o corpo só não pode merecer. Deus, só, por condição alguma pode merecer, porque merecer é próprio do soldado, enquanto do rei é próprio conceder o prémio pelos merecimentos. Quem merece, pois, espera de outrem o prémio. Deus, porém, podia aceitar qualquer obra de Deus Homem pela expiação do pecado do género humano. E, assim, antes do décimo segundo ano e depois do trigésimo ou quase trigésimo, porque completara já o trigésimo, mas ainda não completara o trigésimo primeiro, teria podido merecer bastante e abundantemente, sem o que, ter-se-ia sujeitado às vossas misérias. Contudo, não foi assim, porque não é adequado que um infeliz de algum modo se torne feliz e, depois, novamente infeliz, uma vez que, embora seja adequado passar da miséria à felicidade, porque é possível subir, passar, porém, da felicidade à miséria não é adequado nem conveniente, do mesmo modo que nem entre vós é adequado descer nos graus da dignidade.

Sempre, portanto, até à morte e depois, da Ressurreição até à Ascensão, permaneceu debaixo dos limites do Céu e em corpo e, então, subiu pela primeira vez.

Estava, todavia, no Céu Empíreo interiormente porque o via na essência divina como se estivesse nele e, por isso, construía as vossas moradas no Céu vendo-o de tal modo perfeitamente e mais do que se estivesse no Céu e o não visse em Deus. De facto, aquela visão pela qual as coisas são vistas em Deus ultrapassa toda a visão.

Estava, portanto, sempre no Céu e na Terra, não apenas naqueles dezassete anos, mas em todos os outros, antes e depois. E uma vez que via límpida e cla-

$\leftarrow \mathbf{6 8 7}$ militum] meritum $P \mathbf{6 8 8}$ quasi trigesimum] in trigesimo primo $P$; quasi $31 Q 689$ decem et septem] decem et octo $P ; 18 Q 690$ non est congruum] non congruit $E G H K O P Q 691$ praecellit] praecedit $E H J K M P Q$; praecessit $R 692$ septem et decem] $18 Q$ 
caelestia, in caelo erat semper. Et quia humana curabat, de caelo descendebat. Et quia ista humana in caelum dirigebat, ideo post descensum ${ }^{693}$ in caelum iugiter ascendebat. Per curam itaque et prouidentiam humanarum descendebat. Et quia sursum omnia reducebat ${ }^{694}$, ascendebat. Et quia semper caelestia illa uidebat, iccirco in caelo semper erat.

Nemo ergo ${ }^{695}$ hoc modo descendit de caelo nisi qui descendit ${ }^{696}$ non solum ut iuuaret ${ }^{697}$, sed ut homo fieret. Et iste est Filius Dei primum, deinde hominis, qui semper erat in caelo, illud intuendo et in eo domum Dei aedificando. Ipse quoque [f1. 112] de caelo descendit propter uestram salutem, non mutatione loci, sed assumptione humanitatis. Quia exinaniuit seipsum formam serui accipiens, ideo descendit. Deinde Deus eum exaltauit et dedit illi nomen super omne nomen, ideo ascendit. Et tamen semper in caelo erat, in diuinitate Patri aequalis.

Descendit ergo per effectum incarnationis, Deus non homo. Ascendit exaltatus, Deus Homo. In caelo semper erat ille Filius Hominis qui semper beatus, semper caelum et omnia uidens. Qui ergo de caelo uenit, super omnes est, quia ille qui carnem humanam assumpsit est Dominus uniuersorum.

Quid autem de his tenendum est relinquitur determinationi pastoris electi qui haec declarabit et alteram harum opinionum reprobabit.

Nunc sileo et transeo, quamuis agnoscere posses ${ }^{698}$ cui ego magis adhaereo. ${ }^{699}$ "

His dictis, subito reductus sum ad locum unde raptus fueram, multis me expectantibus et quaerentibus ubi essem ${ }^{700}$.

693 descensum] discensum $P$; discessum $J Q 694$ reducebat] dirigebat $N 695$ de caelo descendebat. (...) in caelo semper erat. Nemo ergo] de caelo descendebat. Nemo ergo IRV 696 Nemo ergo hoc modo descendit de caelo nisi qui descendit] Nemo hoc modo descendit de caelo nisi qui ascendit $E G K N$; Nemo ergo hoc modo ascendit in caelum nisi qui descendit de caelo $Q 697$ iuuaret] uiueret $I 698$ posses] possis $E$;possim $K 699$ Quid autem de his (...) quamuis agnoscere posses cui magis adhaereo.] om. GIRV $\mathbf{7 0 0}$ ubi essem.] Laus Deo. Et sic est finis quinti raptus $K$ 
ramente as coisas celestes, estava sempre no Céu. E porque cuidava das realidades humanas, descia do Céu. E porque encaminhava para o Céu estas realidades humanas, por isso, depois de descer, subia continuamente ao Céu. E, assim, pelo cuidado e pela providência antecipada das coisas humanas, descia. E porque tudo encaminhava para cima, subia. E uma vez que via sempre as realidades celestes, estava, por isso, sempre no Céu.

Ninguém, pois, desceu do Céu, deste modo, senão o que desceu não só para ajudar, mas para se tornar homem. E esse é, primeiro, o Filho de Deus, depois, do homem, que estava sempre no Céu, vendo-o e construindo nele a casa de Deus. Desceu também [f1. 112] do Céu pela vossa salvação, não pela mudança de lugar, mas pela assunção da humanidade. Porque se aniquilou a si mesmo assumindo a forma de servo, por isso desceu. Depois, Deus exaltou-o e deu-lhe um nome que está acima de todo o nome, ${ }^{[156]}$ por isso subiu. E, contudo, estava sempre no Céu, igual ao Pai em divindade.

Desceu, pois, por efeito da incarnação, enquanto Deus não homem. Subiu exaltado, enquanto Deus Homem. Estava sempre no Céu aquele Filho do Homem que foi sempre bem-aventurado, sempre viu o Céu e todas as coisas. Portanto, o que vem do Céu está acima de todos, porque o que assumiu a carne humana é o Senhor do Universo.

Mas o que se deve reter de tudo isto, deixa-se à determinação do Pastor escolhido, que dará estas coisas a conhecer e reprovará uma destas opiniões.

Agora calo-me e passo adiante, embora pudesses reconhecer a qual me ligo mais.

Dito isto, fui de imediato reconduzido ao lugar de onde havia sido arrebatado, havendo muitos à minha espera e a querer saber onde tinha estado. 


\section{RAPTVS SEXTVS}

Paucis postmodum reuolutis diebus, ${ }^{1}$ iterum raptus sum et cantica angelorum atque nostri generis ${ }^{2}$ sanctorum audiui.

Tunc angelus accessit mihique dixit: Qualiter Deus futura ${ }^{3}$ agnoscat neque tamen uestrum liberum arbitrium ullo pacto impeditur, satis tibi ostensum est. Similiter, quali modo Verbum carni uestrae fuerit unitum, abunde diximus. Nunc duo alia difficillima declarare oportet uidelicet de praesentia corporis Christi in altari uestro et de mysterio Supernae ${ }^{4}$ Trinitatis ut Pastor futurus sciat inter tot uestrorum opiniones quid sentire et quid docere oporteat ${ }^{5}$. Nam Dominus noster Iesus Christus, unus ${ }^{6}$ cum Patre et Spiritu Sancto Deus, uoluit corpus assumptum sicut et animam uniuersis decorare donis et muneribus atque priuilegiis insignire. Hoc admirandum instituit sacramentum innumeris miraculis plenum ex quo secuta sunt plurima bona. Primo, diuinae potentiae et eius immensitatis et infinitae magnitudinis ostensio ut, quae impossibilia omnibus hominibus uiderentur, illa iam facta esse et fieri crederentur ${ }^{7}$. Secundo, gloria ingens inde concessa est corpori Christi $^{8}$ ut in tot ac tantis locis simul esset et tam paruulo loco contineretur et cum alio corpore simul esset ${ }^{9}$ et multa alia quae, si alias non considerasti, nunc quando ea tibi reserauero considerabis. Tertio, orta est ex hoc generi uestro gratia et utilitas maxima. Hoc enim cibo $^{10}$ et hoc potu uitam adipiscimini ${ }^{11}$ aeternam et gratiam acquiritis ampliorem.

Dominus autem primo de hoc saepius locutus est ad discipulos suos et alios fideles, quorum plerique ab eo propter talia dicta recesserunt, quia capere non poterant qualiter homines carne sua et sanguine suo cibaret et potaret. Quemadmodum ergo creditis corpus Christi esse ibi reali praesentia et non solum in figura quadam, sed in ueritate, ita firmiter credatis nec paruitas loci sit uobis impedimento. Nam dictis ${ }^{12}$ illis uerbis: Hoc est corpus meum super panem

1 postmodum reuolutis diebus] postmodum diebus $I K O$; postmodum elapsis diebus $V 2$ generis] ordinis $P \quad 3$ futura] uniuersa $N \mathbf{4}$ Supernae] Sanctissime $P$; Supreme $Q \mathbf{5}$ quid sentire et quid docere oporteat] quid sentire. $O 6$ unus] una $Q 7$ crederentur] uiderentur JNP 8 Christi] Christo $I V \rightarrow$ 


\section{SeXto Arrebatamento}

Logo depois, decorridos poucos dias, fui de novo arrebatado e ouvi os cânticos dos anjos e dos santos da nossa condição.

Aproximou-se então o anjo e disse-me: Foi-te suficientemente mostrado como Deus conhece o futuro e, contudo, o vosso livre arbítrio não é, de modo algum, anulado. Descrevemos inteiramente também de que modo o Verbo se uniu à vossa carne. Há agora que esclarecer duas outras questões bem difíceis, ou seja, a da presença do corpo de Cristo no vosso altar e a do mistério da Suprema Trindade, para que o futuro Pastor saiba, no meio de tantas opiniões vossas, o que é conveniente saber e o que é conveniente ensinar. Pois, nosso Senhor Jesus Cristo, Deus único com o Pai e o Espírito Santo, quis ornar com todos os dons e embelezar com todas as graças e privilégios o corpo assumido bem como a alma. Instituiu este admirável sacramento repleto de inúmeras maravilhas, do qual decorrem incontáveis bens. Em primeiro lugar, a manifestação do poder divino, da sua imensidade e infinita grandeza, de modo que acreditassem que aquilo que a todos os homens parecia impossível se tinha verificado já e se estava a verificar; em segundo lugar, a imensa glória que, a partir daí, foi concedida ao corpo de Cristo, a ponto de estar em tantos lugares ao mesmo tempo, e estar contido num lugar tão pequeno, e estar simultaneamente com outro corpo, e muitas outras coisas a que, se antes não atendeste, atenderás agora, quando tas desvendar; em terceiro lugar, nascem daqui para o género humano a maior graça e o maior proveito. Por intermédio deste alimento e desta bebida alcançareis a vida eterna e obtereis graça mais abundante.

Mas o Senhor falou muitas vezes disto, primeiro aos seus discípulos e outros fiéis, muitos dos quais se afastaram dele por causa dessas afirmações, porque não podiam compreender de que modo mataria a fome e a sede aos homens com a sua carne e o seu sangue. Do mesmo modo, pois, que acreditais que o corpo de Cristo aí se encontra em presença real e não só em determinada figura, mas em verdade, assim o acrediteis firmemente e nem a pequenez do lugar se cons-

$\leftarrow \mathbf{9}$ et tam paruulo loco contineretur et cum alio corpore simul esset] add. $M$ in marg. a. $m$. 10 Hoc enim cibo] Hoc est, in cibo $Q \mathbf{1 1}$ adipiscimini] adipiscitis $I$ ( $M$ adipiscimini $s u b$. ras.) $O V 12$ dictis] dicitis $M$ 
triticeum coctum, cum aqua communi et naturali ${ }^{13}$ coagulatum, subito ibi fit corpus Christi. Sed non sufficiunt illa sola uerba, sed aliqua sunt praemittenda sic ut intellegi possit sacerdotem non loqui in propria persona, sed in persona Christi, ut puta: "Dominus Christus accepit panem et benedixit atque dixit: Hoc est corpus meum", uel alio modo, prout uolueris. Similiter super uinum uuarum uitis fluibile ${ }^{14}$ cuiuscumque coloris fuerit. Dictis his uerbis: Hic est sanguis meus uel calix sanguinis [f1. 113] mei, subito aderit ibi sanguis Christi. Sed illa uerba sola non sufficiunt, nisi aliqua praeponantur ${ }^{15}$ per quae intelligatur sacerdotem loqui in persona Christi. Et Latinus dicat illa uerba super panem azimum, Graecus uero super fermentatum, ad hoc ut sine damno proprio conficiat. Vnde Dominus permisit Graecos in pane fermentato conficere ut sciretur quod in utroque confici potest. Veruntamen si minister sine suo damno hoc sacramentum conficere uoluerit, oportebit omnia illa obseruare quae et in uestro missali continentur et in statutis quoad locum, tempus, indumenta, aquam, lumen, socium, altare, calicem, et ipsius quoad ieiunium et animi dispositionem pertinent et spectant. Inter consecrationem unam et alteram sacerdos nulla uerba interponat. Neque his quae ibi a patribus conscripta sunt quicquam addat. Quaedam tamen Pastor ille addet et nomina quorundam sanctorum ex deuotione apponet. Et quod nunc non licet tunc decreto eius licebit. Proferantur ${ }^{16}$ quoque illa uerba sic ut ab aliquo prope existente ${ }^{17}$ audiri possent, quia sacramentum est signum sensibile.

Nemo autem quantumcumque ${ }^{18}$ iustus conficere potest ordinarie $^{19}$ nisi sit sacerdos rite ordinatus. Sacerdos uero quilibet potest quantumcumque malus, haereticus, scismaticus, dummodo uelit et intendat ${ }^{20}$ ea intentione illud facere qua ordinatum est a Christo uel qua utuntur Christiani. Nam si sacerdos non intenderet consecrare uel alia intentione intenderet, nihil faceret. Intentio namque conferentis $^{21}$ quodcumque sacramentum requiritur uidelicet ut tunc ita uelit uel antea uoluerit, quam uolitionem contraria uolitione ${ }^{22}$ non interrumpit ${ }^{23}$. Sed si baptizans baptizare non intenderet neque ea intentione qua Christiani baptizant baptizaret, Deus suppleret, quia ignorantia illa homini baptizato est inuincibilis. Ideo excusat a peccato. Scito enim et firmiter crede hominem numquam damnari pro eo quod non fecit ${ }^{24}$ id quod facere non potuit uel scire non ualuit.

13 communi et naturali] elementali $Q 14$ fluibile] fruibile $O 15$ praeponantur] preparantur $J 16$ Proferantur] Proferentur JM; Proferebantur IV 17 existente] assistente IOV 18 quantumcumque] quicumque $N \mathbf{1 9}$ ordinarie] ordinate $Q$; ordinare $V \mathbf{2 0}$ uelit et intendat] uelit et intendit $I$; credat et intendat $Q 21$ conferentis] conficientis $Q 22$ uolitione] uolutio $N$ (sup. ras.) 23 interrumpit] interrumpat $N Q \mathbf{2 4}$ fecit] facit $Q V$ 
titua para vós em impedimento. Pois, pronunciadas sobre o pão de trigo cozido, amassado com água vulgar e natural, as palavras: Isto é o meu corpo, ${ }^{[157]}$ logo o corpo de Cristo se torna aí presente. Mas não bastam apenas essas palavras. Outras se devem antepor, de modo que se possa compreender que o sacerdote não fala na própria pessoa, mas na pessoa de Cristo, como por exemplo: Cristo Senhor tomou o pão e abençoou-o, e disse: Isto é o meu corpo; ou de outro modo, conforme pretenderes. E o mesmo sobre o vinho das uvas da videira enquanto líquido, seja de que cor for. Pronunciadas estas palavras: Este é o meu sangue ${ }^{[158]}$ ou o cálice do meu sangue, [f1. 113] imediatamente se torna aí presente o sangue de Cristo. Mas só estas palavras não bastam, a menos que se anteponham algumas, pelas quais se entenda que o sacerdote fala na pessoa de Cristo. E pronuncie o latino essas palavras sobre o pão ázimo, e o grego sobre o fermentado, para que se realize sem dano próprio. Por isso é que o Senhor permitiu que os gregos celebrem com pão fermentado, para que se saiba que se pode realizar com ambos. Mas, entretanto, se o celebrante quiser realizar este sacramento sem dano seu, convirá que se observe tudo aquilo que se contém no vosso Missal e nos Rituais, quanto a lugar, tempo, paramentos, água, luz, acólito, altar, cálice. E relativamente a si, no que respeita e se relaciona com o jejum e a disposição da alma. Não ponha o sacerdote palavra nenhuma entre uma consagração e outra, nem acrescente nada às que aí estão escritas pelos antepassados. Mas esse Pastor acrescentará e juntará, por devoção, os nomes de alguns santos. E o que hoje não é permitido, sê-lo-á então por decreto seu. Sejam também aquelas palavras proferidas de modo que possam ser ouvidas por quem esteja próximo, porque o sacramento é um sinal sensível.

Mas ninguém, por mais santo que seja, pode celebrá-lo ordinariamente se não for sacerdote ordenado segundo os ritos. Mas pode qualquer sacerdote, por mau, herético, cismático que seja, contanto que queira e se disponha a fazê-lo com a intenção com que foi mandado por Cristo ou de que usam os cristãos. Pois, se o sacerdote não pretendesse consagrar ou o pretendesse com outra intenção, nada faria. Requer-se, com efeito, a intenção de quem celebra qualquer sacramento, ou seja, que assim queira nesse momento ou tenha querido anteriormente sem interromper o seu propósito com um propósito contrário. Mas se aquele que baptiza não tivesse a intenção de baptizar e nem baptizasse com a intenção com que baptizam os cristãos, Deus supriria, porque essa ignorância é invencível para a pessoa baptizada e, consequentemente, escusa do pecado. Sabe, pois, e acredita firmemente que o homem nunca é condenado por não haver feito aquilo que não pôde fazer, ou não conseguiu saber.

[157] Mt 26:26; Mc 14:22; Lc 22:19.

[158] Mt 26:28; Mc 14:24. 
Prolatis itaque illis uerbis in momentulo siue, ut uestri dicunt, in ultimo instanti terminante ${ }^{25}$ totum tempus in quo uerba proferebantur, adest ibi corpus Christi. Dum ergo uerba profert nondum est ibi, prolatis, illico est ibi. Substantia panis quam uos neque uidetis neque gustatis neque olfatis neque tangitis neque auditis neque ullo sensu percipitis, prolatis uerbis illis, abscedit, non est amplius. Ibi remanet ${ }^{26}$ illa longitudo, latitudo et altitudo quae prius in substantia panis erat $^{27}$, sine ullo subiecto. Neque enim est in pane neque in alia substantia, sed manet per se diuina uirtute. Et in illa quantitate remanet odor panis et sapor et color et omnia alia accidentia quae in pane consequebantur quantitatem panis. Sola quantitas est sine subiecto, omnia alia accidentia sunt in quantitate. Scribe ut tibi dico quia et si tu non bene percipis, ille percipiet. Scribe quoque dubitationem illam utrum quantitas coloris sit alia res a colore uel sit ipse color suis partibus extensus ${ }^{28}$, quia apud uos aliqui tenent quod quantitas est alia res a substantia et qualitate ${ }^{29}$, alii uero quod eadem res sit quantitas cum illa re quae dicitur. Nolo ${ }^{30}$ tibi nunc declarare neque quae pars sit uera determinare. [f1. 114] Sed tempore futuro dabitur Pastori illi gratia et sensus ${ }^{31}$ quod intelliget hoc et multa alia propter quae quotidie altercamini. Quia ergo ibi omnia panis accidentia remanent, uos putatis iudicium sensus ${ }^{32}$ sequentes ita ibi esse panem post consecrationem sicut et ante. Sed non est amplius ibi panis, sed cum illis accidentibus est corpus Christi simul et in eodem loco cum illis ${ }^{33}$. Sed quomodo id possit fieri, postea declarabitur.

Corpus itaque Domini elegans et pulchrum totum est ibi ubi post consecrationem illa accidentia panis cernis. Nec putes illa accidentia esse in corpore Christi, sed per se sine subiecto existere, de quo uestri philosophi ualde mirantur. Et nota, dilectissime, quod si corpus Domini esset sine anima et sine sanguine tunc, prolatis consecrationis uerbis, ibi praesens fieret caro Christi sola sine anima et sine sanguine. Et si diuinitas non esset carni unita, ibi sola caro esset, ita quod diuinitas etsi ubique sit, non tamen tunc ibi esset gratia consecrationis ${ }^{34}$ uel ratione unionis. Quando uero diuinitas est unita ${ }^{35}$ ut nunc, tunc etiam si ubique ${ }^{36}$ non esset, fieret ibi ratione talis unionis. Quia ergo diuinitas ubique est et nullibi proprie ipsa incipit esse, nil de ipsa ulterius hic dicamus. Virtute consecrationis huius et Domini institutionis ibi primo est corpus cui, si anima fuerit unita et sanguis fuerit unitus ${ }^{37}$, comitabuntur corpus sicut et nunc sunt omnia simul in

$\mathbf{2 5}$ terminante] terminant $I \mathbf{2 6}$ amplius. Ibi remanet] amplius ibi. Remanet IJNOPQ $\mathbf{2 7}$ panis erat] permanserat $J \mathbf{2 8}$ extensus] coextensis $J N P$; coextensibus $M \mathbf{2 9}$ alia res a substantia et qualitate] alia res et substantia a qualitate $V \mathbf{3 0}$ quae dicitur. Nolo ( $M$ add. sup. lin. a. $m$. Illam quaestionem)] quae dicitur. Illam quaestionem nolo $I O$; quae dicitur quanta. Illam quaestionem nolo $P Q$; quae dicitur illam quaestionem. Nolo $V \mathbf{3 1}$ Sed tempore futuro dabitur Pastori illi gratia et sensus] Sed $\rightarrow$ 
$\mathrm{E}$, assim, pronunciadas estas palavras, no momento ou, como dizem os vossos, no último instante que encerra todo o tempo em que as palavras eram proferidas, se torna presente aí o corpo de Cristo. Portanto, enquanto profere as palavras, ainda lá não está; proferidas as palavras, imediatamente se torna presente. A substância do pão, que nem vedes, nem saboreais, nem cheirais, nem tocais, nem ouvis, nem apreendeis por sentido algum, pronunciadas essas palavras, desaparece, deixa de aí estar. Permanecem sem sujeito algum o comprimento, a largura e a espessura que antes estavam na substância do pão. Não estão no pão nem noutra substância, mas permanecem per se, por acção divina. E nessa quantidade permanecem o cheiro, o gosto e a cor do pão e todos os outros acidentes que acompanhavam no pão a quantidade do pão. Só a quantidade está sem sujeito, todos os outros acidentes estão na quantidade. Escreve como te digo porque, mesmo que tu não entendas bem, ele entenderá. Escreve também aquela dúvida, se a quantidade da cor é uma coisa distinta da cor ou é a própria cor estendida às sua partes, porque entre vós defendem alguns que a quantidade é uma coisa distinta da substância e da qualidade, enquanto outros defendem que a quantidade é a mesma coisa que aquela outra coisa de que se fala. Não pretendo tornar-te conhecida agora essa questão, nem determinar qual é a parte verdadeira. [f1. 114] Mas, no futuro, há-de ser concedida a esse Pastor graça e capacidade, de modo que há-de entender isto e muitas outras coisas em razão das quais discutis todos os dias. Pois, uma vez que todos os acidentes do pão aí se mantêm, julgais vós, seguindo o juízo dos sentidos, que também o pão aí está depois da consagração, como antes. Mas aí já não está o pão, mas com esses acidentes e no mesmo lugar com eles está simultaneamente o corpo de Cristo. Como pode, porém, isso acontecer, será esclarecido depois.

E, assim, o corpo do Senhor, elegante e belo, está todo onde depois da consagração vês os acidentes do pão. E não julgues que esses acidentes estão no corpo de Cristo, mas subsistem per se, sem sujeito, coisa de que muito se admiram os vossos filósofos. E nota, caríssimo, que se o corpo do Senhor estivesse sem alma e sem sangue, então, proferidas as palavras da consagração, tornar-se-ia aí presente só a carne de Cristo sem a alma e sem o sangue. E se a divindade não estivesse unida à carne, só aí estaria a carne, de modo que, embora a divindade esteja em toda a parte, não estaria aí, contudo, em razão da consagração ou por força da união. Mas quando, como agora, a divindade se acha unida, então, mesmo se não estivesse em toda a parte, tornar-se-ia aí presente em razão dessa união. Porque, pois, a divindade está em toda a parte e em parte alguma começa ela propriamente a estar, nada mais diremos aqui sobre ela. Por força deste sacra-

$\leftarrow$ ipse futuro dabitur Pastori illi gratia et sensus $J$; Sed Deus futuro dabit Pastori illi gratiam et sensum $Q 32$ sensus] sensuum $I V 33$ cum illis] cum illis quamuis ibi sit trina dimensio quae erat in pane. Ecce nolens dixi quantitatem esse aliam a re quanta. $Q \mathbf{3 4}$ consecrationis] conseruationis $V 35$ Quando uero diuinitas est unita] Si uere diuinitas esset unita $Q 36$ etsi ubique sit, (..) tunc etiam si ubique non esset] etsi ubique non esset $P 37$ si anima fuerit unita et sanguis fuerit 
sacramento illo. Eodem modo nunc sunt omnia illa in calice sub speciebus uini, sed alio ordine. Nam, prolatis illis uerbis, primo est ibi sanguis qui, si non sit in corpore, ut tempore mortis, solus ibi erit sine corpore et anima. Si uero fuerit in corpore mortuo, ibi etiam erit corpus mortuum cum sanguine illo. Si autem fuerit in corpore uiuo mortali, ut in cena, uel immortali, ut nunc est, ibi cum sanguine adueniet tale corpus cum anima. In consecratione itaque panis, primo est ibi corpus Christi. Sanguis, anima et ipsorum accidentia concomitantur. Et non solum accidentia anime aut sanguinis, sed etiam ipsius corporis sunt ibi per comitantiam. Vnde, si corpus Christi nullum accidens haberet, sine ullo accidente ibi esset uidelicet sine quantitate et sine qualitate. Et quamuis omnia accidentia quae adueniunt sint ibi per concomitantiam, illa tamen quae sunt accidentia ipsius corporis prius intelliguntur aduenire quam accidentia animae et sanguinis. In consecratione uero uini, primo est ibi sanguis, ex consequenti corpus et anima et omnium trium accidentia. Et inter accidentia omnium trium ${ }^{38}$, prius comitantur accidentia sanguinis quam corporis et animae. Totus ergo Christus sumitur nunc sub utraque specie accidentium panis et uini.

Reuertamur, carissime, quia uideo te admiratione plenum. Sunt et alia in hoc sacramento admiranda. Nam panis omnibus accidentibus spoliatus, nudus, de illo loco recedit. Omnia ipsius indumenta et ornamenta remanent, ipse solus discedit. Nota bene, quia placebit summe illi cuius gratia haec scribuntur. Discedit uero in tempore totius [f1. 115] prolationis uerborum et, illo discedente, in ultimo ipsius discessus, hoc est, quando ibi panis non est tunc, simul cum non esse panis, est ibi esse corporis Christi ${ }^{39}$. Et hoc est quod inspirati a Deo, nescientes quid dicatis, dicitis: "Panis est transubstantiatus in carnem Christi". Non quia aliquid panis ibi remanserit uel in corpore Christi, sed quia panis abscessit, non per motum ${ }^{40}$ localem, sed diuina uirtute, non est amplius ibi. Corpus Christi est ibi, non deserendo locum priorem incipit esse in hoc uel illo loco. Vide mirabilia, in caelo est et in altari. Caelum non relinquendo, incipit esse in uno altari, immo in mille est. Et illa omnia non relinquendo, in alio incipit esse. Acquirit noua loca et uetera propter hoc non amittit. Est ergo haec panis in corpus transubstantiatio quaedam, ut bene aliqui uestrum dixerunt, substantiarum translatio ut, ubi et cum quibus erat ${ }^{41}$ antea substantia panis, cum eisdem sit postea corpus Christi. Dicunt etiam uestri et recte panem in hac conuersione ${ }^{42}$ non anihilari, qui tamen totus desiit ${ }^{43}$ esse. Quomodo ergo non est anihilatus? Hic uestri uarie respondent et nesciunt nodum inuenire ${ }^{44}$. Habeto sic a me et conscribe: Panis non dicitur

unitus] si anima et sanguis fuerunt unita $Q \mathbf{3 8}$ omnium trium] omnium rerum $I$; omnium trium rerum $V 39$ esse corporis Christi] esse corporis (add. sup. lin. a. m. corpus) $M$; corpus Christi $Q$; $\rightarrow$ 
mento e da instituição do Senhor, primeiro está o corpo; se a este estiver unida a alma e estiver unido o sangue, ambos acompanharão o corpo, como agora estão ao mesmo tempo nesse sacramento. Da mesma forma, estão todos eles agora no cálice sob as espécies do vinho, mas por outra ordem. Pois, proferidas essas palavras, primeiramente se faz aí presente o sangue, o qual, se não estiver no corpo, como no momento da morte, estará aí sozinho, sem corpo e sem alma. Se, porém, estiver no corpo morto, também aí estará o corpo morto com esse sangue. Mas se estiver no corpo vivo mortal, como na Ceia, ou imortal, como é agora, com o sangue advirá aí esse corpo com a alma. Portanto, na consagração do pão, está aí em primeiro lugar o corpo de Cristo. São concomitantes, o sangue, a alma e os acidentes de ambos. E não são só os acidentes da alma ou do sangue, mas também os do próprio corpo que aí estão por concomitância. Donde, se o corpo de Cristo não tivesse nenhum acidente, aí estaria sem qualquer acidente, ou seja, sem quantidade e sem qualidade. E embora todos os acidentes que advêm estejam aí por concomitância, entende-se que chegam primeiro os que são acidentes do próprio corpo do que os acidentes da alma e do sangue. Por outro lado, na consagração do vinho está lá, primeiro, o sangue, a seguir, o corpo e a alma e os acidentes dos três. E entre os acidentes dos três, acompanham-no primeiro os acidentes do sangue que os do corpo e da alma. Portanto, toma-se agora todo o Cristo sob cada uma das espécies dos acidentes do pão e do vinho.

Voltemos, caríssimo, ao nosso assunto, porque estou a ver-te muito admirado. Há ainda outras coisas dignas de admiração neste sacramento. Pois, o pão, despido de todos os acidentes, retirou-se nu desse lugar. Permanecem toda a sua roupagem e os seus ornamentos, só ele se afasta. Anota com cuidado, porque irá agradar muito àquele por causa de quem tudo isto se escreve. Retira-se, na verdade, no momento da [f1. 115] prolação integral das palavras e, depois de se afastar, no termo do seu afastamento, isto é, quando o pão já aí não está, simultaneamente então, com o não ser do pão, está aí o ser do corpo de Cristo. E é isto que, inspirados por Deus, sem saber o que afirmais, dizeis: o pão é transubstanciado na carne de Cristo. Não que algum resto de pão se tenha mantido aí ou no corpo de Cristo, mas porque o pão se retirou, não por deslocação de lugar, mas, pelo poder divino, não mais aí se encontra. Aí está o corpo de Cristo. Sem deixar o lugar inicial, começa a estar neste ou naquele lugar. Vê o prodígio, está no Céu e no altar. Sem deixar o Céu, começa a estar num altar, mais, em mil altares. E sem deixar todos esses, começa a estar noutro. Obtém novos lugares e não abandona, por isso, os anteriores. É, pois, esta espécie de transubstanciação do pão no corpo, como bem disseram alguns dos vossos, uma transferência de substâncias, de modo que, onde e com aquelas coisas com que estava antes a substância do pão, com as mesmas esteja depois o corpo de Cristo.

$\leftarrow$ esse corpus Christi $I V 40$ motum] modum $J V 41$ erat] erit $I V \mathbf{4 2}$ conuersione] conseruatione $Q$ $\mathbf{4 3}$ desiit] desinit $M Q$; desit $V \mathbf{4 4}$ inuenire] soluere $Q$ 
anihilatus quia ipsius accidentia remanent, sicut nec aer anihilatur quando in aquam conuertitur, quia aliquid eius, puta materia, remanet ${ }^{45}$. Tamen uerum est substantiam panis desiisse, sed non omnia quae erant panis desierunt. Dicam tibi amplius, substantia panis non destruitur, sed quasi cedit et dat corpori Domini locum. Quo facto, illa panis substantia extinguitur quia nuda et spoliata erat. Ideo neque sui natura sic durare poterat. Desinit ergo esse et anihilatur quasi post transubstantiationem ${ }^{46}$. Primo enim panis recedit in tempore, ut diximus gerendo morem philosophis uestris. Subito, in instanti recessum panis terminante, fit ibi praesens corpus Domini et in tempore illud instans consequens desinit substantia panis. Non ${ }^{47}$ itaque ratione huius conuersionis anihilatur. Si anihiletur, non dicatur anihilatus, sed transubstantiatus uel substantiabiliter translatus et, ex consequenti, non ex ui translationis ${ }^{48}$ anihilatus.

Quomodo ergo panis non anihilatur intellexisti, et quomodo transubstantiatur accepisti, et quod ibi accidentia sint sine subiecto et duo corpora simul et maius corpus uidelicet Christi esse simul cum longe minori uidelicet cum accidentibus panis. ${ }^{49}$ Non ergo desinit esse in caelo et hic esse incipit, qua re in pluribus locis simul inuenitur. In ipsa itaque consecrationis hora non aperiuntur caeli ad hoc ut Christus adueniat ${ }^{50}$ cum de caelo non recedat. Illa tamen dicunt ${ }^{51}$ doctores uestri methaphorice et mistice ut ostendant magnam potentiam Dei in hoc sacramento et Christum, qui in caelis est, ibi esse ueraciter. Neque ergo comitatur eum Genitrix sua neque alii sancti, quia hoc priuilegium est solius Christi, qui est cibus uerus. Quomodo etiam sancti ueniunt secum si ipse non uenit? Non enim transit, sed ibi fit et incipit esse ${ }^{52}$. Potest tamen dici ut cum eo in altari sit mater et omnes beati, quia sunt secum semper, sed non ibi. Sunt simul cum Christo, qui est in altari, sed non sunt ipsi in hostia illa uel altari. Est tamen angelorum semper comitantia ${ }^{53}$. Non quod descendant ${ }^{54}$ de caelo secum, quia neque ipse descendit motu corporali, sed solum incipiendo ibi esse, sed quia angeli iugiter uobiscum uersantur et uos custodiunt et haec inferiora gubernant. Et illi, statim ut cognoscunt hic uel ibi Dominum praesentem, ipsum adorant et sibi assistunt. Et anima eius ibi manens nos uidet et nos ipsum uidemus quem in caelo existentem nos uobiscum in terra existentes non uidemus.[f1. 116] Longum enim est interuallum, longa distantia. Et nota, dilectissime, quod anima illa uidet omnes uos qui in Ecclesia estis et in ciuitate, neque paries aut aliud corporale

45 quia aliquid eius, puta materia, remanet] quia aliquid eius puta intra et materia remota. $Q$ 46 transubstantiationem] transubstantionem $N P$; transubstantialitatem $I V \quad 47$ Domini et in (...) substantia panis. Non] Domini. Non $Q \mathbf{4 8}$ non ex ui translationis] non per uim talis $I$; non ex ui $\rightarrow$ 
Dizem também e correctamente os vossos que o pão, nesta conversão, não é aniquilado, ele que, todavia, deixa absolutamente de ser. Como não é, pois, aniquilado? Aqui respondem os vossos de diferentes maneiras e não sabem sair do embaraço. Sabe-o por mim e escreve: O pão não se considera aniquilado, porque os seus acidentes se mantêm, do mesmo modo que também o ar não é aniquilado quando se converte em água, porque algo de seu, como a matéria, se mantém. Como quer que seja, é verdade que a substância do pão deixou de existir, mas nem tudo o que era pão deixou de existir. Dir-te-ei mais, a substância do pão não é destruída, mas como que cede e dá o lugar ao corpo do Senhor. Feito isso, esta substância do pão extingue-se, porque estava nua e despida, por isso, a sua natureza não podia subsistir assim. Deixa, pois, de ser e aniquila-se quase depois da transubstanciação. Na verdade, primeiro, o pão retira-se no momento próprio, como dissemos, cedendo aos vossos filósofos. Subitamente, no instante em que termina o afastamento do pão, torna-se aí presente o corpo do Senhor e, no momento seguinte àquele instante, a substância do pão deixa de existir. E, assim sendo, não é aniquilado em razão desta mudança. Se fosse aniquilado, não se diria aniquilado, mas transubstanciado ou substancialmente transferido e, consequentemente, não aniquilado por força da transferência.

Compreendeste, portanto, como é que o pão não é aniquilado e percebeste como se transubstancia, e que os acidentes se acham aí sem sujeito, e que dois corpos estão aí ao mesmo tempo, e o corpo maior, ou seja, o de Cristo, está aí em simultâneo com um muito mais pequeno, ou seja, com os acidentes do pão. Portanto, não deixa de estar no Céu e começa a estar aqui, razão pela qual se encontra simultaneamente em vários lugares. E, assim, na própria hora da consagração não se abrem os Céus para que Cristo venha, visto que se não afasta do Céu. Dizem isso os vossos doutores de um modo metafórico e místico, para mostrarem o grande poder de Deus neste sacramento, e que Cristo, que está no Céu, está aí verdadeiramente. Portanto, não o acompanham sua Mãe nem outros santos, porque este é um privilégio exclusivo de Cristo, que é o alimento verdadeiro. Como vêm com ele também os santos se ele mesmo não vem? Na verdade não vem, mas torna-se e começa a estar aí presente. Pode, todavia, dizer-se que com ele no altar estão sua Mãe e todos os bem-aventurados, porque estão consigo sempre, mas não aí. Estão juntamente com Cristo, que está no altar, mas eles mesmo não estão na hóstia ou no altar. Tem sempre, contudo, a companhia dos anjos. Não que desçam do Céu consigo, uma vez que nem ele mesmo desce num movimento corporal, mas apenas começando a estar aí, mas porque os anjos se ocupam permanentemente convosco e vos guardam e dirigem as realidades terrenas e, logo que se apercebem da presença do Senhor aqui ou ali, o adoram e estão diante dele. E a sua alma, ao permanecer aí, vê-nos, e nós vemo-lo a ele

$\leftarrow$ talis $O V 49$ Quomodo ergo panis non anihilatur intellexisti (...) uidelicet cum accidentibus panis.] om. $Q \mathbf{5 0}$ adueniat] ueniat $N V \mathbf{5 1}$ dicunt] debent $V \mathbf{5 2}$ sed ibi fit et incipit esse] sed ibi est et hic incipit esse $Q \mathbf{5 3}$ comitantia] comitatiua $I$; comitiua $O V \mathbf{5 4}$ descendant] discedant $Q$ 
obstaculum impedit uisionem eius. Vnde ipse in caelo existens uos hic existentes non uidet nisi in essentia Dei. Apud uos uero, in sacramento existens, uidet uos et intuetur etiam extra essentiam Dei. Sed uestri oculi corporei ipsum ibi existentem uidere non possunt, quia ipse in hostia illa ${ }^{55}$ est modo mirabili. Non sicut uos in loco ipsum implentes et occupantes, sed est ibi sicut et nos angeli sumus in loco non implentes neque locum occupantes, qui neque a corpore aliquo sumus circumdati aut obtecti ${ }^{56}$. Neque oculus eius corporeus illo modo ibi existens ${ }^{57}$ posset uos uidere, neque aures eius uocem uestram audire, nisi Deus addidisset miraculum miraculo. Miraculum est corpus esse alicubi non localiter, sed solum praesentialiter et cum alio corpore se multo minori. Tamen, posito hoc miraculo, sequitur statim illud corpus sic existens neque agere neque pati posse, neque tangere neque tangi, neque uidere neque uideri, quia omnia ista fiunt per medium aerem uel aquam. Et oportet se tangentia esse localiter et circumscriptiue in illo medio ita quod per illud deferantur similitudines rerum ad sensus. Et quia sic existente oculo rerum similitudines ad ipsum deferri non possunt, ideo sentire eas non potest. Addit huic miraculose corporis Domini praesentiae ${ }^{58}$ aliud miraculum, quia uirtute sua Deus fecit ${ }^{59}$ ut species ille et rerum similitudines perueniant ad oculos et aures Domini. Et ita, Dei uirtute instillante, uos ${ }^{60}$ ibi uidet et uocem uestram audit et sic uos uidet utroque oculo et mentis et corporis. Vos autem ipsum uidere ${ }^{61}$ non potestis sine miraculo nouo, quod communiter Deus non facit. Vnde quando ibi aliqui uestrum uiderunt ${ }^{62}$ carnem aut sanguinem aut puerulum, illa caro non est caro Christi neque ille sanguis eius neque puerulus ille Christus est, sed sacramentum Christi63. Nam sicut non est Christus illud quod uos uidetis, olfacitis ${ }^{64}$, gustatis, tangitis et palpatis, sed sunt accidentia panis et uini sub quibus et in quibus est Christus, sic nec illa caro quae tunc miraculose producitur a Deo siue sanguis ${ }^{65}$ siue puerulus ille est Christus, sed ibi est ubi est caro illa uel sanguis uel puerulus. Sicut ergo uos adoratis illud quod non uidetis neque sentitis et non illud quod uidetis aut sentitis, sic et in casu illo faciendum est ut non puerulus ille aut caro illa aut sanguis ille adoretur, sed Christus Dominus latens sub illis. Apparuit itaque caro aut sanguis ut dubium aliquorum excluderet $^{66}$. Nam, sicut uident tunc loco hostiae carnem, loco uini ${ }^{67}$ sanguinem, sic deberent credere, quando hostia ibi est, hoc est, accidentia illa, tunc ibi esse carnem Christi et sanguinem eius, quia igitur Christus est in sacramento tamquam latitans sub quodam indumento. Ideo qui uidet uestem sub qua rex est, potest dici uidisse regem, sic et uos uidentes accidentia illa sub quibus ${ }^{68}$ latitat Christus et ea tangentes, masticantes, deglutientes et comedentes, potestis dici Christum uidere, tangere, comedere, masticare uel dentibus atterere et inglutire. Similiter potest dici quod sacerdos fert, mouet et eleuat corpus Domini, quod tamen non

$\mathbf{5 5}$ hostia illa] hostia $M P$; illa hora $V \mathbf{5 6}$ obtecti] obtenti $I V 57$ existens] existendi $Q \mathbf{5 8}$ praesentiae] praesente $V 59$ fecit] facit $I N V 60$ Et ita, Dei uirtute instilante uos] Et ita, uos IOV $\mathbf{6 1}$ uidere] audire $V 62$ aliqui...uiderunt] aliquis...uidet $Q 63$ nec ille sanguis eius nec puerulus ille Christus $\rightarrow$ 
a quem, vivendo no Céu e vivendo nós na Terra convosco, não vemos. [f1. 116] É realmente grande o intervalo, é longa a distância. E adverte, dilectíssimo, que aquela alma vos vê a todos que estais na Igreja e na sociedade, e nem as paredes, ou outro obstáculo corporal, impedem a visão dele. Daí que, vivendo ele no Céu, vos não veja a vós que viveis aqui senão na essência de Deus. Ora, vivendo junto de vós no sacramento, vê-vos e observa-vos também fora da essência de Deus. Mas os vossos olhos corporais não podem vê-lo aí presente porque, na hóstia, ele está de modo maravilhoso, não como vós, num lugar, enchendo-o e ocupando-o, mas está aí como também nós anjos, que não somos circundados ou ocultos por qualquer corpo, estamos num lugar não o enchendo nem o ocupando. Nem os seus olhos corporais, estando aí desse modo, vos poderiam ver, nem os seus ouvidos ouvir a vossa voz se Deus não somasse um milagre a outro milagre. Milagre é um corpo estar em toda a parte não localmente, mas só presencialmente, e com outro corpo muito menor do que ele. Posto, todavia, este milagre, segue-se de imediato que aquele corpo assim existente não pode nem ser activo nem passivo, nem tocar nem ser tocado, nem ver nem ser visto, porque todas estas coisas acontecem por intermédio do ar ou da água. E é preciso que sejam tangíveis, local e circunscritivamente, naquele meio, de modo que por ele as imagens das coisas sejam levadas aos sentidos. E uma vez que com uns olhos que assim se apresentam não podem as imagens das coisas ser-lhe levadas, não podem, por isso, senti-las. Somou a esta milagrosa presença do corpo do Senhor outro milagre porque, pelo seu poder, fez Deus que aquelas formas e a representação das coisas cheguem aos olhos e aos ouvidos do Senhor. E, assim, sob a instilação do poder de Deus, vê-vos aí e ouve a vossa voz, e, assim, vos vê com ambos os olhos, os da mente e os do corpo. Vós, porém, não podeis vê-lo sem novo milagre, que Deus geralmente não faz. Daí que, quando alguns de vós viram aí carne ou sangue ou uma criança, essa carne não é a carne de Cristo, nem esse sangue o seu sangue, nem a criança é Cristo, mas o sacramento de Cristo. Pois, assim como não é Cristo o que vós vedes, cheirais, saboreais, tocais e apalpais, mas são os acidentes do pão e do vinho sob os quais e nos quais está Cristo, assim, nem a carne que então é milagrosamente apresentada por Deus ou o sangue ou essa criança são Cristo, mas está aí onde estão a carne ou o sangue ou a criança. Assim, pois, como vós adorais aquilo que não vedes, nem sentis, e não aquilo que vedes ou sentis, assim também, nesse caso, deve acontecer que se não adore essa criança ou a carne ou esse sangue, mas a Cristo Senhor oculto neles. Apareceu, portanto, a carne ou o sangue para afastar a dúvida de alguns. Efectivamente, do mesmo modo que no lugar da hóstia vêem então a carne, no lugar do vinho o sangue, assim deveriam crer, quando a hóstia lá está, isto é,

$\leftarrow$ est sed sacramentum Christi $M$ in marg. a. $m$. 64 olfacitis] olfatis $I V 65$ siue sanguis] siue caro $Q 66$ excluderet] excluderent $I$; excludetur $V 67$ uini] uero $Q 68$ accidentia illa, (...) accidentia illa sub quibus] accidentia illa, sub quibus $P$ 
fertur ab eo neque mouetur nec eleuatur. Nam Dominus pactum uobiscum fecit ut ubicumque accidentia [f1. 117] illa posueritis et collocaueritis ibi ${ }^{69}$ erit ipse propria uirtute sua praesens, propria uoluntate se transferet ipsemet. Et quandoque Christus Dominus propria uirtute sua mouet et transfert hostiam illam eo motu quo anima corpus mouebit post eius glorificationem, sicut uni ex hic ${ }^{70}$ praesentibus ordinis tui (et ostendebat deuotissimum ${ }^{71}$ Bonauenturam), semel hostia ab altari mota intrauit in os, eam Christo Domino eo modo mouente. Si quaeras quid frangatur ${ }^{72}$ et quid ibi rumpitur interdum cum sonitu, dico ${ }^{73}$ tibi quod quantitas. Proprium quantitatis est diuidi. Omnis enim diuisio aut est secundum longitudinem aut latitudinem aut altitudinem. Et ibi sunt haec tria in accidentibus. Ergo poterit diuidi tripliciter et frangi, immo, dico tibi, panis ipse non posset frangi neque diuidi remota quantitate. Et ipsa sola persistente ${ }^{74}$, potest fieri diuisio. Frustra ${ }^{75}$ ergo mirantur homines. Quid ibi frangitur ${ }^{76}$ ? Non panis, quia non est. Non corpus Domini, quia incorruptibile est et ibi eo modo existens intangibile. Quid ergo frangitur? Iam dixi tibi, franguntur accidentia illa uel secundum longitudinem uel latitudinem uel profunditatem ${ }^{77}$ si hostia illa esset spissior et altior uel si panis usualis grossus et altus consecraretur.

Quid ergo intelligendum sit nomine transubstantiationis iam intellexisti, quia duarum substantiarum translationem intelligimus. Panis abscedit uel desinit esse ibi et corpus Christi accedit uel potius incipit esse ibi. Et hoc ${ }^{78}$ modo nulla est difficultas intelligere aliquid conuerti in aliud quod aliud praefuerat et praeexistebat. Immo omne creatum potest conuerti in quodlibet quia, ubi unum ${ }^{79}$ est, potest illud ibi desinere et aliquid aliud ${ }^{80}$ incipere esse. Vnde ergo $^{81}$ ubi est aqua, potest ibi desinere esse et ignis incipere esse. Et sic $^{82}$ de omnibus aliis. Sed nihil potest sic conuerti in Deum, quia Deus non potest incipere esse alicubi, qui ubique est, neque Deus potest conuerti in aliud, quia non potest locum deserere existentem nisi poneretur Deum non esse omnibus praesentem, de quo alias te docebo. Quando ${ }^{83}$ ergo creatura uel locus desineret esse, tunc Deus in illo et cum

69 latitat] latet $Q \mathbf{7 0}$ hic] his $N \mathbf{7 1}$ deuotissimum] beatissimum $N \mathbf{7 2}$ frangatur] frangitur $V \mathbf{7 3} \mathrm{Si}$ quaeras quid frangatur et quid ibi rumpitur interdum cum sonitu, dico] $\mathrm{Si}$ quaeras quid frangatur et quid ibi rumpatur interdum cum sonitu, dico $N$; Si quaeras, quid ibi frangitur et rumpitur interdum etiam cum sonitu? Dico $Q \mathbf{7 4}$ persistente] praeexistente $Q \mathbf{7 5}$ diuidi remota quantitate. Et ipsa sola persistente potest fieri diuisio. Frustra] diuidi. Frustra $V \mathbf{7 6}$ frangitur] frangatur $N \rightarrow$ 
os seus acidentes, que então aí está a carne de Cristo e o seu sangue, porque então Cristo está no sacramento como que oculto sob uma espécie de roupagem. Por isso, aquele que vê a veste sob a qual está o rei, se pode dizer que viu o rei, assim também vós, ao verdes os acidentes sob os quais se oculta Cristo e ao tocá-los, mastigá-los, degluti-los e comê-los, pode dizer-se que vistes, tocastes, comestes, mastigastes ou triturastes com os dentes e engolistes a Cristo. Pode, do mesmo modo, dizer-se que o sacerdote transporta, movimenta e levanta o corpo do Senhor que, todavia, não é por ele transportado, movido ou elevado. De facto, o Senhor fez convosco um pacto que, onde quer que puserdes e colocardes esses acidentes, [fl. 117] aí estará ele presente por si próprio, ele mesmo se transportará de vontade própria. E, às vezes, Cristo Senhor move e transfere por si próprio a hóstia com aquele movimento com que a alma moverá o corpo depois da sua glorificação, como a um dos aí presentes, da tua Ordem (e mostrava o devotíssimo Boaventura), uma vez, a hóstia trazida do altar lhe entrou na boca, movendo-a Cristo desse modo. Se perguntas o que é que entretanto se parte, o que se rompe com ruído, digo-te que é a quantidade. É próprio da quantidade dividir-se. Ora, toda a divisão ou é segundo o comprimento ou a largura ou a espessura. E aí nos acidentes estão presentes estas três coisas. Poderá, portanto, dividir-se e partir-se de três maneiras, e mais, digo-te, o mesmo pão não poderia partir-se nem dividir-se se fosse subtraída a quantidade, e a divisão pode fazer-se apenas porque se mantém a quantidade. Em vão se espantam os homens. $O$ que é que aí se parte? Não é o pão, porque não existe. Não é o corpo do Senhor, porque é incorruptível e intangível ao estar presente aí desse modo. Que se parte então? Já te disse, partem-se os acidentes, ou segundo o comprimento, ou a largura, ou a espessura, se a hóstia fosse mais espessa e mais alta, ou se fosse consagrado pão comum, espesso e alto.

O que, portanto, se deve entender pela designação de transubstanciação já o compreendeste, porque entendemos a transferência de duas substâncias. O pão retira-se ou deixa de aí estar, e o corpo de Cristo aproxima-se, ou antes, começa a estar aí. E, deste modo, não há dificuldade alguma em entender que uma coisa se converte noutra que era anterior e que preexistia. E mais, todo o ser criado se pode converter em qualquer coisa que seja porque, onde está uma coisa, pode essa deixar de aí estar e uma outra começar a estar. Daí que, portanto, onde está água, pode deixar de aí estar e começar a estar fogo. E assim relativamente a todas as outras coisas. Mas nada pode converter-se assim em Deus, porque Deus não pode começar a estar em qualquer parte, ele que está em toda a parte, nem Deus pode converter-se em alguma coisa, porque não pode abandonar o lugar

$\leftarrow 77$ uel secundum longitudinem uel latitudinem uel profunditatem] uel longitudo uel latitudo uel profunditas $O \mathbf{7 8}$ esse ibi et corpus Christi accedit uel potius incipit esse ibi. Et hoc] esse ibi. Et hoc $Q 79$ ubi unum] ubi uno modo $I$; ibi unimodo $V \mathbf{8 0}$ aliquid aliud] aliud quod debet $Q \mathbf{8 1}$ Vnde ergo] enim $M$; Verbi gratia JOP $\mathbf{8 2}$ esse. Vnde ergo ubi est aqua, potest ibi desinere esse et ignis incipere esse. Et sic] esse. Et sic $N 83$ esse. (...) de quo alias te docebo Quando] esse. $\rightarrow$ 
illo non esset, quia ipsum non est, non quia ipse abscedat ${ }^{84}$. Similiter ${ }^{85}$ quando locus nouus fieret, Deus cum illo uel in illo inciperet esse, non quia ipse Deus aduenerit, sed quia locus esse coeperit.

Conuersio, ut dixi, ista non est nisi translatio. Vnde non debetis dicere: "Panis est aut erit corpus Christi". Nec dicere potestis: "Panis poterit esse uel fieri corpus Christi". Nec ergo "panis est", nec "fit", nec "fiet corpus Christi". Sed ${ }^{86}$ dicere potestis: De pane uel ex pane fit corpus Christi, sic intelligendo: ex pane, id est, post panem hic, existit illico corpus $\mathrm{Christi}^{87}$, sicut ex nihilo aliquid fit, quia post nihil, nam prius non est, postea est, et ex nocte fit dies, quia post noctem. Dicere etiam potestis rectius, panis conuertitur uel transubstantiatur uel transit in corpus Christi, hoc est ${ }^{88}$, panis cedit et dat locum corpori Christi. Sic potestis loqui. Nulla tamen aliarum locutionum ${ }^{89}$ est propria ${ }^{90}$, quamuis magis accedat ultima uidelicet panis cedit corpori Christi. Tamen bone sunt illae quas dixi, accipiendo eas in bono sensu qualem [f1. 118], dilecte, tibi ostendi et qualem Dominus inspirabit cito illi quem praesidere Ecclesiae suae statuit et ordinauit ${ }^{91}$. Cogitare iam potes quot mirabilia et stupenda concurrunt in hoc dignissimo sacramento. Adhuc tamen et alia tibi reserabo.

Accidentia illo ${ }^{92}$ modo a substantia separata producere possunt eosdem effectus quos producunt quando inhaerent substantiae. Vnde color ille immutat uisum, sonus illorum immutat auditum quando fraguntur, odor eorum agit in olfatum et in eo suam ${ }^{93}$ similitudinem causat. Hoc enim est immutare sensum, quod est in sensu causare sui similitudinem, quam uos speciem uocatis. Sapor quoque ille immutat gustum et, si in illis accidentibus calor aut frigus aut humor fuerit, immutabunt tactum. Agunt ergo sicut et antea agebant, simili modo et agens naturale, ut ignis uel aqua uel quando trahiciuntur ad stomachum. Virtus nutritiua agit in accidentia illa sic ab omni substantia separata. Conuenit ergo accidentibus agere et pati propria natura et uirtute et non sunt talia ratione substantiae solum. Verum difficultas est qualiter homo nutritur his accidentibus. Nam in nutricione acquiritur ${ }^{94}$ substantia noua et materia alimenti suscipit formam sanguinis. Ibi autem nulla est materia aut forma substantialis. Et uerum est quod philisophi dicunt: "Ex non substantia ${ }^{95}$ non fit substantia". Non enim potest generari substantia

$\leftarrow$ Quando $Q$; esse. Vnde ergo ubi est aqua, potest ibi desinere esse et ignis incipere esse et sic de omnibus aliis. Sed nihil potest sic conuerti in Deum quia Deus non potest incipere esse alicubi, qui ubique est, neque Deus potest conuerti in aliud quia non potest locum deserere existentem. Quando JP; (nisi poneretur Deum non esse omnibus praesentem, de quo alias te docebo) $a d d$. $M$ (in marg. a. m.) 84 abscedat] abscedebat $I V 85$ non esset, quia ipsum non est, non quia ipse abscedat. Similiter] non esset. Similiter $Q \mathbf{8 6}$ Christi". Nec ergo "panis est" nec "fit" nec "fiet corpus $\rightarrow$ 
onde está, a menos que se afirme que Deus não está presente em toda a parte, assunto sobre que te instruirei noutra ocasião. Quando, pois, uma criatura ou um lugar deixassem de existir, então Deus não estaria neles nem com eles, porque eles não existem, não porque ele se afaste. De igual modo, quando se criasse um novo lugar, Deus começaria a estar com ele e nele, não que o próprio Deus adviesse, mas porque o lugar começaria a existir.

Essa mudança, como disse, não é senão uma transferência. Donde, não deveis dizer: O pão é ou será o corpo de Cristo. Nem podeis dizer: O pão poderá ser ou tornar-se o corpo de Cristo. Nem, por consequência: O pão é, nem: torna-se, nem: tornar-se-á o corpo de Cristo. Mas podeis dizer: Do pão, ou, a partir do pão, faz-se o corpo de Cristo, entendendo deste modo: Do pão, isto é, depois do pão, aqui surge imediatamente o corpo de Cristo, do mesmo modo que do nada se faz alguma coisa, porque depois do nada, pois, primeiro não existe, depois existe; e da noite surge o dia, porque depois da noite. Podeis também dizer mais justamente: $\mathrm{O}$ pão converte-se ou transubstancia-se ou muda-se no corpo de Cristo, isto é, o pão cede e dá o lugar ao corpo de Cristo. Podeis falar assim. Todavia nenhuma das outras afirmações é apropriada, embora a última se aproxime mais, ou seja, o pão cede ao corpo de Cristo. Como quer que seja, são boas aquelas que referi, tomando-as no recto sentido que te mostrei, [f1. 118] amigo, e que o Senhor inspirará de imediato àquele que estabeleceu e nomeou para presidir à sua Igreja. Podes imaginar já quanta coisa maravilhosa e digna de admiração concorre neste tão digno sacramento. E, contudo, desvendar-te-ei ainda outras.

Os acidentes deste modo separados da substância podem produzir os mesmos efeitos que produzem quando estão ligados à substância. Daí que a cor afecte a visão, o som deles, quando se partem, afecte a audição, o odor deles actue sobre o olfacto e provoque nele a sua imagem. Isto é realmente afectar os sentidos, porque é causar nos sentidos a representação de si, a que vós chamais aparência. Também esse sabor afecta o gosto e, se houver nesses acidentes calor, frio ou humidade, afectam o tacto. Actuam, pois, como actuavam antes, do mesmo modo que um agente natural, como o fogo ou a água, quando são lançados no estômago. A capacidade nutritiva actua nestes acidentes assim separados de toda a substância. Aos acidentes quadra, pois, pela própria natureza e capacidade, ser activos e passivos e não são o que são em razão da substância apenas. Mas a dificuldade está em como o homem se nutre destes acidentes. Pois, na nutrição obtém-se substância nova, e a matéria do alimento recebe a forma de sangue. Aí, porém, não há matéria ou forma substancial. E é verdade o que dizem os filóso-

$\leftarrow$ Christi”. Sed] Christi”. Sed $Q \mathbf{8 7}$ sic intelligendo (...) corpus Christi] sic intelligendo: ex pane, id est potius, panem hic existit, illico corpus Christi] $M$ (in marg. a. m.) 88 panis conuertitur uel transubstantiatur uel transit in corpus Christi, hoc est,] add. $M$ in marg. a. $m$. 89 locutionum] locutione $Q$; locutio $I V 90$ propria] uera $I J P V 91$ statuit et ordinauit] statuet et ordinabit $Q$ 92 Accidentia illo] Accidentia illa $Q 93$ eo suam] quos natura $I 94$ acquiritur] accipitur $V 95$ substantia] substantiis $Q$ 
una nisi corrupta ${ }^{96}$ alia. Hic uero nulla substantia corrumpitur et tamen sanguis et caro generatur, ut experimento patet.

Quo pacto ergo ex accidentibus panis et uini nutritur homo et ex illis sanguis et caro generatur, dico tibi, audi et considera uerba mea. Primo, dicam tibi quam diu uel quanto tempore corpus Christi manet cum accidentibus illis. Deinde, quomodo ex illis potest generari substantia. Quoad primum, scito corpus Christi tam diu ibi esse quam diu accidentia illa stant in suo uigore, hoc est, quam diu sunt aptum alimentum et conueniens homini nutrimentum. Quando uero fuerint ita alterata quod iam odorem et saporem et alia quae reddunt ${ }^{97}$ panem conuenientem homini cibum amiserint omnino, tunc corpus Christi desinit esse ibi, quia tam diu manet ibi cibus animae quam diu manet cibus idoneus ${ }^{98}$ et conueniens corpori. Ideo enim in tali materia sacramentum instituit ut se cibum animae uestrae praeberet et ostenderet ut cibus corporis esset signum cibi animae sicut et ablutio corporis uestri in baptismo significat ablutionem animae a maculis peccatorum. Desinente autem signo, desinit significare. Et, si non significat, non est sacramentum. Et, si non est ibi amplius sacramentum, ibi non erit amplius Christus, qui statuit eo modo non esse ibi nisi in sacramento.

Nec tamen quilibet cibus est sacramentum, sed principalis et communior, qui est panis et uinum. Vnde si uinum conuerteretur ${ }^{99}$ in aquam, esset bene ${ }^{100}$ potus, sed non ille. Et, si panis conuerteretur ${ }^{101}$ in carnem coctam, esset cibus, sed non ille qui $^{102}$ requiritur [f1. 119] in hoc sacramento. Dixi uero "Si accidentia illa sint omnino ad nutrimentum humanum inepta”. Nam si aliquantulum alterentur et a perfectione cibi recedant ${ }^{103}$ non tamen totaliter, non desinit ibi esse corpus Christi ${ }^{104}$. Quando uero omnino mutata sunt ita quod non solum non sunt alimentum conueniens, sed potius disconueniens, desinit ibi esse Christus. Vnde ${ }^{105}$ si fiant $^{106}$ in tantum uetusta et putrida seu fetida quod gustus ea omnino abhorreat tamquam sibi omnino repugnantia, scito tunc Christum ibi non esse, quia suauissimus panis qui de caelo descendit non stat cum cibo putrido, fetido et horrido. Horridum cibum uoco non illum quem infirmi et male dispositi abhorrent, sed illum quem et bene dispositi nullo uitio bestiali laborantes abhorrent ${ }^{107}$ communiter. Nimia quoque durities quae mollificari nequeat, reddit panem ineptum ad comedendum, quod potest accidere facilius apud Graecos, qui in pane fermentato et grossiori conficiunt. Similiter si uinum sic imbiberetur alicui rei, ut ligno et terrae, quod iam fluere non posset, non est potus conueniens. Si quoque accidentia panis sic reddantur

96 corrupta] corrumpatur $P Q 97$ reddunt] credunt $V 98$ tam diu manet ibi cibus animae quam diu manet cibus idoneus] tam diu manet ibi cibus aut quam diu manet rebus idoneus $O 99$ conuerteretur] conuertitur IJOV 100 bene] bone $Q \quad 101$ conuerteretur] conuertitur $O 102$ sed non ille. (...) sed non ille qui] sed non ille qui $J \mathbf{1 0 3}$ recedant] excedant $Q \mathbf{1 0 4}$ non desinit ibi $\rightarrow$ 
fos: da não substância não se cria substância. Não pode, realmente, produzir-se uma substância, se a outra não for destruída. Neste caso, de facto, nenhuma substância é destruída e, contudo, como resulta da experiência, o sangue e a carne são produzidos.

De que modo, pois, se nutre o homem dos acidentes do pão e do vinho e deles se produz o sangue e a carne, eu digo-te, ouve e atenta nas minhas palavras. Primeiramente dir-te-ei quanto tempo ou em quanto tempo o corpo de Cristo se mantém com esses acidentes. Depois, como deles se pode produzir substância. Quanto ao primeiro, fica a saber que o corpo de Cristo está neles tanto tempo quanto os acidentes se mantêm no seu vigor, isto é, enquanto são um sustento apto e um alimento apropriado para o homem. Mas quando estiverem de tal modo alterados que tenham perdido já completamente o cheiro e o sabor e o mais que faz do pão o alimento apropriado para o homem, então o corpo de Cristo deixa de aí estar, porque o alimento da alma permanece aí tanto tempo quanto tempo permanece alimento apto e apropriado para o corpo. Ora, por isso, instituiu nesta matéria o sacramento para se apresentar como alimento da vossa alma e mostrar que o alimento do corpo seria o sinal do alimento da alma, do mesmo modo que a purificação do vosso corpo significa no baptismo a purificação da alma das manchas do pecado. Cessando, porém, o signo, deixa de significar. E, se não significa, não é sacramento. E se aí já não está o sacramento, já não estará também Cristo, que estabeleceu, desse modo, não estar aí senão em sacramento.

Também não é sacramento qualquer alimento, mas o principal e o mais habitual, que são o pão e o vinho. Daí que, se o vinho se mudasse em água, seria bebida conveniente, mas não essa. E se o pão se mudasse em carne cozida, seria alimento, mas não aquele que se requer [f1. 119] neste sacramento. Disse, de facto: "Se estes acidentes são em absoluto inadequados para a alimentação humana". Pois, se se alterarem um pouco e se afastarem não totalmente da perfeição de alimento, não deixa, contudo, de aí se manter o corpo de Cristo. Mas quando se alteram totalmente, de tal modo que não só não são alimento apropriado, mas antes desapropriado, deixa de aí estar o corpo de Cristo. Daí que, se se tornam a tal ponto velhos e estragados ou mal cheirosos que o gosto os rejeite em absoluto como absolutamente repugnantes, sabe então que Cristo não está aí, porque o pão suavíssimo que desceu do Céu não está com alimento estragado, mal cheiroso e repugnante. Chamo alimento repugnante não àquele que os doentes ou indispostos recusam, mas ao que até os bem-dispostos e os que se não debatem com um desvio animalesco evitam habitualmente. Também a excessiva dureza, que não consegue suavizar-se, torna o pão impróprio para comer, o que pode facilmente acontecer entre os gregos, que celebram com pão fermentado

$\leftarrow$ esse corpus Christi] non desinit esse cibus et corpus Christi $Q 105$ Christi. (...) esse Christus. Vnde] Christi. Vnde $P 106$ si fiant] si fiunt $Q 107$ sed illum quem et bene dispositi nullo uitio bestiali laborantes abhorrent] add. $P$ in marg. $a$. $m$. 
molia quod uideantur esse pura pasta ita quod sint inepta et inconuenientia ad comedendum, desinit ibi esse corpus Christi. Et breuiter ${ }^{108}$, quotiens amittunt rationem cibi conuenientis totiens amittunt rationem sacramenti. Et, si non est ibi sacramentum, non est etiam res sacramenti, communi ordinatione ${ }^{109}$.

Quando ergo uidetis ${ }^{110}$ uermiculos natos in talibus accidentibus, sciatis tunc ibi Christi corpus non esse nisi esset hostia illa uel oblata adeo magna quod in una parte eius esset putredo, alia uero sana consisteret ${ }^{111}$ et incorrupta ita quod posset ab illa putrida separari et sine horrore sic separata comedi. Tunc sub illa parte sola erit Christus. Sed si ab illa putrida non possit separari et sine illa comedi, iam non est cibus conueniens et per consequens nec sacramentum. Eodem modo, quando accidentia uini sumitis, quia illa subito ut sumpta sunt aliis humoribus permiscentur ita quod iam redduntur inepta ad cibum ${ }^{112}$ per os iterum sumendum, subito desinunt esse sacramentum. Accidentia uero panis non ita subito alterantur, ideo diutius retinent quam illa uini rationem sacramenti ${ }^{113}$.

Tunc dico aliquid habere rationem cibi quando illud non solum potest nutrire uel in nutrimentum conuerti, quia sic humores qui sunt in stomacho possent uocari cibus, sed quid sit conueniens homini ore sumere et per guttur in stomachum trahicere. Quod ergo non est talis cibus, non potest esse eucharistiae sacramentum. Et quamuis homines subito ut cibum habent in ore abhorrent eum iterum sumere, ille tamen horror non impedit sacramentum, sed sic si iam in stomacho immissus fuisset. Vnde existentibus in ore accidentibus et per pectus transeuntibus, Dominum secum retinent ${ }^{114}$. Ad stomachum uero peruenientes, quasi subito desinunt esse sacramentum ${ }^{115}$.

Intellexisti iam quanto tempore illa accidentia retinent rationem ${ }^{116}$ sacramenti et quanto tempore cum illis Christus est. Nunc autem qualiter ex illis fiat aliqua substantia intellige.

Accidentia illa duobus [fl. 120] modis alterari possunt. Vno modo, tali alteratione quod solum ${ }^{117}$ amittunt ${ }^{118}$ formam cibi conuenientis non cuicumque, sed soli homini. Quae alteratio interdum fieri posset non corrupta substantia panis, si

108 conueniens. (...) esse corpus Christi. Et breuiter] conueniens. Et breuiter $Q 109$ ordinatione] adoratione $Q \quad 110$ uidetis] uideris $J V \quad 111$ consisteret] existeret $Q \quad 112$ cibum] potum $Q 113$ alterantur, ideo diutius retinent quam illa uini rationem sacramenti.] alterantur. Diutius quam illa uini retinentur et habent rationem sacramenti. $Q \quad 114$ retinent] continent $Q 115$ desinunt esse sacramentum.] Quando ergo accidentia cibi desinunt esse et sacramentum desinit. Si conuerterentur in carnem aut sanguinem, qui sanguis uel caro non sunt sacramentum sed quaedam consequentia sacramenti et tamquam reliquiae sacramenti sunt cum reuerentia conseruanda add. $M$ (in marg. a. m.) $N$; Quando ergo accidentia cibi desinunt et sacramentum desinit ut si conuerterentur in $\rightarrow$ 
e mais espesso. Igualmente, se o vinho se embebe em qualquer coisa, como na madeira ou na terra, a ponto de já não poder fluir, não é bebida apropriada. Se também os acidentes do pão se tornarem tão moles que pareçam simples pasta, a ponto de serem inadequados e impróprios para comer, deixa de neles estar o corpo de Cristo. E, resumidamente, quantas vezes perdem a natureza de alimento apropriado, tantas vezes perdem a natureza de sacramento. E se aí não existe sacramento, não há também matéria de sacramento, segundo a distinção habitual.

Quando, pois, vedes vermezitos nascidos nesses acidentes, sabei então que o corpo de Cristo aí não está, a não ser que a hóstia ou oblata seja tão grande que numa das suas partes esteja a putrefacção e a outra se mantenha sã e incorrupta de modo que se possa separar da putrefacta e, assim separada, comer-se sem repugnância. Sob essa parte apenas estará então Cristo. Se, porém, não puder separar-se da putrefacta e, sem ela, comer-se, já não é alimento apropriado e, consequentemente, nem sacramento. Do mesmo modo, quando tomais os acidentes do vinho, porque logo que são tomados se misturam com outros líquidos de forma a tornarem-se inadequados a serem de novo tomados na boca como alimento, deixam imediatamente de ser sacramento. Os acidentes do pão, na verdade, não se alteram assim tão rapidamente, por isso, mantêm por mais tempo que os do vinho a natureza de sacramento.

Digo então que alguma coisa tem a natureza de alimento quando não só pode alimentar ou converter-se em alimento, porque assim os elementos líquidos que estão no estômago poderiam considerar-se alimento, mas que seja apta para que o homem a tome na boca e a leve ao estômago pela garganta. O que não é alimento assim, não pode ser sacramento da Eucaristia. E embora os homens, logo que têm o alimento na boca, evitem tomá-lo de novo, essa repugnância, todavia, não impede o sacramento, mas apenas se houvesse sido já enviado para o estômago. Daí que, estando os acidentes na boca e passando pelo esófago, conservem consigo o Senhor. Ao chegarem ao estômago, deixam, quase de imediato, de ser sacramento.

Compreendeste já quanto tempo estes acidentes conservam a natureza de sacramento e quanto tempo está Cristo com eles. Compreende agora, por outro lado, de que modo, a partir deles, se gera outra substância.

Estes acidentes podem alterar-se de dois modos. [f1. 120] Num, com tal alteração que perdem apenas a forma de alimento próprio não para quem quer, mas só para o homem. Esta alteração poderia algumas vezes verificar-se sem se

$\leftarrow$ carnem aut sanguinem. Qui sanguis uel caro non sunt sacramentum sed quaedam consequentia sacramenti et tamquam reliquiae sacramenti sunt cum reuerentia conseruanda. add. O; Quod ergo accidentia ubi desinunt et sacramentum desinit ut si conuerteretur in carnem et sanguinem, qui sanguis uel caro non sunt sacramentum sed quaedam consequentia sacramenti. Et tamen reliquiae sacramenti sunt cum reuerentia obseruandae. add. $Q$; et tamquam reliquiae sacramenti sunt cum reuerentia conseruanda $a d d . V 116$ rationem] nomen $I J M P$; rem $Q 117$ solum] solam $N 118$ amittunt] amittant $P Q$ 
panis sub illis esset. Altero modo accidentia illa alterari possent ${ }^{119}$ tali et tanta alteratione quod substantia panis, si sub illis esset, corrumperetur et destrueretur et ex illa aliquid aliud generaretur. Si ergo, nota bene, priori modo accidentia illa alterentur ${ }^{120}$ quod amittant ${ }^{121}$ naturam cibi homini conuenientis, possent tamen stare cum pane, tunc Deus uirtute sua infinita reducit ${ }^{122}$ substantiam panis illius qui recesserat uel uini quod abierat et illa accidentia iterum afficient ${ }^{123}$ substantiam panis. Et ita ibi iterum erit panis, sed non cibus homini conueniens. Et durabit quousque ab agente naturali corrumpatur, sicut fuisset si numquam inde discessisset ${ }^{124}$. Si autem altero modo accidentia illa alterentur sic quod, si panis tunc ibi esset, corrumperetur in aliquid aliud ${ }^{125}$, in tali casu Deus non reducit amplius substantiam panis quae desiit esse, sed inducit ${ }^{126}$ substantiam $^{2}$ illam in quam panis tunc conuersus fuisset si ibi esset siue illud sit sanguis uel caro, ut fit quando comeduntur, uel ignis, ut quando comburentur ${ }^{127}$ accidentia, uel uermis, ut quando putrefiunt ${ }^{128}$.

Sed quare priori illo modo quando accidentia non sunt tantum alterata quod panis corrumperetur si sub eis esset substantia panis, panis reuertitur ${ }^{129}$ ex quo tunc nihil generaretur? Dico tibi propterea id fieri ${ }^{130}$ quia Deus statuit semel accidentia nunquam sine subiecto esse nisi quando sunt sacramentum corporis et sanguinis Christi. Et quia tunc, quando desinunt esse conueniens cibus homini, desinunt esse sacramentum, iccirco ne sint sine subiecto, reducit ${ }^{131}$ eis Deus proprium subiectum. Quando uero alterantur posteriori modo, tunc non est opus ut panis reuertatur, sed satis est ut substantia illa ibi ponatur in quam panis conuerteretur quando ibi fuisset.

Vide et considera qualiter ego plura scio, dixit subridendo, quam omnes doctores uestri.

Tunc ego: Certum est hoc mihi, sanctissime angele. Gratias ago Prouidentiae Diuinae quae et mei et omnium nostrum est miserta. Ego, simplex et idiota, numquam talia intelligere potuissem sine diuina illustratione.

Iterum angelus fari coepit: Adhuc non percipis quae dicere uolui. Aliqui uestrum, quorum unus fuit Pontifex ${ }^{132}$, dixit, non ut Pontifex, sed ut doctor, in utraque alteratione quae fit illis duobus modis praenominatis reuerti substantiam panis quae abscesserat. Alii uero inter quos fuit unus doctor ordinis tui qui hic est plenus sanctitate quia primus gladium suum exemit pro immaculata conceptione

119 possent] possunt $I \quad \mathbf{1 2 0}$ alterentur] alterarentur $P$; alterantur $I V \quad \mathbf{1 2 1}$ amittant] amittunt $V$ 122 reducit] inducit $P \mathbf{1 2 3}$ afficient] efficient $J N O P Q V$; efficietur $I \mathbf{1 2 4}$ inde discessisset] inde decessisset $J$; idem disessisset $V \mathbf{1 2 5}$ corrumperetur in aliquid aliud] corrumperetur et ad aliquid aliud generaretur $Q$; corrumperetur in aliquod aliud $V 126$ inducit] reducit $I P 127$ comburentur] $\rightarrow$ 
corromper a substância do pão, se o pão estivesse presente neles. No segundo, os acidentes poderiam alterar-se com tal e tão profunda alteração que a substância do pão, se estivesse sob eles, se corromperia e se destruiria e dela se produziria alguma outra coisa. Se, portanto, ouve bem, no primeiro modo esses acidentes se alterarem a ponto de perderem a natureza de alimento apropriado para o homem, podendo, todavia, manter-se com o pão, então Deus, no seu infinito poder, traz de novo a substância do pão que se havia retirado ou do vinho que partira, e esses acidentes produzirão de novo a substância do pão. E, assim, aí estará de novo o pão, mas não o alimento apropriado para o homem. E manter-se-á até ser corrompido por um agente natural, como aconteceria se nunca daí se tivesse afastado. Se, porém, os acidentes se alterarem nos termos do segundo modo, de tal modo que se o pão aí estivesse se corromperia em outra qualquer coisa, em tal caso, Deus não faz vir de novo a substância do pão, que deixou de existir, mas induz a substância na qual o pão se teria então convertido se aí estivesse, quer se trate de sangue, quer de carne, como acontece quando se comem, ou de fogo, como quando os acidentes são queimados, ou dos vermes, como quando apodrecem.

Mas porque é que no primeiro modo, quando os acidentes não estão tão alterados que o pão se corrompesse se sob eles estivesse a substância do pão, o pão, de que então nada seria gerado, retorna? Digo-te que isso acontece por isto, porque Deus estabeleceu definitivamente que os acidentes nunca estejam sem sujeito senão quando são sacramento do corpo e do sangue de Cristo. E porque quando então deixam de ser alimento apropriado para o homem, deixam de ser sacramento, por isso, para não estarem sem sujeito, faz Deus retornar-lhes o sujeito próprio. Quando, na realidade, se alteram de acordo com o segundo modo, nesse caso, não é preciso que o pão retorne, mas basta que aí se estabeleça a substância em que o pão se converteria se aí estivesse.

Vê e leva em conta, disse sorrindo, como eu sei mais que todos os vossos doutores!

Isso é claro para mim, anjo santíssimo, disse eu. Dou graças à divina Providência, que se apiedou de mim e de todos nós. Eu, simples e ignorante, nunca poderia entender isto sem a divina iluminação.

Ainda não estás a perceber o que quis dizer, começou o anjo a falar de novo. Alguns de vós, dos quais um foi pontífice, disse, não como pontífice, mas como doutor, que em ambas as alterações que se verificam nos dois modos antes referidos retorna a substância do pão que se havia afastado. Mas outros, entre os quais se conta um doutor da tua Ordem, que se acha aqui pleno de santidade, porque

$\leftarrow$ comburuntur $I Q$; comburantur $V 128$ putrefiunt] interfiunt $I \mathbf{1 2 9}$ si sub eis esset substantia panis, panis reuertitur] si sub eis esset, substantia panis reuertitur NOPQ 130 Dico tibi propterea id fieri] Dico tibi plus, propter id fieri $Q 131$ reducit] adducit $Q 132$ unus fuit Pontifex] Inocentius 3s add. O (in marg. a. m.); Sixtus add.J 
Virginis Matris et Reginae nostrae (et ostendebat Ioannem, Scotum nuncupatum, pro quo decertant Scoti et Anglici), dicunt quod in utraque alteratione subducitur ${ }^{133}$ alia subtantia et quod substantia panis quae desiit numquam amplius reuertitur. Ego dico tibi quod aliquando reuertitur, ut in priori alteratione, aliquando non reuertitur, ut in posteriori alteratione. Et hoc ideo quia in priori alteratione [f 1. 121] substantia panis reducitur propter hanc causam solum, ne accidentia illa, quae iam non sunt sacramentum, maneant sine subiecto ${ }^{134}$ et quia substantia eorum non fuisset corrupta si tunc sub eis fuisset. Melius est ergo eandem substantiam panis reducere quam aliam nouiter creare maxime quia non est ratio quare magis hanc quam illam oporteat creare. Vult ergo Deus ${ }^{135}$ ut potius illa redeat, ex quo nulla causa est reditionis nisi quia non uult haec accidentia esse sine subiecto. Sicut ergo absentia panis uel uini fuit causa ut haec accidentia fierent sacramentum, ita etiam uoluit ${ }^{136}$ quod praesentia panis uel uini esset causa ut non sint amplius sacramentum.

Scribe, scribe hoc ${ }^{137}$ illi, quia delectabitur in his super omnia. Scribe hoc modo. Dico tibi. Primo intellige accidentia uehementer alterari sic ut non sint amplius cibus conueniens. Et haec alteratio fit in tempore. Secundo intellige ${ }^{138}$ quod, in ultimo instanti illius temporis dictam alterationem mensurantis, Deus reducit substantiam panis quae amissa erat et tunc accidentia illa ex tunc ulterius amittunt nomen et rationem sacramenti. Et ita ibi corpus Domini desinit esse. Sic etiam quando creat substantiam nouam. Primo, accidentia alterantur. In ultimo instanti aliqua substantia inducitur ${ }^{139}$, in quo instanti uerum est talem substantiam ibi esse et ita negationem sacramenti cum illa esse, et ita corpus Christi ibi non esse. In eodem ${ }^{140}$ ergo instanti corpus aliud accedit et corpus Domini discedit, siue, illud incipit esse et corpus Domini desinit ${ }^{141}$ esse. Sed posterius natura aliud corpus ibi esse incipit et prius natura corpus Domini ibi esse desinit ${ }^{142}$, sicut quando ${ }^{143}$ peccator de peccatis paenitentiam agit. In eodem instanti sibi culpa remittitur et gratia confertur. Sed prius natura intelligitur culpa remissa quam gratia collata, intelligendo per culpam non solum priuationem gratiae, sed aliquod positiuum $^{144}$. Res namque non potest intelligi aliquid recipere nisi intelligatur aliud quasi prius amittere, quando quod recipitur non potest simul esse cum illo quod amittitur uel ex incompossibilitate ${ }^{145}$ rerum uel ex ordinatione diuina ${ }^{146}$. Scito ergo et animaduerte et diligenter conscribe, ut tibi quae dico sint clariora, quod

133 subducitur] subdicitur $I$; producitur $Q \mathbf{1 3 4}$ substantia panis reducitur propter hanc causam solum, ne accidentia illa quae iam non sunt sacramentum maneant sine subiecto] substantia panis solum propter hanc causam reducitur in accidentia illa, quae iam non sunt, ne maneant sine subiecto $Q 135$ ergo Deus] ergo Deus, ut ex uestris dicunt aliqui $Q \quad 136$ uoluit] noluit $V 137$ hoc] haec $Q$; homini $V \mathbf{1 3 8}$ Secundo intellige] Secundo, maxime quia non est ratio quare magis hanc quam illam nouiter oporteat creare, intellige $V 139$ inducitur] reducitur $V 140$ ibi esse (...) ibi non esse. In eodem] ibi esse. In eodem I 141 Domini discedit siue illud incipit esse et $\rightarrow$ 
foi o primeiro que desembainhou a espada em defesa da imaculada conceição da Virgem Mãe e Rainha nossa (e mostrava João, chamado Escoto, por quem se batem escoceses e ingleses), dizem que em ambas as alterações se induz outra substância e que a substância do pão, que deixou de existir, não retorna mais. Eu digo-te que umas vezes volta, como na primeira alteração, outras vezes não volta, como na segunda. E isto porque, na primeira alteração [fl. 121] a substância do pão é reconduzida por esta razão apenas, para que esses acidentes, que já não são sacramento, não permaneçam sem sujeito, e porque a substância deles não seria corrompida se nessas condições estivesse sob eles. É melhor, portanto, reconduzir a mesma substância do pão do que criar novamente outra, sobretudo porque não há razão pela qual convenha mais criar esta do que aquela. Portanto, Deus prefere que volte aquela, uma vez que não há razão nenhuma de retorno, a não ser que não quer que os acidentes estejam sem sujeito. Assim, pois, como a ausência do pão ou do vinho foi razão para que estes acidentes se tornassem sacramento, assim também quis que a presença do pão ou do vinho fosse a causa para que já não fossem sacramento.

Escreve, escreve isto para ele, porque nisto se irá deleitar acima de tudo. Escreve deste modo, eu digo-te. Primeiro, compreende que os acidentes se alteram profundamente a ponto de não serem mais alimento apropriado. E esta alteração faz-se no momento próprio. Segundo, compreende que, no último instante do tempo que mede a referida alteração, Deus traz de novo a substância do pão que se havia retirado e, nesse momento, esses acidentes perdem daí em diante o nome e a natureza de sacramento. E, assim, o corpo do Senhor deixa de aí estar, como quando cria uma nova substância. Primeiro, os acidentes alteram-se. No último instante, induz-se uma substância, instante em que é verdade que essa substância está aí e, assim, com ela, está a negação do sacramento e, assim, o corpo de Cristo não está aí. Portanto, no mesmo instante chega outro corpo e o corpo do Senhor retira-se, ou, começa aquele a estar e o corpo do Senhor deixa de estar. Mas, depois, de acordo com a ordem natural, começa a estar aí outro corpo, e, antes, de acordo com a ordem natural, deixa de estar aí o corpo do Senhor. Como quando um pecador faz penitência dos seus pecados, no mesmo instante é-lhe perdoada a culpa e conferida a graça. Mas, de acordo com a ordem natural, entende-se que a culpa foi perdoada antes de a graça ser conferida, entendendo por culpa não só a privação da graça, mas algo positivo. Com efeito, não pode entender-se que uma coisa receba algo se não se entender que antes haja perdido

$\leftarrow$ corpus Domini desinit] Domini desinit $P V 142$ Sed posterius natura aliud corpus ibi esse incipit et prius natura corpus Domini ibi esse desinit] Sed posterius, nam aliud corpus ibi esse incipit et prius natura corporis Domini ibi esse desinit $H V 143$ sicut quando] sicut ex uestris aliquid dicunt quando $O V 144$ sed aliquod positiuum] sed aliquod positiuum si poneretur ut ille reatus seu obligatio ad penam $M$ (in marg. a. m.) NOQ; sed aliquo modo positiuum si ponatur sed obligatio ad poenam $P 145$ incompossibilitate] impossibilitate $O 146$ Res namquam non potest intelligi aliquid (...) uel ex incompossibilitate rerum uel ex ordinatione diuina.] om. $Q$ 
Deus potest in eodem instanti in quo substantia panis intelligitur discessisse, in eodem corpus Filii sui facere ibi esse. Sed prius natura substantia panis intelligitur ibi non esse quam corpus Domini ibi esse. Potest etiam non illo instanti, sed in tempore minimo illi instanti propinquissimo, loquendo ut uestri philosophi loquuntur, qui nolunt unum instans alteri immediatum esse nec punctum puncto, quod an uerum sit et qualiter uerum sit illi reuelabitur alio tempore, cui et alia reuelanda sunt. Eodem modo, alteratis accidentibus in tempore aliquo, in ultimo instanti illius temporis Deus potest reducere substantiam panis uel aliam et in eodem instanti prius natura desinit esse corpus Christi et accidentia desinunt esse sacramentum. Potest etiam Deus, et facit sicut sibi placet, in ultimo instanti illius temporis facere ut accidentia illa desinant esse sacramentum et corpus Domini ibi desinat esse et in tempore propinquissimo illi instanti, ut uestrorum philosophorum more loquar, quia et ego opera Aristotelis [f1. 122] uestri legi et intellexi antequam scripsisset (et hoc dicens subrisit) creare substantiam panis uel alterius rei secundum quod alteratio facta fuerit uno modo uel altero. Et tunc pro uno instanti accidentia erunt sine subiecto et sine praesentia corporis Domini. Et sic uerum esset dicere tunc: "Accidentia sunt sine subiecto et non sunt $^{147}$ sacramentum pro instanti non pro tempore." Posset etiam Deus in ultimo instanti alterationis substantiam panis uel aliam ibi ponere nec tamen corpus Domini amouere pro tunc, sed in tempore illi instanti immediato, quia sicut corpus Domini potest esse simul cum quantitate ${ }^{148}$ panis ita potest esse simul cum pane. Eodem modo, quando fit consecratio, posset panis manere adueniente corpore Domini, deinde desinere. Et sic pro aliquo instanti uerum esset dicere: "In hoc sacramento accidentia sunt in subiecto". Posset etiam pro tempore et pro semper Deus panem ibi conseruare cum corpore Christi. Sed tunc non posset ${ }^{149}$ dici: "Panis transubstantiatur ${ }^{150}$ uel transit aut conuertitur in corpus Christi". Et an omnibus modis praedictis Deus utatur uel tantum uno illorum quando fit hoc sacramentum alias dicetur illi de quo totiens diximus. Et an eodem modo uel alio et alio fiat apud uos et alios, ut puta Graecos, Armenos et huiusmodi, tunc declarabitur. Tibi credendum est firmiter, quia uerum est, quod Ecclesia tua tibi dicit, uidelicet panem transubstantiari ${ }^{151}$ et transire in corpus Domini ita ut prius natura panis abscedat ${ }^{152}$ et tunc posterius tantum natura corpus Domini ibi incipiat esse et in tempore immediato panis desinat esse ne sequatur quod in conuersione sit anihilatus ${ }^{153}$. Non enim in conuersione anihilatur, sed quasi post conuersionem, quamuis etiam post conuersionem non sit omnino anihilatus, quia remanserunt accidentia quibus ipse panis est aptus natus affici sicut si alicuius rei u. g. aquae materia desineret esse, forma uero remaneret. Tunc materia illa ${ }^{154}$ non esset anihilata, quia remaneret in forma qua nata est perfici sicut et uos

147 sine subiecto et sine (...) sine subiecto et non sunt] sine subiecto et non sunt $I V \quad 148$ quantitate] qualitate $V \quad 149$ posset] potest $I V \quad 150$ transubstantiatur] transmutatur $P \quad 151$ transubstantiari] transmutari $P \mathbf{1 5 2}$ ita ut prius natura panis abscedat] ut prius natura ita panis $\rightarrow$ 
algo, quando o que é recebido não pode estar simultaneamente com aquilo que se perde, ou por incompossibilidade real, ou por disposição divina. Sabe, pois, e presta atenção e escreve diligentemente, para que o que te digo seja mais claro, que no mesmo instante em que se entende que a substância do pão se afastou, nesse mesmo instante pode Deus tornar aí presente o corpo de seu Filho. Mas, primeiro, de acordo com a ordem natural, entende-se que a substância do pão aí não esteja do que aí esteja o corpo do Senhor. Pode, também, não nesse instante mas na porção mínima de tempo próxima desse instante, para falar como falam os vossos filósofos que não aceitam que um instante seja imediato a outro nem um ponto a outro ponto, o que será revelado noutra ocasião àquele a quem outras coisas devem ser reveladas se é verdade e de que modo é verdade. Do mesmo modo, alterados os acidentes em algum tempo, no último instante desse tempo pode Deus fazer voltar a substância do pão ou outra e, nesse mesmo instante, primeiro, de acordo com a ordem natural, deixa de haver corpo de Cristo e os acidentes deixam de ser sacramento. Pode ainda Deus, e faz como the apraz, no último instante desse tempo fazer que os acidentes deixem de ser sacramento e o corpo do Senhor deixe de aí estar e - no tempo mais próximo desse instante, para falar segundo o hábito dos vossos filósofos, porque também eu li e compreendi as obras do vosso Aristóteles [f1. 122] antes que as escrevesse (e ao dizer isto sorriu-se) - criar a substância do pão ou de outra coisa, conforme a alteração for feita de um modo ou de outro. E, nesse caso, por um instante estarão os acidentes sem sujeito e sem a presença do corpo do Senhor. E, assim, seria justo dizer então: os acidentes estão sem sujeito e não são sacramento por um instante, não por algum tempo. Poderia ainda Deus, no último instante da alteração, colocar aí a substância do pão ou outra e não remover, contudo, o corpo do Senhor nesse momento, mas no tempo imediato a esse instante, porque do mesmo modo que o corpo do Senhor pode estar em simultâneo com a quantidade do pão, pode também estar em simultâneo com o pão. Do mesmo modo, quando se faz a consagração, poderia o pão manter-se enquanto chega o corpo do Senhor, depois, deixar de estar. E, assim, seria justo dizer, relativamente a qualquer instante: neste sacramento os acidentes estão no sujeito. Poderia também Deus, em razão das circunstâncias e definitivamente, manter aí o pão com o corpo de Cristo. Mas, nesse caso, não poderia dizer-se: o pão transubstancia-se ou muda-se ou converte-se no corpo de Cristo. E se Deus usa de todos os modos referidos ou de apenas um deles quando se celebra este sacramento, será dito noutra ocasião àquele de quem tantas vezes falámos. E se se celebra do mesmo modo ou de modo diverso entre vós e outros, como, por exemplo, os gregos, os arménios e outros, será dado a conhecer então. Tu deves acreditar firmemente, porque é 
quando aqua corrumpitur non dicitis formam aquae anihilatam esse, quia remanet in materia quam perficere et informare ${ }^{155}$ potest et in qua agens potest formam inducere, non tamen illam quae destructa est, sed aliam similem. Sed differentia est quia, destructa materia et remanente forma, agens creatum non potest facere ut forma illa ullam materiam informet, sed bene potest facere Deus. Similiter, destructa substantia et remanentibus accidentibus, agens creatum non potest facere ut illa ${ }^{156}$ informent illam substantiam, sed bene potest facere Deus. Satis est $^{157}$ ergo ut sit in accidentibus aptitudo informandi substantiam panis et ita panis non est omnino anihilatus, ut diximus.

Intellexisti iam tu aliqualiter quomodo numquam ex non substantia generatur substantia et qualiter substantia panis destructa multotiens reuertitur et multotiens alia substantia ibi ponitur, illa uidelicet quae tunc ex pane sic alterato generaretur si panis ibi esset. Et oportuit ita facere, carissime, ut iterum uel panis uel alia substantia produceretur ne materia prima ex qua generantur omnia periret. Nam si mundus longo tempore esset duraturus et hoc sacramentum frequentaretur in toto mundo, quotidie magna pars materiae destrueretur [f1. 123] et in decem annis maior et in centum ac mille adhuc maior, et materia corrupta numquam reuerteretur nec alia noua crearetur, posset in processu temporis horum inferiorum materia deficere et ita generatio impediri. Sapientissimus ergo Deus omnia uidit et omnibus prouidit. Ideo tantam ${ }^{158}$ materiam iterum reducit quanta destruitur ${ }^{159}$.

Tunc ego: Domine mi, ex quo posset esse $^{160}$ in hoc sacramento panis simul cum corpore Christi et esset signum efficacius ${ }^{161}$ corporis Christi, quia panis est cibus efficacior accidentibus solis, efficacius ergo significaret cibum animae et non oportet $^{162}$ materiam destrui nec destructam reparari ${ }^{163}$, cur ergo panis destruitur?

155 quam perficere et informare] qua perficere et informari $I 156$ facere ut forma (...) non potest facere ut illa] facere ut illa $O 157$ facere Deus. (...) potest facere Deus. Satis est] facere Deus. Satis est $N P 158$ tantam] totam $M 159$ quanta destruitur] quantum destruetur $P \quad 160$ posset $\rightarrow$ 
verdade, no que a tua Igreja te diz, ou seja, que o pão se transubstancia ou muda no corpo do Senhor de tal modo que, primeiro, de acordo com a ordem natural, o pão se afasta e, somente depois, de acordo com a ordem natural, o corpo do Senhor começa a estar aí e, no tempo imediato, deixa de haver pão, para que não suceda que na conversão seja aniquilado. Efectivamente não é aniquilado na conversão, mas quase depois da conversão, embora também depois da conversão não seja completamente aniquilado, já que se mantiveram os acidentes com os quais o próprio pão está apto a renascer, como se a matéria de uma qualquer coisa, por exemplo, da água, deixasse de existir, mas se mantivesse a forma. Nesse caso, essa matéria não seria aniquilada, porque se manteria na forma em que nasceu para ser completada, como também, quando a água se altera, vós não dizeis que a forma da água foi aniquilada, porque permanece na matéria que pode completar e enformar e na qual um agente pode induzir a forma, não, todavia, aquela que foi destruída, mas outra semelhante. A diferença, pois, está em que, destruída a matéria e mantida a forma, um agente criado não pode fazer que essa forma enforme alguma matéria, mas pode bem fazê-lo Deus. De modo semelhante, destruída a substância e mantendo-se os acidentes, não pode um agente criado fazer que estes enformem aquela substância, mas pode bem fazê-lo Deus. Basta, pois, que exista nos acidentes a aptidão de enformar a substância do pão e, assim, o pão não é totalmente aniquilado, como dissemos.

Tu, de algum modo, já compreendeste como da não substância se não gera nunca a substância, e de que modo a substância do pão, destruída, retorna muitas vezes e muitas vezes aí se põe outra, ou seja, aquela que nessas circunstâncias se geraria do pão assim alterado se o pão aí estivesse. Foi, pois, conveniente agir assim, meu caro, para que de novo se produzisse ou o pão ou outra substância, a fim de que a matéria-prima, da qual tudo se gera, não desaparecesse. Pois, se o mundo houvesse de durar por longo tempo e este sacramento se celebrasse em todo o mundo, em cada dia seria destruída [f1. 123] grande parte da matéria, e em dez anos uma parte maior, e maior ainda em cem e em mil. E se a matéria destruída jamais voltasse e não se criasse outra nova, poderia, na marcha do tempo dos vindouros, faltar a matéria e, deste modo, impedir-se a geração. Por isso, o Deus sapientíssimo tudo viu e a tudo providenciou. Por isso, traz de novo tanta matéria quanta se destrui.

Meu Senhor, perguntei então, desde que neste sacramento o pão pudesse estar em simultâneo com o corpo de Cristo e fosse sinal mais eficaz do corpo de Cristo, porque o pão é alimento mais eficaz do que só os acidentes, portanto, significaria mais eficazmente o alimento da alma e não seria necessário que a matéria fosse destruída nem que fosse reparada depois de destruída, porque se destrui, então, o pão?

$\leftarrow$ esse] posset $I$; possit $N Q 161$ efficacius] effectiuum $V 162$ oportet] opus $I$; oporteret $N O P Q 163$ reparari] recuperari $V$ 
Respondit: Bene scio uobis ualde defficile esse et philosophi respuunt illud et est prauis et obstinatis seu proteruis occasio non sequendi fidem Christi. Sed ualde congruum et utile fuit bonis ingeniis et probis hominibus ut acuerent ingenia sua inuestigando possibilitatem tot mirabilium quae sunt ${ }^{164}$ in hoc sacramento et etiam ut, captiuando intellectum proprium, merita magna sibi accumularent ${ }^{165}$ apud Deum, quia ergo totus mundus credebat haec impossibilia esse, quod fuit deceptio et error. Sicut autem ueritas est bonum intellectus et sanitas eius ita et error est malum et infirmitas eius. Vt ergo Deus uos eriperet a tantis erroribus et illuminaret et erudiret, reuelauit uobis $\mathrm{se}^{166}$ omnia haec facere posse. Et ut firmiter crederetis eum illa posse facere, uoluit ea facere ut uos crederetis et nos angeli experientia comprobaremus id fieri quando illud fieri uideremus. Multum profuit etiam nobis mirabilia quae facere potest Deus uidere uidelicet illa fieri et facta. Vnde assidue, quando talia facit Deus, hoc est, quotidie, cantamus canticum coram Domino, quotidie uidentes tanta mirabilia incendimur ${ }^{167}$, inflamamur, magnificamus et gratias agimus. Quod quidem canticum tibi postea reserabo.

Vt itaque Deus ostenderet potentiam suam, et ut uos homines a tanta infirmitate animi et a tantis erroribus ${ }^{168}$ liberaret, et ut nobis angelis experientia ostenderet ut eum extolleremus et potentiam suam infinitam magnificaremus, et ut uobis merendi occasionem praeberet, uoluit in hoc ineffabili sacramento accidentia sine subiecto conseruare ${ }^{169}$. Et ut sciretis ipsum etiam materiam primam creasse, ideo in hoc sacramento solum eam destruit et ${ }^{170}$ in nihilum redigit et quandoque eam ${ }^{171}$ redire facit, interdum consimilem creat. Haec homines numquam credidissent esse possibilia. Nunc autem et credunt ${ }^{172}$ et tamquam uera tenent et affirmant, parati proprium sanguinem effundere pro tali ueritate.

Propterea ergo Deus sine destructione panis poterat ${ }^{173}$ corpus suum ibi ponere simul cum pane, sed rationibus praedictis uoluit ${ }^{174}$ huic miraculo plura alia annectere ut posset ${ }^{175}$ omnis creatura infinitam Dei uirtutem extollere et sublimare.

Qui ergo dicunt Deum sine conuersione panis non potuisse corpus Christi facere ibi esse, hi ${ }^{176}$ purgati una ignorantia retinent aliam. Credunt enim panem ibi non esse et hoc recte credunt. Sed quia corpus Domini aliter ibi esse non posse nisi panis conuerteretur in illud putant, alio errore [fl. 124] inuoluuntur ${ }^{177}$. Hi enim tantum ea posse fieri affirmant quae fides eos affirmare compellit. Quid confert desitio ${ }^{178}$ panis ad hoc ut corpus Domini sit ibi? Nonne sicut nunc est cum quantitate panis ita tunc esset simul cum ipso pane? Tantum enim repugnat

164 sunt] fiunt $Q \quad 165$ accumularent] accumulent $I N P V \quad 166$ se] Deum $Q \quad 167$ incendimur] iocundimur $I V 168$ et a tantis erroribus] et ueritatis erroribus $Q 169$ conseruare] esse et conseruari $Q \mathbf{1 7 0}$ in hoc sacramento solum...et] non in hoc sacramento solum...et $N$; in hoc sacramento non $\rightarrow$ 
Sei bem, respondeu, que é para vós muito difícil, e os filósofos o rejeitam, e se constituiu para perversos e obstinados ou orgulhosos em ensejo para não seguirem a fé de Cristo. Mas foi muito conveniente e útil aos bons e honestos homens para aguçarem seus engenhos a investigar a possibilidade de tantas maravilhas que há neste sacramento, e ainda para, dominando a inteligência própria, acumularem para si, junto de Deus, grandes méritos, porque todo o mundo considerava que isso era impossível, o que se constituiu em decepção e erro. Porém, assim como a verdade é o bem da inteligência e a sua saúde, assim também o erro é o seu mal e a sua doença. Para que, pois, Deus vos libertasse de tão grandes erros e vos iluminasse e instruísse, mostrou-vos que podia fazer todas estas coisas. $\mathrm{E}$, para que acreditásseis firmemente que podia fazê-lo, quis fazê-lo para que vós acreditásseis e nós anjos comprovássemos pela experiência que isso se realizava, quando o víssemos acontecer. Muito útil nos foi também a nós ver as maravilhas que Deus pode fazer, ou seja, vê-las acontecer e vê-las feitas. Daí que, incessantemente, quando Deus faz estas coisas, isto é, em cada dia, cantemos perante o Senhor um cântico, ao vermos em cada dia tão grandes maravilhas nos abrasemos, nos inflamemos, celebremos e dêmos graças. Canto, precisamente, que te revelarei depois.

E, deste modo, Deus, para mostrar o seu poder e para vos libertar a vós homens de tanta debilidade de espírito e de tão grandes erros, e para nos mostrar a nós anjos, pela experiência, que devíamos exaltá-lo e engrandecer seu poder infinito, e para vos proporcionar ocasião de merecimento, quis conservar neste inefável sacramento os acidentes sem sujeito. $\mathrm{E}$, para que soubésseis que ele também criou a matéria prima, a destrui, por isso, e a aniquila apenas neste sacramento e, por vezes, a faz voltar e, de vez em quando, cria uma semelhante. Nunca os homens acreditariam que isto era possível. Mas agora não só o crêem como o têm por verdadeiro e o afirmam, dispostos a derramar o próprio sangue por esta verdade.

Por causa disso, pois, podia Deus, sem a destruição do pão, pôr aí seu corpo em simultâneo com o pão, mas, pelas razões referidas, quis acrescentar a este vários outros milagres para que toda a criatura pudesse exaltar e glorificar o infinito poder de Deus.

Os que dizem que Deus sem a conversão do pão não teria podido tornar aí presente o corpo de Cristo, esses, expurgados de uma ignorância, conservam outra. Crêem, de facto, que o pão não está aí, e justamente o crêem. Mas porque julgam que o corpo do Senhor não poderia aí estar de outro modo se o pão se não tivesse convertido noutra coisa, envolvem-se em outro erro. [f1. 124] Estes, na verdade, afirmam que apenas pode acontecer aquilo que a fé os impele a afirmar. Em que contribui o afastamento do pão para que o corpo do Senhor aí

$\leftarrow$ solum...sed etiam $Q 171$ eam] eandem $I M 172$ et credunt] tamquam uera credunt $P 173$ poterat] potentiae $V \mathbf{1 7 4}$ sed, rationibus praedictis, uoluit] rationibus praedictis noluit sed uoluit $Q 175$ posset] possit $N Q 176$ hi] si $I V 177$ inuoluuntur] reuoluuntur $P 178$ desitio] deficio $I$; defectio $V$ 
duas substantias esse in uno loco quantum duas quantitates. Immo quia causa essendi in loco circumscriptiue est quantitas, tota repugnantia ne duo corpora essent simul prouenit a quantitate. Certum est panem non remanere in corpore Domini nec quicquam panis in illo corpore esse, quia illud corpus hac conuersione nec augetur nec in aliqua sui parte generatur. Si quoque ${ }^{179}$ panis maneret, unum miraculum esset uidelicet quia duo quanta essent simul. Pane abscedente ${ }^{180}$, fiunt plura miracula. Primum est quod duo quanta sunt simul; secundum est quia accidentia remanent sine subiecto; tertium est quia panis desinit ${ }^{181}$ esse ita quod etiam materia eius destruatur et desinat esse. Omnia ergo miranda quae tunc essent et nunc sunt et multo plura. Remoueantur illa plura, stent illa communia. Facilius intelligitur unum miraculum quam plura inter quae cadit illud unum. Ex quo uides quod difficilius est asserere hoc quod asseritur uidelicet ut ibi non possit esse ${ }^{182}$ corpus Domini nisi pane cedente, quam dicere ibi est corpus Domini cum pane. Quando" ${ }^{183}$ ergo dicebas: "Si panis ibi esset, quia est cibus efficacior solis accidentibus, tunc esset signum efficacius cibi animae", dico tibi, quod uerum est, panem melius nutrire quam accidentia. Immo accidentia non nutriunt, quia non conuertuntur in nutritum ${ }^{184}$. Tamen accidentia magis ostendunt uobis hominibus bonitatem nutrimenti, immo per sola illa iudicatis ${ }^{185}$ et approbatis nutrimenti conuenientiam.

Sacramenta uero uobis data sunt non angelis. Melius ergo fuit ea dari in signo sensibili. Et sacramentum congruum fuit institui in illis signis quae uobis maxime ostendunt bonitatem alimenti, quae sunt accidentia panis et uini. Quando ergo dicebas: "Panis est nutrimentum efficacius", concedimus, immo est solus ipse nutrimentum ${ }^{186}$. Sed panis non esset signum efficacius bonitatis ${ }^{187}$ nutrimenti, immo nullum. Sufficiebat ergo sacramentum hoc in eis rebus instituere quae maxime denotarent bonitatem nutrimenti, non quae maxime nutrirent. Panis autem abscedit propter quattuor rationes paulo ante tibi dictas.

Tunc ego: Fortissime Gabriel, tu dixisti et ego etiam a nostris audiui corpus Domini non esse sub accidentibus nisi in fine prolationis omnium uerborum. Quando ergo accipitur panis et benedicitur dicendo: Hoc est corpus meum; similiter et uinum: Hic est calix sanguinis mei, uel si diceret: Hic est sanguis meus, quid mihi notant ille dictiones hoc est et hic est? Quid demonstrant, quaero? Si corpus

179 Domini nec quicquam (...) sui parte generatur. Si quoque] Domini. Si quoque $Q \quad 180$ abscedente] absente $I V \quad 181$ desinit] desit $Q \mathbf{1 8 2}$ non possit esse] non sit $Q$; non posset esse IV 183 illud unum. Ex quo (...) dicere ibi est corpus Domini cum pane. Quando] illud unum. Quando $N P 184$ nutritum] nutrimentum $Q V \quad 185$ per sola illa iudicatis] per illa substantiam $\rightarrow$ 
esteja? Não estaria então simultaneamente com o pão do mesmo modo que está presentemente com a quantidade do pão? Na verdade, repugna tanto que no mesmo lugar estejam duas substâncias como duas quantidades. E mais, uma vez que a quantidade é a razão de estar num lugar de limitadamente, toda a repugnância a que dois corpos estivessem em simultâneo provém da quantidade. É verdade que o pão não permanece no corpo do Senhor, e nem coisa alguma do pão está nesse corpo, porque esse corpo, nesta conversão, nem é aumentado, nem gerado em parte alguma de si. Se também o pão permanecesse, seria um milagre, ou seja, porque dois quanta existiriam em simultâneo. Com a partida do pão, acontecem vários milagres. O primeiro é que dois quanta estão em simultâneo; o segundo é que os acidentes se mantêm sem sujeito; o terceiro é que o pão deixa de existir a ponto de também a sua matéria ser destruída e deixar de existir. Tudo, pois, coisas dignas de admiração, que então existiriam e agora existem, e muito mais. Afastemos estes todos, deixemos os habituais. Entende-se mais facilmente um milagre do que muitos, entre os quais se situa este. Daí se vê que é mais difícil defender isto que se defende, ou seja, que o corpo do Senhor não pode aí estar a não ser que o pão se afaste, do que dizer: aí está o corpo do Senhor com o pão. Quando, pois, dizias: "Se o pão aí estivesse, porque é alimento mais eficaz do que apenas os acidentes, então seria sinal mais eficaz do alimento da alma”, digo-te, porque é verdade, que o pão alimenta melhor que os acidentes. E mais, os acidentes não alimentam, porque se não convertem no alimentado. Os acidentes, contudo, mostram-vos mais a vós, homens, a bondade do alimento, ou melhor, só por eles ajuizais e aprovais a conveniência do alimento.

Ora, os sacramentos são-vos dados a vós, não aos anjos. Foi, portanto, melhor dá-los em sinal sensível. E foi conveniente que o sacramento fosse instituído naqueles sinais que melhor manifestam a bondade do alimento, que são os acidentes do pão e do vinho. Quando dizias, pois, "o pão é alimento mais eficaz", concedemos. E até só ele mesmo é alimento. Mas o pão não seria sinal mais eficaz da bondade do alimento, pelo contrário, não seria sinal nenhum. Bastava, portanto, instituir este sacramento naquelas matérias que melhor assinalassem a bondade do alimento, não que melhor alimentassem. O pão, por outro lado, retira-se em função das quatro razões há pouco referidas.

Disseste tu, fortíssimo Gabriel, adiantei eu, e eu ouvi-o também aos nossos, que o corpo do Senhor não está sob os acidentes senão no fim da prolação de todas as palavras. Quando, portanto, se pega no pão e se abençoa, dizendo: Isto é o meu corpo; igualmente no vinho: Este é o cálice do meu sangue; ou se se dissesse: Este é o meu sangue, que me indicam essas palavras: Isto é, e, Este é? Que

$\leftarrow$ iudicatis $P 186$ est solus ipse nutrimentum] et non accidentia eius add. $M$ (in marg. a. m.) $O Q$ 187 nutrimentum efficacius", concedimus immo est solus ipse nutrimentum. Sed panis non esset signum efficacius bonitatis] nutrimentum efficacius" bonitatis $V$ 
Christi, ergo ${ }^{188}$ ante finem prolationis est ibi. Si panem, tunc falsa est locutio illa ${ }^{189}$ ut "hoc", id est, panis sit corpus Christi. Multotiens de hoc dubitaui et aliquos theologos interrogaui et uarie mihi respondent nec nunc recordor.

Respondit angelus: Et ego recordor qualiter dicunt neque sum oblitus. Aliqui ex uestris ${ }^{190}$ dicunt quod ostendit et demonstrat corpus Christi, non quia tunc sit ibi, sed quia statim erit ${ }^{191}$. Quia statim accingendus pro accinto habetur et quando parum deest nihil deesse uidetur. [f1. 125]

Alii uero dicunt idem alio modo. Hoc est, idest, hoc quantum quod uides est corpus meum, idest, sub eo et cum eo statim erit. Vel hoc, id est, ens est corpus meum.

Alii quod ${ }^{192}$ omnino non significat nisi pro ultimo instanti totius prolationis. Quando ergo dicis: Hoc est corpus meum, sensus est: Pro illo instanti ultimo est ibi corpus Christi. Quod ergo pro ultimo instanti habes in manibus, illud ostendis, non id quod tunc habes quando dicis $h o c^{193}$. Quando enim dicis: Hoc est corpus meum, oratio illa neque uera neque falsa est, sed neutra. Prolatis autem omnibus dictionibus illis, concipitur tota simul ut uera. Si ergo non est uera nisi in fine totius prolationis et in fine totius prolationis non est oratio sacramentalis, sed antea uidelicet dum profertur ${ }^{194}$, sequitur quod in quantum est oratio sacramentalis nec uera est nec falsa. Nam, dum profertur, est sacramentalis, quia conficit sacramentum, quando prolata est, tunc uera est, sed non conficit sacramentum, quia iam confectum est. Simul enim illa accidentia incipiunt esse sacrammentum et oratio illa est uera et incipit esse uera, quamuis prius natura sit oratio quam intelligatur ut uera.

Alii dicunt illa uerba ${ }^{195}$ quando tunc proferuntur nihil demonstrare ${ }^{196}$. Qui enim recitat alterius uerba, nil ipse ostendit, sicut ${ }^{197}$ quando dicitis: Dixit Iesus matri suae: Mulier, ecce filius tuus. Solum recitatis illud quod Iesus tunc matri demonstrabat uidelicet Ioannem. Vos autem nihil demonstratis. Ita sacerdos dicit Dominum dixisse, accepto pane et iam conuerso in carnem: Hoc est corpus meum. Dicunt itaque quod quando Iesus accepit panem et benedixit, tunc panis fuit conuersus in corpus ipsius. Ideo ipse uere dixit: Hoc est corpus meum quia ${ }^{198}$ quando hoc dixit iam corpus erat ibi.

Ingenia uestra subtilia satis sunt et tota ista altercatio ${ }^{199}$ facta est quia nescitis quomodo Dominus consecrauit nec quomodo uos instruxit et uobis modum consecrandi dedit. Non enim apostoli omnia scripserunt et, quia illa erant eis

188 Christi, ergo] Christi, ergo ante prolationem uerborum uel $Q \quad 189$ illa] tua $V 190$ oblitus. Aliqui ex uestris] oblitus quia aliqui ex uestris $Q \quad 191$ statim erit] statim erit uel hoc est ens corpus meum. $Q 192$ Alii quod] Aliquid $V 193$ dicis "hoc".] dicis "hoc est corpus meum" $Q 194$ dum profertur] dum uerba proferentur $O 195$ uerba] uera $V 196$ demonstrare] demonstrant $I \rightarrow$ 
mostram, pergunto? Se o corpo de Cristo, então está aí antes do fim da prolação. Se o pão, então é falsa esta afirmação que Isto, ou seja, o pão, seja o corpo de Cristo. Muitas vezes duvidei disto e interroguei alguns teólogos, e respondem-me de vários modos que nem recordo agora.

Mas recordo-me eu como respondem, adiantou o anjo, e não estou esquecido. Dizem alguns dos vossos que ostenta e mostra o corpo de Cristo, não que aí esteja então, mas que imediatamente irá estar. Toma-se por pronto o que de imediato deve aprontar-se e, quando pouco falta, parece nada faltar. [f1. 125]

Outros, ainda, dizem o mesmo de outro modo. Isto é, ou seja, este quantum que vês, é o meu corpo, isto é, sob ele e com ele irá estar imediatamente. Ou Isto, ou seja, este ente é o meu corpo.

Outros, que não significa absolutamente nada senão no último instante de toda a prolação. Quando dizes, pois: Isto é o meu corpo, é este o sentido: nesse último instante, está aí o corpo de Cristo. O que tens, pois, na mão no último instante, é isso que mostras, não o que tens quando então dizes: Isto. Na verdade, quando dizes: Isto é o meu corpo, essa afirmação nem é verdadeira nem falsa, mas neutra. Pronunciadas, porém, todas estas palavras, toma-se toda a afirmação ao mesmo tempo como verdadeira. Se, portanto, não é verdadeira senão no fim de toda a prolação, e no fim de toda a prolação não é afirmação sacramental, mas antes, isto é, enquanto é proferida, segue-se que enquanto é afirmação sacramental nem é verdadeira nem falsa. Pois, enquanto se profere, é sacramental, porque realiza um sacramento, depois de proferida, então é verdadeira, mas não realiza um sacramento, porque está já realizado. Ao mesmo tempo, pois, começam esses acidentes a ser sacramento e é essa afirmação verdadeira e começa a ser verdadeira, embora, segundo a ordem natural, seja afirmação antes de ser entendida como verdadeira.

Dizem outros que essas palavras, quando estão a ser proferidas, nada mostram. Aquele que recita as palavras de outrem nada mostra ele próprio, como quando dizeis: Disse Jesus a sua Mãe: Mulher, eis o teu filho. ${ }^{[159]}$ Apenas repetis o que Jesus mostrava a sua Mãe, ou seja, João. Vós, porém, nada mostrais. Assim, o sacerdote diz que o Senhor dissera, depois de pegar no pão e já mudado em carne: Isto é o meu corpo. Dizem, portanto, que quando Jesus tomou o pão e o abençoou, nessa ocasião o pão se mudou no seu corpo. Por isso, ele mesmo disse, com razão: Isto é o meu corpo, porque quando disse isso já o seu corpo aí estava.

As vossas inteligências são bem subtis e toda esta disputa acontece porque não sabeis como é que o Senhor consagrou, nem como vos instruiu e vos transmitiu o modo de consagrar. Os apóstolos, na verdade, não escreveram tudo e, sendo

$\leftarrow \mathbf{1 9 7}$ demonstrare. Qui enim recitat alterius uerba nil ipse ostendit, sicut] demonstrare sicut $Q 198$ corpus meum". (...) dixit: "Hoc est corpus meum" quia] corpus meum" quia $N \mathbf{1 9 9}$ altercatio] alteratio $V$

[159] Jo 19:26 
notissima, non cogitauerunt posterorum dubitationes. Audi tu, serue Dei, et quae tibi dico conscribe, quia ego interfui cenae Domini. Ipse, post multa alia, accepit panem in sanctas ac uere uenerabiles manus suas et, eleuatis oculis in caelum ad suum Patrem Omnipotentem, gratias egit sicut et quando Lazarum suscitauit. Dixit: Gratias tibi ago, Pater, quoniam exaudisti me, sic et tunc. Deinde, inspiciendo panem, benedixit eum uerbis propriis et subito fuit conuersus in corpus Christi. Et sic Christus Dominus ${ }^{200}$ seipsum tenebat totum manibus propriis. Deinde panis accidentia fregit, me cum Michaele et aliis sociis intuentibus et mirantibus, quia etiam nobis illa sunt miranda ${ }^{201}$ et stupenda. Videbamus Christum sedentem, uidebamus accidentia panis separatim existentia ${ }^{202}$, uidebamus panem abire inde et ipsum totum Christum in suis manibus modo mirabili existentem. Circumscriptus ipso loco et circumdatus aere, tenebat se totum ${ }^{203}$ ibi incircumscriptum ullo loco, quia non erat una pars eius in una parte loci et alia in alia, sed totus ${ }^{204}$ simul, hoc est, omnes partes sui corporis inter se distinctae, respectu loci erant indistinctae ${ }^{205}$. Quaelibet enim particula eidem loco respondebat et eidem parti loci, immo ad locum solum respectum praesentiae habebat. Ipse, passibilis, se ibi modo impassibili [f1. 126] existentem tenebat. Ibi enim existens non poterat capi neque ligari neque flagelari aut crucifigi. Et poterat ibi, hoc est, in sacramento solum esse et modo alio desinere esse et ita nullus eum neque uidere neque tangere aut capere potuisset. Ostendit ergo se non fugere mortem qui poterat inter inimicos esse neque tamen ab eis uideri aut tangi posse. Poterat tamen et alio modo se facere inimicis inuisibilem sicut et fecit quando abscondit se ex exiuit de Templo, quia per medium illorum ibat neque ipsum uidebant qui lapides in manibus tenebant et prope erant. Immo aliquos illorum tangebat neque tamen lapides iecerunt, quia quo iacerent eos nesciebant quando illum quem lapidare cupiebant non uiderunt.

Sed in sacramento isto alio modo est inuisibilis, quia hic uideri non potest eo quod non est in loco ut alia corpora. Quando uero se abscondit, erat in loco sicut et antea. Vnde ambulando motu progressiuo de loco ad locum, exiuit de Templo. Sed non uidebatur, quia non permittebat species coloris sui transire ad oculos eorum.

Erat ergo in cena Dominus noster duobus modis, uidelicet passibili et impassibili. Et ipsemet et re et modo essendi passibilis tenebat seipsum tunc passibilem in se, sed modo impassibili, quia a nullo exteriori nocumentum ei inferri poterat. Magna sunt haec quae dico et nos supremos angelos admiratione afficiunt.

200 Christus Dominus] Dominus Deus $N$; Dominus Iesus $Q 201$ miranda] mirabilia $I V \quad 202$ existentia] a substantia $Q \mathbf{2 0 3}$ se totum] seipsum $Q$; se $V \mathbf{2 0 4}$ totus] totum IOV 205 inter se distinctae, respectu loci erant indistinctae.] inter se distinctae distinctae erant, respectu loci indistinctae. $Q$ 
para eles por demais conhecido, não pensaram nas dúvidas dos vindouros. Presta atenção, servo de Deus, e escreve o que te digo, porque eu assisti à Ceia do Senhor. Depois de muitas outras coisas, ele tomou o pão em suas santas e muito veneráveis mãos e, elevando os olbos ao céu, a seu Pai Omnipotente, deu graças, ${ }^{[160]}$ como quando ressuscitou Lázaro. Disse, como então: Dou-te graças, Pai, porque me ouviste. ${ }^{[161]}$ Depois, fixando o pão, abençoou-o com as palavras apropriadas e, de imediato, este se mudou no corpo de Cristo. E, deste modo, se tinha Cristo Senhor a si mesmo todo nas próprias mãos. Depois, partiu os acidentes do pão, comigo, com Miguel e com outros companheiros a observar e a admirar, porque também para nós são estas coisas dignas de admiração e de espanto. Víamos a Cristo sentado, víamos os acidentes do pão subsistindo separadamente, víamos o pão afastar-se dali e todo o corpo de Cristo subsistindo de um modo admirável em suas próprias mãos. Circunscrito pelo próprio lugar e circundado de ar, tinha-se todo aí incircunscrito por nenhum lugar, porque não estava uma parte de si numa parte do lugar e outra noutra, mas todo juntamente, isto é, todas as partes do seu corpo, distintas entre si, estavam indistintas em relação ao lugar. De facto, cada partícula correspondia ao mesmo lugar e à mesma parte do lugar, e mais, tinha uma relação de presença com um só lugar. Ele mesmo, passível, tinha-se a si, subsistindo aí de um modo [fl. 126] impassível. Pois, estando aí, não podia ser preso nem acorrentado nem flagelado ou crucificado. E podia estar aí, isto é, no sacramento, só e, por outro lado, deixar de estar e, assim, ninguém poderia nem vê-lo, nem tocá-lo ou aprisioná-lo. Mostrou, portanto, que não fugia à morte, ele que podia estar entre os inimigos e, todavia, podia não ser visto nem tocado por eles. Podia ainda tornar-se invisível de outro modo aos próprios inimigos, como fez também quando se escondeu e saiu do Templo, porque passava pelo meio deles e não o viam, eles que estavam com pedras na mão e estavam perto. E mais, tocava nalguns deles e, todavia, não lhe atiraram as pedras, porque não sabiam para onde atirá-las ao não verem aquele que pretendiam lapidar.

Mas neste sacramento está invisível de outra maneira, porque aí não pode ser visto, dado o facto de aí não estar como os outros corpos. Quando, porém, se escondeu, estava no lugar como tinha estado antes. Daí que, deslocando-se num movimento progressivo de lugar em lugar, saiu do Templo. Mas não era visto, porque não permitia que a imagem da sua cor passasse para os olhos deles.

Portanto, nosso Senhor estava na Ceia de dois modos, a saber, passível e impassível. E ele próprio, passível na realidade de ser e no modo de ser, tinha-se então, passível em si, mas de modo impassível, porque por ninguém exterior podia ser-lhe infligido mal algum. São grandes estas coisas que refiro e enchem-nos de admiração a nós os supremos anjos.

[160] do Cânon da Missa

[161] Jo 11:14. 
Quando ergo, ut redeamus ${ }^{206}$ ad illa quae dicere inceperamus ${ }^{207}$, Dominus fregit accidentia panis sub quibus ipse totus erat, tunc uidimus sub qualibet particula ipsum eumdem et totum atque integrum ${ }^{208}$ existere $^{209}$. Apostoli panem uel accidentia panis uidebant, aliud non cernebant. Nos angeli omnia uidebamus. Et tunc Dominus Iesus dedit unicuique discipulorum portionem accidentium, sed unicuique se totum modo inuisibili ${ }^{210}$ praestitit. Et tunc uidimus eum in loco suo naturaliter et in multis locis sacramentaliter. Esse autem in loco sacramentaliter non diminuit realem praesentiam, sed otat alium modum essendi qui, etsi sit realis, tamen est inuisibilis et insensibilis. Dixit ergo primo omnibus: Accipite et comedite. Deinde unicuique seorsum, incipiendo a Petro, dicebat: "Accipe et comede, hoc est corpus meum" ita quod, dicendo illa uerba, communicabat eos sicut uos dicitis: "Corpus Domini nostri Iesu Christi custodiat animam tuam in uitam aeternam". Expleta communione, dixit eis: Filioli mei, mandatum nouum do uobis: ut diligatis inuicem sicut et ego dilexi uos et ut hoc quod ego nunc feci et uos in mei memoriam et comemorationem faciatis.

Dixit ei Petrus: Quomodo nos ista facere poterimus?

Respondit ei Iesus: Scito ${ }^{211}$ haec neque uos neque angelos meos, et conuertit se ad nos, apostoli tamen nos tunc non uidebant, facere posse. Ego tamen sicut nunc feci ita semper facere potero.

Dixit iterum Petrus: Si nos ea facere non possumus quare, magister sapientissime, iubes ut faciamus?

Respondit ei Iesus: Illa uos facietis quae potestis, ego faciam illa quae uos non potestis. Vos ista ${ }^{211}$ facietis, accipietis panem in manibus uestris, uos sacerdotes. Nunc enim dicendo Hoc facite, dedi uobis auctoritatem ista ${ }^{212}$ faciendi. Accipiendo panem, dicetis: Dominus noster, pridie quam pateretur, accepit panem et eleuatis oculis in caelum ad Patrem suum Omnipotentem sibique gratias agens, benedixit illum deditque discipulis suis dicens: Accipite et comedite. Hoc est [f1. 127] corpus meum. Vos ista ${ }^{213}$ facere potestis. Et ego subito in fine prolationis illorum uerborum faciam corpus meum ibi praesens absque ulla haesitatione esse. Non ergo sufficit dicere haec uerba: Hoc est corpus meum, sed oportet illa uel consimilia praemittere. Hoc sit memoriale uobis perenne usque ad consumationem saeculi. Recordabimini ${ }^{214}$ cenae huius ultimae et amoris mei in genus humanum.

Vide igitur, dilectissime, quod aliis uerbis consecrauit Dominus, aliis instituit ut uos consecraretis. Ipse enim usus est propria auctoritate, uos, recitando gestus et uerba eius, utimini auctoritate sua. Vnde laudo et ratifico ${ }^{215}$ uos debere, consecrando, panem accipere in manibus et oculos eleuare primo in caelum

206 redeamus] redeam $P 207$ inceperamus] inceperam $P$; inciperemus $V \mathbf{2 0 8}$ et totum atque integrum] atque totum integrum $P \quad \mathbf{2 0 9}$ existere] persistere $I V \quad \mathbf{2 1 0}$ inuisibili] mirabili $Q \quad \mathbf{2 1 1}$ Scito] Scitote $M$; Scio $I O V 211$ ista] ita $Q 212$ ista] itam $I 213$ ista] ita $P Q 214$ Recordabimini] Recordamini $Q 215$ ratifico] gratifico $I Q$ 
Quando, portanto, para voltarmos àquilo que tínhamos começado a dizer, o Senhor partiu os acidentes do pão sob os quais estava todo, vimo-lo, então, a ele mesmo subsistir total e integralmente sob cada parcela. Os apóstolos viam o pão ou os acidentes do pão, o resto não o viam. Nós, anjos, víamos tudo. $\mathrm{E}$ o Senhor Jesus deu então a cada um dos discípulos uma porção dos acidentes, mas, de modo invisível, entregou-se todo a cada um. Vimo-lo, nesse momento, no seu lugar, de um modo natural, e em muitos lugares, de modo sacramental. Estar, porém, sacramentalmente num lugar não diminui a presença real, mas significa outro modo de estar que, embora seja real, é, todavia, invisível e insensível. Primeiramente disse a todos: Tomai e comei. ${ }^{[162]}$ Depois, a cada um de per si, começando por Pedro, dizia: “Toma e come. Isto é o meu corpo”, de modo que, dizendo essas palavras, se lhes dava em comunhão conforme vós dizeis: "O corpo de nosso Senhor Jesus Cristo guarde a tua alma para a vida eterna". ${ }^{[163]}$ Concluída a comunhão, disse-lhes: Meus filbinbos, dou-vos um mandamento novo: que vos ameis uns aos outros como também eu vos amei, ${ }^{[164]}$ e que o que eu fiz agora o façais vós em minha memória e minha comemoração. ${ }^{[165]}$

Como poderemos nós fazer isto, perguntou-lhe Pedro?

Fica a saber, respondeu-lhe Jesus, que nem vós nem os meus anjos (e voltou-se para nós, mas os apóstolos nesse momento não nos viam) podereis fazer isso. Eu, contudo, poderei fazê-lo sempre, como fiz agora.

Se nós, insistiu Pedro, não podemos fazer isso, porque ordenas, Mestre Sapientíssimo, que o façamos?

Vós fareis o que podeis, respondeu-lhe Jesus, eu farei o que vós não podeis. Fareis assim, tomareis o pão em vossas mãos, vós, sacerdotes (na verdade, dizendo agora: Fazei isto, dei-vos autoridade para o fazerdes), tomando o pão, direis: Nosso Senhor, na véspera da sua Paixão, tomou o pão e, elevando os olbos ao Céu, a seu Pai Omnipotente e dando-lhe graças, abençoou-o e deu-o a seus discípulos, dizendo: tomai e comei. Isto é [f1. 127] o meu corpo. ${ }^{[166]}$ Vós podeis fazer isto. E eu, imediatamente no fim da prolação dessas palavras, farei que o meu corpo se torne aí presente sem qualquer hesitação. Não basta dizer estas palavras: Isto é o meu corpo, mas é preciso antepor aquelas ou outras semelhantes. Tende isto como um memorial perpétuo até ao fim dos tempos. Haveis de vos recordar desta última Ceia e do meu amor pelo género humano.

Vê, pois, caríssimo, que o Senhor consagrou com umas palavras, com outras instituiu que vós consagrásseis. Ele, na realidade, usou de autoridade própria, vós, repetindo os seus gestos e as suas palavras, usais da autoridade dele. Donde, louvo e ratifico que, ao consagrar, vós deveis tomar o pão nas mãos e levar os olhos,

\footnotetext{
[162] Mt 26:26,

[163] do Ordinário da Missa,

[164] Jo 13:34,

[165] Jo 13:15.

[166] Cânon da Consagração,
} 
deinde super panem, respiciendo ipsum, reliqua uerba dicere uel similia usque ibi Hoc est corpus meum. Vtimini tamen illo modo quem uobis Sancti Patres uestri afflati ${ }^{216}$ Spiritu Sancto reliquerunt. Noluit Dominus ut uos conficeretis uerbis illis quibus ipse confecit. Non enim decet ministrum uti eisdem uerbis quibus usus est auctor principalis ${ }^{217}$. Quemadmodum enim decuit Christum, qui Deus est, dicere: Lazare, ueni foras et adolescens, tibi dico, surge, non decuit ut Ioannes eius uerbis uteretur quando suscitauit Drusianam, sed istis: "Excitet te Dominus Iesus Christus". Et iam excitata a Christo, praecepit ut iret domum et sibi refectionem praepararet.

Tunc ego: Quibus uerbis, angele Dei, si fas est petere ${ }^{218}$, Dominus consecrauit?

Respondit: Quia ualde et incomparabiliter ${ }^{219}$ maius miraculum est hoc quam Lazarum suscitasse, ideo Dominus, ut ostenderet se aliquid magni facturum cui nihil difficile, accepit panem et oculos ad caelum leuauit. Deinde, facta paruula morula, dixit: Pater mi omnipotens, gratias tibi ago quoniam exaudisti me. Deinde panem inspiciendo, dixit: "Vertatur panis terrestris in panem caelestem et cibus corporis in cibum spiritus". Et subito fuit factum. Haec uerba euangelistae illo uerbo notauerunt benedixit. Quid est benedixit? Est, uerbis illis panem benedictum fecit sicut Mariae ab Elisabeth dictum fuerat: Benedictus fructus uentris tui. Dominus $^{220}$ enim Iesus est uerus panis, uiuus panis, caelestis panis ${ }^{221}$, benedictus panis $^{222}$. Iste uero quem uos comeditis est panis mortuus et morientium, est panis terrestris, est panis maledictus, sicut enim primo homini peccanti dictum est: "Maledicta terra in opere tuo ${ }^{223}$, in sudore uultus tui uesceris pane tuo". Hic nunc factus ${ }^{224}$ est benedictus panis.

Gratias ergo agens et illa uerba proferens, panem benedixit, hoc est, benedictum fecit et in panem benedictum uertit. Deinde non panem benedictum neque alium qui amplius ibi non erat, sed accidentia panis fregit sub quibus, ut dixi, latitabat ${ }^{225}$ Filius Dei. Non est uera illa opinio quae dicit ibi remanere panem ut prius, et quod Verbum Dei illum panem assumebat sicut assumpsit humanitatem ita quod per talem unionem panis esset Deus et Deus panis et caro esset panis et panis caro. Nam si homo est Deus et Deus est panis, tunc homo esset panis et panis homo uel ideo panis est caro, quia ${ }^{226}$ Verbum mediante carne assumpsisset panem ${ }^{227}$. Poterat

216 afflati] affati $N \mathbf{2 1 7}$ Non enim decet ministrum uti eisdem uerbis quibus usus est auctor principalis.] Non enim decet magistrum ut eisdem uerbis quibus ipse confecit quibus uerbis est auctor principalis. $Q \mathbf{2 1 8}$ petere] dicere $Q \quad 219$ incomparabiliter] comparabiliter $I V \quad 220$ fecit sicut Mariae (...) fructus uentris tui”. Dominus] fecit. Dominus $Q 221$ uiuus panis, caelestis panis] uerus panis caelestis, panis substantialis $Q \mathbf{2 2 2}$ uerus panis] uerus panis, uiuus panis, caelestis panis, benedictus panis $M$ in marg. 223 tuo] suo $I Q 224$ factus] fructus $P 225$ latitabat] latebat $Q \quad 226$ et panis homo uel ideo panis est caro, quia] et panis homo, quia JNP 227 ita quod per talem unionem panis (...) homo (uel ideo panis est caro om. JNP) quia Verbum mediante carne assumpsisset panem] ita quod per talem unionem Deus esset homo uel ideo panis et caro quia Verbum mediante carne assumpsit carnem et panem. $Q$ 
primeiro, ao Céu, depois, sobre o pão, fixando-o, dizer as restantes palavras ou semelhantes, até aqui: Isto é o meu corpo. Usai também do modo que os vossos Santos Padres, inspirados pelo Espírito Santo, vos deixaram. Não quis o Senhor que vós consagrásseis com as palavras com que ele consagrou. Não é justo que o ministro use das mesmas palavras de que usou o autor principal. Do mesmo modo que foi oportuno que Cristo, que é Deus, dissesse: Lázaro, vem cá para fora $;^{[167]}$ e: Menina, eu te ordeno, levanta-te ${ }^{[168]}$ não o foi que João usasse das palavras do Mestre quando ressuscitou a Drusiana, mas destas: "Ressuscite-te o Senhor Jesus Cristo". E uma vez ressuscitada por Cristo, ordenou-lhe que fosse para casa e lhe preparasse uma refeição. ${ }^{[169]}$

Anjo do Senhor, perguntei eu então, com que palavras, se me é permitido pedi-lo, consagrou o Senhor?

Porque este é um milagre incomparavelmente maior do que ter ressuscitado Lázaro, respondeu o anjo, por isso o Senhor, para mostrar que iria fazer algo de maior, ele a quem nada é difícil, tomou o pão e levou os olhos ao Céu. Depois, fazendo uma pequena pausa, disse: Meu Pai Omnipotente, dou-te graças porque me ouviste. ${ }^{[170]}$ De seguida, fixando o pão, disse: "Volva-se o pão terrestre em pão celeste e o alimento do corpo em alimento da alma”. E imediatamente assim se fez. Estas palavras resumiram-nas os evangelistas com aquela: abençoou. Que significa abençoou? Significa que com aquelas palavras tornou bendito o pão, como havia sido dito por Isabel a Maria: Bendito o fruto do teu ventre. ${ }^{[171]} \mathrm{O}$ Senhor Jesus é o pão verdadeiro, o pão vivo, o pão do Céu, o pão bendito. Mas esse que vós comeis é um pão morto e de mortos, é pão terrestre, é pão maldito, como na verdade foi dito ao primeiro homem quando pecou: A terra será amaldiçoada por tua causa, comerás o teu pão com o suor do teu rosto. ${ }^{[172]}$ Este agora tornou-se o pão bendito.

Portanto, dando graças e proferindo essas palavras, abençoou o pão, isto é, tornou-o bendito e converteu-o em pão bendito. Depois partiu, não o pão bendito nem o outro, que já aí não estava, mas os acidentes do pão sob os quais, como disse, estava oculto o Filho de Deus. Não é verdadeira a opinião que diz que aí continua a estar, como antes, o pão, e que o Verbo de Deus assumiria esse pão como assumiu a humanidade, de tal modo que, por essa união, o pão seria Deus e Deus seria pão, e a carne seria pão e o pão carne. Pois, se o homem é Deus e Deus é pão, então o homem seria pão e o pão homem, ou então, o pão

\footnotetext{
[167] Jo 11:43,

[168] Lc 7:14,

[169] L.A. IX,91,

[170] Jo 11:14,

[171] Lc 1:42,

[172] Gen 3:17.
} 
quidem et sic fieri, sed non fuit congruum ut totiens panis [f1. 128] assumeretur, deinde dimitteretur. Summa quoque gratia uidelicet unionis fuisset concessa alii creaturae quam homini et, quod nobis angelis non fuit concessum, concederetur insensibili creaturae. Firmiter igitur crede, nulli creaturae praeterquam homini illud donum fuisse concessum ut esset unita deitati et animae eius atque corpori eius.

Valde ergo errant qui corpus Domini uiuum et mortuum dicunt non fuisse idem corpus. Si enim ibi uisset genitum corpus nouum, sequeretur quod illi corpori unita esset deitas. Et ita alicui esset deitas unita quod nec sit homo neque anima aut corpus hominis. Et ita gratia unionis angelis denegata tali creaturae fuisset concessa, quod absurdum est opinari. Qui ergo dicunt aliud corpus esse anima recedente ${ }^{228}$, et aliud anima uiuificante, hi sensum, rationem atque fidem negant. Corpus mortuum nouiter idem est quod erat uiuum. Sed, subito ut est mortuum, incipit alterari et tendere in corruptionem. Et prius corrumpitur caro, posterius ossa, quae diutius durant. Alia est forma carnis, alia ossis, alia cordis, alia hepatis ${ }^{229}$, alia cerebri.

Similiter firmiter crede nulli alii creaturae fuisse concessum esse in sacramento hoc mirabili modo nisi homini illi assumpto et illi corpori illique sanguini quo redempti estis. Nullum ergo umquam corpus fuit sub sacramento nec erit nisi illud. Et, postquam institutum est, numquam fuit dies in quo corpus illud non fuerit sub sacramento. Si itaque corpus illud mortuum fuisset aliud, sequeretur quod illud aliud corpus fuisset ibi sacramentaliter. Et sic illud fuisset panis qui de caelo descendit, et sub accidentibus illis corpus Domini esse desiisset ${ }^{230}$ et aliud corpus ibi fuisset et cibus animarum uestrarum fuisset, quae sunt absurda et nefanda. Noli ergo ea neque cogitare.

Sanguis quoque idem fuit in carne et extra carnem, in corpore et extra corpus et iterum in corpore ${ }^{231}$. Vestri hic confligunt an sanguis Christi fuerit unitus deitati. Alii dicunt quod neque existens in corpore neque separatus a corpore fuit unitus. Alii, quod semper fuit unitus. Alii, ut quidam ex uestris, dixerunt, quando erat in corpore tunc fuit unitus, quando extra corpus tunc non fuit unitus, et quod aliquid remansit sanguinis in terra. Illi alii, quod nihil remansit. Tu scribe uerba mea sic: Non est inconueniens, quia sic fuit, credere in corpore illo fuisse aliquantulum sanguinis superflui. Erat enim uerus homo et omnes miserias hominis pati uoluit praeter miseriam peccati ${ }^{232}$, quae uera est miseria. Et illi sanguini aliqualiter superfluo numquam fuit unita diuinitas. Et de illo aliquid remansit, 
é carne, porque o Verbo, com a mediação da carne, teria assumido o pão. Podia, na verdade, ser também assim, mas não era razoável que o pão [f1. 128] fosse assumido tantas vezes e depois fosse abandonado. Também a suprema graça, ou seja, a da união, teria sido concedida a outra criatura que não o homem e, o que nos não foi concedido a nós anjos, seria concedido a uma criatura insensível. Crê, portanto, firmemente que a nenhuma criatura além do homem foi concedido o dom de estar unida à divindade, à sua alma e ao seu corpo.

Muito se enganam, portanto, os que dizem que o corpo do Senhor, vivo e morto, não seria o mesmo corpo. Se realmente aí fosse gerado um novo corpo, seguir-se-ia que a divindade estaria unida a esse corpo. E, assim, a divindade estaria unida a alguma coisa que não é homem nem alma ou corpo de homem. E, assim, a graça da união, negada aos anjos, teria sido concedida a essa criatura, o que é absurdo pensar. Os que, portanto, dizem que uma coisa é o corpo sem alma, outra, com alma a vivificá-lo, esses negam os sentidos, a razão e a fé. Um corpo acabado de morrer é o mesmo que era em vida. Mas, logo que morre, começa a alterar-se e a entrar em corrupção. E, em primeiro lugar, corrompe-se a carne, depois os ossos, que resistem mais tempo. Um é o teor da carne, outro o dos ossos, outro o do coração, outro o do fígado, outro o do cérebro.

Crê, do mesmo modo, firmemente que a nenhuma outra criatura foi concedido estar neste sacramento de modo admirável senão àquele Homem assumido e àquele corpo e àquele sangue pelo qual fostes redimidos. Portanto, nunca corpo algum esteve, nem estará sob o sacramento senão esse. E, depois de haver sido instituído, não houve um dia em que esse corpo não estivesse sob o sacramento. Se, portanto, esse corpo morto fosse outro, seguir-se-ia que esse outro corpo estaria aí sacramentalmente. E, assim, esse seria o pão que desceu do Céu e, sob esses acidentes, deixaria de estar o corpo do Senhor e aí estaria outro corpo e seria o alimento das vossas almas, o que é absurdo e abominável. Portanto, nem sequer penses nisso.

Também o sangue foi o mesmo na carne e fora da carne, no corpo e fora do corpo e de novo no corpo. Daí que, neste ponto, contendam se o sangue de Cristo esteve unido à divindade. Dizem uns, que não esteve unido, nem subsistindo no corpo nem separado do corpo. Outros, que sempre esteve unido. Outros, como alguns dos vossos, disseram, quando estava no corpo, então esteve unido, quando fora do corpo, então não esteve unido, e que algum sangue ficou na terra. Aqueles outros dizem que não ficou nada. Escreve as minhas palavras assim: Não é despropositado acreditar, porque foi assim, que nesse corpo tivesse existido algum sangue supérfluo. Era realmente verdadeiro homem e quis sofrer todas as misérias humanas, excepto a miséria do pecado, que é a verdadeira miséria. 
immo totus ille sanguis remansit. Sanguini uero homini illi necessario semper fuit unita diuinitas et illum totum reassumpsit ${ }^{233}$. Et sanguinem cui semel unitus erat, numquam dimisit, ipso persistente ${ }^{234}$. Deus ergo sanguine effuso et sibi unito uos redemit. Et quamuis numquam illi legerint ${ }^{235}$ Deum fuisse super terram effusum, fuit tamen per idiomatum communicationem aliquo modo effusus Deus quando sanguis ille pretiosus effundebatur. Verum ergo est quod sanguis qui remansit in terra numquam fuit unitus diuinitati. Verum etiam est quod totus sanguis [f1. 129] unitus diuinitati fuit reassumptus. Et uerum est quod sanguis deitati semel unitus nunquam fuit ab ea separatus. Et uerum est aliquam portionem sanguinis uidelicet illam superfluam numquam etiam in corpore existentem fuisse unitam deitati. Non enim omnibus quae in illo homine ${ }^{236}$ existebant fuit unita diuinitas, quia non saliue quam ${ }^{237}$ spuebat in terram, non capillis, non pilis. Animae solum et corpori fuit unita et sanguini propter id, quia dicitur sedes esse animae et quia fuit instrumentum redemptonis uestrae. Nam redempti estis effusione illius benedicti sanguinis. Hoc sanguine uacui, hodie pleni sunt. Vacui dico omni ueritate, pleni diuitiis et operibus arcu et ense Domini aquisitis ${ }^{238}$. Impinguatus est dilectus sanguine Domini. Impinguatus, incrassatus, dilatatus, dereliquit Deum factorem suum et recessit a Deo salutari suo. Et hic pastor, qui nunc est ${ }^{239}$, bibit multum de sanguine Domini. Et propter disputationem balbutientem ${ }^{240}$, quae nihil erat respectu horum quae nunc tibi dixi $^{241}$, dignitatem primam adeptus est. Et deuotio quam gerit ad Reginam omnium nostrum conseruat eum ita quod non peribit.

Dico tibi, ut reuertamur ad ea quae dicebamus, nullum corpus habuit praerrogatiuam hanc, nisi corpus Christi, ut esset tali modo alicubi. Quare uestimenta Christi et quaecumque corpus eius circumstantia non erant in eucharistia? Quia tunc habuissent res inanimatae ${ }^{242}$ priuilegia quae Regina nostra non habet. Illa ergo ibi sunt sacramentaliter quae sunt diuinitati unita et quaecumque sunt connexa corpori, ut crines $^{243}$ et pili. Indumenta ${ }^{244}$ non sunt huiusmodi quare nec ibi sunt aut fuerunt.

Tunc ego: Domine mi, memini nunc unius quaestionis quae saepe fit, scire cupio ueritatem, ${ }^{245}$ utrum Christus, tempore mortis suae, fuerit homo, quia aliqui dixerunt hominem esse illum qui habet animam humanam et non est opus alio ad

233 reassumpsit] remansit $I 234$ persistente] praeexistente $Q 235$ legerint] legerunt $O$; legerent $Q$ 236 homine] corpore $N 237$ quam] quas $V \mathbf{2 3 8}$ acquisitis] acquisitus $M 239$ qui nunc est] Sixtus 4s $Q$ in marg. a. $m .240$ balbutientem] balbutientium $N Q \mathbf{2 4 1}$ horum (paucorum add. $M$ sup. lin. $a$. $m$.) quae nunc tibi dixi] horum quae dixi paucorum $N O$; horum peccatorum quae diximus $Q 242$ inanimatae] reanimate $M 243$ crines] capili $Q 244$ ut crines et pili. Indumenta] ut crines et indumenta $O 245$ scire cupio ueritatem] om. $O$ 
E a esse sangue, de algum modo supérfluo, nunca esteve unida a divindade. E dele ficou algum, ou melhor, todo esse sangue ficou. Ao sangue necessário a esse Homem esteve sempre unida a divindade, e reassumiu-o todo. E, enquanto viveu, nunca abandonou o sangue a que uma vez se unira. Deus, pois, remiu-vos por meio do sangue derramado e a si unido. E embora eles nunca tenham lido que Deus houvesse sido derramado sobre a terra, contudo, em razão da expressão própria da linguagem, foi Deus de algum modo derramado, quando aquele sangue precioso se derramava. Portanto, é verdade que o sangue que ficou na terra nunca esteve unido à divindade. É igualmente verdade que todo o sangue [f1. 129] unido à divindade foi reassumido. É verdade ainda que o sangue, uma vez unido à divindade, nunca se separou dela. É ainda verdade que uma porção desse sangue, a saber, a supérflua, mesmo subsistindo no corpo, nunca esteve unida à divindade. De facto, a divindade não esteve unida a tudo que existia nesse Homem, porque nem à saliva que cuspia na terra nem aos cabelos nem aos pêlos. Esteve unida apenas à alma e ao corpo e ao sangue, porque se diz que é a sede da alma e porque foi o instrumento da vossa redenção. Efectivamente, fostes remidos pela efusão desse bendito sangue. Os vazios desse sangue estão agora repletos. Vazios, digo, de toda a verdade; repletos com a riqueza e as obras conseguidas pelo arco e pela espada do Senhor. Aquele que foi amado engordou-se no sangue do Senhor. Gordo, cheio, repleto, abandonou o Deus que o criou e retirou-se de Deus, seu Salvador. ${ }^{[173]}$ E o actual pastor bebe muito do sangue do Senhor. E alcançou a dignidade primeira por causa da disputa que se esboçava, a qual disputa nada era em relação àquilo de que acabei de te falar. E mantém-no a devoção que dedica à Rainha de todos nós, de tal modo que não perecerá. ${ }^{[174]}$

Digo-te, para voltarmos àquilo de que falávamos, que nenhum corpo teve esta prerrogativa de estar deste modo em toda a parte senão o corpo de Cristo. Porque é que as vestes de Cristo e todas as coisas que envolviam o seu corpo não estavam na Eucaristia? Porque, nesse caso, as coisas inanimadas teriam tido privilégios que a nossa Rainha não tem. Estão lá, portanto, sacramentalmente as coisas que estão unidas à divindade e quantas estão ligadas ao corpo, como os cabelos e os pêlos. As vestes não pertencem a essa categoria, pelo que, nem estão, nem nunca lá estiveram.

Meu senhor, adiantei eu, lembro-me agora de uma questão que se levanta muitas vezes, quero saber a verdade, se Cristo no momento da sua morte era homem, porque disseram alguns que homem é aquele que tem alma humana $\mathrm{e}$

${ }^{[173]}$ Dt 32:15

[174] Foi na definição dos privilégios de Maria, conceição imaculada e assunção, que Sisto IV teve papel decisivo. 
hoc ut sit homo. Qui ergo habet ${ }^{246}$ animam hominis homo est. Christus Dominus ${ }^{247}$ uel potius Verbum Patris tunc habebat animam eandem quam prius sibi unitam et ita erat homo ex quo sola anima facit hominem. Alii dixerunt animam solam non facere hominem, sed anima simul et corpus. Quia ergo filius Dei tunc habebat utrumque illorum uere fuit homo. Alii dicunt illa non sufficere nisi illa duo sint inter se coniuncta. Quia ergo tunc anima erat separata a corpore, Deus habens corpus et animam non fuit homo?

Respondit angelus: Homo integer non est ullus nisi habeat animam et corpus anima humana animatum. Totus enim homo est compositus ex anima et corpore. Et anima est potior pars hominis et nobilior. Corpus est pars uilior ${ }^{248}$ et inferior. Fuit tamen Deus in triduo homo, aliquo modo loquendi, sicut et sanctus Petrus dicitur in caelo esse, quia anima eius in caelo est. Vbi ergo est potior pars hominis, ibi est homo, sicut ubi sunt potiores ciues, ibi est ciuitas. Et si habens animam solam potest ${ }^{249}$ dici homo, multo magis habens animam et corpus, sicut habens ligna et lapides et alia requisita ad domum dicitur habere domum. Sed utrum 250 requiritur eadem caro omnino ad hoc ut sit idem homo, declarabit ille cui Deus dabit sapientiam et intellectum. Hoc ideo dico quia [f1. 130] caro uestra fluit et resoluitur et iterum recuperatur per alimoniam. Et quia eadem anima informatur et uiuificatur ${ }^{251}$, eadem caro dicitur. Non tamen est eadem, quia non informatur ${ }^{252}$ immediate illa forma qua informabatur caro resoluta. Nam forma propria carnis est alia ab anima. Vnde etiam caro mortua est caro. Ecce tibi, quasi nolens, declaraui. Sed redeamus.

Noli mirari quare hoc sacramentum quasi est duplicatum et totus Christus est sub accidentibus panis, totus est sub accidentibus uini. Hoc, dico, factum est quia hoc sacramentum est alimentum animarum, cuius sumptione animae a poenis temporalibus liberantur et uenialium peccatorum remissionem accipiunt, similiter et uirtutum augmentum suscipiunt, in bono corroborantur, ab inimicis maxime inuisibilibus defenduntur, procliuiores ad bonum redduntur, non ita cito cadunt et, si ceciderint, citius et facilius resurgunt. Quia ergo est alimentum animarum, congruum fuit illud assimilari alimento corporis quod constat ex cibo et potu. Sicut enim cibus et potus sunt unum, integrum et perfectum alimentum, quamuis cibus et potus non sint idem, ita in proposito, quamuis

246 sit homo. Qui ergo habet] sit homo quia ergo qui habet $Q 247$ homo est. Christus Dominus] hoc est, Christus Dominus $P V 248$ uilior] innobilior $Q 249$ potest (M add. sup. lin. a. m. possit)] possit NO 250 et corpus, sicut habens ligna et lapides et alia requisita ad domum, dicitur habere domum. Sed utrum] et corpus. Sed utrum $Q \mathbf{2 5 1}$ informatur et uiuificatur] informat et uiuificat $P 252$ et uiuificatur eadem caro dicitur. Non tamen est eadem, quia non informatur] add. $M$ (in marg. a. m.); om. IV 
nada mais é necessário para ser homem. Aquele que tem alma humana é homem. Cristo Senhor, ou antes, o Verbo do Pai, tinha então a mesma alma que antes esteve unida a si e, por isso, era homem, uma vez que só a alma faz o homem. Outros disseram que só a alma não faz o homem, mas a alma em conjunto com o corpo. Portanto, dado que nessa altura o Filho de Deus os tinha a ambos, foi verdadeiramente homem. Dizem outros que isso não basta se os dois não estiverem unidos entre si. Dado, pois, que nessa altura a alma estava separada do corpo, Deus, que tinha corpo e alma, não era homem?

Ninguém é homem perfeito, respondeu o anjo, se não tiver alma e corpo animado pela alma humana. Na verdade, todo o homem é composto de alma e corpo. E a alma é a mais importante e a mais nobre parte do homem. O corpo é a menos nobre e a menos importante. Como quer que seja, durante o tríduo ${ }^{[175]}$, Deus foi homem, segundo um certo modo de falar, do mesmo modo que também se diz que $S$. Pedro está no céu porque a sua alma está no céu. Portanto, onde está a parte mais importante do homem, aí está o homem, como onde estão os cidadãos mais importantes, aí está a cidade. E, se pode considerar-se homem tendo apenas alma, muito mais tendo alma e corpo, do mesmo modo que, ao ter madeira, pedra e o mais requerido para uma casa, se considera ter a casa. Se, porém, se requer absolutamente a mesma carne para ser o mesmo homem, declará-lo-á aquele a quem Deus dará saber e inteligência. Digo isto porque [f1. 130] a vossa carne enfraquece e gasta-se e é recuperada de novo por meio do alimento. Mas, porque é enformada e vivificada pela mesma alma, considera-se a mesma carne. Não é, todavia, a mesma, porque não é imediatamente enformada segundo aquela forma pela qual era enformada a carne que se desgastou. Pois, a forma própria da carne é diferente da alma. Daí que também a carne morta seja carne. Olha que quase sem querer to disse. Mas voltemos.

Não te admires porque é que este sacramento é como que duplo, e Cristo está todo sob os acidentes do pão e todo sob os acidentes do vinho. Isso, digo, acontece porque este sacramento é alimento das almas e, tomando-o, as almas são livres das penas temporais, recebem a remissão dos pecados veniais, recebem igualmente também o aumento das forças, são revigoradas no bem, são defendidas dos inimigos, sobretudo dos invisíveis, tornam-se mais inclinadas ao bem, não caem assim tão rapidamente e, se caírem, levantam-se mais rápida e mais facilmente. Porque, pois, é alimento das almas, foi conveniente assemelhá-lo ao alimento do corpo, que consta de comida e de bebida. Assim como a comida e a bebida são um único, íntegro e perfeito alimento, embora comida e bebida não

${ }^{[175]}$ O período durante o qual o corpo de Cristo esteve no sepulcro, o designado tríduo pascal. 
hoc sacramentum non sit illud quia accidentia panis non sunt accidentia uini et illa accidentia panis significant ${ }^{253}$ primarie praesentiam corporis Domini, sanguinis et animae secundarie et concomitanter ${ }^{254}$ et per accidens quia accidit illis accidentibus panis continere alia a corpore Christi. Similiter accidentibus uini proprium est significare praesentiam sanguinis Domini. Alia ideo significant, quia sunt coniuncta ${ }^{255}$ suo significato, sicut ista uox "homo" 256 proprie significat naturam humanam, concomitanter ${ }^{257}$ autem alia quae sunt in homine, ut animal et uiuens, uel in quibus est homo, ut Ioannem et Petrum. Quamquam ergo hoc sacramentum non sit illud et ita uideantur esse quasi duo sacramenta, illa tamen duo sunt una et integra alimonia ${ }^{258}$, unum integrum nutrimentum ${ }^{259}$ per quod anima consequitur Dei uisionem, quae est quasi cibus, et Dei fruitionem, quae est quasi potus, et illis conflatur perfectum nutrimentum. Haec ergo fuit ratio ut duo instituerentur et tamen unum essent. Etsi ergo nunc ita sit ut omnia quae sunt sub accidentibus panis sint etiam sub accidentibus uini et omnia quae sunt sub accidentibus uini erunt etiam sub accidentibus panis, non tamen ${ }^{260}$ eodem ordine nec eadem significatione et aliquando, ut tempore mortis Domini, illa erant seiuncta et diuisa, quia sub accidentibus panis non erat nisi corpus, et sub accidentibus uini non erat nisi sanguis. Fuit et ${ }^{261}$ alia ratio talis institutionis. Quia enim morte corporis et effusione illius purissimi ${ }^{262}$ sanguinis redempti estis, seorsum instituit sacramentum quo significaretur mors illius corporis et seorsum ${ }^{263}$ quo significaretur effusio sanguinis.

Tunc ego: Ex hoc percipio melius esse communionem accipere sub utraque specie, ut Graeci faciunt, quam sub una solum, ut Latini.

Respondit: Conficere oportuit sub utraque specie et Graecum et Latinum. Sumere non oportuit nisi conficientem sub utraque specie. Sed ${ }^{264}$ quae instututio sit melior, Graeca uel Latina, Graeca in hoc melior est, quia dat Christiano integrum $^{265}$ alimentum et integram redemptionis memoriam. Latina melior est alia [f1. 131] ratione, quia tanto populo non poterat sanguis tam crebro dispensari sine periculo effusionis ${ }^{266}$. Satis ergo fuit laicos et clericos non sacerdotes, immo et sacerdotes non conficientes, sub speciebus panis tantum sumere, praesertim ex quo ibi sint omnia ${ }^{267}$. Duplicem autem modum redemptionis satis est recolere

253 accidentia panis non sunt accidentia uini et illa accidentia panis significant] accidentia panis significant $I V \quad \mathbf{2 5 4}$ concomitanter] concomitantius $I$; concomitantes J; comitantia $V \quad 255$ coniuncta] cincta $V \mathbf{2 5 6}$ sicut ista uox "homo"] sicut ista. Verum homo $P 257$ naturam humanam, concomitanter] materiam humanam concomitantem $I \mathbf{2 5 8}$ illa tamen duo sunt una et integra alimonia] illa tamen sunt duo integra et una alimonia $Q 259$ nutrimentum] alimentum $I V \rightarrow$ 
sejam o mesmo, assim também relativamente ao exposto, embora um sacramento não seja o outro, porque os acidentes do pão não são os acidentes do vinho, e os acidentes do pão signifiquem primariamente a presença do corpo do Senhor, secundária e concomitantemente e por acidente a presença do sangue e da alma, porque acontece a estes acidentes do pão conterem outras coisas distintas do corpo de Cristo. Do mesmo modo, é próprio dos acidentes do vinho significarem a presença do sangue do Senhor. Por isso significam outras coisas, porque estão associadas ao seu significado, como a palavra "homem" significa propriamente natureza humana, concomitantemente, porém, outras coisas que há no homem, como animal e vivente, ou nas quais há o homem, como João e Pedro. Portanto, embora um sacramento não seja o outro e pareça serem como que dois sacramentos, esses dois, todavia, são um alimento único e completo, um alimento completo pelo qual consegue a alma a visão de Deus, que é como que o alimento, e a fruição de Deus, que é como que a bebida, e com eles se forma um alimento perfeito. Foi esta, pois, a razão para que se instituíssem dois e, todavia, fossem um único. Embora agora, portanto, de tal modo assim seja que tudo o que está sob os acidentes do pão esteja também sob os acidentes do vinho, e tudo o que está sob os acidentes do vinho estará também sob os acidentes do pão, não, todavia, na mesma ordem, nem segundo o mesmo significado, e, algumas vezes, como no tempo da morte do Senhor, estavam separados e divididos, porque sob os acidentes do pão não estava senão o corpo, e sob os acidentes do vinho não estava senão o sangue. Outra foi também a razão desta instituição. Porque, de facto, fostes remidos pela morte do corpo e pelo derramamento desse puríssimo sangue, instituiu separadamente um sacramento que significasse a morte desse corpo e separadamente significasse o derramamento do sangue.

De acordo com isso, atalhei eu então, compreendo que seja melhor receber a comunhão sob ambas as espécies, como fazem os gregos, do que sob uma só, como os latinos.

Era conveniente, respondeu o anjo, que gregos e latinos celebrassem sob as duas espécies. Não o era que comungassem sob as duas espécies, a não ser o celebrante. Mas qual seja a melhor prática, se a grega, se a latina, neste ponto é melhor a grega, porque dá ao cristão o alimento completo e a completa memória da Redenção. A latina é melhor por outra [f1. 131] razão, porque não podia distribuir-se tão frequentemente a tanta gente sem perigo de derramamento. A leigos e a clérigos não sacerdotes e, até, a sacerdotes não celebrantes bastaria comungar apenas sob as espécies do pão, sobretudo porque nelas está tudo. É

$\leftarrow \mathbf{2 6 0}$ panis (...) accidentibus panis, non tamen] panis, non tamen $P 261$ essent. Et (...) sanguis. Fuit et] essent. Fuit et. $Q 262$ purissimi] pretiosissimi $P 263$ et seorsum] et sensuum $Q 264$ specie et Graecum et Latinum. Sumere non oportuit nisi conficientem sub utraque specie. Sed] specie. Sed IN 265 integrum] unicum $Q 266$ periculo effusionis] effusione $V 267$ sint omnia] sit anima $P$; sunt omnia $Q$ 
adorando Christum sub duplici ${ }^{268}$ specie. Qui ergo in hoc Latinos errare aiunt, ipsi errant. Nec Graeci errant neque Latini. Et certe Pastor futurus ordinabit quod quilibet Christianus quandoque sumat hoc alimentum sub utraque specie.

Nec congruum est ut pueruli paruuli ${ }^{269}$, omnino ratione ${ }^{270}$ carentes, hunc cibum sumant, quamuis etiam non sit malum criminale si ob deuotionem hoc eis datum fuisset. Peccant tamen qui dicunt etiam puerulos paruulos ${ }^{271}$ communicari $^{2}$ oportere. Aliud est enim eos communicare propter deuotionem, aliud propter necessitatem, quasi aliter saluari non possent.

Graeci ergo sunt in extremo uno, quia etiam paruulos comunicant. Latini in alio, quia ut plurimum nimis tardant pueris dare communionem, quia multi expectant annum XII in femineo sexu, et annum XIIII in sexu masculino, quod peius est. Subito enim ut pueri peccare possunt, confiteri tenentur. Et eo modo quo confiteri tenentur, illo etiam communicari tenentur. Et melius est per annum incipere quam post annum debitum communicare. Discretio non eodem anno in omnibus est ${ }^{272}$.

Quidam praeceptum communionis nimis stricte exponunt et accipiunt, quia dixit Dominus: “

Nisi manducaueritis carnem Filii Hominis et biberitis eius sanguinem non habebitis uitam in uobis. Dicunt ergo nullum neque paruum neque magnum saluari posse sine communione sicut nec sine baptismo. Et nesciunt quod multi sumunt Christum sine sacramento. Sicut enim baptismus est triplex: fluminis, flaminis et sanguinis, et multi saluantur in sanguine et in flamine qui numquam susceperunt baptismum fluminis, et tamen scribitur: Nisi quis renatus fuerit ex aqua et Spiritu Sancto non poterit intrare in regnum Dei, qui uidelicet potest renasci ex aqua, nisi renascatur ${ }^{273}$, non poterit saluari, quia tunc contemneret, qui non potest non tenetur, qui autem ignorant et scire non possunt baptizarentur baptismo flaminis ${ }^{274}$, nam flumen sine flamine nihil ualet, flamen sine flummine ualet, qui non potest scire quid uelit Deus, subiciat se Deo et pro uiribus curet facere uoluntatem eius et in ipsum opera sua dirigat, et quantum ratio sibi dictat ${ }^{275}$ exequatur, flamine baptizabitur sine flumine. Sicut ergo illa uerba de baptismo fluminis habent exceptiones plures, sic et illud preceptum "Nisi manducaueritis" intelligendum est: Nisi manducaueritis ualentes manducare in aetate discretionis et cognitionis, et nisi manducaueritis spiritualiter aut sacramentaliter non habebitis uitam in uobis. Vnde pueri paruuli, si baptizati fuerint, manducant corpus Christi, quia uniti sunt corpori suo mystico, quod est Ecclesia. Quicumque gratiam Dei

268 duplici] utraque $Q 269$ pueruli paruuli] paruuli $Q$; puellae paruulae $V 270$ omnino ratione] omni ratione $P$; anno ratione $V \mathbf{2 7 1}$ puerulos paruulos] puerulos et etiam paruulos $Q$; puerulos $V 272$ tenentur. (...) Discretio non eodem anno in omnibus est.] tenentur. $Q 273$ renascatur renascitur $V \mathbf{2 7 4}$ flaminis] fluminis $Q \mathbf{2 7 5}$ dictat] dicit $P$ 
suficiente recordar o dúplice modo da redenção adorando a Cristo sob as duas espécies. Os que dizem que, neste ponto, os latinos erram, esses é que erram. Nem erram gregos nem latinos. E, com certeza, o futuro Pastor ordenará que cada cristão tome, por vezes, este alimento sob ambas as espécies.

Nem é correcto que crianças pequenas, carecendo em absoluto de razão, tomem este alimento, embora também não seja crime se, por devoção, lhes fosse dado. Pecam, todavia, aqueles que dizem que convém que também as crianças pequenas comunguem. Uma coisa é, na verdade, comungar por devoção, outra, por necessidade, como se de outro modo não pudessem salvar-se.

Portanto, os gregos estão num extremo, porque também dão a comunhão às crianças. Os latinos, no outro, porque muitas vezes tardam demais a dar a comunhão às crianças, pois que muitos aguardam pelos doze anos, no sexo feminino, e pelos catorze, no sexo masculino, o que é pior. Efectivamente, logo que as crianças podem pecar estão obrigadas a confessar-se. E do mesmo modo porque são obrigadas a confessar-se, são também obrigadas a receber a comunhão. E é melhor começar um ano antes do que comungar depois do ano devido. O discernimento não surge em todos na mesma idade.

Uns apresentam e tomam o preceito da comunhão com excessivo rigor, porque o Senhor disse:

Se não comerdes a carne do Filho do Homem e não beberdes o seu sangue não tereis a vida em vós. ${ }^{[176]}$ Dizem, portanto, que ninguém, nem pequeno nem grande, se pode salvar sem a comunhão, do mesmo modo que sem o baptismo. E não sabem que muitos comungam Cristo sem o sacramento, pois assim como o baptismo é tríplice: de água, do espírito e de sangue, e muitos que nunca receberam o baptismo da água se salvam no sangue e no espírito e, contudo, está escrito: A menos que alguém renasça da água e do Espírito Santo não poderá entrar no reino de Deus, ${ }^{[177]}$ aquele que pode renascer da água, se não renascer, não poderá salvar-se, porque então desprezaria a salvação; aquele que não pode não é obrigado; os que ignoram e não podem saber seriam baptizados no baptismo do espírito, pois a água sem o espírito nada vale, o espírito sem água vale; aquele que não pode saber o que Deus quer submeta-se a Deus e, na medida das suas força, cuide de fazer a sua vontade e encaminhe para ele as suas obras e vá até onde a sua razão lhe dita; esse será baptizado no espírito, sem água. Assim, pois, como as palavras sobre o baptismo da água têm várias excepções, assim também o preceito se não comerdes deve ser entendido: se não comerdes tendo a possibilidade de comer na idade do discernimento e do conhecimento, e se não comerdes espiritual ou sacramentalmente, não tereis a vida em vós. Daí que as 
habet, ipse in Christo manet et Christum sumit. Et sicut multi sumunt sacramentum et non rem sacramenti, quia non sunt uniti Christo per gratiam, ita multi sumunt rem et non sacramentum ${ }^{276}$. Scito accidentia panis et uini esse sacramentum, quia sunt signa sacra praesentiae ${ }^{277}$ corporis et sanguinis [f1. 132] Domini. Corpus autem Domini naturale est sacramentum corporis mystici, et accidentia ${ }^{278}$ etiam panis, qui ex multis granis conficitur, similiter et accidentia uini, quod ex multis racemis confluit, sunt signa non solum corporis naturalis et sanguinis Christi, sed etiam corporis mystici, quod ex multis hominibus constat. Quicumque hoc sacramentum suscipit rem etiam sacramenti uidelicet corpus et sanguinem suscipit siue fuerit dignus siue indignus. Sed, si est indignus ${ }^{279}$, non suscipit rem aliam, id est, significatum aliud, quod est corpus mysticum. Ille enim solus suscipit corpus mysticum ${ }^{280}$ qui per fidem et dilectionem est unitus copori Christi mystico. Sumere itaque rem huius sacramenti est unitum ${ }^{281}$ esse Ecclesiae per gratiam et caritatem. De hoc itaque Domini corpore mystico intelligendo, praeceptum illud est necessarium: Nisi enim manducaueritis carnem Filii Hominis et biberitis eius sanguinem, hoc est, nisi uniti fueritis corpori Filii Hominis, quod est Ecclesia, non habebitis uitam in uobis, sed eritis membra amputata quae, extra totum posita, non uiuunt. Vbi uide quod tam accidentia uini quam accidentia panis designant idem corpus mysticum. Vnde in significando rem istam secundam sunt unum.

Prima res huius sacramenti est corpus naturale Christi, quod significant accidentia panis, et sanguis, quem significant accidentia uini. Secunda res est corpus mysticum, quod est Ecclesia. Et hoc significant accidentia panis et uini. Similiter et corpus et sanguis Christi significant hoc corpus mysticum, quia sumenti ea gratia et uirtutes augentur, quibus magis ac magis unitur Ecclesiae et membris Christi mysticis. Corpus tamen Christi naturale est signum corporis mystici, quia sicut ille ex purissimis membris, ita istud ex puris et caritate coniunctis constat. Quae significatio non potest esse in sanguine.

Mali ergo ${ }^{282}$ sumunt sacramentum et rem illam priorem ${ }^{283}$ uidelicet Christi carnem et sanguinem, sed non sumunt rem illam posteriorem, hoc est, unionem membris Ecclesiae. Boni uero sumunt et sacramentum et utramque rem sacramenti et quandoque solam rem posteriorem sumunt, non sumendo neque rem priorem uidelicet carnem et sanguinem Christi neque sacramentum. Et unus plus sumit

276 sacramentum] acramentum corporis mystici $I V \quad 277$ praesentiae] paenitentiae $V \quad 278$ sacramentum. Scito (...) sacramentum corporis mystici, et accidentia] sacramentum, et accidentia I 279 indignus] dignus $P \mathbf{2 8 0}$ Ille enim solus suscipit corpus mysticum] Hoc enim suscepit quis $Q \mathbf{2 8 1}$ unitum] unitiuus $I$; unitus $V \mathbf{2 8 2}$ mysticis. Corpus (...) potest esse in sanguine. Mali ergo] mysticis. Mali ergo NP $\mathbf{2 8 3}$ et rem illam priorem] et posteriorem, non rem illam priorem $P$ 
crianças pequenas, se forem baptizadas, comam o corpo de Cristo, porque estão unidas ao seu Corpo Místico, que é a Igreja. Todo aquele que tem a graça de Deus, esse permanece em Cristo e comunga Cristo. E assim como muitos comungam o sacramento e não a substância do sacramento, porque não estão unidos a Cristo pela graça, assim também muitos comungam a substância e não o sacramento. Sabe, pois, que os acidentes do pão e do vinho são sacramento porque são sinais sagrados da presença do corpo e do sangue [f1. 132] do Senhor. Por outro lado, o corpo natural do Senhor é sacramento do Corpo Místico. E também os acidentes do pão, que se faz de muitos grãos, e igualmente os acidentes do vinho, que escorre de muitos cachos, são sinal não só do corpo natural e do sangue de Cristo, mas também do Corpo Místico, que se compõe de muitos homens. Todo aquele que recebe este sacramento, recebe também a substância do sacramento, ou seja, o corpo e o sangue, seja digno, seja indigno. Mas, se for indigno, não comunga a outra realidade, isto é, o outro significado, que é o Corpo Místico. Na verdade, só recebe o Corpo Místico aquele que pela fé e pelo amor está unido ao Corpo Místico de Cristo. Portanto, comungar a substância deste sacramento é estar unido à Igreja pela graça e pelo amor. Para o entendimento deste Corpo Místico de Cristo é necessário aquele preceito: se não comerdes a carne do Filbo do Homem e não beberdes o seu sangue, ${ }^{[178]}$ isto é, se não estiverdes unidos ao corpo do Filho do Homem, que é a Igreja, não tereis a vida em vós, mas sereis membros amputados que, postos fora do todo, não vivem. Vê, pois, que, tanto os acidentes do vinho como os acidentes do pão indicam o mesmo Corpo Místico. Daí que sejam um no significar desta segunda realidade.

A primeira realidade deste sacramento é o corpo natural de Cristo, que os acidentes do pão significam, e o sangue, que significam os acidentes do vinho. A segunda, é o Corpo Místico, que é a Igreja. E a este significam-no os acidentes do pão e do vinho. De modo semelhante também o corpo e o sangue de Cristo significam este Corpo Místico, porque àquele que os toma é aumentada a graça e as virtudes com as quais se une cada vez mais à Igreja e aos membros místicos de Cristo. Todavia, o corpo natural de Cristo é sinal do Corpo Místico porque, do mesmo modo que aquele é composto de puríssimos membros, assim este é composto de membros puros e unidos pelo amor. Este significado não pode estar no sangue.

Portanto, os maus tomam o sacramento e a primeira realidade, ou seja, a carne e o sangue de Cristo, mas não tomam a segunda realidade, isto é, a união dos membros da Igreja. Os bons, por seu lado, tomam não só o sacramento, mas também uma e outra realidade do sacramento e, por vezes, tomam só a segunda, não tomando nem a primeira, ou seja, a carne e o sangue de Cristo, nem o sacra- 
de accidentibus, alter minus, secundum quantitatem accidentium. Similiter unus sumit plus corporis mystici, alius minus, quia unus plus unitur fide et gratia, alius minus, secundum dispositionem praeuiam. Sed tantum sumit unus quantum mille de corpore et sanguine Domini, quia quilibet totum Christum sumit, qui tamen non consumitur ${ }^{284}$, sed bene desinit esse tali modo essendi, qui numquam desinit esse modo naturali. Et secundum accidentium quantitatem et qualitatem, unus plus nutritur ${ }^{285}$ et melius quam alius.

Haec quae diximus, Pastor ille per ${ }^{286}$ distinctiones, quaestiones et capitula facile distinguet. Et quia uestri theologi ${ }^{287}$, maxime iste subtilis, "et ostendebat Ioannem Scotum cum diademate beatorum in capite et cum laurea ${ }^{288}$ doctorum", conati sunt omnia mirabilia huius sacramenti ostendere esse saltem possibilia, ne philosophi reprehenderent uos eo quod non [f1. 133] solum falsa, sed impossibilia crederetis, declarant ergo qualiter possibile sit duo corpora simul esse, et qualiter corpus maius in eodem loco cum minori, et qualiter unum corpus in pluribus locis, et qualiter aliquid potest conuerti in illud quod iam est et fuerat ${ }^{289}$ et est ante illam conuersionem, et qualiter panis omnino desinit esse neque tamen est anihilatus, et qualiter accidentia possint esse sine subiecto, et qualiter homo potest ferre ${ }^{290}$ et eleuare tam magnum corpus duobus digitis tam facile ac si in eo nulla grauitas esset, et qualiter accidentia possint mutare ${ }^{291}$ et ex non substantia fieri substantia, et qualiter possit tam cito uidelicet in uno puncto temporis de caelo descendere ${ }^{292}$, et qualiter ex illis creatur ibi caro noua uel sanguis nouus. Omnia haec uestri probant possibilia et uere sunt possibilia, quia illud solum est nihil et impossibile quod includit contradictionem. Sed discutiamus ipsorum rationes ut et ille sciat quae sint bonae et quae non. Afferunt namque arma non quibus offendant, sed quibus defendant ea quae credunt. Et tota difficultas in hoc consistit, quia philosophi multa impossibilia esse dicunt quae theologi dicunt esse possibilia et rationes philosophorum soluunt, sed non possunt eis ostendere possibilitatem talium ueritatum eo quod philosophi non recipiunt ${ }^{293}$ illa principia ex quibus ea sequuntur, quae tamen sunt consona rationi. Philosophi enim negant Deum solum posse omnia quae potest cum aliis causis efficientibus et negant eum agere sicut uult et sicut placet libere, et multa talia, ut quod sit omnipotens qui posset omne illud quod contradictionem ${ }^{294}$ non claudit.

Quantum ergo ad primum mirabile, quomodo est possibile ut duo corpora sint simul, dico tibi, bone uir, et capias ut potes fideliterque conscribe, duo corpora simul esse potest intelligi duobus modis.

284 consumitur] sumitur $Q \mathbf{2 8 5}$ nutritur] mutatur $V \mathbf{2 8 6}$ per] qui $I J V \mathbf{2 8 7}$ theologi] philosophi $N 288$ laurea] laureola J; laureolo $Q$; laureo $I V \mathbf{2 8 9}$ est et fuerat] est et fuerit $I$; etiam et fuerit $V$ 290 ferre] facere $I J M Q 291$ mutare] nutrire $M Q 292$ et qualiter possit tam cito uidelicet in uno $\rightarrow$ 
mento. E um toma mais dos acidentes, outro menos, segundo a quantidade dos acidentes. De modo semelhante, toma um mais do Corpo Místico, outro menos, porque um se une mais pela fé e pela graça, outro menos, segundo a disposição prévia. Mas do corpo e do sangue do Senhor toma tanto um como mil, porque cada um toma Cristo integralmente, que, todavia, se não consome, mas claramente deixa de estar sob esse modo de ser, ele que nunca deixa de estar segundo o modo natural. E, segundo a quantidade e a qualidade dos acidentes, mais e melhor se alimenta um do que outro.

O que dissemos, distinguí-lo-á facilmente aquele Pastor por distinções, questões e capítulos. E porque os vossos teólogos, sobretudo este subtil (e mostrava João Escoto com o diadema dos bem-aventurados na cabeça e com a láurea dos doutores), se esforçaram por mostrar que todas as maravilhas deste sacramento eram, pelo menos, possíveis, para que os filósofos vos não censurassem porque acreditáveis não [fl. 133] só em falsidades, mas em coisas impossíveis, declaram, pois, de que modo é possível que dois corpos coexistam, e de que modo um corpo maior esteja no mesmo lugar com um menor, e de que modo um corpo esteja em vários lugares, e de que modo uma coisa pode converter-se naquilo que já é e tinha sido e é antes daquela conversão, e de que modo o pão deixa em absoluto de existir e, contudo, não é aniquilado, e de que modo os acidentes podem existir sem sujeito, e de que modo pode o homem transportar e levantar tão facilmente corpo tão grande com dois dedos como se nele não houvesse peso algum, e de que modo os acidentes podem mudar e da não substância criar-se a substância, e de que modo pode tão rapidamente, ou seja, num instante, descer do céu, e de que modo, a partir deles, ser aí criada nova carne ou novo sangue. Tudo isto os vossos demonstram possível e é realmente possível, porque só é nada e impossível o que encerra contradição. Mas discutamos as razões deles para que também ele saiba quais são as boas e quais não são. Pois, aduzem armas, não com que ataquem, mas com que defendam aquilo em que acreditam. E toda a dificuldade consiste em os filósofos dizerem que há muita coisa impossível que os teólogos dizem que é possível, e desmontam as razões dos filósofos, mas não podem demonstrar-lhes a possibilidade dessas verdades pelo facto de os filósofos não aceitarem os princípios dos quais decorrem aquelas coisas que, todavia, são conformes com a razão. Os filósofos, de facto, negam que Deus, só, possa tudo que pode com outras causas eficientes, e negam que aja como quer e como livremente lhe agrade, e muitas coisas do género, como, que seja omnipotente aquele que pudesse tudo que não encerra contradição.

Quanto, pois, à primeira maravilha, como é possível que dois corpos coexistam, digo-te, bom homem, e entende como puderes e regista fielmente, que a coexistência de dois corpos pode entender-se de dois modos.

$\leftarrow$ puncto temporis de caelo descendere] add. $K$ in marg. $a . m .293$ recipiunt] accipiunt $O 294$ contradictionem] impossibilitatem $N$ 
Vno modo, quod utrumque sit in eodem loco toto, ut in loco in quo tu et nunc es, te non exeunte, sit alius homo aequalis tibi et quod locus ille utrumque uestrum circumscribat et ambiat et uterque uestrum superficiem ipsius ambientis et circumdantis omni ex parte attingat et sensibiliter in loco existat ita quod et agere possit uterque uestrum et pati et mouere et moueri. Alio modo, quod unum corpus sit in loco modo quantitatiuo et sensibili, attingens ex omni parte circumferentiam corporis ambientis. Aliud uero sit ibi absque modo quantitatiuo, non coextensum partibus ambientis, sed sit in 1 loco $^{295}$ non localiter, hoc est, non occupans locum, sed habens praesentiam simplicem tamen realem eo modo quo habet eam unus angelus existens in eodem loco in quo existit aliquod corpus. Et hoc secundo modo est hic corpus Domini cum accidentibus panis. Accidentia enim panis sunt in loco $^{296}$ extensa ${ }^{297}$ partibus loci et localiter, quia occupant locum et circumscripta a loco. Corpus uero Domini est ibi sine modo quantitatiuo, quia non extensum ${ }^{298}$ partibus loci, sic ut una pars eius respiciat unam partem loci et alia aliam, sed sunt sine ullo respectu ad locum. Esse autem plura corpora in uno loco sine respectu ad locum ${ }^{300}$ uel unum habendo, aliud uero non habendo, non est impossibile. Ratio est quia tota [f1. 134] repugnantia inde prouenire uidetur, quia unum illorum occupando et taliter ${ }^{301}$ implendo locum, aliud pro tunc occupare et implere non potest. Si ergo neutrum implet et occupat uel si unum tantum implet, alterum non, nulla est repugnantia.

Quod autem corpus possit esse sine ullo respectu ad locum, sic probatur: Omne prius $^{302}$ alio, separabile ab alio ${ }^{303}$, potest poni sine illo. Haec regula notanda est, quia multa difficilia patebunt clara, illa concessa. Veritas illius regulae patet, nam prius non dependet a posteriori. Etsi ab eo scilicet suo posteriori sit separabile et distinctum, habens aliam existentiam ab illo, cur non poterit saltem a prima potentia et suprema uirtute, quae est Deus, separari? Si enim nulla uirtute posset separari ab illo, quomodo prius illo esset et separabile ab illo? Regula ergo uera est.

Nunc probandum est quod corpus est prius quam sit in loco et separabile a loco, habens aliam existentiam ab existentia loci. Quod probatur sic: Si non esset alia existentia corporis quam loci continentis ${ }^{304}$, sequeretur quod, posito corpore, poneretur locus illud continens ${ }^{305}$, quod falsum est, quia primum corpus caeleste est et tamen non ponitur locus ${ }^{306}$ continens illud et ambiens, quia tunc non esset

295 sit ibi absque (...) sit in loco] sit ibi in loco $Q 296$ loco] celo $V 297$ extensa] coextensa $N$; coexistentia $Q 298$ extensum] coextensum $N Q 300$ Esse autem plura corpora in uno loco sine respectu ad locum] add. $K$ in marg. a. $m$. 301 taliter] totaliter $O V 302$ prius] corpus $Q 303$ alio] $\rightarrow$ 
De um modo, que um e outro estejam no mesmo lugar e em todo ele, como, no lugar em que tu estás agora, sem que tu saias, esteja outro homem igual a ti, e que esse lugar circunscreva e delimite cada um de vós e cada um de vós coincida em todos os pontos com a superfície desse lugar que o delimita e circunscreve, e esteja de forma visível no lugar de modo tal que cada um de vós possa não só ser agente activo e agente passivo, mover e ser movido. De outro modo, que um corpo esteja num lugar de modo quantitativo e palpável, coincidindo em todos os pontos com a circunferência do corpo que o delimita, enquanto outro lá esteja sem modo quantitativo, não co-extenso às partes do lugar que o delimita, mas esteja no lugar não localmente, isto é, não ocupando lugar, mas tendo presença simples, todavia, real, do mesmo modo que a tem um anjo presente no mesmo lugar em que está outro corpo. E, de acordo com esta segunda modalidade, está aqui o corpo do Senhor com os acidentes do pão. Efectivamente, os acidentes do pão, num lugar, são extensivos às partes do lugar e localmente, porque ocupam o lugar e são circunscritos pelo lugar. Porém, o corpo do Senhor está aí sem modo quantitativo, porque não extensivo às partes do lugar, como se uma parte sua correspondesse a uma parte do lugar e outra a outra, mas estão sem relação alguma com o lugar. Não é impossível, porém, que vários corpos estejam num lugar sem coincidência com o lugar ou um ocupando o lugar, enquanto o outro o não ocupa. A razão reside em que toda [fl. 134] a incompatibilidade parece provir de que, ocupando um deles e, deste modo, enchendo o lugar, não pode o outro, nesse momento, ocupá-lo e enchê-lo. Se, por consequência, nenhum deles enche e ocupa ou se apenas um deles enche, o outro não, não há incompatibilidade alguma.

Que, além disso, possa um corpo estar sem relação alguma com o lugar, prova-se deste modo: todo o anterior a outro, separável dele, pode existir sem ele. Esta regra deve ser levada em linha de conta, porque muita coisa difícil se tornará clara, uma vez ela aceite. A verdade desta regra é evidente, pois o anterior não depende do posterior. E se é separável e distinto dele, a saber, do seu posterior, tendo uma existência distinta dele, porque não há-de poder ser separado, pelo menos, pela Primeira Potência e Suprema Força, que é Deus? Se, de facto, dele não pudesse ser separado por força nenhuma, como seria anterior a ele e dele separável? A regra, portanto, é verdadeira.

Deve agora demonstrar-se que o corpo existe antes de estar no lugar e é separável do lugar, tendo uma existência distinta da existência do lugar. O que se demonstra deste modo: Se a existência do corpo não fosse distinta da do lugar que o contém, seguir-se-ia que, surgido o corpo, se seguiria o lugar que o contém, o que é falso, porque o primeiro corpo é celeste e, no entanto, não se

$\leftarrow$ illo NOPQ 304 existentia loci. Quod (...) quam loci continentis] existentia loci continentis $I 305$ continens] continentis $I$; continentes $V 306$ locus] corpus $Q$ 
primum corpus. Non ergo ${ }^{307}$ eadem res est corpus et locus eius, sed duae. Et corpus est prior res quam locus eius, hoc est, quam sit positum in $1 \operatorname{loco}^{308}$. Tunc si corpus est alia res a loco et est prior illo, igitur separabilis est ab illo. Et ita aliqua uirtute poterit poni corpus et tamen non poni ille respectus qui est esse in loco. Est ergo ibi corpus Domini hoc modo, quia sine ullo respectu ad locum, quia neque circumdatur loco neque coextenditur partibus loci neque occupat locum aut implet. Habet solum unum respectum nouum uidelicet praesentialitatis realis, quia praesens est illis accidentibus realiter. Omne enim circumdatum a loco et omne coextensum loco et omne replens et occupans locum est praesens loco. Non tamen omne praesens $100^{309}$ est replens locum et circumscriptum loco, ut patet de nobis angelis qui sumus praesentes uobis et rebus sensibilibus nec tamen coextendimur eis. Quia ergo praesentia illa est prior repletione et circumscriptione et est alia res, ut patet, quia, ut dixi, nos sumus praesentes sine circumscriptione, ergo ${ }^{310}$ poterit dicta praesentia poni sine ulla circumscriptione et repletione. Et si poneretur aliquod corpus iuxta caelum empyrium, illud esset sibi praesens neque tamen circumdans aut circumdatum.

Hoc ergo facit Deus in hoc sacramento, dat praesentiam nouam corpori suo sine illis quae solent naturaliter concomitare talem praesentiam, ut coextensionem et repletionem et circumscriptionem. Haec ratio bene probat possiblitatem. Illa uero alia non ualet quae dicit quod ideo est ibi cum alio corpore, quia conuersio illa est in substantiam corporis tantum, non in quantitatem ipsius corporis. Similiter autem corpori ${ }^{311}$ Christi non repugnat esse cum illis accidentibus, quia substantia illa ex se non occupat aut replet locum.[f1. 135]

Quia ergo quantitas corporis Christi ibi non est per conuersionem illam, sed solum concomitanter ${ }^{312}$, ideo non repugnabit sibi esse cum alio corpore. Sic dicunt, sed ratio $^{313}$ bene a uestris improbatur, quia qualitercumque adueniat illuc quantitas corporis Christi, uel immediate uel mediate, semel ibi realiter est. Quomodo ergo simul erit cum alia quantitate? Non sufficit dicere quia non primo neque immediate aduenit quantitas, ideo potest esse cum alia quantitate. Relinquatur haec ratio, teneatur illa prior per quam patet quod eodem modo corpus magnum poterit esse cum paruo. Nam etsi corpus magnum non possit circumscribi a paruo neque illi commensurari, potest tamen praesens esse corpus magnum corpori paruo ${ }^{314}$.

307 corpus caeleste (...) primum corpus. Non ergo] corpus. Non ergo $I 308$ Et corpus est prior res quam locus eius, hoc est, quam sit positum in loco.] Et corpus esse prius res est quam locus eius sit, hoc est, quam sit positio eius in loco. $Q \mathbf{3 0 9}$ et omne replens et occupans locum est praesens loco. Non tamen omne praesens loco] add. $M$ in marg. $a . m$. 310 circumscriptione et (...) circumscriptione, ergo] circumscriptione, ergo $J \mathbf{3 1 1}$ Similiter autem corpori] Similiter autem corporis $I$; Substantia autem corporis $O Q$; Similiter substantia corporis $V \mathbf{3 1 2}$ concomitanter] $\rightarrow$ 
segue o lugar que o contém e o delimita, porque então não seria primeiro corpo. Não é, portanto, a mesma coisa o corpo e o seu lugar, mas são duas coisas. E o corpo é uma realidade anterior ao seu lugar, isto é, a ser posto no lugar. Então, se o corpo é uma coisa distinta do lugar e é anterior ao lugar, é, portanto, separável dele. $\mathrm{E}$, assim, por uma qualquer força, poderá surgir um corpo e, todavia, não surgir essa relação que é estar num lugar. Logo, o corpo do Senhor está aí desse modo, porque sem relação alguma com o lugar, porque nem é rodeado pelo lugar, nem se co-estende às partes do lugar, nem ocupa ou enche o lugar. Tem somente uma relação nova, ou seja, de presencialidade real, porque está realmente presente nos acidentes. Na verdade, tudo o que é rodeado pelo lugar, e tudo o que é co-extensivo ao lugar, e tudo o que enche e ocupa o lugar, está presente no lugar. Contudo, nem tudo o que está presente no lugar enche o lugar e é circunscrito pelo lugar, como é claro relativamente a nós anjos, que estamos presentes junto de vós e das coisas sensíveis e, todavia, não nos co-estendemos a elas. Porque, pois, a presença é anterior à ocupação e à delimitação e é uma realidade distinta, como fica claro, porque, como disse, nós estamos presentes sem delimitação, poderá, portanto, a referida presença verificar-se sem nenhuma delimitação e ocupação. E se junto ao Céu Empíreo se colocasse um corpo, aquele estar-lhe-ia presente e, contudo, não delimitaria, nem seria delimitado.

Isto, pois, faz Deus neste sacramento, dá ao seu corpo uma nova presença sem aquilo que costuma naturalmente acompanhar essa presença, como a co-extensão, a ocupação e a delimitação. Esta explicação demonstra convenientemente essa possibilidade. De facto, não vinga aquela outra que diz que, por isso, está aí com outro corpo, porque essa mudança se dá apenas em ordem à substância do corpo, não na quantidade desse mesmo corpo. Do mesmo modo, porém, não repugna ao corpo de Cristo estar com esses acidentes, porque essa substância, de si, não ocupa ou enche o lugar. [f1. 135]

Porque, pois, a quantidade do corpo de Cristo não está aí por essa conversão, mas só concomitantemente, por isso lhe não repugnará estar com outro corpo. Assim afirmam, mas esta explicação é claramente desmentida pelos vossos porque, de qualquer maneira que seja que ali chegue a quantidade do corpo de Cristo, ou imediata ou mediatamente, está aí realmente uma vez por todas. Como estará, pois, em simultâneo com outra quantidade? Não basta dizer que a quantidade não chega primeiro nem imediatamente, por isso pode estar com outra quantidade. Abandonemos esta explicação, fiquemos com aquela anterior, pela qual é claro que, da mesma maneira, poderá um corpo grande estar com um corpo

$\leftarrow$ comitantur $V 313$ ratio] raro $V \mathbf{3 1 4}$ alia quantitate? Non sufficit dicere (...) praesens esse corpus magnum corpori paruo.] Relinquatur haec ratio, teneatur illa prior per quam patet quod eodem modo corpus magnum poterit esse cum paruo. Nam et si corpus magnum non possit circumscribi a paruo neque illi commensurari, potest tamen praesens esse corpus magnum corpori paruo. $P$; Relinquatur haec ratio ut teneatur illa prior. Non enim sufficit dicere quia non primo neque immediate aduenit quantitas, ideo potest esse cum alia quantitate. Per primam autem rationem $\rightarrow$ 
Est ergo Christi corpus illis accidentibus praesens, sed non illis coextensum aut commensuratum, hoc est, ut caput Christi sit in capite hostiae et pes in pede et manus in tali latere et pectus in medio. Et quamuis corpus Domini sit praesens illis accidentibus solis tamen maius est illis et inaequale ${ }^{315}$ ipsis.

Alii ex uestris probant corpus maius posse esse cum minori sic, pars una corporis subintrat aliam ${ }^{316}$. Quaecumque igitur etiam minima particula corporis subintrat aliam et sic ubi una est ibi et aliae omnes. Et quia uni paruae parti corporis Domini non repugnat esse cum hostia illa, et omnes aliae partes ${ }^{317}$ illius subintrant illam, ideo totum corpus erit cum illa hostia uel cum illis accidentibus panis. Sed opinio illa, si eam sic intelligant quod una pars corporis sit in alia, perimit $^{318}$ et destruit figuram corporis speciosissimam et non declarat quomodo una pars possit subintrare aliam. Et sic difficultatis nodus non erit solutus. Si autem intelligatur ${ }^{319}$ partes corporis esse distinctas et unam extra aliam ita quod figura corporis non destruatur, tamen omnes partes corporis respiciunt eundem locum simul ita ut illum locum respiciant omnes aliae partes quem respicit una parua pars corporis Domini, ita quod partes sint inter se distinctae, sed respectu loci sint indistinctae ${ }^{320}$, ita quod sicut duo corpora possunt esse simul, sic et duo, immo et tres et omnes partes illius corporis sint simul, hoc stante ${ }^{321}$, quaero, aut uolunt quod omnes partes ${ }^{322}$ sint ab eodem loco circumscriptae et sensibiliter in eodem loco existant, aut uolunt quod nulla ibi sit sensibiliter neque per circumscriptionem, sed sint ibi modo non quantitatiuo aut coextenso. Et si hoc secundo modo accipiant, tunc idem dicunt quod nos diximus, corpus Domini totum ibi esse praesens illis accidentibus, sed non coextensum illis. Si autem primo modo intelligant, non bene dicunt, quia nulla pars corporis Domini est ibi sensibiliter aut circumscripta.

Sed restat declarare an id possit fieri ut duo corpora sint in loco uno utrumque modo quantitatiuo quia utrumque coextensum et circumscriptum et localiter existens in loco, quod est idem, sicut uestri ponunt de corpore [f1. 136] glorioso quod penetrabit ${ }^{323}$ et faciet se simul cum corpore non glorioso aequali ${ }^{324}$ sibi, $^{2}$

$\leftarrow$ non solum patet quod uerum corpus esse in eodem loco cum alio sed etiam quod corpus magnum non posset circumscribi a paruo neque illi commensurari potest. Potest tamen presens esse corpus magnum corpori paruo. $Q 315$ inaequale] aequale $V 316$ Alii ex uestris probant (...) et sic ubi una est ibi et aliae omnes.] Alii ex uestris probant corpus maius posse esse cum minori, sicut pars una corporis subintrat alliam. Et sic una est ibi et ubi omnes I; Alii ex uestris probant corpus maius posse esse cum minori sicut pars una corporis subintrat aliam quemcumque minima sit. Et sic una ubi est ibi et aliae omnes. $Q$; Quaecumque igitur etiam minima particula corporis $\rightarrow$ 
pequeno. Pois, se um corpo grande não pode ser circunscrito por um pequeno nem comensurar-se com ele, pode, todavia, um corpo grande estar presente com um corpo pequeno. Portanto, o corpo de Cristo está presente naqueles acidentes, mas não lhes é co-extensivo ou comensurado por eles, isto é, que a cabeça de Cristo esteja na cabeça da hóstia, e o pé no pé, e a mão neste lado, e o peito no meio. E embora o corpo do Senhor esteja presente somente naqueles acidentes, é, contudo, maior do que eles e desigual em relação a eles.

Outros de entre vós demonstram que um corpo maior pode estar com um menor deste modo: uma parte de um corpo penetra na outra. Em suma, qualquer partícula que seja de um corpo, ainda que mínima, penetra a outra e, assim, onde está uma, estão aí todas as outras. E dado que a uma pequena parte do corpo do Senhor não repugna estar com a hóstia, e todas as suas outras partes a penetram, por isso todo o corpo estará com essa hóstia ou com esses acidentes do pão. Mas essa opinião, se a entendem de modo que uma parte do corpo esteja na outra, aniquila e destrui a elegantíssima figura do corpo e não esclarece como pode uma parte penetrar a outra. E, assim, o nó da dificuldade não é desatado. Mas, se se entender que as partes do corpo são distintas e uma fora da outra, de modo que a aparência do corpo se não destrua, ainda que todas as partes do corpo digam simultaneamente respeito ao mesmo lugar, de tal forma que todas as outras partes se relacionem com aquele lugar com que se relaciona uma pequena parte do corpo do Senhor, de modo que as partes sejam entre si distintas, mas indistintas em relação ao lugar, de forma que, assim como dois corpos podem estar simultaneamente, assim também estejam em simultâneo duas e até três e todas as partes desse corpo, aceite isto, pergunto, ou pretendem que todas as partes estejam circunscritas pelo mesmo lugar e no mesmo lugar existam sensivelmente, ou pretendem que nenhuma lá esteja sensivelmente nem por delimitação, mas estejam lá segundo o modo não quantitativo ou co-extensivo. E se entendem desta segunda maneira, então dizem o mesmo que nós dizemos, que o corpo do Senhor está lá todo presente naqueles acidentes, mas não co-extensivo com eles. Se, porém, entendem da primeira maneira, enganam-se, porque nenhuma parte do corpo do Senhor aí está sensivelmente ou circunscrita.

Mas falta esclarecer se isto é possível, que dois corpos estejam no mesmo lugar, cada um deles de modo quantitativo porque cada um co-extensivo e circunscrito e localmente presente no lugar, que é o mesmo, como os vossos defendem do corpo [fl.136] glorioso que penetrará e coexistirá com um corpo não glorioso

$\leftarrow$ subintrat aliam et sic ubi una. Alii ex uestris probant corpus maius posse esse cum minori sicut pars una corporis subintrat et una est ibi et aliae omnes. $V 317$ aliae omnes. (...) omnes aliae partes] aliae omnes aliae partes $I 318$ perimit] permittit $V 319$ intelligatur] intelligant $I$; intelligat $J N O P Q V 320$ indistinctae] dictinctae $V 321$ esse simul, (...) simul, hoc stante] esse simul, hoc stante $P \mathbf{3 2 2}$ omnes partes] omnes partes et duae et tres et omnes partes illius corporis $P \mathbf{3 2 3}$ penetrabit] paene transibit $V \mathbf{3 2 4}$ glorioso quod penetrabit et faciet se simul cum corpore non glorioso aequali] glorioso aequali $I$ 
non minori se. Et hic uidetur euidentior difficultas, ut sint duo corpora simul sensibiliter, utrumque coextensum partibus loci. Illud tamen etiam uestris uidetur possibile. Quamuis imaginatio uestra abhorreat, ratio tamen id clare ostendit, si cogitare uolueritis.

Quid est esse in loco? Esse enim in loco est circumscribi a loco et coextendi loco et partibus eius. Circumscribi uero est respectus quidam adueniens corpori, similiter et coextendi. Hoc, primo, notate. Deinde, considerate unum cunscribi non esse contrarium aut repugnans alteri, quia sunt eiusdem speciei. Non ergo repugnant sicut album et nigrum. Tertio, cogitate quod, quando duo corpora dicuntur esse simul, non dicitur quod duo circumscribi sint in corpore ${ }^{325}$ et ita illa duo repugnare non inter se, sed ratione subiecti, quia non possunt esse in eodem subiecto sicut neque duae albedines possunt esse in eadem superficie. Haec difficultas remouetur quia ibi non sunt duo ubi seu duo circumscribi siue duo coextendi ${ }^{326}$ in subiecto uno, sed una coextensio est in corpore uno, alia in alio. Non est ergo in istis duabus coextensionibus aut circumscriptionibus repugnantia neque ratione ipsarum in se, quia sunt eiusdem naturae, neque ratione subiecti, quia non sunt ambae in subiecto uno. Quid ergo restat? Quarto, considerate quod naturaliter loquendo unum circumscribi terminatur ad unum locum circumscribentem et unum coextendi ${ }^{327}$ ad unum locum cui coextenditur, et aliud circumscribi aliudque coextendi terminatur ad alium locum circumscribentem et coextensum. Si ergo ${ }^{328}$ possent duo circumscribi uel duo circumscripta terminari ad unum locum circumscribentem, tunc possent duo corpora simul esse in loco eodem, hoc est, possent duo corpora circumscribi ab eodem circumscribente ${ }^{329}$.

Videamus quid est hoc quod dicimus. Talis est sensus: Duo respectus uel duae circumscriptiones in duobus corporibus existentes non possunt terminari ad eumdem terminum. Quod falsum uidetur esse, quia duae similitudines in duabus albedinibus existentes et duae aequalitates in duabus quantitatibus existentes terminantur ad eandem albedinem et unam ac eandem quantitatem. Duo enim sunt similes uni tertio et duo sunt aequales alicui tertio. Hoc ergo est dicere, duo corpora sunt in loco uno, quod est dicere, duae circumscriptiones termiantur ad unum tertium ${ }^{330}$. Hoc autem ratio capit et amplectitur ${ }^{331}$ ergo et illud. Et ita, quod imaginationi hominum erat ualde difficile, intellectui apparet facile. Potest hoc et aliter declarari: Accepta tali regula, possibile est multiplicari ${ }^{332}$ posterius, quod sit alia res, non multiplicato priori, sed manente ${ }^{333}$ eodem. Haec regula est consona rationi, quia ut sit una substantia et quantitas ${ }^{334}$ cum multis

325 in corpore] in uno loco $Q \mathbf{3 2 6}$ coextendi] coextensi $J \mathbf{3 2 7}$ et unum coextendi] et unum coextensum $N 328$ coextendi ad (..) coextensum. Si ergo] coextendi. Siergo $N 329$ ab eodem circumscribente] ad eumdem circumscribentem $V \mathbf{3 3 0}$ tertium] terminum $I V \quad 331$ amplectitur] $\rightarrow$ 
igual a si, não menor. E, neste ponto, a dificuldade parece mais manifesta, que dois corpos estejam sensivelmente em simultâneo, cada um co-extensivo às partes do lugar. Isso, todavia, parece possível também aos vossos. Embora a vossa imaginação o recuse, mostra-o claramente a razão, se quiserdes pensar.

O que é realmente estar num lugar? Estar num lugar é, de facto, estar delimitado pelo lugar e co-estender-se ao lugar e às suas partes. O delimitar-se e, do mesmo modo, o co-estender-se é, realmente, uma certa relação que advém ao corpo. Primeiro, registai isto. Depois, atendei a que um estar limitado não é contrário ou oposto a outro, porque são da mesma espécie. Não se opõem, portanto, como o branco e o preto. Pensai, em terceiro lugar, que, quando se diz que dois corpos estão em simultâneo, não se diz que as duas delimitações estejam no corpo e, assim, que as duas são incompatíveis, não entre si, mas em razão do sujeito, porque não podem existir no mesmo sujeito, do mesmo modo que duas brancuras não podem existir na mesma superfície. Esta dificuldade é afastada porque aí não há dois onde ou dois delimitar-se ou dois co-estender-se num sujeito, mas uma co-extensão está num corpo, outra noutro. Não há, portanto, incompatibilidade nestas duas co-extensões ou delimitações, nem em razão delas mesmas, em si, porque são da mesma natureza, nem em razão do sujeito, porque não estão ambas num só sujeito. Que resta, pois? Atendei, em quarto lugar, a que, naturalmente falando, um circunscrever-se se termina junto a um lugar circunscrevente, e um co-estender-se, junto ao lugar a que se co-estende, e outro circunscrever-se e outro co-estender-se se terminam junto a outro lugar circunscrevente e co-extensivo. Pois se dois circunscrever-se ou dois circunscritos podem terminar-se junto a um lugar circunscrevente, então poderiam dois corpos estar ao mesmo tempo no mesmo lugar, isto é, poderiam dois corpos ser circunscritos pelo mesmo circunscrevente.

Vejamos o que é isto que estamos a dizer. É este o sentido: duas relações ou duas delimitações existentes em dois corpos não podem terminar-se junto do mesmo limite. Isto afigura-se ser falso, porque duas semelhanças existentes em duas brancuras, e duas igualdades existentes em duas quantidades terminam-se junto da mesma brancura e de uma e da mesma quantidade. Porém, dois são iguais a um terceiro e dois são iguais a um outro terceiro. Isto equivale, pois, a dizer: dois corpos estão num único lugar. O que é dizer: duas delimitações terminam-se junto a um terceiro. Isto capta-o a razão e, consequentemente, abrange também aquilo. E, assim, o que para a imaginação humana era extremamente difícil, mostra-se fácil à razão. Pode isto traduzir-se também de outro modo, aceite esta regra: é possível multiplicar-se o segundo que seja uma realidade distinta, sem multiplicar o primeiro, mas mantendo-se o mesmo. Esta regra é conforme à

$\leftarrow$ amplectatur $V 332$ accepta tali regula possibile est multiplicari] add. $M$ in marg. a. $m .333$ posterius, quod sit alia res, non multiplicato priori, sed manente eodem] posterius, sed manere $V 334$ quantitas] qualitas $P$ 
qualitatibus $^{335}$, sapore, odore, colore, non est inconueniens, immo sic est [f1. 137] uere. Similiter, quod sit una albedo cum multis similitudinibus, non est inconueniens, sed possibile. Nam albedo est prior quam similitudo et alia res a similitudine ${ }^{336}$. Poterit ergo esse ut sint multae similitudines et una albedo uel scientia, sicut dicunt illi philosophi qui ponunt in una albedine tot similitudines quot sunt albedines extra illam. Patet regula neque potest negari nisi ab illis qui dicunt nulla duo accidentia eiusdem speciei esse posse in eodem subiecto simul. Quae opinio bene a uestris improbata est.

Tunc dicamus: superficies concaua prior est quam circumscribat corpus et est alia res a corpore circumscripto. Patet, quia corpora circumscripta adueniunt et recedunt manente eadem superficiae alicuius uasis. Si ergo superficies alicuius uasis prior est quam ambiat ${ }^{337}$ et complectatur corpus aliquod ${ }^{338}$ et est alia res ab illo corpore et ab illa circumscriptione, cur non possumus intelligere ut sit una superficies et duae circumscriptiones in ea fundatae ${ }^{339}$ et ad duo corpora circumscripta terminatae ${ }^{340}$ ? Et hoc est duo corpora esse simul in eodem loco, quod est superficiem unam habere plures circumscriptiones ad duo corpora circumscripta. Sed an hae rationes bene probent, relinquo iudicio illius Pastoris in tempore illo. Certum est quod si duo corpora esse simul nil aliud esset quam duo respectus esse in eadem superficie, ut illa ratio posterior deduxit, uel esset ratio ista, quia duo respectus in duobus corporibus existentes terminantur ad eandem superficiem continentem, facile illud intelligeretur. Sed est alia difficultas quam ipsi fugiunt neque aspicere uolunt, quia nec soluere sciunt et est talis: Inter latera continentis uasis si nihil esset, tunc inter illa latera uacuum esset. Corpus ergo inter latera positum facit ut inter latera sit plenum et non uacuum. Corpus ergo circumscriptum facit latera ${ }^{341}$ continentis distare et implet illa omni ${ }^{342}$ ex parte attingendo. Et illud corpus totaliter implet et totaliter facit latera distare. Si ergo in eodem spatio poneretur aliud corpus, illud etiam totaliter impleret et faceret latera continentis distare. Hoc autem est impossibile et contradictionem includit. Nam si unum corpus totaliter occupat locum et totaliter implet, aliud nullo modo implebit aut occupabit quia, si ponatur, etiam aliud corpus impleret locum aut ergo totaliter implebit locum aut $\mathrm{ex}^{343}$ parte. Si totaliter, ergo illud corpus quod implebat totaliter, nullo modo implet. Ergo exiuit de loco uel si ibidem est ${ }^{344}$ et nullo modo implet et nulla ${ }^{345}$ ex parte occupat, sequitur quod simul totaliter occupabit et nulla ex parte occupabit. $\mathrm{Vbi}^{346}$ uides manifestam contradictionem. Si uero illud aliud corpus ponatur ${ }^{347}$ implere locum ex parte, qui locus alio corpore iam est plenus, tunc primum corpus non implebat ${ }^{348}$ totaliter.

335 qualitatibus] quantitatibus $I 336$ a similitudine] ab ipsa $Q 337$ ambiat] ambiet $I J M V$; ambiget $O 338$ corpus aliquod] corporali quod $V 339$ fundatae] fundare $J M 340$ terminatae] determinatae $Q$, ; terminare $I J V 341$ facit ut (...) facit latera] facit latera $P 342$ omni] omnia $I J 343$ occupat $\rightarrow$ 
razão, porque não há inconveniência em que também a quantidade, com muitas qualidades (sabor, gosto, cor), seja uma substância, pelo contrário, é [f1. 137] realmente assim. Do mesmo modo, não há inconveniência, mas é possível que exista uma brancura com muitas semelhanças. Pois, a brancura existe primeiro que a semelhança e é distinta da semelhança. Poderá, portanto, acontecer que haja muitas semelhanças e uma brancura ou substância, conforme dizem os filósofos, que põem numa brancura tantas semelhanças quantas existem fora dela. A regra é evidente e não pode ser negada senão por aqueles que dizem que dois acidentes da mesma espécie não podem estar ao mesmo tempo no mesmo sujeito. Esta opinião foi completamente rejeitada pelos vossos.

Digamos então, a superfície côncava existe antes de circunscrever o corpo e é distinta do corpo circunscrito. É claro que os corpos circunscritos vêm e vão, enquanto a superfície de qualquer recipiente se mantém a mesma. Se, portanto, a superfície de qualquer vaso existe antes de rodear e encerrar um determinado corpo e é distinta desse corpo e desse contorno, porque não podemos entender que haja uma superfície e duas delimitações baseadas nela e terminadas junto a dois corpos circunscritos? E é isto que é estarem dois corpos em simultâneo no mesmo lugar, que é ter uma superfície várias delimitações relativamente a dois corpos circunscritos. Se estas razões provam suficientemente, deixo-o ao juízo desse Pastor, nesse tempo. É certo que, se estarem dois corpos em simultâneo não fosse senão haver duas relações na mesma superfície, como conclui este segundo raciocínio, ou fosse este raciocínio: que duas relações existentes em dois corpos se terminam junto da mesma superfície continente, isso entender-se-ia facilmente. Ma há outra dificuldade a que eles fogem e nem a querem enfrentar, porque não sabem resolvê-la, e é esta: se nada existisse entre os lados de um vaso receptor, então entre esses lados existiria o vazio. Logo, o corpo colocado entre os lados faz que entre os lados haja um pleno e não o vazio. Portanto, o corpo circunscrito faz que os lados do vaso receptor estejam afastados e enche-os, tocando-os totalmente em todos os pontos. E esse corpo enche completamente e faz que os lados distem completamente um do outro. Se, portanto, no mesmo espaço se pusesse outro corpo, também esse encheria totalmente e faria que os lados do vaso receptor distassem um do outro. Isto, porém, é impossível e envolve contradição. Pois, se um corpo ocupa totalmente um lugar e totalmente o enche, de modo nenhum poderá outro enchê-lo ou ocupá-lo porque, se fosse colocado, também o outro corpo encheria o lugar. Logo, ou o encherá totalmente ou em parte. Se totalmente, logo, o corpo que enchia totalmente de modo nenhum enche. Portanto, saiu do lugar ou, se aí se mantém e de modo nenhum enche e de parte alguma ocupa, segue-se que, ao mesmo tempo, ocupará totalmente e de parte

$\leftarrow$ locum et (...) implebit locum aut ex] occupat locum aut ex $Q 344$ si ibidem est] si ibi dicitur esse $P 345$ implet. Ergo (...) modo implet et nulla] implet et nulla $V 346$ occupat, (...) occupabit. Vbi] occupat. Vbi $I 347$ ponatur] ponitur $O 348$ implebat] implebitur $V$ 
Et ita omnino erit ${ }^{349}$ contradictio. Non ergo implente uno corpore, potest aliud implere simul nisi impleat partem unam, aliud aliam. Esse autem in loco localiter et modo quantitatiuo est implere locum et occupare [f1. 138] et facere latera eius distare attingendo illa ex omni parte. Non possunt itaque duo corpora in uno loco simul esse, quia tunc utrumque impleret totaliter et ita neutrum impleret. Sed quod utrumque sit in loco non implendo locum et modo non quantitatiuo quia non coextendendo partes suas partibus loci, non est inconueniens. Ac etiam si unum sit in loco modo naturali et quantitatiuo, aliud uero non localiter, immo et multa alia non localiter simul cum illo, nullum inconueniens est. Prius enim est praesens corpus quam coextendatur ${ }^{350}$ et prius quam impleat aut occupet. Et praesentia corporis ${ }^{351}$ est quasi causa talis impletionis, commensurationis et occupationis.

Potest ergo Deus conseruare praesentiam corporis ad locum sine tali impletione sicut potest conseruare calorem sine calefactione etiam dato calefactibili et approximato sicut fecit in camino ardenti trium puerorum. Si ergo corpus gloriosum fuerit cum alio corpore, oportebit unum illorum ibi esse non localiter. Et hoc erit propria uirtute Dei, non alicuius qualitatis creatae ${ }^{352}$, ut aliqui somniant corpus gloriosum per dotem subtilitatis se posse facere praesentem alicui loco in quo existit aliud corpus. Digitus Dei est iste. Sed illi qui dixerunt dotem subtilitatis auferre ${ }^{353}$ grossitiem corporis, bene dixerunt, sic intelligendo quod corpori talis animae sic merita habenti ${ }^{354}$ Deus dat ut, cum uoluerit, possit esse cum corpore non glorioso sine modo quantitatiuo. Hoc est auferre grossitiem uidelicet facere ipsum quantum existere ${ }^{355}$ sine modo quantitatiuo. Sed ${ }^{356}$ quidam qui est nobiscum eiusdem ordinis arguit contra illum sui ordinis qui dixit quod dos subtilitatis aufert ${ }^{357}$ grossitiem a corpore glorioso. Et arguit sic: Vbi est corpus gloriosum ibi est corpus sensibile. Et ubi est corpus sensibile ibi est locus plenus, quia fatuum est dicere ut locus in quo est ${ }^{358}$ corpus sensibile sit uacuus ${ }^{359}$. Si ergo locus est plenus, sequitur quod corpus gloriosum replet locum et habet grossitiem, quia aliter non impleret neque occuparet locum.

Nos ita respondemus, quia studio theologiae multis annis uacauimus (et hoc dicens subrisit ${ }^{360}$ ), corpus gloriosum est corpus sensibile. Non tamen semper

349 erit] erat $I V 350$ coextendatur] coextenditur $V 351$ praesentia corporis] praesens corpus $Q$ 352 creatae] creaturae $V \mathbf{3 5 3}$ subtilitatis (...) dotem subtilitatis auferre] subtilitatis auferre $P \mathbf{3 5 4}$ habenti] habentis $Q$,; habente $V 355$ facere ipsum quantum existere] ut illud quantum existat $Q$ 356 quantitatiuo. Hoc (...) modo quantitatiuo. Sed] quantitatiuo. Sed $P 357$ aufert] auferret $Q ; \rightarrow$ 
nenhuma ocupará. Aí se vê uma clara contradição. Mas se se puser esse outro corpo a encher em parte o lugar, lugar que está já cheio com outro corpo, então o primeiro corpo não enchia totalmente e, assim, haverá uma absoluta contradição. Portanto, se um corpo não encher, pode outro, simultaneamente, encher, a menos que este encha uma parte, aquele a outra. Mas estar num lugar localmente e de modo quantitativo é encher e ocupar o lugar [fl. 138] e fazer que os seus lados distem, tocando-os de todos os pontos. E, assim, dois corpos não podem estar simultaneamente num lugar, porque então um e outro enchê-lo-iam totalmente e, deste modo, nem um nem outro encheria. Mas não há inconveniente em que um e outro estejam no lugar sem encher o lugar e de modo não quantitativo porque não co-estendendo as suas partes às partes do lugar. E também nenhum inconveniente há se um estiver no lugar de modo natural e quantitativo e outro não localmente, e até muitos outros simultaneamente com ele não localmente. De facto, um corpo está presente antes de se co-estender e antes de encher ou ocupar. E a presença do corpo é como que a causa dessa implecção, comensuração e ocupação.

Portanto, Deus pode manter a presença de um corpo num lugar sem essa implecção, como pode manter o calor sem calefacção, mesmo existindo e estando próxima a fonte do aquecimento, como fez na fornalha ardente dos três jovens. ${ }^{[179]}$ Se, pois, um corpo glorioso estiver com outro corpo, será imperioso que um deles aí esteja não localmente. Poder um corpo glorioso, pelo dom da subtilidade, tornar-se presente num lugar em que outro corpo está, será devido ao poder de Deus, não de qualquer qualidade criada, como alguns sonham. É este o dedo de Deus. Os que, porém, afirmaram que o dom da subtilidade retira a densidade ao corpo andaram bem, entendendo, deste modo, que Deus concede ao corpo que assim tem os méritos dessa alma que, quando quiser, possa estar com um corpo não glorioso sem modo quantitativo. Isto é retirar a densidade, ou seja, fazer que o próprio quantum exista sem modo quantitativo. Mas alguém que está connosco, da mesma Ordem, argumenta contra aquele da sua Ordem que disse que o dom da subtilidade retira a densidade ao corpo glorioso. E argumenta deste modo: Onde está um corpo glorioso, aí está um corpo sensível. E onde está um corpo sensível, aí está um lugar cheio, porque é insensato dizer que o lugar em que está um corpo sensível esteja vazio. Portanto, se o lugar está cheio, segue-se que um corpo glorioso enche um lugar e tem densidade, porque de outro modo não encheria, nem ocuparia o lugar.

Nós, que por muitos anos nos entregámos ao estudo da teologia (e ao dizer isto sorriu-se), respondemos deste modo: um corpo glorioso é um corpo sensível.

$\leftarrow$ affert $M 358$ ut locus in quo est] quod locus ubi est $P$; quod locus in quo est $Q 359$ sit uacuus] sit uacuus. Si est dicere ut locus in quo est corpus sensibile sit uacuus $V \mathbf{3 6 0}$ subrisit] subiunxit I; subrixit $Q$ 
sentitur. Vnde, quando est cum alio corpore non quantitatiue, tunc non sentitur, alias tamen sentitur. Accipe quae dico et scribe: corpus gloriosum est corpus sensibile et quando est in loco repletiue, tunc naturaliter sentiri potest, quia potest similitudinem coloris $^{361}$ sui transfundere ad sensus circumstantes ${ }^{362}$, quando uero est in loco non repletiue tunc naturaliter sentiri non potest quia, eo modo stando, non potest transfundere species $^{363}$ sui coloris per medium ad oculos circumstantes, quia non existit in illo medio ut in loco cui extendatur. Deus tamen potest facere sua uirtute ut ille species transeant concatenatim ad oculos circumstantium et sic poterit illud corpus uideri. Sed quid, si ad momentum non uiderentur corpora gloriosa [f1. 139] quando uidelicet sunt cum aliis corporibus? Nam in caelo empyrio uidebuntur et erunt in locis suis distinctis neque cum alio corpore, prout tibi dixi quando de illo caelo tibi sermonem feci ${ }^{364}$. Non ergo corpus gloriosum caret grossitie in se sed, quando est cum alio corpore, habet se per modum carentis grossitie, ex quo ${ }^{365}$ non replet locum. Quando ergo Christus natus est, in egressu ex utero, ne clautra uteri uirginalis aperiret (exiuit enim per clausam portam), fuit simul cum carne Virginis Matris. Sed dum erat in utero, fuit in loco modo quantitatiuo et, egrediendo, usquequo peruenit ad ostium uirginale, semper erat in loco sicut alii pueri et eadem uirtute exibat et emittebatur qua et alii infantuli. Sed quando fuit cum carne matris simul, tunc anima sua mouit corpus illud illo motu qui non est organicus, sicut potest moueri a seipso in sacramento, immo potest mouere et ipsum sacramentum. Mater ergo eum effudit usque ad locum illum uirtute propria. Quando erat in loco non localiter, tunc concurrente uirtute Dei speciali et animae illius pueruli lumen aeternum mundo effudit Iesum Christum Dominum nostrum. Scito quoque quod Deus concedit ${ }^{366}$ corpori glorioso ut possit in quamcumque figuram et quantitatem reduci quae non repugnet ${ }^{367}$ corpori organico. Et talis figura uel quantitas non causatur in corporibus illis ab aliqua passione nimia, ut quod a nimio calore rarefaciat $^{368}$ et a nimio frigore condensetur, sed uirtute diuina. Vnde talia corpora possunt transire per ualde strictiora loca quam corpora uestra. Et hoc potest dari cuicumque corpori etiam non glorioso.

Discutiamus nunc quomodo unum corpus possit esse in pluribus locis. Et est una ratio illorum qui dicunt hoc fieri posse quando in tale corpus aliquid conuertitur aliter non sicut in hoc sacramento in quo in corpus Domini conuertitur

361 coloris] corporis $N V 362$ ad sensus circumstantes.] ad sensus circumstantes, quando uero est in caelo non repletiue tunc naturaliter sentiri potest similitudinem coloris sui transferre ad sensus circumstantes, $P 363$ circumstantes, quando (...) transfundere species] circumstantes, $\rightarrow$ 
Nem sempre, contudo, é sentido. Daí que, quando está com outro corpo não quantitativamente, então não é sentido, mas noutras ocasiões é sentido. Atende ao que digo e escreve: um corpo glorioso é um corpo sensível e, quando está num lugar impletivamente, então, naturalmente, pode ser sentido, porque pode transferir a imagem da sua cor para os sentidos circunstantes. Quando, porém, está num lugar não impletivamente, então, naturalmente, não pode ser sentido porque, ao estar desse modo, não pode transferir a imagem da sua cor através do meio para os olhos circunstantes, porque não está nesse meio como num lugar a que se estenda. Pela sua virtude, pode Deus, todavia, fazer que essas imagens passem encadeadamente para os olhos dos circunstantes e, assim, aquele corpo poderá ser visto. Mas se, momentaneamente, os corpos gloriosos não fossem vistos, [f1. 139] a saber, quando estão com outros corpos? Efectivamente, no Céu Empíreo serão vistos e estarão em seus distintos lugares e não com outro corpo, como te disse quando te falei deste Céu. Um corpo glorioso, portanto, não carece, em si, de densidade, mas quando está com outro corpo comporta-se como não tendo densidade, pelo que não enche o lugar. Quando, pois, Cristo nasceu, ao sair do útero, para não abrir a clausura do útero virginal (na verdade saiu pela porta fechada), esteve em simultâneo com a carne da Virgem Mãe. Mas, enquanto estava no útero, esteve no lugar de modo quantitativo e, ao sair, até chegar à saída virginal, estava sempre no lugar, como as outras crianças, e saía por acção da mesma força e era dado à luz pelo mesmo lugar que as outras crianças. Mas, quando esteve em simultâneo com a carne da Mãe, a sua alma moveu então aquele corpo com um movimento que não é orgânico, do mesmo modo que pode mover-se por si mesmo no sacramento e até pode mover também o próprio sacramento. Portanto, a Mãe fê-lo sair por acção própria até esse lugar. Quando estava no lugar não localmente, então, pelo concurso de especial virtude de Deus e da alma desse Menino, derramou no mundo a Luz Eterna, Jesus Cristo, nosso Senhor. Fica a saber também que Deus concede ao corpo glorioso poder ser reduzido a qualquer figura e quantidade que não seja incompatível com um corpo orgânico. E essa figura ou quantidade não é causada num corpo por qualquer excessiva perturbação, como o rarefazer-se pelo excessivo calor e o condensar-se pelo frio excessivo, mas pela acção divina. Daí, poderem esses corpos passar por lugares muito mais apertados do que os vossos corpos. E isto pode ser concedido a qualquer corpo, mesmo não glorioso.

Discutamos agora como pode um corpo estar em vários lugares. E há uma explicação daqueles que dizem que isto pode acontecer quando alguma coisa se converte num dado corpo de modo diferente do que sucede neste sacramento em

$\leftarrow$ species $I 364$ tibi sermonem feci] locuti fuimus $Q 365$ grossitie in (...) carentis grossitie, ex quo] grossitie, ex quo $Q 366$ concedit] confert $Q 367$ repugnet] repugnat $Q$; repugnaret $V 368$ rarefaciat] rarefiat $N O P Q$ 
panis. Quae ratio non ualet quia, ut iam dixi tibi, nihil panis in corpore Domini translatum est. Quid ergo iuuat potentiam Dei ut cum conuersione possit, sine conuersione non possit? Forsan praesentia panis impedit eius potentiam et absentia eam iuuat et ei confert? Certe nihil. Sicut ergo corpus Domini incipit esse cum accidentibus panis uirtute diuina, ita uirtute illa potest esse et incipere esse cum ipso pane. Vnde absolute concedendum est diuina uirtute unum corpus in pluribus locis ${ }^{369}$ simul $^{370}$ esse posse et modo quantiatiuo et non quantitatiuo, stante ueritate regulae superius dictae uidelicet rem priorem quae sit alia res a re posteriori posse conseruari eadem multiplicata et plurificata ${ }^{371}$ re posteriori. Sed corpus in se est res prior quam sit praesens loco uel implens locum. Patet quia non esset praesens neque impleret nisi prius esse intelligeretur. Et est res alia. Patet quia, manente re illa, talis praesentia et repletio amitti potest. Sequitur quod Deus possit facere ut, manente eodem corpore, multiplicetur praesentia eius et repletio. Quando enim replet, tunc est in loco naturaliter et sensibiliter. Quando solum praesens est, ut in sacramento, tunc est in loco non localiter neque sensibiliter. Neque facere corpus in pluribus locis sensibiliter habet euidentiorem difficultatem quam facere illud praesens pluribus locis insensibiliter, immo hoc posterius ad cogitandum uidetur difficilius ut sit in pluribus locis et non localiter. Hic enim sunt duo difficilia uidelicet esse in pluribus locis et, secundo, [f1. 140] esse in loco non localiter. In alio est solum una difficultas uidelicet esse in pluribus locis. Non immerito mirari potestis quomodo aliqui docti uiri concedunt unum corpus posse esse in pluribus locis non localiter et non posse esse in pluribus locis localiter ${ }^{372}$. Et omnes rationes eorum et omnia inconuenientia quae adducunt ${ }^{373}$ possunt facile solui et solutae sunt, immo possent concludere contra pluralitatem ${ }^{374}$ locorum in quibus ponitur corpus Domini non localiter nisi quia tali modo existens non est in loco localiter. Tamen praesentiae ipsius sunt multiplicatae. Et quia uestri hoc bene discusserunt, praetermitto, quia et ille pro quo haec facimus ea in uestris libris uidebit. ${ }^{375}$

369 in pluribus locis] eodem in loco $N 370$ simul] immo nihil $V \quad 371$ eadem multiplicata et plurificata] eandem. Multiplicat et purificat $V \mathbf{3 7 2}$ locis non localiter et non posse esse in pluribus locis localiter] locis localiter. IV (M in marg. a. m.) 373 adducunt] addessent $P 374$ pluralitatem] puritatem $M 375$ ea in uestris libris uidebit.] Ego tamen hoc melius scio. Si enim unum corpus esse (esset $Q$ ) in pluribus locis nihil aliud esset quam, stante unitate prioris, multiplicare (multiplicari $Q$ ) posteriora, bene illud probatum fuisset. Sed non est ita. Alia difficultas est (est om. $Q$ ) propter quam (hanc $Q$ ) unum corpus non potest esse in pluribus locis occupatiue, et est haec: Quia unum corpus non potest impleri (implere $Q$ ) neque occupari (occupare $Q$ ) nisi tantum unum locum (unum locum om. MNO) neque potest facere distare latera continentis (in $M O)$ immensum sed tantum et cum mensura quia corpus bipedale non potest facere distare latera totius aeris neque implere (etiam adimplere $Q$ ) circumferentiam caeli attingendo eam ex omni parte. Sicut enim magnum corpus non potest esse in (aliquo $Q$ ) paruo loco commensuratiue et coextensiue (extensiue $Q$ ) ita neque paruum in magno. Vnumquodque igitur corpus positum in loco implet locum quantum illum (illum om. $N$ ) potest implere et facit latera eius (eius om. $N$ ) distare quantum potest ita quod, stante tali impletione, non potest alium locum implere neque latera alterius (eius $Q$ ) facere distare quia est uirtutis limitatae (limitatae om. $M$ ) et tantae et non $\rightarrow$ 
que o pão se converte no corpo do Senhor. Esta explicação não colhe porque, como já te disse, nada do pão se converte no corpo do Senhor. De que serve então o poder de Deus para que possa com esta conversão, não possa sem esta conversão? Acaso a presença do pão impede o seu poder e a ausência do pão o favorece e lho confere? Não, certamente. Assim, pois, como o corpo do Senhor começa a estar com os acidentes do pão, por acção divina, assim também por essa mesma acção pode estar e começar a estar com o próprio pão. Daí que deva conceder-se em absoluto que, por acção divina, possa um corpo estar simultaneamente em vários lugares não só de modo quantitativo como não quantitativo, mantendo-se a verdade da regra acima formulada, a saber, que uma coisa anterior, que seja distinta de uma coisa posterior, possa manter-se a mesma, multiplicada e plurificada a coisa posterior. Mas o corpo, em si, é uma realidade anterior ao estar presente nesse lugar e ao encher o lugar. É manifesto que não estaria presente nem encheria se não se entendesse que primeiro existia e é uma realidade distinta. É manifesto que, mantendo-se essa realidade, essa presença e implecção pode perder-se. Segue-se que Deus pode fazer que, mantendo-se o mesmo corpo, se multiplique a sua presença e a sua implecção. Quando, pois, enche, está então no lugar natural e sensivelmente. Quando apenas está presente, como no sacramento, então está no lugar não local nem sensivelmente. Nem tornar um corpo presente em vários lugares sensivelmente tem mais clara dificuldade do que torná-lo presente em vários lugares insensivelmente, pelo contrário, este segundo afigura-se mais difícil ao pensamento do que se estivesse em vários lugares e não localmente. Aqui, na verdade, há duas dificuldades, isto é, estar em vários lugares e, segunda, [f1. 140] estar num lugar não localmente. Num caso há apenas uma dificuldade, ou seja, estar em vários lugares. Podeis, não sem razão, admirar-vos como alguns sábios concedem que um corpo possa estar em vários lugares não localmente e não possa estar em vários lugares localmente. E todas as suas razões e todos os inconvenientes que aduzem podem facilmente desmontar-se, e estão desmontados, e até poderiam concluir contra a pluralidade dos lugares em que se põe o corpo do Senhor não localmente. Com esta restrição, que, ao existir dessa maneira, não está no lugar localmente. Contudo, as suas presenças são multiplicadas. E uma vez que os vossos discutiram muito isto, passo à frente, porque aquele em favor de quem fazemos estas coisas as encontrará também nos vossos livros.

$\leftarrow$ maioris. Contradictio ergo est ut tantum possit et plus possit quia plus et non plus et tantum solum et non tantum solum posset (possit $Q$ ). Neque itaque idem locus (corpus $Q$ ) potest impleri (implere $Q$ ) a duobus locis (duo loca $Q$ ) neque idem corpus (locus $Q$ ) potest implere (impleri $Q$ ) duo loca (a duobus corporibus $Q$ ). Ideo potest fieri ut corpus implens unum locum possit poni in alio (loco add. MO) uel aliis locis non implendo quia tunc nulla contradictio est. Sed quod impleat locum hunc quantum potest et iterum alium impleat et occupet et eidem (idem $Q$ ) coextendatur, non est possibile quia tunc minus corpus commensuraretur longe maiori. Fiat enim ex tot locis unus locus. Quomodo occupabitur a paruo corpore? Neque duo corpora in uno loco coextensiue $\rightarrow$ 
Quantum ad quartam difficultatem superius satis ostendimus qualis sit conuersio ista, quo bene intellecto ${ }^{376}$, nulla difficultas est intelligere aliquid posse conuerti in praeexistens. Sed unum est hic uidendum utrum uidelicet posset teneri illa opinio quae istam conuersionem sic declarat. Dicit ${ }^{377}$ enim Deum posse agere in materiam primam ut est prior omni forma ita ut eam in se attingat ut nudam. Et hoc clarum est. Deinde dicit quod materia sic nuda accepta est omnino in se distincta $^{378}$. Tertio dicit quod, sicut Deus potest formam destructam in eandem materiam ${ }^{379}$ iterum inducere, ita potest eandem formam in quamcumque materiam inducere, uerbi gratia, animam ${ }^{380}$ Christi in propositum potest inducere in materiam panis huius et illius et cuiuscumque alterius non educendo eam de corpore suo. Et sic anima Domini informabit plures materias simul. Quarto, dicit quod ad eandem formam numero, sequitur eadem materia ${ }^{381}$ numero, hoc est, in quibus est una forma, in illis est una materia, quia materiae distinguuntur per formas. Sed anima Christi est una forma et est in materia sui corporis et in materia panis. Et sic ille materiae sunt una materia ${ }^{382}$. Vbi ergo est una forma et una materia, ibi est unum corpus.

Sed haec opinio est bene improbata a uestris, quia materia panis, etiam nude accepta, est alia portio materiae ab illa quae est in corpore Christi et quae est in alio pane. Ideo, si forma etiam eadem inducatur in materia panis nuda, non erit propter hoc haec portio materiae illa alia portio. Et ita non omnino hoc corpus erit illud corpus. Deinde non sufficit huic materiae uniri anima, sed oporteret ${ }^{383}$ sibi coniungere formam carnis et ossis et nerui. Anima enim non est forma immediate perficiens $^{384}$ materiam, sed praesupponit alias formas perfectibiles per eam quae est forma corporis organici ad uitam tendentis ${ }^{385}$, non a uita reccedentis, quia naturaliter ita fit quod numquam corpus organicum ad uitam tendens manet sine anima per aliquod tempus. Quando tamen a uita recedit, tunc manet per tempus corpus organicum sine anima. Si quoque materia panis remanet, quomodo dicetur panis transubstantiatus totus ex quo aliquid substantiae eius remansit? Et quomodo saluabitur ut anima Christi non sit mutata quae incipit esse forma huius materiae quam prius non informabat? Et quomodo saluabitur quod nihil panis remansit in corpore Domini? Et si dicat quod illa materia est omnino eadem cum materia corporis Christi, tunc in illa non inducitur anima Christi quia ${ }^{386}$ iam inducta [f1.

$\leftarrow$ et repletiue (coextensiuo et repletiuo $M N$ ) possunt esse neque unum in pluribus locis. Sed unum corpus occupat unum locum tantum. Sed ualde rudes fuerunt (omnes $O$ ) concedentes (omnes ac credentes $Q$ ) duo corpora in loco uno et negantes unum corpus in pluribus locis (locis om. $Q$ ) quia illud difficilius uobis et rationi uidetur. Neque difficilius est facere unum corpus in pluribus locis non implendo quam implendo quia implendo est contradictio et non est contradictio (non implendo $O Q$ ). Non tamen fit in pluribus locis ex eo quod aliquid conuertitur in ipsum. Et sic tu (tu om. MO) uides omnes uos (uos om. $N$ ) (uestros $O$ ) errasse. Quando ergo pater tuus Franciscus $\rightarrow$ 
No que se refere à quarta dificuldade, mostrámos atrás suficientemente o que seja essa conversão. Bem entendido isso, nenhuma dificuldade há em compreender que algo possa converter-se em alguma coisa preexistente. Mas há que ver aqui uma coisa, se, evidentemente, se poderia manter aquela convicção que assim proclama esta conversão. Diz, na verdade, que Deus pode agir sobre a matéria-prima, enquanto é anterior a toda a forma, de modo a atingi-la em si, despida de acidentes. E isto é claro. Diz, depois, que a matéria, tomada assim despida, é absolutamente distinta em si. Diz, em terceiro lugar, que, assim como Deus pode fazer voltar a mesma matéria à forma destruída, pode também fazer voltar a mesma forma a uma qualquer matéria, por exemplo, pode fazer voltar, neste caso, a alma de Cristo á matéria deste, daquele e de qualquer outro pão, sem a fazer sair do seu corpo. E, assim, a alma do Senhor poderá enformar várias matérias ao mesmo tempo. Diz, em quarto lugar, que ao mesmo número de formas se segue o mesmo número de matérias, isto é, naquilo em que existe uma forma, aí existe uma matéria, porque as matérias distinguem-se pelas formas. Mas a alma de Cristo é uma em razão da forma e está na matéria do seu corpo e na matéria do pão. E, assim, estas matérias são uma única matéria. Onde, portanto, há uma forma e uma matéria, há um corpo.

Mas esta opinião foi rejeitada pelos vossos, e bem, porque a matéria do pão, tomada mesmo nuamente, é uma porção de matéria distinta da que está no corpo de Cristo e da que está em outro pão. Por esta razão, se se introduzir a mesma forma na matéria nua do pão, esta porção de matéria não será, por isso, a outra porção. E, deste modo, este corpo não será em absoluto aquele corpo. Além disso, não basta que a alma se una a esta matéria, mas é necessário que associe a si a forma da carne, dos ossos e dos nervos. Na verdade, a alma não é a forma que imediatamente aperfeiçoa a matéria, mas pressupõe outras formas perfectíveis por intermédio daquela que é a forma do corpo orgânico que tende para a vida, não que se afaste da vida, porque naturalmente acontece que nunca o corpo orgânico que tende para a vida permanece sem alma por algum tempo. Quando, contudo, se afasta da vida, então o corpo orgânico permanece por tempo limitado sem alma. Se também a matéria do pão permanece, como poderá dizer-se que todo o pão foi transubstanciado, uma vez que algo da sua substância se manteve? E como se poderá salvaguardar que a alma de Cristo não foi mudada, ela que começou a ser a forma desta matéria que antes não enformava? E como se salvaguardará que do

$\leftarrow$ fuit in pluribus locis, in uno potuit (poterat $O Q$ ) uideri (uidere $Q$ ) et in alio non nisi miraculo nouo. Sic et Ambrosius fuit uisus Turonis. add. $M$ (in alio folio) NOQ 376 quo bene intellecto] qua bene intellecta $N$; quomodo bene intelligo $V 377$ Dicit] Dicitur $M$; Dixit $I Q V 378$ distincta] indistincta $O Q \mathbf{3 7 9}$ in eandem materiam] in eadem materia $P Q \mathbf{3 8 0}$ animam] anima $M V \mathbf{3 8 1}$ eadem materia] eandem materiam $I V \mathbf{3 8 2}$ illae materiae sunt una materia] et sic est una $Q \mathbf{3 8 3}$ oporteret] oportet $N Q 384$ perficiens] proficiens $I N V 385$ tendentis] redemptis $I J 386$ corporis Christi, (...) anima Christi quia] corporis Christi quia $Q$ 
141] est. Quomodo ergo iamdiu inductum? Nunc in illud inducitur in quo manet? Non sunt intelligibilia ista.

Teneas ergo et conscribas hanc transubstantiationem aliud non esse nisi, ut tibi dixi, substantiarum translationem ${ }^{387}$ potestate diuina, ut ibi sit corpus Christi, cibus animae, ubi erat panis, cibus corporis, quod Christi corpus est etiam panis, quia nomine panis omnis cibus intelligi potest. Quia ergo corpus Christi cibus est, ideo et panis est. Et quia cibus animae est, ideo panis spiritualis ${ }^{388}$. Et quia uirtute illius cibi peruenitur ad regnum caeleste, ideo panis caelestis est. Et quia coniunctus est Filio Patris qui in caelis est, ideo est panis qui de caelo descendit. Et quia est unitus illi qui solus aeternaliter uiuit et homines sui sumptione per gratiam uiuificat ad gloriam $^{389}$, ideo panis uiuus est, sicut ipse ait: Qui manducauerit ex hoc pane uiuet in aeternum. Et quia non sicut panis corporis nutrit ${ }^{390}$ ad uitam mortalem sed ad immortalem et non auget uentrem sed mentem, ideo panis uerus est. Quod enim ad momentum confortat, non uere confortat. Quod autem perpetuo confortat, illud uere confortat.

De quinto, qualiter uidelicet panis non sit anihilatus, satis abunde dictum est. Et tres rationes assignari possunt. Prima est quia, quando alicui succedit melius, non dicitur illud destructum, sicut et uestri philosophi dicunt quando ex aqua fit aer tunc esse generationem et non corruptionem. Quando uero ex aere fit terra uel aqua, tunc esse corruptionem. Ita ${ }^{391}$ in proposito, si ubi corpus Christi desineret esse ibi panis inciperet esse, tunc corpus Christi fuisset anihilatum quia non melius, sed deterius sibi successisset. Ita nunc quia pani ${ }^{392}$ succedit melius, panis non est destructus. Non quia aliquid eius remansit, sed quia melius successit. Et secundum hunc modum loquendi, ad hoc ut aliquid sit anihilatum, non sufficit ut nihil eius remaneat, sed oportet ut ei melius non succedat. Secunda ratio est quod panis ille non est anihilatus quia ipsius accidentia quibus informabatur et est aptus informari remanserunt ${ }^{393}$. Tertia ratio est quia etsi panis desineret esse totaliter, ita quod etiam accidentia desinerent esse una secum, non tamen desinit esse ratione istius conuersionis, ut diximus.

Videamus aliquid de sexto ${ }^{394}$ mirabili, quomodo accidentia possunt esse sine subiecto ullo. Aliqui ex theologis qui nobiscum fruuntur Deo crediderunt quod

387 substantiarum translationem] substantiarum translationes $P$; substantia transubstantionem $V 388$ panis spiritualis. (...) panis caelestis] panis caelestis $P 389$ ad gloriam] et glorificat $M$; et gloriam $N O P Q 390$ panis corporis nutrit] panis nutrit corpus $N Q 391$ corruptionem. (...) corruptionem. Ita] corruptionem. Ita $N 392$ pani] panis IMOV 393 et est aptus informari $\rightarrow$ 
pão nada ficou no corpo do Senhor? E, se se disser que essa matéria é absolutamente a mesma com a matéria do corpo de Cristo, então a alma de Cristo não é induzida nela, porque foi já induzida. [f1. 141] Uma vez, pois, que foi induzida há muito tempo, induz-se agora naquilo em que já está? Isto não é compreensível.

Ouve, pois, e escreve que esta transubstanciação não é senão, como te disse, a transferência de substâncias pelo divino poder, para que o corpo de Cristo, alimento da alma, esteja onde estava o pão, alimento do corpo, visto que o corpo de Cristo é também pão, porque pelo nome de pão se pode entender todo o alimento. Porque, pois, o corpo de Cristo é alimento, é, por isso, também pão. E porque é alimento da alma, é, por isso, pão espiritual. E dado que pela virtude deste pão se chega ao reino celeste, é, por isso, pão celeste. E visto que está ligado ao Filho do Pai que está no Céu, é, por isso, o pão que desceu do Céu. E uma vez que está unido àquele que é o único que vive eternamente e, pela sua recepção, vivifica os homens pela graça para a glória, é, por isso, o pão vivo, como ele mesmo dizia: Quem comer deste pão viverá para sempre. ${ }^{[180]} \mathrm{E}$ porque alimenta, não como o pão do corpo para a vida mortal, mas para a imortal, e não aumenta o ventre, mas o espírito, é, por isso, pão verdadeiro. De facto, aquilo que conforta por um instante, não conforta verdadeiramente. Conforta, por outro lado, verdadeiramente, aquilo que conforta para sempre.

Sobre o quinto, a saber, de que modo o pão não é aniquilado, foi dito o suficiente. E podem aduzir-se três razões. A primeira é que, quando a alguma coisa sucede algo melhor, não se considera que haja sido destruída, como também dizem os vossos filósofos quando da água se faz ar, que, nesse caso, há geração e não corrupção. Quando, realmente, do ar se faz terra ou água, então há corrupção. Assim, neste caso, se onde deixa de estar o corpo de Cristo começasse a lá estar o pão, nesse caso o corpo de Cristo teria sido aniquilado, porque lhe teria sucedido não uma coisa melhor, mas o pior. Assim, neste caso, uma vez que ao pão sucede o melhor, o pão não é destruído. Não porque alguma coisa dele permaneceu, mas porque lhe sucedeu uma melhor. E segundo este modo de falar, para que alguma coisa seja aniquilada não basta que nada de si permaneça, mas exige-se que lhe não suceda nada de melhor. A segunda razão é que este pão não foi aniquilado, porque se mantiveram os seus acidentes, pelos quais era enformado e está apto a ser enformado. A terceira razão é que, mesmo se o pão deixasse totalmente de existir a ponto de também os acidentes deixarem de existir juntamente consigo, não deixaria, contudo, de existir a razão desta conversão, como dissemos.

Vejamos algo sobre a sexta maravilha, como podem os acidentes existir sem sujeito algum. Alguns dos teólogos que connosco fruem de Deus acreditaram

\footnotetext{
$\leftarrow$ remanserunt.] et quibus aptus natus est informare remanserunt omnia integra. $Q \quad 394$ sexto] sacramento $P$
} 
accidentia haberent idem esse quod habet subiectum eorum et non perpendebant quod essentia seu natura ${ }^{395}$ alicuius rei non est aliud quam suum esse. Et esse rei non est aliud quam natura ipsius rei, ita quod esse non addit homini seu naturae humanae nisi respectum ad causam, hoc est, quia illud solum dicimus esse quod est in re productum, uel melius, illa natura dicitur esse cuius ${ }^{396}$ essentia est extra causam et extra intellectum. [f1. 142] Vnde esse hominis non aliud est quam corpus tale uniri formae tali. Quae unio fit extra mentem et causam ${ }^{397}$. Res enim dicitur in causa sua esse sicut filius in lumbis patris sui et in mente 398 per similitudinem sui. Quando ergo est extra mentem et causam dicitur habere esse simpliciter et absolute. Si ergo esset idem esse subiecti uidelicet substantiae et accidentis, sequeretur quod esset eadem essentia et natura substantiae et accidentis, quod est falsum. Dicunt ergo aliqui quod, destructa substantia, destruitur esse ipsius et ita etiam esse accidentis destruitur. Ex quo illud esse totius substantiae erat esse accidentis aliquo modo quia illud esse substantiae non primo conuenit accidentibus, sed ex consequenti, destructa ergo substantia, deberet destrui accidens. Sed hic non destruitur, quia Deus dat accidenti nouum esse per quod tunc est sine substantia. Et quia haec dixit amicus noster, quae etiam exponi possent pro honore eius. Ille tamen qui hoc adducit ${ }^{399}$, quem Regina nostra multum diligit quia eam primus publice defensauit, illa solum iunxit quae reprehendi poterant, non illa quae commendari possunt ${ }^{400}$. Et non sine ratione. Nam rationes bonae dimittuntur ${ }^{401}$ tamquam bonae, malae uel minus bonae reprehenduntur ut praetermittantur. Ille autem doctor ${ }^{402}$, etiam deuotus Virginis, qui quamdoque pro ea dixit et corde idem tenuit, tamen cum suspicione ne fidei forsan repugnaret quod non repugnabat, qui nunc non minus gaudet de uictoria illius, immo semper desiderauit illam uictoriam, adducit alias rationes quo pacto sit possibile accidentia persistere sine substantia. Et ratio sua est talis quia quaecumque facere potest causa secunda uel prima per secundam, facere potest prima sola. Hoc etsi aliqui philosophorum negauerint, tamen uerum est et a multis conceditur et, crede mihi, ab omnibus est concedendum, quia prima causa non indiget uirtute alterius causae. Tunc enim non esset Deus summa et perfectissima res in se si indigeret alia re a se. Si ergo accidentia persistunt, substantia creata ea conseruante, quare non poterunt manere solo Deo conseruante qui potest solus omne quod potest aliud uel ipse cum alio? Et haec ratio sufficit in ea parte qua dicitur accidentia conseuari uel fluere a substantia. In quantum uero substantia est subiectum ${ }^{403}$ et causa materialis accidentium adhuc nulla est impossibilitas ea esse sine substantia. Hoc patet, praesuposita regula superius dicta: "Omne prius alio, si sit alia res ab illo, conseruari potest sine illo". Sed accidens ut albedo uel superficies est prius aliquid in se quam inhaereat subiecto. Non enim potest

395 natura] materia IV 396 esse quod est in re productum, uel melius, illa natura dicitur esse cuius] esse cuius $N$; esse quod est in re productum, uel melius, illa natura dicitur esse cuius add. K in marg. a. $m .397$ causam] casum $M 398$ mente] mentem $I M V 399$ adducit] adiiecit $Q \rightarrow$ 
que os acidentes teriam o mesmo ser que tem o seu sujeito, e não consideravam que a essência ou natureza de alguma coisa não é mais do que o seu ser. E o ser de uma coisa não é mais do que a natureza da própria coisa, de tal modo que o ser não acrescenta ao homem ou à natureza humana senão a relação com a causa, isto é, que apenas dizemos que existe aquilo que foi produzido nessa coisa, ou melhor, diz-se que existe aquela natureza cuja essência está fora da causa e fora do intelecto. [f1. 142] Daí que o ser do homem não seja senão este corpo unir-se a esta forma. Esta união dá-se fora do intelecto e fora da causa. De facto, diz-se que uma coisa está na sua causa como o filho nos rins de seu pai e na mente, por semelhança de si. Portanto, quando está fora da mente e fora da causa, diz-se que tem o ser simples e absolutamente. Se, pois, fosse o mesmo o ser do sujeito, isto é, da substância, e o do acidente, seguir-se-ia que seria a mesma a essência e a natureza da substância e a do acidente, o que é falso. Dizem, por isso, alguns que, destruída a substância se destrui o seu ser e, deste modo, se destrui também o ser do acidente. Daí que o ser da totalidade da substância seja de algum modo o ser do acidente, porque o ser da substância não convém aos acidentes primariamente, mas por consequência. Destruída, portanto, a substância, deveria destruir-se o acidente. Mas este não se destrui, porque Deus dá ao acidente um novo ser por intermédio do qual está então sem substância. E porque foi um amigo nosso que afirmou estas coisas, poderiam elas também ser expostas para sua honra. Todavia, aquele que isto avançou, a quem a nossa Rainha muito ama, porque foi o primeiro que com denodo publicamente a defendeu, acrescentou apenas aquilo que podia ser censurado, não aquilo que pode ser recomendado. E não sem razão. Na verdade, as boas razões sacrificam-se, enquanto boas, as más ou menos boas retomam-se para serem ultrapassadas. Porém, esse doutor, também devoto da Virgem, que algumas vezes dela disse e sentiu o mesmo em seu coração, embora com receio, não fosse acaso chocar com a fé aquilo que não chocava, ele que presentemente se não alegra menos com a vitória dela, e até desejou sempre essa vitória, aduz outras razões, de que modo seja possível que os acidentes se mantenham sem a substância. E é esta a sua explicação: que quanto pode fazer a causa segunda ou a primeira por intermédio da segunda, pode fazê-lo a primeira sozinha. E se alguns filósofos vierem a negar isto, é, todavia, verdadeiro e por muitos concedido, e, acredita em mim, deve por todos ser concedido, porque a primeira causa não necessita da virtude da causa segunda. Pois, a ser assim, Deus não seria a Suma e Perfeitíssima Realidade in $s e$, se necessitasse de outra realidade diferente de si. Se, portanto, os acidentes persistem conservando-os essa substância criada, porque não poderão manter-se conservando-os só Deus que, só, pode tudo o que pode outro ou ele com

$\leftarrow \mathbf{4 0 0}$ commendari possunt] commendari possent $N$; condemnari possent $Q \quad \mathbf{4 0 1}$ dimittuntur] remittuntur $Q \mathbf{4 0 2}$ doctor] doctor idest Scotus $V \mathbf{4 0 3}$ subiectum] substantiam $I$; substantia $V$ 
intelligi ut inhaereat et non praeintelligatur illud quod inhaeret. Et albedo est alia res ab inhaerentia, quia albedo est qualitas, inhaerere est relatio ${ }^{404}$. Poterit ergo albedo et linea esse neque tamen inhaerere ${ }^{405}$ alicui substantiae et hoc illa uirtute cui nullum uerbum est impossibile.

Potest, ut probauimus ${ }^{406}$, accidens sine subiecto esse. Qui ergo dicunt quod Deus dat accidentibus quandam uirtutem supernaturalem per quam possunt per se et seorsum esse, si intelligunt de aliqua uirtute, id est, foma supernaturali eis impressa, non bene sentiunt, quia sicut substantiae non potest dari aliqua forma ut [f1. 143] inhaereat subiecto, sic nec accidenti ut per se subsistat siue ut sit substantia ${ }^{407}$. Si autem intelligunt ${ }^{408}$ quod accidenti detur, uirtute Dei supernaturali, ut possit existere sine subiecto, non quod sit substantia, sed quod ab illa seorsum existat, uerum ${ }^{409}$ est et bene dicunt.

De septimo mirabili satis dictum est uos non mouere ${ }^{410}$ neque eleuare corpus Domini, sed uirtute ipsius Christi mouetur ex pacto, hoc est, quia pepigit foedus uobiscum ut ubicumque uos posueritis accidentia, ibi ipse faciet praesens ipsis corpus sum et sanguinem. Vnde uos non mouetis eum per se neque proprie per accidens, sed ualde improprie per accidens, quia solo beneplacito uoluntatis diuinae se illo modo transfert.

De octauo quoque mirabili multa dicta sunt antea et sufficienter. Et qui aliter dicunt, repellantur.

De nono mirabili patet quod non transit per medium nec amittit locum naturalem et acquirit alium non localem. Similiter, manens cum his accidentibus, incipit esse cum illis. Plurificantur ${ }^{411}$ praesentiae corpore manente eodem.

De mirabili decimo dictum est quod aliquando propter consolationem hominum Deus accidentia illa conuertit in carnem quae stat in loco localiter sicut et accidentia stabant, et aliquando in sanguinem. Neque tamen caro illa est caro Christi neque sanguis ille sanguis Christi ${ }^{412}$. Quomodo autem ex accidentibus illis fiat substantia dictum est. Neque dicendum est quod ibi appareat caro et non sit caro, quia in

$\mathbf{4 0 4}$ inhaerere est relatio] inherentia uero relatio $Q$; inhaerere est ratio $J V \mathbf{4 0 5}$ Poterit ergo albedo et linea esse neque tamen inhaerere] Poterit ergo albedo uel linea esse sine eo quod inhaereat $Q \mathbf{4 0 6}$ ut probauimus] et probauimus $M$; ut dixi $Q$; ut probamus $I V \mathbf{4 0 7}$ substantia] subiecta $V \rightarrow$ 
outro? E esta explicação basta, naquela parte em que se diz que os acidentes são conservados pela substância ou dimanam dela. Enquanto, porém, a substância é sujeito e causa material dos acidentes, ainda não há impossibilidade alguma de que estejam sem substância. Isto é manifesto, pressuposta a regra acima referida: "Todo o anterior a outro, se é uma realidade distinta dele, pode conservar-se sem ele". Mas o acidente, como a brancura ou a superfície, é algo em si antes de aderir ao sujeito. Na verdade, não se pode entender que adira e que não se conceba previamente aquilo que adere. E a brancura é uma coisa distinta da adesão, porque a brancura é qualidade, aderir é relação. Poderá, portanto, a brancura ser também uma linha e, contudo, não aderir a qualquer substância, e isto por aquela Força a quem nada é impossível.

$\mathrm{O}$ acidente, como provámos, pode existir sem sujeito. Aqueles, pois, que dizem que Deus dá aos acidentes uma espécie de força sobrenatural pela qual podem existir per se e separadamente, se pensam numa qualquer força, ou seja, numa forma sobrenatural neles impressa, não ajuízam bem porque, assim como se não pode dar à substância forma alguma para que [f1. 143] adira ao sujeito, assim também se não dá ao acidente para que subsista per se ou para que seja substância. Se, porém, entendem que ao acidente se conceda, por uma força sobrenatural de Deus, a possibilidade de existir sem sujeito, não que seja substância, mas que exista separado dela, está certo e falam correctamente.

Sobre a sétima maravilha foi suficientemente afirmado que vós não moveis nem elevais o corpo do Senhor, mas se move por força do próprio Cristo, em função de um pacto, isto é, porque fez convosco uma aliança para que, onde quer que puserdes os acidentes, aí lhes fará ele presente o seu corpo e o seu sangue. Daí que vós não o moveis per se nem propriamente per accidens, mas muito impropriamente per accidens, porque apenas pelo beneplácito da vontade divina se transfere deste modo.

Muito, e quanto baste, foi dito antes também sobre a oitava maravilha. E rejeitem-se os que expõem de outro modo.

Relativamente à nona, é claro que não passa pelo meio, nem perde o lugar natural e adquire outro não local. De modo semelhante, permanecendo com estes acidentes, começa a ser com outros. Plurificam-se as presenças, mantendo-se o mesmo corpo.

Diz-se sobre a décima que, por vezes, para consolação dos homens, Deus converte os acidentes em carne, que está no lugar localmente do mesmo modo que estavam os acidentes, e por vezes em sangue. E, todavia, essa carne não é a carne de Cristo, nem esse sangue o sangue de Cristo. Mas foi dito como destes acidentes se cria a substância. E não deve dizer-se que aparece aí a carne e não é

$\leftarrow \mathbf{4 0 8}$ intelligunt] intelligat $I J O P$; intelligant $N V \mathbf{4 0 9}$ uerum] uerbum $V \mathbf{4 1 0}$ mouere] nouere $V$ 411 plurificantur] purificantur $V \mathbf{4 1 2}$ sanguis Christi.] sanguis Christi neque ibi est amplius sacramentum, ut diximus. $M$ in marg. a. $m$. OPV 
multis locis apud uos talis caro et sanguis remansit et adhuc ostenditur. Numquam tamen creauit aut formauit puerulum qui uere puerulus esset humanae speciei.

Omnia ergo quae miranda uidentur et sunt, diuinae uirtuti sunt possibilia et facillima. Nihil sibi difficile neque per consequens difficilius. Multa sunt mirabilia in hoc sacramento quae nos angeli etiam admiramur. Deumque potentissimum magnificemus ${ }^{413}$.

Et dum Gabriel haec mihi diceret, audiui subito uocem angelorum multorum hoc canticum coram Deo, Michaele principe ita incipiente, canentium ${ }^{414}$.

Quis ut Deus noster? Quis tibi, Deus, potest esse similis?

Magnus nobis apparuisti quando omnia ex nihilo creasti.

Inmensa uirtus illa fuit quae Dei Verbum carnem fecit.

Magna est, Deus, tua potentia, infinita est tua sapientia.

Laudamus te et exaltamus, confitemur et magnificamus.

Beati nos qui te dileximus ${ }^{415}$ et Luciferi monita contempsimus.

Te adoramus in saeculum, te glorificamus in aeternum.

Quis ut Deus noster? Quis tibi, Deus, potest esse similis

Qui propter hominem humanitatem assumpsisti et eam propter ipsum deposuisti,

Qui tuos semper dilexisti et in finem eis nimium amorem ostendisti?

Cenam lautissimam praeparasti et miranda nobis ostendisti, ${ }^{416}$

Cui cum apostolis et nos interfuimus et uirtutem tuam conspeximus.[fl. 144]

Stupenda et incognita uidimus et te, Deum nostrum, magnificauimus. ${ }^{417}$

Teque iugiter laudamus et in aeternum glorificamus.

Quis ut Deus noster? Quis tibi, Deus, potest esse similis?

Cum suis discipulis sedebat, uenerandis manibus panem tenebat,

Oculos ad caelum leuabat, Patri omnipotenti gratias agebat.

Panem deinde aspexit et clara uoce dixit:

"Vertatur panis terrestris in caelestem, cibus corporis in cibum spiritus;

Panis sudoris et maledictionis uertatur in panem quietis et benedictionis."

Ipse mandauit et creata sunt, tunc dixit et facta sunt.

Quis ut Deus noster? Quis tibi, Deus, potest esse similis? ${ }^{418}$

Dictis illis uerbis, haec uidimus mentibus nostris:

Panem inde abscedere, corpus Domini illuc sine mora ${ }^{419}$ accedere,

Panem esse desinere, accidentia omnia integra remanere.

Soluta est ingens colligatio ${ }^{420}$, dissuta ${ }^{421}$ est mira connexio,

Totum Christum uidimus simul cum illis accidentibus.

413 magnificemus] magnificamus $I M N O P Q 414$ canentium] clamantium $I$; Psalmus admirandus in quo exprimuntur omnia mysteria sacramenti bonae gratiae add. $M$ (in marg. a. m.) $O Q 415$ dileximus] diligimus $O Q \mathbf{4 1 6}$ Cenam lautissimam praeparasti et miranda nobis ostendisti] om. $N \rightarrow$ 
carne, porque em muitos locais, entre vós, essa carne e esse sangue permanecem e ainda são mostrados. Nunca, contudo, criou ou formou um menino que fosse realmente um menino da espécie humana.

Tudo, pois, que se afigura e é digno de admiração, é possível e muito fácil ao poder divino. Nada lhe é difícil nem, por consequência, mais difícil. Muitas são neste sacramento as maravilhas que nós, anjos, olhamos também com admiração. Glorifiquemos a Deus todo-poderoso.

E enquanto Gabriel me expunha tudo isto, ouvi de repente a voz de muitos anjos que, perante Deus, entoavam este cântico, assim começando Miguel, o príncipe:

Quem, como o nosso Deus? Quem pode, ó Deus, ser igual a ti?

Apareceste-nos grande quando do nada tudo criaste,

Foi imensa aquela força que fez carne o Verbo de Deus.

É grande, ó Deus, o teu poder, é infinita a tua sabedoria.

Louvamos-te e exaltamos-te, glorificamos-te e enaltecemos-te.

Bem-aventurados nós que te amámos e as sugestões de Lúcifer desprezámos, Adoramos-te para sempre, glorificamos-te eternamente.

Quem, como o nosso Deus? Quem pode, ó Deus, ser igual a ti?

Que, pelo homem, assumiste a humanidade e, por ele, a depuseste;

Que sempre os teus amaste e, no fim, inexcedível amor lhes manifestaste.

Preparaste lautíssima Ceia e mostraste-nos coisas admiráveis,

$\mathrm{Na}$ qual, com os apóstolos, também nós participámos e teu poder contemplámos.

[fl. 144] Vimos coisas maravilhosas e ignoradas e exaltámos-te a ti, nosso Deus, Louvamos-te sem cessar e glorificamos-te para sempre.

Quem, como o nosso Deus? Quem pode, ó Deus, ser igual a ti?

Estava sentado com seus discípulos, nas mãos veneráveis segurava o pão,

Aos céus elevava os olhos, ao Pai omnipotente graças dava,

Depois fixou o pão e em voz alta disse:

"Torne-se o pão terrestre em pão do céu, em alimento espiritual o alimento do corpo.

Mude-se o pão do suor e da maldição em pão de sossego e bênção".

Ele ordenou e tudo foi criado. Então disse e fez-se.

Quem, como o nosso Deus? Quem pode, ó Deus, ser igual a ti?

Pronunciadas essas palavras, isto vimos em nossas mentes,

O pão a afastar-se dali, aproximar-se sem movimento o corpo do Senhor,

O pão a deixar de ser, todos os acidentes a íntegros se manterem.

Desatou-se o forte vínculo, rompeu-se a admirável ligação.

Vimos a um tempo o Cristo total com aqueles acidentes

$\leftarrow \mathbf{4 1 7}$ et te Deum nostrum magnificauimus] et uirtutem tuam conspeximus $P$; et te Deum nostrum magnificamus $N V \mathbf{4 1 8}$ Quis tibi, Deus, potest esse similis] et reliqua $N \mathbf{4 1 9}$ mora] motu $J M N O P Q$ $\mathbf{4 2 0}$ colligatio] collatio $I J P \mathbf{4 2 1}$ dissuta] disiuncta $M$; dissoluta $O Q$; diffusa $V$ 
Rex inclitus uestitus sedebat seque ipsum sine uestibus tenebat.

Quis ut Deus noster? Quis tibi, Deus, potest esse similis?

Praesens accidentibus totus erat neque eum locus claudebat.

Magnus cum paruo manebat nec loco coextensus erat.

Astabamus et mirabamur, obstupebamus et uenerabamur. ${ }^{422}$

Accidentia illa frangebat, sub qualibet particula totus erat,

Se totum unicuique dabat et manu propria porrigebat:

"Accipe et comede" singulis dicebat, "hoc est corpus meum" asserebat.

Quis ut Deus noster? Quis tibi, Deus, potest esse similis?

Calicem uini lymphati ${ }^{423}$ accepit et uenerandis manibus strinxit,

Oculos sursum erexit, iterum Patri omnipotenti gratias egit,

Calicem statim inspexit et uoce aperta dixit:

"Vertatur uinum uitis ${ }^{424}$ terrestris in sanguinem uitis caelestis,

Potus cordis laetificatiuus, in potum animae uiuificatiuum."

Dixit et factum est, mandauit et conuersum est.

Quis ut Deus noster? Quis tibi, Deus, potest esse similis?

Prolatis uerbis illis, mox affuit totus Dei sanguis.

Corpus in quo erat detulit neque anima suam sedem deseruit,

Sed prius uinum recessit statimque sanguis accessit,

Vinum esse desiit, accidens eius integrum remansit.

Christus totus ibi erat neque uini accidens discedebat,

Accidentia uini ibi erant nullique substantiae inhaerebant.

Quis ut Deus noster? Quis tibi, Deus, potest esse similis'

Accidentium plus unus quam alius sumebat, sed totum Christum in se trahiciebat. ${ }^{425}$

Vnicuique de calice dabat, singulis ita dicebat:

"Accipe et bibe, hic est calix sanguinis mei, uide,

Nunc in calice manet et corpore, cito pro uobis effundetur. ${ }^{426}$

Remissionem peccatorum accipietis et in omni uirtute crescetis.

Corroborauit uos non cadetis, cadendo uelocius surgetis."

[f1. 145] Quis ut Deus noster? Quis tibi, Deus, potest esse similis?

Ex adipe frumenti homines cibasti, pane angelorum eos satiasti,

Sacerdotes discipulos instituisti, quando eis ita dixisti:

"Hoc quod ego nunc feci, uos in memoriam mei facietis."

Audiuimus Petrum dicere ista homines non posse facere:

Cui Tu respondisti et nullam creaturam id facere posse dixisti,

Solus Deus haec miranda facere ualuit ${ }^{427}$, nulla creatura umquam potuit.

Quis ut Deus noster? Quis tibi, Deus, potest esse similis?

Petrum coram omnibus instruxisti, sed prius interrogationem eius expectasti:

422 Astabamus et mirabamur, obstupebamus et uenerabamur] om. $Q \mathbf{4 2 3}$ lymphati] lymphato $I M V$ $\mathbf{4 2 4}$ uitis] uitae $P \mathbf{4 2 5}$ Christum in se trahiciebat] ipsum in se trahiciebat $I$; se tribuebat ipsum $V \rightarrow$ 
Vestido, sentava-se o ínclito Rei e, sem vestes, se tinha a si mesmo nas mãos. Quem, como o nosso Deus? Quem pode, ó Deus, ser igual a ti? Estava nos acidentes todo presente e nem o lugar o escondia. Com o pequeno permanecia o Grande e não era co-extensivo ao lugar. Assistíamos e admirávamos, estávamos maravilhados e venerávamos. Partia aqueles acidentes, estava todo em cada partícula, A cada um se dava todo e pela própria mão se oferecia.

"Toma e come" a cada um dizia, "isto é o meu corpo" afirmava. Quem, como o nosso Deus? Quem pode, ó Deus, ser igual a ti? Tomou o cálice do vinho com água, nas veneráveis mãos o estreitou, Elevou os olhos ao alto, ao Pai omnipotente deu de novo graças.

Logo fixou o cálice e, em voz alta, disse:

"Mude-se o vinho da videira terrestre no sangue da videira celeste, A bebida que alegra o coração, na bebida que vivifica a alma".

Disse e fez-se, mandou e converteu-se.

Quem, como o nosso Deus? Quem pode, ó Deus, ser igual a ti? Proferidas aquelas palavras, logo foi presente o sangue todo de Deus. Segurou o corpo em que estava e a alma não abandonou o seu lugar. Mas primeiro retirou-se o vinho, logo o sangue chegou.

$O$ vinho deixou de ser, íntegro se manteve o seu acidente.

Estava aí o Cristo todo e o acidente do vinho permaneceu.

Os acidentes do vinho aí estavam e a nenhuma substância se ligavam.

Quem, como o nosso Deus? Quem pode, ó Deus, ser igual a ti?

Dos acidentes tomava mais um do que outro, mas a si todo o Cristo levava. Dava a cada um do cálice, a todos assim dizia:

"Toma e bebe, este é o cálice do meu sangue, vê,

Está agora no cálice e no corpo, já por vós se derramará.

Dos pecados, o perdão recebereis, e em toda a virtude crescereis.

Dará forças para que vós não caiais e, caindo, mais depressa ressurjais”.

[f1. 145] Quem, como o nosso Deus? Quem pode, ó Deus, ser igual a ti.

Da flor do trigo alimentaste os homens, saciaste-os com o pão dos anjos.

Fizeste os discípulos sacerdotes, quando assim lhes falaste:

"Isto que eu agora fiz, em minha memória o fareis".

Ouvimos Pedro dizer: isto os homens não podem fazer.

Respondeste-lhe tu e disseste que criatura alguma o pode fazer.

Só Deus fazer pôde essa maravilha, nenhuma criatura o pôde algum dia. Quem, como o nosso Deus? Quem pode, ó Deus, ser igual a ti? Na presença de todos a Pedro instruíste, mas primeiro sua pergunta aguardaste:

$\leftarrow \mathbf{4 2 6}$ effundetur] effundetur et diuidetur a corpore $M$ in marg. a. $m$. $O \mathbf{4 2 7}$ ualuit] uoluit $J M V$; potuit $Q$ 
"Si nos ista facere non possumus, quare, magister sapientissime, iubes ut faciamus?"

"Illa uos facietis", respondisti, "quae potestis. Ego perficiam quae uos non potestis.

Panem in manibus accipietis et ita, accepto pane, dicetis:

'Dominus, pridi quam pateretur, panem accepit et oculos ad caelum leuauit

Gratias Patri egit' dicetis, 'quaecumque dixi et feci facietis'."

Quis ut Deus noster? Quis tibi, Deus, potest esse similis?

Totum Christum Dei Filium in pectoribus singulorum cernebamus,

Accidentia illa alterari uidebamus, ex eis sanguinem generari inspiciebamus, ${ }^{428}$

Sanguinem seorsum uidimus et corpus mortuum sub accidentibus inspeximus,

Sanguinem iterum copulari et glorioso corpori uidimus uniri,

Corpus anima iterum ornatum et omni gloria et honore uidimus decoratum.

Haec sunt admiranda et omni ueneratione prosequenda.

Quis ut Deus noster? Quis tibi, Deus, potest esse similis?

Stupenda et incognita uidemus et te Deum nostrum magnificamus,

Laudamus te et exaltamus, confitemur et glorificamus.

Beati nos qui te dileximus et Luciferi monita contempsimus.

Beati nos qui oboediuimus, quia in exultatione semper erimus.

Te Deum omnipotentem adoramus in saecula, te glorificamus in aeternum.

Tibi nos iure ${ }^{429}$ seruos submittimus, ciuem nobiscum hominem tibi commendamus.

Hoc auribus meis suauissimo cantu expleto, Gabriel ad me iterum accessit, nam et ipse cum Michaele et aliis canebat. Dixitque mihi: Tu audisti canticum hoc admirandum in quo huius sacramenti omnia quasi praecipua et mirabiliora mysteria ponuntur. Et quamuis Deo ex laudibus nostris nihil accedat, quia ipse sibi est bonum sufficientissimum ${ }^{430}$, accedit tamen nobis qui ipso in omnibus indigemus. Laudemus Deum iugiter mirabilia opera eius recitando, explicando et more nostro cantando. Illa enim conferunt ad laetitiam nostram. Sed laetitia illa quae de uisione ac eius fruitione procedit nulli ${ }^{431}$ comparanda est laetitiae. Quando Deum glorificamus placet sibi, non ut ipse intumescat aut infletur et exaltetur, sed ut nos intumescamus uirtutibus, inflemur donis eius exaltemur muneribus ${ }^{432}$. Non dico istud, carissime, ac si uirtutes, dona ac beatitudines essent alii et alii habitus in uobis, ut aliqui hominum etiam illorum qui nunc sunt nobiscum beati putauerunt, sed quia idem habitus in gradu tali est solum uirtus, in ampliori donum et in ampliori beatitudo aut fructus Spiritus. Semper tamen ille habitus, 
"Se nós não podemos isto fazer, porque ordenas, sapiente mestre, que o façamos?”

Respondeste: "Mas vós fareis o que podeis. O que vós não puderdes eu completarei,

Em vossas mãos, o pão tomareis e, tomado o pão, assim direis:

'Na véspera da sua paixão, o Senhor tomou o pão e ao Céu levou os olhos,

Deu graças ao Pai', direis, 'quanto disse e fiz, fareis'."

Quem, como o nosso Deus? Quem pode, ó Deus, ser igual a ti?

No peito de cada um, víamos claramente todo o Cristo de Deus Filho.

Os acidentes a alterarem-se contemplávamos, gerar-se deles o sangue observávamos.

Vimos o sangue separado e sob os acidentes vimos o corpo morto,

Vimos o sangue outra vez associar-se e ao corpo glorioso unir-se,

Vimos o sangue de novo pela alma ser ornado e de toda a honra e glória ser decorado.

Deve isto ser admirado e com toda a veneração continuado.

Quem, como o nosso Deus? Quem pode, ó Deus, ser igual a ti?

Vimos o admirável e o ignorado, exaltamos-te a ti nosso Deus.

Louvamos-te e exaltamos-te, proclamamos-te e glorificamos-te.

Bem-aventurados nós que te amámos e as sugestões de Lúcifer desprezámos.

Bem-aventurados nós que obedecemos, porque estaremos sempre em exultação.

Adoramos-te pelos séculos, Deus omnipotente, glorificamos-te para sempre.

Por direito servos, a ti nos submetemos, a ti confiamos o homem, nosso concidadão.

Concluído este cântico agradabilíssimo aos meus ouvidos, de novo Gabriel se abeirou de mim, pois também ele cantava com Miguel e os outros, e disse-me: Tu ouviste este cântico digno de admiração em que se encontram quase todos os principais e mais admiráveis mistérios deste sacramento. E embora dos nossos louvores nada acresça a Deus, porque ele é para si bem suficientíssimo, acresce-nos a nós, todavia, que em tudo dele precisamos. Louvemos, pois, a Deus, recitando, narrando e cantando à nossa maneira as suas obras admiráveis. Elas, na verdade, contribuem para a nossa alegria. Mas a nenhuma alegria deve ser comparada a alegria que procede da sua visão e da sua fruição. Quando glorificamos a Deus, é-lhe grato, não para se ufanar ou envaidecer, orgulhar e exaltar, mas para nos ufanarmos a nós de virtudes, nos envaidecermos em seus dons, exaltarmos com seus benefícios. Não digo isto, caríssimo, como se as virtudes, os dons e as bem-aventuranças fossem em vós uma coisa, e outra os hábitos, como pensaram alguns homens, mesmo daqueles que presentemente são connosco

$\leftarrow$ sapientissimum $I V 431$ nulli] mille $V 432$ inflemur donis eius et exaltemur muneribus] $M$ in marg. a.m. 
in quocumque gradu capiatur, uirtus est. Omnes ergo illi habitus sunt habitus [f1. 146] uirtutum. Sic $^{433}$ ergo nos de uniuersis mirabilibus quae fecit Deus ipsum magnificamus et glorificamus. Et tibi haec sunt reuelata ut ea conscribas ad hoc ut omnes homines magnificent Deum nostrum eisdem psalmis et hymnis et canticis quibus nos angeli ipsum magnificamus et in sempiternum magnificabimus. Sed ualde delectabiliores in lingua nostra sunt quam uestra. Et in uestra etiam fient delectabiliores tempore illo felici quando apparebit Pastor bonus qui haec omnia cantica destinguet in psalmos et in hymnos et quando cantari debeant ordinabit. Venient enim nuptiae Agni in quibus exultabitis laetitia inenarrabili. Ecce audisti miranda quae fecit Deus in hoc altissimo sacramento quod omnibus aliis sine comparatione excelentius est. Primum et maximum mysterium est incarnationis. Secundum est hoc et uere. Hic etiam tot miranda occurrunt quod uidetur aequale mirandis incarnationis. Bene ${ }^{434}$ actum est ut solemniter feria quinta post octauam Pentecostes celebretur, quia propter Domini Passionem in suo die celebrari solemniter non poterat. Tertium mysterium fuit Resurrectionis Domini. Tunc enim anima corpori reunita et sanguis corpori coniunctus et deitas humanitati copulata extitit. Tunc iterum Deus factus est homo, sepulcrum penetrauit, suum corpus dotibus beatitudinis decorauit. Quartum locum inter mysteria fidei Christiane tenet Ascensio Domini. Tunc enim conscendit ${ }^{435}$ super omnes caelos et humanitatem suam in regionem longinquam conduxit. Quae tamen regio, ut alias tibi declaraui, est corpori uestro conuenientissima. Sic enim eam disposuit Deus sublimis et benedictus in saecula. Quintum locum tenet mysterium Natiuitatis Domini, de qua superius diximus. Sed uos illud maiori ueneratione ${ }^{436}$ celebratis, quia tunc ad mentem $^{437}$ Filii Dei incarnationem reducitis. Vobis enim de manifestis iudicium est, non de occultis. Incarnatio uobis fuit occulta, Natiuitas manifesta. Ideo in secunda Natiuitate manifesta recolitis et priorem Natiuitatem immanifestam. Sed nobis angelis ita manifesta fuit Incarnatio sicut et Natiuitas. Recolite haec mysteria, facite in Christi Domini commemorationem haec omnia. Non poterat quicquam uobis donare maius seipso. Ipse donator, ipse et donum est. Gratias agite Deo Trino et Vni qui tantum genus uestrum amauit, tam diligenter salutem uestram procurauit, tam mirabiliter uos dignificauit et exaltauit.

433 Spiritus. Semper tamen ille habitus, in quocumque gradu capiatur, uirtus est. Omnes ergo illi habitus sunt habitus uirtutum. Sic] Spiritus. Sic $Q$; uirtutum sed in tali gradu dicuntur solum uirtutes, in ampliori, dona et adhuc in ampliori beatitudines et fructus $M$ (in marg. a. m.) NO 434 incarnationis. (...) incarnationis. Bene] incarnationis. Bene $I 435$ conscendit] consendit $M$; ascendit $I V 436$ ueneratione] celebratione et ueneratione $Q$; benedictione $V 437$ mentem] mortem $V$ 
bem-aventurados, mas porque o mesmo hábito nesse grau é apenas virtude, no grau mais elevado é dom e no mais elevado ainda é bem-aventurança ou fruto do Espírito. Como quer que seja, o hábito, em qualquer grau que seja, é sempre virtude. Por consequência, todos os hábitos são hábitos [f1. 146] de virtudes. Deste modo, pois, nós exaltamos e glorificamos a Deus em razão de todas as maravilhas que ele fez. E estas coisas foram-te reveladas para que as escrevas a fim de que todos os homens glorifiquem ao nosso Deus com os mesmos salmos, hinos e cânticos com que nós anjos o glorificamos e glorificaremos para sempre. Mas são bem mais agradáveis na nossa que na vossa língua. E também na vossa se hão-de tornar mais agradáveis naquele feliz tempo, quando aparecer o bom Pastor, que dividirá todos estes cânticos em salmos e hinos e ordenará quando se devem cantar. Hão-de chegar realmente as Núpcias do Cordeiro, em que exultareis de inenarrável alegria. Eis que ouviste todas as maravilhas que Deus fez neste altíssimo sacramento que é, sem comparação, mais excelente que todos os outros. O primeiro e máximo mistério é o da Incarnação. O segundo é este, e com toda a verdade. Nele ocorrem também tão grandes maravilhas que parece igual às maravilhas da Incarnação. Foi bem que solenemente se celebrasse na quinta-feira depois da oitava de Pentecostes, ${ }^{[181]}$ uma vez que, por causa da Paixão do Senhor, não podia ser solenemente celebrado no seu dia. O terceiro mistério foi o da Ressurreição do Senhor. Então, de facto, a alma foi reunida ao corpo e o sangue unido ao corpo e a divindade unida à humanidade. Então Deus, de novo feito homem, penetrou no sepulcro, ornou o seu corpo com os dotes da bem-aventurança. O quarto lugar entre os mistérios da fé cristã tem-no a Ascensão do Senhor. Elevou-se, então, de facto, acima de todos os céus e levou a sua humanidade para uma região longínqua. Região que, como antes te declarei, é apropriadíssima para o vosso corpo. Assim a ordenou o Deus sublime e bendito pelos séculos. O quinto lugar pertence ao mistério da Natividade do Senhor, de que falámos antes. Mas vós celebrai-lo com maior veneração porque, actualmente, reduzis a Incarnação do Filho de Deus a um pensamento. Vós tendes opinião sobre o que é evidente, não sobre o oculto. Para vós a Incarnação foi oculta, a Natividade foi manifesta. Por isso, na segunda Natividade, manifesta, recordais também a primeira, não manifesta. Mas para nós anjos tão manifesta foi a Incarnação como a Natividade. Recordai estes mistérios, fazei tudo isto para comemoração de Cristo Senhor. Não podia presentear-vos com algo maior do que ele mesmo. Ele é o doador e também o dom. Dai graças ao Deus Trino e Uno que a tal ponto amou a vossa raça, tão diligentemente cuidou da vossa salvação, tão admiravelmente vos dignificou e exaltou.

${ }^{[181]}$ É a Festa do Corpo de Deus. 
Nunc tu reuertere ad locum unde raptus es et cibum corporis sume, quia nondum uenit tempus resolutionis tuae. Sed omnibus quae Deus disposuit tibi reuelare conscriptis et in uno uolumine redactis puluis tuus reuertetur in terram suam et spiritus reuertetur ad Deum ${ }^{438}$ qui fecit illum. Deum adora et Genitricem [f1. 147] eius. Toti societati huic reuerentiam exhibebis ${ }^{439}$, quia omnes te amant tibique bonum optant. Vale, uir Dei.

Dum ego adorarem, angelum non uidi. Et subito uidi me esse in cellula mea et cauerna. Aperui ostium. Fratres comparuerunt quia dies Dominicae Resurrectionis ${ }^{440}$ erat meque in refectorium ad lautiorem solito ${ }^{441}$ cibum inuitauerunt et adhuc quasi attonitum et in extasi positum conduxerunt.

Finis huius raptus sextus. Laus Deo. Amen.

438 reuertetur ad Deum] ad eum ibit $Q \quad 439$ exhibebis] exhibeatis $I$; exhibeas $V \quad 440$ dies Dominicae Resurrectionis] dies Dominica $Q \mathbf{4 4 1}$ in refectorium ad lautiorem solito] ad refectorium et lauatorium subito $Q$ 
Tu, agora, retorna ao lugar de onde foste arrebatado e toma o alimento corporal, porque ainda não chegou o tempo da tua dissolução. Mas, escrito e reduzido a livro tudo o que Deus dispôs revelar-te, o teu pó retornará à sua terra e o espírito retornará a Deus, que o fez. Adora a Deus e a [f1. 147] sua Mãe. A toda esta Assembleia hás-de manifestar reverência, porque todos te amam e te desejam bem. Adeus, homem de Deus.

$\mathrm{E}$, enquanto estava em adoração, deixei de ver o anjo. $\mathrm{E}$, de repente, vi que estava na minha celazinha e na gruta. Abri a porta. Apareceram os irmãos, porque era Domingo da Ressurreição do Senhor, e chamaram-me para o refeitório para uma refeição mais farta que o habitual, e levaram-me ainda meio atónito e mergulhado em êxtase.

Fim deste Rapto Sexto. Louvor a Deus. Ámen. 


\section{RAPTVS SEPTIMVS 1}

Octaua resurrectionis Domini nostri Iesu Christi, dum feruenter ${ }^{2}$ orarem in cauerna mea Deum meum, raptus fui in spiritu et uidi Dominum sedentem super solium excelsum et eleuatum. Et uidebam in eodem loco tres personas, uidelicet Patrem, Filium et Spiritum Sanctum ita quod non tenebat Pater Filium in sinu aut gremio neque a dextris aut a sinistris, sed ubi erat Pater ibi et Filius atque Spiritus Sanctus pariter erant. Quod a nobis intelligi potest, figurari et pingi non potest. Nos enim ipsas personas pingimus separatas loco. $\mathrm{Illi}^{3}$ autem, quamuis in nullo loco sint circumscriptiue ${ }^{4}$, tamen in omni ${ }^{5}$ loco sunt praesentialiter. Et ideo ubi est Pater ibi est Filius ac Spiritus Sanctus ${ }^{6}$. Erant autem in circuitu throni duo Seraphin. Et erant sex alae uni et sex alae alteri. Duabus ${ }^{7}$ caput uelabant, duabus pedes et tibias, duas ${ }^{8}$ quasi ad uolandum extensas habebant. Et uoce magna clamabant: Sanctus, Sanctus, Sanctus Dominus, Deus Sabaoth. Et erant illi duo Seraphin Vriel' ${ }^{9}$ et Barchiel.

Stabam itaque stupefactus, sentiens tamen non paruam consolationem intus in anima mea. Tunc accessit ad me Gabriel Angelus dixitque mihi: Haec uisio ideo $^{10}$ tibi monstrata est ut hominibus tua scriptura notum facias misterium absconditum Sanctissimae Trinitatis ut pastor futurus sciat determinare quid et qualiter tenendum atque credendum sit et quae uestrarum opinionum uera sit, quae falsa, ut remoueantur a uobis altercationes ${ }^{11}$ et schismata et uarietas ${ }^{12}$ opinionum. Et in hac die Deus haec tibi reuelare uoluit in qua apud uos in missa legitur: Tres sunt qui testimonium dant in caelo: Pater, Verbum et Spiritus Sanctus, et hi tres unum sunt. Firmiter itaque credendum est et nullo modo dubitandum quod, sicut uidisti, Deus omnino unus est et in sua deitate nullo modo diuisus aut plurificatus. Tamen ipsa summa unitas deitatis stat ${ }^{13}$, immo necessario coniuncta est trinitati ${ }^{14}$

1 Raptus Septimus] Raptus Septimus, De Trinitate $I \mathbf{2}$ feruenter] frequenter $V \mathbf{3}$ Illi] Ille $N O Q \mathbf{4}$ circumscriptiue] circunscriptione $P \mathbf{5}$ in omni] communi $V \mathbf{6}$ Spiritus Sanctus] Spiritus Sanctus. Et ita uidebam tres distinctas inter se quia unus non erat alius sed quoad locum erant indistincti quasi ubi erat unus ibi erat alius ita quod omnes tres in una sede uidebantur sedere modo mirabili. $M$ (in marg. a. m.) NOQ 7 Duabus] duobus $P \mathbf{8}$ duas] duabus $V 9$ duo Seraphin. Et $\rightarrow$ 


\section{SÉtimo Arrebatamento}

Na oitava da Ressurreição de Nosso Senhor Jesus Cristo, enquanto na minha gruta orava fervorosamente ao meu Deus, fui arrebatado em espírito e vi o Senhor sentado sobre um nobre e elevado trono. E via no mesmo lugar três Pessoas, a saber, o Pai, o Filho e o Espírito Santo, de tal modo que o Pai não tinha o Filho no seio ou ao colo nem à direita nem à esquerda, mas onde estava o Pai estavam igualmente o Filho e o Espírito Santo. O que pode por nós ser compreendido, não pode figurar-se, nem pintar-se. Nós, de facto, pintamos as mesmas Pessoas separadas no lugar. Estas, porém, embora não estejam em lugar nenhum circunscritivamente, estão, todavia, em todo o lugar presencialmente. E, por isso, onde está o Pai, aí está o Filho e o Espírito Santo. E à volta do trono estavam dois Serafins. E tinham seis asas um e seis asas o outro. Com duas velavam a cabeça, com duas, os pés e as pernas, tinham duas abertas como para voar e, com voz forte, clamavam: Santo, Santo, Santo, Senhor Deus dos Exércitos. ${ }^{[182]}$ E esses dois Serafins eram Uriel e Barquiel.

Estava, pois, estupefacto, sentindo, contudo, não pequena consolação no íntimo da minha alma. Aproximou-se então de mim o anjo Gabriel e disse-me: Esta visão foi-te mostrada com o intuito de, pela tua escrita, dares a conhecer aos homens o oculto mistério da Santíssima Trindade, para que o Pastor futuro saiba determinar o que se deve e como se deve acreditar e crer, e qual das vossas opiniões é a verdadeira, qual é a falsa, para que se afastem de vós disputas, cismas e a diversidade de opiniões. Quis Deus revelar-te estas coisas neste dia em que entre vós se lê na missa: São três os que dão testemunho no Céu: o Pai, o Verbo e o Espírito Santo, e estes três são um só. ${ }^{[183]}$ E assim deve crer-se firmemente e de modo nenhum duvidar-se de que, como viste, Deus é absolutamente uno e de modo nenhum dividido ou plurificado na sua divindade. Todavia, essa

$\leftarrow \operatorname{erant}(\ldots)$ Et erant illi duo Seraphin Vriel] duo Seraphin Vriel $N \mathbf{1 0}$ ideo] Deo $V 11$ altercationes] alterationes $V \mathbf{1 2}$ uarietas] ueritas $V \mathbf{1 3}$ Tamen ipsa summa unitas deitatis stat] Tamen ipse summa unitas et deitas stant $Q$; Tamen ipsa summa unitas deitas stat $J V \mathbf{1 4}$ trinitati] deitati $N$

${ }^{[182]}$ Is $6: 23$

[183] 1 Jo 5:7. 
personarum. Tres sunt personae et omnino unica deitas. Et quia Deum esse et unum Deum esse satis apud uos notum est neque in hoc est altercatio ${ }^{15}$, nil tibi de hoc dico. Dicam illud in quo uestri confligunt et decertantdae unitate deitatis. Postea tibi declarabo magnum misterium Trinitatis.

Dico tibi magnam altercationem inter uestros ${ }^{16}$ theologos esse quomodo [fl. 148] Deus sit omnino una res in se et tamen in ipso ponitur ueritas, bonitas, sapientia, aeternitas, immensitas et plura huiusmodi. Quomodo haec omnia, haec et tot et tanta quae dicuntur de Deo possunt esse una res omnino, indistincta ${ }^{17}$ omnino, unica omnino?

Aliqui ex hominibus dixerunt illa esse plura nomina idem omnino significantia, sicut apud latinos idem est dictu ${ }^{18}$ abditum, absconditum et celatum ${ }^{19}$.

Quae opinio falsa est quia, tali opinione stante, sequeretur quod quando dicitur "Deus est bonus, sapiens, aeternus, immensus", nihil aliud diceretur quam "Deus est Deus". Quod absurdum est, quia tunc non fuisset facta tanta inuestigatio eorum quae attribuuntur Deo et quae non, quia omnia nomina possunt Deo imponi ut dicantur de illo et significent illum. Sed non potest fieri ut omnis res dicatur ${ }^{20}$ de Deo. Si ergo illa nomina solum fuissent imposita ad significandum idem quod significat hoc nomen "Deus", ita potuisset imponi Deo hoc nomen "lapis", hoc nomen "ferrum" et hoc nomen "formica" et ita de omnibus aliis. Non sunt ergo illa solum nomina eiusdem rei $^{21}$ omnino, quia tunc nulla ratio esset quod ${ }^{22}$ illa potius dicerentur ${ }^{23}$ de Deo quam alia nomina, nisi quis diceret illa fuisse imposita Deo, alia non. Ideo illa dicuntur, alia non. Hoc autem dicere omnino falsum est, quia tunc non magis diceretur sapientia de Deo quam lapis. Si ergo uellem imponere $^{24}$ illud nomen Deo et sic, ut supra dixi, idem esset dicere "Deus est sapiens" et "Deus est lapis" quod est dicere "Deus est Deus", et sic dicendo "est sapiens" nihil aliud dicitur nisi "Deus est Deus", frustra ergo tot libri fuissent confecti ${ }^{25}$ de attributis Dei et sequeretur absurdius, quia tunc idem esset dicere "Deus uult" et "Deus intelligit" et "Deus erat" et "Deus potest" et "Deus generat ${ }^{26 "}$ et "Deus spirat quod spirat", quod est dicere "Deus est Deus".

Illa ergo opinio est obmittenda ${ }^{27}$ quae tamen postmodum quomodo possit esse uera declarabitur.

Alii dixerunt illa omnino ${ }^{28}$ esse unam rem omnino ${ }^{29}$, sed differre ratione inter se. Et sic illa uocabula dicunt non esse synonyma ${ }^{30}$ siue idem significantia, quia alia

15 altercatio] alteratio $V \quad 16$ uestros] uos $J Q 17$ indistincta] distincta $V \quad 18$ dictu] dictum $I J P V 19$ celatum] colatum $V \mathbf{2 0}$ omnis res dicatur] omnes res dicantur $O Q \mathbf{2 1}$ rei] Dei $V \mathbf{2 2}$ esset quod] esset quam $M$; esset quare $Q \mathbf{2 3}$ dicerentur] dicentur $O$; diceretur $V \mathbf{2 4}$ uellem imponere] ponerem $\rightarrow$ 
suma unidade da divindade permanece, melhor, está necessariamente unida à trindade das Pessoas. São três as Pessoas e apenas uma única divindade. E dado que a existência de Deus e a existência de um único Deus são suficientemente conhecidas entre vós, e sobre este ponto não há disputa, nada te vou dizer sobre isso. Falarei da unidade da divindade, assunto em que os vossos se digladiam e se combatem. Depois revelar-te-ei o magno mistério da Trindade.

Digo-te que há entre os vossos teólogos uma importante disputa quanto ao modo como [f1. 148] Deus é, em si, absolutamente uma única substância e, todavia, nele se considera a verdade, a bondade, a sabedoria, a eternidade, a imensidade e várias outras coisas da mesma natureza; como tudo isto, estas e tantas e tão grandes coisas que se afirmam de Deus, pode ser uma substância apenas, absolutamente indistinta, absolutamente única.

Disseram alguns homens que essas coisas são nomes vários, que significam absolutamente o mesmo, assim como entre os latinos vale o mesmo dizer-se escondido, abscôndito, oculto.

Esta opinião é falsa porque, a manter-se, seguir-se-ia que, quando se diz "Deus é bom, sábio, eterno, imenso", não se diria senão que "Deus é Deus". O que é absurdo, porque então não se teria feito tão profunda investigação daquilo que se atribui e do que se não atribui a Deus, porque todos os nomes se podem aplicar a Deus para que dele se prediquem e o signifiquem. Mas não pode acontecer que tudo se afirme de Deus. Se, pois, esses nomes fossem atribuídos apenas para significarem o mesmo que significa a palavra Deus, poder-se-ia, certamente, aplicar a Deus este nome "pedra", este nome "ferro" e este "formiga", e assim em relação a todos os outros. Portanto, aqueles não são só e apenas nomes da mesma substância, porque então nenhuma razão haveria para que se afirmassem de Deus aqueles nomes mais do que outros, a não ser que se dissesse que esses foram atribuídos a Deus, os outros não, por isso se afirmam esses, os outros não. Mas dizer isto é redondamente falso, porque então de Deus não se afirmaria mais a sabedoria do que a pedra. Se, portanto, se quisesse atribuir esse nome a Deus e assim, como antes referi, fosse o mesmo dizer, Deus é sábio, e, Deus é pedra, que é dizer, Deus é Deus, e, assim, dizendo: é sábio, não se diz senão Deus é Deus, em vão, pois, tantos livros teriam sido escritos sobre os atributos de Deus e resultaria mais absurdo porque, então, seria o mesmo dizer: Deus quer, e, Deus compreende, e, Deus estava, e, Deus pode, e, Deus gera, e, Deus espira o que espira, que dizer: Deus é Deus.

Deve, pois, essa opinião ser passada em silêncio, ela que, contudo, mais tarde se esclarecerá de que modo pode ser verdadeira.

Disseram outros que esses eram unicamente uma coisa apenas, mas diferiam entre si do ponto de vista da razão. E, assim, dizem que esses nomes não são

$\leftarrow$ et uellem $Q 25$ confecti] scripti $Q 26$ generat] gubernat $Q 27$ obmittenda] admittenda $Q$; dimittenda $V 28$ omnino] omnia $O 29$ unam rem omnino] unam $N$; unam rem numero $Q \mathbf{3 0}$ synonyma] sine nomina $V$ 
est ratio deitatis, alia bonitatis, alia sapientiae, alia immensitatis et aeternitatis. Sed dicunt quod iste rationes sunt uel in uestro intellectu considerante uel in diuino.

Quae opinio etiam falsa est et bene a uestris improbata. Nam tenendo illam opinionem, sequeretur quod bonitas et sapientia non essent aliquid in Deo, sed tantum in mente Dei uel in mente angelica aut humana sicut logici dicunt entia rationis dici solum de rebus cognitis et prout habent esse cognitum, non autem prout habent esse reale. Vnde dicunt et bene: Quando dicitur "homo est sapiens", illud non est uerum prout homo est res quaedam existens in suis indiuiduis ${ }^{31}$, immo quando dicitur "Plato ${ }^{32}$ est homo", tunc homo non est species. Similiter quando dicitur "homo est animal", tunc neque homo est species neque ${ }^{33}$ animal genus.[f1. 149]

Animal ergo, ut seorsum cognoscitur et consideratur, genus est. Et homo, in quantum consideratur, species est ${ }^{34}$. Sic, a simili, si Deo sapientia conueniat et intellectus et uoluntas solum secundum considerationem, tunc quando dicitur "Deus est spiritus ${ }^{35 "}$ uel "Pater est Deus ${ }^{36 ", ~ D e o ~ n o n ~ c o m p e t i t ~ s a p i e n t i a ~ a u t ~ b o n i t a s ~}$ aut intellectus aut uoluntas, quia entia rationis ${ }^{37}$ non conueniunt rebus sumptis secundum esse reale, sed secundum esse consideratum quod esse habent in mente considerantis $^{38}$. Et sic Deus re ipsa non esset sapiens neque intelligens neque uidens aut uolens uel fruens, sed solummodo secundum considerationem. Et ita, remota consideratione, non esset sapiens neque uolens uel, si esset, tunc illa essent synonyma, idem omnino significantia, ut prior opinio dicebat. Singularis ratio est contra illos qui dicunt intellectum diuinum conficere ista entia rationis, et hanc distinctionem rationis fieri per intellectum diuinum. Nam quaero a te: aut ista pluralitas rationum et distinctionum est in natura diuina ${ }^{39}$ aut non est in natura, sed in intellectu diuino. Si ista pluralitas est in ipsa natura Dei, tunc non est $^{40}$ secundum considerationem, sed secundum rem, quod est contra opinionem tuam. Si autem ista pluralitas est in ipso intellectu considerante et non in re, sequitur quod intellectus iam intelligitur distinctus a natura ex quo ipse facit pluralitatem, non autem eam facit natura et confirmatur. Nam haec pluralitas praesupponit considerationem, consideratio praesupponit intellectum. Ergo intellectus iam est ibi distinctus a natura si ante ${ }^{41}$ considerationem intelligatur ibi esse. Nam si in illo priori ante considerationem est iam ibi intellectus, sequitur quod non est ibi per considerationem solam. Si autem ante considerationem non sit ibi intellectus ullo modo ${ }^{42}$, sed tantum natura, tunc natura erit illa qua haec distinguentur et plurificabuntur ${ }^{43}$. Si ergo pluralitas rationum fiat ibi per solam

31 indiuiduis] diuiduis $I V 32$ Plato] prolatio $V 33$ est species. Similiter (...) homo est species neque] est species neque $P 34$ species est] species eius $V 35$ Deus est spiritus] Deus est sapiens $P Q$; Deus est species $I V 36$ Pater est Deus] Deus est bonus $Q 37$ entia rationis] etiam rationes $V 38$ considerantis] considerationis $I V 39$ natura diuina] materia diuina $I V \mathbf{4 0}$ non est in natura, $\rightarrow$ 
sinónimos ou não significam o mesmo, porque uma é a razão da divindade, outra a da bondade, outra a da sabedoria, outra a da imensidade e da eternidade. Mas dizem que estas razões existem ou no vosso intelecto pensante ou no divino.

Também esta opinião é falsa e completamente rejeitada pelos vossos. Pois, mantendo esta opinião, seguir-se-ia que bondade e sabedoria não seriam alguma coisa em Deus, mas apenas na mente de Deus ou na mente angélica ou na humana, conforme afirmam os lógicos, que entes da razão são consideradas apenas as coisas conhecidas enquanto têm ser conhecido e não enquanto têm ser real. Daí que digam e digam bem: quando se diz: "o homem é sábio", isso não é verdadeiro enquanto homem é uma certa substância que existe nos seus indivíduos; mais ainda, quando se diz: "Platão é homem”, então homem não é espécie. Do mesmo modo, quando se diz: "o homem é animal", então nem homem é espécie, nem animal é [fl. 149] género.

Animal, pois, enquanto se conhece e se considera separadamente, é género. E homem, enquanto se considera separadamente, é espécie. Assim, semelhantemente, se sabedoria ou bondade, inteligência ou vontade convêm a Deus apenas em função da consideração, então quando se diz: "Deus é espírito", ou: "o Pai é Deus", sabedoria ou bondade ou inteligência ou vontade não se atribuem a Deus, porque os entes da razão não convêm às coisas tomadas segundo o ser real, mas segundo o ser considerado, que tem ser na mente do considerante. E, assim, Deus, na realidade, não seria sábio nem inteligente, nem ser que vê ou quer ou frui, mas unicamente o seria segundo a consideração. E, assim, afastada a consideração, não seria nem sapiente nem dotado de vontade ou, se fosse, então os dois termos seriam sinónimos, significando absolutamente o mesmo, como afirmava a primeira opinião. A razão singular está contra aqueles que dizem que o intelecto divino produz estes entes da razão e que esta distinção da razão se faz por meio do intelecto divino. Com efeito, pergunto-te: ou esta pluralidade de razões e distinções existe na natureza divina, ou não existe na natureza divina, mas no intelecto divino. Se esta pluralidade existe na própria natureza de Deus, então não existe segundo a consideração, mas segundo a substância, o que está contra a tua opinião. Se, pelo contrário, esta pluralidade existe no próprio intelecto considerante e não na substância, segue-se que o intelecto se reconhece já distinto da natureza, pelo que ele mesmo cria a pluralidade, não a cria nem a confirma a natureza. Pois esta pluralidade pressupõe a consideração, a consideração pressupõe o intelecto. Logo, o intelecto já existe distinto da natureza se se entender que existe antes da consideração. Pois, se no primeiro o intelecto existe já antes da consideração, segue-se que não existe apenas por meio da con-

$\leftarrow \operatorname{sed}(\ldots)$ ipsa natura Dei tunc non est] non est in natura tunc non est $O \mathbf{4 1}$ eam facit natura et (...) ibi distinctus a natura si ante] eam facit natura si ante $P \mathbf{4 2}$ est iam ibi intellectus, (...) ibi intellectus ullo modo] est iam ibi intellectus ullo modo $Q 43$ plurificabuntur] purificabuntur $I M V$; plurificantur $Q$ 
considerationem intellectus et non per naturam, sequitur quod ibi iam est pluralitas ante considerationem. Et sic est contradictio dicere: "Per solam considerationem in Deo est pluralitas". Quia si ante considerationem est ibi intellectus, sequitur ergo ante considerationem est ibi pluralitas.

Alii dicunt ${ }^{44}$ quod sapientia est aliquid in Deo ante omnem considerationem cuiuscumque intellectus ita quod in re sapientia est alia entitas a natura et intellectus alia et uoluntas alia. Sed haec omnia sunt una res omnino. Nam natura diuina omnia illa sibi perfecte unit et coniungit ita quod sine illis esse non potest. Omnia ergo sunt una res, sed non omnia una entitas siue formalitas siue realitas, ut utar eorum uocabulis. Neque unum illorum perficit aliud neque perficitur neque informat neque informatur neque ex illis aliquid componitur aut constituitur, quod sic declarant: "Sapientia in creaturis perficit naturam et inhaeret ei tamquam subiecto ${ }^{45}$, et subiectum ${ }^{46}$ perficitur et informatur et ex illis fit unum aggregatum per accidens, ut "homo sapiens". [f1. 150] Et ultra haec omnia, sapientia denominat hominem uel angelum quando dicitur "angelus est sapiens" uel "homo est sapiens". Dicunt ergo et bene: "Quaecumque atribuuntur Deo, resecatis omnibus imperfectionibus, debent in eo poni”. Et quia inhaerere et informare et perficere notant imperfectionem, similiter perfici et informari et aggregari et componi, eodem modo denominare uero et denominari nullam imperfectionem dicunt, remoueantur ergo a sapientia et ab aliis quae de Deo dicuntur omnia quae imperfectionem significant, remaneant illa quae perfectionem dicunt. Sapientia erit in Deo solum denominans, non componens neque perficiens. Dicunt hi quod sapientia Dei et natura non sunt omnino idem ex parte rei $^{47}$, sed aliquantula inter ea est distinctio et differentia. Sed haec opinio contrariatur simplicitati Dei ac etiam ex ea sequeretur quod nulla entitas sit in Deo perfectissima formaliter, sed solum quod omnes simul iuncte complent unam rem perfectissimam. Et ita natura diuina non erit per se sumpta ${ }^{48}$ pellagus infinitae perfectionis. Neque oportet dicere ut ipsa prout distinguitur ab attributis contineat omnia attributa eminenter, quia tunc non oporteret ea continere formaliter. Qui enim habet aliquid eminenter, non oportet ut illud habeat formaliter. Sed superfluum est illud haberi alio modo ${ }^{49}$. Deinde si sapientia Dei formaliter sumpta sit infinita, ipsa non poterit in alio contineri eminenter, quia tunc nobiliori modo esset in

44 est pluralitas". Quia (si ante considerationem est ibi intellectus add. $M$ in marg.), sequitur ergo ante considerationem est ibi pluralitas. Alii dicunt] est pluralitas. Alii dicunt I; est pluralitas". Quia sequitur ergo ante considerationem est ibi pluralitas. Alii dicunt $J V \mathbf{4 5}$ subiecto] subiecta IJMV 46 subiectum] solummodo $P \mathbf{4 7}$ rei] Dei $Q \mathbf{4 8}$ per se sumpta] perfecte sumpta $I J$; perfecte unita $V \mathbf{4 9}$ alio modo.] alio modo. Quando tamen haberet aliquid uirtualiter tunc non est inconueniens illud $\rightarrow$ 
sideração. Mas se antes da consideração não existe de modo nenhum o intelecto, mas apenas existe a natureza, então será a natureza aquela pela qual estas coisas serão distintas e plurificadas. Se, pois, a pluralidade das razões existe apenas pela consideração do intelecto e não pela natureza, segue-se que a pluralidade existe antes da consideração. E, assim, é contraditório afirmar: só pela consideração existe em Deus pluralidade. Pois que, se o intelecto existe antes da consideração, segue-se, portanto, que a pluralidade existe antes da consideração.

Dizem outros que a sabedoria é uma coisa em Deus antes de toda a consideração de qualquer intelecto, de tal modo que, na realidade, a sabedoria é uma entidade distinta da natureza, e o intelecto, outra, e a vontade, outra. Mas todas estas coisas são absolutamente uma única substância. Pois a natureza divina une-as e associa-as todas a si de um modo perfeito, a ponto de sem elas não poder existir. São todas, pois, uma única substância, mas não são todas uma única entidade, ou forma, ou realidade, para usar das palavras deles. E nenhuma delas aperfeiçoa a outra nem é aperfeiçoada, nem estrutura nem é estruturada, nem a partir delas se compõe ou constitui coisa alguma, pois que assim afirmam: a sabedoria nas criaturas aperfeiçoa a natureza e a ela adere como a um sujeito, e o sujeito é aperfeiçoado e estruturado, e deles se constitui por acidente um agregado, como "homem sábio". [f1. 150] E, além de todas estas coisas, a sabedoria caracteriza o homem ou o anjo, quando se diz: "o anjo é sábio", ou, "o homem é sábio". Dizem, pois, e correctamente: tudo quanto se atribui a Deus, suprimidas todas as imperfeições, deve nele ser considerado. E uma vez que aderir, estruturar e aperfeiçoar indicam imperfeição; igualmente ser aperfeiçoado e ser estruturado e ser agregado e ser constituído; do mesmo modo, designar e ser designado não afirmam imperfeição nenhuma; remova-se, portanto, da sabedoria e daquilo que se afirma de Deus tudo quanto significa imperfeição; permaneçam aquelas coisas que significam perfeição. A sabedoria será em Deus apenas designante, não constituinte nem aperfeiçoante. Dizem estes que a sabedoria e a natureza de Deus não são, de modo nenhum, o mesmo, do ponto de vista da substância, mas há entre elas alguma pequena distinção e alguma diferença. Mas esta opinião opõe-se à simplicidade de Deus e dela seguir-se-ia também que nenhuma entidade é em Deus formalmente perfeitíssima, mas apenas que todas simultaneamente juntas realizam uma substância perfeitíssima. E, deste modo, a natureza divina não será, tomada em si, o pélago da infinita perfeição. Nem é preciso dizer que ela própria, na medida em que se distingue dos atributos, os contém a todos

$\leftarrow$ haberi formaliter sicut graue habet motum deorsum primo uirtualiter deinde formaliter. Aliud enim est habere aliquid eminenter aliud uirtualiter. Qui enim habet aliquid uirtualiter, potest illud producere et potest illud quandoque percipi formaliter. Qui uero habet eminenter, habet illud excelentiori modo quam si haberet illud formaliter. Et melius est sic habere quam formaliter. $M$ ( in marg. a. m.) $N O P Q$ 
alio quam in se ipsa. Et ita etiam non esset infinita in se ipsa, ex quo exceditur et excellentius in alio haberetur ${ }^{50}$.

Tunc ego dixi: Domine mi, ego numquam audiui theologiam neque didici. Tamen omnia quae de sacramento illo maximo et excelentissimo dixisti intellexi, quia intus et extra simul doceor ${ }^{51}$. Nunc etiam quae dicis percipio, sed miror quid finaliter dices. Si enim in Deo non est tantum pluralitas nominum sed significatorum, ergo illa significata aliquo modo distinguuntur et non realiter ita quod sint plures res, quia hoc et falsum est et nemo dixit tantam fatuitatem. Ergo distinguuntur aut ratione, uidelicet secundum considerationem intellectus aut ratione quidditatiua ${ }^{52}$ et formali. Et tu utramque opinionem improbasti ${ }^{53}$ et aliud dici non potest, ut mihi uidetur. Nullus enim alius dicendi modus restat.

Angelus subridens ait: Et ego theologiam diu est ${ }^{54}$ didici et alium modum dicendi bene noui. Intellige nunc, homo Dei, et arrige ${ }^{55}$ aures. Natura Dei, intellectus, uoluntas, sapientia et reliqua omnia quae dicuntur de Deo et quae uestri attributa uocant, sunt omnino unica res, unica realitas, unica formalitas, unica entitas, simplicissima entitas. Nos uidemus Deum et nullam pluralitatem nisi personarum intuemur. Et hoc est uerum. Noli ergo credere plures entitates quasi simul conexas et colligatas esse in Deo, sed omnino ${ }^{56}$ unicam entitatem. Quando ergo dicitis [f1. 151] deitas, sapientia, uoluntas, intellectus Dei, eandem entitatem dicitis omnino, non aliam et aliam. Scito tamen et animaduerte unam entitatem posse aequiualere pluribus.

Et haec dicens, uocauit Thomam Aquinatem et Ioannem Scotum qui ante me simul cum angelo in medio eorum stante steterunt. Repetiit angelus uerba sua

50 haberetur] habetur $N O P Q \mathbf{5 1}$ doceor] doctor $V \quad \mathbf{5 2}$ quidditatiua] quidditatiue $I M V \mathbf{5 3}$ opinionem improbasti] rationem improbasti $N$; opinionem probasti $Q \mathbf{5 4}$ diu est] omnem $P$; diu $\rightarrow$ 
de modo eminente, porque então não seria preciso contê-los formalmente. De facto, quem tem de modo eminente alguma coisa, não é preciso que a tenha formalmente, mas é supérfluo que ela seja tida de outro modo. Todavia, tendo alguma coisa de modo virtual, então não é incompatível que ela fosse tida de modo formal, do mesmo modo que o que é pesado tem um movimento para baixo, de modo virtual primeiro, depois de modo formal. Efectivamente, uma coisa é ter algo de modo eminente, outra, de modo virtual. Quem de facto tem alguma coisa de modo virtual, pode manifestá-la e, por seu intermédio, pode às vezes completar-se de modo formal. Mas quem a tem de modo eminente, tem-na de forma mais excelente do que se a tivesse de modo formal. E é melhor tê-la deste modo do que formalmente. Depois, se a sabedoria de Deus formalmente tomada é infinita, não poderá ela mesma ser contida noutro de modo eminente porque, então, estaria de um modo mais nobre em outro do que em si mesma. $\mathrm{E}$, deste modo, também não seria infinita em si mesma, visto que se excede e se acha de modo mais elevado em outro.

Meu senhor, afirmei então, nunca estudei, nem nunca aprendi teologia. Todavia compreendi tudo o que disseste desse máximo e supremo mistério, porque estou a ser ensinado ao mesmo tempo por dentro e por fora. Capto também o que estás a dizer agora, mas causa-me admiração o que vais dizer por fim. Se, com efeito, em Deus não há apenas pluralidade de nomes mas de significados, então esses significados distinguem-se de qualquer modo e não realmente de modo a serem várias as substâncias, porque isto não só é falso como ninguém terá dito tanta tolice. Portanto, distinguem-se ou pela razão, a saber, segundo a consideração do intelecto, ou pela razão quididativa e formal. Mas tu rejeitaste ambas as opiniões e, segundo me parece, não se pode dizer outra coisa. Não resta, de facto, nenhum outro modo de dizer.

Mas eu, disse o anjo a sorrir, há muito que aprendi teologia e conheço bem outro modo de dizer. Aprende agora, homem de Deus, e presta atenção. A natureza de Deus, a inteligência, a vontade, a sabedoria, e tudo o resto que de Deus se afirma e a que os vossos chamam atributos, são apenas uma única substância, uma única realidade, uma única forma, uma única entidade, entidade simplicíssima. Nós vemos a Deus e não intuímos nenhuma pluralidade senão a das Pessoas. E isto é a verdade. Não acredites, pois, que em Deus haja várias entidades como que simultaneamente conexas e coligadas, mas apenas uma única entidade. Quando, pois, dizeis [f1.151] divindade, sabedoria, vontade, inteligência de Deus, afirmais absolutamente a mesma entidade, não várias. Sabe, todavia, e adverte que uma entidade pode equivaler a várias.

E, ao dizer isto, chamou Tomás de Aquino e João Escoto que, juntamente com o anjo, de pé no meio deles, pararam à minha frente. O anjo repetiu as suas 
dicens: "Scito unicam entitatem posse aequiualere pluribus, quod et uos docuistis", dixit ad illos. Nam uterque uestrum posuit elementa non esse formaliter in mixto, sed quod forma mixti sit aequiualens formis elementorum. Tamen uos nunc scitis, tunc nesciebatis, istam ueritatem. Sunt enim formae elementorum in mixto formaliter, quod sensus et experientia docet. Nam mixta resoluuntur in elementa et mirabilis est mixtio illa, mirabilior illa quam uos in uestris electuariis facitis. Ad propositum sufficit hoc quod res una potest aequiualere rebus multis. Quod autem elementa remaneant aliqualiter secundum naturam propriam, Petrus Aureolus inter alios apertius probat. Videat pastor rationes eius, quia aliquae illarum ostendunt ${ }^{57}$ aperte propositum. Similiter uterque uestrum posuit in homine unicam animam, tamen aequiualentem tribus uel duabus aliis, uidelicet uigetatiue, sensitiue et, secundum locum, motiue.

Ecce $^{58}$ una res aequiualet pluribus, de quo etiam, si uerum sit, discutiet ipse pastor tempore suo, uidelicet an sit unica anima in corpore humano. Non sunt omnia simul aperienda ut et illa tempora gaudere possint reuelationibus propriis.

Intellectus denique qui in nobis est angelis, immo et in anima uestra, unicus est $^{59}$, qui tamen aequiualet omni sensui. Nos enim in intellectu uidemus colores, in intellectu audimus sonos, in intellectu olfacimus odores ${ }^{60}$, in intellectu gustamus sapores, in intellectu tangimus primas qualitates. Ecce unica res aequiualet multis rebus, et tanti ualet nobis intellectus noster quanti uobis omnes sensus simul cum intellectu uestro in ista uita tenebris inuoluto. Nonne etiam aureus unus aequiualet pluribus nummis communibus ${ }^{61}$ ? Et tantum est bonum habere illum unum quantum omnes illos, immo et melius quam habere omnes illos nummos.

Deitas est talis res quae omnibus perfectionibus aequiualet, immo melior est ualde et incomparabiliter illa unica res quam si ponerentur omnia bona et omnes perfectiones simul non sic unitae. Illa deitas aequiualet intellectui, aequiualet uoluntati, aequiualet sapientiae, scientiae, arti et prudentiae, immensitati, aeternitati et omnibus talibus. Tantum ergo potest Deus unica re illa quantum creature possunt illis multis, immo multo amplius. Vnde et uos dicitis: "Quae sunt sparsa in inferioribus sunt unita in superioribus".

57 illarum ostendunt] earum probant $Q \mathbf{5 8}$ Ecce] Esse $Q 59$ Intellectus denique qui in nobis est angelis, immo et in anima uestra unicus est] Intellectus denique qui nobis angelis immo etiam in humano corpore uestro unicus est $Q \mathbf{6 0}$ in intellectu uidemus colores, in intellectu audimus sonos, in intellectu olfacimus odores] in intellectu uidemus odores $I V$; in intellectu uidemus colores, in intellectu audimus sonos, intellectu nostri potestate olfacimus olores $Q \mathbf{6 1}$ communibus] usualibus $Q$ 
palavras, dizendo: Sabe que essa única entidade pode equivaler a muitas, o que também vós ensinastes, disse-lhes. Pois, cada um de vós defendeu que os elementos não estão de modo formal no composto, mas que a forma do composto é equivalente às formas dos elementos. Todavia vós agora conheceis esta verdade, antes ignorávei-la. As formas dos elementos estão, de facto, de modo formal no composto, coisa que os sentidos e a experiência ensinam. Efectivamente, os compostos desdobram-se nos elementos e é maravilhosa essa mistura, mais admirável do que aquela que vós fazeis nos vossos electuários. Para essa finalidade basta o facto de uma substância poder equivaler a muitas substâncias. Que, porém, os elementos se mantêm de outra qualquer maneira, segundo a própria natureza, prova-o muito claramente Pedro Aureolo, ${ }^{[184]}$ entre outros. Que o Pastor preste atenção às razões dele, porque algumas delas mostram claramente o objectivo. De modo semelhante, cada um de vós defendeu uma única alma no homem, equivalente, contudo, a três ou a duas outras, a saber, vegetativa, sensitiva e, segundo o lugar, movente.

Vê, uma coisa equivale a várias. Também sobre isso, se é verdadeiro, discutirá o próprio Pastor em seu tempo, a saber, se no corpo humano há uma alma única. Nem tudo deve ser desvendado ao mesmo tempo, para que também aqueles tempos possam alegrar-se com revelações próprias.

Por fim, a inteligência que há em nós anjos, e mesmo também na vossa alma, é única e, no entanto, equivale a todos os sentidos. Na verdade, no nosso intelecto, vemos nós as cores, no nosso intelecto ouvimos os sons, no intelecto sentimos os odores, no intelecto experimentamos os sabores, no intelecto atingimos as primeiras qualidades. Vê, uma única coisa equivale a muitas coisas e vale tanto em nós a nossa inteligência quanto em vós todos os sentidos em conjunto com a vossa inteligência envolvida em trevas nesta vida. Não equivale também um soldo de ouro a várias moedas comuns? E vale tanto ter só esse como todas as outras, e mais ainda e melhor que ter todas as outras moedas.

A divindade é essa substância que equivale a todas as perfeições, e mais ainda, essa única realidade é até muito melhor e incomparavelmente melhor do que se todos os bens e todas as perfeições se pusessem em conjunto, mas não desta maneira. Esta divindade equivale à inteligência, equivale à vontade, equivale à sabedoria, ao conhecimento, à arte e à prudência, à imensidade, à eternidade e a todas as coisas idênticas. Logo, pode tanto Deus com essa única substância quanto podem as criaturas com a multiplicidade de todas as outras, e pode até muito mais. É por isso que vós dizeis: o que nos seres inferiores está disperso, está unido nos superiores.

${ }^{[184]}$ Petrus Aureoli ou Aureolus, doctor facundus, $\uparrow 1322$, franciscano, era mestre de teologia em Paris e arcebispo de Aix-en-Provence. Opôs-se a S. Tomás e a Escoto, defendendo uma doutrina considerada precursora da de Occam. 
Accipe talem regulam quae numquam excidat a corde tuo: Quando aliquid omnino unum in se perfecte aequiualet pluribus, tantum illud unum potest quantum et illa plura possent, immo plus et melius.

Haec regula non potest negari, quia si non potest tantum quantum illa plura, ergo non perfecte aequiualet illis pluribus. Addidi, immo et plus ${ }^{62}$ et melius [f1. 152], quia uirtus unita perfectior est seipsa ${ }^{63}$ dispersa.

Hoc de Deo dicite quod nunc doceo, hoc scribe ${ }^{64}$, hoc praedicate. Vterque uestrum, dixit Thomae et Scoto, hoc dicere uoluit, sed exprimere tunc non potuit. Tu enim, Thoma ${ }^{65}$, dixisti unicam rem omnino et simplicissimam Deum esse et si aliqua distinctio sit inter illa, illa erit per considerationem, non in re, quia in re illa nulla pluritas ${ }^{66}$ entitatum est. Sed dicere debuisti: Illa tamen res in se, ante omnem considerationem cuiusque intellectus, est aequiualens omnibus illis quae de illa uere dicuntur. Tu quoque, Ioannes, idem dixisti, uidelicet illam rem omnino unam esse et illa plura non esse eadem ex natura rei neque eadem formaliter. Sed non declarasti quid esset intelligendum per illam distinctionem. Sunt plura ex natura rei uel sunt in Deo plura formaliter? Non enim est intelligendum quod ibi in re illa sint plures entitates in se distinctae et ad inuicem quasi conexae uel colligatae, sed quod illa unica res omnino est aequiualenter illa plura ${ }^{67}$. Nam duplex est aequiualentia, una uoluntaria, alia naturalis. Exemplum prioris: aureus ualet $^{68}$ tot nummos communes. Hoc sancitum ${ }^{69}$ est uoluntate legislatoris. Exemplum posterioris: intellectus angelicus aequiualet omnibus potentiis cognitiuis quae sunt in homine naturaliter, non uoluntate aut statuto uel decreto cuiusquam. Igitur dicere uoluisti illa esse plura ex natura rei, hoc est, illam unam rem aequiualere pluribus, non uoluntate alicuius aut statuto, sed ex natura rei, hoc est, naturaliter, ita quod, semota consideratione cuiuscumque intellectus, sic est in re, quod illa res ualet tot et tantis rebus. Et intellectus, considerando, potest illam rem unicam distinguere in multa ex quo ipsa ualet quantum illa multa. Ideo, illa re ostensa, uerum est dicere: haec res est sapientia et bonitas et immensitas et paternitas. Similiter dici potest: haec sapientia est haec bonitas et haec paternitas, immo et ${ }^{70}$ haec res paternitas est res quae est filiatio. Et hac re est Prima Persona et Secunda et Tertia. Similiter illi qui dixerunt illa omnia nomina esse synonyma ${ }^{71}$ possent bene intelligi quia omnia illa eandem significant ${ }^{72}$, sed nunc huic nunc illi aequiualentem. Sed quomodo Pater non sit Filius statim declarabimus.

62 Addidi "immo et plus] Adde et plus $Q 63$ seipsa] sapientia $M 64$ scribe] scribite $N O P$; hoc tu conscribe $Q 65$ Thoma] dixit Thomae $Q$; Thoma $I V 66$ pluritas] pluralitas INOPQ 67 illa plura.] illa plura. Non enim est intelligendum quod ibi in re illa sint plures entitates. $V \mathbf{6 8}$ ualet] habet $Q 69$ sancitum] factum $V \mathbf{7 0}$ et paternitas. (...) et haec paternitas, immo et] et paternitas immo et $V \mathbf{7 1}$ synonyma] seminomina $V \mathbf{7 2}$ eandem significant] eandem significant essentiam $J$ ( $M$ in marg. a. m.) NO 
Ouve esta regra, que nunca saia do teu coração: Quando alguma coisa absolutamente única em si equivale perfeitamente a várias, pode tanto essa única quanto poderiam todas as outras, e até mais e melhor.

Esta regra não pode ser negada porque, se não puder tanto quanto aquelas todas, logicamente não equivale perfeitamente a todas elas e, acrescento, até mais e melhor, [f1. 152] porque a força unida é mais eficaz do que ela mesma dispersa.

Afirmai de Deus isto que estou agora a ensinar, escrevei-o, pregai-o. Quisestes um e outro, disse a Tomás e a Escoto, afirmar isto, mas nesse tempo não o conseguistes exprimir. Tu, na verdade, Tomás, disseste que Deus é uma substância absolutamente única e simplicíssima e, se alguma distinção existe entre essas substâncias, essa existirá na razão, não in re, porque nessa substância não há pluralidade de entidades. Mas deverias ter dito: todavia, em si, essa substância, antes da reflexão de qualquer intelecto, é equivalente a todas aquelas que dela verdadeiramente se afirmam. Também tu, João, disseste o mesmo, a saber, que essa substância é absolutamente una e que as várias outras não são o mesmo pela natureza da coisa, nem são o mesmo formalmente. Mas não deste a conhecer o que se deve entender por essa distinção. São várias pela natureza da coisa ou são várias formalmente em Deus? Não deve, na verdade, entender-se que aí, nessa substância, haja várias entidades distintas em si e reciprocamente como que conexas ou coligadas, mas que essa única substância é absolutamente todas as outras de forma equivalente. Efectivamente há duas equivalências, voluntária uma, a outra natural. Exemplo da primeira: uma moeda de ouro vale tantas moedas comuns. Isto é prescrito pela vontade do legislador. Exemplo da segunda: a inteligência dos anjos equivale a todas as potências cognitivas que há no homem, naturalmente, não por vontade, decisão ou decreto de quem quer que seja. Quiseste, portanto, dizer que eram várias pela natureza da coisa, isto é, que essa única substância equivale a várias, não por vontade ou decisão de alguém, mas pela natureza da coisa, isto é, naturalmente, de tal modo que, removida a consideração de qualquer intelecto, assim é na realidade, que essa substância vale tantas e tão importantes substâncias. E o intelecto, reflectindo, pode separar essa única substância em muitas, uma vez que ela vale quanto valem todas essas. Por isso, apresentada essa substância, é verdadeiro dizer-se: esta substância é sabedoria, e bondade, e imensidade, e paternidade. Pode igualmente dizer-se: esta sabedoria é esta bondade e esta paternidade, e mais, esta substância paternidade é a substância que é filiação, e nesta substância está a Primeira Pessoa e a Segunda e a Terceira. Do mesmo modo, aqueles que disseram que todos esses nomes são sinónimos poderiam ser perfeitamente compreendidos, porque todos esses nomes significam a mesma essência, mas equivalente ora a este ora àquele. Mas iremos de imediato mostrar de que modo o Pai não é o Filho. 
Vsque huc ostendimus quomodo Deus noster est unica res et omnino simplex. Nunc uideamus quomodo cum tanta unitate possit stare et intelligi realis distinctio personarum. Si enim omnia quae sunt in Patre sunt omnino una res, immo illa unica res quae deitas dicitur et nulla alia, similiter si omnia quae sunt in Filio et quae sunt in Spiritu Sancto sunt omnino illa deitas et nihil aliud sunt nisi illa deitas, quomodo illi tres distinguntur realiter? Nam eodem omnino conuenire et eodem omnino diferre est impossibile. Vt igitur ista perfecte intelligas, animaduerte ad ea quae tibi clare quantum fieri potest propono.

Ponamus, dilectissime, quod deitas siue natura diuina sit una res uel una realitas distincta ab omni alia realitate quae de ipsa dicitur. Ponamus [f1. 153] deinde quod alia res uel alia realitas illi adiungatur ${ }^{73}$ tamquam differentia quaedam contrahens ipsam. Illa diceretur constituta ex illis duabus rebus uel realitatibus sicut homo est constitutus ex anima et corpore uel ex animalitate et rationalitate. Tunc nulla difficultas esset intelligere quod persona una ab alia realiter distinguatur, quia prima persona esset constituta ex deitate et illa alia re contrahente, et secunda persona esset constituta similiter ${ }^{74}$ ex deitate et illa alia realitate iterum contrahente. Similiter tertia persona esset constituta ex deitate et tertia realitate contrahente sicut hic homo conuenit cum alio homine quia uterque homo est et unus differt ab alio aliqua differentia. Si ita esset inter personas diuinas, tunc nullas angustias mens uestra pateretur. Sed neque nunc patiemini ${ }^{75}$ angustias si ad uerba mea tu nunc animaduerteris et ea fideliter conscripseris. Accipe regulam tibi iam datam: "Quandocumque ${ }^{76}$ aliquid perfecte aequiualet pluribus, quicquid illis pluribus facere posset ${ }^{77}$ etiam seipso facere potest $^{78}$ ". Si ergo deitas perfecte aequiualeret ${ }^{79}$ ex natura rei differentiae ipsam a quocumque alio distinguenti, et ex alia parte conueniret cum aliis prout aequiualet enti, sic eadem re omnino conueniret et differret prout illa aequiualeret duabus realitatibus. Vnde illa regula falsa est. Impossibile ${ }^{80}$ est aliqua conuenire et differre eodem. Falsa, dico, est quando illud unum aequiualet perfecte duobus. Sed utrum Deus et creatura conueniant in ente uel in re tamquam quodam utrique communi ex parte rei et non solum ratione uidebitur tempore illo.

Nunc illud praetermitto et deuenio ad ostendendum quomodo tres personae diuinae realiter distinguntur et tamen in omnibus tribus personis non est alia realitas quam deitas ita quod in Patre est tantum una res omnino simplex, in

73 adiungatur] adueniat $Q \mathbf{7 4}$ esset constituta ex (...) esset constituta similiter] esset constituta similiter $V 75$ Sed neque nunc patiemini] Sed nunc etiam nullas pateremini $Q 76$ Quandocumque] Quando $I 77$ facere posset] facere potest $N$; fieri posset $O$; fieri potest $Q \mathbf{7 8}$ facere potest] fieri $\rightarrow$ 
Mostrámos até agora de que modo o nosso Deus é uma substância única e absolutamente simples. Vejamos agora como a real distinção de Pessoas pode coexistir com tão grande unidade e ser compreendida. Se realmente todas as substâncias que estão no Pai são uma substância apenas, sim, aquela única substância que se designa divindade, e nenhuma outra; se igualmente todas as substâncias que estão no Filho e que estão no Espírito Santo são apenas essa divindade e nada mais são que essa divindade, como se distinguem realmente os três? Efectivamente, é impossível convergir absolutamente e absolutamente divergir em relação ao mesmo. Portanto, para poderes entender perfeitamente estas coisas, atenta naquilo que com tanta clareza quanta é possível te vou expor.

Admitamos, dilectíssimo, que a divindade ou natureza divina seja uma substância ou uma realidade distinta de toda outra realidade que dela se afirma. Admitamos, [fl. 153] depois, que se lhe acrescente outra substância ou outra realidade como uma espécie de diferença que a restringe. Considerar-se-ia esta constituída por aquelas duas substâncias ou realidades do mesmo modo que o homem é constituído de alma e de corpo ou de animalidade e racionalidade. Nenhuma dificuldade haveria então em entender que uma Pessoa se distinga realmente da outra, porque a Primeira Pessoa seria constituída de divindade e dessa outra substância restritiva; e a Segunda Pessoa seria constituída, de modo semelhante, de divindade e dessa outra realidade por sua vez restritiva; igualmente a Terceira Pessoa seria constituída de divindade e da terceira realidade restritiva, como este homem convergiria com outro homem porque um e outro são homens e um difere do outro por uma pequena diferença. Se assim acontecesse entre as Pessoas divinas, a vossa inteligência não se acharia em dificuldades. Mas nem agora vós tereis dificuldades se tu deres atenção às minhas palavras e as escreveres fielmente. Ouve a regra que já te foi dada: "Sempre que uma coisa equivale perfeitamente a várias, o que quer que possa fazer com essas, pode fazê-lo também por si própria.” Se, pois, a divindade equivalesse perfeitamente, pela natureza da coisa, à diferença que a distingue de uma outra coisa e, por outro lado, convergisse com outras coisas enquanto equivale ao ente, convergiria, assim, e divergiria absolutamente da mesma coisa, na medida em que ela equivaleria a duas realidades. Daí ser falsa esta regra. É impossível que uma coisa convirja e divirja em relação ao mesmo. É falsa, digo, quando esse um equivale perfeitamente a dois. Mas se Deus e a criatura convergem no ente ou na substância como em algo comum a ambos por parte da coisa e não só pela razão, ver-se-á naquele tempo.

Agora, passo isso à frente e encaminho-me a mostrar como as três Pessoas divinas se distinguem realmente e, contudo, não há nas três Pessoas outra coisa que não seja a divindade, de tal modo que no Pai há somente uma substância

$\leftarrow$ potest $O Q 79$ aequiualeret] aequiualet $I J P Q V$; aequiualeat $N O \mathbf{8 0}$ falsa est. Impossibile] falsa est uidelicet impossibile $Q$ 
Filio est una res, uidelicet eadem deitas omnino simplex et in Spiritu ${ }^{81}$ Sancto est eadem res omnino simplex et non alia ${ }^{82}$ quam eadem deitas. Neque tamen Pater est Filius neque Filius Pater et neuter ipsorum est Spiritus Sanctus. Similiter neque $^{83}$ Spiritus Sanctus est Pater aut Filius. Haec sunt admiranda, haec uobis aperienda. Sed hoc ideo est quia illa unica res aequiualet tribus realitatibus quibus subsistit. Nam prima persona includit ${ }^{83 \mathrm{~A}}$ in se illam solam rem quae deitas est quae tamen aequiualet entitati incommunicabili. Et in quantum illi aequiualet quasi adiungeretur naturae diuinae, facit eam subsistere incommunicabilem et ita personam. Si enim perfecte deitas sit natura et perfecte aequiualet entitati incommunicabili, persona illa subsistet illa re et incommunicabilis erit. Et sic habemus primam personam constitutam ex una $\mathrm{re}^{84}$ duabus rebus aequiualente ${ }^{85}$. Cogita ulterius quod haec res quae deitas dicitur et qua prima subsistit prout aequiualet entitati incommunicabili habet aequiualenter principium productiuum per modum naturae. Et ita producit aliquid per modum naturae. Et quia ${ }^{86}$ illud $^{87}$ principium productiuum ${ }^{88}$ immensam uirtutem habet, producit aliquod immensum. Non [f1. 154] accidens, quia tale nil est in Deo. Neque etiam immensum accidens esse potest. Producit ergo substantiam infinitam. Et nulla substantia praeter Deum est infinita. Producit ergo Deum. Et quia non est nisi Deus unus, persona producta erit idem Deus. Et quia deitas aequiualet illi entitati, quia sic productum ${ }^{89}$ subsistit, ideo illa persona producta deitate, prout illi entitati aequiualet, subsistit. Sicut enim si alia entitate subsisteret prima persona improducta, alia secunda producta $^{90}$, manifeste ibi essent duae subsistentiae ${ }^{91}$ et duae personae distinctae et sic etiam erunt $^{92}$ eadem re duabus rebus perfecte aequiualente duae subsistentiae ${ }^{93}$ et duae personae distinctae. Et quia haec res in his duabus personis existens perfecte aequiualet principio productiuo per modum doni et libere, iccirco hae duae personae producunt libere ipsa deitate prout tali principio aequiualet aliquid. Et quia producunt principio infinito, oportet ut productum sit infinitum. Et quia nil est infinitum in entitate nisi Deus, producunt Deum. Et quia Deus non est nisi unus, producunt eundem Deum. Et producens et productum realiter distinguntur. Ideo alia subsistentia ${ }^{94}$ et alia persona erit producta $a b$ illis duabus producentibus. Et quia Deus simplex est, non erit alia res quam deitate distincta prout tamen illa perfecte aequiualet aliae ${ }^{95}$ rei. Sicut ergo si essent tres res distinguentes tres personas manifestum esset personas esse tria subsistentia ${ }^{96}$ distincta ${ }^{97}$ ita quia una res perfecte aequiualet tribus, fit ipsa unica quod fieret tribus. Aliter si non posset fieri illa unica re illud quod fieret illis tribus ${ }^{98}$, illa unica non perfecte ${ }^{99}$

81 res omnino simplex, (...) deitas omnino simplex et in Spiritu] res omnino simplex et in Spiritu I 82 omnino simplex (...) omnino simplex et non alia] omnino simplex et non alia $Q \mathbf{8 3}$ Filius Pater et neuter ipsorum est Spiritus Sanctus. Similiter neque] Filius Pater. Similiter neque $Q$ 83A includit] inducitur $I$; inducit $V \mathbf{8 4}$ una re] natura rei $Q \mathbf{8 5}$ aequiualentem] aequiualente INOP; aequiualenter Q $\mathbf{8 6}$ per modum naturae. Et ita producit aliquid per modum naturae. Et quia] per modum naturae. Et quia $G \mathbf{8 7} \mathrm{Et}$ ita producit aliquid per modum naturae. Et quia illud] Et illud $Q \mathbf{8 8}$ productiuum] productum $V \mathbf{8 9}$ productum] productam $M 90$ Sicut enim si alia $\rightarrow$ 
absolutamente simples, no Filho há uma substância, a saber, a mesma divindade, absolutamente simples, e no Espírito Santo há a mesma substância absolutamente simples e não outra que não seja a divindade. Como quer que seja, nem o Pai é o Filho, nem o Filho é o Pai e nenhum deles é o Espírito Santo; de igual modo, nem o Espírito Santo é o Pai ou o Filho. São estas as coisas que devem ser admiradas, estas as coisas que devem ser-vos desvendadas. Mas isto é porque essa única substância equivale às três realidades pelas quais subsiste. Com efeito, a Primeira Pessoa inclui em si aquela substância única que é a divindade, que, contudo, equivale à entidade incomunicável. $\mathrm{E}$, na medida em que lhe equivale, como se acrescesse à natureza divina, fá-la subsistir incomunicável e, deste modo, Pessoa. Se, de facto, a divindade é totalmente natureza e totalmente equivale à entidade incomunicável, essa Pessoa subsistirá por essa substância e será incomunicável. E, deste modo, temos a Primeira Pessoa constituída de uma coisa equivalente a duas coisas. Pondera, de seguida, que esta substância que se designa divindade e pela qual a Primeira subsiste, enquanto equivale à entidade incomunicável, tem equivalentemente um princípio produtivo per modum naturae. $\mathrm{E}$, assim, produz alguma coisa per modum naturae. E uma vez que esse princípio produtivo tem uma força imensa, produz alguma coisa imensa.[fl. 154] Não um acidente, porque em Deus não há nada disso, nem um acidente pode também ser imenso. Portanto, produz uma substância infinita. E nenhuma substância além de Deus é infinita. Por consequência, produz Deus. E dado que não existe senão um Deus único, a Pessoa produzida será o próprio Deus. E uma vez que a divindade equivale a essa entidade, porque o que assim é produzido subsiste, por isso aquela Pessoa produzida pela divindade, na medida em que equivale a essa entidade, subsiste. Pois, assim como se por uma entidade subsistisse a Primeira Pessoa, que não é produzida, e por outra a Segunda, que é produzida, claramente haveria aí duas subsistências e duas Pessoas distintas, assim também serão duas subsistências e duas Pessoas distintas em razão de uma substância que equivale perfeitamente a duas substâncias. E uma vez que esta substância existente nestas duas Pessoas equivale perfeitamente ao princípio produtivo per modum doni e livremente, por essa razão estas duas Pessoas produzem livremente pela divindade, na medida em que a este princípio equivale alguma coisa. E dado que produzem segundo um princípio infinito, é inevitável que o produto seja infinito. E porque nada é infinito em entidade senão Deus, produzem Deus. E visto que somente Deus é uno, produzem o mesmo Deus. E o que produz e o que é produzido distinguem-

$\leftarrow$ entitate subsisteret prima persona improducta, alia secunda producta,] Sicut enim si aequalia entitate subsisteret prima persona producta, alia secunda etiam producta, $G 91$ subsistentiae] substantiae $P Q V 92$ erunt] erant $I J V 93$ subsistentiae] substantiae $Q V 94$ subsistentia] substantia $Q V 95$ aliae] alii $G N$; ali $Q 96$ subsistentia] substantia $V 97$ manifestum esset personas esse tria subsistentia distincta] manifestum esset tres esse personas, trina subsistentia distincta $Q 98$ illud quod fieret illis tribus] quod potest fieri tribus $Q 99$ illa unica re illud quod fieret illis tribus, illa unica non perfecte] illa unica non perfecte $V$ 
aequiualeret illis tribus. Recte ergo dicunt ${ }^{100}$ ita unamquamque personam esse simplicem sicut et deitas est simplex. Vnaquaeque enim persona illam solam rem habet quae est deitas. Sed illa una ${ }^{101}$ persona aequiualet alicui rei cui non aequiualet prout alia persona est ${ }^{102}$.

Et haec dicendo, uocauit Augustinum et dixit ad Thomam et Scotum: Ecce doctor a quo praecipue ista accepistis. Et ibi resident multi alii (et ostendebat Ambrosium, Hieronymum, Gregorium, Anselmum, Boetium, Richardum, Hilarium) ex una parte doctores Latinos. Et ibi sunt alii in alia parte (et ostendebat Basilium, Gregorium Nazianzenum, Chrysostomum et alios doctores Graecos, Didymum, Athanasium et alios). Sed, ut dixi, ab isto Augustino plura habetis. Ipse uero dixit: "Non eo est Deus, immo neque eo est quo Pater est ille est" (et ostendebat Deum Patrem); "neque ille" (ostendebat Filium) "eodem est Deus et Filius; neque ille" (ostendebat Spiritum Sanctum) "eodem est Deus et Spiritus Sanctus. Sed alio Deus, alio persona".

Hoc dictum tuum repugnat eis quae ego nunc doceo. Docui enim deitate, re unica, omnia esse et distingui ${ }^{104}$.

Respondit Augustinus: Fateor, angele sancte, me tunc non ita clare ista accepisse. Numquam tamen intellexi ut in persona sint duae res, sed tamen quod aliqua duo sint dixi, quia aliter non poteram capere personarum distinctionem inter quas nulla differentia esset. Nunc tamen scio, quia uideo ita esse, quod in una [f1. 155] persona non est alia res nisi eadem omnino quae in alia, sed tamen est alia et alia ${ }^{105}$ per aequiualentiam. Ideo potest dici ut alio sit et alio sit persona distincta, quia eodem alteri aequiualente ${ }^{106}$.

Ex his, inquit angelus, manifesta erit omnibus simplicitas diuinae naturae, quia omnia attributa erunt una res omnino. Manifesta etiam erit simplicitas personarum, quia in qualibet erit una et eadem res. Manifesta etiam erit personarum distinctio ${ }^{107}$, quia illa unica res, prout aequiualet uni rei ${ }^{108}$, constituit unam personam et, prout aequiualet alii rei, constituit aliam personam. Vbi uide quod aliquid potest constitui ex uno uicem duorum habente siue duobus aequiualente. Et uide quod aliquid

100 dicunt] dicuntur $I M P$; diceretur $Q \mathbf{1 0 1}$ sed illa una] sed una $M$; sed illa in una $O P Q$; si illa unica $V 102$ alia persona est] in alia persona est $N O$; in illa persona est $Q 104$ re unica, omnia esse et distingui] re unica, omnia ex se distingui $P$; re unica, idest, omnia esse et distingui $V \rightarrow$ 
-se realmente. Por isso, serão produzidas por esses dois produtores outra subsistência e outra Pessoa. E visto Deus ser simples, não será distinta por outra coisa que não seja a divindade, conforme, todavia, ela perfeitamente equivale a outra substância. Do mesmo modo, pois, que se fossem três substâncias a distinguir três Pessoas seria claro que as Pessoas seriam três em razão da distinta subsistência, assim, dado que uma substância equivale perfeitamente a três, acontece com essa única o que aconteceria com as três. De outro modo, se não pudesse fazer-se com essa única substância o que se faria com aquelas três, essa única não equivaleria perfeitamente àquelas três. Consequentemente, dizem assim, e bem, que cada Pessoa é simples como também a divindade é simples. Na verdade, cada Pessoa tem essa única substância que é a divindade. Mas essa equivale numa Pessoa a alguma coisa a que não equivale enquanto é outra Pessoa.

E ao dizer isto, chamou Agostinho e disse a Tomás e a Escoto: Eis o doutor de quem sobretudo recebestes estas coisas. E aí estão muitos outros doutores latinos, de um lado (e mostrava Ambrósio, Jerónimo, Gregório, Anselmo, Boécio, Ricardo, Hilário). E outros aí estão, do outro lado (e mostrava Basílio, Gregório Nazianzeno, Crisóstomo e outros doutores gregos, Dídimo, Atanásio e outros). Mas, como disse, é deste Agostinho que mais coisas tendes. Este, porém, disse: "Não é Deus, e nem sequer é por aquilo por que é Pai"(e mostrava Deus Pai). Nem aquele (mostrava o Filho) é Deus e Filho pela mesma coisa. Nem ele (mostrava o Espírito Santo) é Deus e Espírito Santo pela mesma coisa, mas por uma é Deus, por outra é Pessoa.

Esta tua afirmação colide com o que estou agora a ensinar. Ensinei, de facto, que tudo existe e se distingue na divindade por uma única substância.

Confesso, anjo santo, que eu então não captei tão claramente estas coisas, respondeu Agostinho. Nunca, porém, entendi que na Pessoa houvesse duas substâncias, mas afirmei que algumas coisas são duas porque, de outro modo, não podia compreender a distinção de Pessoas entre as quais nenhuma diferença houvesse. Agora, contudo, sei, porque vejo que assim é, que numa [f1. 155] Pessoa não há senão a mesma substância que há na outra, mas cada uma é o que é por equivalência. Por isso se pode dizer que por uma coisa existe e por outra é Pessoa distinta, porque pelo mesmo equivalente ao outro.

A partir disto, diz o anjo, será para todos clara a simplicidade da natureza divina, porque todos os atributos serão uma substância apenas. Manifesta será também a simplicidade das Pessoas, porque em cada uma será uma e a mesma a substância. Será clara também a distinção das Pessoas, porque essa única substância, enquanto equivale a uma coisa, constitui uma Pessoa e, enquanto equivale a outra coisa, constitui outra Pessoa. Vê, portanto, que uma coisa pode

$\leftarrow \mathbf{1 0 5}$ alia et alia] aliter alia $I V \mathbf{1 0 6}$ aequiualente] aequiualentem $I J V$; aequiualenti $Q 107$ Manifesta etiam erit personarum distinctio] Manifesta etiam erit una et eadem distinctio $P$ 108 uni rei] uniri $V$ 
constitutum est ita simplex sicut et constituens. Et potest dici: "Hoc constitutum est omnino simplex, quia in plures entitates inresolubile, sed non ita simplex ut pluribus non aequiualeat". Si ergo resolutio in plura aequiualenter intelligatur, quanto aliquid est perfectius tanto est resolubilius in plura et quanto aliquid est imperfectius ${ }^{109}$ tanto est paucioribus aequiualens et simplicius. Et hoc modo Deus est summe resolubilis in plura et materia prima simplicissima et forma elementi uel ens rationis. Si autem resolutio intelligatur in plura distincta inter se tamquam plura entia, tunc Deus est omnino irresolubilis et incompositus, sine ulla $^{110}$ constitutione. Similiter et quaelibet persona diuina ${ }^{111}$. Vbi etiam uide et diligenter conscribe quod ens perfectissimum est maxime resolubile et maxime constitutum per aequipolentiam et minime, immo nullo modo per pluralitatem entium. Ens uero imperfectissimum ${ }^{112}$, siue illud sit materia prima siue forma elementi siue accidens aliquod, est irresolubile ${ }^{113}$ in plura utroque modo. Non enim resoluitur ${ }^{114}$ in plura aequiualenter, quia nulli aequiualet, neque in plura entia distincta inter se. Omnia uero alia entia quae sunt inter summum et infinitum ens sunt altero illorum modorum constituta. Nam aut pluribus aequiualent aut plura distincta in se includunt. Melius est plura includere aequiualenter, ceteris paribus, uidelicet loquendo de eisdem inclusis, quam plura inter se distincta. Et melius est esse constitutum ex pluribus distinctis quam nullo modo constitutum esse neque aequiualenter neque ex pluribus.

Haec tibi subtilia sunt. Ea tamen conscribe ut tempora illa felicia oblectentur in bonis animi, quia remittetur delectatio carnis et erunt iterum homines docibiles Dei.

Audi nunc, homo Dei, aliqui ex doctoribus uestris dixerunt personas diuinas constitui relationibus, aliqui aliquibus rebus absolutis. Et tu dicito et conscribe personas constitui sola deitate, quae res absoluta est. Nulla ibi relatio est quae non sit ipsa deitas, nullum est ibi attributum quod non sit ipse Deus. Quicquid est in Deo, Deus est, quia una ${ }^{115}$ res omnino multis aequiualens. Tamen prout aequiualet uni non aequiualet alteri sicut et anima uestra intellectiua prout ${ }^{116}$ aequiualet sensitiue non aequiualet uegetatiue. Hoc nunc tibi dico quod si diuinae personae constituerentur ipsa essentia in qua conueniunt et aliqua alia re in qua distinguntur, illa alia res non posset esse relatio, ut patebit tempore pastoris cuius temporibus hoc declarabitur, quia personae illae quae summe existunt, quarum existentiae nulla existentia est similis $^{117}$, non habent esse per relationes, quae

109 imperfectius] perfectius $I V \quad \mathbf{1 1 0}$ sine ulla] sine ulla compositione et $Q \quad \mathbf{1 1 1}$ similiter et quaelibet persona diuina] similiter aequiualet persona diuina $Q \mathbf{1 1 2}$ imperfectissimum] perfectissimum IV 113 irresolubile] resolubile $I \mathbf{1 1 4}$ resoluitur] resoluuntur $Q 115$ una] nulla $J \rightarrow$ 
ser constituída por um que faz as vezes de dois ou que equivale a dois. E vê que um constituído é tão simples como o constituinte. Pode também dizer-se: este constituído é absolutamente simples porque irresolúvel em várias entidades, mas não tão simples que não equivalha a várias coisas. Se, pois, a resolução em várias coisas for entendida de modo equivalente, quanto mais perfeita uma coisa é, tanto mais resolúvel é em várias coisas; e quanto mais imperfeita é uma coisa, tanto mais equivalente é a poucas coisas e mais simples. E, deste modo, Deus é sumamente resolúvel em várias coisas, e matéria-prima simplicíssima, e forma do elemento ou ente da razão. Se, porém, a resolução for entendida em várias coisas distintas entre si, como vários entes, então Deus é absolutamente irresolúvel e incompósito, sem nenhuma constituição; igualmente também cada Pessoa divina. Vê, pois, também, e escreve cuidadosamente, que o Ente mais Perfeito é maximamente resolúvel e maximamente constituído por equivalência e minimamente, melhor, de modo nenhum pela pluralidade de entes. Mas o ente mais imperfeito, quer ele seja matéria-prima, quer forma de elemento ou algum acidente, é irresolúvel em várias coisas de um e de outro modo. Não se resolve de facto em coisas várias de modo equivalente porque não equivale a nenhuma, nem em vários entes distintos entre si. Mas todos os outros entes que estão entre o Sumo e Infinito Ente são constituídos de acordo com o segundo daqueles modos, pois ou equivalem a vários ou incluem em si vários distintos. É preferível incluir vários de modo equivalente, incluídos os outros iguais, falando, é claro, dos mesmos, do que vários distintos entre si. E é preferível ser constituído de muitos distintos do que não ser de modo nenhum constituído, nem de modo equivalente nem de vários.

Estas coisas são para ti subtis. Escreve-as, contudo, a fim de que esses felizes tempos se deleitem nos bens do espírito, porque o prazer da carne será abandonado e os homens serão de novo instruídos por Deus.

Ouve agora, homem de Deus, disseram alguns dos vossos doutores que as Pessoas divinas são constituídas pelas relações; outros, por algumas coisas absolutas. E tu diz e escreve que as Pessoas divinas são constituídas só pela divindade, que é uma substância absoluta. Não ocorre aí relação nenhuma que não seja a própria divindade, não há aí atributo nenhum que não seja o próprio Deus. O que quer que haja em Deus é Deus, porque é uma substância que equivale absolutamente a muitas. Todavia, na medida em que equivale a uma não equivale a outra, como também a vossa alma intelectiva, na medida em que equivale à sensitiva não equivale à vegetativa. Digo-te agora isto, que, se as Pessoas divinas fossem constituídas pela própria essência em que convergem e por outra coisa qualquer em que se distinguem, essa outra coisa não poderia ser a

$\leftarrow \mathbf{1 1 6}$ prout] quae $P \mathbf{1 1 7}$ quarum existentiae nulla existentia est similis] et quarum existentia est similis $P$ 
uel nil sunt aliud a fundamentis, ut aliqui ex uestris dixerunt, uel si sint ali [f1. 156] quid a fundamentis minime entitatis sunt et forsan omnis relatio est tantum in mente et nulla in re. Videatur tempore illo felici etiam hoc cum aliis multis. Nolo nunc omnia propalare et omnia declarare.

Mirum est quare maior pars hominum qui docent et scribunt, omnes dixerunt personas diuinas subsistere relationibus, quod non est aliud dicere nisi quod accidentia sunt illa quibus personae diuinae subsistunt. Accipe hanc regulam: "Impossibile est perfectam et maximam substantiam accidente esse substantiam". Immo dico tibi quod essentia diuina, prout aequiualet relationi, non constituit personam, sed prout aequiualet rei absolute. Vnde essentia diuina primum debet intelligi ipsa natura Dei in se. Deinde illa aequiualet enti ${ }^{118}$ quo Deus a quolibet

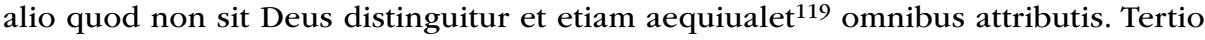
loco illa aequiualet enti a quo prima persona constituitur. Quarto, aequiualet principio productiuo per modum naturae siue memoriae perfectae ${ }^{120}$. Quinto, aequiualet ipsi productioni seu genito. Sexto, aequiualet ipsi productioni siue generationi actiuae qua prima persona dicitur generare, et passiuae qua secunda persona dicitur generari. Septimo, aequiualet duabus relationibus: paternitati, quae fundatur in prima persona ex eo quia genuit, et filiationi, quae fundatur in secunda persona ex eo quia genita est. Octauo, aequiualet principio productiuo per modum doni cui et si secundo loco aequiualebat, quia illud principium est uoluntas habens obiectum sibi praesens quo Deus amat se, tamen in octauo signo ipse tali principio producit. Ideo in hoc signo aequiualet sibi ut iam productiuo, quia hoc principium non producit nisi memoria intelligatur produxisse. Sicut enim uoluntas non fertur nisi in praecognitum neque fugit aut contemnit nisi cognitum ita neque producit nisi produxisse intelligatur intellectus. Talis enim est ordo ipsarum potentiarum. Nono, essentia diuina aequiualet personae per modum doni et uoluntate productae, et illi rei qua distinguitur a producente. Decimo, aequiualet ipsi spirationi actiuae qua prima et secunda persona dicuntur spirare, et passiuae qua tertia persona dicitur spirari, hoc est, uoluntate produci. Vndecimo, aequiualet duabus relationibus apud uos innominatis, quarum una fundatur in duabus personis ex eo quia spirauerunt, et altera ${ }^{121}$ in tertia ex eo quia spirata est. Quae duae relationes ita in suo conceptu differunt a spirare ${ }^{122}$ et spirari sicut paternitas et filiatio a generare et generari. Et possetis illas nominare sicut illa $^{123}$ quae est in spirantibus dicatur donatio actiua et illa quae est in persona

118 aequiualet enti] aequiualet enti quo prima persona constituitur et $Q \mathbf{1 1 9}$ aequiualet] quilibet $I J P V 120$ perfectae] personae $I V 121$ et altera] et altera fundatur solum $M($ sup. lin. a. m.) $O Q \rightarrow$ 
relação, como ficará claro no tempo do Pastor, em cujos tempos isto será dado a conhecer, porque essas Pessoas que têm a existência no grau máximo, a cuja existência nenhuma existência é igual, não têm o ser baseado nas relações que, ou não são distintas dos fundamentos, como disseram alguns dos vossos, ou, a serem [f1. 156] distintas dos fundamentos, não são de modo nenhum próprias da entidade e, talvez, toda a relação exista apenas na mente e não na realidade. Veja-se isto com muitas outras coisas nesse feliz tempo. Não vou divulgar nem dar a conhecer tudo agora.

É surpreendente porque é que a maior parte dos homens que ensina e escreve disse que as Pessoas divinas subsistem pelas relações, o que não é senão dizer que os acidentes são aquilo por que subsistem as Pessoas divinas. Atende a esta regra: "É impossível que a Substância Perfeita e Máxima Substância seja substância pelo acidente". Bem pelo contrário, digo-te que a essência divina não constitui a Pessoa na medida em que equivale à relação, mas na medida em que absolutamente equivale à substância. Daí que, primeiro, a essência divina deva entender-se a própria natureza de Deus em si. Depois, ela equivale ao ente pelo qual Deus se distingue de qualquer outro que não seja Deus, e equivale também a todos os atributos. Em terceiro lugar, ela equivale ao ente pelo qual a Primeira Pessoa é constituída. Em quarto, equivale ao princípio produtivo per modum naturae ou memória perfeita. Em quinto, equivale à própria produção ou ao Filho. Em sexto, equivale à própria produção ou à geração activa, pela qual se diz que a Primeira Pessoa gera, e passiva, pela qual se diz que a Segunda Pessoa é gerada. Em sétimo, equivale a duas relações: à paternidade, que se funda na Primeira Pessoa pelo facto de haver gerado; à filiação, que se funda na Segunda Pessoa pelo facto de haver sido gerada. Em oitavo, equivale ao princípio produtivo per modum doni, ao qual embora equivalha no segundo ponto, porque este princípio consiste em a vontade ter presente a si o objecto pelo qual Deus se ama, no oitavo, contudo, ele produz segundo esse princípio. Por isso, neste ponto equivale a si como já produtivo, porque este princípio não produz se não se entender que a memória produziu. Assim como a vontade não é atraída senão para o previamente conhecido, nem foge ou despreza senão o conhecido, assim também não produz se não se entender que a inteligência produz. É esta, na verdade, a ordem das próprias potências. Em nono, a essência divina equivale à Pessoa per modum doni e produzida pela vontade, e àquela substância pela qual se distingue de quem a produziu. Em décimo, equivale à própria espiração activa, pela qual se diz que a Primeira e a Segunda Pessoas espiram, e passiva, pela qual se diz que a Terceira Pessoa é espirada, isto é, produzida pela vontade. Em undécimo, equivale às duas relações entre vós inominadas, uma das quais se

$\leftarrow \mathbf{1 2 2}$ a spirare] et spirare $P$; aspirare $V \mathbf{1 2 3}$ illas nominare sicut illa] illas numerare sic atque etiam nominare et illas $Q$ 
spirata dicatur donatio passiua. Sed melius est ut ipsam productionem uocetis donationem sicut alteram uocatis generationem, et illas relationes quae insurgunt uocetis $^{124}$ spirationem actiuam et passiuam. Vnde sicut persona genita dicitur Filius sic persona donata dicitur Spiritus quasi spiratus et Spiritus Sanctus, quia casta et sancta totaque benigna uoluntate producitur. Vnde accipiendo [f1. 157] Spiritum pro persona spirata, Pater non est Spiritus ${ }^{125}$ neque Filius est Spiritus, sed sola persona donata est Spiritus. Accipiendo autem spiritum pro substantia incorporea et immateriali ${ }^{126}$, sic Pater est spiritus et Filius est spiritus et Spiritus, id est, Persona Spirata est spiritus, quia Deus est spiritus ${ }^{127}$. Duodecimo, diuina natura aequiualet tribus relationibus fundatis in Patre ad Filium et tribus fundatis in Filio ad Patrem. Pater enim est idem Filio in natura et substantia et aequalis in uirtute et omni perfectione et similis in omni qualitate. Similiter et Filius est idem et aequalis et similis Patri suo. Et hoc poterat poni octauo signo. Hic tamen ponitur simul quia in hoc signo aequiualet identitati, aequalitati ${ }^{128}$ et similitudini fundatis in Patre ad Spiritum Sanctum et in Filio ad Spiritum Sanctum et in Spiritu Sancto ad Patrem et in eodem Spiritu Sancto ad Filium ${ }^{129}$. Similitudines autem plures intelliguntur in eadem persona eandem ${ }^{130}$ secundum quod plura concipiuntur in quibus assimilantur, ut ueritas, bonitas, sapentia et alia huiusmodi. Quae omnia sunt in qualibet persona, quia diuina essentia quae est in qualibet persona aequiualet omnibus illis et sic aequiualet et omnibus similitudinibus. Similiter in omni perfectione et uirtute sunt aequales, diuina natura aequiualente omnibus perfectionibus et omnibus uirtutibus.

124 uocetis] uocatis $J$; possetis uocare $Q 125$ Pater non est Spiritus] Pater non est Filius $Q \mathbf{1 2 6}$ immateriali] immortali IPV 127 et Spiritus, idest, Persona Spirata est spiritus quia Deus est Spiritus.] et similiter Spiritus Sanctus. Persona donata est Spiritus Sanctus quia Deus est Spiritus. Vocamus autem illam productionem donationem quia uoluntati tribuitur et communicatur liberaliter illi personae omnis perfectio quia productio illa libera est et persona illa tertia potest dici donum, non quia hominibus datum uel donatum quia a uoluntate libera productum. Ab aeterno illa persona est donum, ab aeterno est donata quia uoluntate libera producta. Vestri hoc non percipiunt, referentes illa nomina ad creaturas. Verum est enim quia nobis et uobis datus est Spiritus sed si numquam creaturis fuisset datus, ipse tamen est datum et donum ab aeterno, hoc est, libere productum. $Q$; Vocamus autem illam productionem donationem quia uoluntas tribuitur et communicatur liberaliter illi personae. Omnis perfectio quia productio illa libera est et persona illa tertia potest dici donum uel datum seu donatum quia uoluntate libere productum, non quia hominibus datum uel donatum. Ab aeterno ergo illa persona est donum, ab aeterno est donata quia uoluntate libere producta. Vestri hoc bene non perceperunt, referentes illa nomina ad creaturas. Verum est enim quod uobis et nobis datus est Spiritus. Sed si numquam creaturae fuisset datus, ipse tamen est datum et donatum ab aeterno, hoc est, libere productum. $M$ (in marg. $a$. $\rightarrow$ 
funda nas duas Pessoas pelo facto de haverem espirado, e a outra se funda na Terceira porque é espirada. Assim, estas duas relações no seu conceito diferem de espirar e ser espirado, como paternidade e filiação diferem de gerar e ser gerado. E poderíeis designá-las como aquela que se encontra naqueles que espiram se designa doação activa e aquela que reside na Pessoa Espirada se designa doação passiva. Mas é melhor que à própria produção chameis doação, como à segunda chamais geração e àquelas relações que surgem chamais espiração activa e passiva. Daí que, [fl. 157] assim como a Pessoa gerada se diz Filho, assim a Pessoa dada se diz Espírito, sob o pretexto de ser espirada, e Espírito Santo, porque é produzida por uma vontade casta e santa e totalmente fecunda. Por essa razão, tomando Espírito pela Pessoa espirada, o Pai não é Espírito, nem o Filho é Espírito, mas só a Pessoa dada é Espírito. Tomando, porém, espírito pela substância incorpórea e imaterial, assim o Pai é espírito e o Filho é espírito e o Espírito, isto é, a Pessoa Espirada, é espírito, porque Deus é espírito. Em duodécimo, a natureza divina equivale às três relações fundadas no Pai relativamente ao Filho, e às três fundadas no Filho relativamente ao Pai. O Pai, na verdade, é idêntico ao Filho em natureza e em substância, e igual em virtude e em toda a perfeição, e semelhante em todas as qualidades. De igual modo, também o Filho é idêntico e igual e semelhante a seu Pai. E isto podia situar-se no ponto oitavo. Põe-se, contudo, simultaneamente aqui porque neste ponto equivale à identidade, à igualdade e à semelhança fundadas no Pai em relação ao Espírito Santo, e no Filho em relação ao Espírito Santo, e no Espírito Santo em relação ao Pai, e no mesmo Espírito Santo em relação ao Filho. As semelhanças, porém, reconhecem-se várias, a mesma na mesma Pessoa, segundo se entendem como várias naquilo em que se assemelham, como verdade, bondade, sabedoria e outras da mesma natureza. Todas estas estão em cada Pessoa, porque a essência divina que existe em cada Pessoa equivale a todas elas e, deste modo, equivale também a todas as semelhanças. De um modo semelhante, são iguais em toda a perfeição e virtude, visto que a natureza divina equivale a todas as perfeições e a todas as virtudes.

$\leftarrow m$.) $O$; Vocamus autem illam productionem donationem quia uoluntas tribuitur et comuunicatur liberaliter illi personae omnis perfectio quia productio illa est libera et persona illa tertia potest dici donum uel datum seu donatum quia uoluntate libere productum, non quia hominibus datum uel donatum. Ab aeterno ergo illa persona est donum, ab aeterno est donata quia uoluntate libere producta. Vestri hoc non bene perceperunt, referentes illa nomina ad creaturas. $N$; Vocamus autem illam productionem donationem quia uoluntate tribuitur et communicatur liberaliter illi personae omnis perfectio. Et quia productio illa libera est et persona illa tertia potest dici donum uel datum seu donatum quia uoluntate libere productum, non quia hominibus datum uel donatum. Ab aeterno ergo illa persona est donum, ab eterno est donata quia uoluntate libere producta. Vestri hoc bene non perceperunt, referentes illa nomina ad creaturas. Verum est enim quod nobis et uobis datus est Spiritus Sanctus. Sed si numquam creaturae fuisset datus, ipse tamen fuisset. Est datus et donatum ab aeterno, hoc est, libere productum. $P \mathbf{1 2 8}$ aequalitati] aequiualenti $J \mathbf{1 2 9}$ in Patre ad Spiritum Sanctum et in Filio ad Spiritum Sanctum et in Spiritu Sancto ad Patrem et in eodem Spiritu Sancto ad Filium.] in Patrem et Spiritum Sanctum et in Spiritu Sancto ad Patrem et Filium. $Q 130$ eandem] eadem $N$; eaedem $P$ 
Identitas autem dicitur de personis secundum substantiae unitatem. Vbi uide quod in Patre sunt tres relationes, quas communes appellatis, ad Filium et tres ad Spiritum Sanctum. Et hoc loquendo generaliter. Sex ergo sunt in Patre generaliter loquendo. Nam in speciali tot sunt similitudines in Patre ad Filium et ad Spiritum Sanctum quot sunt illa in quibus assimilari potest. Similiter tot sunt aequalitates quot sunt illa in quibus aequalitas esse potest.

Similiter in Filio sunt sex in communi, tres ad Patrem et tres ad Spiritum Sanctum et tot in speciali ad utrumque quot et in Patre. Similiter sex sunt in Spiritu Sancto in communi, tres ad Patrem et tres ad Filium et tot in speciali quot in altero ipsorum. Quam multa sunt haec et tamen unica re omnino sunt omnia ista. Per diuinam igitur naturam persona est similis et aequalis prout illa aequiualet perfectionibus diuinis quae dicuntur quantitates ${ }^{131}$ et qualitatibus diuinis ${ }^{132}$.

Natura itaque diuina ut in Patre est, primo aequiualet rei qua constituitur in esse distincto ab illis. Secundo aequiualet principio productiuo per modum naturae. Tertio aequiualet ipsi generare uel ipsi generationi actiuae. Quarto aequiualet relationi paternitatis. Quinto aequiualet principio per modum doni productiuo. Sexto aequiualet donationi actiuae. Septimo aequiualet relationi spirationis actiuae quam habet eo quia donauit. Octauo aequiualet sex relationibus communibus in generali. Nono aequiualet multis relationibus communibus in speciali.

Natura diuina prout est in Filio, primo aequiualet illi rei per quam distinguitur a Patre et Sipitu Sancto et constituitur in esse personali. Secundo aequiualet ipsi potentiae $^{133}$ passiuae secundum quam potest dici producibilis et generabilis. Tertio aequiualet ipsi generari uel generationi passiuae. Quarto aequiualet relationi filiationis. Quinto aequiualet principio [f1. 158] per modum doni productiuo. Sexto aequiualet donationi actiuae quae in ipso est ita perfecte sicut in Patre, quamuis eam habeat a Patre. Septimo aequiualet relationi spirationis actiuae quam habet eo quod Spiritum Sanctum donauit, hoc est, per modum donationis seu liberae productionis produxit. Octauo aequiualet $\operatorname{sex}^{134}$ relationibus communibus in generali. Nono aequiualet multis relationibus communibus ${ }^{135}$ in speciali.

Natura diuina prout est in Spiritu Sancto, primo aequiualet rei qua Spiritus Sanctus distinguitur a Patre et Filio. Secundo aequiualet ipsi potentiae ${ }^{136}$ passiuae secundum quam potest dici donabilis a Patre. Tertio aequiualet ipsi potentiae passiuae secundum quam potest dici donabilis a Filio. Quarto aequiualet ipsi donari $^{137}$ a Patre. Quinto aequiualet ipsi donari ${ }^{137}$ a Filio. Sexto aequiualet ipsi

131 quantitates] quantitates ut imensitas, aeternitas, uirtus seu potentia $M$ (in marg. a. m.) $N O P Q$ 132 qualitatibus diuinis] qualitatibus diuinis bonitatis et sapientiae $M$ (in marg. a. m.) NO $133 \rightarrow$ 
A identidade, porém, afirma-se das Pessoas de acordo com a unidade da substância. Vê, por isso, que no Pai são três as relações a que chamais comuns, relativamente ao Filho, e três relativamente ao Espírito Santo. E isto falando de um modo geral. Portanto, falando de um modo geral, no Pai há seis. De facto, em especial são tantas as semelhanças no Pai com o Filho e o Espírito Santo quantos os aspectos em que se pode assemelhar. De modo semelhante, são tantas as igualdades quantos são os aspectos em que pode haver igualdade. Igualmente no Filho são seis em comum, três para com o Pai e três para com o Espírito Santo, e são tantas em relação a cada um quantas são no Pai.

De modo semelhante, há seis em comum no Espírito Santo, três em relação ao Pai e três em relação ao Filho, e tantas em especial quantas em cada um deles. Quão numerosas elas são e, contudo, todas elas existem numa única substância! Portanto, pela natureza divina é a Pessoa semelhante e igual, na medida em que equivale às perfeições divinas que se designam quantidades, como imensidade, eternidade, força ou potência, e às qualidades divinas.

Também a natureza divina tal como existe no Pai equivale, primeiro, à substância pela qual se constitui em ser distinto daqueles. Segundo, equivale ao princípio produtivo per modum naturae. Terceiro, equivale ao próprio gerar ou à própria geração activa. Quarto, equivale à relação de paternidade. Quinto, equivale ao princípio produtivo per modum doni. Sexto, equivale à doação activa. Sétimo, equivale à relação de espiração activa, que tem pelo facto de haver dado. Oitavo, equivale às seis relações comuns em geral. Nono, equivale a muitas relações comuns em especial.

A natureza divina conforme existe no Filho equivale, primeiro, àquela substância pela qual se distingue do Pai e do Espírito Santo e se constitui em ser pessoal. Segundo, equivale à própria potência passiva segundo a qual se pode considerar produzível e gerável. Terceiro, equivale a ser gerado ou à geração passiva. Quarto, equivale à relação de filiação. Quinto, equivale ao princípio [f1. 158] produtivo per modum doni. Sexto, equivale à doação activa, que existe nele tão perfeita como no Pai, embora a tenha do Pai. Sétimo, equivale à relação de espiração activa, que tem pelo facto de haver dado o Espírito Santo, isto é, que produziu per modum doni ou de livre produção. Oitavo, equivale às seis relações comuns em geral. Nono, equivale a muitas relações comuns em especial.

A natureza divina conforme existe no Espírito Santo equivale, primeiro, à substância pela qual o Espírito Santo se distingue do Pai e do Filho. Segundo, equivale à própria potência passiva segundo a qual se pode considerar passível de ser dado pelo Pai. Terceiro, equivale à própria potência passiva segundo a qual se pode considerar passível de ser dado pelo Filho. Quarto, equivale a

$\leftarrow$ potentiae] personae $P 134$ sex] multis $I V 135$ communibus] omnibus $V 136$ potentiae] personae $P 137$ donari] donanti $V$ 
relationi spirationis passiuae prout refertur ad primam personam spirantem. Septimo aequiualet relationi spirationis passiuae secundum quam refertur ad secundam personam spirantem, quae est Filius, quamuis non referatur ad ipsum filiatione, sed alia ${ }^{138}$. Octauo aequiualet essentia diuina prout est in Spiritu Sancto sex relationibus communibus in genere ${ }^{139}$. Nono aequiualet relationibus communibus in specie ${ }^{140}$.

Vbi uide tot notionalia et propria esse in persona una quot in alia ${ }^{141}$, quod neque Alexander neque Bonauentura neque Thomas neque Scotus, quos hic uides, cogitauerunt dum in carne uiuerent. Et nullus doctorum posuit plus quam quinque notionalia, connumerando ingenitum, de quo nihil adhuc diximus. Sine illo posuerunt quattuor notionalia, uidelicet generare, generari, spirare, spirari. Reliqua omnia praetermiserunt.

Haec theologia est, ut uides, enucleata. Conscribe omnia ut dico, quia haec uenient in manus illorum qui melius quam tu illa intelligent. Tu uero uidisti qualiter in qualibet persona sunt nouem ${ }^{142}$ notionalia quae simul collecta complent numerum ${ }^{143}$ uigesimum septimum. Et in octauo notionali continentur tria notionalia ${ }^{144}$, uidelicet identitas, aequalitas, similitudo, quae triplicando ${ }^{145}$ erunt sex, quia una trium tacta ${ }^{146}$ est et erunt triginta tria ${ }^{147}$. Et ultra hoc, tot sunt in qualibet persona similitudines quot sunt in ea aequalitates ${ }^{148}$ et tot aequalitates ${ }^{149}$ quot sunt illa secundum quae aliquis potest dici alii aequalis, quae longum esset connumerare nunc.

Qui ergo arguunt diuinas relationes nullam perfectionem dicere, ex eo quia tunc plures essent perfectiones in Patre quam in Spiritu Sancto, non bene arguunt quia, ut uidisti, in omnibus sunt nouem. Sed bene argueretur sic: $\mathrm{Si}^{150}$ diuinae relationes dicunt perfectionem, ergo omnis persona caret aliqua perfectione, quia in qualibet est aliquod notionale quod non est in alia. De quo postmodum dicetur.

Tota haec multitudo est unica res omnino, aequiualens tamen omnibus istis. Sicut ergo qui habet talentum auri habet multa milia aureorum, ita qui habet essentiam ${ }^{151}$ diuinam habet multa entia aequipollenter. His omnibus praeintellectis in duodecim signis, haec deinde addantur ${ }^{152}$.

Tertiodecimo, diuina essentia aequiualet principio productiuo rerum aliarum a Deo quoad cognosci. Nam, in hoc signo existens, offert intellectui [f1. 159] diuino

138 ad ipsum filiatione, sed alia] ad ipsam filiationem sed alia $I J$; ad ipsam filiationem secundum alia $Q$; ad ipsum filiationem sed alia $V 139$ genere] generali $P \quad \mathbf{1 4 0}$ specie] speciali. Sed quia unica est donatio et spiratio actiua in Patre et Filio, unica est etiam donatio et spiratio passiua in Spiritu Sancto ad utrumque. Et ita non erunt omnino tot propria in una quot in alia persona $M$ (in marg. a. m.) $N O Q \mathbf{1 4 1}$ quot in alia] in diuinis personis $Q \mathbf{1 4 2}$ nouem] multa $O Q \mathbf{1 4 3}$ complent numerum] complent numerum longe maiorem quinario $M$ (in marg. a. m.) NO 144 complent numerum uigesimum septimum. Et in octauo notionali continentur tria notionalia] $\rightarrow$ 
ser dado pelo Pai. Quinto, equivale a ser dado pelo Filho. Sexto, equivale à própria relação de espiração passiva conforme se refere à primeira Pessoa que espira. Sétimo, equivale à relação de espiração passiva segundo a qual se refere à Segunda Pessoa que espira, que é o Filho, embora se lhe não refira em razão da filiação, mas por outra relação. Oitavo, a essência divina conforme existe no Espírito Santo equivale às seis relações comuns em geral. Nono, equivale às relações comuns em especial.

Vê, pois, que pertencem a uma Pessoa tantos conceitos quantos pertencem a outra, o que não pensaram nem aqui Alexandre, nem Boaventura, nem Tomás, nem Escoto enquanto viveram na carne. E nenhum doutor avançou mais de cinco conceitos, contando o conceito de ingénito, de que nada dissemos ainda. Sem esse, avançaram quatro conceitos, a saber, gerar, ser gerado, espirar, ser espirado. Deixaram de lado todos os restantes.

Esta teologia foi, como vês, profundamente explanada. Escreve tudo como digo porque estas coisas vão passar à mão daqueles que as entendem melhor do que tu. Tu, de facto, viste de que modo, em cada Pessoa, são nove os conceitos, que, somados, completam o número de vinte e sete. E no oitavo contêm-se três, a saber, identidade, igualdade, semelhança, os quais, ao serem triplicados, serão seis, porque um dos três é retirado, e serão trinta e três. E, além destes, são tantas em cada Pessoa as semelhanças quantas são as qualidades em cada uma, e tantas as igualdades quantas aquelas coisas segundo as quais pode alguém ser considerado igual a outro, o que seria longo enumerar agora.

Portanto, os que argumentam que as relações divinas não indicam nenhuma perfeição, porque então haveria mais perfeições no Pai que no Espírito Santo, não argumentam bem, porque, como viste, são nove em todas. Mas argumentar-se-ia bem deste modo: se as relações divinas indicam perfeição, então cada Pessoa carece de alguma perfeição porque em cada Pessoa há algum conceito que não há na outra. Disto falaremos depois.

Toda esta grande quantidade é absolutamente uma só substância, equivalendo, contudo, a todas essas. Assim, pois, como aquele que possui um talento de ouro possui muitos milhares de moedas de ouro, assim aquele que tem a essência divina tem, de modo equivalente, muitos entes. A todas essas coisas previstas nos doze conceitos acrescentem-se ainda estas.

Décimo terceiro, a essência divina equivale ao princípio produtivo das coisas distintas de Deus relativamente a ser conhecido. Com efeito, ao existir neste

$\leftarrow$ complent numerum longe maiorem quinario uidelicet uigesimum setpimum, et octauo notionali continentur. Tria notionalia $Q 145$ quae triplicando] quatriplicando $I \quad 146$ tacta] facta $N \quad 147$ triginta tria] adhuc plura $A O$; triginta $H J P \mathbf{1 4 8}$ in ea aequalitates] in ea qualitates $A G J M N O S$; inaequalitates IRV 149 tot aequalitates] tot inaequalitates $V 150$ argueretur sic: "Si] arguunt se in $V 151$ essentiam] scientiam $V 152$ habet multa entia aequippolenter. His omnibus praeintellectis in duodecim signis haec deinde addantur.] habet multa etiam aequippolenter his omnibus praeintellectis in duodecim signis. Haec deinde addantur $V$ 
omnia creabilia ${ }^{153}$ et factibilia. Nam essentia diuina pro unoquoque creabili ${ }^{154}$ et factibili correspondet intellectui suo, hoc est, sibi prout aequiualet intellectui ac si ibi esset in seipso illud creabile ${ }^{155}$ et factibile uel in sui similitudine. Essentia enim diuina est similitudo perfecta omnium intelligibilium. Et ita ibi sunt tot similitudines aequiualenter quot intelligibilia. Alia ergo ratione intelliguntur aequus, alia bos, quia essentia diuina alii et alii aequiualente, ideo aliqui dixerunt una ratione essentiae intelligi ${ }^{156}$ omnia, alii diuersis rationibus. Vtrique recte dicebant, sed non perfecte intelligebant. Vna enim essentia intelligit omnia Deus neque opus est ut sint in ea relationes ullae ad intelligibilia praecedentes eorum intellectionem neque ullae rationes distinctae, sed sufficit essentia sola prout aequiualet rationibus omnium. Non ergo sola omnino, sed sola prout tamen aequiualet multis. Verum est quidem quod intellectus, considerans essentiam aequiualentem tot et tantis ${ }^{157}$ et intus et extra potest in ea sic considerata facere multa entia rationis, ut sapientiae et bonitatis quo ad intra, et similitudinem lapidis et ferri quo ad extra. Neque tamen talis consideratio et fabricatio est necessaria ac si bonitas non esset in Deo neque sapientia nisi Deus uel alius aliquis cogitaret. Similiter talis fabricatio entium rationis non est necessaria ad hoc ut dicatur in Deo similitudo et ideo lapidis uel ligni. Similitudines itaque rerum sunt in essentia Dei in priori signo quam intelligantur a Deo? Sunt, dico, aequiualenter, non aliquo modo distincte et ratione fabricata ab intellectu. Et hoc modo hic doctor acutus intellexit (et ostendebat Scotum). Non quod non sint aequiualenter, sed quod non sunt distinctae ratione, ut hic alius (ostendebat Thomam), dicere uidebatur. Immo dico tibi quod priori signo Deus intellexit lapidem quam fabricauerat ${ }^{158}$ in essentia sua, considerata distinctione similitudinum. In primo enim signo, essentia aequiualet similitudini lapidis et ligni, in secundo Deus lapidem et lignum intelligit, in tertio potest distinguere in essentia sua similitudinem lapidis a similitudine ligni.

Quarto decimo ergo signo diuina essentia aequiualet cognitioni omnium creabilium et factibilium, immo et cognitioni omnium non entium et impossibilium eo modo quo non ens et impossibile potest cognosci. Non ens quidem cognosci non potest tamquam quid sit, ponendo aliquid, quia tunc non esset non ens, sed ens. Sed potest cognosci quid non est ${ }^{159}$, negando omnia entia ut sit sensus:

153 creabilia] credibilia $M Q 154$ creabili] credibili $Q \quad 155$ illud creabile] ad credibile $Q \quad 156$ intelligi] intelligi a Deo $O Q$, intellexi $V 157$ et tantis] entitates $Q 158$ fabricauerat] fabricauerunt $\rightarrow$ 
conceito, proporciona ao intelecto [f1. 159] divino tudo quanto é susceptível de ser criado e feito. Pois, relativamente a cada coisa criável e factível, a essência divina corresponde ao seu intelecto, isto é, a si enquanto equivale ao intelecto, como se nele estivesse realmente ou na sua imagem aquilo que é susceptível de ser criado e feito. Com efeito, a essência divina é a semelhança perfeita de todos os inteligíveis. E, deste modo, estão lá equivalentemente tantas semelhanças, quantos os inteligíveis. Portanto, por uma razão se reconhece o cavalo, por outra, o boi, porque, equivalendo a essência divina a um e a outro, por isso, uns disseram que tudo era reconhecido por uma razão da essência, outros por diversas. Uns e outros tinham razão, mas não perfeita compreensão. Na verdade, Deus tudo compreende numa única essência, e não seria preciso que nela houvesse algumas relações respeitantes aos inteligíveis que precedessem a compreensão deles, nem algumas razões distintas, mas basta apenas a essência, na medida em que equivale às razões de todas. Portanto, não absolutamente só, mas só todavia, enquanto equivale a muitos. É sem dúvida verdade que o intelecto ao considerar a essência equivalente a tantas e tão grandes coisas, interna e externamente, pode nela assim considerada suscitar muitos entes da razão, como a semelhança da sabedoria e da bondade, no que respeita ad intra, e a semelhança da pedra e do ferro, no que respeita ad extra. E, todavia, esse olhar e esse produzir não são necessários, como se nem a bondade nem a sabedoria existissem em Deus se Deus ou qualquer outro as não pensasse. Nem, de igual modo, é necessária essa fabricação dos entes da razão para que se afirme em Deus a semelhança e, consequentemente, a semelhança da pedra ou da madeira. Portanto, as semelhanças das coisas estão na essência de Deus, no primeiro conceito, antes de serem pensadas por Deus. Estão, afirmo, de modo equivalente, não de qualquer outro modo, distintamente e por uma razão fabricada pelo intelecto. E foi deste modo que aqui o Doutor Subtil entendeu (e apontava Escoto). Não que não estejam de modo equivalente, mas porque não estão distintamente na razão, como estoutro (apontava Tomás) parecia dizer. E até te digo que, no primeiro conceito, Deus reconheceu na sua essência a pedra que produzira, levada em conta a distinção das semelhanças. Mas, no primeiro conceito, a essência equivale à semelhança da pedra e da madeira. No segundo, Deus reconhece a pedra e a madeira. No terceiro, pode distinguir na sua essência a semelhança da pedra da semelhança da madeira.

Décimo quarto conceito, portanto a essência divina equivale ao conhecimento de todos os criáveis e factíveis e, até, ao conhecimento de todos os não ente e impossíveis, na medida em que o não ente e o impossível podem ser conhecidos. O não ente, com efeito, não pode ser conhecido como algo existente, representando alguma coisa, porque então não seria não ente, mas ente. Mas pode-se 
per non ens concipio neque substantiam neque accidens neque Deum neque creaturam. Et tamen uos homines dicitis: "Illud est non ens quod neque substantia ulla neque accidens ullum est." Et uidemini illud facere ens, dicendo "illud". Sicut etiam dicitis: "extra caelum nihil est" ac si locus esset extra caelum. Et dicendo: "extra caelum nihil est", uidemini ponere extra caelum aliquid, quia locum. Nam intus et extra sunt differentiae loci. Tales sermones intelligendi sunt negatiue non positiue. Vel est positio imaginaria solum, quod certe non caelum nec intra caelum. Nihil [fl. 160] est illa dictio ${ }^{160}$ quod uidetur aliquid ponere. Neque aliter loqui potestis. Et imaginatio apprehendit non ens tamquam ens, ideo dicitis quod non ens est ens et non intelligibile intelligibile. Quicquid autem concipitis ut impossibile, concipitis aliquid ex partibus repugnantibus coniunctum, ut hircumceruum $^{161}$ et hominem-bouem.

Quintodecimo signo essentia Dei aequiualet amori quo omnia talia placent Deo, quia in omnibus est participatio bonitatis suae, immo omnia sunt ipsa participatio bonitatis Dei, ne uideamini distinguere inter participans et participatum. Tota enim creatura est quaedam participatio diuinae bonitatis ${ }^{162}$. Vnde participans et quod participatur idem sunt in re omnino. Complacet sibi Deus in omnibus.

Sexto decimo signo essentia diuina aequiualet uolitioni aliquorum quae Deus non solum amat amore simplici ${ }^{163}$ sed etiam efficaci, quia uult ea esse pro aliquo tempore. Aequiualet et cognitioni, quia cognoscit ea esse pro tali tempore. Et ulterius aliquibus uult gratiam et gloriam, ut alias diximus quando de praescientia ${ }^{164}$ Dei et praedestinatione sermonem haberemus ${ }^{165}$. Praetermitto haec.

Intellexisti qualiter non est aliud in Deo quam deitas et qualiter aequiualet sibi pro tot et tantis rebus et perfectionibus. Quae enim sparsa sunt in inferioribus, collecta sunt omnia in natura diuina et ipsa sola fiunt omnia ac si essent ibi multa realiter distincta. Nunc audi quaedam de hac notione quae ponitur in prima persona et dicitur ingenitum. Illa dictio potest quattuor denotare.

Primo negationem geniti et illo modo multa sunt ingenita, uidelicet omnia illa quae non sunt genita. Omnia igitur creata sunt ingenita. Et Spiritus Sanctus, qui non est genitus, dici poterit ingenitus. Et ita non solum Pater est ingenitus.

160 non est caelum nec intra caelum. Nihil est illa dictio] quod certe non est caelum nec intra caelum nihil. Illa dictio quod $J$; non est locus neque ultra caelum nihil est, illa dictio $Q \quad 161$ hircum-ceruum] hircum coruum J; hircoceruum $P 162$ diuinae bonitatis.] diuinae bonitatis, quia $\rightarrow$ 
conhecer o que não é negando todos os entes, neste sentido: "Por não ente concebo não a substância, nem o acidente, nem Deus, nem a criatura”. E, todavia, vós, homens, dizeis: "É não-ente aquilo que não é nem substância alguma nem acidente algum". E parece que o tornais ente ao dizerdes "aquilo". Como também dizeis: "Fora do céu nada existe", como se fora do céu existisse um lugar. E ao dizerdes: "Fora do céu nada existe", parece que pondes alguma coisa fora do céu, porque pondes um lugar. Com efeito, dentro e fora são diferenças de lugar. Essas expressões devem entender-se negativa, não positivamente, ou é apenas uma localização imaginária, porque, seguramente, nem céu nem dentro do céu. [f1. 160] Essa afirmação é o nada que parece afirmar alguma coisa. E não podeis expressar-vos de outra maneira. E a imaginação apreende o não ente como ente, por isso dizeis que o não ente é ente e o não inteligível, inteligível. O que quer que concebais como impossível, concebei-lo como algo formado de partes contraditórias, como bode-viado e homem-boi.

Décimo quinto conceito, a essência de Deus equivale ao amor pelo qual todas essas coisas agradam a Deus, porque em todas há a participação da sua bondade, e mais, todas são a própria participação da bondade de Deus, de modo a não parecer que distinguis entre participante e participado. Com efeito, a criatura no seu todo é uma certa participação da bondade divina. Daí que participante e o que é participado sejam, na realidade, absolutamente o mesmo. Em tudo Deus se compraz consigo.

Décimo sexto conceito, a essência divina equivale à volição de algumas coisas que Deus ama não só com um amor simples, mas também eficaz, porque quer que elas existam por algum tempo. Equivale também ao conhecimento, porque conhece que elas existem por esse tempo. E, além disso, quer para algumas graça e glória, como dissemos quando falávamos da presciência de Deus e da predestinação. Passo adiante.

Entendeste como em Deus não há senão divindade e como ela equivale nele a tantas e tão grandes coisas e perfeições? $\mathrm{Na}$ verdade, as coisas que se acham dispersas nos seres inferiores, estão todas concentradas na natureza divina, e elas sós tornam-se tudo como se lá estivessem muitas realmente distintas. Ouve agora algumas coisas acerca deste conceito que se atribui à Primeira Pessoa e se designa ingénito. Essa palavra pode denotar quatro coisas.

Primeiro, a negação de gerado - geniti. E desse modo são muitas as coisas ingénitas, a saber, todas aquelas que não são geradas - genita. Portanto, todas as coisa criadas são ingénitas. Também o Espírito Santo, que não é gerado, poderá considerar-se ingénito. E, deste modo, nem só o Pai é ingénito.

$\leftarrow$ creatura pars quaedam est bonitatis diuinae quia longe minor illa et ab illa $M$ (in marg. a. m.) $N O Q V 163$ non solum amat amore simplici] uult non solum amore simplici $Q 164$ praescientia] sapientia $M 165$ haberemus] habebamus $M O$; faceremus $Q$ 
Alio modo potest denotare negationem productionis actualis sic ut ingenitum sit idem quod improductum. Et illo modo creata non sunt ingenita, quia sunt producta. Neque Spiritus Sanctus est ingenitus, quia et ipse productus. Tamen etiam illud quod non est nec fuit nec erit, ingenitum dici potest, quia improductum, ut aliqua rosa quae numquam fuit aut erit producta tamen producibilis est. Et hoc modo ingenitum non conuenit Deo Patri, quia ipse improductus et improducibilis est.

Tertio modo ingenitum potest denotare negationem productionis actualis et aptitudinalis sic ut non sit productum neque producibile et hoc absolute. Et isto modo impossibilia, ut hircus-ceruus ${ }^{166}$, sunt ingenita, non solum Deus Pater.

Quarto modo ingenitum dicit negationem productionis cuiuscumque et actualis et aptitudinalis cum respectu ${ }^{167}$ quod illud tale sit ens, sic intelligendo ingenitum, hoc est, ens uel suppositum improductum uel improducibile. Et ita conuenit soli Deo Patri. Ipse enim solus est et non est ab alio. Vbi dico tibi quod ratio illa quae ponit quod prius competit illi personae esse ingenitum quam generare, uera est et bene concludit. Nam, si prima persona esset ab [f1. 161] alia, prius respiceret illam personam a qua esset quam illam quae ab ipsa est. Ita ex quo non est ab alio prius sibi competit negatio illa "non esse ab alio" quam affirmatio ista "aliquid esse ab illa, quia pro quocumque signo affirmatio uera esset. Si non esset, pro illo eodem erit uera negatio si affirmatio pro illo falsa sit $^{168}$. Et ille qui, contra hoc arguendo, dicit negationem non posse alicui ante omnem affirmationem competere, bene arguit, quia primum quo Pater subsistit et est persona non potest esse negatio. Non tamen bene concludit quod generare sit prius in Patre quam ingenitum. Sed bene concludit quod aliquid positiuum prius competit Patri quam illa negatio. Et ideo essentia diuina non prout aequiualet ipsi generationi uel paternitati constituit personam illam, sed prout aequiualet entitati hypostatice quae est entitas absoluta non relatiua.

Personae diuinae sunt in se absolutae et referuntur relationibus superadditis. Neque tamen constitutae sunt ex duabus rebus uel ${ }^{169}$ entitatibus neque ex deitate et relatione tamquam alia re superueniente, sed ex deitate sola et unica re omnibus his aequiualente. Relatio igitur superaddita non est nisi essentia diuina aequiualens relationi. Constituitur itaque persona diuina. Multa ei superadduntur et tamen simplicissima est neque habet plura entia in se sed tantum unum ens quod est dietas. Ridemus ${ }^{170}$ nos angeli, ut loquar modo humano, quando audimus

166 hircus-ceruus] hircoceruus $P$; hirco-coruus $M 167$ cum respectu] cum intellectu $P 168$ si affirmatio pro illo falsa sit] et tamen pro aliquo signo negatio possit esse uera etiam si pro illo $\rightarrow$ 
Pode, de outro modo, denotar a negação da produção actual, de tal modo que ingénito seja o mesmo que não produzido - improductum. E, deste modo, as coisas criadas não são ingénitas, porque são produzidas. E nem o Espírito Santo é ingénito, porque também ele é produzido. Também o que não existe, nem existiu, nem virá a existir se pode considerar ingénito, porque não produzido, como uma rosa que nunca foi ou será produzida, contudo, é produzível. E, deste modo, ingénito não convém a Deus Pai, porque é improduzido e improduzível.

De acordo com a terceira modalidade, ingénito pode denotar a negação da produção actual e aptitudinal, de tal modo que não seja produzido nem produzível, e isto de uma forma absoluta. E, deste modo, os impossíveis, como bode-boi, são ingénitos, não só Deus Pai.

No quarto modo, ingénito exprime a negação de qualquer produção, não só actual, como aptitudinal, tendo em conta que esse mesmo seja ente, entendendo ingénito desta forma, isto é, ente ou sujeito improduzido ou improduzível. E, assim, convém apenas a Deus Pai. Ele, realmente, é único e não depende de outrem. Por isso te digo que a razão que sustenta que a esta Pessoa compete antes ser ingénita do que gerar é verdadeira e conclui correctamente. Pois, se a Primeira Pessoa [fl. 161] dependesse de outra, relacionar-se-ia antes com a Pessoa de quem dependesse do que com aquela que dela depende. Assim, visto que não depende de outrem, cabe-lhe mais esta negação: "e não depende de outrem", do que aquela afirmação: "algo depende dela", porque a afirmação seria verdadeira relativamente a qualquer conceito. Se o não fosse, a negação seria verdadeira em relação a ele se a afirmação em relação a ele fosse falsa. E aquele que, argumentando contra isto, afirma que a negação não pode competir a ninguém antes de toda a afirmação, argumenta correctamente, porque a negação não pode existir antes daquilo pelo qual o Pai subsiste e é Pessoa. Não conclui correctamente, contudo, que, no Pai, o gerar seja anterior a ser ingénito. Mas conclui correctamente que ao Pai compete antes algo de positivo do que aquela negação. E, por esta razão, a essência divina, enquanto equivale à própria geração ou à paternidade, não constitui esta Pessoa, mas enquanto equivale à entidade hipostática, que é entidade absoluta e não relativa.

As Pessoas divinas são, em si, absolutas e relacionam-se na base das relações supervenientes. E não são também constituídas por duas substâncias ou entidades, nem de divindade e relação, como alguma coisa superveniente, mas só da divindade e da única substância que equivale a todas estas. Portanto, a relação superveniente não é mais do que a essência divina que equivale à relação. Constitui-se, portanto, como Pessoa divina. Muita coisa lhe é acrescentada e, todavia, é simplicíssima. Nem tem vários entes em si, mas apenas um ente,

$\leftarrow$ esset falsa affirmatio, et hoc sine aliquo inconuenienti $Q \mathbf{1 6 9}$ ex duabus rebus uel] ex duobus relationibus, rebus et $Q \mathbf{1 7 0}$ Ridemus] Redeamus $I P V$ 
uos homines disputantes et dicentes quod personae constituuntur ex relatione originis ${ }^{171}$ et distinguntur per illas prout differunt ratione absentia ${ }^{172}$. Et hoc ideo quia nomina personis imposita sunt relatiua et quia Christus dixit: "In nomine Patris et Filii et Spiritus Sancti". Et non aduertunt quod nomina imponuntur a proprietatibus, quod et ipsi alias dicunt, et quia proprium Primae Personae est generare et ita Patrem esse. Nomen sibi impositum est a sua proprietate sicut nomen illius rei quae laedit pedem dicitur lapis. Quamuis ergo illud nomen a proprietate accipiatur, illi tamen personae imponuntur sicut et nomen lapis non lesionem pedis significat, sed rem illam. Vnde istud nomen "Pater" est nomen proprium Primae Personae. Non sic est quando aliquem hominem patrem uocatis. Quando enim dicitis: hic homo est pater ${ }^{173}$, dicitis nomen commune et accidens de illo in quo est. Quando autem dicitis: hic est Pater, ostensa Prima Persona, non dicitis accidens de subiecto, sed sicut si diceretis: iste est Ioannes, ostenso filio Zachariae uel Zebedei. Est ergo nomen proprium et substantiuum. Ex quo ergo nulli ${ }^{174}$ alii est tale nomen proprium, iustum est ut quandocumque nominatur uel profertur "Pater" sine alia additione ${ }^{175}$ intelligatur Prima Persona diuina. Quod nomen prout significat personam illam, ut dixi, est substantiuum, prout uero significat relationem in concreto, quae significat ipsum referri ad filium, tunc illud nomen accipitur quasi adiectiue, quia significat relationem illam et illum concernit in quo est.

Similiter nomen Secundae Personae impositum est illi a proprietate sua quae est generari, et a relatione filiationis quae consequitur talem generationem et est nomen proprium Secundae Personae. Vnde quando propheta dicit: Filius datus est nobis, stat ibi filius pro Secunda Persona, quae carnem assumpsit. Ideo sequitur ${ }^{176}$ Vocabitur nomen eius Deus, ac si diceret "Filius qui datus est nobis Deus est". Est ergo "Filius" nomen proprium Secundae Personae et nomen substantiuum ${ }^{177}$. Quando uero significat relationem illam qua persona illa refertur ad Patrem, tunc est quasi adiectiuum et nomen commune, ut ibi Quid nomen filii eius, si nosti? Ac si diceret: Filii Dei nomen si nosti agnosces, aliud non esse ${ }^{178}$ reperies quam hoc nomen "Filius". Vnde [f1. 162] dicendo: "Filius est filius", potest intelligi in subiecto pro persona et ut est nomen proprium, et in praedicato pro filio prout est nomen commune, sicut diceretur: "Ioannes est filius". Sic etiam dicendo "Pater est pater", potest intelligi sic: "Prima Persona est Pater, quia genuit". Et alio modo: "prima Persona est Prima Persona". Vnde Christus dixit: Confiteor tibi, Pater.

171 ex relatione originis] per relationes originis $O Q$; per relationes $V \mathbf{1 7 2}$ absentia] ab essentia $N O P Q 173$ "Hic homo est pater"] "hic apud uos", hoc est, "pater" $O Q \mathbf{1 7 4}$ nulli] multi $I \mathbf{1 7 5}$ sine alia additione] sine alio adiuncto $Q \mathbf{1 7 6}$ sequitur] semper $P$; dicitur $Q 177$ nomen substantiuum] nomen proprium substantiuum $M$ (in marg. a. m.) $O P \mathbf{1 7 8}$ aliud non esse] neque aliud nomen $Q$ 
que é a divindade. Nós anjos, para falar ao modo humano, rimo-nos quando vos ouvimos a vós homens disputar e dizer que as Pessoas são constituídas pelas relações de origem e por elas se distinguem, na medida em que se distinguem em razão da ausência. E isto também porque os nomes impostos às Pessoas são relativos e porque Cristo disse: Em nome do Pai e do Filho e do Espírito Santo. E não advertem que os nomes são impostos em função das propriedades, o que aliás também eles dizem, e que o que é próprio da Primeira Pessoa é gerar e, por isso, ser Pai. Foi-lhe imposto o nome em função da sua propriedade, do mesmo modo que o nome daquela coisa que fere o pé se chama pedra. Embora, pois, o nome se receba da propriedade, os nomes impõem-se à Pessoa, do mesmo modo que também o nome pedra não significa lesão do pé, mas aquela realidade. Daí que este nome "Pai" seja o nome próprio da Primeira Pessoa. Não é assim quando chamais pai a um qualquer homem. Na verdade, quando dizeis: "este homem é pai”, enunciais um nome comum e um acidente daquele em quem se encontra. Mas quando dizeis: "este é o Pai”, mostrando a Primeira Pessoa, não afirmais um acidente acerca de um sujeito, mas é como se dissésseis: "este é João", apontando o filho de Zacarias ou de Zebedeu. É, pois, nome próprio e substantivo. Dado que nenhum outro tem este nome próprio, é justo que todas as vezes que se diga ou se profira "pai", sem nenhum adjectivo, se entenda a Primeira Pessoa divina. Enquanto significa essa Pessoa, como referi, este nome é substantivo, mas enquanto significa uma relação em concreto, que significa o próprio referir-se ao filho, então esse nome toma-se quase adjectivamente, porque significa essa relação e respeita àquele em quem está.

Semelhantemente o nome da Segunda Pessoa é-lhe imposto em função da sua propriedade, que é ser gerado, e da relação de filiação pela qual se obtém essa geração, e é nome próprio da Segunda Pessoa. Daí que, quando o profeta diz Um filho nos foi dado, ${ }^{[185]}$ filho esteja aí pela Segunda Pessoa, que assumiu a carne. Por isso se segue Chamar-se-á Deus, como se dissesse "O filho que nos foi dado é Deus". Filho é, portanto, nome próprio da Segunda Pessoa e nome substantivo. Mas quando significa a relação pela qual esta Pessoa se refere ao Pai, então está como adjectivo e nome comum, como neste passo: Qual é o nome de seu filbo, se é que o sabes? ${ }^{[186]}$ Como se dissesse: Se sabes, reconhecerás o nome do Filho de Deus, descobrirás que não há outro nome senão este nome "Filho". Daí que, [f1. 162] dizendo "O Filho é filho", se possa reconhecer, no sujeito, como Pessoa e na medida em que é nome próprio, e no predicado, como filho, isto é, nome comum, como se dissesse "João é filho". Assim também dizendo: "O Pai é pai", se pode entender deste modo: "a Primeira Pessoa é pai porque gerou”. E

[185] Is 9:6

[186] Prov 30:4 
Vocauit eum nomine communi ac si dixisset: "Confiteor tibi quia me genuisti et es mihi Pater, aliorum uero omnium Dominus". Ideo subiunxit: Domine caeli et terrae et omnium quae in eis sunt. Quando postmodum dixit: Nemo nouit Filium nisi Pater neque Patrem quis nouit nisi Filius et cui uoluerit Filius reuelare, tunc nomen filii et patris accepit substantiue non adiectiue, quia quando capitur adiectiue, tunc est nomen commune et stat ${ }^{179}$ indifferenter pro hoc patre uel illo, pro hoc filio uel illo ${ }^{180}$. Ibi autem in uerbis Domini est talis sensus: "Nemo nouit Secundam Personam nisi Prima et ipsamet Secunda et Spiritus Sanctus, qui etiam est Deus, neque Primam Personam ${ }^{181}$ quis nouit nisi Filius et ipsamet Prima Persona et Spiritus Sanctus." Non excludebat ergo personas a cognitione tali, sed creaturas omnes quae nequeunt Deum noscere nisi ipse uoluerit. Vnde sequitur: et cui uoluerit Filius reuelare. Qui tamen illud numquam reuelat sine Patre et Spiritu Sancto.

Similiter nomen "Spiritus Sanctus" impositum est Tertiae Personae a proprietate sibi propria quae est spirari seu uoluntate produci. Quae uoluntas benigna et sancta est. Ideo nomen illius Personae recte uocatum est Spiritus Sanctus, cui omnia dona et omnis gratia attribuuntur ${ }^{182}$. Nihil in mundo est ipso benignius, nihil dulcius, nihil suauius. Neque tamen suauior est Patre et Filio, quia suauitas una est in tribus.

Vidisti ergo qualiter illa dictio "pater" nunc significat suppositum diuinum, nunc proprietatem eius, et interdum accipitur equiuoce pro Creatore. Et sic omnes tres Personae sunt unus Pater omnium creaturarum. Immo interdum accipitur pro sanctificatore et sic est in speciali Pater angelorum et hominum tota Trinitas. Haec itaque tria nomina sunt magne uirtutis. Vnumquodque enim significat personam diuinam sub propria ratione, quamuis personae a uobis non intelligantur sub propria ratione. Ille qui tamen dixit: Baptizantes eos in nomine Patris et Filii et Spiritus Sancti, bene cognoscebat personas illas sub ratione propria. Nec licet dicere "in nomine Ingeniti ${ }^{183}$ aut Verbi aut Amoris Spirati", neque "in nomine Genitoris uel utriusque Spiratoris", quia alia non significant personas sub ratione propria. Vnde, quamuis proprietas Verbi et Filii non sint duae proprietates, sed una, et solum dicunt rationem ${ }^{184}$, tamen baptizando ac etiam inuocando Sanctam Trinitatem non congrue dicitur "in nomine Patris et Verbi". Dicitur autem Verbum

179 quia quando capitur adiectiue ( $M$ in marg. $a . m$.) tunc est nomen commune et stat] quia tunc est nomen commune et stat IJP; quia tunc non est nomen commune et stat $N$; quia quando accipitur adiectiue stat $Q$; quia quando accepit adiectiue tunc est nomen commune et stat $V \mathbf{1 8 0}$ pro hoc patre uel illo, pro hoc filio uel illo] pro hoc uel ideo patre, pro hoc uel ideo filio $Q \mathbf{1 8 1}$ Primam Personam] Primam $Q$, Prima Persona $V 182$ attribuuntur] tribuuntur $Q$; attribuitur $V 183$ Ingeniti] Geniti $I J V 184$ dicunt rationem] differunt ratione $O P$; distant ratione $Q$ 
de outra maneira: "A primeira pessoa é a Primeira Pessoa". Daí que Cristo haja dito: Eu te bendigo, Pai! ${ }^{[187]}$ Invocou-o pelo nome comum, como se dissesse: "Bendigo-te porque me geraste e és para mim pai, para todos os outros, porém, és Senhor". Por isso acrescentou: Senhor do céu e da terra e de tudo o que neles existe. ${ }^{[187]}$ Quando, a seguir, disse: Ninguém conbece o Filho senão o Pai, e ninguém conhece o Pai senão o Filbo e a quem o Filbo o quiser revelar, ${ }^{[189]}$ tomou então substantiva e não adjectivamente os nomes Filho e Pai porque, quando se tomam adjectivamente, são então nomes comuns e estão indiferentemente por este ou aquele pai, por este ou aquele filho. Neste passo, as palavras do Senhor têm este sentido: "Ninguém conhece a Segunda Pessoa senão a Primeira e a própria Segunda Pessoa e o Espírito Santo, que também é Deus, e ninguém conhece a Primeira Pessoa senão o Filho e a própria Primeira Pessoa e o Espírito Santo". Portanto, não excluía deste conhecimento as Pessoas, mas todas as criaturas que não podem reconhecer a Deus a não ser que ele queira. Daí que se siga: $e$ a quem o Filho o quiser revelar. Filho que, contudo, nunca o revela sem o Pai e sem o Espírito Santo.

De modo semelhante, o nome Espírito Santo é atribuído à Terceira Pessoa em razão do atributo que lhe é próprio, que é ser espirado ou ser produzido pela vontade. Vontade que é benigna e santa. Por isso, o nome desta Pessoa justamente se chama Espírito Santo, a quem são atribuídos todos os dons e toda a graça. Nada há no mundo mais benigno, nada mais amável, nada mais suave. E, contudo, não é mais suave do que o Pai e o Filho, porque reside nos três a mesma suavidade.

Viste, portanto, de que modo a palavra Pai ora significa sujeito divino, ora a sua propriedade e, às vezes, se toma equivocamente por Criador. E, deste modo, as três Pessoas são o único Pai de todas as criaturas. Mais, às vezes se toma por Santificador e, deste modo, toda a Trindade é, em especial, Pai dos anjos e dos homens. E, assim, estes três nomes são de grande poder. Cada um, na verdade, significa a Pessoa divina sob razão própria, embora as Pessoas não sejam por vós entendidas sob razão própria. Mas aquele que disse: Baptizai-os em nome do Pai e do Filbo e do Espírito Santo, ${ }^{[190]}$ conhecia bem estas Pessoas sob razão própria. E não se pode dizer "Em nome do Ingénito, ou do Verbo, ou do Amor Espirado", nem "Em nome do Gerador ou dos dois Espiradores", porque estoutros não significam as Pessoas sob razão própria. Daí que, embora a propriedade de Verbo e de Filho não sejam duas propriedades, mas uma, e apenas afirmem a razão, ao baptizar, contudo, e também ao invocar a Santíssima Trindade se não

[187] Mt 11:25; Lc 10:21

${ }^{[188]}$ Mt 11:25; Lc 10:21

[189] Mt 11:27.

[190] Mt 28:19 
inquantum producitur memoria Patris, Filius inquantum gignitur de substantia gignentis ${ }^{185}$ in natura intellectuali, ut diximus.

In primo itaque signo intelligitur Persona Prima ${ }^{186}$ constituta ex deitate, ut natura est, et deitate, ut aequiualens ${ }^{187}$ est rei absolute qua ${ }^{188}$ persona constituitur et distinguitur. In secundo signo intelligitur generare. In tertio Pater, ut diximus. An tamen genuisse dictat ${ }^{189}$ relationem paternitatis uel eam praecedit, declarabit suo tempore ille qui electus est ad hoc officium. Nam quidam ex uestris putant nil aliud esse Patrem quam hoc quod est genuisse ${ }^{190}$, et Filium hoc quod est ${ }^{191}$ esse genitum. Et quia illum qui genuit impossibile est non genuisse, similiter et Genitum impossibile est [f1. 163] non esse genitum, ideo qui Pater semel est, semper est, et qui Filius semel est, semper Filius est. Et ita Maria numquam desiit esse mater Dei. Et hoc modo non esset in Patre deitas aequiualens generationi seorsum et paternitati seorsum, prout superius diximus. Similiter non esset aliud deitatem aequiualere generari uel genito quam aequiualere filiationi. Neque in Spiritu Sancto esset alia ratio ipsius donari uel produci libere et alia relationis quam spirationem passiuam nominauimus superius. Et eodem modo nomen Patris et Gignentis uel Genitoris idem omnino significarent. Similiter et nomen Geniti atque Filii quod an sit uerum discutiet pastor ille. Pro nunc sequimini quod te superius docui, uidelicet aliam rationem esse generationis actiue et passiue, aliam paternitatis et filiationis.

Tunc ego interrogaui quomodo una persona non sit maior alia, et quare una persona non careat aliqua perfectione, quia in una sunt alia propria quam in alia, et quare non sunt ibi plures productiones quam duae.

Sic me interrogante, angelus ita loqui coepit: "Iam uidendum est quomodo non est maior una persona quam alia. Et aduerte. Sicut duo numeri ${ }^{192}$ in quibus est par multitudo unitatum non dicitur maior alio, quamuis aliae sint unitates in uno quam in alio; sicut non est maior quinarius manus dextrae quam sinistrae licet alii digiti sint in dextra quam in sinistra, sic quia in personis diuinis tot sunt proprietates in una quot sunt in alia, ut superius ostendimus, licet non sint eaedem in una quae sunt in alia, ideo una non est maior alia. Sed accipiendo maius pro eo quod est dignius et nobilius, possetis mirari quare Pater non sit maior Filio ex quo est dignior. Nam generare et ex se habere ${ }^{193}$ omnia dignius est quam generari et ab alio accipere omnia et similiter, quia beatius est ex excellentius dare quam accipere. Sed Pater generat et habet omnia ex se et Filio dat omnia. Filius uero generatur et omnia habet ab alio et omnia accipit a Patre. Ergo dignior est

185 de substantia gignentis] substantia genitoris $Q 186$ Persona Prima] Persona Prima distincta et $Q 187$ ut aequiualens] et aequiualens $I J M V 188$ qua] quia $I M N P V$; quod $Q 189$ dictat] dicat $M N O P Q 190$ quam hoc quod est genuisse] quam genuisse Filium $Q \mathbf{1 9 1}$ et Filium hoc quod est] $\rightarrow$ 
diga apropriadamente "em nome do Pai e do Verbo". Mas diz-se Verbo na medida em que é produzido pela memória do Pai; Filho, na medida em que é gerado da substância do que o gera na natureza intelectual, como dissemos.

No primeiro conceito, portanto, apreende-se a Primeira Pessoa constituída de divindade, enquanto é natureza, e pela divindade, enquanto é equivalente à substância absoluta pela qual a Pessoa se constitui e se distingue. No segundo conceito apreende-se o gerar. No terceiro, o Pai, como dissemos. Mas se o ter gerado exprime a relação de paternidade ou a precede, declará-lo-á em seu tempo aquele que foi eleito para esta tarefa. Pois, alguns de vós consideram que Pai não é senão o ter gerado, e Filho, o ser gerado. E porque é impossível que aquele que gerou não tenha gerado, de modo semelhante é impossível que o Filho [f1. 163] não tivesse sido gerado, por isso aquele que é Pai uma vez é sempre Pai, e o que uma vez é Filho é Filho sempre. E, assim, Maria nunca deixou de ser a Mãe de Deus. E, deste modo, não haveria no Pai a divindade a equivaler isoladamente à geração e isoladamente à paternidade, como dissemos atrás. De modo semelhante, seria o mesmo a divindade equivaler a ser gerado ou a Filho que equivaler a filiação. Nem no Espírito Santo seria uma a razão do próprio ser dado ou livremente produzido, e outra, a da relação que atrás chamámos espiração passiva. E, do mesmo modo, significariam exactamente o mesmo os nomes de Pai e Progenitor ou Criador. E o mesmo também o nome de Génito e de Filho, o que aquele Pastor discutirá se é verdade. De momento, segui o que te ensinei antes, a saber, que uma é a razão da geração activa e passiva, outra a da paternidade e filiação.

Perguntei então de que modo uma Pessoa não é maior do que a outra, e porque não carece uma Pessoa de nenhuma perfeição, porque numa existem coisas próprias que não existem na outra, e porque não há aí mais de duas produções.

Há que ver já, começou deste modo a responder o anjo, quando assim o interrogava, de que modo uma Pessoa não é maior que outra. Presta atenção. Assim como dois números em que é a mesma a quantidade das unidades se não considera um maior que outro, embora sejam distintas as unidades de um das unidades do outro; assim como não é maior o número cinco da mão direita que o da mão esquerda, embora sejam uns os dedos da mão direita e outros os da esquerda; assim, porque nas Pessoas divinas são tantas as propriedades numa como na outra, como demonstrámos antes, embora não sejam as mesmas numa que são na outra; por isso não é uma maior que a outra. Mas, tomando maior por aquilo que é mais digno e mais nobre, poderíeis admirar-vos porque é que o Pai não é maior que o Filho, em relação ao qual é mais digno, pois gerar e ter de si tudo é mais digno do que ser gerado e tudo receber de outrem e, igualmente,

$\leftarrow$ et Filium, hoc est, quod $M V$; et Filium hoc esse quod $N$; et Filium nihil aliud esse quam hoc quod $Q 192$ numeri] nummi $P$; numerum $I V 193$ Nam generare et ex se habere] Nam generare et se habere $I$; Nam generare est et ex se habere $P$; generare et se habere $V$ 
Pater Filio et uterque Spiritu Sancto. Quoniam ergo non potest negari quin sit ${ }^{194}$ dignius dare secundum suam rationem quam accipere, ideo ea ratione non est inconueniens Patrem putare digniorem, non quod sit dignior in deitate, sed in largitione deitatis. Vnde aliqui ex uestris illum uocauerunt auctoritatem, dicentes: "In Patre est auctoritas, in Filio subauctoritas". Vnde et logici dicunt paternitatem esse relationem superpositionis et filiationem suppositionis. Habet ergo illam auctoritatem, sed non est maior propter id nisi ualde improprie, intelligendo pro maius idem quod ${ }^{195}$ dignius uel habens auctoritatem ${ }^{196}$. Vnde quidam ex hic stantibus (et ostendebat Hillarium Pictauiensem) dixit: "Pater est maior Filio neque tamen Filius est minor Patre". Quod sic intelligendum est: Pater, secundum quid, est maior Filio. Filius tamen simpliciter loquendo non est minor Patre. Si tamen Pater aliquo modo est maior Filio, Filius aliquo modo est minor Patre. Sed neque Pater est maior Filio simpliciter neque Filius est minor Patre simpliciter. Adde quod Pater non est maior Filio quia et generare atque dare est deitas, similiter generari atque dari. Si ergo alia res esset generare alia generari, Pater posset dici aliquo modo dignior Filio. Sed quia deitas est ita generari sicut generare et deitas est in Patre et in Filio ${ }^{197}$, sequitur quod cum eadem res sit in uno omnino quae in alio, unus non potest dici nobilior alio. Immo res illa quae est generare est in Filio, quia deitas ${ }^{198}$. Quamuis deitas non aequiualeat ipsi ge [f1. 164] nerare prout est in Filio, ipsa tamen est in Filio. Nam Filius est illa res quae est generare et Pater est quae est generari. Quicquid ergo habet Pater formaliter, habet et Filius et Spiritus Sanctus uel formaliter uel realiter aut identice. Et quicquid habet Filius formaliter, habet et Pater et Spiritus Sanctus uel formaliter uel realiter seu identice. Et quicquid habet Spiritus Sanctus formaliter, habet Pater et Filius uel formaliter uel realiter seu identice ${ }^{199}$. Illa ergo eadem sunt in omnibus personis, sed non eadem eodem modo sunt in omnibus personis. Non ergo maior est una quam alia, quia tot sunt in una quot in alia. Deinde quia illa eadem, quamuis alio modo, sunt in una quam in alia ${ }^{200}$, Deus est omnia in omnibus illis.

194 Quoniam ergo non potest negari quin sit] Sic ergo cum sit $O Q 195$ idem quod] idem quae $M$; idemque $J 196$ pro maius idem quod dignius uel habens auctoritatem] pro maius et dignius idem quod habens auctoritatem $Q \mathbf{1 9 7}$ et deitas est in Patre et in Filio] et deitas est in Patre et in Filio eandem confitentur $M$ (in marg. a m.) $O$; et deitatem eandem in Patre et Filio confitemur $Q$ 198 generare est in Filio quia deitas] ut puta deitas, est in Filio $Q 199$ Et quicquid habet Spiritus (...) realiter seu idemptice.] et similiter dicendum est de Spiritu Sancto circa illud quod formaliter habet, est formaliter in Patre et Filio $Q \mathbf{2 0 0}$ Non ergo maior est una (...) est omnia in omnibus illis.] Non ergo maior est una quam alia quia tot illa eadem sunt in una quae et in alia, quamuis alio modo. Deus est omnia in omnibus illis. $O$; Non ergo maior est una persona quam alia quia illa omnia sunt in unaquaque sed non eodem modo in omnibus personis. Deus enim est omnia in omnibus illis quamuis alio modo. $Q$ 
porque há mais felicidade e é mais nobre dar do que receber. ${ }^{[191]}$ Ora, o Pai gera e tem tudo de si e tudo dá ao Filho. O Filho é gerado e tem tudo de outrem e tudo recebe do Pai. Portanto, o Pai é mais digno que o Filho, e ambos mais dignos que o Espírito Santo. Porque, pois, não pode negar-se que seja mais digno dar, segundo a sua natureza, do que receber, por isso, de acordo com esta razão, não é inconveniente considerar o Pai mais digno. Não que seja mais digno em divindade, mas na repartição a divindade. Daí que alguns de vós o tenham chamado autoridade, dizendo: A autoridade está no Pai, no Filho a sub-autoridade. Daí também que os lógicos digam que a paternidade é a relação de superposição e a filiação, de sub-posição. Tem, pois, essa autoridade, mas não é maior por isso senão muito impropriamente, entendendo por maior o mesmo que mais digno ou o que tem autoridade. Daí que um dos que aqui estão (e apontava Hilário de Poitiers) tenha dito: "O Pai é maior que o Filho e nem por isso o Filho é menor que o Pai”. O que deve ser assim entendido: $O$ Pai, sob certo aspecto, é maior que o Filho. Todavia, o Filho, simplesmente falando, não é menor que o Pai. Se, contudo, o Pai é, de algum modo, maior que o Filho, o Filho é, de algum modo, menor que o Pai. Mas nem o Pai é, simplesmente, maior que o Filho, nem o Filho é, simplesmente, menor que o Pai. Acresce que o Pai não é maior que o Filho porque o gerar e o dar é divindade ao mesmo título que ser gerado e ser dado. Se, pois, gerar fosse uma coisa e outra ser gerado, poderia o Pai considerar-se de algum modo mais digno que o Filho. Mas porque a divindade está tanto em ser gerado como em gerar, e a divindade está no Pai e no Filho, segue-se que, havendo num absolutamente a mesma substância que há no outro, não pode um ser considerado mais nobre que o outro. E mais, a substância que é gerar existe no Filho, porque é divindade. Embora a divindade conforme existe no Filho não equivalha ao próprio [fl. 164] gerar, ela, contudo, existe no Filho. Pois, o Filho é a substância que é gerar e o Pai é a que é ser gerado. Portanto, o que quer que o Pai tenha formalmente, tem-no também o Filho e o Espírito Santo, ou formal, ou realmente, ou de modo idêntico. E o que quer que tenha o Filho formalmente, tem-no também o Pai e o Espírito Santo, ou formal, ou realmente, ou de modo idêntico. E o que quer que tenha o Espírito Santo formalmente, tem-no o Pai e o Filho, ou formal, ou realmente, ou de modo idêntico. Essas coisas são as mesmas em todas as Pessoas, mas não são as mesmas do mesmo modo em todas as Pessoas. Portanto, não é maior uma do que a outra, porque tantas há numa como na outra. Depois, porque elas são as mesmas, embora de outro modo, numa como na outra. Deus é tudo em todas elas. 
Nunc uidendum est ex quo totum quod est in una persona sit deitas, et totum quod est in alia sit deitas, et deitas sit una res, an possint dici tres personae tres res. Et dico tibi, carissime, quod uos iam confitemini tres res ${ }^{201}$ et negare non potestis, quia iste dixit (et ostendebat Augustinum) et uestri ita confitentur. Non tamen illi tres proprie ${ }^{202}$ sunt tres res, sed unica res omnino. Tres enim sunt uere et proprie, sed non proprie tres res, sed unica. Ideo dictum est Et hi tres unum sunt, id est, sunt una res omnino. Eadem enim re conueniunt et distinguntur, ut ostensum est. Vna ergo res sunt, quia totum quod est in qualibet persona deitas est. Tamen, ut dictum huius (et ostendebat Augustinum) quod accepistis uerum sit, sic declaro illud: "Deitas, prout aequiualet tribus rebus uel entitatibus, distinguit personas". Ideo possunt dici tres res, quia re una tribus aequiualente sunt distinctae. Vnde subiunxit ipse, uidelicet Augustinus "Et hi tres sunt una quaedam res summa", hoc est, hi, quos dixi esse tres, sunt una res summa per cuius aequipollentiam tribus rebus dicti sunt hi tres res.

Ecce habes quomodo sunt una res et quomodo sunt tres res per aequiualentiam unius rei tribus rebus. Vna ergo sunt res $^{203}$ summa, quia illa res maxima diuinae essentiae est ratio trium rerum personalium ${ }^{204}$.

Quando ergo dicitur "tres sunt", si quaeratur quid tres, hoc est, tu dicis esse tres, expone et adde substantiuum illi adiectiuo "tres". Quid? Tres homines uel tres dii? Vel quid tres? Noli respondere "tres dii" ne uideatur deitas in ipsis distincta, quamuis posset dici tres dii, hoc est, tres habentes deitatem. Tamen dicendo tres dii, illa dictio "tres" uidetur determinare deitatem. Illa uero determinatio est quaedam multiplicatio et plurificatio et sic uidetur deitas multiplicata et plurificata. Sed si plurificaretur illud quod illa dictio "dii" concernit, omnino esset uera: Tres sunt dii, hoc est, tres sunt habentes deitatem. Et illo modo dictum est: "In principio creauit Deus caelum et terram". Et dicendo "hi sunt", ostensis personis, locutio est minus incongrua quam dicendo "tres dii", quia ista est uera absolute: "Hi sunt dii", id est, habentes deitatem. Sed ista: "Hi sunt tres dii" est suspecta, quia illa dictio "tres" uidetur cadere super significatum illius substantiui "dii" et non super illud quod concernit, uidelicet super illam dictionem "habentes". Nam si caderet super eam, oratio esset uera. Noli ergo respondere quod sint tres dii nisi in sensu illo neque respondeas quod sint tres res, quia uidereris concedere pluralitatem rei qua sunt personae et qua existunt. Tamen possunt dici tres res illo modo quo

201 tres res] tres personae $J$; quod tres presonae sunt tres res $Q \quad \mathbf{2 0 2}$ illi tres proprie] ille tres personae $Q \mathbf{2 0 3}$ res] tres $M \mathbf{2 0 4}$ illa res maxima diuinae essentiae est ratio trium rerum personalium.] est res magna diuinae essentiae et ratio trium rerum personalium. $Q$ 
Agora havemos de ver, uma vez que tudo quanto há numa Pessoa é divindade e tudo quanto há noutra é divindade e a divindade é uma substância, se as três Pessoas podem ser consideradas três substâncias. E digo-te, caríssimo, que vós reconheceis já três substâncias, e não podeis negar visto que este o afirmou (e mostrava Agostinho) e os vossos assim o confessam. Todavia, os três não são propriamente três substâncias, mas uma única substância apenas. São, de facto, real e propriamente três, mas não propriamente três substâncias, mas uma única. Por isso foi dito: E estes três são um só, isto é, são absolutamente uma única substância. Na mesma substância, de facto, convergem e se distinguem, como foi mostrado. São, pois, uma substância, porque tudo quanto há em cada Pessoa é divindade. Todavia, para que a afirmação deste, que vós recebestes (e mostrava Agostinho), seja verdadeira, formulo-a deste modo: "A divindade, na medida em que equivale a três substâncias ou entidades, distingue as Pessoas". Por Isso, podem considerar-se três substâncias, porque se distinguem por uma substância que equivale a três. Daí que ele, ou seja, Agostinho, tenha acrescentado "E estes três são uma espécie de substância suprema”, isto é, estes, que eu disse serem três, são uma substância suprema por cuja equivalência a três substâncias são eles considerados três substâncias.

Aí tens de que modo são uma substância, e de que modo são três substâncias por equivalência de uma substância a três substâncias. São, pois, em conjunto, a substância suma, porque essa substância máxima da divina essência é a razão das três substâncias das Pessoas.

Quando, pois, se diz "São três", se se pergunta, que três, isto é, o que é que tu dizes que são três, explica e acrescenta um substantivo a esse adjectivo "três". O quê? Três homens ou três deuses? Ou que três? Não respondas "três deuses", para não parecer distinta neles a divindade, embora possa considerar-se "três deuses", isto é, três que têm divindade. Contudo, dizendo "três deuses", parece que essa palavra "três" determina a divindade. Mas essa determinação é uma espécie de multiplicação e plurificação e, deste modo, parece que a divindade foi multiplicada e plurificada. Mas se se plurificasse aquilo a que essa palavra "deuses" respeita, seria absolutamente verdadeira: "São três Deuses", isto é, três que têm a divindade. E desse modo foi dito: No princípio Deus criou o céu e a terra. ${ }^{[192]} \mathrm{E}$ dizendo "estes são", mostradas as Pessoas, é menos incongruente a afirmação do que dizer "três deuses", porque esta é absolutamente verdadeira: "Estes são deuses", isto é, que têm a divindade. Mas esta: "Estes são três Deuses" é suspeita, porque essa palavra "três" parece recair sobre o significado daquele substantivo "deuses" e não sobre aquilo a que respeita, a saber, sobre a expressão "que têm". Pois, se recaísse sobre esta, a afirmação seria verdadeira. Não respon- 
declarauimus. Sed respondeas: sunt tres personae siue tres subsistentiae ${ }^{205}$ seu hypostasis, non tres substantiae, quia substantia [f1. 165] idem est quod usia siue essentia uel natura diuina. Si tamen nomine substantiae intelligatur subsistentia ${ }^{206}$ uel persona quasi per se una, potest dici quod sunt tres substantiae sicut Graeci solent dicere quando dicunt: sunt tres hypostases. Sed melius est nomen hypostasis uocare subsistentiam quam substantiam.

Sunt etiam tres existentes, sed non tres existentiae, quia deitas ipsa est existentia qua ipsi tres existunt. Et nota quod ratio illa quam posuit iste (ostendebat Scotum) bona est, uidelicet, quia ideo possumus dicere tres sunt creantes et tres existentes, non tres creatores neque tres existentiae. Quia dicendo "tres creantes", ponuntur duo nomina adiectiua quorum neutrum alterum determinat sicut neutrum ab altero dependet, sed utrumque determinat substantiuum ${ }^{207}$ subintellectum sicut utrumque illorum ad ipsum ${ }^{208}$ dependet. Illud autem substantiuum quod determinat illam dictionem "tres" non est Deus, ut diximus, neque proprie res, sed persona, subsistentia ${ }^{209}$ seu hypostasis.

Est ergo sensus: Tres creantes uel tres existentes, hoc est, tres personae existentes uel creantes. Dicendo autem tres creatores, illa dictio "tres" cadit super significatum ipsius creationis et plurificat eam. Et quia ipsa uis creatiua et creatio est una in tribus, dicendo tres, plurificatur ${ }^{210}$. Et sic oratio fit falsa.

Tunc interrogaui: Domine mi, quamuis non omnia perfecte capiam, hoc tamen intellexi quod in diuina persona nil est quod non sit deitas et etiam quod persona est Deus et Deus est persona. Quomodo ergo sunt tres personae et non tres dii?

Respondit angelus: Augustinus hic existens ualde de hoc dubitauit.

Et cum angelus hoc diceret, Augustinus suspirauit quasi compatiens uiatoribus qui ista non ualent intelligere perfecte.

Dixitque angelus: Necesse est ut huic adiectiuo "tres" correspondeat aliquod substantiuum ${ }^{211}$. Non tantum propter haereticos interrogantes "quid tres", sed propter rei ueritatem. Nam persona notat et significat aliquid subsistens et incommunicabile in natura intellectuali. Oportet igitur in persona esse duo: naturam intellectualem et aliam rem uel entitatem per quam subsistat incommunicabiliter ${ }^{212}$ et distinguatur ab alio in tali natura subsistente. Si ergo in Patre esset talis res alia ab essentia, tunc manifestum esset a quo sumeretur ratio personae. Sed nunc

205 subsistentiae] substantiae $V \mathbf{2 0 6}$ subsistentia] substantia $J V 207$ alterum determinat (...) utrumque determinat substantiuum] alterum determinat substantiuum $I V \quad 208$ ad ipsum] ad $\rightarrow$ 
das, pois, que são três deuses, a não ser naquele sentido. E nem respondas que são três substâncias, porque pareceria que concedes a pluralidade à substância pela qual são Pessoas e pela qual existem. Podem-se, contudo, considerar três substâncias, de acordo com o modo como declarámos. Mas deverias responder: "São três Pessoas", ou três subsistências ou hipóstases, não, "três substâncias", porque a substância [f1. 165] é o mesmo que ussia, ou essência, ou natureza divina. Se, porém, pelo nome de substância se entender subsistência ou pessoa una como que per se, pode dizer-se que são três substâncias, do mesmo modo que os gregos costumam dizer quando dizem: "São três hipóstases". Mas é melhor designar como subsistência o nome hipóstase do que como substância.

São também três os que existem, mas não três existências, porque a própria divindade é a existência pela qual os mesmos três existem. E nota que a razão que este apresentou (apontava Escoto) é boa, a saber, que, por isso, podemos dizer que são três os que criam e três os que existem, não três os criadores, nem três as existências. Porque ao dizer "três os que criam", avançam-se dois nomes adjectivos, nenhum dos quais determina o outro, assim como nenhum depende do outro, mas um e outro determinam o substantivo subentendido, do mesmo modo que ambos estão dependentes em relação a ele. Todavia, esse substantivo que determina a palavra "três" não é Deus, como dissemos, nem propriamente "substância", mas pessoa, subsistência ou hipóstase.

Portanto, o sentido é: três os que criam ou três os que existem, isto é, três Pessoas que existem ou que criam. Dizendo, porém, "três criadores", a palavra "três" recai sobre o significado da própria criação e plurifica-a. E dado que a força criativa e a criação é única nos três, ao dizer "três", plurifica-se. E, deste modo, a frase torna-se falsa.

Meu senhor, perguntei então, embora não tenha apreendido perfeitamente tudo, isto, porém, compreendi, que na Pessoa divina não há nada que não seja divindade e, também, que Pessoa é Deus e Deus é Pessoa. Como são, pois, três Pessoas e não três Deuses?

Aqui Agostinho duvidou bastante disso, afirmou o anjo.

Quando o anjo disse isto, Agostinho suspirou como que se compadecendo dos que ainda peregrinam, que não conseguem entender perfeitamente isto.

É necessário, disse o anjo, que a este adjectivo "três" corresponda um substantivo. Não apenas por causa dos heréticos, que perguntam "que três", mas por causa da verdade de facto. Pois, pessoa indica e significa algo subsistente e incomunicável na natureza intelectual. Portanto, é preciso que na pessoa haja duas coisas, natureza intelectual e outra coisa ou entidade pela qual subsista de modo incomunicável e se distinga de outro subsistente nessa natureza. Se, pois, no Pai existisse essa entidade distinta da essência, seria então claro de onde

$\leftarrow$ utrumque $N$; ab ipso $Q \mathbf{2 0 9}$ subsistentia] substantia $V \mathbf{2 1 0}$ plurificatur] plenificatur $Q$; plurificant $V 211$ substantiuum] substantiuo $I J V 212$ incommunicabiliter] in communi causabiliter $V$ 
quoque ponendo personas simplices et in eis solam deitatem, idem erit quia diuina essentia est natura intellectualis et perfecte supplet uicem illius rei per quam persona subsistit et distinguitur. Totus ergo Pater est persona et duo in se includit: naturam et rem per quam est persona. Non quidem tamquam duo distincta, sed unum duobus perfecte aequiualens includit. Quia tamen ratio personae ab illa re quae distinguit sumitur, quia per illam habet esse incommunicabile, ideo alia est ratio naturae, alia personae. Non quia sola illa res sit persona, sicut homo non dicit solam rationem, sed etiam sensum, tamen esse hominis ratione sumitur. In proposito tamen illa alia res qua persona distinguitur non est alia res ab essentia diuina, sed essentia supplet uicem illius rei perfecte ac si ibi poneretur tamquam distincta ab ipsa. Totum ergo quod est in Patre est Deus et deitas. Nam et quo Pater Deus est et quo absolute est, deitas est. Et quo persona est, non est alia res a deitate, sed est ipsa deitas prout aequiualet tali rei et supplet uicem eius ${ }^{213}$. [f1. 166] Tres sunt ergo personae, quia tres subsistentes, tres per se existentes. Sed non sunt tres dii, sed bene tres deitatem habentes. Et quia distinctio trium non est per deitatem ut dietas et essentia est, sed est per deitatem prout supplet uicem trium rerum, ideo plurificando personas non plurificamus deitatem. Quando ergo una res duabus perfecte aequiualet, non sequitur ratione qua aequiualet uni plurificetur, ergo et ratione qua aequiualet alii plurificabitur. Sicut ergo eadem re conueniunt personae et differunt, ita eadem re plurificantur et unificantur ${ }^{214}$ prout illa una aequiualet pluribus. Vnde non est contra primum principium quia, sicut tu saluas, dixit Thomae, ibi non esse contradictionem propter pluritatem entium rationis, et tu, dixit Scoto, propter non identitatem illorum formalem uel ex natura rei, ita ego tertius theologus de utroque uestrum sapiens, utrumque declarans et utrumque concilians, saluabo non esse contradictionem ibi ullam propter aequiualentiam deitatis pluribus rebus. Eadem ergo res manet una et plurificatur quia deitas, ut natura et ut deitas est, manet una et ipsa eadem prout aequipollet tribus rebus hypostaticis plurificatur. Alia ergo ratione manet, alia plurificatur. Vnde ipsamet prout aequiualet rationi paternitatis uel rationi qua haec persona est persona differt a seipsa et non est eadem secum, sed alia a se prout est ratio alii personae ut sit alia persona et prout aequiualet rationi filiationis. Vnde sicut paternitas non est filiatio, ita neque deitas prout aequiualet paternitati est deitas prout aequiualet filiationi. Ideo dicitur quod paternitas, ut comparata ad essentiam, transit, ut comparata ad suppositum ${ }^{215}$, manet. Semper tamen manet et semper transit, ut iste Scotus dixit ${ }^{216}$ : "Proprietas hypostatica comparata ad aliam uidetur manere distincta ab illa, comparata ad naturam transit in illam". Tamen nota quod ostendendo diuinam, naturam seu deitatem, haec oratio est uera: "Hoc est paternitas et hoc est filiatio". Non tamen "paternitas est filiatio" conceditur. Et hoc ideo quia deitas bene potest dici paternitas ${ }^{217}$, quia 
tiraria a razão de pessoa. Mas, olhando agora também as Pessoas individualmente e nelas apenas a divindade, será o mesmo, porque a essência divina é, por natureza, intelectual e substitui perfeitamente aquela coisa pela qual a pessoa subsiste e se distingue. O Pai é, pois, integralmente pessoa e inclui em si duas coisas: a natureza e a entidade pela qual é pessoa. Não certamente como duas coisas distintas, mas inclui uma que equivale perfeitamente a duas. Mas porque a razão de pessoa se tira daquela entidade que distingue, porque por ela tem o ser incomunicável, por isso, uma é a razão de natureza, outra a de pessoa. Não que apenas essa entidade seja pessoa, do mesmo modo que homem não consta só de razão mas também de sentimento, contudo o ser do homem tira-se da razão. Também, na mesma linha, aquela outra entidade pela qual a pessoa se distingue não é distinta da essência divina, mas a essência supre perfeitamente a vez dessa entidade, como se fosse aí posta como distinta dela. Portanto, tudo quanto há no Pai é Deus e divindade. Pois, por aquilo por que o Pai é Deus, e por aquilo por que é absolutamente é divindade. E por aquilo por que é pessoa não é uma entidade distinta da divindade, mas é a própria divindade enquanto equivale a essa entidade e supre a sua vez. [fl. 166] São, portanto, três Pessoas, porque três os que subsistem, três os que existem per se. Mas não são três deuses, mas somente três que têm a divindade. E porque a distinção dos três se não faz pela divindade enquanto a divindade é também essência, mas se faz pela divindade na medida em que supre a vez das três entidades, por isso, plurificando as Pessoas, não plurificamos a divindade. Quando, pois, uma coisa equivale perfeitamente a duas, não se segue que, se se plurifica pela razão por que equivale a uma, logo se plurificará pela razão por que equivale à outra. Assim, pois, como as Pessoas convergem e divergem em razão da mesma substância, assim também pela mesma se plurificam e se unificam na medida em que essa única equivale a várias. Daí que não seja contra o primeiro princípio porque, como tu ressalvas, disse a Tomás, que aí não há contradição por causa da pluralidade dos entes da razão, e tu, disse a Escoto, por causa da sua não identidade formal ou pela natureza da coisa, assim eu, o terceiro teólogo sábio graças a vós, clarificando um e outro e um e outro conciliando, manterei que não há aí contradição nenhuma em razão da equivalência da divindade a várias substâncias. A mesma substância, pois, mantém-se una e plurifica-se porque a divindade, enquanto é natureza e enquanto é divindade, se mantém una, e ela mesma, na medida em que equivale a três substâncias hipostáticas, se plurifica. Mantém-se, pois, por uma razão, plurifica-se por outra. Daí que ela mesma, na medida em que equivale à razão de paternidade ou à razão pela qual esta Pessoa é pessoa, difira de si mesma; e não é a mesma consigo, mas distinta de si, na medida em que serve de razão a outra Pessoa para ser outra pessoa e na medida em que equivale à

$\leftarrow$ iste sanctus dixit $V \mathbf{2 1 7}$ quia deitas bene potest dici paternitas] quia paternitas bene potest dici deitas et est deitas $Q$ 
aequiualet ei. Similiter potest dici filiatio, quia aequiualet ei. Sed non potest dici "paternitas est filiatio", quia nullo modo est neque formaliter neque aequiualenter. Paternitas enim non aequiualet filiationi neque filiatio paternitati. Quando ergo dicuntur duo de tertio quod utrique illorum aequiualet et neutrum illorum alteri aequiualet, tunc illa duo non propter hoc dicuntur inter se nisi sic: "paternitas est illa res quae est filiatio uel quae aequiualet filiationi". Vnde non est omnino hoc dicere falsum: "paternitas est filiatio". Non quod ratio paternitatis sit ratio filiationis, sed quod res illa quae est paternitas, ipsa eadem est filiatio. Aduerte melius quare haec ratio conceditur.

Deitas est sapientia, et deitas est bonitas, ergo bonitas est sapientia. Et tamen deitas aequiualet et sapientiae et bonitati, non autem sapientia bonitati aut econtra. Hoc autem non conceditur absolute. Deitas est paternitas et deitas est filiatio, ergo paternitas est filiatio, non sequitur. Quare hoc non sequitur et ibi sequitur? Dico tibi hoc ideo esse quia sapientia et bonitas se habent ad deitatem conuertibiliter, quia sunt secum in omni persona. Deitas enim in [f1. 167] qualibet persona aequiualet sapientiae et bonitati. Paternitas autem et filiatio et aliae proprietates personarum se habent ad deitatem sicut quasi contrahens ad quasi contractum. Quando ergo una res illimitata ad duas aequiualet illis duabus, tunc quamuis utraque illarum dicatur uere de illa, non tamen propter id una illarum dicitur de alia, sicut duae differentiae dicuntur de animali, puta rationale et irrationale. Neque tamen rationale est irrationale. Vnde si animal aequiualeret rationali et irrationali, non sequitur ex affirmatione utriusque illorum de animali affirmatio eorum inter se.

Haec ergo est causa quare paternitas non est filiatio, cum utraque sit deitas et non illa quam posuistis uos, dixit Scoto et Thomae. "Vos enim a rationibus hypostaticis remouistis omnem perfectionem et dixistis eas abstrahere a finito et infinito. Et hoc fecistis quia, aliter tenendo, sequeretur quod aliqua perfectio esset in persona una qua careret alia. Sed nos iam ostendimus nihil esse in persona una quod realiter et identice non sit in alia, quia deitas est res una cum 
razão de filiação. Por isso, assim como paternidade não é filiação, assim também divindade, na medida em que equivale a paternidade, não é divindade na medida em que equivale a filiação. Por isso se diz que paternidade, quando relacionada com essência, transita, quando comparada com sujeito, mantém-se. Mantém-se, contudo, sempre e sempre se transfere, como disse aqui Escoto: "A propriedade hipostática associada a outra parece manter-se distinta dela; associada à natureza, transfere-se para ela". Nota, contudo, que, apontando para a natureza divina ou para a divindade, é verdadeira esta afirmação: "por uma coisa é paternidade e por outra é filiação". Não se concede, contudo: "paternidade é filiação". E isso por esta razão, porque a divindade pode perfeitamente considerar-se paternidade, porque lhe equivale. Pode igualmente considerar-se filiação, porque lhe equivale. Mas não pode dizer-se "paternidade é filiação", porque o não é de modo nenhum, nem formal, nem equivalentemente. Paternidade, de facto, não equivale a filiação, nem filiação a paternidade. Portanto, quando duas coisas se afirmam de uma terceira que equivale a cada uma delas e nenhuma delas equivale à outra, então, por causa disso, essas duas não se afirmam entre si senão deste modo: "paternidade é aquela coisa que é filiação ou que equivale a filiação”. Daí que não seja completamente falso afirmar isto: paternidade é filiação. Não que a razão de paternidade seja a razão de filiação, mas porque a substância que é paternidade é ela mesma filiação. Atenta melhor porque é que se concede este raciocínio:

Divindade é sabedoria, e divindade é bondade, logo, bondade é sabedoria. E, todavia, divindade equivale a sabedoria e a bondade, mas não sabedoria a bondade, ou vice-versa. Isto, porém, não se concede de forma absoluta. Divindade é paternidade, e divindade é filiação, logo, paternidade é filiação. Não tem coerência. Porque não tem coerência este e tem coerência aquele? Digo-te que isto é assim porque sabedoria e bondade se posicionam relativamente a divindade conversivelmente, porque estão consigo em cada Pessoa. Divindade, de facto, [fl. 167] equivale em cada Pessoa a sabedoria e a bondade. Mas paternidade e filiação e outras propriedades das Pessoas posicionam-se relativamente a divindade como uma espécie de contraente perante uma espécie de contrato. Quando, pois, uma coisa ilimitada a duas equivale a essas duas, então, embora cada uma delas se afirme realmente dessa, nem, contudo, por causa disso uma delas se afirma da outra, do mesmo modo que duas diferenças se afirmam de um animal, por exemplo, racional e irracional. E, no entanto, racional não é irracional. Por isso, equivalendo animal a racional e irracional, nem por isso se segue da afirmação de ambos acerca de animal a afirmação deles entre si.

É, portanto, esta a causa por que paternidade não é filiação, embora uma e outra sejam divindade, e não essa que vós avançastes, disse a Escoto e a Tomás. Efectivamente vós removestes das razões hipostáticas toda a perfeição e dissestes que elas se diferenciavam de finito e infinito. E fizestes isso porque, defendendo outra posição, seguir-se-ia que haveria numa Pessoa alguma perfeição de que outra careceria. Mas nós já mostrámos que nada há numa Pessoa que real e iden- 
illis et illud sufficit propter summam perfectionem personae ut in ea sit deitas quae aequiualeat omni perfectioni etiamsi non aequiualeat prout in ipsa est. Satis est personae habere illud quod in se continet omnem perfectionem. Relationes certe diuinae si res sint et entia non solum erunt ens in communi sed tale ens et tale unum et tale uerum et tale bonum. Si enim non abstrahunt a bonitate ${ }^{218}$ et ueritate etiam non abstrahunt a perfectione. Et si non abstrahunt ab unitate quae, secundum te, dixit ad Scotum, posterior est quam quantitas uirtutis, quomodo uis ut abstrahant ab ipsa quantitate? Nonne quantitas illa est modus intrinsecus? Nonne modus intrinsecus uel est de quidditate uel propinquissimus quidditati? Vnitas, ueritas, bonitas, passiones sunt et posteriores quantitate uirtutis. Ens in communi abstrahit ab omni gradu ex sui natura. Ens sub illo contentum abstrahere non potest a gradu et non abstrahere ab unitate, ueritate et bonitate quia, includens posteriora, includit et illorum priora. Quod si quantitas uirtutis non sit prius unitate, tunc diuisio per unum et multa esset prior quam diuisio per quantum et non quantum uel per finitum uel infinitum, quod esset pro Thoma, hic contra te et tuos. Idem ergo dicendum est de proprietatibus diuinarum personarum quod et de essentialibus, quod nullis ${ }^{219}$ earum repugnat perfectio. Si enim alicui ex sua ratione formali et natura propria repugnaret perfectio, illi etiam repugnaret uniri et copulari realiter illi quod est perfectum. Et cui non repugnat esse rem perfectionis infinitae, non repugnat etiam naturae suae perfectio ${ }^{220}$. Si quoque non quantitas ${ }^{221}$ per se includeretur in natura relationum diuinarum, nullo modo quantitas eis competere posset per regulam uestram quae dicit: "Quando aliquid competit alicui per se, oppositum illius nec per se nec per accidens potest illi competere". Deitas ergo non potest supplere uicem rei illius cui omnis perfectio repugnaret, siqua talis esset. Nulla tamen talis est. Et quia non est alia entitas deitas et alia perfectio eius infinita neque alia ${ }^{222}$ sapientia, alia perfectio sapientiae, sed deitas est omnia, non est opus inquirere an sapientia Dei sit formaliter infinita, quia deitas ipsa, prout aequiualet omnibus illis, est pelagus perfectionis infinitae. Et ipsa solum ut natura considerata non est pelagus.[f1. 168] Ipsa ergo unica est pelagus ex eo quia omnino unica res existens aequiualet omnibus. Neque oportet dicere quod ipsa deitas, ab omnibus attributis et proprietatibus abstracta, est pelagus, quia omnia illa in se continet eminenter. Non est ita dicendum quia tunc esset bis pelagus per duplicem continentiam, primo eminentialem, deinde formalem. Et tunc iterum possemus quaerere utrum ipsa deitas ut abstrahit ab omni continentia eminentiali et formali sit pelagus. Deinde deitas non continet illa formaliter tamquam entitates distinctas, sed est unica et simplicissima entitas in se, aequiualens tamen omnibus illis ratione cuius aequiualentie est pelagus. Nullum ergo illorum quibus aequiualet ipsa est pelagus, quia nullum aliorum

218 ab unitate] a bonitate $P Q \mathbf{2 1 9}$ quod nullis] quod nullus $I$; quod nulli $O$; quia nulla $Q 220 \mathrm{Si}$ enim alicui ex sua ratione (...) non repugnat etiam naturae suae perfectio.] Illi etiam repugnaret uniri et copulari realiter illi quod est perfectum et eum repugnat esse rem perfectionis infinitae. $\rightarrow$ 
ticamente não haja na outra, porque a divindade é uma substância única com elas e isso basta, por causa da suma perfeição da Pessoa, para que nela esteja a divindade que equivalha a toda a perfeição, embora não equivalha conforme nela existe. Basta à Pessoa ter aquilo que em si contém toda a perfeição. As relações divinas, sem dúvida, se são substâncias e entes, não serão apenas entes em geral, mas este ente, e este um, e esta verdade, e este bem. Se, de facto, não diferenciam de bondade e de verdade, também não diferenciam de perfeição. E se não diferenciam de unidade que, segundo tu, disse a Escoto, é posterior à quantidade da virtude, como queres que diferenciem da própria quantidade? Não é esta quantidade uma medida intrínseca? Não é a medida intrínseca relativa à quididade ou muito próxima da quididade? Unidade, verdade, bondade são afecções (passiones) da quantidade da virtude e são-lhe posteriores. O ente em geral, de sua natureza, diferencia de todo o grau. O ente sob ele contido não pode diferenciar de grau e não diferenciar de unidade, verdade e bondade porque, incluindo o que está depois, inclui também o que está antes deles. Pois, se a quantidade da virtude não estiver antes da unidade, então a divisão por um e por muitos estaria primeiro que a divisão por quantum e não quantum, ou por finito e infinito, o que seria favorável a Tomás, contra ti e os teus, neste ponto. Deve, pois, dizer-se das propriedades das Pessoas divinas o mesmo que se diz também dos essenciais, que a nenhuma delas repugna a perfeição. Se, na verdade, a alguma, de sua razão formal ou da própria natureza, repugnasse a perfeição, repugnar-lhe-ia também unir-se e associar-se realmente àquilo que é perfeito. E a quem não repugna ser objecto de perfeição infinita, também não repugna a perfeição à sua natureza. Se também a não quantidade se incluísse per se na natureza das relações divinas, de modo nenhum poderia a quantidade competir-lhes pela vossa regra, que diz: "Quando alguma coisa compete per se a outra, o seu oposto não pode competir-lhe nem per se nem per accidens". Portanto, a divindade não pode suprir o lugar daquela substância a que repugnasse toda a perfeição, se alguma substância assim existisse. E nenhuma assim existe. E dado que não existe uma entidade divindade e uma perfeição sua infinita, nem uma sabedoria, uma perfeição da sabedoria, mas a divindade é todas as coisas, não é necessário indagar se a sabedoria de Deus é formalmente infinita, porque a própria divindade, na medida em que equivale a todas elas, é pélago de perfeição infinita. E ela, considerada só como natureza, não é pélago. [f1. 168] Portanto, ela sozinha é pélago, uma vez que, absolutamente única substância existente, equivale a todas as substâncias. Nem é preciso dizer que a própria divindade, separada de todos os atributos e propriedades, é pélago, porque contém em si todas essas coisas de um modo eminente. Nem deve assim dizer-se porque, então,

$\leftarrow$ Si alicui ex sua ratione formali et natura propria repugnaret perfectio non etiam repugnat naturae suae perfectio. $Q \mathbf{2 2 1}$ non quantitas] non quantitas eis competeret $Q \mathbf{2 2 2}$ talis est. Et quia non est alia entitas deitas et alia perfectio eius infinita neque alia] talis est neque alia $Q$ 
aequiualet omnibus. Nam illa res deitas est illud quod habet esse suum et aequiualet essentiis omnium aliorum.

Ecce uidetis quid sit sentiendum de relationibus diuinis et rationibus hypostaticis, et quare paternitas non sit filiatio, tamen est id quod filiatio, et quare sapientia est bonitas et etiam id quod bonitas, et quod quicquid est in persona una est aliquo modo in alia ${ }^{223}$. Nunc autem considerandum est quare neque Pater neque Filius possunt gignere alium Filium aut Spiritum Sanctum spirare, et quare Spiritus Sanctus neque generat neque spirat.

De hoc tu, dixit ad Ioannem Scotum, satis acute scripsisti. Nam generatio Dei, sicut et Deus et omnia diuina, est de se haec. Omne autem de se singulare est implurificabile 224 . Vnica ergo est generatio, unica spiratio. Nam si possent esse plures, possent esse infinitae. Et ita essent de facto infiniti Filii et infiniti Spiritus Sancti, nam in aeternis omne quod potest esse iam est. Et ita essent personae infinitae, quod recte respuistis, et non solum esset multitudo infinita finitorum, sed infinitorum. Accidit ${ }^{25}$ ad rem nostram et propositum nostrum quia Pater generat uigore infinito et aeterno et Genitum est aeternum et infinitum et semper terminat generationem Patris, quia generatio illa non transit in praeteritum. Ipso autem terminante complete et adaequate ${ }^{226}$, nil aliud eam terminare potest. Similiter Spiritus Sanctus totaliter et adaequate ac semper ${ }^{227}$ terminat spirationem Patris et Filii. Ideo nulla alia persona potest eam terminare. Sed ratio prior est euidentior quia generatio est de se haec et singularis, similiter et spiratio. Ideo plurificari non potest, quia omne quod pluribus communicari potest etiam infinitis communicari poterit. Et si hoc potest esse, in diuinis iam est. Scito tamen quod principium gignendi, uidelicet memoria perfecta et uoluntas perfecta est in omnibus tribus personis, quia deitas illis perfecte aequiualens. Sed quia in memoria non potest fundari nisi unica generatio, quae iam in ipsa fundatur prout in Patre existit, ideo prout memoria in alia persona existit non fundatur generatio in ea. Similiter quia spiratio unica potest fundari in uoluntate perfecta et illa fundatur in ipsa prout in Patre et Filio est ideo prout in Spiritu Sancto est non fundatur in illa. Vnde Filius et Spiritus Sanctus habent principium generandi, hoc est, quo Filius generatur. Habent enim memoriam fecundam, quae est principium ex sui natura, tamen non

223 in alia.] in alia. Vos aliquomodo consueuistis abnegare istum: Paternitas est filiatio et iam bonitas est sapientia concedere. Omnia tamen illa sunt unica res. $P \mathbf{2 2 4}$ Omne autem de se $\rightarrow$ 
por causa do duplo conter, eminente primeiro, depois formal, seria duas vezes pélago. E então poderíamos perguntar de novo se a própria divindade, enquanto separa de todo o conter eminente e formal, é pélago. Depois, a divindade não contém essas substâncias formalmente, enquanto entidade distinta, mas é em si entidade única e simplicíssima, equivalendo, contudo, a todas elas, em razão de cuja equivalência é pélago. Por consequência, nada daquilo a que ela equivale é pélago, porque nenhuma dessas coisas equivale a tudo. Pois, essa substância divindade é aquilo que tem o ser como seu e equivale às essências de todas as outras coisas.

Aí tendes o que se deve pensar das relações divinas e das razões hipostáticas, e porque é que paternidade não é filiação, ainda que seja o que é filiação, e porque é que sabedoria é bondade, e também aquilo que é bondade, e que tudo o que existe numa Pessoa existe de algum modo na outra. Mas agora deve ver-se porque é que nem o Pai pode gerar outro Filho, nem o Pai e o Filho podem espirar outro Espírito Santo, e porque é que o Espírito Santo nem gera, nem espira.

Sobre isto, disse a João Escoto, escreveste tu com muita subtileza. Pois, a geração de Deus, como também Deus e tudo o que é divino, é, de si, isto. E tudo o que, de si, é singular, é implurificável. Por isso, a geração é única, única é a espiração. Pois, se pudessem ser várias, poderiam ser infinitas. E, assim, seriam, de facto, infinitos os Filhos e infinitos os Espíritos Santos, pois, in aeternis, tudo o que pode ser já é. E, assim, seriam infinitas as Pessoas, coisa que rejeitastes e bem, e não seria infinita apenas a multidão dos finitos, mas também a dos infinitos. Acresce ao nosso tema e ao nosso propósito que o Pai gera com energia infinita e eterna, e o Filho é eterno e infinito e encerra uma vez por todas a geração do Pai, porque essa geração não se transpõe para o passado. Terminando ela completa e adequadamente, nenhuma outra coisa a pode encerrar. De igual modo, o Espírito Santo encerra total e adequadamente e de uma vez por todas a espiração do Pai e do Filho. Por isso a não pode encerar nenhuma outra Pessoa. Mas a primeira razão é mais clara, porque a geração é, de si, esta espiração, que é de igual modo singular. Por isso se não pode plurificar porque, tudo o que pode comunicar-se a vários, poderá também comunicar-se a infinitos. E se isto pode acontecer, in diuinis já aconteceu. Fica também a saber que o princípio de geração, a saber, a memória perfeita e a vontade perfeita, existe nas três Pessoas, porque a divindade é-lhes perfeitamente equivalente. Mas, porque não pode fundar-se na memória senão uma única geração, que nela se funda já enquanto existe no Pai, por isso, na medida em que a memória exista noutra Pessoa não se funda nela a geração. De modo semelhante, porque a única espiração se pode fundar na vontade perfeita e nela se funda conforme existe

$\leftarrow$ singulare est implurificabile.] Quod autem de se est singulare et implurificabile $Q 225$ Accidit] Accedit $M O P Q \mathbf{2 2 6}$ adaequate] ad aequale $I J M V \mathbf{2 2 7}$ et adaequate, nil (...) et adaequate ac semper] et adaequate ac semper $I$ 
est principium generandi, sicut Spiritus Sanctus habet uoluntatem perfectam, quae est principium [f1. 169] spirandi, sed non est ei principium spirandi. Voluntas quae est in ipso spirat, sed non prout in ipso est spirat. Quaecumque ergo potest Pater, potest Filius et Spiritus Sanctus quia eandem potentiam omnino habent, quamuis productio in uno ipsorum fundetur et ad alium ipsorum terminetur. Et sic productio in persona ad quam terminatur non fundatur. Sic illa persona in qua fundatur productio non terminat productionem.

Ex his uidere potes ${ }^{228}$ numerum personarum diuinarum et quomodo plures esse non possunt, et quod ratio personae est deitas prout aequiualet rei hypostatice et quasi contrahenti. Et ita persona notat aliquid reale. Potest tamen deinde comparari ad naturam diuinam. Quae nantura diuina uel qui Deus uidetur se habere ad Patrem et Filium et Spiritum Sanctum sicut quasi homo ad Petrum, Paulum et Ioannem qui, ex eo quia subsunt omnibus, dicuntur supposita et personae, quia quilibet illorum est hoc aliquid et per se unus. Sic quia Pater et Filius et Spiritus Sanctus uidentur respectu Dei ita se habere, dicuntur supposita et personae per translationem et methaphorice. Non est igitur mirum si aliqui dixerunt personam in diuinis ${ }^{229}$ significare secundam intentionem et esse secundam intentionem, non quia constitutum personarum non sit aliqua res, hoc est, essentia, ut aequiualens rei tali, sed quia illa tria possunt comparari ${ }^{230}$ ad essentiam Dei et illis potest attribui talis intentio qualis, ut diximus, Petro, Paulo et Ioanni respectu hominis. In hoc tamen differunt, quia Petrus, Paulus et Ioannes comparantur ad naturam humanam tamquam indiuidua ad naturam quae non est una numero. In diuinis ${ }^{231}$ uero, tres personae comparantur ad hanc naturam diuinam, ut haec est, quia tres personae sunt unus Deus numero. Illi uero non sunt unus homo numero, sed tres homines.

Bene intellexisti quomodo persona est ens reale et quomodo est ens rationis. Sed restat declarare unum uidelicet quando dicimus "Tres sunt personae", quid ibi plurificatur? Essentia non, neque proprietas, quia proprietates sunt unice et incommunicabiles. Aut ergo plurificatur sola intentio secunda ut sit sensus "tres personae", hoc est, tres quorum quilibet est per se unus, aut negatio communicabilitatis ut sit sensus "tres personae", hoc est, tria incommunicabilia. Et certum est his duobus modis esse tres personas et nomen personae abstrahere ab illis tribus ut persona in communi notet per se unum uel incommunicabile et sub illo communi intentionali uel negatiuo sit hoc et illud per se unum et hoc uel 
no Pai e no Filho, por isso se não funda nela enquanto existe no Espírito Santo. Daí que o Filho e o Espírito Santo tenham o princípio de geração, isto é, pelo qual o Filho é gerado. É um facto que têm a memória fecunda, que é princípio próprio da sua natureza, mas não é princípio de geração, assim como o Espírito Santo tem a vontade perfeita, que é princípio [f1.169] de espiração, mas lhe não pertence como princípio de espiração. A vontade, que nele reside, espira, mas não espira conforme nele reside. Portanto, tudo quanto pode o Pai podem o Filho e o Espírito Santo porque têm absolutamente o mesmo poder, embora a produção se funde num deles e se termine no outro. E, deste modo, a produção não se funda na Pessoa em que se termina. Por esta razão, a Pessoa na qual se funda a produção não termina a produção.

A partir disto, podes aperceber-te do número das Pessoas divinas, e como não podem ser várias, e que a razão de Pessoa é a divindade, na medida em que equivale à substância hipostática e, de algum modo, ao contraente. E, assim, Pessoa assinala algo real. Pode, enfim, comparar-se depois à natureza divina. Esta natureza divina, ou este Deus, parece estar para Pai, Filho e Espírito Santo quase como homem está para Pedro, Paulo e João, os quais, dado o facto de serem suporte de tudo, se designam sujeitos e pessoas, porque cada um deles é esse algo e esse uno per se. Deste modo, porque parece que Pai, Filho e Espírito Santo assim estão para Deus, designam-se Sujeitos e Pessoas por transposição e metaforicamente. Não é, pois, de estranhar se alguns disseram que Pessoa in diuinis significa segunda intenção e é segunda intenção, não que o constituto das Pessoas não seja uma determinada substância, isto é, essência, enquanto é equivalente a essa substância, mas porque as três se podem comparar à essência de Deus e se lhes pode atribuir a mesma intenção, como dissemos, que a Pedro, Paulo e João relativamente a homem. Diferem, contudo, nisto, em que Pedro, Paulo e João são comparados à natureza humana como indivíduos a uma natureza que não é una quantitativamente. Mas in diuinis as três Pessoas são comparadas a esta natureza divina, como é esta, porque as três Pessoas são, em número, um único Deus. Aqueles não são um, em número, mas três homens.

Entendeste perfeitamente de que modo Pessoa é ente real e de que modo é ente da razão. Mas falta esclarecer uma coisa, a saber, quando dizemos "São três Pessoas”, o que é que aí se plurifica? Não é a essência nem as propriedades, porque as propriedades são únicas e incomunicáveis. Portanto, ou se plurifica apenas a intenção segunda, para que o sentido seja "três Pessoas", isto é, três, cada uma das quais é per se única; ou a negação da comunicabilidade, para que o sentido seja "três Pessoas", isto é, três incomunicáveis. E é seguro que nestes dois modos são três as Pessoas, e que o nome pessoa se separa desses três a fim de que Pessoa, em geral, exprima per se o uno ou o incomunicável, e debaixo 
illud incommunicabile. Sed an tribus rationibus personalibus in re possit abstrahi aliquid commune reale ita quod sicut Pater est persona per $\mathrm{A}^{232}$ et Filius per $\mathrm{B}^{233}$ et Spiritus Sanctus per $\mathrm{C}^{234}$, hoc est, per tria realia, ita omnes tres sint pesona per aliquod commune reale ${ }^{235}$ ipsi $\mathrm{A}$ et $\mathrm{B}$ et $\mathrm{C}$. Vtor his litteris, quia uos caretis nominibus illarum proprietatum.

Ad hanc dubitationem ita dicendum est et ita tu conscribe: Ex quo illa tria entia $\mathrm{A}$ et $\mathrm{B}$ et $\mathrm{C}$ sunt ultimo personarum distinctiua, nullum reale est ipsis tribus entibus omnino etiam secundum aequiualentiam simplicibus commune, quia illa tria entia non sunt aliud quam deitas ipsis tribus aequiualens. Et si ipsa tria essent alia a deitate adhuc tamen essent simplicia omnino et non constituta, quia sunt ultima distinctiua. Non ergo ipsa ulterius [f1. 170] distinguuntur, quod fieret si ab ipsis posset abstrahi aliquid commune in quid Nam in illo conuenirent et per aliqua alia distinguerentur et esset aliquid commune solis diuinis personis quod se haberet ad illas tamquam species ad indiuidua, quod neuter uestrum, dixit ad Thomam et Scotum, posuit. Vterque enim uestrum remouit genus et speciem a diuinis. De quo pastor iudicabit utrum uos uel nominales ${ }^{236}$ in hoc melius dixeritis. Et uos iam scitis et uidetis, sed nolo illud nunc scribi ${ }^{237}$. Multa enim illi futuro reseruantur. Neque potest bene dici ut conueniant in persona tamquam in proprietate communi, non tamquam in specie uel genere, nam proprietates diuinae essentiae non plurificantur et proprietates personales non communicantur neque ab ipsis potest abstrahi commune, ex quo sunt omnino simplices.

Tunc ego: Vtrum subsistentia ${ }^{238}$, res naturae et suppositum et hypostasis siue substantia ${ }^{239}$ sint idem.

Angelus subrisit dicendo: Vis quod te doceam uocabula? Quando res constat, quid curas de uocabulis? Apud uestros philosophos substantia uno modo est omnis natura et omnis essentia, quia substat non semper accidentibus, sed semper aliquibus quasi circumstantibus naturam. Substantia igitur rei non sunt eius proprietates aut ea circumstantia, sed ipsa natura rei. Et ita omnes species etiam accidentium sunt substantiae, et Deus est substantia. Et hoc modo etiam quod alii circumstat dici potest substantia, non quia circumstat aliud, sed quia alia circumstant ipsum, sicut dicunt: substantia coloris uel lucis inquantum lux uel color intelliguntur nature habentes aliquas proprietates, condicionem et accidentia.

232 per A] prima $V 233$ per B] persona secunda $V 234$ per Cl persona tertia $V 235$ commune reale] communicabile $Q \mathbf{2 3 6}$ nominales] moniales $V \mathbf{2 3 7}$ sed nolo illud nunc scribi] sed illum $\rightarrow$ 
desse intencional comum ou negativo esteja uma coisa ou outra una per se, e uma coisa ou outra incomunicável. Mas, se das três razões pessoais em concreto se pode retirar algum real comum, de forma que, assim como o Pai é Pessoa por A e o Filho por B e o Espírito Santo por C, isto é, por três reais, assim também os três sejam Pessoa por algum real comum ao próprio A e ao B e ao C. Sirvo-me destas letras porque vos faltam os nomes dessas propriedades.

Em relação a esta dúvida, deve assim dizer-se e tu assim escreve: A partir do momento em que esses três entes A, B e C são, enfim, distintivos das Pessoas, não há absolutamente nenhum real comum a esses três entes, mesmo segundo a equivalência com os simples, porque esses três entes não são senão a divindade equivalendo a esses três. E se esses três fossem distintos da divindade, seriam, todavia, ainda absolutamente simples e não compostos, porque são os últimos susceptíveis de estabelecerem a distinção. Eles mesmos, por consequência, não se distinguem, [f1. 170] o que aconteceria se deles pudesse retirar-se alguma coisa comum em qualquer aspecto. Pois nisso convergiriam, e distinguir-se-iam por qualquer outra coisa, e haveria alguma coisa comum apenas às Pessoas divinas que se comportaria relativamente a elas como a espécie relativamente aos indivíduos, o que nenhum de vós, disse a Tomás e a Escoto, afirmou. Na verdade, ambos removestes da divindade género e espécie. Sobre isso o Pastor ajuizará se tereis andado melhor vós ou os nominalistas. E vós já sabeis e já vedes, mas não quero que seja escrito agora. Efectivamente muita coisa está reservada a esse que há-de vir. Nem se pode seguramente dizer que convergem na pessoa como numa propriedade comum, não como na espécie ou no género, pois as propriedades da essência divina não se plurificam, e as propriedades pessoais não se comunicam e nem delas se pode retirar algo que seja comum, uma vez que são absolutamente simples.

Perguntei então se subsistência, natureza e sujeito, e hipóstase ou substância são o mesmo.

Queres que te esclareça sobre as palavras, sorriu-se o anjo ao responder? Quando a realidade se patenteia, porque te preocupas com as palavras? Para os vossos filósofos substância é, de algum modo, toda a natureza e toda a essência, porque subestão, nem sempre, aos acidentes, mas sempre a alguma coisa que parece rodear a natureza. A substância de uma coisa, portanto, não são as suas propriedades ou as coisas que a rodeiam, mas a própria natureza da coisa. E, assim, todas as espécies, mesmo as dos acidentes, são substâncias, e Deus é substância. E, deste modo, também o que rodeia alguma coisa se pode considerar substância, não porque rodeia outro, mas porque outros o rodeiam, como dizem: Substância da cor ou da luz, enquanto luz ou cor, entendem-se as naturezas que têm algumas propriedades, condição e acidentes.

\footnotetext{
$\leftarrow$ nunc scribe $Q 238$ subsistentia] substantia $Q 239$ substantia] subsistentia $Q$
} 
Alio modo, substantia dicitur illa essentia quam omnia circumstant et ipsa nihil circumstat. Et ita nullum accidens est subtantia, neque attributa Dei ut sapientia et potentia sunt substantia. Et hoc modo distingunt philosophi uestri substantiam ab accidente. Et quando natura non solum substat aliquibus circumstantibus ${ }^{240}$, sed etiam accidentibus, sic ab istis, id est, Thoma et Scoto, ponitur praedicamentum distinctum et remouetur a tali substantia Deus. Quando uero solum natura substat quibusdam ${ }^{241}$ eam circumstantibus quae sunt una res secum et non accidentibus, tunc etiam potest dici substantia. Et eo modo etiam Deus est substantia. Substantia uero plus notat, quia substantiam incommunicabilem. Omne enim subsistens est substantia et non omnis substantia est subsistens. Et quando tale subsistens est in natura intellectuali, dicitur persona a uestris, quia uocabula sunt ad placitum. Quando uero tale subsistens est in aliis naturis non solet uocari persona, sed suppositum. Hypostasis autem nunc pro persona nunc pro quolibet supposito accipitur. Et prout persona uel suppositum seu subsistentia respicit naturam cuius est suppositum dicitur res naturae. Ecce linguam tuam te doceo, nam in lingua mea aliis uocabulis utimur in quibus nulla est aequiuocatio, nulla amphibologia aut dubitatio, sed omnium rerum sunt propria nomina et accomodata uocabula.

Ecce uidisti quid personae nomine sit intelligendum et quod tres sunt personae ${ }^{242}$. Vnde ibi est trinitas personarum, uidelicet numerus ternarius, non quaternarius, non quinarius. Haec autem Sanctissima Trinitas est unus Deus cuius imaginem nos angeli et uestrae animae gerunt. In eo enim quia habemus intellectum cum obiecto qui memoria dicitur et est uerbi productiua, et in eo quia habemus uoluntatem fecundam amoris productiuam repraesentamus Deum Patrem qui est principium Verbi uel Filii sui et Spiritus Sancti [fl. 171] qui amor dicitur. In eo uero quod habemus intellectum sub actu intelligendi, repraesentamus Deum Filium. In eo uero quod habemus uoluntatem cum actu amoris repraesentamus Deum Spiritum Sanctum. Quae tria in nobis ratione actuum distinguuntur realiter. Alius est enim actus memoriae siue mentis, hoc est, intellectus cum obiecto et uoluntatis perfectae, alia res est notitia, alia amor. Et haec eadem tria sunt in nobis consubstantialia ratione potentiarum. Intellectus namque et uoluntas non sunt alia res ab anima, ut hic dixit (ostendebat Scotum) neque Thomas iste alius aliter sensit ${ }^{243}$. Et quando dixit potentias esse alias res ab anima, intellexit quod non sunt sola entitas animae, sed aliqua sibi superaddita quae dicitur distingui ab anima realiter. Non quia alia existentia sit potentiarum et alia animae, sed quia ita est in re etiam nullo considerante quod anima est una entitas, alia potentia ${ }^{244}$. Quae tamen duae entitates sunt una res, quia unam habent existentiam ${ }^{245}$ et una

240 aliquibus circumstantibus] quibusdam eam circumstantibus $Q \quad \mathbf{2 4 1}$ solum natura substat quibusdam] natura non solum substat quibusdam $Q \mathbf{2 4 2}$ et quod tres sunt personae] et quod sunt personae $N$; et quid personae sint $Q \mathbf{2 4 3}$ Neque Thomas iste alius aliter sensit] teque Thomas. Iste $\rightarrow$ 
Por outro lado, designa-se substância aquela essência que é rodeada por tudo e ela não rodeia coisa nenhuma. E, assim, nenhum acidente é substância, nem os atributos de Deus, como sabedoria e poder, são substância. E deste modo distinguem os vossos filósofos substância de acidente. E quando a natureza não só subestá a alguns circunstantes, mas também aos acidentes, nestas circunstâncias é estabelecida por estes, isto é, Tomás e Escoto, uma categoria distinta e remove-se Deus dessa substância. Mas quando a natureza subestá apenas a certas coisas que a rodeiam, que constituem consigo uma substância única, e não aos acidentes, ainda então se pode considerar substância. E, nessa medida, também Deus é substância. Mas substância abrange mais, porque abrange a substância incomunicável. Todo o subsistente é, de facto, substância, e nem toda a substância é subsistente. E quando esse subsistente existe na natureza intelectual, é pelos vossos considerado pessoa, porque os vocábulos são arbitrários. Mas, quando esse subsistente se encontra noutra natureza, não se costuma chamar pessoa, mas sujeito. Hipóstase, porém, ora se toma por pessoa, ora por um qualquer sujeito. E, na medida em que pessoa, ou sujeito, ou subsistência diz respeito à natureza de que é sujeito, considera-se natureza. Vê que te estou a ensinar a tua língua, pois na minha usamos de outros termos, em que não há equívoco algum, nenhuma anfibologia ou dúvida, mas os nomes são próprios de cada coisa e os termos apropriados.

Viste o que se deve entender pelo nome de pessoa e que são Três as Pessoas. Por isso, aí se encontra trindade de Pessoas, o número ternário, bem entendido, não o quaternário nem o quinário. Esta Trindade Santíssima é um Deus único, cuja imagem ostentamos nós anjos e as vossas almas. No facto de termos inteligência com objecto, que se designa memória e é produtora da palavra, e no facto de termos vontade fecunda, produtora do amor, representamos a Deus Pai, que é o princípio do Verbo ou seu Filho e do Espírito Santo, [fl. 171] que se designa amor. No facto de termos inteligência, sob o acto de entender representamos a Deus Filho. No facto de termos vontade, com acto de amor representamos a Deus Espírito Santo. Estas três faculdades em nós distinguem-se realmente em razão dos actos. Um é, de facto, o acto da memória ou da mente, isto é, do intelecto com objecto e da vontade perfeita, outra coisa é o conhecimento, outra, o amor. E estas mesmas três coisas são em nós consubstanciais, em razão das potências. $E$, de facto, a inteligência e a vontade não são distintas da alma, como este disse (apontava Escoto) e nem estoutro, Tomás, entendeu de modo diferente. E, quando disse que as potências são coisa distinta da alma, entendeu que não são apenas a entidade da alma, mas alguma coisa a si acrescentada que se considera distinguir-se realmente da alma. Não que seja uma a existência das potências e outra a da alma, mas porque assim é de facto, mesmo sem que se considere que

$\leftarrow$ alius aliter sensit $J \mathbf{2 4 4}$ quod anima est una entitas, alia potentia] quia anima est unica entitas alia a potentia $O Q 245$ existentiam] essentiam $I$ 
sine alia esse non potest. Non est anima unquam sine intellectu et uoluntate neque intellectus et uoluntas ab anima aut substantia uestra separari potest. Et sicut ex Patre nascitur Filius, in nobis de memoria nascitur notitia et de uoluntate, iam nata notitia, procedit amor. Sicut ex Patre, nato Filio, procedit Spiritus Sanctus et productio Spiritus Sancti communicatur Filio, non sic proprie productio amoris communicatur notitiae uestrae. Hoc tamen uerum est quod, quia uoluntas amorem producere non potest nisi notitia illius rei quae amatur praecedente, ideo notitia est aliquo modo causa amoris. Et sicut Filius naturaliter et Spiritus Sanctus libere producitur $^{246}$, ita notitia nostra a memoria naturaliter nascitur, amor uero a uoluntate libere producitur. Haec igitur est quantulacumque Trinitatis illius in nobis imago.

Vestigium quoque Trinitatis est in omni creatura. Omne enim creatum est unum, uerum, bonum. Vnitate Patrem, qui est unicum principium omnium et a quo omnium enim entium multitudo deriuatur et procedit, denotant, ueritate Filium, qui est sapientia Patris, bonitate Spiritum ${ }^{247}$, qui uoluntate producitur cui bonum pro obiecto conceditur. Omnia quoque diuina arte facta sunt et unitatem et speciem et ordinem in se ostendunt. Species et pulchritudo rerum est ueritas ${ }^{248}$ earum qua redduntur ${ }^{249}$ intelligibilia et suimet manifestatiua. Et ordo uero in ultimum finem bonum denotat. Nil enim bonum est nisi finis et quae ordinantur in finem. Et ita haec assignatio uestigii est similis illi priori, secundum hanc nouam expositionem quae melior est quam illa ualde difficilis quam dedit hic noster frater etiam tempore illo eruditus (et ostendebat Sanctum Augustinum).

Omnia quoque Deus creauit in numero, pondere et mensura. Vnumquodque enim additum alteri facit numerum. Ergo unumquodque est unum et unumquodque mensuratur per accessum ad primum bonum uel per recessum ab eo, quod non fit sine cognitione. Et unumquodque inclinatur in bonum et in suam perfectionem ${ }^{250}$. Quae inclinatio est amor naturalis. Vnitas, ut praesens, Patrem, mensura, quae cum ratione intelligitur, Filium, pondus, hoc est, inclinatio seu amor Spiritum Sanctum denotat et significat. Haec tria dicuntur uestigium et non imago, quia uestigium est signum partis ${ }^{251}$. Sic ista non dicunt nisi partem ${ }^{252}$ Trinitatis et imaginis. Imago enim est similitudo totius, significat enim distinctionem personarum, consubstantialitatem earum et originem. Vnum, uerum, bonum significant non omnia haec, sed partem eorum. Notant [f1. 172] enim consubstantialitatem, sed non distinctionem neque originem. Mens itaque notitia et amor uel memoria,

246 producitur] proceditur IV 247 Spiritum] Spiritum Sanctum $P Q$; Spirituum $I V \quad 248$ ueritas] unitas $Q 249$ redduntur] redundat $V 250$ Ergo unumquodque est (..) in bonum et in suam perfectionem.] Et unumquodque est unum et unumquodque mensuratur per accessum ad primum $\rightarrow$ 
a alma é uma entidade, outra a potência. Todavia, estas duas entidades são uma única substância, porque têm uma única existência, e uma não pode existir sem a outra. Não há, de modo nenhum, alma sem inteligência e sem vontade, nem a inteligência e a vontade se podem separar da alma ou da vossa substância. E, assim como do Pai nasce o Filho, nasce em nós da memória o conhecimento, e da vontade, nascido já o conhecimento, procede o amor. Assim como do Pai, nascido já o Filho, procede o Espírito Santo, e a produção do Espírito Santo se comunica ao Filho, não se comunica propriamente assim ao vosso conhecimento a produção do amor. Isto, contudo, é verdade porque, uma vez que a vontade não pode produzir o amor senão precedendo o conhecimento daquilo que se ama, por isso, o conhecimento é de alguma forma a causa do amor. E, assim como o Filho produz naturalmente, e o Espírito Santo livremente, assim também o nosso conhecimento nasce naturalmente da memória, mas o amor procede livremente da vontade. Esta é, pois, a difusa imagem desta Trindade em nós.

$O$ vestígio da Trindade existe também em toda a criatura. De facto, todo o criado é uno, verdadeiro e bom. Pela unidade indica-se o Pai, que é o único princípio de tudo e de quem deriva e procede a multidão de todos os seres; pela verdade, o Filho, que é a sabedoria do Pai; pela bondade, o Espírito, que é produzido pela vontade, à qual se atribui o bem por objecto. Tudo foi igualmente feito pelo divino talento e em si ostenta unidade, beleza e ordem. A forma e a beleza das coisas são a sua verdade, pela qual se tornam inteligíveis e reveladoras de si mesmas. Mas também a ordem mostra o bem para o fim último. Nada, de facto, é bom senão o fim e o que se ordena para o fim. E, assim, esta demarcação do vestígio é semelhante àquela primeira, de acordo com esta nova exposição, que é melhor do que aquela bem difícil que fez este nosso irmão, erudito também naquele tempo (e apontava Santo Agostinho).

Deus tudo criou também com conta, peso e medida. De facto, cada coisa somada a outra faz um número. Por isso, cada coisa é una e cada coisa é medida pela aproximação ao primeiro bem ou pelo afastamento dele, o que não acontece sem o conhecimento. E cada coisa se inclina para o bem e para a sua perfeição. Esta inclinação é o amor natural. A unidade, enquanto presente, mostra e significa o Pai; a medida, que se atinge com a razão, o Filho; o peso, isto é, a inclinação ou amor, o Espírito Santo. Estas três coisas designam-se vestígio e não imagem, porque vestígio é sinal de parte. Deste modo, estes não indicam senão parte da Trindade e da imagem. Imagem, com efeito, é semelhança do todo, significa, na verdade, a distinção das Pessoas, a sua consubstancialidade e origem. Uno, verdadeiro, bom significam não todas estas coisas, mas parte delas. Indicam, [f1. 172] de facto, consubstancialidade, mas não distinção nem origem. E assim,

$\leftarrow$ unum et unumquodque mensuratur per accessum ad suum bonum et unumquodque inclinatur in bonum et in suam perfectionem. $Q 251$ partis] Patris IJMV 252 partem] patrem $I J V$ 
intelligentia et uoluntas cum amore simul est imago, quia ibi est consubstantialitas ratione potentiarum, et distinctio propter actus qui sunt distincti realiter, et origo quia notitia producitur a memoria et amor a uoluntate perfecta et aliquo modo a notitia. Et hic deficit ualde imago a Trinitate perfecta. Nomine autem mentis et memoriae intelligitur utrumque principium productiuum.

Sed arrige aures et audi qualiter angeli iugiter laudant et magnificant Sanctissimam Trinitatem. Et audi cantum triplici lingua inchoatum, sed latina deinde continuatum.

Michael Hebraice inchoauit:

Kados, Kados, Kados. Adonay et Sabaoth.

Gabriel Graece idem dixit:

Agios, Agios, Agios. Kyrios o Theos ton Stration.

Raphael Latine idem reiterauit:

Sanctus, Sanctus, Sanctus, Dominus Deus militiarum.

Benedicamus Patrem et Filium cum Sancto Spiritu. Laudemus et magnificemus eum in saecula.

Deinde nunc Michael nunc alii prosequebantur omnia Latine uel ad hoc ut ego melius intelligerem uel ut ostenderent Deum plus laudari in lingua Latina hodie quam in aliis. Michael itaque prosecutus est haec quae sequuntur, quae coniungantur cum superiori sententia sicut quando uos, dixit angelus, haec nostra cantica cantaueritis. Continuate illa ${ }^{253}$ :

In solio excelso et eleuato tres omnino similes uideo.

Aequales illi sunt undique, in nullo inter se differentes.

Non est unus ante, alius retro, neque unus sursum, alius deorsum.

Inter se sunt uere distincti, sed quoad locum et solium omnino indistincti. ${ }^{254}$

Vnusquisque trium in eadem sede quae residebat.

Non est a dextris unus, a sinistris alius, sed quilibet est in quolibet.

Nomen primi ${ }^{255}$ proprium Pater est, ipse namque solus genuit.

Nomen secundi est Filius, solus etenim ${ }^{256}$ genitus est.

Nomen tertii Spiritus Sanctus est, ipse solus spiratus est.

Multa sunt ipsorum agnomina, uaria certo cognomina.

Ingenitus est innascibilisque Pater, improductus et a nullo procedens.

Memoria, unitas et potentia, soli sibi attribuuntur. 
'mente, conhecimento e amor' ou 'memória, inteligência e vontade com o amor' são imagem, porque aí reside a consubstancialidade, em razão das potências, e distinção, por causa dos actos que são realmente distintos, e origem, porque o conhecimento é produzido pela memória e o amor pela vontade perfeita e, de algum modo, pelo conhecimento. E, neste ponto, a imagem afasta-se muito da Trindade perfeita. Além disso, pelo nome de razão e de memória entende-se ambos os princípios produtivos.

Mas presta atenção e ouve como os anjos insistentemente louvam e glorificam a Santíssima Trindade. Ouve o cântico iniciado em três línguas, mas continuado depois na latina.

Miguel começou em hebraico:

Kados, Kados, Kados. Adonai et Sabaoth.

Gabriel repetiu em grego:

Agios, Agios, Agios. Kyrios o Theos ton Stration.

Rafael repetiu o mesmo em latim:

Sanctus, Sanctus, Sanctus. Dominus Deus militiarum.

Bendigamos o Pai e o Filho com o Espírito Santo. Louvemo-lo e exaltemo-lo para sempre.

Depois, ora Miguel, ora os outros prosseguiam tudo em latim, quer para que eu melhor entendesse, quer para mostrarem que Deus se louva hoje melhor na língua latina do que nas outras. E Miguel continuou isto que segue, que deve ligar-se com a frase anterior, como quando vós, disse o anjo, cantardes estes nossos cânticos. Continuai-os:

Num nobre e elevado trono vejo três em tudo semelhantes.

Eles são iguais em tudo, em nada entre si diferindo.

Não está um à frente e outro atrás, nem um em cima e outro em baixo.

São realmente entre si distintos, mas de todo indistintos quanto ao lugar e ao trono.

Sentava-se cada um dos três no mesmo lugar, justamente.

Não está um à direita outro à esquerda, mas quem quer em qualquer lugar.

Pai é nome próprio do primeiro, pois só ele gera.

Do segundo o nome é Filho, porquanto só ele é gerado.

Espírito Santo é do terceiro o nome, apenas ele é espirado.

São muitos os seus apelidos, vários, certamente, os sobrenomes.

Ingénito e inascível é o Pai, improduzido e de ninguém procedente.

Memória, unidade e poder só a si se atribuem. 
Filio splendor, species, ueritas, mensura et sapientia, $\operatorname{ars}^{257}$ plena omnium rationum uiuentium.

Spiritui Sancto bonitas, ordo, pondus et suauitas ${ }^{258}$, gratia, caritas et benignitas.

Solus Filius Verbum est, quia de memoria solus productus.

Solus Spiritus Sanctus amor spiratus, solus donum proprie nuncupatus.

Sed unumquodque illorum trium nominum suam personam sub ratione propria significant.

In his latet magnum sacramentum, in his magna uirtus abscondita est.

In ipsis hominum uita et salus consistit, in ipsis omnis gratia et peccatorum expiatio existit.

Nomen tetragrammaton utile erat antiquis, sed haec utilioria sunt modernis.

[f1. 173]

Benedicamus Patrem et Filium cum Sancto Spiritu, laudemus et magnificemus eos in saecula.

Simillimos eos in tantum uidemus quod unum ab alio non discernimus.

Quaecumque uidemus aut aspicimus, eandem rem omnino iudicamus.

Et quia nihil est in aliquo ipsorum nisi Deus, quemcumque ${ }^{259}$ uidemus Deum solum uidemus.

Deus est quo conueniunt et quo differunt, Deus est omnia in ipsis omnibus. Maximus et simplicissimus est omnipotens noster Deus.

Nulla tamen bonitas est aut perfectio quam ipse non contineat.

Simplicissima est natura diuina, sola tamen ad omnia ualet.

Ipsa est Deo nostro loco potentiarum et operationum et omnium aliorum quae de ipso dicuntur.

Quae in rebus creatis ${ }^{260}$ sunt sparsa et diuisa, in Deo sunt collecta et unita.

Quae homines per multa instrumenta conficiunt, unica re in Deo peraguntur.

Quando unum pluribus aequipollet, quae pluribus fierent et illo uno fient. ${ }^{261}$ Immo et perfectius illo uno fient, quia uirtus unica ${ }^{262}$ est potentior. ${ }^{263}$

Singulis ipsorum simplex est et quilibet constitutus.

Simplex, quia non nisi Deus, constitutus quia Deus pluribus aequiualet.

Qui producit et quo producit aeque est Deus cum producto.

Natura non generat neque spirat, non generatur neque spiratur.

Ipsa tamen est generatio, ipsa generari et spirari.

Vna summa quaedam res est Deus, omni bonitate in se fretus. ${ }^{264}$

257 ars] res $P 258$ suauitas] sanitas $V 259$ quemcumque] quocumque $J$; quodcumque $Q$; quaecumque $V 260$ creatis] diuinis $O$; creatis et humanis $Q$; certis $V 261$ fient] fiunt $N O Q$, fierent $V \rightarrow$ 
Ao Filho, esplendor, harmonia, verdade, medida e sabedoria, arte repleta das razões de todos os vivente.

Ao Espírito Santo, bondade, ordem, ponderação e suavidade, graça, amor e benignidade.

Palavra é só o Filho, porque é o único produto da memória.

Só o Espírito Santo é amor espirado, único propriamente designado dom.

Mas cada um destes três nomes significa sua Pessoa sob razão própria.

Neles se oculta magno sacramento, ocultou-se neles magno poder.

Neles se firma a vida e a salvação dos homens, reside neles toda a graça e a expiação dos pecados

[f1. 173] Aos antigos era útil o nome tetragrama, mas aos modernos são mais úteis estes.

Bendigamos Pai, Filho e Espírito Santo, louvemo-los e exaltemo-los para sempre.

A tal ponto os vemos semelhantes, que não distinguimos um do outro,

Quanto vemos ou olhamos, o mesmo em absoluto consideramos.

E porque em cada um nada há senão Deus, vejamos quem virmos, só a Deus vemos.

É Deus onde convergem e de onde divergem, Deus é tudo em todos eles.

Máximo e simplicíssimo, é omnipotente o nosso Deus,

Não há beleza ou perfeição que ele não contenha,

É simplicíssima a natureza divina, sozinha, porém, por tudo vale.

Tem-na Deus em vez das potências, das operações e de tudo quanto dele se afirma.

O que nas criaturas disperso está e dividido, unido está em Deus e associado.

O que por instrumentos vários realizam os homens, em Deus se conclui numa acção única.

Quando um equivale a muitos, o que por muitos seria feito, sê-lo-á por esse só.

Mais perfeitamente será, até, só por um feito, porque a força única é mais potente.

É simples cada um deles e cada um deles é composto.

Simples, porque apenas Deus, composto, porque, Deus, equivale a muitos.

$\mathrm{O}$ que produz e por meio de quem produz são o mesmo Deus com o produzido.

A natureza não gera nem espira, não é gerada nem espirada.

Ela, contudo, é geração, ela é ser gerado e ser espirado.

Deus é uma espécie de substância suprema, cheio em si de toda a bondade.

$\leftarrow 262$ unica] unita $O P 263$ potentior] perfectior $I V 264$ fretus] refertus $Q$ 
Benedicamus Patrem et Filium cum Sancto Spiritu, laudemus et magnificemus eum in saecula.

Vim quandam uidemus in Patre per modum naturae productiuam.

Vis illa est Deus et Deus est ipsa uis productiua.

Intellectus est cum essentia quae solet appellari memoria.

In rebus profecto aeternis in quibus est uis omnino immutabilis.

Quia non distat esse a posse, quod potest esse, necesse est esse.

Quicquid ergo est productiuum et producens actu erit.

Constat nobis accidens in Deo esse non posse, quod producitur substantia erit.

Vis producens est infinita, productum infinitum erit.

Infinitum nihil est nisi Deus, productum ergo Deus erit.

Nequit esse nisi unus Deus, idem cum gignente Deus erit.

Impossibile est aliquem seipsum gignere, genitum alia persona erit.

Ex quo memoria producitur, productum uerbum erit.

Quia de substantia gignentis natura intellectuali oritur, filius certe erit.

Quia gignenti simillimus, imago perfecta erit.

Generatio una est et incommunicabilis ${ }^{265}$, unicus Filius erit.

Benedicamus iam Patrem et Filium et qui ab eis procedit Spiritum Sanctum.

Quomodo autem procedit nos uidemus, propter uos homines ita canimus.

Vt aliqualiter audiatis quae in ciuitate nobis communi ${ }^{266}$ uidebitis.

Est in Patre et eius Filio et alia uis productiua.

Non quidem per modum naturae et intellectus, sed per modum doni et uoluntatis.

Est namque in Deo perfecta uoluntas, est et eius obiectum infinita bonitas. ${ }^{267}$

Quicquid autem in Deo potest esse, illud necesse est esse.

Producitur itaque non gignitur, quia uoluntate non natura procedit.

Ideo neque Filius neque Verbum est, imago aliquo modo dici potest.

Substantia est immensa atque Deus et tamen a producentibus alius.

Alia est ab ipsis persona, quia mens non capit ut aliquid seipsum producat.

Donum ipse est uerum et amor uere spiratus. [f1. 174]

Non a Patre solum sed etiam a Filio, sicut Latini recte canunt.

Vis enim haec praesupponit priorem et iam in Filio esse quando produci.

Neque tamen ueri Graeci errant qui ipsum ex Patre non ex Filio dicunt.

Qui ipsum ex Patre procedere et in Filium dicunt permanere.

Non est certe ex Filio tamquam ex fonte ipsum ex se effundente.

Neque est ex Patre et Filio tamquam ex duobus principiis, sed tamquam ex uno.

Ex Patre procedit per Filium et in Filio quiescit ${ }^{268}$ talis processio.

265 incommunicabilis] incommutabilis $N P V 266$ nobis communi] uobis communi $I$; nobiscum $P 267$ est et eius obiectum infinita bonitas] est et eius subiectum infinita bonitas $O$; est etiam $\rightarrow$ 
Bendigamos o Pai e o Filho e o Espírito Santo, louvemo-lo e exaltemo-lo para sempre.

Vemos no Pai determinada força, que produz per modum naturae.

Essa força é Deus e Deus é a própria força produtiva.

A inteligência está com a essência, que costuma chamar-se memória,

Nas coisas verdadeiramente eternas em que está a força absolutamente imutável.

Porque não dista o ser do poder, o que pode ser é forçoso que seja,

Pois o que quer que seja produtivo, em acto será produtor.

Sabemos que acidente em Deus não pode existir, o que é produzido será substância.

Infinita é a força produtora, infinito será o produto.

Nada é infinito senão Deus, Deus será, pois, o produto.

Não pode haver senão um só Deus, Deus será o mesmo com o Progenitor.

É impossível que alguém se gere a si próprio, o gerado será outra Pessoa.

Porque se produz da memória, o produto será a Palavra,

Porque nasce da substância do Progenitor na ordem intelectual, será seguramente Filho,

Porque absolutamente ao Progenitor semelhante, será imagem perfeita.

Una e incomutável é a geração, único será o Filho.

Bendigamos já o Pai e o Filho e o que deles procede, o Espírito Santo.

Como procede, nós vemos; por vós, homens, assim cantamos,

Para que de algum modo ouçais o que na cidade que nos é comum vereis.

Há no Pai e em seu Filho outra força também produtiva,

Não certamente per modum naturae e da inteligência, mas per modum doni e da vontade.

Pois que em Deus há vontade perfeita, é seu objecto a bondade infinita.

$\mathrm{O}$ que quer que em Deus possa existir é necessário que exista.

É produzido, pois, não é gerado, porque da vontade procede, não da natureza.

Por isso, não é Filho nem é Verbo, de algum modo Imagem se pode dizer.

É substância imensa e é também Deus e, todavia, distinto dos produtores.

É Pessoa distinta deles, pois que a razão não concebe que algo a si se produza.

Ele é dom verdadeiro e amor verdadeiramente espirado, [fl. 174]

Não só pelo Pai, mas também pelo Filho, como com verdade cantam os latinos.

Mas esta força pressupõe a primeira e já existe no Filho quando produz.

E não erram os verdadeiros gregos, que do Pai o dizem que não do Filho,

Eles que dizem que procede do Pai e no Filho permanece.

Não sai certamente do Filho como da fonte que de si o derrama,

Nem do Pai sai e do Filho como de dois princípios, mas como de um só.

Procede do Pai pelo Filho e no Filho repousa essa processão, 
A Patre namque talem processionem accipit Filius neque ipsam ulli alii communicat.

Sed quia non minus est a Filio quam a Patre, ab utroque procedere bene dicitur. ${ }^{269}$ Verba trahenda sunt ad sensum, non sensus ad uerba.

Hic labor est hominum ${ }^{270}$ mortalium, nobis angelis haec omnia ex se patent. Nulla apud nos est aequiuocatio, nulla amphibologia.

Ecce ingenitus generat et ipsemet etiam spirat.

Sed generare consequitur ingenitum, non ingenitum generare.

Pro illo signo inest ${ }^{271}$ negatio, pro quo inesset eius affirmatio.

Sed si generans esset ab alio pro priori signo, esset ab alio qui generaret.

Negatio tamen semper oportet ut aliquam affirmationem comitetur. ${ }^{272}$

Est itaque in ipso generante ens uerum ad quod ingenitum et generare consequitur.

Quia ergo genuit, Pater est et quia Dominum, idem, similis et aequalis est genito. Idem est in essentia, aequalis in uirtute et potentia.

Similis est in sapientia et bonitate et omni alia qualitate.

Haec tamen tam uaria non sunt nisi sua essentia.

Spirat uel potius donat cum suo caro Filio illum qui amor est et donum.

Ille Filius est genitus et sua entitate constitutus.

Entitas constitutiua in ipso correspondet entitati constitutiuae Patris.

Esse ab alio correspondet ingenito, genitum uero generanti.

Filiatio paternitati, identitas identitati.

Similitudo similitudini, aequalitas uero aequalitati.

Tot sunt in uno quot in alio, communis est utrique donatio.

Spiratus Spiritus ${ }^{273}$ et ipse habet entitatem qua constituitur in suo esse.

$\mathrm{Ab}$ alio est, ut patet, non genitus, sed donatus.

Quod Patri est paternitas et Filio filiatio, hoc sibi est spiratio.

Idem est Patri et equalis, immo et in omnibus similis.

Idem est Filio et aequalis eique in nullo difformis.

Tot sunt similitudines et aequalitates ${ }^{274}$ in uno quot et in alio.

Deus tamen est omnia in personis omnibus.

Benedicamus Patrem et Filium cum Sancto Spiritu, laudemus et magnificemus eum in saecula. ${ }^{275}$

269 procedere bene dicitur] coniunctim procedit $Q 270$ hominum] omnium $P Q 271$ inest] non est $P 272$ comitetur] amittetur $P 273$ Spiratus Spiritus] Spiritus Sanctus $M O Q 274$ aequalitates] qualitates IOV 275 et magnificemus eum in saecula] et magnificemus eum in saecula/In unoquoque trium sunt proprie notiones et aliquae sunt duobus communes / In Patre est ratio personae constitutiua, ingenitum ac generare necnon et ipsa paternitas / In Filio est suum constitutiuum, generari quoque ac filiatio/In Spiritu Sancto est lux principio aequiualens, constitutio est spirari ac relatio doni / Est spirare et donatio unica et eadem in Patre et Filio/Filiatio non est paternitas nisi per identitatem sicut autem solum sapientia est caritas / Deus certo producit Deum sed non $\rightarrow$ 
Pois, do Pai recebe o Filho essa processão e a nenhum outro ele a comunica.

Mas, porque não é menos do Filho do que é do Pai, diz-se, e bem, que dos dois procede.

Devem as palavras ser puxadas ao sentido, não o sentido às palavras.

É isto labor de homens mortais, todas estas coisas são de si claras para nós, os anjos.

Não há entre nós equívoco algum, nenhuma anfibologia.

Vê, o Ingénito gera e ele mesmo espira também,

Mas gerar segue-se a ingénito, não ingénito a gerar.

Está a negação por aquele conceito pelo qual estaria a sua afirmação.

Mas se aquele que gera estivesse pelo primeiro conceito, estaria por aquele que gera.

E é preciso sempre que a negação acompanhe alguma afirmação.

Naquele que gera há, pois, o ente verdadeiro, a quem acompanham gerar e ingénito.

Porque gerou, logo é Pai e, porque é Senhor, é o mesmo, semelhante e igual ao gerado.

É o mesmo em essência, igual em poder e em força,

É semelhante em sabedoria e bondade e em outra qualquer qualidade.

Tão variadas, contudo, estas coisas não são senão sua essência.

Espira, ou melhor, dá com seu querido Filho aquele que é amor.

Esse Filho é gerado e em sua essência constituído,

Nele a entidade constitutiva corresponde à entidade constitutiva do Pai.

Ter de outrem o ser corresponde a ingénito, mas gerado, a progenitor,

Filiação a paternidade, a identidade, identidade,

Semelhança, a semelhança, mas igualdade, a igualdade.

São tantas em um, quantas são no outro, comum a ambos é a doação.

O espirado Espírito também ele tem a entidade com que em seu ser se constitui,

Tem de outro o ser, como fica expresso, gerado não é, mas é dado.

Porque o Pai tem a paternidade e o Filho a filiação, ele tem a espiração.

É idêntico ao Pai e é também igual, e até, em tudo semelhante também.

É o mesmo que o Filho e também igual e em nada é dele dissemelhante.

Semelhanças e igualdades são tantas em um, quantas no outro também.

Deus, porém, é tudo nas Pessoas todas.

Bendigamos o Pai e o Filho com o Espírito Santo, louvemo-lo pelos séculos e exaltemo-lo.

$\leftarrow$ eundem nec alium / Duo sunt spirantes, non duo spiratores. Tres creantes, non tres creatores / Adiectiuum non determinat adiectiuum sed utrumque declarant substantiuum/Quamuis Filius sit sapientia et ars Patris, Filius tamen sapere sapientia ingenita rectius affirmatur/Spiritus Sanctus est uirtus et amor qui tamen potius amat se reducentibus / Est quaedam affinitas Verbi cum notitia et/ $\rightarrow$ 
Huius imago est in omnibus, quae relucet etiam in hominibus. ${ }^{276}$

Mens, notitia, amor seu memoria, intelligentia et uoluntas.

In his est consubstantialitas gratia potentiarum, distinctio gratia operationum.

Ex mente seu memoria procedit notitia, ex utroque oritur amor. ${ }^{277}$

Mens siue memoria utramque uim productiuam designat.

Quarum uirium utraque in Patre, altera tantum in Filio.

Ambae representant solum Patrem, intelligentia sola Filium.

Voluntas Spiritum Sanctum, non ipsa sola, sed amori coniuncta repraesentat.

Sole namque potentiae aut soli earum actus non sunt imago Trinitatis.

Potentiae coniunctae actibus pro modulo suo Trinitatem Sanctam ostendut.

Mens seu memoria, notitia seu intelligentia, amor seu uoluntas cum amore.

Si in Deum ipsum tendant, sunt Trinitatis perfecta imago. [f1. 175]

Si tendant in seipsum uel similia a ratione perfectae imaginis decidunt.

Si ad inferiora seipsis, ratio Tinitatis imperfectior ${ }^{278}$ erit in illis.

Et quanto ad imperfectiora protendetur ${ }^{279}$, tanto magis diminuetur.

Aliqui mortalium dixere imaginem Trinitatis in corpore pollere.

Linea, inquiunt, est Pater, superficies Filius, altitudo Spiritus Sanctus.

Linea in se ducta superficiem producit, utraque in se ducta corpus facit.

Omnia sunt ualde dissimilia et tantae maiestati difformia.

Benedicamus Patrem et Filium cum Sancto Spiritu, lademus et magnificemus eum in saecula.

Vestigium Trinitatis est in omnibus, quod notum est etiam hominibus.

Quicquid factum est, unitatem, speciem et ordinem in se ostendit.

Quaecumque creata sunt, in numero, pondere et mensura facta sunt.

Omne ens ostensum est unum, uerum et bonum.

Vnitate Patri similatur, specie, mensura et ueritate ipsi Filio.

$\leftarrow$ est uicinitas doni cum amore/Filius naturaliter, Spiritus Sanctus libere uterque tamen necessario praecedit / Quo Filius et quouis persona specialiter constituitur, illo a quocumque alio potissime distinguitur/Qui ordinem et personarum negat productionem, et tertium a secundo negabit/Cui attribuitur (aliquid/Q) sine metaphora, ab illo remoueri nequit ipsius uerum (verbi/Q) superius / Contingens praessupponit necessarium, creatura et (autem est/ $Q$ ) incognosci omnes personas consequitur / Quando (Qui/Q) unum aequiualet perfecte multis, praesupponit et consequitur seipsum prout stat pro illis / Vna persona est uere in alia, ut diximus, ratione solum aut perfecte essentiae praesentiae sed etiam complecte continentiae. (Vna persona est uere in alia, non solum ratione essentiae aut perfecte praesentiae sed perfecte continentiae. Q) / Quaecumque sunt in uno formaliter, sunt in aliis per identitatem et realiter / Quod est Patri potentia generandi et utrumque (utrique/ $Q$ ) spirandi, est in omnibus, non tamen est eo modo in ipsis omnibus / Nihil est in uno quod non sit in aliis, iccirco unus non est maior aliis / Omni perfectione spoliatus, imperfectius est quantulacumque uestito / Si Pater ille esset maior suo naturali Filio, Filius ipse, cuius sunt omnia Patris, non esset minor eo/Deus qui nec genus est, species nec ullum proprie singulare, in nullo genere diuiditur / (Deus qui nec genus nec species est neque ullum improprium singulare, in nullo genere diuiditur $Q$ ) / Deus ultimae speciei quamuis dissimilior sit, assimilatur tres personae tribus particularibus (om. Q) / Idem est unus alii (uni ali $Q$ ) in essentia $\rightarrow$ 
Em todos existe a imagem deste, que nos homens brilha também.

'Mente, conhecimento, amor' ou 'memória, inteligência e vontade',

Neles existe consubstancialidade em razão das propriedades, distinção em razão das operações.

Da mente ou da memória procede o conhecimento, de ambos procede o amor. Mente ou memória, as duas indicam a força produtiva.

Ambas essas forças existem no Pai, no Filho existe somente a segunda.

Ambas representam apenas o Pai, só a inteligência representa o Filho.

A vontade, não ela sozinha, mas ao amor unida, representa o Espírito Santo, Pois só as potências ou delas os actos não são da Trindade a imagem.

Unidas aos actos, segundo seu ritmo, as potências mostram a Trindade Santa. Mente ou memória, conhecimento ou inteligência, amor ou vontade com amor, Se para Deus tendem, da Trindade são imagem perfeita, [fl. 175]

Se para si mesmos ou para iguais, fogem da razão de imagem perfeita,

Se para os a si inferiores, nelas há-de ser bem mais imperfeita a razão da Trindade.

E quanto mais para os inferiores se encaminha, tanto mais se diminuirá.

Dos mortais disseram alguns que a imagem da Trindade no corpo se afirma,

A linha, dizem, representa o Pai, a superfície o Filho, profundidade o Espírito Santo.

A linha sobre si dobrada gera a superfície, ambas sobre si dobradas produzem o corpo.

São as coisas todas muito diferentes, e de tão grande majestade dissemelhantes.

Bendigamos o Pai e o Filho com o Espírito Santo, louvemo-lo e exaltemo-lo pelos séculos.

Em tudo existe da Trindade a marca, que dos homens é também conhecida.

Tudo quanto é feito em si manifesta beleza, unidade e ordem.

Quanto é criado, tudo feito foi com conta, peso e medida.

Todo o ente conhecido é uno, verdadeiro e bom.

Pela unidade ao Pai se assemelha, assemelha-se ao Filho pela proporção, verdade e beleza,

$\leftarrow$ et similis in qualitate, (aequalis $a d d . Q$ ) in magnitudine, aeternitate et potentia. / Identitas similis est et aequalis, aequalitas eadem et similis, similitudo eadem et aequalis / Persona negationem in genere denotat, intentionem et rem ueram designat/Relatiuum persona cum nonnullis aliis neque essentiale est neque notionale / Numerus ( $\operatorname{Nec} N$ ) numeratus in diuinis sunt tres personae, numerus quo numerantur (quoque numeratus $N$ ) est in ipsis / Illi duntaxat mittuntur qui in ligno (signo $Q$ ) sensibili producti manifestantur/Omnes tamen ut mittant illos oportet quia omnes illo tales manifestantur (om. $Q$ ) / Omnes ad nos ueniunt er nobis (cum add. $Q$ ) dantur omnesque id efficiunt $M$ (in a.f. a. m.) NOQ 276 Huius imago est in omnibus, quae relucet etiam in hominibus] Huius imago est in angelis et hominibus et in creaturis inferioribus $M$ (sup. ras.), Huius imago est in angelis et hominibus et non in creaturis inferioribus $O$; Huius imago est in angelis ac hominibus, non in creaturis inferioribus $Q \mathbf{2 7 7}$ oritur amor] amor progreditur $O$; procedit amor $Q 278$ imperfectior] imperfectio $I M P V \mathbf{2 7 9}$ protendetur] procedetur $V$ 
Ordine in ultimum finem, pondere ac bonitate conformatur producto ${ }^{280}$ uoluntate.

In his non est origo neque realis distinctio, ideo secundum partem est repraesentatio.

Non ergo imago, quae totius est, dicitur, sed quia partim assimilatur, uestigium appellatur.

Vestigium admodum singulare refulgebit in singulari pastore.

Ipse erit uerus Trismegistus ${ }^{281}$, ter, inquam, maximus.

Dominus erit atque rex potentissimus, pontifex omnium maximus.

Omnia possidebit et ius in omnibus habebit.

Dominus ergo erit, quia rebus ut suis potiri ualebit.

Omnia gubernabit, reget et pascet, maximus ergo rex erit.

Veri namque reges non sunt nisi populorum pastores.

Consecrabit $^{282}$, benedicet et sanctificabit et pontifex benedictus et sanctus erit.

Dominii $^{283}$ dignitate Patri, ex quo sunt omnia, assimilari ualebit.

Sapientis est regere regia dignitate, sapientiam Patris demonstrabit.

Omnis benedictio et omne donum Spiritui Sancto est iure attributum.

Pastor sapientia sibi caelitus concessa lupos arcebit, auctoritate sibi dimissa.

Arietes gregis cornibus se petentes ${ }^{284}$ mitigabit atque in bonum conciliabit.

Conflictus ipsorum ualde diros in dracones et scorpiones conuertet.

Omnes feras ui accurabit ${ }^{285}$, omnia animalia ouibus assimilabit.

Ex omnibus fiet unum ouile sub uno coadunatum pastore.

Agnus qui tollit peccata mundi regnabit in aeternum et in saeculum saeculi.

Benedicamus Patrem et Filium cum Sancto Spiritu, laudemus et magnificemus eum in saecula. ${ }^{286}$

Pater non est nisi Deus, Filius similiter ac Spiritus Sanctus.

Vnus non est alius, id tamen quod est unus est et alius.

Secundus oritur ${ }^{287}$ a primo, tertius ab utroque egreditur.

Vnusquisque tamen trium in unoquoque ipsorum esse constituitur. ${ }^{288}$

Duo sunt spirantes, non tamen duo spiratores.

Tres etiam recte creantes confitemur neque tamen tres creatores.

Tres sunt in omnibus adiectiue, non tres, sed unus substantiue.

Haec omnia dicimus ut hunc hominem doceamus.

Adiectiuum non determinat adiectiuum, sed utrumque declarat substantiuum.

$\mathbf{2 8 0}$ conformatur producto] confirmatur productio IOV $\mathbf{2 8 1}$ Trismegistus] tris magister $V \quad \mathbf{2 8 2}$ Consecrabit] Conseruabit $I J V 283$ Dominii] Donum $P$; Domini $V 284$ se petentes] serpentes $P$ 285 ui accurabit] enim curabit $I V$; ui curabit $N$; citarabit $P$; accubabit $Q 286$ laudemus et $\rightarrow$ 
Pela ordenação para o último fim, pelo peso e pela bondade conforma-se ao que é produzido pela vontade.

Não há nestes origem nem real distinção, por isso, segundo a parte é a representação.

Não se diz, pois, imagem, que do todo é, chama-se vestígio por à parte se assemelhar.

Vestígio todo singular há-de refulgir no singular Pastor.

Ele mesmo será vero Trismegisto, sim, o três vezes grande,

Ele será Senhor e Rei todo-poderoso, de todos será Sumo Pontífice,

De tudo ele será possuidor e sobre todos exercerá o direito.

Será, pois, Senhor, porque como suas conseguirá dominar as coisas.

Dirigirá tudo, tudo regerá e apascentará, será, pois, Supremo Rei.

Pois reis verdadeiros não são senão os Pastores dos povos.

Ele consagrará, abençoará e santificará, e Bendito e Santo Pontífice será.

Pela dignidade do senhorio, ele conseguirá assemelhar-se ao Pai, de quem tudo vem.

Reger ao sábio pertence, pela dignidade régia há-de demonstrar a sabedoria do Pai.

Toda a bênção e todo o dom, por direito, atributo são do Espírito Santo.

Pela sabedoria a si concedida por favor do Céu, o Pastor conterá os lobos,

Pela autoridade a si confiada dominará e harmonizará os carneiros do rebanho que com os chifres procurarão atingi-lo.

Em dragões e escorpiões converterá seus bem cruéis conflitos.

Cuidará pela força de todas as feras, a ovelhas assemelhará os animais todos.

De todos fará um rebanho só, reunido sob um só Pastor.

O Cordeiro que tira do mundo o pecado reinará para sempre e pelos séculos.

Bendigamos o Pai e o Filho com o Espírito Santo, louvemo-lo e exaltemo-lo pelos séculos.

O Pai não é senão Deus, igualmente o Filho e o Espírito Santo.

Um não é o outro, contudo, aquilo que é um é também o outro.

Gera-se o Segundo a partir do Primeiro, de ambos eles procede o Terceiro.

Mas cada um dos Três estabelece o ser em cada um deles.

São dois os que espiram, não são, porém, dois os espiradores.

Confessamos, e bem, que três são também os que criam, e não são, contudo, três os criadores.

Em tudo são três adjectivamente, não são três, mas um, substantivamente.

Tudo isto afirmamos, para este homem ensinar.

Adjectivo não determina adjectivo, mas cada um deles aclara o substantivo.

$\leftarrow$ magnificemus eum in saecula] et cetera $N \mathbf{2 8 7}$ oritur] erit $M \mathbf{2 8 8}$ constituitur] conspicitur $O Q$ 
Duo ergo et tres non actione, sed determinant ipsas personas. ${ }^{289}$

Sed nos ad nostra redeamus et nostrum canticum resumamus:

Kados, Kados, Kados. Adonai et Sabaoth.

Agios, Agios, Agios. Kyrios o Theos ton Stration.

Sanctus, Sanctus, Sanctus. Dominus Deus militiarum.

Benedicamus Patrem et Filium cum Sancto Spiritu, laudemus et benedicamus eum in saecula.

[fl. 176] His dictis, dixit angelus: Audisti canticum nostrum quod nunc coram te in lingua tua cecinimus ${ }^{290}$ ut omnia paene secreta Sanctissimae Trinitatis saltem ex parte degustares et pro captu ingenii uestri intelligeres. Conscribe illud et pastor cito uenturus, qui iam uenit, sed nondum est pastor, ex illo psalmos et hymnos eliciet et faciet. Stilum in aliquibus mutabit, tempora decantandi ordinabit et multa auctoritate sibi tradita addet illis. Sed post paucos menses hinc discedes, Mediolanum adibis, ibique in Domino obdormies et canticum istud in lingua nostra audies et intelliges. Et uidebis inter istud et illud tantam differentiam esse quanta est inter diem et noctem, inter lucem et tenebras, inter corpus et umbram corporis. Vita enim uestra mors est, scientia uestra ignorantia est, lumen uestrum obscuritas est. Age melius ut potes quousque animus tuus uires suas adeptus fuerit. Declina a malo et fac bonum. Deum time et mandata eius serua. Deum adora, Genitrici suae reuerentiam exhibe. Toti colegio hic assistentium te commenda et reuertere ad speluncam tuam et confirma in oboedientia sancta fratres tuos.

Quibus dictis subito ut adoraui et reuerentiam exhibui et me commendaui, inuentus sum in spelunca mea. Exceptus sum cum honore et amore a fratribus meis et pluribus diebus absque raptu steti.

Finis Septimi Raptus ${ }^{291}$.

289 Duo ergo et tres non actione sed determinant ipsas personas] Duo ergo et tres non actiones sed determinant ipsas personas $M$; Duo ergo et tres non actionem sed determinant ipsas personas $O$; Duo ergo et tres non actionem determinant ad ipsas personas $Q \mathbf{2 9 0}$ tua cecinimus] nostra cecinimus I; uestra cantauimus $V \mathbf{2 9 1}$ Finis Septimi Raptus.] Finis septimi raptus. Sequitur raptus octauus et ultimus $N$ 
São, pois, dois e três, não pela acção, mas determinam as próprias Pessoas. Mas voltemos nós ao que nos ocupa e retomemos o nosso cântico:

Kados, Kados Adonai et Sabaoth.

Agios, Agios, Agios Kyrios o Theos ton Stration.

Sanctus, Sanctus, Sanctus Dominus Deus militiarum.

Bendigamos o Pai e o Filho com o Espírito Santo, louvemo-los e bendigamo-los pelos séculos.

[f1. 176] Depois disto dizer, afirmou o anjo: Ouviste o nosso cântico que na tua presença acabámos de cantar na tua língua para saboreares, pelo menos em parte, e compreenderes, na medida da capacidade do vosso engenho, quase todos os segredos da Santíssima Trindade. Escreve-o. E o Pastor que em breve há-de vir, que já veio, mas ainda não é Pastor, dele retirará e a partir dele comporá salmos e hinos. Nalguns alterará o estilo, determinará o tempo de os cantar e, pela autoridade que lhe foi conferida, acrescentar-lhe-á muita coisa. Mas, poucos meses depois, ir-te-ás daqui embora, dirigir-te-ás a Milão e aí dormirás no Senhor. E ouvirás este cântico na nossa língua e verás que entre um e outro há tanta diferença quanta existe entre o dia e a noite, entre a luz e as trevas, entre um corpo e a sua sombra. A vossa vida é morte, o vosso conhecimento é ignorância, a vossa luz é obscuridade. Age o melhor que puderes enquanto o teu espírito for senhor das suas forças. Afasta-te do mal e pratica o bem. ${ }^{[193]}$ Teme a Deus e observa os seus preceitos. ${ }^{[194]}$ Adora a Deus, venera sua Mãe. Encomenda-te a todo o colégio dos que estão aqui presentes e volta à tua gruta e confirma os teus irmão na santa obediência.

Ditas estas coisas, depois de adorar, prestar reverência e me encomendar, encontrei-me na minha gruta. Fui recebido pelos meus irmãos com honra e amor e permaneci sem arrebatamento por vários dias.

Fim do Sétimo Arrebatamento. 


\section{OCTAVVS RAPTVS ${ }^{1}$}

Vltimus raptus meus postquam cito in Domino me obdormire oportebat, secundum quod angelus sanctus mihi reuelauerat, fuit die triduo ${ }^{2}$ ante Ascensionem Domini, die Lunae diluculo. Me itaque in cauerna mea deuotius solito orante, in excessu ${ }^{3}$ mentis meae in rotam illam iterum raptus fui. Et Deum cum Regina atque solita societate, immo et ampliori uidi. Et omnes uidebantur, cum adorarem ${ }^{4}$, mihi arridere quasi dicentes: Bene ueneris, quia cito huc uenies et foras ulterius non egredieris.

Cantabant uero angeli et coram Dei Genitrice Maria laudes longe plures solito canebant, ipsam adorantes atque magnificantes. Et omnes sancti idem faciebant. Et quia nullus mihi loquebatur et illa cantica illaque adoratio diu durabat, in meipso ualde admirabar atque obstupebam cur tam diu Virginem adorarent. Illico affuit Gabriel meque confortauit, haec uerba dicens: Nihil quasi de Maria euangelistae scripserunt quia satis tunc erat promulgari ea quae ad Redemptorem, Filium eius, Christum Dominum pertinebant, ne uideretur superflua dicere et feminam quamdam praedicare atque extollere. Qui sexus ${ }^{5}$ hominibus uilis uidetur et abiectus. Quia ergo salus hominum in Christo consistebat, satis eis uidebatur Christum hominibus annuntiare. Sed fide iam per totum mundum et bono Christi odore sparso, Dominus uoluit sanctos suos laudibus Matris suae insistere et circa illas occupari. Et eo modo paulatim innotuit hominibus qualiter totius corporis

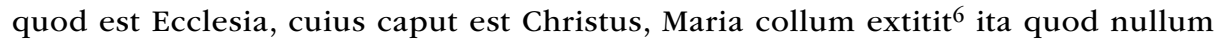
bonum, nullum donum, nulla gratia, nullum priuilegium a capite illo in corpus nisi per hoc mirabile collum, quod est Virgo Dei Genitrix Maria, descendit. Innotuit conceptio eius immaculate, [f1. 177] innotuit ipsius sapientia et dum in hac uita paruula uiueret et dum in matris suae utero moraretur. Nunc autem, quia Dominus in breui precibus eiusdem suae Genitricis totum mundum ad cultum suum est reducturus $^{7}$ et colla omnium fidei iugo est subiecturus ${ }^{8}$, uult ut huius Virginis

1 Octauus Raptus] Raptus Octauus et Vltimus IMNP 2 triduol tertio $V \quad 3$ excessul extasi $Q \quad 4$ uidebantur, cum adorarem] uidebamur eum adorare $I$; uidebamur, cum adorarem $V \quad \mathbf{5}$ sexus] $\rightarrow$ 


\section{Oitavo Arrebatamento}

O meu último arrebatamento, desde que se tornara certo que eu rapidamente descansaria no Senhor, segundo o que o santo anjo me havia revelado, aconteceu três dias antes da Ascensão do Senhor, segunda-feira, ao romper do dia. $\mathrm{E}$, assim, enquanto na minha gruta orava mais devotamente do que o habitual, fui arrebatado em êxtase até àquela Assembleia. E vi a Deus com a Rainha e a habitual companhia, e mais alargada até. E enquanto fazia a minha adoração, parecia que todos se sorriam para mim como que a dizer: Que tenhas chegado bem, porque depressa para cá virás e não mais sairás.

Ora os anjos cantavam e, diante de Maria, Mãe de Deus, entoavam louvores mais prolongados que habitualmente, adorando-a e glorificando-a. E todos os santos faziam o mesmo. E dado que nenhum me dirigia a palavra e aqueles cânticos e aquela adoração se prolongavam muito, admirava-me e estranhava muito porque é que tão longamente estariam a adorar a Virgem. Apareceu ali Gabriel e confortou-me, dizendo estas palavras: Sobre Maria quase nada escreveram os evangelistas, porque então bastava dar a conhecer o que dizia respeito ao Redentor, seu Filho, Cristo Senhor, não fosse parecer que se anunciavam extravagâncias e se elogiava e exaltava uma mulher. Este sexo é considerado pelos homens como vil e desprezível. Uma vez que a salvação do homem radicava em Cristo, parecia-lhes suficiente anunciar Cristo aos homens. Mas, dispersa a fé e o odor de Cristo pelo mundo inteiro, quis o Senhor que os seus santos se entregassem aos louvores de sua Mãe e deles se ocupassem. E, assim, paulatinamente se foi tornando claro para os homens de que modo Maria se apresenta como o pescoço de todo o corpo que é a Igreja, cuja cabeça é Cristo, de tal modo que nenhum bem, nenhum dom, nenhuma graça, nenhum privilégio desce da cabeça para o corpo senão por este admirável pescoço que é a Virgem Maria, Mãe de Deus. Tornou-se conhecida a sua concepção [f1. 177] imaculada, tornou-se manifesta a sua sapiência, não só enquanto vivia como criança nesta vida, como enquanto

$\leftarrow$ sensus $R$; secus $V \mathbf{6}$ extitit] existit $J N Q 7$ reducturus] rediturus $O Q \mathbf{8}$ subiecturus] subiugaturus $M Q$ 
puritas, sanctitas, gratia, decus, splendor atque magnificentia innotescat. Ideo, dilectissime, te huc aduenire uoluit ut ea quae tibi dixero describas cunctisque hominibus manifestentur a pastore qui uiuit, sed nondum regnat. Regnabit tamen, ut tibi antequam hinc recedas ostendetur.

Et quia de ipsa Virgine multa inepte scribuntur quae uera non sunt, et multa uera praetermittuntur, tu nunc iterum nota et quae dico de illa animaduerte. Ideo enim nunc omnes eam adoramus, quia Deus uult eius gloriam palam facere omnibus hominibus ut eius meritis et precibus cuncti salutem et uitam sortiantur aeternam. Quae alio tempore dixi nunc ex parte repetam et quaedam noua, maxime de eius assumptione in caelum aperiam, excludendo multos et uulgatos errores?

Firmiter credendum est ipsam quam Deus supra omnes, etiam angelos, elegit in gratia et gloria, et quam primam post se in regno suo esse uoluit, et per quam omne bonum et omne donum in homines transfundere ${ }^{10}$ statuit, et quam in suam matrem elegit, numquam fuisse filiam ire, numquam fuisse aliquo peccato maculatam, numquam neque dum existeret neque antequam existeret et in mente diuina uisione apprehenderetur fuit apprehensa tamquam inimica aut gratia carens, sic quod gratia ${ }^{11}$ Dei pro suo tempore quo existeret ${ }^{12}$ non esset sibi concedenda. Quandocumque ergo Deus eam uidit (semper autem uidit), numquam eam et pro nullo tempore ut inimicam apprehendit, quod de nullo aliorum filiorum Adae est credendum. Et si forsan aliqui concepti sint amici et parum ante conceptionem ${ }^{13}$ purgati, ut diximus de Ioanne Baptista, nullus tamen est ex filiis Adam quem pro aliquo tempore Deus non uiderit ut inimicum pro tunc. Aliqui ergo, antequam orti essent, in utero erant inimici, sed in ortu et post numquam fuerunt inimici. Aliqui uero ante ortum et in ortu et post, semper inimici permanserunt, ut qui numquam a peccato originali fuerunt purgati. Aliqui uero non solum inimici permanserunt inimicitia prima, sed etiam propria actione facti sunt inimici, addentes inimicitiam inimicitiae. Aliqui item a prima inimicitia purgati fuerunt sed, in nouam incidentes, in ea perseuerauerunt. Alii a prima et secunda purgati, tandem amici ${ }^{14}$ ex ista uita uestra migrauerunt. Sola Dei Genitrix pro nullo umquam tempore inimica fuit, sed semper amica, Deo nolente sibi umquam iram et semper uolente gratiam et gloriam, quae tamen in quantum filia talis patris merebatur iram sicut et alii eius liberi.

9 uulgatos errores] uulgatos errores. De Assumptione Virginis Mariae $V \quad 10$ transfundere] transfundere uoluit et $Q \mathbf{1 1}$ sic quod gratia] si quod summa $I J R V$; sed quod scientia $B$; si quidem sententia $H$; sic quod sententia $M$; ita quod scientia $N$; sic quod scientia $P \mathbf{1 2}$ quo $\rightarrow$ 
residia no útero de sua mãe. Agora, porém, que em breve o Senhor, pelas preces desta mesma sua Mãe, vai reconduzir ao seu culto o mundo inteiro e vai submeter ao jugo da fé a cerviz de todos, quer que a pureza, a santidade, a graça, a honra, o esplendor e a magnificência desta Virgem se tornem conhecidos. Por isso, dilectíssimo, quis que tu viesses até aqui para escreveres aquilo que te vou dizer, e a todos os homens seja dado a conhecer pelo Pastor que vive mas ainda não reina. Reinará, todavia, como te será dado ver antes de ires daqui embora.

E uma vez que muitas coisas se têm inabilmente escrito da Virgem que não são verdade, e muitas verdades se têm omitido, regista tu agora, de novo, e dá atenção ao que sobre ela digo. Pois, por isso, todos presentemente a adoramos, porque Deus quis revelar a todos os homens a sua glória a fim de que pelos seus méritos e preces todos obtenham a salvação e a vida eterna. O que disse noutra ocasião vou em parte repeti-lo agora e vou revelar algumas coisas novas, mormente sobre a sua assunção ao céu, excluindo muitos e divulgados erros.

Deve-se firmemente crer que aquela a quem Deus acima de todos, mesmo dos anjos, distinguiu em graça e glória, e a quem quis que, depois de si, fosse a primeira no seu reino, e por meio de quem estabeleceu comunicar aos homens todo o bem e todo o dom, e a quem escolheu para sua Mãe, nunca fosse filha da ira, nunca fosse manchada por pecado algum, nunca, nem enquanto existiu, nem antes de existir e ser vista em visão pela mente divina, foi apreendida como inimiga ou carecida de graça, se quanto a isso a suma graça de Deus lhe não devesse ser concedida durante o tempo em que existisse. Todas as vezes que Deus a viu (de facto, sempre a viu), nunca e em tempo algum a apreendeu como inimiga, o que de nenhum outro dos filho de Adão se deve crer. Embora talvez alguns tenham sido concebidos como amigos e tenham sido purificados pouco antes da concepção, como dissemos de João Baptista, não há, todavia, nenhum filho de Adão a quem por algum tempo Deus não tenha visto então como inimigo. Portanto, alguns, antes de haverem nascido, eram no útero inimigos, mas, ao nascerem e depois, nunca foram inimigos. Mas outros, como aqueles que nunca foram purificados do pecado original, sempre permaneceram inimigos antes do nascimento, no nascimento e depois. Outros, ainda, não só se mantiveram inimigos em razão da primeira inimizade, mas tornaram-se inimigos também em razão da acção própria, somando inimizade a inimizade. E outros foram purificados da primeira inimizade, mas, ao incidirem em nova, persistiram nela. Outros, purificados da primeira e da segunda, partiram finalmente desta vossa vida como amigos. A Mãe de Deus foi a única que nunca e em tempo algum foi inimiga, mas sempre amiga, não querendo Deus nunca para ela a ira e querendo sempre a graça e a glória, ela que, todavia, enquanto filha de tal pai, merecia a ira como todos os outros filhos dele.

$\leftarrow$ existeret] coexisteret $Q \mathbf{1 3}$ ante conceptionem] ante conceptionem, hoc est, natiuitatem $Q \quad 14$ amici] inimici $Q$ 
Firmiter credendum est animam Virginis Mariae creatam cum omnibus scientiis et rerum similitudinibus, sicut et nos angelos, et a principio sui ortus Deum cognouisse et amauisse, sed non notitia intuitiua neque uisionis, quia hoc proprium est beatorum. Ipsa tamen quandoque ipsum Deum et frequenter, dum uiueret, uidit, sed in tali uisione non perseuerauit. Tantam ergo cognitionem a principio [fl. 178] habuit quantam et nos angeli. Habuit et eo clariorem ${ }^{15}$ quo Deus ipsam plus quam nos angelos diligebat.

Firmiter credendum est Mariam omnium gentium litteras et linguas et artes liberales et illiberales nouisse. Similiter scientias speculatiuas et practicas tam actiuas quam factiuas ${ }^{16}$.

Firmiter credendum est Mariam gratia maiori quocumque angelo uel homine ornatam fuisse et omnibus uirtutibus supra omnes post Filium decoratam extitisse ${ }^{17}$, immo plures habuit uirtutes quam suus Filius. Habuit namque fidem et spem quibus Christus, tamquam ab initio beatus, caruit.

Firmiter credendum est corpus Mariae optime complexionis fuisse ita quod, nisi Deus uoluisset eam glorificare et complexionem non impediuisset, longe amplius quam uixit uixisset. Membra ipsius omnia quae uiro ${ }^{18}$ et mulieri sunt communia erant simillima membris Christi ita ut caro unius uideretur esse caro alterius. Fuit pulcherrima mulierum et in omnibus optime disposita.

Qualiter in trienio in Templo Domini praesentata est, qualiter ibi uixit, qualiter desponsata fuit, qualiter ab angelo, hoc est, me Gabriele salutata Verbum Dei concepit, qualiter Elisabeth uisitauit et tandem Iesum peperit, qualiter educauit et in Templo disputantem una cum uiro suo Ioseph inuenit, qualiter cum Ioseph aliquo tempore postea uixit, dicta sunt. Omnem statum in se habuit. Fuit enim innupta puella, fuit deinde nupta, fuit postmodum uidua, fuit uirgo, fuit et mater. Postquam autem Iesus disputauit anno duodecimo, aliqui dixerunt Ioseph defunctum et Mariam intrasse in Templum Domini et locum tenuisse Annae prophetissae, Iesum uero ascendisse in caelum et cum Patre et Spiritu Sancto usque ad quintum decimum annum Tiberii Cesaris superius mansisse et ciuitatem beatorum construxisse. Vnde ipse dixit: Nemo ascendit in caelum nisi qui descendit de caelo $^{19}$. Et ita credunt ${ }^{20}$ Christum Dominum bis in caelum ascendisse. Sed firmiter credendum est Christum Dominum in caelum corpore non ascendisse umquam nisi die quadragessimo post ressurrectionem suam. Ipse tamen dicitur descendisse de caelo, quia deitate ubique est et in caelo praecipue, quia ibi se

15 Habuit et eo clariorem] Et adeo clariorem $O Q 16$ factiuas] passiuas $I V \mathbf{1 7}$ extitisse] fuisse $N$; stetisse $Q 18$ omnia quae uiro] omni uiro $I V 19$ de caelo.] de caelo, Filius Hominis qui est in caelo. $Q 20$ credunt] crediderunt $O$; credere $Q$ 
Deve-se firmemente acreditar que a alma da Virgem Maria foi criada com todos os conhecimentos e com as imagens das coisas, como também nós anjos, e que conheceu e amou a Deus desde o início do seu nascimento, mas não com o conhecimento intuitivo nem de visão, porque esse é próprio dos bem-aventurados. Ela, porém, enquanto viveu, viu às vezes e frequentemente o próprio Deus, mas não persistiu nessa visão. Teve, pois, desde o princípio, [f1. 178] tão grande conhecimento como nós anjos. Teve-o tanto mais distinto quanto Deus a amava mais do que a nós anjos.

Deve-se firmemente acreditar que Maria conheceu a literatura e as línguas e as artes liberais e os ofícios de todos os povos. Conheceu igualmente as ciências especulativas e práticas, tanto as de concepção como as de realização.

Deve-se firmemente acreditar que Maria foi ornada com maior graça do que qualquer homem ou anjo, e se mostrou ornada de todas as virtudes acima de todos, depois de seu Filho. E até teve mais virtudes que seu Filho, pois teve fé e esperança, de que seu Filho, enquanto bem-aventurado desde o princípio, foi privado.

Deve-se firmemente acreditar que o corpo de Maria teve óptima constituição, de tal modo que, se Deus a não tivesse querido glorificar e não tivesse posto um limite a essa constituição, teria vivido muito mais do que viveu. Todos os seus membros que são comuns ao homem e à mulher eram exactamente semelhantes aos membros de Cristo, de tal modo que a carne de um parecia ser a carne do outro. Foi a mais bela das mulheres e em tudo perfeitissimamente constituída.

Foi dito de que modo foi apresentada no Templo do Senhor aos três anos, como aí viveu, como foi desposada, como, saudada pelo anjo, isto é, por mim Gabriel, concebeu o Verbo de Deus, como visitou Isabel e, por fim, como deu Jesus à luz, como o educou e, na companhia de José, seu marido, o encontrou no Templo enquanto discutia, como depois viveu com José por algum tempo. Reuniu em si todos os estados. Com efeito, foi donzela virgem, foi depois casada, foi a seguir viúva; foi virgem, foi também mãe. Depois de Jesus aos doze anos haver discutido no Templo, disseram alguns que José teria morrido e Maria teria entrado no Templo do Senhor e ocupado o lugar da profetisa Ana, e que Jesus teria subido ao céu e teria permanecido nas alturas com o Pai e o Espírito Santo até ao décimo quinto ano do reinado de Tibério César, e que teria construído a cidade dos bem-aventurados. Daí que tenha dito: Ninguém sobe ao céu senão aquele que desceu do céu. ${ }^{[195]} \mathrm{E}$, assim, crêem que Cristo Senhor subiu ao céu por duas vezes. Mas deve-se crer firmemente que Cristo Senhor nunca subiu ao céu em corpo senão no quadragésimo dia depois da sua ressurreição. Todavia, 
ostendit hominibus per gloriam. Descendit autem per effectum, quia carnem assumpsit et seipsum exinaniuit et humiliauit. Ascendit uero, quia corpus suum illuc in gloriam transuexit. Vnde sequitur: Filius Hominis qui est in caelo. Semper enim erat in caelo qui de loco non transit ${ }^{21}$ ad locum. Et ille idem descendit, quia humanatus est. Deinde ascendit in corpore a se assumpto. Tamen Dominus Iesus illo tempore mystice fuit in caelo, quia apud solum Patrem pro uobis operabatur ${ }^{23}$ et merebatur ${ }^{24}$ et opera eius atque merita non agnoscebantur apud homines sicut postea fuerunt agnita quando publice praedicabat, miracula faciebat et se Deum publicabat $^{25}$. Semper ergo ipse ciuitatem supernam pro uobis hominibus construebat meritis suis praeclarissimis. Et Maria mater eius erat secum ut plurimum.

Neque uerum est ut Anna prophetissa usque ad illud tempus uixisset neque quod Ioseph tunc mortuus esset, sed custodiuit Mariam usque ad baptismum Christi et conuersionem ac familiaritatem Mariae Magdalenae et Marthae sororis suae, quibus Dominus [fl. 179] matrem suam comendauit iam existentem uiduam, quia ille status sibi deficiebat. Et in illo statu orbata est filio suo ita quod inuenta est simul sine marito et sine filio et antea pupilla fuerat et orphana.

Ioseph ergo senex annorum circiter septuaginta sex migrauit et appositus est plenus sanctitate et iustitia et omni uirtute et gratia ad patres suos quibus annuntiauit ${ }^{26}$ qualiter factum erat uerbum Domini super Ioannem, Zachariae filium, in deserto et praedicabat baptismum paenitentiae in remissionem peccatorum et qualiter Christus Dominus ab eo baptizari uoluit et ipse quoque praedicare coeperat et iam discipulos congregabat et multa miracula faciebat. Tunc omnes sancti Patres et sanctae Matres ualde exultauerunt et letati sunt in Deum Viuum ${ }^{27}$ et ipsi Ioseph, tamquam nutricio Domini maritoque Genitricis Dei et custodi, locum dederunt ipsumque non solum Adam, Seth, Abel et Noe, sed ipse Abraham,

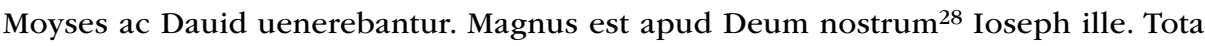
caelestis curia ipsum tamquam thesauri Christi Domini custodem et ministrum fidelissimum honorat, colit et ueneratur. Oportet ut et uos eum honoretis et officium eius solemnius ${ }^{29}$ celebretis. Et hic pontifex, qui nunc est, incipiet. Sed ille qui postea sedebit et nunc inter uos simpliciter incognitus ambulat perficiet et complebit. Ioseph ergo ablatus fuit eo tempore ad hoc ut Maria Virgo uidua remaneret et fructum non solum trigesimum ${ }^{30}$, sed etiam sexagesimum afferret et toti Ecclesiae mereretur et omnem statum honoraret et uirginalem et matrimonialem et uidualem et esset caput et spes atque unicum refugium uirginum, nuptarum et

21 transit] transuexit $Q$,; transiit $V \mathbf{2 3}$ operabatur] cooperabatur $I$; comprobatur $V \mathbf{2 4}$ merebatur] morabatur $P 25$ publicabat] predicabat $P \quad 26$ quibus annuntiauit] qui annuntiauit patribus suis $N 27$ Deum Viuum] Deum unum $I$; Dominum unum $V \mathbf{2 8}$ Deum nostrum] Deum Viuum $M$; Dominum nostrum $V \mathbf{2 9}$ solemnius celebretis] solemniter decantetis $P \quad \mathbf{3 0}$ trigessimum] trigessimum et centesimum. $M$ (in marg. a. m.) 
diz-se que ele desceu do céu porque em divindade está em toda a parte e no céu principalmente porque aí se mostra aos homens pela sua glória. Mas desceu de facto, porque assumiu a carne e se aniquilou e humilhou a si mesmo. Subiu realmente, porque para ali transportou o seu corpo para a glória. Daí seguir-se: o Filbo do Homem que está no céu. ${ }^{[196]} \mathrm{Na}$ verdade, estava sempre no céu aquele que não passou do céu para um lugar. E ele mesmo desceu porque se fez homem. Depois subiu no corpo por si assumido. Todavia, o Senhor Jesus, nesse tempo, esteve misticamente no céu, porque trabalhava e merecia por vós apenas junto do Pai, e as suas obras e os seus méritos não eram conhecidos junto dos homens como foram conhecidos depois quando pregava publicamente, fazia milagres e anunciava que era Deus. Portanto, sempre ele por seus preclaríssimos méritos construía para vós homens a cidade celeste. E Maria, sua Mãe, estava habitualmente com ele.

E não é verdade que a profetisa Ana tivesse vivido até àquela data, nem que José tivesse então morrido, mas protegeu Maria até ao baptismo de Cristo e à convivência e familiaridade de Maria Madalena e de Marta, sua irmã, às quais o Senhor [f1.179] confiou sua Mãe já viúva, porque lhe faltava aquele estado. E nesse estado perdeu seu filho, de modo que se achou ao mesmo tempo sem marido e sem filho e, antes, tinha sido menina do Templo e órfã.

Portanto, José partiu desta vida com cerca de setenta e seis anos de idade e, cheio de santidade e justiça e de toda a virtude e graça, foi juntar-se aos seus antepassados, a quem anunciou de que modo a palavra do Senhor fora comunicada no deserto a João, filho de Zacarias, e como este pregava o baptismo de penitência para a remissão dos pecados, e como Cristo Senhor quis ser por ele baptizado e também ele começara a pregar e reunia já discípulos e fazia muitos milagres. Todos os Santos Pais e as Santas Mães exultaram então e se alegraram no Deus Vivo. E concederam um lugar ao próprio José, na qualidade de quem criou o Senhor e de marido da própria Mãe de Deus. E não só Adão, Seth, Abel e Noé, mas também Abraão, Moisés e David o veneravam. É grande perante o nosso Deus esse José! Toda a corte celeste o honra, o respeita e o venera enquanto protector e servidor fidelíssimo do tesouro que é Cristo Senhor. É conveniente que também vós o honreis e celebreis o seu ofício com maior solenidade. E este pontífice, o que hoje governa, será o primeiro a começar. Mas aquele que depois tomará o seu lugar e anda agora simplesmente incógnito no meio de vós levará a tarefa a cabo e completá-la-á. Portanto, José foi levado nessa altura para que Maria ficasse viúva e produzisse fruto, não só trinta por um, mas também sessenta, e merecesse para toda a Igreja e honrasse cada estado, o de virgem, o de casada e o de viúva, e fosse a cabeça e a esperança e o único refúgio de virgens, 
uiduarum. Sed ante obitum sanctissimi Ioseph, singulis annis et festis, Maria cum Iesu, Iosephque committante, in Ierusalem ascendebant, doctores et sacerdotes qui credebant confortantes et exhortantes. Sed nolebat Dominus Iesus aperte praedicare sicut postea fecit, quia omnia secundum dispositionem Prouidentiae Diuinae et secundum prophetarum oracula et testimonia faciebat et exercebat et in aetate condecenti ut etiam posteris ${ }^{31}$ exemplum praeberet.

Maria ergo interfuit nuptiis Ioannis Euangelistae et deinde assidue conuersabatur cum sororibus Lazari, defuncto Ioseph, et manebat ut plurimum in Bethania. Et de passione Christi futura, quam praeuidebat, semper doluit. Sed tanto magis dolebat quanto eam propinquiorem ${ }^{32}$ inspiciebat. Et quando eius dolores, hoc est, unigeniti Filii sui uidit et aspexit et obprobria et ignominias, ualde tristabatur et de malo Filii et de nimia ingratitudine et ignorantia et impietate atque crudelitate hominum et de damnatione ipsorum. Multa ergo dolorem eius augebant sicut et Filii sui, non obstante quod salutem humani generis ualde cuperet et desideraret. Sed illud non diminuebat dolorem quando cogitabat etiam sine tali passione humanum genus redimi posse ${ }^{33}$. Immo uidebat sufficere ad hoc promptam uoluntatem Filii sui se offerentis absque ulla executione. Videbat quoque illos mala [f1. 180] intentione poenam Filio suo inferre. Valde itaque doluit de tam atroci, ignominiosa et iniqua Filii sui passione. Sed in eius quoque resurrectione exultauit supra omnes.

Firmiter namque tenendum est Christum Dominum ante omnes alios matri suae apparuisse ipsamque confortasse atque gaudio et exultatione summa impleuisse et antequam ad caelos ascenderet, quod eam secum non duceret se excusasse quia oportebat eam in uita mortali remanere et secreta suae conceptionis et natiuitatis Paulo, Lucae, Dionysio, Ignatio multisque aliis reuelare et manifestare et pusilanimes confortare et discipulos aliosque credentes admonere et uiam Dei docere.

Dixitque Dominus matri suae quando ad caelos ascendere uolebat: "Ecce, mater mea dulcissima, Filium tuum Iesum uides extra omnem dolorem et laborem, extra omnem miseriam et calamitatem. Ecce ipsum cernis laetissimum et iucundissimum, uiuum uita immortali, impassibili et gloriosa. Data est mihi, Genitrix mea, omnis potestas in caelo et in terra. Factus sum Dominus uniuersorum. Angeli omnes et Archangeli, Principatus et Potestates, Virtutes et Dominationes, Throni, Cherubin et Seraphin subiciuntur mihi. Et tu eris ante omnes iuxta me et iuxta solium Sanctissimae Trinitatis sicuti quando me concepisti et peperisti, suauissima mater, uidisti et audisti et experta es. Et mihi, Filio tuo, summe placeret ut in regnum istud nostrum simul intraremus, simul illud possideremus, simul regnaremus. Sed propter apostolos et alios discipulos praesentes et futuros Prouidentia Diuina 
casadas e viúvas. Mas antes da morte do muito santo José, todos os anos e em todas as festas, Maria com Jesus e na companhia de José subiam a Jerusalém, confortavam e exortavam os doutores e os sacerdotes que criam. Mas o Senhor Jesus não queria pregar abertamente, como fez depois, porque tudo fazia e tudo executava segundo a disposição da Providência Divina e segundo os oráculos e os testemunhos dos profetas e na idade própria, para dar também o exemplo aos vindouros.

Maria esteve, pois, presente nas bodas de João Evangelista e, depois, morto José, convivia assiduamente com as irmãs de Lázaro e ficava em Betânia muitas vezes. E sempre sentiu a dor da futura Paixão de Cristo, que previa. Mas a sua dor era tanto maior quanto mais próxima a via. E quando viu e presenciou suas dores, isto é, de seu Filho Unigénito, o seu opróbrio e ignomínias, mais se entristecia, não só por causa do mal do Filho, mas da desmesurada ingratidão, da ignorância e da impiedade e crueldade do homem e da sua condenação. Muitas eram, pois, as coisas que atormentavam a sua dor assim como a de seu Filho, não obstante desejar muito e aspirar pela salvação da raça humana. Mas isso não diminuía a dor, quando pensava que a raça humana podia ser redimida também sem essa Paixão. Pelo contrário, via que para isso bastava a pronta vontade de seu Filho, que se oferecia, sem qualquer execução. Via também que eles infligiam a seu Filho o castigo por intenção [f1. 180] malévola. E, deste modo, muito sofreu por causa da Paixão de seu Filho, tão atroz, ignominiosa e iníqua. Mas na sua Ressurreição exultou mais que todos.

Deve, pois, seguramente afirmar-se que Cristo Senhor apareceu a sua Mãe antes de todos e a confortou e a encheu do maior gozo e da máxima alegria e, antes de subir ao céu, uma vez que a não levava consigo, se escusou, porque convinha que ela permanecesse na vida mortal e revelasse e expusesse os segredos da sua concepção e do seu nascimento a Paulo, a Lucas, a Dionísio, a Inácio e a muitos outros, confortasse os fracos, exortasse os discípulos e os outros crentes e ensinasse o caminho de Deus.

Quando pretendia subir ao céu, disse o Senhor a sua Mãe: Minha dulcíssima Mãe, eis que vês teu Filho acima de toda a dor e de todo o trabalho, acima de toda a miséria e de toda a desgraça. Eis que o vês alegre e feliz, vivo de vida imortal, impassível e glorioso. Foi-me dado, minha Mãe, todo o poder no Céu e na Terra. Tornei-me o Senhor de todas as coisas. Todos os Anjos e Arcanjos, Principados e Potestades, Virtudes e Dominações, Tronos, Querubins e Serafins me estão subordinados. Mas antes de todos estarás tu junto a mim e junto ao trono da Santíssima Trindade, como quando me concebeste e me deste à luz, suavíssima Mãe, me viste e me ouviste e me tocaste. E seria para mim, teu Filho, sumamente agradável que entrássemos ao mesmo tempo neste nosso reino, o possuíssemos em comum, em comum reinássemos. Mas determinou a Providência 
decreuit ut tu in ista uita adhuc remaneas propter consolationem fidelium. Veniet ad fidem Paulus, ueniet areopagita Dionysius, uenient plurimi alii quos tu confortabis et corroborabis. Et Lucae et Ignatio et aliis, prout oportuerit, quae de me nosti reuelabis. Et pro tepidis fidelibus multa merita accumulabis. Ego te numquam deseram diuinitate, tecum assidue ero in isto sacramento panis et uini. Et meum corpus ${ }^{34}$ atque me totum ibi oculis tuae mentis saepissime et quotiens placuerit et opus fuerit offeram et ostendam. Videbis me Filium tuum etiam corpore praesentem tibi et numquam te derelinquentem. Commendo tibi fratres meos apostolos et Magdalenam teque ipsis committo. Ascendo ecce ad Patrem meum et Patrem uestrum, Deum meum et Deum uestrum ${ }^{35}$.

Ioannes, accede huc. Magdalena, appropinqua ad me. Matrem meam uobis committo, Genitricem meam carissimam uobis commendo. Seruite sibi et obsequia praestate opportuna, nam et ipsa mihi tanto tempore seruiuit meque cum tanto amore et diligentia educauit, in Aegyptum et de Aegypto associauit et quasi in omni itinere comitata est. Multa pro me pertulit. Vos etiam pro ipsa mei gratia et sui amore perferre uelitis ${ }^{36}$. Eam curam de ipsa habetote qualem ipsa de me habuit. Veneramini et obseruate eam. Mater Domini uestri est et Saluatoris, Genitrix Dei est omnium plasmatoris."

Et coram omnibus [fl. 181] complexans ${ }^{37}$ eam brachiis uenerabilibus et sancta labia ori suo imprimens, cunctis qui aderant prae deuotione et gaudio lacrimas effundentibus, dixit: Regina caelorum et Domina angelorum et omnium hominum es. Laetare. Ego enim sum Iesus ille Filius tuus quem concepisti et in sancto utero portasti, tam delicate et diligenter educasti et supra omnes semper amasti, quem afflictum, sputis deturpatum et proprio sanguine uidisti, quem flagellis caesum, spinis coronatum ${ }^{38}$, clauis confixum aspexisti. Haec est caro tua, haec ossa tua, hic sanguis tuus. Vale, mater sanctissima atque pientissima ${ }^{39}$.

Tunc Maria dixit: Cor meum et caro mea exultauerunt in Deum Viuum. Anima mea te Deum meum magnificat. Spiritus meus in te Deo salutari meo gaudet nimium et letatur. Cuperem et ego, carissime fili, tecum iam assidue uiuere, morari et conuersari et in gloria caelesti lumen incircumscriptum uidere. Nullum tamen recuso laborem, fiat uoluntas tua. Remanebo, curam omnium habere conabor, docebo quos ${ }^{40}$ oportuerit, secreta tua reuelabo quibus et quando et quantum opus fuerit. Ioannem ut Filium, Magdalenam ut sororem complectar. Mandata tua non praeteribo, custodiam omnia et adimplebo, pro toto populo Dei orabo laudesque Domino pro omnibus decantabo. Confortabo praesentes apostolos,

34 diuinitate tecum assidue ero in isto sacramento panis et uini. Et meum corpus] diuinitate tecum semper ero, in isto sacramento panis et uini meum corpus $Q \quad 35$ et Deum uestrum] et Deum uestrum, Iesus ad Ioannem et Magdalenam $Q \quad 36$ uelitis] ualetis $Q \quad 37$ complexans] complexens $I$; amplexans $O Q$; complectens $V 38$ flagelis caesum, spinis coronatum] flagelis cum spinis coronatum $V 39$ pientissima] sapientissima $Q V \mathbf{4 0}$ quos] quo $I$; quae $J M$ 
Divina, por causa dos apóstolos e outros discípulos presentes e futuros, que tu permanecesses ainda nesta vida para consolação dos fiéis. À fé virá Paulo, virá o areopagita Dionísio, virão muitos outros, a quem tu confortarás e tornarás mais fortes. E revelarás a Lucas e a Inácio e outros, conforme for preciso, as coisas que sabes a meu respeito. E acumularás muitos méritos a favor dos fiéis tíbios. Enquanto Deus, nunca te abandonarei, estarei contigo assiduamente no sacramento do pão e do vinho. E nele exporei e mostrarei, todas as vezes e sempre que for conveniente e necessário, aos olhos da tua mente o meu corpo em toda a plenitude. Ver-me-ás a mim, teu Filho, presente junto a ti, mesmo em corpo, sem nunca te abandonar. Confio-te os meus irmãos apóstolos e Madalena, a eles te entrego. Eis que subo para junto de meu e vosso Pai, de meu e vosso Deus. ${ }^{[197]}$

João, vem cá! Madalena, aproxima-te de mim! Entrego-vos minha Mãe, confio-vos aquela que me gerou. Servi-a, prestai-lhe o apoio de que carecer, pois também ela me serviu por tanto tempo, me educou com tanto amor e tanto zelo, fez-me companhia no caminho para o Egipto e no regresso do Egipto, acompanhou-me em quase todos os caminhos. Por mim suportou muita coisa. Queirais vós sofrer também por ela, por causa de mim e por amor dela. Tende em relação a ela a preocupação que ela teve em relação a mim. Venerai-a e respeitai-a, é a Mãe do vosso Senhor e Salvador, é a Mãe de Deus, Criador de todas as coisas.

E estreitando-a [f1. 181] em seus muito veneráveis braços, na presença de todos, e imprimindo seus santos lábios na face dela enquanto todos os presentes derramavam lágrimas por devoção e alegria, disse: Alegra-te, és Rainha do Céu e Senhora dos anjos e de todos os homens. Eu sou Jesus, o filho que tu concebeste e trouxeste em teu santo ventre, tão afectuosa e diligentemente amamentaste e mais que todos sempre amaste, a quem viste atormentado, desfigurado pelos escarros e pelo próprio sangue, a quem contemplaste flagelado, coroado de espinhos, trespassado pelos cravos. Esta é a tua carne, estes os teus ossos, este o teu sangue. Adeus, santíssima e piíssima Mãe.

O meu coração e a minha carne, disse então Maria, exultam de alegria no Deus Vivo. ${ }^{[198]}$ A minha alma glorifica-te a ti, Deus meu. O meu espírito rejubila e se alegra em ti, Deus, meu Salvador. ${ }^{[199]}$ Também eu gostaria, meu muito querido Filho, de viver, morar e habitar já contigo indefinidamente e ver na glória celeste a luz sem limites. Não recuso, contudo, nenhum trabalho, faça-se a tua vontade. Ficarei, tentarei cuidar de todos, ensinarei aqueles que for preciso, revelarei os teus segredos a quantos for preciso, quando for preciso e quanto for preciso. Receberei João como filho e Madalena como irmã. Não esquecerei os teus mandamentos, guardá-los-ei e cumpri-los-ei a todos, hei-de orar por todo o povo de Deus, por

[197] Jo 20:17

[198] S1 83:3

[199] Lc 1:46,47 
Petrum uicarium tuum et reliquos omnes et eos similiter qui postea uenturi sunt. Gratias ago quia me etiam praesentia corporali non derelinquis. Videbo te namque in sacramento, ubi manes modo corporeis oculis ${ }^{41}$ inuisibili, sed oculo mentis manifestus et uisibilis. Abscedes a me neque tamen discedes a me. Ad Patrem ibis et mecum iugiter manebis. Caelos caelorum penetrabis ${ }^{42}$ et mecum terrenum hunc globum inhabitabis ${ }^{43}$. Benedic mihi, Deus meus, benedic mihi, Domine meus, benedic mihi suauissime fili mi.

Ad quam Dominus: Diu est quod tibi Pater meus benedixit simul cum Verbo suo et Spiritu Paraclito. Semper enim ${ }^{44}$ benedicta fuisti et nulli umquam maledictioni subiecta extitisti ${ }^{45}$. Omnem gratiam quae Dei matrem habere decet habuisti. Nil tibi aliud quam beatitudo aeterna conferri potest et corporis immortalitas cum aliis dotibus. Benedicta sis sicut et es mater mea omni benedictione. Sed et tu mihi Filio tuo benedicas, Genitrix dulcissima.

Maria dixit: Deus es. Ad te benedicere spectat. In quantum tamen Filius meus es, minor me aliquo modo es. Ideo, ut aliquo modo maior, tibi benedico, fili mi, hoc est, benedictum praedico omnibus et benedictionem tuam annuntio uniuersis uiuentibus praesentibus et futuris, quia non est benedictio ulla sine te, Saluatore et Redemptore omnium hominum, sed meo praecipue. Nullum enim magis saluasti neque magis redemisti quam me. Te igitur sicut Deum meum, Redemptorem meum, Saluatorem meum benedico et in aeternum magnifico.

Tunc accersito Petro, dixit Dominus Iesus: Petre, ${ }^{46}$ diu est quod tibi claues regni caelorum tradere promisi. Duae sunt, non una. Vtramque tibi nuper dedi, utramque iterum coram his omnibus discipulis meis et fratribus meis tibi tribuo ut possis scire, cognoscere [f1. 182] et examinare ac etiam sententiam dare, decidere ac declarare. Esto princeps fratrum tuorum. Incuruentur ante te filii matris tuae. Gregem meum tibi committo, oues meas tibi do et commendo. Tuae sint. Esto earum dominus. Pasce omnes agnos meos medio aliorum, hoc est, ouium. Pasce agnos tu absque medio, pasce etiam oues meas. Oues enim sunt doctores, praedicatores, praelati et omnes episcopi regesque ac principes qui lacte scientiae et lacte exemplaris uitae agnos pascunt et nutriunt. Agni sunt qui solum docentur et nutriuntur. Tu itaque pasces agnos medio ouium tuarum quas institues ad pascendum gregem. Pasce nihilominus et tu agnos tuos sine tali medio. Quaecumque enim ipse oues facere possunt et tu facere poteris. Pasce tandem et ipsas oues. Quia ergo pastor es, uere rex es. Nil enim aliud est regere homines nisi eos pascere. Et pascere est regere. Pastor ergo rex est et rex est pastor. Et

41 oculis] omnibus $N 42$ penetrabis] inhabitabis $N 43$ iugiter manebis. (Caelos caelorum penetrabis et mecum terrenum hunc globum inhabitabis. $M$ in marg. $a$. $m$.)] iugiter manebis. IJV 44 Semper enim] Semper et pro semper $M$ (in marg. a. m.) $N O Q 45$ extitisti] fuisti $N$; stetisti $Q$ 46 Dominus Iesus: "Petre] Dominus Iesus Petro $P$ 
todos cantarei louvores ao Senhor. Darei força aos apóstolos presentes, a Pedro, o teu vigário, e a todos os outros e igualmente aos que hão-de vir depois. Dou graças porque me não abandonas, mesmo com a presença corporal, pois vou ver-te no sacramento, onde permanecerás de modo invisível aos olhos do corpo, mas evidente e visível aos olhos da mente. Ausentas-te de mim, mas não partes de junto de mim. Irás para o Pai, mas ficarás permanentemente comigo. Penetrarás no mais alto dos céus e habitarás comigo este globo terrestre. Abençoa-me, Deus meu, abençoa-me, meu Senhor, abençoa-me meu suavíssimo Filho.

Há muito, respondeu-lhe o Senhor, que meu Pai juntamente com seu Verbo e o Espírito Paráclito te abençoaram. De facto, sempre e desde sempre foste abençoada e nunca estiveste sujeita a maldição alguma. Tiveste toda a graça que à Mãe de Deus convém ter. Nada mais que a bem-aventurança eterna e a imortalidade do corpo com outros dotes te pode ser atribuído. Sê bendita com toda a espécie de bênçãos como de facto és minha Mãe. Mas abençoa-me tu também a mim, teu Filho, Mãe dulcíssima.

És Deus, disse Maria. A ti cabe abençoar. Todavia, na medida em que és meu filho, és de algum modo inferior a mim. Nessa medida, como de algum modo superior, te abençoo, meu Filho, isto é, te proclamo bendito perante todos e anuncio a todos os viventes presentes e futuros a tua bênção, porque sem ti, Salvador e Redentor de todos os homens, mas principalmente meu, não há bênção nenhuma. Na verdade, ninguém salvaste nem redimiste mais do que a mim. Por isso te bendigo como meu Deus, meu Redentor, meu Salvador, e eternamente te glorifico.

Chamado então Pedro, disse o Senhor Jesus: Pedro, há muito que prometi entregar-te as chaves do Reino dos céus. São duas, não uma. Não há muito que tas dei, entrego-tas novamente perante todos estes meus discípulos e meus irmãos para que possas saber, [f1. 182] conhecer e examinar e também sentenciar, decidir e explicitar. Sê o primeiro entre os teus irmãos. Que se curvem perante ti os filhos de tua mãe. ${ }^{[200]}$ Entrego-te o meu rebanho, dou-te e confio-te as minhas ovelhas. Que elas sejam tuas. Sê o senhor delas. Apascenta todos os meus cordeiros por intermédio dos outros, isto é, das ovelhas. Apascenta os cordeiros sem mediação, apascenta também as minhas ovelhas. As ovelhas são os doutores, os pregadores, os prelados e todos os bispos e reis e príncipes que com o leite da ciência e o leite de uma vida exemplar apascentam os cordeiros e os alimentam. Os cordeiros são aqueles que apenas são ensinados e alimentados. Tu apascentarás os cordeiros por intermédio das tuas ovelhas, a quem instruirás para apascentarem o rebanho. Apascenta, contudo, tu também os cordeiros sem essa mediação, pois, quanto podem fazer as próprias ovelhas, poderás também tu fazer. Apascenta, 
ueri reges nil aliud sunt quam pastores. Tu ergo non solum dominus propter oues proprias eris, sed etiam rex eris. Et quia quaecumque super terram solueris aut ligaueris etiam in caelo erit solutus aut ligatus, cuicumque benedixeris erit benedictus, cui maledixeris erit maledictus, consecrabis, benedices, sanctificabis et eos qui haec sub te facient institues et ordinabis. Et ideo summus sacerdos et maximus pontifex eris. Peccatores, Petre, tibi commendo, pro quibus reducendis, sanctificandis et saluandis multa perpessus sum. Recordare, Petre, quia et tu multotiens peccasti. Compatere peccator peccatori, homo homini, cinis cineri, puluis pulueri. Nullum a poenitentia excludas, nulli uiam reconciliationis praecludas. Mansuetus et modestus atque mitis esto peccatoribus. Nullum spernas, nullum abhorreas, nullum abiicias ${ }^{47}$. Te pastorem ouium ${ }^{48}$ tamquam firmiorem, solidiorem, feruentiorem et humaniorem et tamquam illum qui infirmis compati poteris, quia et ipse infirmus fuisti, instituo. Discretione et circumspectione gubernabis omnia, confortabis, monebis, hortaberis, argues, reprehendes, corripies et castigabis. Virtutes atque merita ouium tuarum et agnorum tuorum considerabis et aequa lancee ponderabis. Cetera te cito uenturus Spiritus Sanctus docebit pariter cum omnibus his.

Et haec dicendo, Petrum coram se genuflexum amplexatus atque osculatus, Ioannem uocauit sibique matrem iterum commendauit. Andream et Iacobum utrumque cum Thoma, Simone, Thaddaeo, Philippo, Matthaeo, Bartholomaeo similiter allocutus est. Et quae super eos uentura erant annuntiauit. Similiter et discipulos alios, praesertim Lucam et Marcum et Barnabam, quem cum Paulo assumpturus erat ad apostolatum, conuocauit. Omnibus futura super eos denuntiauit $^{49}$ et quid facturi et quid passuri forent intimauit. Omnes singillatim amplexatus est atque osculatus omnibusque benedicebat.

Erant ibi multae mulieres quae ipsum secutae [f1. 183] fuerant, sed precipue Maria Salome et Maria Alphaei a marito siue Iacobi a filio. Nam Maria Salome fuit uxor Zebedaei et numquam nominatur a marito, sed tantum a patre. Maria Alphaei nominatur a marito. Illa eadem uocatur Maria Iacobi uidelicet Minoris qui fuit filius suus. Illa eadem appellatur Maria Cleophae a patre. Omnes hae mulieres et plures aliae ibi aderant, inter quas erant duae Mariae, ambae Magdalenae, ambae Domini Iesu unctrices ${ }^{50}$. Sed una fuerat peccatrix in ciuitate, altera obsessa a septem spiritibus malignis. Vtramque Dominus diligebat, sed illam sororem Lazari super omnes. Erat enim feruentissima zelatrix Christi Domini et omnium operum eius. Ipsaque cum Martha, sorore sua, ultra omnes de facultatibus suis ministrabat Christo Domino et matri eius et omnibus discipulis. Omnibus ergo 
por fim, também as próprias ovelhas. Pois, porque és Pastor, és verdadeiramente rei. Reger os homens não é senão apascentá-los. E apascentar é reger. Portanto, o Pastor é rei, e o rei é Pastor. E os verdadeiros reis não são senão Pastores. Em razão das ovelhas próprias, não serás, pois, apenas senhor, mas serás também rei. E uma vez que tudo quanto desligares ou ligares na terra será desligado ou ligado no céu, quem abençoares será bendito, quem amaldiçoares será maldito, hás-de consagrar, abençoar, santificar e instruirás e ordenarás aqueles que sob a tua ordem isto hão-de fazer e, por isso, serás Sumo Sacerdote e Pontífice Máximo. Entrego-te, Pedro, os pecadores, por cuja conversão, santificação e salvação muito sofri. Lembra-te, Pedro, que também tu pecaste muitas vezes. Pecador, tem compaixão do pecador; homem, do homem; cinza, da cinza; pó, do pó. Ninguém excluas da penitência, a ninguém feches a via da reconciliação. Sê afável, comedido e misericordioso para com os pecadores. Não desprezes nenhum, a nenhum evites, a nenhum enjeites. Estabeleço-te Pastor das ovelhas como o mais firme, o mais sólido, o mais ardente e humano, e como aquele que poderás compadecer-te dos fracos, porque também tu foste fraco. Tudo governarás com discrição e ponderação, confortarás, advertirás, instigarás, arguirás, repreenderás, corrigirás e castigarás. Olharás com atenção virtudes e méritos das tuas ovelhas e dos teus cordeiros e pesá-los-ás em justa balança. O resto, juntamente com tudo isto, ensinar-to-á o Espírito Santo, que em breve há-de vir.

E, dizendo isto, abraçou e beijou Pedro ajoelhado à sua frente, chamou João e entregou-lhe de novo a Mãe. Confortou igualmente André e os dois Tiagos com Tomé, Simão, Tadeu, Filipe, Mateus, Bartolomeu, e anunciou o que estava para lhes sobrevir. Chamou também os outros discípulos, sobretudo Lucas, Marcos e Barnabé a quem com Paulo havia de assumir para o apostolado. A todos anunciou o que estava para lhes acontecer e a todos expôs o que haviam de fazer e o que haviam de sofrer. A todos abraçou e beijou individualmente e a todos abençoava.

Estavam lá muitas mulheres que o tinham [fl. 183] seguido, mas sobretudo Maria Salomé e Maria de Alfeu, pelo marido, ou de Tiago, pelo filho. Pois Maria Salomé foi mulher de Zebedeu e nunca é designada pelo nome do marido, mas apenas pelo do pai. E Maria de Alfeu é designada pelo do marido. Esta mesma é chamada Maria de Tiago, a saber, do Menor, que foi seu filho. Chama-se esta mesma Maria de Cléofas, pelo pai. Todas estas mulheres e muitas outras lá estavam. Entre elas estavam duas Marias, ambas Madalena, ambas haviam ungido o Senhor. Mas uma havia sido pecadora na cidade, a outra possuída por sete espíritos malignos. $O$ Senhor amava-as a ambas, mas a irmã de Lázaro acima de todas. Era realmente uma fervorosíssima zeladora de Cristo Senhor e de todas as suas obras. E ela mesma com Marta, sua irmã, servia mais que todas com seus bens a Cristo Senhor e a sua 
etiam mulieribus benedicens, has duas Marias unctrices suas aduocauit et qualiter longo tempore de ipsis duabus in Ecclesia Christi foret decertatio indicauit an fuerint duae mulieres uel una solum ${ }^{51}$. Et tandem tempore illo felici pastoris felicissimi haec ueritas ostendetur et quod fuerunt duae declarabitur et quod una peccatrix in ciuitate, altera a daemonibus obsessa, nullo tamen uitio notabili subiecta. De hac alias tibi multa dixi.

Christus itaque Dominus utramque Magdalenam uocauit et utrique benedixit, utramque confortauit et sorori Lazari Mariam matrem suam similiter et Marthae atque Lazaro commendauit. Non quia indigeret eorum auxilio, sed ut ipsi, sibi ministrantes et obsequentes, merita accumularent et ut eam associarent et eius exempla sequerentur. O quantum profuit ipsi Ioseph uiro suo conuersatio Mariae! Quamuis enim esset iustus et bonus, propter tamen conuersationem Mariae factus est perfectus et in omni uirtute excellens. Maria enim erat omnibus cum ea conuenientibus ${ }^{52}$ tamquam quidam ignis acutus, penetrans diuino amore corda omnium, inflamans et incendens, purificans et abstergens, illuminans, omnia mala consumans et omnia in Deum aliquo modo conuertens. O quantum profuit Magdalenae, Marthae et Lazaro, Lucae et Ignatio atque beato Dionysio et omnibus qui cum ea conuersabantur. Ignitum erat eloquium eius uehementer, sermo pretiosus erat in ore suo. Imitabilem ${ }^{53}$ se praebebat omnibus, speculum nitidum erat in quo cuncti se inspiciebant. Vox eius dulcis super mel et fauum, pedes graues et omnino gressus eius modesti, gestus maturi, nil reprehensibile, omnia diuina erant. Commendauit ergo Dominus ipsis matrem suam ut uestigiis eius inhaererent et eius exempla sequerentur et, pauca tribuentes, plurima reciperent ${ }^{54}$.

Tandem congregati sunt cum Maria Domini Genitrice omnes apostoli et discipuli et sanctae mulieres in monte Oliueti, die quadragesima post Domini resurrectionem, hora quasi sexta. [f1. 184] Erat dies Iouis, ut uos dicitis, et quinta dies mensis Maii. Et tunc Dominus Iesus talia coram ipsis locutus est antequam ascenderet: Tanta cura semper fuit Deo de hominibus ut nihil aliud umquam curasse putari assumere ut Deus homo et homo Deus esset. Deinde uoluit hominem illum, qui ego sum, ac etiam matrem eius, quae est Maria Virgo hic praesens coram uobis existens, super omnes angelos exaltare, cuius causa magnus numerus angelorum cum Lucifero de caelo caelorum cecidit, abhorrentes tantam seruitutem tantamque subiectionem et, credentes se liberos esse, serui facti sunt. Vos autem alios socios et simul cum angelis suis, filiis innocentibus qui numquam peccauerunt, ciues caelestis Ierusalem facere decreuit si usque in finem perseueraueritis. Misit tot patriarchas, tot prophetas et doctores ut

$\mathbf{5 1}$ foret decertatio indicauit, an fuerint due mulieres uel una solum.] fuerit decertatio an uel una uel duae fuerint, indicauit $Q \mathbf{5 2}$ conuenientibus] conuersantibus $J$; conuiuentibus $Q \quad 53$ imitabilem] imitabile $J P$; et mirabilem $Q$; immutabile $V \mathbf{5 4}$ plurima reciperent] plurima reciperent et eius exempla sequerentur $Q$ 
Mãe e a todos os discípulos. Abraçando-os, pois, a todos e também às mulheres, chamou estas duas Marias, que o haviam ungido, e anunciou como durante muito tempo na Igreja de Cristo haveria controvérsia relativamente a ambas, se foram duas mulheres ou uma só. E, por fim, nesse feliz tempo do mais feliz dos Pastores, será esta verdade dada a conhecer e será tornado claro que foram duas e que uma era pecadora na cidade, a outra possuída pelos demónios, não sujeita, contudo, a nenhum vício censurável. Desta, muita coisa te disse já noutro lugar.

E, assim, Cristo Senhor chamou as duas Madalenas, abençoou-as a ambas e a ambas encorajou, e confiou Maria, sua Mãe, à irmã de Lázaro e igualmente a Marta e a Lázaro. Não que precisasse do auxílio deles, mas para que eles, servindo-a e obsequiando-a, acumulassem méritos, a ela se associassem e seguissem o seu exemplo. Oh! quão proveitoso foi ao próprio José, seu marido, a convivência de Maria! Embora fosse justo e bom, todavia, em razão da convivência com Maria, tornou-se perfeito e eminente em toda a espécie de virtudes. Maria era, realmente, para com todos que com ela conviviam como uma espécie de fogo vivo, penetrando com divino amor os corações de todos, inflamando e incendiando, purificando e limpando, iluminando, consumindo todos os males e tudo de algum modo convertendo a Deus. Quão proveitosa foi a Madalena, a Marta e a Lázaro, a Lucas e a Inácio e também ao bem-aventurado Dionísio e a todos que com ela conviviam! Vivamente ardente era a sua conversação, ${ }^{[201]}$ a palavra era preciosa em sua boca. Apresentava-se a todos como modelo, era um espelho transparente em que todos se descobriam. A sua voz era mais doce que o mel e ofavo, ${ }^{[202]}$ os passos graves, $\mathrm{e}$ comedido o seu andar, os gestos dignos. Nada era repreensível, tudo era divino. Confiou-lhes, pois, o Senhor sua Mãe para que se mantivessem ligados a seus passos e seguissem os seus exemplos e, tendo de dar pouco, recebessem muitíssimo.

Por fim, todos os apóstolos e discípulos e as santas mulheres se reuniram com Maria, Mãe do Senhor, no Monte das Oliveiras, no quadragésimo dia depois da Ressurreição do Senhor, por volta da hora sexta. [f1. 184] Era quinta-feira, como vós dizeis, e o quinto dia do mês de Maio. E, então, o Senhor Jesus, antes de subir, disse perante eles isto: Tão grande preocupação teve sempre Deus com os homens que poderia considerar-se que nunca se preocupou com outra coisa. Realmente, primeiro, quis que eu, o seu Verbo, me tornasse homem e assumisse a natureza humana para que Deus fosse homem e o homem fosse Deus. Quis, depois, exaltar acima de todos os anjos esse Homem, que sou eu, e também sua Mãe, que é a Virgem Maria que está aqui presente perante vós, por causa de quem um grande número de anjos caiu do mais alto dos céus juntamente com Lúcifer ao rejeitar tão magna servidão e tão nobre sujeição. E acreditando serem livres tornaram-se escravos. A vós, porém, outros companheiros e, em simultâneo com

[201] S1 118:140

[202] S1 18:11 
genus humanum conseruarent et in uiam salutis dirigerent ${ }^{55}$ et angelos custodes adiuuarent. Nouissime misit me filium suum qui quanta passus sim mater mea et uos experte ${ }^{56}$ testes $^{57}$ esse potestis. Ecce iam ressurrexi. Genitrici meae primum, deinde huic feruentissimae Magdalenae apparui et aliis hic praesentibus Mariis ${ }^{58}$ quarum uerba tamquam deliramenta uobis uidebantur. Apparui Petro, apparui Cleophae et Lucae, apparui omnibus simul. Et semper tardi corde fuistis ad credendum. Nimia cordis duritia in uobis fuit. Valde increduli ${ }^{59}$ fuistis. Cornea et saxea corda sunt in uobis. Sed, me ascendente et Spiritu Consolatore adueniente, super ceram mollificabuntur et dabuntur ${ }^{60}$ uobis corda mollia et carnea et docebimini omnem ueritatem. Manebitis omnes unanimiter in oratione in Cenaculo ciuitatis Hierosolymitane cum Genitrice mea et his sanctis mulieribus donec induamini uirtute ex alto. Qua induti, uolo ut prius Iudaeis ouibus quae perierunt, incipientes ab Hierosolyma, annuntietis uerba mea et opera mea omnia quae feci et operatus sum in populo Iudaeorum. Et quaecumque uos et alios docui praedicabitis ${ }^{61}$ ipsis. Deinde euntes in uniuersum mundum, praedicate Euangelium omni creaturae, annuntiate pacem omnibus gentibus. Pro omnibus ueni, quamuis ad solos Iudaeos tamquam eis promissus et ex eorum patribus ortus uenerim. Docete ergo seruare ea quae praecepi uobis omnes gentes, baptizantes eos in nomine Patris et Filii et Spiritus Sancti sicut antea docui uos. Qui crediderit in me et doctrinam Euangelii receperit et baptizatus fuerit saluus erit. Qui uero uobis praedicantibus non crediderit condemnabitur. Et quia sine signis, quae nemo alius quam Deus facere potest, ad credendum non compellerentur, uos omnia quae ego feci facietis et maiora horum facietis. Et ne credant uos aliqua arte illa facere signa, uolo ut et ipsi eadem signa faciant. Et tunc [f1. 185] agnoscent ea nulla fieri arte, sed potestate diuina. Signa ergo eos qui crediderint. Haec sequentur ${ }^{62}$ : In nomine meo daemonia eicient, linguis loquentur nouis, serpentes tollent et, si mortiferum quid biberint, non eis nocebit, super aegros manus imponent et bene habebunt. Et omnia illa quae ego feci et ipsi facere poterunt et maiora illorum facient nulla adhibita arte, sed solo nomine meo uel nomine Trinitatis, quae Deus est, inuocato. Manete in ciuitate donec ueniat ad uos Spiritus Consolator. Ego in caelum cum his omnibus nunc conscendam.

$\mathbf{5 5}$ dirigerent] diligerent $Q \mathbf{5 6}$ experte] ex parte $I N \mathbf{5 7}$ testes] testis $M N V \mathbf{5 8}$ Mariis] mulileribus $V$ 59 increduli] incredibiles $I 60$ dabuntur] aguntur $Q$; dabunt $V 61$ praedicabitis] praedicationibus $V 62$ haec sequentur] exequentur $Q$ 
os seus anjos, filhos inocentes que nunca pecaram, decidiu tornar-vos cidadãos da Jerusalém Celeste se perseverardes até ao fim. Enviou todos os patriarcas, todos os profetas e doutores para defenderem o género humano e o dirigirem na via da salvação e ajudarem os anjos da guarda. Por último, enviou-me a mim, seu Filho, de cujo sofrimento podeis ser testemunhas vós e minha Mãe. Eis que ressuscitei já. Primeiro, apareci a minha Mãe, depois, a esta fervorosíssima Madalena e às outras Marias aqui presentes cujas palavras vos pareceram como que delírios. Apareci a Pedro, apareci a Cléofas e a Lucas, apareci a todos ao mesmo tempo. E fostes sempre lentos de coração em acreditar. ${ }^{[203]}$ Foi grande em vós a dureza de coração. Fostes demasiado incrédulos. Há em vós córneos e pétreos corações, mas, quando eu subir ao céu e vier o Espírito Consolador, tornar-se-ão mais moles que a cera e ser-vos-ão dados corações mansos e de carne, e sereis ensinados em toda a verdade. Permanecereis todos, unanimemente, em oração no Cenáculo da cidade Jerosolimitana com minha Mãe e estas santas mulheres até serdes revestidos pela força do alto. ${ }^{[204]}$ Dela revestidos, quero que, primeiro, anuncieis a minha palavra e todas as minhas obras que fiz e realizei entre o povo judeu, às ovelhas judias que pereceram, ${ }^{[205]}$ começando por Jerusalém. E quanto vos ensinei a vós e aos outro pregar-lho-eis. Depois, indo pelo mundo todo, pregai o Evangelho a toda a criatura, ${ }^{[206]}$ anunciai a paz a todos os povos. Vim para todos, embora tenha vindo só até aos judeus, como a eles prometido e dos seus pais nascido. Ensinai, pois, todos os povos a guardar aquilo que vos ordenei, baptizando-os em nome do Pai, do Filho e do Espírito Santo, ${ }^{[207]}$ como antes vos ensinei a vós. Aquele que acreditar em mim e receber a doutrina do Evangelho e for baptizado será salvo. Mas aquele que, pregando vós, não acreditar será condenado. ${ }^{[208]}$ E uma vez que sem milagres, que ninguém além de Deus pode fazer, não serão levados a crer, fareis vós tudo o que eu fiz, e fareis coisas maiores do que estas. E para que não creiam que vós realizais esses milagres por alguma arte, quero que também eles realizem os mesmos milagres. E então hão-de [f1. 185] reconhecer que, por nenhuma arte, mas pelo poder divino são eles realizados. Àqueles que acreditarem acompanhá-los-ão estes sinais: Em meu nome expulsarão demónios, falarão línguas novas, pegarão em serpentes $e$, se beberem algo mortífero, não os prejudicará. Imporão as mãos sobre os doentes, e estes terão melboras. ${ }^{[209]} \mathrm{E}$ tudo aquilo que eu fiz, também eles poderão fazê-lo, e farão coisas maiores do que essas sem usarem de qualquer arte, mas pela invocação apenas do meu nome ou do nome da Trindade, que é Deus. Permanecei na cidade até que venha até vós o Espírito Consolador. Eu vou agora subir ao céu com todos estes.

\footnotetext{
[203] Lc 24:25

[204] Lc 24:49

[205] Mt 15:24

[206] Mc 16:15

[207] Mt 28:19

[208] Mc 16:16.

[209] Mc 16:17,18
} 
Erant autem cum eo Adam et Eua, Abel iustus et Seth, frater suus, cum multis aliis fratribus et sororibus de quibus apud uos nulla mentio est quia non oportuit omnes describere, sed per genealogiam ad sancta sanctorum deuenire ${ }^{63}$. Erat ibi Noe cum sui generis iustis utriusque sexus. Erat Thare, Heber et Abraham, uir ille coram Deo magnus, cum omnibus sui generis iustis. Erat excellens ille uertex Antiqui Testamenti Moyses cum Aaron et reliquis sui generis iustis.

Erat $^{64}$ et eximius omnium prophetarum Dauid cum Salomone et omnibus sui generis iustis. Erant alii prophetae et Machabaei. Erant secum animae iustorum innumerabiles ${ }^{65}$ etiam gentilium, non solum ipsius Iob, nominatissimi uiri, sed etiam plurimorum philosophorum etiam, quorum opera in magno pretio habetis: Aegyptiorum, Chaldaeorum, Graecorum et Latinorum qui unum Deum ${ }^{66}$ caeli colebant et in ipso sperabant, ipsum omnium bonorum remuneratorem existimantes. Erant ergo cum Christo omnes animae quas de limbo et de purgatorio liberauerat. Liberauit autem omnes qui inuenti sunt tempore descensus ipsius ad inferos. Hoc enim decebat tam inuictum tamque nobilem triumphatorem ut sanguine illo pretioso recenter effuso omnes adiuuarentur amici. Congruebat ut de tam glorioso triumpho amici omnes consolarentur. Quomodo enim tam piissimus et clementissimus princeps, ad amicos suos afflictos cum trimpho ueniens, potuisset eos relinquere in tormentis? Decebat carceres aperiri et amicos refocilari et satisfactionem longam in breuem ${ }^{67}$ commutare $^{68}$.

"Ego in caelum cum his omnibus conscendam ${ }^{69 " . ~ E t ~ n o s ~ a n g e l i ~ o m n e s ~ a s t a b a m u s . ~}$ Et hortatus est eos ad perseuerantiam fractionis panis benedicti, dicens: "Ascendo ad Patrem meum et Patrem uestrum, Deum meum et Deum uestrum. Et tamen ecce ego in sacramento illo sum uobiscum et ero cum omnibus fidelibus meis omnibus diebus usque ad consumationem saeculi."

Et uale dicens Genitrici suae et apostolis, Magdalenae ceterisque omnibus, Dominus Iesus postquam ea quae tibi reuelaui locutus est, coepit paulatim, recta statura, eleuatis manibus, remoueri a terra et ire uersus caelum. Et in circuitu eius erant omnes animae iustorum quarum numerus erat quasi infinitus. Et tota regio aeris erat plena illis. Quae omnes, antequam discederent, Reginae caeli tamquam Dominae reuerentiam exhibuerunt. Et propinquissime Christo erant Ioannes Baptista, Abraham, Ioseph uir Mariae matris Domini ${ }^{70}$ et Moyses atque Dauid, Isaias ac Ieremias. Et uidebantur aeque appropinquantes. Et sic eos sequebantur

63 ad sancta sanctorum deuenire.] ad sanctos sanctum deuenire $Q$; ad sanctam sanctorum deuenire $V \mathbf{6 4}$ sui generis iustis. Erat excelens ille uertex Antiqui Testamenti Moyses cum Aaron et reliquis sui generis iustis. Erat] sui generis iustis. Erat $Q V$; sui generis iustis. Erat et Elias, alius uertex prophetarum, confirmator et zelator summus legis. $M$ (in marg. a. m.) NO 65 iustorum innumerabiles] immortales $N 66$ Deum] Dei $I M 67$ breuem] breue $I V 68$ commutare] committare $M N 69$ "Ego in caelum cum his omnibus conscendam"] In caelum ergo cum is omnibus conscendit $Q \mathbf{7 0}$ matris Domini] matris Domini et Saluatoris nostri $Q$ 
Estavam com ele Adão e Eva, o justo Abel e Seth, seu irmão, com muitos outros irmãos e irmãs de quem não há entre vós menção alguma, porque não foi necessário descrevê-los a todos, mas, pela genealogia, chegar ao Santo dos Santos. Estava lá Noé com os justos de ambos os sexos da sua família. Estavam Taré, Héber e Abraão, homem este grande diante de Deus, com todos os justos da sua família. Estava aquele eminente vértice do Antigo Testamento, Moisés, com Aarão e os restantes justos da sua família.

Estava o maior de todos os profetas, David, com Salomão e todos os justos da sua família. Estavam os outros profetas e os Macabeus. Estavam consigo inumeráveis almas de justos e até de gentios, não só a do próprio Job, varão ilustríssimo, mas também as de vários filósofos, e até as daqueles cujas obras tendes em grande apreço: egípcios, caldeus, gregos e latinos, que veneravam um único Deus do céu e nele esperavam, o consideravam o Retribuidor de todos os bens. Portanto, estavam com Cristo todas as almas que libertara do Limbo e do Purgatório. Libertou, com efeito, todos os que foram encontrados ao tempo da sua descida aos infernos. Na verdade, convinha a tão invencível e a tão nobre triunfador que pelo seu precioso sangue acabado de derramar todos os amigos fossem beneficiados. Era natural que todos os amigos fossem consolados em razão de tão grande triunfo. De facto, como poderia príncipe tão piedoso e clemente, ao chegar triunfante junto de seus amigos em situação desesperada, deixá-los em tormentos? Seria justo que os cárceres fossem abertos e que os amigos fossem reconfortados e abreviada a longa justificação.

"Eu subirei ao céu com todos estes", e estávamos presentes nós, os anjos todos. E exortou-os à perseverança na fracção do pão bendito, dizendo: Subo para meu Pai e vosso Pai, meu Deus e vosso Deus. ${ }^{[210]} \mathrm{E}$, todavia, eis que eu estou convosco neste sacramento e estarei com todos os meus fiéis todos os dias até à consumação do mundo.

E dizendo adeus a sua Mãe e aos apóstolos, a Madalena e a todos os outros, depois de haver dito o que te revelei, o Senhor Jesus, erecto, com as mãos erguidas, começou paulatinamente a afastar-se da terra, de pé, e a dirigir-se para o Céu. E em volta dele estavam todas as almas dos justos cujo número era quase infinito. E toda a linha do horizonte estava cheia delas. Todas elas, antes de partirem, reverenciaram como Senhora a Rainha do Céu. E mais próximo de Cristo estavam João Baptista, Abraão, José, marido de Maria, a Mãe do Senhor, e Moisés e David, Isaías e Jeremias. E parecia aproximarem-se indistintamente. 
alii prophetae et Anna ac Simeon iustus et Anna prophetissa, Eua, Adam et alii in ordine suo. Vidisses [f1. 186] ibi Adam et Euam, Abraham et omnes patriarchas atque prophetas, Annam, Saram et Rachel et Ruth et Hester et Iudith singillatim benedicere et adorare Mariam Dei nostri Genitricem et omnes ante eam suo modo procedere atque dicere: "Ascendat ante nos Regina nostra, praecedat nos Domina nostra. Non est dignum, non est aequum ut nos ante ipsam caelos ascendamus ${ }^{71}$ ". Sed cognita causa dilationis ${ }^{72}$, omnes uota sua diuinae submiserunt uoluntati. Virtute itaque diuina, immo et uirtute animae gloriosae quam a Deo acceperat, Dominus Iesus quoad corpus suum paulatim ferebatur in caelum, Matre ${ }^{73}$ et apostolis et multis aliis in monte illo congregatis cum gaudio et exultatione atque admiratione intuentibus, omnibus angelis atque innumerabilibus iustis ipsum commitantibus. Et ex una parte nos angeli canebamus et ex alia animae iustae, et quasi chorus choro respondebat. Et interdum pars angelorum cum parte iustorum unum chorum faciebat. Et alia pars angelorum cum alia parte iustorum tamquam alius chorus respondebat. Psalmus uero talis $\mathrm{erat}^{74}$ :

Ascendit Deus in iubilatione et Dominus in uoce tubae.

Ascendit unicus ${ }^{75}$ Deus noster neque extimabitur a nobis alius ad illum.

Descendit propter nos de caelis et nunc recedit de nostris terris.

Ascendit in iubilatione Deus noster quia angelis sola mente canentibus conscendit.

Ascendit etiam in uoce tubae quia animabus etiam per corporea organa quandoque canentibus sursum iuit. ${ }^{76}$

Nos angeli sola mente canimus et quandoque in aere nobis extraneo ${ }^{77}$ uoces formamus.

Nos animae quae corpora informare possumus, corpore ipso tamquam tuba utimur.

Ascendit ergo Deus angelis iubilantibus et iustis tamquam tubicen canentibus.

Omnes gentes plaudite manibus, iubilate Deo in uoce exultationis.

Psallite Deo nostro, psallite, psallite regi nostro, psallite,

Quoniam rex omnis terrae Deus, psallite sapienter.

Tu Dominus Altissimus super omnem terram, nimis exaltatus es super omnes Deos.

Psallite Domino in cithara, in cithara et uoce psalmi, in tubis ductilibus et uoce tubae corneae.

Cantate Domino canticum nouum quia mirabilia fecit.

71 ascendamus] scandamus IMOP 72 dilationis] dilectionis $V \mathbf{7 3}$ Matre] Marthe $V \mathbf{7 4}$ talis erat:] talis erat:: Psalmus in Ascensione Domini $Q 75$ unicus] unitas $I$ (M sup. ras.); unitus $J P V 76$ sursum iuit] sursum iniuit $M$; surrexit inuie $V 77$ extraneo] extraneos $J$; extraneas $I M V$ 
E seguiam-se, deste modo, os outros profetas: Ana e o justo Simeão, e Ana, a profetisa, Eva, Adão e os outros, segundo a sua ordem. Ter-se-ia podido ver [fl. 186] lá Adão e Eva, Abraão e todos os patriarcas e profetas, Ana, Sara e Raquel e Rute e Ester e Judite a adorarem e a bendizerem individualmente Maria, Mãe de nosso Deus, e todos, cada um a seu modo, a desfilarem diante dela e a dizerem: Que antes de nós suba a nossa Rainha, que nos preceda a Senhora nossa. Não é digno, não é justo que nós subamos ao céu antes dela. Mas, depois de conhecida a razão do adiamento, todos subordinaram os seus desejos à vontade divina. Pela divina força e também pela força da alma gloriosa que de Deus recebera, o Senhor Jesus elevava-se em seu corpo para o céu enquanto Maria e os apóstolos e muitos outros reunidos naquele monte contemplavam com alegria e exultavam de admiração, e todos os anjos e inumeráveis justos o acompanhavam. E de um lado cantávamos nós os anjos, e do outro as almas justas, e como que um coro respondia a outro. E, entretanto, uma parte dos anjos com uma parte dos justos formava um coro, e a outra parte dos anjos com a outra parte dos justos respondia como outro coro. Era este o salmo:

Deus sobe por entre aclamações, e o Senhor ao som de trombetas. ${ }^{[211]}$

Sobe o nosso Deus, Deus único, e além dele não temos outro.

Por nós desceu dos céus e agora afasta-se da nossa terra.

Sobe o nosso Deus por entre aclamações, porque se eleva cantando os anjos com a mente apenas.

Sobe também ao som das trombetas, porque se encaminha para o alto, cantando as almas também com os órgãos do corpo

Nós, anjos, cantamos com a mente apenas e, por vezes, no ar, que nos é estranho, formamos vozes.

Nós, as almas que aos corpos podemos dar forma, usamos o corpo como trombeta.

Sobe Deus, portanto, aclamando-o os anjos e cantando os justos como trombetas.

Povos todos, batei palmas, aclamai o Senhor ao som da exultação, ${ }^{[212]}$

Salmodiai ao nosso Deus, salmodiai, salmodiai ao nosso rei, salmodiai,

Porque Deus é o Rei de toda a terra, salmodiai sabiamente. ${ }^{[213]}$

$\mathrm{Tu}$, o Senhor Altíssimo sobre toda a terra, maior que todos os deuses. ${ }^{[214]}$

Salmodiai ao Senhor ao som da cítara, ao som da cítara e do salmo, com as tubas curvas e o som do corno. ${ }^{[215]}$

Cantai ao Senhor um cântico novo, porque ele fez maravilhas. ${ }^{[216]}$

\footnotetext{
${ }^{[211]}$ S1 46:6

${ }^{[212]}$ S1 46:2

${ }^{[213]}$ S1 46:7,8

${ }^{[214]}$ S1 96:6

[215] S1 97:5,6

[216] S1 97:1
} 
Dominus in Sion magnus et excelsus super omnes Deos.

Dominus in celo parauit sedem suam et regnum ipsius omnibus dominabitur.

Cantate Domino et benedicite nomini eius, annuntiate de die in diem salutare eius.

Ascendens, in altum captiuam duxit captiuitatem, dedit dona hominibus.

Qui nunc ascendit, ipse primum descendit in inferiores partes terrae.

Mors fuit humanae mortis, morsus fuit ipsius inferni.

Spoliauit infernum, expectantes diu inde extraxit.

Eduxit populum suum in exultatione et electos ${ }^{78}$ suos in laetitia.

Eduxit eos de lacu in quo non erat aqua ${ }^{79}$ et transtulit in regnum suum.

Alios eduxit de tribulatione et multorum supplicia abreuiauit.

Omnes amicos qui decesserant, secum in gloriam transuexit aeternam.

Petro Ecclesiam suam commisit omnibusque abscedens ${ }^{80}$ benedixit.

Matrem suam in mundo dimisit et tamquam ancoram fidei suae reliquit.

Paulatim eleuatis manibus corpus ab anima ferebatur in caelum. [f1. 187]

Non erat motus ille progressiuus, sed alius quo tunc anima utetur.

Omnes sancti eius comitabantur eum et angeli benedicebant ei:

"Quis est iste qui uenit de Edon tinctis uestibus de Bosra" canebant. ${ }^{81}$

Non ignorantes dicebant, sed maiestatem tantam admiratione ampliabant:

"Dominus fortis est et potens, Dominus est potens in proelio. ${ }^{82}$

Quis est iste rex gloriae? Dominus uirtutum ipse est rex gloriae.

Formosus ualde progreditur, stola maiestatis indutus."

Antequam tamen Dominus ascendit, omnibus clara uoce dixit:

"Perseuerate in fractione panis benedicti, ibi sum uobiscum semper usque in finem saeculi.

Mater mea excelentissima in sacramento illo sicut et alias uidebit.

Alii me fide propria intuebuntur, ex quo non parum consolabuntur."

Ascendit ad Patrem suum ex cuius sinu numquam descendit.

Descendit tamen de caelis quia humanitatem sibi coniunxit.

Cum matre et suis remansit et tamen eos relinquendo ad caelos ascendit.

78 electos] populos $N \mathbf{7 9}$ non erat aqua] erant $V \mathbf{8 0}$ abscedens] ascendens $Q \mathbf{8 1}$ canebant] cantabant $Q \mathbf{8 2}$ Dominus fortis est et potens, Dominus est potens in proelio] Quia Dominus fortis et potens in proelio $Q$ 
O Senhor é grande em Sião e excelso acima de todos os deuses. ${ }^{[217]}$

O Senhor preparou no céu o seu trono, e o seu reino a todos dominará. ${ }^{[218]}$

Cantai ao Senhor e bendizei o seu nome, anunciai de dia para dia a sua salvação. ${ }^{[219]}$

Subindo ao céu, levou cativo o nosso cativeiro, presenteou os homens com dons.

$\mathrm{O}$ que agora sobe, primeiro desceu às partes inferiores da terra. ${ }^{[220]}$

Foi a morte da humana morte, foi o aguilhão do próprio inferno. ${ }^{[221]}$

Espoliou o inferno, de lá retirou os que há muito esperavam.

Conduziu seu povo por entre aclamações e seus eleitos na alegria. ${ }^{[222]}$

Arrancou-os do lago que não tinha água e transferiu-os para o seu reino.

Arrancou outros da tribulação e abreviou o suplício de muitos.

Fez passar consigo para a glória eterna todos os seus amigos que haviam morrido.

Entregou a Pedro a sua Igreja e, ao partir, a todos abençoou.

Deixou sua Mãe no mundo e como âncora da sua fé a deixou.

$\mathrm{E}$ aos poucos, de mãos erguidas para o alto, pela alma era o corpo levado ao céu.

[f1. 187] Não era progressivo aquele movimento, mas outro, de que um dia se servirá a alma.

Todos os seus santos o acompanhavam e os anjos o louvavam.

Quem é este que vem de Édon com vestes de Bosra tintas, ${ }^{[223]}$ cantavam.

Não falavam sem saber, mas com o espanto aumentavam tão grande majestade.

O Senhor é forte e poderoso, o Senhor é poderoso no combate. ${ }^{[224]}$

Quem é este Rei da Glória? O Senhor do Poder, esse é o Rei da Glória. ${ }^{[25]}$

Avança cheio de beleza, envolto na estola da majestade.

Antes, contudo, de o Senhor subir, a todos em voz alta disse:

"Perseverai na fracção do pão bendito, aí estou sempre convosco até ao fim dos tempos.

Nesse sacramento, como de outras formas, me há-de ver minha nobre Mãe.

Outros me verão com a própria fé, de que não pouco se consolarão".

Sobe para seu Pai, de cujo seio nunca se afastou.

Sim, desceu do céu porque a humanidade a si ajuntou,

Ficou com a Mãe e os seus e, contudo, deixando-os, subiu ao céu,

\footnotetext{
[217] S1 98:2

[218] S1 102:19

[219] S1 95:2

${ }^{[220]}$ Ef $4: 8,9$

[221] Os 13:14.

[222] S1 104:43

[223] Is 63:1

[224] S1 23:8

[225] S1 23:10
} 
Descenderat uno modo, quia perfectum ${ }^{83}$, ascendit alio modo per corpus assumptum.

Qui tamen descendit et ascendit numquam a suo Patre discessit.

Ille solus ascendit qui descendit, qui tamen semper in caelo quieuit.

Remouebatur paulatim ab oculis eorum et appropinquabat polis caelorum.

Quando nullus ipsorum eum ulterius uidere potuit, tunc celerius ualde conscendit.

Genitrix post omnes eum in aere uidit et, ab eo benedicta, ipsum adorauit.

Quo digniores inter eos erant eo ulterius prospiciebant.

Vnumquemque in termino uisionis Dominus respexit et unicuique ipsorum benedixit,

Et, iam non uidentes eum, stupidi stabant et oculos ad caelum dirigebant,

Quousque duo angeli eis dicerent ut in propria et Ierusalem redirent.

Quia Dominus omnes caelos ascenderat, Spiritum daturus ${ }^{84}$ quem promiserat

Sic eum descensurum crederent sicut ascendisse uiderent. ${ }^{85}$

Benedicamus Verbo Domini quo firmati sunt caeli

Benedicamus Spiritui oris eius quo consistit omnis uirtus eorum.

Benedicamus Ingenito cum Genito et magno Spiritui Paraclito. Amen.

Tunc Angelus dixit: Conscribe hunc psalmum ut pastor Ecclesiae ex illo et psalmos et hymnos conficiat. Auctoritate enim qua potietur poterit ${ }^{86}$ multa et huic mysterio Ascensionis ac etiam Resurrectionis atque aliis plura addere ut omnes particulae cuiuscumque ${ }^{87}$ mysterii particulariter decantentur et sit laus Dei semper in ore uestro.

Dominus ergo caelos ascendit et sedet ille Homo in potestate maxima et maiestate quae post Deum potest intelligi et hoc est eum sedere in dextra Dei. Omnes quidem electi sunt in dextris prout dextra distinguitur a sinistra, sed non prout dextra per quamdam excellentiam intelligitur. Sic enim solus Homo ille in dextra Dei sedet. Christus in quantum homo non mediocre gaudium ex talis loci adeptione $^{88}$ assecutus est. Maria uero cum omnibus illis perseuerabat in oratione et omnes confortabat et corroborabat ut se diligenter ad Spiritus Sancti susceptionem praepararent, quem decima die ab Ascensione Filii sui omnes susceperunt.

Ecce loqui uolentes de obitu et assumptione ad caelum ${ }^{89}$ Genitricis Dei ut ostenderemus ex parte totam uitam suam, ascensionem Christi Domini interseruimus. Maria, in Cenaculo existens cum apostolis et discipulis [f1. 188] perseuerabat in fractione panis benedicti et Dominum Christum, filium suum, ipsa etiam in humanitate ${ }^{90}$ cernebat oculo mentis suae. Et alii solum credebant

83 perfectum] per effectum $J N O P Q \mathbf{8 4}$ Spiritum daturus] Spiritus Sanctus $V \mathbf{8 5}$ uiderent] uident $N$; uiderunt $Q$; uiderant $V 86$ potietur, poterit] potius poterat $I V 87$ cuiuscumque] uniuscuiuscumque $O Q 88$ ex talis loci adeptione] ex tali loco adeptione $M$; ex illa talis loci adeptione $Q$; ex tali $\rightarrow$ 
Descera de um modo, porque era perfeito, sobe de outro modo, pelo corpo assumido.

Ele que desce e sobe, nunca do Pai se afastou.

Apenas sobe aquele que, contudo, sempre no céu se manteve.

Dos olhos deles se afastava aos poucos e aproximava-se do alto dos céus.

Quando deles já nenhum o podia ver, subiu mais depressa então.

Depois de todos, a Mãe o viu no ar e, abençoada por ele, o adorou.

Quanto mais dignos entre eles eram, tanto mais longe o contemplavam.

A cada um deles, ao fim da visão, o Senhor olhou e a cada um abençoou.

E, não o vendo já, estupefactos estavam e os olhos ao céu dirigiam,

Até que dois anjos lhes viessem dizer para a casa tornarem e a Jerusalém,

Porque o Senhor aos céus subira, para dar o Espírito que lhes prometera.

Assim acreditassem que havia de descer como o tinham visto subir

Bendigamos o Verbo do Senhor, por quem os céus foram firmados,

Bendigamos o Espírito de sua boca, em quem reside toda a nossa força,

Bendigamos o Ingénito com o Gerado e o Grande Espírito Paráclito. Ámen.

Escreve este salmo, disse então o anjo, a fim de que o Pastor da Igreja a partir dele componha salmos e hinos. Em função da autoridade de que gozará, muita coisa poderá acrescentar a este mistério da Ascensão e também ao da Ressurreição e a outros, para que todos os pormenores de qualquer mistério sejam celebrados e esteja sempre em vossa boca o louvor de Deus.

Portanto, o Senhor subiu aos céus e aquele Homem senta-se no máximo poder e majestade que depois de Deus se pode conceber, e é isto que é sentar-se ele à direita de Deus. Sem dúvida que todos os eleitos estão à direita, na medida em que a direita se distingue da esquerda, mas não na medida em que a direita se toma por uma certa excelência. Deste modo, pois, só aquele Homem se senta à direita de Deus. Cristo, enquanto Homem, alcançou não pequena alegria pela consecução desse lugar. E Maria perseverava com todos eles em oração e a todos confortava e revigorava para se prepararem diligentemente para receber o Espírito Santo, que todos receberam no décimo dia depois do Ascensão de seu Filho.

Vê que, ao querermos falar da morte e assunção ao céu da Mãe de Deus, para mostrarmos em parte toda a sua vida, inserimos a ascensão de seu Filho. Maria, estando no Cenáculo com os apóstolos e os discípulos, [f1. 188] perseverava na fracção do pão bendito e, em vida humana ainda, via na visão da sua mente a Cristo Senhor, seu Filho. E os outros acreditavam apenas como acreditam os que

$\leftarrow$ loco adoptione $V \mathbf{8 9}$ de obitu et assumptione ad caelum] de obitu et ascensione ad caelum uel assumptione, ut melius loquar $Q \mathbf{9 0}$ humanitate] humilitate $V$ 
sicut uiatores credunt et tanto firmius quanto illud multis miraculis ratificatum iam uidissent. Et post aduentum Spiritus Sancti Maria numquam in habitaculo suo sine hoc sacramento manebat, et ita Filium suum quotiens desiderabat uidere poterat et uidebat, eumque angelica lingua alloquebatur et responsa eadem lingua ab ipso accipiebat. Solum non tangebat eum. Tamen etiam saepius diuinitatem eius uidebat. Quandoque etiam non sacramentaliter sibi praesens erat et tunc eum amplexabatur et corporeis oculis uidebat. Accidentia panis sumebat et ex illis sanguis generabatur et caro, non ut caro Mariae accidentia pro subiecto formae haberet ${ }^{91}$, ut nonnulli etiam ex his qui nobiscum sunt putauerunt, sancti quidem, sed in hoc multum simplices. Oportet enim ut uel substantia panis redeat uel substantia noua creetur miraculo antiquo. Sic enim statuit Deus a principio. Si enim substantia neque rediret neque noua crearetur, quomodo illud componeretur? Quomodo accidens formae substantiali substaret? Quomodo materia prima paulatim non deficeret tota? Quomodo caro uel animal sic componi posset? Repugnat formae subici suae materiae ${ }^{92}$, repugnat materiae informare, repugnat accidenti esse materiam substantialis formae ${ }^{93}$. Opinio illa est risu digna ${ }^{94}$ et contradictionem includit.

Maria haec omnia perfecte sciebat. Et, apostolis praedicantibus, ipsa domi orabat, legebat, docebat et in lege Domini assidue meditabatur. Magdalena, soror Lazari, assistebat ei, et Maria Salome, mater filiorum Zebedaei, et Maria, mater Ioseph Iusti et Iacobi Minoris et Simonis et Thaddaei apostolorum, quae illa eadem nuncupatur Maria Cleophae a patre et Maria Alphaei a uiro, et illae Mariae uidelicet Cleophae et Salome fuerunt sorores Virginis Mariae, non tamen filiae Annae, ut apud uos hodie dicitur.

Anna solet dici tres concepisse Marias. Non est id uerum. Anna quippe non habuit nisi unam filiam, et hoc dono Dei, quia ex sui natura sterilis erat. Et, genita illa magna filia, matre Dei, sterilis permansit. Illa non habuit nisi unam filiam et Virgo Maria unicum filium. Haec fuit semper uirgo, illa et ante et post sterilis semper. Non decebat certe ut, genita matre Dei, ipsa Anna nuberet ad procreandum filias alias. Quomodo etiam fingunt ut, orta Virgine Maria, statim Ioachim moreretur? Et si statim mortuus fuisset, non tamen statim Anna sanctissima alteri nupsisset uiro et, luctu prioris manente, nuptias secundas fecisset cum gaudio. Quae non est condicio bonae et sanctae matronae. Deinde etiam si nuptias secundas ita effrenate celebrasset, adhuc per unum annum natiuitatem secundae filiae expectasset. Qua orta, subito pater huius secundae sicut et prioris mortuus fuisset. Turpe [f1. 189] tunc fuisset statim tertias nuptias celebrare et luctum

91 sanguis generabatur et caro, non ut caro Mariae accidentia pro subiecto formae haberet] sanguis generabatur et caro. Non ut caro Mariae accidentia pro subiecto formae haberet $M O$; sanguis generabatur. Et caro non ut caro Mariae, accidentia personae forma haberet $P 92$ subici $\rightarrow$ 
peregrinam, e tanto mais firmemente quanto o tinham já visto confirmado por muitos milagres. E depois da vinda do Espírito Santo, nunca Maria ficava na sua morada sem esse sacramento. E, deste modo, todas as vezes que desejava, podia ver e via a seu Filho, falava com ele na língua dos anjos e dele recebia as respostas na mesma língua. Apenas o não tocava. Via, contudo, muitas vezes também, a sua divindade. Às vezes estava também com ela de modo não sacramental e, então, abraçava-o e via-o com os olhos do corpo. Tomava os acidentes do pão e deles gerava-se o sangue e a carne, embora a carne de Maria não tivesse os acidentes como suporte da forma, como julgaram alguns, mesmo entre aqueles que estão connosco, santos sem dúvida, mas, neste ponto, muito ingénuos. Efectivamente, é necessário que ou a substância do pão retorne ou seja criada uma substância nova por um milagre antigo. Assim, de facto, o decidiu Deus desde o princípio. Se realmente a substância não retornasse, nem fosse criada uma nova, como se organizaria isso? Como substaria o acidente à forma substancial? Como se não extinguiria gradualmente toda a matéria-prima? Como poderia a carne ou o animal organizar-se assim? À forma repugna sujeitar-se à sua matéria, à matéria repugna enformar, repugna ao acidente ser matéria da forma substancial. Essa opinião é ridícula e encerra contradição.

Maria conhecia perfeitamente todas estas coisas. E, enquanto os apóstolos pregavam, em casa ela rezava, lia, ensinava e meditava continuamente na Lei do Senhor. Madalena, a irmã de Lázaro, prestava-lhe assistência. E Maria Salomé, a mãe dos filhos de Zebedeu, e Maria, mãe de José, o justo, e dos apóstolos Tiago Menor, Simão e Tadeu, aquela que se chama Maria Cléofas, pelo pai, e Maria Alfeu, pelo marido, e estas Marias, ou seja, Cléofas e Salomé, foram irmãs da Virgem Maria, ainda que não filhas de Ana como hoje se diz entre vós.

É hábito dizer-se que Ana concebeu as três Marias. Isso não é verdade. Ana, verdadeiramente, não teve senão uma única filha, e isso por dom de Deus, porque de sua natureza era estéril. E, nascida essa ilustre filha, a Mãe de Deus, permaneceu estéril. Ela não teve senão uma única filha, e a Virgem Maria um único filho. Esta foi sempre virgem, ela sempre estéril, antes e depois. Não ficaria bem, com certeza, que, nascida a Mãe de Deus, Ana se casasse para procriar outras filhas. Como inventam também que, nascida a Mãe de Deus, Joaquim teria logo morrido. E se tivesse morrido logo, Ana santíssima certamente não se teria casado logo com outro homem e não realizaria em alegria segundas núpcias enquanto vigorava o luto do primeiro. Esta não é condição de uma boa e santa matrona. Depois, mesmo se celebrasse assim tão desenfreadamente as segundas núpcias, haveria ainda de esperar por um ano o nascimento da segunda filha. Nascida esta,

$\leftarrow$ suae materiae] substantiae siuae materiae $P 93$ repugnat materiae informare, repugnat accidenti esse materiam substantialis formae] repugnat materiae informare $Q \mathbf{9 4}$ risu digna] res digna $P$ 
secundi mariti gaudio tertii subito expellere, et nullam uerecundiam mulierem sanctam habere neque moralem uitam et ciuilem tenere.

Fictio ergo est ut, orta ${ }^{95}$ prima filia, mox pater mortuus sit. Fictio est ut, mortuo primo marito, mox secundo nupserit. Similiter fictio est ut, orta secunda filia, mox pater illius mortuus est et quod, mortuo illo, mox Anna tertio nupsit uiro. Tamen etiam admittendo has fictiones, quae derogant sanctitati Annae et dignitati matris Dei ut ex tam incontinenti matre nata sit, immo non decebat ut uterus ille post Reginam omnium alias femellas ${ }^{96}$ foueret. Tamen oportuit ut, quando tertia Maria orta est, Virgo Maria tunc haberet ad minus quattuor annos uel circiter et iam in Templo praesentata esset. Et ulterius ipsa primo nupta est per quattuor annos uel tres ante sorores suas. Et ipsa primo anno desponsationis suae peperit Saluatorem. Forsan secunda et tertia non ita primo anno desponsationis suae concepissent, quia hoc rarum est. Deinde, dato quod omnes tres primo anno conceperint, tamen secunda Maria quattuor filios habuit: Iacobum Minorem, Simonem et Thaddaeum et Ioseph Iustum. Et unum peperit ad minus per annum post alium. Valde ergo ipsos iuuenculos Dominus uocauisset et domum suam pueris impleuisset. Cleophas ergo non fuit maritus Annae neque Salome, sed fratres eius et Hismerie, matris Elisabeth quae Ioannem Baptistam genuit.

Ioachim ergo et Anna Mariam Virginem uirgini Ioseph, miraculo cogente, in uxorem dederunt. Cleophas suam filiam Alphaeo dedit, et Salome suam Zebedaeo, et Hismeria suam Zachariae. Et quia Anna sterilis fuit, prius nata est Elizabeth pluribus annis quam Virgo Maria. Similiter nata est prius Maria Cleophae et Maria Salome et prius fuerunt nuptae quam Maria mater Dei. Et prius natus est Simon et Thaddaeus et uterque Iacob quam Dominus Christus. Sed Ioannes Euangelista tredecim annis iunior erat Christo ${ }^{97}$.

Elisabeth ergo fuit soror Mariae, quia nata ex sorore matris. Sed Elisabeth ex Hismeria fecunda ${ }^{98}$ cito nata est, Maria ex Anna sterili post illam uigesimo quinto anno nata est. Quo tempore Elisabeth iam erat nupta Zachariae. Ex fecunda Hismeria nata est Elisabeth sterilis et ex sterili Anna nata est Maria fecundissima, quia peperit Saluatorem uestrum et Regem omnium ${ }^{99}$.

Elisabeth itaque defuncta diu ante, Maria Cleophae et Maria Salome Mariae Genitrici Dei inseruiebant eamque comitabantur et ut plurimum in domo Magdalenae et Marthae morabantur. Virgo illa electissima uerbis atque litteris suis

95 orta] mortua $Q 96$ femellas] feminas $Q$; feminellas $V 97$ iunior erat Christo] minor erat Christo $M N Q$; iunior erat Christo. Hismeria erat primogenita, Salome frater sequitur eam, Anna ipsum et Cleophas ipsam. Anno Hismeria decimo sexto, generat Elisabeth, Anna tunc habente annum undecimum. Et quando peperit matrem Domini quadragesimum quartum agebat. $P 98$ fecunda] $\rightarrow$ 
teria morrido o pai da segunda do mesmo modo que o da primeira. Teria sido então vergonhoso [f1. 189] celebrar logo as terceiras núpcias e aliviar o luto do segundo marido com a alegria do terceiro, e que uma santa mulher não tivesse vergonha nenhuma não levando uma vida moral e digna.

É, pois, uma invenção que, nascida a primeira filha, logo o pai tenha morrido. É invenção que, morto o primeiro marido, logo desposasse o segundo. É igualmente invenção que, nascida a segunda filha, logo o seu pai tivesse morrido, e que, morto este, logo Ana desposasse o terceiro marido. Todavia, mesmo aceitando estas duas invenções, que diminuem a santidade de Ana e a dignidade da Mãe de Deus, dado haver nascido de tão incontinente mãe, não era justo, mesmo assim, que aquele útero, depois da Rainha Universal, desse a vida a outras filhas. Fora também necessário que, quando a terceira Maria nasceu, a Virgem Maria tivesse então pelo menos cerca de quatro anos e tivesse sido já apresentada no Templo. E, além disso, ela casou-se primeiro, três ou quatro anos antes de suas irmãs. E, no primeiro ano do seu casamento, deu à luz o Salvador. Talvez que a segunda e a terceira não tivessem, deste modo, concebido no primeiro ano de seu casamento, visto ser isso raro. Depois, admitindo que as três tenham concebido no primeiro ano, a segunda Maria, porém, teve quatro filhos, Tiago Menor, Simão e Tadeu, e José, o justo. E deu à luz um a seguir ao outro com o intervalo de pelo menos um ano. Muito jovens, pois, os teria chamado o Senhor e teria enchido a sua casa de crianças. Portanto, nem Cléofas nem Salomé foram maridos de Ana, mas seus irmãos, nem de Hisméria, a mãe de Isabel que gerou João Baptista.

Assim, pois, Joaquim e Ana, por força do milagre, deram por esposa a José, que era virgem, a Virgem Maria. Cléofas deu sua filha a Alfeu, e Salomé a sua a Zebedeu, e Hisméria deu a sua a Zacarias. E uma vez que Ana era estéril, Isabel nasceu vários anos antes da Virgem Maria. De qualquer modo, Maria Cléofas e Maria Salomé nasceram primeiro e primeiro se casaram que Maria, Mãe de Deus. E, antes de Cristo Senhor, nasceram Simão e Tadeu e os dois Tiagos. Mas João Evangelista era treze anos mais novo que Cristo.

Isabel foi, pois, irmã de Maria porque nascida da irmã de sua mãe. Mas Isabel nasceu prontamente da fecunda Hisméria, Maria nasceu de Ana, que era estéril, vinte e cinco anos depois daquela. Nesse tempo já Isabel estava casada com Zacarias. Da fecunda Hisméria nasceu a estéril Isabel, e da estéril Ana nasceu a fecundíssima Maria, porque deu à luz o vosso Salvador e Rei Universal.

E, assim, falecida Isabel muito tempo antes, Maria Cléofas e Maria Salomé serviam Maria, Mãe de Deus, e acompanhavam-na e, muitas vezes, demoravam-se em casa de Madalena e Marta. Aquela Virgem eleita confortava por palavras e com as

$\leftarrow$ secunda IJOV 99 et Regem omnium] et Regem omnium. Hismeria erat primogenita. Salome frater sequitur eam, Anna ipsum et Cleophas ipsam. Anno Hismeria (Hismeriae $N$ ) sexto decimo generat Elisabeth, Anna tunc agente annum decimum. Et quando parit (peperit $Q$ ) matrem Domini (annum $N$ ) quadragesimum quintum agebat. $M$ (in marg. a. m.) $N O Q$ 
apostolos confortabat et alios credentes. Quae, ut accepit Paulum, uas electionis ${ }^{100}$, ad ipsum Lucam [f1. 190] misit. Qui, antequam iuisset in Arabiam, uoluit Dei Genitricem uidere, quam cum sapientissime Filii sui mysteria ${ }^{101}$ propalantem audiret et Veteris Testamenti omniumque dubiorum nodos dissoluere uideret, prostratus in terram Christum Dominum et matrem eius adorauit. Dixitque: Vsque nunc, a die conuersionis meae, Christum Filium Dei credidi. Nunc ex diuinitate matris deitatem Filii clare cognoui. Benedictus sit Dominus Iesus Christus qui me, minas sibi spirantem, illuminauit et ad se cor meum auersum attraxit. Benedicta sis tu, mater Domini Dei mei et Regis omnium, quia in te omnes thesauros sapientiae ac scientiae Dei reconditos uideo.

Instructus ergo ab ea de omnibus secretis abiit in Arabiam. Diuini amoris flamma totus ${ }^{102}$ ardens et totus succensus incendebat omnes. Et plus fructus ipse solus laboribus suis Ecclesiae Christi attulit quam quicumque alius apostolorum. Et hoc est quod ipse de se ait: "Plus omnibus laboraui". Non quidem omnibus simul collectis, sed plus quocumque aliorum seorsum sumpto. Et dum conuertisset Dionysium, philosophum egregium, et ei iam bene credenti secreta quae a matre Christi audierat reserasset, ille, permotus desiderio eam uidendi, licentia a Paulo obtenta, tandem ad ipsam peruenit. Et illico ut uidit faciem eius immutatum est atque exhilaratum cor eius et, gaudio atque exultatione plenus, in haec uerba prorupit: "Vere Dei Genitrix es, Maria, quia tota diuinitate plena es. Si te uidere tantum bonum est tamque res iucunda est, quid erit uidere ipsum Deum, bonum omnis boni?" Et prostratus in terram dixit: "Deum Trinum et Vnum quem me Paulus docuit, in te, o Virgo purissima, adoro et te tamquam ueram Dei Genitricem colo."

Tunc ait Maria: Antequam Paulus tibi praedicaret, uidi te et uocem tuam audiui quando dixisti, Sole obtenebrato praeter cursum naturae: "Aut Deus totius naturae conditor patitur aut machina mundi dissoluitur". Et altare etiam a uobis ignoto Deo constructum uidi neque tamen corpore umquam in Graecia fui." Et locuta est secum disertissime lingua Graeca ita ut stupore et admiratione nimia repleretur. Et post longam et Trinitatis Sanctissimae et Filii sui incarnationis et aliorum mysteriorum instructionem, remisit eum ad Paulum, perfectum in fide perfectumque non solum in humana, cuius partem et ante conuersionem habuerat, sapientia sed etiam diuina.

Ignatius quoque, feruentissimus zelator euangelicae legis et praecipuus Ioannis Euangelistae discipulus, nimio desiderio accensus fuit uidere Genitricem

100 uas electionis] uas electionis factum Christi discipulum $M$ (in marg. a. m.) OPQ 101 mysteria] mysterium $Q$; materia $V \mathbf{1 0 2}$ flamma totus] flammatus $I V$ 
suas cartas os apóstolos e outros crentes. Esta, logo que soube de Paulo, o vaso de eleição, enviou-lhe Lucas. [f1. 190] Aquele, antes de partir para a Arábia, quis conhecer a Mãe de Deus. Ao ouvi-la proclamar com tanta sapiência os mistérios de seu Filho e ao vê-la resolver as dificuldades de todas as dúvidas do Antigo Testamento, prostrado em terra, adorou a Cristo Senhor e sua Mãe. E disse: Até hoje, desde o dia da minha conversão, acreditei em Cristo, Filho de Deus. Agora, pela divindade da Mãe conheço claramente a divindade do Filho. Bendito seja o Senhor Jesus Cristo que me iluminou a mim que respirava ameaças e atraiu a si o meu coração transviado. Bendita sejas tu, Mãe do Senhor, meu Deus e Rei Universal, porque vejo encerrados em ti todos os tesouros da sabedoria e do conhecimento de Deus.

Instruído, pois, por Maria acerca de todos os segredos, partiu para a Arábia. Todo a arder e todo inflamado pela chama do amor divino, a todos incendiava. $\mathrm{E}$, pelos seus trabalhos, trouxe ele só à Igreja de Cristo mais frutos do que qualquer outro apóstolo. E é isto o que ele diz de si: Trabalhei mais que todos. ${ }^{[26]}$ Não certamente que todos tomados em conjunto, mas mais que cada um deles individualmente tomado. E enquanto convertia Dionísio, filósofo egrégio, e lhe desvendava, a ele já consumado na fé, os segredos que ouvira da Mãe de Cristo, movido este pelo desejo de a ver, obtida autorização de Paulo, chegou por fim junto dela. E logo que viu sua face, alterou-se e alegrou-se o seu coração e, cheio de exultação e alegria, prorrompeu nestas palavras: "És realmente a Mãe de Deus, Maria, porque estás toda cheia da divindade. Se é tão bom e coisa tão deleitável ver-te, que será ver o próprio Deus, o Bem de todo o bem!?” E prostrado por terra disse: "Adoro em ti, ó Virgem puríssima, o Deus Trino e Uno que Paulo me deu a conhecer, e venero-te como Mãe verdadeira de Deus."

Vi-te, disse então Maria, antes de Paulo te haver pregado e ouvi a tua voz quando, tendo-se obnubilado o Sol contrariamente ao seu curso natural, disseste: "Ou o Deus Criador da natureza sofre, ou a máquina do mundo se desagrega". E vi também o altar por vós erigido ao Deus desconhecido e, contudo, nunca estive fisicamente na Grécia. E falou com ele fluentemente na língua grega a ponto de ele se encher de espanto e de uma admiração sem limites. E depois de longos ensinamentos, não só sobre a Santíssima Trindade, mas também sobre a incarnação de seu Filho e outros mistérios, reenviou-o a Paulo consumado na fé e consumado no conhecimento não só humano, de que tivera parte mesmo antes da conversão, mas também no divino.

Também Inácio, defensor fervorosíssimo da Lei Evangélica e principal discípulo de João Evangelista, ardeu no inexcedível desejo de ver Maria, Mãe de Deus, a 
Dei Mariam, ad quam pluries scripsit et ab eadem plures epistulas accepit quae sunt cum magna ueneratione ${ }^{103}$ legendae. Latet in eis diuinae uirtutis operatio.

Ioannes ad eam frequenter ueniebat et Ignatius eum comitabatur quia non poterat aliud cogitare quam Iesum, Filium Dei et Mariae, ita ut in corde eius sculptum Iesu nomen repertum fuit. Vir erat sanctissimus et matri Dei Mariae acceptissimus doctorque et eruditor plebis Dei nominatissimus qui gloriosa morte martyr seu testis meruit fieri [f1. 191] ineffabilis ueritatis ${ }^{104}$.

Ad Virginem ergo Dei Genitricem et apostoli saepius ueniebant et discipuli eorum et ab ea ignotis dubiis docebantur ${ }^{105}$, in dubiis certi reddebantur, in certis firmiores et certiores et solidiores agnoscebantur. Multum profuit apostolis et aliis credentibus uita matris Dei prolixior. Multum profuit toti Ecclesiae merito.

Tenebat autem sacramentum corporis Filii sui cum maxima ueneratione et ipsum interdum mentis oculo ibi uidebat et aliquando, diuina uirtute similitudines ipsius corporis ad oculos Mariae transferente, uidebat eum oculo corporeo. Manebat in Bethania in domo Marthae, manebat in Magdalo in domo Magdalenae, sed rarius, manebat in domo Lazari iuxta montem Sion frequentius. Et omnia loca, praesertim notabiliora, Filii sui circuibat aliquando, sicut locum ubi Cenam fecerat et maximum sacramentum instituerat, ubi orauerat et guttas sudoris adustas et rubeas ut sanguis guttatim ${ }^{106}$ in terram cadere uideretur emiserat, ubi captus et ligatus, derisus, consputus, flagellatus, spinis coronatus fuerat, ubi sibi occurrerat et syncopem passa est, ubi cruci affixus, ubi sepultus et ubi tandem ultimo omnibus apparuit et in caelum ascendit.

Vixit autem post passionem Domini annis circiter quindecim et quindecim antequam filius eius nasceretur, quem anno quarto decimo conceperat, qui simul iuncti sunt anni triginta. Et triginta tres uixit cum Filio nato. Et sic annos sexaginta tres in uita mortali stetit. Cum Christo tamen antequam nasceretur, gestando ipsum in utero, uixit menses nouem ample ${ }^{107}$, et postquam natus est secum annis triginta tribus et circiter tribus mensibus, quantum uidelicet est interualum inter XXV Decembris et XXV Martii, qui fuerunt dies octoginta nouem, qui tres menses iuncti illis nouem conficiunt menses duodecim. Et ita a conceptione Christi usque ad passionem fluxerunt anni triginta quattuor. Eadem die Dominus conceptus est et mortuus. Tamen in media nocte conceptus, in meridie mortuus. Maria itaque quartodecimo anno et mense septimo concepit Christum ${ }^{108}$. Cum eo in utero et extra uterum existente uixit annis triginta quattuor. Et post ipsum uixit annis

103 ueneratione] admiratione $O Q$; deuotione $P \quad 104$ ineffabilis ueritatis] infalibilis uirtutis $M$; infalibilis ueritas $I V \quad \mathbf{1 0 5}$ ab ea ignotis dubiis docebantur] ab ea in ignotis docebantur $O$; ab ea ignotis et dubiis docebantur $P$; ab ea quae Dei et notis dubiis docebantur $Q \mathbf{1 0 6}$ sanguis guttatim] sanguinis guttam $Q \mathbf{1 0 7}$ menses nouem ample] menses nouem ample quia diebus CC septuaginta $\rightarrow$ 
quem escreveu muitas vezes e de quem recebeu cartas várias, que devem ser lidas com grande veneração. Nelas se esconde a acção do poder divino.

Também João vinha até ela frequentemente, e Inácio acompanhava-o, porque não conseguia pensar noutra coisa que não fosse em Jesus, Filho de Deus e de Maria, de tal modo que foi encontrado esculpido em seu coração o nome de Jesus. Era um varão santíssimo, muito estimado de Maria, Mãe de Deus, e famosíssimo doutor e mestre do povo de Deus, que mereceu, por uma morte gloriosa, tornar-se mártir ou testemunha [f1. 191] da Inefável Verdade.

Também os apóstolos e seus discípulos vinham muitas vezes até junto da Virgem Mãe de Deus e eram por ela ensinados sobre obscuras dúvidas, tornavam-se seguros nas incertezas, mais firmes relativamente às certezas e reconheciam-se mais seguros e mais fortes. Foi muito proveitosa aos apóstolos, e a outros crentes, uma vida mais longa da Mãe de Deus. Aproveitou muito a toda a Igreja.

Guardava também o sacramento do corpo de seu Filho com a máxima veneração e via-o aí durante esse tempo com os olhos da mente e, algumas vezes, transferindo o poder divino as imagens do próprio corpo para os olhos de Maria, via-o com os olhos do corpo. Ficava em Betânia, em casa de Marta; ficava em Magdala, em casa de Madalena, mas raramente; ficava mais frequentemente em casa de Lázaro, junto ao Monte Sião. E, algumas vezes, percorria todos os lugares de seu Filho, sobretudo os mais importantes, como o lugar onde celebrara a Ceia e instituíra o maior sacramento, onde orara e deixara cair as abrasadas e rubras gotas de suor, a ponto de parecer que o sangue gotejava sobre a terra, onde fora preso e amarrado, escarnecido, cuspido, flagelado, coroado de espinhos, onde ela viera ao seu encontro e desmaiara, onde ele fora crucificado, sepultado e onde, por fim, apareceu a todos e subiu ao céu.

Depois da Paixão do Senhor, Maria viveu aproximadamente quinze anos, e quinze anos antes que o seu Filho, a quem concebera aos catorze, nascesse, os quais, juntos, perfazem trinta anos. E viveu trinta e três na companhia de seu Filho. E, assim, permaneceu na vida mortal sessenta e três anos. Viveu, entretanto, com Cristo, antes de ele nascer, transportando-o em seu ventre, nove meses completos. E depois de nascer viveu consigo trinta e três anos e cerca de três meses, ou seja, o intervalo que vai de vinte e cinco de Dezembro a vinte e cinco de Março, que foram oitenta e nove dias, três meses que, juntos àqueles nove, perfazem doze meses. E, deste modo, desde a concepção até à Paixão de Cristo decorreram trinta e quatro anos. O Senhor foi concebido e morto no mesmo dia. Mas foi concebido à meia-noite e morreu ao meio-dia. E, assim, Maria concebeu Cristo aos catorze anos e sete meses. Com ele, estando ele no útero e fora do

$\leftarrow$ sex inclusive $M$ (in marg.) NO 108 concepit Christum.] concepit Christum. Habebat quippe tunc dies centum nonaginta nouem super quattuordecim annos, quantum uidelicet est a die octauo Septembris usque ad diem XXV Martii, includendo extrema. $M$ ( in marg.) NOP 
quattuordecim, mensibus circiter quinque ${ }^{109}$, qui omnes simul iuncti conficiunt annos sexaginta tres, non tamen completos. Pauci enim dies deficiebant qui non impediunt quin uere possit dici tot annos uixisse. ${ }^{110}$ Sed quid dico uixisse? Immo obcubuisse. Tunc enim assidue moriebatur. Ex tunc autem uiuere coepit.

Ecce uides uitam mortalem Mariae nostrae Reginae. Antequam ergo a uobis migraret, ego Gabriel attuli ramum palmae de paradiso Dei uirentibus foliis in signum eius uictoriae. Quae palma ferri debebat ante feretrum eius. Et eam tunc salutaui ut gauderet, quia ad infinitum gaudium ${ }^{111}$ transferenda erat, quod et ipsa bene nouerat. Sed illud quod apud uos legitur Mariam interrogasse angelum ut sibi suum nomen reuelaret, falsum et fictum est. Ipsa enim me optime cognoscebat neque alios angelos ignorabat. Quod etiam apud uos legitur ipsam rogasse [f1. 192] ne in suo exitu ullum ${ }^{112}$ spiritum taeterrimum uideret, falsum est ${ }^{113}$ et derrogat tantae maiestati. Non enim timebat ipsa spiritus immundos super quos potestatem acceperat et, egrediendo, magis accipiebat. Illud ex illis tribus solum uerum est quod Maria tunc, gaudio plena, dixit coram me, non me rogando ut rogarem, quia potentior omnibus angelis erat, sed ad Christum locuta est: Fili mi Iesu, cuperem ut adessent omnes apostoli tui qui supersunt et anima Iacobi fratris mei nuper ab Herode decollati utque uideatur ab apostolis praesentim Ioanne fratre suo. Hoc rogo. Adsint et alii discipuli qui supersunt. Et non solum adsint apostoli qui tecum in uita mortali fuerunt, sed etiam quos Spiritu Sancto etiam postmodum elegisti et segregasti, Paulus uidelicet et Barnabas, quos docui omnia secreta ${ }^{114}$ tua.

Apostoli tempore illo non discesserant totaliter a Iudaea, immo saepius congregabantur in Ierusalem, nam plures synodos seu plura concilia fecerunt in ciuitate illa. Et Ioannes saepissime cum Ignatio ad Genitricem Dei ueniebat. Et alii eam quandoque uisitabant. Ioannes etiam tunc primus affuit. Qui Hierosolymis erant accesserunt. Qui remotiores erant, angelis eos ducentibus, peruenerunt ita quod una die, una hora, omnes simul ibi affuerunt et agnouerunt Genitricis Domini felicissimum transitum. Affuit autem cum Paulo etiam Dionysius. Aderat et magna angelorum multitudo.

Petrus itaque coram omnibus aperiens os suum, laudes Virginis dicere coepit hoc modo: Scio, fratres mei, notum esse uobis omnibus quantae dignitatis sit haec

109 circiter quinque] circiter quinque, quia diebus centum quadraginta duobus, quantum uidelicet est a die uigesima quinta Marti exclusiue usque ad diem decimum quintum (quartum NO) Augusti inclusiue. $M$ (in marg. a. m.) $N O Q \mathbf{1 1 0}$ tot annos uixisse.] tot annos uixisse. Habebat namque annos sexaginta duos, menses XI, dies octo. Et in utero suae matris, plena gratia et scientia, $\rightarrow$ 
útero, viveu trinta e quatro anos. E depois dele, viveu catorze anos, cerca de cinco meses que, todos juntos, perfazem sessenta e três anos, mas não completos. Faltavam de facto poucos dias, que não impedem que se possa dizer que viveu tantos anos. Mas porque digo que viveu? Pelo contrário, sucumbiu. De facto, morria então incessantemente. Mas a partir de então começou a viver.

Aqui tens a vida mortal de Maria, Rainha nossa. Antes, porém, de ela partir de junto de vós, trouxe eu, Gabriel, do Paraíso de Deus, um ramo de palma, de folhas verdes, em sinal da sua vitória. Palma que devia ser levada à frente do seu féretro. Saudei-a então, dizendo-lhe que se alegrasse porque devia ser transladada para uma infinita alegria, coisa que ela bem sabia. Mas o que se lê entre vós, que Maria havia interrogado o anjo para que lhe revelasse o seu nome, é falso e mentiroso. ${ }^{[227]}$ Ela conhecia-me muito bem e não desconhecia os outros anjos. O que também se lê entre vós, que Maria havia pedido [f1. 192] para não ver na sua partida nenhum desses hediondíssimos espíritos, é falso e ofensivo de tão grande majestade. Pois ela não temia os espíritos imundos, sobre os quais havia recebido poder e mais recebia ao partir. Dessas três coisas, é verdade apenas aquela que Maria, cheia de alegria, disse então perante mim, não a solicitar-me para que eu pedisse, porque era mais forte que todos os anjos, mas falou a Cristo: Jesus, meu Filho, desejaria que estivessem presentes todos os teus apóstolos vivos e a alma de Tiago, meu irmão, recentemente degolado por Herodes, e que fosse vista pelos apóstolos, sobretudo por seu irmão João. Isto te peço. Estejam presentes também os outros discípulos vivos, e não estejam presentes apenas os apóstolos que contigo estiveram na vida mortal, mas também aqueles que escolheste e segregaste depois pelo Espírito Santo, a saber, Paulo e Barnabé, a quem ensinei todos os teus segredos.

Nessa altura os apóstolos não se tinham afastado totalmente da Judeia, pelo contrário, reuniam-se muitas vezes em Jerusalém, pois realizaram Sínodos vários e vários Concílios naquela cidade. E João vinha muitíssimas vezes com Inácio até junto da Mãe de Deus, e os outros visitavam-na às vezes. João, também então, foi o primeiro a chegar. Chegaram os que estavam em Jerusalém. Os que estavam mais longe chegaram, trazidos pelos anjos, de tal modo que num dia, numa hora, todos aí chegaram ao mesmo tempo e tomaram conhecimento do felicíssimo transito da Mãe de Deus. Dionísio também estava com Paulo. Estava também uma grande multidão de anjos.

Pedro, pois, tomando a palavra diante de todos, começou a proclamar os louvores da Virgem, deste modo: Sei, meus irmãos, que todos vós conheceis

$\leftarrow$ uixerat mensibus nouem, quantum uidelicet est ab octaua (octauo $Q$ ) die Decembris usque ad octauam Septembris. Et sic inuenitur uere uixisse annos sexaginta tres, menses octo, dies octo. $M$ (in marg. a. m.) NOQ 111 gaudium] gaudium etiam corporis non solum animae $O Q \mathbf{1 1 2}$ ullum] illum $O Q$; nullum $V \mathbf{1 1 3}$ falsum est] falsum est et ridiculum $Q \mathbf{1 1 4}$ secreta] sacramenta $Q$ 
quam coram cernimus Virgo, in qua et si omnes collectae sint ${ }^{115}$ uirtutes et omnia collecta dona, feruor tamen diuini honoris ${ }^{116}$ et zelus diuinae uenerationis in ea super omnia effulsit. Quia et si uere Deo nil maius sit aut esse possit, homines tamen etiam sancti, quadam familiaritate Dei assueti, ipsum tamquam amicum quemdam et familiarem existimant et non tanti faciunt quanti ipse est. Sed haec, quamuis semper gratiam Dei habuerit et Deum ipsum uiderit et ab eo super omnes exaltata fuerit, semper tamen quadam ineffabili humilitate se quottidie minorem, Deum uero quo magis ei appropinquabat remotiorem a se extimabat. Remotiorem dico, quia semper ipsum digniorem iudicabat. Haec est illa quae, dum eligeretur in matrem Dei, dixit: "Ecce ancilla Domini, fiat mihi secundum uerbum tuum". Haec est illa quae, iam electa in matrem, concepto iam Filio, dicebat: "Respexit Deus humilitatem ancillae suae". Quo ergo magis crescebat eo se minorem censebat. Et quo minor erat in oculis suis eo maior coram Deo efficiebatur. Et recte id egit quia omne bonum sibi collatum donum Dei fuit et nihil habebat quod non acceperat. Omnia in ea sunt laude digna.

Sed omnia mihi, uobis fratribus meis me peritioribus cetera relinquens, non sunt recensenda. Et quia Magister noster Christus dixit: Qui se humiliat exaltabitur, et: Qui plus se humiliauerit maior erit in regno caelorum, quia ergo Domina nostra Dei Genitrice Maria nemo humilior fuit, iustum est ut in regno caelorum nemo sit maior aut sublimior ea. Nos igitur, fratres carissimi, humilitatem sectemur Mariae, imitemur quo [f1. 193] ad possumus uestigia eius ut ille qui eam super omnes sublimauit, nos quoque tantae gloriae ac sublimitatis participes efficiat. Qui cum Patre suo et Spiritu Sancto uiuit et regnat in saecula saeculorum. Amen.

Post ipsum Ioannes ita locutus est: Ego, patres atque fratres mei, quid de tanta maiestate dicere potero, qui sicut aetate ita et scientia minor sum uobis omnibus? Ex quo tamen cum Petro et Iacobo, fratre meo decollato, cuius anima ecce hic est (et tunc omnes eam uiderunt), quem alia uita iam uiuentem loqui mortali lingua non decet, Dominus ad fidei suae splendorem elegit et ut uos in quibus modo nulla inuidia est, quia in gratia confirmati estis et de bono meo tamquam de bono communi gaudetis, mihi hunc locum dedistis, loquar et laudibus huius Virginis non cessabo. Est enim omni laude dignissima. Et quamuis omnia sint in ea laude digna, omnia splendida, omnia pulchra, omnia decora, id tamen pro nunc, cetera 
quão grande seja a dignidade desta Virgem que vemos perante nós, em quem, mesmo que estejam reunidas todas as virtudes e associados todos os dons, nela, contudo, brilharam acima de tudo o fervor da divina honra e o zelo da divina veneração. Pois que, embora realmente nada seja ou possa ser maior que Deus, os homens, contudo, mesmo os santos, acostumados a alguma familiaridade com Deus, consideram-no como um amigo e um familiar e não se esforçam tanto quanto ele merece. Mas esta, embora sempre tenha tido a graça de Deus e sempre tenha visto o próprio Deus e tenha por ele sido exaltada acima de todos, sempre, contudo, por uma inefável humildade, se julgava a si cada dia menor, e a Deus, quanto mais dele se aproximava, mais afastado o considerava de si. Digo mais afastado porque sempre o considerava mais digno. Esta é aquela que, antes de ser escolhida para Mãe de Deus, disse: Eis a serva do Senhor, faça-se em mim segundo a tua palavra. ${ }^{[228]}$ Esta é aquela que, escolhida já para Mãe, tendo já concebido o Filho, dizia: Deus olbou para a bumildade da sua serva. ${ }^{[229]}$ Pois, quanto mais crescia, tanto menor se julgava. E quanto menor era a seus olhos, tanto maior se tornava perante Deus. E agiu sabiamente, porque todo o bem a si concedido foi dádiva de Deus e nada tinha que não tivesse recebido. Tudo nela é digno de louvor.

Mas não devo eu enumerar tudo, deixando-vos o restante a vós, irmãos meus, mais versados do que eu. E visto que Cristo, nosso Mestre, disse: Quem se humilha será exaltado; ${ }^{[230]} \mathrm{e}$, quem mais se humilhar maior será no reino dos céus, ${ }^{[231]} \mathrm{e}$, porque ninguém foi mais humilde que Maria, Mãe de Deus e Senhora nossa, é justo que no reino dos céus ninguém seja maior ou mais sublime do que ela. Sigamos, pois, irmãos caríssimos, a humildade de Maria, imitemos até [fl. 193] onde pudermos os seus passos, a fim de que aquele que a sublimou acima de todos nos torne a nós também partícipes de tão grande glória e de tanta grandeza. Ele que com seu Pai e o Espírito Santo vive e reina pelos séculos dos séculos. Ámen.

Depois dele, assim falou João: Que poderei eu dizer, pais e irmãos meus, de tão grande majestade, eu que em idade e saber sou inferior a todos vós? Todavia, desde que com Pedro e Tiago, meu irmão, que foi degolado, cuja alma, como vedes, está aqui (e todos então a viram), a quem, vivendo já na outra vida, não é possível falar a língua mortal, o Senhor escolheu para esplendor da sua fé, e desde que vós, em quem agora nenhuma inveja existe porque fostes confirmados na graça e vos alegrais do meu bem como do bem comum, me destes este lugar, proclamarei incessantemente os louvores desta Virgem. É, de facto, sumamente digna de todo o louvor. E embora nela tudo seja digno de louvor, tudo resplan-

[227] Apócrifos Assumpcionistas.

[228] Lc 1:38

${ }^{[229]}$ Lc 1:48

[230] Lc 14:11

[231] Mt 18:14. 
uobis relinquens, in ea commendabo quod digna fuit esse Mater Dei Genitrixque Verbi Diuini appellari. Permagni puto seruum Dei appellari. Qui enim Deo seruit, regnat. Sed plus est amicum Dei nuncupari, plus certe filium. Sed haec omnia nihil sunt respectu huius quod est matrem Dei appellari et esse. Ioseph quidem pater Dei appellatus est, sed non fuit nisi putatiue. Haec uero uere mater Dei est. Verum enim Deum concepit, uerum peperit. Sed in ipsa conceptione mater est facta, quia non solum hominem purum, ut aliae matres, sed Deum carni humanae unitum genuit. Et primo concepit, quamuis et ipsa conceptio sit generatio. Formata carne illa et omnibus membris distincta, in eodem ictu oculi et anima creata et infusa fuit et diuinitas humanitati unita, hoc est, illi rei quae homo dicitur quae non solum est anima aut corpus, sed ex eis est illa res.

Tu, o Genitrix Dei nostri, haec quae ad fratres meos apostolos, discipulos et has sanctas mulieres quae hic sunt loquor melius nosti. Nosti profecto te Filio tuo unico, Domino et Saluatori nostro, totam ut aliae matres ministrasse, de qua caro illa pretiosa formaretur, materiam et omnem operationem habuisse quam et aliae matres habent in proles suas ${ }^{117}$. Et nosti quod, te operante et Spiritu Sancto superueniente, antequam humanitas illa in se staret, a Verbo Dei Filioque eius ante saecula a Patre genito assumpta fuit ut non in seipsa, sed in ipso Verbo staret et a Verbo sustentaretur. Iccirco uere Dei nostri Genitrix et non alicuius puri ${ }^{118}$ hominis mater dici, nominari et praedicari per totum mundum poteris. Multi mirabuntur quomodo Deus, qui semper est et ab aeterno est, concipi potuit. Et non considerant quomodo unus homo alterius filius dici possit et unus homo ab alio genitus esse. Ratio admirationis erit similis. Nam homo per animam est homo. Corpus aliquid facit ad esse hominem, sed anima dat completum esse. Tamen quia illa anima a Deo creata in eodem ictu oculi corpori infunditur in quo corpus a parentibus plasmatur, ideo hominem totum et non solum carnem genuisse dicuntur, sic et tu, o dignissima Dei nostri Genitrix, Spiritu Sancto tibi uirtutem tribuente, quam et habebas, sed [f1. 194] non ut sola posses, et tecum concurrente et modum ut secum talia exercere posses praestante, quia et esse carneum et esse humanum Deo tribuisti, uere Deum concepisti, uere genuisti. Quod nomen et res nominis ualde ${ }^{119}$ te, o Domina et Regina nostra, dignificat. Dignare tu, o caelorum et angelorum omnium Regina et Domina, nos et omnes qui nos in hac confessione sequentur adiuuare et saluare. Et me quem in filium uoce a cruce delata accepisti et ego uirtute uerborum Christi Domini similiter te ex tunc meam accepi in matrem, non derelinquas, sed me filium tuum indignum, 
decente, tudo belo, tudo harmonioso, de momento, contudo, deixando-vos todas as outras coisas, nela invocarei isto, a saber, o facto de ter sido digna de ser a Mãe de Deus e ser chamada Progenitora do Verbo Divino. Considero sumamente importante ser chamado servo de Deus, pois quem serve a Deus, reina. Mas é maior ser chamado amigo de Deus e, mais ainda, seguramente, filho. Mas todas estas coisas nada são em comparação com esta que é chamar-se e ser Mãe de Deus. Sem dúvida que José foi chamado pai de Deus, mas foi-o apenas putativamente. Mas esta é verdadeiramente Mãe de Deus. Concebeu, de facto, o Deus verdadeiro, deu à luz o verdadeiro Deus. Mas tornou-se mãe na própria concepção porque gerou não apenas um simples homem, como as outras mães, mas gerou a Deus unido à carne humana. Mas, primeiro, concebeu, embora a própria concepção seja geração. Formada aquela carne e organizada em todos os membros, no mesmo pestanejar de olhos foi criada e infundida a alma e a divindade unida à humanidade, isto é, àquela realidade que se designa homem, a qual não é só alma ou corpo, mas aquela realidade que resulta de ambos.

Melhor conheces tu, ó Mãe de Deus, as coisas que digo aos meus irmãos apóstolos, discípulos e a estas santas mulheres que aqui estão. Sabes sem dúvida que tu, como as outras mães, proporcionaste a teu Filho único, Senhor e Salvador nosso, toda a matéria da qual seria formada aquela carne preciosa e todo o trabalho que as outras mães têm para com seus filhos. E sabes que, operando tu e o Espírito Santo em ti, antes de aquela humanidade existir em si, foi assumida pelo Verbo de Deus e seu Filho, gerado pelo Pai antes dos séculos, para que não existisse em si mesma, mas no próprio Verbo e pelo Verbo fosse sustentada. Por isso poderás verdadeiramente ser considerada, chamada e proclamada por todo o mundo Progenitora do nosso Deus e não mãe de um simples homem. Muitos se hão-de admirar como pôde ser concebido Deus, que existe sempre e desde toda a eternidade. E não atentam no modo como pode um homem considerar-se filho de outro, e ser um homem gerado por outro. A razão da admiração será semelhante. Pois o homem é homem pela alma. O corpo contribui alguma coisa para o ser homem, mas a alma dá o ser completo. Como quer que seja, já que aquela alma criada por Deus é infundida no corpo no mesmo instante em que o corpo é plasmado pelos pais, diz-se, por isso, que geraram o homem todo e não apenas a carne. Assim também tu, ó digníssima Mãe do nosso Deus, concedendo-te o Espírito Santo a virtude, que também já tinhas, mas [fl. 194] não para poderes sozinha, e contigo concorrendo e assegurando-te o modo para com ele poderes realizar tão grandes coisas, porque deste a Deus não só o ser carnal, mas também o ser humano, concebeste verdadeiramente e verdadeiramente geraste a Deus. Esse nome e a substância do nome muito te dignificam, ó Senhora e Rainha nossa. Digna-te tu, ó Rainha e Senhora dos Céus e de todos 
qui seruus magis tuae maiestatis dici debeo, habeas in omnibus aduersitatibus commendatum utque omnes alios hic existentes et qui sequuntur pro filiis saltem adoptiuis habeas rogo, qui tuam credent et ore confitebuntur maternitatem. O mater Dei, o mater Dei, o mater Dei ..., conticeo, sileo, dicere non audeo, o mater mea, quia et si iam te accepi in meam, timeo tamen dicere meam, quia tunc meipsum facerem fratrem Domini Iesu Filii tui omnino ueri fratremque ipsius Dei. Mater tamen etiam mea es peculiari modo. Non tamen illo modo quo es mater Filii Dei neque illo modo quo es mater omnium hominum, sed quodam medio modo. Sum enim filius tuus magis quam alii, sed longe minus quam ille quem cuncti colimus, ueneramur et adoramus.

Accedit ${ }^{120}$ post hunc Andreas apostolus et laudes Virginis Gloriosae ita decantare coepit: Pulchra es et ualde decora, Genitrix ueri Dei nostri. Tuamque pulchritudinem Sol et Luna et cuncta sidera, immo et omnes uirtutes caelorum admirantur. Iustum et rationabile fuit ut mater Dei tanta puritate splenderet et tanta pulchritudine fulgeret ut sub Dei nostri pulchritudine nulla in terris aut in caelis maior cogitari posset. Tota enim pulchra es, nulla macula est in te, nil in te horridum ${ }^{121}$, nil taetrum, omnia splendent, omnia rutilant, omnia radiant. Quia ergo Ioannes, frater meus et filius tuus licet illi primogenito tuo longe impar, de maternitate tua tamquam filius multa praeclare ${ }^{122}$ attulit, et Petrus, nouus ouium pastor, tamquam omnium nostrum humillimus tuam humilitatem quemadmodum in te Deo complacuit extulit, ego germanus ipsius qui decoris nomen gero, de tuo decore, de tua speciositate et formositate et pulchritudine aliquid coram his maioribus fratribus meis dicere curabo. Maxime quia tu sola ita electa es ut numquam salus tua, beatitudo tua felicitasque tua fuit in dubio etiam quando angelis mandata dabantur cum condicione, si ea seruarent beatitudinem obtinerent. Quando totum humanum genus damnatum erat, totum perierat, totum hereditate priuatum fuerat, tu sola ab uniuersali omnium damnatione praeseruata fuisti. Electa enim eras in Genitricem Dei et omnium Reginam ita ut, si homo non peccasset, tu inter omnes post Filium tuum prima in regno [f1. 195] Dei esses. Peccante uero homine, iam remedium, si peccaret, paratum erat, labores, inquam, et dolores Iesu Christi Filii tui et Domini nostri. Sicque decreto aeterno firmatum erat ut passio illius super omnes tibi prodesset, quamuis nondum exhibita esset, quae tantum ualuit quantum a Deo accepta fuit. Non ergo tu mortua in Adam fuisti, quamuis ratione propaginis tuae, quia sicut et alii ex utroque parente nata es, 
os anjos, auxiliar-nos e salvar-nos a nós e a todos aqueles que nos hão-de seguir nesta confissão. E a mim, a quem pela voz vinda da cruz recebeste como filho, e eu, pelo poder das palavras de Cristo Senhor, do mesmo modo te recebi desde então como minha mãe, não me abandones, mas me protejas em todas as adversidades, a mim, teu filho indigno, que mais devo ser considerado servo da tua majestade. E peço-te que tenhas todos estes aqui presentes e os que se hão-de seguir pelo menos como filhos adoptivos, eles que hão-de crer e confessar a tua maternidade. Ó Mãe de Deus..., ó Mãe de Deus..., ó Mãe de Deus..., emudeço, calo-me, não ouso dizer, ó minha Mãe, porque, embora te tenha já recebido em minha casa, tenho, todavia, medo de dizer minha, porque então far-me-ia irmão do Senhor Jesus, teu verdadeiro Filho, realmente, e irmão do próprio Deus. És também minha Mãe de um modo especial. Não, todavia, do modo como és Mãe do Filho de Deus, nem do modo como és Mãe de todos os homens, mas de um certo modo intermédio. Sou realmente mais teu filho que os outros, mas muito menos do que aquele a quem todos honramos, veneramos e adoramos.

Depois deste, aproximou-se o apóstolo André e começou desta maneira a enaltecer os louvores da Virgem: És formosa e verdadeiramente bela, ó Mãe do nosso verdadeiro Deus. Sol, Lua e todos os astros e todas as forças celestes admiram a tua formosura. Foi justo, foi racional que a Mãe de Deus brilhasse com tão grande pureza, resplandecesse com tão grande beleza que, abaixo da beleza do nosso Deus, nenhuma pudesse ser pensada maior na terra ou no céu. Toda és formosa, em ti não há mancha alguma, nada em ti é sombra, nada é escuridão. Tudo reluz, tudo brilha, tudo é resplandecente. Uma vez, porém, que João, meu irmão e teu filho, embora muito inferior àquele que é o teu Primogénito, na qualidade de teu filho muita coisa brilhantemente aduziu sobre a tua maternidade; e Pedro, o novo Pastor das ovelhas, como o mais humilde de todos nós exaltou a tua humildade segundo o modo como Deus se comprouve em ti; eu, irmão dele, que tenho o nome de perfeito, procurarei perante estes meus irmãos mais velhos dizer alguma coisa sobre a tua perfeição, a tua graça, a tua formosura e a tua beleza. Sobretudo porque só tu foste de tal modo escolhida que nunca a tua salvação, a tua bem-aventurança e a tua felicidade estiveram em dúvida, mesmo quando aos anjos eram dados os mandamentos sob condição: se os observassem, obteriam a bem-aventurança. Quando toda a raça humana havia sido condenada, havia decaído toda, toda havia sido privada da herança, só tu foste preservada da universal condenação. Havias sido escolhida para Mãe de Deus e Rainha de todas as coisas de tal modo que, se o homem não tivesse pecado, tu serias, depois de teu Filho, a primeira entre todos a estar no Reino [f1. 195] de Deus. Vindo o homem a pecar, estava preparado já, se pecasse, o remédio, ou seja, os trabalhos e as dores de Jesus Cristo, teu Filho e Senhor nosso. Havia, assim, sido firmado por decreto eterno que a sua Paixão te aproveitasse a ti mais que a todos, apesar de se não haver verificado ainda, ela que teve tanto valor quanto foi por Deus aceite. Tu, portanto, não morreste em Adão, embora, em razão da 
mortua fuisses, quamuis uterque illorum parentum sanctissimus fuisset. Vnica es columba sine felle, unica immaculata. Recessisti a peccato quocumque, recedere tam longe a peccato nemo potuit. De te propheta recte locutus est: "Egredietur uirga de radice Iesse, tota gracilis, recta tota, erecta non curua, sine nodo et sine cortice”. O Maria Dei Genitrix et Virgo perpetua, recte cecinisti: Ecce ex hoc beatam me dicent omnes generationes. Laudabunt ${ }^{123}$ et praeconia tuae puritatis tandem omnes agnoscent. Plerique de tua uirginitate dubitabunt et credent $^{124}$ te alios Filios quam Dominum nostrum habuisse. Alii dubitabunt de tua maternitate et credent te esse matrem unius hominis et non prorsus Dei. Et si Dei, non tamen ueri Dei. Alii ueri Dei te putabunt matrem, sed illum non distisguent a suo Patre, sed credent Patrem eundem esse qui et Filius est. Propter quod saepius rogaui ut talia fieri non sineret Altissimus. Et dictum est mihi: "Sufficit tibi quod tibi datur. Noli sapientior esse Deo". Sed scio quod, exclusis de tua puritate aliis opinionibus falsis, ultimo haec quoque falsitas a tota Ecclesia excludetur.

De pulchritudine et de maximo decore tuo, o Domina nostra, loqui uolens, tetigi tantum principium pulchritudinis tuae quae nihil aliud est quam donum Dei. Et de tuo ingenti ${ }^{125}$ decore et uirtutum omnium tuarum splendore Thomas, Iacob, Philippus, Matthaeus et hi astantes altiori ingenio altiora dicent. Nos omnes peccatores ${ }^{126}$ sumus et fuimus. Tu quae peccatorum omnium Redemptorem uirgo concepisti, uirgo peperisti, inuiolata ${ }^{127}$ semper fuisti, tibi et Filio tuo unico commendatos nos facere uelis ut, quae sine peccato semper fuisti, nos et posteros peccatores tua caritate et dilectione complecti digneris. Mihique si prolixior fuerim, senes quippe abundantius quando incipiunt loqui consueuerunt, ignosce Domina, ignosce Regina, ignosce ${ }^{128}$ Dei nostri mater suauissima.

Post hunc Simon apostolus, accitus a Simone Petro ut uerbum proponeret, in hunc modum loqui coepit: Quamuis plurima ${ }^{129}$ sint iam dicta de laudibus Reginae caeli, nil tamen dignum tanta maiestate. In ea namque omnia pulchra, omnia magna, omnia excelsa. Quemadmodum enim Saluator noster, Christus Dominus, factus est oboediens usque ad mortem, mortem autem crucis et Deus propter oboedientiam ipsius exaltauit illum et donauit illi nomen quod est super omne nomen, nam omnis lingua sibi confitebitur et data est ei omnis potestas in caelo et in terra, ita certo quia Genitrix eius Maria, Domina nostra, et ipsa oboediens fuit usque ad mortem, [f1. 196] mortem autem crucis quam in mente passa est et cooperata

123 generationes". Laudabunt] generationes". Omnes gentes te laudabunt. $Q \mathbf{1 2 4}$ credent] reddent $V 125$ ingenti] ingenii $P 126$ peccatores] praedicatores $I V \quad 127$ inuiolata] immaculata $Q V 128$ Regina, ignosce] Regina, ignosce, rogo $Q 129$ plurima] pulchra $V$ 
tua filiação, uma vez que, como os outros, nasceste de dois progenitores, tivesses morrido, apesar de muito santos serem ambos esses pais. És a única que é pomba sem fel, a única imaculada. Tu distanciaste-te de todo o pecado, ninguém pôde distanciar-se tanto do pecado. De ti falou justamente o profeta: "Uma vergôntea sairá da raiz de Jessée, ${ }^{[232]}$ toda grácil, toda bela, erecta, não inclinada, sem nó e sem casca." Ó Maria, Mãe de Deus e sempre Virgem, sabiamente cantaste: De hoje em diante, todas as gerações me proclamarão bem-aventurada. ${ }^{[233]}$ Todos hão-de louvar e, por fim, reconhecer o encómio da tua pureza. Muitos duvidarão da tua virgindade e acreditarão que tiveste outros filhos além de nosso Senhor. Outros duvidarão da tua maternidade e acreditarão que tu és mãe de um simples homem e de modo nenhum de Deus. E, se Mãe de Deus, não, todavia, do Deus verdadeiro. Outros considerar-te-ão Mãe do verdadeiro Deus, mas não o distinguirão de seu Pai, acreditando que o Pai é o mesmo que o Filho. Por isso, muitas vezes pedi que o Altíssimo não consentisse que tal acontecesse. E foi-me dito: "Basta-te o que se te dá, não queiras ser mais sábio que Deus". Mas sei que, arredadas algumas falsas opiniões sobre a tua pureza, por fim, também esta falsidade será erradicada de toda a Igreja.

Querendo falar, ó Senhora nossa, da tua beleza e da tua inexcedível perfeição, toquei apenas o princípio da tua beleza, que não é mais que um dom de Deus. E da tua ingente perfeição e da magnificência de todas as tuas virtudes dirão com mais profundo engenho coisas mais profundas Tomé, Tiago, Filipe, Mateus e os presentes. Todos nós somos e fomos pecadores. Queiras tu que, sendo virgem, concebeste o Redentor de todos os pecados, virgem o deste à luz, que sempre foste inviolada, encomendar-nos a ti e a teu Filho único a fim de que tu, que sempre foste sem pecado, te dignes proteger-nos a nós e aos futuros pecadores com o teu amor e a tua afeição. E a mim, se tiver sido longo, perdoa-me, Senhora, pois os velhos, quando começam, têm o hábito de falar demais. ${ }^{[234]}$ Perdoa, Rainha, perdoa, suavíssima Mãe do nosso Deus.

Depois deste, chamado por Simão Pedro para se pronunciar, o apóstolo Simão começou a falar nestes termos: Apesar de muito se haver dito já sobre os méritos da Rainha do Céu, nada, contudo, foi dito digno tão grande majestade. Nela, na verdade, tudo é belo, tudo é grande, tudo é sublime. Realmente, assim como o nosso Salvador, Cristo Senhor, se fez obediente até à morte, e morte de cruz, e Deus, em razão da sua obediência, o exaltou e lhe deu um nome que está acima de todo o nome, ${ }^{[235]}$ pois toda a língua o confessará, e lhe foi dado todo o poder no céu e na terra, assim, visto que Maria, sua Mãe, Senhora nossa, também ela foi obediente até à morte, [f1. 196] e morte de cruz, que sofreu em seu espírito,

[232] Is $11: 1$

${ }^{[233]}$ Lc 1:48

[234] Cícero, De senectute XVI, 55

[235] F1 2:8. 
est cruci Filii sui ad redemptionem humani generis, nam Simeonis uaticinium in ipsa fuit impletum quando dixit sibi: "Et tuam ipsius animam pertransibit gladius, mortuo Filio, commortua est et mater et quantum potuit redemptioni nostrae auxiliata est et martirii gloriam adepta est. Ad uitam hanc, milite ${ }^{130}$ lancea latus Domini perforante, reuersa est ut iterum nobiscum existens, nobis et toti Ecclesiae prodesset, sicut certe et profuit ut omnes nouimus omnesque experti sumus. Quia ergo cum uehementi dolore mortua est et Christum Dominum in doloribus suis associauit, nunc non decet ut ullo dolore afficiatur, sed cum gaudio et laetitia anima sua a corpore separetur ${ }^{131}$, quia oportet ut legem pro omnibus statutam, a qua non fuit excepta, quia non oportebat eam eximi, seruaret plublice et pro se. Tunc enim pro nobis et pro martyrii gloria defuncta est. Nunc est solutura debitum commune et ad tempus breue corpus exanime remanebit. Et propter oboedientiam factam, quae omnes uirtutes complectitur, exaltabiur super omnes choros angelorum et super omnem potestatem et uirtutem. De qua re et ipsi angeli gaudent et gratias agunt Deo, quorum plurimi hic sunt nobiscum, praesertim ille magnus Gabriel, unus de septem et secundus inter primos septem. Nos itaque, fratres, oboedientiae iugo colla nostra submittamus et uestigia Domini et matris eius cum puritate cordis sectantes ut post Reginam nostram nos, serui eius, illuc quo ipsa properat scandere possimus, quod facile erit ipsa pro nobis interueniente, cui nos omnes omneque genus humanum humiliter commendamus.

Post hunc uocatur Thomas apostolus ut laudes Virginis ad consolationem astantium commemoret. Ita ergo loqui coepit: Abyssus abyssum inuocat. Petrus, noster princeps, propter humilitatem exaltatus, de humilitate multa dixit. Ioannes, filius, de maternitate. Andreas, uirilis, Dei uirtutem Mariam Reginam nostram ab omni labe praeseruantis proclamauit et, decorus ipsius pulchritudinem summam post Deum ostendit. Simon uero, iuxta sui nominis interpretationem, de oboedientia et de cruce atque morte ex compassione pleraque attulit. Ego quoque alludam nomini meo. Abyssum enim me uocatis. Et ideo de abyssu diuinae praedestinationis, qua Genitricem suam super omnes elegit et praeelegit, quaedam afferam coram uobis.

Mirantur homines et adhuc mirabuntur cur Deus ipsam Mariam potius elegit in matrem et ad tantam beatitudinem praeordinauerit quam quamcumque aliam mulierem aut creaturam. Et non cogitant quod, si aliam filiam Adae in genitricem elegisset, eadem admiratio de illa quoque fuisset. Vnam oportebat esse, unius 
e cooperou com a cruz de seu Filho para a redenção do género humano, pois cumpriu-se nela o vaticínio de Simeão, quando lhe disse: e uma espada trespassará a tua alma, ${ }^{[236]}$ morto o Filho, foi igualmente morta a Mãe, e auxiliou, na medida do possível, à nossa redenção e alcançou a glória do martírio. Voltou a esta vida quando a lança do soldado trespassou o lado do Senhor para, vivendo de novo connosco, nos auxiliar a nós e a toda a Igreja, como seguramente nos auxiliou, como todos sabemos e experimentámos. Porque foi morta com lancinante dor e em suas dores se associou a Cristo, não é justo agora que seja afectada por qualquer dor, mas a sua alma se separe do corpo com gozo e alegria, porque é preciso que publicamente e em relação a si se cumpra a lei estatuída para todos, da qual não foi exceptuada porque não era preciso livrá-la. De facto, morreu então por nós e para glória do martírio. Agora há-de ser liberta dessa dívida universal, e o corpo permanecerá sem vida por tempo reduzido. E por causa da consumada obediência, que contém todas as virtudes, será exaltada acima de todos os Coros dos anjos e acima de todas as Potestades e Virtudes. Deste facto até os anjos, a maioria dos quais está aqui connosco, sobretudo o grande Gabriel, um dos sete e o segundo entre os sete primeiros, se alegram e dão graças a Deus. Submetamos nós também, irmãos, a nossa cerviz ao jugo da obediência e, seguindo com pureza de coração os passos do Senhor e de sua Mãe, a fim de podermos, nós seus servos, subir depois da nossa Rainha àquele lugar aonde ela se dirige, o que será fácil com a sua intervenção a nosso favor, a quem humildemente nos encomendamos e a todo o género humano.

Depois deste, é chamado a reavivar os louvores da Virgem, para consolação de todos os presentes, o apóstolo Tomé. Começou, pois, a falar deste modo: Abismo atrai abismo. ${ }^{[237]}$ Pedro, nosso príncipe, exaltado por causa da humildade, muito disse sobre a humildade. João, filho, sobre a maternidade. André, corajoso, enalteceu o poder de Deus que preservou Maria, Rainha nossa, de toda a mancha; perfeito, mostrou a perfeição de Maria, a maior depois de Deus. E Simão, segundo a interpretação de seu nome, aduziu muita coisa sobre a obediência, a cruz e a morte, em razão da partilha da Paixão. Também eu farei referência ao meu nome. Com efeito, chamais-me abismo. E, por isso, trarei perante vós alguma coisa sobre o abismo da predestinação divina, em razão da qual escolheu e preferiu acima de todas as outras a sua Progenitora.

Admiram-se e admirar-se-ão ainda os homens porque é que Deus preferiu Maria a qualquer outra mulher ou criatura para sua mãe e a predestinou para tão grande glória. E não pensam que se tivesse escolhido para mãe outra filha

[236] Lc 2:35

[237] S1 41:8

[238] Prov 31:29 
munus illud erat, perfectissimam et anima et corpore illam et in naturalibus atque accidentalibus optime dispositam esse decebat. Congruebat quoque ut, quemadmodum homo ille a Deo assumptus plenus fuit et est et erit gratiae et ueritatis et esset super omnes creaturas, ita post ipsum Genitrix sua superaret [f1. 197] omnes in gratia et beatitudine ${ }^{132}$. Donum maternitatis consequitur donum beatitudinis. Et si sibi et Filio suo unico, Domino nostro, absolute uoluit beatitudinem, deinde merita siue media, non tamen uoluit utrique tantam beatitudinem nisi ratione assumptionis humanitatis ex tali uirgine. Voluit ab aeterno et in initio uiarum suarum, quia generatio Filii a Patre aeterna uia est qua Deus exiuit a Deo Patre, aeterna ab utroque est processio Spiritus Sancti quam tamen Filius a Patre accepit ${ }^{133}$ et illa quoque processio uia aeterna ad aeternum terminum est, aeterna est cognitio omnium creaturarum quae quoque ${ }^{134}$ uia quaedam est, in tribus enim personis, Patre uidelicet Filio ac Spiritu Sancto, simul cognitio existens, ad omnes creaturas terminatur, uolitio praeterea in tribus ipsis unica existens in initio, ad ipsos duos, Filium uidelicet et matrem, terminata est praecipue, et supra alios omnes uoluit hominem deificatum et matrem in qua humanitas copularetur diuinitati, in initio itaque uiarum suarum Deus, antequam quicquam faceret, immo facere disponeret, quodammodo loquendi, quia omnia haec sunt aeterna tamen quemdam ordinem in se tenent, uoluit humanitatem plenam gratia, plenam beatitudine assumere ita ut sic assumptam simul et beatam faceret et Genitrici suae maximam post ipsum gratiam praestaret ${ }^{135}$.

O Maria, quam felix es, quam fortunata, quae ab initio et ante saecula et in initio uiarum Dei ab ipso electa fuisti et, Adae peccato praeuiso, non fuisti cum aliis omnibus condemnata, sed uoluit ut merita Filii tui tibi super omnes prodessent. Teque pro minimo momento noluit inimicam, sed semper amicam carissimam. Alios omnes beatos cum condicione facere uoluit si uidelicet mandata seruarent. Verum est tamen quod et alios plures, antequam quicquam boni uel mali egissent, elegit et uocauit et sanctificauit. Sed cur non omnes ita sanctificauerit? Hic est et altitudo et profunditas et abyssus scientiae et sapientiae Dei. Aliquos enim ita praedestinauit et omnino sanctificauit ut nullo modo damnare uellet. Et aliquos reliquit in manu consilii sui usque ad extremum uitae diem et quales eos ibi uidit tales ab aeterno et in aeternum iudicauit. Nullus tamen est ex filiis Adae quem aliquando non habuerit pro inimico praeter te, o Maria. Nullum punit nisi peccatis praecedentibus, multos praemio dignos ipse facit, nulli debitor 
de Adão haveria em relação a ela a mesma admiração. Era necessário que fosse uma, a função era de uma só mulher, e convinha que essa fosse perfeitíssima não só na alma como no corpo, e sumamente dotada de todas as qualidades naturais e acessórias. Era também conveniente que, do mesmo modo que aquele homem assumido por Deus foi, é e será cheio de graça e de verdade, e estivesse acima de todas as criaturas, assim também sua Mãe a todos depois dele superasse [f1. 197] em graça e bem-aventurança. O dom da bem-aventurança é consequência do dom da maternidade. E se quis de modo absoluto para si e para seu Filho único, nosso Senhor, a bem-aventurança, depois os méritos, ou seja, os meios, não quis, contudo, para ambos uma tão grande bem-aventurança senão em razão da assunção da humanidade a partir desta Virgem. Quis desde a eternidade e no início do seu percurso, porque a geração do Filho pelo Pai é a eterna via pela qual, sendo Deus, saiu de Deus Pai; eterna é a partir de ambos a processão do Espírito Santo que, contudo, o Filho recebeu do Pai e também essa processão é a eterna via para o fim eterno; eterno é o conhecimento de todas as criaturas, que é também uma espécie de caminho; de facto, existindo o conhecimento simultaneamente nas três Pessoas, ou seja, no Pai, no Filho e no Espírito Santo, tem como seu termo todas as criaturas; existindo, ademais, nos mesmos três uma única volição no início, tem seu termo particularmente nos dois, ou seja, no Filho e na Mãe; sobretudo e acima de todos os outros quis o Homem deificado e a Mãe, na qual a humanidade se ligaria à divindade; portanto, no início de seu percurso, Deus, antes de fazer, e até, antes de se dispor a fazer fosse o que fosse, segundo um determinado modo de falar, porque todas estas coisas são eternas e encerram em si determinada ordem, quis assumir a humanidade cheia de graça, cheia de bem-aventurança de modo a torná-la, assim assumida, simultaneamente bem-aventurada e dar a sua Mãe a graça máxima depois dele.

Ó Maria! quão feliz, quão afortunada és, tu que desde o princípio, e antes do tempo, e no início dos caminhos de Deus, foste por ele escolhida e, na previsão do pecado de Adão, não foste condenada com todos os outros, mas quis que os méritos de teu Filho te aproveitassem a ti mais que a todos. Não te quis, nem por um instante, como inimiga, mas sempre como amiga muito querida. Quis que todos os outros se tornassem bem-aventurados sob condição, isto é, se guardassem os mandamentos. É verdade que escolheu e chamou e santificou também muitos outros antes de praticarem qualquer bem ou qualquer mal. Mas porque é que não santificou deste modo a todos? Aqui reside não só a sublimidade, mas também a profundidade e o abismo do conhecimento e do saber de Deus. De tal modo predestinou e a tal ponto santificou alguns que de

$\leftarrow$ et tamen Filius a Patre procedit et quam tamen Filius a Patre accepit $Q \quad \mathbf{1 3 4}$ quae quoque] quaecumque $I J M N V 135$ prestaret] speraret $N$; appraestaret $V$ 
est. Punire etiam nullo crimine praecedente posset, sed numquam sine crimine proprio creaturae eam punit. Neque propter peccatum Adae solum quemquam ullo supllicio aut poena in alia uita afficit aut dolore seu quauis tristitia plectit, sed solum beatitudine supernaturali priuat. Sic tamen quod et si tales habeant damnum, numquam tamen tristantur de tali damno, sed sunt sua sorte contenti, ignorantes talem priuationem eis accidisse.

Magnus es, Deus noster, et iudicia tua abyssus multa. Te adiuuante, te patrocinium afferente, o Maria, plurimi saluabuntur. Obstinati in malo et in peccatis damnabuntur quorum ideo poena aeterna, quia et uita sempiterna. De hoc abysso plurima dicere possem, quia uere abyssus abyssum et difficultas inuocat difficultatem. Sed satis est dixisse de praecipua et praeuia aliis omnibus creaturis electione Mariae, Dominae nostrae, et de bonitate Dei [f1. 198] quod tantum tamque magnum bonum contulit creaturae, sua uoluntate, sua bonitate, nil inde sperans accipere quia bonorum nostrorum non eget. Est enim sibi in seipso bonum sufficientissimum ${ }^{136}$. Satis est etiam ostendisse quod nulli iniuriam facit, quia et nulli debitor est. Et nullum affligit aeternaliter propter peccatum alterius et unumquemque beatificare quantum in ipso est non postponit. Et quod soli obstinati in peccatis damnentur, sperandum est igitur in Deo et omnia nostra sibi committenda, quod tu, o Dei Genitrix Maria, nos facere docuisti. Nos igitur adiuuabis tuoque Filio commendabis ut et nos post te in odorem unguentorum ipsius currere possimus.

Postmodum uocatur Philippus ut ipse quoque et ea quae sibi uidentur aperiret. Sic igitur exorsus est: Equos quibus Sol iste corporeus et inter corpora pretiosissimus uehitur multos esse Graeci, fingentes nomina, tradunt. Et ueritas ex multis eorum uanitatibus colligenda est. Non enim sequimur indoctas fabulas, sed ueritatem quantum possumus complectimur. Sol est Christus Dominus noster. Ecce hic stellam ex qua Sol prodiit uidetis Mariam. Et tamen et ipsa Sol est non cessans moueri, sed semper proficiscens et numquam deficiens neque sibi neque aliis, amorem in altari cordis sui tamquam ignem indeficientem iugiter portans. Sol est non solum ipsa Regina nostra quae nobis Solem ${ }^{137}$ protulit, sed omnis anima supernam quaerens beatitudinem et Deum suum ex toto corde diligens et proximum sicut se ipsum.

Sol habet equos quibus uehitur qui nihil aliud sunt quam uirtutes infusae et acquisitae. Supernaturales primum, deinde et naturales, intellectuales et ille quae 
modo nenhum os haveria de querer condenar. E deixou outros entregues ao seu arbítrio até ao derradeiro dia de vida e desde sempre e para sempre os julgou conforme os viu então. Não há, todavia, entre os filhos de Adão nenhum, além de ti, ó Maria, a quem um dia não haja tido por inimigo. A nenhum pune sem antes haver pecado, a muitos torna-os ele dignos de prémio, não é devedor de ninguém. Também poderia punir sem qualquer crime prévio, mas sem crime próprio da criatura nunca a pune. Nem exclusivamente por causa do pecado de Adão condena qualquer um ao suplício ou à pena na outra vida, ou o castiga com dor ou qualquer tristeza que seja, mas apenas o priva da bem-aventurança sobrenatural. Como quer que seja, ainda que esses sofram tal dano, nunca, contudo, se entristecem em razão desse dano, mas contentam-se com sua sorte, desconhecendo que essa privação lhes sobreveio.

És grande, Deus nosso, e os teus juízos, abismos sem fim. Com o teu auxílio, sob o teu patrocínio, ó Maria, muitos se salvarão. Condenar-se-ão os obstinados no mal e no pecado, cuja pena, por isso, será eterna porque também a vida é sempiterna. Sobre este abismo poderia dizer muitíssimo mais, porque realmente "abismo atrai abismo" e dificuldade, dificuldade. Mas basta que tivesse falado da eleição de Maria, Senhora nossa, notável e anterior à de todas as criaturas, e da bondade de Deus, [f1. 198] porque na sua vontade e na sua bondade confiou à criatura tão importante e tão grande bem, nada esperando receber dela, porque não precisava dos nossos bens. Tem realmente em si o bem suficientíssimo. Basta que tivesse mostrado que não comete injúria contra ninguém, porque não é devedor de ninguém, e a ninguém atormenta eternamente por causa do pecado alheio, e, quanto dele depende, não desdenha tornar alguém bem-aventurado, e que apenas os obstinados no pecado se condenam. Deve, pois, esperar-se em Deus e confiar-lhe quanto é nosso, o que tu, Maria, Mãe de Deus, nos ensinaste a fazer. Auxiliar-nos-ás, pois, e confiar-nos-ás a teu Filho para que também nós possamos, depois de ti, correr para o odor dos seus perfumes.

Logo depois foi chamado Filipe, para que também ele desse a conhecer a sua visão das coisas. Assim começou, pois: Dizem os gregos, inventando os nomes, que são muitos os cavalos pelos quais este Sol corpóreo e o mais precioso entre todos os corpos é transportado. E das suas múltiplas mentiras deve ser colhida a verdade. Não corremos, de facto, atrás de histórias grosseiras, mas, até onde podemos, amamos a verdade. O Sol é Cristo, Senhor nosso. Eis que vedes aqui Maria, a estrela da qual brotou o Sol. E, contudo, também ela é Sol que não cessa de se movimentar, mas está sempre em acção e nunca se põe nem para si nem para os outros, transportando incessantemente no altar de seu coração, como fogo que se não extingue, o amor. Sol é, não apenas a nossa própria Rainha, que nos ofertou o Sol, mas toda a alma que busca a bem-aventurança eterna e ama a seu Deus de todo o coração e o próximo como a si mesmo.

O Sol tem os cavalos com que é transportado, que não são senão as virtudes infusas e adquiridas. Primeiro, as sobrenaturais, depois, também as naturais, as 
in appetitu consistunt. Primus, ualidissimus et fortissimus equus est caritas quo mouemur in dilectionem Dei et proximi ac nostri in ipso Deo. Respicit solum Deum in se et cuncta alia in ipsum refert. Non cupit aliquid sibi, sed omnia cupit Deo. Non praestolatur retributionem, non munera, sed summo bono summe afficitur ${ }^{138}$. Alius equus est spes ipsa qua cupimus Deum nobis, uolumus eum tamquam bonum nostrum. Tertius equus est fortior secundo, debilior primo, fides qua credimus, quae est substantia et fundamentum huius Ecclesiae cui praeest Petrus, Christi Domini locum tenens, cui succedent perpetuo pastores et uicarii Christi, non in hac ciuitate, sed alia quam suo martyrio consecrabit. Vbi nunc homines regnant, ibi Agnus regnabit. Deficere uidebitur, sed uires perpetuas assumet et conseruabit.

Multi alii sunt equi in mente hominum. Inter alios est prudentia, quae est uirtutum moralium regula, ut iustitiae, fortitudinis et temperantiae, sub quibus reliquae uirtutes collocantur. Et unaquaeque homini equus quidam est currendi, ad brauium caeleste suscipiendum praebens uires. Horum equorum amator uir bonus est, Deo carus est. Qui ipsis uehitur cadere non poterit. Quadratae figurae manens perpetuo stabilis firmusque manebit. Mundi huius rectores equos habent in quibus confidunt, animalia bruta, irrationabilia. Nos his utamur equis, his uehamur, his conducamur et perire nullatenus poterimus.

Videte, fratres mei apostoli, inspicite, discipuli Domini, considerate, ${ }^{139}$ [ff. 199] o sanctae mulieres carissimae, Reginam nostram quam potentissimam, quam fortissimam. Omnes ei insunt uirtutes perfectae et loco imperfectarum successerunt uirtutes perfectissimae. Non amplius sperat sed tenet, non desiderat sed amat, non exspectat sed habet, non credit sed uidet. Videndo, tenet et fruitur, fruendo, gaudet et laetatur in Deo salutari suo in quo et nos gaudebimus. Modicum tamen oportebit prius contristari, sed haec tristitia in summum gaudium uertetur quando post tenebras deducemur ad lucem inaccessibilem humanis uiribus, receptibilem tamen, Deo uolente, a nostris mentibus. Quod facile meritis et precibus Reginae nostrae assequemur, cuius gratia et nomen diffunditur in omnes gentes.

Post hunc uocatur Iacob Minor et huiusmodi uerba proponit ${ }^{140}$ : Subplantari ab inimicis nostris, fauore praediti Mariae Dei nostri et magistri Genitricis, non poterimus. Ipsa enim contriuit caput uenenosi serpentis, ipsa uicit mundum. 
intelectuais e aquelas que se firmam no apetite. O primeiro, o mais vigoroso e mais forte cavalo é a caridade, pelo qual somos impelidos para o amor de Deus e do próximo e de nós mesmos no próprio Deus, vendo o próprio Deus em si, e tudo o mais a ele referindo. Não deseja para si coisa alguma, mas tudo deseja para Deus. Não espera retribuição nem benefícios, mas é sumamente compensado pelo Sumo Bem. O segundo cavalo é a própria esperança, pela qual desejamos a Deus para nós e o queremos como nosso bem. O terceiro cavalo, mais forte que o segundo, mais fraco que o primeiro, é a fé, pela qual acreditamos, que é a substância e o fundamento desta Igreja a que preside Pedro, que mantém o lugar de Cristo Senhor, a quem continuamente hão-de suceder, não nesta cidade, mas noutra que consagrará com o seu martírio, Pastores e vigários de Cristo. Onde hoje reinam os homens, aí reinará o Cordeiro. Parecerá sucumbir, mas retornará e manterá forças perpétuas.

Muitos outros são os cavalos na mente dos homens. Entre eles está a prudência, que é a regra das virtudes morais, como a justiça, a fortaleza, a temperança, abaixo das quais estão as outras virtudes colocadas. Constitui-se cada uma para o homem como uma espécie de cavalo de corrida, fornecendo forças para alcançar o prémio eterno. Aquele que ama estes cavalos é um homem de bem, é querido de Deus. Aquele que por eles é conduzido não poderá cair, agarrando-se continuamente com firmeza a essa imagem quadrada das quatro virtudes, e manter-se-á inabalável. Os senhores deste mundo têm cavalos em que confiam, animais brutos, irracionais. Sirvamo-nos nós daqueles cavalos, sejamos por eles levados, por eles conduzidos, e de modo nenhum poderemos perecer.

Vede, apóstolos, meus irmãos, considerai, [f1. 199] discípulos do Senhor, prestai atenção, santas mulheres caríssimas, como é poderosa, como é forte a nossa Rainha. Nela residem todas as virtudes perfeitas, e as mais perfeitas virtudes tomam o lugar das imperfeitas. Não espera, mas tem; não deseja, mas ama; não aguarda, mas possui; não crê, mas vê. Vendo, tem e desfruta; desfrutando, regozija-se e alegra-se em Deus seu Salvador, no qual também nós nos regozijaremos. Será, todavia, necessário que antes nos contristemos um pouco, mas esta tristeza volver-se-á em sumo gozo quando, depois das trevas, houvermos de ser conduzidos à luz inacessível às forças humanas, susceptível, contudo, de ser recebida, querendo Deus, pelas nossas mentes. O que facilmente alcançaremos pelos méritos e preces da nossa Rainha, cuja graça e cujo nome irradiam por todos os povos.

Depois deste, é chamado Tiago Menor e profere as seguintes palavras: Protegidos pelo apoio de Maria, Mãe do nosso Deus e Mestre, não poderemos ser suplantados pelos nossos inimigos. Ela, de facto, esmagou a cabeça da serpente

\footnotetext{
$\leftarrow$ proponit] eiusdem uerba proponit $M$; huiusmodi uerba protulit $O Q$; eiusmodi proponit $V$
} 
Victoria eius talis fuit quod cunctas haereses interemit. Haec est mons ille de quo abscisus est lapis sine manibus qui impleuit sua magnitudine totam terram, qui cito praedicabitur in toto orbe. Sed bestia insurget, cuius uox implebit terram et durabit quousque adimpleatur uoluntas Altissimi. Et iterum emerget quasi submersa $^{141}$ fides et regnabit Agnus in toto orbe terrarum. Quod fiet precibus et assiduis intercessionibus huius gloriosae Virginis quam prono uertice omnes ueneramur. Supplantauit et uicit diabolum, uicit Luciferum, principem huius mundi eiecit foras. Iterum et continue eicietur et illo tempore perfecte eicietur ${ }^{142}$, qui parentes nostros ex paradiso uoluptatis eiciet. Qui tunc eos supplantauit, a filiis ipsorum supplantabitur, sed praecipue ab hac filia sancta et immaculata, perfecta et in omni bonitate, sanctitate, ueritate et sinceritate plena, in qua sunt

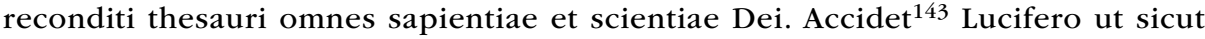
per arborem Euam supplantauit et per Euam Adam ita et ipse per arborem seu lignum crucis Christi, quod exterius erat, et per lignum crucis Mariae, quod interius gerebat, fuit supplantatus. Et qui matrem superauit et supplantauit et uicit a filia eius superaretur et supplantaretur et uinceretur ${ }^{144}$. Multae certe et aliae filiae congregauerunt sibi diuitias, sed Maria supergressa est uniuersas. Haec est illa mulier fortis de qua scriptum est: Mulierem fortem quis inueniet? Procul et de ultimis finibus pretium eius.

O fortissima mulierum, o sanctissima omnium creaturarum, o constantissima omnium hominum, fac nos quoque ueros inimicorum nostrorum supplantatores, ueros rectores, ueros superatores ut uincamus diabolum, superemus mundum et uincamus proprios contra rationem insurgentes appetitus ${ }^{145}$. Ecce in continuo proelio sumus, hostes nos numquam deserunt, inimici nostri intra nos sunt. Si proelium non esset neque uictoria esset. Bonum est proelium quando illud consequitur uictoria. Bonum est malum quod uertitur in bonum. Bonus est dolor cui succedit gaudium. Bona infirmitas quam perpetua consequitur sanitas. Diligentibus autem Deum [fl. 200] omnia in bonum conuertuntur. Ex omnibus tam bonis quam malis bonum oritur bonis ${ }^{146}$. Et sicut mundis omnia sunt munda, ita et bonis omnia bona. Exteriora quidem bona in bonum corporis, bona corporis in bona animae diriguntur et illa in summam beatitudinem et ipsum Deum. Certamen ${ }^{147}$ itaque et proelium et assidua militia data est homini in uita ista ut ex ea boni ueluti

141 submersa] subuersa $V \mathbf{1 4 2}$ et illo tempore perfecte eicietur] et praecipue illo tempore $Q$ 143 Accidet] Accidit $I Q V 144$ superaretur et supplantaretur et uinceretur] fuit supplantatus et uictus $Q \quad 145$ insurgentes appetitus] insurgentes inimicos appetitus $Q \mathbf{1 4 6}$ Ex omnibus tam bonis quam malis bonum oritur bonis.] Et omnibus tam bonis quam malis, bonum erit bonis. $M$; Ex omnibus tam bonis quam malis, bonum erit bonis. IJP 147 ipsum Deum. Certamen] ipsum Deum creatorem $V$ 
venenosa, ela venceu o mundo. A vitória dela foi tal que destruiu todas as heresias. Esta é aquele monte de que se desprendeu, sem acção de mãos, a pedra que encheu com sua grandeza toda a Terra, que rapidamente será pregado em toda o orbe. Mas levantar-se-á a Besta cuja voz encherá a Terra e manter-se-á até que se cumpra a vontade do Altíssimo. E a fé, quase submersa, emergirá de novo, e o Cordeiro reinará em todo o globo terrestre. O que acontecerá pelas preces e permanentes intercessões desta gloriosa Virgem a quem todos, de cabeça inclinada, veneramos. Suplantou e venceu o diabo, venceu Lúcifer, expulsou o príncipe deste mundo. Será de novo e sempre expulso e, naquele tempo, será definitivamente expulso, ele que expulsou os nossos Pais do Paraíso Terreal. Ele que então os suplantou, será suplantado pelos filhos deles, mas sobretudo por esta filha santa e imaculada, perfeita e cheia de toda a bondade, santidade, verdade e sinceridade, em quem estão ocultos todos os tesouros da sabedoria e do conhecimento de Deus. Acontecerá a Lúcifer que, assim como pela árvore suplantou Eva e, por Eva, suplantou Adão, assim também, pela árvore ou lenho da Cruz de Cristo, que era exterior, e pelo lenho da cruz de Maria, que trazia dentro de si, foi ele suplantado. E o que superou e suplantou e venceu a mãe, será superado e suplantado e vencido pela Filha dela. Certamente muitas outras filhas acumularam para si riquezas, mas Maria ultrapassou-as a todas. ${ }^{[238]}$ Esta é aquela mulher forte de quem está escrito: Uma mulher forte, quem a achará? o seu valor é maior que tudo o que pode vir de longe e dos últimos confins da Terra. ${ }^{[239]}$

Ó mais forte de todas as mulheres, ó mais santa de todas as criaturas, ó mais constante de todos os homens, torna-nos também verdadeiros suplantadores dos nossos inimigos, verdadeiros guias, verdadeiros vencedores, para vencermos o diabo, superarmos o mundo e vencermos os apetites próprios que se insurgem contra a razão! Eis que estamos em luta permanente, os adversários não nos largam nunca, os nossos inimigos estão dentro de nós. Se não houvesse luta, também não haveria vitória. É bom o combate quando o segue a vitória. É bom o mal que se volve em bem. Boa é a dor a que se segue a alegria. É boa a doença a que se segue uma saúde permanente. Tudo se volve em bem [f1. 200] para aqueles que amam a Deus. ${ }^{[240]}$ De tudo, quer do bem quer do mal, surge o bem para os bons. E do mesmo modo que tudo é puro para os puros, ${ }^{[241]}$ assim também para os bons tudo é bem. Na verdade, os bens exteriores encaminham-se para o bem do corpo, os bens do corpo, para o bem da alma, e estes para a bem-aventurança 
aurum in fornace probentur, ut stipulae, fenum et palea et lignum comburantur, et diligentes Deum tamquam Sol fulgeant et tamquam lapides pretiosi rutilent ${ }^{148}$.

Tu ergo, o mater Dei et Domina nostra, succurre, opem fer, praesidio esto, esto nobis turris fortitudinis a facie inimici ut ipsum supplantare et procul a nobis pellere et Deo nostro cumulatioribus ${ }^{149}$ meritis adhaerere possimus.

Vocatur post ipsum ${ }^{150}$ Matthaeus apostolus et euangelista, cuius sermo talis fuit: Dono Christi Domini, o Regina angelorum ${ }^{151}$ et hominum, cum festinatione uocatus fui cum publicanus essem et negotiis atque curis huius uitae implicitus. Donatoremque ${ }^{152}$ consilii euangelici secutus sum, qui me deinde in apostolum elegit et euangelistam. Genti meae mea lingua cripsi, praedicaui. Sed ipsi, dura ceruice ut soliti sunt, renuerunt me et Euangelium sacrum, ut tu, Domina, nosti et hi fratres mei maiores non ignorant. Transiuimus et iterum transibimus ad gentes annuntiari immensa dona a Donatore omnium tibi, o Maria, collata.

Euam legimus et audiuimus de costa Adae plasmatam, nobilissimam et delicatissimam complexionisque optime fuisse et ipsi uiro, de quo sumpta erat, simillime. Sed te nobiliorem et meliorem in cunctis membris, humoribus et corporis partibus in utero felicissime Annae incomparabiliter plasmauit et in omnibus corpori Filii tui, quod per donum Spiritus Sancti, te quoque coadiuuante ut matre, optimum et perfectissimum plasmatum est, simillimam reddidit. Ipse est speciosus forma prae filiis bominum. Tu similiter post ipsum et ualde parum distans ab ipso, pulcherrima mulierum es et supra omnes pulchra et decora. Congruum quippe erat ut mater gratiae, ueritatis et misericordiae Genitrixque Dei, dignioris complexionis esset quam mater carnalis omnium uiuentium. Iustum certe erat ut illa dignior esset etiam in corpore omnibus aliis, ex cuius purissimo sanguineo humore plasmandum erat dignissimum corpus Redemptoris omnium.

Annuntiabimus et animae tuae, o Maria, praeclarissimas uirtutes. Nulla tibi scientia, nulla cognitio deest. Tu nosti et aeterna et temporalia, mortalia et immortalia, corporea et incorporea, quae sunt extra nos et quae in nobis, quae Deus, quae natura, quae intellectus fabricauit. Nil te latet, nil fugit, nil abscondit Deus, qui seipsum tibi aperte ostendit. Et postquam Christo commortua fuisti, in carne adhuc mortali beatam uitam duxisti sicut et ducis. Beata es, beatitudinem mors ista breuis tibi subripere non poterit. Resuscitata cito, corpus gloriosum in sempiternum habebis. Omnes tibi insunt uirtutes, quamuis non credas neque [fl.

148 pretiosi rutilent] pretiosi fulgeant et rutilent $Q 149$ cumulatioribus] cumulatoribus $J M V 150$ Vocatur post ipsum] Vocatus est post eum $Q \quad 151$ angelorum] celorum $Q \quad 152$ Donatoremque] denuntiatoremque $Q$ 
suma e o próprio Deus. E, assim, tem o homem o combate e a luta e a milícia contínua nesta vida para que depois dela sejam os bons provados como o ouro na fornalha, ardam como o colmo, o feno e a palha e a madeira, e os que amam a Deus resplandeçam como o Sol e brilhem como pedras preciosas. ${ }^{[242]}$

Tu, pois, ó Mãe e Senhora nossa, socorre-nos, vem em nosso auxílio, sê nossa protecção, sê o bastião da resistência perante o inimigo $^{[243]}$ para podermos vencê-lo e afastá-lo para longe de nós e ligar-nos ao nosso Deus com maior abundância de méritos.

Depois deste, é chamado o apóstolo e evangelista Mateus, cujo sermão foi o seguinte: Sendo publicano e mergulhado nos assuntos e preocupações desta vida, ó Rainha dos anjos e dos homens, fui, por dom de Cristo Senhor, imprevistamente chamado. Segui o Dispensador dos Preceitos Evangélicos que, depois, me escolheu para apóstolo e evangelista. Na minha língua, escrevi, preguei à minha gente. Mas eles, de cerviz dura como costumam ser, rejeitaram-me a mim e ao sagrado Evangelho, como tu, Senhora, sabes e estes meus irmãos mais velhos não ignoram. Passámos e passaremos outra vez a anunciar aos povos, ó Maria, os incontáveis dons a ti conferidos pelo Dispensador de todas as coisas.

Lemos e ouvimos dizer que Eva foi formada da costela de Adão. Muito nobre e delicada, tinha um óptimo aspecto, semelhante ao do próprio homem de quem havia sido tirada. Mas a ti formou-te incomparavelmente mais nobre e mais perfeita em todos os membros, humores e partes do corpo, no útero da felicíssima Ana, e formou-te em tudo sumamente semelhante ao corpo de teu Filho que, por dom do Espírito Santo, colaborando tu como mãe, foi formado excelente e perfeitíssimo. Ele é o mais belo entre os filhos dos homens. ${ }^{[244]}$ De modo semelhante, depois dele, e dele distando muito pouco, tu és a mais bela das mulheres e mais que todas bela e formosa. Era, com efeito, justo que a Mãe da Graça, da Verdade e da Misericórdia e Mãe de Deus tivesse uma aparência mais digna do que a mãe carnal de todos os viventes. Era seguramente justo que fosse mais digna que todas as outras, até no corpo, de cujo puríssimo humor sanguíneo devia ser formado o digníssimo corpo do Redentor de todas as coisas.

Anunciaremos também, Maria, as preclaríssimas virtudes da tua alma. Não careces de nenhum saber, de nenhum conhecimento. Tu conheces o eterno e o temporal, o mortal e o imortal, o corpóreo e o incorpóreo, o que existe fora de nós e em nós, o que fez Deus, o que fez a natureza, o que fez a inteligência. Nada te escapa, nada te foge, nada te esconde o Deus que a si mesmo se te mostrou abertamente. E depois de haveres morrido com Cristo, ainda na carne mortal, levaste, como ainda levas, vida bem-aventurada. És bem-aventurada, e esta curta morte não poderá roubar-te a bem-aventurança. Logo ressuscitada, terás para

\footnotetext{
${ }^{[242]} \mathrm{Jz} 5: 31$

[243] Jz 5:31

[244] S1 44:3
} 
201] speres, quia uides et possides. Niuei candoris es, o Maria immaculata. Scirpus es nodo carens. Poenas corporales ob peccatum primi parentis in posteritatem deriuatas, pro parte et tu, tamquam carne corruptibili obtenta ${ }^{153}$, substulisti. Poenas animae, quae obsunt et non prosunt, non habuisti. Non ergo alicui ignorantiae subiecta fuisti. Ingenio et industria, uirtute et bonitate semper uiguisti. Semper integra fuisti. Magna sunt dona tua, ingentia munera tua, quae lingua humana exprimi non possunt, mente cogitari uel apprehendi uix possunt. Neque mirum, nam Spiritus Sanctus, qui est aeternum donum, te sanctificauit, praeseruauit, purgauit, illuminauit et singularibus priuilegiis decorauit.

Ista dona non statim omnibus propalabuntur, non statim omnibus manifestabuntur. Sed in uariis temporibus, prout Donator Magni Consilii ordinauit, nunc haec nunc illa reuelabuntur. Et tandem postquam uenerit discessio ${ }^{154}$, quae per multa saecula durabit et tandem consumabitur ${ }^{155}$, et disiuncti coniungentur, miserebitur Dominus populo suo et mittet nouum Agnum ${ }^{156}$ qui docebit secreta fidei omnes gentes et tua dona uniuersa narrabit, conscribet et annuntiabit. Multiplicabuntur solemnitates tuae, augebuntur festa tua et declarabitur ${ }^{157}$ martyrium tuum et compassio tua et dolores tui et mors tua occulta, quando mortua fuisti simul cum Christo. De quibus tunc mirabuntur saecula illa tamquam de ignotis et quae in opinione hominum non fuerunt usque ad tempora illa felicia.

Haec autem omnia Filius tuus Iesus Christus Dominus noster faciet intercessionibus tuis et meritis tuis quem, ut pro nobis quoque, maxime pro me peccatore et plublicano, o aduocata peccatorum, depreceris, cuncti hic astantes rogamus et ego pro me, suplex et flexis genibus, oro.

Matthaeo cum magna gratia omnium explente dicta superiora, uocatur Bartholomaeus apostolus. Sicque loqui coepit: Filius suspendentis aquas uocor ego. Coram illis loquor qui melius me quae loquor nouerunt. Ecce Dei Genitricem, Deum assidue iam uidentem postquam commortua fuit, ante oculos nostros aspicimus. In quo uiso uidet omnia etiam nos ipsos quos oculis praesentes cernit. Non solum agnoscit quae dicturus sum, sed mentem ipsam et cogitationem meam uidet, immo antequam cogitarem cogitaturum sic omnino sicut cogito me praeuidit. Nouit enim omnia, praeterita et futura. De praesentibus nihil dico, quia illud manifestius est.

Quae sunt aquae suspensae? Ille sunt quae super caelos sunt, quae super firmamentum sunt, non sub caelo. Quis eas suspendit nisi qui diuisit aquas 
sempre um corpo glorioso. Encerras em ti todas as virtudes, embora não creias, nem [fl. 201] esperes, porque vês e possuis. Tens a alvura da neve, ó Maria Imaculada. És tronco sem nó. Também tu, como alcançada da carne corruptível, sofreste em parte as penas corporais caídas sobre a posteridade por causa do pecado dos primeiros pais. Não sofreste as penas da alma, que causam dano e não aproveitam. Não foste, portanto, sujeita a nenhuma ignorância. Sempre gozaste de talento e zelo, força e bondade. Foste sempre intacta. São grandes os teus dons, incontáveis os favores, que não podem ser expressos pela língua humana, dificilmente podem ser pensados ou apreendidos pela mente. E não é de admirar, pois o Espírito Santo, que é eterno dom, santificou-te, preservou-te, purificou-te, iluminou-te e ornou-te com privilégios singulares.

Estes dons não serão divulgados imediatamente a todos, não serão de imediato dados a conhecer a todos. Mas, conforme ordenou o Dispensador do Grande Conselho, serão em diferentes tempos revelados ora uns ora outros. E, por fim, depois de haver chegado a divisão, que se manterá por muitos séculos e finalmente há-de terminar, e os desunidos se unirem, o Senhor apiedar-se-á do seu povo e enviará o novo Cordeiro que ensinará a todos os povos os segredos da fé e exporá, registará e proclamará a universalidade dos teus dons. Serão multiplicadas as tuas solenidades, as tuas festas serão solenizadas, celebrar-se-á o teu martírio e a tua partilhada Paixão e a tua secreta morte, quando foste morta juntamente com Cristo, de que aqueles tempos se admirarão como de algo desconhecido e que esteve afastado da crença humana até àqueles felizes tempos.

Tudo isto fará teu Filho, Jesus Cristo, nosso Senhor, por teus méritos e intercessões, a quem, ó advogada dos pecadores, rogamos todos os presentes e eu, suplicante e de joelhos em terra, peço que rogues por nós também e, sobretudo, por mim, pecador e publicano.

Acabando Mateus, com muito agrado de todos, a exposição anterior, é chamado o apóstolo Bartolomeu. Começou a falar deste modo: Chamam-me filho do que suspende as águas. Falo perante aqueles que melhor do que eu conhecem as coisas de que falo. Aqui temos perante os nossos olhos a Mãe de Deus, que frequentemente vê a Deus, depois de com ele haver morrido. Nessa visão vê todas as coisas e também a nós que, estando presentes, vê com seus olhos. Não só tem conhecimento do que estou para dizer, mas vê a minha própria mente e o meu pensamento, e até, antes de eu pensar o que estou para pensar, assim me vê absolutamente como penso. Conhece, pois, todas as coisas passadas e futuras. Das presentes nada digo porque isso é mais evidente.

Quais são as águas suspensas? São as que estão sobre o céu, as que estão sobre o firmamento, não debaixo do céu. Quem as suspendeu senão aquele que 
ab aquis? Quis est ille? Deus est, Pater, Filius et Spiritus Sanctus. Qui etiam Spiritus Sanctus ferebatur super aquas ex quibus factae sunt hae et ille aquae Ipse quidem specialiter ferebatur, quia diuina uoluntas, una in tribus, [f1. 202] ferebatur. Volebat enim ex aquis ${ }^{158}$ illis producere omnia corpora praeter primum corpus quod caelum empyrium uocabitur. Illud enim solum simplex est, cetera composita ${ }^{159}$. Nam et ipsa elementa composita corpora sunt, quamuis simplicia respectu mixtorum dicantur.

Non sum tamen eo modo filius suspendentis et conseruantis aquas illas sicut apud nos dicuntur filii natura. Hae aquae per similitudinem quamdam dictae sunt aquae. Sunt enim lucidae et fluidae, non quia fluant, sed quia cum summa et indicibili mouentur uelocitate. Et secum trahunt inferiora corpora sicut aqua currens trahit secum reliqua corpora in ipsa posita. Non tamen caelum illud aqueum ui trahit alios caelos, sed angelus, mouens illud, mouet simul omnes caelos inferiores quos alii angeli singuli uidelicet singulos circulos caelorum in oppositum uel alio motu mouent. Habet caelum illud pleraque similia aquis, iccirco aqueum ${ }^{160}$ uocatum est.

Non ergo natura sed gratia adoptionis filius aquas ab aquis diuidentis uocatus sum. Sed omnes nos eo modo filios illius aquas suspendentis ${ }^{161}$ esse censeo. Sed mihi uni nomen illud, quo me indignum puto, inter hic existentes ${ }^{162}$ impositum $^{2}$ est. Aquae denique multae, populi multi quos suspensos tenet Deus ne cadant. Si namque ipse non conseruaret creaturas suas, deciderent subito et in nihilum omnino reuerterentur non solum in puluerem aut cinerem, sed nullo modo esse haberent. Nil omnino essent sicut erant antequam quicquam factum ${ }^{163}$ fuisset. Populi sunt aquae ob sui uolubilitatem et frigiditatem ${ }^{164}$. Immo creatura omnis ex se frigida est, quod est in animalibus signum mortis et interitus, ex se non habet esse neque umquam illud haberet nisi datum sibi esset. Et postquam illud habuit, stare non posset, ruinam semper minatur et casum, nisi Deus conseruaret et suspensam teneret. Quod etiam ipsis angelis et uirtutibus caelestibus quotidie et assidue accideret. Quando Deus non suspendit, non conseruat, res decidit uel tota uel secundum partem, prout non conseruat Deus. Radius Solis est omnis creatura $^{165}$.

Aquae quoque dicuntur tribulationes et anxietates, iuxta illud: Torrentem pertransiuit anima nostra. Forsitan pertransisset anima nostra aquam intolerabilem. Has Deus suspendit quia tolerabiles reddit, quia diminuit, quia omnino tollit.

158 ex aquis] ex aliquis $J 159$ composita] composita corpora $Q \quad 160$ aqueum] aqua NOPV 161 filios illius aquas suspendentis] filios aquas ab aquis suspendentis $N \mathbf{1 6 2}$ hic existentes] hos assistentes $O$; hic assistentes $Q 163$ quicquam factum] creaturae $Q 164$ frigiditatem] fragilitatem $V 165$ Radius Solis est omnis creatura] Radius solis et omnis creatura I; Radios Solis et omnis creatura $M$; Radius Solis et omni creaturae $N P V$ 
dividiu as águas das águas? Quem é esse? É Deus, Pai, Filho e Espírito Santo. Espírito Santo que pairava sobre as águas ${ }^{[245]}$ de que resultaram essas águas e as outras. Mas pairava especialmente ele porque pairava a vontade divina, una nos três. [fl. 202] Pretendia, de facto, produzir daquelas águas todos os corpos, com excepção do primeiro corpo que se chamará Céu Empíreo. Na verdade, apenas este é simples, todos os outros são compostos. Pois também os próprios elementos compostos são corpos, embora se considerem mais simples relativamente aos mistos.

Não sou, todavia, filho do que suspende e conserva essas águas do mesmo modo que entre nós se designam os filhos segundo a natureza. Estas águas designam-se águas por uma espécie de semelhança. São realmente transparentes e fluidas, não porque corram, mas porque se movem com grande e indizível velocidade e arrastam consigo os corpos inferiores do mesmo modo que a água corrente consigo arrasta os restantes corpos nela imersos. Todavia esse Céu Aquoso não arrasta os outros Céus pela força, mas um anjo, ao movê-lo, move simultaneamente todos os céus inferiores, ou seja, cada círculo celeste que outros anjos individualmente movem em sentido oposto ou com outro movimento. Tem esse céu várias coisas semelhantes à água, por isso se designa aquoso.

Não é pela natureza, portanto, que sou chamado filho do que divide as águas, mas pela graça da adopção. Mas penso que todos nós somos desse modo filhos do que divide as águas. Mas a mim somente, de entre todos os presentes, foi imposto esse nome, de que me considero indigno. As muitas águas, em suma, são os muitos povos que Deus tem suspensos para não caírem. Porque, se ele não mantivesse as suas criaturas, imediatamente cairiam e tornariam absolutamente ao nada, não só ao pó e às cinzas, mas de maneira nenhuma teriam ser. Seriam absolutamente nada como eram antes de haverem sido alguma coisa. Os povos são as águas em razão da sua volubilidade e frigidez. E mais, toda a criatura, de si, é frígida, o que nos animais é sinal de morte e destruição; de si, não tem ser, nem alguma vez o teria se lhe não fosse dado. E, depois de o ter, não poderia manter-se, ameaça incessantemente ruína e queda se Deus a não conservasse e a não mantivesse suspensa. O que aconteceria também cada dia e incessantemente aos próprios anjos e às potências celestes. Quando Deus não suspende, não conserva, a realidade sucumbe, ou toda, ou em parte, conforme a não conserva Deus. Toda a criatura é um raio do Sol.

Também as tribulações e as angústias são consideradas águas, segundo aquele passo: A nossa alma atravessou a torrente. Talvez que a nossa alma tivesse atravessado uma torrente impetuosa. ${ }^{[246]}$ Deus suspendeu-as porque as tornou supor- 
Nam et inimicorum suorum poenas et damnatorum tormenta, quamuis aeterna, sua misericordia suspendit et leuius quam merentur punit e quibus aliquos iam eruit et nonnullos eripiet, excipiendo eos a generali sententia. Et omnes quidem eripere posset, sed lex extat sua. Tamen decretum suum non alicuius ipso superioris positum ut post iudicium illi in supplicium aeternum, iusti uero eant in uitam aeternam. Quam Dominum nostrum, tuum uero, Maria, primogenitum et unicum Filium, nobis quoque qui relinquimus omnia et saecuti sumus ipsum, nobis daturum speramus.

Placuit et hic sermo sicut et reliqui omnibus astantibus.

Vocatur Thaddaeus qui facta pro more reuerentia Petro [f1. 203] tamquam uicario et Mariae quae ratione corporis nondum glorificati in uia erat et ea ratione ouis Petri dici poterat et ita loquitur: Principium ${ }^{166}$ omnium creaturarum, Christum Dominum, omnia enim per ipsum facta sunt et nulla res facta est sine ipso apprehendi, tenui eum nec dimittam, confessus sum, laudaui et glorificaui, corde quasi apprehendi quia uoluntate, quae cordis nomine accipitur, et amore prosecutus ${ }^{167}$ sum. Sicuti enim a corde tamquam a principio et fonte uitae progreditur uita ad reliquos corporis artus, ad alia membra et ad alias partes, sic a uoluntate bonum et malum omnium aliarum potentiarum quae laude aut uituperio dignae sunt profluit. Prima laus, primum uituperium uoluntas est aliarum potentiarum solum in quantum iussa bona uel mala uoluntatis exequuntur ${ }^{168}$. Ipsius est fugere et prosequi, ipsius nolle et uelle. Et nil fugit nisi quia aliquid diligit. Diligit autem ob aliud, diligit etiam non propter aliud, sed quia res talis ex sui natura est uel ex eius beneplacito propter se diligitur. Dilectio est primum bonum opus. Ipsa similiter est primum prauum ${ }^{169}$ opus. Respuere et nolle sicut non est primum opus, ita neque primum bonum aut primum malum opus. Dilectio quoque ob aliud praesupponit dilectionem propter se. Primum ergo bonum opus est dilectio propter se et primum malum dilectio propter se. Si Deum ${ }^{170}$ diligamus propter ipsum, optima, perfectissima ex sui natura dilectio bona est. Si aliud ab eo propter se, in ipsum non referendo, diligatur, dilectio praua ${ }^{171}$ et mala est. Si denique Deus propter creaturam diligatur ita quod creatura sit finis et Deus ad finem in creatura sistendo, pessima operatio est. Pessima utique dilectio Deum ob aliud diligere, in illo alio sistendo ${ }^{172}$. Dico autem sapientibus et perfectius me omnia cognoscentibus loquor, sistendo ${ }^{172}$ in illo alio. Nam siquis diligeret

166 Principium] Principem NP 167 prossecutus] perfectus $V 168$ Prima laus, primum (...) uel mala uoluntatis (uoluntas $I$; uoluntate $M N$ ) exequuntur.] ...uoluntate sequuntur $B H$; Prima laus, primum uituperium uoluntatis est. Aliarum potentiarum solum in quantum iussa bona uel mala uoluntatis exequuntur. $O$; Prima laus, primum uituperium aliquarum potentiarum uoluntas est, solum in quantum iussa bona uel mala uoluntate exequuntur. $Q 169$ prauum] paruum IJMV 170 propter se. Primum (...) propter se. Si Deum] propter se. Si Deum $I V 171$ praua] proterua $Q 172$ sistendo] insistendo $V$ 
táveis, porque as diminuiu, porque totalmente as juntou. Pois a sua misericórdia suspende não só as penas dos seus inimigos, mas também os tormentos, ainda que eternos, dos condenados, dos quais libertou já alguns e libertará alguns outros, eximindo-os à sentença universal, e pune-os de um modo mais ligeiro do que merecem. E poderia, sem dúvida, libertá-los a todos, mas a sua lei subsiste. Foi, contudo, estabelecido o decreto, que é seu, não de nenhum outro superior a si, que vão para o suplício eterno depois do julgamento aqueles, e os justos para a vida eterna. Esta, esperamos que nosso Senhor, mas teu Filho Primogénito e Único, ó Maria, no-la dê também a nós que deixámos tudo e o seguimos.

A todos os presentes agradou este bem como os restantes sermões.

É chamado Tadeu que, de acordo com o costume, fez uma reverência a Pedro, [f1. 203] como vigário, e a Maria que, em razão do corpo ainda não glorificado, peregrinava e, por esse motivo, se poderia considerar ovelha de Pedro, e assim falou: A Cristo Senhor, princípio de todas as criaturas, tudo, de facto, foi feito por ele e sem ele nenhuma coisa foi feita, agarrei-o, retive-o e não o abandonarei, ${ }^{[247]}$ exaltei-o, louvei-o e glorifiquei-o, como que o retive no coração, porque o segui com a vontade, que recebe o nome de coração, e com o amor. Pois, assim como do coração, como do princípio e fonte da vida, promana a vida para os restantes órgãos do corpo, para os outros membros e as outras partes, assim dimana da vontade o bem e o mal de todas as outras faculdades que são merecedoras de louvor ou de reprovação. A vontade é a primeira causa de louvor, a primeira causa de vitupério das outras faculdades, apenas na medida em que as suas boas ou as más determinações são seguidas. A ela cabe fugir ou evitar, a ela cabe querer e não querer. E nada evita senão porque ama alguma coisa. Ama, porém, por causa de outra coisa, ama também, não por causa de outra coisa, mas porque tal coisa é assim por sua natureza ou, por beneplácito seu, é amada por causa de si. O amor é a primeira boa acção. Ele é igualmente a primeira má acção. Recusar e não querer, assim como não é a primeira acção, também não é a primeira boa acção ou a primeira acção má. Também o amor por causa de outra coisa pressupõe o amor por causa de si. A primeira boa acção, pois, é o amor por causa de si, e a primeira acção má é o amor por causa de si. Se amamos a Deus por si mesmo, o amor, por sua natureza, é bom, óptimo, perfeitíssimo. Se se ama outra coisa distinta dele em razão de si mesma sem a referir a ele, o amor é perverso e mau. Se, por fim, Deus é amado por causa da criatura, de tal 
Deum propter retributionem et tamquam bonum sui ipsius, hoc est, diligentis neque tamen ibi figeret dilectionem, sed ulterius tenderet dilectionem in Deum ita ut, si nulla retributio esset nullumque praemium sequeretur, adhuc diligeret ipsum tamquam bonum immensum, dignum prima et dignissima dilectione, talis dilectio Dei tamquam boni proprii bona esset. Vnde praeter fidem sunt in nobis duae aliae uirtutes a Deo nobis datae: spes, qua diligimus Deum tamquam bonum nostrum, et caritas, qua diligimus eum in seipso et propter seipsum. Caritas donum est hominibus concessum et a Deo infusum quo nullum dignius. Per hoc enim praecipue Deus, Caritas increata, et Spiritus Sanctus, cui caritas praecipue attribuitur, habitat in cordibus nostris. Per hanc emplum Dei sumus, per hanc Deo grati et accepti reddimur, per hanc opera nostra grata et accepta sunt Deo. Quicquid enim suo instinctu fit, illud Deus praemio aeterno dignum iudicat. Nulla actio nostra digna est uita aeterna nisi uoluntaria fuerit et ab ipsa caritate infusa eliciatur et a Deo tamquam digna uita aeterna acceptetur. Ipse uero Deus ab aeterno decreuit omnem talem actionem pro tanto acceptaturum. Quantum ergo acceptat tantum ipsa operatio ualet et tantum operanti confert [f1. 204] praemium quantum operationem ipsius acceptauit, non plus aut minus. Verum quidem est quod Altissimus Deus maius nobis praemium confert quam ipsa operatio a uoluntate et gratia seu caritate emanans ex sui natura mereretur, sed non maius quam acceptauerit. Neque uoluntas neque caritas seu gratia compellunt Deum opera nostra ad uitam aeternam acceptare. Sed ipsa sua clementia talia opera eo modo facta seu elicita semper sic et pro tanto acceptare disposuit. Et sicut disposuit uoluntarie ita et acceptat uoluntarie.

Haec uirtus sola nullum crimen compatitur, haec dum quis sanctificatur, dum iustificatur, infunditur. Haec, quotiens quis contra legem Dei uoluntarie praeuaricatur, aufertur, quotiens in Deum redit sibi redditur ${ }^{173}$. Haec ut bona opera reuiuiscant ${ }^{174}$ facit. Hac uirtute supra alias Regina nostra et angelorum pollet. Haec a Deo est et Deus est. Ceterae quidem a Deo sunt, non Deus. Haec uero Deus est et a Deo angelis et hominibus conceditur. Nulla alia uirtus digna facit praemio aeterno opera sua. Actionesque suas haec sola et ex ipsa profluentem

173 in Deum redit sibi reditur] in Deum uenit, reuertitur et reditur $Q 174$ reuiuiscant] conuiuiscant $Q$, reuiuiscunt $V$ 
modo que a criatura seja o fim e Deus o caminho para o fim, parando na criatura, é uma obra péssima. Em qualquer caso é amor péssimo amar a Deus por causa de outra coisa, parando nessa outra coisa. Digo, porém, a sábios e falo a quem tudo conhece de um modo mais perfeito do que eu, parando nessa outra coisa. Pois, se alguém amasse a Deus por causa da retribuição e enquanto bem de si mesmo, isto é, daquele que ama, e nela não fixasse o amor, mas dirigisse o amor para além, para Deus, de tal modo que, se nenhuma retribuição existisse e nenhum prémio se seguisse ainda o amasse como a um bem imenso, digno do primeiro e mais digníssimo amor, esse amor de Deus como de um bem próprio seria bom. Daí que, além da fé, haja em nós duas outras virtudes a nós concedidas por Deus: a esperança, pela qual amamos a Deus como a um bem nosso; e a caridade, pela qual o amamos em si e por causa de si mesmo. A caridade é o dom, concedido ao homem e por Deus infundido, mais digno do que o qual não há outro. Por ele, sobretudo, Deus, Caridade incriada, e o Espírito Santo, a quem especialmente se atribui a caridade, habitam em nossos corações. Por ela somos o templo de Deus, por ela tornamo-nos agradáveis e aceites por Deus, por ela as nossas obras são agradáveis a Deus e por ele aceites. Na verdade, o que quer que aconteça por inspiração sua julga-o Deus merecedor de eterno prémio. Nenhuma acção nossa é digna da vida eterna se não for voluntária e não for motivada pela própria caridade infusa e aceite por Deus como digna da vida eterna. Ora o próprio Deus decretou desde sempre que aceitaria nessa medida toda a acção. Na medida, pois, em que a aceita, assim vale a própria obra, e ao agente confere [f1. 204] o prémio na medida em que aceitou a sua obra. Nem mais nem menos. É, sem dúvida, verdade que o Deus Altíssimo nos concede um prémio maior do que, por sua natureza, mereceria a própria acção procedente da vontade e da graça ou caridade, mas não maior do que ele poderia aceitar. Nem a vontade nem a caridade ou graça forçam Deus a aceitar as nossas obras para a vida eterna. Mas ele mesmo, em sua clemência, decidiu aceitar assim sempre e nessa medida essas obras feitas ou motivadas desse modo. E assim como o dispôs voluntariamente, assim também voluntariamente o aceita.

Esta é a única virtude que não é compatível com nenhuma falta. É infundida enquanto alguém se santifica, enquanto se justifica. É retirada todas as vezes que alguém voluntariamente se afasta da lei de Deus, é-lhe restituída todas as vezes que a Deus retorna. Ela faz que as boas obras renasçam. Nesta virtude, mais que nas outras, avulta a Rainha nossa e dos anjos. Ela vem de Deus e é Deus. As outras vêm de Deus, não são Deus. Mas esta é Deus e por Deus é concedida a anjos e aos homens. Nenhuma outra virtude torna dignas de eterno prémio 
operationem et ex aliis uirtutibus emanantes facit praemio superno dignas ${ }^{175}$, haec uero non ulla naturae necessitate, sed benignissima Dei nostri pietate.

Hanc ut nobis adaugeat Deus, cuius culmen post Filium tu possides, o Maria, Domina mea et soror matris meae, (tu enim ex Anna, Simon, Iacob, Ioseph iustus et ego ex Maria Cleophae, fratris Annae felicissime sterilis orti sumus), tu rogabis, tu impetrabis ut omnes curramus post te in odorem ungentorum tuorum.

Vocatur Matthias apostolus cuius uerba haec fuerunt: Donatus Domino, dona ipsius in Genitrice Domini Dei et Saluatoris nostri Iesu Christi laudare et commendare teneor. Sed ex una parte cogito quid supra ea quae uicarius Christi Petrus, noster nouus pastor, de humilitate humiliter attulit, Ioannes de maternitatis dignitate, aliique fratres mei de aliis innumeris, ut Andreas primo uocatus a Domino, ut Simon cum Iacobo et Thaddaeo fratribus Domini, ut Thomas et si non natiuitate tamen similitudine geminus Saluatoris, et Philippus ille omnium amator uirtutum, Matthaeus mihi nomine paene similis, officio maior, et Bartholomaeus animo et sanguine admirandus, quid supra, ego ultimus duodecim apostolorum, qui non fui a Domino in apostolatum electus, sed in loco illius qui cecidit ab apostolatu et cuius episcopatum ego, uobis sortes ad Domini uoluntatem mittentibus, accepi, dicere potero aut audebo? Verum quia a Domini uoluntate et dono Domini assumptus fui in apostolatum, cuius officium etiam exercere coepi. Audebo et ego dona Genitricis Dei nostri, quam omnes ueneramur ut Dominam et Reginam nostram, ore licet indigno commendare et laudare? Laudes enim eius honores diuini sunt. Nihil namque habet ${ }^{176}$ quod non accepit et profecto ita est quia ex se nihil prorsus habet ${ }^{177}$. Eam itaque laudando, diuina dona, diuinas gratias, munera ${ }^{178}$ sponte a Superno Largitore concessa [f1. 205] magnificamus. Neque credo fas esse ullam creaturam extollere si illa nihil boni ex se habet ${ }^{179}$. Sed in ipsa creatura extollenda est clementia Dei, magnificanda sunt munera Dei. Immo dico uobis, scientibus enim diuina misteria loquor, nullus minor ${ }^{180}$ dignus laude uidetur homine illo a diuinitate assumpto. Et post illum, nullus minori ${ }^{181}$ commendatione dignus hac ipsius Domini nostri Genitrice Maria. Ille enim absque ullis meritis praecedentibus et diuinitati hypostatice unitus et beatitudine summa et qua maior creari nequit affectus fuit. Ipso nil agente, ipso nil cooperante Deus factus est. Plenitudem omnium gratiarum, omnium donorum, omnium uirtutum ac ipsius beatitudinis accepit. Alii, ut angeli sancti et beati, et ipsi probati sunt et cooperati sunt, temptati sunt ${ }^{182}$. Potuerunt transgredi, non erant confirmati ut

175 haec sola et ex ipsa profluentem operationem et ex aliis uirtutibus emanantes facit praemio superno dignas,] haec sola et ex ipsa profluentem operatione et ex aliis uirtutibus emanantes facit praemio superno dignas $I$; Haec sola et ex seipsa profluentem operatione et ex aliis uirtutibus emanantes facit praemio superno dignas $M$; Haec sola ex seipsa profluentem et ex aliis uirtutibus manantem operationem seu operationes facit praemio superno dignas $Q$; Haec sola et ex ipsa profulgente operatione et ex aliis uirtutibus emanantes facit praemio superno dignas. $V \rightarrow$ 
as suas obras e as suas acções, só esta torna dignas do prémio do alto a obra que dela nasce e as acções que emanam das outras virtudes. Mas isto, não por qualquer imposição da natureza, mas pela benigníssima piedade do nosso Deus.

Que Deus nos aumente esta, cujo cúmulo, depois de teu Filho, tu deténs, ó Maria, Senhora minha e irmã de minha mãe; tu, de facto, nasceste de Ana; Simão, Tiago, José, o justo, e eu nascemos de Maria Cléofas, irmã de Ana, a felicíssima estéril; tu rogarás, tu impetrarás para que todos corramos após ti no odor dos teus perfumes.

É chamado o apóstolo Matias, cujas palavras foram estas: Dado ao Senhor, sou impelido a louvar e a encarecer seus dons na Mãe de nosso Senhor, Deus e Salvador, Jesus Cristo. Mas, por um lado, penso no que poderei ou ousarei dizer além do que Pedro, vigário de Cristo, nosso novo Pastor, humildemente expôs sobre a humildade; João, sobre a dignidade da maternidade; e os outros irmãos meus, sobre tantas outras coisas, como André, primeiro a ser chamado pelo Senhor, como Simão com Tiago e Tadeu, irmãos do Senhor; como Tomé, gémeo do Senhor se não pelo nascimento, pelo menos pela semelhança, e Filipe, esse amante de todas as virtudes, Mateus, só no nome semelhante a mim, maior na função, e Bartolomeu, digno de admiração pelo espírito e pela linhagem; que mais, eu, o último dos doze apóstolos, que não fui escolhido pelo Senhor para o apostolado, mas no lugar daquele que decaiu do apostolado e cujo episcopado eu, perscrutando vós a vontade do Senhor, aceitei? Mas, porque foi por vontade e por dom do Senhor que fui elevado ao apostolado, cuja função comecei já a exercer, ousarei eu também, embora em linguagem humilde, enaltecer e louvar os dons da Mãe do nosso Deus, que todos veneramos como Senhora e Rainha nossa. Os seus títulos de louvor são, efectivamente, honras divinas. Pois nada tem que não recebesse e, na verdade, assim é, porque, de si, nada inteiramente tem. E, assim, louvando-a, exaltamos os divinos dons, as graças divinas, os dons livremente concedidos [f1. 205] pelo Supremo Dispensador. E nem creio que seja legítimo elogiar criatura alguma se ela, de si, nada tem de bom. Mas na própria criatura deve realçar-se a clemência de Deus, devem engrandecer-se os dons de Deus. E até vos digo mais, falo, de facto, a quem conhece os mistérios divinos, ninguém parece menos digno de louvor do que aquele homem assumido pela divindade e, a seguir a ele, ninguém digno de menos apreço do que a própria Maria, Mãe do mesmo Senhor nosso. Ele, de facto, sem quaisquer méritos prévios e unido hipostaticamente à divindade, foi dotado da bem-aventurança suprema, maior do que a qual não é possível criar outra. Foi feito Deus sem ele nada fazer,

$\leftarrow \mathbf{1 7 6}$ Nihil namque habet] Nihil omnium quae habet $Q \mathbf{1 7 7}$ nil prorsus habet] homo nil habet $Q$ 178 munera] innumera bona $N 179$ habet] haberet $N$; habeat $O 180$ minor] maior $M$ (in marg. $a$. m.) $N$; minore $Q, 181$ minori] maiori $M$ ( in marg. a. $m$.) $N$; minore $Q \mathbf{1 8 2}$ Alii, ut angeli, sancti et beati et ipsi probati sunt et cooperati sunt, temptati sunt.] Cuncti angeli, sancti et beati et ipsi operati sunt, probati sunt, tentati sunt. $O$; Cuncti angeli, sancti et beati operati sunt, probati sunt, temptati sunt $Q$ 
peccare nequirent. Virgo quoque quibus meritis praecedentibus, quibus operibus praeuenientibus a peccato omni praeseruata fuit? Nullis, inquam! Antequam esset, non solum ipsa sed caelum et terra et ipsa natura angelica, iam electa erat, iam, si alii caderent ${ }^{183}$, in uno patre prouisum fuit remedium alios releuandi ${ }^{184}$, ipsam uero omnino dono Dei et remedio passionis Filii sui praeseruandi. Et ordinatum fuit ut, dono Dei et diuina acceptatione, passio praeuisa plus sibi proficeret quam aliis exhibita, quibus meritis praeuiis in peccato non fuit concepta. Omni gratia et omni scientia et arte fuit impleta. Nullum donum creaturae conueniens fuit sibi denegatum. In ipsius ergo laudibus potius uidetur magnificari Deus quam in aliorum laudibus, nam in ea solus Deus magnificatur. Non enim in eo quod recipimus proprie laudamur, sed in eo quod agimus et operamur. Enimuero non est dubitandum Mariam Dominam cooperatam fuisse talibus donis. Sicut et alii suis donis cooperati fuerunt, sic et Filius eius ut homo. Sed praeuenti fuerunt dono Dei et data fuerunt eis talia dona sine ullis operibus, sine ullis petitionibus, sine ullis motibus ${ }^{185}$ et desideriis praecedentibus ad quae cooperati fuissent si praeuenti non extitissent. Non itaque minori commendatione digni sunt qui maiora dona sine ulla cooperatione, sine ullo actu uoluntatis praeuio perceperunt, dummodo, si praeuenti non fuissent, cooperati fuissent. Voluit autem Deus aliquos ita extollere, ita exaltare, ita sublimare ut nil in eis nisi prorsus gratia, nisi clementia, nisi misericordia Dei reluceret. Laudemus, immo magnificemus, immo glorificemus Dominum Deum nostrum in omnibus uiis, in omnibus operationibus, in omnibus donis, in omnibus muneribus suae Genitrici datis, exhibitis ac sponte concessis utque nostra in nobis dona ${ }^{186}$ conseruet augeatque ipsius meritis et praecibus supplices deprecemur.

Expletis laudibus iam tibi recitatis, Petrus apostolus dixit, [f1. 206] congregatis nobis coram Genitrice Domini nostri: Viri ${ }^{187}$ fratres, notum est iam uobis qualiter, excluso impio Iuda a societate nostra, loco ipsius annumerauimus nobis hunc qui ultimo nunc locutus est, Matthiam. Deinde, Spiritu Sancto mandante, electi fuerunt in apostolatum Paulus, hic existens, et Barnabas, qui ualde utiles extiterunt fidei nostrae et Ecclesiae. Et uere hic Paulus a Christo Domino uas electionis nominatus est. Hic sumus coram Regina et Domina nostra. Iustum et congruum existimo ut ei tribuatur locus inter nos et dignus locus, nam ipse scientia atque eloquentia dignus et excelsus est et gratia Dei est in ipso et abundans donum

183 caderent] crederent $I V 184$ releuandi] reuelandi $V 185$ motibus] motiuis $Q 186$ dona] dona concessa $Q 187$ Viri] Veri $Q$ 
sem ele em nada cooperar. Recebeu a plenitude de todas as graças, de todos os dons, de todas as virtudes e da própria bem-aventurança. Outros, como os anjos, os santos e os bem-aventurados, foram postos à prova e colaboraram, foram tentados. Puderam transgredir, não haviam sido fortificados de modo a poderem não pecar. Também a Virgem, com que méritos precedentes, com que obras prévias foi preservada de todo o pecado? Nenhumas, afirmo. Antes de existirem não só ela, mas o céu e a terra e a própria natureza angélica, já ela havia sido escolhida; já, se outros caíssem, havia sido previsto no pai comum o remédio que livrasse os outros e a ela a preservasse de modo absoluto pelo dom de Deus e pelo remédio da Paixão de seu Filho. E foi disposto que, por dom de Deus e aceitação divina, lhe aproveitasse mais a ela a Paixão, enquanto prevista, do que aos outros, já realizada, por cujos méritos prévios não foi concebida em pecado. Foi cheia de toda a graça e de todo o conhecimento e saber. Nenhum dom próprio da criatura lhe foi negado. Nos seus louvores, pois, parece que é Deus mais exaltado do que nos louvores dos outros, pois nela só Deus é exaltado. De facto, não somos louvados propriamente por aquilo que recebemos, mas por aquilo que fazemos e realizamos. Efectivamente, não se deve duvidar de que Maria, Senhora nossa, tivesse colaborado com tais dons. Assim como outros colaboraram com seus dons, assim também seu Filho, enquanto homem. Mas por dom de Deus foram acautelados e foram-lhes concedidos esses dons sem nenhumas obras, sem preces nenhumas, sem nenhuns movimentos e desejos prévios relativamente aos quais tivessem colaborado se não houvessem sido acautelados. Não são dignos de menor apreço aqueles que maiores dons receberam sem qualquer colaboração, sem qualquer prévio acto de vontade, desde que tivessem colaborado, se não houvessem sido acautelados. Deus, porém, quis elevar, exaltar e sublimar alguns de tal modo que neles não brilhasse senão, sobretudo, a graça, a clemência, a misericórdia de Deus. Louvemos, mais, exaltemos, mais, glorifiquemos ao Senhor nosso Deus em todas as vias, em todas as obras, em todos os dons, em todas as graças a sua Mãe dadas, proporcionadas e livremente concedidas, e oremos suplicantes que, por seus méritos e preces, conserve e aumente em nós os dons.

Concluídos os louvores que já te foram expostos, [f1. 206] reunidos nós perante a Mãe do nosso Deus, disse o apóstolo Pedro: Homens irmãos, sabeis já como, afastado o ímpio Judas da nossa convivência, acrescentámos ao nosso número, no lugar dele, este que agora falou em último lugar, Matias. Depois, por inspiração do Espírito Santo, foram escolhidos para o apostolado Paulo, que aqui vedes, e Barnabé, os quais muito úteis se mostraram à nossa fé e à Igreja. E com razão foi Paulo designado por Cristo Senhor vaso de eleição. Estamos aqui na presença da nossa Rainha e Senhora. Considero justo e conveniente que lhe seja atribuído um lugar, e um lugar digno, entre nós, pois ele é digno e grande em 
Spiritus Sancti. Nunc ergo considerate quem locum inter nos mereatur et ille sibi detur sententia communi omnium nostrum ut, sicut a Domino est electus, etiam a nobis non sit neglectus.

Tunc Andreas apostolus ait: Dominus noster nos instruxit, dicens: Qui maior est inter uos, erit minister uester, quia dignitas et praesidentia nostra ministerium est et seruitus. Nos undecim iterum ${ }^{188}$ sumus. Iacob enim Herodis gladio decollatus est, cuius anima hic, ut uidistis, adest. Paulus erit unus de duodecim. Et mihi non uidetur ut alicuius nostrum locum accipiat, sed illius qui ad patres suos appositus est. Tribuatur sibi locus Iacobi, fratris Ioannis, ut sicut Dominus Petrum et Iacobum et Ioannem intimiores habebat ita post Petrum uicarium Paulus et Ioannes digniores inter nos existant. Et priores sint in proponendo, respondendo et decidendo. Hoc mihi uidetur, si Reginae nostrae non displicet et hi fratres mei sint contenti.

Virgo mater commendauit Andreae apostoli sententiam quae omnibus summopere placuit. Vocauit ergo Petrus, licentia a matre Dei accepta, Paulum ad se et eum cum Ioanne iuxta se sedere iussit. Placuit namque unanimiter omnibus sententia et iudicium apostoli Andreae. Barnabas uero adiunctus est ut esset post Matthiam tertius decimus apostolus, Lucas post illum et Marcus, quorum laus est in Euangelio.

Quo facto, dixit Petrus: Paule frater, apostole dignissime, tu quoque aliquid ad propositum pertinens, gratia Dei docente, dices. Deinde Barnabas, Lucas et Marcus dicent et ipsi unusquisque secundum gratiam a Domino sibi collatam

Paulus itaque ita uerba sua in medio fratrum proposuit: Numquam ego, Genitrix inclita Dei nostri, et tu, Petre, cui claues regni caelorum specialiter date sunt, uosque apostoli dignissimi Domini nostri Iesu Christi, in hunc locum conscendissem, nisi me uerba Andreae apostoli constantissimi et sapientissimi, immo uerba ipsius Sapientiae, Christi Domini, mouissent, dicentis: "Qui maior est uestrum, erit minor et minister uester". Non enim inter nos debet esse prout in curiis et domibus regum huius saeculi. Maiorem itaque me faciendo, minorem me fecistis. [f1. 207] Enitar ergo tanto humilior esse in omnibus quanto me maiorem fecistis, quia haec maioritas seruitus est Iesu Christi. Ille utique maior est qui Deo se magis humiliat, ille dignior est qui se indigniorem putat, ille sanctior qui se iniustiorem credit, cuius rei exemplum ecce coram nobis habemus in Virgine humillima, cuius humilitatem supra omnia alia respexit Deus. Quamuis enim ipsa sit decora mente et corpore et nulla uirtus sibi defficiat, tamen Altissimus,

188 iterum sumus] intersumus $V$ 
saber e eloquência, e nele está a graça de Deus e o abundante dom do Espírito Santo. Considerai agora que lugar merece entre nós e seja-lhe ele atribuído por decisão comum de todos nós para que, assim como foi escolhido pelo Senhor, não seja por nós esquecido.

Nosso Senhor, disse então o apóstolo André, instruiu-nos, dizendo: Quem entre vós for o maior, será vosso servo, ${ }^{[248]}$ porque a dignidade e o mando são, em nós, serviço e sujeição. Nós somos, outra vez, onze. Pois Tiago, cuja alma, como vistes, está presente, foi degolado pela espada de Herodes. Paulo será um dos doze. E não me parece que deva receber o lugar de nenhum de nós, mas o daquele que se juntou a seus pais. Atribua-se-lhe o lugar de Tiago, irmão de João, para que, do mesmo modo que o Senhor tinha Pedro, Tiago e João como mais íntimos, assim, depois de Pedro, o vigário, sejam Paulo e João os de maior dignidade entre nós. E sejam os primeiros a propor, a responder e a decidir. Isto me parece, se não desagrada à nossa Rainha e estes meus irmãos estiverem de acordo.

A Virgem Mãe elogiou a opinião do apóstolo André, que sobremaneira agradou a todos. Pedro, tendo recebido o assentimento da Mãe de Deus, chamou, pois, Paulo para junto de si e mandou-o sentar, com João, a seu lado. A todos, unanimemente agradou a opinião e o alvedrio do apóstolo André. Foi ainda associado Barnabé para ser, depois de Matias, o décimo terceiro apóstolo; depois dele, Lucas e Marcos, cujos títulos de louvor residem no Evangelho. ${ }^{[249]}$

Feito isto, disse Pedro: Irmão Paulo, apóstolo digníssimo, também tu, instruindo-te a graça de Deus, dirás alguma coisa relativa a este assunto. Depois Barnabé, Lucas e Marcos, também eles falarão, cada um segundo a graça a si concedida por Deus.

E, no meio de seus irmãos, Paulo expressou-se deste modo: Nunca, ínclita Mãe do nosso Deus, e tu, Pedro, a quem foram especialmente dadas as chaves do reino dos céus, e vós, apóstolos digníssimos de nosso Senhor Jesus Cristo, nunca eu subiria a este lugar se me não tivessem movido as palavras de André, apóstolo inquebrantabilíssimo e sapientíssimo, ou melhor, as palavras da própria Sabedoria, Cristo Senhor, que disse: aquele que entre vós é o maior, será o menor e vosso servo. ${ }^{[250]}$ Efectivamente, entre nós não deve ser como nas cortes e nos palácios dos reis deste mundo. Por essa razão, ao fazerdes-me grande, tornastes-me mais pequeno. [f1. 207] Procurarei eu, pois, ser tanto mais humilde em tudo, quanto maior me fizestes, porque ser maior é serviço de Jesus Cristo. Na verdade, é maior quem mais se humilha perante Deus, mais digno é quem mais indigno se julga, mais santo, quem mais injusto se crê, de cuja verdade temos perante nós o exemplo na muito humilde Virgem, cuja humildade mais que todas as coisas olhou Deus. Embora, efectivamente, ela seja formosa de espírito e de corpo e nenhuma

[248] Mt 23:11

[249] 2 Co $8: 18$

[250] Mt 23:11; Mc 10:43 
qui in excelsis habitat, bumilia respicit in caelo et in terra, humilitatem eius respexisse ${ }^{189}$ dicitur. Superbum Luciferum de caelis ad ima detrusit et Mariam humillimam super omnes choros angelorum sublimauit, de cuius ingenti gloria et inenarrabili gaudio in sempiternum duraturo et de caelestis curiae dispositione, tamquam ille qui raptus fui usque ad tertium caelum, quaedam coram uobis, ego minimus apostolorum, dicam. Caeli ad quos Maria nunc properat, ut oculis mentis meae clare conspexi, septem sunt, quorum unumquodque unam lucem tantum gerit. Primum quidem Lunam, secundum Mercurium, tertium Venerem, quartum Solem, quintum Martem, sextum Iouem, septimum Saturnum. Deinde est octauum caelum in quo sunt omnes aliae stellae quas uidemus. Et plurimae sunt quas uidere non possumus. Omnes tamen sunt in caelo illo in quo etiam sunt duodecim signa: Aries, Taurus, Gemini, Cancer, Leo, Virgo, Libra, Scorpius, Sagittarius, Capricornus, Aquarius, Pisces. Super illud est nonum caelum in quo nulla stella est, sed ipsum motu diurno iugiter mouetur, cuius motus unicus et uelocissimus est et miro modo secum ducit omnes caelos inferiores. Qui caeli etiam alio modo mouentur et motu contrario. Nam et si uelocissime moueantur ab Oriente in Occidentem, tamen mixtim et cum mirabili proportione mouentur tardius ab Occidente in Orientem. In quolibet enim minuto uel momento, magna portio caeli inferioris ab Oriente in Occidentem fluit. Et fluendo illa magna portione, parua et paene imperceptibilis portio eiusdem reuertitur. Quam reuersionem Luna citissime consumit, Mercurius, Venus atque Sol paene in tempore aequali (cursus autem Solis sub circulo zodiaco notus est omnibus), Mars in sex annis, Iupiter in tredecim, Saturnus in triginta, Caelum stellatum in centum annis gradu uno. Super omnes caelos istos mobiles est caelum immobile in quo tamquam in loco omnia mouentur. Locus autem ipse manet immobilis. Vnde omne aliud continens, ut contentum continet et, prout ratione illius continet, immobiliter continet. Vnde omnes de loco tractantes ipsum immobilem dixerunt. Et uerum est quia et si immediate continens ut aqua uel aer fluat, non tamen continens ultimum fluit, ratione cuius firmitatis et immobilitatis locus dicitur immobilis. Et res, nunc existens in uno continente [fl. 208] proximo, nunc in alio, non dicitur locum mutare, quia ad primum continens eumdem respectum habet. Si illud caelum non esset, nihil proprie locum haberet. Illud autem caelum est mira arte confectum ut non solum spiritibus, sed etiam corporibus humanis sit habitaculum aptissimum et gratissimum. Ibi, prima post Deum, erit anima Christi Domini Filii tui, o Maria suauissima ${ }^{190}$, quae ab ipsa Trinitate purgatur, illuminatur et perficitur. Tu uero ab illa purgaberis, illuminaberis et perficeris, Michael abs te, a Michaele Gabriel et ita ulterius, iuxta quod Dionysius meus hic existens iam

189 respexisse] non despexisse $Q 190$ o Maria suauissima] o Maria, suauissimi $M N O$ 
virtude lhe falte, diz-se, todavia, que o Altíssimo, que nas alturas mora, olha o que é bumilde no céu e na terra, ${ }^{[251]}$ olhou para a sua humildade. Precipitou do céu no abismo o soberbo Lúcifer e elevou a muito humilde Maria acima de todos os Coros dos anjos, de cuja ingente gloria e inenarrável alegria, que para sempre durará, e da disposição da corte celeste, eu, o menor dos apóstolos, como aquele que fui arrebatado até ao terceiro céu, exporei perante vós alguma coisa. Os céus para que Maria se encaminha agora, conforme claramente vi com os olhos da minha mente, são sete, cada um dos quais leva consigo uma luz apenas. O primeiro é, sem dúvida, a Lua, o segundo Mercúrio, o terceiro Vénus, o quarto o Sol, o quinto Marte, o sexto Júpiter, o sétimo Saturno. Depois, está o oitavo céu, no qual estão todas as outras estrelas que vemos e muitas são as que não podemos ver. Todas, porém, estão naquele céu em que estão também os doze signos: Carneiro, Touro, Gémeos, Câncer, Leão, Virgem, Balança, Escorpião, Sagitário, Capricórnio, Aquário e Peixes. Acima deste está o nono Céu, em que nenhuma estrela existe, mas se move continuamente num movimento constante, movimento que é único e muito veloz e consigo arrasta de um modo admirável todos os Céus inferiores. Estes Céus movem-se também de outro modo e com movimento contrário. Pois, embora se movam muitíssimo velozmente de oriente para ocidente, movem-se também ao mesmo tempo e com admirável proporção de ocidente para oriente mais lentamente. De facto, em cada minuto ou momento, grande parte do Céu inferior corre de oriente para ocidente. E enquanto aquela enorme porção corre, uma pequena e quase imperceptível porção do mesmo retorna. Reversão que a Lua esgota muito celeremente, Mercúrio, Vénus e Sol quase em tempo igual (o curso do Sol abaixo do círculo do Zodíaco é de todos conhecido), Marte em seis anos, Júpiter em treze, Saturno em trinta, Céu Estrelado, com passo uniforme, em cem anos. Acima de todos estes Céus móveis está o Céu Imóvel, no qual todas as coisas se movem como num lugar. Esse lugar, porém, permanece imóvel. Daí que, contendo tudo o resto, contém como contido e, na medida em que contém em razão daquele, contém de modo imóvel. Por isso, todos quantos trataram do lugar, o consideraram imóvel. E é verdade porque, embora o que imediatamente contém flua como a água e o ar, o último continente, contudo, não flui, em razão de cuja firmeza e imobilidade o lugar é designado imóvel. E a coisa que ora se encontra num continente [fl. 208] próximo, ora noutro, não se considera que mudou de lugar, porque mantém a mesma relação relativamente ao primeiro continente. Se aquele Céu não existisse, nada teria particularmente um lugar. Aquele Céu é feito com tal arte que é habitação apropriadíssima e agradabilíssima não só para os espíritos, mas também para os corpos humanos. Lá estará como primeira depois de Deus, ó Maria suavíssima, a alma de Cristo Senhor, teu Filho, a qual é purificada, iluminada e aperfeiçoada pela própria Trindade. E tu 
litteris committere coepit. Scio te, o Maria, nil horum quae ego hodie loquor fugere. Loquor tamen ut probes coram fratribus meis uerba mea. Merces tua, ut ipsa nosti, est magna nimis, omnium certe mercedem et beatitudinem superans. Tui sumus famuli, tui omnes serui. Memor esto nostri, Summi Regis Mater, ut uota nostra persoluentes digni efficiamur promissionibus Christi cum quo ecce uiuere et regnare feliciter pergis, qui cum Patre et Spiritu Sancto uiuit et regnat per infinita saecula saeculorum. Amen.

Barnabas post Paulum, licentia accepta, ita locutus est: Consolationes tuae, inquit propheta, laetificauerunt animam meam. Barnabas sum, filius consolationis est nomen meum. Dulce est tibi super omnes matres, o altissima Maria, nomen filii. Illud namque nomen est proprium nomen Verbi Dei et Filii tui. Tu certo mater es illius qui ab aeterno fuit filius. Et ille sempiternus Filius, tuus ex tempore coepit esse filius. Quod nomen si, ut dicitur, aliquid in homine ponat tunc, perempta humanitate, perimitur ${ }^{191}$ filiatio atque maternitas. Et ita tempore mortis Christi maternitatem amisisti et ea de re ualde doluisti. Nunc quoque ad aeterna gaudia tibi properanti nil mali nilque sinistri accidere posse uideo nisi hoc solum quia, morte interueniente, maternitatem tuam iterum amissura es. Quod an uerum sit difficile est cognitu et nouissimis diebus, ut audio, declarabitur. Si statutum non fuisset semel omnem hominem mortem subire, bonum esset ut te Deus de uita ista transferret ad uitam illam ne nomen tantae dignitatis in te extingueretur ad tempus. Quid tamen, etiam si re non eris Dei mater, eris in mente ipsius et nostra et, citissime resurgendo, re ipsa nomen illud recuperabis. Et quod parumper interrumpitur, non interruptum, sed continuum censendum est. Consolare itaque, Maria, in Filio, consolare in maternitatis nomine. Maximas consolationes citissime experieris, Deo unione perpetua copulaberis, Filii tui amplexibus indissolubilibus astringeris, omnibus bonis afflues, nihil tibi umquam deficiet. Proxima solio Sanctissimae Trinitatis assistes, sessione propinquissima Deo Trino et Vno eris. Illi nos commendatos facito. Abscedens, non abscedas a nobis. Opitulare nobis in hac uita mortali. Et, ut ad gaudia illa et nos peruenire [f1. 209] ualeamus, exora.

Post hunc, accepta licentia, Lucas ita loqui coepit: Plurima iam ab his patribus allata sunt in medium. Mihi, ceteris praetermissis, tua uirginitas, o mater Dei Maria, est laudanda ${ }^{192}$. Tu namque sola ante partum et in partu et post partum

191 perimitur] permittitur $O$; peremitur $Q 192$ Plurima iam (...) o mater Dei Maria, est laudanda.] Plurima iam ab istis patribus allata sunt in memoriam. Mihi, ceteris praetermisis, uidetur tua uirginitas, o mater Dei Maria, quod sit laude dignissima et omni praeconio celebranda. $P$ 
serás por ela purificada, iluminada e aperfeiçoada; depois de ti, Miguel; depois de Miguel, Gabriel, e assim sucessivamente, conforme o meu amigo Dionísio, aqui presente, começou já a escrever. Sei, Maria, que nada do que digo agora te é desconhecido. Falo, contudo, para que diante dos meus irmãos aproves as minhas palavras. A tua recompensa, como tu própria sabes, é muito grande, superando incontestavelmente a recompensa e a bem-aventurança de todos. Somos todos teus criados, somos todos teus servos. Lembra-te de nós, Mãe do Supremo Rei, a fim de que, cumprindo as nossas promessas, nos tornemos dignos das promessas de Cristo, com quem te preparas para viver e reinar em felicidade, ele que vive e reina com o Pai e o Espírito Santo por infinitos séculos dos séculos. Ámen.

A seguir a Paulo, depois de haver recebido autorização, assim falou Barnabé: As tuas consolações, diz o profeta, alegraram a minha alma. ${ }^{[252]}$ Sou Barnabé, Filho da Consolação é o meu nome. É doce para ti, ó sublime Maria, mais que para todas as mães, a palavra filho. Pois essa palavra é o nome próprio do Verbo de Deus, teu Filho. Tu, sem dúvida, és Mãe daquele que desde sempre foi Filho. E esse Filho sempiterno começou no tempo a ser teu Filho. Pois se, como se diz, o nome acrescenta alguma coisa ao homem, então, desaparecida a humanidade, desaparece a filiação e a maternidade. E, assim, ao tempo da morte de Cristo perdeste a maternidade e, por essa razão, sofreste muito. Também agora vejo que a ti, que te apressas para a eterna glória, nada de mal ou desfavorável te pode acontecer, a não ser apenas isto: que, sobrevindo a morte, de novo perderás a tua maternidade. O que é difícil saber se é verdade, e será esclarecido, segundo ouço dizer, nos últimos dias. Se não tivesse sido determinado que todo o homem sofresse a morte uma vez, seria bom que Deus te transferisse desta vida para a outra, para que título de tanta dignidade em ti se não extinguisse momentaneamente. O que, contudo, ainda que não sejas de facto Mãe de Deus, serás em espírito nossa e dele e, ressuscitando de imediato, recuperarás, de facto, esse título. E, o que por pouco tempo é interrompido, deve considerar-se não interrompido, mas continuado. E, assim, Maria, conforta-te em teu Filho, conforta-te no título da maternidade. Muito brevemente experimentarás as consolações supremas, ligar-te-ás a Deus em união perpétua, serás estreitada pelos indissolúveis abraços de teu Filho, abundarás em todos os bens, nada te faltará jamais. Estarás próxima do trono da Santíssima Trindade, terás assento muito próximo do Deus Trino e Uno. A ele nos encomenda. Partindo, não te afastes de nós. Socorre-nos nesta vida mortal. E roga para que também nós consigamos alcançar [f1. 209] esses gozos.

Depois deste, recebida autorização, começou Lucas a falar deste modo: Muitas foram já as coisas dadas a conhecer por estes Padres. Devo eu, ó Maria, Mãe de Deus, deixando de lado tudo o resto, louvar a tua virgindade. Pois só tu foste 
uirgo fuisti, sola sine corruptione grauida, sine uiolatione fecunda, sine pudore genitrix fuisti. Virginitas heroica uirtus est, quam donat Deus his quos omnino spirituales ${ }^{193}$ esse decernit. In carne enim uiuere et carnis incitamenta non sentire diuinum est. Sensus habere et praeter sensum uiuere, angelicum. Virginitas non est uirtus uulgaris, sed singularis, non popularis, sed specialis. Crescendum est enim et semen afferendum et populus Deo seruiens augendus et modo naturali non supernaturali ut non auferantur a causis creatis actiones earum. Non licet unicuique uirginem esse. Nam digna res est liberorum secundum Deum procreatio. Vnde praecepta naturae obseruanda sunt. In aliquibus congruum fuit uirginitatem reperiri, sed non fuit congruum in omnibus. Sed tu sola utrumque, o mater Dei nostri, complexa es et uirginitatem et maternitatem. Et praeceptum Dei de crescendo et consilium uirginitatis sola obseruasti. Excellens donum, sublimis corona, alta uirtus est ipsa uirginitas et potius datur ad decorem quam ad necessitatem salutis. Nam coniugalis continentia in multis praeferenda est uirginitati aliquorum. Vnde et Dominus ipse Christus te matrem suam ex coniugio sanctissimo nasci uoluit et omnes suos auos omnesque suas auias ex coniugio procreari uoluit. In te sola potentiae suae magnitudinem ostendit ut sine uiro conciperes, ut sicut fuerat uir ex nullo, mulier ex solo uiro, alii omnes ex uiro et muliere, ita ipse esset ex muliere sine uiro. Bonum ergo est coniugium, digna res est liberorum naturalis procreatio, admirabilior Filii Dei ex uirgine conceptio. Sic oportebat, sic congruum erat ut illa quae omnibus angelis dominaretur, nulli uiro subiceretur, non dico desponsatione, sed carnali copulatione. Hoc te non decebat, matrem Dei, Reginam angelorum et a peccato originali liberam. Hoc enim dictum est Euae in poenam: Sub uiri potestate eris et ipse dominabitur tui. Quia ergo illo peccato gratia Dei caruisti, iustum erat ut in uiri potestatem non transmittereris, quia subiectio illa uilis est et apud homines obprobriosa. Nihil honoris, nihil uenerationis, nihil dignitatis tibi Filius tuus deesse uoluit, qui te perfectam undique creauit. Ad ipsum igitur nunc accedens cum ipso ex tunc perpetuo mansura, nostri quoque miserere, nobis ueniam impetrare digneris ut et ipsi tuis precibus ad uisionem Dei Trini qui unus est, peruenire ualeamus.

Marcus Euangelista, sicut breuis in scribendo sic et in loquendo, haec dixit: [f1. 210] Recessurae a nobis corporali praesentia matri Domini et ad aetherium thalamum accessurae omnes nos commendamus ${ }^{194}$. Laudatissimam Virginem

193 spirituales] spirituales et diuinos $M$ (in marg. a. m.) $O Q 194$ commendamus] commendemus $M$ (sup. lin. a. m.) NOPQ 
virgem antes do parto, no parto e depois do parto, foste a única grávida sem corrupção, fecunda sem profanação, mãe sem desonra. A virgindade é uma virtude heróica que Deus concede àqueles a quem determina que sejam em absoluto espirituais. Viver na carne e não sentir as pulsões carnais é divino. Ter sentidos e viver para lá dos sentidos, angélico. A virgindade não é uma virtude comum, mas rara; não é popular, mas especial. Deve-se crescer e produzir frutos, e o povo que serve a Deus deve ser aumentado, e de um modo natural, não sobrenatural, para que se não retirem às causas criadas as acções próprias. Não cabe a cada um ser virgem. Pois a procriação de filhos segundo Deus é coisa digna. Daí que se devam observar os ditames da natureza. Encontrar a virgindade em alguns é ajustado, não é ajustado em todos. Mas só tu, ó Mãe do nosso Deus, associaste uma e outra, a virgindade e a maternidade. Só tu respeitaste não só o preceito de Deus relativo ao crescimento, mas também o conselho da virgindade. Excelso dom, sublime coroa, nobre virtude é a própria virgindade, e mais se concede para ornamento do que em razão da necessidade de salvação. Pois a continência conjugal em muitos é preferível à virgindade em alguns. Por isso quis o próprio Cristo Senhor que tu, sua Mãe, nascesses de um casamento santíssimo, e quis que todos os seus avôs e as suas avós fossem procriados de um casamento. Só em ti mostrou a grandeza do seu poder, para que concebesses sem a intervenção de homem, a fim de que, assim como o homem fora criado do nada, e a mulher somente do homem, todos os outros do homem e da mulher, assim fosse ele próprio criado da mulher sem a intervenção do homem. Bom é, pois, o casamento, é coisa digna a procriação natural dos filhos, mais admirável a concepção do Filho de Deus a partir de uma virgem. Assim convinha, assim era adequado que aquela que dominaria sobre todos os anjos se não sujeitasse a nenhum homem, não digo no casamento, mas na relação carnal. Essa condição não se adequava a ti, Mãe de Deus, rainha dos anjos e isenta do pecado original. A Eva foi isto dito como castigo: Estarás sob o poder do marido e ele te dominará. ${ }^{[253]}$ Dado, pois, que pela graça de Deus foste isenta desse pecado, era justo que te não sujeitasses ao poder do homem porque essa sujeição é vil e é infamante entre os homens. Não quis o teu Filho que te faltasse honra alguma, nenhuma veneração, nenhuma dignidade, ele que te criou perfeita em tudo. Dirigindo-te agora, pois, para junto dele para, desde esse momento, com ele permaneceres para sempre, tem compaixão de nós também, digna-te obter para nós o perdão a fim de que também nós, pelas tuas preces, consigamos alcançar a visão de Deus Trino, que é também Uno.

O evangelista Marcos, breve na fala como foi na escrita, disse o seguinte: [f1. 210] Todos nos encomendamos à Mãe do Senhor, que vai afastar-se de nós segundo a presença corporal e abeirar-se do tálamo etéreo. Todos louvastes dig- 
omnes ample laudastis omnesque procul dubio a laude defecistis. Si namque omnia grana arenae maris, omnia folia herbarum et arborum, omnes guttae maris, omnes stellae caeli, omnia lilia, rosae et alii flores, omnia animalia, artus et partes eorum, omnes angelorum exercitus et quaecumque alia excogitari possunt in linguas conuerterentur et mille annis loquerentur, quanta et qualis sit haec Virgo quam laudamus numquam exprimere possent. Laudauimus non quantum debuimus, quia id impossibile est, sed quantum potuimus. Tu quoque nos Filio tuo, o piissima Genitrix, et si non quantum potes saltem plus quam meremur commendabis ut una tecum tempore suo gaudia aeterna possidere ualeamus, praestante illud tuis obsecrationibus, Patre et Filio et Spiritu Sancto, unico Deo cui sit honor et gloria in saecla saeclorum. Amen.

Dionysius et Ignatius et multi aliorum discipulorum genu flexi breui eloquio Virginem laudauerunt et ei coetum discipulorum et totum humanum genus commendauerunt.

Post haec, Mariae spiritus exultauit in gaudio et, eleuatis oculis in caelum atque extensis manibus, decantauit suum mirabile canticum quod in domo Zachariae alias decantauerat ${ }^{195}$. Addiditque hos uersiculos:

Ad te uenio, ecce, Deus meus. Ad te accedo, Fili, Pater et Deus.

Ascendo ad Deum meum et Dominum meum, ad Filium meum et Creatorem meum. ${ }^{196}$

Ad Genitorem Genitrix pergo, a uobis, filii mei, hodie discedo.

Corpore uos nunc dimitto, corde et animo non relinquo.

Panem sanctum pariter frangamus, carnem Filii mei simul comedamus.

Tu, Petre, pastor Christi ouium, benedices hoc sanctum edulium.

Gratias agamus omnes Deo Trino, benedicamus cuncti uni Domino.

His dictis, Petrus accepit panem et benedixit, similiter et calicem. Non enim licebat unum sacramentum sine alio conficere et conficientem oportebat primum sumere. Et cum particulam unam accepisset et Mariae dare uellet, illa uoce aliquantulum eleuata et in feruore spiritus, dixit:

Ecce uideo Filium meum, ecce intueor Deum meum.

Bene adueniat Deus meus, bene ueniat Dominus Saluator meus.

Vt ad te citius ueniam, ad me uenis, qui a beatis numquam recedis.

195 decantauerat.] decantauerat uidelicet Magnificat anima mea Dominum $I 196$ Ascendo ad Deum (...) et Creatorem meum] Accedo (Ascendo $O$ ) ad Deum meum et Deum uestrum, ad natum meum et Creatorem uestrum $O Q$ 
namente a eternamente louvada Virgem e todos sem dúvida falhastes no louvor. Pois, se todos os grãos da areia do mar, todas as folhas das ervas e das árvores, todas as gotas da água do mar, todas as estrelas do céu, todos os lírios, rosas e outras flores, todos os animais, seus membros e suas partes, todos os exércitos dos anjos e tudo quanto pode ser pensado se tornassem línguas e por mil anos falassem, nunca poderiam exprimir a grandeza e a importância desta Virgem a quem louvamos. Louvámos, não quanto devemos, porque isso é impossível, mas quanto pudemos. Também tu, ó piíssima Mãe, nos encomendarás a teu Filho, se não quanto podes, pelo menos mais do que merecemos, a fim de que juntamente contigo consigamos possuir no tempo oportuno as alegrias eternas que o Pai e o Filho e o Espírito Santo, Deus Único, a quem seja dada honra e glória pelos séculos dos séculos, hão-de conceder por tuas preces.

Dionísio e Inácio e muitos outros discípulos, de joelhos, em curto discurso louvaram a Virgem e recomendaram-lhe a multidão dos discípulos e todo o género humano.

Depois disso, o espírito de Maria exultou de alegria e, de olhos elevados ao céu e mãos estendidas, entoou o admirável cântico que cantara em casa de Zacarias. Acrescentou-lhe estes versículos:

Eis que venho a ti, Deus meu. De ti me abeiro, Filho, Pai e Deus.

Subo para junto do meu Deus e meu Senhor, para junto do meu Filho e meu Criador.

Mãe, encaminho-me para junto do Filho, de vós me afasto hoje, filhos meus.

Deixo-vos agora corporalmente, não vos abandono no coração e em espírito.

Procedamos juntos à fracção do Pão Santo, comamos juntos a carne de meu Filho.

Abençoarás tu, Pedro, Pastor das ovelhas de Cristo, este santo edúlio.

Demos todos graças ao Deus Trino, bendigamos todos o Deus Uno.

Dito isto, Pedro pegou no pão e abençoou-o e fez o mesmo com o cálice. Não era lícito celebrar um sacramento sem o outro, e ao celebrante cabia tomá-lo primeiro. E tendo pegado numa partícula e querendo dá-la a Maria, de voz um tanto elevada e no fervor de seu espírito, disse ela:

Eis que vejo o meu Filho, eis que contemplo o meu Deus.

Chegue em boa hora o meu Deus, venha em boa hora o Senhor, meu Salvador.

Para mais rapidamente ir a ti, vens a mim tu, que nunca te afastas dos bem-aventurados. 
Accedis ut hinc recedam neque a te umquam amplius recedam.

Deinde dixit Petro: Particulam istam repone, comunionem omnibus his prius dabis. Ego ultima sumam et uiaticum integrum mecum deferam.

Accepto itaque corpore et sanguine Domini ab omnibus, Maria iterum loqui coepit: Ecce cibum uitae accepistis, non esurietis neque sitietis quousque me sepelieritis et in caelum [f1. 211] conscendere uideritis. In domo mea alios cibos non habetis neque uidetis. Et omnes erant communione illa confortati et corroborati ac si cibaria quaeque delicatissima sumpsissent.

Dixit igitur Maria: Constantes estote, firmi et fortes, quia multas persecutiones pro nomine Domini Iesu oportet uos pati et tandem, corpore soluti, et gloria paradisi potiri. Tu, Petre, cum omnibus his Christum per passiones multas sequeris. Et hoc est quod ad te Dominus Iesus, Filius meus, dixit: Sequere me per mortem et passionem. Et tu, conuersus, uidisti Ioannem et interrogasti: Domine, bic autem quid? Et ille: Si ego uolo eum manere sic uiuum, quid ad te? Tu me sequere. Et hi circumstantes crediderunt quod Ioannes numquam moreretur. Sed non dixit Dominus Iesus quod numquam moriretur ${ }^{197}$. Sed dixit: "Si ego uolo ut uiuat ${ }^{198}$ donec ueniam ad iudicium, quid ad te"? Morietur ergo et ipse, sed tarde. Viuet enim cum Enoch et Elia translatus inuisibiliter ab angelis in paradisum terrestrem et iterum ueniet in mundum ad perhibendum testimonium ueritati. Decet ut trium testimonio fides Trinitatis iterum fulciatur et de quolibet statu testis adsit ueritatis. Dixit ergo Dominus: Si eum uolo manere sic donec ueniam, quid ad te? Accipitur ibi si uolo pro quia uolo. Filius meus Iesus a uobis discedens seipsum uobis usque ad consumationem saeculi in hoc sacramento reliquit, quod nulli alii corpori congruit. Ipse enim est solus panis et cibus, uinum et potus animarum. Notum facio uobis, filioli mei (et quando dicebat "filioli", uoluebat se ad iuniores; quando uero dicebat "patres", uoluebat se ad antiquiores praesertim ad Petrum; quando dicebat "fratres", uoluebat se indifferenter ad omnes), dixit ergo: Notum facio uobis quod gratia Domini mei Iesu Christi etiam ego corpore ero uobiscum usque ad consumationem saeculi. Non quidem in sacramento, quia id non licet, sed in imaginibus pictis et sculptis. Et quomodo hoc scietis quod ego sum praesens illi imagini? Tunc certe quando ibi miracula fieri uidebitis.

197 Sed non dixit Dominus Iesus quod numquam moriretur] Sed non dixit hoc Dominus Iesus $Q$ 198 Si ego uolo ut uiuat] Si eum uolo manere ut uiuat $N$; Sic eum uolo ut uiuat $Q$ 
Vens, para que eu parta daqui e de ti me não afaste mais.

Volta a guardar esta partícula, disse depois a Pedro, vais dar a comunhão primeiro a todos estes. Eu serei a última a comungar e levarei comigo o viático intacto.

Assim, recebido por todos o corpo e o sangue do Senhor, começou Maria novamente a dizer: Eis que recebestes o alimento da vida, não tereis fome nem sede até me sepultardes e me [f1. 211] verdes subir ao céu. Não tendes nem vedes em minha casa outro alimento. E todos estavam confortados e robustecidos por aquela comunhão como se tivessem tomado quaisquer finíssimas iguarias.

Sede perseverantes, firmes e fortes, disse então Maria, porque é preciso que sofrais muitas perseguições pelo nome do Senhor Jesus e, finalmente, libertos do corpo, alcanceis a glória do Paraíso. Tu, Pedro, por meio de muitos sofrimentos seguirás a Cristo com todos estes. E é isto o que o Senhor Jesus, meu Filho, te disse: Segue-me na morte e na paixão. E tu, voltando-te, viste João e perguntaste: Senhor, e deste, que será? E ele: Se eu quero que ele fique assim vivo, que tens $\mathrm{tu}$ com isso? Tu, segue-me. ${ }^{[254]} \mathrm{E}$ estes que estavam presentes acreditaram que João nunca morreria. Mas o Senhor Jesus não disse que nunca morreria. Mas disse: Se eu quero que viva até que eu venha para julgar, que tens a ver com isso? Também ele morrerá, pois, mas mais tarde. Viverá certamente com Henoch e Elias invisivelmente transladado pelos anjos para o Paraíso Terrestre, e virá novamente a este mundo para dar testemunho da verdade. Convém que a fé na Trindade seja de novo sustentada por tríplice testemunho e de cada situação haja uma testemunha da verdade. Disse, portanto, o Senhor: Se quero que fique assim até que eu venha, que tens com isso? Toma-se aí o se quero por porque quero. O meu Filho Jesus, partindo de junto de vós, deixou-se a si mesmo a vós neste sacramento até à consumação do mundo, o que se não coaduna com nenhum outro corpo. Só ele é pão e alimento, vinho e bebida das almas. Faço-vos saber, meus filhinhos (e quando dizia filhinhos voltava-se para os mais novos; mas quando dizia pais, voltava-se para os mais velhos, sobretudo para Pedro; quando dizia irmãos, voltava-se indiferentemente para todos), faço-vos saber, disse pois, que pela graça do meu Senhor Jesus Cristo também eu estarei corporalmente convosco até à consumação do mundo. Não certamente no sacramento, porque isso não é possível, mas em imagens pintadas e esculpidas. E como sabereis isto, que eu estou presente naquela imagem? Seguramente então, quando virdes que aí se fazem milagres. 
Deinde dixit: Praeceptum Domini et mandatum unicum est ut diligatis inuicem propter ipsum, omnem dilectionem uestram referentes in ipsum. Meum corpus in uallis Iosaphat medio sepelite, ubi est lapis et sepulcrum lapideum et nouum in quo nullus adhuc positus est. Neque inde recedite quousque anima mea iterum uniatur corpori meo.

Monuit quoque et sorores Magdalenam et Martham et alias sanctas mulieres quae aderant ut in uia mandatorum Domini perseuerarent et uerborum Domini Iesu recordarentur, praesertim Magdalena et Martha quia beatius est dare quam accipere. Ipse autem multa ministrauerant, sed maiora et longe praeclariora erant ministrata ${ }^{199}$ eis secus ipse beatiores fuissent sententia Domini.

Dixit ergo Maria: Multa in me, sorores, contulistis [f1. 212] beneficia sed, me interueniente, centuplum accipietis et mille pro uno. Benedicat uobis omnibus Deus Pater, benedicat Deus Filius, benedicat uos Deus Spiritus Sanctus. Vale, Petre, pastor etiam meus, quia et ego Christi Domini ouicula sum. Vale, Paule, uas electionis. Porta nomen Domini coram gentibus et regibus et filiis Israel. Vale, Ioannes, fili et frater mi. Annuntia diuinitatem $\mathrm{Christi}^{200}$ et prophetare ante translationem et postea. Vale, Andrea, qui primo et ante omnes secutus es Iesum. Nec praemio eris posterior. Vale, Philippe, et flamma supernorum accensus, Scythis Christum praedica. Vale, Simon Zelotes, quia Dei amore feruens ${ }^{201}$, cum Thaddaeo atque Iacobo, fratribus tuis et meis, et Ioseph Iusto qui et si non sit apostolus nomine est tamen merito. Vale, Matthaee publicane, prius notus infame arte, nunc publice testis uerbis et factis Filii Dei Viui. Vale, Thoma, sancte et prudens Didyme, et meum cinctorium, quod tibi ascendens porrigam, suscipe. Et gentem utriusque Indiae in aqua et igne baptiza. Vale, Bartholomaee, et praestolare tribulationum tuarum suspensionem atque mentis in Deum eleuationem iugiter habeto. Vale, Matthia et donatus, dona Dei conserua. Vale, Barnaba, et considerata futura consolatione, labores perpetim non formides. Vale, Luca mi carissime, et secreta quae tibi reseraui ${ }^{202}$ conscripta aliis porrige et reseruanda futuro saeculo reserua et, ut coepisti, in bono perseuera. Vale, Marce, pastoris nostri discipule carissime. Et Euangelii tui uerba longe lateque diffunde. Vale, Dionysi eruditissime, et ea quae a Paulo accepisti diligenter conscripta conserua. Vale, Ignatii feruentissime, et mei Iesu nomen in tuo corde sculptum perseueret (et subito ad uerba illa sculptum fuit; et in omnibus 203 amor et feruor mirabilis remansit). Valete, omnes discipuli Domini, et maioribus uestris oboedite et iuxta eorum praecepta incedite. Valete, sorores meae carne ${ }^{204}$, Cleophae et Salome. Valete et uos, sorores meae spiritu,

199 ministrata] ministeria $V \mathbf{2 0 0}$ diuinitatem Christi] humanitatem $Q \quad 201$ feruens] seruis 202 reseraui] reseruaui $J P 203$ omnibus] orationibus $I J V 204$ carne] carissime $V$ 
O preceito do Senhor, disse depois, e o mandamento único é que vos ameis uns aos outros por causa dele, a ele referindo todo o vosso amor. Sepultai o meu corpo no meio do vale de Josafat, onde há uma rocha e um sepulcro novo, em pedra, no qual ainda ninguém foi sepultado. E não vos afasteis daí até que a minha alma se una de novo ao meu corpo.

Exortou também as irmãs Madalena e Marta e as outras santas mulheres que lá estavam a que perseverassem na via dos mandamentos do Senhor e se recordassem das palavras do Senhor Jesus, sobretudo Madalena e Marta, pois que $a$ felicidade está mais em dar do que em receber. ${ }^{[255]}$ Ora elas haviam dado muito, mas maiores coisas e coisas muito mais importantes lhes foram dadas a elas. De outro modo, não teriam elas sido tão bem-aventuradas, segundo as palavras do Senhor.

Muitas mercês, irmãs, - disse Maria - me dispensastes, [f1. 212] mas com a minha intervenção recebereis o cêntuplo e mil por um. Que a todos vos abençoe Deus Pai, abençoe-vos Deus Filho, abençoe-vos Deus Espírito Santo. Adeus, Pedro, Pastor meu também, porque também eu sou ovelhinha de Cristo Senhor. Adeus, Paulo, vaso de eleição. Leva o nome do Senhor aos gentios, aos reis e aos filhos de Israel. Adeus, João, meu filho e meu irmão. Anuncia a divindade de Cristo e profetiza antes e depois da transladação. Adeus, André, que a Jesus seguiste primeiro e antes de todos. E no prémio não serás segundo. Adeus, Filipe, incendiado pela chama do alto, prega Cristo aos Citas. Adeus, Simão Zelote, tu que és fervoroso no amor de Deus, com Tadeu e Tiago, irmãos teus e meus, e José, o justo, que, embora não seja apóstolo de nome, o é, contudo, no mérito. Adeus, Mateus publicano, conhecido, primeiro, pela infamante função, és agora pública testemunha das palavras e das obras do Filho de Deus Vivo. Adeus, Tomé, santo e sábio Dídimo, aceita também a minha faixa, que te entregarei quando subir ao céu. E baptiza na água e no fogo o povo de ambas as Índias. Adeus, Bartolomeu, e aguarda a suspensão das tuas tribulações e mantém constante a elevação da tua mente para Deus. Adeus, Matias, tu que és dado, conserva os dons de Deus. Adeus, Barnabé, e, tendo em conta a consolação futura, não temas as constantes fadigas. Adeus, meu caríssimo Lucas, e transmite por escrito aos outros os segredos que te desvendei, e guarda para os tempos futuros as coisas que devem ser guardadas, e persevera no bem, como começaste. Adeus, Marcos, discípulo muito caro ao nosso Pastor. E leva muito longe as palavras do teu Evangelho. Adeus, eruditíssimo Dionísio, e conserva por escrito diligentemente as coisas que de Paulo recebeste. Adeus, fervorosíssimo Inácio, e que o nome do meu Jesus se mantenha gravado em teu coração (e, a estas palavras, foi imediatamente esculpido; e em todos se manteve um amor e um fervor admiráveis). 
Magdalena et Marttha. Retribuat uobis Deus pro uniuersis beneficiis uestris. Valete, omnes sanctae mulieres. Valete, uniuersi. Et Mariam in uobis clementissimam numquam uos aut genus uestrum obliuioni tradituram ${ }^{205}$ pro certo agnoscatis. Ecce mox ut corpus Filii mei sumpsero, anima mea a corpore meo egredietur et tam diu sacramentaliter erit mecum Dominus meus Iesus quam diu naturaliter apparuerit. Ecce hic inter uos anima fratris mei Iacobi Zebedaei est, quae nihil locuta est quia aliud est commercium illud, aliud istud. Non licet conuersationem illam facere istam. Da mihi, Petre, pastor ouium Domini Iesu, particulam repositam ubi stat et manet Iesus totus, Filius meus dilectus.

Tunc Petrus suscipiens particulam illam obtulit cum timore et reuerentia sanctissimo ori eius. Et ipsa deuotissime uiaticum suscepit. Et, eo suscepto, illico haec uerba dixit:

Paratum cor meum, Deus, paratum cor meum ${ }^{206}$.

Cantabo et psallam in [f1. 213] gloria mea.

Et usque ad finem compleuit. Dominus autem in sacramento corporaliter sibi praesens animam ipsius a corpore suo miro modo, absque ullo dolore et langore, separauit, astante angelorum multitudine et adueniente magno animarum sanctarum exercitu. Quae quidem anima, a corpore separata gratia Filii sui cum anima Ioannis Baptistae, Ioseph, Annae, Ioachim, Iacob, Abraham et aliorum patriarcharum et prophetarum ad purgatorium descendit et omnes animas amicorum suorum causa uictoriae et noui regni eripuit et secum in uallem Iosaphat, ubi corpus sepultum erat, deduxit. Quando autem anima a corpore fuit separata erat circiter tertia hora noctis. Et tribus horis stetit cum animabus illis in loco illo et iuxta locum illum ubi est purgatorium. Deinde iuit in paradisum terrestrem et confortauit Eliam et Enoch et narrauit eis qualiter illuc uenturus esset tertius testis, Ioannes Zebedaeus. Reuersa tandem in aurora est anima illa in uallem Iosaphat.

Et tunc Christus Dominus modo naturali et uisibili descendit, relinquendo habitaculum caeleste, cum omnibus angelis.

Sed animaduerte quod, egressa de corpore anima illa felicissima, omnes apostoli et discipuli et sanctae mulieres quae aderant uiderunt eam pulcherrimam et formosissimam. Et corpus eius non fuit lotum, quia nulla immunditia in illo erat. Sed detulerunt illud cum illis caerimoniis quae apud uos iam scriptae sunt, neque oportet eas iterare, cum miraculis illis quae scribuntur de temeritate Iudaeorum. 
Adeus, discípulos todos do Senhor, e obedecei aos vossos maiores e andai segundo os seus preceitos. Adeus, minhas irmãs segundo a carne, Cléofas e Salomé, a vós também, minhas irmãs segundo o espírito, Madalena e Marta. Que Deus vos dê a paga por todas as vossas mercês. Adeus, todas as santas mulheres. Adeus a todos. E reconhecereis como certo que Maria, para vós tão clemente, nunca vos esquecerá a vós ou à vossa descendência. Eis que, depois de tomar o corpo de meu Filho, a minha alma sairá de meu corpo, e o meu Senhor Jesus estará sacramentalmente comigo tanto tempo quanto for naturalmente visível. Eis que a alma do meu irmão Tiago Zebedeu está entre vós, ela nada disse porque uma é a convivência lá, outra aqui. Não pode tornar aquela nesta. Pedro, Pastor das ovelhas do Senhor Jesus, dá-me a partícula que guardaste onde está e se mantém integralmente Jesus, o meu Filho dilecto.

Pedro então, tomando a partícula, apresentou-a com temor e reverência à sua santíssima boca e Maria recebeu devotissimamente o Viático. E tendo-o recebido, prorrompeu imediatamente nestas palavras:

Firme está o meu coração, ó Deus, o meu coração está firme.

Vou cantar e entoar salmos ${ }^{[256]}$ [fl. 213] em minha glória.

E recitou o salmo até ao fim. E depois, o Senhor em si presente corporalmente no sacramento separou de um modo admirável, sem qualquer dor ou fadiga, a sua alma de seu corpo, estando presente uma multidão de anjos, enquanto se aproximava um grande exército de santas almas. Entretanto, esta alma, separada do corpo pelo favor de seu Filho, desceu ao Purgatório com a alma de João Baptista, José, Ana, Joaquim, Tiago, Abraão e dos outros patriarcas e profetas. Em razão da vitória e do novo reino libertou todas as almas de seus amigos e levou-as consigo para o vale de Josafat onde o seu corpo estava sepultado. Era cerca da terceira hora da noite quando a alma foi separada do corpo. E ficou três horas com estas almas naquele lugar e junto ao lugar onde está o Purgatório. De seguida, foi ao Paraíso Terrestre e confortou Elias e Henoc e contou-lhes o modo como haveria de ali chegar a terceira testemunha, João Zebedeu. Por fim, esta nobre alma retornou ao vale de Josafat, ao nascer do dia.

E então, de um modo natural e visível, deixando a habitação celeste, desceu Cristo Senhor com todos os anjos.

Mas nota que, saída aquela felicíssima alma do corpo, todos os apóstolos e os discípulos e as santas mulheres que estavam presentes a viram muito bela e muito formosa. E o seu corpo não foi purificado porque nele não havia impureza alguma. Mas levaram-no, com aqueles rituais que já são entre vós conhecidos e não importa repetir, com os milagres que estão escritos sobre a temeridade dos 
Et primo cantauerunt: In exitu Israel de Aegypto, domus Iacob de populo barbaro, sicut scribitur in psalmis ${ }^{207}$. Deinde, illud exponendo, ita canere ${ }^{208}$ coeperunt $^{209}$ :

In exitu Deum uidentis de tenebris, in exitu domus Dei de populis barbaris, Facta est, laudans Deum, sanctificatio eius, Deum uidens, potestas eius; Amaritudo omnis aufugit, fluuius ${ }^{210}$ iudicantis $^{211}$ conuersus est retrorsum, Angeli ecce ut arietes exultant, sancti gaudent sicut agni ouium.

Quare tu, mare, fugisti? Quare, Iordanis, retro conuerteris?

Quia transeuntes in terram promissionis de Aegypto, opus est omnem amaritudinem relinquere.

Et qui per humilitatem descendit, Dei benignitate ascendit;

Angeli ecce ut arietes exultant et sancti gaudent sicut agni ouium.

A facie Domini mota est uirginea terra, a facie, inquam, Dei diabolum subplantantis,

Qui ex se uirtutibus sicca conuertit in gratiarum stagna ${ }^{212}$ et arida in fontes gratiarum.

Nihil est enim boni in nobis quasi a nobis, sed omne donum est a Dei Gloria.

Ex nobis omnes sicci et aridi sumus, humectatio ${ }^{213}$ a Deo tribuitur.

Super hoc corpus misericordiae tuae et ueritatis tuae, nunc respice, Deus,

Nequando perfidi, illudentes ei, dicant: "Vbi est Deus Christianorum?"

Deus certe noster est altus et sublimis sicut et alia quae uult etiam hoc nunc faciet.

Simulacra hominum non sunt haec neque opus manuum hominum;

Illi enim ex argento et auro conficiunt ${ }^{214}$, Deus ex solis uirtutibus.

Haec nostra sine ore loquuntur, sine oculis optime uident,

Sine auribus audient, sine naribus odorabunt,

Sine manibus palpabunt, sine pedibus ambulabunt, sine gutture clamabunt;

Simulacra uero ipsorum omnia instrumenta sine actionibus habent,

Similes illis fient qui faciunt ea et qui confidunt in eis. [f1. 214]

Domus haec Deum uidens semper sperauit in Domino, adiutor eius et protector eius est.

207 domus Iacob de populo barbaro", sicut scribitur in psalmis (in psalmo $I$ )] et cetera $Q 208$ canere] cantare $Q 209$ ceperunt] ceperunt. Psalmus discipulorum $V 210$ fluuius] fluminis $J \mathbf{2 1 1}$ iudicantis] indicantis $N$; iocundantis $Q 212$ stagna] statuta $V 213$ humectatio] aucmentatio $V 214$ conficiunt] concipiunt $Q$; confidunt $V$ 
judeus. E em primeiro lugar cantaram: Quando Israel saiu do Egipto, a Casa de Jacob do meio de um povo bárbara, ${ }^{[257]}$ como está escrito nos salmos. De seguida, a modos de glosa, começaram a cantar assim:

Quando o que vê a Deus saiu das trevas, quando a casa do Senhor saiu das nações bárbaras,

Fez-se, louvando a Deus, a sua santificação, vendo a Deus, o seu poder,

Toda a amargura fugiu, o rio da condenação retrocedeu.

Vê, os anjos rejubilam como carneiros, os santos saltam de alegria como cordeiros.

Porque fugiste tu, ó mar? Porque retrocedeste, Jordão? ${ }^{[258]}$

Pois os que do Egipto passam à Terra da Promissão é preciso que deixem toda a amargura,

E o que pela humildade desceu, sobe pela bondade de Deus.

Vê, os anjos saltam de prazer como carneiros, e os santos alegram-se como cordeiros. ${ }^{[259]}$

Diante do Senhor comoveu-se a terra virgem, sim, diante de Deus que venceu o diabo,

Que converte em lagos de graça o que, de si, é seco de virtudes, e em fontes de graças o deserto.

Nada há de bom em nós enquanto nosso, mas todo o dom existe pela glória de Deus.

Por nós, somos todos secos e áridos, a irrigação é dada por Deus.

Sobre este corpo da tua misericórdia e da tua verdade vela, Deus, agora, Não vão os pérfidos, zombando dele, dizerem: ${ }^{[260]}$ Onde está o Deus dos cristãos!

Alto e sublime é o nosso Deus, fará isto agora como faz tudo o que quer.

Estas coisas não são imagens de homens nem obra das mãos dos homens. [261]

De ouro e prata as fabricam eles, Deus de virtudes só.

Sem boca, estas nossas falam, sem olhos vêem muito bem,

Sem ouvidos ouvem, cheiram sem nariz,

Apalpam sem mãos, sem pés andarão, sem garganta clamam.

Mas sem acção têm as imagens deles os recursos todos.

Sejam a elas semelhantes os que as fabricam e os que nelas confiam ${ }^{[262]}$ [f1. 214]

Esta Casa que a Deus vê sempre esperou no Senhor, ele é seu amparo e protector.

[257] S1 113:1

[258] S1 113:4,5

[259] S1 113:4

[260] S1 113:10

${ }^{[261]}$ S1 113:12

${ }^{[262]}$ S1 113:16 
Domus haec fortitudinis sperauit in Domino, adiutor eius et protector eius est;

Semper timens Dominum sperauit in Domino, adiutor eius et protector eius est. ${ }^{215}$

Dominus noster semper fuit memor nostri, semperque benedixit nobis;

Benedicat nunc huic domui suae eum uidentis, benedicat domui suae fortitudinis,

Benedicat et nobis qui timemus Dominum, discipulis cum apostolis;

Adiiciat Dominus benedictionem super in eum credentes et super discipulos eius.

Benedicti uos hodie a Domino, qui fecit caelum et terram;

Caelum omnium caelorum est habitaculum Domini spirituum, terra uero corpora filiorum bominum excipiet.

Non mortui Deo laudabunt Deum neque ullus sectans haec mundane,

Sed qui gratia uiuunt etiam si corpore sint mortui, benedicunt Dominum ex hoc nunc et usque in saeculum.

Detulerunt itaque cum hymnis et canticis corpus Mariae in uallem Iosaphat, confusis Iudaeis incredulis et omnibus discipulis Domini atque nobis angelis exultantibus et cum ipsis in uia pariter cantantibus ${ }^{216}$. Numquam ego eam reliqui, comitatus magno exercitu angelorum. Tamen ego animam associaui, Vriel, frater meus, corpus in sepulcro. Et cum ipsa anima, spoliato ${ }^{217}$ purgatorio, uersus sum in aurora eiusdem noctis in uallem Iosaphat. Et animam illam septies fulgentiorem Sole in ultima maiestate sua, tunc omnes apostoli uiderunt eam beatam.

Subito enim ut corpore egressa est, Deum uidere coepit uisione umquam amplius interrumpenda. In egressu uero uidebat Christum Hominem in uiatico quod in armariolo sui pectoris ${ }^{218}$ tamquam in pyxide quadam reseruatum ferebat. Stans autem in purgatorio et paradiso terrestri Deum, qui ubique totus est, uidebat, sed non Christi humanitatem. Reuersa uero anima eius ad corpus, uidit in pectore sui corporis adhuc Christum integrum existentem.

Stabat itaque anima illa beata comitata me et exercitu angelorum et animabus sanctorum multorum. Et post se duxerat magnam multitudinem animarum quas ex purgatorio extraxerat, ubi erant multi concentus ${ }^{219}$ angelorum, animarum sanctarum, animarum de purgatorio liberatarum et apostolorum atque aliorum discipulorum adhuc in uita mortali existentium. Neque anima Mariae caelos ascendit ante resurrectionem sed, ut dixi, uictrix reuersa est in uallem Iosaphat. Et

215 eius est ] eius est, domus haec fortitudinis $Q 216$ cantantibus] comitantibus $P$; canentibus $Q 217$ spoliato] spogliato $O 218$ pectoris] corporis $M 219$ concentus] conuentus $Q$; contentus $V$ 
Esta Casa, a casa da fortaleza, esperou no Senhor, é ele seu amparo e protector. $^{[263]}$

Sempre o que teme o Senhor esperou no Senhor, ele é seu amparo e protector.

Sempre de nós se lembrou o Senhor nosso, sempre nos abençoou. [264]

Abençoe agora esta sua Casa que o vê, abençoe a casa da sua Fortaleza.

Abençoe-nos também a nós, que o Senhor tememos, seus discípulos e apóstolos.

Multiplique o Senhor a bênção sobre aqueles que nele confiam e sobre os seus discípulos.

Sede hoje benditos, vós, pelo Senhor, que fez o Céu e a Terra.

o Céu de todos os Céus é habitação do Senhor dos espíritos, mas a terra há-de receber os corpos dos filbos dos homens. ${ }^{[265]}$

Não são os mortos para Deus que a Deus louvarão, nem nenhum dos que seguem as coisas do mundo.

Mas os que em graça vivem, mesmo se no corpo mortos, bendizem o Senhor desde agora e para sempre. ${ }^{[266]}$

E assim, entre cânticos e hinos, levaram o corpo de Maria para o vale de Josafat, estando os incrédulos judeus perturbados, e saltando de alegria todos os discípulos do Senhor e nós anjos, e cantando juntamente com eles pelo caminho. Acompanhado por um grande exército de anjos, nunca eu a deixei. Eu acompanhei a alma, Uriel, meu irmão, acompanhou o corpo no sepulcro. E, depois de o Purgatório haver sido espoliado, voltei ao vale de Josafat na manhã da mesma noite. E todos os apóstolos viram então aquela bem-aventurada alma sete vezes mais brilhante que o Sol no auge do seu brilho.

Logo que saiu do corpo, começou a ver a Deus numa visão que jamais deve ser interrompida. Mas, no percurso, via a Cristo-Homem no viático que levava guardado no sacrário do seu peito como numa espécie de píxide. Porém, enquanto se manteve no Purgatório e no Paraíso Terrestre, via a Deus, que está em todo o lado, mas não via a humanidade de Cristo. Mas quando a sua alma voltou ao corpo, no peito de seu corpo viu a Cristo, que ainda se mantinha intacto.

Estava, portanto, aquela bem-aventurada alma acompanhada por mim e por um exército de anjos e pelas almas de muitos santos. E tinha trazido atrás de si uma grande multidão de almas que libertara do Purgatório, onde estavam muitos coros de anjos, de santas almas, das almas libertadas do purgatório e os apóstolos e outros discípulos que viviam ainda nesta vida mortal. Nem a alma de Maria subiu ao céu antes de ressuscitar, mas, como disse, retornou vitoriosa ao vale de

[263] S1 113:17

[264] S1 113:20

[265] S1 113:22,24

[266] S1 113:26. 
ibi longo spatio allocuta est apostolos et sanctas mulieres ${ }^{220}$ qui etiam ibi coram ipsa, Petro missam more illius temporis celebrante, communicati sunt corpore et sanguine Domini Iesu Christi. Neque alio cibo illis diebus usi sunt. Sufficiebat eis esca et ille panis uiuus.

Stetit itaque corpus Mariae in sepulcro decem horis et mortuum quindecim horis. Circa igitur meridiem illius diei, Dominus Iesus Christus, dimisso caelo empyreo et caelesti habitaculo, descendit de caelis comitante eum Michaele principe cum omnibus angelis et cum omnibus quotquot erant in patria caelesti cum hymnis et canticis. Et omnes uiderunt Dominum Christum qui adueniens dixit astantibus: Pax uobis omnibus.

Et respiciens animam Virginis uultu iucundissimo, dixit: Estne tibi melius sine corpore et an magis uelles esse in corpore?

Respondit anima illa lingua angelica et Christus eam interrogauerat lingua humana, sic dicens: Gratia tua mihi semper bene fuit et numquam male. Sed nunc, quia fruor ${ }^{221}$ assidue tua diuinitate, optimam partem obtinui [f1. 215] et numquam mihi melius fuit. Quia tamen parti extra suum totum existenti non est omnimoda consolatio, libenter illud informarem, si tibi placeret, et in illo existens libentius tua diuinitate fruerer. Non quia fruitio intensior esset, sed quia frui in natura perfecta melius et optabilius est.

Tunc ait Dominus: "Ego te cunctis muneribus decoraui et nihil eorum quae fieri possent circa te et corpus tuum praetermisi nisi hoc quod a corpore separata es. Poteram certe te glorificare nulla morte interueniente. Id tamen nolui quia decretum firmum est et, multo magis, ne isti fratres mei mortem timerent aut alii de resurrectione dubitarent. Tamen sic a corpore separata es quod non uideberis fuisse separata". Et conuersus ad discipulos dixit iterum: Pax uobis.

Et ipsi responderunt: Bene aduenerit Dominus noster ${ }^{222}$ et Magister noster.

Et prae gaudio coeperunt omnes flere, praesertim Petrus. Dicebant ergo: Gratias agimus tibi, Magister et Domine, qui facis tot et tanta mirabilia solus.

Tunc Petrus dixit: Ecce omnes congregati iterum sumus neque quisquam deest ex nobis praeter filium perditionis. Et Iacobus Zebedaei adest in anima, alii sumus sicut prius mortales, sed in gratia tua confirmati. Ecce adsunt et multi qui tunc non erant. Ecce Paulum, quem de caelo uocasti et uas uere electionis nuncupasti. Ecce Barnabam, quem Spiritu tuo segregasti. Ecce Ignatium qui te semper in corde gerit. Ecce Dionysium, quem theologum futuri saeculi elegisti. Ecce multos alios quos tu melius nosti. Sciebas eos prout erant in te, non sciebas

$\mathbf{2 2 0}$ apostolos et sanctas mulieres] sanctis mulieribus primusque apostolis $Q \mathbf{2 2 1}$ Sed nunc quia fruor] Sed nunc quia fauor $I$; Sed quod fauor $V \mathbf{2 2 2}$ Bene aduenerit Dominus noster] Venias bene, Domine, et $Q$ 
Josafat. E aí confortou por longo tempo os apóstolos e as santas mulheres, que na sua presença, tendo Pedro celebrado Missa segundo o ritual daquele tempo, comungaram o corpo e o sangue do Senhor Jesus Cristo. E durante aqueles dias não se serviram de outro alimento. Bastava-lhes como alimento aquele Pão Vivo.

Portanto, o corpo de Maria permaneceu no sepulcro durante dez horas, e morto durante quinze. Cerca, pois, do meio dia daquele dia, o Senhor Jesus Cristo, tendo deixado o Céu Empíreo e a habitação celeste, desceu do Céu acompanhado pelo príncipe Miguel, com todos os anjos e com todos quantos estavam na pátria celeste, com hinos e cânticos. E todos viram a Cristo Senhor que, ao chegar, disse aos presentes: A paz esteja convosco.

E, olhando com ar felicíssimo a alma da Virgem, disse: Estás melhor sem o corpo ou preferias estar no corpo?

Aquela nobre alma respondeu na língua dos anjos, e Cristo tinha-a interrogado na língua humana, assim dizendo: Por graça tua, estive sempre bem e nunca mal. Mas, agora que fruo assiduamente da tua divindade, alcancei a melhor parte, [f1. 215] e nunca estive tão bem. Porque, contudo, não há consolação perfeita para a parte que está fora do seu todo, ${ }^{[267]}$ de boa vontade o enformaria, se fosse do teu agrado, e, vivendo nele, com mais gosto fruiria da tua divindade. Não que a fruição fosse mais intensa, mas porque é melhor e mais desejável fruir na natureza perfeita.

Eu, diz então o Senhor, ornei-te com todos os dons e nada omiti daquilo que pudesse ser feito relativamente a ti e ao teu corpo, a não ser isto, o facto de estares separada do corpo. Podia certamente glorificar-te sem a intervenção de morte alguma. Mas não quis isso porque o decreto está firmado e, muito mais, para que estes irmãos meus não temessem a morte ou duvidassem os outros da ressurreição. Todavia, foste de tal forma separada do corpo que não parece que hajas sido separada. E voltando-se para os discípulos, disse de novo: $A$ paz esteja convosco.

E eles responderam: Seja bem-vindo nosso Senhor e o nosso Mestre.

E todos, sobretudo Pedro, começaram a chorar de alegria. Diziam, pois: Damos-te graças, Mestre e Senhor, que, sozinho, fazes tantas e tão grandes maravilhas.

Eis que estamos todos novamente reunidos, disse então Pedro, e, com excepção do filho da perdição, nenhum de nós falta. E Tiago, filho de Zebedeu, está presente em espírito, os outros estamos vivos como antes, mas confirmados na tua graça. Estão ainda muitos que então não estavam. Eis Paulo, a quem do Céu chamaste e designaste vaso de verdadeira eleição. Eis Barnabé, a quem pelo teu Espírito segregaste. Eis Inácio, que te tem sempre no coração. Eis Dionísio, a quem escolheste como teólogo da geração futura. Eis muitos outros, a quem tu melhor

[267] "Nulla autem pars perfecta est a suo toto separata." Summa Teologiae, Prima Pars, Quaestio LXI, De productione angelorum in se naturae, art. 3. 
prout erant in se nisi nunc. Tu es Rex noster, tu Magister, tu Princeps. Da nobis uirtutem contra hostes tuos, fac ut te perpetuo laudare possimus.

Iesus autem dixit eis: Noui omnia quae pro me sustinuistis et adhuc maiora sustinebitis. Sed ad magna praemia peruenietis per magnos labores. Non

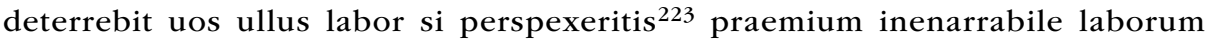
uestrorum. Vos estis fratres mei, eritis heredes regni Patris mei. Durate, usque in finem perseuerate. Petrum uicarium meum agnoscite et unusquisque in loco sibi deputato agat uiriliter et praesideat humiliter ${ }^{224}$. Semper docui uos, semper dixi uobis: Discite a me quia mitis sum et humilis corde. Benignus sum, benigni estote quia non est seruus maior domino suo neque discipulus maior magistro suo dum eius magister est. Qui mitior et humilior et benignior fuerit, hic toti Ecclesiae quandoque praesidebit. Totum mundum enim ad me conuertetis. Deinde ueniet filius iniquitatis et bestia uorax ab Oriente, cuius uox usque ad gentes Punicas protendetur et auferet magnam partem regni mei ${ }^{225}$. Sed paulatim, non subito propter peccata populi, regnum meum dilatabitur. Et Hiberi ${ }^{226}$ auersi conuersi alios quoque, unito regno eorum, ad me conuertent et omnes spurcitias eliminabunt et abominationem stantem in loco sancto dissipabunt. Et iterum Euangelium praedicabitur in uniuerso mundo. Et uicarium reformantem omnia transmittam, humilem, mitem, benignum et clementem. Et tunc uidebitur fructus labiorum ${ }^{227}$ uestrorum.

Tunc uocauit Paulum [fl. 216] et dixit ei: Quando spirabas ut taurus minas per nares tuas et gladium contra me ferebas euaginatum, quid tibi uidebaris? Aemulator maximus eras paternarum tuarum traditionum. Et credebas, contra me agendo, pro me agere. Ideo, ignorans, fecisti, ideo dignus uenia fuisti, ideo te de caelo in meridie uocaui et apostolum elegi. Ecce Stephanum, uide, gloriosum, quem lapidari tam uehementer optasti, cuius precibus alleuiatum est peccatum ignorantiae tuae. Esto constans, Paule, ut coepisti. Reposui enim tibi coronam iustitiae quam tibi reddam tamquam iustus iudex.

Et tu, Barnaba, docebis et annuntiabis populis tuis et aliis omnibus qui mecum et antea fuisti, sed ex discipulis te post ascensionem meam ad apostolatum assumpsi. Antea te uidi ut discipulum, nunc cerno ut dignum meum apostolum.

Et tu, Ignati, accede ad me. Ego enim sum amor tuus qui crucifixus quondam fui, sed nunc regnabo in aeternum. Et tu cum tuo amore uiues in saecula.

223 perspexeritis] prospexeritis $N P Q 224$ humiliter] humiliter ut semper docui $Q 225$ regni mei.] regni mei. [maumethanus] add. in marg. $O 226$ Hiberi] liberi $V 227$ labiorum] laborum $N Q$ 
conheces. Conhecia-los como eram em ti, não os conhecias como eram em si, a não ser agora. Tu és o nosso Rei, tu o nosso Mestre, tu o nosso Príncipe. Infunde em nós coragem contra os teus inimigos, faz que sempre te possamos louvar.

Sei tudo o que por mim sofrestes, disse-lhes Jesus, e suportareis coisas maiores ainda. Mas, por meio dos maiores trabalhos, alcançareis os maiores prémios. Nenhum trabalho vos assustará, se tiverdes em mente o inenarrável prémio dos vossos trabalhos. Vós sois meus irmãos, sereis herdeiros do Reino de meu Pai. Resisti, perseverai até ao fim. Reconhecei a Pedro como meu vigário e, no lugar que lhe for destinado, aja cada um corajosamente e administre com humildade. Sempre vos ensinei, sempre vos disse: Aprendei de mim que sou manso e bumilde de coração. ${ }^{[268]}$ Sou indulgente, sede indulgentes, porque o servo não é maior que o seu senhor, nem o discípulo maior que o seu mestre enquanto é seu mestre. $\mathrm{O}$ que for mais pacífico, mais humilde e mais indulgente, esse presidirá um dia a toda a Igreja. A mim convertereis o mundo todo. Depois, virá do Oriente o Filho da Iniquidade e a Besta Voraz cujo bramido se propagará até aos povos cartagineses e arrebatar-me-á uma grande parte do meu reino. Mas paulatinamente e não de repente, por causa dos pecados do povo, o meu reino será dilatado. E os desviados iberos, ${ }^{[269]}$ uma vez convertidos, depois de unido o seu reino, a mim converterão também os outros e eliminarão todos os dissolutos costumes e banirão a abominação que reina no Lugar Santo. E, de novo, o Evangelho será pregado em todo o mundo. E enviarei um vigário humilde, pacífico, benigno e clemente que reformará todas as coisas. E então se verá o fruto dos vossos lábios.

Chamou então Paulo [fl. 216] e disse-lhe: Quando, como um touro, espiravas ameaças pelas narinas e levavas contra mim a espada desembainhada, qual era a tua ideia? Eras o émulo máximo das tradições de teus pais. E acreditavas agir em meu favor, quando contra mim agias. Actuaste, por isso, ignorando, foste, por isso, merecedor de perdão, por isso te chamei do Céu em pleno meio-dia e te escolhi para apóstolo. Olha, vê Estêvão, glorioso, a quem tão violentamente decidiste que fosse lapidado, por cujas preces foi o pecado da tua ignorância tornado mais leve. Sê constante como começaste, Paulo. Reservei-te realmente a coroa de justiça que como justo juiz te darei.

E tu, Barnabé, ensinarás e anunciarás aos teus e a todos os outros povos, tu que também comigo estiveste antes, mas que depois da minha ascensão te assumi de entre os discípulos para o apostolado. Antes, vi-te como discípulo, agora, olho-te como meu digno apóstolo.

E tu, Inácio, vem junto de mim. Eu sou realmente o teu amor, eu que um dia fui crucificado, mas reinarei agora eternamente e tu, com o teu amor, viverás para sempre.

[268] Mt 11:29

[269] Presumivelmente Constantinopla acabada de cair em mãos turcas. 
Et tu, Dionysi, ala caeli, caelestia conscribes et ad caelos tandem ad me conscendes cum palma martyrii.

Et omnes pariter suauissimis uerbis allocutus est. Dixitque: Quid uobis uidetur de anima illa felici quae hac nocte a suo corpore separata fuit?

Responderunt omnes: Surrexisti tu, Domine. Surgat et Arca sanctificationis tuae. Mortem non merebatur, ab omni peccato immunis. Iustum saltem est ut caro illa, quae tua est, in aliam naturam non uertatur.

Tunc ait Dominus Michaeli et mihi: Associate cum his aliis animam istam quousque iuxta corpus suum fuerit.

Et subito ipse dixit: Reuniatur corpori innocenti innocens anima. Viuatque in aeternum dulcissima mater mea.

Et illico anima corpori, Dei uirtute, unita est. Et corpus dotibus gloriae decoratum est. Et de monumento diuina uirtute exiuit. Et nos Mausoleum aperuimus, quod uacuum omnibus apparuit. Maria uero tota gloriosa et fulgida iuxta Christum Dominum stetit uestita stola claritatis et aeternae immortalitatis. Et subito ut anima corpori unita est, Dominus clamauit: Veni ad me, Mater mea electa, ueni ad Filium tuum, Genitrix praedilecta, ueni, coronaberis.

Et tunc Michael mecum et cum aliis omnibus Matrem Dei adorauimus et ei tamquam Reginae nostrae perpetuam oboedientiam dedimus ${ }^{228}$, ita Michael pro omnibus nobis dicente ${ }^{229}$ :

Quod ante mundum sensibilem Deo promisimus, hoc tibi, Maria, hodie reddimus. Quod tempore conceptionis Dei exhibuimus, illud nunc ratificamus.

Te Mariam in nostram Reginam acceptamus et nos tuae maiestati submittimus.

Te Reginam caelorum ${ }^{230}$ appellamus, te Dominam angelorum ${ }^{231}$ iugiter praedicamus

Tibi omnes angeli et archangeli, tibi uirtutes et uniuersae potestates.

Tibi principatus et dominationes infinitis diebus deseruient et obsequentur.

Tibi Throni et Cherubin atque Seraphin humili uoce confitentur.

Omnes te nostram superiorem agnoscimus, omnes Dei nostri Genitricem adoramus.

Ex alia parte omnes Patres Testamenti Veteris, Abraham, Moyses ac Dauid annuentibus, clamare coeperunt ${ }^{232}$ : [f1. 217]

228 oboedientiam dedimus] oboedientiam exhibuimus $O$; reuerentiam exhibuimus $Q 229$ nobis dicente] nobis dicente: Canticum Michaellis in laudem Virginis $V \mathbf{2 3 0}$ Te Reginam caelorum] Te Reginam angelorum caelorumque $Q 231$ Dominam angelorum] Dominam nostram $Q 232$ clamare coeperunt:] clamare coeperunt: Patres ueteris testamenti laudant $V$ 
E tu, Dionísio, pena do céu, escreverás coisas celestes e, por fim, subirás ao céu, para junto de mim, com a palma do martírio.

E falou a todos do mesmo modo com palavras de muito afecto. E disse: Que pensais desta feliz alma que esta noite se separou do corpo?

Ressuscitaste tu, Senhor, responderam todos. Ressuscite também a Arca da tua santificação. Imune a todo o pecado, não merecia a morte. É justo até que essa carne, que é a tua, se não mude noutra natureza.

Com esses outros, diz então o Senhor a Miguel e a mim, associai-vos a esta alma enquanto não estiver junta a seu corpo.

Reúna-se a irrepreensível alma ao irrepreensível corpo, disse subitamente. Viva para sempre a minha dulcíssima Mãe.

E imediatamente, pelo poder de Deus, a alma se uniu ao corpo. E o corpo foi ornado com os dotes gloriosos e, pelo poder de Deus, saiu do túmulo. E nós abrimos o mausoléu, que a todos se mostrou vazio. Ora Maria, toda gloriosa e refulgente, ficou junto a Cristo revestida com a estola da claridade e da eterna imortalidade. E logo que a alma se uniu ao corpo, o Senhor exclamou: Vem a mim, Mãe, minha eleita, vem a teu Filho, predilecta, vem, serás coroada.[270]

E então Miguel comigo e com todos os outros adorámos a Mãe de Deus e prestámos-lhe obediência perpétua como nossa Rainha, dizendo Miguel em nome de todos nós:

O que a Deus prometemos antes do mundo sensível, isso te rendemos hoje a ti, Maria.

O que manifestámos no momento da concepção de Deus, aqui o ratificamos agora.

Aceitamos-te a ti, Maria, como Rainha nossa, à tua majestade nos submetemos.

A ti, todos os Anjos e Arcanjos, a ti, Virtudes e todas as Potestades.

A ti, Principados e Dominações te servirão e te obedecerão por infinitos dias

A ti, Tronos e Querubins mais Serafins te confessarão com voz melodiosa.

Todos te reconhecemos superior a nós, todos adoramos a Mãe do nosso Deus.

Do outro lado, todos os Padres do Antigo Testamento, com a anuência de Abraão, Moisés e David, começaram a proclamar: [f1. 217] 
Tu gloria Ierusalem, tu, Maria, laetitia Israel, tu honorificentia populi nostri.

O beati nos qui talem filiam habere meruimus, quam Deus in matrem sibi elegit.

O felices nos et ualde fortunatos qui in Maria nostra nos uidemus sublimatos.

Sicut lilium inter spinas sic Maria inter filias nostras.

Sicut malus inter ligna siluarum sic Iesus inter hominum filios.

Speciosus est forma prae filiis hominum, diffusa est gratia in labiis suis.

Sub umbra illius quem desideramus sedimus et fructus eius dulcis gutturi nostro.

Ioannes Baptista cum Iacobo decollato et Ioseph uiro Mariae, Anna et Ioachim, Simeone et Anna prophetissa, Stephano, primo martyre, et sanctis pueris innocentibus atque aliis qui post ortum Domini Iesu occubuerunt, ut Zacharia et Elizabeth, dicebant:

Ecce genus nostrum et caro nostra, ecce Domina et Regina nostra.

Ecce scandit ad aethera in aeternum regnatura.

Ipsa est gloria nostra, ipsa magnificentia nostrae ciuitatis.

Prosequamur eam laudibus, comitemur cantilenis dulcibus.

Pulchrae sunt genae eius sicut turturis, collum eius sicut monilia. ${ }^{233}$

Murenulas aureas faciemus ei uermiculatas argento.

Ecce tu pulchra es, Maria, et oculi tui columbarum.

Postea Petrus pro omnibus mortalibus locutus est:

Oleum effusum est, o Iesu, nomen tuum, ideo adolescentulae te dilexerunt. Introducis ecce, o rex, Mariam in cellaria tua, exultabit et laetabitur in te.

Inuenit quem diligit anima eius, tenet neque umquam dimittet.

Introduxit enim eum in domum matris et in cubiculum genitricis. 
Tu, glória de Jerusalém, tu, Maria, a alegria de Israel, tu, a honra do nosso povo. ${ }^{[271]}$

Ó bem-aventurados nós que tal filha merecemos ter, a quem Deus escolheu para sua Mãe.

Ó felizes nós e tão afortunados que em Maria, que é nossa, nos vemos tão exaltados.

Como a açucena entre os espinhos, assim é Maria entre as nossas filhas.

Como a macieira entre as árvores do bosque, assim é Jesus entre os filhos dos homens. ${ }^{[272]}$

Belo de aparência entre os filhos dos homens, em seus lábios se difundiu a graça. ${ }^{[273]}$

Sentámo-nos à sombra daquele a quem tínhamos desejado, e o seu fruto é doce à nossa boca. ${ }^{[274]}$

João Baptista, com Tiago degolado e José, marido de Maria, Ana e Joaquim, Simeão e a profetisa Ana, Estêvão, proto-mártir, e os santos meninos inocentes e outros que morreram depois do nascimento de Jesus, como Zacarias e Isabel, diziam:

Eis a nossa raça e a nossa carne, eis a Senhora e Rainha nossa.

Eis que sobe aos céus para reinar para sempre.

Ela é a nossa glória, ela a magnificência da nossa cidade.

Sigamo-la com louvores, acompanhemo-la com suaves cânticos.

As suas faces têm a beleza da rola, seu pescoço a dos mais ricos colares.

Nós lhe faremos gargantilhas de ouro com embutidos de prata. ${ }^{[275]}$

Como és formosa, Maria, e os teus olhos são pombas. ${ }^{[276]}$

Depois falou Pedro por todos os vivos:

É teu nome, ó Jesus, como um perfume derramado, por isso as jovens te amaram.

Eis que introduzes, ó Rei, Maria em teus aposentos, em ti exultará e se alegrará. ${ }^{[277]}$

Encontrou aquele que sua alma ama, segura-o e não o deixará.

Introduziu-o, pois, em casa de sua mãe e no quarto da que a gerou. ${ }^{[278]}$

\footnotetext{
[271] Jdt 15:10

[272] Cant 2:2

[273] S1 44:3

[274] Cant 2:3

[275] Cant 1:9,10

[276] Cant 1:14

[277] Cant 1:2,3

[278] Cant 3:4
} 
Inspicite regem Christum in diademate suo, coronauit eum mater sua.

Fulciamus eam floribus, stipemus malis, quia amore Filii languet.

Trahe nos quoque, Maria, post te, curremus in odorem unguentorum tuorum.

Omnes itaque apostoli et discipuli et fideles et sanctae mulieres atque uirgines in obsequium matris Dei deputatae, uidentes Mariam in tanta gloria et maiestate, ipsam adorauerunt. Et omnibus Iesus Filius eius atque ipsa benedicebant. Erat in cordibus singulorum laetitia ingens. Ex omni parte augebatur gaudium.

Tunc Iesus, uolens ut omnes conscenderent in montem Oliueti, quasi praecedens et iter ostendens matri suae, sic ad eam loqui coepit:

Veni de Libano, sponsa mea, ueni de Libano, ueni;

Surge, propera, amica mea et columba mea, propera, formosa mea, et ueni.

Iam hiems transiit, imber abiit et recessit;

Flores apparuerunt in terra nostra, tempus putationis aduenit.

Surge, propera, amica mea, propera, columba speciosa, et ueni;

Ostende faciem tuam decoram populo meo, sonet uox tua dulcis in auribus eius.

Multae sunt mibi reginae, multae concubinae, puellarum non est numerus;

Vna tu es, columba mea, perfecta mea, una Genitrici Trinitati electa, ${ }^{234}$

Vident te filiae Sion et beatissimam praedicant, omnes undique collaudant.

[f1. 218] Et quasi totum septimum capitulum ${ }^{235}$ Canticorum Dominus direxit in matrem suam. Nam et Salomon in spiritu praeuiderat et illum librum conscripsit non solum propter coniunctionem animae sanctae cum Deo neque solum propter coniunctionem capitis Christi cum Ecclesia, sed ultra hoc et praecipue propter coniunctionem Filii Dei cum Maria sua Genitrice dulcissima, quam praeuiderat futuram praesertim in hac die suae assumptionis ${ }^{236}$. Dominus ergo multa de Libro Canticorum induxit, loquens ad Mariam. Et ipsa ex eodem Libro locuta est respondendo sibi, quae facile a uobis inueniri possunt, et pastor ille inueniet et hymnos atque psalmos et cantica compilabit.

234 una Genitrici Trinitati electa] una Genitrix Trinitati electa $H P$; ueni, Genitrix, absolute electa $O Q 235$ capitulum] canticum $N$; caput $Q 236$ in hac die suae assumptionis] in hac die assumptionis $P$; in hac die et suae conceptionis $V$ 
Contemplai a Cristo Rei no seu diadema, sua mãe o coroou. ${ }^{[279]}$

Confortemo-la com flores, robusteçamo-la com frutos, porque desfalece com o amor do Filho. ${ }^{[280]}$

Leva-nos também contigo, Maria, correremos atrás das fragrâncias de teus perfumes. ${ }^{[281]}$

E, assim, todos os apóstolos, e discípulos, e fiéis, e santas mulheres e virgens escolhidas para honrarem a Mãe de Deus, ao verem Maria em tão grande glória e majestade, adoraram-na. E a todos abençoavam Jesus, seu Filho, e ela própria. No coração de cada um reinava uma grande alegria. O gozo aumentava de todo o lado.

Então Jesus, querendo que todos subissem ao Monte das Oliveiras, como que indo à frente a mostrar o caminho a sua Mãe, começou a falar-lhe deste modo:

Vem do Líbano, esposa minha, vem do Líbano, vem. ${ }^{[282]}$

Levanta-te, apressa-te, amiga minha e minha pomba. Apressa-te, formosa minha, e vem.

O Inverno passou já, a chuva cessou e foi-se.

Apareceram as flores na nossa terra, chegou o tempo da poda.

Levanta-te, apressa-te, amiga minha, apressa-te, pomba graciosa, e vem.

Mostra a meu povo tua graciosa face, soe tua doce voz aos meus ouvidos. ${ }^{[283]}$

São minhas muitas rainhas, tenho muitas concubinas, as donzelas não têm conta.

Tu és única, pomba minha, perfeita minha, única escolbida pela Geradora Trindade.

Vêem-te as filhas de Sião e proclamam-te bem-aventurada, por todo o lado te louvam todas. ${ }^{[284]}$

[f1. 218] E dirigiu a sua Mãe quase todo o capítulo sétimo do Cântico dos Cânticos. Pois também Salomão havia previsto em espírito e escreveu este Livro não só por causa da ligação da alma santa com Deus, nem só por causa da ligação da cabeça, que é Cristo, com a Igreja, mas, mais do que isso e sobretudo, por causa da ligação do Filho de Deus com Maria, sua Mãe dulcíssima, que previra aconteceria sobretudo neste dia da sua assunção. Muita coisa do Livro dos Cânticos, portanto, usou o Senhor falando a Maria. E ela, respondendo-lhe, serviu-se também do mesmo Livro, o que pode ser por vós facilmente encontrado e aquele Pastor encontrará e comporá, não só hinos e salmos, mas também cânticos.

\footnotetext{
[279] Cant 3:11

[280] Cant 2:5

[281] Cant 11:3

[282] Cant 4: 8

[283] Cant 2:10,14

[284] Cant 6:7,8
} 
Progrediebatur itaque Dominus per aera et Maria innixa supra dilectum suum procedebat. Nos angeli secundum gradus hierarchias et choros nostros in circuitu assistebamus. Animae sanctorum et iustorum similiter per aera sequebantur Regem et Reginam. Apostoli adhuc mortales et alii progrediebantur more humano, sed sine ulla lassitudine, sine ullo labore. In uia uero nunc nos angeli, nunc animae beatorum, nunc ipsi apostoli, ex eodem Libro Canticorum uerba sumentes, dicebant: "Quae est ista quae ascendit per desertum"? Quia de ualle Iosaphat ad montem Oliueti. Non enim adhuc ascendebat in caelum. Nam postea, ascendendo in caelum, dicebant: "Quae est ista quae ascendit de deserto et de uita mortalium sicut uirgula fumi ex aromatibus myrrhae et thuris et uniuersi pulueris pigmentarii"?

Alii dicebant: En lectulum Salomonis, id est, Mariam matrem ueri Salomonis, Christi. Sexaginta fortes (hoc est, perfectissimi fortes, quia ibi denarius ducitur per senarium, qui est numerus primus perfectus, ut homines scribunt) sexaginta, igitur, fortes lectulum Salomonis ambiunt ex fortissimis Israel, quia nos primi et fortissimi omnium creaturarum aderamus in defensionem Virginis et in uita et in morte et dum ad sepulcrum deportaretur), omnes tenentes gladios et ad bella doctissimi (Dimicauimus enim contra Luciferum a principio et contra daemones et malos homines saepissime). Vniuscuiusque ensis super femur suum (quia uirtus et fortitudo data est unicuique nostrum, maior et minor secundum diuersitatem naturarum nostrarum), propter timores nocturnos (hoc est, ad repellendum ab amicis Dei $^{237}$ et filiis lucis timores qui concitantur a noctibus principibus ${ }^{238}$ tenebrarum).

Alii dicebant: Quae est ista quae progreditur quasi aurora consurgens, pulchra ut Luna, electa ut Sol, terribilis ut castrorum acies ordinata?

Alii dicebant: Egredimini, filiae Sion, et uidete regem Salomonem in diademate quo coronauit eum mater sua.

Et inter alios Thomas, non dubius tunc sed fidelis, clamauit ad Dominam dicens: Tu ad felicia regna, o mater Dei, progrederis. Relinque aliquid pro signo amoris tuis fidelibus ${ }^{239}$.

Maria dixit: Annulum meum quo me desponsauit Ioseph, uir meus, cum omnibus uestimentis meis et parte capillorum meorum ob deuotionem fidelium reliqui. Magdalena ${ }^{240}$ de lacte quo Deum nutriui et de sanguine Filii mei quem pariter collegimus et praeputium, id est, pelliculam circumcisam ${ }^{241}$ et pelliculam in qua natus est Filius meus Iesus apud se conseruat. Et tu, Thoma, accipe cinctorium renum meorum. Ecce illud mecum ex industria detuli ut tu, qui dubius

$237 \mathrm{ab}$ amicis Dei] ab amicis (sup. ras. diei) $O$; ab inimicis Dei $J$ ( $M$ add. sup. lin. inimicis) $Q V$ 238 a noctibus principibus] a noctibus et principibus $O$; a noctibus id est a principibus $P$; a principibus $Q 239$ amoris tuis fidelibus] amoris tui fidelibus $N P 240$ reliqui. Magdalena] reliqui Magdalenae $O P 241$ circumcisam] circumcisam preputii $Q$ 
E assim avançava o Senhor pelos ares e Maria progredia apoiada sobre o seu dilecto. Nós, anjos, acompanhávamos, rodeando-os segundo as categorias, as hierarquias e os nossos Coros. As almas dos santos e dos justos seguiam igualmente pelos ares o Rei e a Rainha. Os apóstolos ainda vivos, e outros, avançavam ao modo humano, mas sem nenhum cansaço, sem qualquer esforço. E, no percurso, ora nós anjos, ora as almas dos bem-aventurados, ora os próprios apóstolos, tirando as palavras do mesmo Livro dos Cânticos, dizíamos: Quem é esta que sobe pelo deserto? Porque vinha do vale de Josafat para o Monte Oliveti. De facto ainda não subia ao Céu. Pois a seguir, quando subia ao Céu, diziam uns: Quem é esta que sobe do deserto e da vida dos homens como suave coluna de fumo de aromas de mirra e de incenso e de todos os perfumes dos mercadores? [285]

Outros diziam: Eis a liteira de Salomão, isto é, Maria, a mãe do verdadeiro Salomão, Cristo. Sessenta valentes (isto é, valentes fortíssimos, porque aí o número dez multiplica-se pelo número seis, que é o número primo perfeito, como escrevem os homens; portanto) sessenta valentes dos mais fortes de Israel escoltam a liteira de Salomão (porque nós, as primeiras e as mais fortes de todas as criaturas, estávamos presentes para defender a Virgem não só em vida como também na morte e até ser levada ao sepulcro), todos munidos de espadas e exercitados no combate. [286] (Lutámos, de facto, contra Lúcifer, no princípio, e contra os demónios e os maus homens, muitíssimas vezes). A espada de cada um sobre sua coxa (porque a coragem e a força foram dadas a cada um de nós, mais ou menos, segundo a diversidade das nossas naturezas), por causa dos perigos nocturnos (isto é, para afastar dos amigos de Deus e dos filhos da luz os perigos que são causados de noite pelos príncipes das trevas).

Quem é esta, diziam outros, que avança como a aurora que surge, bela como a Lua, brilhante como o Sol, temível como um exército formado para a batalha? ${ }^{[287]}$

Saí, filhas de Sião, diziam outros, e vede o rei Salomão com o diadema com que o coroou sua mãe. ${ }^{[288]}$

E, entre outros, Tomé, não incrédulo então, mas fiel, chamou por Maria dizendo: Tu, Mãe de Deus, encaminhas-te para os reinos da felicidade. Deixa alguma coisa a teus fiéis como sinal de amor.

Por causa da devoção dos fiéis, disse Maria, deixei o anel com que José, meu marido, me desposou, com todos os meus vestidos e com parte dos meus cabelos. Madalena guarda consigo do leite com que alimentei a Deus e do sangue de meu Filho, que colhemos juntas, e o prepúcio, isto é, a porção da pele da circuncisão, e a película em que o meu Filho Jesus nasceu. E tu, Tomé, recebe a faixa com que me cinjo. Trouxe-a propositadamente comigo para que tu, que

[285] Cant 3: 6

[286] Cant 3:7, 8.

[287] Cant 6:9

[288] Cant 3:11 
uocaberis, fidem Domini plus aliis credens, usque in superiorem Indiam amplies et augmentes. [f1. 219]

Et accedente illo in montem Oliueti, Maria suis propriis manibus cingulum porrexit Thomae et dimisit ei pleno gaudio et gratiarum actione.

Dominus itaque Iesus in aere satis uicino terris cum Maria matre in medio angelorum et sanctarum animarum stans, Petrum et unumquemque apostolorum allocutus est sicut et in die Ascensionis suae. Et Maria eodem modo. Et uale dicentes omnibus mortalibus, paulatim ascendebant in caelum, apostolis et uirginibus, discipulis atque sanctis mulieribus cum gaudio inspicientibus et prae nimia laetitia flentibus et lacrimantibus, nobis autem angelis psallentibus et cantantibus. Et postquam paulatim procedendo, ad altissimam aeris partem ultra quam ab apostolis uideri non poteramus, applicuimus citissime. Deinde transiuimus omnes caelos et ad empyrium caelum peruenimus ubi Christus Dominus cum sua Genitrice uiuit et regnat ${ }^{242}$ in saecula saeculorum. Amen.

Nunc, dilectissime, poteris intelligere et conscribere matris Domini assumptionem et errores euitare. Noluit Dominus resurrectionem Mariae differre, sicut suam, in tertium diem, quia non oportebat probare ueritatem mortis eius neque resurrectionis neque prophetiae Ionae adimpletionis. Mansit ergo in sepulcro corpus eius horis decem, mortuum uero horis quindecim, quas horas pro diebus aliqui computant, ut uos in reuelationibus beatae Brigidae deuotissimis habetis. Scito sibi fuisse reuelatum hoc eodem modo, sed ille qui scripsit cogitauit intra se quomodo ipsa citius Christo surrexisset et dixit: "Debent esse quindecim dies, non quindecim horae". Et rationem apposuit. Corrigatur itaque in ea parte reuelatio sanctissimae Christi sponsae Brigidae. Causa erroris non fuit ipsa, sed confessor eius qui uoluit plus sapere quam oportuit, credens eam male intellexisse. Similiter corrigatur reuelatio alterius deuotissimae uiduae sanctae Elisabeth, de tertio ordine patris tui, cuius etiam confessor in numero dierum, pie credens eam male intellexisse, errauit. Ipsa enim dixit Mariam resurrexisse hora quartadecima cum dimidia et plus. Et ipse dixit ex suo sensu quod fuerunt dies quadraginta. Qui tamen confessores non perierunt tamen aliquantulum uapulauerunt.

Neque anima Beatae Virginis ante resurrectionem eius ascendit in caelum. Eadem die a corpore separata, eadem etiam die corpori unita fuit. Quod etiam confessor beatae Elisabeth scribit, Mariam anno integro et tot diebus quot ab 
serás chamado incrédulo, ao acreditares mais que os outros, alargues e aumentes a fé do Senhor até à Índia Superior. [f1. 219]

E ao chegar ao Monte Oliveti, Maria entregou a Tomé com suas próprias mãos a faixa e deixou-o pleno de felicidade e de acção de graças.

E, assim, estando Jesus com sua Mãe entre os anjos e as santas almas um pouco elevado acima da Terra, confortou Pedro e cada um dos apóstolos, como no dia da sua Ascensão. E Maria fez o mesmo. E dizendo adeus a todos os vivos, subiam paulatinamente ao céu enquanto apóstolos e virgens, discípulos e santas mulheres olhavam e choravam e derramavam lágrimas de muita alegria, e nós anjos salmodiávamos e cantávamos. E depois de avançarmos paulatinamente, aproximámo-nos muito rapidamente do ponto mais alto do Céu, para lá do qual não podíamos ser vistos pelos apóstolos. Depois, atravessámos todos os Céus e chegámos ao Céu Empíreo, onde Cristo Senhor vive e reina pelos séculos dos séculos. Ámen.

Agora, dilectíssimo, poderás compreender e descrever a Assunção da Mãe do Senhor e evitar erros. Não quis o Senhor adiar para o terceiro dia a ressurreição de Maria, como adiou a sua, porque não era preciso provar a verdade da sua morte e da sua ressurreição nem o cumprimento da profecia de Jonas. O seu corpo permaneceu, pois, no sepulcro dez horas, mas morto permaneceu quinze, horas que alguns contaram por dias, como tendes nas devotíssimas revelações da bem-aventurada Brígida. Fica a saber que deste mesmo modo the foi revelado, mas aquele que escreveu pensou consigo como teria ela ressuscitado mais depressa do que Cristo, e disse: "Devem ser quinze dias, não quinze horas.” E acrescentou razões. Corrija-se, por isso, neste ponto a revelação da santíssima esposa de Cristo, Brígida. Não foi ela a causa do erro, mas o seu confessor, que pretendeu saber mais do que convinha, crendo que ela havia entendido mal. ${ }^{[289]}$ Corrija-se do mesmo modo a revelação de outra devotíssima viúva, santa Isabel, da Ordem Terceira de teu Pai, cujo confessor, crendo também piedosamente que ela entendeu mal, errou no número de dias. Ela disse, de facto, que Maria havia ressuscitado à décima quarta hora e mais meia. E ele disse, por raciocínio seu, que foram quarenta dias. Estes confessores, contudo, não morreram, mas de algum modo foram castigados.

Nem a alma da bem-aventurada Virgem subiu ao céu antes da sua ressurreição. Separada do corpo num dia, foi também nesse mesmo dia unida ao corpo. Também o que escreve o confessor da bem-aventurada Isabel, que Maria sobreviveu

[289] Cum essem in valle Iosaphat, ad sepulchrum gloriose virginis orans, apparuit michi eadem virgo, choruscans splendore nimio dicens: 2 "Attende, filia! Ego, postquam filius meus ascendit ad celos, vixi in mundo per XV annos et tanto tempore plus, quantum est de festo Ascensionis eiusdem filii mei vsque ad mortem meam. 3 Et tunc mortua iacui in isto sepulchro per XV dies. Deinde fui assumpta in celo cum infinito honore et gaudio. S. BIRGITTA OF SWEDEN, Reuelationes, Book VII, Chapter 26, Edited, Birger Bergh. http:// www.umilta.net/bk.html. 
ascensione Domini usque ad eius assumptionem fluxerunt superuixisse, male scribitur quia sic ei reuelatum fuit annis integris et tot diebus de quibus annis iam tibi indicaui.

Apostoli uero pleni gaudio et laetitia reuersi sunt in Ierusalem cum mulieribus sanctis, sed non cum Maria matre Iesu et esurire coeperunt et in domo Lazari in Ierusalem pariter cenauerunt et uerbo Domini insistebant. Et facta ultima synodo, et multis quaestionibus absolutis circa ritus gentilium et circa caerimonias et onera Legis, et ostenso quod gentes non erant subiciendae dictis oneribus Legis et postea, dum apostoli diuiderentur per totum orbem terrarum, afflati Spiritu Sancto promulgauerunt et declarauerunt nulli ex tunc hominum neque Iudaeo neque Graeco licitum esse circumdidi [f1. 220] aut legalia seruare, quia illa figura erant Nouae Legis et umbra quae, adueniente rerum ueritate, euanescere debebant.

Firmiter igitur tenendum est et nullo modo dubitandum circumcisionem et alias caerimonias Iudaicas perniciosas esse omni homini, Iudaeo primum ac Graeco. Conuersis tamen ex Iudaeis in pricipio illud illicitum non fuit neque prohibitum, sed tandem, Spiritu Sancto instigante, etiam Iudaeis illud fuit omnino prohibitum. Apostolis namque tamquam Iudaeis proprios ritus dimittere nefas uidebatur. Sed instructi Spiritu Sancto, tandem in ultima ipsorum diuisione omnes apostoli simul decreuerunt et ita determinauerunt quod nulli esset ex tunc licitum circumcidi aut legem caerimoniarum sub praecepto obseruare aut ullam spem in sacramentis Legis Veteris ponere. Exinde diuisi sunt apostoli per uniuersas prouincias orbis ${ }^{243}$. Et quilibet in sua prouincia occubuit, nisi quod Ioannes ab Effeso fuit translatus in paradisum et Petrus ac Paulus simul Romae interfecti sunt una die. Petrus quidem in ipso loco ubi tu oras. Prope illum, ut notum est, fuit cruci capite deorsum affixus. Paulus uero eadem die, in loco quem uos Tres Fontes dicitis, fuit decollatus. Et uerum est quod caput eius abscisum tres saltus fecit clamando "Iesus", prout uestri scribunt. Locum illum pro electo atque deuotissimo habeatis. Paulus enim est uas electionis diuinae et lumen fidei Christianae. In signum trium saltuum et exclamantium tres fontes sunt uerum indicium ${ }^{244}$.

Tunc ego, qui diu tacueram, dixi: Domine mi, quod canticum cantabatis Maria simul in caelum ascendente cum dilecto Filio suo?

Et ille respondit: Scribe illud et conserua. Tale fuit: ${ }^{245}$

Egressa est uirga de radice Iesse, et flos de radice eius conscendit.

Ecce ipsamet iterum progreditur sicut uirgula fumi myrrhae et thuris.

243 per uniuersas prouincias orbis] per mundum in prouincias orbis $Q \mathbf{2 4 4}$ Paulus enim est uas (...) tres fontes sunt uerum indicium] Paulus enim est uas electionis diuinae et lumen fidei Christianae insigne. Trium saltuum et exclamantium tres fontes sunt uerum iudicium. INPV 245 Tale fuit.] Tale fuit. Canticum angelorum Maria ascendente $V$ 
um ano inteiro e tantos dias quantos decorreram da Ascensão do Senhor até à sua Assunção, está erradamente escrito, porque assim lhe foi revelado por anos inteiros e tantos dias, anos de que já te falei.

Os apóstolos, então, cheios de contentamento e alegria voltaram a Jerusalém com as santas mulheres, mas não com Maria, Mãe de Jesus. E começaram a sentir fome e jantaram juntos em Jerusalém, em casa de Lázaro, e persistiam na palavra do Senhor. E concluído o último Sínodo, e solucionadas muitas questões relativas aos ritos dos gentios e às práticas religiosas e às obrigações legais, e dado a conhecer que os gentios não deviam ser submetidos às referidas obrigações da Lei e depois, enquanto os apóstolos se não distribuíam por todo o orbe da Terra, inspirados pelo Espírito Santo, promulgaram e tornaram conhecido que, desde então, a nenhum homem, nem grego nem judeu, seria lícito ser [f1. 220] circuncidado ou observar os preceitos legais, porque esses eram figura da Nova Lei e sombra que, com a chegada da verdade das coisas, deviam desaparecer.

Deve, pois, ter-se por seguro e de modo nenhum se deve duvidar de que a circuncisão e outras práticas religiosas judaicas são funestas para todo o homem, para o judeu, primeiro, e também para o grego. No princípio, contudo, isso não foi ilícito nem proibido aos judeus convertidos, mas, por fim, sob a acção do Espírito Santo, foi isso totalmente proibido, mesmo aos judeus. Na verdade, aos apóstolos, enquanto judeus, afigurava-se impiedade abandonarem as práticas religiosas próprias. Mas, instruídos pelo Espírito Santo, por fim, na sua última separação, todos os apóstolos em uníssono decidiram e determinaram que, a partir de então, a ninguém seria lícito circuncidar-se ou observar sob preceito a norma ritual, ou depositar esperança alguma nos mandamentos da Velha Lei. Desde então os apóstolos dividiram-se por todas as províncias do orbe. E cada um repousou na sua província, menos João, que foi transladado de Éfeso para o Paraíso, e Pedro e Paulo, que foram mortos em Roma no mesmo dia. Sim, Pedro, no lugar em que tu oras. Perto dele, como é sabido, foi preso à cruz de cabeça para baixo. E Paulo foi degolado no mesmo dia, no lugar a que chamais Três Fontes. E é verdade que a sua cabeça cortada deu três saltos clamando "Jesus", conforme escrevem os vossos. Tende esse lugar como lugar de excepção e de muita devoção. Paulo, na verdade, é vaso de eleição divina e facho da fé cristã. As três fontes são a prova verdadeira em sinal dos três saltos e das exclamações.

Meu senhor, disse então eu que me havia mantido calado por muito tempo, que cântico cantáveis quando Maria subia ao Céu juntamente com seu dilecto Filho?

Escreve-o e guarda-o, respondeu ele. Foi este:

Do tronco de Jessé surgiu um rebento, de sua raiz brotou uma flor. ${ }^{[290]}$

Eis que ela de novo avança como suave coluna de fumo de mirra e incenso. ${ }^{[291]}$

[290] Is $1: 1$.

[291] Cant 3:6. 
Haec est Maria, omni odore plena, sola semper benedicta.

Haec est unica Mater Verbi Dei, Genitrix omnium plasmatoris.

Haec post Filium in terris remansit et merita meritis auxit.

Plus omnibus ipsa sola meruit, plus omnibus generi suo profuit. ${ }^{246}$

Multi congregauerunt meritorum diuitias, ipsa supergressa est uniuersas.

Ecce quilibet angelorum chorus mille millia defert cados.

Thesaurus est magnus et incomparabilis, ingens et inexhauribilis.

Agnouit boc et laetata est Sion et filiae Iudae exultauerunt.

Meritis igitur innumeris iam peractis ${ }^{247}$, appropinquauit hora suae mortis.

Conuenerunt ${ }^{248}$ omnes apostoli, palmam de paradiso ego Gabriel attuli.

Omnes eam commendabant et singillatim eius uirtutes recitabant.

Paulus positus in loco Iacobi, cuius tamen anima erat ibi.

Gratias omnibus egit, unicuique seorsum uale dixit.

In lectulum suum ipsa sospes ${ }^{249}$ conscendit, Dei uirtute anima a corpore recessit.

Non solum dolore caruit, sed etiam in gaudio exultauit.

In paradiso Enoch et Eliam uisitauit et eos qui erant in poenis liberauit. [f1. 221]

Corpus suum apostoli simul cum angelis ferebant cum hymnis et canticis.

Gens perfida eos temere aggreditur et tamquam caeca ${ }^{250}$ in terra prosternitur.

Sola communione uiuunt credentes neque esuriunt aut sunt sitientes.

Corpus sindone inuoluitur et sepulcro nouo clauditur.

Diluculo felix anima reuertitur, ab angelis et iam captiuis associatur.

Verbum Homo de caelo descendit, omnes beatos secum duxit.

Animam sanctam ${ }^{251}$ alloquitur, pax consueta iterum proponitur.

Exultant omnes uiso Domino, iubilant in Deo Salutari suo.

Decem iam horis iacuerat et quindecim anima sine corpore fuerat.

Intrat cum angelis in monumentum, illico factum est magnum portentum:

Corpori felix anima unitur et corpus subito glorificatur.

Ex sepulcro laeta egreditur, ab omnibus Maria immortalis cernitur.

Adorant eam omnes angeli, uenerantur omnes apostoli.

De ualle ad montem deducitur, laeta nimis progreditur.

Per aera Dominus procedebat ${ }^{252}$, Maria sibi innixa pergebat.

Nos angeli assistebamus et haec omnia uidebamus.

Oboedientiam proni Mariae dedimus eique seruire in aeternum promisimus.

Ecce nunc iubilando ascendimus, apostolos in terris relinquimus.

Omnes in nos suspiciunt, omnes ecce in caelum prospiciunt.

Benedicamus Patri et Filio, benedicamus et Spiritui Sancto,

Laudemus Deum trinum et unum, glorificemus eum in aeternum.

246 profuit] placuit $O 247$ peractis] partis JOP; paratis $V 248$ conuenerunt] connumerauerunt $I$ 249 sospes] hospes $Q 250$ caeca] cera $P 251$ sanctam] laetam $N 252$ procedebat] praecedebat $Q$ 
Esta é Maria, cadinho de todo o perfume, única sempre bendita.

Esta é Mãe única do Verbo de Deus, Progenitora do Criador de todas as coisas.

Esta permaneceu na Terra depois do Filho e com méritos aumentou os méritos. Mereceu só ela mais que todos, mais que todos foi proveitosa a seu povo.

Muitos acumularam riquezas de merecimentos, ela superou-as a todas. ${ }^{[292]}$

Eis que cada Coro de anjos leva mil milhares de presentes.

É grande e incomparável esse tesouro, incomensurável e inexaurível.

Sião soube disso e alegrou-se, exultaram as filhas de Judá. ${ }^{2293]}$

Consumados, pois, os incontáveis méritos, aproximou-se a hora da sua morte, Convergiram todos os apóstolos, do Paraíso trouxe eu, Gabriel, a palma,

Todos a elogiavam e um a um suas virtudes enumeravam.

Paulo foi posto no lugar de Tiago, cuja alma, contudo, estava lá.

A todos agradeceu, a cada um individualmente disse adeus.

Feliz, subiu ela a seu leito, pelo poder de Deus a alma do corpo se separou.

Não foi só isenta de dor, mas exultou também de alegria.

Henoc e Elias no Paraíso visitou, libertou os que em penas estavam.[f1. 221]

Entre hinos e cânticos os apóstolos e os anjos seu corpo levavam.

Gente pérfida ousadamente os ataca e como cega é prostrada por terra.

Só da comunhão vivem os crentes e não têm fome ou estão sequiosos.

Em fina mortalha é o corpo envolto e em sepulcro novo é depositado.

Pela manhã, feliz torna a alma, pelos anjos e já pelos cativos é acompanhada.

Desce do Céu o Verbo-Homem, traz consigo todos os bem-aventurados.

A alma santa saúda, de novo deseja a paz costumada.

Todos exultam com a visão do Senhor, jubilam em Deus, seu Salvador.

Tinha jazido por dez horas já, e a alma por quinze estivera sem corpo.

Entra com os anjos no monumento, logo acontece grande portento.

Ao corpo se une a alma bendita e logo o corpo se glorifica.

Do sepulcro sai alegremente, por todos Maria é vista imortal.

Todos os anjos a adoram, veneram-na os apóstolos todos.

Do vale é levada ao Monte, avança sumamente alegre.

Pelo ar progredia o Senhor, em si apoiada prossegue Maria.

Nós, os anjos, assistíamos e todas estas coisa víamos.

Prostrados, prestámos obediência a Maria, prometemos para sempre servi-la.

Eis que agora subimos em júbilo, os apóstolos na Terra deixámos.

Todos olham de baixo para nós, todos perscrutam o céu.

Bendigamos o Pai e o Filho, bendigamos o Espírito Santo,

Louvemos a Deus Trino e Uno, glorifiquemo-lo para sempre.

[292] Prov 31:29

[293] S1 96:8. 
Dixit angelus: Quotidianae et indefessae sunt uoces nostrae et cantus nostri ${ }^{253}$. Maria est gloria humani generis et magnum decus angelorum et omnium creaturarum honor et splendor.

Tunc ego: Mi Domine, quem situm seruat Mater et ex qua parte assistit Filio suo?

Respondit angelus: Maria non proprie stat a dextris aut sinistris Filii sui, sed ante ipsum ita quod semper sese mutuo inspiciunt. Caputque Domini paulo altius est capite Mariae et illo modo etiam ascendebant de ualle in montem et de monte in caelum. Sicque incedunt per empyrium caelum ut numquam uultum suum uultu matris Dominus auertat.

Dixi iterum: Euangelium promiseras olim Lucae te de hac assumptione mihi reuelaturum.

Respondit: Recte dicis. Tunc fuit conscriptum, sed non fuit tempus tunc praedicandi gloriam Matris quando uix suaderi poterat gloria Filii. Euangelium uero tale est, secundum Lucam: Impleti sunt dies Mariae ut transiret de hoc mundo ad Filium suum unigenitum. Et missus est ad eam cum palma uictoriae ante feretrum deferenda Gabriel angelus. Quae cum non sibi ignota neque ingrata audiuisset, turbata nullo modo est. Desiderabat enim relinquere mundum et semper esse cum unigenito Filio. Affuit statim discipulus ille quem diligebat Iesus et cui de cruce dixerat: Ecce mater tua. Affuit et Petrus cum omnibus apostolis et potioribus discipulis. Erant ibi quoque Maria Magdalenae et Maria Iacobi et mater filiorum Zebedaei. Aderant et plures uirgines atque sanctae mulieres. Vnusquisque uerba sua protulit et in laudem Virginis matris direxit. Et unicuique ipsorum humiliter respondit Maria et omnibus pariter [f1. 222] benedixit. In lectulum coram omnibus conscendit et anima cum ingenti gaudio a corpore suo discessit. Ad inferos et paradisum adueniens, quotquot amicos in poenis uiderat eripuit. Corpus in uallem Iosaphat delatum est et, sindone munda inuolutum, positum est in monumento nouo in quo nondum quisquam positus fuerat. Diluculo anima reuersa est ad apostolos. Tunc Dominus Iesus cum omni militia caelestis exercitus in maiestate sua uenit. Dixit omnibus: Pax uobis. Gauisi sunt ualde discipuli, uiso desiderato Domino. Felicem animam alloquitur omnibusque discipulis benedixit, animam corpori iterum coniungi iussit. Surgit uere Maria et prodiit de monumento tota decora nimis, progreditur cum Domino per aera ad Montem Oliuarum, comitantibus angelis et animabus iustis. Thome balteum dimittit et omnibus suspicientibus in caelum ante faciem Filii sui assumitur. Et sedet in gloria maiestatis. Regressi ${ }^{254}$ sunt Hierosolymam apostoli cum discipulis et sanctis mulieribus gratias agentes de omnibus quae audierant et uiderant, annuntiantes magnalia Dei in omnes gentes. Finis ${ }^{255}$

253 Quotidianae et indefessae sunt uoces nostrae et cantus nostri.] Quotidiani et indefessi sunt cantus nostri $Q 254$ Regressi] Reuersi $N Q$; Egressi $I J V 255$ Finis] Finis. Epilogatio adimplendorum ante et tempore pastoris $V$ 
Quotidianas e indefectíveis são as nossas vozes e os nossos cânticos, disse o anjo. Maria é glória da raça humana e grande ornamento dos anjos e honra e esplendor de todas as criaturas.

Meu senhor, perguntei eu então, que lugar ocupa a Mãe e de que lado está de seu Filho?

Maria, respondeu o anjo, não está propriamente à direita ou à esquerda de seu Filho, mas diante dele, de tal modo que se vêem sempre mutuamente. A cabeça do Senhor está um pouco mais alta que a de Maria e, desse modo, subiam também do vale ao monte e do monte ao Céu. Assim andam pelo Céu Empíreo, de modo que nunca o Senhor desvia sua face da face da Mãe.

No passado, disse eu de novo, havias prometido a Lucas que me revelarias um Evangelho sobre esta assunção.

Dizes bem, respondeu. Foi então escrito, mas não foi então o tempo para anunciar a glória da Mãe, quando mal podia defender-se a glória do Filho. Ora o Evangelho segundo Lucas é este: Completaram-se os dias de Maria passar deste mundo para junto de seu Filho Primogénito. E foi enviado até ela o anjo Gabriel com a palma da vitória que devia ser levada à frente do féretro. Ouvindo estas coisas, que lhe não eram desconhecidas nem desagradáveis, não se perturbou nada. Desejava, de facto, deixar o mundo e estar sempre com seu Filho Unigénito. Chegou imediatamente aquele discípulo que Jesus amava e a quem, da cruz, dissera: Eis a tua Mãe! Chegou também Pedro com todos os apóstolos e os discípulos mais importantes. Estavam lá também Maria Madalena e Maria, mãe de Tiago, e a mãe dos filhos de Zebedeu. Estavam também muitas virgens e santas mulheres. Expressou cada um a sua opinião e orientou-a para os louvores da Virgem Mãe. E a cada um deles respondeu Maria com humildade e a todos igualmente [f1. 222] abençoou. Subiu na presença de todos a seu leito e, com grande alegria, a alma saiu de seu corpo. Ao chegar aos infernos e ao Paraíso, libertou quantos amigos tinha visto em penas. O corpo foi levado para o vale de Josafat e, envolvido num lençol por estrear, foi depositado num túmulo novo onde ninguém havia sido depositado ainda. Pela manhãzinha, a alma voltou para junto dos apóstolos. Veio então o Senhor Jesus na sua majestade com toda a milícia do exército celeste. A paz esteja convosco, disse a todos. Os discípulos ficaram cheios de muita alegria ao verem o Senhor, que era esperado. Saudou a feliz alma e abençoou todos os discípulos e ordenou que a alma se unisse de novo ao corpo. Maria ergueu-se e, extremamente bela, saiu do túmulo, pelo ar avançou com o Senhor em direcção ao Monte das Oliveiras, sendo acompanhada pelos anjos e pelas almas santas. Entregou a Tomé a faixa e, à vista de todos, é levada ao Céu diante de seu Filho e senta-se na glória da majestade. Os apóstolos com os discípulos e com as santas mulheres regressaram a Jerusalém dando graças por tudo quanto ouviram e viram, anunciando no meio de todos os povos as grandezas do Senhor. Fim. 
Ecce audisti et uidisti mysteria magna fidei Christianae quae, adueniente pastore nouo, renouabitur sicut aquila et reiuuenescet ${ }^{256}$ et renouabitur adueniente pastore illo de quo saepius locutus sum. Tunc implebitur illud Apocalypsis: Vidi ciuitatem sanctam, Ierusalem Nouam descendentem de caelo a Deo ${ }^{257}$.

Haec Ierusalem Noua est ipsa Roma ad quam Deus transtulit regnum suum et sacerdotium, quae iterum diebus istis renouabitur et toti mundo praesidebit ${ }^{258}$. Et pastor iste assimilabitur Dauid regi quia, sicut ipse renouauit ipsam Ierusalem et in ea fecit arcem et ciuitatem suam, ita iste reformabit nouam Ierusalem ${ }^{259}$, hoc est $^{260}$, Romam et Ecclesiam. Et sicut Dauid nutritus est in illa antiqua Ierusalem, sic et iste in hac noua Ierusalem. Et erit uerus filius Ecclesiae et pastor omnibus acceptus, Deo et hominibus. Dabit ei Dominus gratiam et prudentiam et soluet uinculum labiorum eius et linguae et loquetur Dei magnalia aperte et uocem

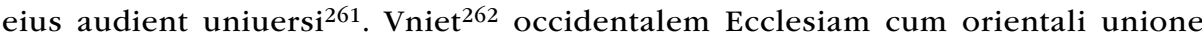
perpetua. Decem cardinales ex orientalibus faciet et duos magnos patriarchatus ${ }^{263}$ in occidente. Inter alios assistent ei septem uiri et praelati ${ }^{264}$ dignissimi sicut septem angeli coram Deo astant. Mittet legatos per orbem ut curam habeant ouium Dei. Ipse uacabit diuinis. Constituet unum ex cardinalibus qui curam habebit temporalium. Redibit pax uniuersalis et reformatio ${ }^{265}$.

Adhaerebunt ei Veneti et tota Italia iuuabuntque et classem praeparabunt. Et pacato $^{266}$ mundo, promulgabit omnibus uoluntatem Dei et uiuent in puritate fidei et timore Dei cunctis temporibus.

Florentini electum pastorem amabunt et suscipient et eius monitiones et praecepta super alios seruabunt et auxiliabuntur ei in omni suo bono proposito. Et iuuabunt ad faciendam conuersionem infidelium. Peccata multa in quibus [f1. 223] diu uixerunt dimittent et in fide omnium infidelium ${ }^{267}$ laetabuntur, quia fides Domini in toto mundo erit. Sed ipsi, id est, Florentini ante haec omnia et cito, quia diebus tuis quorum peccata grauissima multis eleemosynis et bonis

256 reiuuenescet] reuiuiscet $H$; reiuuenesset $M P R$; reiuuenisset $I V 257$ a Deo.] a Deo paratam sicut sponsam $P 258$ praesidebit.] praesidebit. Tempus alias intellexisti. Post istum ueniet remissus, non displicebit et sequetur ardens set potius ad malum. Sequetur ouis et quasi non sequetur. Sequentis autem uox cum rugitu sequente per totum audietur, longe lateque dilatabitur. Superna miseratione caliginem taetram et nigras nubes instigabit. Hoc est initium annorum felicium. $M$ (in marg. a. $m$.); Tempus alias intellexisti. Post istum ueniet remissus neque displicebit. Sequetur ardens sed potius ad mala. Sequetur ouis et quasi non sequetur. Sequentis autem uox per totum audietur, longe lateque dilatabitur, superna miseratione caliginem taetram et nigras nubes effugabit. Hic est initium annorum felicium. $O$; Tempus alias intellexisti. Post istud ueniet remissus, neque displicebit, sequetur ardens sed potius ad malum. Sequetur ouis quasi non sequetur. Sequentis autem uox cum rugitu sequente per totum audietur longe lateque dilatabitur. Superna miseratio caliginem taetram et nigras nubes effugabit. $Q 259$ quia sicut ipse $(\ldots)$ iste $\rightarrow$ 
Olha que ouviste e viste os grandes mistérios da fé cristã, fé que, com o advento do novo Pastor, se renovará como a águia e se rejuvenescerá, e com a chegada daquele Pastor de quem muitas vezes falei se renovará. Então será cumprida aquela passagem do Apocalipse: Vi a Cidade Santa, a Nova Jerusalém, que descia do Céu, de junto de Deus. ${ }^{[294]}$

Esta Nova Jerusalém é a própria Roma, para a qual transferiu Deus o seu reino e o sacerdócio, a qual por estes dias será outra vez renovada e presidirá a todo o mundo. E este Pastor assemelhar-se-á ao rei David porque, assim como ele renovou a própria Jerusalém e nela estabeleceu a sua cidadela e a sua cidade, assim este reformará a nova Jerusalém, isto é, Roma e a Igreja. E assim como David se criou naquela antiga Jerusalém, assim também este nesta nova Jerusalém. E será o verdadeiro filho da Igreja e o Pastor por todos aceite, por Deus e pelos homens. Dar-lhe-á o Senhor a graça e a prudência e desatará o nó dos seus lábios e da sua língua e terá sempre claramente em sua boca as grandes obras do Senhor e todos ouvirão a sua voz. Unirá em união perpétua a Igreja ocidental com a oriental. Criará de entre os orientais dez cardeais, e dois grandes patriarcados no ocidente. Assisti-lo-ão, entre outros, sete varões e prelados muito dignos, do mesmo modo que perante Deus estão sete anjos. Enviará legados por toda a Terra para velarem pelas ovelhas de Deus. Ele entregar-se-á às coisas divinas. Estabelecerá um dos cardeais que se ocupará das temporais. A paz universal e a reforma voltarão.

Os venezianos e a Itália inteira unir-se-ão a ele e ajudá-lo-ão e prepararão uma frota. E, pacificado o mundo, a todos ensinará a vontade de Deus, e viverão na pureza da fé e no temor de Deus durante todo o tempo.

Os florentinos amarão e aceitarão o Pastor eleito e cumprirão suas admoestações e preceitos mais que os outros e auxiliá-lo-ão em todo o seu bom propósito. E auxiliarão na conversão que deve ser feita dos infiéis. Abandonarão os muitos pecados em que [fl. 223] por muito tempo viveram e alegrar-se-ão na fé de todos os infiéis, porque a fé do Senhor estará em todo o mundo. Mas estes, isto é, os florentinos, antes de tudo isto e rapidamente, porque em tua vida os seus gra-

\footnotetext{
$\leftarrow$ reformabit nouam Ierusalem] quia sicut ipse renouabit Ierusalem et in ea faciet arcem et ciuitatem $Q 260$ ipsam Ierusalem (...) nouam Ierusalem, hoc est] ipsam Ierusalem, hoc est $R \mathbf{2 6 1}$ audient uniuersi.] audient uniuersi. Tempus alias intellexisti. Post istum ueniet remissus, non displicebit, sequetur ardens sed potius ad malum. Sequitur ouis et quasi non sequatur. Sequentis autem uox cum rugitu sequente per totum mundum audietur, longe lateque dilatabitur. Superna miseratur. Caliginem taetram et nigras nubes effugabit. Hoc est initium annorum felicium $N \mathbf{2 6 2}$ Vniet] Vniet iste nouus et sanctus pastor $N 263$ patriarchatus] patriarchas $Q 264$ praelati] praeclari $V 265$ reformatio] renouatio $V 266$ pacato] placato IRV 267 infidelium] fidelium $Q$
} 
operibus occultantur, multas habebunt perturbationes et ad inuicem insidias machinabuntur. Et non transibit tempus multum quod proditio eorum qui contra ciues maiores insurgent manifestabitur, tamen cum damno utriusque partis ${ }^{268}$. Et propter hanc rem magnos et potentes habebunt contra se et innumarabilia sustinebunt ${ }^{269}$ et uincent.

Antea quoque Veneti quam tempora felicia adueniant confederabuntur, timebunt, suspicabuntur et non sine dolo amicos habebunt. Sed prudenter se gerent et pro futura liberatione ${ }^{270}$ reseruabuntur. Acquirent et amittent. Tandemque desiderata et diu cogitata obtinebunt.

Anglia in grandi angulo posita est. Laedi poterit et saepius laedetur a seipsa.

Scotia sibi aemula quandoque reddetur tremula. Ferient pacem, sed labiis non corde, usque ad felicia tempora.

Hesperia ex multis regnis unum efficiet. Mulier circumdabit uirum. Nouam gentem Domino subiugabunt, foedera rumpent, bellabunt et praeliabuntur. Reges longo tempore discordes concordabuntur. Conabuntur noui Pharisaei discordiam intromittere neque poterunt quia non est sapientia neque consilium contra Dominum. Ante aduentum pastoris non fiet uera expugnatio infidelium.

Neque in Panonia neque in regnis sibi propinquis spes est uobis ponenda. Mouebuntur ad motum aliorum.

Germaniae inoboedientia et principum eius ineptia atque lasciuia prolongabit tempora felicia.

Cum magno pastore surget rex magnus ${ }^{271}$ et uoluntas Dei tempore illo perfecte adimplebitur.

Haec secreta non sunt dicenda omnibus, sed plublicabit ${ }^{272}$ ea electus pastor benedictus quem Deus, ut audisti, cito missurus est pro consolatione fidelium et conuersione gentilium ${ }^{273}$. Ab illo enim incipiet promulgatio libri et per illum Deus omnia quae dixi perficiet. Tu uero ad aliam ciuitatem ibis et tuos oculos ibi cum gratia Dei claudes et laetaberis in Deo salutari tuo.

Et sic uisio disparuit.

Ad honorem et gloriam haec sint Domini nostri Iesu Christi, Mariae Virginis Filii Vnigeniti ${ }^{274}$.

Amen ${ }^{275}$.

268 utriusque partis] utriusque partis. Fuit et factio contra domum de Medicis anno 1478, uiuente Amadeo $O$ (in marg.) 269 sustinebunt] sustinebunt, ampliabuntur HIJMOR 270 liberatione] deliberatione $Q \mathbf{2 7 1}$ surget rex magnus] surget rex magnus qui regnum nouae ciuitatis obtinebit et in Africa et postea in Europa infideles percutiet et fidem Domini augebit et gratus erit omnibus quia grata erunt obsequia eius $Q \mathbf{2 7 2}$ publicabit] promulgabit $Q \mathbf{2 7 3}$ gentilium] infidelium $P$; gentium $Q 274$ Vnigeniti] tui $V$; Vnigeniti Domini et Saluatoris nostri $O$; Vnigeniti Dei atque Saluatoris et Redemptoris nostri $Q 275$ Amen] Amen. Finis octauus Raptus $J$; Finis omnium raptuum $O$ 
víssimos pecados estão ocultos por muitas esmolas e boas obras, sofrerão muitos tumultos e maquinarão muitas traições entre si. E não passará muito tempo sem que a traição daqueles que se levantam contra os cidadãos mais importantes se manifeste, com prejuízo de ambas as partes, contudo. E, por essa razão, terão contra si os grandes e poderosos e suportarão incontáveis danos e vencerão.

$\mathrm{E}$, antes de chegarem os tempos felizes, os venezianos unir-se-ão, recearão, suspeitarão e, não sem fraude, terão amigos. Comportar-se-ão com prudência e guardar-se-ão para uma futura libertação. Ganharão e perderão. E, por fim, obterão aquilo que desejam e há tanto tempo sonharam.

A Inglaterra está lá num ponto muito retirado. Poderá ser afectada, mas mais vezes se prejudica a si própria.

A Escócia, sua rival, agitar-se-á algumas vezes. Até esses felizes tempos assinarão a paz, mas com palavras, não de coração.

A Hespéria de muitos reinos formará um só. A mulher rodeará o bomem. ${ }^{[295]}$ Submeterão ao Senhor nova gente, rasgarão os tratados, combaterão e lutarão. Os reis, desavindos por muito tempo, viverão em harmonia. Novos fariseus tentarão insinuar a discórdia e não o conseguirão, porque contra o Senhor não há sabedoria nem conselho. Antes de chegar o Pastor não se verificará a verdadeira sujeição dos infiéis.

Não deveis depositar confiança nem na Panónia nem nos reinos que lhe são próximos. Andarão ao sabor dos outros.

A desobediência da Germânia e a inépcia e intemperança dos seus príncipes prolongarão o tempo de felicidade.

Com o grande Pastor surgirá o grande Rei e, nesse tempo, a vontade de Deus será cumprida.

Estes segredos não devem dar-se a conhecer a todos, mas publicitá-los-á o bendito Pastor escolhido que Deus, como ouviste, há-de enviar brevemente para consolação dos fiéis e conversão dos gentios. Por ele será iniciada, de facto, a promulgação do Livro e, por seu intermédio, realizará Deus tudo quanto eu disse. Mas tu irás para outra cidade e lá, com a graça de Deus, fecharás teus olhos e alegrar-te-ás em Deus, teu Salvador.

E deste modo desapareceu a visão.

Sejam todas estas coisas para honra e glória de nosso Senhor Jesus Cristo, Filho Unigénito da Virgem Maria.

Ámen! 
(Página deixada propositadamente em branco) 


\section{ÍNDICE ONOMÁSTICO}

\section{A}

Abel, 58, 59, 120, 121, 520, 521, 534, 535.

Abraão, 59, 109, 123, 157, 273, 303, 315, 317, $327,333,337,521,535,537,599,609$.

Adão, 59, 81, 83, 85, 87, 91, 95, 97, 107, 109, $115,117,119,121,123,125,127,129,131$, 133, 135, 137, 139, 141, 143, 147, 155, 159, $161,163,165,167,169,171,173,175,177$, 179, 183, 185, 229, 257, 259, 261, 265, 291 , $293,295,517,521,535,537,557,563,565$, $569,571$.

Admirável, 321, 323, 327, 329.

Adonai, 290, 291, 292, 293, 294, 295, 512, 513.

Afonso V, D.

Ageu, 139, 319, 325.

Agostinho, (Santo), 9, 17, 27, 36, 37, 455, 481, 483, 499.

Águeda, (Santa), 217.

Alemanha, 30

Alexandre de Hales, 9, 36, 465.

Alexandria, 13.

Alfarrobeira, 6 .

Alfeu, 545.

Amadeítas, 9, 11, 21, 27.

Ambrósio, (Santo), 36, 455.

Ana, (Santa/profetisa), 183, 189, 233, 239, 297, $303,305,311,313,519,521,537,543,545$, $571,581,599,611$.

André (apóstolo), 215, 529, 557, 561, 581, 585 , 597.

Anselmo, (Santo), 36, 37, 455.
Apolinário, 13, 28, 29.

Apolónia, (Santa), 217.

Aquário, 587.

Arábia, 547

Arcanjos, 523, 606.

Aristóteles, 27, 30, 36, 373.

Arrábida, 16.

Artaxerxes, 352.

Assembleia, 57, 59, 61, 67, 101, 151, 199, 225, 229, 235, 269, 435, 515.

Assírios, 319.

Assis, 7.

Atanásio, (Santo), 13, 36, 285, 455.

Ático, 32.

Aveiro, Duque(s) de, 11, 16, 17, 18, 19, 20.

Azevedo, Pero Vaz de, 5.

B

Balaão, 131.

Balança, 587.

Bárbara, (Santa), 216, 217.

Barbosa Machado, Diogo, 30, 31, 32, 39.

Barcelona, 10, 11, 12, 15, 18, 19, 48.

Bargas, Francisco de, 16, 18, 32, 48, 49.

Barnabé, (Apóstolo), 63, 529, 551, 583, 585, 589, 597, 605, 607.

Barquiel, 85, 239, 255, 259, 437.

Bartolomeu, (Apóstolo), 529, 573, 581, 597.

Basílio, (São), 36, 455.

Beirute, 13.

Belarmino, S. Roberto, 20, 30, 32, 39 . 
Belém, 305, 307, 321, 323, 331.

Beluiz, S. Francisco de, 16, 49.

Belzebu, 245, 249.

Benigno, Zorzo, 21, 22, 44, 45, 265.

Betânia, 215, 523, 549 .

Bianca Maria, 7, 8 .

Biondo, Francesco, 22, 23, 44, 45.

Boaventura, (São), 36, 361.

Boécio, 36, 455.

Bolonha, 10, 12, 14, 20, 37, 46.

Bondade, 213.

Borromeu, S. Carlos, 9.

Bósnia, 21.

Brasil, 12.

Bréscia, 7.

Brígida, Santa, 35, 40, 51, 306, 307, 617.

Bzovio, 30, 31, 32.

\section{C}

Caetano, Tomás de Vio, 30, 31.

Calvo, Fr. João, 16, 20, 49.

Campo Maior, 5, 6.

Câncer, 586, 587.

Cântico dos Cânticos, 329, 613.

Capricórnio, 587.

Carmelo, 323, 331

Carneiro (signo), 107, 587, 629.

Castro, D. João de, 39,29.

Catarina, (Santa), 217.

Catarino, Ambrósio, 29, 32.

Catherina (Catarina) de Áustria, D., 17, 50.

Cecília, (Santa), 217.

Cenáculo, 532-533, 540-541.

Céu Aquoso, 575.

Céu Cristalino ou Céu da Água, 199.

Céu das Águas, 67.

Céu dos Planetas, 67.

Céu Empíreo, 63, 65, 69, 109, 155, 157, 159, 197, 199, 281, 287, 343, 345, 405, 415, 575, $605,617,623$.

Céu Estrelado, 67, 587.

Céu Ígneo, 199.
Céu Inferior, 69, 587.

Céu Móvel, 65, 67, 291.

Céu Sideral, 69.

Céu Superior, 69.

Céus dos Planetas, 65, 67.

Ceuta, 5, 51 .

Cícero, 32, 37, 38, 559.

Cléofas, 533.

Concepcionistas, 11.

Confessores, 217, 347, 616-617.

Conselheiro, 321, 327, 329.

Cória, 17.

Corpo de Cristo, 26, 181, 183, 349, 351, 353, $355,361,363,365,367,371,373,375,377$, 381, 383, 391, 393, 395, 399, 405, 407, 419, 421.

Corpo Místico, 399, 401.

Costa, António Domingos de Sousa, 5, 6, 7, 8, 9, $11,12,24,27,30,31,32,37,38,51$.

Cremona, 7, 10, 45 .

Criador, 73, 75, 107, 187, 231, 245, 251, 255 , 257, 263, 265, 269, 271, 275, 299, 307, 475, $477,525,547,593,621$.

Crisóstomo (São), 36, 455.

Cristina, (Santa), 217.

Cristo Senhor, 135, 209, 211, 217, 227, 271, 307, 341, 343, 359, 361, 383, 393, 433, 515, 519, $521,523,529,531,541,547,557,565,567$, $583,587,597,599,617$.

Cristo-Homem, 313, 341, 541, 543, 477.

Cristo passim.

Cunha, Luís Vaz da, 5

D

Daniel, 58, 59, 193, 317, 318, 319, 320, 321, $325,333,335$.

Danielou, J., 13.

David, 59, 109, 123, 235, 241, 307, 317, 327, $329,331,525,535,609,625$.

Deus de Israel, 189, 235.

Deus Homem, 77, 105, 119, 163, 173, 243, 249, 251, 253, 257, 261, 275, 3455, 347. 
Deus Pai, 79, 239, 241, 243, 265, 271, 281, 327, 329, 455, 471, 497, 563, 575, 597.

Deus Trino e Uno, 115, 261, 295, 433, 547, 589, 621.

Deus Trino, 115, 121, 123, 195, 257, 591, 593.

Deus-Anjo, 253.

Deus-Homem, 77, 105, 119, 163, 173, 243, 249, 251, 253, 257, 261, 275, 345, 347.

Diabo, 87, 89, 99, 117, 119, 569, 601.

Dídimo, 36, 217, 455, 597.

Dionísio, 523, 525, 531, 547, 551, 589, 593, 597, $605,609$.

Dominações, 523, 609.

Doutor Subtil, 467.

Doutores, 38, 149, 159, 167, 173, 179, 201, 217, $315,317,319,321,325,327,333,335,339$, 343, 357, 367, 401, 455, 457, 527, 533.

Dragisic, Juraj, 21.

Duarte, Infante D., 6.

Duarte, rei D., 5, 28, 37, 38, 51.

Duns Escoto, (cf. Escoto, João), 8, 36, 38.

\section{E}

Eclesiastes, 327, 329.

Efratá, 323.

Egídio Romano, 21, 22, 37, 44.

Egipto, 311, 325, 601.

Eleazar, 240, 241.

Elias, 534, 595, 599, 621 .

Emanuel, 193, 317, 321, 323, 329.

Esaú, 152, 153, 629.

Escócia, 627.

Escorial, 10, 19, 20.

Escorpião, 587.

Escoto, João, 9, 24, 27, 36, 37, 38, 371, 401, 445, $447,449,455,465,467,483,485,487,489$, 491, 495, 497.

Escritura, 26, 83, 105, 157, 199, 243, 267, 327, 331.

Espanha, 6, 7, 9, 11, 19, 20, 32, 37.

Espírito do Senhor, 65, 237.

Espírito Santo, 65, 232.
Ester, 537.

Eucaristia, 35, 367, 391.

Eucudiel, 85, 239, 249.

Eva, 83, 85, 87, 95, 97, 99, 107, 119, 121, 125, $127,129,131,133,159,161,181,183,257$, 259, 261, 265, 290, 291, 293, 294, 295, 535, $537,569,571,591$.

Ezequiel, 59, 317.

F

Fermín, Fr. Antonio, 16, 48,49.

Ferreira, M. E. Cordeiro, 11.

Filho da Iniquidade, 607.

Filho do Homem, 347, 397, 399, 521.

Filho Unigénito, 243, 523, 623, 627.

Filho, 597, 599, 609, 613, 615, 619, 621, 623, 627.

Filipe (Apóstolo), 529, 575, 581, 597.

Firenze, 42, 44, 51.

Firenze, Fr. Mariano da, 6, 7, 8.

Florença, 7.

Florentinos, 39, 625.

Fontaines, Godofredo de, 37.

Forte, 327, 329.

Frades Menores, 7.

França, 11.

Franciscanos, 9, 20, 27, 32.

Francisco (de Assis), 7, 27, 51, 63, 157, 217, 632.

Frederico III de Alemanha, 6.

\section{G}

Gabriel de Badaxós, São, 16, 17.

Gabriel, (Anjo), 288, 289, 301, 308, 309, 378, 379, 426, 427, 430, 431, 436, 437, 500, 501, $514,515,519,550,551,560,561,586,589$, $620,621,622,623$.

Galileia, 231, 299.

Gand, 37.

Gémeos, 587.

Génova, 7.

Germânia, 627. 
Gomes, Pero, 6.

Gonçalves, Pero, 5.

Gouveia, 11.

Grande Pastor, 627.

Grande Rei, 221, 311, 627.

Gregório, São, 36, 37, 45, 455.

Gregos, 36, 217, 319, 351, 365, 373, 395, 397, $455,483,505,535,565$.

Guadalupe, 6, 16, 39.

\section{$\mathbf{H}$}

Hastingham, 37.

Héber, 314, 315, 534, 535.

Hebreus, 109, 315.

Heli, 194, 195, 232, 233, 240, 241.

Henoc, 599, 621.

Henrique de Gand, 37.

Henrique, Cardeal D., 32.

Herodes, 551.

Hespéria, 626, 627.

Hilário de Poitiers, 479.

Hilário, 36, 455.

Hisméria, 544, 545.

Homem-Deus, 163, 227, 249, 251, 257, 289.

Hugo de S. Victor, 37

\section{I}

Idida, 326, 327.

Igreja de Santa Maria della Pace, 7, 9.

Igreja, 7, 14, 16, 23, 28, 30, 33, 36, 38, 39, 40, $51,57,93,103,109,149,153,155,157,167$, 185, 285, 287, 289, 309, 359, 363, 375, 399, $515,521,531,539,541,547,549,559,561$, $567,583,607,613,625$.

Imaculada Conceição, 40, 51, 185, 371.

Inácio de Antioquia, 523, 525, 531, 547, 549, 551, 593, 597, 605, 607 .

Inês, Santa, 217.

Inferno, 94, 95, 124, 125, 138, 139, 227, 329, 539.

Inglaterra, 627.

Iquazafigo, P. Jacome, 11.
Isaac, 314, 315, 316, 317

Isabel (a Católica), 11.

Isabel (parente da Virgem Maria), 243, 291, 299, 301, 303, 305, 387, 519, 545, 611.

Isabel de Meneses, 5 .

Isabel de Portugal, 37.

Isabel, Santa (da Ordem Terceira), 616, 617.

Isaías, 58, 59, 193, 317, 319, 323, 325, 534.

Israel, 188, 189, 196, 197, 234, 235, 272, 273, 322, 323, 326, 327, 330, 331, 332, 333, 334, 335, 336, 337, 596, 597, 600, 601, 610, 611, 614, 615,Itália.

Itália, 9, 10, 20, 21, 42, 150, 153, 209, 624, 625.

$\mathbf{J}$

Jacob, 153, 155, 233, 241, 317, 319, 325, 327, $601,629$.

Januenses, 153.

Jardim das Delícias, 83, 85, 107, 111, 121, 201, 265.

Jeremias, 59, 193, 317, 327, 535.

Jericó, 293.

Jerónimo (São), 6, 9, 36, 61, 455.

Jerónimo, Frei, 28.

Jerusalém Celeste, 533.

Jerusalém, 393, 311, 313, 315, 325, 339, 523, $533,541,551,611,619,623,625$.

João Baptista, 61, 63, 155, 179, 215, 343, 517, 535, 545, 599, 611.

João Escoto (cf. Escoto, João), 401, 445, 49.

João Evangelista, 215, 523, 545, 547

João I, D., 5.

João II, D., 16

Joaquim (pai de Maria), 183, 189, 233, 239, 241, $305,311,313,543,545,599,611$.

José (esposo de Maria), 59, 231, 233, 235, 239, 241, 291, 297, 303, 305, 307, 309, 311, 313, 317, 321, 331, 333, 339, 341, 343, 519, 521, $523,531,535,543,545,555,581,597,599$, $611,615$.

Judá (tribo de), 231, 307, 327, 331.

Judas, 217, 583. 
Judite, 537.

Juliano Apóstata, 13.

Júlio III (papa), 28, 29, 32.

Júpiter, 263, 587.

\section{L}

Laodiceia, 13.

Lapide, Cornelio a, 30, 31, 32, 38.

Lázaro, 215, 217, 383, 387, 523, 529, 530, 531, 543, 549, 619.

Leão (signo), 587 .

Leão (da tribo de Judá), 327.

Leão X (papa), 30.

Lei, 61, 187, 189, 205, 229, 231, 233, 235, 241, $303,311,315,317,325,327,329, .333,335$, $337,543,547,579,619$.

Lencastre, D. João de, 16.

Leonor, D. (irmã de Afonso V), 6, 37.

Levi (tribo de), 321.

Liège, 37.

Limbo, 534, 535.

Lisboa, 17, 18, 50, 51.

Lombardia, 9, 10, 37.

Lombardo, Pedro, 37.

Lourenço de Panisperva, S., 307.

Lua, 67, 81, 237, 263, 291, 557, 587, 615.

Lucas (evangelista), 63, 214, 215, 238, 239, 286, 287, 2888, 289, 302, 303, 310, 311, 314, 315, $523,525,529,531,533,547,584,585,588$, 589, 597, 623 .

Lúcia, Santa, 216, 217.

Lúcifer, 61, 75, 76, 77, 79, 81, 84, 85, 86, 87, 88, 89, 91, 93, 97, 98, 99, 108, 109, 116, 117, $118,119,120,121,208,211,226,227,228$, 229, 244, 245, 246, 247, 248, 249, 250, 251, 252, 253, 273, 274, 275, 280, 281, 292, 293, 427, 431, 531, 569, 587, 615.

Luís XI (rei de França), 11.

Lutero, 30.

\section{M}

Macabeus, 535.
Macedo, Jorge de, 11.

Macedónios, 319.

Madalena, 215, 521, 525, 529, 531, 533, 535, $543,545,549,597,599,615,623$.

Madrid, 10, 11, 12, 13, 19, 51.

Mãe de Deus, 57, 61, 75, 77, 81, 119, 143, 149, $151,155,157,163,167,169,171,175,177$, 179, 181, 183, 185, 193, 195, 197, 215, 227, 241, 243, 249, 253, 261, 269, 271, 275, 281, 287, 289, 295, 297, 301, 303, 307, 311, 313, $315,319,331,333,339,341,343,357,371$, $381,415,435,477,513,515,517,519,521$, $523,525,527,529,531,533,535,537,539$, $541,543,545,547,549,551,553,555,557$, $559,561,563,565,567,571,573,581,583$, 585, 589, 591, 593, 609, 611, 613, 615, 617, $619,621,623$.

Magdala, 215, 549.

Magos, os, 311.

Manrique, cardeal D. Alonso, 48, 49.

Marcos (evangelista), 63, 529, 585, 591, 597.

Marcos de Lisboa, Frei, 5, 6, 30, 31, 37, 51.

Maria Cléofas, 529, 543, 545, 581, 599.

Maria de Alfeu, 529, 543.

Maria de Cléofas, 529, 543, 545, 581, 599.

Maria, passim.

Marrou, $\mathrm{H}$.

Marta, 531, 545, 549, 597, 599.

Marte, 263, 587.

Mártires, 343.

Mascarenhas, D. José de, 11.

Mateus (evangelista), 109, 529, 559, 571, 573, 581, 597.

Matham, 233.

Medos, 319.

Mendes, Álvaro, 5.

Meneses, D. Pedro de, 5, 6.

Meneses, D. Rodrigo de, 11.

Meneses, Isabel de, 5 .

Meneses, João da Silva (cf. Silva, João Meneses da), 6 .

Meneses, João de, 6. 
Menino Jesus, 309, 311, 313, 321.

Mercúrio, 263, 587.

Messias, 193, 195, 238, 239, 241, 297, 317, 318, $319,320,321,322,323,325,326,327,329$, 330, 331, 332, 333, 334, 335, 338, 339.

Miguel (arcanjo), 61, 75, 77, 79, 81, 83, 209, $211,215,227,229,239,245,247,251,253$, 255, 281, 383, 427, 431, 501, 589, 601, 609,

Milão, 6, 7, 9, 11, 15, 19, 20, 22, 40, 157, 513.

Miqueias, 323, 331.

Missal, 351.

Moisés, 59, 65, 107, 109, 123, 317, 327, 336, $337,338,339,521,535,609$.

Montanha, 155.

Monte da Casa do Senhor, 321, 323, 331.

Monte das Oliveiras, 287, 531, 613, 623.

Monte Gargano, 208, 209.

Monte Sião, 157, 323, 549.

Monte Sinai, 323, 330.

Morliano, 7.

Morlion, Bispo, 21, 44.

\section{$\mathbf{N}$}

Nascimento, Aires, 38.

Natividade, 287, 289, 433.

Nazaré, 21, 231, 239, 241, 299, 311, 321, 331, 339, 341.

Niceia, 13.

Núpcias do Cordeiro, 59, 229, 433.

$\mathrm{O}$

Ocidente, 103, 587, 625 .

Ordem Seráfica, 16, 30, 31.

Oreno, 7.

Oriente, 102, 103, 586, 587, 606, 607.

Ortiz, D. António, 16, 17, 18, 19, 20, 32, 48, $49,50$.

Ouguela, 5 .

\section{$\mathbf{P}$}

Pai (Deus), 79, 101, 117, 191, 197, 213, 225, $227,229,239,241,243,255,259,265,271$,
273, 277, 281, 297, 299, 307, 313, 321, 327, 329, 331, 339, 341, 343, 347, 349, 383, 385, $387,393,421,427,429,431,437,441,449$, $451,453,455,461,463,465,469,471,473$, $475,477,479,483,485,491,493,495,497$, 499, 501, 503, 505, 507, 509, 511, 513, 519, $521,525,527,533,535,539,541,553,555$, $559,563,575,589,593,597,607,617,621$.

Pai do Futuro Século, 327, 329.

Paixão (de Cristo), 157, 171, 289, 313, 341, 385, $431,433,523,549,557,561,573,583$.

Panónia, 626, 627.

Paraíso das Delícias, 67, 83, 85, 87, 107, 111, 121, 201, 265, 345.

Paraíso, 35, 67, 87, 89, 97, 99, 103, 105, 107, $109,111,117,119,121,125,153,141,149$, 155, 181, 197, 199, 311, 345, 551, 569, 595, 599, 603, 619, 621, 623.

Paris, 10, 11, 36, 37, 447.

Patriarcas, 317, 343, 533, 537, 599.

Patrística, 35.

Paulo (Apóstolo), 47, 63, 79, 214, 215, 303, 325, 492, 493, 522, 523, 525, 528, 529, 546, 547, $547,551,563,585,589,596,597,605,607$, 619, 621 .

Paulo VI (papa), 5.

Pedro Auréolo, 36, 447.

Pedro de Alcântara, São, 16, 17, 18, 49.

Pedro in Montorio, São, 8, 10, 21.

Pedro, (1. ${ }^{\circ}$ papa), 59, 63, 101, 215, 303, 385, 393, 429, 493, 527, 529, 533, 539, 551, 553, $557,559,561,567,577,581,583,585,593$, 595, 597, 599, 605, 607, 611, 617, 619, 623.

Pedro, Infante D., 37.

Peixes, 587.

Persas, 319.

Perúsia, 7.

Pichon, René, 32.

Pio II, 7.

Plaça, P. Dias de la, 16, 48.

Plasência, 17.

Pontífice Máximo, 529. 
Portalegre, 12.

Potestades, 237, 257, 265, 523, 561, 609.

Precursor, 58, 59, 298, 299, 301, 303, 305.

Primeira Pessoa, 449, 451, 453, 459, 465, 469, 471, 473, 475, 477.

Primeira Potência, 403.

Principados, 237, 287, 523, 609.

Príncipe da Paz Eterna, 327.

Profetas, 28, 67, 119, 193, 239, 287, 317, 327, 329, 333, 335, 343, 523, 533, 535, 537, 599.

Profetisa Ana, (cf. Ana, Santa), 311, 519, 521, $537,611$.

Purgatório, 138-139, 534-535, 599, 602, 603.

\section{$\mathbf{R}$}

Rafael, 61, 81, 85, 209, 227, 249, 501.

Rainha do Céu, 59, 61, 63, 85, 87, 165, 167, 169, 179, 183, 185, 195, 197, 229, 245, 255, 275, 281, 287, 303, 305, 307, 309, 371, 391, 423, 515, 525, 535, 537, 545, 551, 555, 557, 559, $561,565,567,571,579,581,583,585,591$, 609, 611, 615.

Rainha Universal, 545.

Raquel, 537.

Redentor, 115, 119, 135, 137, 139, 171, 193, 203, 295, 515, 527, 559, 571.

Rei, 59, 61, 63, 75, 123, 135, 153, 187, 221, 225, 227, 231, 255, 263, 287, 299, 305, 309, 311, $327,329,333,339,345,361,429,511,529$, $537,539,545,547,589,607,611,613,615$, 627,630 .

Reis Católicos, 11.

Ressurreição, 23, 209, 211, 215, 287, 313, 325, $345,433,435,437,519,523,531,541,605$, 617.

Ricardo (de S. Victor), 9, 36, 37, 455.

Rodolfo, Pietro, 31.

Roma, 7, 8, 9, 10, 11, 16, 17, 18, 19, 20, 22, 26, $27,40,41,43,44,45,46,49,151,157,239$, $619,624,625$.

Rute, 537.

\section{S}

Sabedoria, 213, 239, 265, 585 .

Sagitário, 587.

Salomão, 327, 329, 331, 535, 613, 615.

Salomé (Maria), 528, 529, 542, 543, 544, 545, $596,599$.

Saltiel, 80, 81, 84, 85, 252, 253.

Samuel, 58, 59, 316, 317.

Santa Croce, Cardeal (vd. Cruz, Cardeal Santa), $17,22,40,41,43,46$.

Santa Cruz, Cardeal (vd. Santa Cruz, Cardeal), $11,16,17,19,20,21,22,49$.

Santa Maria, Fr. Martinho de, 16.

Santa Sé, 7.

Santíssima Trindade, 35, 201, 227, 407, 475, $501,513,523,547,589$.

Santo Ofício, 17, 32 .

Santos Padres, 283, 285, 343, 387.

Santos, Fr. Miguel dos, 17, 18, 19, 20, 32, 50.

Sara, 537.

Saturno, 263, 587

Savona, Francesco di, 8.

Sebastião, D., 39.

Segunda Pessoa, 451, 459, 465, 473, 475.

Séneca, 37, 38, 143.

Senhora dos anjos, 85, 275, 525.

Serafins, 437, 523, 609.

Seth, 520, 521, 534, 535 .

Sforza, Francesco, 7.

Sforza (Família), 7.

Silva, Amadeu Meneses da, (i. e. Beato Amadeu), 26.

Silva, João da (2. ${ }^{\circ}$ marques de Gouveia), 11.

Silva, João Meneses da (vd. Meneses, João da Silva), 6, 38.

Silva, Rui Gomes da, 5, 6.

Silva, Santa Beatriz da, 5 .

Simão (apóstolo), 529, 543, 545, 559, 581, 597.

Simão Mago, 151, 153.

Simão Pedro, 559.

Simão, o fariseu, 215. 
Simão, o leproso, 215.

Simeão, 311, 537, 561, 611 .

Sinagoga de Deus, 195.

Síria, 13.

Sisto IV, 8, 10, 21, 26, 391.

Sol, 64, 65, 66, 67, 68, 69, 78, 81, 101, 106, 107, 109, 221, 237, 250, 251, 255, 259, 263, 269, 288, 289, 290, 291, 296, 297, 547, 556, 564, $565,570,571,575,586,187,603,614,615$.

Srebrenica, 21.

Sumo-Sacerdote, 633.

\section{$\mathbf{T}$}

Tabor, 323, 331.

Tadeu, 529, 543, 545, 577, 581, 597.

Taré, 535.

Tecla, 216, 217.

Templo,34, 35, 118, 119, 150, 151, 153, 154, 155, 178, 179, 184, 185, 188, 189, 190, 191, 192, 193, 194, 195, 196, 197, 229, 240, 241, 288, 289, 298, 299, 302, 304, 305, 314, 319, 321, 323, 324, 325, 326, 327, 333, 340, 341, $342,343,382,383,518,519,521,544,545$, 579.

Terceira Pessoa, 243, 451, 459, 475.

Tetragrama, 317, 327, 503.

Tiago Menor, 529, 543, 545, 567.

Tiago, 259, 551, 553, 559, 581, 585, 597, 599, 605, 611, 621, 623.

Tiagos, os dois, 529, 545.

Tobias, 529, 545 .

Toledo, 10, 19.

Tomás (de Aquino), 9, 27, 30, 36, 37, 445, 447, 449, 455, 465, 467, 485, 487, 489, 495, 497.

Tomé, 217, 529, 559, 561, 581, 597, 615, 617, 623.

Touro, 587.

Trecha, Fr. Miguel de, 21, 29, 44, 45.

Trismegisto, 511

Tronos, 523, 609 .
$\mathbf{U}$

Ubeda, 7 .

Uriel, 61, 81, 85, 227, 251, 437, 603.

$\mathbf{V}$

Vale de Josafat, 597, 599, 603, 615, 623.

Vasconcelos, António de, 31.

Venezianos, 625, 627.

Vénus, 263, 586, 587.

Verbo de Deus, 57, 63, 197, 267, 301, 387, 427, $519,555,589,621$.

Verbo do Eterno Pai, 299.

Verbo do Pai, 393.

Verbo Eterno de Deus Pai, 265.

Verbo-Homem, 621.

Verdade, 213, 549, 571.

Vieira, Padre António, 11, 12, 20, 51.

Vigário de Cristo, 33, 111, 155, 581.

Vila Real, 5 .

Virgem (i. e. Maria), 155, 165, 169, 173, 175 , 177, 193, 195, 197, 225, 229, 231, 235, 239, 241, 243, 265, 267, 269, 271, 289, 299, 303, $305,307,317,319,321,323,341,423,515$, $517,545,547,551,553,557,559,561,563$, $569,583,585,593,605,615,617$

Virgem (signo), 587.

Virgem Mãe (de Deus), 167, 171, 181, 371, 415, $549,585,623$

Virgem Maria, 173, 197, 241, 253, 275, 287, 515, 519, 531, 543, 545, 627 .

Virgens, 217, 229, 239, 343, 521, 613, 617, 623.

Virtudes, 257, 291, 523, 561, 609.

Vitorino, Jerónimo, 20, 29, 32, 38.

\section{$\mathbf{Z}$}

Zacarias, 299, 305, 325, 473, 521, 545, 593, 611. Zebedeu, 473, 529, 543, 545, 599, 605, 623.

Zodíaco, 586, 587. 


\section{ÍNDICE GERAL}

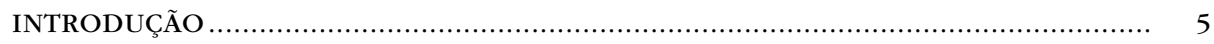

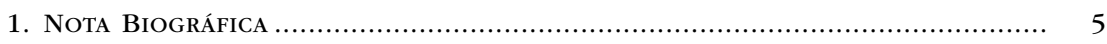

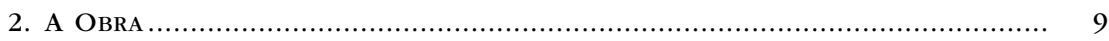

2.1. Os manuscritos

2.1.1. Tradição manuscrita .................................................. 9

2.1.2. Tentativa de constituição de um stemma....................... 14

2.2. Abertura do Livro ............................................................. 20

2.3. Mediador da revelação........................................................ 24

2.4. História de uma deturpação...................................................... 30

2.5. Remissões internas......................................................... 33

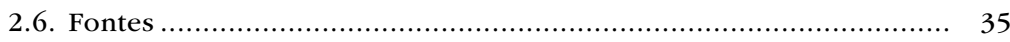

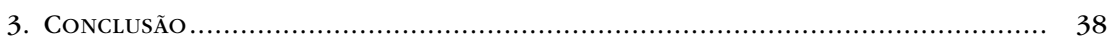

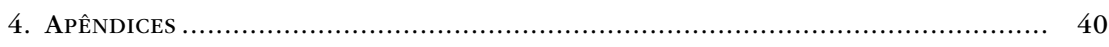

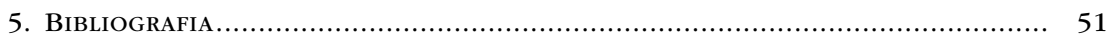

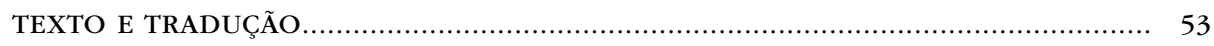

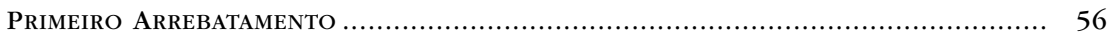

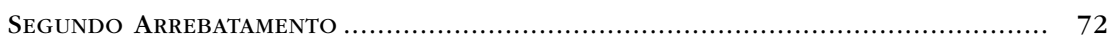

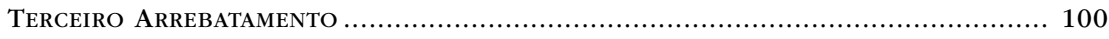

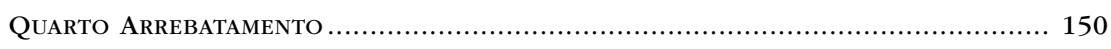

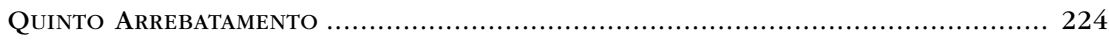

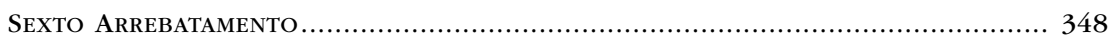

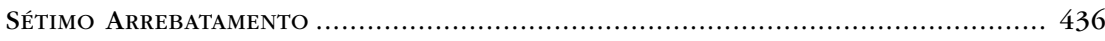

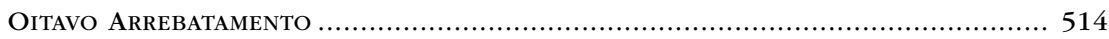

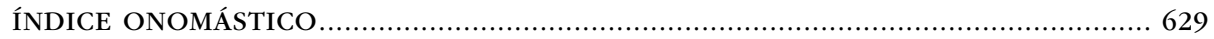


(Página deixada propositadamente em branco) 


$$
\frac{\mathrm{I}}{\mathrm{U}}
$$

9 